\title{
Metrologi Manufaktur Pengukuran geometri dan analisis ketidakpastian
}

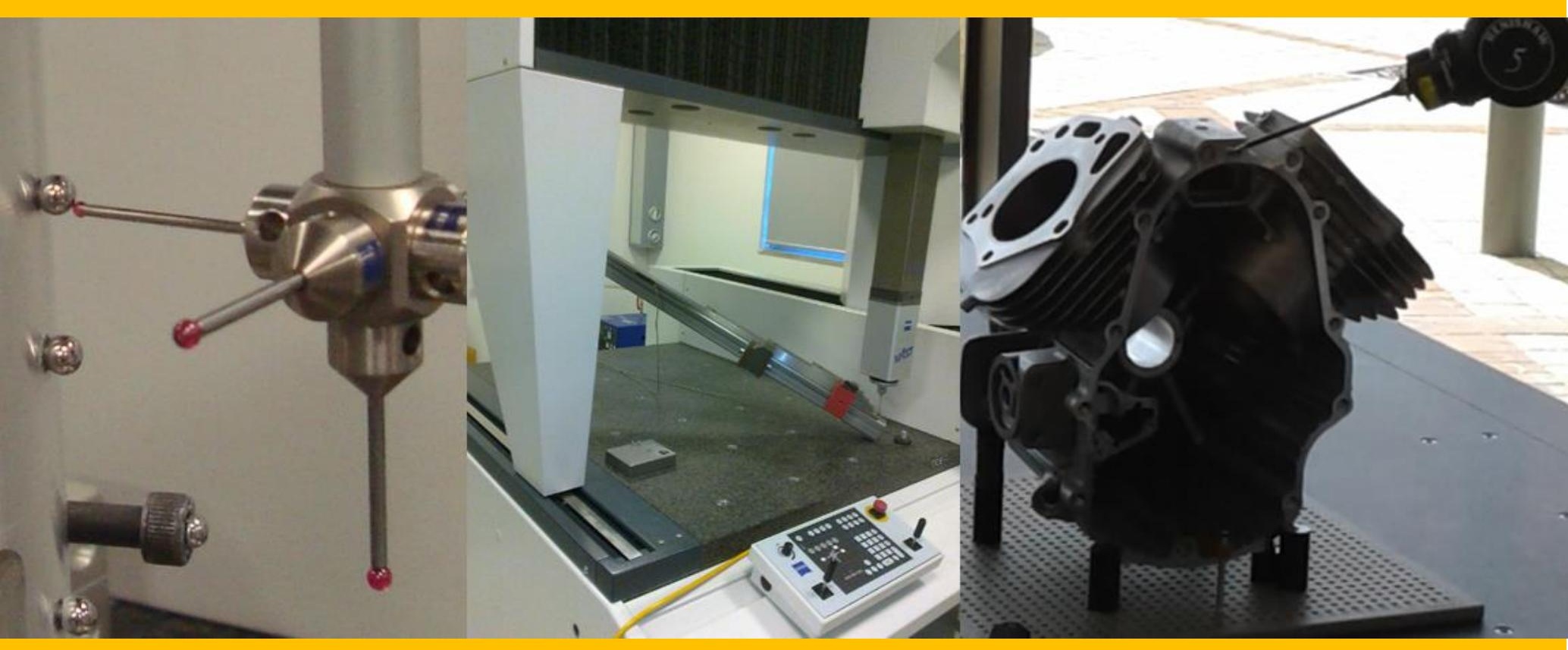

Dr. Wahyudin P. Syam 


\section{Kata pengantar}

Bismillaahirrahmaanirrahiim,

Atas berkat rahmat Allah SWT, buku ini dapat terselesaikan. Salawat serta salam tercurahkan kepada Rasulullah SAW.

Semoga buku ini bermanfaat dan bisa menjadi kontribusi untuk keilmuan bidang metrologi bagi para pembaca.

Industri manufaktur adalah salah satu penyokong utama negara-negara maju di dunia karena pada esensinya industri manufaktur memberikan nilai tambah suatu material sehingga material tersebut memiliki nilai ekonomi yang lebih tinggi daripada sebelum material tersebut diproses. Metrologi, sebagai ilmu pengukuran, merupakan salah satu faktor utama yang menentukan suatu industri manufaktur untuk tetap beroperasi dan berkembang. Hal ini disebabkan karena dengan adanya metrologi (pengukuran), maka suatu proses dan produk dari suatu industri manufaktur dapat diukur dan ditingkatkan, sehingga proses tersebut dapat lebih efisien dan produk tersebut dapat dijaga kualitasnya dan dapat berfungsi sesuai dengan yang diinginkan.

Latar belakang penulisan buku ini adalah sebagai berikut. Metrologi atau pengukuran pada industri-industri manufaktur banyak dipandang hanya sebagai cost center karena tidak menghasilkan suatu produk, sehingga investasi (misalnya investasi untuk pembelian instrumen metrologi dengan tingkat presisi yang tinggi dan investasi untuk proses kalibrasi) untuk metrologi di industri-industri tersebut tidak dipandang serius. Latar belakang berikutnya adalah dengan mengimplementasikan metrologi dengan tepat dan baik, maka suatu industri manufaktur dapat meningkatkan keuntungan ekonominya, misalnya turunnya biaya produksi dengan peningkatan efisiensi suatu proses produksi, turunnya jumlah produk yang cacat dan meningkatnya kualitas produk yang menyebabkan suatu produk dapat bersaing di pasar komersial. Terakhir, latar belakang buku ini adalah untuk promosi metrologi di Indonesia. Metrologi adalah suatu bidang keilmuan yang sangat luas, bukan hanya mengenai pengukuran, tetapi juga mengenai disain instrument, mekatronika, algoritma dan lain sebagainya. Dengan luasnya ilmu metrologi, maka banyak inter-disiplin keilmuan yang dibutuhkan sehingga banyak hal-hal menarik yang bisa dilakukan untuk metrologi.

Pentingnya buku ini dapat dilihat dari berbagai macam aspek. Buku ini dapat digunakan sebagai sumber materimateri yang berhubungan dengan metrologi, terutama untuk pengukuran geometri (form). Metrologi secara umum dari mulai prinsip-prinsip dasar sampai tingkat lanjut dibahas dalam buku ini. Referensi-referensi utama dalam bidang metrologi juga disediakan dalam buku ini, sehingga apabila pembaca ingin mengetahui lebih lanjut tentang suatu bahasan, maka pembaca dapat merujuk pada referensi-referensi tersebut, sehingga buku ini dapat digunakan sebagai portal untuk masuk ke bidang-bidang keilmuam metrologi lainnya. Bab-bab dalam buku ini ditulis sedemikian rupa sehingga bab-bab tersebut juga bisa dibaca secara independen. Pembaca bisa langsung membaca bab-bab yang dirasa penting untuk pembaca tersebut. Buku ini juga menyajikan berbagai informasi praktis yang langsung dapat diaplikasikan pada suatu industri manufaktur, khususnya departemen inspeksi kualitas. Dan terakhir, buku ini membahas ketidakpastian (uncertainty) yang merupakan salah satu topik penting dari metrologi dan sebagai landasan suatu proses pengukuran. Pembahasan ketidakpastian dibahas dengan detil dalam buku ini. Materi ketidakpastian dalam metrologi tidak banyak ditemukan di buku-buku lainnya.

Buku ini diperuntukan untuk berbagai macam kalangan, yaitu mahasiswa sarjana tingkat tiga atau empat yang sudah pernah mengambil mata kuliah statistik, mahasiswa pasca-sarjana, praktisi industri manufaktur terutama orang yang bekerja di departemen inspeksi kualitas, dan kalangan umum yang mempunyai latar belakang keteknikan yang ingin mempelajari konsep-konsep penting metrologi. Hal yang menyebabkan buku ini bisa untuk berbagai kalangan adalah karena banyak konsep-konsep keilmuan metrologi juga dipakai untuk keilmuan lainnya, seperti konsep ketidakpastian, algoritma dan disain presisi. 
Bidang metrologi memiliki lingkup keilmuan yang sangat luas, sehingga banyak topik-topik menarik yang bisa diteliti. Bidang metrologi tidak hanya selalu tentang kontrol kualitas. Topik-topik riset menarik (selain kontrol kualitas, pengukuran, kalibrasi dan keterlacakan) yang bisa didalami untuk kemajuan metrologi adalah misalnya topik riset mengenai disain inovatif komponen dengan tingkat presisi yang tinggi, pengembangan berbagai macam algoritma dan berbagai macam jenis pemrograman (misanya, komputasi paralel), riset eksperimental untuk meningkatkan performansi suatu instrument pengukuran, riset teoritikal mengenai model matematik berbagai macam proses pengukuran dan mektronika.

Bab-bab pada buku ini disusun sedemikian rupa sehingga bisa dibaca secara berurutan atau terpisah tergantung topik mana yang pembaca ingin pahami. Penjelasan singkat mengenai bab-bab dan interrelasi bab-bab tersebut dalam buku ini adalah sebagai berikut:

- Bab 1: Introduksi untuk metrologi manufaktur.

Bab 1 merupakan pengantar untuk bab-bab berikutnya yang mempresentasikan tujuan metrologi sebagai ilmu pengukuran. Selain itu, sejarah penting tentang asal mula metrologi, mulai dari zaman mesir kuno sampai zaman modern sekarang, juga dipresentasikan. Organisasi-organisasi internasioanl yang mengatur penerapan metrologi pada industri juga dibahas. Dan terakhir, tiga konsep dasar metrologi, yaitu keterlacakan (traceability), kalibrasi (calibration) dan ketidakpastian (uncertainty) dijelaskan dengan detil berikut contoh penerapan praktisnya di industri-industri. Bab 1 disarankan untuk dibaca oleh semua kalangan pembaca sebelum melanjutkan bacaan pada bab-bab selanjutnya atau lainnya.

- Bab 2: Data, analisis statistik dan komputasi numerik.

$\mathrm{Bab}$ ini berisi mengenai berbagai macam istilah-istilah dalam metrologi, seperti akurasi dan presisi. Istilahistilah tersebut akan sangat banyak ditemui dalam bab-bab selanjutnya. Kemudian, bab ini mengulas kembali secara singkat mengenai dasar-dasar statistik, terutama mengenai distribusi statistik, regresi linier, analisis varian (ANOVA) dan tes GR\&R. Selain itu, aspek-aspek penting dalam komputasi numerik dibahas. Dalam metrologi, konsep-konsep statistik sangat penting karena banyak kesimpulan-kesimpulan hasil pengukuran dianalisis dengan metode statistik, misalnya analisis ketidakpastian (Bab 9). Sedangkan komputasi numerik sangat berperan penting dalam proses kalkulasi, misalnya hasil perhitungan suatu diameter dari point cloud. Komputasi numerik akan diahas detil dalam bab 7. Bagi pembaca yang sudah ahli di bidang statistik dan komputasi numerik, pembaca tersebut dapat melewati bab ini.

- Bab 3: Toleransi dimensional dan geometri.

Esensi dari metrologi adalah verifikasi dimensi dan geometri, yaitu proses untuk mengecek apakah dimensi dan geometri dari suatu produk yang dimanufaktur masih dalam batas toleransi dimensional dan geometri yang diberikan pada dimensi nominal produk tersebut. Bab ini membahas mengenai toleransi dimensional dan geometri tersebut. Bab ini menjelaskan kekurangan dari toleransi dimensional dan bagaimana cara menginterpretasikan arti dari toleransi geometri (GD\&T). Hal yang sangat penting dibahas dalam bab ini adalah analisis akumulasi toleransi (tolerance stack-up analysis) yang bertujuan untuk mengecek disain suatu produk apakah akan berfungsi seperti yang diinginkan atau tidak sebelum produk tersebut dimanufaktur. Bab ini ditutup dengan bagaimana cara memverifikasi (mengukur) toleransi dimensional dan geometri (GD\&T). Untuk verifikasi toleransi geometri, mesin pengukur koordinat (CMM) sangat dibutuhkan, sehingga bab ini sangat terkait dengan Bab 5 yang membahas tentang CMM.

- Bab 4: Pengukuran dimensi dan geometri.

Bab ini merupakan salah satu inti dari buku ini. Bab ini dimulai dengan penjelasan mengenai arti dari pengukuran dimensi dan pengukuran geometri. Kemudian, berbagai macam kesalahan dasar dalam disain dan pengukuran, seperti Abbe error dijelaskan dengan detil. Berbagai macam jenis-jenis alat pengukuran dipresentasikan mulai dari alat pengukuran dasar yaitu end standard dan line standard, jangka sorong (caliper), mikrometer, laser interferometer, komparator dan mesin pengukur koordinat (CMM). Contoh riil analisis GR\&R dipresentasikan berlandaskan pada teori GR\&R yang dijelaskan pada Bab 2. Bab ini ditutup dengan penjelasan singkat mengenai aspek-aspek yang harus diperhatikan untuk metrologi pada skala mikro dan nano. 
- Bab 5: Coordinate measuring machine / mesin pengukur koordinat (CMM).

Bab ini menjelaskan secara detil instrumen pengukuran CMM yang merupakan solusi dari verifikasi toleransi geometri GD\&T (dan juga toleransi dimensional) yang telah dijelaskan pada Bab 3. Bab ini membahas CMM dengan metode kontak (tactile CMM) dan multi-sensor CMM. Penjelasan lebih detil akan difokuskan pada tactile CMM karena CMM jenis ini merupakan CMM yang paling umum digunakan di industri-industri. Penjelasan detil mengenai tactile CMM meliputi: jenis-jenis, prinsip kerja, cara pengoperasioan sampai dengan metode alignment.

- Bab 6: Non-contact CMM.

Bab fokus pada jenis CMM dengan metode non-kontak yang berbasis optik (optical-CMM). Optical CMM yang akan dibahas adalah laser scanner, photogrammtery dan fringe projection. Untuk pengukuran pada skala mikro, optical CMM yang akan dibahas adalah focus variation microscopy dan point auto-focus. Selain itu, tomografi berbasis sinar-X juga dibahas. Tomografi berbasis sinar- $X$ merupakan instrumen yang digunakan untuk pengukuran dimensioanal dan geometri yang mempunyai kemampuan yang tidak dimiliki oleh CMM lainnya, yaitu instrumen jenis ini bisa mengukur dimensi dan geometri internal dari sebuah produk tanpa harus merusak produk tersebut. Awalnya, instrumen ini digunakan pada bidang kesehatan, kemudian instrumen ini mulai digunakan untuk mengukur dimensi dan geometri sebuah produk. Penggunaan instrumen jenis ini untuk pengukuran masih terbilang baru, sehingga masalah-masalah yang terdapat pada instrumen ini dan solusinya untuk mengukur dimensi dan geometri dipresentasikan dalam bab ini.

- Bab 7: Algoritma.

Bab ini sangat berhubungan dengan ilmu komputer dan pemrograman karena bab ini menjelaskan mengenai berbagai jenis algoritma yang digunakan untuk metrologi, seperti rekonstruksi 3D dari point cloud dan algoritma pengukuran otomatis. Salah satu topik bahasan yang penting dalam bab ini adalah mengenai optimisasi numerik yang merupakan pemrosesan data hasil pengukuran untuk mendapatkan suatu hasil pengukuran, misalnya diamater sebuah silinder dan flatness dari sebuah bidang yang diukur. Bab ini sangat berhubungan dengan Bab 3, Bab 4, Bab 5, Bab 6 dan Bab 8.

- $\quad$ Bab 8: Kompensasi error.

Pada kenyataannya, semua instrumen pengukuran mempunyai limitasi pada seberapa bagus tingkat akurasi geometri komponen-komponen yang membangunnya. Maka dari itu, untuk dapat menigkatkan akurasi sebuah instrumen pengukuran melebhi batas akurasi geometri komponen-komponennya, kompensasi error dapat diterapkan. Bab ini membahas prinsip dasar mengenai kompensasi error sebuah instrumen pengukuran, terutama pada CMM.

- Bab 9: Ketidakpastian.

Bab in imerupakan salah satu inti pembahasan pada buku ini. Semua pembaca buku ini diharapkan untuk membaca bab ini. Bab ini membahas secara detil salah satu konsep fundamental dari metrologi, yaitu ketidakpastian. Sumber-sumber ketidakpastian dari hasil suatu pengukuran dijelaskan secara umum dan berlaku untuk semua jenis instrumen pengukuran, baik pengukuran dimensi dan geometri. Pentingnya estimasi nilai ketidakpastian juga dijelaskan dengan menggunakan contoh-contoh riil di industri. Berbagai macam metode untuk mengestimasi nilai ketidakpastian dari suatu pengukuran dipresentasikan dengan detil dalam bab ini. Metode-metode estimasi ketidakpastian tersebut adalah metode GUM, metode tabel, metode Monte-Carlo dan metode ISO 15530. Metode ISO 15530 memfokuskan untuk instrumen pengukuran dengan CMM baik tactile maupun optical CMM.

- Bab 10: Keuntungan ekonomi dari metrologi manufaktur.

Bab ini mungkin salah satu bab yang sangat penting untuk kalangan praktisi industri manufaktur. Karena, bab ini menjelaskan bagaimana metrologi manufaktur dapat memberikan manfaat ekonomi yang sangat signifikan pada industri-industri manufaktur maupun industri-industri lainnya. Bab ini menjelaskan berbagai macam contoh kasus bagaimana metrologi manufaktur bisa memberikan manfaat langsung secara ekonomi kepada industri-industri tersebut, seperti cara memilih CMM yang tepat, cara meningkakan efisiensi inspeksi kualitas dan cara meningkatkan efisiensi interoperabilitas antar-CMM. 
Kesepuluh bab di atas membahas prinsip-prinsip utama dalam metrologi dan mengkhususkan pada pengukuran geometri. Topik pengukuran tekstur permukaan tidak dibahas dalam buku ini.

Dalam proses penulisan buku ini, penulis didukung oleh orang-orang yang dengan ikhlas memberi semangat dan memberi saran-saran dan kritik yang membangun untuk buku ini. Pertama-tama, penulis ingin mengucapkan terima kasih kepada orang tua yang terus mendukung penulis dan mendoakan penulis. Kemudian, penulis ingin mengucapkan terima kasih kepada istri penulis, Nadia Afif, yang terus memberikan semangat agar buku ini terselesaikan. Temanteman penulis yang memberikan masukan teknis dan juga membantu mengecek penulisan setiap babnya merupakan kontribusi yang sangat besar untuk terselesaikannya buku ini.

Penulis sangat sadar bahwa masih banyak kekurangan-kekurangan pada buku ini seperti kesalahan-kesalahan pengetikan, dan kurang jelasnya dan kurang detilnya penjelasan mengenai topik-topik tertentu. Maka dari itu, penulis ingin menyampaikan permohonan maaf yang sebesar-besarnya atas kekurangan-kekurangan tersebut. Penulis terus melakukan perbaikan-perbaikan dan revisi-revisi untuk edisi berikutnya buku ini, sehingga buku ini bisa semakin baik memenuhi kebutuhan para pembaca. Seluruh ilustrasi 3D dalam buku ini dibuat menggunakan perangkat lunak CATIA V5 R21 dari Dassault Systemes.

Untuk terus meningkatkan kualitas buku ini pada edisi berikutnya, penulis sangat mengharapkan saran, kritik dan diskusi yang membangun dari para pembaca buku ini. Maka dari itu, penulis membuka seluas-luasnya pintu diskusi apabila para pembaca ingin menyampaikan ide-ide mereka. Para pembaca dapat mengirimkan saran, kritik dan diskusi mereka ke email pribadi penulis: gebe_top.yahoo.com.

Penulis,

Wahyudin P. Syam

Nottingham, UK.

24 Desember 2017 


\section{Daftar isi}

BAB 1: Introduksi untuk metrologi manufaktur 1

1.1 Pentingnya pengukuran dimensi dan geometri 1

1.2 Sejarah pengukuran $\quad 3$

1.3 Definisi "Meter" 10

1.4 Temperatur standar $20^{\circ} \mathrm{C} \quad 14$

1.5 Keterlacakan (traceability), kalibrasi (calibration) dan ketidakpastian (uncertainty) 15

1.6 Standardisasi internasional 19

BAB 2: Data, analisis statistik dan komputasi numerik 23

2.1 Data 23

2.2 Analisis statistik 27

$\begin{array}{ll}\text { 2.2.1 Variabel acak dan distribusi statistik } & 27\end{array}$

2.2.2 Berbagai macam distribusi probabilitas dan central limit theorem 32

2.2.3 Deviasi standar (standard deviation) dari data dan deviasi standar dari rata-rata $\begin{array}{ll}\text { (standard deviation of the mean) } & 47\end{array}$

2.2.4 Analisis regresi $\quad 49$

2.2.5 Analisis varian (analysis of variance/ANOVA) $\quad 56$

2.2.6 Gauge repeatability dan reproducibility (GR\&R) $\quad 60$

2.3 Komputasi numerik $\quad 65$

2.3.1 Overflow dan underflow data 66

2.3.2 Error pembulatan (rounding error) 66

$\begin{array}{ll}\text { 2.3.3 Poor conditioning } & 67\end{array}$

$\begin{array}{ll}\text { 2.3.4 Kebocoran memori komputer (memory leak) } & 68\end{array}$

$\begin{array}{ll}\text { 2.3.5 Kecepatan pemrosesan data (processing speed) } & 68\end{array}$

$\begin{array}{ll}\text { 2.3.6 Optimisasi numerik } & 69\end{array}$

BAB 3: Toleransi dimensional dan geometri $\quad 71$

$\begin{array}{ll}3.1 \text { Introduksi toleransi } & 71\end{array}$

$\begin{array}{ll}\text { 3.1.1 Sumber-sumber variasi } & 73\end{array}$

3.1.2 Kapabilitas prosess (process capability $C_{p}$ dan $C_{p k}$ ) 74

$\begin{array}{ll}\text { 3.1.3 Tipe-tipe toleransi } & 75\end{array}$

3.2 Toleransi dimensional "Plus/minus"

3.3 Toleransi geometri (Geometric dimensioning and tolerancing/GD\&T) 77

3.3.1 Toleransi bentuk (form) 82

3.3.2 Toleransi orientasi (orientation) $\quad 83$

$\begin{array}{ll}\text { 3.3.3 Toleransi lokasi (location) } & 85\end{array}$

3.3.4 Toleransi run-out $\quad 85$

3.3.5 Kondisi material (material condition) dan bonus toleransi $\quad 87$

3.4 Alokasi dan Analisis toleransi 91

3.4.1 Analisis akumulasi toleransi (tolerance stack-up analysis) 91

3.4.2 Analisis toleransi: berbasis worst-case and berbasis statistik 92 
3.4.3 Analisis toleransi dimensional 93

$\begin{array}{ll}\text { 3.4.5 Analisis toleransi geometri } & 102\end{array}$

3.4.6 Matriks homogenous dan matriks roto-translasi 106

$\begin{array}{ll}\text { 3.4.7 Transformasi matriks } & 108\end{array}$

$\begin{array}{ll}\text { 3.4.8 Analisis 3D toleransi geometri } & 109\end{array}$

3.4.9 Keuntungan apabila model toleransi stack-up diketahui $\quad 123$

$\begin{array}{ll}3.5 \text { Verifikasi toleransi } & 123\end{array}$

$\begin{array}{ll}\text { 3.5.1 Verifikasi toleransi dimensional } & 123\end{array}$

$\begin{array}{ll}\text { 3.5.2 Verifikasi toleransi geometri (GD\&T) } & 124\end{array}$

BAB 4: Pengukuran dimensi (dimensional) dan geometri (form) 127

4.1 Prinsip dasar pengukuran $\quad 127$

4.2 Tipe pengukuran: dimensi dan geometri $\quad 128$

4.3 Pengukuran koordinat (coordinate measurement) 129

4.4 Jenis-jenis kesalahan umum dalam pengukuran (error) 129

4.4.1 Error Abbe (The first principle) 130

4.4.2 Error sine dan error cosine 131

4.4.3 Error referensi dan datum 132

4.4.4 Error nol (Zeroing error) 132

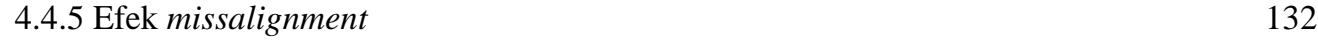

4.4.6 Efek kekasaran permukaan (roughness effect) 132

$\begin{array}{ll}\text { 4.4.7 Efek debu } & 133\end{array}$

$\begin{array}{ll}\text { 4.4.8 Error } \text { struktur instrumen pengukuran } & 134\end{array}$

$\begin{array}{lr}\text { 4.4.9 Error pengontrolan instrumen pengukuran } & 139\end{array}$

$\begin{array}{lr}\text { 4.4.10 Error non-teknis } & 140\end{array}$

4.5 Jenis-jenis alat ukur dimensi dan geometri 140

$\begin{array}{ll}\text { 4.5.1 Standar End dan standar line } & 140\end{array}$

4.5.2 Standar 2D 144

$\begin{array}{ll}\text { 4.5.3 Alat bantu pengukuran dimensi } & 145\end{array}$

$\begin{array}{ll}\text { 4.5.4 Jangka sorong (vernier caliper) } & 148\end{array}$

$\begin{array}{ll}\text { 4.5.5 Mikrometer } & 149\end{array}$

4.5.6 Perbedaan fundamental antara jangka sorong (vernier caliper) dan mikrometer $\quad 149$

$\begin{array}{ll}\text { 4.5.7 Komparator } & 150\end{array}$

4.5.8 Laser interferometer $\quad 155$

4.5.9 Mesin pengukur coordinate (coordinate measuring machine /CMM) 163

4.6 Analisis sistem pengukuran (Gauge R\&R) 166

4.7 Aspek-aspek penting dalam pengukuran pada skala mikro/nano $\quad 171$

BAB 5: Coordinate measuring machine (CMM) $\quad 175$

$\begin{array}{ll}5.1 \text { Introduksi tentang CMM } & 175\end{array}$

$\begin{array}{ll}\text { 5.1.1 Jenis-jenis CMM } & 176\end{array}$

$\begin{array}{lr}\text { 5.1.2 Pertimbangan untuk aplikasi } & 178\end{array}$

$\begin{array}{lr}\text { 5.1.3 Aplikasi umum } & 185\end{array}$

$\begin{array}{ll}5.2 \text { Cartesian tactile CMM } & 187\end{array}$

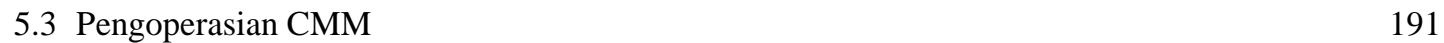

5.4 Sistem probing CMM 198

5.5 Alignment pengukuran CMM 211

5.6 Strategi sampling 215

5.7 Non-Cartesian tactile dan non-contact CMM 219 
5.8 Multi-sensor CMM 223

5.9 Sumber error (error sources)

$\begin{array}{ll}\text { 5.9.1 Efek temperatur } & 227\end{array}$

$\begin{array}{ll}\text { 5.9.2 Kontrol lingkungan } & 229\end{array}$

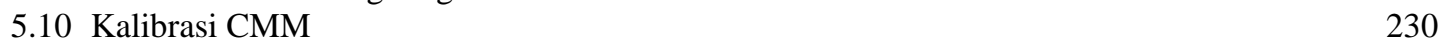

5.11 Verifikasi performansi CMM 232

5.12 Estimasi ketidakpastian CMM 235

$\begin{array}{ll}\text { BAB 6: Non-contact CMM } & 237\end{array}$

6.1 Optical CMM 237

6.1.1 Laser triangulation/laser scanner $\quad 237$

$\begin{array}{ll}\text { 6.1.2 Photogrammetry } & 241\end{array}$

$\begin{array}{ll}\text { 6.1.3 Fringe projection (structure light scanner) } & 249\end{array}$

6.2 Optical CMM untuk pengukuran skala mikro 254

6.2.1 Focus variation microscopy (FVM) 254

6.2.2 Point auto-focus (PAI) 258

6.3 Tomografi berbasis sinar-X (X-ray computed tomography) 261

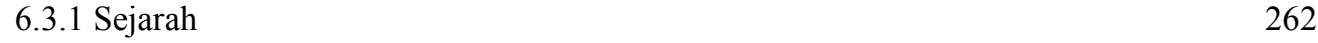

$\begin{array}{ll}\text { 6.3.2 Prinsip kerja } & 263\end{array}$

6.3.3 Aplikasi 266

$\begin{array}{ll}\text { 6.3.4 Karakteristik } & 267\end{array}$

6.4 Dua keterbatasan fundamental dari sistem optik 268

6.5 Verifikasi performansi CMM non-kontak $\quad 270$

$\begin{array}{ll}\text { 6.6 Estimasi ketidakpastian CMM non-kontak } & 273\end{array}$

$\begin{array}{ll}\text { BAB 7: Algoritma } & 275\end{array}$

7.1 Fitting geometri dasar $\quad 275$

$\begin{array}{ll}\text { 7.1.1 Fitting berbasis jarak total maksimum } & 276\end{array}$

$\begin{array}{ll}\text { 7.1.2 Fitting berbasis least-square } & 277\end{array}$

$\begin{array}{ll}\text { 7.1.3 Fitting berbasis minimum-zone } & 278\end{array}$

$\begin{array}{ll}\text { 7.1.4 Fitting minimum-circumscribed } & 280\end{array}$

$\begin{array}{ll}\text { 7.1.5 Fititng maximum-inscribed } & 280\end{array}$

7.1.6 Fitting geometri linier berbasis least-square: garis dan bidang datar 280

7.1.7 Fitting geometri non-linier berbasis least-square: lingkaran, bola dan silinder $\quad 282$

7.2 Filtering data 286

$\begin{array}{ll}\text { 7.2.1 Filtering berbasis konvolusi } & 287\end{array}$

$\begin{array}{ll}\text { 7.2.2 Filtering berbasis morfologi } & 289\end{array}$

7.3 Masalah estimasi solusi awal untuk fitting non-linier 291

$\begin{array}{ll}\text { 7.3.1 Estimasi solusi awal } & 291\end{array}$

$\begin{array}{ll}\text { 7.3.2 Optimasi solusi awal berbasis algoritma chaos } & 292\end{array}$

7.3.3 Peningkatan performansi fitting dengan algoritma chaos 294

7.4 Algoritma untuk aplikasi pengukuran 295

7.4.1 Algoritma pengukuran sudut rake (cutting tool) secara otomatis 296

7.4.2 Algoritma untuk menentukan sebuah error perpendicularity 298 
BAB 8: Kompensasi error $\quad 303$

8.1. Kenapa kompensasi? 303

8.2 Jenis-jenis kompensasi error 304

8.2.1 Kompensasi berbasis perangkat keras dan lunak 304

8.2.1 Kompensasi berbasis non-real-time dan real-time 306

8.3 Tahapan kompensasi error $\quad 307$

$\begin{array}{ll}\text { 8.3.1 Pembuatan model matematis dari error: Analitik atau empiris } & 307\end{array}$

$\begin{array}{ll}\text { 8.3.2 Perangkat lunak dan peralatan untuk kompensasi } & 309\end{array}$

$\begin{array}{ll}\text { 8.3.3 Kalibrasi instrumen } & 310\end{array}$

8.4 Model matematis dari error instrumen pengukuran CMM $\quad 312$

8.5 Dasar-dasar metode rehearsal untuk pemisahan error dan self-calibration 316

BAB 9: Ketidakpastian (uncertainty)

9.1 Ekspresi hasil pengukuran yang ideal $\quad 319$

9.2 Model pengukuran $\quad 320$

9.3 Sumber-sumber ketidakpastian (uncertainty) 321

9.4 Tujuan estimasi ketidakpastian $\quad 323$

9.5 Contoh kasus $\quad 328$

9.6 Metode estimasi ketidakpastian 330

9.7 Metode GUM 331

9.8 Metode Tabel (spreadsheet)

9.9 Metode simulasi Monte-Carlo 343

9.10 Metode ISO $15530 \quad 350$

9.10.1 Metode ISO/DTS 15530-2 352

9.10.2 Metode ISO 15530-3 355

9.10.3 Metode ISO 15530-4 357

9.11 Metode berbasis standar yang lain $\quad 360$

9.12 Contoh kasus: estimasi ketidakpastian hasil pengukuran laser interferometer 361

BAB 10: Keuntungan ekonomi dari metrologi manufaktur $\quad 363$

10.1 Integrasi pengukuran dan CMM 363

10.2 Pemilihan CMM dan evaluasi keuangan $\quad 365$

10.3 Keuntungan ekonomi 367

$\begin{array}{ll}\text { 10.3.1 Berbandingan biaya inspeksi per komponen } & 367\end{array}$

10.3.2 Nilai balik investasi untuk CMM otomatis dan biaya kontrol proses $\quad 369$

$\begin{array}{ll}\text { 10.3.3 Evaluasi impak ekonomi dari metrologi dalam manufaktur } & 371\end{array}$

$\begin{array}{ll}\text { 10.3.4 Keuntungan interoperabilitas CMM } & 376\end{array}$

10.3.5 Value adding metrologi manufaktur untuk efisiensi rantai produksi 378

$\begin{array}{ll}\text { Daftar pustaka } & 381\end{array}$

$\begin{array}{ll}\text { Biografi penulis } & 388\end{array}$ 


\section{BAB 1}

\section{Introduksi untuk metrologi manufaktur}

Industri manufaktur merupakan industri utama negara-negara maju di dunia. Hal ini disebabkan karena manufaktur merupakan suatu proses yang memberikan suatu nilai tambah pada sebuah produk. Metrologi sangat dibutuhkan oleh setiap proses manufaktur untuk menjamin suatu produk atau proses manufaktur tersebut memenuhi suatu tingkat kualitas yang telah ditetapkan. Oleh sebab itu, metrologi tidak dapat dipisahkan dari manufaktur.

Metrologi yang sangat penting dalam suatu proses manufaktur adalah pengukuran dimensi dan geometri, dan pengukuran tekstur permukaan. Pada buku ini, pengukuran dimensi dan geometri dibahas secara detil. Pembahasan detil pengukuran dimensi dan geometri pada buku ini meliputi: sejarah, prinsip dasar, analisis toleransi, instrumeninstrumen pengukuran dimensi dan geometri, analisis ketidakpastian dan keuntungan ekonomi metrologi dalam suatu industri manufaktur.

Pada bab ini, gambaran umum tentang pentingnya pengukuran dimensi dan geometri dijelaskan beserta dengan berbagai sejarah yang menceritakan evolusi dan perkembangan pengukuran dimensi dan geometri dari zaman mesir kuno, zaman awal abad ke-19 sampai dengan zaman sekarang. Hal ini berguna untuk memberikan gambaran bagaimana metrologi sebenarnya sudah diperhitungkan dari zaman dahulu dan mempunyai peranan penting untuk perkembangan teknologi pada setiap zaman. Sejarah membuktikan bahwa perkembangan teknologi manufaktur sangat bergantung pada perkembangan teknologi metrologi.

Prinsip-prinsip dasar dari metrologi, yaitu: keterlacakan (traceability), kalibrasi (calibration) dan ketidakpastian (uncertainty) akan dibahas dengan detil berikut dengan contoh-contoh praktis yang dilakukan di industri. Berbagai macam standar internasional, yang berhubungan dengan toleransi dan pengukuran dimensi dan geometri, dan berbagai lembaga atau institusi-institusi nasional yang bertanggung jawab untuk merealisasikan rantai keterlacakan di berbagai negara juga dipresentasikan.

\subsection{Pentingnya pengukuran dimensi dan geometri}

Hal pertama yang menjadi pertanyaan adalah kenapa pengukuran harus dilakukan atau dibutuhkan? Jawaban dari pertanyaan ini minimal bisa dibagi mejadi tiga aspek, yaitu:

- Untuk merepresentasikan suatu ilmu pengetahuan.

- Untuk mengontrol kualitas suatu proses dan produk.

- Untuk meningkatkan/memperbaiki kualitas suatu proses dan produk.

Gambar 1 memperlihatkan bagaimana sebuah pengukuran merupakan jembatan untuk merealisasikan proses pengembangan sebuah ilmu pengetahuan, proses kontrol kualitas dan proses peningkatan kualitas suatu produk. Dalam bidang sains, langkah pertama untuk mempelajari suatu ilmu pengetahuan adalah dengan mencari sebuah prinsip numerik yang menggambarkan ilmu pengetahuan tersebut dan mencari metode praktis bagaimana mengukur suatu kuantitas yang menggambarkan atau merepresentasikan prinsip numerik tersebut. Pengukuran mengkuantifikasi suatu detail atau properti sebuah proses atau produk, misalnya diameter, panjang, tekanan dan temperatur.

Pengukuran sangat berperan penting untuk kontrol suatu kualitas baik suatu proses manufaktur maupun suatu produk. Hanya dengan mengukur properti suatu produk, kualitas suatu produk dapat diketahui apakah sesuai dengan desain yang diinginkan atau tidak. Pada situai riil di indutri, tidak ada satu pun proses atau mesin produksi yang sempurna, melainkan semua proses atau mesin produksi selalu menghasilkan variasi terhadap produk yang dihasilkan sehingga pengukuran sangat penting untuk memonitor apakah proses atau mesin produksi tersebut bekerja dalam batas 
toleransi yang telah ditetapkan.

Kontrol kualitas suatu produksangat berhubungan dengan peningkatan kualitas produk tersebut atau suatu proses manufaktur yang membuat produk tersebut. Seperti yang dikatakan salah satu ilmuwan terkemuka dunia, yaitu Kelvin, hanya dengan pengukuran suatu peningkatan kualiatas bisa diterapkan.

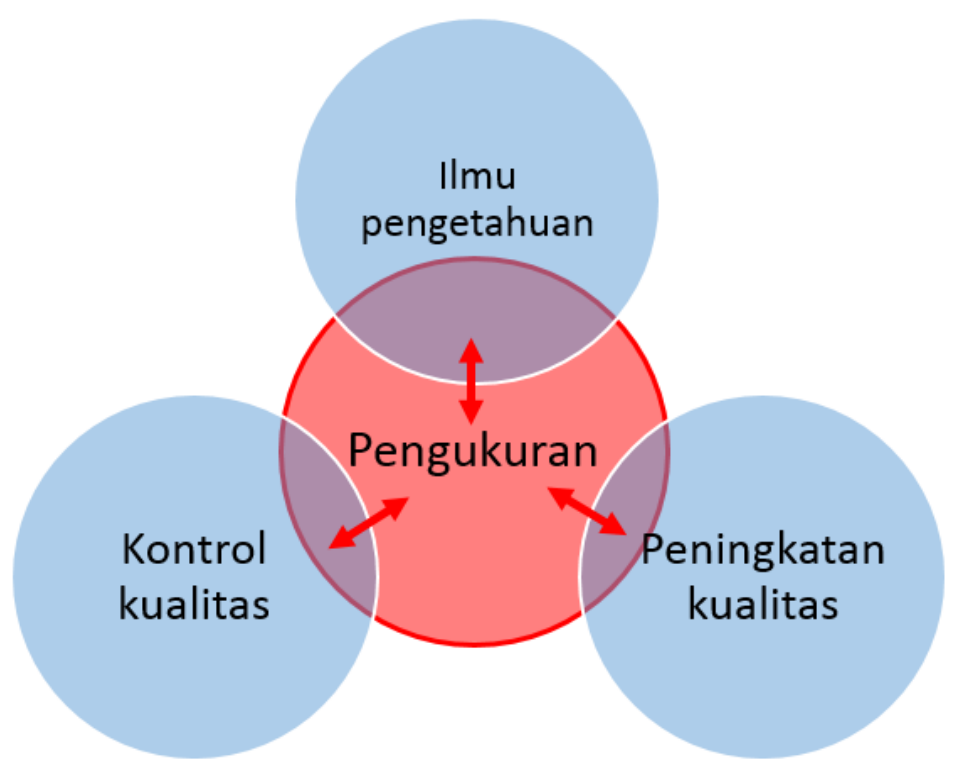

Gambar 1: Tiga hal utama dari pentingnya sebuah pengukuran.

Selain ketiga aspek yang telah dijelaskan sebelumnya, jawaban mendasar kenapa pengukuran sangat penting dan dibutuhkan adalah karena pengukuran tidak bisa lepas dari kehidupan sehari-hari manusia. Beberapa contoh adalah sebagai berikut: orang-orang membeli bahan makana pokok berdasarkan berat makanan tersebut, pengobatan sangat bergantung dengan seberapa besar dosis obat yang diberikan, kebutuhan rumah tangga selalau dimeterkan (listrik, gas dan air), keamanan suatu gedung selalu mengkur kadar asap dalam ruangan dan pakaian sesorang selalau diukur agar sesuai dengan tubuh orang tersebut.

Strategi pengukuran dibagi menjadi tiga kelompok utama, yaitu:

- Pengukuran dilakukan sebelum proses manufaktur (termasuk proses perakitan).

Pengukuran pada fase ini padaumumnya adalah untuk menginspeksi kualitas suatu produk atau benda kerja, yang dihasilkan oleh jalur produksi yang lain pada industri yang sama atau dari industri yang berbeda, sebelum produk atau benda kerja tersebut diproses lebih lanjut atau di rakit lebih lanjut pada suatu proses manufaktur selanjutnya. Sebagai contoh, bagaimana diameter suatu piston diinspeksi sebelum piston tersebut dirakit pada suatu mesin otomotif.

Selain itu, proses pengukuran pada fase ini juga berguna untuk suatu proses rekayasa balik (reverse engineering). Proses rekayasa balik tersebut berguna untuk, misalnya, menghasilkan model 3D (Computeraided design/CAD) dari suatu benda kerja yang mempunyai bentuk yang kompleks. Dengan tersedianya model CAD tersebut, sebuah program mesin CNC yang kompleks untuk memproses benda kerja yang kompleks tersebut dapat dihasilkan sehingga mempersingkat waktu pemrograman mesin CNC tersebut.

- Pengukuran dilakukan setelah proses manufaktur (termasuk proses perakitan) dan pengukuran tersebut dilakukan di luar jalur produksi.

Pengukuran pada fase ini merupaka pengukuran yang paling umum ditemui. Pendekatan pengukuran setelah proses produksi merupakan pendekatan tradisional. Pada umumya, proses ini bertujuan untuk menerima, menolak atau memperbaiki suatu benda kerja yang telah diproses oleh suatu mesin produksi. 


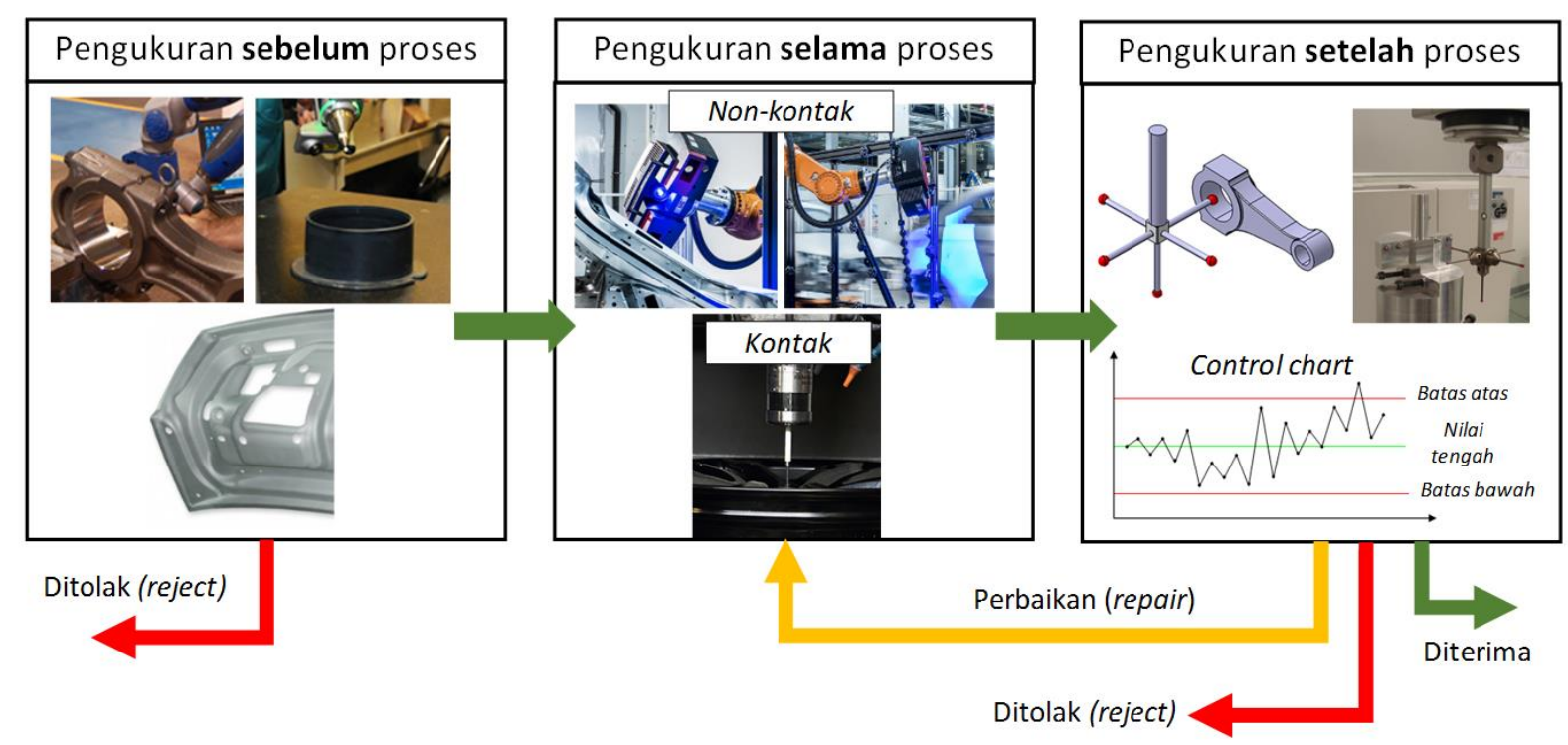

Gambar 2: Ilustrasi proses pengukuran yang dilakukan sebelum, selama dan sesudah proses produksi.

Pengukuran pada fase ini kurang efektif apabila ingin digunakan sebagai alat untuk meningkatkan kualitas suatu produk yang dimanufaktur. Alasannya adalah pengukuran setelah proses manufaktur tidak bisa digunakan untuk meningkatkan proses manufaktur yang membuat benda kerja tersebut dan sistem feedback terhadap proses bersifat offline. Selain itu, pengukuran pada fase ini biasanya memperpanjang total waktu produksi. Hal yang paling utama untuk pengukuran pada fase ini adalah untuk mencegah suatu produk yang cacat dapat terkirim atau terjual ke suatu kostumer.

- Pengukuran dilakukan selama proses manufaktur (termasuk proses perakitan), baik saat bersamaan dengan suatu proses manufaktur atau langsung setelah suatu proses manufaktur (masih di dalam jalur produksi).

Pengukuran pada fase ini merupakan pengukuran yang paling susah dilakukan dan merupakan salah satu topik riset yang sangat aktif pada saat ini untuk teliti. Pengukuran pada fase ini susah dilakukan karena persyaratan yang sangat susah untuk dipenuhi oleh suatu instrumen pengukuran selama proses manufaktur (in-line measurement). Beberapa persyaratan yang mutlak untuk jenis pengukuran tersebut adalah waktu pengukuran yang singkat (minimal secepat cycle time suatu proses manufaktur yang ingin dikontrol) dan gangguna-gangguna dari lingkungan yang sangat tinggi (vibrasi, temperature yang tinggi dan bervariasi, debu dan fluide permesinan dan lain-lain). Apabila pengukuran selama proses produksi ini bisa tercapai, maka suatu proses manufaktur dan suatu produk yang dibuatnya dapat dikontrol dan ditingkatkan secara signifikan karena setiap cacat terhadap produk dapat dideteksi dan proses produksi tersebut dapat diatur langsung untuk memperbaiki cacat produk tersebut.

\subsection{Sejarah pengukuran}

Pengukuran dimensi sudah dimulai sejak dari zaman peradaban mesir kuno ketika di bawah kekuasaan Firaun. Hal ini menunjukkan bahwa pengukuran dimensi sudah dianggap sesuatu yang penting sejak zaman dahulu, terutama ketika suatu peradaban sudah memulai membangun sebuah bangunan, seperti piramida mesir yang sangat terkenal. Oleh sebab itu, sedikit sejarah dan pengetahuan mengenai piramida di mesir adalah penting untuk diketahui agar pentingnya pengukuran dalam kehidupan manusia dapat lebih dimengerti (NPL-history of length measurement).

Piramida mesir peniggalan kerajaan Firaun merupakan salah satu monumen dunia yang sangat terkenal (gambar 3). Untuk kebanyakan orang umum, piramida terkenal karena merupakan sebuah bangunan yang sangat besar. Namun, untuk sebagian peneliti, piramida mempunyai elemen-elemen teknis yang sangat diperhitungkan. 

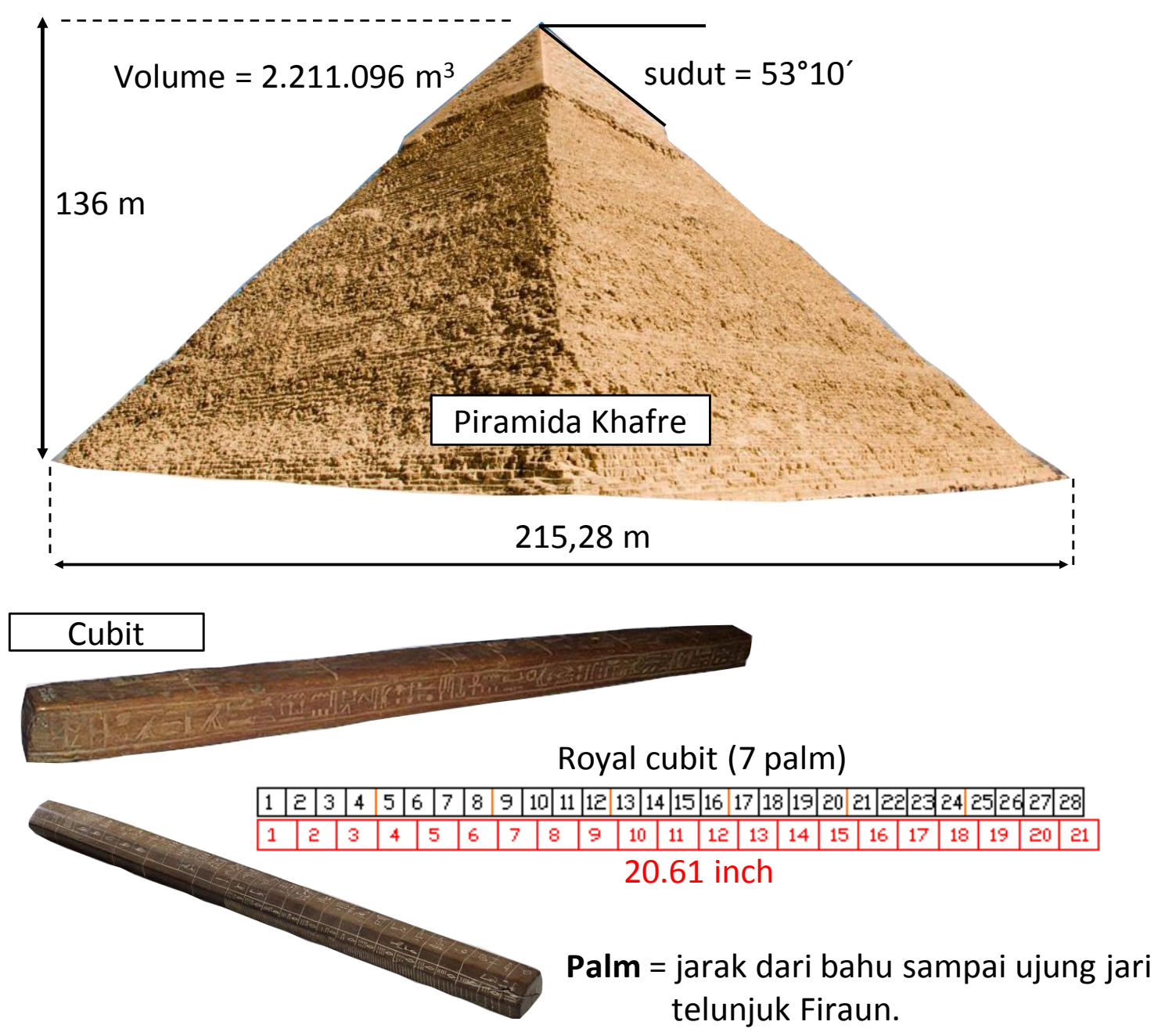

Gambar 3: Piramida Kahfre, yang merupakan piramida terbsear kedua dari piramida peninggalan Firaun, dan cubit sebagai alat ukur dimensi.

Piramida peniggalan Firaun, terdiri dari 500 ribu lebih batuan-batuan besar yang tersusun sangat rapih sebagai struktur utama bangunan. Batuan-batuan besar tersebut mempunyai massa hingga 70 ton. Struktur batuan piramidapiramida tersebut ditutup dengan sebuah lapisan batuan yang berfungsi sebagai lapisan terluar dari piramida-piramida tersebut. Lapisan terluar tersebut tersusun dari 140 ribu lebih batu-batuan yang sangat dipoles dengan tingkat kerataan (flatness) sekitar $0.2 \mathrm{~mm}$ (Lihat bagian puncak dari piramida Kahfre pada gambar 3). Nilai kerataan $0.2 \mathrm{~mm}$ dari hasil polesan batuan tersebut yang mempunya area dalam ukuran meter adalah sesuatu pencapaian teknis yang sangat tinggi, bahkan sampai zaman modern seperti sekarang ini. Batuan-batuan penyusun lapisan luar tersebut mempunya ketebalan $2.5 \mathrm{~m}$ dan mempunya berat masing-masing sekitar 15 ton. Batuan-batuan tersebut dipotong dengan sangat presisi dengan sudut pada batuan-batuan tersebut hampir sempurna mencapai $90^{\circ}$. Hal lain yang sangat mengagumkan dari piramida-piramida tersebut adalah batuan-batuan terluarnya disusun secara rapih dengan tingkat akurasi sebesar $0.1 \mathrm{~mm}$ dengan lapisan semen antar-batuan tersebut setebal $0.4 \mathrm{~mm}$.

Cubit merupakan standar panjang pada zaman kerajaan Firaun yang digunakna untuk mengukur berbagai benda (gambar 3 bagian bawah). Ukuran sebuah Cubit adalah sebesar jarak antara ujung telunjuk sampai bahu Firaun. Cubit 
ini merupakan alat yang digunakan sebagai penggaris pada zamannya untuk mengukur panjang. Pada Cubit tersebut, terdapat garis-garis yang merupakan skala dari Cubit tersebut, seperti skala pada penggaris zaman sekarang yang sering digunakan. Sistem Cubit tersebut sudah dipakai pada zaman 1300 sebelum masehi (Kunzmann et al 1993). Sistem pengukuran dengan menggunakan satuan bagian dari tubuh suatu penguasa juga dilakukan di Cina pada saat dinasti yellow emperor sekiatr 3000 tahun sebelum masehi.

Abad ke-9 dan setelahnya, yaitu mulai pada saat kerajaan Islam tumbuh, berbagai macam alat ukur yang menjadi basis alat-alat ukur pada zaman sekarang mulai bermunculan. Seiring dengan berkembangnya alat-alat pengukuran di dunia Islam, perkembangan ilmu pengetahuan di dunia Islam sangat intensif pada periode abad ke-9 sampai abad ke12. Pada abad ke-9 secara bersamaan juga mulai berkembangnya ilmu matematika seperti yang dipelopori oleh AlKhwarizmi dan Abu Kamil. Al-Khwarizmi adalah salah satu ilmuwan besar matematik yang menemukan angka 0 dan menemukan bidang ilmu algoritma yang sangat penting dalam ilmu komputer, sedangkan Abu Kamil menulis buku Kitab al-misaha wa'l-handasa yaitu kitab yang menjelaskan tentang pengukuran dan geometri (Selin 2008). Selain Al-Khawarizmi dan Abu Kamil, Abu Ja' far Muhammad ibn al-Husa al-Khazin yang berasal dari Korasan adalah juga seorang matematikawan besar pada abad ke -9. Beliau adalah seorang ahli matematik dan astronomi. Karya beliau yang paling terkenal adalah penggunaan conic section untuk penyelesaian geometri dari persamaan cubic. Pada abad ke-11, Ibn al-Haytham al Hazan merintis dasar-dasar ilmu optik yang dipakai sampai zaman sekarang (Selin 2008, Noughtin 2008).

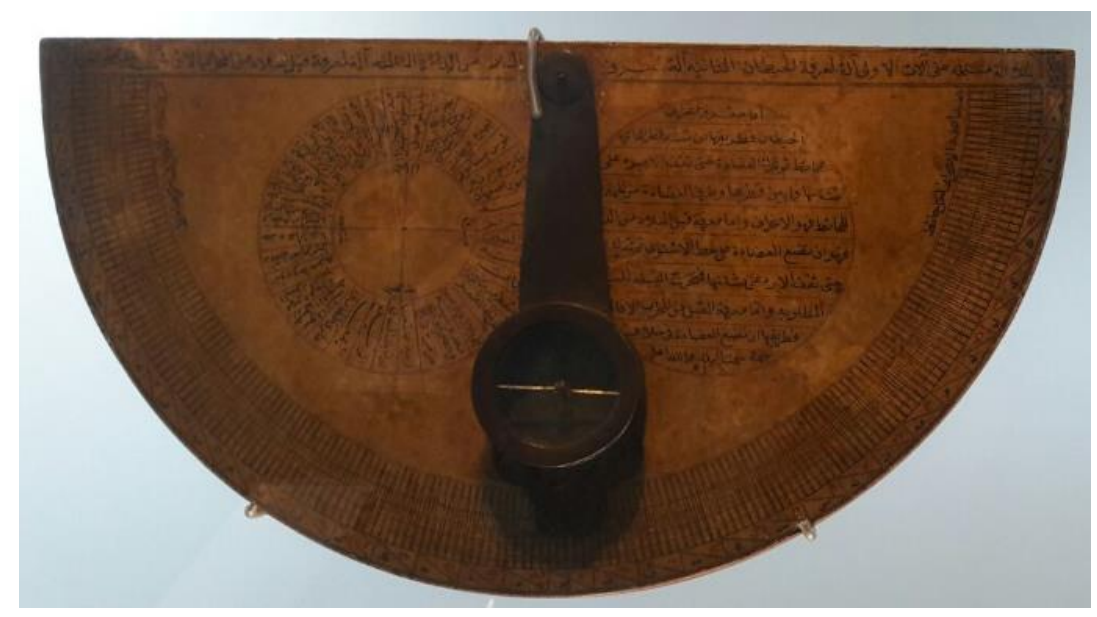

Gambar 4: Sebuah busur untuk mengukur sudut yang dikembangkan pada zaman Islamic civilisation di dunia arab pada abad ke-9 (difoto dari musium institut du monde arabe di Paris, 2017).

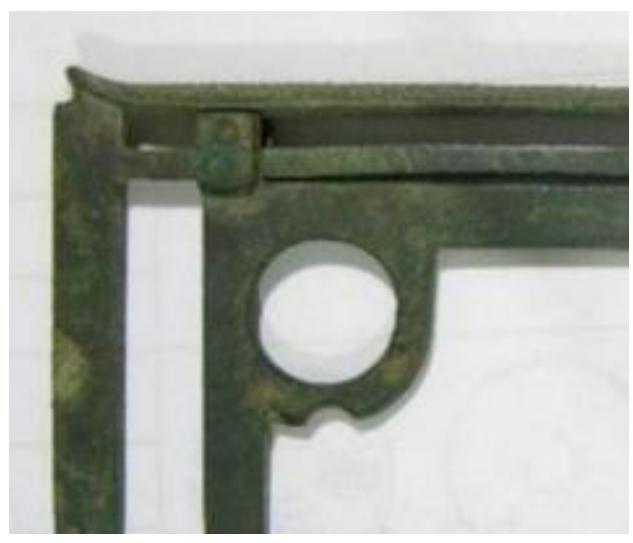

Gambar 5: Vernier caliper pertama di dunia yang berasal dari era dinasti Xing-Mang di Cina di abad ke-9

(Kunzmann et al 1993). 
Pada abad ke-9, ilmu pengetahuan, khususnya ilmu dan alat pengukuran, mulai berkembang di daerah timur tengah pada zaman Islamic emperor dan di daerah Cina. Sebagai contoh, sebuah busur yang terbuat dari perunggu sudah ditemukan dan digunakan untuk mengukur sudut (Gambar 4). Pada saat itu, penggunaannya banyak untuk alat bantu penunjuk arah. Di Cina, konstruksi dasar dari jangka sorong (vernier caliper) sudah digunakan untuk mengukur panjang (Gambar 5).

Dokumentasi untuk menstandardisasi unit pengukuran dimulai di kerajaan Ingris pada zaman Richard the Lionheart. Dokumnetasi tersebut direalisasikan dalam The Magna carta pada tahun 1215. Pada periode Raja Edward (1272-1307) unit yard ditetapkan. Yard yang ditetapkan pada masa Raja Edward tersebut adalah sebagai berikut: 1 Yard $=3$ feet dan 1 foot $=12$ inches. Pada saat itu, 1 inch didefinisikan sebagai panjang tiga barley kering yang dijejerkan satu sama lain seperti yang terlihat pada gambar 6 (NPL-history of length measurement).

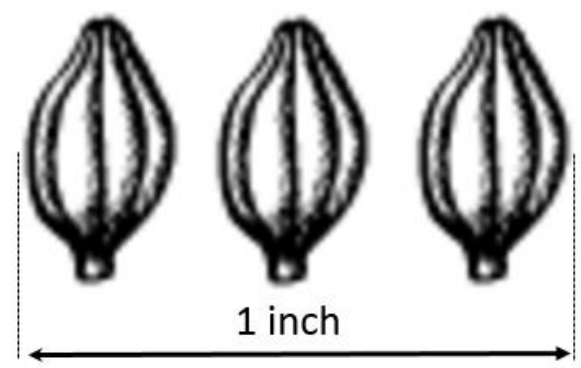

Gambar 6: Tiga barley kering yang dijejerkan adalah panjang 1 inch.

Pada sekitar abad-18, sebuah standar pengukuran yang universal mulai dipikirkan. Standar universal tersebut haruslah sebuah konstanta natural. Pada tahun 1791, badan national di Perancis (French National Assembly) memutuskan bahwa standar universal untuk panjang adalah:

\section{"one ten millionth part of a quarter of the earth's circumference" [French National Assembly].}

Terjemahan langsung dari definisi di atas adalah panjang lintasan sebesar 1/10000000 dari seper-empat keliling bumi, dimana lintasan tersebut bermula dari ekuator sampai kutub utara yang melewati Dunkirk di Perancis dan Barcelona di Spanyol (Gambar 7).

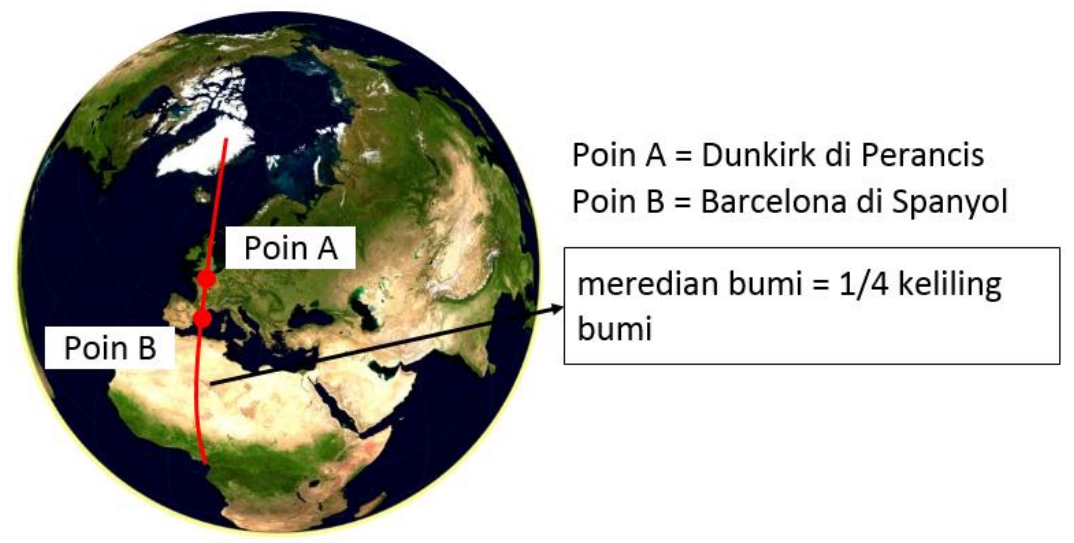

Gambar 7: Dua kota yang dilewati lintasan dari ekuator ke kutub utara (seper-embat keliling bumi) untuk menentukan definisi Meter.

Masuk ke zaman modern mulai abad ke-19 pada saat periode revolusi industri, pengukuran menjadi sesuatu yang sangat penting dengan mulai berkembangnya komponen-komponen yang bisa diganti-ganti (interchnageable parts). Komponen-komponen yang bisa diganti-ganti tersebut didorong oleh berkembangnya industri persenjataan yang diawali oleh perusahaan Eli Whitney dan Colt di amerika (Dorion 2008). Pada masa ini, industri-industri tidak seperti 
yang terlihat seperti industri zaman sekarang. Industri-industri pada masa itu terdiri dari beberapa tenaga manuasia yang ahli yang membuat sendiri seluruh komponen-komponen senjata dan merkaitnya sampai menjadi senjata yang utuh dengan alat bantu berupa jig-jig yang sederhana. Pada masa itu, pengukuran cukup dilakukan dengan membandingkan benda kerja dengan kaliper yang sangat sederhana. Pada pertengahan abad ke-19, teknologi manufaktur berkembang dengan sangat cepat didorong oleh lahirnya berbagai macam mesin bubut dan perkakas pada industri manufaktur. Dengan berkembangnya mesin-mesin manufaktur (bubut dan perkakas), akurasi dan kecepatan dari alat ukur sangat dibutuhkan. Untuk memnuhi kebutuhan pengukuran tersebut, limit gange, yang mempunyai dimensi sesuai dengan benda yang mau diukur, mulai digunakan untuk mengukur dimensi-dimensi kritis dari suatu komponen. Gauge adalah sebuah instrumen yang digunakan untuk mengukur suatu kuantitas, seperti panjang, massa dan temperature, dan memvisualisasikan hasil pengukuran tersebut. Gauge pada umumnya memenuhi spesifikasi dari akurasi dan kecepatan pengukuran.

Pada masa setelah pertengahan abad ke-19, instrumen gauge di industri dibagi menjadi beberapa hirarki, yaitu: master gauge, inspeksi gauge dan working gauge. Untuk setiap working gauge di lantai produksi, selalu ada inspeksi gauge dan master gauge untuk mengecek tingkat kerusakan working gauge karena masa pemakaian. Dengan perkembangan mesin-mesin manufaktur yang sangat pesat, toleransi kualitas dari produk-produk yang dihasilkan mesin-mesin tersebut semakin ketat. Hal ini mendorong pengembangan alat ukur ketahap selanjutnya karena sistem gauge sebelumnya yang terdiri dari tiga hirarki (master, inspeksi dan working gauge) menjadi tidak efisien karena biayanya sangat mahal. Biaya yang sangat mahal dari sistem gauge yang sebelumnya adalah karena gauge harus dibuat sesuai dengan dimensi benda yang mau diukur dimana dengan kemajuan mesin-mesin manufaktur, variasi jumlah benda yang ingin diukur sangat banyak. Syarat utama untuk alat ukur tersebut adalah mempunyai tingkat akurasi yang tinggi dan dapat digunakan untuk mengukur dengan cepat.

Solusi pertama dari permintaan sistem pegukuran yang akurat dan cepat adalah dengan berkembangnya kombinasi dari metode gambar teknik, pelat permukaan datar (surface plate), vernier height dan limit gauges. Gambar teknik muncul karena didorong oleh kebutuhan untuk saling berkomunikasi antar-departemen dalam suatu pabrik (pada bagian kedua revolusi industri, yaitu sekitar pertengahan sampai akhir abad ke-19). Transisi untuk menggunakan gambar teknik untuk berkomunikasi antar-departemen tidaklah mudah, karena banyak teknisi pada saat itu tidak terbiasa untuk membaca gambar teknik suatu benda kerja yang berskala tertentu karena mereka selalu mengandalkan bentuk fisik suaut benda kerja. Selain itu, kombinasi antara berbagai metode tersebut menjadi kurang efisien untuk menghasilkan pengukuran yang cepat.

Sistem gauge block merupakan sebuah solusi yang tepat dan pada saat yang tepat. Sistem gauge block dapat memenuhi tuntutan pengukuran yang akurat dan cepat. Sistem gauge block pertama kali ditemukan oleh seorang perekayasa dari Swedia yang bernama C. E. johansson, yang berasal dari sebuah kota bernama Eskiltuna (Dorion 2007). C. E. Johanssn pada saat itu adalah seorang pekerja di perusahaan pembuat senjata di Swedia. Ide dasar C. E. Johansson ketika menemukan sistem gauge block adalah untuk mengurangi secara signifikan jumalah suatu standar panjang. Sistem gauge block tersebut ditemukan pada tahun 1896.

Sistem gauge block terdiri dari sebuah set yang terdiri dari potongan-potongan metal yang berbentu balok dengan tingkat kekasaran permukaan yang sangat rendah dan memiliki dimensi yang sangat akurat (Gambar 8). Sifat utama gauge block yang paling menguntungkan adalah gauge block dapat didempetkan (wrung) secara bersama-sama untuk menghasilkan suatu ukuran panjang yang lain. Sifat dapat didempetkan ini dihasilkan oleh suatu gaya yang besar akibat due permukaan metal dengan kekasaran yang sangat rendah saling bertemu. Besarnya gaya permukaan tersebut dapat mencapai 30 kali dari aya gravitasi sehingga dapat menahan berat dari masing-masing gauge block yang didempetkan (wrung) secara bersama-sama (Gambar 9). Jarak antara dua gauge block yang didempetkan hanya sebesar seperbagian dari mikrometer. Gambar 8 memperlihatkan sebua set gauge block dengan panjang bervariasi dari $0.5 \mathrm{~mm}$ sampai dengan $100 \mathrm{~mm}$. Gambar 9 memperlihatkan tiga buah gauge block yang didempetkan secara bersamasama sehingga menghasilkan panjang akumulasi sebesar $110 \mathrm{~mm}$.

Sistem gauge block menjadi sesuatu yang sangat penting untuk kemajuan industri di Amerika pada saat itu karena sistem ini sangat digunakan sebagai limit gauge internal dan eksternal dengan akurasi yang sangat tinggi dan sangat mudah penggunaannya serta cost-effective. Karena sangat pentingnya sistem gauge block untuk industri, pemerintahan Amerika pada saat itu memutuskan untuk mendirikan National Institute for Standard and technology (NIST) untuk mengembangkan metode memproduksi masal gauge block karena pada saat itu ada keterbatasan suplai gauge block 
karena adanya perang dunia pertama di Eropa. Sifat-sifat gaguge block yang ingin diproduksi (dan merupakan properti wajib yang harus dimiliki oleh suatu sistem gauge block) adalah memiliki panjang yang stabil dalam waktu yang sangat lama, dapat didempetkan (wrung) antar-gauge block dan mempunyai panjang yang bervariasi yang bisa dikombinasikan untuk mendapatkan panjang yang lain. Setelah masa ini, gauge block menjadi sumber utama traceability pada pengukuran dimensi untuk lebih dari 100 tahun setelahnya.

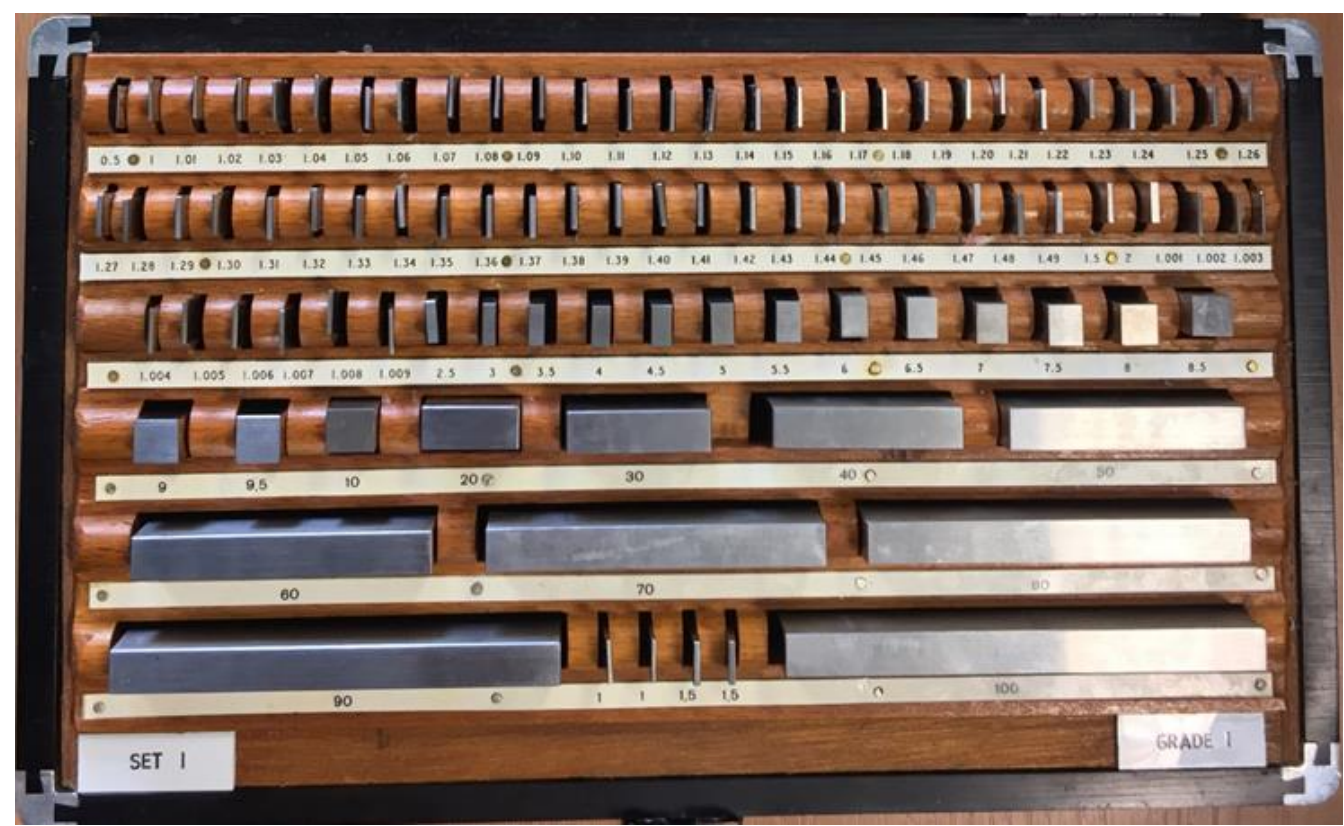

Gambar 8: Sebuah set dari gauge block.

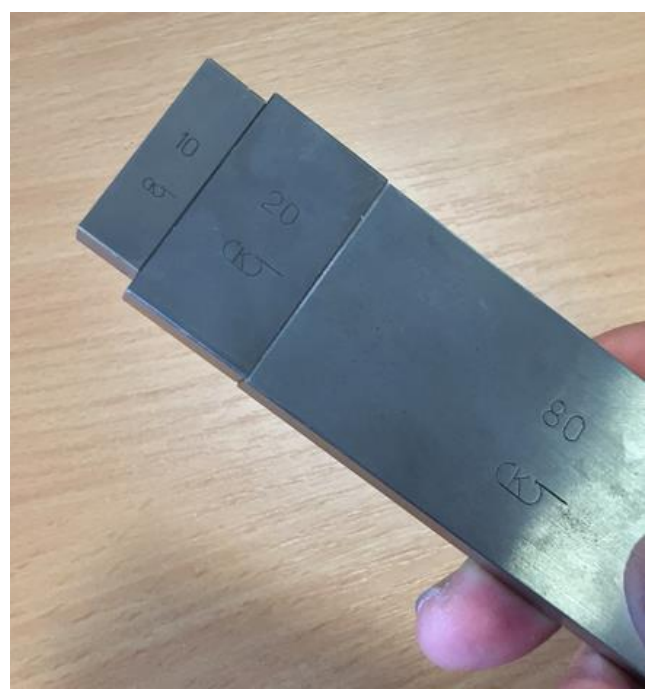

Gambar 9: Tiga gauge block yang disambungkan (wrung) bersama-sama untuk mendapatkan panjang yang lebih besar.

Memasuki abad ke-20, sekitar tahun 1930-an, perkembangan teknologi mesin-mesin manufaktur semakin pesat dan mendorong perkembangan alat-alat ukur ke tahap selanjutnya. Perkembangan alat-alat ukur tersebut sampai 
kepada tingkat sensitifitas yang sangat tinggi, seperti dikembangkannya berbagai macam sistem gauge berbasis udara dan berbasis elektronik. Sistem gauge berbasis elektronik yang paling berkembang pada saat itu adalah linear voltage differential transformer (LVDT) pada tahun 1946. LVDT mendominasi gauge sistem selama bertahun-tahun. Kelebihan utama LVDT adalah memiliki resolusi yang sangat tinggi, yaitu mencapai $0.1 \mu \mathrm{m}$. Sedangkan, keterbatasan utama dari LVDT adalah kemampuan LVDT hanya untuk pengukuran panjang yang sangat pendek. Sehingga, pada abad ke-20 sistem gauge block secara umum mendominasi pengukuran di indutrsi karena sistem gauge block dapat melakukan pengukuran panjang sampai mencapai ratusan milimeter walaupun tingkat accuracynya di bawah LVDT.

Pada pertengahan abad ke-20, yaitu sekitar tahun 1960, banyak studi yang dilakukan untuk mempelajari stabilitas dari sebuah gauge block. Berbagai macam metode dan material baru untuk membuat sebuah gauge block sangat berkembang pada periode ini. Sekarang ini, sebuah gauge block mempunyai tingkat kestabilan panjang yang sangat tinggi. Variasi panjang sebuah gauge block bervariasi antara $(0.1-0.5) \mathrm{nm} / \mathrm{tahun}$ (Dorion 2008).

Perkembangan selanjutnya dari teknologi pengukuran panjang adalah teknologi laser interferometer dan skala linier (linear scale). Perkembangan dari kedua teknologi tersebut adalah didorong oleh dibutuhkannya sebuah alat ukur panjang yang mempunyai tingkat keakuratan yang lebih tinggi dari gauge block dan mempunya kemampuan untuk mengukur berbagai skala panjang (Kunzmann et al 1993). Hal pertama yang dikembangkan adalah sistem interferometer yang mempunyai tingkat akurasi yang sangat tinggi, bahkan lebih tinggi dari LVDT. Laser interferometer bahkan digunakan untuk mengukur atau mengecek (meng-kalibrasi) sistem gauge block. Namun, pada saat itu, interferometer merupakan sistem yang sangat mahal dan penggunaannya terbatas pada laboratoriumlamoratorium metrology tingkat nasional di beberapa negara tertentu. Hal ini mendorong berkembangnya alat skala linier (linear scale) yang juga menggunakan laser dengan konfigurasi yang jauh berbeda dengan sistem laser interferometer.

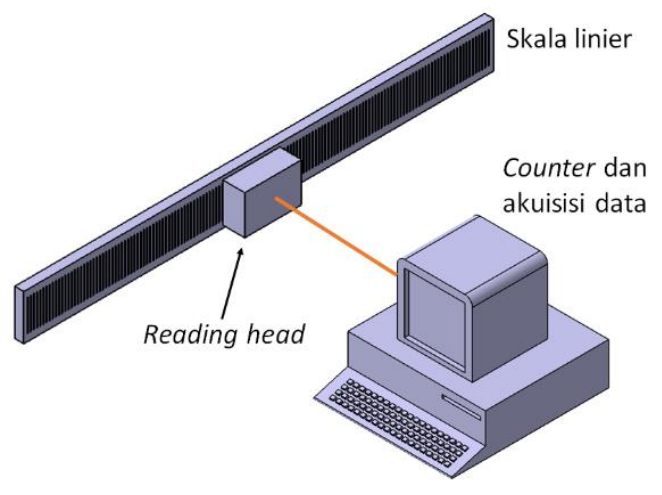

(a) Sistem Skala linier

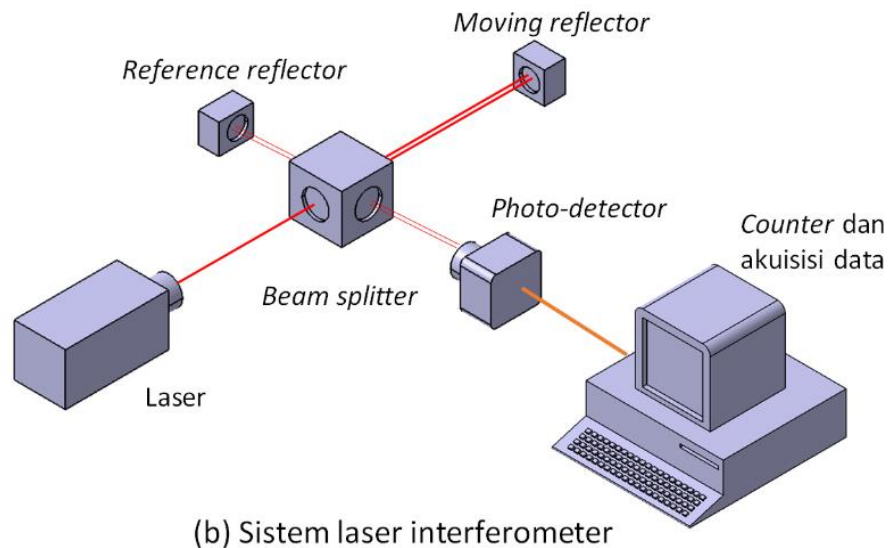

(b) Sistem laser interferometer

Gambar 10: (a) Sistem skala linier dan (b) sistem laser interferometer.

Gambar 10 memperlihatkan sistem skala linier dan laser interferometer. Sistem skala linier terdiri dari suatu metal atau keramik yang mempunyai garis-garis sebagai skala dan sebuah reading head yang membaca skala tersebut ketika reading head tersebut bergerak. Pada sistem skala linier, posisi diketahui dengan menghitung skala yang terdapat pada metal atau keramik tersebut. Sistem laser interferometer terdiri dari sebuah laser, beam splitter dan dua reflektor (mirror). Kedua reflektor tersebut adalah moving dan referense reflektor. Pada sistem interferometer, posisi dapat diketahui dengan menganalisis sinyal interferensi yang dideteksi oleh photo-detector. Skala linier merupakan teknologi yang terdapat hampir di semua mesin-mesin manufaktur dan mesin-mesin pengukuran koordinat pada umumnya. Sistem interferometer dan sistem skala linier akan dibahas dengan lebih detil pada bab-bab selanjutnya

Pada industri-industri dalam bidang pengukuran dan manufaktur, terutama industri pengukuran dan manufaktur pada skala mikro dan bahkan nano, standardisasi merupakan hal yang sangat penting untuk menjamin kesuksesan industri-industri tersebut (Leach 2010). Hal ini disebabkan oleh interchangeability dari suatu komponen akan semakin mudah untuk dicapai apabila standardisasi, seperti proses, intrumen dan produk, dalam industri pengukuran dan 
manufaktur dapat tercapai. Selain itu, standardisasi sangat dibutuhkan untuk kerberlangsukan suatu transaksi perdagangan antara industri-industri baik industri manufaktur ataupun yang lain. Dalam rangka untuk terciptanya standardisasi internasional, berbagai macam institusi baik regional maupun internasional diciptakan utnuk mendesain, menyebarluaskan dan megatur berbagaimacam standardisasi untuk pengukuran dan manufaktur. Peran pengukuran bukan hanya untuk menopang industri manufaktur, tetapi, pengukuran juga berperan untuk menyelesaikan berbagai permasalahan lain seperti masalah hukum perdagangan, keamanan dan etika (Leach 2010).

\subsection{Definisi "Meter"}

Meter adalah salah satu dari tujuh unit fundamental, yaitu meter, detik, kilogram, Amper, mol, candela dan Kelvin. Meter merupakan sesuatu yang paling penting dalam ilmu metrologi yang mencakup pengukuran dimensi (seperti panjang dan lebar), geometri dan tekstur permukaan. Definisi modern Meter yang dipakai sampai sekarang adalah sesuai dengan yang didefinisikan oleh Bureu International des Poids et Measures (BIPM):

"The metre is the length of the path travelled by light in vacuum during a time interval of 1/299 792458 of a second" (BIPM 1983).

Terjemahan langsung dari definisi tersebut: Meter adalah panjang dari sebuah lintasan yang dilalui oleh cahaya di ruang vakum dalam interval waktu 1/299 792458 detik. Definisi ini didapatkan melalui suatu proses yang sangat panjang. Sebelum definisi meter tersebut disepakati, meter didefinisikan dengan panjang suatu benda fisik. Definisi meter dengan merepresentasikan sebagai suatu panjang benda fisik memiliki berbagai kendala, seperti benda fisik akan mengalami degradasi kualitas seiring bertambahnya waktu dan benda fisik membutuhkan suatu sistem ruang penyimpanan khusus yang membuatnya sulit untuk dipindahkan atau didistribusikan.

Sejarah definisi meter dimulai dengan dibentuknya Bureu International des Poids et Measures (BIPM) pada tanggal 20 Mei 1875 di Paris (Noughtin 2008). Pada tanggal tersebut, sebuah konferensi besar diadakan yang bertujuan untuk membahas mengenai standardisasi dari pengukuran. Pada saat itu, terdapat 20 negara yang berbartisipasi. Konferensi tersebut membahas definisi meter dan menghasilkan sebuah konvensi yang bernama Convention du Mètre (Treaty of the Metre). Hal lain yang dihasilkan dari konferensi di Paris tersebut selain konveni Meter adalah dibentuknya organisasi atau badan yang bernama Bureu International des Poids et Measures (BIPM).

Dari 20 negara, tidak semua negara yang berbartisipasi pada saat itu menandatangani konvensi tersebut. Negaranegara yang menandatangani konvensi tersebut adalah Austria-Hungary, Argentina, Belgium, Brazil, Denmark, France, Germany, Italy, Peru, Portugal, Russia, Sweden-Norway, Switzerland, Turkey, the United State of America dan Venezuela. Tiga negara ynag tidak menandatangani konvensi tersebut adalah The UK dan Northern Ireland, Netherands dan Greece (Hellenic Republic). Sebilan tahun setelah konvensi meter tersebut, The UK dan Northern Ireland menandatangani konvensi tersebut. Untuk dua negara lain, yaitu Netherlands dan Greece, dibutuhkan waktu yang lama sampai kedua negara tersebut menandatangani konvensi tersebut, yaitu Netherlands menandatangani konvensi meter pada tahun 1929 dan Greece menandatangani konvensi meter tersebut pada tahun 2001. Slaah satu pertimbangan ketiga negara tersebut tidak langsung menandatangani konvensi meter adalah karena ada tanggung jawab ekonomi untuk merealisasikan, memelihara dan mendistribusikan standar meter tersebut. Australia dan negara common wealth yang lain pada saat itu tidak berpartisipasi pada konferensi tersebut karena semua negara common wealth sudah diwakilkan oleh UK. Pada tahun 1984 ketika The UK akhirnya menandatangani konvensi tersebut, pada saat itu The UK masih menolak untuk menerapkan sistem berbasis Meter tersebut (Metric). Baru pada tahun 1897, The UK melegalkan penggunaan sistem metric, untuk satuan pengukuran dan massa, pada sistem perdagangan mereka.

Mulailah dari tahun 1875, definisi Meter mengalami revisi selama beberapa kali. Proses revisi dari meter tersebut melalui proses yang lama dan komplek yang didorong oleh berkembangnya beberapa bidang, yaitu ekonomi, sains dan teknologi. Detil tahapan-tahapan definisi meter dari tahun 1875 sampai definisi sekarang oleh BIPM (definisi BIPM 1983) diperlihatkan pada tabel 1. Tabel 1 memperlihatkan sejarah revisi-revisi definisi meter secara kronologis. Selain Meter, unit fundamental yang lain, yaitu detik, Amper, mo, candela dan Kelvin, memiliki definis terbaru berbasis konstanta natural kecual satuan kilogram yang sampai saat ini (tahun 2017) masih mempunyai definisi berupa 
fisik sebuah masa benda berbentuk bola. Definisi kilogram tersebut segera akan direvisi agar berbasis konstanta natural seperti unit fundamental lainnya.

Tabel 1: Sejarah mengdefinisikan Meter.

\begin{tabular}{|c|c|}
\hline Tahun & Definisi Meter \\
\hline 8 May 1790 & $\begin{array}{l}\text { French Natinal Assembly mendeklarasikan bahwa panjang dari } \\
\text { Meter sama dengan panjang dari sebuah pendulum dengan } \\
\text { setengah periode dari satu detik }\end{array}$ \\
\hline 30 Maret 1791 & $\begin{array}{l}\text { French Academy of Science mengajukan proposal untuk } \\
\text { definisi Meter. Proposal tersebut diterima oleh French } \\
\text { National Assembly. } \\
\text { Definisi baru dari Meter adalah Meter sama dengan one ten- } \\
\text { millionth dari panjang lintasan meridian bumi. Panjang } \\
\text { lintasan meridian bumi adalah sama dengan jarak dari ekuator } \\
\text { sampai dengan kutup utara. Panjang lintasan tersebut melewati } \\
\text { kota Dunkirk di Perancis dan kota barcelona di Spanyol. }\end{array}$ \\
\hline 1 Agustus 1793 & $\begin{array}{l}\text { Definisi Meter sebagai } 1 / 10000000 \text { dari jarak lintasan dari } \\
\text { ekuator ke kutub utara dikonfirmasi. }\end{array}$ \\
\hline 7 April 1795 & $\begin{array}{l}\text { Sebuah prototipe balok Meter (Meter bar) dibuat dari material } \\
\text { perunggu. }\end{array}$ \\
\hline 10 Desember 1799 & $\begin{array}{l}\text { French Nastional Assembly memutuskan bahwa balok Meter } \\
\text { (Meter bar) sebagai standar panjan dari Meter. Balok tersebut } \\
\text { dibuat dari platinum dan dibuat pada } 22 \text { Juni } \mathbf{1 7 9 9} \text { dan } \\
\text { disimpan dalam arsip national Perancis. }\end{array}$ \\
\hline 20 Mei 1875 & $\begin{array}{l}\text { Terbentuknya Bureu International des Poids et Measures } \\
\text { (BIPM) dari hasil konferensi di Paris. }\end{array}$ \\
\hline 28 September 1889 & $\begin{array}{l}\text { Sebuah konferense besar yang bernama General Conference } \\
\text { on Weights and Measures (CGPM) pertama kali diadakan. } \\
\text { CGPM merupakan lanjutan dari konferensi pada } 20 \text { Mei } 1875 \\
\text { yang menghasilkan treaty of Meter dan BIPM. Pada konferensi } \\
\text { ini, definisi Meter diperbaru, yaitu jarak antara dua garis pada } \\
\text { standar balok yang terbuat dari platinum alloy dengan } 10 \% \\
\text { campuran iridium, yang diukur pada titik lebur sebuah es. } \\
\text { Prototipe dari standar balok tersebut mempunyai bentuk cross- } \\
\text { section berupa bentuk 'X' untuk meningkatkan stabilitas balok } \\
\text { tersebut (lihat gambar 11). }\end{array}$ \\
\hline Tahun 1906 & $\begin{array}{l}\text { Definisi panjang dari meter didefinisikan ulang sebagai } \\
1000000 / 0.64384696 \text { dari panjang gelombang garis merah } \\
\text { spektrum cadmium yang merambat dalam udara. }\end{array}$ \\
\hline
\end{tabular}




\begin{tabular}{|l|l|} 
& $\begin{array}{l}\text { Konferensi ke tujuh dari General Conference on Weights and } \\
\text { Measures (CGPM) meredifinisikan lagi Meter sebagai jarak, } \\
\text { yang diukur pada 0 }{ }^{\circ} \text { C, antara axis dari dua garis tengah yang } \\
\text { ditandai pada balok meter platinum-iridium. Balok tersebut } \\
\text { ditempatkan pada ruangan dengan tekanan 1 atm dan } \\
\text { disanggah oleh dua silinder dengan diamater minimal 10 mm, } \\
\text { yang diposisikan secara simetri pada bidang horisontal yang } \\
\text { sama yang terpisah dengan jarak 571 mm antare kedua silinder } \\
\text { penyanggah tersebut. }\end{array}$ \\
\hline 20 Oktober 1960 1927 & $\begin{array}{l}\text { Konferensi k-11 dari General Conference on Weights and } \\
\text { Measures (CGPM) meredifinisikan meter sebagai sama dengan } \\
\text { 1650763.73 kali panjang gelombang dari radiasi yang berasal } \\
\text { dari transisi antara 2p10 dan 5d5 level kuantum dari krypton- } \\
\text { 86 atom didalam ruang vakum. }\end{array}$ \\
\hline 21 Oktober 1983 & $\begin{array}{l}\text { Konferensi k-17 dari General Conference on Weights and } \\
\text { Measures (CGPM) mendefinisikan (sampai saat ini) meter } \\
\text { sebagai panjang dari lintasan yang dilalui cahaya selama } \\
\text { interval waktu 1/299792458 s didalam ruang vakum. Realisasi } \\
\text { dari definis Meter tersebut pada umumnya dilakukan di } \\
\text { institusi metrology nasional dnegan menggunakan laser dengan } \\
\text { frekuensi yang stabil. }\end{array}$ \\
\hline Tahun 2002 1983$]$ & $\begin{array}{l}\text { CIPM merekomendasikan (bukan meredifinisikan) bahwa } \\
\text { definisi meter pada tahun 1983 terbatas pada: panjang yang } \\
\text { cukup pendek dimana efek yang diprediksi oleh teori relativitas } \\
\text { general dapat diabaikan terhadap ketidakpastian dari realisasi } \\
\text { Meter tersebut. }\end{array}$ \\
\hline
\end{tabular}

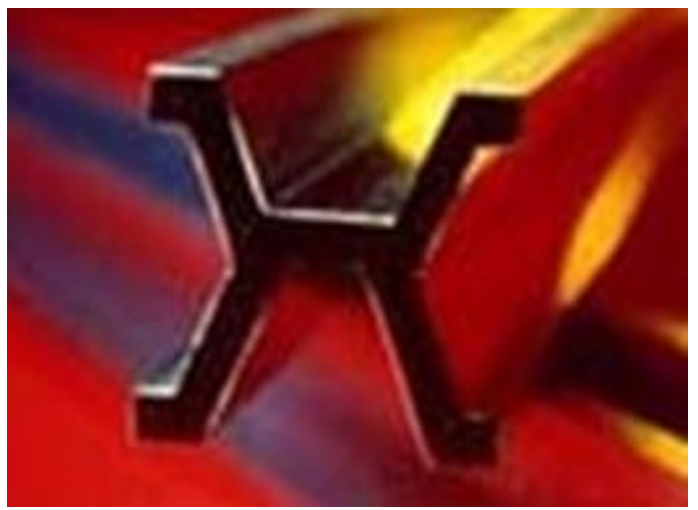

Gambar 11: Balok Meter yang terbuat dari platinum-iridium denga cross-section berbentuk ' $\mathrm{X}$ ' [Wikipedia].

Para peneiliti sepakat bahwa definsi system metrik pertama kali dimulai pada tanggal 22 Juni 1799 yang dikaitkan dengan pertamakalinya dibuat balok Meter dari material platinum. Konvensi dan dua institusi yang terlibat pada mendefinisian Meter dan sistem SI yang lain diperlihatkan pada tabel 2. Pada tabel 2, diperlihatkan bahwa CGPM adalah otoritas tertinggi yang mengatur sistem SI.

Realisasi meter di berbagai negara menjadi tanggung jawab institusi pengukuran di masing-masing negara tersebut. Maka dari itu, hampir disetiap negara memiliki sebuah institusi pengukuran nasional (National Metrology Institute/NMI). Institusi-institusi pengukuran nasional tersebut bertugas untuk merealisasikan Meter, 
mendistribusikan (seperti memproduksi atau mengkalibrasi) dan menjaga sistem keterlacakan ke Meter. Tabel 3 memperlihatkan berbagai macam institusi-intitusi pengukuran nasional di berbagai negara.

Tabel 2: Institusi-institusi dan konvensi yang mendefinisikan Meter.

\begin{tabular}{|c|c|c|c|}
\hline Konvensi/Institusi & Kepanjangan & Deksripsi & Peran \\
\hline CGPM & $\begin{array}{c}\text { Confèrence Gènèrale des } \\
\text { Poids et Measures / General } \\
\text { Conference on Weights and } \\
\text { Measures }\end{array}$ & $\begin{array}{l}\text { Konverensi besar yang } \\
\text { terdiri dari berbagai negara, } \\
\text { terutama negara yang } \\
\text { bertanggung jawab } \\
\text { terhadap SI. Jumlah negara } \\
\text { yang berpartisipasi } \\
\text { mencapai } 50 \text {. }\end{array}$ & $\begin{array}{l}\text { Peran utama CGPM adalah } \\
\text { bertanggung jawab untuk } \\
\text { memastikan sistem SI dapat } \\
\text { tersebarluas dan } \\
\text { memodifikasi sistem SI } \\
\text { apabila dibutuhkan } \\
\text { sehingga sistem SI } \\
\text { merepresentasikan } \\
\text { perkembangan terakhir dari } \\
\text { ilmu pengetahuan. }\end{array}$ \\
\hline CIPM & $\begin{array}{l}\text { Comitè International des } \\
\text { Poids et Measures / } \\
\text { International committee for } \\
\text { Weights and Measures }\end{array}$ & $\begin{array}{l}\text { CIPM adalah dibawah } \\
\text { otoritas CGPM. }\end{array}$ & $\begin{array}{l}\text { Peran utama CIPM adalah } \\
\text { memberikan saran tentang } \\
\text { pemodofikasian sistem SI } \\
\text { ke CGPM untuk dilegalkan } \\
\text { dan diadopsikan. CIPM } \\
\text { berperan untuk } \\
\text { mengklarifikasi dan } \\
\text { merekomendasikan sistem } \\
\text { SI. }\end{array}$ \\
\hline BIPM & $\begin{array}{l}\text { Bureau International des } \\
\text { Poids et Measures / } \\
\text { International Bureau of } \\
\text { Weights and Measures }\end{array}$ & $\begin{array}{l}\text { BIPM merupakan "institusi } \\
\text { pengukuran internasional" } \\
\text { dan beroperasi diwah } \\
\text { supervisi CIPM. }\end{array}$ & $\begin{array}{l}\text { Peran utaman BIPM adalah } \\
\text { untuk menjamin unifikasi } \\
\text { sistem pengukuran fisik di } \\
\text { dunia. }\end{array}$ \\
\hline
\end{tabular}

Tabel 3: Institusi-institusi (badan) nasional (National Metrology Institute) yang bertugas untuk merealisasikan Meter dan menjaga sistem keterlacakan ke Meter. Institusi-intitusi tersebut merupakan representasi BIPM di setiap negara.

\begin{tabular}{|c|c|c|}
\hline Institusi & Deskripsi & Deksripsi \\
\hline NIST & National Institute of Standard and technology & Amerika Serikat \\
\hline NPL & National Physical Laboratory & Inggris (UK) \\
\hline PTB & Physikalisch-Technische Bundesanstalt & Jerman \\
\hline LNE & Laboratoire national de métrologie et d'essais & Perancis \\
\hline BSN & Badan Standardisasi Nasional & Indonesia \\
\hline INRIM & Istituto Nazionale di Ricerca Metrologica & Italia \\
\hline NMIJ & National Metrology Institute of Japan & Jepang \\
\hline KRISS & National metrology Institute of Korea & Korea \\
\hline SMC & Spanish Metrology Centre & Spanyol \\
\hline DFM & Danish Fundamental Metrology & Denmark \\
\hline
\end{tabular}




\begin{tabular}{|c|c|c|} 
SP & Technical Research Institute fo Sweden & Swedia \\
\hline MIKES & National metrology Institute of Finland & Finlandia \\
\hline METAS & Federal Institute of Metrology & Swiss \\
\hline INMETRO & $\begin{array}{c}\text { National Institute of Metrology, Standardization and } \\
\text { Industrial Quality }\end{array}$ & NIM \\
\hline NIM & $\begin{array}{c}\text { National Institute of Metrology, Standardization and } \\
\text { Industrial Quality }\end{array}$ & Malaysia \\
\hline NMIM & National Metrology Institute Of Malaysia & Australia \\
\hline NMI & National Measurement Institute of Australia \\
\hline \multicolumn{2}{|c|}{ dan lain-lain } \\
\hline
\end{tabular}

\subsection{Temperatur standar $20^{\circ} \mathrm{C}$}

Salah satu prinsip dasar dari pengukuran dimensi (nama lainnya size measurement) adalah fakta bahwa dimensi setiap material akan berubah dengan berubahnya temperatur yang disebabkan oleh fenomena ekspansi termal. Pada 15 April 1931, temperatur standar untuk pengukuran dimensi telah ditetapkan pada $20^{\circ} \mathrm{C}$ yang ditetapkan oleh CIPM (Dorion 2007). Sebelum ditetapkannya temperatur standar pengukuran dimensi, proses panjang terjadi sampai disepakatinya temperatur standar tersebut. Proses tersebut berasal dari proses diskusi dan negosiasi yang berlangsung selama 20 tahun .Sebagian besar orang tidak mengetahui alasan kenapa dan bagimana temperatur standar tersebut ditetapkan. Maka dari itu, sejarah singkat mengenai temperatur standar $20^{\circ} \mathrm{C}$ akan dijelaskan secara singkat dan untuk sejarah yang lebi detil, dapat dilihat di laporan oleh Dr. Ted Dorion (Dorion 2007).

Pada awalnya, standar temperature ditetapkan pada titik lebur es pada $0{ }^{\circ} \mathrm{C}$. Masalah mendasar pada temperature $0{ }^{\circ} \mathrm{C}$ adalah situasi riil diindustri mempunyau temperatur lingkungan jauh dari temperatur tersebut. Selain itu, temperature $0{ }^{\circ} \mathrm{C}$ sangat tidak nyaman untuk manusia yang bekerja pada temperatur tersebut. Contoh praktis masalah mendasar dari temperatur standar $0{ }^{\circ} \mathrm{C}$ adalah sebagai berikut. Apabila ada dua buah material yang terbuat dari steel $\left(\mathrm{CTE} 12 \times 10^{-6} /{ }^{\circ} \mathrm{C}\right)$ dan perunggu $\left(\mathrm{CTE} 24 \times 10^{-6} /{ }^{\circ} \mathrm{C}\right)$ akan dirakit pada temperatur $20^{\circ} \mathrm{C}$, karena perunggu akan terekspansi sebanyak dua kali lipat dari steel, maka perakitan tidak bisa dilakukan. Pada umumnya proses perakitan dilakukan pada suhu ruangan sebesar $25^{\circ} \mathrm{C}$. Oleh karena itu, akan sangat praktikal apabila temperatur standar dekat dengan suhu ruangan, misalnya pada $20^{\circ} \mathrm{C}$.

Apabila temperatur standar pada $20^{\circ} \mathrm{C}$, ada saat itu solusinya adalah untuk membuat standar balok Meter yang mempunyai panjang yang sama dengan balok Meter standar internasioanl pada suhu $0{ }^{\circ} \mathrm{C}$ (pada saat itu standar Meter masih didefinisikan oleh sebua balok Meter). Hal ini membutuhkan pengetahuan koefisien ekspansi termal (CTE) dari balok Meter sengan material tertentu dan balok Meter standar internasional pada saat itu. Solusi ini sangat sulit untuk dilakukan karena untuk menjaga kestabilan panjang balok Meter standar internasioanl, maka balok tersebut harus digunakan sesedikit mungkin.

Pada saat itu, Dr. Sratton, direktur NIST, meminta ke direktur BIPM Dr. Guillaume agar NIST bisa mengirim standar balok meter mereka untuk dilakukan komparasi dengan standar balok meter insternasioanl yang disimpan di Paris. Dr. Guillaume, direktur BIPM, menjawab permintaan Dr. Stratton dan mengatakan bahwa komparasi tersebut tidak bisa dilakukan pada saat itu karena balok Meter standar internasional disimpan pada sebuah tempat di dalam sebuah goa dibawah gedung institusi Dr. Guillaume. Tempat tersebut dibawah kekuasaan komite internasional dan dikunci dengan tiga kunci yang dipegang oleh tiga orang yang berbeda, yaitu Dr. Huillaume, presiden dari komiter internasioanl tersebut Prof. Foerster di Berlin dan terakhir dipegang oleh nasional arsip Perancis. Akses ke tempay penyimpanan balok Meter internasioanl tersebut harus diputuskan oleh komite internasioanl tersebut.

Akhirnya studi CTE material untuk balok meter pada suhu $20^{\circ} \mathrm{C}$ harus dilakukan pada replika dari balok Meter standar internasioanal. Jumlah replika balok Meter internasioanl pada saat itu sebanyak 29 buah. Replika tersebut didistribusikan kepada nagara-negara yang mengikuti konvensi Meter. Masalah mendasar lainnya pada saat itu adalah 
studi CTE membutuhkan termometer yang sangat akurat pada suhu $0{ }^{\circ} \mathrm{C}$ sampai $20{ }^{\circ} \mathrm{C}$. Pada saat itu, alat pengukur temperatur juga dalam masih dalam pengembangan.

Dari perspektif modern, masalah ketidakpastian (uncertainty) adalah masalah serius. Masalah tersebut adalah karena Meter didefinisikan sebagai jarak antara dua garis pada balok Meter internasioanl pada suhu $0{ }^{\circ} \mathrm{C}$, Balok meter lainnya, bahkan apabila bisa dikomparasi pada suhu $0{ }^{\circ} \mathrm{C}$, balok meter tersebut akan mempunya nilai ketidakpastian yang lebih besar pada $20^{\circ} \mathrm{C}$ dibandingkan dengan ketidakastian dari balok Meter internasioanal. Nilai ketidakpastian tersebut tergantung pada nilai CTE material yang digunakan dan tingkat akurasi dari alat ukut temperatur yang digunakan. Pada kondisi di laboratorium pada umumnya, nilai CTE dan keakuratan alat ukur temperatur mempunya kontribusi yang sanga besar pada nilai ketidakpastian suatu balok Meter pada suhu $20{ }^{\circ} \mathrm{C}$ dibandingkan nilai ketidakpastian balok Meter internasioanl pada suhu $0{ }^{\circ} \mathrm{C}$. Namun, pada saat itu, masalah ketidakpastian tidak menjadi perhatian utama karena ilmu tentang ketidakpastian (uncertainty) suatu hasil pengukuran masih dalam tahap awal pengembangan.

Pada saat temperature standar internasioanal untuk melakukan pengukurna dimensi belum disepakati, hanya Perancis yang menggunakan temperatur standar pada $0{ }^{\circ} \mathrm{C}$. Sedangakan, negara lainnya tidak menggunakan temperature standar $0{ }^{\circ} \mathrm{C}$. Inggris menggunakan temperatur standar pada $62^{\circ} \mathrm{F}\left(16.67{ }^{\circ} \mathrm{C}\right)$. Swedia menggunakan temperatur standar $66^{\circ} \mathrm{F}$ untuk standar pengukuran gauge block Johansson. Berlin mengadopsi temperatur standar pada $25{ }^{\circ} \mathrm{C}$. Jepang menggunakan temperatur standar pada $62^{\circ} \mathrm{F}$. Pada saat itu, Amerika Serikat sudah menggunakan temperatur standar $20^{\circ} \mathrm{C}$, walaupun beberapa perusahaan di Amerika Serikat pada saat itu ada yang menggunakan standar temepratur pada $62^{\circ} \mathrm{F}$, yaitu perusahan Brown \&Shape. Setelah berbagai macam diskusi dan dengan diterbitkannya sebuah laporan yang sangat penting dari C. E. Johansson (penemu sistem gauge block dan merupaka "bapak metrologi") dimana laporan tersebut merekomendasikan agar temperatur standar ditetapkan pada $20{ }^{\circ} \mathrm{C}$, Pada rapat CIPM pada tanggal 15 April 1931, dengan kesepakatn mutlak, CIPM menetapkan bahwa temepratur standar sebagai referensi pengukuran dimensia adalah $20^{\circ} \mathrm{C}$. Adopsi dari hasil keputusan temperatur standar $20^{\circ} \mathrm{C}$ diterapkan sebagai standar pertama dari ISO, yaitu ISO 1 pada tahun 1951. Di Amerika Serikat, standar nasionalnya ASME/ANSI Y.14.5 tentang dimensi dan toleransi menggunakan temperatur $20^{\circ} \mathrm{C}$ untuk semua dimensi gambar teknik.

\subsection{Keterlacakan (traceability), kalibrasi (calibration) dan ketidakpastian (uncertainty)}

Pada bagian sebelumnya pentingnya pengukuran pada suatu industri telah dijelaskan. Selain tentang pentingnya pengukuran, sejarah pengukuran, sejarah Meter dan sejarah temperatur standar $20{ }^{\circ} \mathrm{C}$, juga sudah dijelaskan. Dari sejarah-sejarah tersebut, dapat dimengerti bahwa standardisasi proses pengukuran sangatlah penting, terutama untuk komparasi antar pengukuran dan interchangeability berbagai macam produk yang dibuat dari berbagai macam industri berbeda dan juga dari berbagai negara yang berbeda. Proses untuk melakukan standardisasi tersebut, yaitu standar Meter dan standar temperature pengukuran dimensi, membutuhkan usaha yang sangat banyak dalam rentang waktu yang lama pula. Maka dari itu, untuk menjamin standar Meter dapat diterapkan untuk berbagai macam aplikasi yang membutuhkan pengukuran, baik di industri maupun riset, maka keterlacakan (traceability) dari hasil suatu pengukuran harus direalisasikan. Apabila suatu hasil pengukuran dapat terlacak sampai dengan definisi Meter, maka hasil pengukuran tersebut akan reliabel dan dapat dikomparasikan.

Bagian ini akan menjelaskan tiga konsep fundamental dari metrologi, yaitu keterlacakan (traceability), kalibrasi (calibration) dan ketidakpastian (uncertainty). Kalibrasi dan ketidakpastian sangatlah penting, karena keterlacakan dapat terealisasikan dengan proses kalibrasi dan dengan mencantumkan nilai ketidakpastian dari proses kalibrasi tersebut.

\subsubsection{Keterlacakan (traceability)}

Definisi dari keterlacakan (traceability) didefinisikan oleh BIPM sebagai:

"Traceability is the property of the result of a measurement whereby it can be related to stated references, usually national or international standards, through a documented unbroken chain of comparisons all having stated uncertainties" (BIPM 2008a). 
Dari definisi BIPM, terjemahan langsung dari keterlacakan adalah property dari hasil suatu pengukuran, dimana hasil tersebut dapat direlasikan ke suatu referensi, pada umumnya referensi standar nasional atau internasional, melalui sebuah rantai dokumentasi komparasi yang tidak terputus yang kesemuanya disertai dengan nilai ketidakpastian (pada setiap tingkatan referensi tersebut).

Apabila suatu hasil pengukuran dapat terlacak sampai ke definisi meter, maka hasil pengukuran tersebut dapat dikomparasikan karena merujuk pada definis Meter yang sudah disebakati secara internasional. Selain itu, berbagai macam inspeksi produk dapat dilakukan untuk menjamin interchangability berbagai macam komponen yang dibuat dari berbagai tempat yang berbeda. Gambar 12 memperlihatkan sistem keterlacakan suatu hasil pengukuran yang tidak terputus sampai ke definisi dari Meter.

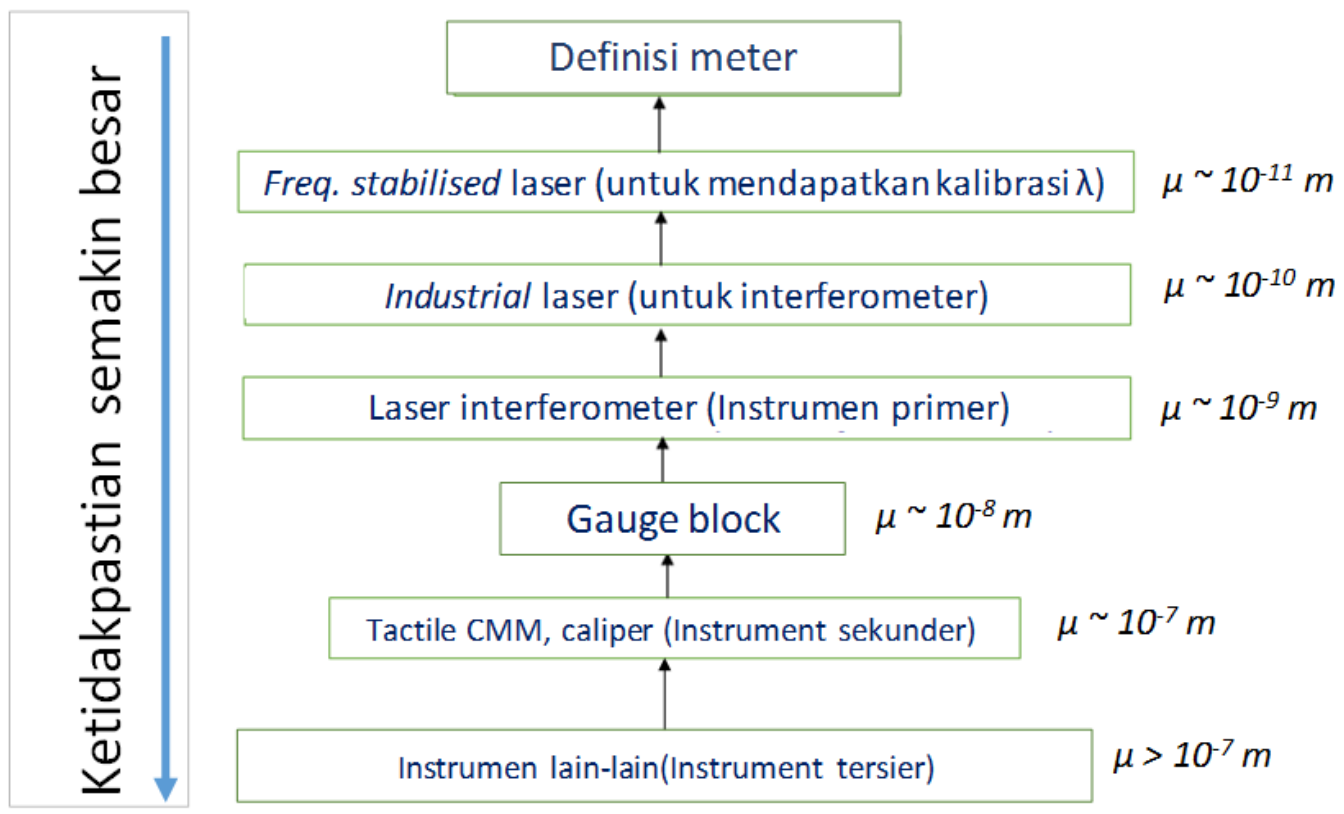

Gambar 12: Rantai keterlacakan suatu pengukuran ( $\mu$ = order dari ketidakpastian).

Definisi Meter adalah definisi nominal (teoritikal) sehingga nilai Meter tersebut adalah diangap eksak (nominal) dan tidak memiliki nilai ketidakpastian. Pada gambar 12, "tanda panah" ke atas adalah proses yang mengaitkan/melacak duatu hasil pengukuran pada tingkat bawah ke tingkat atasnya. Tanda panah tersebut adalah "rantai keterlacakan".

Untuk menciptakan rantai keterlacakan tersebut, sebuah proses kalibrasi harus dilakukan. Pada hakekatnya, proses kalibrasi adalah proses membandingkan suatu hasil pengukuran dengan suatu hasil pengukuran lainnya yang lebih akurat dengan mencantumkan nilai ketidakpastian dari proses kalibrasi atau komparasi tersebut. Apabila seluruh rantai keterlacakan tidak terputus sampai dengan definisi meter, maka hasil pengukuran tersebut bisa dikatakan "terlacak" dan reliabel. Pada gambar 12, terlihat bahwa semakin rendah tingkat keterlacakan, maka tingkat keakuratan suatu pengukuran akan semakin rendah dengan memiliki nilai ketidakpastian yang semakin besar.

Penjelasan dari realisasi rantai keterlacakan adalah sebagai berikut:

- Hal pertama adalah merealisasikan definisi dari Meter kedalam situasi riil, yaitu mengtransformasi nilai teoritis dan definisi Meter kedalam suatu nilai praktis yang dapat digunakna untuk proses komparasi. Untuk merealisasikan definisi Meter, digunakan suatu setup eksperimen menggunakan laser yang mempunyai frekuensi yang terstabilkan (frequency stabilised laser) dan yang mempunyai presisi sangat tinggi.

Laser tersebut digunakan untuk menghasilkan suatu panjang gelombang yang yang sangat akurat $\left(\lambda_{0}\right)$. Panjang gelombang tersebut didapatkan dari rumus: 


$$
f=\frac{c}{\lambda_{0}}
$$

dimana dimana $f$ adalah frekuensi laser yang terstabilisasi, $c$ adalah kecepatan cahaya diruang hampa yaitu $1 / 299792458 \mathrm{~m} \cdot \mathrm{s}^{-1}$ dan $\lambda_{0}$ adalah suatu panjang gelombang dengan tingkat akurasi dan presisi yang sangat tinggi.

$\lambda_{0}$ tersebut digunakan sebagai "penggaris" untuk mengukur suatu panjang gelombang lainnya, misalnya panjang gelombang suatu laser yang digunakan untuk pengukuran di industri. Pada tingkat ini, nilai ketidakpastiannya pada order $10^{-11} \mathrm{~m}$. Proses realisasi dari meter ini pada umumnya direalisasikan di institute metrologi nasional suatu negara.

- Pada tingkatan level dibawahnya, dengan menggunakan $\lambda_{0}$ tersebut, suatu nilai panjang gelombang, misalnya panjang gelombag suatu laser merah atau hijau (red/green laser) dapat diukur. Nilai ketidakpastian dari pengukuran suatu $\lambda$ tersebut berada pada order $10^{-10}$ (berada pada level sub-nanometer).

- Ketika $\lambda$ dari suatu laser telah diketahui, misalnya laser merah dengan $\lambda=633 \mathrm{~nm}$, sebuah interferometer dapat dibuat dengan menggunakan laser merah tersebut (Yoshizawa 2009). Sistem laser interferometer akan dijelaskan dengan lebih detil pada bab 4. Dengan dibuatnya sistem laser interferometer tersebut, paka besaran Meter dapat diketahui secara fisik. Pada tingkat ini, nilai ketidakpastiannya berada pada order $10^{-9} \mathrm{~m}$ (berada pada level nanometer).

- Tingkat keterlacakan dibawahnya lagi adalah sistem gauge block. Pada tingkat ini, suatu gauge block dikalibrasi dengan menggunakan sebuah sistem interferometer. Gauge block tersebut digunakan untuk melacak hasil pengukuran yang dilakukan dengan suatu sistem pengukuran pada umumnya di industri, seperti mesin pengukuran koordinat (CMM), mikrometer dan jangka sorong. Nilai ketidakpastian pada tingkat ini berada pada level $10^{-8}$ (masih dalam level puluhan nanometer). Berbagai macam contoh kalibrasi gauge block dapat dilihat di sumber lainnya (Dorion dan Stoup 1997).

- Tingkatan pada level paling bawah adalah sistem pengukuran dimensi dan geometri berbasis optik yang tidak menggunakan sistem interferometer. Pada umumnya, keterlacakan sistem pengukuran optik tersebut direalisasikan dengan suatu artefak referensi yang dikalibrasi dengan menggunakan suatu CMM (Syam 2015).

Gambar 13 memperlihatkan sebuah ilustrasi bagaimana rangkaian keterlacakan direalisasikan dalam kondisi praktis. Setiap rantai keterlacakan direalisasikan dengan suatu proses kalibrasi. Proses-proses kalibrasi tersebut mengkomparasi suatu hasil pengukuran (yang juga merepresentasikan instrumen pengukuran yang digunakan) dengan hasil lain yang lebih akurat. Nilai ketidakpastian dari suatu proses kalibrasi harus dicantumkan pada setiap tingkat rantai keterlacakan.

Penjelasan gambar 13 adalah sebagai berikut. Pada tingkat rantai keterlacakan yang paling bawah, sebuah pengukuran dimensi dan geometri dilakukan dengan menggunakan suatu CMM berbasis optik. Rantai keterlacakan CMM berbasis optik tersebut diciptakan dengan melakukan komparasi hasil pengukuran dengan suatu CMM berbasis kontak yang lebih akurat. Proses komparasi dengan CMM berbasis kontak tersebut menggunakan suatu artefak terkalibrasi. Artefak terkalibrasi tersebut diukur dengan CMM berbasis kontak dan kemudian diukur lagi dengan CMM berbasis optik tersebut. Perbedaan hasil pengukuran antara CMM berbasis optik dan berbasis kontak merupakan error dari CMM berbasis optik tersebut.

Untuk menciptakan rantai keterlacakan CMM berbasis kontak tersebut, sebuah gauge block yang sudah dikalibrasi dengan suatu sistem laser interferometer diukur menggunakan CMM berbasis kontak tersebut. Dengan mengukur gauge block terkalibrasi tersebut, CMM berbasasis kontak tersebut dapat dikomparasi dengan sistem laser interferometer tersebut.

Untuk mengkalibrasi sistem laser interferometer tersebut, Panjang gelomang $\lambda$ dari laser yang digunakan pada sistem interferometer tersebut dikomparasi dengan panjang gelombang referensi $\lambda_{0}$ yang dihasilkan dari suatu laser dengan frekuensi yang terstabilkan. Dengan demikian, laser interferometer tersebut dapat dikalibrasi. Dan terakhir, panjang gelombang referensi tersebut, yaitu $\lambda_{0}$, mempunyai rantai keterlacakan langsung ke definisi Meter, karena panjang gelombang referensi $\lambda_{0}$ tersebut merupakan realisasi langsung dari definisi teoritis dari Meter. Dengan demikian, rantai keterlacakan dari CMM berbasis optik sampai ke definis Meter dapat direalisasikan. 


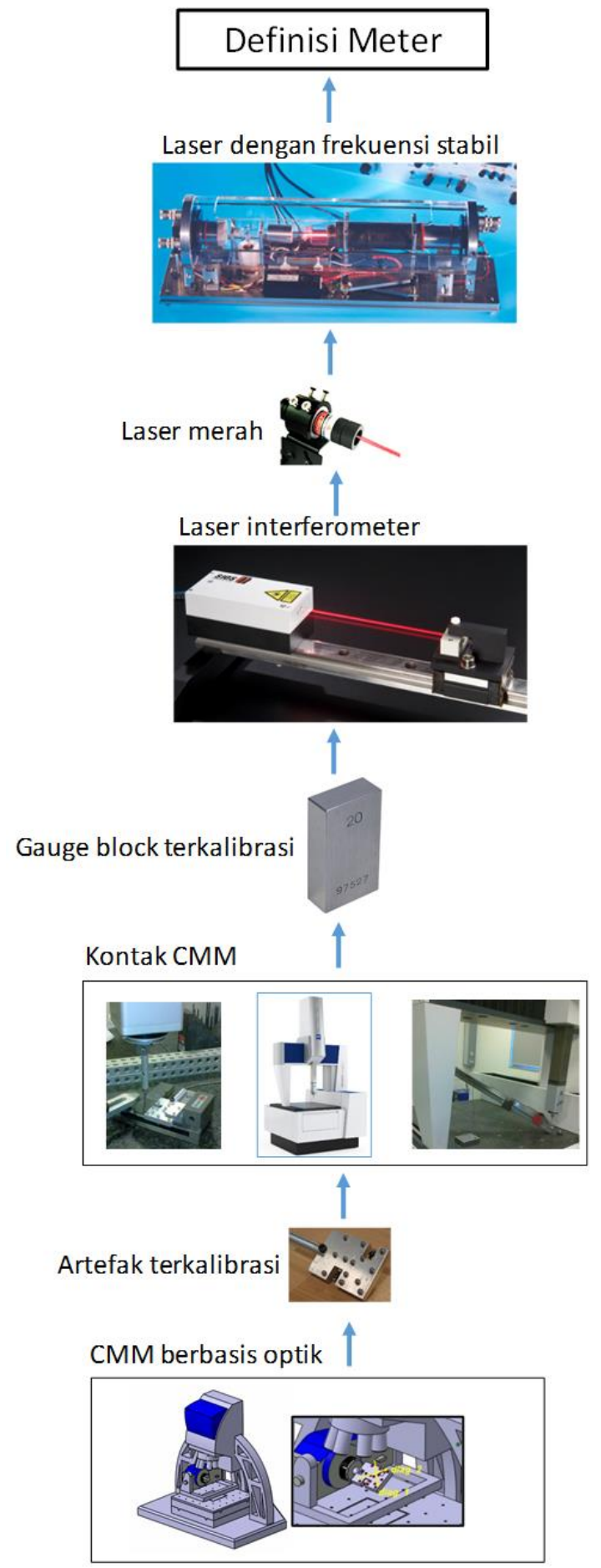

Gambar 13: Ilustrasi keterlacakan suatu hasil pengukuran dengan sebuah mikrometer melalui serangkaian proses kalibrasi. 


\subsubsection{Kalibrasi (calibration)}

Definisi kalibrasi oleh BIPM adalah:

"operation that, under specified conditions, in a first step, establishes a relation between the quantity values with measurement uncertainties provided by measurement standards and corresponding indications with associated measurement uncertainties and, in a second step, uses this information to establish a relation for obtaining a measurement result from an indication" (BIPM 2008a).

Terjemahan langsung dari kalibrasi adalah suatu proses, dengan spesifikasi tertentu, langkah pertama, menetapkan sebuah relasi dengan suatu kuantitas dengan nilai ketidakpastian yang dihasilakn oleh standar pengukuran dengan suatu indikasi (alat ukur) beserta nilai ketidakpastiannya dan, langkah kedua, menggunakan informasi tersebut untuk menetapkan sebuah relasi untuk mendapatkan sebuah hasil pengukuran dari sebuah indikasi (alat ukur). Pengertian praktis dari kalibrasi adalah membandingkan suatu hasil pengukuran dengan hasil pengukuran lainnya yang lebih akurat disertakan dengan nilai ketidakpastian dari hasil proses komparasi tersebut.

Proses kalibrasi adalah proses yang menciptakan relasi (link) antara setiap tingkat pada rantai keterlacakan. Proses kalibrasi ini sering disalah artikan dengan proses adjustment. Padahal kalibrasi dan proses adjustment merupakan dua buah proses yang sangat berbeda. Proses adjustment adalah suatu proses untuk mengetahui error sebuah instrumen atau komponen dari suatu instrumen dan apabila memungkinkan dilakukan koreksi geometri atau apabila tidak dimungkinkan, maka koreksi dilakukan didalam perangkat lunak instrumen tersebut.

\subsubsection{Ketidakpastian (uncertainty)}

Definisi BIPM dari ketidakpastian adalah:

"non-negative parameter characterizing the dispersion of the quantity values being attributed to a measurand, based on the information used" (BIPM 2008a).

Terjemahan langsung dari ketidakpastian adalah sebuah parameter non-negatif yang mengkarakterisasi interval atau sebaran dari nilai suatu kuantitas yang diatribusikan pada sebuah hasil pengukuran berdasarkan informasiinformasi yang ada (yang berhubungan dengan pengukuran tersebut dan instrumen pengukuran yang digunakan). Hal penting yang menjadi catatan adalah ketidakpastian hanya diasosiasikan dengan suatu hasil pengukuran bukan instrumen pengukuran. Untuk instrumen pengukuran, nilai yang diasosiasikan terhadap suatu instrumen adalah error.

Nilai ketidakpastian memiliki peran yang sangat fundamental di bidang metrologi. Peran tersebut bukan hanya untuk merealisasikan keterlacakan suatu hasil pengukuran, melainkan digunakan juga untuk, misalnya menentukan suatu komponen diterima atau ditolak dalam suatu proses inspeksi dan mempengaruhi keputusan dalam studi kapabilitas suatu mesin manufaktur. Bahasan ketidakpastian akan dijelaskan secara detil di bab lainnya.

\subsection{Standardisasi internasional}

Berbagai macam standardisasi internasional (termasuk beberapa standar nasional yang sering diterapkan pada level internasioanal) yang berhubungan dengan pengukuran dimensi dan geometri serta toleransi. Standar-standar yang paling utama dalam aplikasi industri dan dibahas detil pada buku ini ditandai dengan penebalan pada nama standar-standar tersebut. Standar-standar tersebut adalah sebagai berikut:

Standar internasional mengenai definisi-definisi:

- BIPM VIM 2008: Referensi utama untuk definisi-definisi yang berkaitan dengan metrologi.

$\underline{\text { Standar internasional mengenai kuantitas, unit dan temperatur referensi: }}$

- ISO 1 2016: Refernesi utama standar temperatur pada $20^{\circ} \mathrm{C}$. 
- ISO 31-0 1992: Prinsip umum dari penggunaan unit-unit fisika.

- ISO/IEC 80000-3 2007: unit dan kuantitas dimensi dan waktu.

- ISO 80000-2 2009: Tanda dan simbol matematika yang digunakan pada sains dan teknologi.

- ISO/IEC 80000-11 2009: Angka karakteristik pada sains dan teknologi.

- ISO/IEC 80000-7 2009: Satuan dan kuantitas cahaya dan radiasi elektromanetik.

- ISO/IEC 80000-3 2007: Satuan dan kuantitas periodic.

- ISO/IEC 80000-4 2006: Satuan dan kuantitas mekanika.

- ISO/IEC 80000-5 2007: Satuan dan kuantitas kalor.

- ISO/IEC 80000-5 2007: Satuan dan kuantitas listrik dan magnet.

Standar internasional mengenai akurasi dan presisi:

- ISO 5725-1 1994: Prinsip general dan definisi dari akurasi (trueness and precision).

- ISO 5725-2 1994: Metode dasar untuk menentukan repeatability dan reproducibility dari sebuah metode pengukuran.

- ISO 5725-3 1994: Metode untuk menentukan tingkat presisi suatu pengukuran.

- ISO 5725-4 1994: Metode untuk menentukan tingkat trueness suatu pengukuran.

- ISO 5725-5 1994: Metode alternatif untuk menentukan tingkat presisi suatu pengukuran.

- ISO 5725-5 1994: Penggunaan praktis dari nilai keakuratan.

Standar internasional mengenai standar dan alat ukur panjang:

- ISO 3650 1998: Standar mengenai gauge block.

- ISO 13102 2012: Standar mengenai indicator-gauge dijital berbasis elektronik.

- ISO 13225 2012: Standar mengenai Height gauge.

- ISO 13385-1 2011: Standar mengenai vernier caliper (jangka sorong).

- ISO 13385-2 2011: Standar mengenai depth caliper.

$\underline{\text { Standar internasional yang utama mengenai ketidakpastian: }}$

- BIPM GUM 2008: Referensi utama untuk menentukan nilai ketidakpastian.

Standar internasional mengenai inspeksi kualitas:

- ISO 14253-1 2013: Standar mengenai aturan pengambilan keputusan dari suatu proses inspeksi kualitas.

- ISO 14253-2 2011: Standar mengenai estimasi ketidakpastian pada suatu pengukuran, kalibrasi dan verifikasi.

- ISO 14253-3 2011: Standar mengenai petunjuk untuk mencapai kesepakatan penyertaan katidakpastian.

- ISO 14253-5 2015: Standar mengenai ketidakpastian pada tes verifikasi suatu instrumen pengukuran.

$\underline{\text { Standar internasional mengenai verifikasi unjuk kerja CMM: }}$

- ISO 10360-1 2000: Standar mengenai definisi-definisi pada tes verifikasi performansi dan penerimaan suatu CMM.

- ISO 10360-2 2009: Standar mengenai tes verifikasi performansi dan penerimaan suatu CMM untuk pengukuran panjang.

- ISO 10360-3 2000: Standar mengenai tes verifikasi performansi dan penerimaan suatu CMM dengan rotaryaxis.

- ISO 10360-4 2000: Standar mengenai tes verifikasi performansi dan penerimaan suatu CMM dengan menggunakan pengukuran berbasis scanning.

- ISO 10360-5 2010: Standar mengenai tes verifikasi performansi dan penerimaan suatu CMM yang menggunakan sistem kontak dengan satu atau multipel stylus.

- ISO 10360-6 2001: Standar mengenai estimasi error dalam perhitungan Gaussian features (fitting). 
- ISO 10360-7 2011: Standar mengenai tes verifikasi performansi dan penerimaan suatu CMM berbasis image sensor.

- ISO 10360-8 2013: Standar mengenai tes verifikasi performansi dan penerimaan suatu CMM berbasis optical sensor.

- ISO 10360-9 2013: Standar mengenai tes verifikasi performansi dan penerimaan suatu CMM berbasis multi sensor.

- ISO 10360-10 2016: Standar mengenai tes verifikasi performansi dan penerimaan suatu laser tracker.

- ISO 10360-12 2016: Standar mengenai tes verifikasi performansi dan penerimaan suatu CMM berbasis articulated arm.

$\underline{\text { Standar internasional mengenai ketidakpastian hasil pengukuran CMM: }}$

- ISO 15530-1 2013: Standar mengenai definisi-definisi dan karakteristik metrologi untuk menentukan nilai ketidakpastian pengukuran berbasis CMM.

- ISO/DTS 15530-2 2003: Standar mengenai metode untuk menentukan nilai ketidakpastian pengukuran berbasis CMM dengan menggunakan strategi pengukuran multipel.

- ISO 15530-3 2011: Standar mengenai metode untuk menentukan nilai ketidakpastian pengukuran berbasis CMM dengan menggunakan artefak terkalibrasi.

- ISO 15530-4 2008: Standar mengenai metode untuk menentukan nilai ketidakpastian pengukuran berbasis CMM dengan menggunakan metode simulasi Monte-Carlo.

Standar internasional mengenai toleransi:

- $\quad$ ISO 14405-1 2016: Standar mengenai toleransi dimensi: linear sizes.

- ISO 14405-2 2011: Standar mengenai toleransi dimensi: selain linear sizes.

- ISO 14405-3 2016: Standar mengenai toleransi dimensi: Angular sizes.

- ISO 1101 2017: Standar mengenai toleransi geometri (GD\&T).

- ASME Y14.5 2009: Standar mengenai toleransi di Amerika Serikat. Standar ini merupakan standar utama untuk toleransi geometri (GD\&T).

- $\quad$ ASME Y14.5.1 1994: Standar mengenai definisi matematik dari toleransi geometri (GD\&T).

Untuk standar CMM baik mengenai verifikasi performansi dan ketidakpastian, standar Jerman VDI/VDE juga sering digunakan, terutama oleh industri-industri manufaktur dan otomotif di Jerman. 


\section{BAB 2}

\section{Data, analisis statistik dan komputasi numerik}

Bab ini menjelaskan tentang prinsip-prinsip matematika yang sering digunakan sebagai alat untuk merekonstruksi, memproses dan menganalisis data yang didapatkan dari suatu instrument pengukuran, baik berbasis kontak maupun non-kontak. Bab ini terdiri dari penjelasan mengenai data dan istilah-istilah yang terkait dengannya, berbagai macam analisis statistik yang paling umum dan mendasar untuk bidang pengukuran dan aspek-aspek yang berhubungan dengan komputasi numerik. Untuk komputasi numerik, hal ini merupakan aspek yang sangat penting karena semua analisis dan pemrosesan data hasil pengukuran, seperti pengukuran yang dilakukan dengan menggunakan mesin pengukur koordinat (coordinate measuring machine/CMM)), dilakukan oleh komputer sehingga properti-properti dari suatu pemrosesan data oleh suatu komputer harus diketahui.

\subsection{Data}

Berbagai istilah dan definisi dari data dan aspek-aspek yang berkaitan dengan pengukuran dimensi dan geometri sangat penting untuk diketahui sebelum masuk ke pembahasan pengukuran tersebut. Sumber utama berbagai definisi dan istilah dalam pengukauran terdapat di VIM (BIPM 2008a). Berbagai macam definisi dan istilah yang penting diketahui dalam bidang pengukuran adalah (BIPM 2008a):

- Data.

Data adalah fakta yang dikumpulan sebagai referensi untuk dianalisis (berdasarkan kamus Oxford). Dalam bidang pengukuran, data adalah semua yang hasilkan dari suatu instrumen pengukuran. Seluruh data hasil pengukuran dimensi dan geometri adalah berupa angka atau numerik yang bisa diproses secara matematik. Data ini sering juga disebut dengan data mentah ( $r a w$ data), yaitu semua angka yang dihasilkan oleh suatu alat pengukuran, seperti CMM. Pada umumnya, alat-alat pengukuran menghasilkan data mentah yang tersimpan dalam sebuah file ASCII dengan format tertentu. Untuk memudahkan pembacaan, di dalam file ASCII tersebut, terdapat beberapa keterangan tentang data yang dihasilkan tersebut.

Seluruh data yang dihasilkan oleh suatu alat pengukuran berupa data spatial baik 1D, 2D dan 3D. Contoh data 1D adlaah data yang dihasilkan oleh suatu alat pengukur panjang, seperti jangka sorong. Contoh data 2D adalah data yang dihasilkan oleh suatu alat pengukuran permukaan benda, seperti contact stylus. Dan, contoh data 3D adalah data yang dihasilkan oleh mesin pengukur coordinat (CMM). Data 3D tersebut pada umumnya diistilahkan dengan awan poin (point cloud) dan mengandung posisi koordinat poin, yaitu koordinate $x, y$ and $z$. Beberapa instrument pengukuran juga menambahkan data orientasi poin terhadap suatu aksis selain data $x, y$ dan $z$ tersebut. Pada umumnya, point cloud mengandung ratusan hingga ribuan bahkan jutaan koordinat spasial poin yang dihasilkan oleh suatu CMM. Gambar 1 memperlihatkan contoh data mentah yang didapatkan dari suatu CMM berbasis optik. Pada gambar 1, data mentah tersebut terdiri dari 15 poin data. Pada praktisnya, CMM berbasis optik bisa menghasilkan data mentah (berupa koordinat spasial dari poin-poin suatu pernukaan benda yang diukur) sebanyak 3000000 poin hanya dalam waktu satu menit saja. 


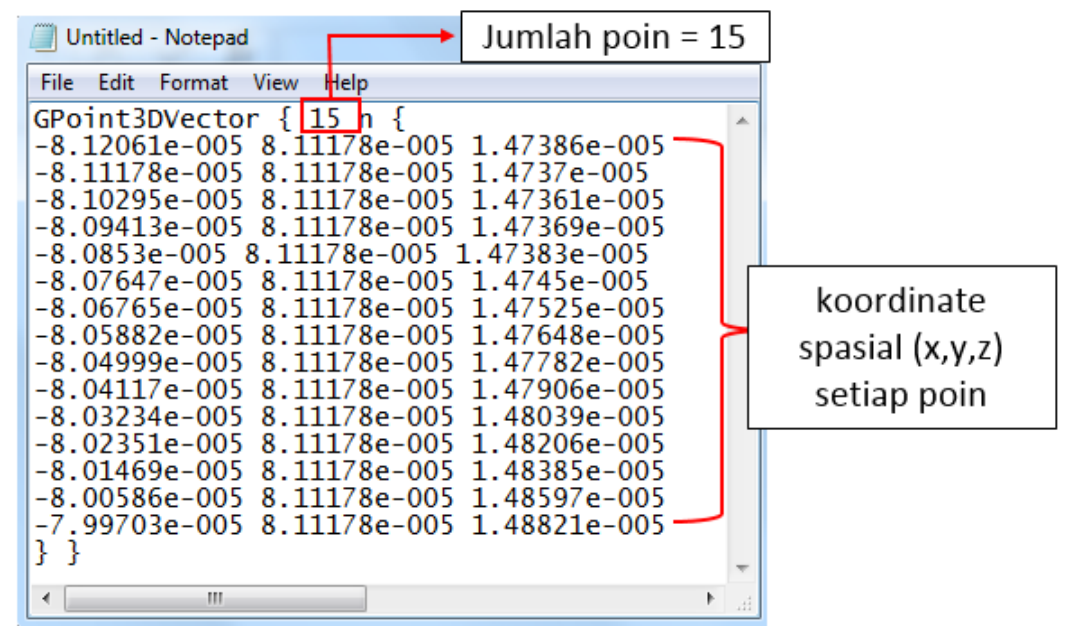

Gambar 1: Contoh data mentah (raw data) yang dihasilakn oleh suatu CMM berbasis optik. Data mentah tersebut berupa koordinat spasial $x, y$ dan $z$ dari poin-poin yang direkonstruksi dari pengukuran CMM tersebut. Tipe data mentah lainnya dapat menghasilkan koordinat spasial poin-poin berserta dengan rotasi poin-poin tersebut terhadap suatu axis.

- Informasi.

Informasi adalah data yang sudah disimpan dan diproses (berdasarkan kamus Oxford). Pada tahap ini, data yang sudah diproses sudah memiliki arti yang bisa digunakan. Sebagai contoh langsung dari informasi adalah suatu hasil suatu pengukuran dimensi, misalnya diameter. Diameter tersebut dihasilkan dari data-data mentah berupa koordinat spasial poin-poin yang dihasilkan dari suatu alat pengukuran dan diproses secara numerik sehingga diamater tersebut dapat dihasilkan.

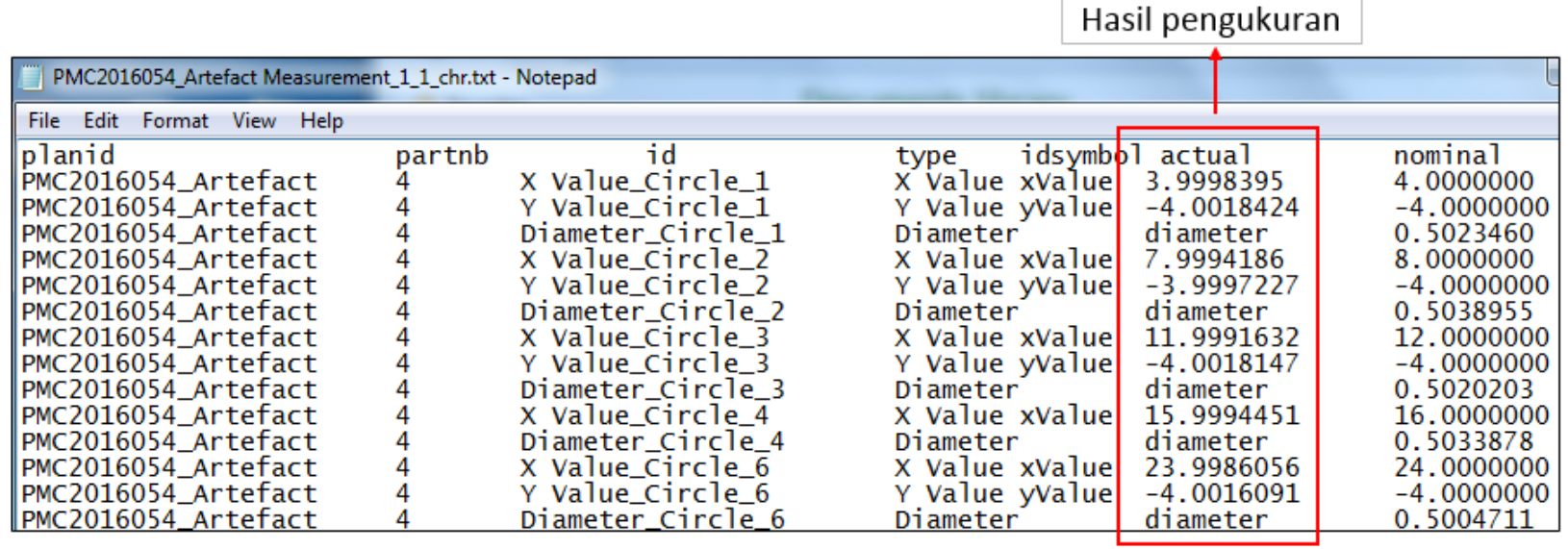

Gambar 2: Contoh file yang berisi informasi hasil pengukuran yang diakkan oleh suatu CMM berbasis kontak. Pada umumnya setiap CMM menghasilkan informasi hasil pengukuran yang ditampilkan langsung pada layar komputer dan disimpan dalam sebuah file.

- Measurand.

Measurand adalah kuantitas atau properti yang ingin diukur, misalnya diameter, panjang, volume dan roundness. Definisi measurand adalah hal pertama yang harus dilakukan sebelum melakukan suatu pengukuran apapun. Untuk menentukan suatu measurand, bebera aspek yang harus diketahui misalnya: 
pengetahuan tentang fenomena yang akan diukur, deskripsi dari fenomena atau benda yang mempunyai kuantitas yang akan diukur, dan pengetahuan mengenai material dari benda yang mempunyai kuantitas untuk diukur tersebut. Proses pengukuran measurand tersebut sangat dipengaruhi oleh prosedur pengukuran dan sistem pengukuran yang digunakan. Hal tersebut menyebabkan kuantitas yang diukur akan berbeda dengan definisi measurand tersebut. Dalam kasus ini, suatu koreksi dari hasil pengukuran measurand tersebut harus dilakukan. Sebagai contoh, pengukuran panjang sebuah aluminium aloy yang dilakukan pada suhu $25{ }^{\circ} \mathrm{C}$ akan mempunyai hasil yang berebeda apabila pengukuran tersebut dilakukan pada suhu standar $20^{\circ} \mathrm{C}$. Maka dari itu, koreksi panjang hasil pengukuran dari aluminium aloy tersebut harus dilakukan.

- Resolusi.

Resolusi adalah perubahan terkecil dari kuantitas yang diukur (measurand) yang menyebabkan perubahan indikasi pada suatu alat ukur yang dapat terlihat atau terekam. Dengan kata lain, resolusi adalah perubahan atau bacaan terkecil dari skala suatu alat ukur. Resolusi berbeda dengan akurasi dan presisi dan bergantung pada, misalnya, gangguan (noise) internal atau eksternal dan nilai dari kuantitas yang diukur.

- Akurasi.

Akurasi adalah perbedaan antara suatu kuantitas yang diukur dan nilai sebenarnya dari suatu measurand (kuantitas yang diukur). Dari definisi akurasi, akurasi merupakan suatu parameter yang tidak terkuantifikasi dengan nilai karena pada kenyataannya dalam setiap pengukuran, nilai yang sebenarnya dari suatu measurand tidak dapat diketahui karena ada faktor ketidakpastian (uncertainty) dalam suatu pengukuran (lihat bab ketidakpastian). Untuk akurasi, seseorang hanya bisa mengetahui suatu instrumen lebih akurat dibandingkan dengan suatu instrumen lainnya (komparasi relatif). Standar ISO memberikan definisi praktis untuk akurasi, yaitu kombinasi dari trueness dan presisi (ISO 5725-1 1994). Sehingga, pada praktisnya apabila akurasi didefinisikan secara numerik (yang sangat umum ditemui di kondisi riil), maka nilai numerik tersebut sudah mengandung nilai trueness dan presisi.

- $\quad$ Trueness.

Trueness adalah perbedaan antara nilai rata-rata suatu hasil pengukuran dengan replikasi yang tak terhingga (sangat banyak) dan suatu nilai kuantitas referensi. Trueness mempunyai hubungan terbalik dengan kesalahan sistematik (systematic error) dan tidak berhubungan dengan kesalahan acak (random error).

- $\quad$ Presisi.

Presisi adalah perbedaan antara kuantitas nilai atau indikasi yang diukur dan nilai yang didapatkan dari replikasi (pengulangan) pengukuran pada objek yang sama atau mirip pada kondisi tertentu. Kondisi tertentu tersebut misalnya: pengulangan dengan opertaor yang sama dan pengulangan dengan operator yang berbeda. Presisi dikuantifikasikan sebagai ketidakpastian (uncertainty) yang akan dibahas secara khusus pada bab lainnya. Hal pertama yang harus dimiliki oleh suatu alat pengukuran adalah presisi.

Pada kondisi praktis, nilai yang sering diestimasi adalah nilai resolusi, trueness dan presisi. Akurasi merupakan hasil kombinasi dari trueness dan presisi. Namun demikian, ketiga istilah tersebut: resolusi, truenss dan presisi sering disalahartikan atau sering tertukar antara ketiga istilah tersebut. Untuk lebih jelasnya, ilustrasi dari resolusi, trueness dan presisi diperlihatkan pada gambar 3. Hasil pengukuran pada gambar 3 diperlihatkan sebagai simbol " •" dan nilai referensi diistilahkan dengan "Target". Pada gambar 3, trueness diperlihatkan sebagai perbedaan dari rata-rata hasil pengukuran yang diulang-ulang (dilambangkan dengan simbol "•") dengan nilai referensi "Target". Presisi diperlihatkan sebagai diameter lingkaran yang memuat $x \%$ dari total pengulanan pengukuran $n$ yang dilakukan. Pada umumnya, lingkaran tersebut yang merepresentasikan presisi memuat $95 \%$ (2 $\sigma$, dimana $\sigma$ adalah deviasi standar dari rata-rata) dari total hasil pengulangan pengukuran. Estimasi presisi menggunakan metode statistika dan pada umumnya mengasumsikan hasil pengukuran memiliki distribusi normal (Gaussian). Terakhir, resolusi digambarkan sebagai jarak terkecil yang dapat dicapai dari pergerakan atau indikasi suatu alat ukur. 


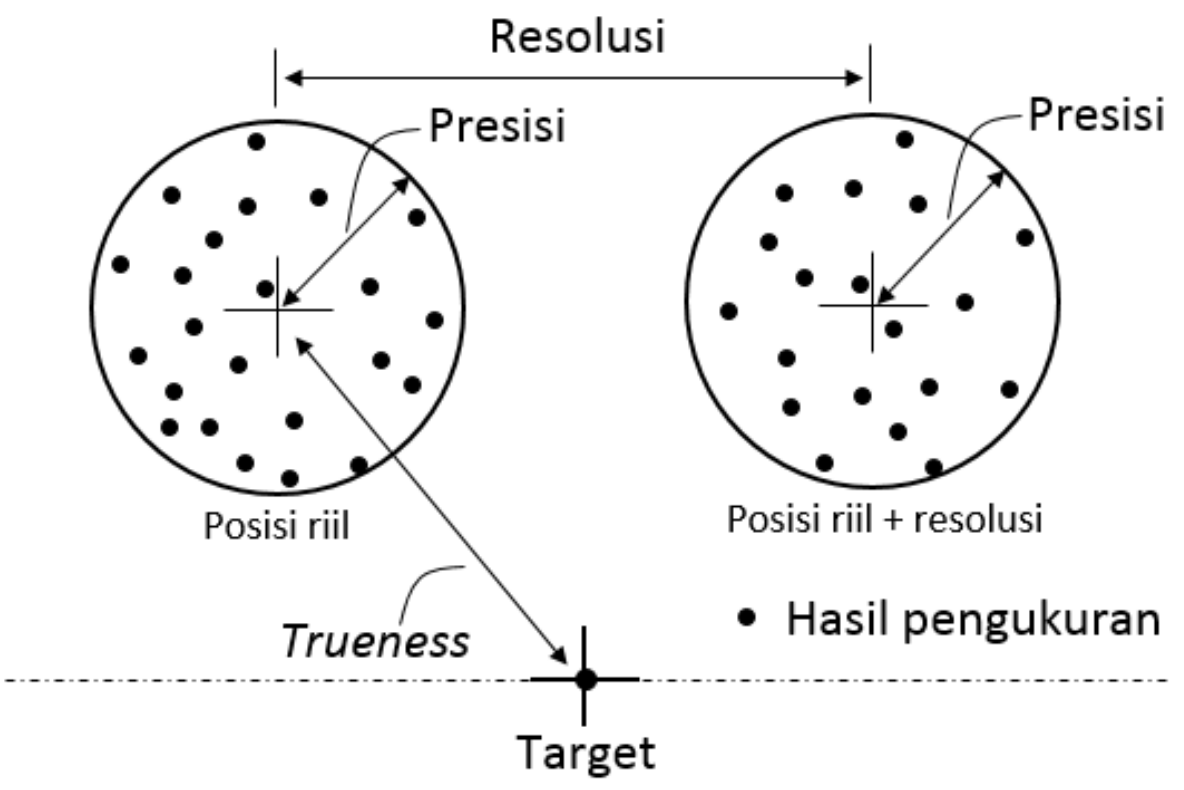

Gambar 3: Ilustrasi dari resolusi, trueness dan presisi.

- Kesalahan (error).

Kesalahan adalah nilai yang diukur dikurangi dengan nilai referensi. Pada umumnya, nilai referensi merujuk pada nilai yang terkalibrasi atau nilai nominal pada gambar teknik. Kesalahan (error) terbagi menjadi dua bagian, yaitu: kesalahan sistematik (systematic error) dan kesalahan acak (random error). Kesalahan $\varepsilon_{\text {total }}$ dapat diformulasikan sebagai:

$$
\varepsilon_{\text {total }}=\varepsilon_{\text {sistematik }}+\varepsilon_{\text {acak }}
$$

- Kesalahan sistematik (systematic error).

Kesalahan sistematik adalah komponen kesalahan yang mempunyai nilai konstan apabila pengukuran diulang atau bervairasi dengan caa yang dapat ditebak (patterned variation). Kesalahan sistematik harus dikoreksi apabila sumber dari kesalahan tersebut dapat diketahui. Nilai referensi dari kesalahan sistematik dalam praktisnya adalah nilai yang terkalibrasi atai nilai nominal.

- Kesalahan acak (random error).

Kesalahan acak adalah komponen kesalahan yang mempunyai sifat tidak dapat diprediksi apabila pengukuran diulang. Pada umumnya, nilai referensi dari kesalahan acak adalah nilai rata-rata dari hasil pengulangan pengukuran. Kesalahan acak mempunyai sebuah distribusi statistik yang dapat dikarakterisasikan dengan niai rata-rata dan standar deviasi dari distribusi statistik tersbeut.

- Bias.

Bias adalah estimasi dari kesalahan sistematik. Dengan kata lain, pada praktisnya kesalahan sistematik yang didapatan disebut sebagai bias.

- Ketidakpastian hasil pengukuran (measurement uncertainty)

Ketidakpastian hasil pengukuran adalah suatu nilai (parameter) non-negatif yang mengkarakterisasikan sebaran dari nilai suatu hasil pengukuran. 


\subsection{Analisis statistik}

Pada bagian ini, teori-teori statitika yang umum digunakan dalam pengukuran dimensi dan geometri, seperti untuk metode analisis data dan interpretasi data dijelaskan. Fokus utama pada penjelasan tersebut adalah mengenai distribusi statistik, karakterisasi dari distribusi statistik, dan metode analisis varian dan regresi linear. Pembaca diharapkan sudah mempunyai dasar-dasar ilmu probabilitas dan statistika sehingga sub-bab ini bisa dijadikan bahan pengingat untuk memahami isi buku secara keseluruhan.

Statistika adalah ilmu yang meliputi pengumpulan, presentasi dan pengolahan data yang digunakan untuk mencari solusi permasalahan (baik permasalahan teknis maupun non-teknis) dengan memperhitungkan variabilitas yang terkandung dalam data tersebut (Hines et al 2003). Konsep variabilitas selalu ditemui dalam kehidupan seharihari. Contoh yang paling releban yang dibahas dalam buku ini adalah pengukuran. Apabila suatu pengukuran diulang dengan kondisi yang sama persis, maka hasil pengulangan pengukuran tersebut akan berbeda dengan hasil pengukuran sebelumnya. Misalnya, apabila kita mengukur suatu panjang besi, mungkin pengukuran pertama memberikan hasil $25.56 \mathrm{~mm}$ dan pengukuran kedua (dengan situasi yang sama persis) memberikan hasil $25.54 \mathrm{~mm}$ dan seterusnya akan memberikan hasil yang berbeda apabila pengukuran tersebut diulang terus-menerus.

Statistika berbasis teori probabilitas yaitu teori yang digunakan untuk mengkuantifikasi derajat kepercayaan pada suatu kejadian atau situasi yang sedang diobservasi. Teori probabilitas dapat dipelajari dengan lebih detil di Hines et al 2003 dan Montgomery dan Runger 2003. Variabilitas dari suatu data observasi, misalnya data hasil pengukuran, menunjukan derajat ketidaktahuan kita dalam proses observasi (dalam hal ini) pengukuran tersebut. Semakin tinggi tingkat pamahaman kita terhadap suatu observasi atau pengukuran, maka hal-hal yang menyebabkan variabilitas pada data hasil observasi tersebut dapat dikurangi, misalnya dengan melakukan koreksi apabila kesalahan sistematik dari proses tersebut dapat diketahui.

\subsubsection{Variabel acak dan distribusi statistik}

\section{Variabel acak, fungsi distribusi probabilitas dan fungsi distribusi komulatif.}

Variabel acak (random variable) didefinisikan sebagai suatu variabel $X$ yang diasosiasikan dengan suatu hasil dari sebuah eksperimen acak $e$ (dalam hal ini bisa diartikan dengan suatu pengukuran) (Montgomery dan Runger 2003). Variabel $X$ tersebut diasosiasikan dengan setiap hasil eksperimen $e$ (suatu nilai riil) dalam ruang sample $S$ (e $\epsilon$ $S$ ). Karena hasil suatu eksperimen $e$ belum diketahui, maka nilai variabel acak $X$ yang akan muncul juga belum diketahui secara pasti. Dengan kata lain, variabel acak $X$ adalah suatu fungsi yang menyematkan sebuah nilai riil $e$ pada setiap nilai dalam ruang sampel haisl dari sebuah ekperimen acak.

Variabel acak pada umumnya dituliskan dengan huruf besar $X$. Nilai yang diukur dari variabel acak tersebut pada umumnya dituliskan dengan huruf kecil $x$. Sebagai contoh, misalnya $X$ adalah suatu variabel acak dari hasil pengukuran diameter, maka nilai variabel acak tersebut yang diukur dituliskan, misalnya sebagai $x=5 \mathrm{~mm}$.

Variabel acak dibagi menjadi dua macam, yaitu variabel acak diskrit (discrete random variable) dan variabel acak kontinu (continuous random variable). Variabel acak diskrit adalah variabel acak yang mempunyai batas jarak yang terbatas, misalnya banyaknya catat pada permukaan sebuah benda, proporsi dari komponen yang cacat per 1000 komponen dan banyaknya orang yang masuk ke sebuah laboratorium. Variabel acak kontinu adalah variabel acak yang mempunyai interval bilangan riil, baik dengan jarak yang terbatas (finite) maupun tak terbatas (inifinite), misalnya panjang, diameter, waktu, temperature dan massa.

Distribusi probabilitas dari sebuah variabel acak $X$ adalah sebuah fungsi yang menggambarkan atau merepresentasikan probabilitas atau kemungkinan variabel $X$ didapatkan (Montgomery dan Runger 2003). Distribusi probabilitas juga terbagi menjadi dua macam mengikuti jenis variabel acaknya, yaitu distribusi probabilitas kontinu dan distribusi probabilitas diskrit. Gambar 4 memperlihatkan distribusi probabilitas kotinu untuk variabel acak kontinu dan gambar 5 memperlihatkan distribusi probabilitas diskrit untuk variabel acak diskrit. Distribusi probabilitas kontinu dinamakan fungsi kepadatan probabilitas (probability density function/PDF) dan distribusi probabilitas diskrit dinamakan fungsi massa probabilitas (probability mass function/PMF). Dari gambar 4, dapat terlihat bahwa untuk distribusi kontinu, interval variabelnya merupakan bilangan riil (kontinu). Sedangkan pada gambar 5, terlihat bahwa distribusi diskrit, interval variabelnya merupakan bilangan bulat (integer). Untuk aplikasi 
pengukuran dimensi dan geometri, pada umumnya analisis pengukuran tersebut mengacu pada distribusi kontinu, misalnya distribusi normal, distribusi uniform (seragam) dan distribusi $U$.

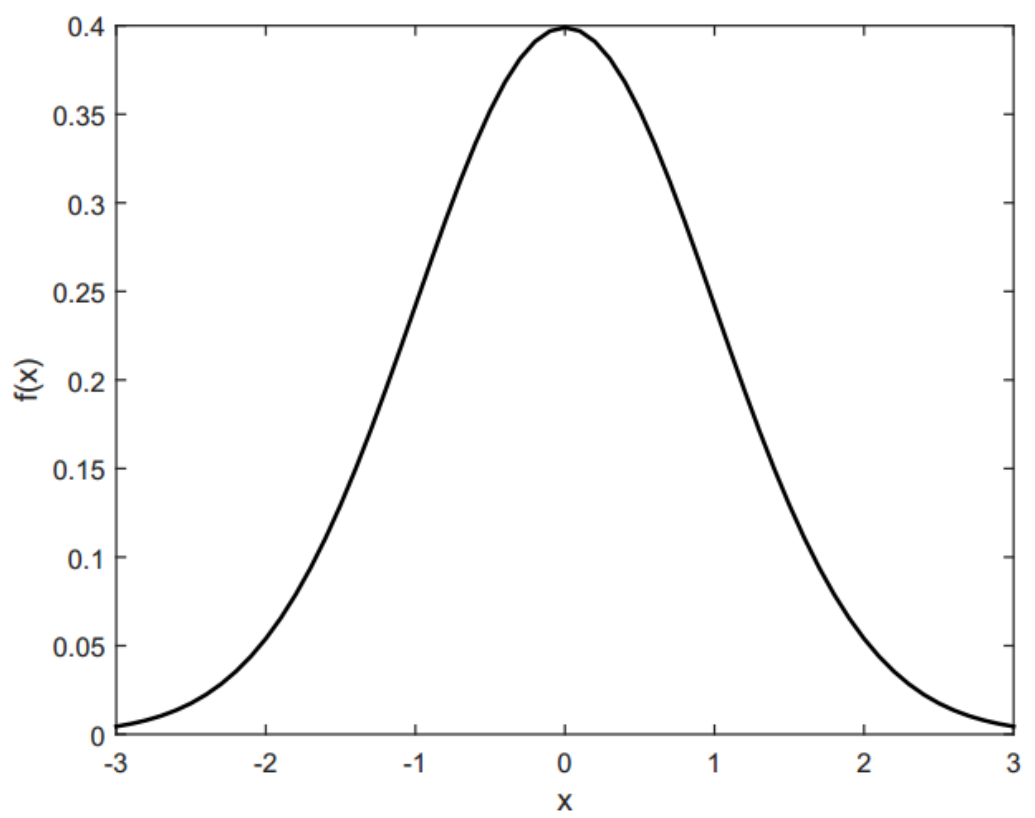

Gambar 4: Distribusi probabilitas kontinu.

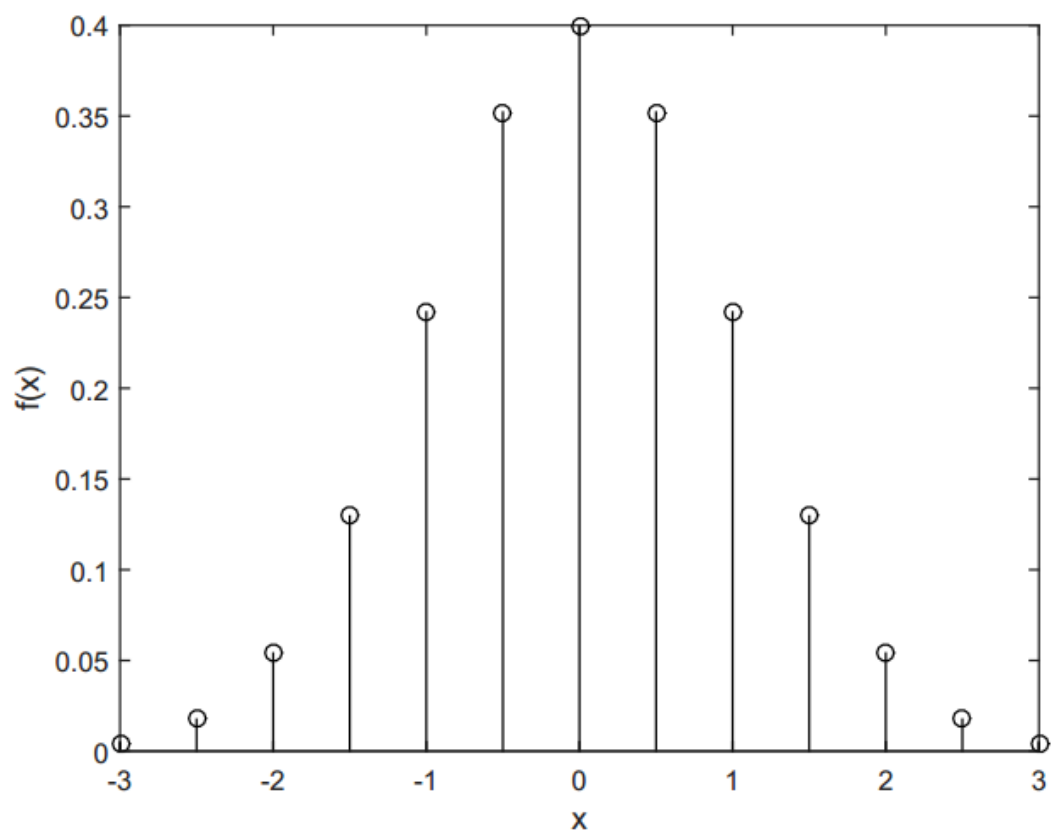

Gambar 5: Distribusi probabilitas diskrit. 
fungsi massa probabilitas (probability mass function/PMF) $P_{X}\left(x_{i}\right)$ diformulasikan sebagai:

$$
f\left(x_{i}\right)=P_{X}\left(x_{i}\right)=P_{X}\left(X=x_{i}\right)=\sum_{j \in \phi_{i}} P_{X}\left(x_{i j}\right)
$$

dimana $\mathrm{X}$ adalah suatu variabel acak diskrit, nilai $x_{i 1}, x_{i 2}, \ldots, x_{i k}$ merepresentasikan nilai $\mathrm{X}$ sedemikian rupa sehingga $H\left(x_{i j}\right)=x_{i}$ untuk suatu set nilai indeks $\phi_{i}=\left\{j: j=1,2, \ldots, s_{i}\right\}$. Gambar 5 memperlihatkan contoh suatu fungsi massa probabilitas.

properti PMF adalah sebagai berikut:

- $f\left(x_{i}\right) \geq 0$

- $\sum_{i=1}^{n} f\left(x_{i}\right)=1$

- $f\left(x_{i}\right)=P\left(X=x_{i}\right)$

Untuk probabilitas diskrit, pada umumnya dikatakan probabilitas suatu nilai $X=a$ muncul (dapat diambil) dari suatu ruang sampel $S$.

$$
f(x=a)=P_{X}(x=a)=\sum_{m=1}^{n}\left(x_{m}=a\right) /_{N}
$$

dimana $a$ adalah suatu nilai variabel acak diskrit yang muncul dari ruang sampel $S$ dan $n$ banyaknya jumlah kemunculan nilai $a$ tersebut dari ruang sampel $S$. Sebagai contoh, misalkan probabilitas nilai 2 muncul dari suatu distribusi diskrit $X$ (pada gambar 5), yaitu probabilitas $x=2$ atau $P(x=2)$, diperlihatkan pada gambar 6 .

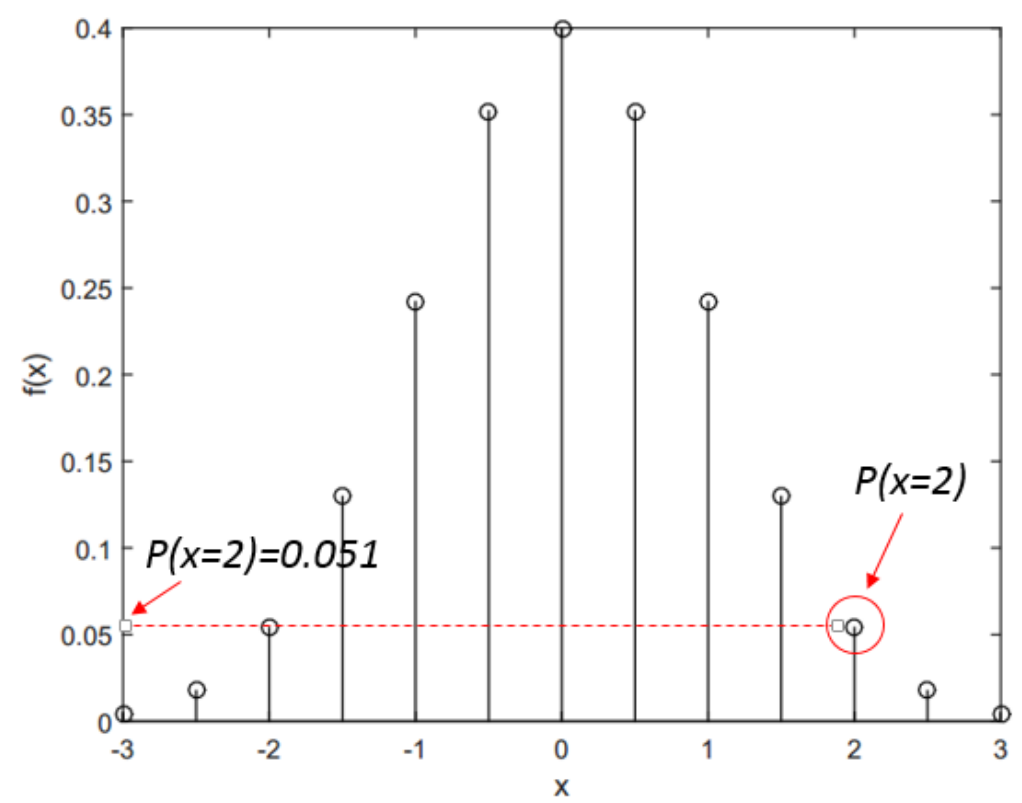

Gambar 6: Contoh presentasi probabilitas $x=2$ dari suatu variabel acak diskrit $X$ yang mempunyai fungsi probabilitas seperti pada gambar 5 .

Fungsi distribusi kumulatif (comulative distribution function) dari fungsi massa probabilitas (PMF), dinotasikan dengan $F(x)$, didefinisikan sebagai:

$$
F(x)=P(X \leq x)=\sum_{x_{i} \leq x} f\left(x_{i}\right)
$$


Untuk varibel acak diskrit, $F(x)$ mempunyai properti sebagai:

- $F(x)=P(X \leq x)=\sum_{x_{i} \leq x} f\left(x_{i}\right)$

- $0 \leq F(x) \leq 1$

- $\quad$ Jika $x \leq y$, maka $F(x) \leq F(y)$

fungsi densitas probabilitas (probability density function/PDF) $f(x)$ adalah sebuah fungsi dimana:

- $f(x) \geq 0$

- $\int_{-\infty}^{\infty} f(x) d x=1$

- $\quad P(a \leq X \leq b)=\int_{a}^{b} f(x) d x=$ area dibawah kurva $f(x)$ dari $a$ sampai $b$.

Untuk probabilitas kontinu, pada umumnya dikatakan probabilitas suatu nilai $X<a$ muncul (dapat diambil) dari suatu ruang sampel $S$ atau probabilitas suatu nilai $a<X<b$ muncul (dapat diambil) dari suatu ruang sampel $S$.

$$
\begin{aligned}
& (X \leq a)=\int_{-\infty}^{a} f(x) d x \\
& P(a \leq X \leq b)=\int_{a}^{b} f(x) d x
\end{aligned}
$$

Sebagai contoh, misalkan probabilitas suatu variabel acak kontinu $X$ muncul dengan nilai antara 1 dan $2 P(1<x<2)$, dimana variabel acak tersebut mempunyai fungsi probabilitas seperti yang diperlihatkan (pada gambar 4), diperlihatkan pada gambar 7 .

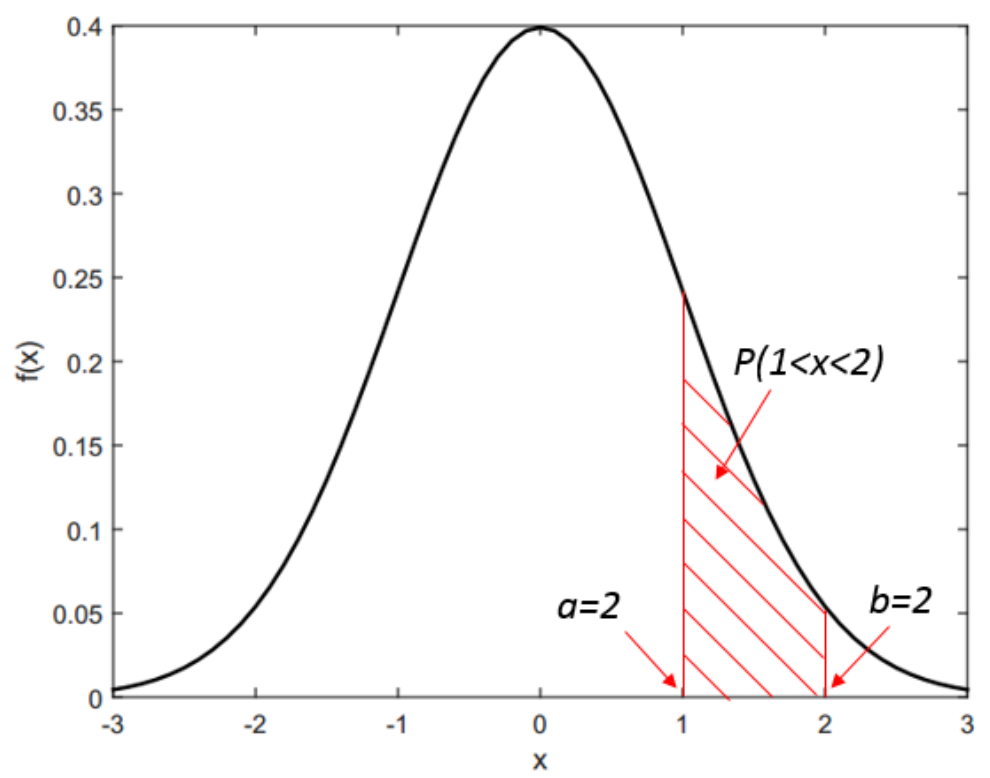

Gambar 7: Contoh presentasi probabilitas $1<x<2$ dari suatu variabel acak kontinu $X$ yang mempunyai fungsi probabilitas seperti pada gambar 4 .

Fungsi distribusi kumulatif (comulative distribution function) dari fungsi densitas probabilitas (PDF), dinotasikan dengan $F(x)$, didefinisikan sebagai:

$$
F(x)=P(X \leq a)=\int_{-\infty}^{a} f(x) d(x) \text { untuk }-\infty<a<\infty
$$




\section{Mean (niai rata-rata) dan varian.}

Mean (nilai rata-rata atau average) $\mu$ adalah suatu nilai yang menggambarkan atau mengkuantifikasikan kecenderungan dari lokasi tengah (central tendency) dari suatu distribusi probabilitas. Seringkali mean (nilai rata-rata) $\mu$ diekspresikan sebagai nilai ekspektasi (expected value) $E(x)$ yaitu nilai rata-rata (average) dengan sampel atau pengulangan yang banyak (long-run) dari suatu variabel acak (Montgomery 2001). Mean atau nilai ekspektasi diformulasikan sebagai:

$$
\begin{aligned}
& \mu=E(x)=\int_{-\infty}^{\infty} x f(x) d x ; \text { untuk varibel acak kontinu } \\
& \mu=E(x)=\sum_{x} x P(x) ; \text { untuk variabel acak diskrit }
\end{aligned}
$$

Varian $\sigma^{2}=\operatorname{Var}(x)$ adalah suatu nilai yang menggambarkan atau mengkuantifikasi sebaran (variabilitas) dari suatu distribusi statistik. Varian $\sigma^{2}$ diformulasikan sebagai:

$$
\begin{aligned}
\sigma^{2} & =\operatorname{Var}(x)=\int_{-\infty}^{\infty}(x-\mu) f(x) d x ; \text { untuk variabel acak kontinu } \\
\sigma^{2} & =\operatorname{Var}(x)=\sum_{x}(x-\mu) p(x) ; \text { untuk variabel acak diskrit }
\end{aligned}
$$

Varian $\sigma^{2}$ dapat diekspresikan dengan dalam bentuk sebuah nilai ekspektasi, yaitu:

$$
\sigma^{2}=\operatorname{Var}(x)=E\left[(y-\mu)^{2}\right]
$$

Istilah lain untuk menyebutkan mean atau nilai ekspektasi adalah momen pertama (first moment) dan istilah lain untuk menyebutkan varian adalah momen kedua (second moment) dari suatu distribusi probabilitas. Akar quadrat dari $\sigma^{2}$, yaitu $\sigma$, disebut sebagai deviasi standar. Beberapa properti yang penting dari nilai ekspektasi $E(x)$ dan varian $\operatorname{Var}(x)$ adalah:

- $E(C)=C ; c$ adalah suatu nilai konstanta

- $E(x)=\mu ; x$ adalah suatu variabel acak

- $E(C x)=C E(x)=C \mu$

- $\operatorname{Var}(C)=0$

- $\operatorname{Var}(x)=\sigma^{2}$

- $\operatorname{Var}(C x)=C^{2} \operatorname{var}(x)=C^{2} \sigma^{2}$

Jika ada dua varianbel acak $x_{1}$ dan $x_{2}$, maka:

- $E\left(x_{1}+x_{2}\right)=E\left(x_{1}\right)+E\left(x_{2}\right)=\mu_{1}+\mu_{2}$

- $\operatorname{Var}\left(x_{1}+x_{2}\right)=\operatorname{Var}\left(x_{1}\right)+\operatorname{Var}\left(x_{2}\right)+2 \operatorname{Cov}\left(x_{1}, x_{2}\right)$

dimana:

$$
\operatorname{Cov}\left(x_{1}, x_{2}\right)=E\left[\left(x_{1}-\mu_{1}\right)\left(x_{2}-\mu_{2}\right)\right]
$$

Properti-properti dari nilai ekspektasi $E(x)$ dan varian $\operatorname{Var}(x)$ sangat penting untuk diketahui. Salah satu penggunaan properti-properti tersebut adalah ketika menurunkan formula GUM untuk menentukan nilai ketidakpastian dari hasil suatu pengukuran (lihat bab ketidakpastian). 


\subsubsection{Berbagai macam distribusi probabilitas dan central limit theorem}

Distribusi probabilitas kontinu dan diskrit memiliki berbagai macam jenis distribusi. Bagian ini memperlihatkan berbagai macam jenis distribusi probabilitas tersebut yang paling umum digunakan atau muncul dalam berbagai aplikasi praktis, baik aplikasi pengukuran maupun aplikasi non-pengukuran. Distribusi probabilitas kontinu yang akan dipresentasikan adalah distribusi Normal, Uniform, Eksponensial, Gamma, Weibull dan Lognormal. Sedangkan, distribusi probabilitas diskrit yang akan dipresentasikan adalah distribusi Bernoulli, Uniform, Binomial, Geometrik dan Poison. Distribusi yang paling umum digunakan dalam aplikasi pengukuran adalah distribusi Normal dan Uniform. Berbagai macam distribusi tersebut dapat digunakan untuk, misalnya, memodelkan data historis dari suatu kontributor nilai ketidakpastian suatu hasil pengukuran (lihat bab ketidakpastian).

\section{Distribusi probabilitas kontinu.}

\section{- Distribusi Normal}

Distribusi statistik yang paling utama adalah distribusi normal (Gaussian). Distribusi normal pertama kali dipelajari pada abad ke-18 dimana pola dari kesalahan pengukuran diketahui mengikuti sebuah pola yang simetri. Distribusi normal memiliki bentuk kurva seperti lonceng (bell curve) yang mempunyai pola yang simetri. Distribusi jenis ini memiliki peran penting dalam menentukan nilai ketidakpastian tipe A dan berbagai analisis lainnya yang berhubungan dengan data hasil pengukuran, seperti analisis regressi dan analisis varian (ANOVA). Gauss adalah orang yang pertama kali mempubilasikan distribusi normal pada tahun 1809, sehingga distribusi normal juga disebut sebagai distribusi Gaussian. Distribusi normal merupakan basis dari semua distirbusi kontinu. Hal ini yang menyebabkan distribusi ini dinamakan dengan distribusi "Normal".

Fungsi kepadatan probabilitas dari distribusi Uniform diformulasikan sebagai:

$$
f(x)=\frac{1}{\sigma \sqrt{2 \pi}} e^{\frac{-(x-\mu)^{2}}{2 \sigma^{2}}}
$$

dimana $-\infty \leq x \leq \infty,-\infty \leq \mu \leq \infty$ dan $\sigma>0$. Adalah $\mu$ mean dari distribusi tersebut dan $\sigma^{2}$ adalah varian dari distribusi tersebut. Notasi singkat distribusi normal pada umumnya ditulis $X \sim N\left(\mu, \sigma^{2}\right)$. Fungsi kepadatan probabilitas dari distribusi Normal diperlihatkan pada gambar 8. Gambar 9 memperlihatkan fungsi kepadatan probabilitas distribusi Normal dengan berbagai macam nilai mean dan varian.

Distribusi Normal mempunyai properti-properti sebagai berikut:

1. $\int_{-\infty}^{\infty} f(x) d x=1$

2. $f(x) \geq 0$, untuk semua $x$ Properti nomor 1 dan 2 merupakan properti yang dimiliki oleh semua fungsi kepadatan probabilitas.

3. $\lim _{x \rightarrow \infty} f(x)=0$ dan $\lim _{x \rightarrow-\infty} f(x)=0$

4. $f(\mu+x)=f(\mu-x)$. Fungsi tersebut simetri terhadap $\mu$

5. Nilai maksimum $f(x)$ adalah di $x=\mu$

6. Poin infleksi, yaitu point dimana perubahan arah terjadi, dari $f(x)$ adalah di $x=\mu \pm \sigma$ 


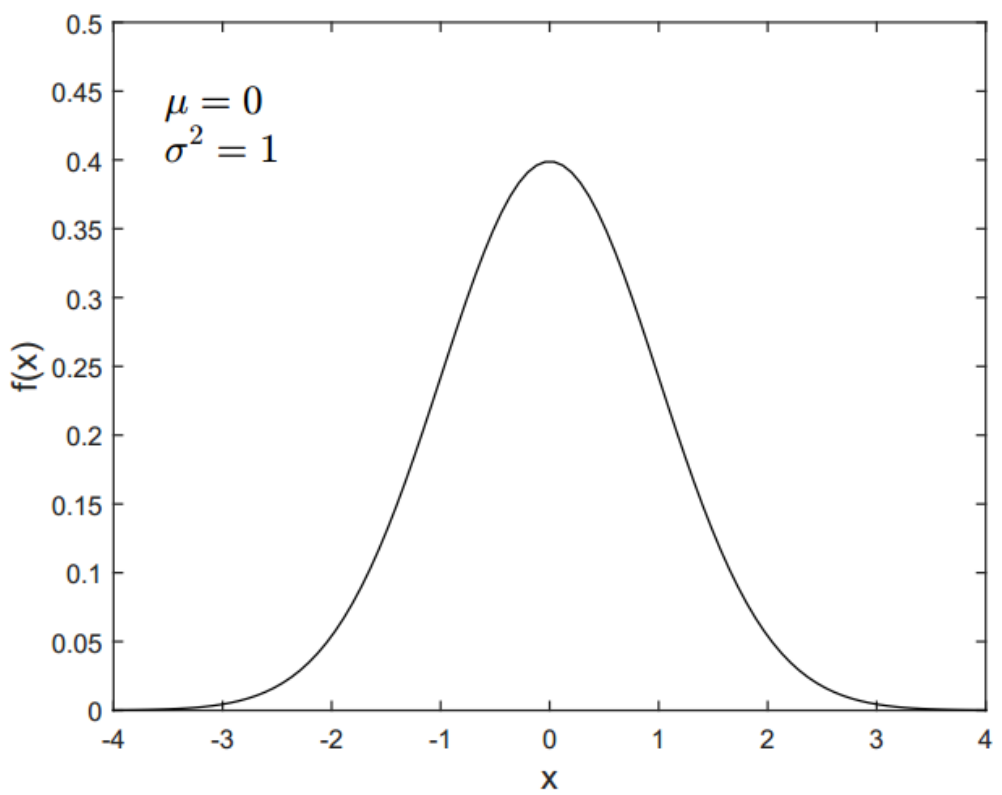

Gambar 8: Fungsi kepadatan probabilitas dari distribusi Normal dengan mean $\mu=0$ dan varian $\sigma^{2}$.

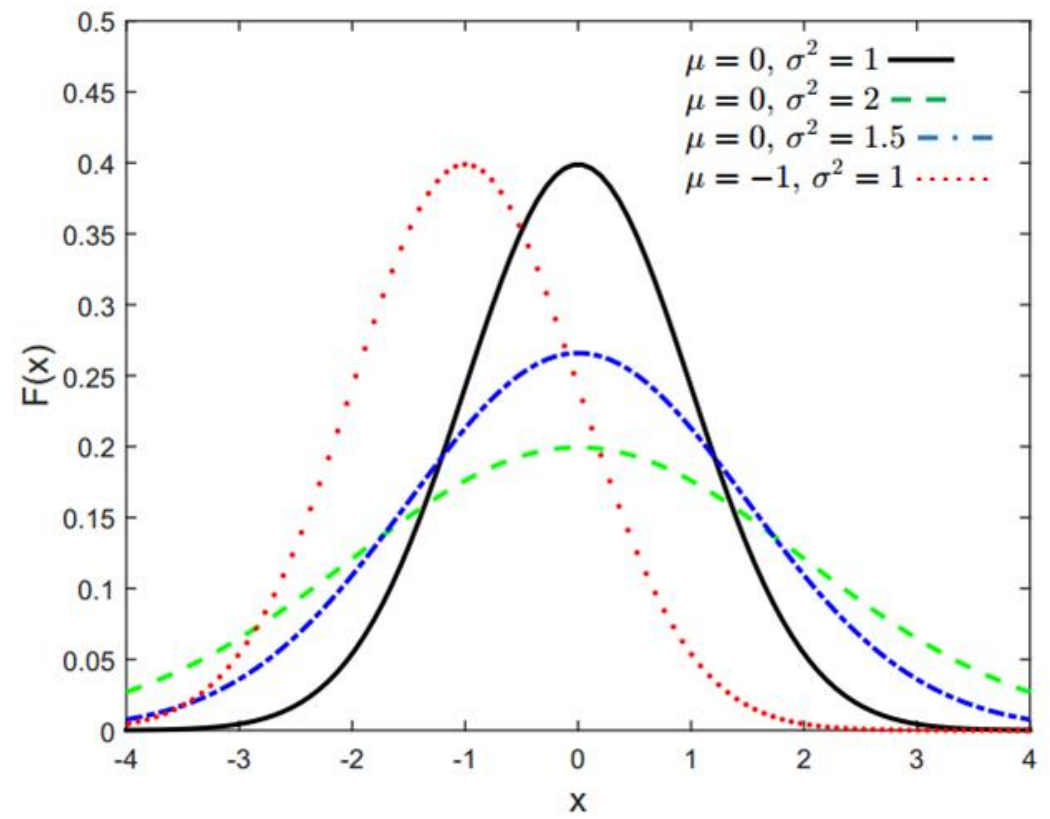

Gambar 9: Fungsi kepadatan probabilitas distribusi normal dengan berbagai nilai mean dan varian. 
Mean $\mu$ dari distribusi Normal adalah:

$$
\mu=\int_{-\infty}^{\infty} x f(x) d x=\int_{-\infty}^{\infty} \frac{x}{\sigma \sqrt{2 \pi}} e^{\frac{-(x-\mu)^{2}}{2 \sigma^{2}}} d x
$$

Dengan menggunakan variabel $z=\frac{(x-\mu)}{\sigma}$, maka didapatkan:

$$
\mu=\int_{-\infty}^{\infty} \frac{1}{\sqrt{2 \pi}}(\mu+\sigma z) e^{\frac{-z^{2}}{2}} d z=\mu \int_{-\infty}^{\infty} \frac{1}{\sqrt{2 \pi}} e^{\frac{-z^{2}}{2}} d z+\sigma \int_{-\infty}^{\infty} \frac{1}{\sqrt{2 \pi}} z e^{\frac{-z^{2}}{2}} d z
$$

Karena $\int_{-\infty}^{\infty} \frac{1}{\sqrt{2 \pi}} e^{\frac{-z^{2}}{2}} d z$ adalah sebuah fungsi kepadatan probabilitas distribusi normal dengan $\mu=0$ dan $\sigma^{2}=$ 1 , maka sesuai dengan properti $\int_{-\infty}^{\infty} f(x) d x=1$, nilai $\int_{-\infty}^{\infty} \frac{1}{\sqrt{2 \pi}} e^{\frac{-z^{2}}{2}} d z=1$. Kemudian, $\int_{-\infty}^{\infty} \frac{1}{\sqrt{2 \pi}} z e^{\frac{-z^{2}}{2}} d z=$ $-\left.\frac{1}{\sqrt{2 \pi}} z e^{\frac{-z^{2}}{2}}\right|_{-\infty} ^{\infty}=0$, maka:

$$
\mu=\mu[1]+\sigma[0]=\mu
$$

varian $\sigma^{2}$ dari distribusi Normal adalah

$$
\sigma^{2}=\int_{-\infty}^{\infty}(x-\mu) f(x) d x=\int_{-\infty}^{\infty}(x-\mu)^{2} \frac{1}{\sigma \sqrt{2 \pi}} e^{\frac{-(x-\mu)^{2}}{2 \sigma^{2}}} d x
$$

Dengan menggunakan variabel $z=\frac{(x-\mu)}{\sigma}$, maka didapatkan:

$$
\begin{gathered}
\sigma^{2}=\int_{-\infty}^{\infty} \sigma^{2} z^{2} \frac{1}{\sqrt{2 \pi}} e^{\frac{-z^{2}}{2}} d z=\sigma^{2} \int_{-\infty}^{\infty} z^{2} \frac{1}{\sqrt{2 \pi}} e^{\frac{-z^{2}}{2}} d z=\sigma^{2}\left[\left.\frac{-z e^{\frac{-z^{2}}{2}}}{\sqrt{2 \pi}}\right|_{-\infty} ^{\infty}+\int_{-\infty}^{\infty} \frac{1}{\sqrt{2 \pi}} e^{\frac{-z^{2}}{2}} d z\right] \\
\sigma^{2}=\sigma^{2}[0+1]=\sigma^{2}
\end{gathered}
$$

Fungsi komulatif dari distribusi Normal adalah:

$$
F(x)=P(X \leq x)=\int_{-\infty}^{x} \frac{1}{\sigma \sqrt{2 \pi}} e^{\frac{-(x-\mu)^{2}}{2 \sigma^{2}}} d x
$$

Fungsi komulatif dari distribusi Normal diperlihatkan pada gambar 10. Gambar 11 memperlihatkan fungsi komulatif dari distribusi Normal dengan berbagai macam nilai mean dan varian. 


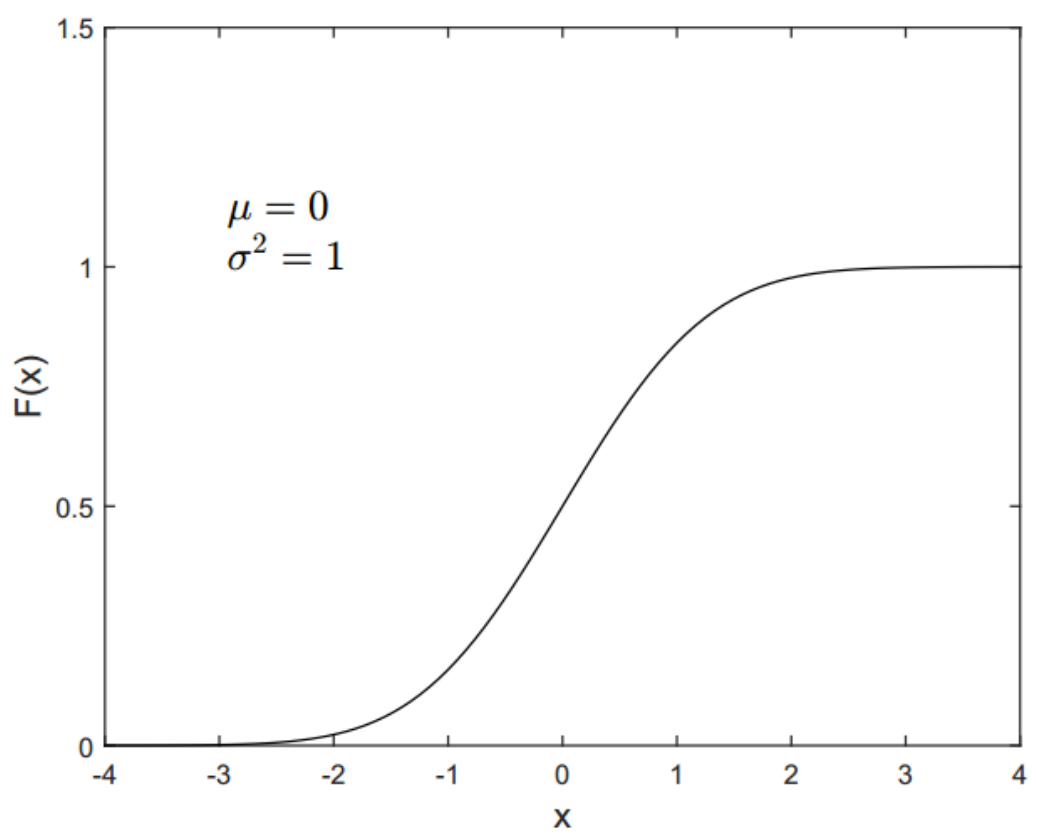

Gambar 10: Fungsi komulatif dari distribusi Normal.

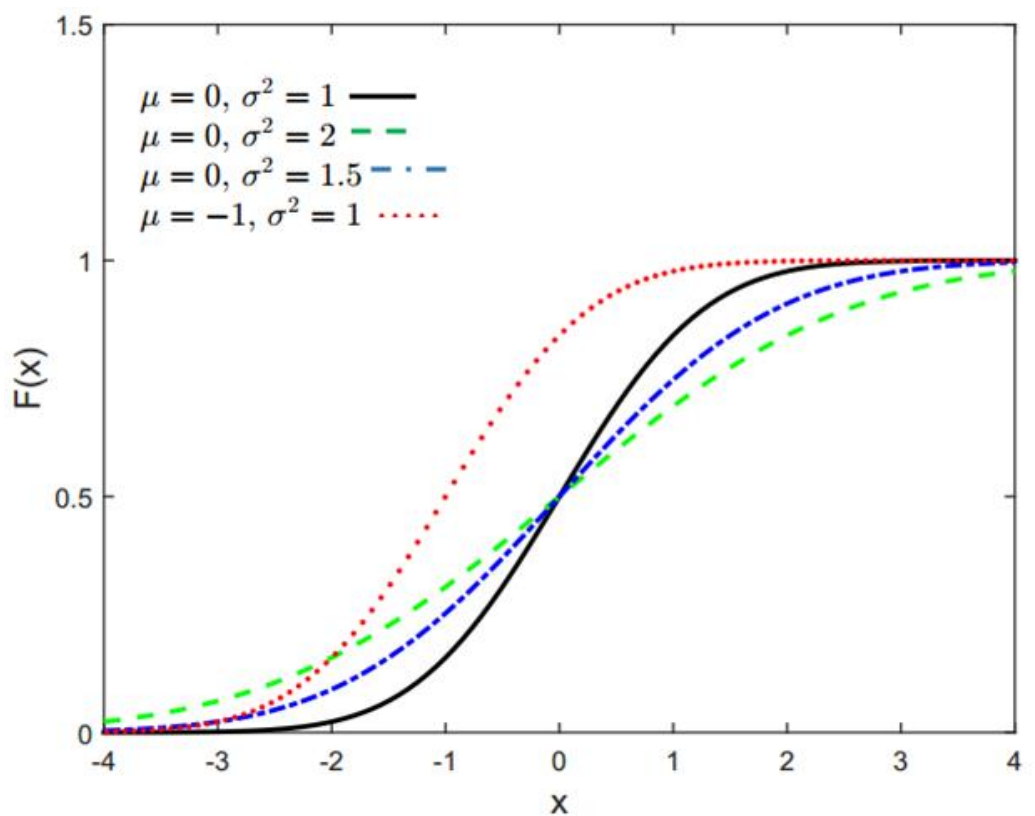

Gambar 11: Fungsi komulatif dari distribusi Normal dengan berbagai nilai mean dan varian.

\section{- Distribusi Uniform}

Distribusi Uniform mempunyai aplikasi dalam bidang pengukuran terutama untuk menentukan kontribusi ketidakpastian dari suatu toleransi dalam gambar teknik atau dari sertifikat kalibrasi (lihat bab ketidakpastian). Fungsi kepadatan probabilitas dari distribusi Uniform diformulasikan sebagai: 


$$
f(x)=\left\{\begin{array}{cc}
\frac{1}{b-a}, & a \leq x \leq b \\
0, & \text { selainnya }
\end{array}\right.
$$

dimana $a$ adalah nilai minimum dan $b$ adalah nilai maksimum dari variabel acak $X$. ). Fungsi kepadatan probabilitas dari distribusi Uniform diperlihatkan pada gambar 12 .

Mean $\mu$ dan varian $\sigma^{2}$ dari distribusi Uniform adalah:

$$
\begin{gathered}
\mu=\int_{-\infty}^{\infty} x f(x) d x=\int_{a}^{b} \frac{x d x}{b-a}=\frac{b+a}{2} \\
\sigma^{2}=\int_{-\infty}^{\infty}(x-\mu) f(x) d x=\int_{a}^{b} \frac{x^{2} d x}{b-a}-\left[\frac{b+a}{2}\right]^{2}=\frac{(b-a)^{2}}{12}
\end{gathered}
$$

Fungsi komulatif dari distribusi Uniform adalah:

$$
F(x)=\left\{\begin{array}{c}
0, x<a, \\
\int_{a}^{x} \frac{d x}{b-a}=\frac{x-a}{b-a}, \quad a \leq x<b, \\
1, \quad x \geq b .
\end{array}\right.
$$

Fungsi komulatif dari distribusi Uniform diperlihatkan pada gambar 13.

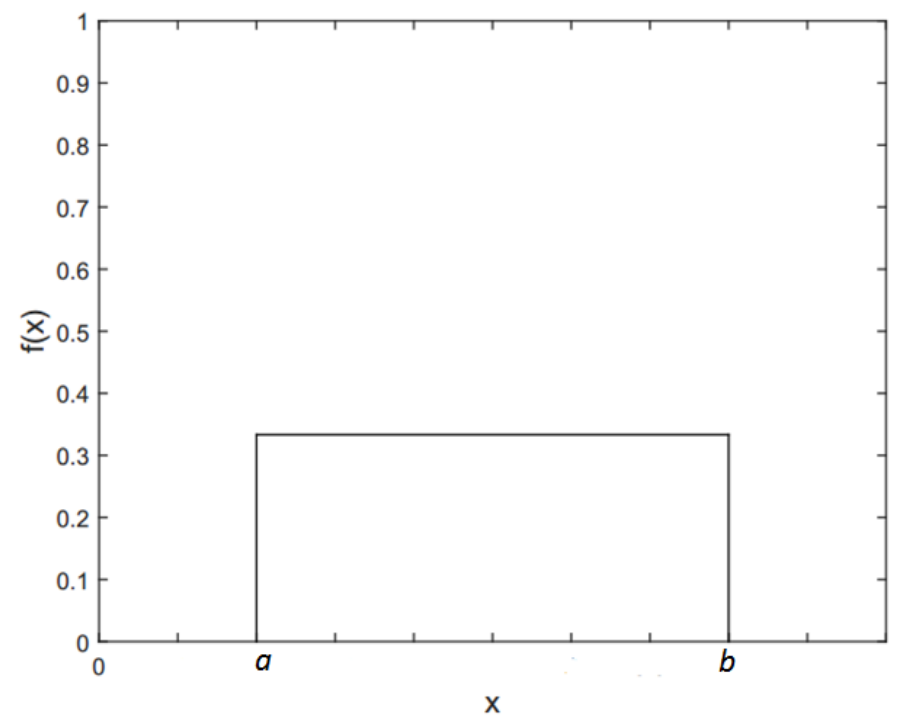

Gambar 12: Fungsi kepadatan probabilitas dari distribusi Uniform. 


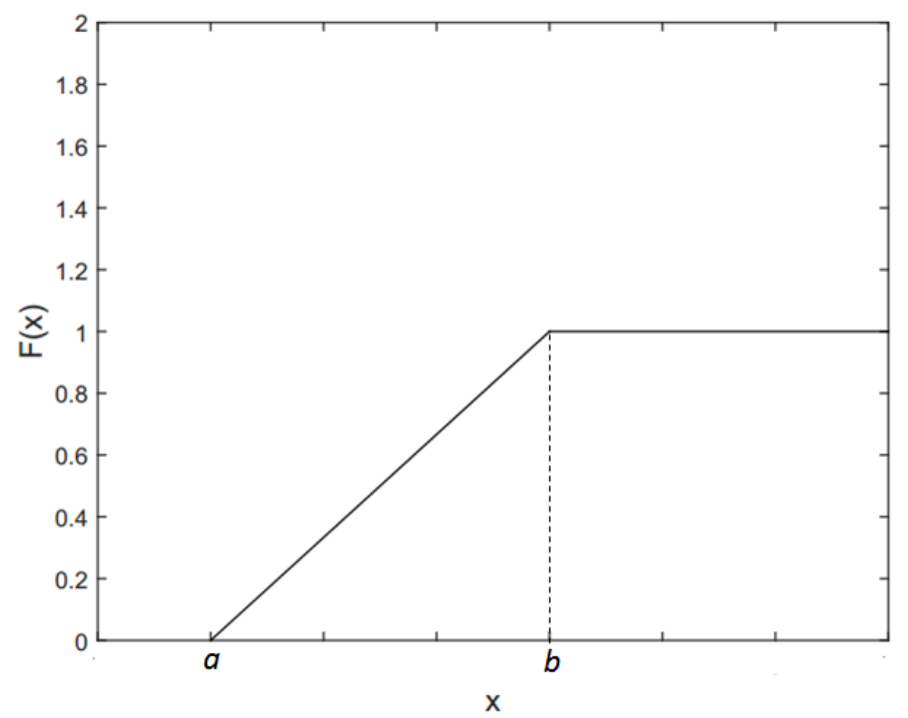

Gambar 13: Fungsi komulatif dari distribusi Uniform.

\section{- Distribusi Eksponensial}

Fungsi kepadatan probabilitas dari distribusi Eksponensial diformulasikan sebagai:

$$
f(x)=\left\{\begin{array}{c}
\lambda e^{-\lambda x}, \quad x \geq 0 \\
0, \quad x<0
\end{array}\right.
$$

dimana parameter $\lambda$ adalah bilangan riil dan konstanta positif. Fungsi kepadatan probabilitas dari distribusi Eksponensial diperlihatkan pada gambar 14.

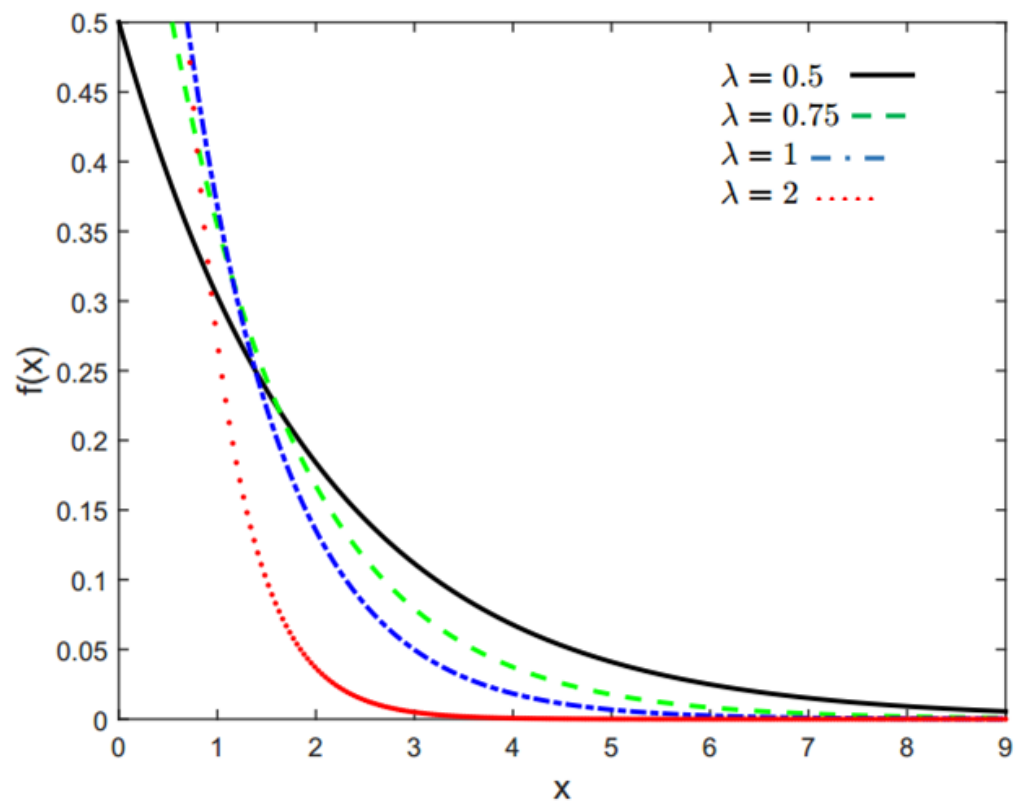

Gambar 14: Fungsi kepadatan probabilitas dari distribusi Eksponensial. 
Mean $\mu$ dari distribusi Eksponensial adalah:

$$
\begin{gathered}
\mu=\int_{-\infty}^{\infty} x f(x) d x=\int_{0}^{\infty} x \lambda e^{-\lambda x} d x=-\left.x e^{-\lambda x}\right|_{0} ^{\infty}+\int_{0}^{\infty} e^{-\lambda x} d x \\
\mu=\frac{1}{\lambda}
\end{gathered}
$$

varian $\sigma^{2}$ dari distribusi Eksponensial adalah:

$$
\begin{aligned}
& \sigma^{2}=\int_{-\infty}^{\infty}(x-\mu) f(x) d x=\int_{-\infty}^{\infty} x^{2} \lambda e^{-\lambda x} d x-\left(\frac{1}{\lambda}\right)^{2} \\
& \sigma^{2}=\left[-\left.x^{2} e^{-\lambda x}\right|_{0} ^{\infty}+2 \int_{0}^{\infty} x e^{-\lambda x} d x\right]-\left(\frac{1}{\lambda}\right)^{2}=\frac{1}{\lambda^{2}}
\end{aligned}
$$

Fungsi komulatif dari distribusi Eksponensial adalah:

$$
F(x)=\left\{\begin{array}{c}
0, x<0, \\
\int_{0}^{x} \lambda e^{-\lambda x} d x=1-e^{-\lambda x}, x \geq 0 .
\end{array}\right.
$$

\section{- Distribusi Gamma}

Fungsi kepadatan probabilitas dari distribusi Gamma diformulasikan sebagai:

$$
f(x)=\left\{\begin{array}{c}
\frac{\lambda}{\Gamma(r)}(\lambda x)^{r-1} e^{-\lambda x}, x>0, \\
0, \quad x \leq 0 .
\end{array}\right.
$$

dimana parameter $\lambda>0$ dan $r>0 . r$ adalah parameter bentuk dan $\lambda$ adalah parameter skala. $\Gamma(r)$ adalah fungsi Gamma $=(r-1)$ !. Dapat dilihat bahwa distribusi eksponensial merupakan bentuk khusus dari distribusi Gamma dengan $r=1$. Fungsi kepadatan probabilitas dari distribusi Gamma diperlihatkan pada gambar 15 . 


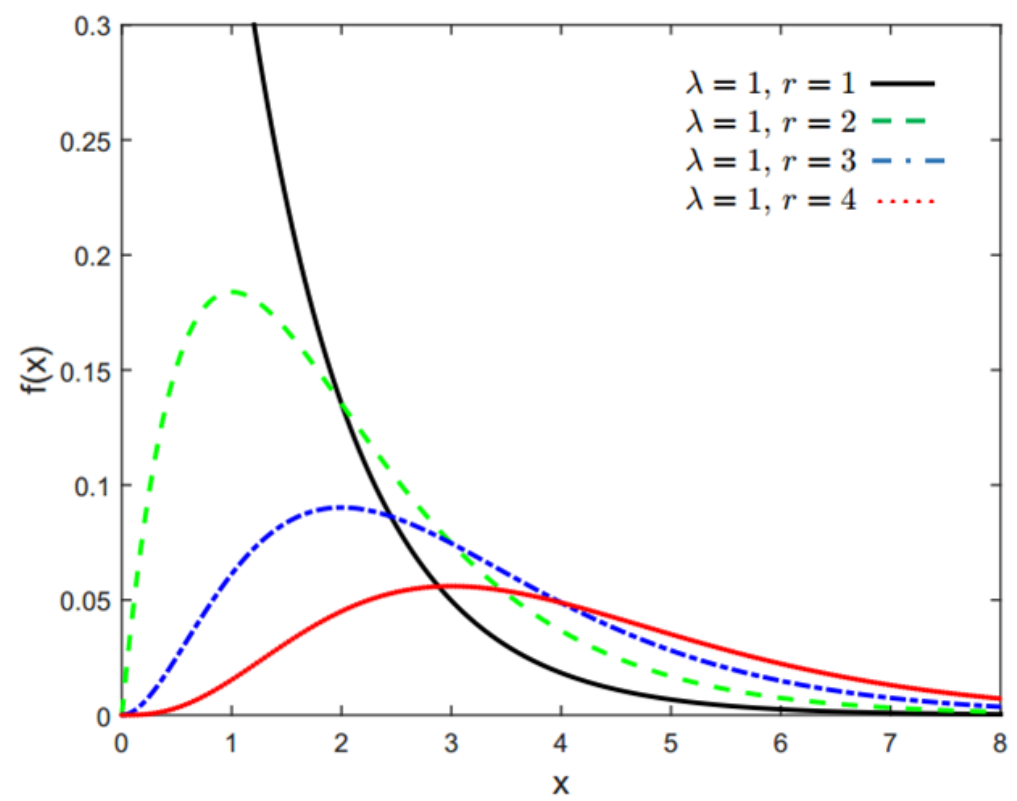

Gambar 15: Fungsi kepadatan probabilitas dari distribusi Gamma dengan $\lambda=1$. Pada gambar ini, terlihat bahwa distribusi Gamm dengan $r=1$ merupakan distribusi Eksponensial.

Mean $\mu$ dan varian $\sigma^{2}$ dari distribusi Gamma adalah:

$$
\begin{gathered}
\mu=\frac{r}{\lambda} \\
\sigma^{2}=\frac{r}{\lambda^{2}}
\end{gathered}
$$

Fungsi komulatif dari distribusi Gamma adalah:

$$
F(x)=1-\sum_{k=0}^{r-1} e^{-\lambda x}(\lambda x)^{k} / k !
$$

\section{- Distribusi Weibull}

Distirbusi Weibull banyak dipakai untuk memodelkan waktu kegagalan (time-to-failure) suatu sistem mekanik atau elektrik. Fungsi kepadatan probabilitas dari distribusi Weibull diformulasikan sebagai:

$$
f(x)=\left\{\begin{array}{c}
\frac{\beta}{\delta}\left[\frac{x-\gamma}{\delta}\right]^{\beta-1} \exp \left[-\left(\frac{x-\gamma}{\delta}\right)^{\beta}\right], x \geq \gamma \\
0, x<\gamma .
\end{array}\right.
$$

dimana parameter $\gamma$ adalah parameter lokasi $-\infty<\gamma<\infty, \delta$ adalah parameter skala dan $\beta$ adalah parameter bentuk. Keunikan distribusi Weibull adalah dengan mengatur parameter-parameter tersebut, berbagai macam jenis distribusi probabilitas dapat diaproksimasi dengan menggunakan distribusi Weibull. Fungsi kepadatan probabilitas dari distribusi Weibull diperlihatkan pada gambar 16. 


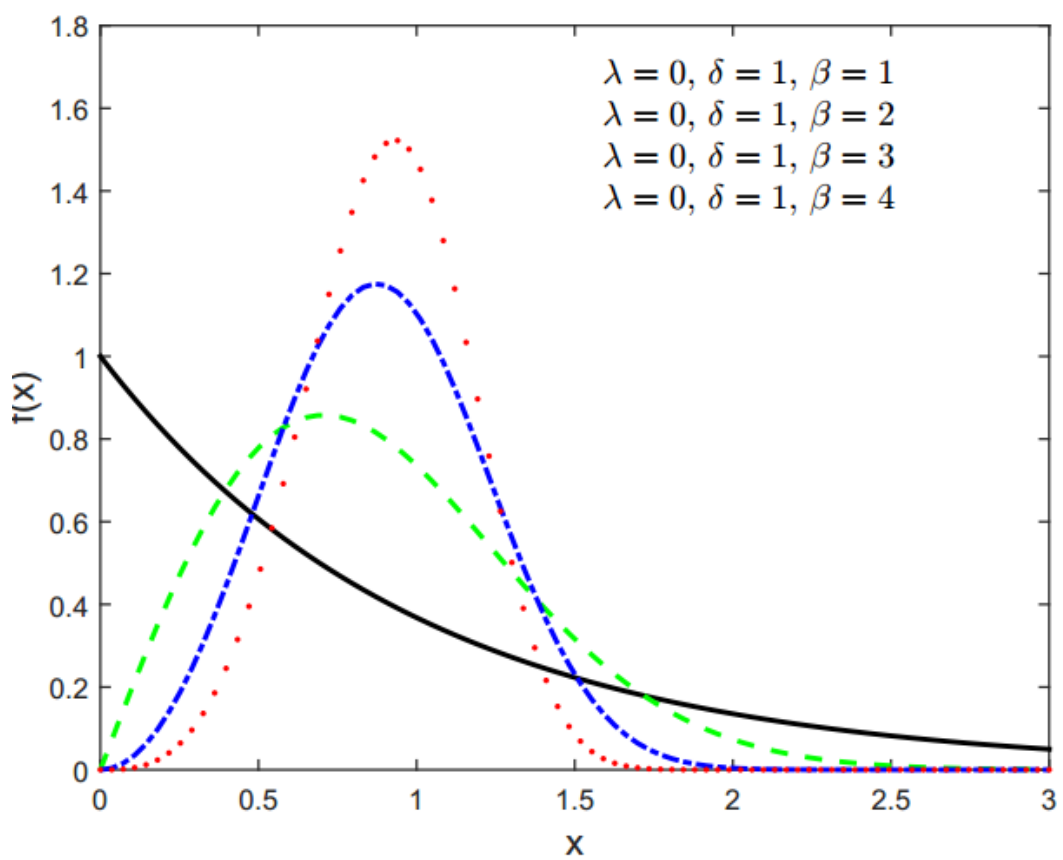

Gambar 16: Fungsi kepadatan probabilitas dari distribusi Weibull.

Mean $\mu$ dan varian $\sigma^{2}$ dari distribusi Weibull adalah:

$$
\begin{aligned}
& \mu=\gamma+\delta \Gamma\left(1+\frac{1}{\beta}\right) \\
& \sigma^{2}=\delta^{2}\left\{\Gamma\left(1+\frac{2}{\beta}\right)-\left[\Gamma\left(1+\frac{1}{\beta}\right)\right]^{2}\right\}
\end{aligned}
$$

Fungsi komulatif dari distribusi Weibull adalah:

$$
F(x)=1-\exp \left[-\left(\frac{x-\gamma}{\delta}\right)^{\beta}\right], x \geq \gamma
$$

Dapat terlihat bahwa distribusi Weibull mempunyai beberapa parameter yang dapat diatur nilainya untuk memodelkan berbagai macam jenis distribusi suatu variabel acak. Hal ini sangat bermanfaat, misalnya, dalam memodelkan suatu kontributor nilai ketidakpastian, dimana kontributor tersebut dimodelkan dari suatu data historis hasil pengukuran (lihat bab ketidakpastian).

\section{- Distribusi Lognormal}

Fungsi kepadatan probabilitas dari distribusi Lognormal diformulasikan sebagai:

$$
f(x)=\frac{1}{x \sigma \sqrt{2 \pi}} \exp \left[-\frac{(\ln x-\theta)^{2}}{2 \omega^{2}}\right], 0<x<\infty
$$

dimana parameter distribusi tersebut adalah $\theta$ dan $\omega^{2}$. Fungsi kepadatan probabilitas dari distribusi Lognormal diperlihatkan pada gambar 17. 


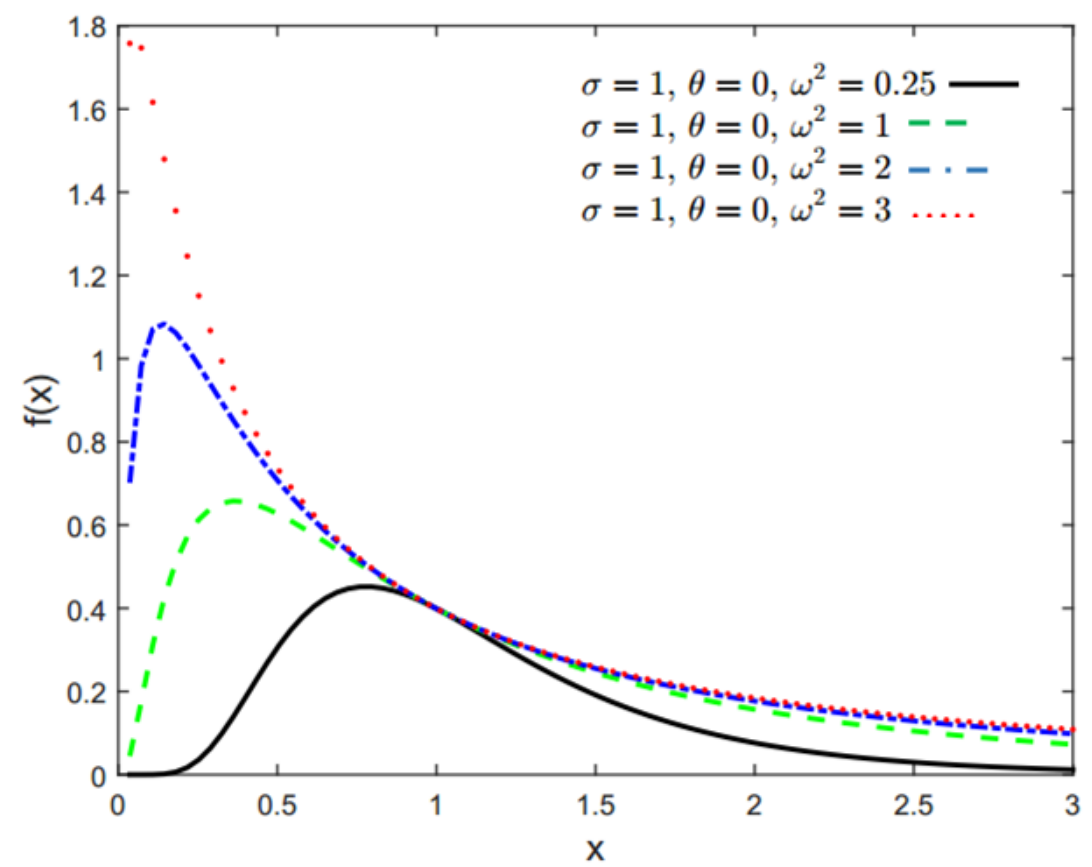

Gambar 17: Fungsi kepadatan probabilitas dari distribusi Lognormal.

Mean $\mu$ dan varian $\sigma^{2}$ dari distribusi Lognormal adalah:

$$
\begin{aligned}
& \mu=e^{\theta+\omega^{2} / 2} \\
& \sigma^{2}=e^{2 \theta+\omega^{2}}\left(e^{\omega^{2}}-1\right)
\end{aligned}
$$

\section{Distribusi probabilitas diskrit.}

Fungsi massa probabilitas (kalau untuk variabel kontinu disebut fungsi kepadatan probabilitas) suatu distribusi variabel diskrit $X$ dinotasikan sebagai $P\left(X=x_{i}\right)=f\left(x_{i}\right)$. Variabel $X$ merupakan bilangan bulat (integer). $f\left(x_{i}\right)$ mempunyai bentuk representasi berupa diagram garis (line diagram). Fungsi distribusi probabilitas diskrit berguna untuk memodelkan hasil pengukuran yang bersifat kualitatif, yang biasanya hasil pengukuran diklasifikasikan dalam bentuk sebuah bilangan bulat, misalnya: hasil inspeksi warna sebuah permukaan benda berupa terang (dikodekan sebagai 2), cerah (dikodekan sebagai 1) dan gelap (dikodekan sebagai 0).

\section{- Distribusi Bernoulli}

Distribusi Bernoulli hanya mempunyai dua jenis keluaran (output). Fungsi massa probabilitas dari distribusi Bernoulli diformulasikan sebagai:

$$
f\left(x_{i}\right)=\left\{\begin{aligned}
p, & x_{j}=1, j=1,2,3 \ldots n \\
1-p=q, & x_{j}=0, j=1,2,3 \ldots n \\
0, & \text { selainnya } .
\end{aligned}\right.
$$


Fungsi massa probabilitas dari distribusi Bernoulli diperlihatkan pada gambar 18 .

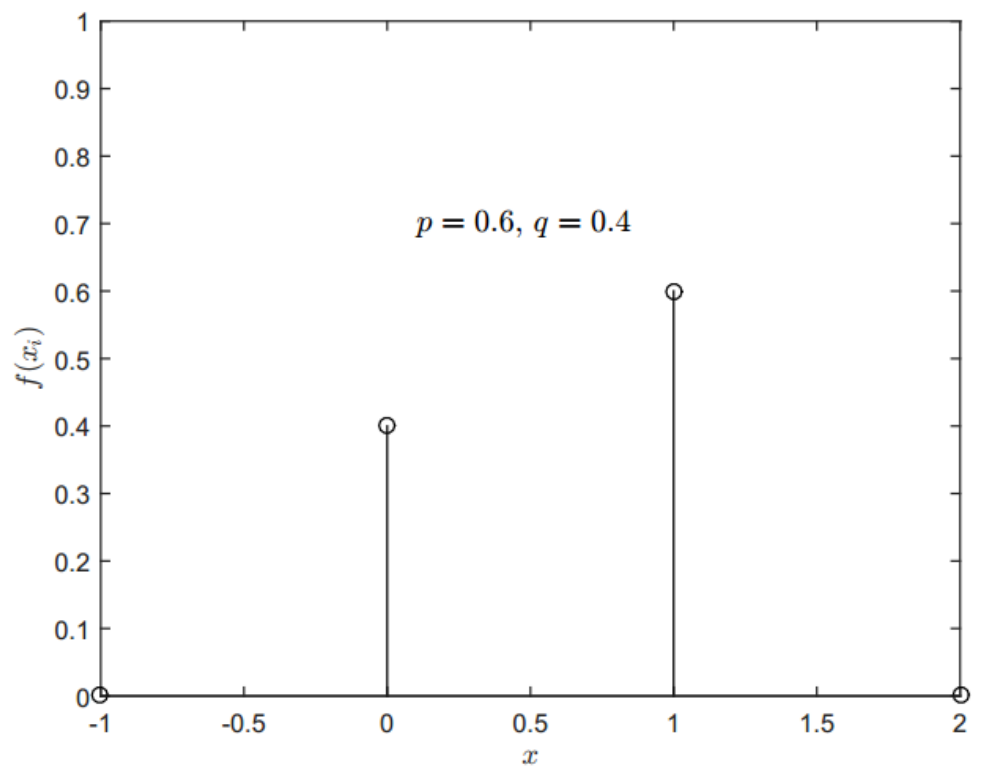

Gambar 18: Fungsi massa probabilitas dari distribusi Bernoulli.

Mean $\mu$ dan varian $\sigma^{2}$ dari distribusi Bernoulli adalah:

$$
\begin{gathered}
\mu=\sum_{x} x P(x)=(1 \cdot p)+(0 \cdot q)=p \\
\sigma^{2}=\sum_{x}(x-\mu) p(x)=\left[\left(1^{2} \cdot p\right)+\left(0^{2} \cdot q\right)\right]-p^{2}=p(1-p)=p q
\end{gathered}
$$

- Distribusi Uniform diskrit

Fungsi massa probabilitas dari distribusi Uniform diformulasikan sebagai:

$$
f\left(x_{i}\right)=\frac{1}{n}
$$

Fungsi massa probabilitas dari distribusi Uniform diperlihatkan pada gambar 19. 


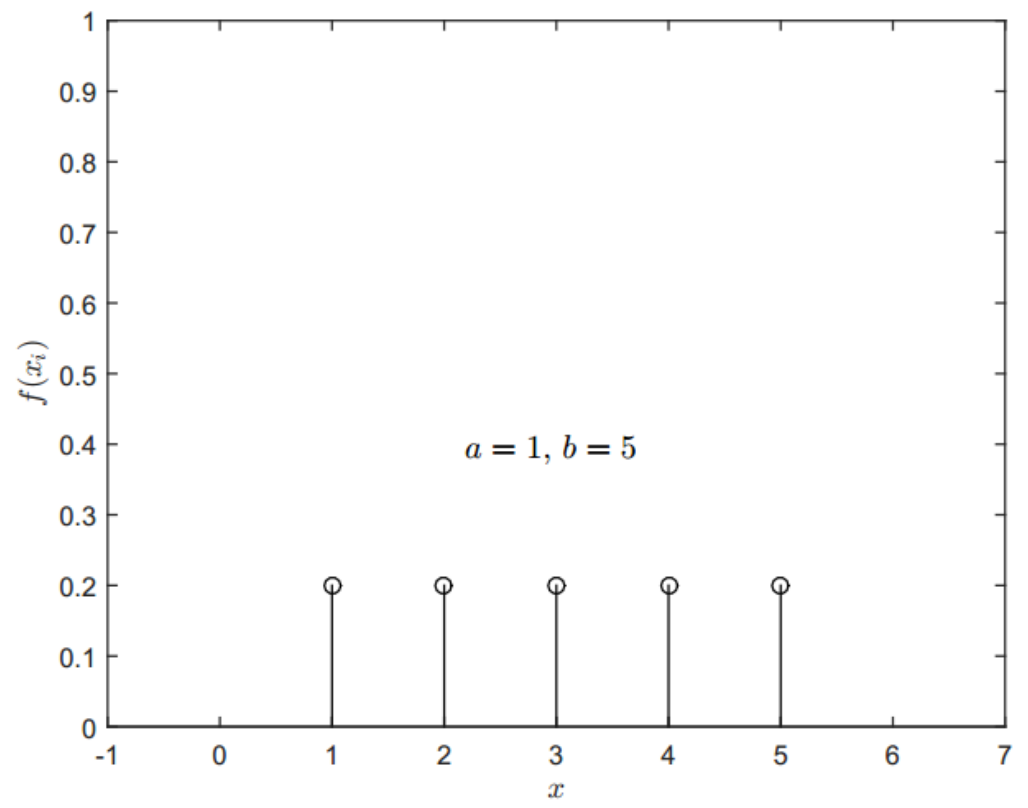

Gambar 19: Fungsi massa probabilitas dari distribusi Uniform.

Mean $\mu$ dan varian $\sigma^{2}$ dari distribusi Uniform adalah:

$$
\begin{aligned}
& \mu=\frac{b+a}{2} \\
& \sigma^{2}=\frac{(b-a+1)^{2}-1}{12}
\end{aligned}
$$

dimana $a$ adalah nilai minimum dan $b$ adalah nilai maksimum dari suatu variabel acak diskrit $X$.

\section{- Distribusi Binomial}

Fungsi massa probabilitas dari distribusi Binomial diformulasikan sebagai:

$$
\begin{gathered}
f\left(x_{i}\right)=\left(\begin{array}{l}
n \\
x
\end{array}\right) p^{x}(1-p)^{n-x} \\
f\left(x_{i}\right)=\left(\begin{array}{l}
n \\
x
\end{array}\right) p^{x}(q)^{n-x}, x=0,1,2,3, \ldots \text {. n dan } q=1-p .
\end{gathered}
$$

dimana $n$ adalah banyaknya percobaan (trials) independen. Setiap percobaan (trial) hanya mempunyai dua jenis keluaran, misalnya 0 dan 1. $p$ adalah probabilitas keluaran $=1$ pada setiap percobaan dan merupakan bilangan bulat $0<p<1$. Fungsi massa probabilitas dari distribusi Binomial diperlihatkan pada gambar 20 . 

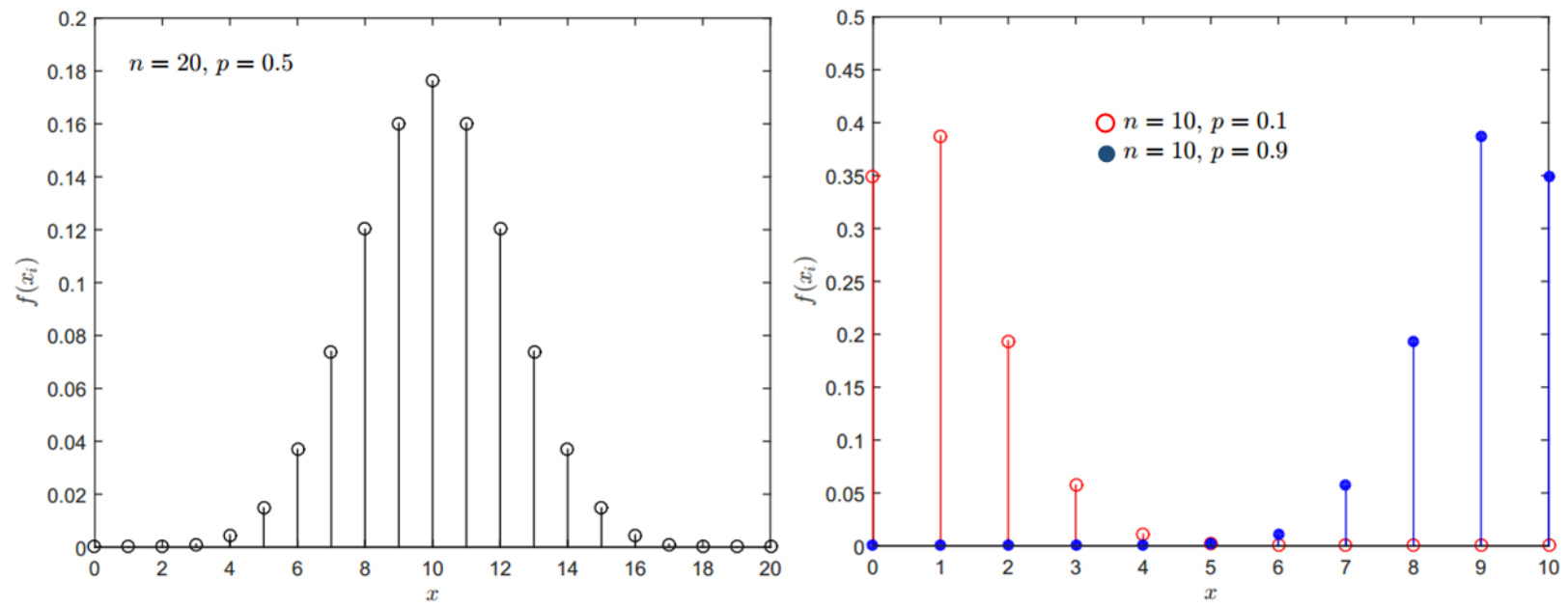

Gambar 20: Fungsi massa probabilitas dari distribusi Binomial.

Mean $\mu$ dan varian $\sigma^{2}$ dari distribusi Binomial adalah:

$$
\begin{aligned}
& \mu=n p \\
& \sigma^{2}=n p q
\end{aligned}
$$

\section{- Distribusi Geometrik}

Distribusi geometrik menggambarkan jumlah percobaan sebuah variabel acak $X$ sampai mendapatkan suatu hasil A yang dinginkan (first failure atau first success). Fungsi massa probabilitas dari distribusi Geometrik diformulasikan sebagai:

$$
f\left(x_{i}\right)=(1-p)^{x-1} p, \quad \mathrm{x}=1,2,3, \ldots
$$

dimana $p$ adalah parameter distribusi yaitu $0<p<1$. Fungsi massa probabilitas dari distribusi Geometrik diperlihatkan pada gambar 21. 


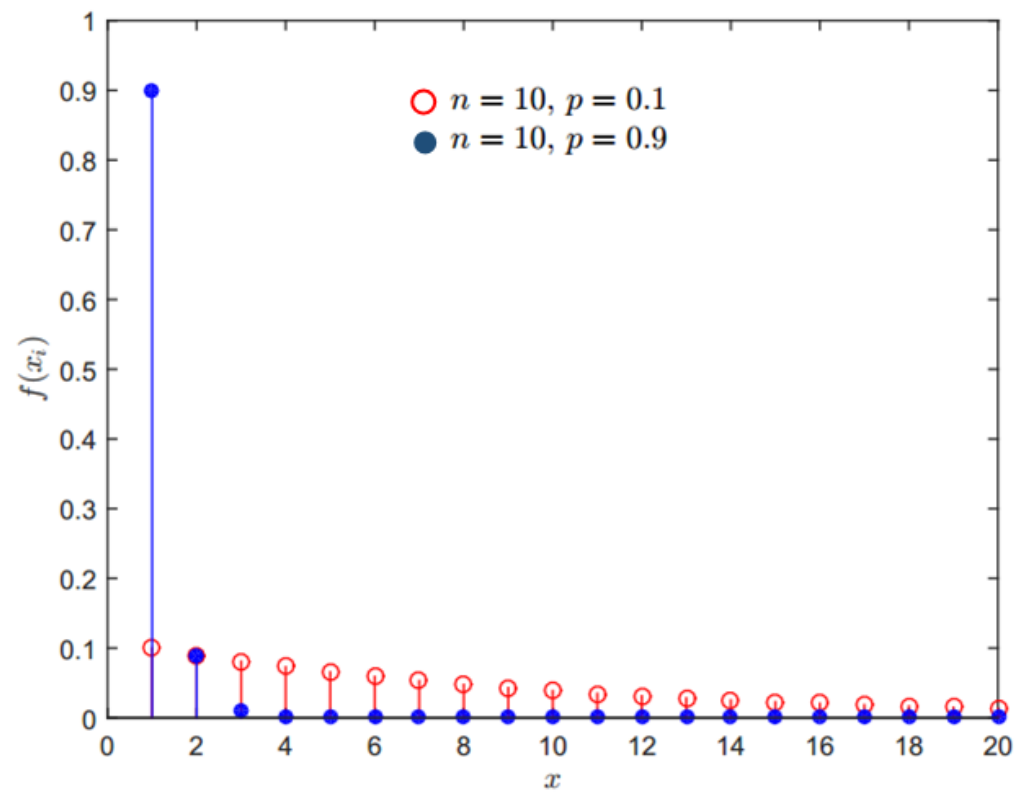

Gambar 21: Fungsi massa probabilitas dari distribusi Geometrik.

Mean $\mu$ dan varian $\sigma^{2}$ dari distribusi Geometrik adalah:

$$
\begin{aligned}
& \mu=\frac{1}{p} \\
& \sigma^{2}=\frac{(1-p)}{p^{2}}
\end{aligned}
$$

\section{- Distribusi Poisson}

Fungsi massa probabilitas dari distribusi Poisson diformulasikan sebagai:

$$
f\left(x_{i}\right)=\frac{e^{-\lambda} \lambda^{x}}{x !}, x=0,1,2,3, \ldots
$$

dimana $0<\lambda$ dan $\lambda=p n$. $n$ adalah jumlah percobaan dan $p$ adalah sebuah hasil percobaan sama dengan suatu nilai A. Fungsi massa probabilitas dari distribusi Poisson diperlihatkan pada gambar 22. 

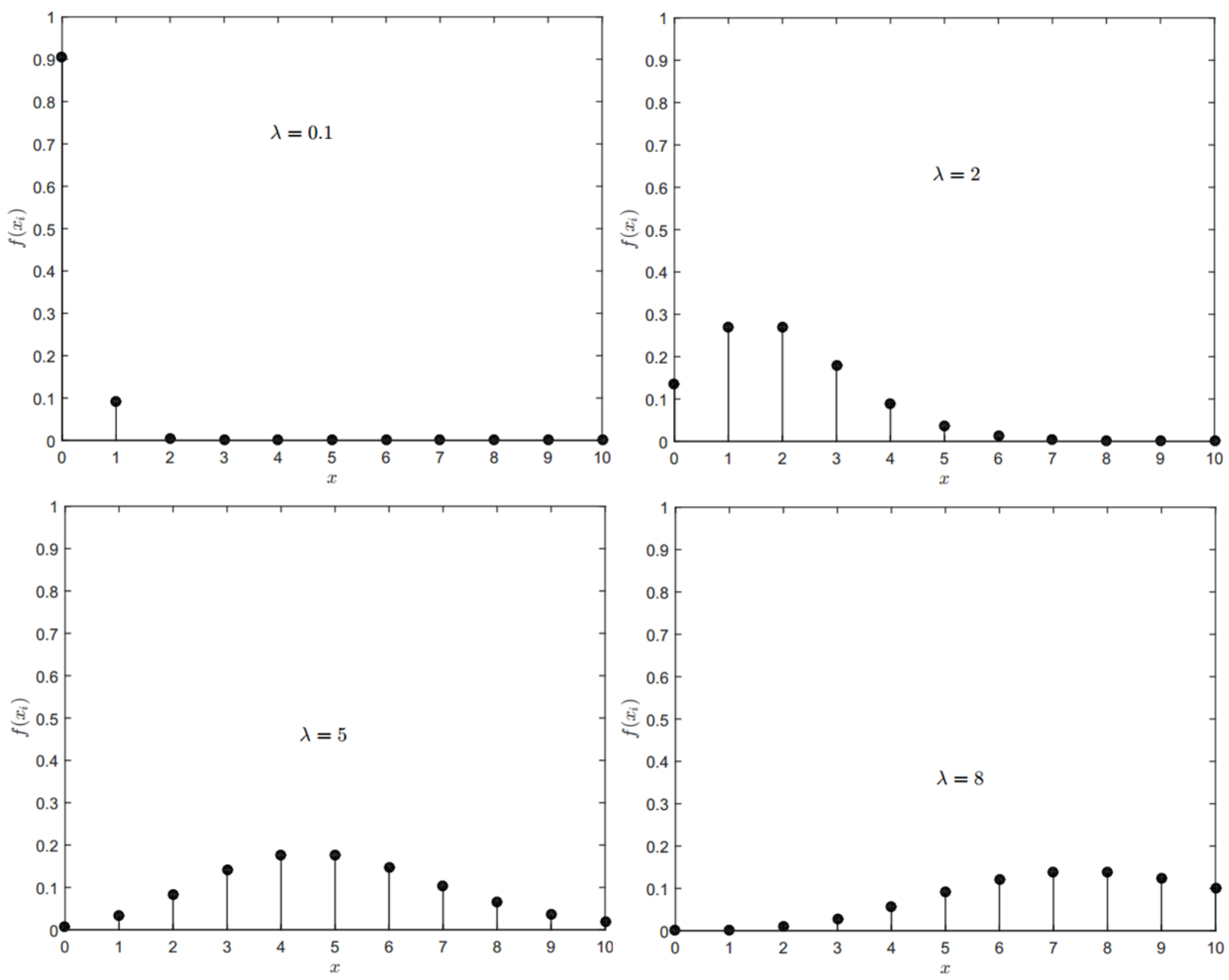

Gambar 22: Fungsi massa probabilitas dari distribusi Poisson.

Mean $\mu$ dan varian $\sigma^{2}$ dari distribusi Poisson adalah:

$$
\begin{aligned}
& \mu=\lambda \\
& \sigma^{2}=\lambda
\end{aligned}
$$

\section{Central limit theorem.}

Central limit theorem menyatakan bahwa apabila berbagai macam variabel acak dengan distribusi probabilitas yang berbeda-beda, apabila variabel-variabel tersebut saling dijumlahkan, maka jumlah dari variabel-variabel tersebut cenderung mengikuti distribusi normal. Selain itu, teori tersebut mengatakan bahwa rata-rata aritmatik dari sebuah variabel acak, dengan pengulangan yang banyak, akan terdistribusi secara normal. Central limit theorem dapat dirangkum sebagai berikut (Montgomery 2001):

- Apabila $y_{1}, y_{2}, \ldots, y_{n}$ adalah sebuah seri dari $n$ percobaan dan merupakan variabel acak bebas dengan 
$E\left(y_{i}\right)=\mu$ dan $V\left(y_{i}\right)=\sigma^{2}$ (keduanya merupakai bilangan hingga) dan $x=y_{1}+y_{2}+\cdots+y_{n}$, maka: $z_{n}=$ $\frac{x-n \mu}{\sqrt{n \sigma^{2}}}$ mempunyai sebuah aproksimasi distribusi $N(0,1)$ sedemikian rupa sehingga jika $F_{n}(z)$ adalah fungsi distribusi dari $z_{n}$ dan $\varphi(z)$ adalah fungsi distirbusi dari variabel acak $N(0,1)$, maka $\lim _{n \rightarrow \infty} F_{n}(z) / \varphi(z)=1$.

Ilustrasi dari central limit theorem diperlihatkan pada gambar 23. Gambar 23 memperlihatkan apabila ada tiga variabel acak yang mempunyai distribusi Uniform dengan parameter yang berbeda, ketika rata-rata aritmatik dikalkulasi dari ketiga variabel acak tersebut, maka rata-rata artimatik tersebut akan mengikuti distribusi Normal.

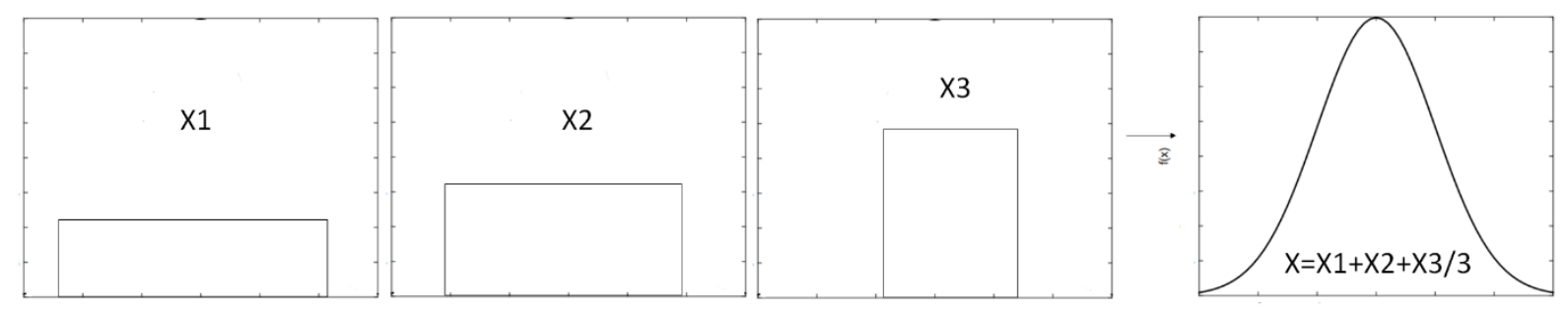

Gambar 23: Ilustrasi dari central limit theorem.

Aplikasi Central theorem pada pengukuran salah satu contohnya adalah untuk mennetukan nilai ketidakpastian dengan metode simulasi Monte-Carlo (lihat bab ketidakpastian). Metode simulasi tersebut mempunyai input data yang mempunyai berbagai macam distribusi propabilitas dan hasil simulasi tersebut, dengan jumlah simulasi yang banyak, mengikuti distirbusi Normal. Dengan demikian, estimasi nilai ketidakpastian dengan metode simulasi Monte-Carlo pada umumnya mengasumsikan standar deviasi dari banyaknya hasil simulasi dengan mengikuti distribusi Normal. Namun demikian, estimasi ketidakpastian dari simulasi Monte-Carlo tidak selalu mengikuti distribusi Normal. Maka dari itu, hasil dari simulasi Monte-Carlo harus diobservasi terlebih dahulu untuk menentukan jenis distribusi yang paling tepat untuk hasil simulasi tersebut.

Untuk mengetahui berbagai macam teknik-teknik analisis statistik secara lebih detil, referensi utama yang dapat dijadikan rujukan adalah Montgomery 2001, Montgomery dan Runger 2003, dan Hines et al 2003.

\subsubsection{Deviasi standar (standard deviation) dari data dan deviasi standar dari rata-rata (standard deviation of the mean)}

Dalam pengukuran, nilai sebaran hasil pengukuran dikuantifikasi dengan parameter standar deviasi dari rata-rata (standard deviation of the mean). Hal ini berbeda dengan deviasi standar (standard deviation). Pada umumnya, dalam bidang pengukuran, standar deviasi dari rata-rata selalu digunakan untuk mengestimasi sebaran data hasil pengukuran. Namun demikian penggunaan standar deviasi dari rata-rata atau satndar deviasi juga tergantung dari jenis suatu pengukuran. Selain itu, ketidakpastian tipe A (lihat bab ketidakpastian) dikalkulasi menggunkaan formulasi standar deviasi dari rata-rata (BIPM 2008b). Ada dua alasan utama mengenai hal ini, yaitu: jumlah data hasil pengukuran pada umumnya tidak banyak, misalnya hanya tiga atau lima data, dan standar deviasi dari rata-rata memperhitungkan jumlah data hasil pengukuran yang digunakan untuk mengkalkulasi sebaran data, misalnya apabila suatu pengukuran diulang sebanyak tiga kali dan sepuluh kali, maka sebaran data yang dikalkulasi dari sepuluh jumlah pengulangan pengukuran lebih kecil dari sebaran data yang dikalkulasi dari tiga pengulangan pengukuran.

Untuk lebih jelasnya, perbedaan tersebut akan dijelaskan dengan sebuah ilustrasi sebagai berikut. Sebuah contoh pengukuran diameter $D$ sebuah silinder dengan menggunakan jangka sorong. Apabila pengukuran diulang dan pengukuran dilakukan dengan orientasi yang berbeda (dilakukan dengan memutar silinder tersebut pada orientasi yang berbeda/acak), maka hasil yang berbeda-beda akan didapatkan. Hal ini disebabkan bahwa silinder yang diukur tersebut tidaklah sempurna (ada kesalahan-kesalahan yang bersumber dari, misalnya, kesalahan proses manufaktur). Hasil pengukuran diameter silinder tersebut dinotasikan sebagai $d_{i}$, nilai rata-rata (mean) dari $n$ pengukuran independen diameter $D$ adalah $\bar{d}$, dengan berasumsi data hasil pengukuran tersebut mempunyai distribusi Normal. Tabel 1 
memperlihatkan contoh hasil data pengukuran dengan jumlah $n=5$.

Tabel 1: Ilustrasi hasil perhitungan statistik dari pengukuran diameter silinder tersebut dengan $n=5$.

\begin{tabular}{|c|c|c|c|}
\hline $\begin{array}{c}\text { Urutan } \\
\text { pengukuran }\end{array}$ & Nilai yang diukur $d_{i} / \mathrm{mm}$ & $\begin{array}{c}\text { Perbedaan dengan nilai rata- } \\
\text { rata (mean) } \delta_{i}=\left(d_{i}-\bar{d}\right) / \mathrm{mm}\end{array}$ & $\begin{array}{c}\text { Kuadrat dari perbedaan } \\
\text { dengan nilai rata-rata }(\text { mean }) \\
\delta_{i}^{2} / \mathrm{mm}^{2}\end{array}$ \\
\hline 1 & 12.61 & 0.06 & 0.0030 \\
\hline 2 & 12.53 & -0.03 & 0.0006 \\
\hline 3 & 12.56 & 0.01 & 0.0001 \\
\hline 4 & 12.59 & 0.04 & 0.0016 \\
\hline 5 & 12.47 & -0.08 & 0.0064 \\
\hline Jumlah & 62.75 & 0 & 0.0118 \\
\hline
\end{tabular}

Dari hasil pengukuran yang diperlihatkan pada tabel 1 , Nilai rata-rata (mean) $\bar{d}$ dari pengukuran diamater $d_{i}$ dengan jumlah pengukuran $n=5$ adalah (terdistribusi Normal):

$$
\bar{d}=\frac{\sum_{i=1}^{n} d_{i}}{n}=\frac{62.75}{5}=12.55 \mathrm{~mm}
$$

Kemudian, deviasi standar $\sigma$ adalah deviasi standar dari hasil pengukuran tak terhingga (infinite number of measurements) atau dari hasil pengukuran dengan jumlah yang sangat banyak (mewakili populasi dari pengukuran). $\sigma$ dapat diestimasi dengan $s$, yaitu deviasi standar dari hasil pengukuran dengan jumlah terbatas $n$. $s$ dikalkulasi sebagai berikut:

$$
s=\sqrt{\frac{1}{n-1} \cdot \sum_{i=1}^{n}\left(d_{i}-\bar{d}\right)^{2}}=\sqrt{\frac{1}{4} \cdot(0.0118)}=0.054 \mathrm{~mm}
$$

Hasil dari rata-rata $\bar{d}$ adalah aproksimasi dari nilai diameter yang sebenarnya (true diameter) $D$ dan nilai $S$ aproksimasi dari deviasi standar populasi $\sigma$. Kesimpulan dari hasil perhitungan rata-rata dan deviasi standar mendeskripsikan prosess pengukuran diameter silinder tersebut, yaitu diameter silinder tersebut mempunyai nilai diameter yang sebenarnya $D$. Namun demikian, karena berbagai macam kesalahan selama produksi, maka silinder yang dihasilkan tidaklah sempurna, dan dari silinder tersebut mempunyai deviasi dari nilai $D$ dan sebaran dari deviasi dari nilai $D$ dikarakterisasikan dengan nilai $s$. Sedangkan, aproksimasi dari nilai $D$ adalah $d_{i}$. Dengan demikian, deviasi standar dari populasi $\sigma$ adalah ukuran besarnya deviasi $d_{i}$ dari nilai diameter yang sebenarnya $D$.

Namun demikian, dalam kasus ini, nilai rata-rata $\bar{d}$ merupakan parameter yang lebih tepat untuk mengaproksimasi diameter yang sebenarnya $D$ dari pada setiap pengukuran nilai $d_{i}$. Parameter yang mengkarakterisasi dispersi nilai $\bar{d}$ dari $D$ adalah $s_{m} . s S_{m}$ adalah deviasi standar dari rata-rata dan merupakan estimasi dari dari standar dari rata-rata populasi $\sigma_{m}$. Standar deviasi dari rata-rata pada umumnya digunakan untuk merepresentasikan sebaran hasil pengukuran (contoh lainnya adalah $S_{m}$ digunakan untuk estimasi nilai ketidakpastian tipe A). $s_{m}$ diformulasikan sebagai: 


$$
s_{m}=\frac{s}{\sqrt{n}}=\sqrt{\frac{1}{n \cdot(n-1)} \cdot \sum_{i=1}^{n}\left(d_{i}-\bar{d}\right)^{2}}
$$

Sehingga, untuk kasus pengukuran silinder diatas:

$$
s_{m}=\sqrt{\frac{1}{5 \cdot 4} \cdot(0.0118)}=0.024 \mathrm{~mm}
$$

Kesimpulan dari contoh kasus pengukuran silinder tersebut adalah standar deviasi dari rata-rata $S_{m}$ akan menurun apabila jumlah pengukuran ditambah sedangkan $S$ mempunyai nilai yang stabil walaupun jumlah pengukuran ditambah. Namun demikian, walaupun nilai $S_{m}$ dapat diturunkan dengan menambah jumlah pengukuran, pada banyak keadaan riil, penambahan pengukuran sangat tidak effisien. Faktor-faktor yang menyebabkan penambahan jumlah pengukuran tidak efisien adalah, misalnya, menambah waktu pengukuran secara signifikan, menambah jumlah produk yang harus diukur dan kebutuhan energi untuk menjalankan mesin pengukuran meningkat karena jumlah pengukuran bertambah. Kesimpulan dari deviasi standar $S$ dan deviasi standar dari rata-rata $s_{m}$ diperlihatkan pada tabel 2 .

Tabel 2: Rangkuman dari relasi antara parameter-parameter statistik (nilai rata-rata dan dispersi) dan metode aproksimasi parameter-perameter tersebut dengan jumlah pengukuran yang terbatas (dikaitkan dengan contoh kasus

\begin{tabular}{|c|c|c|c|}
\hline $\begin{array}{c}\text { Nilai yang sebenarnya } \\
\text { (true value) }\end{array}$ & Aproksimasi & $\begin{array}{c}\text { Karakterisasi dispersi } \\
\text { (perbedaan dengan nilai yang } \\
\text { sebenarnya) }\end{array}$ & Deskripsi dispersi \\
\hline$D$ & $d_{i}$ & $s$ & $d_{i}$ terhadap $D$ \\
\hline$D$ & $\bar{d}$ & $s_{m}=s / \sqrt{n}$ & $\bar{d}$ terhadap $D$ \\
\hline
\end{tabular}

Dari pembahasan di atas, dapat terlihat perbedaan antara standar deviasi dari data (atau hasil pengukuran) dan standar deviasi dari rata-rata. Standar deviasi dari rata-rata memperhitungkan banyaknya jumlah pengukuran yang diakukan. Semakin banyak pengukuran yang dilakukan, maka deviasi standar dari rata-rata akan semakin kecil. Tipe A dari nilai ketidakpastian mengikuti formulasi standar deviasi dari rata-rata (lihat bab ketidakpastian).

\subsubsection{Analisis regresi}

Pengertian solusi numerik berbasis least square adalah solusi tersebut meminimalisasi total jumlah dari akar kuadrat (sum-of-square) dari residu-residu data (data residuals). Residu-residu data tersebut merupakan hasil dan suatu nilai yang diestimasi dikurangin dengan nilai data aktual pada setiap persamaan. Solusi least square pada umumnya mencoba mengestimasi suatu persamaan yang over-constraint, yaitu jumlah data yang ada lebih banyak dari minimal jumlah variabel atau paramater persamaan tersebut, misalnya: estimasi least squre sebuah garis, yang membutuhkan minimal dua poin untuk menentukan persamaan sebuah garis, dari lima point data. Solusi numerik berbasis least square mempunyai efek averaging (merata-ratakan) dari total data point yang ada.

\section{$\underline{\text { Analisis regresi linier. }}$}

Regresi linier merupakan metode analisis numerik data berbasis least square untuk mengetahui hubungan antara berbagai macam variabel. Analisis regresi linier merupakan salah satu metode analisis data yang paling penting. Istilah 
lain untuk regresi linier adalah ordinary least square (Castillo 2007). Penjelasan dari regresi linier adalah sebagai berikut. Bentuk umum data, misalkan data dari hasil pengukuran, adalah:

$$
\begin{array}{rrrrr}
y_{1} \cong x_{11} & x_{12} & x_{13} & \ldots & x_{1 k} \\
y_{2} \cong x_{21} & x_{22} & x_{23} & \ldots & x_{2 k} \\
y_{3} \cong x_{31} & x_{32} & x_{33} & \ldots & x_{3 k} \\
\ldots \ldots & \multicolumn{5}{c}{\ldots . .} \\
y_{n} \cong x_{n 1} & x_{n 2} & x_{n 3} & \ldots & x_{n k}
\end{array}
$$

dimana $k$ adalah banyaknya variabel dan $n$ adalah banyaknya data yang dikumpulkan. Misalkan, diasumsikan bahwa hubungan antara variabel-variabel dengan data tersebut mempunyai hubungan linier order pertama yang dimodelkan sebagai:

$$
y_{i}=\beta_{0}+\sum_{j=1}^{k} \beta_{j} x_{i j}+\varepsilon_{i}, \quad i=1,2, \ldots n
$$

Maka, analisis least square adalah bagaimana mengestimasi $\widehat{\beta_{0}}, \widehat{\beta_{1}}, \ldots, \widehat{\beta_{k}}$ (yang merupakan estimator dari parameter $\beta_{0}, \beta_{1}, \ldots, \beta_{k}$ ) sedemikian hingga sum-of-square dari residu-residu data dapat diminimalisasikan. Kriteria least square adalah:

$$
R\left(\widehat{\beta_{0}}, \widehat{\beta_{1}}, \ldots, \widehat{\beta_{k}}\right)=\sum_{i=1}^{n} \widehat{\varepsilon_{l}^{2}}=\sum_{i=1}^{n}\left(y_{i}-\hat{y}\right)^{2}=\sum_{i=1}^{n}\left(y_{i}-\widehat{\beta_{0}}-\sum_{j=1}^{k} \widehat{\beta_{j}} x_{i j}\right)^{2}
$$

Fungsi di atas merupakan fungsi konveks sehingga gardient dari fungsi tersebut selalu menuju ke minimum global (Castillo 2007). Maka dari itu, untuk mendapatkan nilai yang meminimalisasi fungsi tersebut, $\partial R / \partial \beta=0 ; j=$ $0,1,2, \ldots, k$. Jika jumlah persamaan (data) $n \geq$ jumlah parameter $p$ yang mau diestimasi $\left(\widehat{\beta_{0}}, \widehat{\beta_{1}}, \ldots, \widehat{\beta_{k}}\right)$, maka fungsi tersebut mempunyai satu solusi yang unik. Tanda " $\wedge$ " (disebut hat) menunjukkan hasil estimasi. Misal, $\hat{z}$ merupakan hasil estimasi, dalam hal ini menggunakan metode least square, dari $z$.

Representasi data-data tersbut (persamaan 79) dapat dinotasikan dalam bentuk matriks, yaitu:

$$
\mathbf{Y}=\mathbf{X} \boldsymbol{\beta}+\boldsymbol{\varepsilon}
$$

dimana:

$$
\mathbf{Y}=\left[\begin{array}{c}
y_{1} \\
y_{1} \\
\vdots \\
y_{n}
\end{array}\right] ; \mathbf{X}=\left[\begin{array}{ccccc}
1 & x_{11} & x_{12} & \ldots & x_{1 k} \\
1 & x_{21} & x_{22} & \ldots & x_{2 k} \\
\vdots & \vdots & \ddots & \vdots & \vdots \\
1 & x_{n 1} & x_{n 2} & \ldots & x_{n k}
\end{array}\right] ; \boldsymbol{\beta}=\left[\begin{array}{c}
\beta_{0} \\
1 \\
\vdots \\
\beta_{k}
\end{array}\right] ; \boldsymbol{\varepsilon}=\left[\begin{array}{c}
\varepsilon_{1} \\
\varepsilon_{2} \\
\vdots \\
\varepsilon_{n}
\end{array}\right]
$$

maka, total jumlah dari akar kuadrat dari residu-residu data (sum-of-square of residuals):

$$
R(\widehat{\boldsymbol{\beta}})=\boldsymbol{\varepsilon}^{\prime} \boldsymbol{\varepsilon}=(\mathbf{Y}-\mathbf{X} \boldsymbol{\beta})^{\prime}(\mathbf{Y}-\mathbf{X} \boldsymbol{\beta})
$$

dari $\partial R(\widehat{\boldsymbol{\beta}}) / \partial \widehat{\boldsymbol{\beta}} .=0$, sebuah persamaan, yang dinamakan persamaan normal, didapatkan sebagai berikut:

$$
\mathbf{X}^{\prime} \mathbf{X} \boldsymbol{\beta}=\mathbf{X}^{\prime} \mathbf{Y}
$$


Estimasi least square dari parameter $\beta$ adalah:

$$
\boldsymbol{b}=\widehat{\boldsymbol{\beta}}=\left(\mathbf{X}^{\prime} \mathbf{X}\right)^{-1} \mathbf{X}^{\prime} \mathbf{Y}
$$

dimana:

$$
\mathbf{X}^{\prime} \mathbf{X}=\left[\begin{array}{ccccc}
\mathrm{n} & \sum x_{i 1} & \sum x_{i 2} & \ldots & \sum x_{i k} \\
\sum x_{i 1} & \sum x_{i 1}^{2} & \sum x_{i 1} x_{i 2} & \ldots & \sum x_{i 1} x_{i k} \\
\vdots & \vdots & \ddots & \vdots & \vdots \\
\text { simetri } & & & & \sum x_{i k}^{2}
\end{array}\right]
$$

$\mathbf{X}^{\prime} \mathbf{X}$ adalah varian-covarian matriks yang merupakan sebuah matriks simetri. Elemen diagonal dari matriks $\mathbf{X}^{\prime} \mathbf{X}$ merupakan varian dari setiap $\widehat{\beta}_{J}$, sedangkan elemen non-diagonalnya merupakan covarian dari pasangan $\left(\widehat{\beta}_{l}, \widehat{\beta}_{J}\right)$. Dapat dilihat dari $\mathbf{X}^{\prime} \mathbf{X}$ bahwa apabila jumlah data atau persamaan kurang dari jumlah variabel atau parameter yang akan diestimasi, maka matriks $\mathbf{X}^{\prime} \mathbf{X}$ tidak dapat diinversikan, sehingga estimasi regresi linier tidak dapat dikalkulasi. berikut:

Properti dari regresi linier (ordinary least-square), dengan asumsi model general $\mathbf{Y}=\mathbf{X} \boldsymbol{\beta}+\boldsymbol{\varepsilon}$, adalah sebagai

- $E[\varepsilon]=0$

- $\operatorname{Var}[\varepsilon]=\sigma^{2} \mathbf{I}$

- $\varepsilon \sim N\left(0, \sigma^{2} \mathbf{I}\right)$

Analisis regresi linier mengasumsikan bahwa setiap residual $\varepsilon_{i}$ mempunyai distribusi normal, sehingga estimasi regresi linier juga terdistribusi normal sebagai berikut:

$$
\boldsymbol{b}=\widehat{\boldsymbol{\beta}} \sim N\left(\beta, \sigma^{2}\left(\mathbf{X}^{\prime} \mathbf{X}\right)^{-1}\right) .
$$

Parameter $\boldsymbol{b}=\widehat{\boldsymbol{\beta}}$ yang diestimasi dengan regresi linier juga mempunyai varian. Varian dari $\boldsymbol{b}$ atau $\widehat{\boldsymbol{\beta}}$ tersebut adalah:

$$
\begin{gathered}
\operatorname{Var}[\boldsymbol{b}]=\operatorname{Var}[\widehat{\boldsymbol{\beta}}]=\operatorname{Var}\left[\left(\mathbf{X}^{\prime} \mathbf{X}\right)^{-1} \mathbf{X}^{\prime} \mathbf{Y}\right]=\left(\mathbf{X}^{\prime} \mathbf{X}\right)^{-1} \mathbf{X}^{\prime}[\operatorname{var}[\mathbf{Y}]] \mathbf{X}\left(\mathbf{X}^{\prime} \mathbf{X}\right)^{-1} \\
\operatorname{Var}[\boldsymbol{b}]=\sigma^{2}\left(\mathbf{X}^{\prime} \mathbf{X}\right)^{-1} \mathbf{X}^{\prime} \mathbf{X}\left(\mathbf{X}^{\prime} \mathbf{X}\right)^{-1} \\
\operatorname{Var}[\boldsymbol{b}]=\sigma^{2}\left(\mathbf{X}^{\prime} \mathbf{X}\right)^{-1}
\end{gathered}
$$

dimana $\sigma^{2}$ dapat diestimasi dengan:

$$
\widehat{\sigma^{2}}=s^{2}=\frac{1}{n-p} \sum_{i=1}^{n} \varepsilon_{i}^{2}=\frac{1}{n-p}(\mathbf{Y}-\mathbf{X} b)^{\prime}(\mathbf{Y}-\mathbf{X} b)
$$

dimana $n$ adalah jumlah data atau persamaan dan $p$ adalah jumlah variabel yang diestimasi. Contoh dari hasil kalkulasi varian dari parameter $\boldsymbol{b}=\widehat{\boldsymbol{\beta}}$ yang diestimasi dapat dilihat pada gambar 24 dan gambar 26.

Hal penting yang perlu diingat dalam regresi linier adalah pengertian linier tersebut adalah untuk parameter yang akan diestimasi dan bukan untuk variabel dari data atau persamaan yang ada. Apabila variabel-variabel yang ada dalam data, misalnya, dalam bentuk kuadrat, maka regresi linier tersebut dinamakan regresi linier orde dua. Untuk lebih jelasnya adalah sebagai berikut:

$$
y=\beta_{0} x_{1}^{2}+\beta_{1} x_{2}^{2}+\beta_{2} x_{1}+\beta_{3} x_{2}
$$


pada persamaan (93), walaupun persamaan tersebut mempunyai variable $x_{i}$ yang non-linier, tetapi paramaterparameternya $\beta_{i}$ adalah linier. Maka, estimasi least square dari variabel-variabel $\beta_{i}$ termasuk dalam regresi linier (ordinary least square).

\section{Analisis interval dari regresi linier.}

Setelah estimasi parameter didapatkan, yaitu $\widehat{\boldsymbol{\beta}}=\widehat{\beta_{0}}, \widehat{\beta_{1}}, \ldots, \widehat{\beta_{k}}$, dengan metode regresi linier dari suatu persamaan $\mathbf{Y}$ (berdasarkan $n$ data atau persamaan yang ada), maka estimasi dari $\mathbf{Y}$, yaitu $\widehat{\boldsymbol{Y}}$, didapatkan:

$$
\widehat{\boldsymbol{Y}}=\mathbf{X} \widehat{\boldsymbol{\beta}}
$$

Maka, estimasi $\widehat{\boldsymbol{Y}}$ juga mempuyai variasi yang digambarkan dengan sebuah interval kepercayaan seperti halnya estimasi parameter $\widehat{\boldsymbol{\beta}}$ juga mempunyai variasi yang dikalkulasi dengan persamaan (91).

Ada dua macam interval untuk $\boldsymbol{Y}$, yaitu interval kepercayaan (confidence interval) dan interval prediksi (prediction interval). Interval kepercayaan merupakan variasi dari variasi estimasi data yang sudah terobservasi $\left(\boldsymbol{x}=\boldsymbol{x}_{0}\right)$, dengan kata lain data yang digunakan untuk analisis regresi linier. Sedangkan, interval prediksi merupakan variasi estimasi dari data yang belum terobservasi $\left(\boldsymbol{x} \neq \boldsymbol{x}_{0}\right)$,

$$
\hat{y}\left(\boldsymbol{x}_{0}\right) \pm t_{\alpha / 2, n-p} \hat{\sigma} \sqrt{\boldsymbol{x}_{0}^{\prime}\left(\mathbf{X}^{\prime} \mathbf{X}\right)^{-1} \boldsymbol{x}_{0}} .
$$

Sedangkan, interval prediksi diformulasikan sebagai:

$$
\hat{y}(\boldsymbol{x}) \pm t_{\alpha / 2, n-p} \hat{\sigma} \sqrt{1+\boldsymbol{x}_{0}^{\prime}\left(\mathbf{X}^{\prime} \mathbf{X}\right)^{-1} \boldsymbol{x}_{0}} .
$$

dapat dilihat bahwa interval prediksi selalau lebih besar dari interval kepercayaan karena interval prediksi mengandung data yang belum terobservasi (data diluar yang digunakan untuk analisis regresi linier). Gambar 24 dan 25 memperlihatkan contoh dari interval kepercayaan dan interval prediksi pada regresi linier orde satu dan orde dua.

\section{$\underline{\text { Analisis residual dari regresi linier. }}$}

Hal yang penting pada regresi linier yang harus diperhitungkan adalah data atau poin yang secara signifikan mempengaruhi hasil total regresi linier. Ciri-ciri dari data tersebut adalah data tersebut mempunyai jarak numerik yang sangat jauh dipandingkan dengan rata-rata seluruh data, atau sering disebut dengan outlier (Castillo 2007). Bukan hanya itu, poin yang berpengaruh tersebut juga tergantung pada posisi data tersebut terhadap data-data lainnya. Sehingga, data yang berpengaruh mempuyai ciri-ciri, yaitu:

- Mempunyai jarak numerik yang sangat jauh dibandingkan dengan data-data lainnnya.

- Berada pada posisi di limit bawah atau atas dari data-data yang ada (levarage point)

Gambar 26 memperlihatkan contoh dari suatu poin yang berpengaruh yang dengan adanya poin tersebut dalam suatu kalkulasi regresi linier, maka poin tersebut akan mempengaruhi hasil regresi tersebut secara signifikan.

\section{Tes hipotesis dan goodness-of-fit dari regresi linier.}

Setelah estimasi parameter suatu persamaan dengan metode regresi linier dilakukan. Langkah selanjutnya adalah memverifikasi (tes) apakah hasil estimasi parameter tersebut relevan atau signifikan berdasarkan statistik. Langkah pertama untuk melakukan tes hasil regresi adalah untuk mengetes dua hipotesis: 


$$
\begin{aligned}
& H_{0}: \beta_{1}=\beta_{1}=\cdots=\beta_{k}=0 \\
& H_{1}: \text { minimal salah satu dari } \beta_{i} \neq 0
\end{aligned}
$$

Pengertian dari dua hipotesis tersebut adalah $H_{0}$ mempunyai arti bahwa hasil estimasi parameter dengan regresi linier suatu persamaan tidak signifikan, sedangkan arti dari $H_{1}$ adalah estimasi parameter tersebut signifikan secara statistik.

Untuk melakukan uji atau tes hipotesis tersebut, metode analisis varian (ANOVA) digunakan. Metode ANOVA mengelompokkan sum-of-squre (SS) dari residu-residu data sebagai berikut:

$$
S S_{\text {total }}=S S_{\text {regression }}+S S_{\text {error }}
$$

dimana $S S_{\text {error }}$ diformulasikan sebagai:

$$
\begin{aligned}
& S S_{\text {error }}=(\mathbf{Y}-\mathbf{X} \widehat{\boldsymbol{\beta}})^{\prime}(\mathbf{Y}-\mathbf{X} \widehat{\boldsymbol{\beta}}) \\
& S S_{\text {error }}=\mathbf{Y Y}^{\prime}-\mathbf{Y}^{\prime} \mathbf{X} \widehat{\boldsymbol{\beta}}
\end{aligned}
$$

$S S_{\text {error }}$ merupakan ukuran besarnya deviasi atau sebaran dari pusat data. Ukuran besarnya deviasi dari rata-rata hasil persamaan (observasi), $y_{i}-\bar{Y} . \bar{Y}$ adalah nilai rata-rata dari hasil persamaan (observasi). Dengan berasumsi bahwa $\beta_{0}=0$ (the constant term/intercept), maka seluruh sum-of-squre (SS) dari residu-residu dapat dirangkum sebagai berikut:

$$
\begin{aligned}
& S S_{\text {total }}=\mathbf{Y Y}^{\prime}-n \bar{Y}^{2} \\
& S S_{\text {regresi }}=\mathbf{Y}^{\prime} \mathbf{X} \widehat{\boldsymbol{\beta}}-n \bar{Y}^{2} \\
& S S_{\text {error }}=\mathbf{Y Y}^{\prime}-\mathbf{Y}^{\prime} \mathbf{X} \widehat{\boldsymbol{\beta}}
\end{aligned}
$$

Dimana $n$ adalah jumlah persamaan ata data terobservasi. Setelah seluruh sum-of-squre SS (total, regresi dan error) didapatkan, maka tes statistik regeresi linier dapat dilakukan dengan:

$$
F_{0}=\frac{S S_{\text {regresi }} /(p-1)}{S S_{\text {error }} /(n-p)}
$$

Variabel $F_{0}$ mempunyai distribusi $F_{p-1, n-p}$ untuk $H_{0} . P$ adalah jumlah regressor. Jika hipotesis $H_{0}$ ditolak, maka variasi yang dimodelkan dengan regresi linier tersebut lebih besar secara signifikan dibanding dengan variasi yang tidak terjelaskan (unexplained random variation), dengan kata lain, estimasi parameter hasil regresi tersebut signifikan secara statistik.

Selain tes hipotesis, hal yang sangat penting untuk regresi linier adalah mengukur seberapa baik model regresi tersebut memodelkan data yang terobservasi. Hal ini dinamakan tes goodness-of-fit dari regresi linier. Parameter statistik yang merepresentasikan goodness-of-fit adalah:

$$
R^{2}=\frac{S S_{\text {regresi }}}{S S_{\text {total }}}
$$

$R^{2}$ merupakan parameter yang mengukur seberapa besar variasi dari data yang terobservasi dapat direpresentasikan dari suatu model regresi linier. Nilai dari $R^{2}$ adalah ukuran dari goodness-of-fit dan mempunyai nilai $0 \leq R^{2} \leq 1$. Nama lain dari goodness-of-fit untuk $R^{2}$ adalah koefisien determinasi (coefficient of determination). $R^{2}$ bisa 
digunakan apabila kita hanya mempunya satu model regresi linier pada sebuah set data terobservasi.

Namun demikian, apabila kita ingin mengaplikasikan model regresi linier dengan berbagai macam jumlah data yang berbeda-beda atau ingin membandingkan berbagai macam model regresi linier pada suatu data, maka nilai

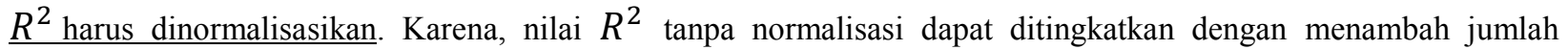
parameter (regressor) atau menambah interval data. Hal tersebut karena mereduksi elemen dari matriks $\left(\mathbf{X}^{\prime} \mathbf{X}\right)^{-1}$, sehingga $S S_{\text {error }} \rightarrow 0, S S_{\text {regresi }} \rightarrow S S_{\text {total }}$, sehingga $R^{2} \rightarrow 1$.

Oleh sebab itu, apabila kita ingin mengaplikasikan suatu model regresi linier pada berbagai jumlah data yang berbeda atau mengkomparasikan berbagai macam model regresi linier, parameter statistik $R_{\text {adjusted }}^{2}$ lebih tepat untuk digunakan. $R_{\text {adjusted }}^{2}$ adalah $R^{2}$ yang ternormalisasikan. Diformulasikan sebagai berikut:

$$
R_{\text {adjusted }}^{2}=1-\left(1-R^{2}\right)\left(\frac{n-1}{n-p}\right)
$$

Dimana $n$ adalah jumlah data terobservasi (jumlah persamaan) dan $p$ adalah jumlah parameter (regressor). Dengan menggunakan $R_{\text {adjusted }}^{2}$ untuk mengkomparasi berbagai model regresi, kesimpulan yang sama pada umumnya akan didapatkan jika komparasi dilakukan dengan menggunakan parameter $M S_{\text {error }}$. Parameter $M S_{\text {error }}$ akan dijelaskan pada bagian selanjutnya, yaitu ANOVA.

\section{Contoh dari regresi linier.}

Contoh regresi linier diperlihatkan pada gambar 24 dan 25. Pada gambar 24, jenis regresi linier tersebut adalah orde satu, yaitu variabel-variabel pada persamaan tersebut maksimal berpangkat satu. Sedangkan, gambar 25 memperlihatkan jenis regresi orde dua, yaitu variabel-variabelnya makimal berpangkat dua. Pada gambar 24 dan 25, dapat dilihat bahwa jarak antar dua garis interval kepercayaan lebih kecil dari jarak antar dua garis interval prediksi. Hal ini sesuai dengan konsep dari interval prediksi yang merupakan variasi dari prediksi variabel yang belum terobservasi dengan mengunakan suatu model regresi linier. Hal ini disebabkan karena interval prediksi juga mengandung variasi dari data yang berlum terobservasi. Pada gambar 24, diperlihatkan dengan lengkap interval kepercayaan dari parameter yang diestimasi berikut dengan parameter goodness-of-fit.

Gambar 26 memperlihatkan contoh dari poin yang berpengaruh (outlier) terhadap model hasil regresi linier. Pada gambar 26, model hasil regresi linier dari poin-poin data yang terobservasi (bentuk bulat warna biru) diperlihatkan dengan garis tersambung. Pada model regresi ini, nilai $R^{2}$ adalah 0.99 .

Poin yang berpengaruh diperlihatkan dengan simbol “*” pada gambar 26. Dapat dilihat bahwa poin berpengaruh tersebut bersifat seperti tongkat "lever" yang menarik garis persamaan hasil regresi linier ke arah bawah. Pada gambar 26, garis persamaan hasil regresi linier yang mengikutkan poin berpengaruh tersebut diperlihatkan dengan garis putusputus. Pada model regresi ini yang mengikutkan poin berpengaruh, nilai $R^{2}$ adalah 0.73 . Dari perbandingan hasil persamaan regresi linier tanpa dan dengan mengikutkan poin berpengaruh, poin berpengaruh mengurangi kualitas hasil dari regresi linier. Hal tersebut menjelaskan bahwa untuk melakukan analisis regresi linier, suatu poin berpengaruh (outlier) harus tidak diikutsertakan dalam analisis tersebut.

Maka dari itu, pada umumnya dalam bidang pengukuran (terutama pengukuran dengan menggunakan instrumeninstrumen non-kontak berbasis optik), sebelum proses kalkulasi assosiasi suatu feature ke data poin yang didapatkan, outlier dari dalam data tersebut harus disaring agar tidak diikutsertakan dalam analisisi regresi (lihat bab algoritma). Apabia suatu point berpengaruh dalam suatu set data diikutsertakan dalam analisis regresi, maka hasil suatu pengukuran akan menjadi salah atau tidak akurat. 


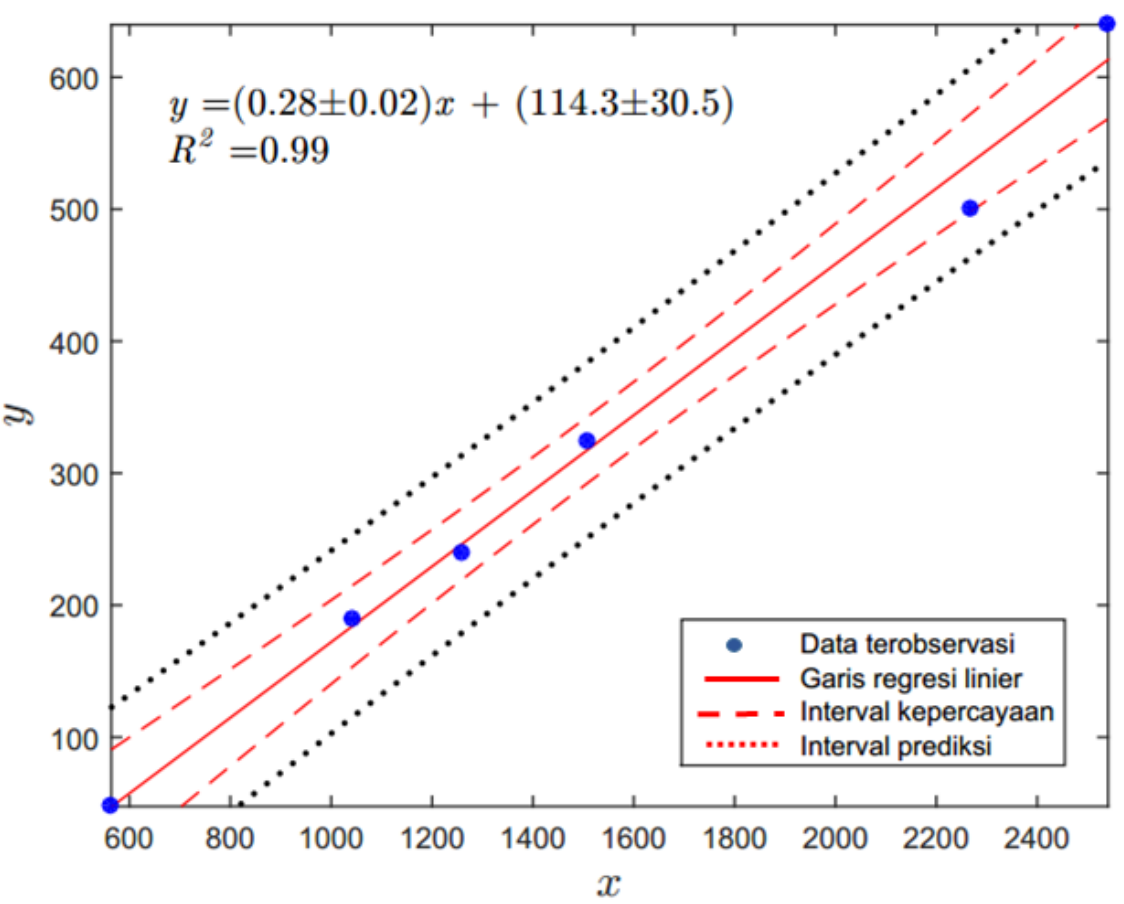

Gambar 24: Contoh regresi linier orde satu.

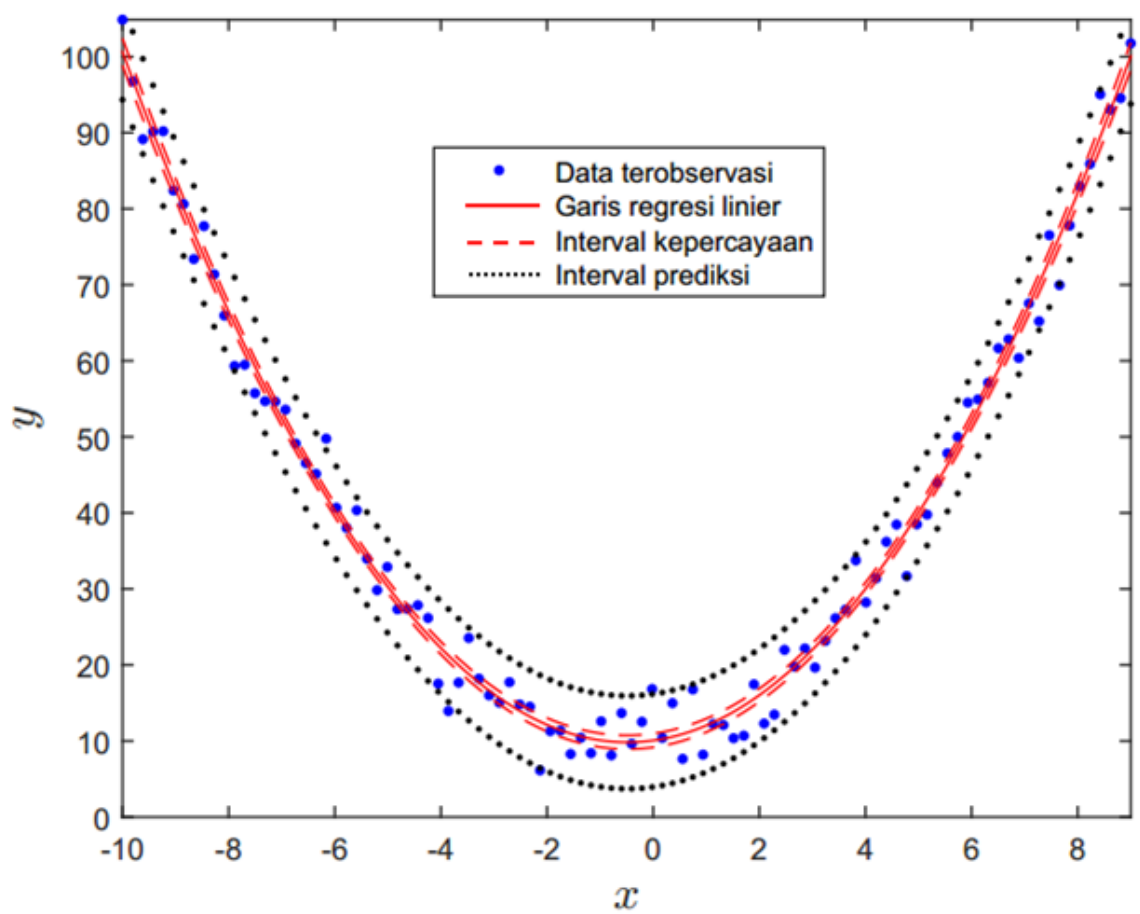

Gambar 25: Contoh regresi linier order dua. 


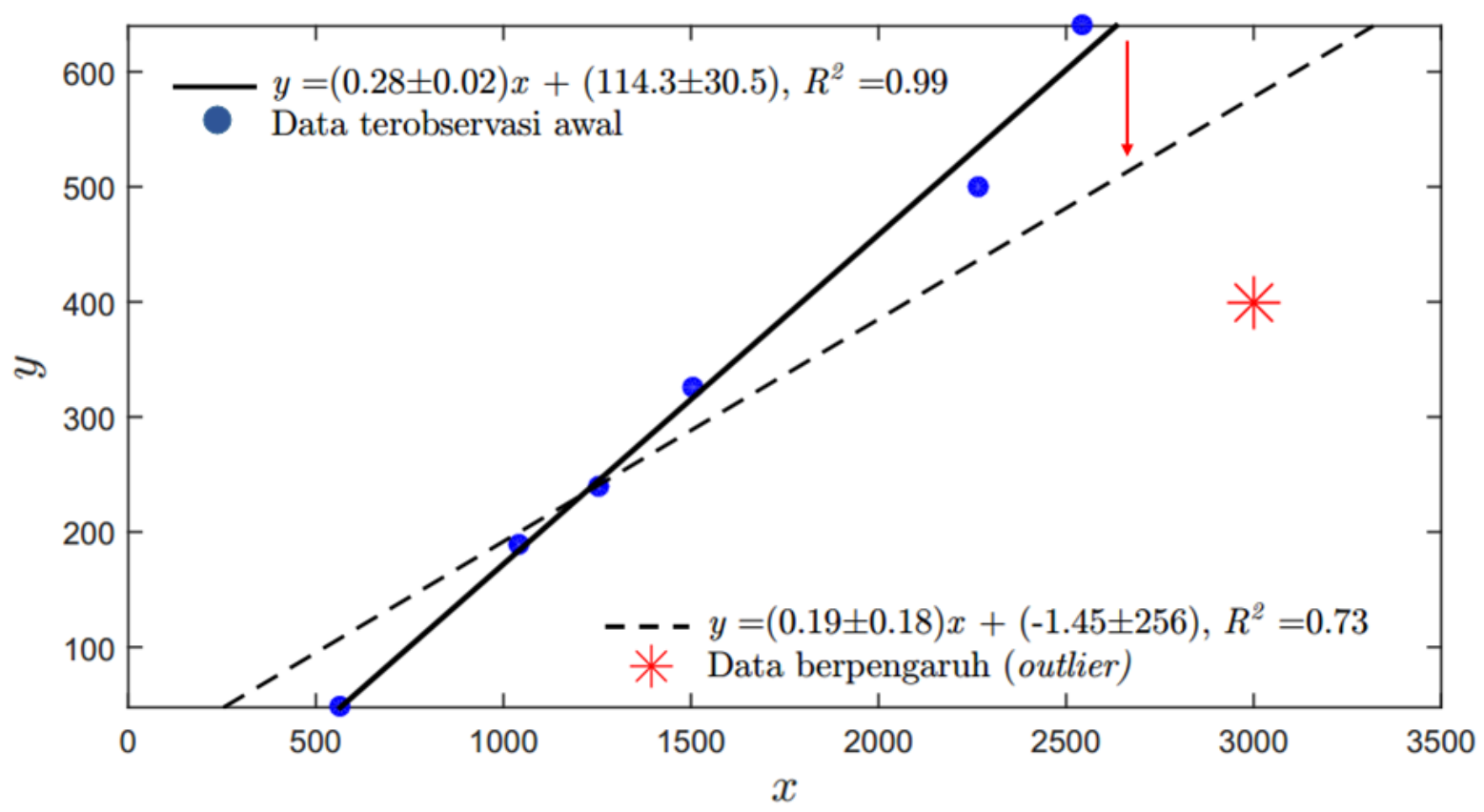

Gambar 26: Contoh poin atau data yang berpengaruh (outlier). Data outlier "**" tersebut mempengaruhi secara signifikan hasil dari regresi linier.

\subsubsection{Analisis varian (analysis of variance/ANOVA)}

Analisis varian (ANOVA) pertama kali dikembangkan oleh R. Fisher pada tahun 1920-an untuk meningkatkan produktivitas pertanian. ANOVA merupakan salah satu metode analisis yang paling sering digunakan dalam bidang statistik dan analisis data (Burdick et al 2005), dan mempunyai palikasi yang sangat penting dalam bidang pengukuran. Dengan metode ANOVA, analisis berbagai macam faktor, dengan berbagai jumlah $(>2)$ level atau nilai pada setiap faktor tersebut, yang mempengaruhi suatu observasi dapat dilakukan (Montgomery 2001). Hal ini dapat dilakukan karena analisis ANOVA adalah hasil generalisasi dari analisis dasar $t$-tes dengan dua sampel untuk mengetes kesamaan rata-rata dari dua macam populasi (Castillo 2007). Dengan demikian, analisis ANOVA dapat digunakan untuk mengetes kesamaan rata-rata dari $\geq 2$ macam populasi.

Contoh paling umum aplikasinya dalam pengukuran adalah untuk optimisasi dan improvisasi berbagai proses dan instrumen pengukuran, dan untuk analisis gauge repeatability and reproducibility (GR\&R). Sebagai contoh, aplikasi ANOVA untuk optimisasi proses pengukuran adalah, misalnya, untuk optimisasi nilai parameter scanning speed dan jumlah poin yang diambil pada suatu pengukuran dimensi dan geometri menggunakan mesin pengukuran koordinat (CMM) sehingga menghasilkan hasil pengukuran dengan meminimalkan nilai ketidakpastian.

Pada bab ini, dasar-dasar analisis ANOVA dengan satu factor (one-way ANOVA) yang merupakan dasar dari seluru analisis ANOVA akan dipresentasikan, sedangkan untuk jenis-jenis analsis ANOVA yang lain dapat dilihat di (Montgomery 2001). Analisis ANOVA adalah sebagai berikut. Misalkan kita mempunyai eksperimen optimalisasi process perlakuan panas sebuah material. Eksperimen tersebut mempunyai sebuah faktor (misalnya: temperatur) dengan berbagai macam level $p$ (misalnya: $100^{\circ} \mathrm{C}, 200^{\circ} \mathrm{C}$ dan $300{ }^{\circ} \mathrm{C}$ ) yang kita ingin komparasi ( $p$ sering disebut sebagai jumlah perlakuan/treatment). Pada setiap perlakuan atau level tersebut, eksperimen atau pengukuran diulang sebanyak $r$ kali. Dengan demikian, hasil eksperimen atau pengukuran yang diobservasi merupakan sebuah variabel acak. Data observasi untuk analisis ANOVA dengan satu faktor diperlihatkan pada tabel 3. Pada tabel 3, isi dari tabel tersebut adalah nilai $y_{i j}$ yang merepresentasikan observasi ke- $j$ dengan perlakuan ke- $i$. 
Tabel 3: Susunan data observasi untuk analisis ANOVA dengan satu faktor dengan berbagai jenis level.

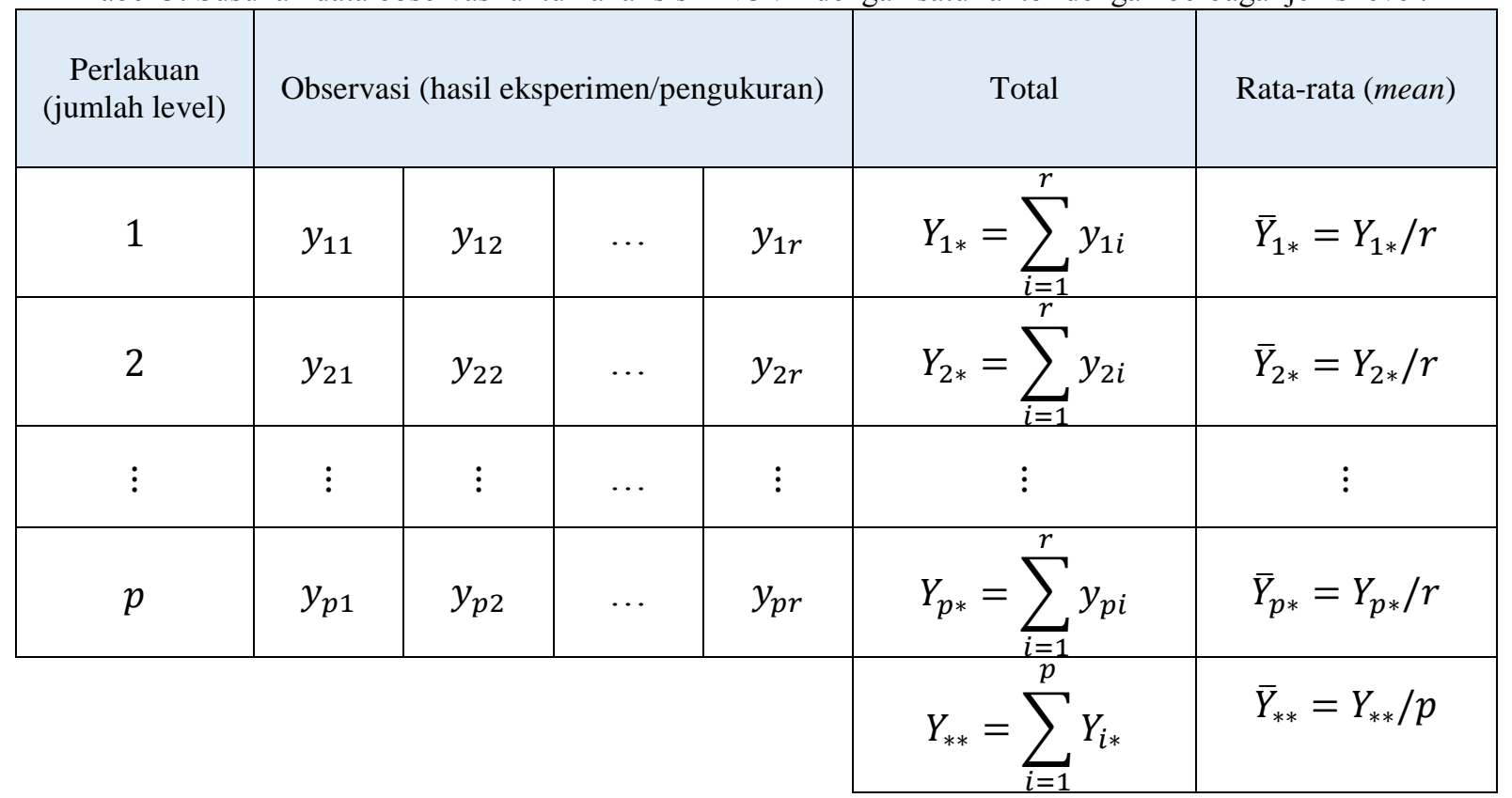

Dari susunan data pada tabel 3, data-data tersebut dapat dimodelkan dengan:

$$
y_{i j}=\mu+\tau_{i}+\epsilon_{i j}
$$

dimana $i=1,2, \ldots, p, j=1,2, \ldots, r . \mu$ adalah sebuah nilai konstan, $\tau_{i}$ adalah variabel acak dari perlakuan ke- $i$ (efek perlakuan/treatment effect), dan $\epsilon_{i j}$ adalah sebuah variabel acak dari error. Asumsi dari model tersebut adalah $\tau_{i} \sim N\left(0, \sigma_{\tau}^{2}\right)$ dan $\epsilon_{i j} \sim N\left(0, \sigma_{\epsilon}^{2}\right)$.

Dalam analsis ANOVA, ada dua tipe model, yaitu:

- Model dengan efek acak (random effect model)

- Model dengan efek tetap (fixed effect model).

Model dengan efek acak (random effect model) mengasumsikan bahwa perlakuan (treatment) merepresentasikan sebuah sampel acak dari sebuah populasi perlakuan yang lebih besar. Dengan demikian, model dengan efek acak mempunyai hasil kesimpulan, yang didapat berdasarkan sampel perlakuan, yang dapat digeneralisasi untuk semua perlakuan dalam populasi perlakuan tersebut. Sedangkan, Model dengan efek tetap (fixed effect model) mempunyai hasil kesimpulan yang terbatas hanya pada perlakuan tertentu yang dipertimbangkan dalam analisis ANOVA dan hasil tersebut tidak bisa digeneralisasi pada semua tipe perlakuan yang mirip yang tidak dipertimbangkan secara eksplsit. Model dengan efek tetap mempunyai perlakuan yang secara spesifik dipilih dan ditetapkan oleh orang yang melakukan eksperimen.

Dengan demikian, model dari efek tetap adalah (dengan mengasumsikan $\tau_{i}=\tau=$ konstan):

$$
y_{i j}=\mu_{i}+\epsilon_{i j}
$$

dimana $i=1,2, \ldots, p, j=1,2, \ldots, r, \mu_{i}$ adalah rata-rata dari perlakuan ke- $i$ dan $\epsilon_{i j}$ adalah variabel acak dari error $\epsilon_{i j} \sim N\left(0, \sigma_{\epsilon}^{2}\right)$. Hal yag aling utama yang menjadi hipotesis dari model dengan efek tetap adalah untuk 
membandingkan apakah nilai rata-rata $\mu_{i}$ dari setiap perlakuan adalah sama atau tidak. Sedangkan pada model dengan efek acak, hal yang utama menjadi hipotesis adalah membandingkan varias antarperlakuan apakah homogen atau tidak.

Dengan mempertimbangkan model dengan efek tetap, analisis ANOVA dimulai dengan mempartisi total variasi menjadi beberapa komponen, yaitu:

$$
S S_{\text {total }}=S S_{\text {treatment }}+S S_{\text {error }}
$$

dimana $S S_{\text {total }}$ adalah sum-of-square total, $S S_{\text {treatment }}$ adalah sum-of-square antarperlakuan dan $S S_{\text {error }}$ adalah sum-of-square dari error (dalam setiap perlakuan ke-i). Penjelasan detil dari $S S_{\text {total }}=S S_{\text {treatment }}+$ $S S_{\text {error }}$ adalah sebagai berikut. Sum-of-square total, yang merupakan ukuran dari seluruh variasi dalam data terobservasi, adalah:

$$
\begin{gathered}
S S_{\text {total }}=\sum_{i=1}^{p} \sum_{j=1}^{r}\left(Y_{i j}-\bar{Y}_{* *}\right)^{2} \\
\sum_{i=1}^{p} \sum_{j=1}^{r}\left(Y_{i j}-\bar{Y}_{* *}\right)^{2}=\sum_{i=1}^{p} \sum_{j=1}^{r}\left[\left(\bar{Y}_{i *}-\bar{Y}_{* *}\right)+\left(Y_{i j}-\bar{Y}_{i *}\right)\right]^{2} \\
\sum_{i=1}^{p} \sum_{j=1}^{r}\left(Y_{i j}-\bar{Y}_{* *}\right)^{2}=\operatorname{r} \sum_{i=1}^{p}\left(\bar{Y}_{i *}-\bar{Y}_{* *}\right)^{2}+\sum_{i=1}^{p} \sum_{j=1}^{r}\left(Y_{i j}-\bar{Y}_{i *}\right)^{2} .
\end{gathered}
$$

persamaan (113) mempunyai arti bahwa total variasi dalam data terobservasi, yaitu sum-of-square total, dapat dipartisi menjadi sum-of-square dari perbedaan antara rata-rata nilai perlakuan dan rata-rata total ditambah dengan sum-ofsquare dari perbedaan antara observasi dalam sebuah perlakuan dan rata-rata dari setiap perlakuan tersebut. Total observasi adalah $p r$. Dimana, $p$ adalah jumlah perlakuan (level dari faktor) dan $r$ adalah jumlah pengulangan setiap perlakuan. Maka, $S S_{\text {total }}$ mempunyai $p r-1$ derajat kebebasan (degree-of-freedom), $S S_{\text {treatment }}$ mempunyai $p-1$ derajat kebebasan dan $S S_{\text {error }}$ mempunyai $p(r-1)$ derajat kebebasan (karena pada setiap perlakuan, derajat kebebasan dari error adalah $r-1$ ). Dengan membagi setiap sum-of-sqare dengan derajat kebabasannya masing-masing, maka didapatkan:

$$
\begin{aligned}
& M S_{\text {treatment }}=\frac{S S_{\text {treatment }}}{p-1} \\
& M S_{\text {error }}=\frac{S S_{\text {error }}}{p(r-1)}
\end{aligned}
$$

dimana $M S_{\text {treatment }}$ dan $M S_{\text {error }}$ masing-masing disebut sebagai mean-squre dari perlakuan dan error.

Uji hipotesis dari model dengan efek tetap (fixed effect model) adalah:

$$
\begin{aligned}
& H_{0}: \tau_{1}=\tau_{2}=\cdots=\tau_{p}=0 \\
& H_{1}: \tau_{i} \text { untuk minimal salah satu } i
\end{aligned}
$$

Statistik test untuk uji hipotesis model dengan efek tetap adalah:

$$
F_{0}=\frac{M S_{\text {treatment }}}{M S_{\text {error }}}
$$

$F_{0}$ mempunyai distirbusi statitsik berupa distribusi $F$. Apabila $F_{0}>F_{\alpha, p-1, p r-p}$, maka $H_{0}$ ditolak dan kesimpulannya adalah ada perbedaan yang signifikan pada rata-rata perlakuan dan sebaliknya. Tabel ANOVA untuk 
satu faktor untuk model engan efek tetap diperlihatkan pada tabel 4. Gambar 27 memperlihatkan salah satu bentuk distirbusi $F$. Dari gambar 27, apabila $F_{0}>F_{\alpha, 4,20}$ maka hipotesis akan ditolak $H_{0}$, sedangkan apabila $F_{0} \leq$ $F_{\alpha, 4,20}$ maka hipotesis $H_{0}$ akan diterima.

Tabel 4: Tabel ANOVA untuk satu faktor, model dengan efek tetap.

\begin{tabular}{|c|c|c|c|c|}
\hline Sumber variasi & Sum-of squqre & $\begin{array}{c}\text { derajat } \\
\text { kebebasan }\end{array}$ & Mean square & $F_{0}$ \\
\hline Faktor (antar perlakuan) & $S S_{\text {treatment }}$ & $p-1$ & $M S_{\text {treatment }}$ & $F_{0}=\frac{M S_{\text {treatment }}}{M S_{\text {error }}}$ \\
\hline Error (dalam perlakuan) & $S S_{\text {error }}$ & $p(r-1)$ & $M S_{\text {error }}$ & - \\
\hline Total & $S S_{\text {total }}$ & $p r-1$ & & - \\
\hline
\end{tabular}

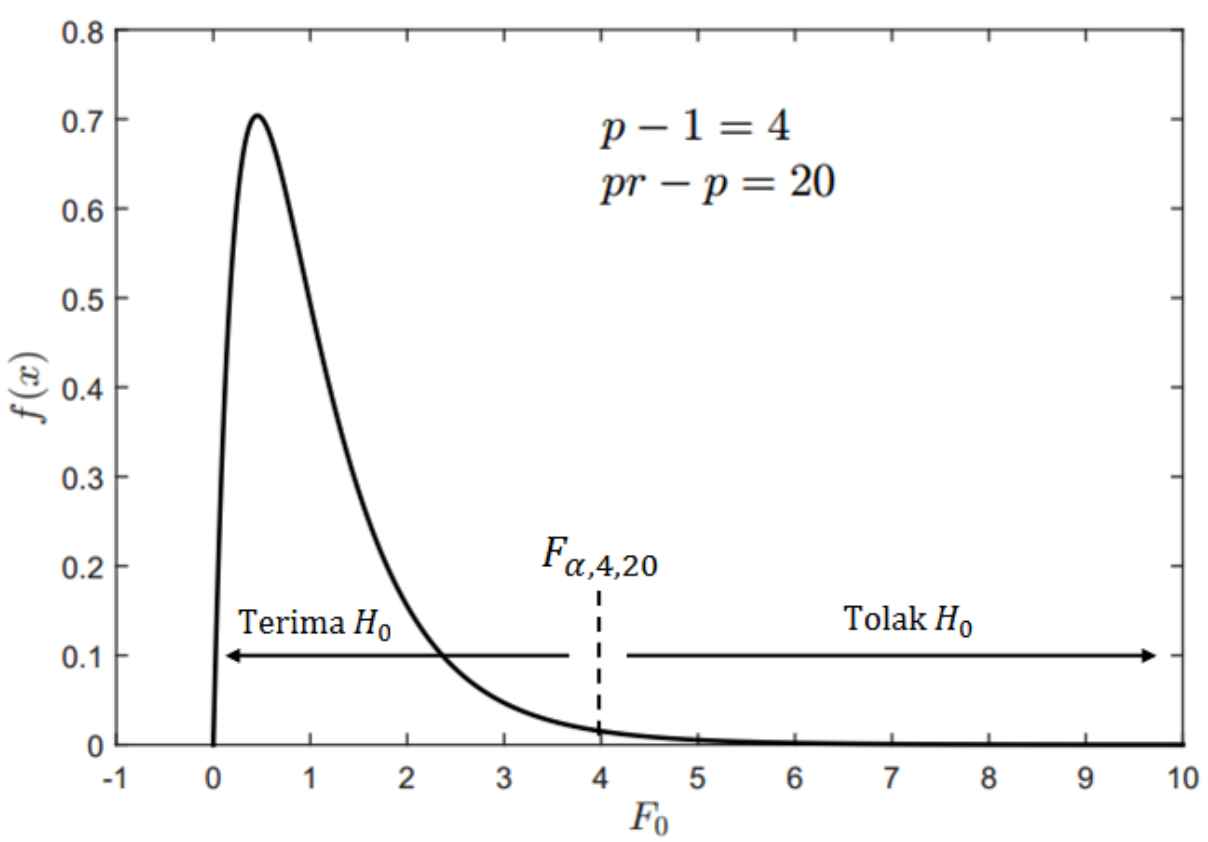

Gambar 27: Salah satu bentuk kurva distribusi $F$.

Pada umumnya, analisis ANOVA dilakukan dengan menggunakan perangkat lunak komersial, seperti Minitab atau SPSS. Apabila analisis ANOVA dilakan menggunakan suatu perangkat lunak, pada umumnya perangkat lunak tersebut akan mengkonversi nilai $F_{0}$ menjadi nilai $P\left(P-\right.$ value). Nilai $F_{0}$ berkebalikan dengan nilai $P$. Apabila nilai $F_{0}$ besar, maka nilai $P$ menjadi kecil sehingga hipotesis $H_{0}$ akan ditolak. Dan sebaliknya, apabila nilai $F_{0}$ kecil, maka nilai $P$ menjadi besar sehingga hipotesis $H_{0}$ diterima. Nilai $P$ adalah luas area dibawah kurva distribusi $\mathrm{F}$ dari batas $F_{0}$ sampai dengan ujung distribusi $F$ tersebut. Sehingga, hubungan terbalik antara $F_{0}$ dan $P$ didapatkan karena semakin besar nilai $F_{0}$, maka area dibawah kurva distribusi $F$ dari $F_{0}$ sampai ujung kurva distribusi tersebut semakin kecil.Gambar 28 memperlihatkan pengertian dari nilai $P$ dan hubungannya dengan $F_{0}$. 


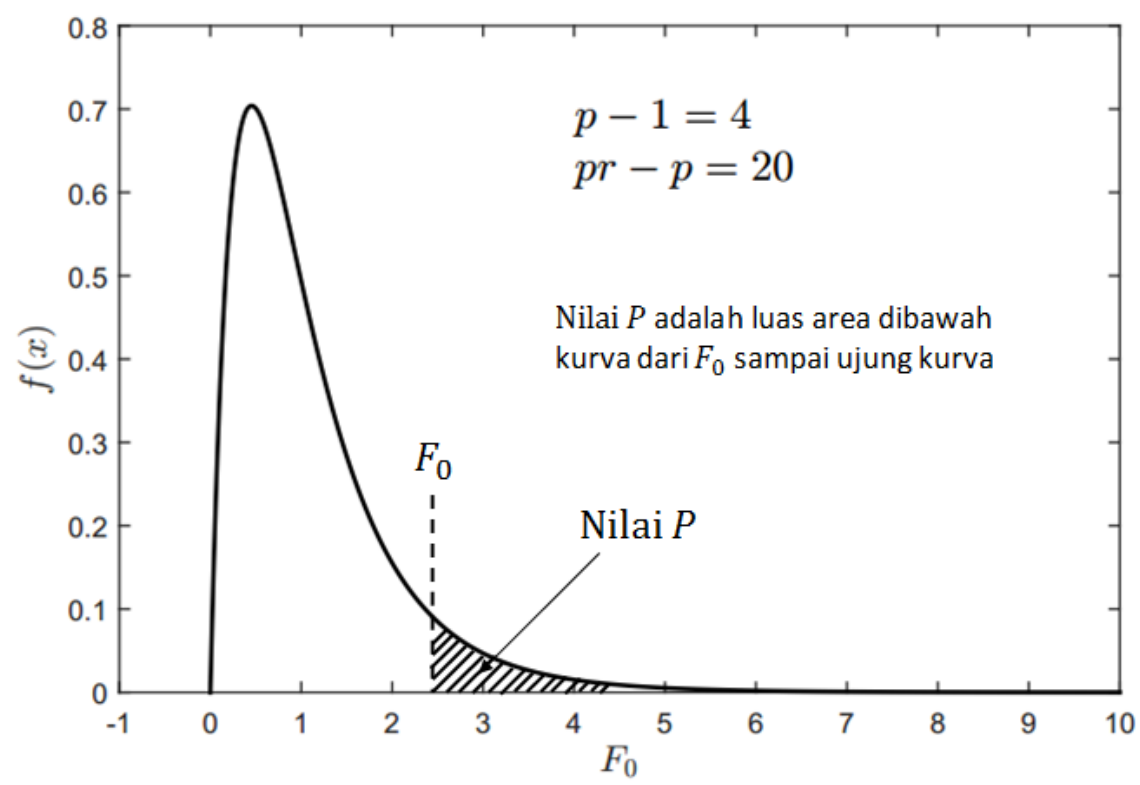

Gambar 28: Hubungan antara nilai $F_{0}$ dan nilai $P$ pada kurva distribusi $F$.

Untuk analisis ANOVA yang mempertimbangkan model dengan efek acak (random effect model), hal yang ingin dikomparasi adalah variasi antarperlakuan. Uji hipotesisnya adalah sebagai berikut:

$$
\begin{aligned}
& H_{0}: \sigma_{p}^{2}=0 \\
& H_{1}: \sigma_{p}^{2}>0
\end{aligned}
$$

Perlu diperhatikan bahwa, untuk ANOVA dengan satu faktor, paraeter uji statistik model dengan efek acak adalah sama dengan model dengan efek tetap, namun demikian, uji statistik akan berbeda apabila ANOVA dilakukan untuk lebih dari satu faktor (lebih dari satu perlakuan).

Untuk mengestimasi komponen dari setiap variasi (dari perlakuan atau dari error) adalah sebagai berikut:

$$
\begin{gathered}
\hat{\sigma}_{\epsilon}^{2}=\frac{S S_{\text {error }}}{p(r-1)}=M S_{\text {error }} \\
\hat{\sigma}_{\tau}^{2}=\left(\frac{S S_{\text {treatment }}}{p-1}-\hat{\sigma}_{\epsilon}^{2}\right) / n=\frac{M S_{\text {treatment }}-M S_{\text {error }}}{n}
\end{gathered}
$$

Pada perangkat lunak Minitab, untuk memunculkan komponen dari setiap variasi tersebut, operator harus memilih opsi ini agar Minitab dapat memunculkan komponen variasi dari data yang sedang dianalisis.

\subsubsection{Gauge repeatability dan reproducibility (GR\&R)}

Gauge repeatability dan reproducibility (GR\&R) merupakan sebuah metode analisis yang sangat penting dan bermanfaat untuk menganalisis suatu instrumen pengukuran, atau sering disebut sebagai analisis sistem pengukuran (Burdick et al 2005). Pada bab ini, landasan matematik yang digunakan untuk melakukan analisis GR\&R dipresentasikan dengan memfokuskan pada metode analisis GR\&R yang paling umum digunakan dan diaplikasikan. Sedangakn untuk contoh aplikasinya, dapat dilihat pada bab pengukuran dimensi dan geometri. Untuk model analisis 
GR\&R lainnya, pembaca dapat merujuk ke (Burdick et al 2005).

Analisi GR\&R berbasis analisis ANOVA yang berguna untuk menentukan apakah suatu instrument pengukuran mampu memonitor suatu process manufaktur (reliabel), atau dengan kata lain, apakah suatu instrumen dapat mengukur suatu produk atau tidak. Dibutuhkan suatu alat pengukuran yang reliabel untuk dapat mengukur suatu atribut dari suatu hasil proses manufaktur agar proses optimisasi proses manufaktur tersebut dapat dilakukan atau untuk mengidentifikasi dan memisahkan suatu produk yang cacat dari suatu produk yang bagus. Prinsip utama dalam melakukan suatu pengukuran adalah variasi yang disebabkan oleh instrumen pengukuran yang digunakan harus jauh lebih kecil dari pada variasi komponen atau benda yang diukur.

Tujuan utama analisis GR\&R adalah:

- Untuk menentukan besaran variasi yang terdapat dari data yang terobservasi atau data hasil pengukuran yang berasal dari suatu instrumen pengukuran yang digunakan.

- Untuk mengisolasi sumber-sumber yang menyebabkan variasi pada suatu alat pengukuran, dan

- Untuk menentukan apakah suatu instrumen pengukuran dapat digunakan untuk suatu pengukuran atau untuk pengukuran lainnya.

Pada umumnya, suatu instrumen pengukuran digunakan untuk mengukur dan mereplikasi suatu pengukuran dengan operator, waktu dan setup yang berbeda-beda. Analisis suatu instrumen pengukuran adalah pada umumna untuk mengkuantifikasi repeatability dan reproducibility dari instrumen tersebut. Repeatability adalah besaran variasi dari suatu instrumen ketika digunakan untuk mengukur unit yang sama dengan operator, setup dan periode waktu yang sama. Sedangkan, reproducibility adalah variasi dari suatu instrumen yang disebabkan karena instrumen tersebut digunakan oleh operator, dengan setup dan pada periode waktu yang berbeda.

GR\&R adalah metode yang sangat populer pada di industri manufaktur, terutama pada industri semi-konduktor. Bahkan, pada industri semi-konduktor, analisis GR\&R harus dilakukan terlebih dahulu sebelum mengimplementasikan sebuah proses yang baru. Analisis GR\&R harus diulang lagi apabila suatu proses manufaktur dimodifikasi karena variasi proses yang semakin kecial dari hasil modifikasi tersebut dapat menyebabkan suatu instrumen pengukuran yang sebelumnya dapat digunakan untuk mengukur menjadi tidak reliabel lagi digunakan untuk mengukur suatu hasil produksi proses yang telah dimodifikasi tersebut.

Untuk analisis GR\&R, berdasarkan pada model analisis ANOVA, sebuah observasi $\left(y_{i j}\right)$ adalah sebuah hasil pengukuran pada komponen ke- $p$ (lihat persamaan (108)). Metode ANOVA yang aling sering diaplikasikan untuk analisis GR\&R adalah balanced two-factor crossed random model dengan memperhitungkan interaksi antara kdua faktor tersebut.

Dari model ANOVA yang telah dijelaskan sebelumnya, seluruh model tersebut dapat dianggap merupakan bentuk khusus dari sebuah model umum:

$$
Y=X+E
$$

dimana $Y$ adalah nilai yang diukur dari suatu komponen yang diambil secara acak dari sebuah proses manufaktur, $X$ adalah nilai pengukuran yang sebenarnya dari komponen tersebut dan $E$ adalah error pengukuran yang berasal dari suatu sistem pengukuran yang digunakan. $X \sim N\left(\mu_{p}, \gamma_{p}\right)$ dan $E \sim N\left(\mu_{m}, \gamma_{m}\right) . p$ menotasikan suatu proses, sedangkan $m$ menotasikan suatu sistem pengukuran. Hal ini mengindikasikan bahwa $Y \sim N\left(\mu_{Y}=\mu_{p}+\mu_{m}, \gamma_{Y}=\gamma_{p}+\gamma_{m}\right)$. covarian antara $Y$ dan $X$ dinotasikan sebagai $\gamma_{p}$ dan korelasi antara $Y$ dan $X$ adalah: $\sqrt{\gamma_{p} /\left(\gamma_{p}+\gamma_{m}\right)} Y$, sehingga apabila sistem pengukuran yang digunakan mempunya variasi yang sangat kecil (sangat reliabel), maka $\gamma_{m}$ akan berkurang dan korelasi antara nilai yang diukur $Y$ dan nilai pengukuran yang sebenarnya $X$ mendekati 1 . Tabel 5 memperlihatkan berbagai parameter yang digunakan dalam analisis GR\&R. 
Tabel 5: Parameter-parameter utama dalam analisis GR\&R.

\begin{tabular}{|c|l|}
\hline Simbol & \multicolumn{1}{|c|}{ Definisi } \\
\hline$\mu_{Y}$ & Rata-rata dari populasi hasil pengukuran \\
\hline$\gamma_{p}$ & Variasi dari prosess manufaktur \\
\hline$\gamma_{m}$ & Variasi dari sistem pengukuran \\
\hline$\gamma_{r}=\frac{\gamma_{p}}{\gamma_{m}}$ & Ratio antara variasi proses dan variasi sistem pengukuran \\
\hline
\end{tabular}

Nilai rata-rata $\mu_{m}$ adalah bias (error sistematik) dari sistem pengukuran yang digunakan untuk analisis. Pada umumnya, bias ini sudah diminimalisasi atau ditiadakan dengan mengkalibrasis dan mengatur sistem pengukuran tersebut. Sehingga, diasumsikan bahwa $\mu_{m}=0$. Dengan demikian, $\mu_{y}=\mu_{p}$. Apabila asumsi ini tidak benar, maka analisis GR\&R akan hanya berpengaruh kepada estimasi $\mu_{p}$, tetapi tidak berpengaruh kepada estimasi varian. Dalam analisis GR\&R, estimasi varian adalah hal yang lebih utama dan menjadi fokus analisis.

Ilustrasi dasar dari GR\&R adalah sebagai berikut. Sebuah proses permesinan bubut digunakan untuk memproduksi sebuah silinder dalam jumlah banyak. Silinder hasil produksi tersebut akan diinspeksi dengan menggunakan jangka sorong. Maka:

1. Mesin bubut untuk memproduksi silinder.

2. Error pengukuran yang berasal dari sistem pengukuran.

Tujuan utama dari GR\&R adalah untuk menganalisis apakah variasi hasil pengukuran yang berasal dari sistem pengukuran (nomor 2) jauh lebih kecil dibandingkan dengan variasi yang berasal dari silinder tersebut dan proses produksinya (nomor 1). "Golden rule" mengenai seberapa besar variasi dari sistem pengukuran sehingga dianggap reliabel untuk melakukan suatu pengukuran adalah apabila variasi yang berasal dari sistem pengukuran $<20 \%$ dari total variasi hasil pengukuran. Maka dari itu, hal paling pertama yang dibandingkan adalah rasion antara variasi dari kedua hal tersebut, yaitu $\gamma_{r}$. Sehingga, sebuah instrument atau sistem pengukuran dapat digunakan apabila nilai $\gamma_{r}$ besar. Ukuran besarnya nilai $\gamma_{r}$ dapat tergantung dengan definisi dari ikuran performansi suatu pengukuran.

\section{Ukuran performansi sistem pengukuran dengan metode GR\&R.}

Berbagai ukuran performansi analisis GR\&R untuk menentukan suatu sistem pengukuran dapat digunakan adalah sebagai berikut (Burdick et al 2005):

- Rasio antara presisi dan toleransi (Precision-to-tolerance ration/PTR).

$$
P T R=\frac{k \sqrt{\gamma_{m}}}{U S L-L S L}
$$

dimana $U S L$ dan $L S L$ adalah limit atas dan bawah dari spesifikasi, $k$ adalah konstanta dengan nilai $k=5.15$ atau $k=6$. Hasil dari nilai PTR dapat dikategroikan sebagai berikut:

- $\quad P T R \leq 0.1$ : Suatu sistem pengukuran dianggap kapabel.

- $\quad 0.1<P T R \leq 0.3$ : Suatu sistem pengukuran dianggap kapabel tetapi bergantung dengan kapabilitas suatu prosess dan resiko biaya dari kesalahan inspeksi.

- $\quad P T R>0.3$ : Suatu sistem pengukuran tidak kapabel.

- $\quad$ Rasio antara sinyal dan noise (Signal-to-noise ratio/SNR).

$$
S N R=2 \sqrt{\gamma_{r}}
$$


SNR didefinisikan sebagai jumlah dari kategori yang berbeda yang dapat dibedakan secara relaibel oleh suatu sistem pengukuran. Secara umum, suatu sistem pengukuran dianggap kapabel apabila $S N R>5$.

- Korelasi intra-kelas (Interclass correlation) $\rho$.

$$
\rho=\frac{\gamma_{r}}{1+\gamma_{r}}=\frac{\gamma_{p}}{\gamma_{p}+\gamma_{m}}
$$

- Kapabilitas prosess (prosee capability) $C_{p}$.

$$
C_{p}=\frac{U S L-L S L}{6 \sqrt{\gamma_{p}}}
$$

\section{Analisis GR\&R paling umum: balanced two-factor crossed random model.}

Analisis GR\&R dengan menggunakan model balanced two-factor crossed random adalah metode yang paling umum digunakan untuk analisis tersebut. Dua jenis faktor dalam model balanced two-factor crossed random adalah merujuk pada "Benda kerja (part)" dan "operator."

Model dari balanced two-factor crossed random adalah sebagai berikut:

$$
Y_{i j k}=\mu_{r}+P_{i}+O_{j}+(P O)_{i j}+E_{i j k}
$$

dimana $i=1,2, \ldots, p, j=1,2, \ldots, o, k=1,2, \ldots, r . P_{i}, O_{j},(P O)_{i j}, E_{i j k}$ adalah variabel acak mengikuti distribusi normal dengan nilai rata-rata 0 dan varian $\sigma_{P}^{2}, \sigma_{O}^{2}, \sigma_{P O}^{2}, \sigma_{E}^{2}$. Susunan data untuk analisis GR\&R denan model tersebut diperlihatkan pada tabel 6. Analisis ANOVA untuk model GR\&R tipe ini diperlihatkan pada tabel 7 dan perhitungan mean-square $(M S)$ untuk setiap sumber variasi diperlihatkan pada tabel 8. Untuk contoh analisis GR\&R dengan metode balanced two-factor crossed random, pembaca dapat merujuk pada bab pengukuran dimensi dan geometri. Sedangkan estimasi parameter-parameter dari analisis GR\&R diperlihatkan pada tabel 9. Pada tabel 9, estimasi dari parameter $\gamma_{r}$ didapatkan.

Tabel 6: Susunan data untuk analisis GR\&R.

\begin{tabular}{|c|c|c|c|c|}
\hline Benda kerja & Operator 1 & Operator 2 & $\ldots$ & Operator $o$ \\
\hline 1 & pengukuran $1, \ldots, r$ & pengukuran $1, \ldots, r$ & $\ldots$ & pengukuran $1, \ldots, r$ \\
\hline 2 & pengukuran $1, \ldots, r$ & pengukuran $1, \ldots, r$ & $\ldots$ & pengukuran $1, \ldots, r$ \\
\hline$\ldots$ & $\ldots$ & $\ldots$ & $\ldots$ & $\ldots$ \\
\hline$p$ & pengukuran $1, \ldots, r$ & pengukuran $1, \ldots, r$ & $\ldots$ & pengukuran $1, \ldots, r$ \\
\hline
\end{tabular}


Tabel 7: Analisis ANOVA untuk model GR\&R tersebut.

\begin{tabular}{|c|c|c|}
\hline Sumber variasi & Derajat kebebasan & Mean-square (MS) \\
\hline Benda kerja (P) & $p-1$ & $M S_{P}^{2}$ \\
\hline Operator (O) & $o-1$ & $M S_{O}^{2}$ \\
\hline Interaksi $(P \times O)$ & $(p-1)(o-1)$ & $M S_{P O}^{2}$ \\
\hline Replikasi (pengulangan) & $p o(r-1)$ & $M S_{E}^{2}$ \\
\hline
\end{tabular}

Tabel 8: Perhitungan mean-square (MS) untuk setiap sumber variasi GR\&R tersebut.

\begin{tabular}{|c|c|}
\hline Statistik & Definisi \\
\hline$M S_{P}^{2}$ & $\frac{o \cdot r \cdot\left(\bar{Y}_{i * *}-\bar{Y}_{* * *}\right)^{2}}{p-1}$ \\
\hline$M S_{O}^{2}$ & $\frac{p \cdot r \cdot\left(\bar{Y}_{* j *}-\bar{Y}_{* * *}\right)^{2}}{o-1}$ \\
\hline$M S_{P O}^{2}$ & $\frac{r \cdot \sum_{i} \sum_{j}\left(\bar{Y}_{i j *}-\bar{Y}_{i * *}-\bar{Y}_{* j *}+\bar{Y}_{* * *}\right)^{2}}{(p-1)(o-1)}$ \\
\hline$M S_{E}^{2}$ & $\frac{\sum_{i} \sum_{j} \sum_{k}\left(\bar{Y}_{i j k}-\bar{Y}_{i j *}\right)^{2}}{p o(r-1)}$ \\
\hline $\bar{Y}_{i * *}$ & $\frac{\sum_{j} \sum_{k} Y_{i j k}}{o r}$ \\
\hline $\bar{Y}_{* j *}$ & $\frac{\sum_{i} \sum_{k} Y_{i j k}}{p r}$ \\
\hline $\bar{Y}_{i j *}$ & $\frac{\sum_{k} Y_{i j k}}{r}$ \\
\hline $\bar{Y}_{* * *}$ & $\frac{\sum_{i} \sum_{j} \sum_{k} Y_{i j k}}{p o r}$ \\
\hline
\end{tabular}


Tabel 9: GR\&R parameter dan estimasinya.

\begin{tabular}{|c|c|}
\hline $\begin{array}{c}\text { GR\&R } \\
\text { parameter }\end{array}$ & Estimasi \\
\hline$\mu_{y}$ & $\hat{\mu}_{y}=\bar{Y}_{* * *}$ \\
\hline$\gamma_{p}$ & $\hat{\gamma}_{p}=\frac{M S_{P}^{2}-M S_{P O}^{2}}{o \cdot r}$ \\
\hline$\gamma_{m}$ & $\hat{\gamma}_{m}=\frac{M S_{O}^{2}+(p-1) M S_{P O}^{2}+p(r-1) M S_{E}^{2}}{p \cdot r}$ \\
\hline$\gamma_{r}$ & $\widehat{\gamma}_{\boldsymbol{r}}=\frac{\widehat{\gamma}_{\boldsymbol{p}}}{\widehat{\gamma}_{m}}$ \\
\hline
\end{tabular}

Baik analisis ANOVA maupun analisis GR\&R, kedua analisis tersebut memerlukan suatu desain eksperimen sedemikian rupa sehingga paramter-parameter yang akan diestimasi dari kedua analisis tersebut dapat dikalkulasi. Dengan demikian, suatu eksperimen harus didesain dengan sebaik-baiknya. Panduam umum untuk melakukan desain suatu eksperimen adalah (Montgomery 2001):

- Pengenalan dan pernyataan dari masalah atau topik yang akan dianalisis.

- Penentuan jumlah faktor, level dan kisaran jarak level per faktor.

- Penetapan dari variabel keluaran yang akan diobservasi dan dianalisis.

- Pemilihan tipe dari eksperimen, seperti: balanced, unbalance, dan campuran.

- Melakukan eksperimen yang sudah didesain sebelumnya.

- Analisis statistik, seperti ANOVA dan regresi, dari data-data hasil eksperimen atau observasi.

- Kesimpulan dan rekomendasi.

\subsection{Komputasi numerik}

Dalam bidang pengukuran dimensi dan geometri modern, komputasi data mempunyai peranan yang sangat penting. Instrumen-instrumen pengukuran modern banyak menggunakan algoritma-algoritma level tinggi untuk memproses data pengukuran. Aplikasinya seperti, pengukuran surface yang kompleks, pengukuran dengan metode non-kontak dan kompensasi kesalahan (error). Bab algoritma dan bab kompensasi error memperlihatkan pentingnya peran komputasi numerik untuk pengukuran.

Algoritma-algoritma tersebut diimplementasikan dengan suatu bahasa pemrograman yang dijalankan oleh suatu komputer dijital. Komputer dijital adalah suatu mesin yang memproses sinyal listrik dalam dua keadaan, yaitu dalam keadaan 1 atau 0 dan merupakan sistem berbasis diskrit. Sistem tersebut dinamakan sistem binari. Dapat dilihat bahwa, dalam pemrosesan data-data hasil pengukuran, pada umumnya pemrosesan data tersebut berupa kalkulasi dari suatu fungsi-fungsi matematik. Fungsi-fungsi matematik tersebut pada umumnya merupakan fungsi kontinu, sedangkan komputer yang memproses fungsi tersebut berbasis sistem diskrit dan binari. Sebagai tambahan, pada umumnya data yang dikalkulasi adalah bilangan riil, sedangkan komputer hanya memproses data binari.

Dari dua keadaan tersebut: komputer bersifat diskrit dan binari, implementasi suatu algoritma dan fungsi matematis pada komputer pada kondisi riil terdapat banyak limitasi. Bagian bab ini menjelaska aspek-aspek yang harus diperhatikan dalam mengimplementasikan suatu algoritma pengukuran pada komputer, seperti data overflow dan underflow, rounding error dan poor conditioning (Goodfellow et al 2016). Selain itu, implementasi algoritmaalgoritma tersebut akan berbeda tergantung pada jenis bahasa pemrograman yang digunakan, seperti; C, Fortran dan Pascal (Press et al 1992). 


\subsubsection{Overflow dan underflow data}

Hal yang paling fundamental dalam komputasi numerik dengan komputer adalah sebuah angka atau bilangan riil, yang tak terhingga, harus direpresentasikan dengan suatu bilangan yang terhingga dalam bentuk pola-pola bit, yang mempunyai nilai 0 atau 1 . Misalnya, sebuah bilangan riil $x=3.141592653589793 \ldots$ (nilai dari $\pi$ ) harus direpresentasikan dalam bentuk bit dengan jumlah terhingga. Hal ini merupakan error fundamental yang berkontribusi pada error numerik dalam proses komputasi numerik dengan komputer. Error tersebut adalah error approksimasi. Error approksimasi ini mempunyai peranan yang sangat penting adalam suatu komputasi numerik yang sangat intensif karena efeknya akan terakumulasi seiring dengan bertambah banyaknya dan bertambah kompleksnya suatu rantai komputasi.

Dua jenis dari error aproksimasi adalah: overflow dan underflow. Kedua error ini sering menjadi penyebab banyaknya algoritma komputasi numerik yang secara teori sudah benar namun pada implementasi riilnya, algoritma tersebut tidak bekerja sesuai dengan yang diharapkan. Error jenis ini sangat sering terjadi dan sebagian besar sulit untuk diidentifikasi karena banyak orang-orang yang melakukan pemrograman mengabaikan atau meremehkan error tersebut.

- Underflow adalah error yang muncul ketika sebuah angka yang mendekati 0 dianggap sebagai 0 . Hal ini mempunyai implikasi yang sangat besar terhadap hasil perhitungan. Misalnya, apabila kita ingin mengkalkulasi $x=100000000000 \times 0.0000000001$, maka secara teori, hasil dari kalkulasi tersebut adalah $x=10$. Namun demikian, pada implementasi riilnya, misalnya, karena kesalahan memilih tipe data, maka komputer akan menganggap perhitungan tersebut sebagai $x=100000000000 \times 0=$ 0 . Hal tersebut mempunyai implikasi yang sangat berbeda terhadap hasil perhitungan kita.

Contoh lainnya adalah apabila kita ingin melakukan suatu perhitungan dengan pembagian, misalnya $x=1 / 0.0000000001$. Apabila terjadi underflow, maka yang terkalkulasi adalah $1 / 0=\infty$ yang dapat menyebabkan program berhenti berjalan.

- Overflow adalah error yang muncul ketika sebuah nilai yang sangat besar diaproksimasi sebagai bilangan takhingga $\infty$. Dalam keadaan riil, kebanyakan komputer akan menganggap hal ini sebagai nilai yang bukan angka (not-a-number). Error jenis ini juga mempunyai implikasi yang sangat besar terhadap suatu perhitungan. Misalnya, suatu nilai $x=\frac{10000000000}{0.0000000001}=10^{20}$. apabila terjadi overflow, maka nilai tersebut adalah $x=\infty$.

Contoh yang lebih kompleks adalah sebagai berikut. Apabila kita ingin mengkalkulasi sebuah fungsi:

$$
y\left(x_{i}\right)=\frac{e^{x_{i}}}{e^{c}}
$$

Pada persamaan (129) di atas, apabila nilai c adalah suatu nilai yang sangat negatif, maka persamaan tersebut akan megalami underflow, yaitu persamaan tersebut mempunyai penyebut $=0$. Sehingga, hasil dari komputasi persamaan tersebut tidak dapat didefinisikan.

\subsubsection{Error pembulatan (rounding error)}

Error pembulatan mempunyai hubungan dengan error approksimasi yang telah dijelaskan sebelumnya (yang menyebabkan keadaaan overflow atau underflow). Error pembulatan mempunyai efek yang sangat signifikan apabila suatu kalkulasi numerik mempunyai rantai kalkulasi yang panjang dan kompleks. Error pembulatan bisa disebabkan oleh dua faktor:

1. Error aproksimasi yang dilakukan oleh komputer, misalnya menngeset tipe data yang salah untuk sebuah 
variabel, misalnya variabel untuk menampung nilai riil kita set sebagai variabel bilangan bulat (integer).

2. Error yang disebabakan karena orang yang memprogram suatu komputasi dengan sengaja melakukan pembulatan numerik pada data yang dimilikinya.

Contoh dasarnya adalah sebagai berikut. Misalnya, kita ingin mengkalkulasi suatu persamaan yang mempunyai rantai komputasi yang tidak panjang dan tidak kompleks sebagai berikut:

$$
f(x, y, z)=20 x+5 y+2 z
$$

apabila nilai-nilai dari variabel persamaan (130) di atas adalah $x=4.56, y=3.57, z=5.12$ maka hasik kalkulasi tersebut adalah $f(x, y, z)=119.29$. Sedangkan, apabila nilai-nilai dari variabel persamaan (130) di atas dibulatkan menjadi $x=4.5, y=3.5, z=5$ maka hasil kalkulasi tersebut adalah $f(x, y, z)=117.5$. Untuk persamaan (130), apabila dikalkulasi dengan variabel-variabel tanpda dan dengan pembulatan, maka perbedaan hasilnya adalah $1.5 \%$. Perbedaan ini dianggap kecil.

Namun, apabila kita mempunyai persamaan yang cukup panjang dan kompleks, seperti:

$$
f(x, y, z)=\left(\frac{20 x+5 y^{5}+2 z}{z-2}\right)^{3}-1000 \cdot \log (x)
$$

apabila nilai-nilai dari variabel persamaan (131) di atas adalah $x=4.56, y=3.57, z=5.12$ maka hasik kalkulasi tersebut adalah $f(x, y, z)=8.8 \times 10^{8}$. Sedangkan, apabila nilai-nilai dari variabel persamaan (131) di atas dibulatkan menjadi $x=4.5, y=3.5, z=5$ maka hasil kalkulasi tersebut adalah $f(x, y, z)=7.5 \times 10^{7}$. Untuk persamaan (131), apabila dikalkulasi dengan variabel-variabel tanpda dan dengan pembulatan, maka perbedaan hasilnya adalah $15.6 \%$. Perbedaan ini adalah sangat besar dan akan mempunyai pengaruh yang signifikan terhadap hasil perhitungan secara total.

Proses pembulatan angka dalam kalkulasi numerik juga bergantung kepada jenis bahasa pemrograman yang digunakan untuk melakukan kalkulasi numerik tersebut. Maka dari itu, orang yang melakuan pemrograman untuk suatu kalkulasi numerik harus berhati-hati terhadap perbedaan pembulatan angka oleh bahasa pemrograman yang berbeda. Sebagai contoh, bahasa pemrograman MATLAB akan membulatkan ke atas untuk suatu nilai $\geq X$. 5 , misalnya 4.5 akan dibulatkan menjadi 5. Sedangkan, bahasa pemrograman PYTHON akan membulatkan ke bawah untuk suatu nilai $\leq X .5$, misalnya 4.5 akan dibulatkan menjadi 4 .

Salah satu saran praktis untuk mengatasi hal ini adalah, misalnya, apabila kita ingin mengetes suatu hasil komputasi numerik adalah sama dengan atau tidak sama dengan 0 , maka sebaiknya pada implementasinya, sebaiknya nilai 0 tersebut diganti dengan sebuah konstanta $\varepsilon$ yang mempunyai nilai yang sangat kecail, misalnya $\varepsilon=$ 0.0000001 . Besar $\varepsilon$ adalah tergantung dengan jenis dan tujuan suatu komputasi numerik yang dilakukan.

\subsubsection{Poor conditioning}

Pengkondisian numerik (numerical conditioning) merupakan seberapa besar sebuah fungsi berubah nilainya terhadap suatu perubahan yang sangat kecil terhadap nilai input-input yang dimiliki olehfungsi tersebut. Suatu fungsi ,yang nilainya berubah secara drastis ketika input-input fungsi tersebut hanya mempunyai perubahan nilai yang sangta kecil (dengan kata lain, fungsi tersebut sangat sensitif), adalah mempunya potensi masalah yang besar dalam komputasi (Goddfellow et al 2016). Karena, apabila ada sedikit pembulatan dari nilai input fungsi tersebut, maka hasil dari fungsi tersebut akan secara drastis berubah. Contoh yang paling dasar untuk masalah poor conditioning adalah fungsi yang memiliki komponen invers dari suatu matriks.

Sebagai contoh, misalnya sebuah fungsi: 


$$
f(\boldsymbol{x})=\mathbf{A}^{-1} \boldsymbol{x}, \mathbf{A} \in \mathbb{R}^{n \times n}
$$

Fungsi tersebut mempunyai nilai pengkondisian sebagai:

$$
\max _{i, j}\left|\frac{\lambda_{i}}{\lambda_{j}}\right|
$$

dimana fungsi tersebut merupakan rasio dari nilai Eigen yang terbesar $\lambda_{i}$ dan terkecil $\lambda_{j}$ dari persamaan tersebut. Ketika nilai rasio ini besar, maka fungsi tersebut sensitif terhadap berupahan pada nilai-nilai inputnya.

Contoh lain dari fungsi yang memiliki poor conditioning adalah fungsi yang salah satu atau lebih variabelnya mempunya pangkat yang besar, sehingga sedikit perubahan dari nilai variabel tersebut, akan berpengaruh besar pada nilai fungsi tersebut. Misalnya, $f(x)=x+5 y-z^{40}$ adalah fungsi yang memiliki properti poor conditioning karena salah satu variabelnya, yaitu $z$, memiliki pangkat yang sangat besar sehingga sangat sensitif terhadap perubahan nilai $z$.

\subsubsection{Kebocoran memori komputer (memory leak)}

Kebocoran memori komputer dalam suatu perangkat lunak adalah situasi dimana sebuah blok memori komputer (random access memory/RAM) sudah diset untuk suatu variabel tertentu (sehingga tidak dapat digunakan untuk varibel lainnya) dan setelah variabel tersebut tidak digunakan lagi dalam perangkat lunak tersebut, memori yang sudah diset untuk variabel tersebut tidak dibebaskan, dengan kata lain memori tersebut tidak dapat digunakan untuk variabel lainnya. Masalah kebocoran memori ini sering terjadi pada perangkat lunak yang menggunakan bahasa pemrograman yang dapat mengakses memori secara langsung, misalnya $\mathrm{C} / \mathrm{C}++$. Keuntungan dari fitur akses memori langsung ini adalah keepatan perangkat lunak bisa dioptimisasi apabila manajemen akses memori tersebut dapat diimplementasikan dengan benar.

Kebocoran memory akan mempunyai dampak negatif terhadap seluru sistem komputer, dan bukan hanya pada perangkat lunak yang mempunyai masalah tersebut. Misalnya, apabila kita menggunakan komputer yang memiliki memori sebesar 4 GB. Apabila ada sebuah perangkat lunak yang ditulis dengan menggunakan bahasa $\mathrm{C} / \mathrm{C}++$ mempunyai masalah kebocoran memori, yaitu perangkat lunak tersebut memblok area di memori sebesar $8 \mathrm{~kb}$ untuk sebuah variabel. Apabila variabel tersebut dipanggil dari suatu fungsi dengan sebuah pengulangan sebanyak $1 \times 10^{6}$ kali dan pada setiap pemanggilan fungsi tersebut area sebesar $8 \mathrm{~kb}$ diblok untuk variabel tersebut, maka ketika perangkat lunak tersebut memangil fungsi tersebut sebanyak 524288 kai, maka sistem komputer akan kehabisan memori dan berhenti, sehingga mengganggu perangkat lunak lainnya. Masalah kebocoran memori komputer dapat diatasi dengan meng-reboot seluruh sistem komputer.

Pada bahasa pemrograman $\mathrm{C}$, akses memori langsung untuk mengalokasikan memori langsung untuk sebuah variabel dilakukan dengan menggunakan fungsi malloc(). Maka dari itu, setiap variabel yang dihasilkan dengan memanggil fungsi malloc(), pembebasan memori untuk variabel tersebut harus dilakukan dengan memanggil fungsi free() apabila variabel tersebut tidak lagi digunakan. Dengan demikian, area memori RAM yang sudah diblok untuk variabel tersebut dapat digunakan untuk variabel lainnya.

\subsubsection{Kecepatan pemrosesan data (processing speed)}

Kecepatan komputasi suatu perangkat lunak sangat bergantung dengan jenis bahasa pemrograman yang digunakan untuk membuat perangkat lunak tersebut. Pada prinsipnya, semakin dekat suatu bahasa pemrograman kepada bahasa mesin (dalam hal ini komputer), maka akan semakin cepat perangkat lunak yang dibuat dengan bahasa pemrograman tersebut. Namun demikian, bahasa pemrograman yang dekat dengan bahasa mesin disebut dengan bahasa pemrograman tingkat rendah. Bahasa pemrograman tersebut sulit dipahami apabila dibandingkan dengan bahasa natural manusia dan bahasa tersebut akan menjadi panjang untuk suatu tugas komputasi yang simpel. Conoth 
dari bahasa tingkat rendah tersebut adalah bahasa assembly.

Untuk bahasa pemrograman tingkat tinggi, yaitu bahasa pemrograman yang mempunyai gaya bahasa mendekati bahsa natural manusia, mempunyai kecepatan eksekusi yang lebih lambat dari bahasa Assembly, namun demikian bahasa tersebut lebih mudah dipahami dan lebih ringkas untuk membuat suatu perangkat lunak dengan fungsi yang sama apabila dibuat dengan bahasa Assembly. Pada saat ini, dua bahasa pemrograman tingkat tinggi yang mempunyai keceatan eksekusi paling cepat diantara bahasa pemrograman tingkat tinggi lainnya adalah $\mathrm{C}$ dan Fortran. Maka dari itu, $\mathrm{C}$ dan Fortran pada umumnya digunakan sebagai baseline untuk komparasi kecepatan eksekusi berbagai macam bahasa pemrograman tingkat tinggi. Bahasa pemrograman tingkat tinggi yang mempunyai kecepatan eksekusi yang tinggi pada umumnya berbasis compiler.

Bahasa pemrograman tingkat tinggi lainnya yang mempunya kecepatan eksekusi lebih rendah dari $\mathrm{C}$ dan Fortran adalah, misalnya Python, MATLAB, R, Ruby dan PhP. Pada umumnya bahasa tingkat tinggi tersebut berbasis interpreter. Pada saat ini, bahasa tingkat tinggi berbasis interpreter yang populer adalah Python. Python mempunyai kecepatan yang relatif lebih cepat dibandingkan bahasa berbasis interpreter lainnya dan mempunyai banyak fungsifungsi numerik yang dapat digunakan untuk menyelesaikan berbagai macam masalah komputasi numerik dari tingkat dasar sampai tingkat yang paling rumit.

\subsubsection{Optimisasi numerik}

Optimisasi numerik adalah suatu proses untuk menentukan atau mengestimasi parameter-parameter dari suatu fungsi sehingga nilai fungsi tersebut minimal atai maksimal. Dari definisi tersebut, optimisasi numerik dibagi menjadi dua macam, yaitu: maksimisasi dan minimisasi. Pada umumnya optimisasi numerik dapat diselesaikan secara lansung atau dengan proses iterasi. Proses iterasi untuk optimisasi numerik adalah suatu proses berupa pengulangan kalkulasi fungsi yang dioptimisasi, dimana pada setiap pengulangan estimisasi parameter-parameter yang dioptimisasi di-update dengan nilai baru yang mengoptimalkan hasil fungsi tersebut. Proses optimisasi dengan itarasi membutuhkan nilai awal sebagai nilai acuan untuk memulai proses itarasi. Untuk fungsi-fungsi numerik yang linear atau bisa dilinearkan, optimisasi numerik fungsi tersebut dapat dilakukan dengan suatu perhitungan langsung. Sedangkan, untuk fungsi nonlinier, optimisasi numerik harus dilakukan dengan proses iterasi. Namun demikian, ada bebera fungsi non-linier yang dapat diselesaikan secara langsung tanpa proses iterasi.

Bentuk umum dari optimisasi numerik adalah sebagai berikut. Apabila ada sebuah set input atau parameter $\boldsymbol{x}$ dan sebuah fungsi $f(\boldsymbol{x})$. Nama lain dari $\boldsymbol{x}$ adalah variabel keputusan atau variable pengontrol. Apabila kita ingin menemukan sebuah set variabel $\boldsymbol{x}^{*}, \boldsymbol{x}^{*} \in \boldsymbol{x}$, sehingga didapatkan $f\left(\boldsymbol{x}^{*}\right)$ dimana nilai $f\left(\boldsymbol{x}^{*}\right)$ adalah nilai optimal dari $f(\boldsymbol{x})$ (bisa maximum atau minimum dari fungsi tersebut). Bentuk umum optimisasi adalah sebagai berikut:

$$
\max _{\boldsymbol{x}} f(\boldsymbol{x}) \text { atau } \min _{\boldsymbol{x}} f(\boldsymbol{x}) ; \mathbf{A} \in \mathbb{R}^{n}
$$

Dengan atau tanpa restriksi (constraints):

$$
\begin{array}{ll}
c_{i}(\boldsymbol{x}) \leq C_{1}, & \text { dan/atau } \\
c_{j}(\boldsymbol{x}) \geq C_{2}, & \text { dan/atau } \\
c_{k}(\boldsymbol{x})=C_{3}, & \text { dan/atau }
\end{array}
$$

Persamaan (134) dinamakan fungsi objectif, yaitu fungsi yang ingin diminimalisasikan atau di maksimalkan. Persamaan-persamaan(135-137) merupakan restriksi dari fungsi objektif tersebut. Restriksi-restriksi dari suatu fungsi objektif bisa dimiliki secara bersamaan atau salah satu dari restriksi-restriksi tersebut. Tergantung dengan tipe dari fungsi objektifnya, ada fungsi yang memiliki restriksi dan ada fungsi yang tidak memiliki restriksi.

Untuk optimisasi fungsi linear, optimisasi tersebut harus mempunyai restriksi. Hal ini disebabkan karena apabila fungsi linear tersebut tidak mempunyai restriksi, maka solusi yang mungkin didapatkan menjadi tak terbatas. Berbeda dengan optimisasi fungsi non-linear, pada dasarnya fungsi non-linear mempunya batas yang bersasal dari fungsi 
tersebut, misalnya persamaan $f(x)=x^{2}+x+5$. Fungsi $f(x)$ tersebut mempunyai satu titik minimum walaupun fungsi tersebut tidak mempunyai restriksi tambahan yang diberikan. optimisasi numerik banyak digunakan dalam bidang pengukuran dimensi dan geometri. Untuk lebih jelasnya, pembaca bisa melihat bab algoritma yang akan mempresentasikan lebih detil mengenai aplikasi optimisasi numerik untuk memproses data hasil pengukuran.

Optimisasi numerik dapat dibagi menjadi beberapa kelas (Bonnans et al 2003). Pembagian-pembagian kelas tersebut dibagi menjadi tiga bagian sebagai berikut:

- Model tanpa restriksi (unconstrained problems)

1. Model kuadratik, misalnya: $f(x)=\frac{1}{2} x^{2}$.

2. Model yang bukan linear dan bukan kuadratik, misalnya: $f(x)=\frac{1}{4} x^{3}+2 x$.

- Model linier dengan restriksi (linearly constrained problem)

1. Model dengan equality constraint (persamaan (137)).

2. Model dengan inequality constraint (persamaan (135-136)).

- Model non-linear

1. Model dengan equality constraint (persamaan (137)).

2. Model dengan bentuk umum dan berbagai macam restriksi.

Model non-linear membutuhkan proses iterasi dengan menentukan solusi awal. Pada bidang pengukuran, model ini sangat sering ditemui, fitting atau mengasosiasikan suatu geometri dari point cloud yang didapatkan dari suatu instrumen pengukuran untuk mendapatkan suatu nilai pengukuran yang diinginkan, misalnya pada kasus fitting silinder dari point cloud untuk mendapatkan diameter silinder tersebut. 
Toleransi dimensional dan geometri

\section{BAB 3}

\section{Toleransi dimensional dan geometri}

Toleransi adalah aspek yang sangat penting dalam sebuah desain produk. Karena, toleransi merupakan "bahasa" yang menjelaskan seberapa besar deviasi dari nominal suatu produk diperbolehkan sehingga prduk tersebut bisa berfungsi sesuai dengan yang diinginkan. Hal ini disebabkan karena pada prinsipnya, tidak ada sebuah proses manufaktur yang sempurna, sehingga pada semua kondisi riil, setiap produk yang dihasilkan dari suatu proses manufaktur, pasti mempunyai variasi, baik dimensi dan geometri dari produk tersebut. Bab ini menjelaskan mengenai aspek-aspek toleransi, mulai dari definisi, tipe sampai dengan analisis dari toleransi. Selain itu, bab ini hanya membahas mengenai toleransi dimensi dan geometri, sedangkan toleransi tekstur permukaan tidak dibahas.

Pada bab ini, toleransi dimensional dan geometri dipresentasikan dari tingkat pengenalan sampai tingkat menengah. Toleransi dimensional dan geometri merupakan suatu subjek bahasan tersendiri yang meliputi area yang sangat luas, sehingga tidak dapat dipresentasikan hanya dalam satu bab saja. Toleransi mempunyai hubungan yang sangat erat dengan metrologi, dalam hal ini pengukuran dimensi dan geometri. Karena pada prinsipnya, pengukuran, baik dimensi maupun geometri, dilakukan untuk memverifikasi apakah suatu properti (feature) dari sautu produk berada di dalam atau di luar batas toleransi, sehingga pengukuran (metrologi) disebut juga sebagai verifikasi toleransi (tolerance verification).

\subsection{Introduksi toleransi}

Toleransi adalah suatu nilai yang mengkuantifikasikan seberapa besar suatu fitur boleh terdeviasi atau berbeda dengan nilai nominal yang diinginkan. Fitur-fitur tersebut dapat berupa ukuran (size), geometri (form), orientasi dan lokasi. Toleransi berfungsi untuk memperhitungkan kesalahan-kesalahan (error) yang berasal dari suatu proses manufaktur dan pengukuran. Yang dimaksud dengan ukuran (size) adalah misalnya diameter suatu silinder, tebal sebuah pelat besi, dan panjang sebuah balok. Sedangkan, yang dimaksud dengan fitur geometri (form) adalah misalnya flatness, straigthness, lokasi, orientasi dan run-out. Pengukuran dimensi adalah pengukuran yang dilakukan untuk fitur ukuran (size) dan pengukuran geometri adalah pengukuran yang dilakukan untuk fiture geometri.

Toleransi merupakan satu dari dua parameter yang mendefinisikan geometri dari suatu komponen atau benda kerja. Dua komponen tersebut adalah deskrisi dari keadaan nominal (dimensi nominal) dan deskripsi dari deviasi yang diperbolahkan dari nominal tersebut (toleransi). Sehingga, proses dimensi adalah suatu proses untuk memberikan nilai nominal dari suatu fitur yang menggambarkan suatu kondisi yang sempurna tanpa deviasi dan proses toleransi adalah suatu proses untuk mendefinisikan devisasi yang diperbolehkan pada suatu fitur dalam satu produk atau suatu fitur antara dua atau lebih produk, misalnya jarak ( $g a p$ ) antara dua bidang dari dua produk yang berbeda.

Besarnya nilai teoleransi harus didefinisikan oleh setiap disainer sautu produk. Untuk menentukan toleransi, seorang disainer produk harus memiliki pengetahuan yang luas mengenai fungsi dari produk yang didisain, efek dari setiap variasi komponen-komponen dari produk tersebut, berbagai macam proses manufaktur dan kemampuan komunikasi dengan berbagai orang atau perekayasa pada setial tingkat proses produksi. Dengan demikian, menentukan nilai suatu toleransi bukanlah suatu pekerjaan yang mudah. Proses untuk menentukan seberapa besar nilai suatu toleransi disebut sebagai alokasi toleransi.

Standar internasional mengenai toleransi dimensi adalah seri standard ISO 14405 (ISO 14405-1 2016, ISO 14405-2 2011, ISO 14405-3 2016). Sedangkan, untuk toleransi geometri, standar insternasional yang umum adalah ASME Y14.5 (ASME Y14.5 2009) dan ISO 1101 (ISO 1101 2017). Untuk toleransi dimensi, toleransi tersebut sangat 
mudah dipahami karena mempunya bentuk ' \pm ' yang dapat diinterpretasikan secara langsung, misalnya suatu dimensi $x=90 \pm 0.1 \mathrm{~mm}$ mempunyai arti bahwa dimensi tersebut boleh bervariasi selama nilainya $89.99 \mathrm{~mm} \leq x \leq 90.01 \mathrm{~mm}$. Sedangkan, untuk toleransi geometri, dibutuhkan pemahaman mendalam dan khusus untuk meninterpretasikan arti dari toleransi tersebut. Pembahasan toleransi geometri akan berbasis pada standar ASME Y14.5 dan ISO 1101 tersebut. Bab ini akan membaha arti, interpretasi dan analsis dari toleransi geometri. Selain itu, toleransi dimensional akan dibahas juga, terutama lebih ke bagaimana menganalisis suatu toleransi dimensional.

Toleransi (baik alokasi dan analisis toleransi) sangat penting untuk menjawab pertanyaan-pertanyaan pada kondisi riil sebelum suatu proses manufaktur diterapkan, seperti:

- Apakah komponen-komponen yang didisain akan dapat dirakit bersama menjadi suatu produk?

- Apakah komponen-komponen yang mempunyai deviasi dari nominal masih bisa dirakit menjadi sebuah produk?

- Apakah apabila suatu komponen dibuat lebih kecil atau lebih besar dari nilai nominalnya masih bisa dirakit untuk menjadi suatu produk?

- Seberapa besar deviasi suatu fitur dari nilai nominalnya masih diperbolehkan?

- Dan lain sebagainya.

Dari sebagian kecil pertanyaan-pertanyaan tersebut, maka pentingnya toleransi dalam sebuah disain produk dapat dipahami.

Contoh riil dari toleransi dimensional, geometrik dan tekstur permukaan pada sebuah disain produk diperlihatkan pada gambar 1. Pada gambar 1, diperlihatkan sebuah komponen berupa balok solid yang diproses dengan slot milling dan pengeboran. Nilai-nilai dimensi pada gambar 1 diperlihatkan dengan nilai toleransi untuk masing-masing dimensi tersebut. Untuk menentukan nilai-nilai toleransi tersebut tidaklah mudah, karena untuk menentukan nilai toleransi tersebut dibutuhkan kombinasi dari pengetahuan yang mendalam mengenai keilmuan teknik dan pengalaman praktis dalam bidang manufaktur. Kesalahan dalam menentukan nilai toleransi pada sebuah produk akan sangat berakibat fatal, bukan hanya pada produk tersebut, tetapi juga pada proses manufaktur dari produk tersebut. Hal ini akan dijelaskan kemudian pada bagian alokasi dan analisis toleransi.
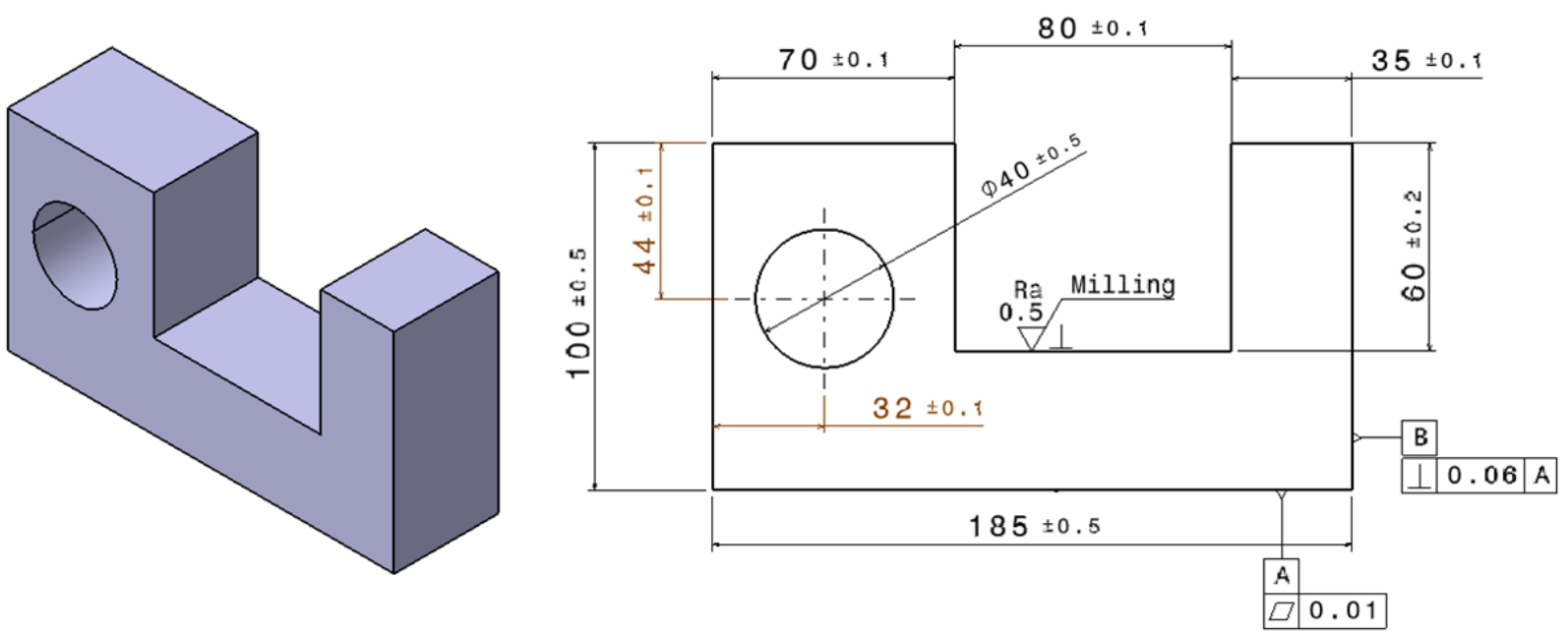

Gambar 1: Contoh dari jenis-jenis toleransi: toleransi dimensi, geometrik (GD\&T) dan texture permukaan. 


\subsubsection{Sumber-sumber variasi}

Setiap produk pada kondisi riil pasti mempunyai variasi atau dengan kata lain tidak akan sempurna seperti apa yang telah didisain. Misalnya, apabila kita mendisain sebuah silinder dengan panjang $l=100 \mathrm{~mm}$ dan diameter $d=25 \mathrm{~mm}$, maka pada kenyataanya, hasil silinder yang diproduksi tidaklah sama persis mempunyai ukuran panjang $l=100 \mathrm{~mm}$ dan diameter $d=25 \mathrm{~mm}$. Melainkan, silinder tersebut akan mempunyai dimensi yang perbeda dari nominal (terdeviasi), walaupun sangat dekat dengan nilai nominalnya tergantung dengan tingkat keakuratan proses produksi dan pengukuran yang dilaluinya, yaitu misalnya $l=100.02 \mathrm{~mm}$ dan diameter $d=24.98 \mathrm{~mm}$. Dengan demikian, apabila ada dua komponen yang dibuat dengan suatu proses manufaktur dengan kondisi parameter proses yang identik, kedua komponen tersebut tidaklah identik, selalu ada perbedaan dimensi dan geometri dengan derajat tertentu tergantung dengan keakuratan proses manufaktur tersebut.

Sumber-sumber variasi dari suatu komponen hasil manufaktur adalah:

- Variasi dari toleransi yang diberikan pada gambar teknik suatu disain.

Sumber pertama variasi dari suatu komponen adalah dari toleransi yang diberikan kepada komponen tersebut. Hal ini memperlihatkan bahwa sebelum suatu komponen dibuat, sudah ada potensi variasi untuk komponen tersebut.

- Variasi dari error suatu proses manufaktur.

Semua proses manufaktur memiliki derajat error (kesalahan), tergantung pada seberapa besar tingkat akurasi proses manufaktur tersebut. Hal ini menyebabkan komponne yang dibuat dari suatu proses manufaktur akan terdeviasi dari nilai nominalnya karena error dari proses manufaktur tersebut. Pada umumnya untuk mengecek apabila suatu proses manufaktur dapat digunakan untuk membuat suatu komponen dengan tingkat toleransi tertentu, test kapabilitas dilakukan yang akan dibahas pada bagain selanjutnya.

- Variasi dari suatu proses perakitan.

Pada saat suatu komponen dirakit dengan komponen lainnya untuk membentuk suatu produk dengan fungsi tertentu, maka ada faktor-faktor lain yang mempengaruhi variasi dari hasil perakitan tersebut yang berasal bukan dari variasi komponen tersebut. Faktor-faktor tersebut anatara lain efek gaya gravitas sehingga menimbulkan efek assembly shift (akan dibahas kemudian) dan efek dari operator, misalnya operator memperi gaya impak yang terlalu besar untuk merakit suatu komponen sehingga menyebabkan deformasi pada komponen tersebut.

- Variasi dari suatu proses pengukuran.

Variasi yang berasal dari pengukuran sangat relevan (dibahas lebih detil pada bab ketidakpastian). Variasivariasi tersebut adalah misalnya variasi dari suatu instrumen pengukuran dan variasi dari prosedur melakukan suatu pengukuran.

- Variasi dari lingkungan.

Variasi lingkungan seperti efek variasi temperatur temat dilakukannya suatu proses pengukuran atau suatu proses perakitan, efek variasi tekanan dan efek variasi kelembapan lingkungan. Untuk pengukuran dengan berbasis laser, perubahan kecil pada kondisi lingkungan tersebut mempunyai efek yang signifikan terhadap variasi hasil pengukurannya.

Gambar 2 memperlihatkan beberapa sumber variasi dari proses manufaktur suatu produk, proses assembly dan proses pengukuran produk tersebut. 

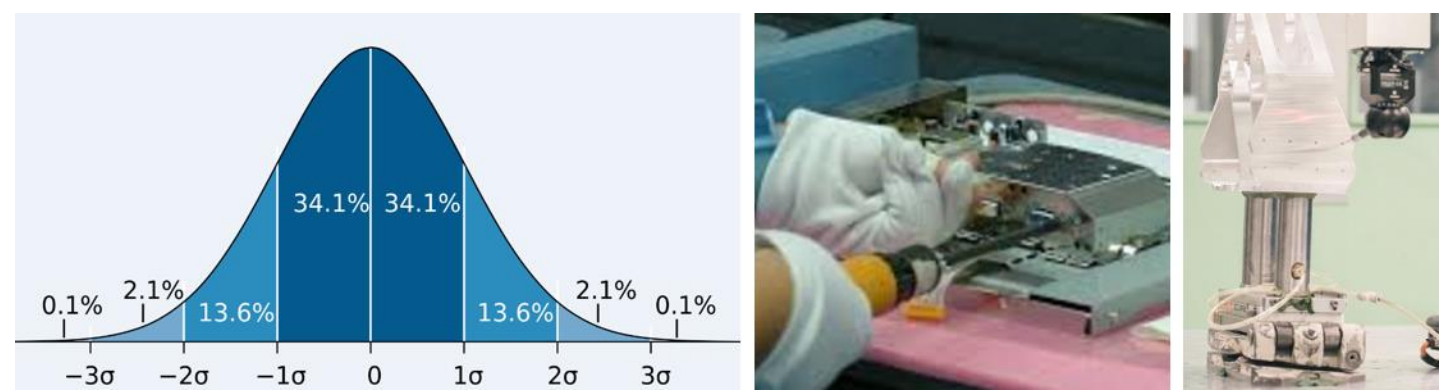

Gambar 2: Ilustrasi berbagai sumber variasi: (kiri) variasi dari suatu komponen hasil manufaktur, (tengah) variasi dari proses perakitan komponen tersebut dan (kanan) variasi dari proses pengukuran komponen tersebut.

\subsubsection{Kapabilitas prosess (Process capability $C_{p}$ dan $C_{p k}$ )}

Dalam suatu proses manufaktur, sebelum proses tersebut dijalankan, maka ada uji kapabilitas untuk menentukan apakah suatu proses manufaktur, dengan suatu mesin tertentu, kapabel untuk membuat suatu produk dengan tingkat toleransi tertentu. Proses tersebut dinamakan sebagai kapabilitas proses.

Definisi kapabilitas proses adalah sebuah ukuran apakah suatu proses manufaktur dapat secara efisien memproduksi sebuah komponen atau tidak. Arti efisien dalam definisi kapabilitas proses adalah karena suatu proses bisa saja menghasilkan suatu produk dengan bentuk tertentu, namun karena kurangnya tingkat akurasi mesin tersebut, maka dibutuhkan banyak proses perbaikan atau pengerjaan ulang sehingga meningkatkan biaya produksi secara signifikan. Kapabilitas suatu proses sangat bergantung secara langsung dari seberapa besar toleransi yang dimiliki oleh suatu komponen.

Ada dua indeks utama untuk mengukur suatu kapabiltas proses, yaitu $C_{p}$ dan $C_{p k}$. Penjelasan dari kedua indeks proses kapabilitas tersebut adalah:

- $\quad$ Indeks $C_{p}$

$C_{p}$ adalah sebuah ukuran seberapa besar dispersi dari suatu proses manufaktur dibandingkan dengan limit bawah dan limit atas dari spesifikasi toleransi yang dimiliki oleh suatu komponen yang dibuat dengan proses manufaktur tersebut. Diformulasikan sebagai berikut:

$$
C_{p}=\frac{U S L-L S L}{6 \sigma}
$$

dimana $U S L$ adalah batas atas tolernasi dan $L S L$ adalah batas bawah toleransi. $\sigma$ adalah deviasi standard dari ukuran suatu roduk yang dibuat dengan proses manufaktur tersebut. Gambar 3 a memperlihatkan representasi visual dari $C_{p}$.

- Indeks $C_{p k}$

$C_{p k}$ adalah sebuah ukuran pergeseran (shift) dari niai tengah (centre) dari suatu proses manufaktur. $C_{p k}$ diformulasikan sebagai:

$$
C_{p k}=\min \left[\frac{U S L-\mu}{3 \sigma}, \frac{\mu-L S L}{3 \sigma}\right]
$$

dimana $\mu$ adalah nilai rata-rata dari dimensi produk yang dibuat dengan proses manufaktur tersebut. Gambar 3b memperlihatkan representasi visual dari $C_{p k}$ 


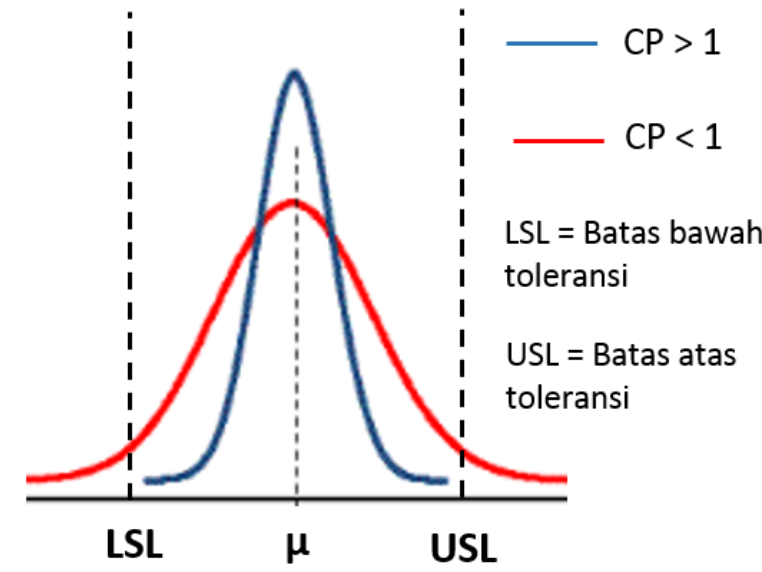

(a)

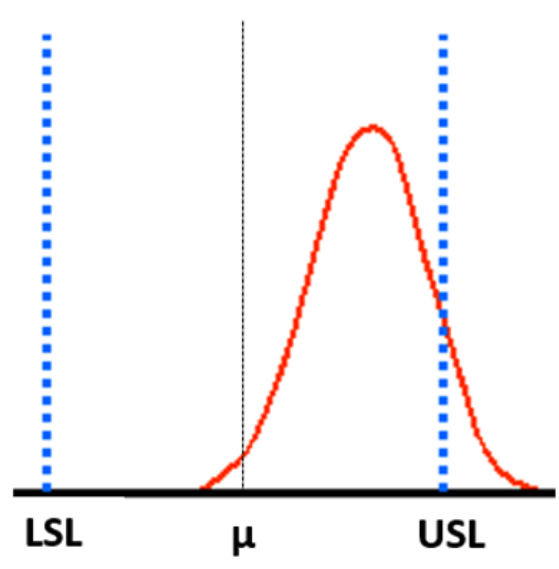

(b)

Gambar 3: (a) Representasi visual dari $C_{p}$ dan (b) representasi visual dari $C_{p k}$.

Untuk lebih jelasnya, gambar 4 memperlihatkan representasi visual dari berbagai macam nilai $C_{p}$ dan $C_{p k}$. Pada umumnya, semakin besar nilai $C_{p}$ dan $C_{p k}$, maka kapabilitas suatu proses semakin tinggi. Pada umumnya rekomendasi nilai tersebut adalah $C_{p} \geq 1.3$ dan $C_{p k} \geq 1.3$.

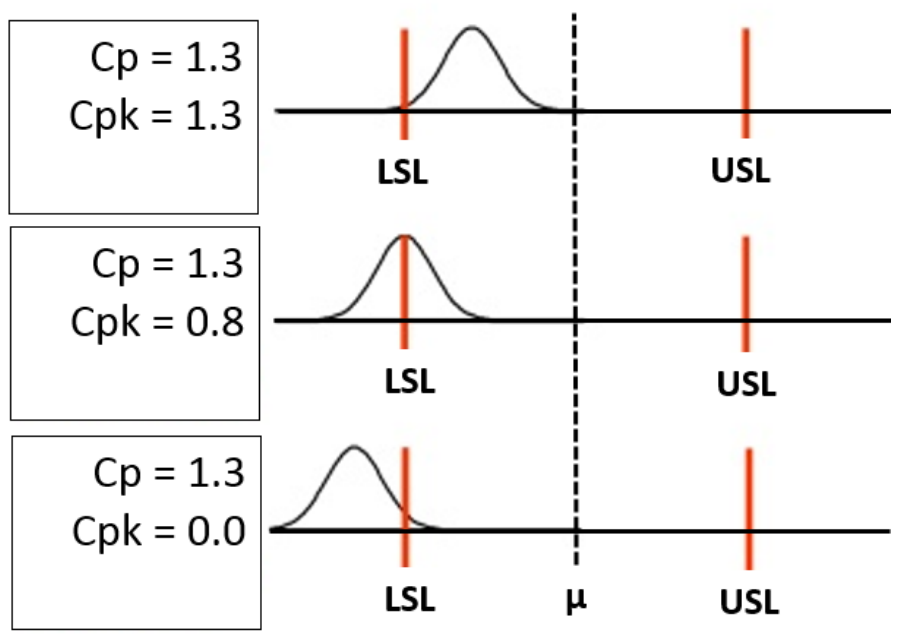

Gambar 4: Representasi visual dari berbagai macam nilai $C_{p}$ dan $C_{p k}$.

\subsubsection{Tipe-tipe toleransi}

Berdasarkan jenis-jenis variasi yang ingin dikontrol oleh suatu toleransi, maka toleransi dibagi menjadi tiga kelas, yaitu toleransi untuk mengontrol:

- Fitur individual dari size, misalnya: panjang, lebar, diameter, kedalaman dan gap.

- Fitur geometri individu dan fitur relasi geometri antara komponen-komponen dan antara fitur-fitur perakitan (assembly feature). Contoh dari fitur geometri individu, misalnya: flatness, roundness dan cylindricity. Sedangkan contoh dari fitur relasi geometri, misalnya: perpendicularity, location, concentricity dan orientasi. 
- $\quad$ Fitur dari tekstur permukaan suatu komponen, misalnya: $R_{a}, R_{a}, R_{z}, S_{a}, S_{q}$, dan $S_{z}$.

Bab ini hanya membahas mengenai toleransi yang mengontrol variasi dari fitur size dan geometri. Dengan demikian, bab ini membahas dua metode untuk menentukan suatu toleransi pada komponen atau produk. Dua metode toleransi tersebut adalah:

1. Toleransi dimensional "plus/minus".

Toleransi dimensinal adalah metode toleransi yang digunakan untuk mengontrol fitur size dari suatu komponen atau produk.

2. Toleransi geometri (geometric tolerancing and dimensioning/GD\&T).

Toleransi geometri (GD\&T) adalah metode toleransi yang digunakan untuk mengontrol baik fitur geometri individual dan fitur relasi geometri antara komponen-komponen dan antara fitur-fitur perakitan

Pertama-tama, metode toleransi dimensional akan dibahas. Metode toleransi dimensional adalah suatu metode toleransi yang bersifat konservatif. Toleransi jenis ini mempunyai banyak aspek-aspek inkonsistensi sehingga banyak menimbulkan ambiguitas pada suatu kondisi riil. Sehingga, metode toleransi dimensional saja tidak cukup untuk dapat merepresentaiskan control variasi dari suatu produk yang semakin kompleks seperti sekarang ini. Untuk menyempurnakan metode toleransi dimensioanal, maka metode toleransi geometrik (GD\&T) dikembangkan. Toleransi geometrik dapat merepresentasikan apa yang diinginkan oleh seorang disainer agar produk yang didisainnya dapat berfungsi seperti yang diinginkan.

\subsection{Toleransi dimensional "Plus/minus"}

Toleransi dimensional "plus/minus" adalah cara tradisional untuk menentukan nilai toleransi suatu fitur dengan cara menentukan batas minium dan maximum dari nilai nominal suatu fitur. Tolernasi "plus/minus" dapat langsung dipahami secara intuitif, yaitu nilai dimensi suatu fitur dapat bervariasi di antara batas minimum dan maksimum yang diberika. Bentuk dari toleransi "plus/minus": $X \pm T$, dimana $X$ adalah dimensi nominal dari suatu fitur dan $T$ adalah nilai toleransi dari fitur tersebut. adalah Contoh dari toleransi "plus/minus"adalah, misalnya:

- Panjang suatu balok adalah $(3 \pm 0.2) \mathrm{mm}$.

- Diameter sebuah silinder adalah $(\varnothing 5 \pm 0.01) \mathrm{mm}$.

- Jarak antara dua lubang adalah $(15 \pm 0.5) \mathrm{mm}$.

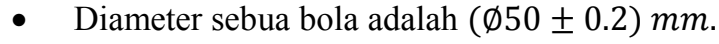

- Dan lain sebagainya.

Nilai nominal dan toleransinya (bentuk ideal)

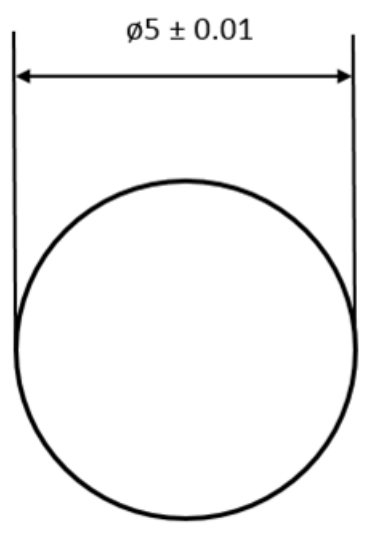

Nilai yang terukur: Nilai yang sama tetapi bentuknya berbeda

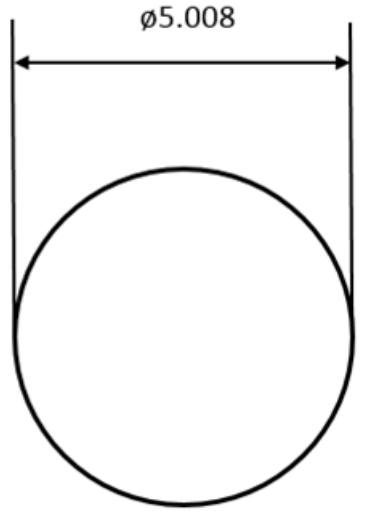

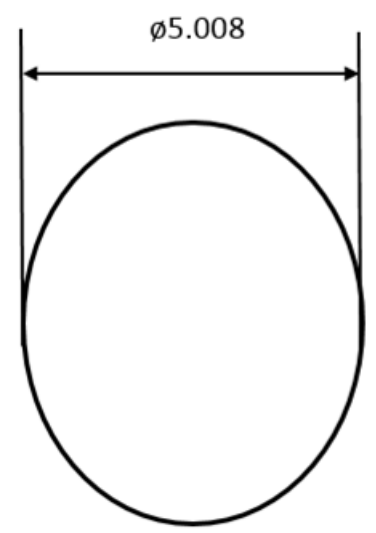

Gambar 5: Ambiguitas pada toleransi dimensional. 
Toleransi dimensional sangat mudah dipahami. Namun demikian, toleransi dimensional mempunyai kelemahan untuk menginterpretasikan maksud dari disainer suatu produk pada gambar teknik, yang kemudian gambar teknik ini yang merupakan landasan seorang perekayasa manufaktur untuk membuat produk yang telah didesain tersebut. Kelemahan tersebut adalah adanya ambiguitas pada toleransi dimensional.

Gambar 5 memperlihatkan ambiguitas yang terdapat pada toleransi dimensional. Pada gambar 5, diperlihatkan sebuah bentuk lingkaran ideal dengan dimensi dan toleransinya: $(\varnothing 5 \pm 0.01) \mathrm{mm}$. Kemudian, pada gambar 5 juga, diperlihatkan dua bentuk lingkaran yang mempunyai hasil pengukuran diameter yang sama, yaitu $\varnothing 5.008 \mathrm{~mm}$, tetapi mempunyai bentuk yang berbeda. Hasil kedua diameter yang terukur tersebut masih dalam batas toleransi, namun hanya salah satu yang bisa diterima (gambar 5 tengah) dan yang lainnya tidak dapat diterima karena mempunyai bentuk yang terlalu oval (gambar 5 kanan). Toleransi dimensioanal tidak dapat menangkap dan merepresentasikan bentuk lingkaran tersebut secara keseluruhan, sehingga ketika lingkaran tersebut diukur dengan suatu alat ukur yang sama namun dengan orientasi yang berbeda, maka hasil pengukuran yang sama didapatkan, dengan bentuk rill lingkaran yang berbeda. Hal ini menimbulkan sebuah ambiguitas!.

\subsection{Toleransi geometri (Geometric dimensioning and tolerancing/GD\&T)}

Toleransi geometri (GD\&T) adalah sebuah bahasa desain yang digunakan oleh seorang disainer produk/perekayasa produk/penggambar teknik untuk merepresentasikan keinginan disainer/perekayasa/penggambar tersebut bagaimana fungsi produk yang didisainnya, bagaimana cara proses manufakturnya, dan bagaimana cara proses perakitannya agar setelah produk tersebut selesai dibuat, maka produk tersebut akan berfungsi sesuai dengan yang dinginkan. Referensi utama yang mengatur toleransi geometri (GD\&T) adalah standard ASME Y14.5 (ASME Y14.5 2009) and ISO 1101 (ISO 1101 2012). Standard ASME Y14.5 pada umumnya digunakan di Amerika Serikat dan standar ISO 1101 pada umumnya digunakan di Eropa dan negara lainnya. Pada prinsipnya, kedua standar tersebut memberikan informasi yang sama tentang GD\&T. Selanjutnya, toleransi geometri akan disebut sebagai GD\&T, karena istilah GD\&T lebih umum digunakan.

Kelebihan utama GD\&T adalah GD\&T dapat merepresentasikan bentuk sebuah produk secara keseluruhan dan dapat merepresentasikan relasi antar-fitur. Hal ini tidak dapat dilakukan dengan toleransi dimensional. Namun demikian, GD\&T tidak mengantikan toleransi dimensional, melainkan GD\&T melengkapi toleransi dimensional, sehingga pada penggunaannya, GD\&T juga mengikutsertakan toleransi dimensioanal. Gambar 6 memperlihatkan contoh elemen-elemen dari GD\&T pada sebuah gambar teknik. Pada gambar 6, elemen-elemen GD\&T yang diperlihatkan adalah datum A, B, dan C, perpendicularity, flatness, parallelism dan toleransi dimensional pada kedua lingkaran (dalam 3D adalah sebuah lubang)

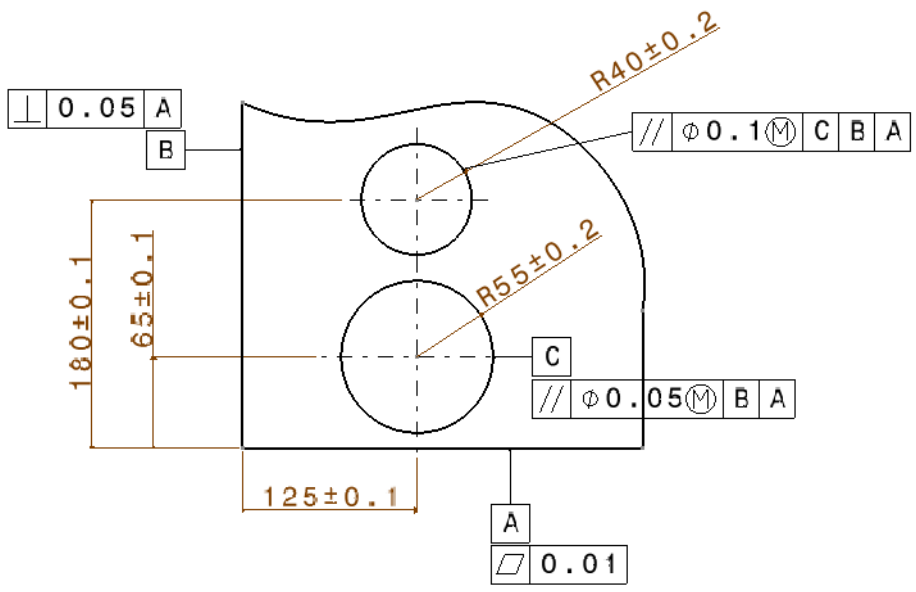

Gambar 6: Beberapa contoh elemen-elemen GD\&T beserta dengan toleransi dimensional. 
Tabel 1: Jenis-jenis dari toleransi geometri (GD\&T).

\begin{tabular}{|c|c|c|c|c|c|}
\hline No. & Toleransi & Karakteristik & Simbol & Datum & hkan \\
\hline \multirow{6}{*}{1} & \multirow{6}{*}{ Bentuk (form) } & Straigthness & - & tidak & \multirow{6}{*}{$\begin{array}{c}\text { Toleransi } \\
\text { tidak } \\
\text { berelasi } \\
\text { (unrelated } \\
\text { tolerance) }\end{array}$} \\
\hline & & Flatness & $\square$ & tidak & \\
\hline & & Roundness & & tidak & \\
\hline & & Cylindricity & & tidak & \\
\hline & & Profil garis (profile line) & $\cap$ & tidak & \\
\hline & & $\begin{array}{l}\text { Profil permukaan (profile } \\
\text { surface) }\end{array}$ & & tidak & \\
\hline \multirow{5}{*}{2} & \multirow{5}{*}{$\begin{array}{c}\text { Orientasi } \\
\text { (orientation) }\end{array}$} & Parallelism & & ya & \multirow{13}{*}{$\begin{array}{l}\text { Toleransi } \\
\text { dengan } \\
\text { relasi } \\
\text { (related } \\
\text { tolerance) }\end{array}$} \\
\hline & & Perpendicularity & & ya & \\
\hline & & Angularity & & ya & \\
\hline & & Profile line (oriented) & & ya & \\
\hline & & profile surface (oriented) & $\curvearrowright$ & ya & \\
\hline \multirow{6}{*}{3} & \multirow{6}{*}{ Lokasi (location) } & Posisi & & ya & \\
\hline & & $\begin{array}{l}\text { Concentricity (for centre } \\
\text { points) }\end{array}$ & & ya & \\
\hline & & Coaxiality (for axes) & (2) & ya & \\
\hline & & Symetry & $\begin{array}{l}- \\
-\end{array}$ & ya & \\
\hline & & Profile line (located) & $\frown$ & ya & \\
\hline & & Profile surface (located) & $\curvearrowright$ & ya & \\
\hline \multirow{2}{*}{4} & \multirow{2}{*}{ Run-out } & Circular run-out & p & ya & \\
\hline & & Total run-out & 1 & ya & \\
\hline
\end{tabular}


Ada dua macam tipe GD\&T, yaitu:

- $\quad$ Fitur tidak berelasi (fitur independen).

Yaitu toleransi bentuk (form), seperti: straightness, flatness, roundness, cylindricity, profil.

- Fitur dengan relasi (fitur dependen).

Yaitu toleransi orientasi, lokasi dan run-out. Toleransi orientasi contohnya: paralelisme, perpendicularity, angularity, oriented-profile. Toleransi lokasi contohnya: posisi, concentricity, coaxiality, symmetry dan location-profile. Toleransi run-out misalnya circular run-out dan total run-out.

Untuk GD\&T fitur dengan relasi (orientasi, lokasi dan run-out), sebuah sistem datum, yang berupa datum A, B dan $\mathrm{C}$, dan datum referensi (datum reference frame), dibutuhkan untuk mendefinisikan koordinat asal (origin of the coordinate system) untuk verifikasi toleransi-toleransi tersebut. Tabel 1 memperlihatkan seluruh tipe-tipe dari GD\&T tersebut.

\section{Datum dan datum referensi (datum reference frame)}

GD\&T untuk fitur yang mempunyai relasi, dibutuhkan suatu sistem datum yang menjadi referensi dari suatu GD\&T yang diberikan. Sistem datum tersbut pada umumnya datum A, B dan C (datum juga bisa dengan simbolsimbol alfabet lainnya, misalnya D dan E). Datum-datum tersebut akan beririsan dan membentuk sebuah datum referensi (datum reference frame). Datum referensi tersebut adalah referensi acuan dari suatu GD\&T yang terdapat pada suatu komponen. Gambar 7 memperlihatkan sistem datum dan datum referensi.

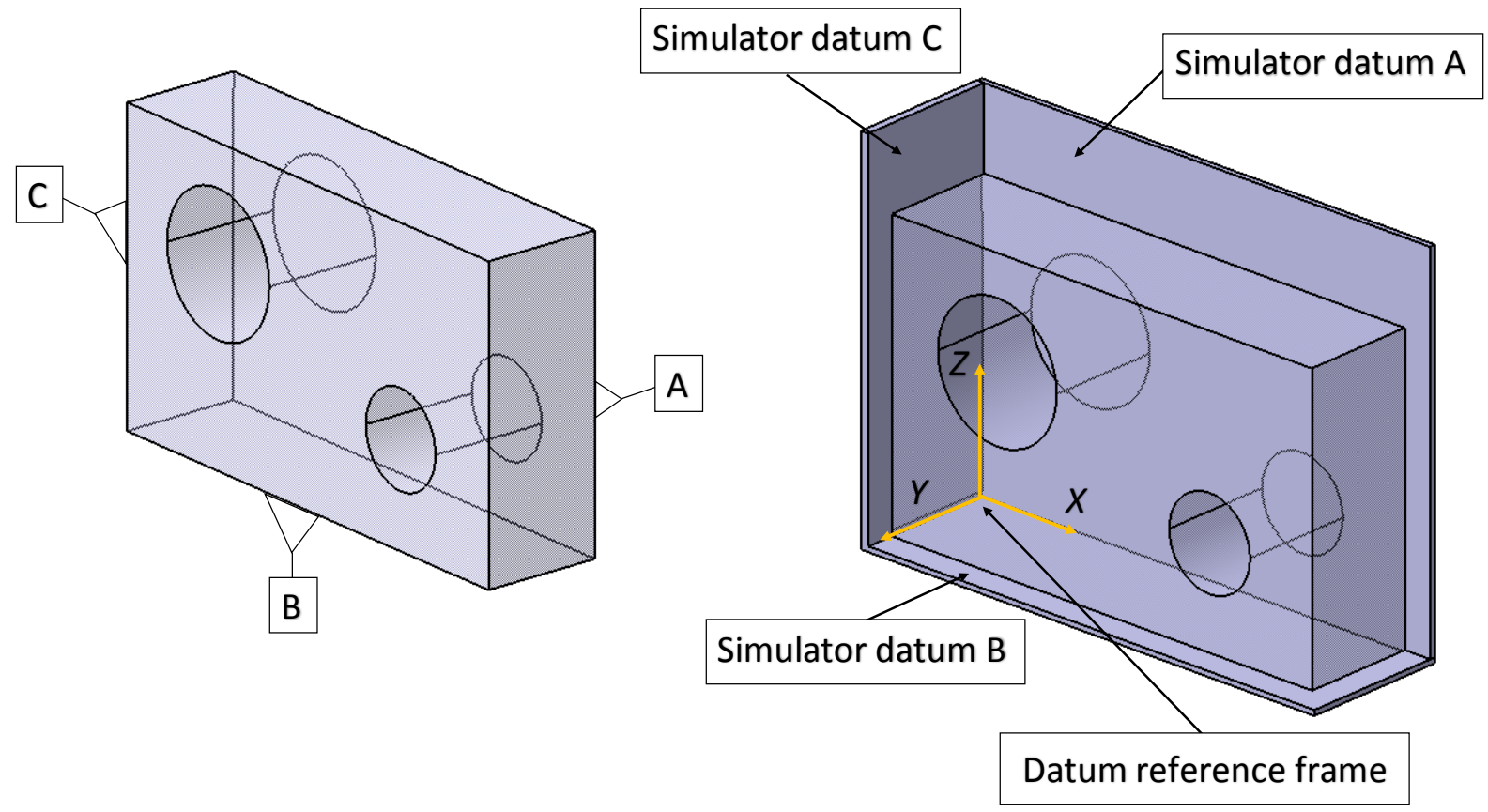

Gambar 7: (Kiri) Sistem datum dan (kanan) datum referensi (datum reference frame).

Pada gambar 7 sebelah kiri, diperlihatkan sistem datum yang terdiri dari tiga jenis datum, yaitu datum A, datum B dan datum C. Sebuah datum bisa berupa permukaan dan axis dari suatu fitur simetri. Datum A merupakan datum pertama yang menjadi acuan utama sebuah GD\&T dan juga menjadi acuan datum-datum lainnya. Datum A pada umumnya harus diterapkan pada fitur yang paling stabil dianatar fitur-fitur lainnya pada suatu produk, misalnya sebuha permukaan yang paling besar pada produk tersebut. Pada gamber 7 (kiri), datum A diterapkan pada bagian 
belakang balok tersebut karena mempunyai permukaan yang paling luas dan paling stabil. Jenis GD\&T yang diterapkan pada datum A adalah jenis GD\&T untuk fitur tidak berelasi, misalnya flatness dan cylindricity, karena datum A adalah datum pertama dan tidak mengacu pada fitur lainnya melainkan hanya mengacu pada fiturnya sendiri. Kemudian, permukaan atau fitur lainnya yang digunakan sebagai datum A harus ditempatkan terlebih dahulu pada permukaan meja pengukuran, karena datum A akan menjadi referensi utama dari datum dan fitur lainnya.

Pada gambar 7 (kanan), datum referensi (datum reference frame) diperlihatkan. Datum referensi adalah titik hasil dari irisan seluruh datum yang direpresentasikan dengan datum simulator (lihat gambar 7 sebelah kanan). Datum simulator adalah permukaan yang langsung bertemu dengan suatu datum, sehingga permukaan tersebut seperti mensimulasi datum yang menempel pada permukaan tersebut. Datum referensi merupakan acuan koordinat untuk memverifikasi suatu GD\&T untuk fitur yang berelasi. Pada kondisi riil, simulator datum pada umumnya berupa: meja pengukuran untuk datum A dan peralatan fixturing untuk datum lainnya.

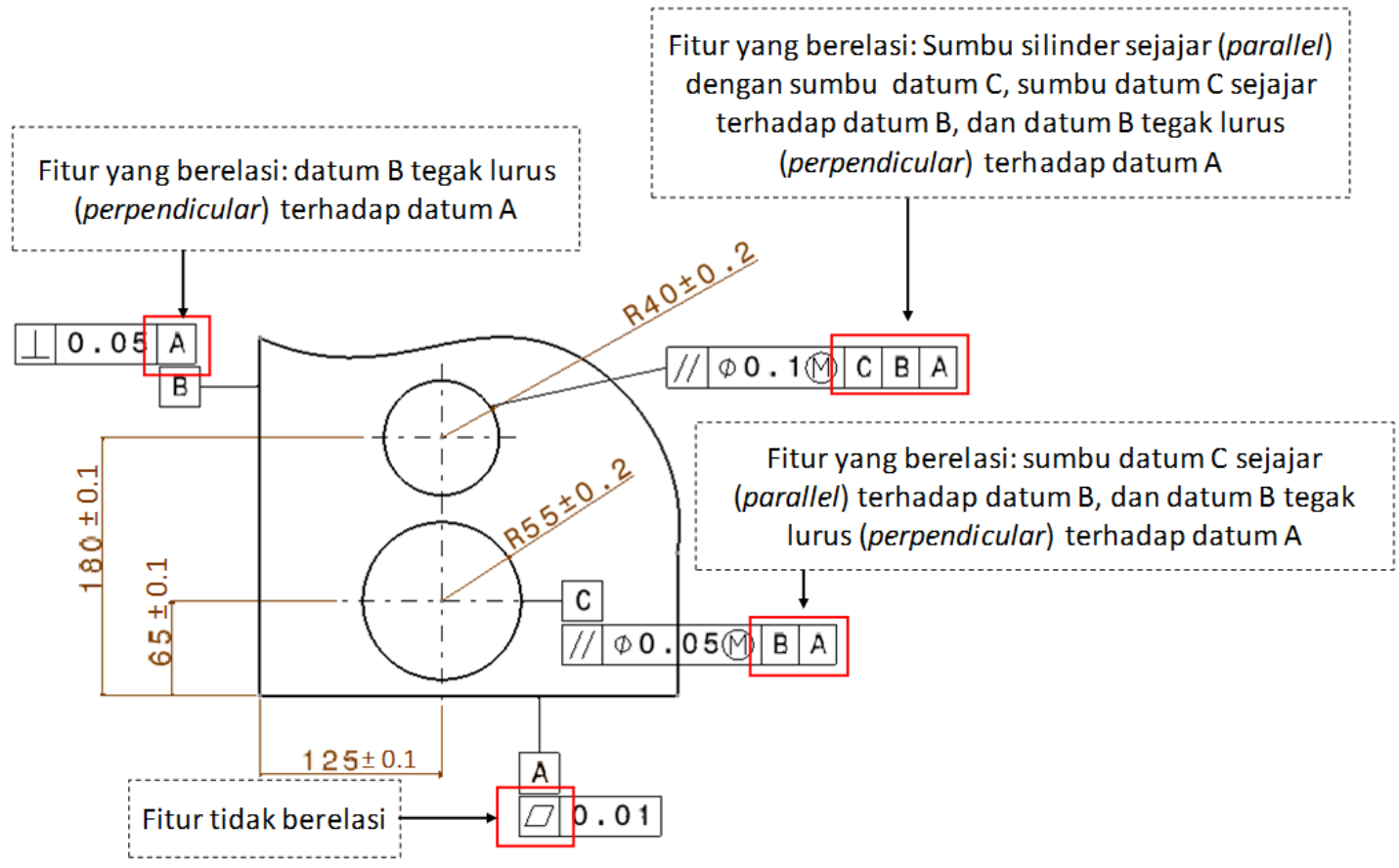

Gambar 8: Fungsi dari datum pada GD\&T.

Penjelasan lebih jelas mengenai sistem datum diperlihatkan pada gambar 8. Pada gambar 8, datum A adalah datum utama sehingga toleransi yang diberikan kepadanya adalah toleransi untuk fitur tidak berelasi, dalam hal ini flatness. Hal penting yang harus diingat adalah karena datum A adalah datum yang paling penting, maka fitur yang merepresentasikan datum A tersebut haruslah mempunyai akurasi yang paling tinggi diantara fitur-fitur lainnya, sehingga nilai toleransi geometri untuk datum A haruslah paling kecil dibandingkan dengan nilai toleransi lainnya. Kemudian untuk datum B dan C, datum-datum tersebut mempunyai toleransi untuk fitur yang berelasi, karena datum A sudah ada sehingga bisa dijadikan referensi. Datum B adalah datum kedua, sehingga hanya mempunyai refrensi datum A. Datum C adalah datum ketiga sehingga mempunyai dua referensi, yaitu terhadap datum B dan datum A. Sedangkan pada fitur silinder kecil (gambar 8), sumbu silinder tersebut mempunyai referensi toleransi pada datum C, B dan A.

Hal lain yang perlu diketahui adalah urutan referensi datum dan urutan penempatan produknya adalah sebagai berikut. Untuk referensi datum, referensi dibaca dari kiri-ke-kanan, sehingga untuk penempatan produknya pada meja pengukuran, dilakukan dari kanan-ke-kiri menurut penulisan datum pada gambar tekniknya. Misalnya: penulisan 
datum adalah \begin{tabular}{|l|l|l|l|l}
$\| /$ & $\Phi 0.1(M)$ & $C$ & $B$ & $A$ \\
\hline
\end{tabular} , maka referensi untuk fitur tersebut dibaca terhadap datum C, datum C terhadap datum B dan datum B terhadap datum $A$. kemudian, untuk penempatan produk tersebut di meja pengukuran, dilakukan sebagai berikut: produk tersebut ditempatkan pada meja pengukuran dimulai dengan permukaan datum A, kemudian permukaan datum B dan terakhir permukaan datum C.

Dari penjelasan-penjelasan di atas, dapat dilihat bahwa GD\&T mempunya arti yang sangat mendalam dibalik simbol-simbil yang dimilikinya. Hal ini adalah untuk mengakomodasi keinginan seorang disainer produk.

\section{Zona toleransi (tolerance zone)}

Zona toleransi (tolerance zone) adalah zona dimana permukaan suatu fitur yang ditoleransi berada di dalamnya. Zona toleransi dapat berbentuk:

- Bidang planar.

Zona yang dibatasi antara dua bidang planar (datar) yang saling sejajar satu dengan lainnya.

- Circular atau cylindrical (nilai toleransi didahului dengan simbol " $\emptyset ")$.

Zona yang dibatasi antara dua lingkaran atau dua silinder yang konsentrik antara satu dengan lainya..

- Spherical (nilai toleransi didahului dengan simbol " $S \emptyset ")$.

Selama permukaan suatu fitur masih berada pada salah satu zona toleransi tersebut (terlepas dari bentuk permukaan fitur tersebut), maka fitur tersebut dianggap masih berada pada batas toleransinya. Misalnya, suatu lingkaran dengan bentuk yang acak asalkan masih dalam zona toleransi yang didefinisikan, maka bentuk linkaran tersebut masih dapat diterima (gambar 9). Pada gambar 9, contoh toleransi geometri roundness pada sebuah lingkaran diperlihatkan. Pada gambar 9, walaupun lingkaran tersebut mempunyai bentuk yang acak, tetapi lingkaran tersebut masih berda didalam zona toleransinya, sehingga lingkarang tersebut dapat diterima. Oleh karena itu, GD\&T merepresentasikan suatu fitur secara keseluruhan (tidak seperti toleransi dimensional).

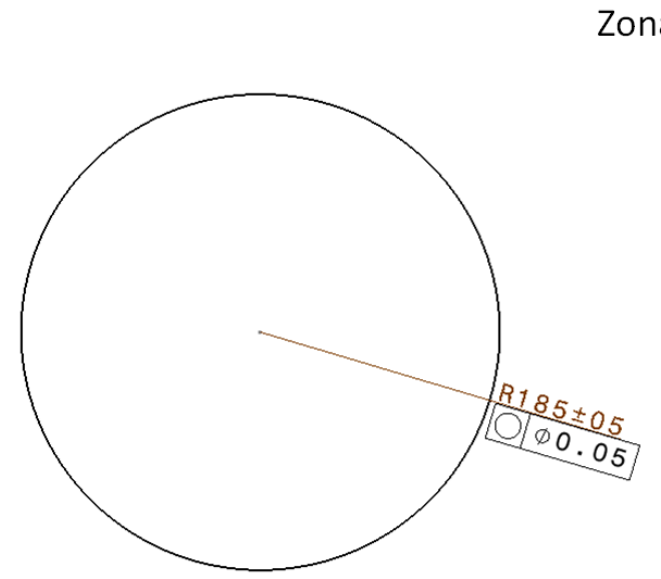

(a)
Zona toleransi Bentuk aktual lingkaran

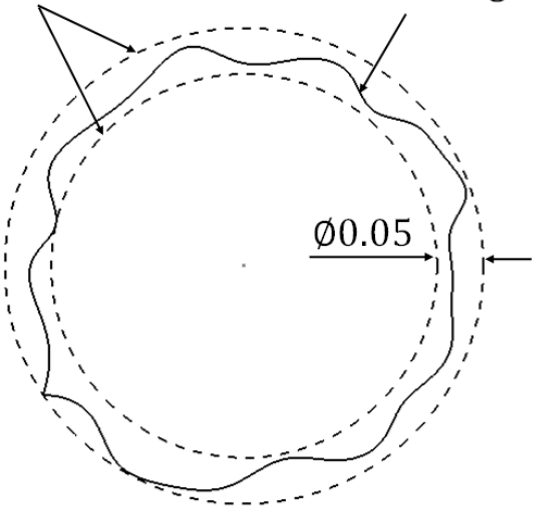

(b)

Gambar 9: (a) lingkaran dengan toleransi dimensional dan geometrik roundness dan (b) zona toleransi dan bentuk aktual lingkaran tersebut.

Gambar 10 memperlihatkan contoh zona toleransi berbentuk silinder untuk toleransi geometri parallelism. Pada gambar 10, sebuah komponen yang memiliki dua buah lubang dengan diameter $85 \mathrm{~mm}$ dan $44 \mathrm{~mm}$. Lubang dengan diameter $85 \mathrm{~mm}$ dipilih sebagai datum A. GD\&T yang diberikan adalah lubang yang kecil dengan diameter $44 \mathrm{~mm}$ harus parallel terhadap lubang yang besar dengan diameter $85 \mathrm{~mm}$ dengan nilai zona toleransinya berbentu silinder dengan diameter $0.1 \mathrm{~mm}$. Representasi dari GD\&T tersebut diperlihatkan pada gambar 10 (kanan), yaitu selama axis dari lubang yang kecil tersebut berada dalam sebuah silinder dengan diameter $0.1 \mathrm{~mm}$ dan axis dari silinder tersebut 
paralel terhadap axis dari datum A, maka lubang kecil tersebut dianggap pararel terhadap lubang yang besar tersebut dan sebaliknya.
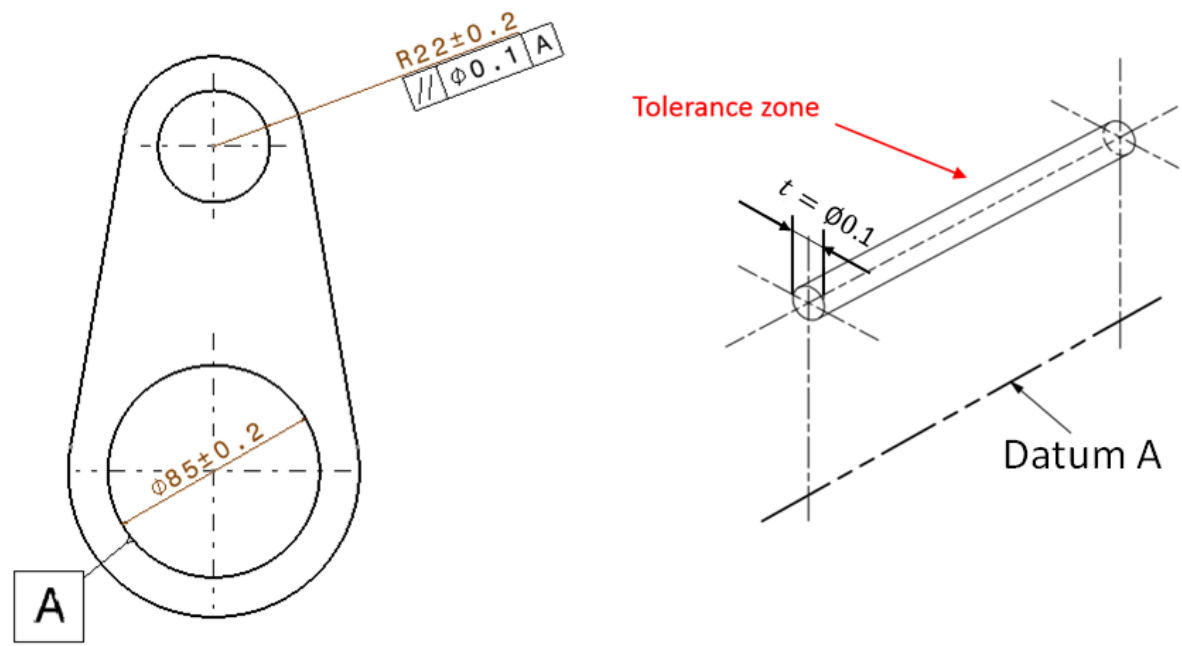

Gambar 10: Contoh toleransi geometri parallelism dan zona toleransi (tolerance zone) berbentuk silinder.

Beberapa penjelasan dengan menggunakan contoh untuk toleransi bentuk (form), orientasi (orientation), lokasi (location) dan run-out akan dijelaskan pada bagian selanjutnya.

\subsubsection{Toleransi bentuk (form)}

Contoh pertama dan yang paling umum untuk tolernasi bentuk (form) adalah flatness. Gambar 11 memperlihatkan contoh dari komponen yang mempunyai toleransi flatness dan arti dari toleransi tersebut. Pada gambar 11 bagian kira, diperlihatkan sebuah balok yang sisi atasnya mempunya toleransi flatness sebesar $0.5 \mathrm{~mm}$. arti dari flatness tersebut diperlihatkan pada gambar 11 bagian kiri. Arti dari tolernasi flatness tersebut adalah apapun bentuk dari permukaan sisi atas dari balok tersebut, asalkan permukaannya masih berada diantara dua bidang datar yang saling sejajar yang berjarak $0.5 \mathrm{~mm}$ antara satu dengan lainnya, maka permukaan sisi atas balok terebut masih dianggap datar sesuai dengan toleransi flatness yang diberikan.

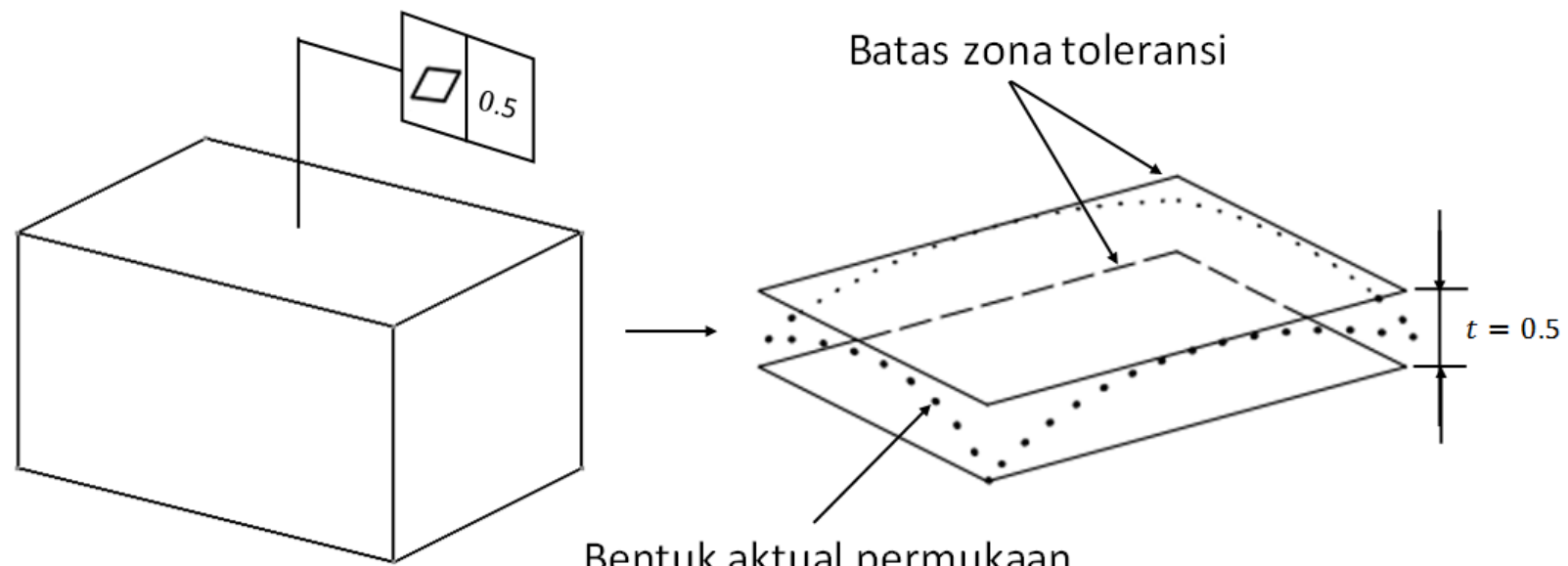

Gambar 11: Toleransi geometri flatness. 
Contoh kedua adalah toleransi roundness. Gambar 12 memperlihatkan contoh dari toleransi roundness dari sebuah silinder. Pada gambar 12 sebeah kiri, sebuah silinder dengan toleransi roundness sebesar $0.3 \mathrm{~mm}$ diperlihatkan. Pada gambar 12 sebelah kanan, arti dari toleransi roundness tersebut adalah bahwa silinder tersebut akan dianggap masih dalam batas toleransi terlepas bagaimanapun bentuk permukaan selinder tersebut, asalakan permukaan cilinder tersebut seluruhnya masih berada diantara zona yang dibatasi oleh dua buah silinder yang mempunyai aksis yang sama dan kedua silinder tersebut perbedaan jari-jarinya antara silinder yang kecil dan yang besar adalah sebesar $0.3 \mathrm{~mm}$.

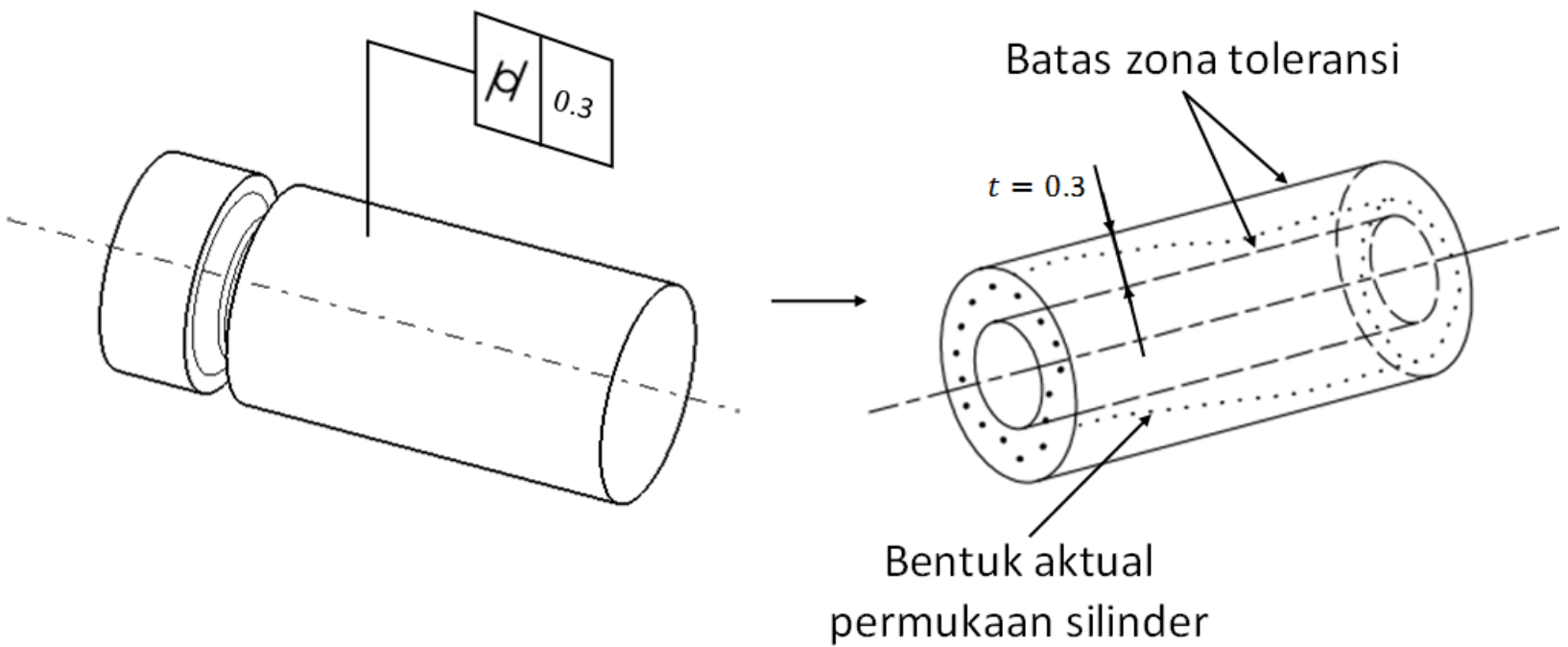

Gambar 12: Toleransi geometri roundness.

\subsubsection{Toleransi orientasi (orientation)}

Mulai dari toleransi orientasi dan seterusnya, toleransi-toleransi geometri tersebut adalah toleransi yang berelasi. Dengan kata lain, dalam pendefinisian toleransi-toleransi tersebut, selalu membutuhkan datum (fitur referensi).

Contoh pertama yang dipresentasikan untuk toleransi orienatsi adalah toleransi parallelism yang diperlihatkan pada gambar 13. Contoh tersebut dipresentasikan oleh sebuah komponen yang memiliki dua buah fitur silinder yang terdiri dari sebuah silinder yang kecil dan yang besar (gambar 13 sebelah kanan). Kedua silinder tersebut mempunyai toleransi parallelism. Namun demikian, yang akan dijelaskan lebih rinci adalah toleransi parallelism silinder dengan diameter yang lebih kecil. Toleransi parallelism pada silinder yang kecil tersebut adalah sebesar $0.1 \mathrm{~mm}$ relatif terhadap datum B dan datum A. datum B adalah axis dari silinder yang lebih besar dan datum A adalah bidang planar (datar) pada sisi bawah komponen tersebut.

Arti dari toleransi parallelism pada silinder yang kecil adalah bahwa silinder kecil tersebut dianggap masih sejajar dengan silinder yang besar (datum B), dimana, datum B tersebut sejajar dengan datum A, apabila seluruh axis dari silinder tersebut masih berada pada zona yang dibatasi oleh dua buah bidang datar yang sejajar yang terpisah dengan jarak $0.1 \mathrm{~mm}$. Kedua bidang datar tersebut sejajar (dengan sempurna) terhadap aksis dari silinder yang besar (datum B) dan axis dari datum B tersebut sejajar (dengan sempurna) terhadap bidang datar datum A. 

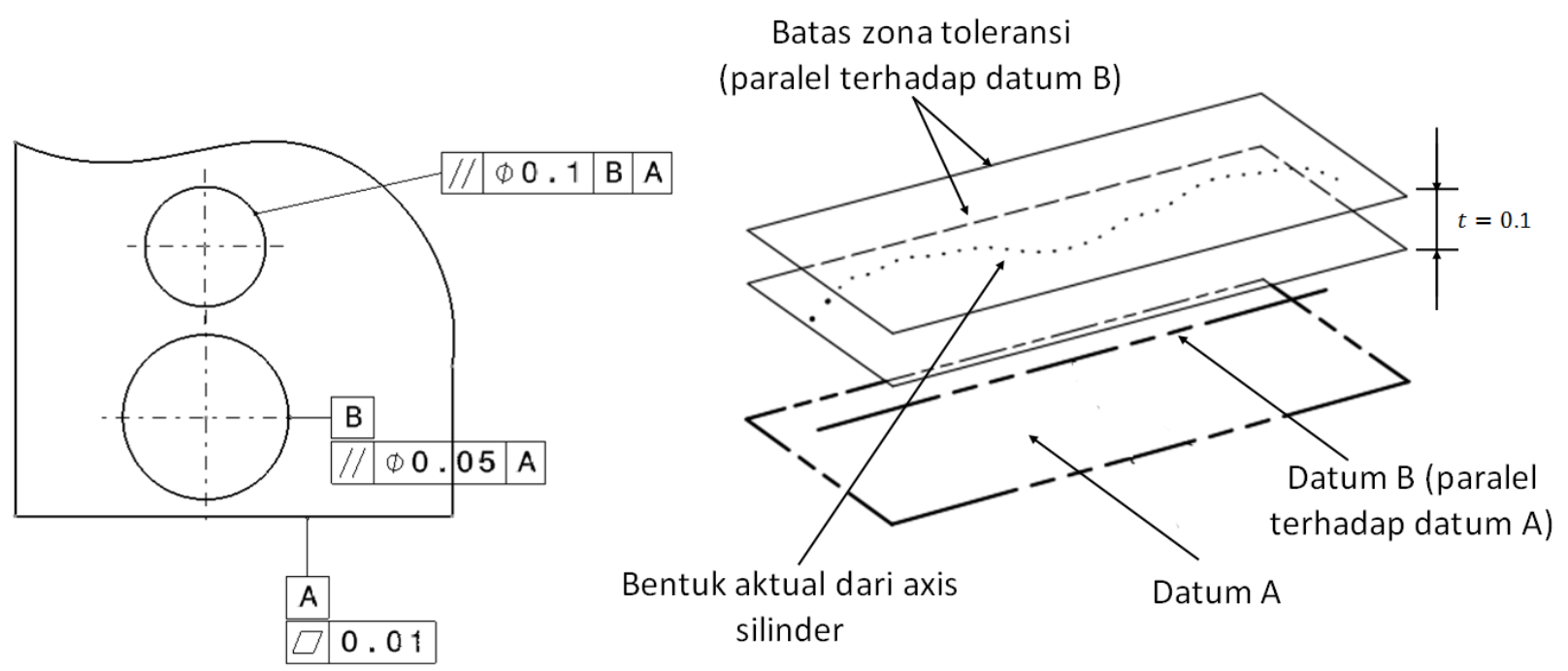

Gambar 13: Toleransi geometri parallelism.

Conto kedua adalah toleransi perpendicularity yang diperlihatkan pada gambar 14. Pada gambar 14 sebelah kiri, diperlihatkan toleransi perpendicularity untuk sebuah lubang vertical pada suatu komponen. Lubang vertikal tersebut mempuyai toleransi perpendicularity sebesar $0.01 \mathrm{~mm}$ terhadap datum A yang merupakan axis dari silinder horisontal. Gambar 14 sebelah kanan memperlihatkan arti dari toleransi tersebut, yaitu lubang tersebut dianggap masih tegak lurus terhadap datum A (silinder horisontal) apabila seluruh axis atau sumbu dari silinder vertikal tersebut kesemuanya berada diantara dua bidang datar yang saling sejajar dan terpisah dengan jarak $0.01 \mathrm{~mm}$ dan kedua bidang datar tersebut teak lurus (secara sempuran) terhadap sumbu silinder horisontal tersebut, yaitu datum A.

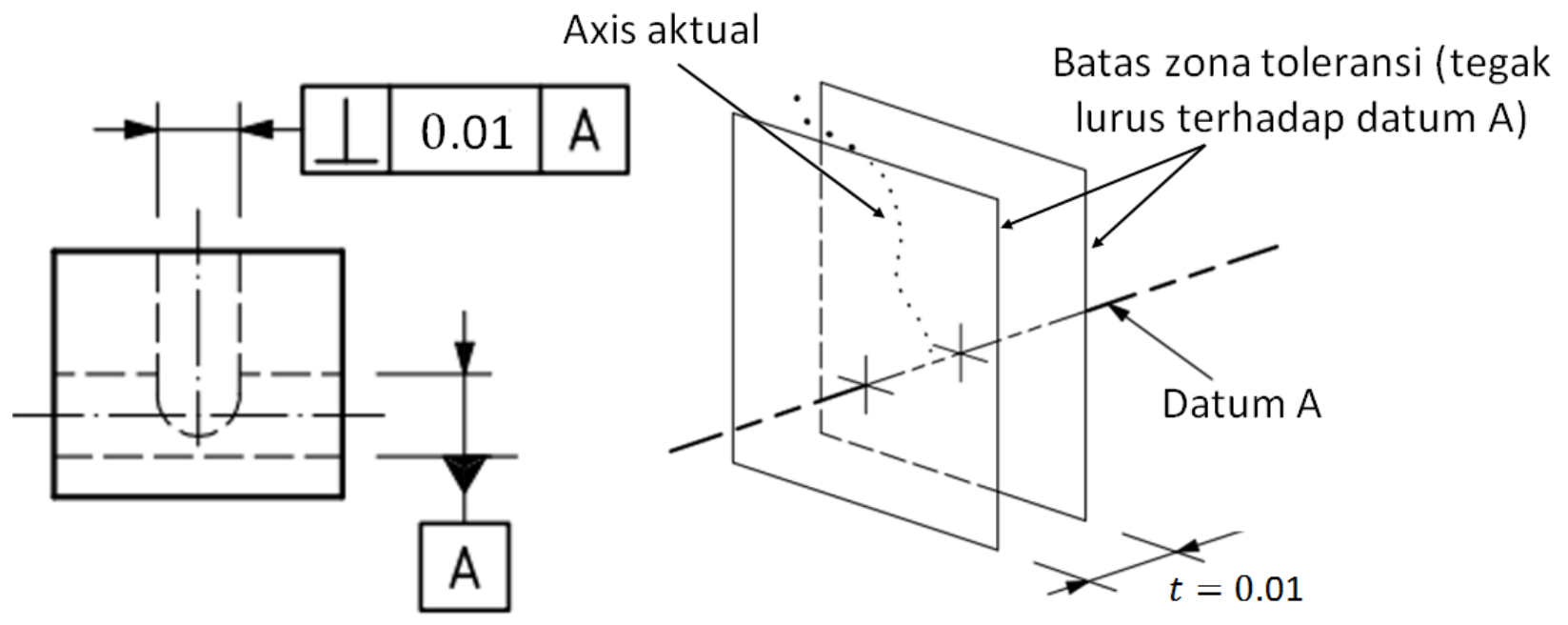

Gambar 14: Toleransi geometri perpendicularity (ketegaklurusan). 


\subsubsection{Toleransi lokasi (location)}

Toleransi lokasi merupakan salah satu toleransi geometri yang paling sering digunakan. Toleransi lokasi pada umumnya digunakan untuk mengoptimalisasi posisi lubang-lubang baut untuk menggabungkan dua buah komponen atau untuk mengoptimalisasi dan mengontrol komponen berporos (shaft). Toleransi lokasi selalu menggabungkan antara toleransi dimensional yang mengontrol jarak sumbu suatu lubang terhadap sisi-sisi suatu komponen. Gambar 15 memperlihatkan contoh dari toleransi lokasi. Pada gambar 15, diperlihatkan sebuah komponen yang mmeiliki sebuah fitur lubang. Lubang tersebut mempunyai jarak $L 1$ dan $L 2$ dari sisi kanan (datum A) dan sisi kiri (datum B). lubang tersebut mempunyai toleransi lokasi sebesar $0.08 \mathrm{~mm}$.

Gambar 15 sebelah kanan memperlihatkan arti dari toleransi lokasi pada lubang tersebut. Lubang tersebut dapat disimpulkan mempunyai lokasi sumbu sesuai dengan toleransi apabila seluruh sumbu lubang tersebut berada dalam zona toleransi yang berbentuk silinder dengan diamater $0.08 \mathrm{~mm}$ (gambar $15 \mathrm{kanan}$ ). Zona toleransi tersebut harus sejajar (secara sempurna) dangan datum B dan datum A.

pada kondisi riilnya, untuk memverifikasi toleransi lokasi lubang tersebut, pertama-tama, lokasi sumbu lubang tersebut harus diukur terlebih dahulu, yaitu jarak lubang tersebut dari datum A (sisi kiri) dan datum (B) sisi kanan dari komponen tersebut. Setelah jarak sumbu lubang tersebut diketahui, kemudian toleransi lokasi lubang tersebut dapat diverifikasi. Untuk verifikasi toleransi geometri, akan dibahas pada akhir bab ini.

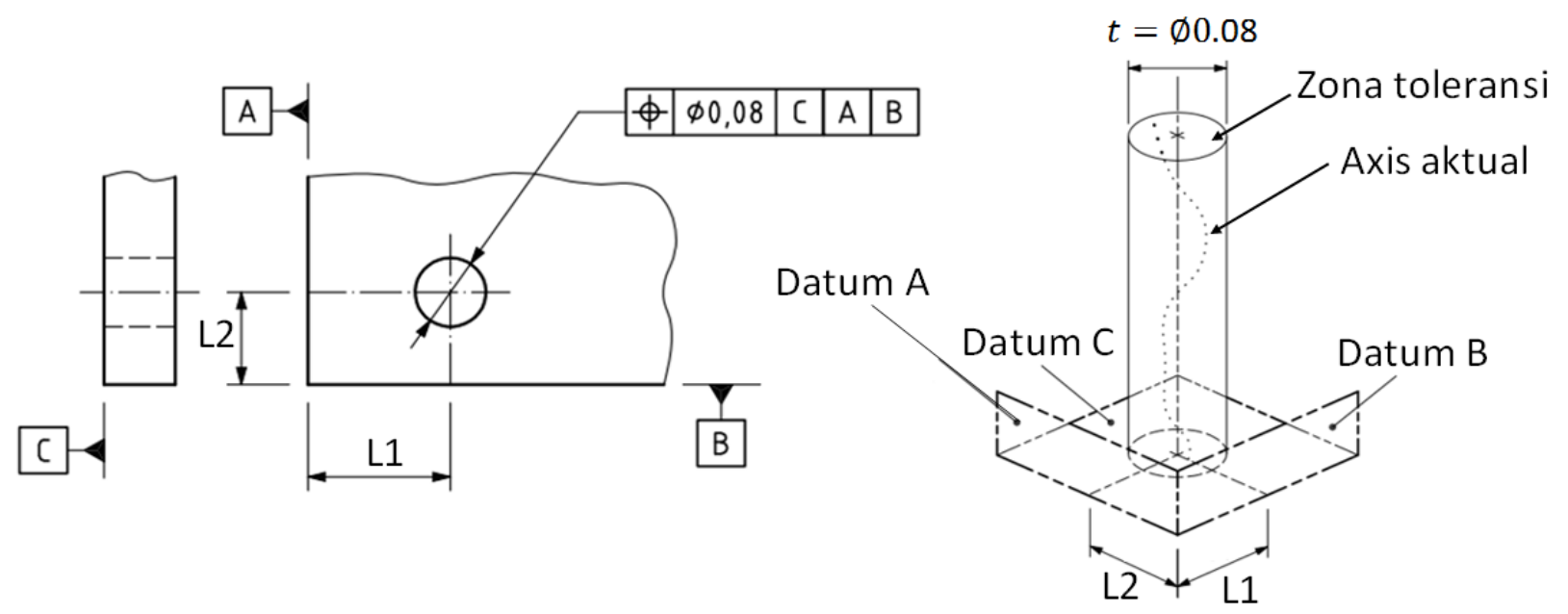

Gambar 15: Toleransi geometri lokasi.

\subsubsection{Toleransi run-out}

Jenis toleransi geometri (GD\&T) lainnya adalah toleransi run-out. Toleransi jenis ini sangat berguna untuk mengontrol fitur-fitur yang berotasi pada aplikasinya, seperti poros yang berputar. Toleransi run-out mengontrol agar suatu fitur yang berotasi pada saat fitur tersebut beroperasi masih mempunya deviasi sesuai dengan yang ditentukan. Gambar 16 dan 17 memperlihatkan contoh dari aplikasi toleransi run-out.

Pada gambar 16, toleransi run-out mengontrol agar permukaan suatu poros yang berputar ketika beroperasi mempunyai deviasi maksimal sebesar $0.5 \mathrm{~mm}$ terhadap suatu datum A-B yang merupakan sumbu putar dari poros tersebut. Poros tersebut dianggap masih dalam batas toleransi apabila seluruh permukaan poros tersebut masih berada pada zona toleransi yaitu diantara dua buah lingkaran sesumbu dengan perbedaan jari-jari sebesar $0.5 \mathrm{~mm}$ (gambr 16). Kedua lingkaran tersebut mempunyai titik pusat yang berhimpitan pada garis sumbu datum A-B. Pada umumny, toleransi tersebut menjaga agar tidak ada gesekan antara poros dengan housing-nya ketika berputar saat beroperasi. 

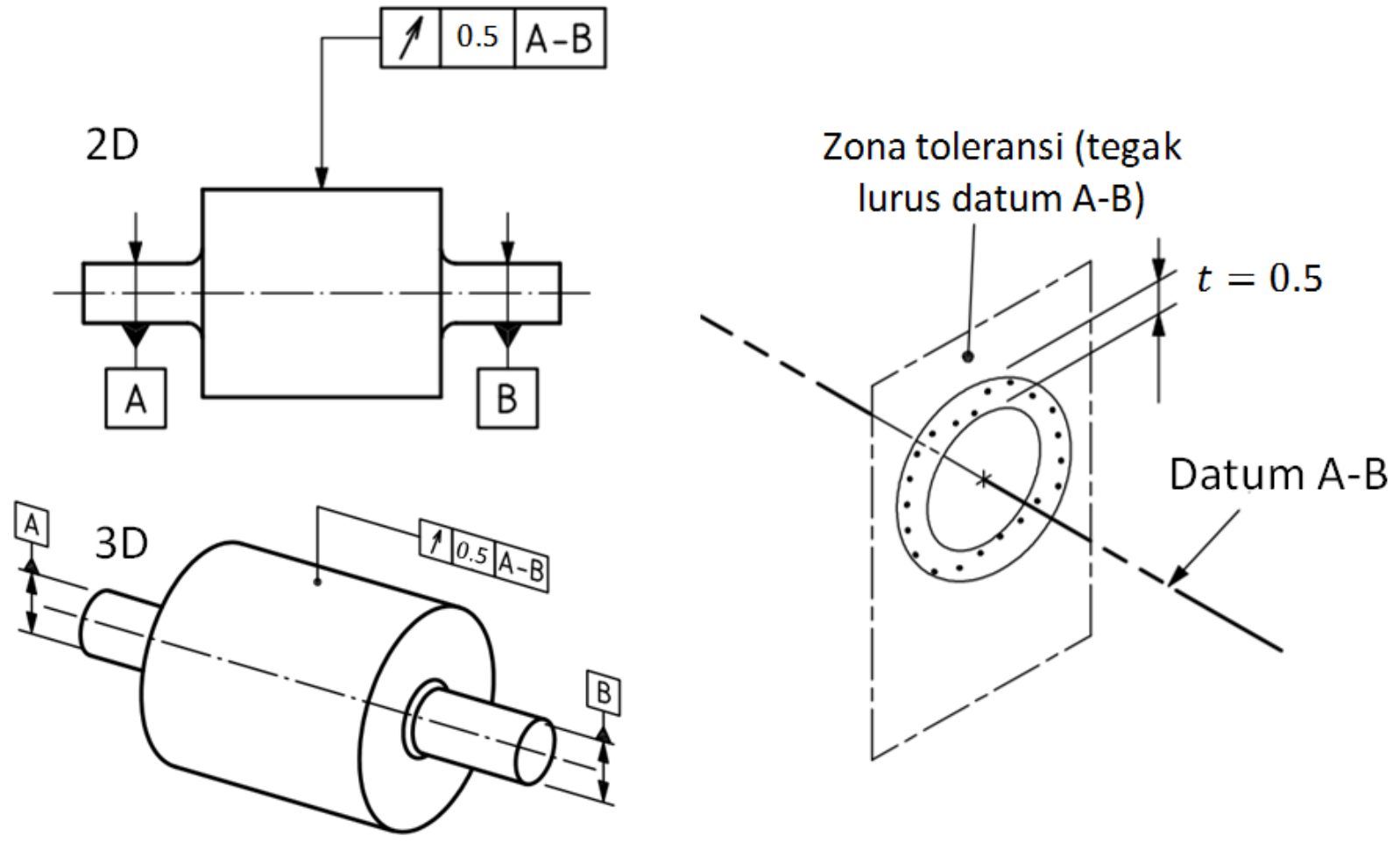

Gambar 16: Toleransi geometri run-out sebuah axis.
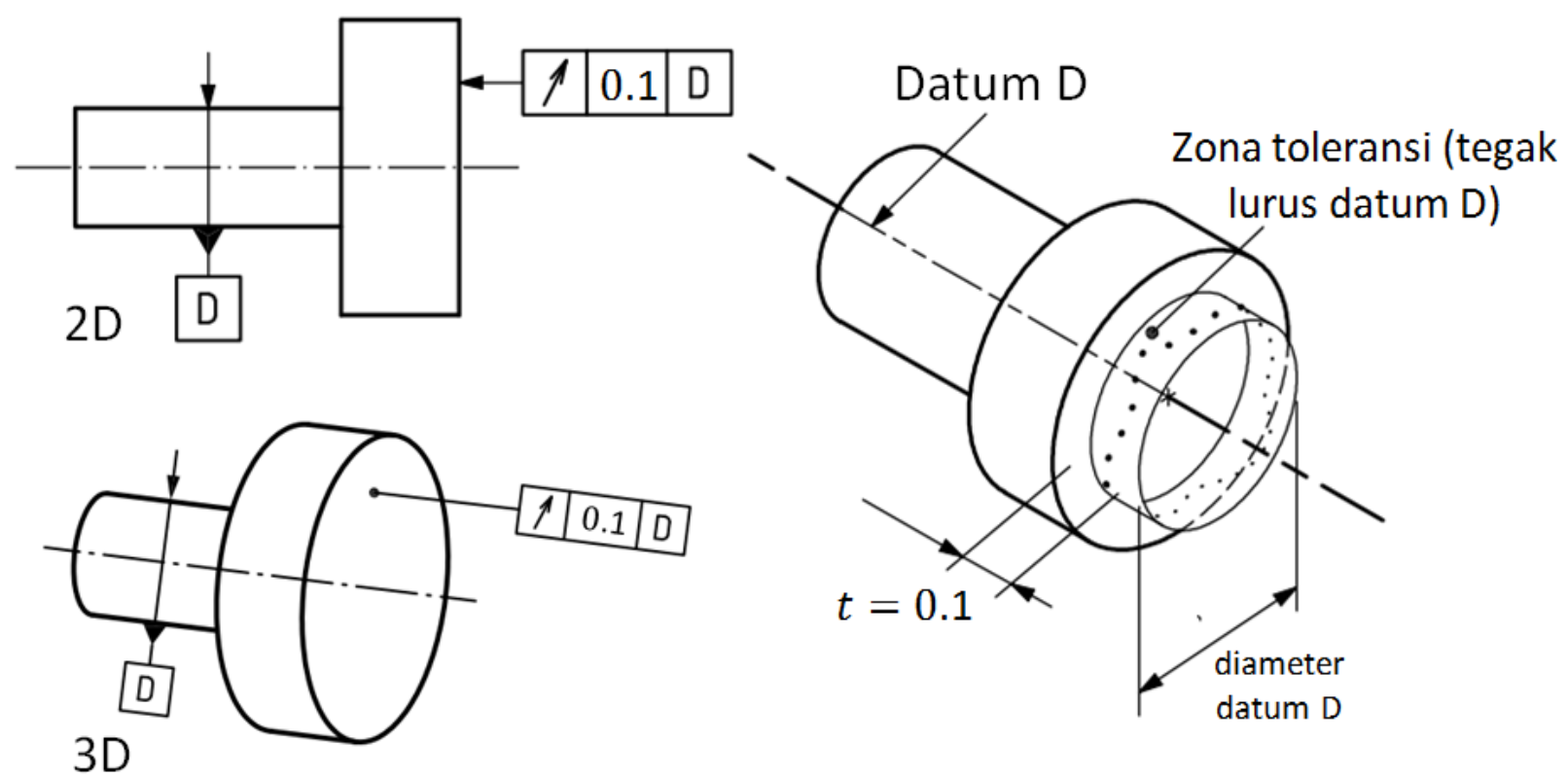

Gambar 17: Toleransi geometri run-out sebuah bidang datar. 
Gambar 17 memperlihatkan contoh toleransi run-out untuk sebuah bidang datar yang berputar. Pada gambar 17, sebuah komponen mempunyai toleransi run-out pada permukaan atasnya yang lebar. Toleransi tersebut mengontrol permukaan datar tersebut agar tetap datar sesuai dengan nilai toleransinya ketika komponen tersebut berputar. Nilai toleransi run-out dari permukaan datar tersebut adalah $0.1 \mathrm{~mm}$ terhadap datum $\mathrm{D}$, yaitu axis dari komponen tersebut. Arti dari definisi toleransi tersebut adalah permukaan tersebut akan dianggap datar apabila selama komponen tersebut berputar, seluruh permukaan datar tersebut masih berada dalam zona toleransi yang berupa dua buah bidang datar yang saling sejajar dan terpisah dengan jarak $0.1 \mathrm{~mm}$. Kedua bidang datar tersebut tegak lurus (secara sempurna) terhadap sumbu putar dari komponen tersebut yang merupakan datum D (gambar 17 kanan).

Untuk mengetahui berbagai contoh variasi dari toleransi-toleransi bentuk, orientasi, lokasi dan run-out, pembaca dapat merujuk ke standar ASME Y14.5 dan ISO 1101.

\subsubsection{Kondisi material (material condition) dan bonus toleransi}

Pada toleransi geometri, terdapat dua konsep penting yang perlu diketahui, yaitu kondisi material (material condition) dan bonus toleransi. Kedua konsep tersebut sangat penting dan sangat besar perannya pada kondisi assembly, dimana dengan adanya bonus sesuai dengan kondisi material pada saat diinspeksi, maka jumlah part yang gagal uji inspeksi dapat berkurang, karena dengan adanya bonus, sebuah komponen masih boleh mempunyai deviasi dengan besar tertentu melebihi batas toleransinya.

\section{Kondisi material (material condition)}

Konidis material hanya dimiliki oleh fitur-fitur size, seperti silinder dan bola. Fitur yang paling sering diterapkan kondisi material pada saat fitur tersebut diberikan toleransi adlaah silinder. Kondisi material adalah kondisi dimana sebuah fitur-fitur size tersebut diproduksi lebih besar atau lebih kecil dari ukuran atau dimensi nominalnya, misalnya sebuah silinder dibuat lebih kecil atau sebuah lubang dibor lebih besar dari nilai nominalnya.

Pin atau poros (silinder)

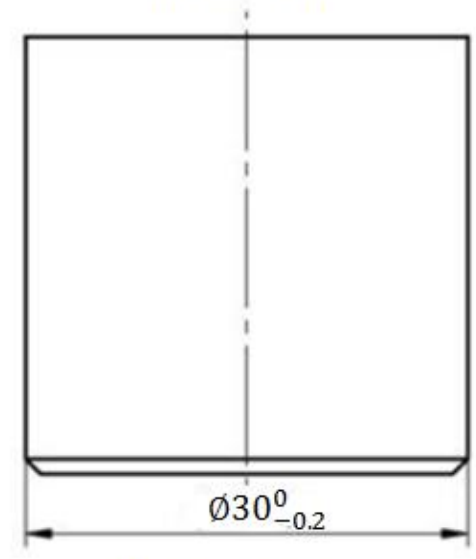

$\mathrm{MMC}=30.0 \mathrm{~mm}$

$$
\mathrm{LMC}=29.8 \mathrm{~mm}
$$

Lubang

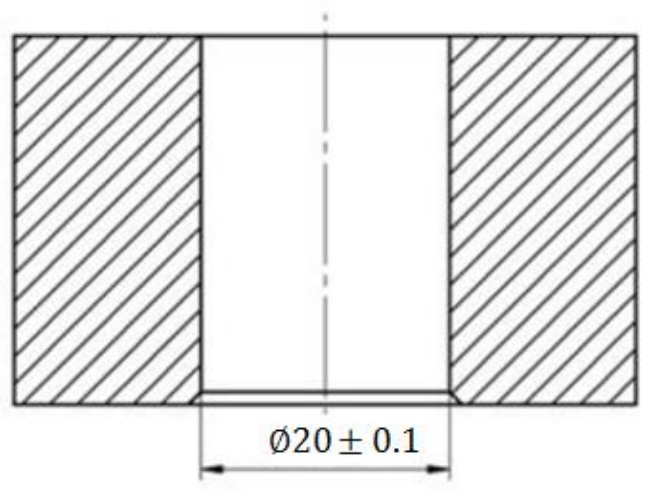

$$
\begin{aligned}
M M C & =19.9 \mathrm{~mm} \\
\mathrm{LMC} & =20.1 \mathrm{~mm}
\end{aligned}
$$

Gambar 18: Kondisi material pada sebuah pin atau poros (silinder) dan lubang. 
Dua macam kondisi material yang akan dibahas adalah:

- Kondisi material maksimum (maximum material condition/MMC).

- Kondisi material minimum (least material condition/LMC).

Pengertian dari kondisi material maksimum (MMC) adalah misalnya, ketika pin atau poros yang berbentuk silinder diproduksi dengan ukuran diameter terbesarnya (the largest shaft) atau ketika sebuah lubang dibor dengan ukuran diamater terkecilnya (the smallest hole) sesuai dengan nilai dimensi yang diberikan. Pengertian kondisi material minimum (LMC) adalah misalnya, ketika pin atau poros yang berbentuk silinder diproduksi dengan ukuran diameter terkecilnya (the smallest shaft) atau ketika sebuah lubang dibor dengan ukuran diamater terbesarnya (the largest hole) sesuai dengan nilai dimensi yang diberikan. Gambar 18 memperlihatkan contoh dari MMC dan LMC pada sebuah pin atau poros (yang berbentuk silinder) dan sebuah fitur lubang. Untuk pin tersebut, MMC adalah ketika diamaternya $30 \mathrm{~mm}$ dan LMC adalah ketika diameternya $29.8 \mathrm{~mm}$ (gambar 18 kiri). Untuk lubang tersebut, MMC adalah ketika diamaternya $19.9 \mathrm{~mm}$ dan LMC adalah ketika diameternya $20.1 \mathrm{~mm}$ (gambar 18 kanan).

\section{Diameter nominal dan toleransinya}

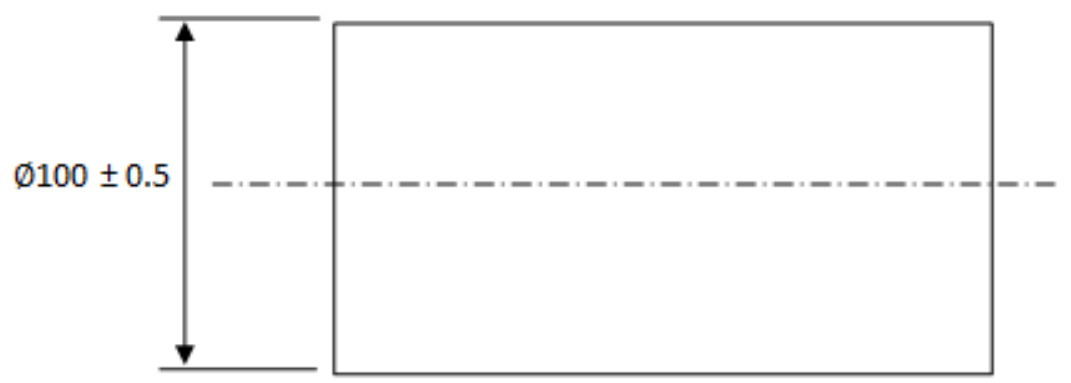

Sejumlah deviasi masih diperbolehkan (bonus)
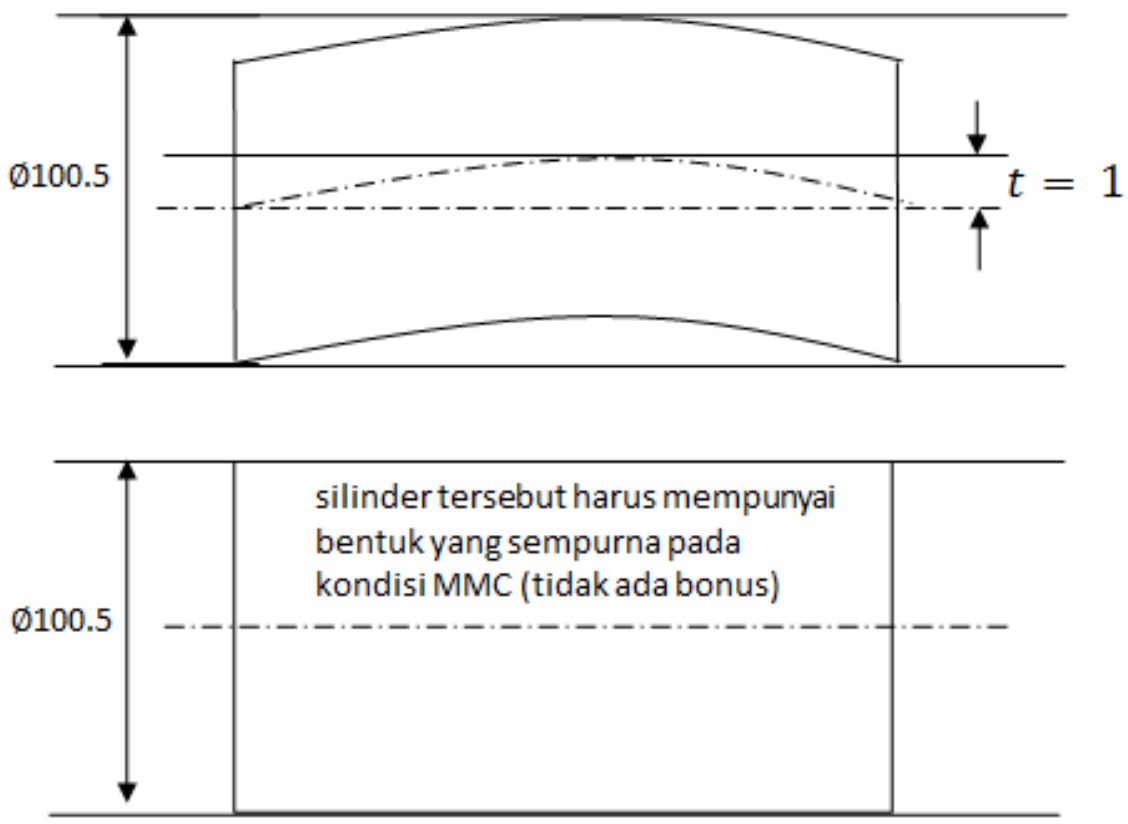

Gambar 19: Ilustrasi dari kondisi materiall maksimum (MMC). 
Ilustrasi dari kondisi material maksimum (MMC) sebuah pin silinder dan implikasi dari MMC tersebut pada kondisi riil silinder tersebut diperlihatkan pada gambar 19. Pada gambar 19 atas diperlihatkan sebuah disain silinder dengan nilai diameter nominalnya beserta toleransinya sebesar $100 \pm 0.5 \mathrm{~mm}$. Secara fisik, MMC pin silinder tersebut adalah sebuah lubang dimana pin tersebut harus bisa masuk sehingga mempunyai fungsi yang diinginkan, seperti menggabungkan dua pelat yang berbeda. Dengan nominal dimensi tersebut, kondisi maksimum material $(\mathrm{MMC})$ silinder tersebut adalah sebesar $100+0.5=100.5 \mathrm{~mm}$. Pada gambar 19 tengah, ketika silinder tersebut diproduksi lebih kecil dari nilai MMC-nya dan masih lebih besar dari nilai minimum toleransinya, maka sejumlah deviasi dari bentuk silinder tersebut diperbolehkan, dengan kata lain "bonus". Misalnya, apabila silinder tersebut diproduksi dengan diameter $99.9 \mathrm{~mm}$, maka silinder tersebut diperbolehkan mempunyai deviasi sebesar 100.5 $99.9=0.6 \mathrm{~mm}$. Selama pin silinder tersebut mempunyai deviasi tidak melebihi $0.6 \mathrm{~mm}$, maka pin silinder tersebut masih bisa masuk kedalam lubang tersebut. Pada gambar 19 bawah, ketika pin silinder tersebut diproduksi pada kondisi MMC-nya, yaitu mempunyai diameter $100.5 \mathrm{~mm}$, maka silinder tersebut harus mempunyai bentuk yang sempurna agar bisa berfungsi sesuai dengan yang diinginkan.

\section{Bonus toleransi}

Sebelum bonus toleransi dibahas, ada dua hal penting yang harus dipahami yaitu kita harus membedakan arti dari "MMC" dan "Simbol MMC":

- MMC (kondisi maksimum material) artinya adalah lubang terkecil atau poros/pin terbesar.

- Simbol MMC pada gambar teknik artinya adalah sebuah bonus toleransi akan didapatkan apabila sebuah fitur size terdeviasi dari nilai MMC-nya (misalnya sebuah lubang dibuat lebih besar dari diameter minimumnya atau sebuah pin/poros dibuat lebih kecil dari diameter maksimumnya).

Hal ini berlaku juga untuk simbol "LMC" dan "Simbol LMC", yaitu:

- LMC (kondisi maksimum material) artinya adalah lubang terbesar atau poros/pin terkecil.

- Simbol LMC pada gambar teknik artinya adalah sebuah bonus toleransi akan didapatkan apabila sebuah fitur size terdeviasi dari nilai LMC-nya (misalnya sebuah lubang dibuat lebih kecil dari diameter maksimumnya atau sebuah pin/poros dibuat lebih besar dari diameter minimumnya).

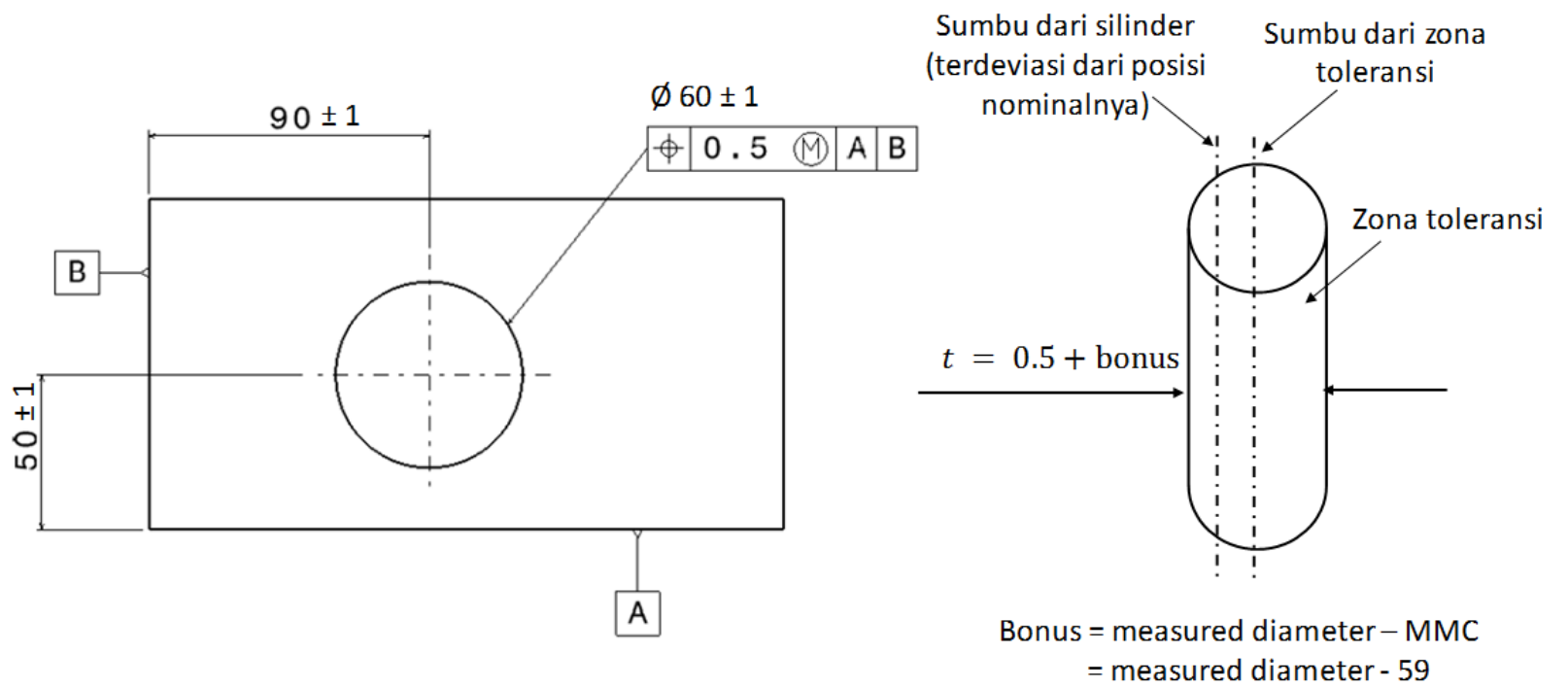

Gambar 20: Contoh dari bonus toleransi pada sebuah fitur lubang (hole) karena MMC. Bonus memberikan zona toleransi yang lebih besar dari zona toleransi awal yang diberikan. 


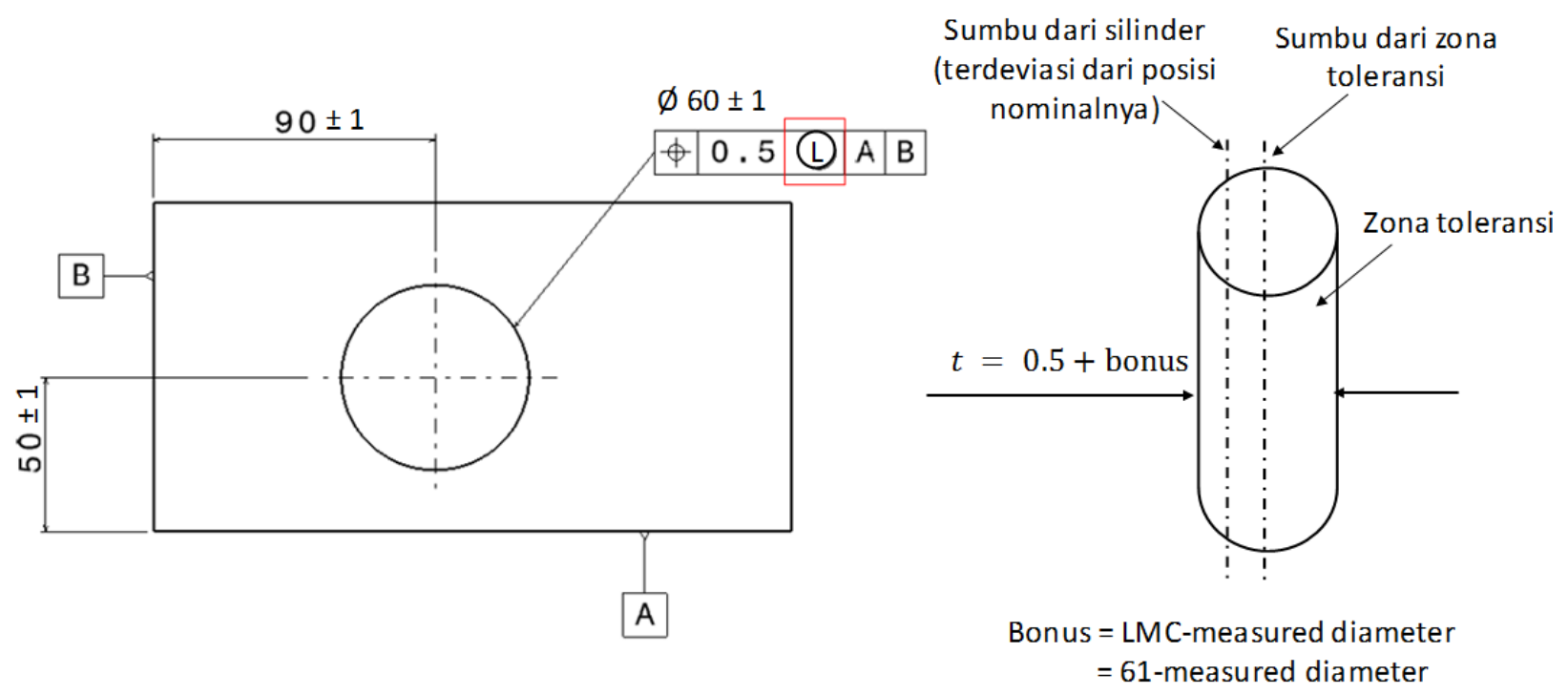

Gambar 21: Contoh dari bonus toleransi pada sebuah fitur lubang (hole) karena LMC.

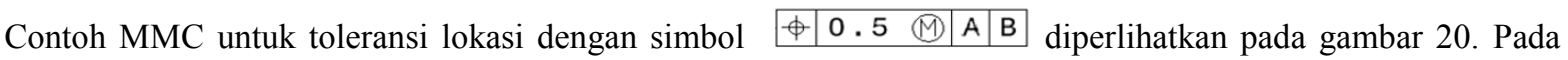
gambar 20, sebuah lubang mempunyai toleransi lokasi sebesar $0.5 \mathrm{~mm}$ terhadadap datum B dan datum A. toleransi lokasi tersebut mmepunyai simbol MMC "M" yang berarti apabila lubang tersebut dibuat lebih besar dari nilai diameter minimumnya (terdeviasi dari nilai MMC-nya), yaitu misalnya sebesar $60 \mathrm{~mm}$ (nilai terukur) $>$ $59 \mathrm{~mm}$ (nilai MMC - nya), maka lokasi sumbu dari lubang tersebut bisa bergeser lebih dari $0.5 \mathrm{~mm}$ karena adanya bonus toleransi. Dalam hal ini, bonus toleransi adalah sebesar: nilai diamater terukur - MMC, yaitu $60-59=1 \mathrm{~mm}$. Sehingga total zona toleransi dari sumbu lubang tersebut adalah sebesar $0.5 \mathrm{~mm}+1 \mathrm{~mm}=1.5 \mathrm{~mm}$. Hal ini disebabkan karena apabila lubang tersebut dibuat lebih besar dari nilai diameter minimumnya, maka apabila lubang tersebut bergeser lebih dari nilai toleransi lokasinya, maka pin yang didisain untuk masuk ke lubang tersebut masih dapat masuk karena ukuran lubang yang lebih besar tersebut.

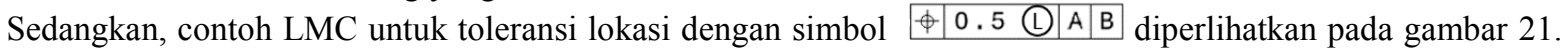
Pada gambar 21, sebuah lubang mempunyai toleransi lokasi sebesar $0.5 \mathrm{~mm}$ terhadadap datum B dan datum A. toleransi lokasi tersebut mmepunyai simbol LMC "L" yang berarti apabila lubang tersebut dibuat lebih kecil dari nilai diameter maksimumnya (terdeviasi dari nilai LMC-nya), yaitu misalnya sebesar $60 \mathrm{~mm}$ (nilai terukur) $<61 \mathrm{~mm}$ (nilai LMC - nya), maka lokasi sumbu dari lubang tersebut bisa bergeser lebih dari $0.5 \mathrm{~mm}$ karena adanya bonus toleransi. Dalam hal ini, bonus toleransi adalah sebesar: LMC - nilai diamater terukur, yaitu $61-60=1 \mathrm{~mm}$. Sehingga total zona toleransi dari sumbu lubang tersebut adalah sebesar $0.5 \mathrm{~mm}+1 \mathrm{~mm}=1.5 \mathrm{~mm}$. Hal ini disebabkan karena apabila lubang tersebut dibuat lebih besar dari nilai diameter minimumnya, maka apabila lubang tersebut bergeser lebih dari nilai toleransi lokasinya, maka ada material lebih pada lubang tersebut untuk bisa dibor untuk proses finishing lubang tersebut (ada material lebih untuk proses permesinan/pengeboran selanjutnya).

Contoh riil manfaat mengaplikasikan MMC dan LMC pada fitur size (misalnya: sebuha lubang) adalah:

- Manfaat menggunakan simbol MMC.

Simbol MMC digunakan untuk menginformasikan bahwa lubang tesebut berfungsi untuk sebagai, misalnya, lubang untuk memasukkan sebuah baut untuk mengikat dua pelat. Apabila lubang tersebut dibuat lebih besar, maka artinya, kemungkinan baut pengencang tersebut bisa masuk kelubang tersebut akan bertambah besar. Karena hal inilah terdapat bonus toleransi pada kondisi tersebut. Hal ini sangat berguna pada proses inspeksi. Dengan adanya bonus toleransi, maka toleransi yang diinspeksi akan semakin besar yang artinya, kemungkinan komponen tersebut ditolak akan semakin kecil sehingga bisa menurunkan biaya perbaikan atau scrap. Dan akhirnya, biaya inspeksi kualitas akan berkurang. 
- Manfaat menggunakan simbol LMC.

Simbol LMC digunakan untuk menginformasikan bahwa sejumlah material harus disisakan pada sebuah fitur, misalnya sebuah lubang, agar fitur tersebut dapat dilakukan proses permesinan, misalnya pengeboran, selanjutnya. Hal ini menjelaskan bahwa apabila, misalnya, sebuah lubang dibut lebih kecil diameternya, maka artinya lubang terebut mempunyai material lebih untuk proses pengeboran selanjutnya, sehingga apabila lubang tersebut dapat terdeviasi lebih dari nilai toleransi lokaisnya, karena adanya bonus toleransi, maka lubang tersebut masih menyisakan material untuk dibor pada proses selanjutnya.

Seperti yang sudah dijelaskan sebelumnya, kondisi material pada kodisi riilnya pada saat proses inspeksi sebuah fitur dapat memberikan sebuah bonus toleransi, sehingga toleransi yang dimiliki lebih besar dari pada toleransi yang didefinisikan dari awalnya. Hal ini akan mengurangi biaya inspeksi karena akan menurunkan jumlah komponen yang tidak lolos tes pengukuran. Namun demikian, bonus toleransi akan meningkatkan variasi dari sebuah fitur perakitan pada proses analisis akumulasi (stack-up) toleransi. Penjelasan lebih detil akan diperlihatkan pada bagian selanjutnya yaitu alokasi dan analisis toleransi.

\subsection{Alokasi dan Analisis toleransi}

Alokasi dan analisis toleransi merupakan satu kesatuan yang tidak dapat dipisahkan. Alokasi dan analisis toleransi adalah suatu proses yang ber-ulang (repetitive) sampai alokasi toleransi yang optimal didapatkan. Untuk menguragi jumlah pengulangan pada suatu proses alokasi dan analisis toleransi, maka dibutuhkan suatu pendekatan sistematik untuk proses tersebut.

Alokasi toleransi bukanlah suatu proses yang mudah. Apabila nilai suatu toleransi pada suatu fiture terlalu kecil, maka biaya produksi semakin tinggi. Biaya produksi yang semakin tinggi disebabkan karena semakin kecil nilai toleransi suatu produk, maka tingkat presisi produk tersebut akan semakin tinggi sehingga dibutuhkan suatu proses permesinan yang mahal untuk membuatnya. Dan sebaliknya, apabila nilai toleransi pada suatu fitur terlalu besar, maka fitur tersebut akan mempunya variasi yang terlalu besar, sehingga komponen yang mempuyai fitur tersebut tidak bisa dirakit (Moroni et al 2011).

Alokasi dan analisis toleransi adalah suatu proses untuk menjawab pertanyaan-pertanyaan lebih detil apabila suatu fitur yang terdeviasi dari nilai nominalnya sebelum suatu proses manufaktur dikerjakan untuk membuat fitur tersebut, misalnya:

- Apa efek yang ditimbulkan apabila posisi suatu lubang yang dibuat bergeser beberapa milimiter dari posisi nominalnya?

- Berapa banyak material yang harus disisakan dalam proses permesinan agar cukup untuk dilakukan postprocessing, misanya: boring, agar surface yang dimiliki suatu fitur menjadi sangat mulus atau dimensi suatu lubang menjadi sangat akurat?

- Apa efek apabila lubang yang dibuat lebih besar dari nilai nominalnya?

- Apa efek apabila jumlah komponen pada suatu assembly ditambah?

- Apakah suatu rotor dan stator akan bersentuhan satu sama lainnya selama beroperasi?

- Berapa variasi gap antar dua buah bidang setelah proses perakitan dilakukan?

- Berapa suhu optimal suatu proses perakitan produk mikro agar gap dari produk tersebut dapat mengikuti toleransinya?

\subsubsection{Analisis akumulasi toleransi (tolerance stack-up analysis)}

Definisi formal analisis akumulasi toleransi (tolerance stack-up analysis) adalah sebuah alat yang digunakan untuk mengetahui efek kumulatif dari toleransi-toleransi yang dialokasikan kepada fitur-fitur pada suatu komponen dan untuk memastikan bahwa efek kumulatif tersebut dapat diterima untuk menjamin fungsionalitas dari suatu produk setelah dilakukan suatu proses perakitan.

Dengan demikian, analisis akumulasi toleransi adalah suatu proses untuk mengalokasikan toleransi pada suatu fitur, baik toleransi dimensional maupun toleransi geoetri (GD\&T) dan mengkalkulasi akumulasi toleransi terhadap 
suatu fitur perakitan (misalnya: gap atau jarak antara dua belat dan jarak antara rotor dan stator) berdasarkan toleransi yang telah dialokasikan tersebut. Tujuan dari analisis toleransi adalah untuk mengecek suatu dimensi dan toleransi yang diberikan pada suatu komponen, sehingga ketika komponen tersebut dirakit, maka total produk yang dirakit akan berfungsi sesuai dengan yan didisain. Analisis toleransi merupakan hal yang unik karena analisis toleransi adalah setengah ilmu pengetahuan dan setengah seni (half-science dan half-art).

Analisis toleransi dapat diaplikasikan untuk semua jenis komponen, dari skala besar sampai dengan skala kecil. Hal pertama yang harus dimiliki untuk menganilisis suatu toleransi adalah model dari akumulasi toleransi harus direkonstruksi terlebih dahulu.

Ada dua jenis metode untuk analisis akumulasi toleransi, yaitu:

- Metode analisis 1D/2D, yaitu dengan menggunakan metode spraed-sheet.

- Metode analisis matriks, yaitu metode general secara 3D dengan memperhitungkan efek rotasi. Metode ini akan dijelaskan secara detil pada bagian bab 3.4.8

Langkah-langkah untuk melakukan analisis akumulasi toleransi adalah sebagai berikut:

1. Definisikan dimensi (fitur) kritikal yang akan dianalisis, yaitu fiture-fitur perakitan (assembly features), seperti gap antarat dua pelat setelah perakitan.

2. Rekontruksi rantai toleransi (tolerance chain). Dari fitur kritikal tersebut yang ingin dianalisis.

3. Definisikan atau rekonstruksi model akumulasi toleransi.

4. Pertimbangkan semua sumber-sumber variasi pada model akumulasi toleransi tersebut.

5. Jumlahkan seluruh komponen variasi, baik dengan metode worst-case atau metode statistik (lihat bab selanjutnya).

\subsubsection{Analisis toleransi: berbasis worst-case and berbasis statistik}

Untuk menjumlahkan seluruh komponen variasi untuk mendapatkan total variasi dari fitur perakitan suatu produk yang telah dirakit, ada dua jenis metode penjumlahan komponen variasi tersebut:

- Analisis toleransi berbasis worst-case.

- Analisis toleransi berbasis statistik.

\section{Analisis toleransi berbasis worst-case.}

Analisis berbasis worst-case adalah sebuah metode analisis toleransi yang menjumlahkan seluruh nilai maximum dari toleransi yang dialokasikan. Total toleransi (variasi) yang dikalkulasi dengan menggunakan metode worst-case adalah sebagai berikut:

$$
\text { Toleransi total }=\operatorname{Tol}_{1}+\operatorname{Tol}_{2}+\cdots+\operatorname{Tol}_{n}=\sum_{i=1}^{n} \operatorname{Tol}_{i}
$$

dimana $\operatorname{Tol}_{i}$ adalah nilai toleransi pada dimensi ke-i dalam format equally-bilateral $\left( \pm\right.$ tol $\left._{i}\right)$.

Analisis berbasis worst-case mempunyai karakteristik sebagai berikut:

- Metode kalkulasi worst-case merepresentasikan kemungkinan variasi terbesar pada suatu fitur berdasarkan nilai-nilai toleransi yang diberikan.

- Metode worst-case mengasumsikan bahwa semua komponen berada pada kondisi terdeviasi ekstrim pada nilai masimum toleransinya pada saat bersamaan pada saat kondisi inspeksi kualitas (dalam kenyataannya, kondisi seperti ini akan sangat jarang terjadi).

- Metode worst-case mengimplikasikan bahwa semua komponen yang diproduksi harus diinspeksi satu-persatu untuk menjamin bahwa tidak ada satu komponen pun yang berada di luar toleransi yang diberikan.

- Metode worst-case diaplikasikan untuk suatu produksi dengan jumlah sedikit (low-volume) dan untuk komponen-komponen yang sangat mahal dan penting, misalnya untuk komponen mesin jet pesawat. 


\section{Analisis toleransi berbasis statistik.}

Analisis berbasis statistik adalah sebuah metode analisis toleransi yang menjumlahkan seluruh nilai-nilai toleransi secara akar kuadrat dari jumlah kuuadrat seluruh nilai toleransi tersebut (sum-of-squared). Metode ini menentukan kemungkinan variasi yang paling memungkinkan untuk suatu dimensi dan fitur perakitan. Total toleransi (variasi) yang dikalkulasi dengan menggunakan metode statistik adalah sebagai berikut:

$$
\text { Toleransi total }=k \sqrt{\operatorname{Tol}_{1}^{2}+\operatorname{Tol}_{2}^{2}+\cdots+\operatorname{Tol}_{n}^{2}}=k \sqrt{\sum_{i=1}^{n} \operatorname{Tol}_{i}^{2}}
$$

dimana $\operatorname{Tol}_{i}$ adalah nilai toleransi pada dimensi ke-i dalam format equally-bilateral $\left( \pm\right.$ tol $\left._{i}\right) . k$ adalah faktor keamanan untuk memperhitungkan variasi dari komponen-komponen yang disupplai dari tempat atau perusahaan lain. Pada umumnya, nilai $k=1.5$. tetapi, apabila semua komponen dibuat pada suatu tempat yang sama, maka nilai $k=$ 1.

Analisis berbasis statistik mempunyai karakteristik sebagai berikut:

- Metode kalkulasi statistik berbasiskan pada asumsi bahwa semua dimensi yang diukur akan cenderung pada nilai nominal mereka (dengan berasumsi variasi-variasi dari fitur tersebut terdistribusi normal).

- Metode kalkulasi statistik akan mempunyai nilai tolernasi total lebih kecil dari worst-case. Hal ini merupakan hasil yang sangat berguna karena nilai toleransi pada setiap fitur menjadi lebih besar sehinga biaya produksi fitur tersebut dapat dikurangi.

- Metode kalkulasi statistik meingimplikasikan bahwa tidak perlu untuk menginspeksi semua komponen, sehinga yang dibutuhkan adalah hanya sejumlah sampel komponen, yang diambil dari seluruh komponen, untuk dilakukan suatu proses inspeksi kualitas.

- Metode kalkulasi statistik berbasis pada beberapa restriksi tertetu, yaitu:

1. Semua proses manufaktur suatu komponen harus dalam kondisi terkontrol. Maka dari itu, sebelum melakukan produksi, studi kapabilitas proses (process capability study) harus dilakukan terlebih dahulu $\left(C_{p}\right)$. Studi kapabilitas proses akan menunjukkan kondisi riil dari suatu proses manufaktur.

2. Semua proses manufaktur harus "centered" atau berada pada nilai rata-ratanya (tidak ada mean-shift). Hal ini menunjukkan bahwa proses tersebut tidak mempunyai pergeseran dari proses rata-ratanya $\left(C_{p k}\right)$. Apabila terjadi pergeseran proses, maka proses manufaktur tersebut harus diset ulang.

3. Sampel komponen-komponen yang akan diinspeksi haruslah diambil secara acak (random). Sampel acak ini berbasis pada ide untuk kemampuan-tukar/interchangeability (dari sudut pandang mekanik) dan berbasis apda ide dari variabel independen (dari sudut pandang statistik).

4. Hal penting yang harus dipahami adalah dengan metode statistik untuk menghitung nilai toleransi total, maka akan ada kemungkinan beberapa komponen atau produk akan ditolak (di luar batas toleransinya). Hal ini tergantung dari seberapa besar nilai keamana $k$ diterapkan untuk menghitung nilai tolernasi total.

Dapat dilihat bahwa, dari persamaan (3) dan (4), analisis toleransi berbasis statistik akan mempunyai nilai toleransi total yang lebih kecil dari analisis toleransi berbasis worst-case. Hal ini menyebabkan, dengan menggunakan metode statistik, maka setiap fitur dapat diberikan nilai toleransi yang lebih besar sehingga mempermudah proses manufaktur dan inspeksi fitur tersebut.

\subsubsection{Analisis toleransi dimensional "plus/minus"}

Untuk analisis toleransi dimensional "plus/minus" pada umumnya menggunakan metode 1D/2D. Penjelasan mengenai analisis toleransi tersebut diperlihatkan dengan menggunakan bebera contoh kasus. 


\section{Contoh 1: Analisis akumulasi toleransi dimensioanal "plus/minus" dengan metode 1D/2D untuk komponen tunggal.}

Untuk contoh 1, terdapat sebuah disain baut dengan dimensi serta toleransinya. Gambar 22 memperlihatkan model 3D dan gambar teknik (2D) serta dimensi dan toleransi dari disain baut tersebut. Pada contoh ini, fitur yang ingin dianalisis dimensinya dengan metode analisis akumulasi toleransi adalah jarak (gap) antara titik A dan B (gambar 22 bawah). Untuk menganalisis akumulasi toleransi pada fitur tersebut, rantai toleransi (tolerance chain) dari fitur tersebut harus direkonstruksi. Rantai toleransi merepresentasikan perambatan toleransi dan dimensi pada suatu fitur yang dimulai dari fitur tersebut, melewati seluruh dimensi fitur-fitur lain yang berpengaruh terhadap fitur yang sedang dianalisis tersebut, dan kempali ke fitur tersebut.

Oleh karena itu, rantai toleransi untuk baut tersebut harus direkonstruksi. Gambar 23 memperlihatkan rantai toleransi dari fitur jarak A dan B pada baut tersebut. Pada gambar 23, kepala baut tidak mempengaruhi fitur jarak antara A dan B tersebut, sehingga kepala baut dapat dihiraukan untuk menyederhanakan rantai toleransi. Pada gambar 23, rantai toleransi tersebut direpresentasikan dengan panah merah. Rantai toleransi tersebut dimulai dari titik B, kemudian mengikuti seluruh dimensi fitur pada baut tersebut yang berpengaruh, kemudian kembali ke titik A. Untuk kasus ini, dan secara umum untuk kasus analisis dengan metode $1 \mathrm{D} / 2 \mathrm{D}$, model akumulasi toleransi dengan mudah dapat direkonstruksi, yaitu:

$$
\begin{aligned}
& \text { Toleransi total }=\text { Tol }_{1}-\mathrm{Tol}_{2}-\mathrm{Tol}_{3}+\mathrm{Tol}_{4}+\mathrm{Tol}_{5}, \text { untuk analisis worst-case } \\
& \text { Toleransi total }=k \sqrt{\text { Tol }_{1}^{2}+\text { Tol }_{2}^{2}+\text { Tol }_{3}^{2}+\text { Tol }_{4}^{2}+\text { Tol }_{5}^{2}}, \text { untuk analisis statistik }
\end{aligned}
$$

Dimana secara konvensi umum, arah kanan dan atas adalah "positif", dan arah kiri dan bawah adalah “negatif". Nilai diasumsikan sebagai $k=1$.

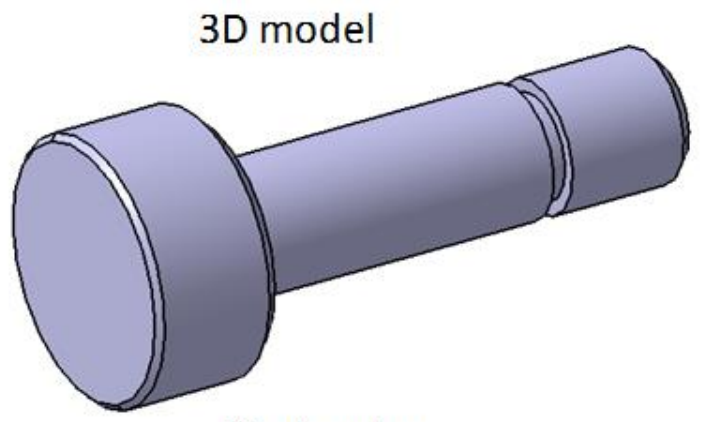

\section{D drawing}
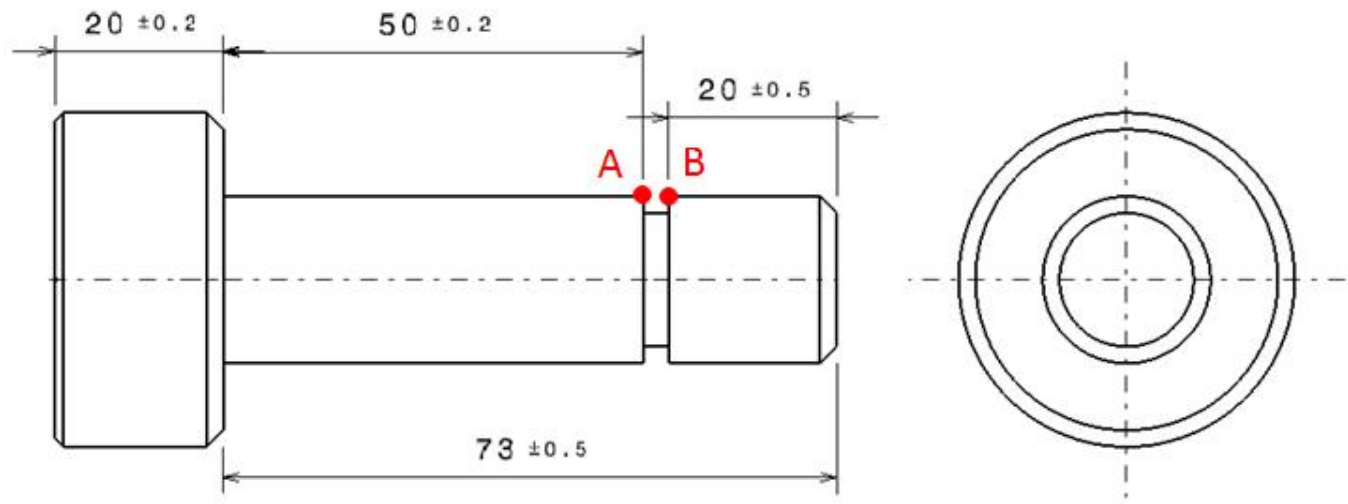

Gambar 22: Model 3D baut dan gambar teknik (2D)-nya. Only toleransi dimensional (plus/minus). 


\section{Rantai toleransi (tolerance chain)}

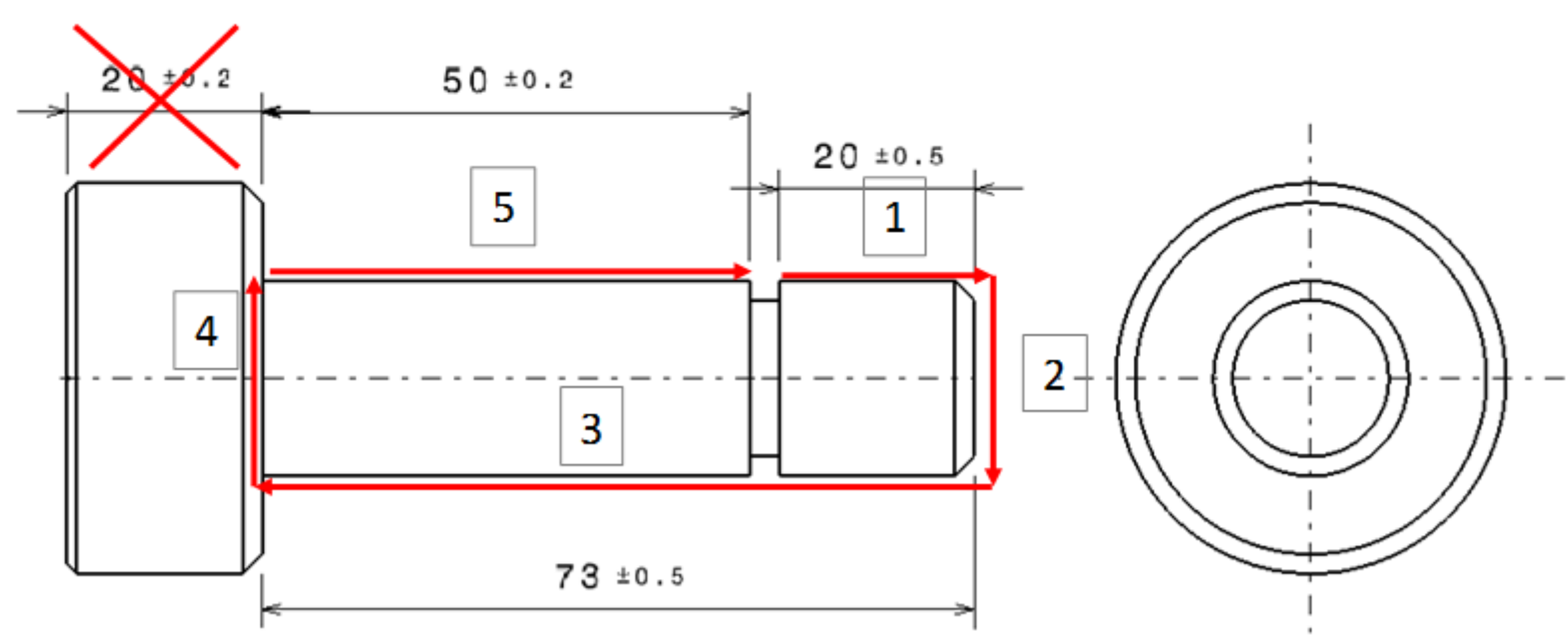

Gambar 23: Rantai toleransi dari contoh baut.

Pada umumnya, untuk analisis akumulasi toleransi berbasis 1D/2D, model persamaan seperti pada persamaan (5) dan (6) tidak diperlihatkan, melainkan langsung direpresentasikan dalam suatu tabel. Hanya dengan metode analisis matriks (yang akan dijelaskan pada bab 3.4.8) model persamaan analisis akumulasi toleransi diperlihatkan. Untuk contoh kasus baut ini, perhitungan akumulasi toleransinya diperlihatkan pada tabel 2 untuk analisis worst-case dan tabel 3 untuk analisis statistik.

Pada tabel 2, total akumulasi toleransi jarak A dan B dijumlahkan langsung dari nilai maksimum toleransinya (dimana nilai toleransi tersebut harus dalam format equally-bilateral). Total akumulasi toleransi (yang merepresentasikan total variasi dari jarak A dan B) dengan metode worst-case adalah $1.2 \mathrm{~mm}$.

Pada tabel 3, total akumulasi toleransi jarak A dan B di-sum-squared-kan dari nilai maksimum toleransinya (dimana nilai toleransi tersebut harus dalam format equally-bilateral). Total akumulasi toleransi untuk jarak A dan B tersebut dengan metode statistik adalah $0.73 \mathrm{~mm}$.

Dari kedua hasil akumulasi toleransi tersebut, total akumulasi toleransi dengan metode statistik adalah lebih kecil $39 \%$. Hal ini menunjukkan bahwa perhitungan akumulasi toleransi dengan metode statistik memungkinkan untuk memberikan nilai toleransi yang lebih besar pada setiap fitur dibandinkan dengan metode worst-case. Dengan nilai toleransi yang lebih besar, maka biaya produksi dan biaya inspeksi kualitas akan semakin berkurang.

Sebagai contoh adalah sebagai berikut. dengan metode worst-case, nilai toleransi baut tersebut (pada rantai toleransi pada gambar 23) adalah $50 \pm 0.2 \mathrm{~mm}, 20 \pm 0.5 \mathrm{~mm}$ dan $73 \pm 0.5 \mathrm{~mm}$. Perhitungan akumulasi tolernasi dengan metode statistik menghasilkan total toleransi sebesar $0.73 \mathrm{~mm}$. Untuk mencapai total akumulasi sebesar $1.2 \mathrm{~mm}$ (seperti hasil perhitungan dengan metode worst-case), maka toleransi baut tersebut dapat direalokasikan lagi sebagai berikut: $50 \pm 0.5 \mathrm{~mm}, 20 \pm 0.5 \mathrm{~mm}$ dan $73 \pm 0.7 \mathrm{~mm}$. Dari nilai toleransi yang baru tersebut, maka persyaratan proses manufaktur dan proses inspeksi kualitas dari baut tersebut akan semakin mudah. Dengan demikian, biaya produksi dan biaya inspeksi baut tersebut akan semakin murah. 
Tabel 2: Analisis akumulasi toleransi berbasis worst-case untuk contoh baut.

\begin{tabular}{|c|c|c|c|c|c|}
\hline No & Deskripsi & Dims /mm & $\begin{array}{c}\text { Tol } \\
\text { /mm }\end{array}$ & Sumber Dim/Tol \& kalkulasi & \% Kontribusi \\
\hline 1 & Dimensi (arah kanan) & 20 & 0.5 & Dari gambar teknik & 41.67 \\
\hline 2 & Dimensi (vertikal) & 0 & 0 & Arah vertical tidak diperhitungkan & 0 \\
\hline 3 & Dimensi (arah kiri) & -73 & 0.5 & Dari gambar teknik & 41.67 \\
\hline 4 & Dimensi (vertikal) & 0 & 0 & Arah vertical tidak diperhitungkan & 0 \\
\hline 5 & Dimensi (arah kanan) & 50 & 0.2 & Dari gambar teknik & 16.67 \\
\hline & Total jarak A dan B & 3 & 1.2 & & \\
\hline
\end{tabular}

Tabel 3: Analisis akumulasi toleransi berbasis statistik untuk contoh baut.

\begin{tabular}{|c|c|c|c|c|c|}
\hline No & Deskripsi & Dims & Tol & $\begin{array}{c}\text { Squared } \\
\text { Tol. }\end{array}$ & $\begin{array}{c}\text { Sumber Dim/Tol \& } \\
\text { kalkulasi }\end{array}$ \\
\hline 1 & Dimensi (arah kanan) & 20 & 0.5 & 0.25 & Dari gambar teknik \\
\hline 2 & Dimensi (vertikal) & 0 & 0 & 0 & $\begin{array}{c}\text { Arah vertikal tidak } \\
\text { diperhitungkan }\end{array}$ \\
\hline 3 & Dimensi (arah kiri) & -73 & 0.5 & 0.25 & Dari gambar teknik \\
\hline 4 & Dimensi (vertikal) & 0 & 0 & 0 & $\begin{array}{c}\text { Arah vertikal tidak } \\
\text { diperhitungkan }\end{array}$ \\
\hline 5 & Dimensi (arah kanan) & 50 & 0.2 & 0.04 & Dari gambar teknik \\
\hline & Total jarak A dan B & 3 & & 0.73 & \\
\hline
\end{tabular}

Contoh 2: Analisis akumulasi toleransi dimensioanal "plus/minus" dengan metode 1D/2D untuk komponen tunggal.

Contoh berikutya adalah analisis akumulasi toleransi untuk sebuah fitur slot pada sebuah komponen yang dibuat dengan suatu proses perkakas (milling). Gambar 24 memperlihatkan dimensi dan toleransi dari fitur-fitur komponen tersebut dalam dua bentuk format presentasi, yaitu format unequal bilateral dan equal bilateral. Analasis akumulasi toleransi dengan metode 1D/2D dan metode matriks, baik berbasis worst-case maupun statistik, menggunakan format toleransi equal bilateral. Maka dari itu, toleransi yang berformat unequal bilateral harus dikonversi menjadi format equal bilateral. Format dimensi dan toleransi equal bilateral $( \pm)$ adalah sebagai berikut:

$$
X \pm T
$$

dimana $X$ adalah dimensi nominal suatu fitur dan $T$ adalah toleransi dari dimensi $X$ fitur tersebut. 
Toleransi format Unequal bilateral

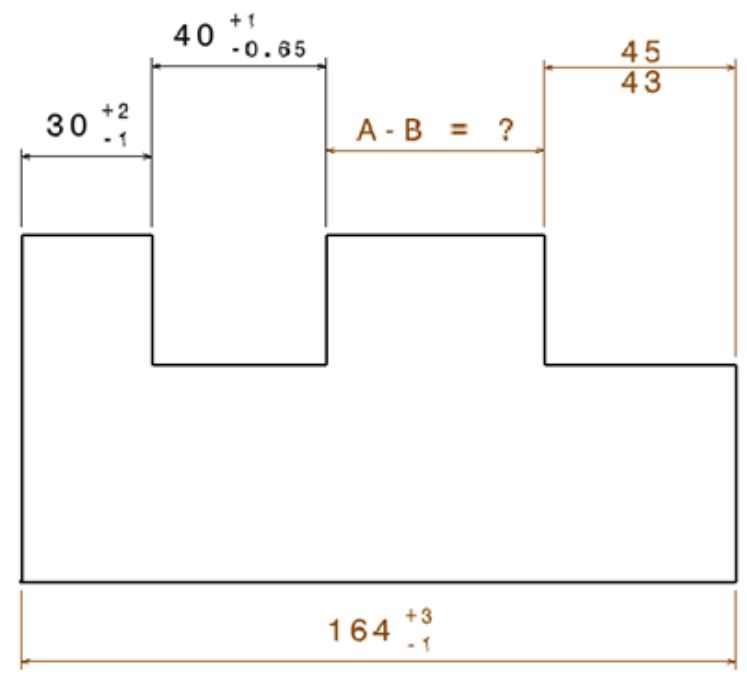

Toleransi format Equal bilaterally

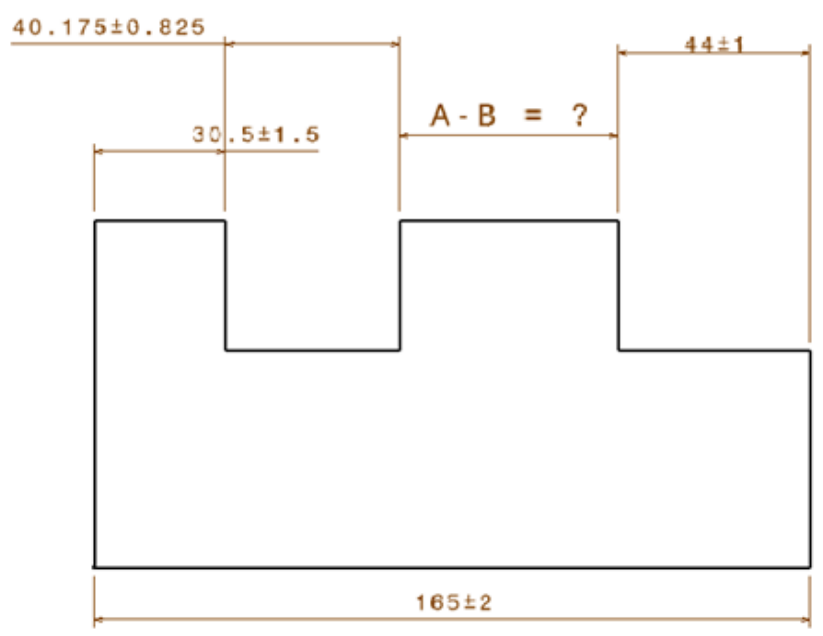

Gambar 24: (kiri) toleransi dengan format unequal bilateral dam (kanan) toleransi dengan format equal bilateral.

Untuk mengkonversi suatu dimensi dan toleransi dari unequal bilateral ke equal bilateral sebagai berikut:

$$
\begin{aligned}
& X=\frac{\min +\max }{2} \\
& T=\frac{m a x-\min }{2}
\end{aligned}
$$

dimana min adalah dimensi minimum dan max adalah dimensi maksimum dari suatu fitur pada suatu komponen. Pada gambar 24 (kiri), fitur-fitur komponen tersebut mempunyai dimensi dalam format unequal bilateral, sehingga pada gamabr 24 (kanan), fitur-fitur tersebut memiliki format toleransi equal bilateral setelah dilakukan konversi menggunakan persamaan (8) dan (9).

Langkah selanjutnya, adalah menentukan rantai toleransi yang menggambarkan perambatan akumulasi toleransi untuk jarak A dan B (lihat gambar 25). Gambar 25 memperlihatkan rantai toleranasi pada komponen yang di-miling tersebut. Berdasarkan rantai toleransi tersebut, analisis akumulasi toleransi $1 \mathrm{D} / 2 \mathrm{D}$ berbasis worst-case dan statistik dapat dilakukan.

Tabel 4 memperlihatkan analisis akumulasi toleransi berbasis wors-case. Arah perambatan toleransi yang berpengaruh hanyalah arah horisontal. Hasil dari analisis akumulasi toleransi berbasis worst-case adalah jarak A ke B mempunyai akumulasi toleransi, yang merupakan variasi dari jarak tersebut, sebesar $5.325 \mathrm{~mm}$ dengan nominal dimensi sebesar $50.33 \mathrm{~mm}$.

Sedangkan hasil analisis akumulasi toleransi berbasis statistik diperlihatkan pada tabel 5. Pada tabel 5, total dimensi nominal jarak A ke B adalah $50.33 \mathrm{~mm}$ dan total akumulasi toleransinya adalah sebesar $2.82 \mathrm{~mm}$. Seperti yang sudah dijelaskan sebelumnya, bahwa total akumulasi toleransi yang dikalkulasi berdasarkan metode statistik akan mempunyai nilai yang lebih rendah dari hasil kalkulasi worst-case. Untuk kasus ini, total akumulasi toleransi berbasis statistik mempunyai nilai lebih rendah $47 \%$ dari nilai yang dikalkulasi dangan berbasis worst-case. 
Rantai toleransi (tolerance chain)

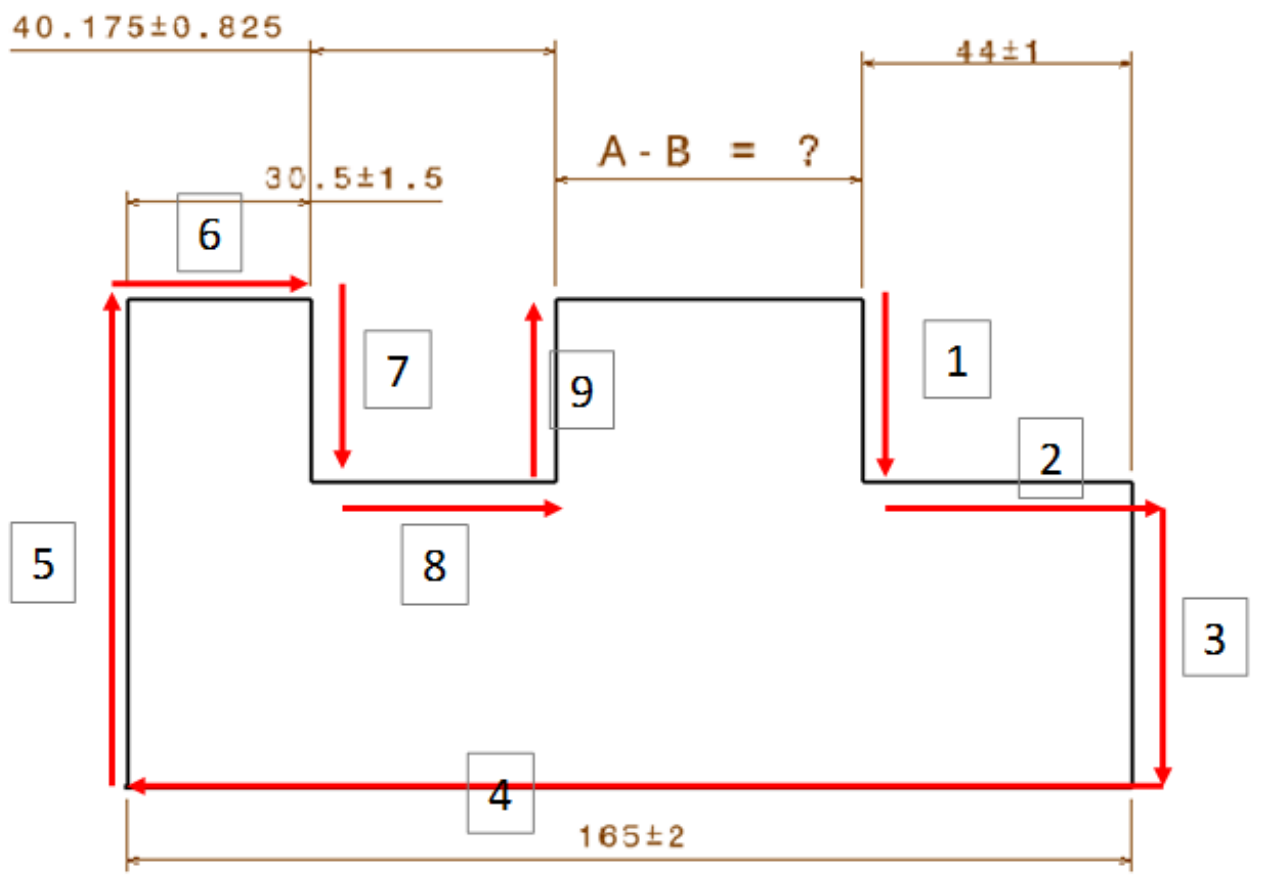

Gambar 25: Rantai toleransi untuk jarak A-B.

Tabel 4: Analisis akumulasi toleransi berbasis worst-case untuk contoh 2.

\begin{tabular}{|c|c|c|c|c|c|}
\hline No & Deskripsi & Dims $/ \mathbf{m m}$ & $\begin{array}{c}\text { Tol } \\
\mathbf{/ m m}\end{array}$ & Sumber Dim/Tol \& kalkulasi & \% Kontribusi \\
\hline 1 & Dimensi (vertikal) & 0 & 0 & Arah vertical tidak diperhitungkan & 0 \\
\hline 2 & Dimensi (arah kanan) & 44 & 1 & Dari gambar teknik & 18.78 \\
\hline 3 & Dimensi (vertikal) & 0 & 0 & Arah vertical tidak diperhitungkan & 0 \\
\hline 4 & Dimensi (arah kiri) & -165 & 2 & Dari gambar teknik & 37.56 \\
\hline 5 & Dimensi (vertikal) & 0 & 0 & Arah vertical tidak diperhitungkan & 0 \\
\hline 6 & Dimensi (arah kanan) & 30.5 & 1.5 & Dari gambar teknik & 28.17 \\
\hline 7 & Dimensi (vertikal) & 0 & 0 & Arah vertical tidak diperhitungkan & 0 \\
\hline 8 & Dimensi (arah kanan) & 40.17 & 0.825 & Dari gambar teknik & 15.49 \\
\hline 9 & Dimensi (vertikal) & 0 & 0 & Arah vertical tidak diperhitungkan & 0 \\
\hline & Total jarak A dan B & 50.33 & 5.325 & & \\
\hline
\end{tabular}


Tabel 5: Analisis akumulasi toleransi berbasis statistik untuk contoh 2.

\begin{tabular}{|c|c|c|c|c|c|}
\hline No & Deskripsi & Dims & Tol & $\begin{array}{c}\text { Squared } \\
\text { Tol. }\end{array}$ & Sumber Dim/Tol \& kalkulasi \\
\hline 1 & Dimensi (vertikal) & 0 & 0 & 0 & Arah vertical tidak diperhitungkan \\
\hline 2 & Dimensi (arah kanan) & 44 & 1 & 1 & Dari gambar teknik \\
\hline 3 & Dimensi (vertikal) & 0 & 0 & 0 & Arah vertical tidak diperhitungkan \\
\hline 4 & Dimensi (arah kiri) & -165 & 2 & 4 & Dari gambar teknik \\
\hline 5 & Dimensi (vertikal) & 0 & 0 & 0 & Arah vertical tidak diperhitungkan \\
\hline 6 & Dimensi (arah kanan) & 30.5 & 1.5 & 2.25 & Dari gambar teknik \\
\hline 7 & Dimensi (vertikal) & 0 & 0 & 0 & Arah vertical tidak diperhitungkan \\
\hline 8 & Dimensi (arah kanan) & 40.17 & 0.825 & 0.68 & Dari gambar teknik \\
\hline 9 & Dimensi (vertikal) & 0 & 0 & 0 & Arah vertical tidak diperhitungkan \\
\hline & Total jarak A dan B & 50.33 & 2.82 & & \\
\hline
\end{tabular}

\section{Contoh 3: Analisis akumulasi toleransi dimensioanal "plus/minus" dengan metode 1D/2D untuk sebuah assembly (komponen multipel).}

Contoh ini memperlihatkan kasus berbeda dengan contoh-contoh sebelumnya. Pada contoh ini, kasus analisis akumulasi toleransi pada sebuah produk yang merupakan hasil perakitan dari lebih dari satu komponen diperlihatkan. Kasus tersebut lebih merepresentasikan kondisi riil karena pada prinsipnya tidak ada produk yang dapat berfungsi hanya dengan satu komponen saja, melainkan produk tersebut dirakit dari beberapa komponen yang berbeda.

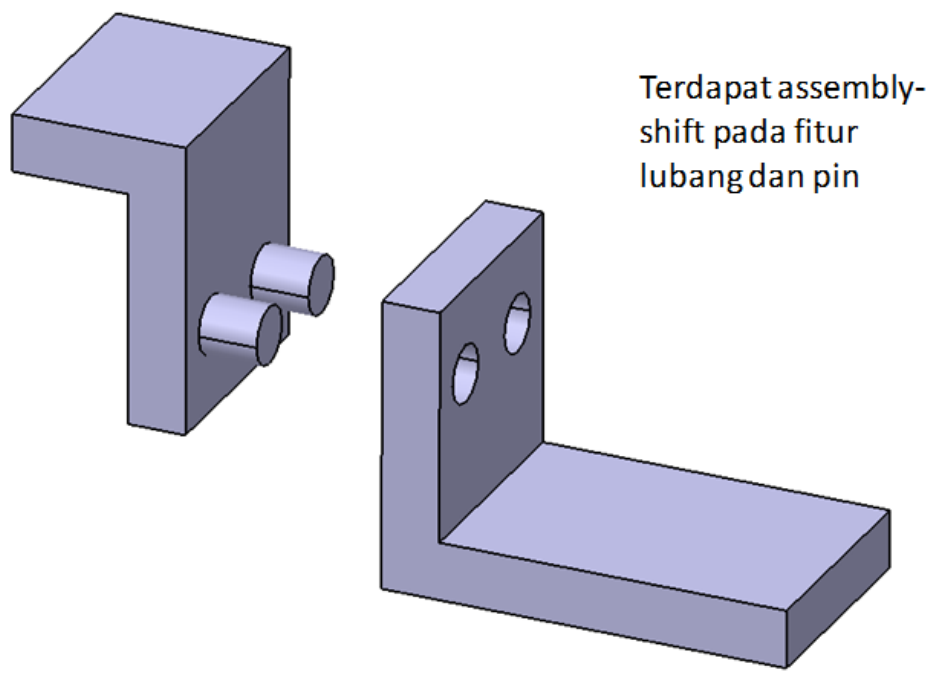

Gambar 26: Contoh kasus dengan dua buah komponen. 
Gambar 26 memperlihatkan sebuah produk yang terdiri dari dua buah komponen yang dirakit bersama. Kedua komponen tersebut dapat dirakit melalui dua buah fitur perakitan dalam bentuk pin dan lubang. Gambar teknik berserta dimensi dan toleransi dimensionalnya diperlihatkan pada gambar 27 dan 28. Pada gambar 27, dimensi nominal dan toleransi dimensionalnya diperlihatkan untuk komponen 1, sedangkan untuk komponen 2 diperlihatkan pada gamabr 28. Nilai toleransi simensional seluruh dimensi pada kedua komponen tersebut adalah sebesar $\pm 0.2 \mathrm{~mm}$.

\section{Komponen 1}
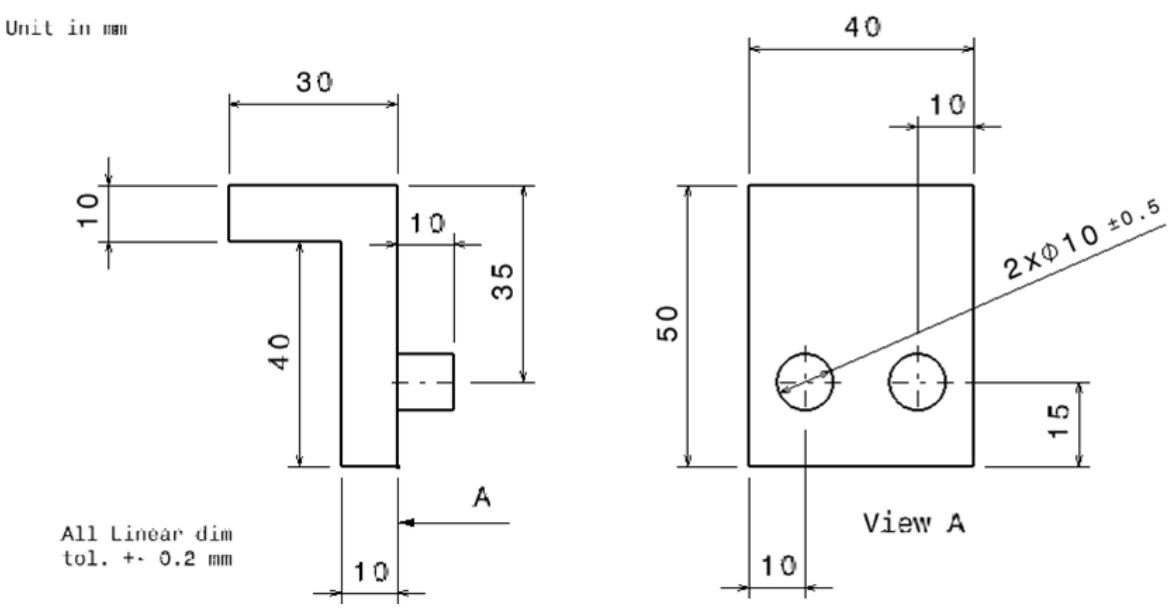

Gambar 27: Dimensi nominal dan toleransi untuk komponen 1.

Komponen 2

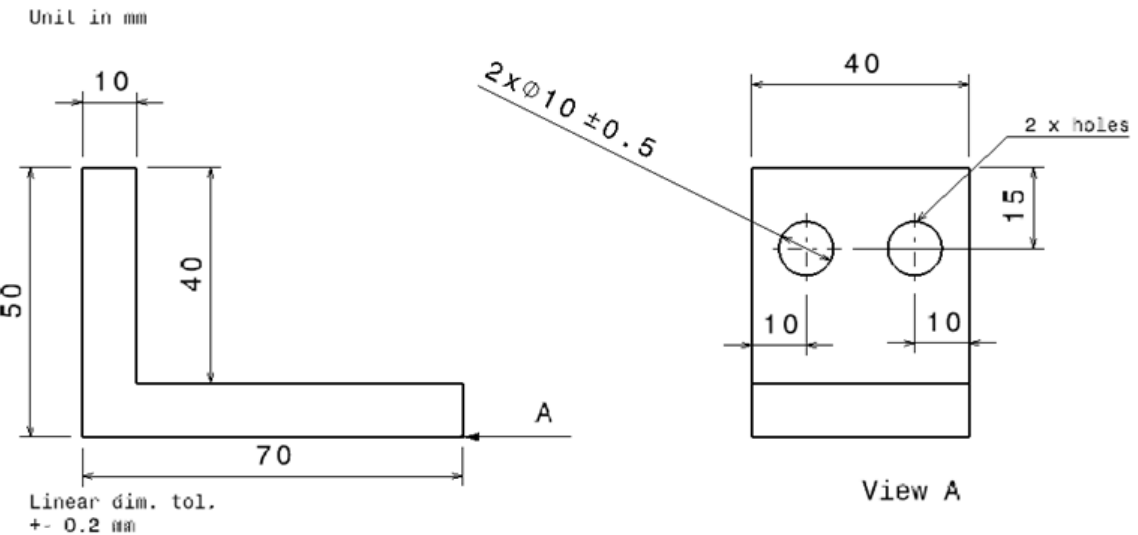

Gambar 28: Dimensi nomial dan toleransi untuk komponen 2.

Hal yang sangat penting yang ingin diperlihatkan pada contoh ini adalah suatu konsep yang bernama assemblyshift. Assembly-shift adalah suatu variasi berupa sebuah pergeseran yang muncul dari fitur-fitur sambungan pin/poros dan lubang. Pergeseran tersebut dapat disebabkan oleh beberapa hal, seperti gaya gravitas dan gaya impak yang diberikan oleh seorang operator ketika merakit komponin-komponen. 


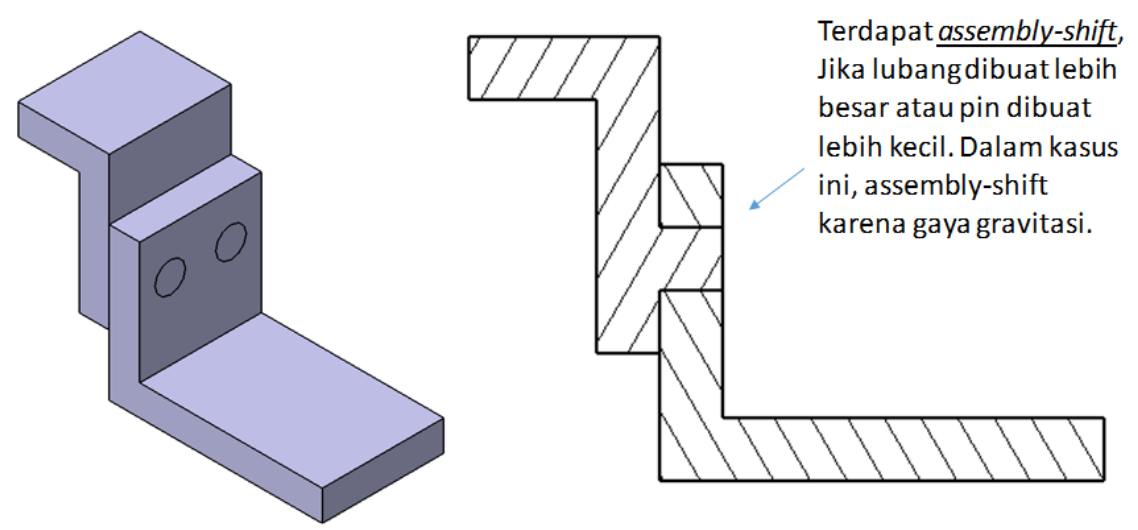

Gambar 29: Assembly-shift pada sebuah fitur pin dan lubang.

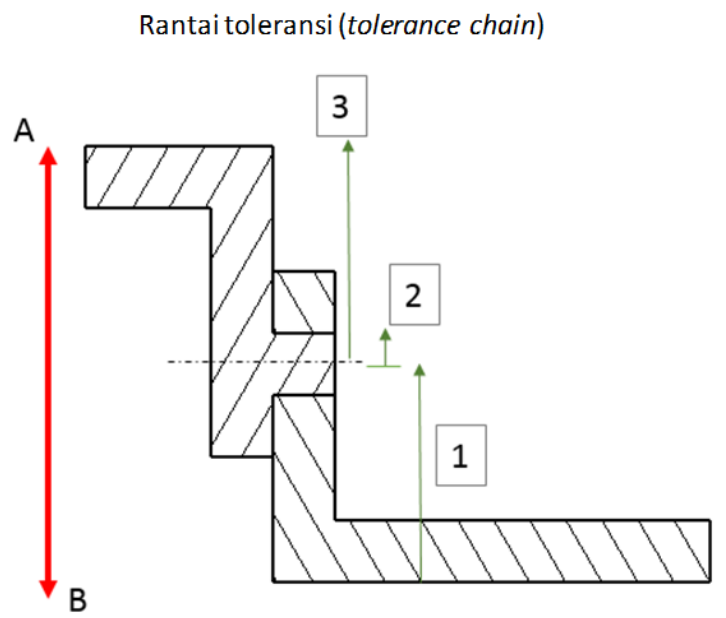

Gambar 30: Rantai toleransi untuk contoh kasus sebuah perakitan produk dengan dua komponen.

Konsep assembly-shift adalah sebagai berikut. ketika dua buah komponen disambung dengan fitur-fitur pin dan lubang, maka ketika lubang tersebut dibuat lebih besar atau pin tersebut dibuat lebih kecil dari nilai nominalnya, maka ketika kedua komponen tersebut dirakit, akan ada pergeseran yang diakibatkan dari terdeviasinya fitur pin dan lubang tersebut dari nilai nominalnya. Pergeseran tersebut disebabkan, misalnya, oleh gaya gravitasi karena komponene tersebut dirakit dengan posisi vertikal atau gaya yang diberikan untuk mengeset atau mengepaskan kedua komponen tersebut pada saat kedua komponen tersebut dirakit. Hal yang penting untuk diingat adalah assembly-shift selalu mempunya nilai dimensi nominal sebesar 0 , karena pada prinsipnya dalam keadaan ideal atau sempurna (yaitu suatu pin atau lubang mempunyai diameter yang sama persis), assembly-shift tidak muncul. Gambar 29 memperlihatkan konsep assembly-shift dari yang disebabakan oleh gaya gravitasi yang bekerja pada komponen-komponen tersebut.

Langkah berikutnya adalah menentukan rantai toleransi dari contoh kasus tersebut. fitur yang ingin dianalisis akumulasi toleransinya pada contoh kasus ini adalah tingga (jarak) titik A dari dasar komponen 2, yaitu titik B. Rantai toleransi tersebut diperlihatkan pada gambar 30. Pada gambar 30, diperlihatkan toleransi tambahan, nomor 2, yang disebabakan karena assembly-shift. Sumber toleransi lain berasal dari fitur-fitur yang mempunyai dimensi dan toleransi yang telah ditentukan pada gambar teknik komponen-komponen tersebut (gambar 27 dan gambar 28).

Hasil analisis akumulasi toleransi pada contoh kasus ini diperlihatkan pada tabel 6 untuk perhitungan berbasis worst-case dan tabel 7 untuk perhitungan berbasis statistik. Hasil akumulasi toleransi yang dikalkulasi berdasarkan metode worst-case (tabel 7) adalah jarak A-B akan mempunyai dimensi dan toleransi total yaitu (70 \pm 1.4$) \mathrm{mm}$. 
Sedangkan, hasil dari kalkulasi berdasarkan metode statistik, jarak A-B mempunyai dimensi dan toleransi total sebesar $(70 \pm 1.04) \mathrm{mm}$. Untuk contoh kasus ini, total akumulasi toleransi yang dikalkulasi berdasarkan statistik adalah $25.7 \%$ lebih kecil dari hasil kalkulasi berdasarkan metode worst-case.

Tabel 6: Analisis akumulasi toleransi berbasis worst-case untuk contoh 3: assembly.

\begin{tabular}{|c|c|c|c|c|c|}
\hline No & Deskripsi & $\begin{array}{c}\text { Dims } \\
\text { /mm }\end{array}$ & $\begin{array}{c}\text { Tol } \\
\text { /mm }\end{array}$ & Sumber Dim/Tol \& kalkulasi & \% Kontribusi \\
\hline 1 & $\begin{array}{c}\text { Dimensi vertikal } \\
\text { (arah atas) }\end{array}$ & 35 & 0.2 & Dari gambar teknik & 14.28 \\
\hline 2 & Assembly-shift & 0 & 1 & $\begin{array}{c}\text { Assembly-shift karena gaya gravitasi, lubang } \\
\text { terbesar }- \text { pin/silinder terkecil = } 10.5-9.5=1 \\
\text { mm }\end{array}$ & 71.43 \\
\hline 3 & $\begin{array}{c}\text { Dimensi vertikal } \\
\text { (arah atas) }\end{array}$ & 35 & 0.2 & Dari gambar teknik & 14.28 \\
\hline & Total jarak A dan B & 70 & 1.4 & & \\
\hline
\end{tabular}

Tabel 7: Analisis akumulasi toleransi berbasis statistik untuk contoh 3: assembly.

\begin{tabular}{|c|c|c|c|c|c|}
\hline No & Deskripsi & Dims & Tol & $\begin{array}{c}\text { Squared } \\
\text { Tol. }\end{array}$ & Sumber Dim/Tol \& kalkulasi \\
\hline 1 & $\begin{array}{c}\text { Dimensi vertikal (arah } \\
\text { atas) }\end{array}$ & 35 & 0.2 & 0.04 & Dari gambar teknik \\
\hline 2 & Assembly-shift & 0 & 1 & 1 & $\begin{array}{c}\text { Assembly-shift karena gaya } \\
\text { gravitasi, lubang terbesar }- \\
\text { pin/silinder terkecil }=10.5-9.5=1 \\
\text { mm }\end{array}$ \\
\hline 3 & $\begin{array}{c}\text { Dimensi vertikal (arah } \\
\text { atas) }\end{array}$ & 35 & 0.2 & 0.04 & Dari gambar teknik \\
\hline & Total jarak A dan B & 70 & & 1.04 & \\
\hline
\end{tabular}

\subsubsection{Analisis toleransi geometri}

Analisis akumulasi toleransi dengan memperhitungkan toleransi geometri (GD\&T) lebih tepat dianalisis dengan metode matriks secara 3D dimana error rotasi juga dapat dikalkulasi dengan metode matriks tersebut (metode matriks akan dijelaskan kemudian). Namun demikian pada bagian ini, analisis akumulasi toleransi geometri (GD\&T) akan dipresentasikan dengan metode $1 \mathrm{D} / 2 \mathrm{D}$.

Dengan memperhitungkan toleransi geometri (GD\&T), maka akumulasi toleransi akhir akan menjadi lebih besar. Hal ini disebabkan karena adanya tambahan toleransi yang diakibatkan dari toleransi geometri, seperti adanya bonus toleransi. Namun demikian, analisis akumulasi toleransi dengan memperhitungakan toleransi geometri lebih merepresentasikan kondisi riil suatu proses manufaktur, sehingga hasil analisis akumulasi toleransi dengan memperhitungkan toleransi geometri akan lebih akurat.

Hal penting yang perlu diingat adalah toleransi geometri adalah toleransi satu sisi, dalam artian nilainya dari 0 sampai dengan nilai toleransi yang diberikan (selalu merupakan nilai positif). Pada tabel akumulasi toleransi, dimensi dari toleransi geometri selalu 0 (seperti assembly-shift). Hal ini disebabkan karena, pada kondisi ideal atau sempurna ketika geomerti semua komponen sempurna, maka nilai toleransi geometri komponen-komponen tersebut akan menjadi 0 . 


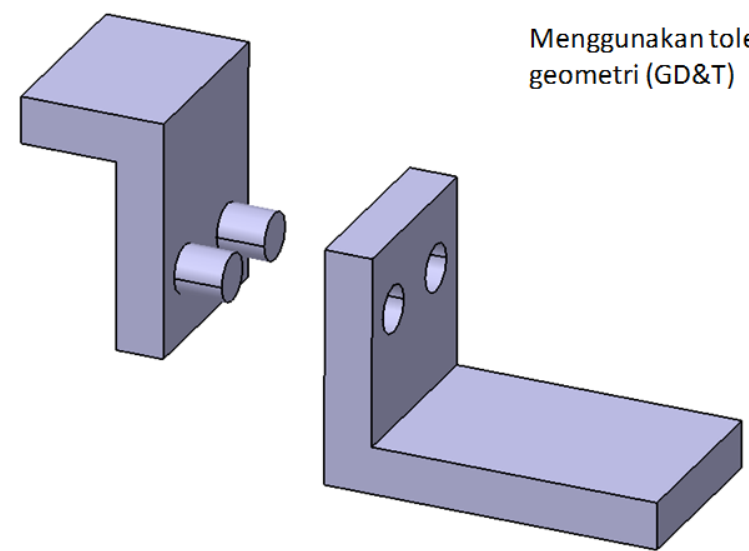

Gambar 31: Contoh kasus dengan dua buah komponen dengan memperhitungkan toleransi geometri (GD\&T).

Gambar 31 memperlihatkan dua buah komponen yang sama sengan contoh sebelumnya, namun pada kasus ini toleransi geometri (GD\&T) juga diperhitungkan. Detil dan nilai dimensi nominal, toleransi dimensional dan toleransi geometri kedua komponen tersebut diperlihatkan pada gambar 32 untuk komponen 1 dan pada gambar 33 untuk komponen 2. Dapat dilihat dari gamabr 32 dan 33, karena toleransi geometri berelasi juag digunakan, maka datumdatum sebagai referensi yang akan membentuk datum reference frame harus didefinisikan terlebih dahulu.

Datum A merupakan datum pertama dan utama sehingga pada umumnya permukaan yang dipilih untuk sebagai datum A adalah permukaan yang paling stabil, yang bisa sebagai permukaan yang paling luas atau permukaan yang paling mudah diakses atau yang bisa dijadikan landasan suatu komponen. Pada komponen 1 (gambar 32), Datum A dipilih yaitu permukaan paling atas dari komponen tersebut dan diberikan toleransi flatness, yaitu toleransi yang tidak berelasi. Datum B dan C dialokasikan pada permukaan-permukaan disamping permukaan datum A. Datum B dan C mempunyai toleransi perpendicularity, yaitu toleransi yang berelasi, yaitu datum B tegak lurus terhadap datum A, dan datum $\mathrm{C}$ tergak lurus terhadap datum B dan tegak lurus terhadap datum A. Semua toleransi geometri berelasi pada komponen ini akan mempunyai referensi pada datum $\mathrm{C}$, B dan A.

\section{Komponen 1}

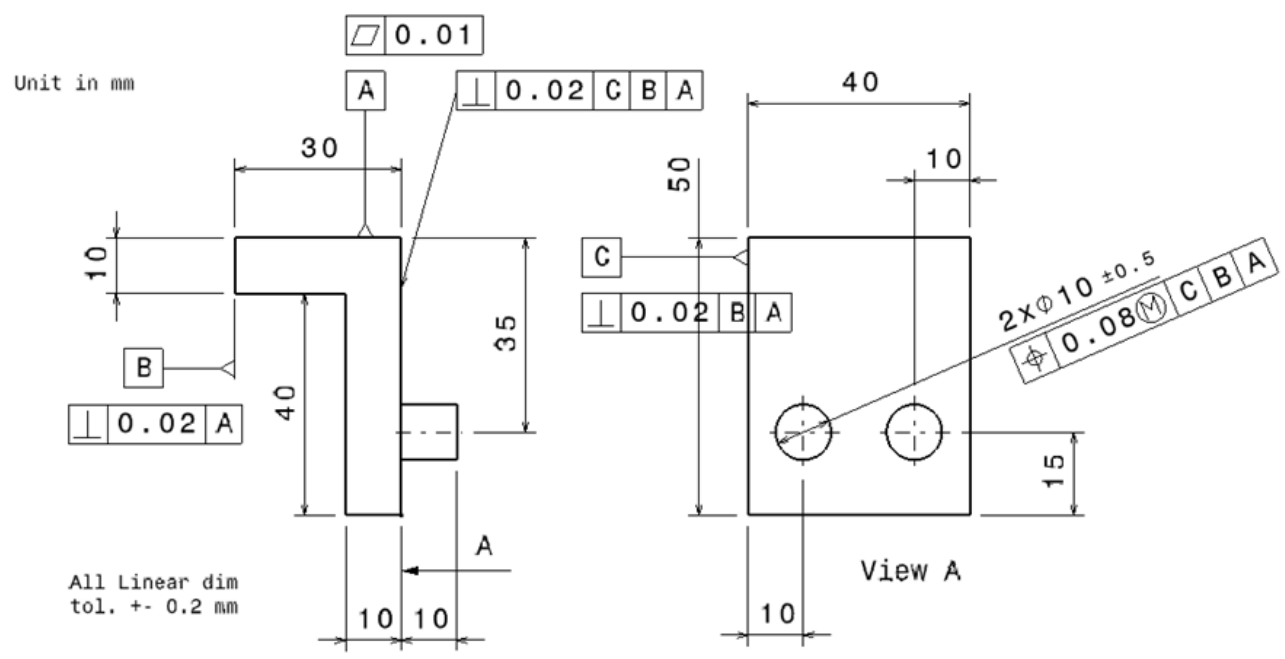

Gambar 32: Dimensi nominal dan toleransi dimensional dan geometri untuk komponen 1. 


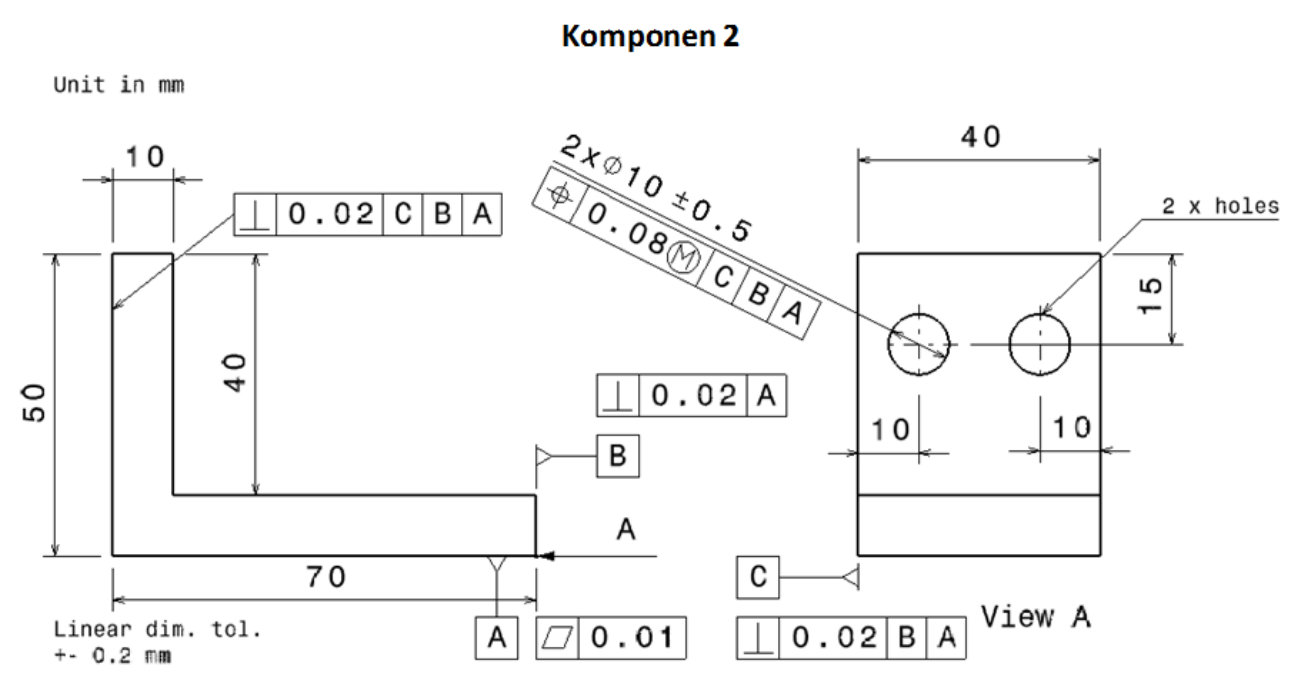

Toleransi lokasi juga mengikutsertakan cylindricity error. Hal inilah yang menyebabkan toleransi lokasi sering digunakan untuk fitur lubang atau pin/poros.

Gambar 33: Dimensi nominal dan toleransi dimensional dan geometri untuk komponen 2.

Pada komponen 2, datum A dialokasikan pada permukaan bawah komponen tersebut karena permukaan tersebut merupaka permukaan yang paling luas dan paling stabil. Kemudian, datum B dan C dialokasikan pada permukaanpermukaan disamping permukaan datum A tersebut. Pengalokasian toleransi untuk datum A, B dan C tersebut sama seperti pengalokasian toleransi geometri untuk datum A, B dan C pada komponen 1. Hal yang perlu diperhatikan adalah datum A, pada komponen 1 dan 2, memiliki nilai tolernasi yang paling kecil, karena datum A harus dibuat seakurat mungkin (lebih akurat dari fitur-fitur lainnya).

\section{Rantaitoleransi (Tolerance stack-up chain)}

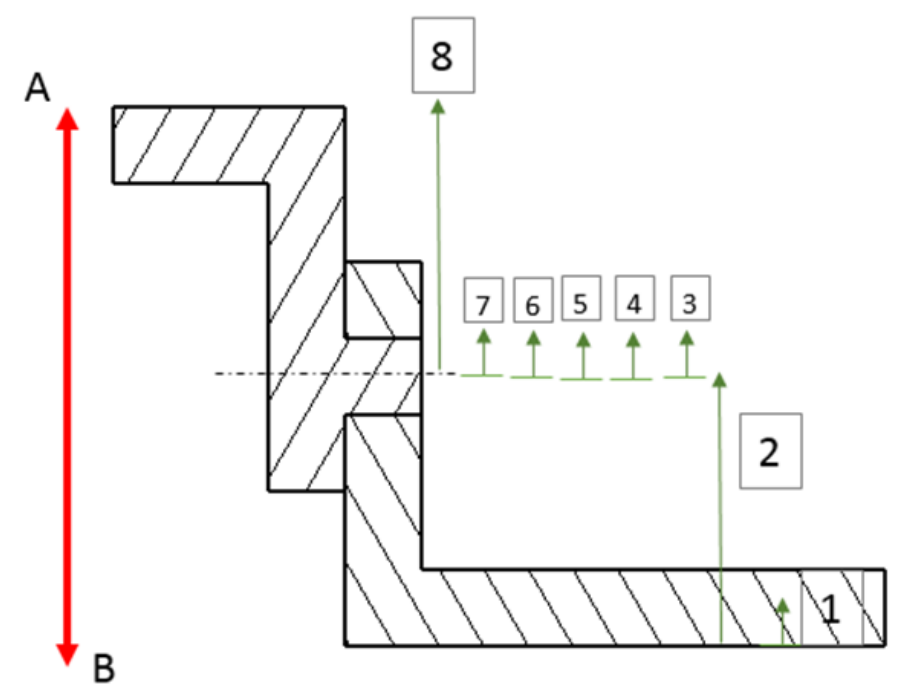

Gambar 34: Rantai toleransi untuk contoh kasus sebuah perakitan produk dengan dua komponen dengan memperhitungkan toleransi geometri (GD\&T). 
Untuk toleransi geometri sebuah fitur lubang atau pin, toleransi lokasi (location tolernace) pada umumnya digunakan dari pada menggunakan toleransi cilindricity. Hal ini disebabkan bahwa toleransi lokasi juga mengontrol bentuk silinder (cilindricity) dari suatu lubang atau pin atau poros, selain juga mengontrol lakasi titik tengah lubang atau pin atau poros tersebut. Sehingga, dengan menggunakan toleransi lokasi, toleransi ini mengontrol posisi dan bentuk silinder secara bersamaan.

Gambar 34 memperlihatkan rantai toleransi untuk contoh kasus dua buah komponen dengan memperhitungkan toleransi geomertri tersebut. dari gambar 34, dapat dilihat bahwa dengan memeperhitungkan toleransi geometri, sumber-sumber variasi akan semakin banyak. Hal ini dapat dilihat pada komponen-komponen variasi pada gambar

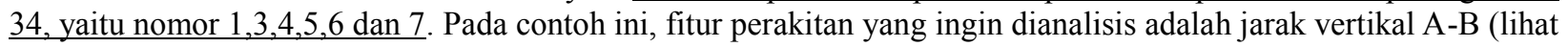
gambar 34).

Tabel 8 memperlihatkan hasil analisis akumulasi toleransi berbasis worst-case dan tabel 9 memperlihatkan hasil analisis berbasis statistik untuk contoh kasus tersebut. Dari tabel 8 dan tabel 9 tersebut, dapat dilihat, selain assembly shift, bonus toleransi juga didapatkan yang diakibatkan suatu fitur lubang atau pin terdeviasi dari nilai MMC-nya. Hasil dari analisis akumulasi toleransi untuk dimensi dan toleransi akhir jarak A-B tersebut (lihat gambar 34) adalah $(70 \pm 2.485) \mathrm{mm}$ dengan kalkulasi berdasarkan metode worst-case. Sedangkan, Hasil dari analisis akumulasi toleransi untuk dimensi dan toleransi akhir jarak A-B tersebut dengan kalkulasi berdasarkan metode statistik adalah $(70 \pm 1.26) \mathrm{mm}$.

Pada contoh kasus ini, dengan kalkulasi worst-case, hasil akhir akumulasi toleransi dengan memperhitungkan toleransi geometri adalah lebih besar $43.6 \%$ daripada hasil kalkulasi worst-case dengan hanya memperhitungkan toleransi dimensional "plus/minus"saja. Sedangkan, dengan kalkulasi statistik, hasil akhir akumulasi toleransi dengan memperhitungkan toleransi geometri adalah lebih besar $17.5 \%$ daripada hasil kalkulasi statistik dengan hanya memperhitungkan toleransi dimensional "plus/minus"saja.

Tabel 8: Analisis akumulasi toleransi berbasis worst-case untuk contoh toleransi geometri.

\begin{tabular}{|c|c|c|c|c|c|}
\hline No & Deskripsi & $\begin{array}{c}\text { Dims } \\
\text { /mm }\end{array}$ & $\begin{array}{c}\text { Tol } \\
\text { /mm }\end{array}$ & Sumber Dim/Tol \& kalkulasi & \% Kontribusi \\
\hline 1 & Flatness & 0 & 0.005 & Error dari flatness $=0.01 / 2=0.005$ & 0.2 \\
\hline 2 & Dimensi & 35 & 0.2 & Dari gambar teknik & 8 \\
\hline 3 & $\begin{array}{c}\text { Toleransi lokasi } \\
\text { (pada komponen 2) }\end{array}$ & 0 & 0.04 & Error dari lokasi $=0.08 / 2=0.04$ & 1.6 \\
\hline 4 & $\begin{array}{c}\text { Bonus toleransi } \\
\text { karena MMC (pada } \\
\text { komponen 2) }\end{array}$ & 0 & 0.5 & (max. diameter-MMC)/2 $=(10.5-9.5) / 2=0.5$ & 20.1 \\
\hline 5 & $\begin{array}{c}\text { Assembly-shift } \\
6\end{array}$ & 0 & 1 & $\begin{array}{c}\text { Assembly-shift karena gaya gravitasi, lubang } \\
\text { terbesar }- \text { silinder terkecil }=10.5-9.5\end{array}$ & 40.2 \\
\hline 7 & $\begin{array}{c}\text { Toleransi lokasi } \\
\text { kada komponen 1) }\end{array}$ & 0 & 0.04 & Error dari lokasi $=0.08 / 2=0.04$ & 20.1 \\
\hline 8 & koma MMC (paderansi & 0 & 0.5 & (max. diameter-MMC)/2 $=(10.5-9.5) / 2=0.5$ & 8 \\
\hline & Total jarak A dan B & 70 & 2.485 & Dari gambar teknik & \\
\hline
\end{tabular}


Tabel 9: Analisis akumulasi toleransi berbasis statistik untuk contoh toleransi geometri.

\begin{tabular}{|c|c|c|c|c|c|}
\hline No & Deskripsi & Dims & Tol & $\begin{array}{c}\text { Squared } \\
\text { Tol. }\end{array}$ & Sumber Dim/Tol \& kalkulasi \\
\hline 1 & Flatness & 0 & 0.005 & 0.000025 & Error dari flatness $=0.01 / 2=0.005$ \\
\hline 2 & Dimensi & 35 & 0.2 & 0.04 & Dari gambar teknik \\
\hline 3 & $\begin{array}{c}\text { Toleransi lokasi (pada } \\
\text { komponen 2) }\end{array}$ & 0 & 0.04 & 0.0016 & Error dari lokasi $=0.08 / 2=0.04$ \\
\hline 4 & $\begin{array}{c}\text { Bonus toleransi karena } \\
\text { MMC (pada komponen 2) }\end{array}$ & 0 & 0.5 & 0.25 & $\begin{array}{c}\text { (max. diameter-MMC)/2 }=(10.5- \\
9.5) / 2=0.5\end{array}$ \\
\hline 5 & $\begin{array}{c}\text { Assembly-shift } \\
\text { Toleransi lokasi (pada } \\
\text { komponen 1) }\end{array}$ & 0 & 1 & 1 & $\begin{array}{c}\text { Assembly-shift } \text { karena gaya gravitasi, } \\
\text { lubang terbesar }- \text { silinder terkecil }= \\
10.5-9.5\end{array}$ \\
\hline 7 & $\begin{array}{c}\text { Bonus toleransi karena } \\
\text { MMC (pada komponen 1) }\end{array}$ & 0 & 0.5 & 0.25 & $\begin{array}{c}\text { (max. diameter-MMC)/2 }=(10.5- \\
9.5) / 2=0.5\end{array}$ \\
\hline 8 & Dimensi & 35 & 0.2 & 0.04 & Dari gambar teknik \\
\hline & Total jarak A dan B & 70 & & 1.26 & 0.0016 \\
\hline
\end{tabular}

\subsubsection{Matriks homogenous dan matriks roto-translasi}

Untuk menganalisis akumulasi toleransi secara 3D dengan menggunakan metode matriks, pemahaman mengenai dasar-dasar matriks harus dimiliki. Maka dari itu, sebelum metode matriks untuk analisis toleransi secara 3D dilakukan, penjelasan mengenai matriks homogenous berukuran $4 \times 4$ dan matriks roto-translasi, akan dipresentasikan. Manfaat utama dari matriks homogenous adalah dua operasi transformasi matriks berupa translasi dan rotasi koordinat titik dapat direpresentasikan dengan sebuah matriks homogenous berukuran $4 \times 4$.

\section{Matriks homogenous.}

Jika matriks M adalah sebuah matriks homogenous (Folley et al 1994), maka:

$$
\mathbf{M}=\left[\begin{array}{llll}
c_{11} & c_{12} & c_{13} & c_{14} \\
c_{21} & c_{22} & c_{23} & c_{24} \\
c_{31} & c_{32} & c_{33} & c_{34} \\
c_{41} & c_{42} & c_{43} & k
\end{array}\right]
$$

dimana $c_{i j}$ adalah element matriks ke- $i, j$ dan $k$ adalah sebuah konstanta yang merupakana skala dari elemen-elemen matriks tersebut. Pada umumnya, seluruh nilai elemen matriks $\mathbf{M}$ dibagi dengan nilai $k$ tersebut, sehingga nilai $k$ pada element terakhir matriks $\mathbf{M}$ tersebut menjadi 1.

Dalam sistem kalkulasi transformasi koordinat suatu titik $P$ dengan menggunakan matriks homogenous, titik $P$ tersebut juga harus direpresnetasikan dalam bentuk koordinate homogenous, yaitu: 


$$
\mathbf{P}=\left[\begin{array}{l}
x \\
y \\
z \\
1
\end{array}\right]
$$

\section{Matriks rotasi dan translasi.}

Matriks transformasi translasi $\operatorname{Tr}$ dari sebuah koordinat titik adalah sebagai berikut:

$$
\mathbf{T r}=\left[\begin{array}{cccc}
1 & 0 & 0 & t_{x} \\
0 & 1 & 0 & t_{y} \\
0 & 0 & 1 & t_{z} \\
0 & 0 & 0 & 1
\end{array}\right]
$$

dimana $t_{x}$ adalah translasi searah sumbu $-x, t_{y}$ adalah translasi searah sumbu - $y$ dan $t_{z}$ adalah translasi searah sumbu $-z$.

Matriks transformasi rotasi terhadap sumbu $x, y$ dan $z$ direpresentasikan dengan simbol $R_{x}$ untuk rotasi terhadap sumbu $x, R_{y}$ untuk rotasi terhadap sumbu $y$ dan $R_{z}$ untuk rotasi terhadap sumbu $z$. Matriks rotasi $R_{x}, R_{y}$ dan $R_{z}$ dari sebuah titik adalah sebagai berikut:

$$
\begin{aligned}
\mathbf{R}_{\mathbf{x}} & =\left[\begin{array}{cccc}
1 & 0 & 0 & 0 \\
0 & \cos \theta_{x} & -\sin \theta_{x} & 0 \\
0 & \sin \theta_{x} & \cos \theta_{x} & 0 \\
0 & 0 & 0 & 1
\end{array}\right] \\
\mathbf{R}_{\mathbf{y}} & =\left[\begin{array}{cccc}
\cos \theta_{y} & 0 & -\sin \theta_{y} & 0 \\
0 & 1 & 0 & 0 \\
\sin \theta_{y} & 0 & \cos \theta_{y} & 0 \\
0 & 0 & 0 & 1
\end{array}\right] \\
\mathbf{R}_{\mathbf{z}} & =\left[\begin{array}{cccc}
\cos \theta_{z} & -\sin \theta_{z} & 0 & 0 \\
\sin \theta_{z} & \cos \theta_{z} & 0 & 0 \\
0 & 0 & 1 & 0 \\
0 & 0 & 0 & 1
\end{array}\right]
\end{aligned}
$$

dimana $\theta_{i}$ adalah besar sudut putaran terhadap sumbu ke $-i$.

\section{Matriks roto-translasi.}

Matriks roto-translasi adalah sebuah matriks yang merepresentasikan transformasi translasi dan rotasi dari sebuah titik terhadap suatu sumbu putaran. Matriks roto-translasi tersebut digunakan untuk merepresentasikan variasi atau error geometrik suatu fitur karena nilai toleransinya (Whitney 2004). Sering kali, matriks roto-translasi tersebut disebut sebagai matriks error.

Matriks error berupa matriks roto-translasi dari kordinat $i$ ke koordinat $j$ disimbolkan sebagai $\mathbf{T}_{\mathbf{i j}}$. Matriks berisi error karena rotasi dan translasi pada suatu fitur karena suatu nilai toleransi yang dialokasikan kepada fitur tersebut. Matriks $\mathbf{T}_{\mathbf{i j}}$ adalah sebagai berikut: 


$$
\mathbf{T}_{\mathbf{i j}}=\left[\begin{array}{cc}
\mathbf{R o t} & \mathbf{T r a n s} \\
0 & 1
\end{array}\right]=\left[\begin{array}{cccc}
1 & d \theta_{z} & d \theta_{y} & d_{x} \\
d \theta_{z} & 1 & d \theta_{x} & d_{y} \\
-d \theta_{y} & d \theta_{x} & 1 & d_{z} \\
0 & 0 & 0 & 1
\end{array}\right]
$$

dimana Rot adalah dan Trans adalah. $d_{i}$ adalah komponen translasi searah axis $i$ pada matriks Trans. $d \theta_{i}$ adalah komponen rotasi terhadap sumbu $i$ (dalam radian) pada matriks Rot.

Matriks error $\mathbf{T}_{\mathbf{i j}}$ pada persamaan (13) tidak mempunyai elemen sin dan cos. Hal ini disebabkan karena elemenelemen pada matriks $\mathbf{T}_{\mathbf{i j}}$ merepresentasikan error yang secara umum diasumsikan mempunyai nilai yang sangat kecil. Sehingga, untuk sudut yang sangat kecil $(<0.3$ radian) nilai sin-nya mendekati nilai sudutnya (dalam radian) dan nilai cos-nya mendekati 1 . Hal ini dapat dijelaskan dengan proses limit dalam matematik, yaitu:

$$
\begin{aligned}
& \lim _{d \theta \rightarrow 0} \sin d \theta=d \theta \\
& \lim _{d \theta \rightarrow 0} \cos d \theta=1
\end{aligned}
$$

Matriks roto-translasi yang memiliki dua komponen transformasi (translasi dan rotasi) beroperasi sebagai berikut. Matriks roto-translasi tersebut pertama-tama melakukan translasi suatu kooridnat $P$ terlebih dahulu, kemudian melakukan rotasi pada koordinat $P$ tersebut.

\subsubsection{Transformasi matriks}

Selain konsep matrik homogenous, konsep transformasi matriks juga harus dipahami untuk mengimplementasikan metode matriks untuk analisis akumulasi toleransi secara 3D. Dengan merujuk pada matriks roto-translasi $\mathbf{T}_{\mathbf{i j}}$ sebelumnya yang merepresnetasikan transformasi dari suatu koordinat $i$ ke koordinat $j$, maka konvensi simbol untuk merepresentasikan suatu titik $P$ dan proses transformasinya adalah sebagai berikut:

- $\quad P_{i}$ merepresentasikan suatu titik $P$ yang merujuk pada sistem koordinat $i$.

- $\quad P_{j}$ merepresentasikan suatu titik $P$ tersebut yang merujuk pada sistem koordinat $j$.

- $\quad \mathbf{T}_{\mathbf{i j}}$ adalah transformasi koordinat dari sistem koordinat $i$ ke sistem koordinat $j$.

- Representasi matematik yang memodelkan adalah:

$$
P_{i}=\mathbf{T}_{\mathbf{i j}} \cdot P_{j}
$$

Persamaan (16) tersebut diartikan sebagai berikut: suatu titik $P$ yang merujuk pada koordinat $i$ adalah hasil transformasi titik $P$ yang merujuk pada koordinat $j$ oleh suatu matriks transformasi $\mathbf{T}_{\mathbf{i j}}$ dari koordinat $i$ ke $j$. Untuk mendapatkan titik $P$ yang merujuk pada koordinat $j, P_{j}$, maka:

$$
P_{j}=\mathbf{T}_{\mathbf{i j}}^{-1} \cdot P_{i}
$$

dimana $\mathbf{T}_{\mathbf{i j}}^{-\mathbf{1}}=\boldsymbol{T}_{\boldsymbol{j i}}$. Untuk memudahkan penghitungan transformasi koordinat, maka indeks dari titip $P$ dan matriks tersebut dapat digunakan sebagai pedoman. Matriks transformasi yang menggambarkan variasi suatu fitur ke- $i$ adalah: 


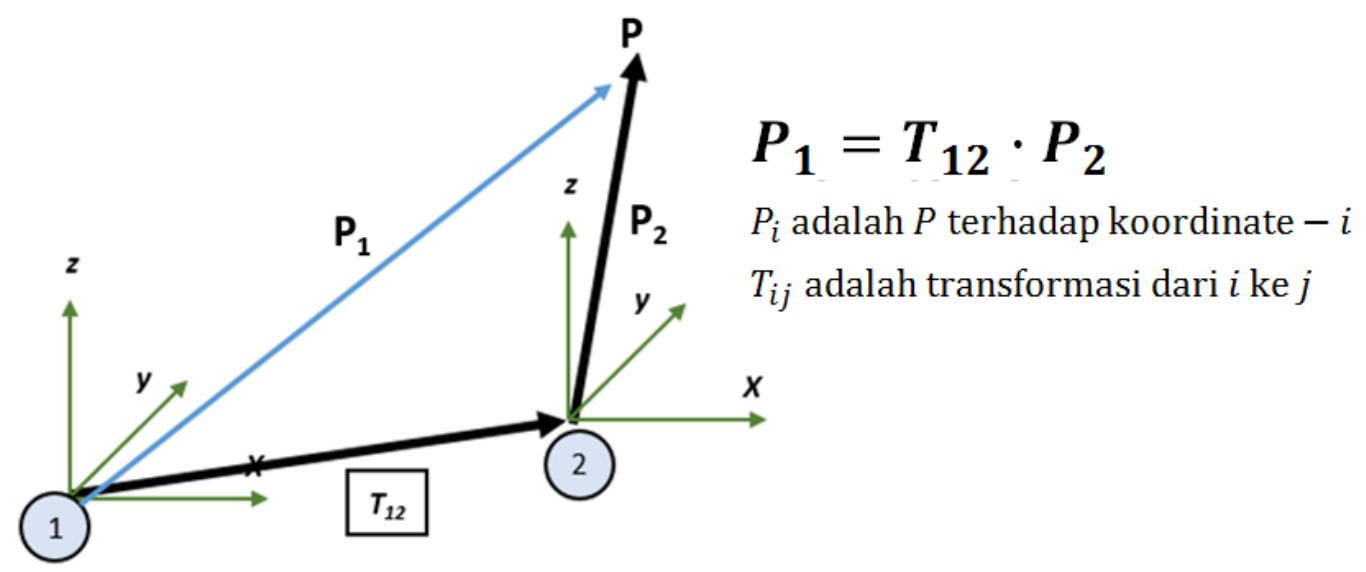

Gambar 35: Ilustrasi dari sebuah transformasi koordinat dari sistem koordinat 1 ke 2.

Gambar 35 memperlihatkan penjelasan mengenai transformasi koordinat suatu titik. Pada gambar 35, titik $P_{1}$ adalah suatu titik yang merujuk atau mempunyai asal pada pusat koordinat 1 . Sedangkan, $P_{2}$ adalah suatu titik yang merujuk pada pusat koordinat 2. Representasi matematik dari transformasi titik $\mathrm{P}$ tersebut adalah $P_{1}=\mathbf{T}_{12} \cdot P_{2}$. Dan sebaliknya, apabila titik $P$ yang merujuk ke sistem koordinat 2, maka titik $P_{2}$ didapatkan dengan mengalikan inverse matriks $\mathbf{T}_{12}$ dengan $P_{1}$, yaitu $P_{2}=\mathbf{T}_{12}^{-1} \cdot P_{1}$.

\subsubsection{Analisis 3D toleransi geometri}

Metode analisis akumulasi toleransi (tolerance stack-up analysis) dengan metode matriks merupakan sebuah metode yang sangat berguna dan sangat kuat. Dengan metode matriks ini, analisis toleransi dapat dilakukan secara 3D dan seluruh tipe error, yaitu error linier dan rotasional, dapat diikutsertakan dan dianalisis.

Metode matriks untuk analisis toleransi 3D adalah sebagai berikut:

- Sebuah metode analisis toleransi yang digunakan untuk merepresentasikan akumulasi toleransi dengan rantai transformasi koordinat.

- Koordinat transformasi tersebut, yang merepresentasikan perambatan toleransi secara nilai dimensi nominal dan nilai variasinya, direpresentasikan sebagai sebuah matriks homogenous $4 \times 4$. Matriks tersebut adalah sebuak matriks roto-translasi.

- Dengan metode matriks, analisis akumulasi toleransi akan lebih akurat karena metode tersebut memperhitungkan juga variasi rotasioanal setiap fiturnya (analisis 3D).

Ilustrasi rantai toleransi nominal dan variasi yang dipresentasikan dengan transformasi koordinatnya diperlihatkan pada gambar 36. Pada gambar 36 (kiri), rantai toleransi nominal mengikuti dimensi nominal setipa fitur yang dilalui oleh ratai toleransinya. Sedangkan pada gambar 3 (kanan), karena ada variasi pada setiap fiturnya sesuai dengan nilai toleransinya, maka ketika suatu koordinat transformasi mencapai suatu fitur, maka koordinate tersebut memiliki tambahan transformasi yang menggambarkan variasi dari fitur tersebut.

Penjelasan lebih detil mengenai transformasi variasi tersebut adalah sebagai berikut. Pada gambar 36 (kanan), matriks $\mathbf{T}_{\mathbf{1 2}}$ mengtransformasikan sistem koordinat 1 (pada fitur 1) ke sistem koordinat 2 (pada fitur 2). Karena ada variasi dalam fitur 2 (direpresentasikan dengan nilai dan jenis toleransi yang dialokasikan kepadanya), maka ada transformasi tambahan yang mengambarkan variasi pada fitur 2 , yaitu $\mathbf{T}_{\mathbf{2 2}}$. Dan seterusnya, yaitu ketika transformasi $\mathbf{T}_{23}$ mencapai fitur 3, maka karena ada toleransi pada fitur tersebut, maka ada tambahan transformasi yaitu $\mathbf{T}_{\mathbf{3 3}^{\prime}}$. Dan seterusnya sampai pada transformasi ke fitur yang terakhir pada rantai toleransi tersebut. Hal penting yang perlu diingat adalah pergeseran karena transformasi $\mathbf{T}_{i i^{\prime}}$ variasi adalah sangat kecil. 

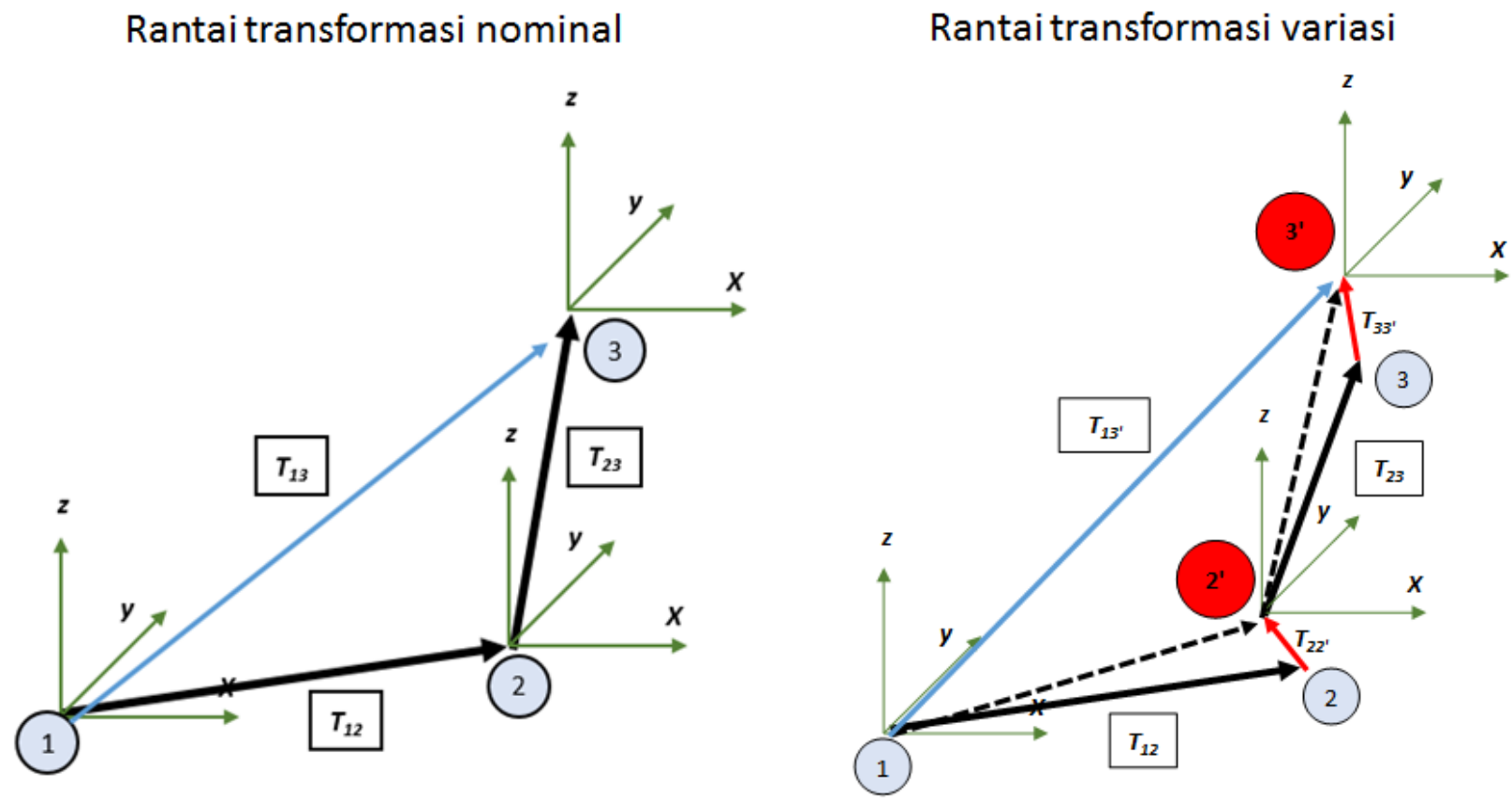

Gambar 36: Ilustrasi perbedaan antara rantai transformasi nominal (kiri) dan rantai transformasi variasi (kanan).

\section{Contoh kasus:}

Untuk contoh kasus analisis akumulasi toleransi 3D dengan metode matriks, produk yang sama dengan dua buah komponen, yang dirakit bersamaan, digunakan lagi. Detil produk tersebut dan gambar tekniknya yang digunakan untuk contoh kasus ini dapat dilihat pada gambar 31 (untuk gambar produk tersebut), dan gambar 32 dan gambar 33 (untuk gambar tekniknya). Fitur perakitan yang akan dianalisis adalah jarak vertikal dari A ke B yang dapat dilihat pada gambar 37.

Ratai toleransi 3D untuk analisis akumulasi toleransi kasus ini diperlihatkan pada gambar 37. Pada gambar 37, rantai toleransi mempunyai representasi yang lebih kompleks karena rantai toleransi tersebut menjelaskan perambatan toleransi secara 3D. Hal penting yang perlu dingat adalah dalam menentukan suatu rantai toleransi sebuah produk, yang memiliki dua buah atau lebih komponen, rantai toleransi tersebuh harus melewati seluruh fitur yang berfungsi untuk menyambungkan komponen-komponen tersebut. Proses untuk menentukan rantai toleransi adalah suatu proses yang bersifat ilmu pengetahuan dan juga bersifat seni. Karena, akan ada berbagai macam piliha rantai toleransi. Sehingga, penentuan rantai toleransi yang paling tepat harus mengikuti bagaimana produk itu akan berfungsi pada prakteknya atau kondisi riil nantinya.

Setelah rantai toleransi ditentukan, maka ada dua model transformasi matriks yang harus direkonstruksi berdasarkan rantai toleransi yang telah ditentukan tersebut, yaitu untuk rantai toleransi nominal dan untuk rantai toleransi variasi.

Rantai transformasi nominal (nominal transformation chain) adalah:

$$
\mathrm{T}_{1.12}=\mathrm{T}_{1.2} \cdot \mathrm{T}_{2.3} \cdot \mathrm{T}_{3.4} \cdot \mathrm{T}_{4.5} \cdot \mathrm{T}_{5.6} \cdot \mathrm{T}_{6.7} \cdot \mathrm{T}_{7.8} \cdot \mathrm{T}_{8.9} \cdot \mathrm{T}_{\mathbf{9 . 1 0}} \cdot \mathrm{T}_{10.11} \cdot \mathrm{T}_{11.12}
$$

dimana elemen-elemen dari matriks-matriks homogenous tersebut terdiri dari $d_{x}, d_{y}, d_{z}, d \theta_{x}, d \theta_{y}, d \theta_{z}$. Untuk lebih jelasnya bagaimana menentukan nilai-nilai varianel tersebut pada setiap matriksnya, representasi dengan menggunakan sebuah tabel digunakan. 


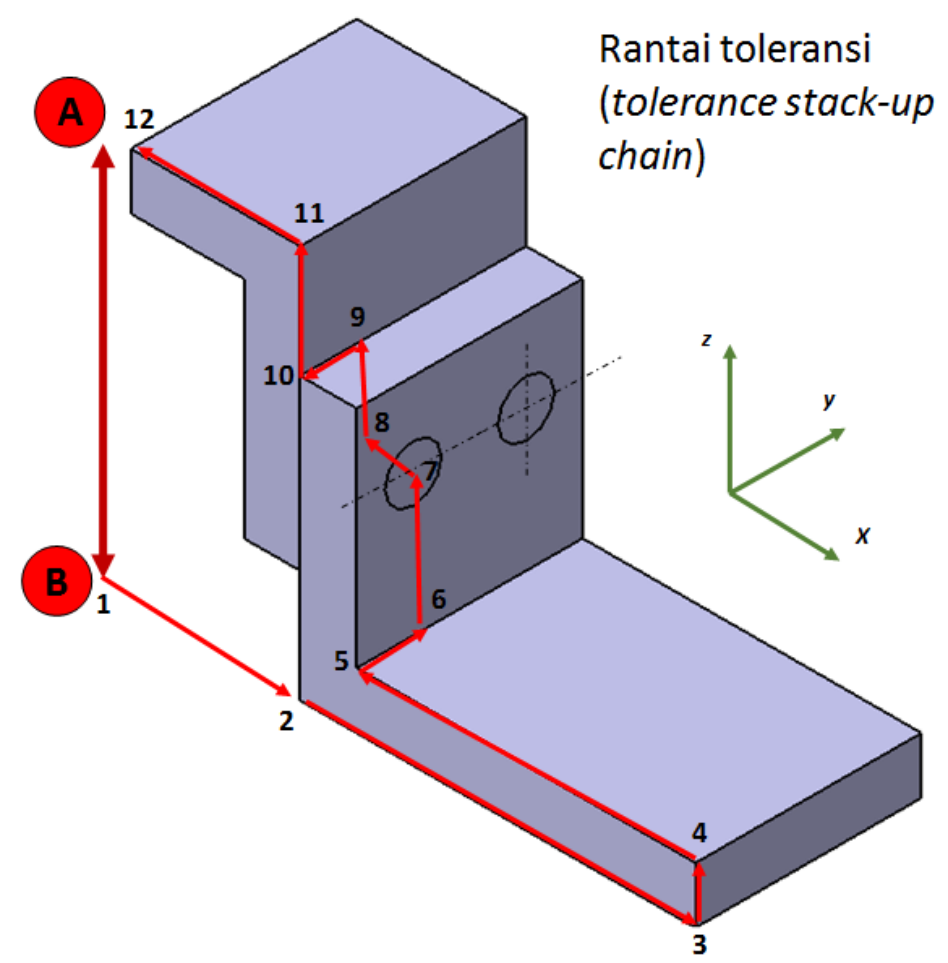

Gambar 37: Rantai toleransi untuk contoh kasus dengan dua buah komponen.

Tabel 10 memperlihatkan dengan detil bagaimana cara untuk menentukan nilai elemen-elemen matriks transformasi untuk rantai toleransi nominal tersebut. Pada tabel 10, setiap barisnya menggambarkan jenis transformasi dari satu sistem koordinat (suatu fitur) ke sistem koordinat lainnya (fitur lainnya) dan menjelaskan juga niai setiap elemen $d_{x}, d_{y}, d_{z}, d \theta_{x}, d \theta_{y}, d \theta_{z}$ untuk setiap matriks transformasinya.

Setelah seluruh nilai elemen matriks transformasi pada rantai toleransi nominal tersebut terlah ditentukan, maka seluruh matriks transformasi tersebut dikalikan sehingga menghasilkan suatu matriks yang mempunyai nilai-nilai elemen matriksnya yang merupakan hasil perkalian tersebut. Hasil dari perkalian matriks pada rantai transformasi nominal tersebut diperlihatkan pada gambar 38. Pada gambar 38, dari hasil kalkulasi rantai transformasi nominal tersebut, dihasilkan sebuah matriks $\mathbf{T}_{\mathbf{1 . 1 2}}$ hasil yang juga berukuran $4 \times 4$ dimana, pada matriks ini kita mempunyai semua informasi mengenai jarak A ke B dan orientasi dari jarak A ke B.

Pada gambar 38, jarak nominal A ke B adalah $70 \mathrm{~mm}$, yang merupakan elemen ke $(3,4)$ dari matriks $\mathbf{T}_{\mathbf{1 . 1 2}}$. elemen ke $(1,4)$ dan $(2,4)$ merupakan informasi jarak searah sumbu $X$ dan $Y$. Dan, elemen ke $(1,2),(1,3),(2,1),(2,3)$, $(3,1)$ dan $(3,2)$ dari matriks tersebut merupakan nilai rotasi dari jarak A ke B, dalam hal ini orinetasi dari jarak tersebut.

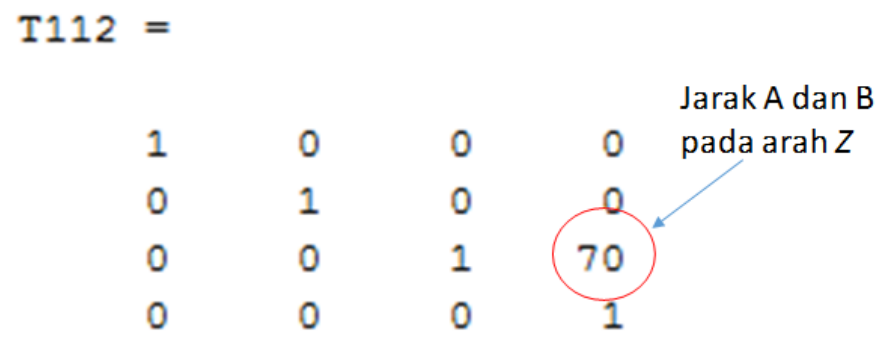

Gambar 38: Matriks akhis hasil dari perkalian matriks transformasi untuk rantai toleransi nominal. 
Tabel 10: Rantai transformasi nominal.

\begin{tabular}{|c|c|c|c|c|c|c|c|c|}
\hline \multirow{3}{*}{$\begin{array}{c}\text { Urutan } \\
\text { perambatan } \\
\text { toleransi }\end{array}$} & \multirow{3}{*}{ Deskripsi } & \multicolumn{6}{|c|}{ matriks Roto-translation } & \multirow{3}{*}{$\begin{array}{c}\text { Sumber dan } \\
\text { kalkulasi } \\
\text { Dim/Tol }\end{array}$} \\
\hline & & \multicolumn{3}{|c|}{ Translasi (nilai max) } & \multicolumn{3}{|c|}{ Rotasi (nilai max.) } & \\
\hline & & $d_{x}$ & $d_{y}$ & $d_{z}$ & $d \theta_{x}$ & $d \theta_{y}$ & $d \theta_{z}$ & \\
\hline 12 & $\begin{array}{l}\text { Dimensi } \\
\text { nominal }\end{array}$ & 30 & 0 & 0 & 0 & 0 & 0 & $\begin{array}{c}\text { Dari gambar } \\
\text { teknik }\end{array}$ \\
\hline 23 & $\begin{array}{l}\text { Dimensi } \\
\text { nominal }\end{array}$ & 70 & 0 & 0 & 0 & 0 & 0 & $\begin{array}{c}\text { Dari gambar } \\
\text { teknik }\end{array}$ \\
\hline 34 & $\begin{array}{l}\text { Dimensi } \\
\text { nominal }\end{array}$ & 0 & 0 & 10 & 0 & 0 & 0 & $\begin{array}{c}\text { Dari gambar } \\
\text { teknik }\end{array}$ \\
\hline 45 & $\begin{array}{l}\text { Dimensi } \\
\text { nominal }\end{array}$ & -60 & 0 & 0 & 0 & 0 & 0 & $\begin{array}{c}\text { Dari gambar } \\
\text { teknik }\end{array}$ \\
\hline 56 & $\begin{array}{l}\text { Dimensi } \\
\text { nominal }\end{array}$ & 0 & 10 & 0 & 0 & 0 & 0 & $\begin{array}{c}\text { Dari gambar } \\
\text { teknik }\end{array}$ \\
\hline 67 & $\begin{array}{l}\text { Dimensi } \\
\text { nominal }\end{array}$ & 0 & 0 & 25 & 0 & 0 & 0 & $\begin{array}{c}\text { Dari gambar } \\
\text { teknik }\end{array}$ \\
\hline 78 & $\begin{array}{l}\text { Dimensi } \\
\text { nominal }\end{array}$ & -10 & 0 & 0 & 0 & 0 & 0 & $\begin{array}{c}\text { Dari gambar } \\
\text { teknik }\end{array}$ \\
\hline 89 & $\begin{array}{l}\text { Dimensi } \\
\text { nominal }\end{array}$ & 0 & 0 & 15 & 0 & 0 & 0 & $\begin{array}{c}\text { Dari gambar } \\
\text { teknik }\end{array}$ \\
\hline 910 & $\begin{array}{l}\text { Dimensi } \\
\text { nominal }\end{array}$ & 0 & -10 & 0 & 0 & 0 & 0 & $\begin{array}{c}\text { Dari gambar } \\
\text { teknik }\end{array}$ \\
\hline 1011 & $\begin{array}{l}\text { Dimensi } \\
\text { nominal }\end{array}$ & 0 & 0 & 20 & 0 & 0 & 0 & $\begin{array}{c}\text { Dari gambar } \\
\text { teknik }\end{array}$ \\
\hline 1112 & $\begin{array}{l}\text { Dimensi } \\
\text { nominal }\end{array}$ & -30 & 0 & 0 & 0 & 0 & 0 & $\begin{array}{c}\text { Dari gambar } \\
\text { teknik }\end{array}$ \\
\hline
\end{tabular}

Perhitungan rantai toleransi nominal adalah untuk memverifikasi apakah desain dari rantai toleransi yang kita disain sudah benar atau tidak. Apabila hasil dari perhitungan rantai toleransi nominal memberikan hasil yang sesuai dengan yang kita harapkan pada suatu fitur yang ingin dianalisis, maka disain dari rantai toleransi yang kita buat sudah benar.

Langkah selanjutnya adalah merekonstruksi model transformasi dari rantai toleransi variasi dari rantai toleransi yang telah didisain sebelumnya. Rantai transformasi variasi (variance transformation chain) adalah:

$$
\begin{aligned}
& \mathbf{T}_{1.12}=\mathbf{T}_{1.2} \cdot \mathbf{T}_{2.2^{\prime}} \cdot \mathbf{T}_{2.3} \cdot \mathbf{T}_{3.3^{\prime}} \cdot \mathbf{T}_{3.4} \cdot \mathbf{T}_{4.4^{\prime}} \cdot \mathbf{T}_{4.5} \cdot \mathbf{T}_{5.5^{\prime}} \cdot \mathbf{T}_{5.6} \cdot \mathbf{T}_{6.6^{\prime}} \cdot \mathbf{T}_{6.7} \cdot \mathbf{T}_{7.7^{\prime}} \cdot \mathbf{T}_{7.8} \cdot \\
& \mathrm{T}_{8.8^{\prime}} \cdot \mathrm{T}_{8.9} \cdot \mathrm{T}_{9.9^{\prime}} \cdot \mathrm{T}_{\mathbf{9 . 1 0}} \cdot \mathrm{T}_{10.10^{\prime}} \cdot \mathrm{T}_{10.11} \cdot \mathrm{T}_{11.11} \cdot \mathrm{T}_{11.12} \cdot \mathrm{T}_{12.12}
\end{aligned}
$$

dimana elemen-elemen dari matriks-matriks homogenous tersebut terdiri dari $d_{x}, d_{y}, d_{z}, d \theta_{x}, d \theta_{y}, d \theta_{z}$. Representasi dengan menggunakan sebuah tabel digunakan untuk menjelaskan nilai setiap elemen matriks transformasi tersebut.

Tabel 11 memperlihatkan detil bagaimana cara menentukan elemen-elemen matriks transformasi untuk rantai toleransi variasi. Setiap baris pada tabel 11 memperlihatkan jenis transformasi (nominal atau variasi), elemen-elemen matriks transformasi tersebut dan penjelasannya. Setiap baris yang menunjukkan transformasi nominal diikuti baris yang menunjukkan transformasi variasinya. Hal yang perlu diperhatikan adalah nilai elemen-elemen matriks nominal 
jauh lebih besar dari nilai variasinya dan elemen-elemen $d \theta_{x}, d \theta_{y}, d \theta_{z}$ adalah dalam satuan radian.

Untuk matriks-matriks trasformasi variasi (tabel 11), misalnya $22^{\prime}, 33^{\prime}, \ldots$, dan $1212^{\prime}$, elemen-elemen $d_{x}, d_{y}$ $\underline{d}_{z}$ pada umumnya berasal dari nilai toleransi dimensional fitur-fitur tersebut atau bonus toleransi. Sedangkan, elemen-elemen $d \theta_{x}, d \theta_{y}, d \theta_{z}$ membutuhkan suatu kalkulasi yang berhubungan dengan ukuran dimensi fitur-fitur tersebut. Pada umumnya, nilai $d \theta_{x}, d \theta_{y}, d \theta_{z}$ adalah 0 untuk matriks transformasi nominal.

Penjelasan detil mengenai cara menentukan nilai dari elemen-elemen $d \theta_{x}, d \theta_{y}, d \theta_{z}$ adalah sebagai berikut. Pada prinsipnya, penentuan dari nilai $d \theta_{x}, d \theta_{y}, d \theta_{z}$ adalah dengan menentukan zona toleransi geometri terbesar suatu toleransi geometri pada suatu fitur (zona toleransi tersebut dapat berupa silinder atau dua bidang datar sejajar). Untuk lebih jelasnya, perhatikan gambar 39. Untuk zona tolernasi berupa dua bidang sejajar, nilai $d \theta_{i}$ adalah besarnya zona toleransi dibagi dengan panjang atau lebar permukaan suatu fitur. Sedangkan untuk zona toleransi berupa silinder, nilai $d \theta_{i}$ adalah besarnya zona toleransi dibagi dengan tinggi suatu fitur silinder. Untuk mengikuti format equal bilateral, maka nilai $d \theta_{i}$ yang terkalkulasi dibagi 2.
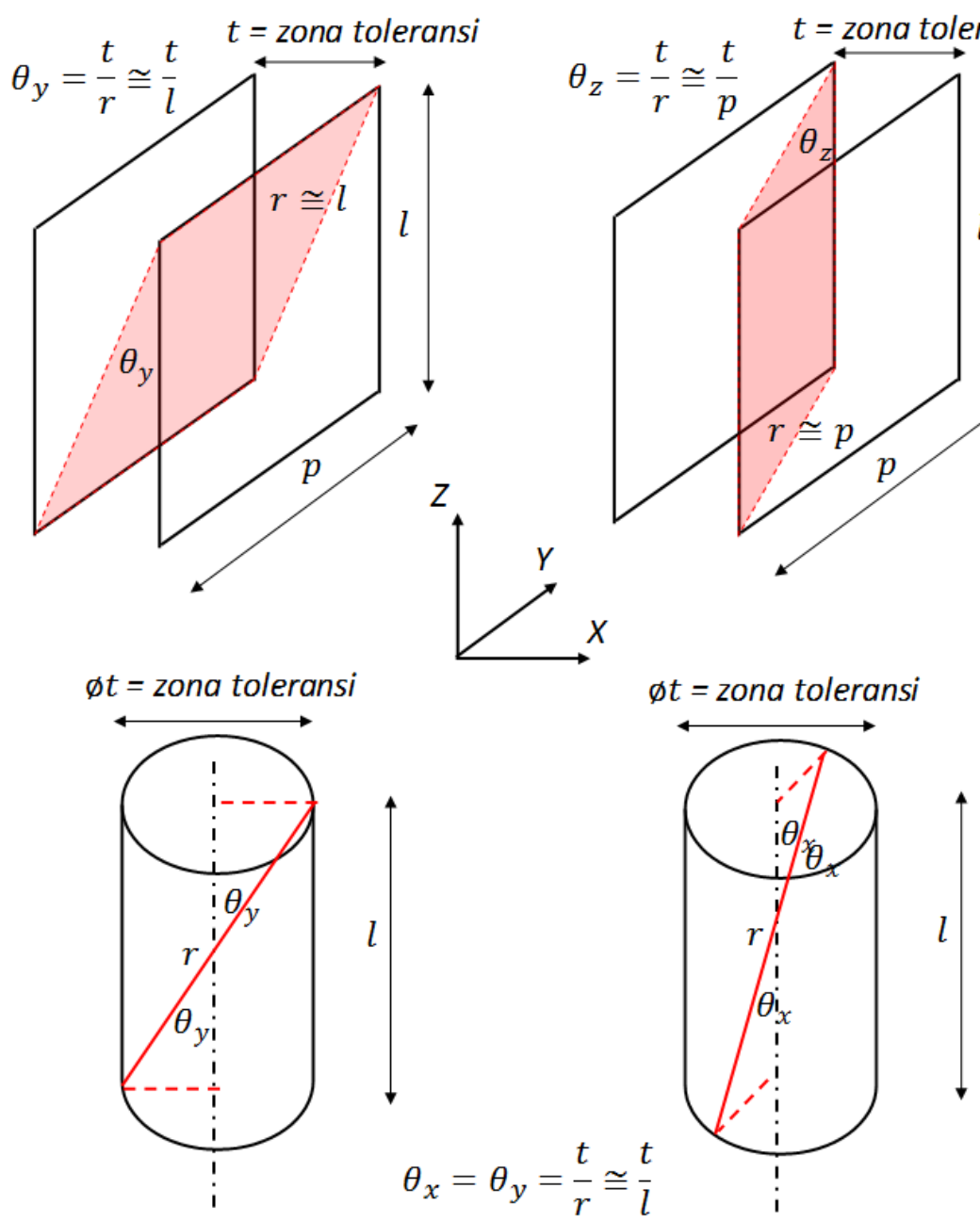

Gambar 39: Cara menentukan besarnya nilai $d \theta_{x}, d \theta_{y}, d \theta_{z}$ dari suatu toleransi geometri. 
Tabel 11: Rantai transformasi variasi.

\begin{tabular}{|c|c|c|c|c|c|c|c|c|}
\hline \multirow{2}{*}{$\begin{array}{c}\text { Urutan } \\
\text { perambatan } \\
\text { toleransi }\end{array}$} & \multirow{2}{*}{ Deskripsi } & \multicolumn{3}{|c|}{$\begin{array}{l}\text { Translasi (nilai } \\
\text { max) }\end{array}$} & \multicolumn{3}{|c|}{$\begin{array}{l}\text { Rotasi (nilai max.) dalam } \\
\text { radian }\end{array}$} & \multirow{2}{*}{$\begin{array}{c}\text { Sumber dan } \\
\text { kalkulasi Dim/Tol }\end{array}$} \\
\hline & & $d_{x}$ & $d_{y}$ & $d_{z}$ & $d \theta_{x}$ & $d \theta_{y}$ & $d \theta_{z}$ & \\
\hline 12 & $\begin{array}{l}\text { Dimensi } \\
\text { nominal }\end{array}$ & 30 & 0 & 0 & 0 & 0 & 0 & Dari gambar teknik \\
\hline $22^{\prime}$ & $\begin{array}{c}\text { Toleransi } \\
\text { dimensional } \\
+ \\
\text { perpendicula } \\
\text { rity }\end{array}$ & 0.2 & 0 & 0 & 0 & 0.0002 & 0.0003 & $\begin{array}{l}\mathrm{dx} \text { dari toleransi di } \\
\text { gambar } \pm 0.2, \\
\mathrm{~d} \theta \mathrm{y}=(0.02 / 50) / 2= \\
2 \times 10^{-4}, \\
\mathrm{~d} \theta \mathrm{z}=(0.02 / 40) / 2=2.5 \\
\times 10^{-4} . \text { dibagi } 2 \text { untuk } \\
\text { mendapatkan } \pm \\
\text { (toleransi equal- } \\
\text { bilateral). }\end{array}$ \\
\hline 23 & $\begin{array}{l}\text { Dimensi } \\
\text { nominal }\end{array}$ & 70 & 0 & 0 & 0 & 0 & 0 & Dari gambar teknik \\
\hline $33^{\prime}$ & $\begin{array}{c}\text { Toleransi } \\
\text { dimensional } \\
+ \\
\text { perpendicula } \\
\text { rity }\end{array}$ & 0.2 & 0 & 0 & 0 & 0.001 & 0.0003 & $\begin{array}{l}\text { Lihat } 22^{\prime} \text { (kecuali } \\
\text { perubahan pada } \\
\text { denominator) }\end{array}$ \\
\hline 34 & $\begin{array}{l}\text { Dimensi } \\
\text { nominal }\end{array}$ & 0 & 0 & 10 & 0 & 0 & 0 & Dari gambar teknik \\
\hline $44^{\prime}$ & $\begin{array}{c}\text { Toleransi } \\
\text { dimensional }\end{array}$ & 0 & 0 & 0.2 & 0 & 0 & 0 & $\begin{array}{l}\text { dz dari gambar } \\
\text { teknik. Tidak ada } \\
\text { toleransi geometri. }\end{array}$ \\
\hline 45 & $\begin{array}{l}\text { Dimensi } \\
\text { nominal }\end{array}$ & -60 & 0 & 0 & 0 & 0 & 0 & Dari gambar teknik \\
\hline $55^{\prime}$ & $\begin{array}{c}\text { Toleransi } \\
\text { dimensional }\end{array}$ & 0.2 & 0 & 0 & 0 & 0 & 0 & $\begin{array}{l}\text { dx dari gambar } \\
\text { teknik. Tidak ada } \\
\text { toleransi geometri. }\end{array}$ \\
\hline 56 & $\begin{array}{l}\text { Dimensi } \\
\text { nominal }\end{array}$ & 0 & 10 & 0 & 0 & 0 & 0 & Dari gambar teknik \\
\hline $66^{\prime}$ & $\begin{array}{l}\text { Tidak ada } \\
\text { toleransi }\end{array}$ & 0 & 0 & 0 & 0 & 0 & 0 & - \\
\hline 67 & $\begin{array}{l}\text { Dimensi } \\
\text { nominal }\end{array}$ & 0 & 0 & 25 & 0 & 0 & 0 & Dari gambar teknik \\
\hline
\end{tabular}




\begin{tabular}{|c|c|c|c|c|c|c|c|c|}
\hline $77^{\prime}$ & $\begin{array}{c}\text { Toleransi } \\
\text { lokasi }+ \\
\text { bonus } \\
\text { toleransi } \\
\text { (karena } \\
\text { MMC) }\end{array}$ & 0 & 0.54 & 0.54 & 0 & 0.054 & 0.054 & $\begin{array}{l}\text { Toleransi } \\
\text { lokasi+bonus: } \\
(0.08+10.5- \\
9.5[\text { bonus])/2 [equal- } \\
\text { bilaterally] }=0.54 \\
\text { untuk dy dan dz. d } 0 \mathrm{y} \\
=\mathrm{d} \theta \mathrm{z}=(0.08+10.5- \\
9.5 / 10) / 2=0.054 . \\
\text { Catatan: MMC } \\
\text { memberikan "bonus" } \\
\text { toleransi, tetapi } \\
\text { menyebabkan } \\
\text { "sumber error" } \\
\text { tambahan pada } \\
\text { akumulasi toleransi. } \\
\text { (pada komponen 2) }\end{array}$ \\
\hline 78 & $\begin{array}{l}\text { Dimensi } \\
\text { nominal }\end{array}$ & -10 & 0 & 0 & 0 & 0 & 0 & Dari gambar teknik \\
\hline $88^{\prime}$ & $\begin{array}{l}\text { Assembly } \\
\text { shift+ } \\
\text { location } \\
\text { tolerance + } \\
\text { bonus }\end{array}$ & 0 & 1.04 & 1.04 & 0 & 0.104 & 0.104 & $\begin{array}{l}\text { location+bonus+ } \\
\text { assembly shift: } \\
(0.08+10.5- \\
9.5[\text { bonus] }+10.5- \\
9.5[\text { shift] }) / 2=1.04 \text { for } \\
\mathrm{dz} \text { and dy. } \mathrm{d} \theta \mathrm{y}=\mathrm{d} \theta \mathrm{z} \\
=((0.08+10.5- \\
9.5+10.5-9.5) / 10) / 2= \\
0.104 \text {. }(\text { pada } \\
\text { komponen 1) }\end{array}$ \\
\hline 89 & $\begin{array}{l}\text { Dimensi } \\
\text { nominal }\end{array}$ & 0 & 0 & 15 & 0 & 0 & 0 & Dari gambar teknik \\
\hline $99^{\prime}$ & $\begin{array}{l}\text { Tidak ada } \\
\text { toleransi }\end{array}$ & 0 & 0 & 0 & 0 & 0 & 0 & - \\
\hline 910 & $\begin{array}{l}\text { Dimensi } \\
\text { nominal }\end{array}$ & 0 & -10 & 0 & 0 & 0 & 0 & Dari gambar teknik \\
\hline 1010' & $\begin{array}{c}\text { Tolernasi } \\
\text { perpedicular } \\
\text { ity }\end{array}$ & 0 & 0.01 & 0 & 0.0002 & 0 & 0.0003 & $\begin{array}{l}\mathrm{dy}=0.02 / 2=0.01 \\
\text { Flatness error } \text { dari } \\
\text { datum } C \text { pada } \\
\text { komponen } 1 \\
\mathrm{~d} \theta \mathrm{x}= \\
(0.02 / 50) / 2=0.0002 \\
\mathrm{~d} \theta \mathrm{z}= \\
(0.02 / 30) / 2=0.000333\end{array}$ \\
\hline 1011 & $\begin{array}{l}\text { Dimensi } \\
\text { nominal }\end{array}$ & 0 & 0 & 20 & 0 & 0 & 0 & Dari gambar teknik \\
\hline
\end{tabular}




\begin{tabular}{|c|c|c|c|c|c|c|c|c|}
\hline $1111^{\prime}$ & $\begin{array}{l}\text { Toleransi } \\
\text { flatness }\end{array}$ & 0 & 0 & 0.005 & 0.00013 & 0.00017 & 0 & $\begin{array}{l}\mathrm{dz}=0.01 / 2=0.005 \\
\mathrm{~d} \theta \mathrm{x}=(0.01 / 40) / 2=0.0 \\
00125 \\
\mathrm{~d} \theta \mathrm{y}=(0.01 / 30) / 2=0.0 \\
00167\end{array}$ \\
\hline 1112 & $\begin{array}{l}\text { Dimensi } \\
\text { nominal }\end{array}$ & -30 & 0 & 0 & 0 & 0 & 0 & Dari gambar teknik \\
\hline $1212^{\prime}$ & $\begin{array}{c}\text { Toleransi } \\
\text { dimensional }\end{array}$ & 0.2 & 0 & 0 & 0 & 0 & 0 & $\begin{array}{l}\text { dx dari gambar } \\
\text { teknik. Tidak ada } \\
\text { toleransi geometri. }\end{array}$ \\
\hline
\end{tabular}

Pada gambar 39 mengenai cara penentuan nilai $d \theta_{x}, d \theta_{y}, d \theta_{z}$, hal penting yang harus dipahami adalah error rotasi akan mempunyai nilai yang besar apabila suatu fitur lubang, yang digunakan untuk memasukkan pin, dibuat terlalu pendek atau fitur permukaan datar, yang biasanya digunakan untuk kontak antar dua permukaan komponen yang berbeda, dibuat terlalu kecil. Hal ini disebabkan karena pembai untuk menentukan nilai error sudut menjadi kecil, sehingg nilai error sudut tersebut menjadi besar.

Pada tabel 11, elemen-element matriks variasi $\mathbf{7 7}$ ', yaitu $\mathbf{T}_{\mathbf{7 7}}$, mempunyai error sudut yang paling besar karena efek dari panjang lubang yang terlalu pendek. Begitu juga dengan elemen-elemen matriks 88', yaitu $\mathbf{T}_{\mathbf{8 8}}{ }^{\prime}$, matriks variasi tersebut mempunnyai error sudut yang besar yang disebabkan oleh hal yang sama pada matriks variasi 77', yaitu $\mathbf{T}_{\mathbf{7 7}}$. Hal penting yang bisa diambil dari kasus ini adalah, apabila sebuah lubang atau pin (fitur silinder) mempunyai bentuk yang pendek, maka toleransi geometri yang dialokasikan kepada fitur tersebut haruslah kecil.

Langkah selanjutnya adalah menganalisis rantai toleransi 3D dengan mengalikan seluruh rangkain matriks yang merepresentasikan perambatan toleransi pada produk contoh kasus ini, baik matriks transformasi nominal maupun matriks transformasi variasi seperti yang terdapat pada persamaan (20). Analisis tersebut dilakukan dengan cara simulasi Monte-Carlo, yaitu, dengan cara mengsample elemen-elemen error $d_{x}, d_{y}, d_{z}, d \theta_{x}, d \theta_{y}, d \theta_{z}$ pada matriks-matriks variasi dari suatu distribusi Normal dengan nilai rata-rata 0 dan deviasi standar dengan nilai besarnya elemen-elemen error di bagi dengan 3 (untuk mendapatkan $1 \sigma$ ), yaitu $N \sim\left(0, \sigma^{2}\right), \sigma=\frac{d_{i}}{3}$ atau $\frac{d \theta_{i}}{3}$. Pembaca bisa mereferensi bab 2 untuk mengingat kembali aspek-aspek statistik, terutama mengenai distribusi statistik.

Untuk mengaplikasikan analisis toleransi 3D ini, dengan simulasi Monte-Carlo, maka perhitungan untuk mendapatkan matriks $\mathbf{T}_{\mathbf{1 . 1 2}}$ pada persamaan (20), dilakukan berulang-ulang dengan jumlah yang banyak. Setiap pengulangan, elemen-elemen error disampel dan mempunyai nilai yang baru. Pada setiap pengulangan, hasil kalkulasi matriks $\mathbf{T}_{\mathbf{1 . 1 2}}$ disimpan. Dari seluruh hasil kalkukasi $\mathbf{T}_{\mathbf{1 . 1 2}}$ yang disimpan tersebut, parameter statistik, berupa ratarata, deviasi standar, dan nilai maksimum dan minimum dimensi totalnya dapat diketahui. Pemrograman MATLAB digunakan untuk mengaplikasikan analisis toleransi 3D tersebut. Tabel 12 memperlihatkan kode pemrograman MATLAB tersebut.

Hasil 10000 pengulangan untuk analisis 3D dengan metode matriks tersebut diperlihatkan pada gambar 40. Pada gambar 40, rotasi searah sumbu $Z$ tidak dikalkulasi karena error orientasi cukup dipresetasikan dengan dua jenis rotasi saja, dalam hal ini rotasi searah sumbu $X$ dan $Y$. lagi pula, error rotasi pada sumbu $Z$ untuk jarak A-B tersebut tidak mempunyai pengaruh. Histogram setiap data $d_{x}, d_{y}, d_{z}, d \theta_{x}, d \theta_{y}$ yang dikumpulkan pada setiap pengulangan kalkulasi $\mathbf{T}_{\mathbf{1 . 1 2}}$ direkonstruksi untuk mengkarakterisasi parameter statstik dari setiap error tersebut, yaitu: nilai ratarata, deviasi standa, dan batas minimum dan maksimum variasi dari setiap dimensi searah sumbu $X, Y$ dan $Z$, dan variasi dari setiap rotasi pada sumbu $X$ dan $Y$. dari hasil tersebut, variasi jarak A ke B yang merupakan jarak vertikal searah sumbu $Z$ adalah $(69.99 \pm 3.82) \mathrm{mm}$, yaitu $66.18 \mathrm{~mm}-73.81 \mathrm{~mm}$. 

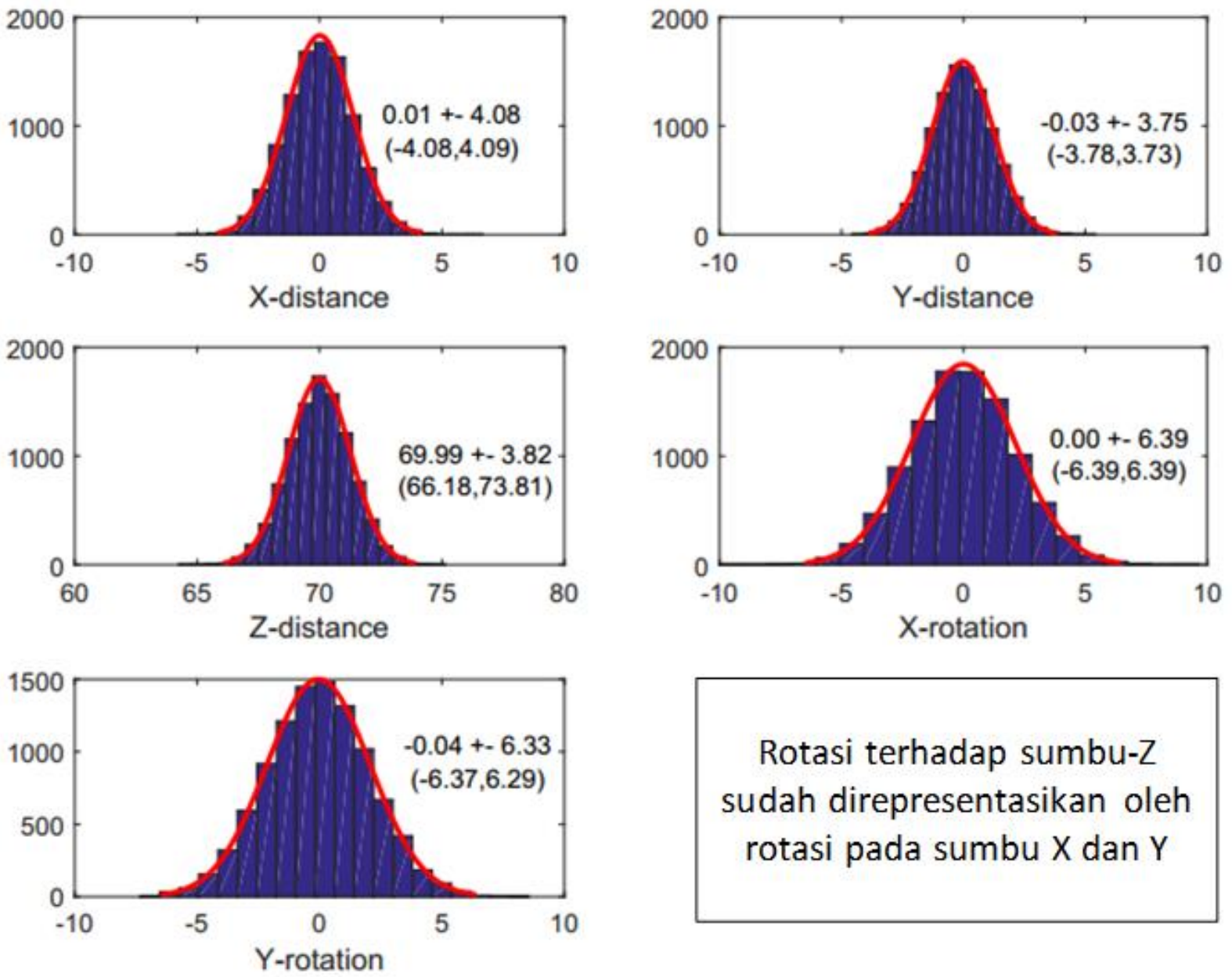

Rotasi terhadap sumbu-Z sudah direpresentasikan oleh rotasi pada sumbu $X$ dan $Y$

Gambar 40: Hasil simulasi analisis akumulasi toleransi 3D dengan metode matriks. 
Tabel 12: Kode pemrograman MATLAB untuk simulasi analisis akumulasi toleransi 3D dengan metode matriks.

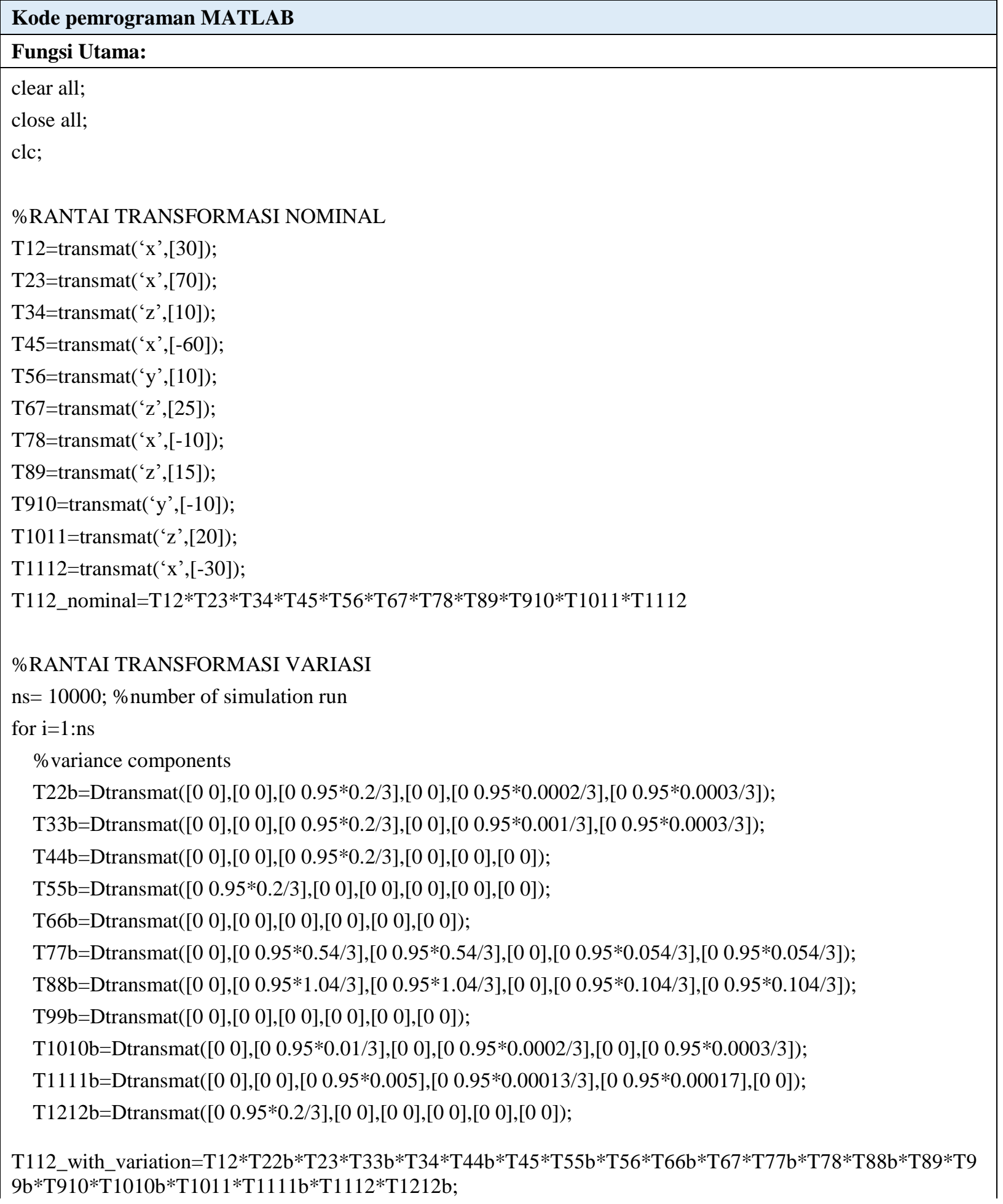


kc1(i)=T112_with_variation(1,4); \%X-distance clearance kc2(i)=T112_with_variation(2,4); \% Y-distance clearance kc3(i)=T112_with_variation(3,4); \%Z-distance clearance kc4(i)=asin(T112_with_variation(1,3))*180/pi; \%Rotation Angle from X-axis kc5(i)=asin(T112_with_variation(1,2))*180/pi; \%Rotation Angle from Y-axis kc6(i)=asin(T112_with_variation $(1,1)) * 180 /$ pi; \%Rotation Angle from Z-axis end

\section{\%PLOT HASIL}

[muhat,sigmahat]=normfit $(\mathrm{kc} 1)$; $\mathrm{kcmin}=$ muhat $-3 *$ sigmahat;

$\mathrm{kcmax}=$ muhat $+3 *$ sigmahat;

text $1=\operatorname{sprintf}($ ' $\% .2 \mathrm{f}+-\% .2 \mathrm{f} \backslash \mathrm{n}$ ', muhat, $3 *$ sigmahat);

text2=sprintf('(\%.2f, $\% .2 \mathrm{f})$ ', $\mathrm{kcmin}, \mathrm{kcmax})$;

textTotal=sprintf(' $\%$ s\%s', text 1 ,text 2 );

subplot $(3,2,1)$

histfit $(\mathrm{kc1} 1,20)$

text(kcmax,ns/15,textTotal,'HorizontalAlignment', 'center')

xlabel('X-distance');

[muhat,sigmahat]=normfit $(\mathrm{kc} 2)$;

$\mathrm{kcmin}=$ muhat $-3 *$ sigmahat;

kcmax $=$ muhat $+3 *$ sigmahat;

text $1=\operatorname{sprintf}\left({ }^{\circ} \% .2 \mathrm{f}+-\% .2 \mathrm{f} \backslash \mathrm{n}\right.$ ', muhat, $3 *$ sigmahat);

text2=sprintf('(\%.2f, \%.2f)', $\mathrm{kcmin}, \mathrm{kcmax})$;

textTotal=sprintf(' $\%$ s\%s',text1,text2);

subplot $(3,2,2)$;

histfit $(\mathrm{kc} 2,20)$

text(kcmax,ns/15,textTotal,'HorizontalAlignment','center')

xlabel('Y-distance');

[muhat,sigmahat]=normfit $(\mathrm{kc} 3)$;

$\mathrm{kcmin}=$ muhat $-3 *$ sigmahat;

$\mathrm{kcmax}=$ muhat $+3 *$ sigmahat;

text $1=\operatorname{sprintf}\left({ }^{\circ} \% .2 \mathrm{f}+-\% .2 \mathrm{f} \backslash \mathrm{n}\right.$ ', muhat, $3 *$ sigmahat);

text2=sprintf('( $\% .2 \mathrm{f}, \% .2 \mathrm{f})$ ', $\mathrm{kcmin}, \mathrm{kcmax})$; 


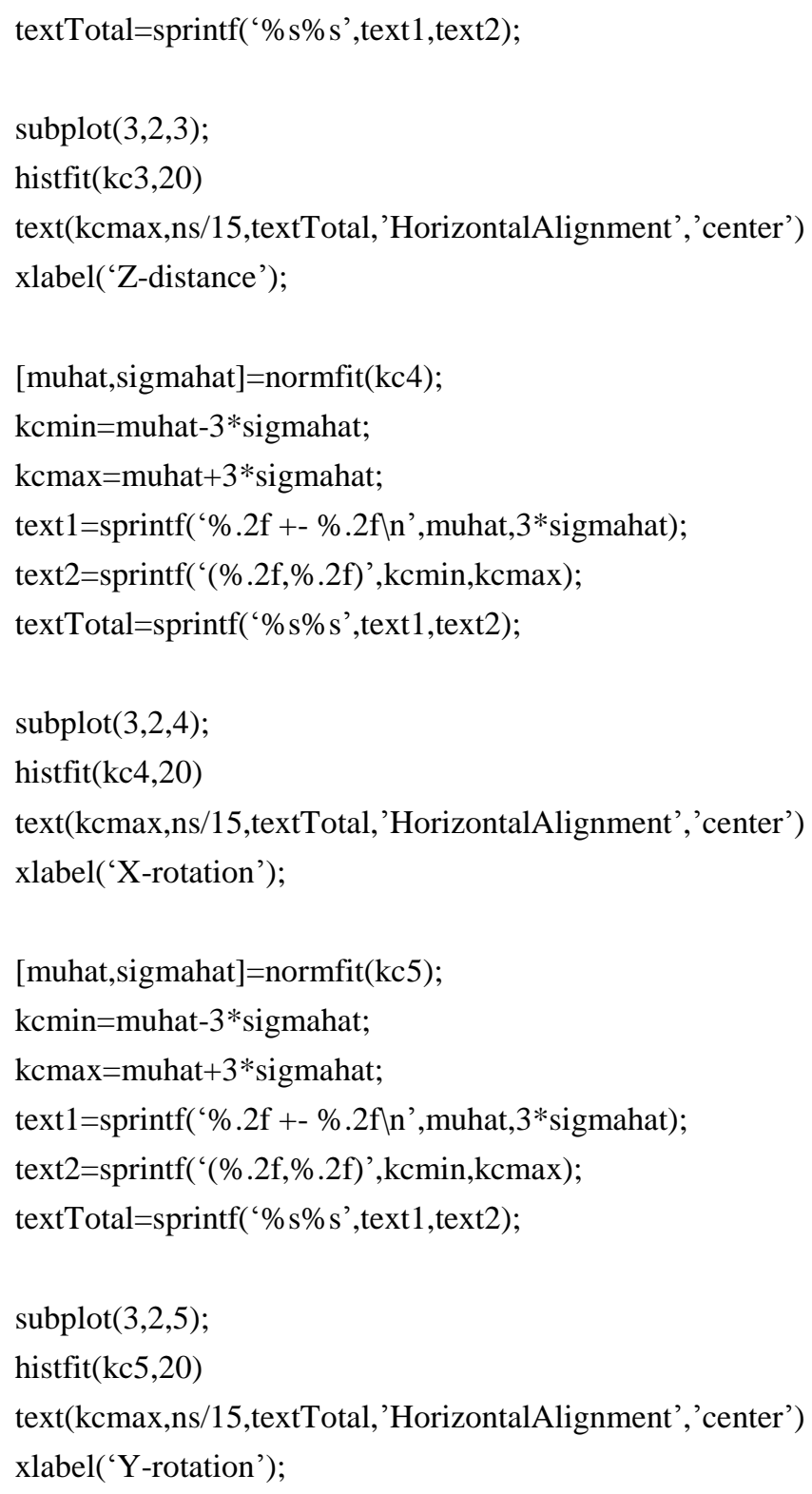


$\mathrm{T}(1,4)=$ values $(\mathrm{h})$;

elseif which(h)=='y'

$\mathrm{T}(2,4)=$ values $(\mathrm{h})$;

elseif which(h)=='z'

$\mathrm{T}(3,4)=$ values $(\mathrm{h})$;

elseif which(h)=='a'

$\mathrm{T}(2,2)=\cos (\operatorname{degtorad}(\operatorname{values}(\mathrm{h})))$;

$\mathrm{T}(2,3)=-\sin (\operatorname{degtorad}(\operatorname{values}(\mathrm{h})))$;

$\mathrm{T}(3,2)=\sin (\operatorname{degtorad}(\operatorname{values}(\mathrm{h})))$;

$\mathrm{T}(3,3)=\cos (\operatorname{degtorad}(\operatorname{values}(\mathrm{h})))$;

elseif which $(\mathrm{h})==$ 'b'

$\mathrm{T}(1,1)=\cos (\operatorname{deg} \operatorname{corad}(\operatorname{values}(\mathrm{h})))$;

$\mathrm{T}(1,3)=\sin (\operatorname{degtorad}(\operatorname{values}(\mathrm{h})))$;

$\mathrm{T}(3,1)=-\sin (\operatorname{degtorad}(\operatorname{values}(\mathrm{h})))$;

$\mathrm{T}(3,3)=\cos (\operatorname{degtorad}(\operatorname{values}(\mathrm{h})))$;

elseif which(h)=='c'

$\mathrm{T}(1,1)=\cos (\operatorname{degtorad}(\operatorname{values}(\mathrm{h})))$;

$\mathrm{T}(1,2)=-\sin (\operatorname{degtorad}(\operatorname{values}(\mathrm{h})))$;

$\mathrm{T}(2,1)=\sin (\operatorname{degtorad}(\operatorname{values}(\mathrm{h})))$;

$\mathrm{T}(2,2)=\cos (\operatorname{deg} t o r a d(\operatorname{values}(\mathrm{h})))$;

end

end

end

\section{Fungsi Dtransmat}

function DT=Dtransmat (dTx,dTy,dTz, dx,dy,dz) \%Fungsi untuk merekonstruksi matriks variasi

$\%$ input element adalah sebagai 2-elements vector, ex: $\mathrm{dx}=[\mathrm{mu}, \mathrm{sigma}]$

$\mathrm{Dx}=\operatorname{normrnd}(\mathrm{dx}(1), \mathrm{dx}(2))$;

$\operatorname{Dy}=\operatorname{normrnd}(\operatorname{dy}(1), \mathrm{dy}(2))$;

$\mathrm{Dz}=$ normrnd(dz(1), dz(2));

$\mathrm{DTx}=\operatorname{normrnd}(\mathrm{dTx}(1), \mathrm{dTx}(2))$;

$\operatorname{Dty}=\operatorname{normrnd}(\mathrm{dTy}(1), \mathrm{dTy}(2))$;

$\mathrm{DTz}=$ normrnd $(\mathrm{dTz}(1), \mathrm{dTz}(2))$;

DT=[1 -Dz Dy DTx; Dz 1 -Dx Dty; -Dy Dx 1 DTz; 000 1];

end 


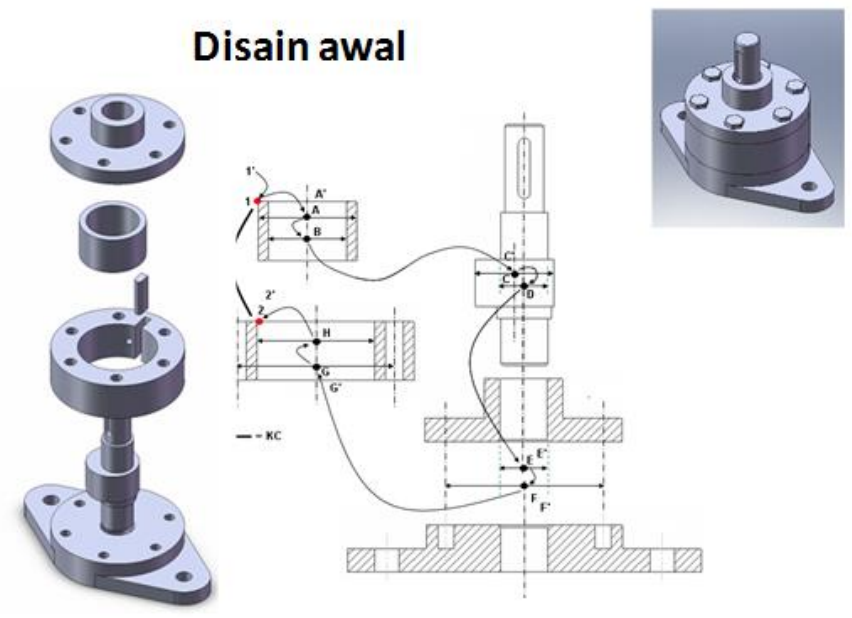

\section{Disain baru}
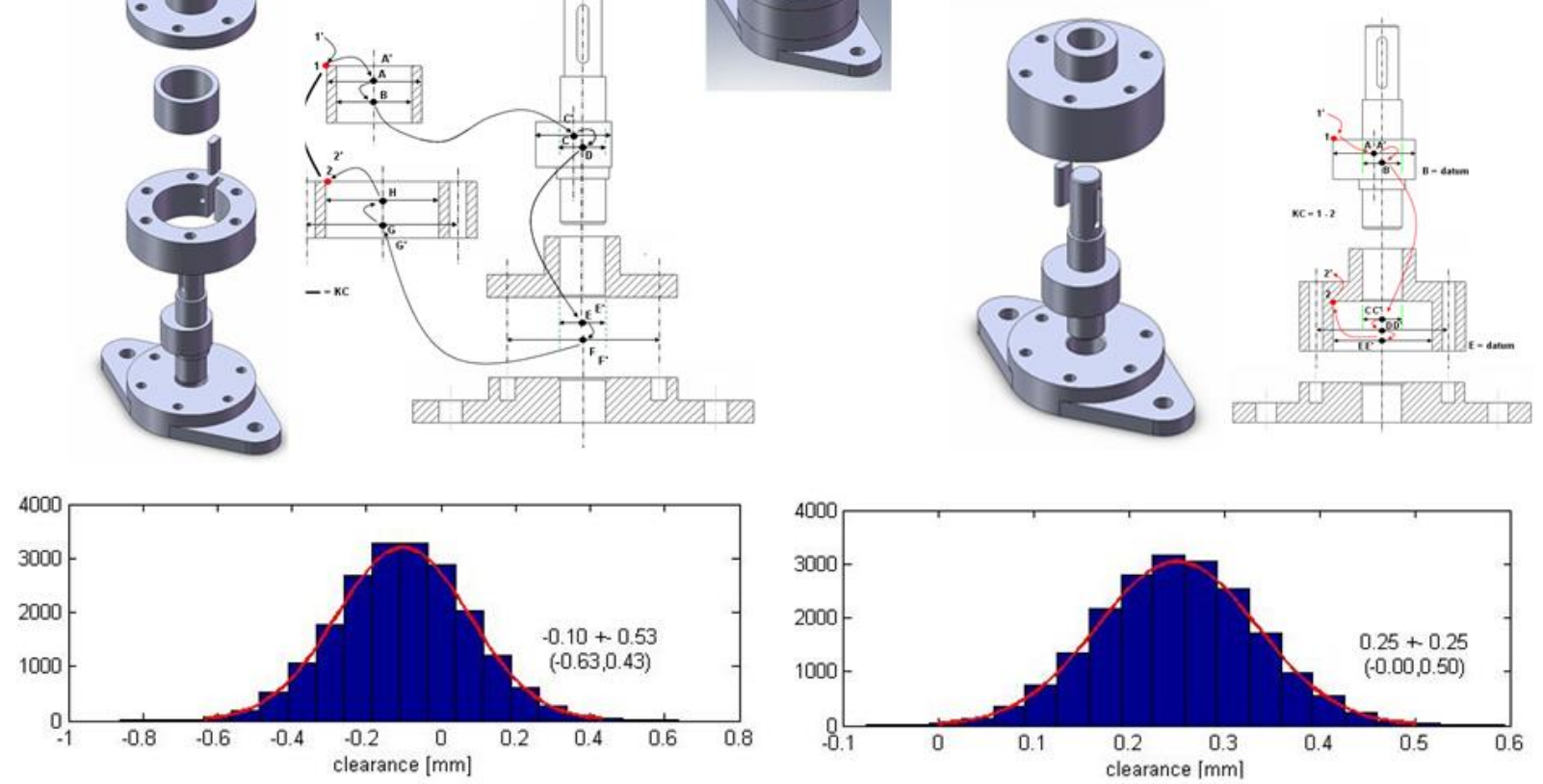

Gambar 41: Contoh kompleks analisis toleransi 3D pada sebuah kompresor udara. Dengan melakukan analisis toleransi 3D tersebut, sebuah disain dari kompressor tersebut dapa dianalisis dan ditingkatkan sebelum kompressor tersebut dimanufaktur.

Contoh lain dari analisis akumulasi toleransi 3D, yang dilakukan dengan metode matriks, untuk komponen riil yang kompleks diperlihatkan pada gambar 41. Penentuan elemen-elemen matriks dan peritungan matriks transformasi nominal dan variasinya tidak dibahas dalam buku ini. Penjelasan singkat mengenai contoh ini adalah sebagai berikut. Pada contoh gambar 41, terdapat sebuah disain dari rotary-compressor udara. Rotary-compressor tersebut mempunyai fitur perakitan yang kritikal, yaitu gap antara titiak A dan B (lihat gambar 41) yang merupakan gap antara rotor dan stator kompresor.

Pada kasus kompresor tersebut, analisis akumulasi toleransi 3D digunakan untuk menganalisis akumulasi toleransi pada fitur perakitan tersebut pada disain pertama. Hasil dari analisis toleransi 3D tersebut digunakan untuk mengrealokasikan toleransi dan mengoptimalkan toleransi pada disain pertama untuk kemudian merevisi disain tersebut untuk mendapatkan disain kedua yang lebih bagus. Pada gambar 41 (kiri), disain pertama dari kompresor tersebut diperlihatkan. Pada desain pertama tersebut, terdapat komponen pengusun kompresor tersebut. Hasil analisis toleransi 3D tersebut menghasilkan bahwa pada disain pertama tersebut, berikut alokasi toleransinya, akan ada kemungkinnan komponen rotor dan statornya akan bersentuhan, karena gap minimum antara rotor dan statornya adalah $-0.63 \mathrm{~mm}$ (gambar 41 kiri).

Dari hasil analisis toleransi 3D tersebut, maka pada disain kedua (gambar 41 kanan), jumlah komponen kompresor tersebut dikurangi, dari 6 menjadi 4 komponen, dengan memodifikasi disain pertama untuk mengurangi panjang dari rantai toleransi. Setelah jumlah komponen dikurangi, pada disain kedua realokasi toleransi dilakukan. Hasil analisis untuk disain kedua tersebut menunjukkan bahwa dengan nilai toleransi yang baru pada disain kedua, gap minimum antara rotor dan stator yang dapat terjadi adalah $0 \mathrm{~mm}$. Hal ini menunjukkan bahwa, selama komponenkomponen kompresor tersebut dalam batas toleransinya, maka tidak ada sentuhan antara rotor dan stator. 


\subsubsection{Keuntungan apabila model toleransi stack-up diketahui}

Sangat banyak keuntungan-keuntungan yang didapatkan apabila model dan analisis akumulasi toleransi suatu produk dikonstruksi dan dilakukan. Hal yang sangat berguna apabila kita mempunyai dan menanalisis model dari akumulasi toleransi tersebut adalah:

- Analisis akumulasi toleransi dapat dilakukan.

- Informasi lebih dapat dimasukkan ke dalam model akumulasi toleransi suatu produk untuk juga mengikutsertakan efek lingkungan terhadap perakitan produk tersebut. Informati tersebut adalah misalnya deformasi yang disebabkan oleh temperatur. Dengan melakukan pemodelan ini, maka kondisi perakitan untuk suatu komponen yang sangat sensitif, misalnya perakitan mesin jet pesawat, akan diketahui, misalnya: pada temperatur berapa perakitan mesin jet tersebut akan optimal. Temperatur lingkungan untuk suatu proses perakitan produk sangat penting terutama untuk produk-produk berskala mikro.

- Sumber-sumber variasi dari produk yang dirakit dapat dikorelasikan dengan kemampuan suatu proses manufaktur yang dimiliki. Dengan demikian, kita dapat mengalokasikan toleransi sesuai dengan mesin manufaktur yang kita miliki. Misalnya, kita dapat mengalokasikan toleransi yang lebih besar untuk suatu proses yang memiliki tingkat presisi yang tidak tinggi dan mengurangi nilai toleransi suatu fitur lain dalam suatu produk yang sama untuk diproses dengan suatu mesin manufaktur yang lebih presisi.

- Toleransi perakitan akan dapat diprediksi. Hal ini berguna untuk memilih jenis instrumen pengukuran, mislanya mesin pengukur koordinat (CMM), yang paling tepat untuk menginspeksi suatu produk yang telah dirakit.

- Error budgetting pada suatu disain produk dapat dilakukan karena pada esensinya, model akumulasi toleransi adalah suatu proses error budgetting.

\subsection{Verifikasi toleransi}

Pada prinsipnya, metrologi atau pengukuran dimensi dan geometri adalah verifikasi toleransi, yaitu proses untuk mengecek apakah suatu fitur komponen berada di dalam batas toleransinya atau tidak. Maka dari itu, toleransi dan pengukuran dimensi dan geometri tidak dapat dipisahkan dan harus dibahas dan dianalisis secara bersamaan. Untuk masing-masing jenis toleransi dimensi dan geometri, metode dan jenis alat ukurnya juga berbeda. Namun demikian, terdapat alat ukur universal yang dapat digunakan untuk mengukur baik dimensi dan geometri, yaitu mesin pengukur koordinat (CMM). Bab 4 menjelaskan dengan detil mengeai pengukuran (verifikasi) dimensi dan geometri, dan bab 5 membahas detil mengenai mesin pengukur koordinat (CMM/Coordinate Measuring Machine).

\subsubsection{Verifikasi toleransi dimensional}

Toleransi dimensional merupakan suatu jenis toleransi yang paling pertama digunakan. Alat-alat ukur yang digunakan untuk memverifikasi toleransi dimensional pada umumnya tidak rumit dan sudah umum diketahui, seperti: gauge block, jangka sorong (vernier caliper) dan mikrometer. Gambar 42 memperlihatkan alat-alat ukur tersebut yang paling umum digunakan untuk memverifikasi suatu toleransi dimensional. Tidak banyak perkembangan yang signifikan untuk alat-alat ukur tersebut. pada umumnya, pengembangan alat-alat ukur tersebut, seperti untuk jangka sorong dan mikrometer, adalah pada penggunaan alat pembaca digital sehingga memudahkan operator untuk melihat suatu hasil pengukuran dimensi dan mendapatkan hasil bacaan yang lebih akurat. Pengukuran dimensi akan dibahas dengan detil pada bab 4. 


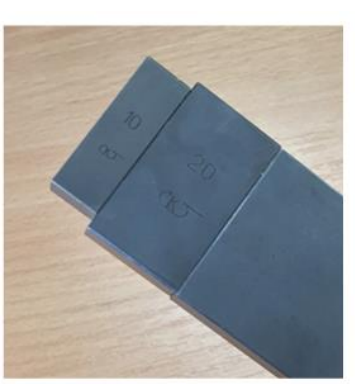

(a)

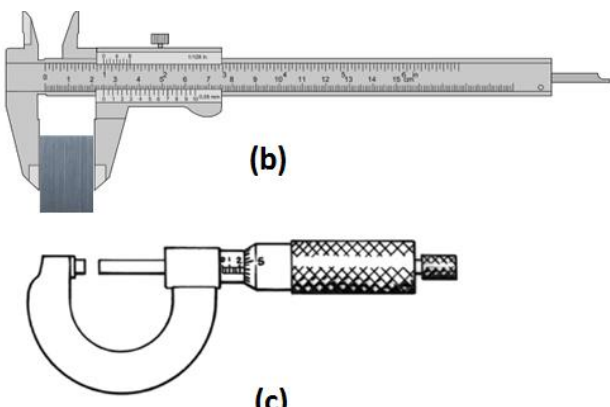

(c)

Gambar 42: Contoh alat yang digunakan untuk memverifikasi dimensi suatu fitur. (a) Gauge block, (b) jangka sorong/vernier caliper dan (c) mikrometer.

\subsubsection{Verifikasi toleransi geometri (GD\&T)}

Proses verifikasi toleransi geometri, terutama untuk toleransi geometri yang berelasi, seperti peprendicularity, coaxiality dan run-out, membutuhkan suatu alat dan prosedur yang lebih kompleks daripada proses verifiaksi toleransi dimensional. Untuk memverifkasi suatu toleransi geometri, ada dua jenis alat ukur yang dapat digunakan, yaitu alat ukur konvensional dan modern. Alat ukur konvensional untuk memverifikasi toleransi geometri adalah dial-gauge dan alat ukur modern dan universal (bisa digunakan untuk memverifikasi baik toleransi geometri maupun dimensional) adalah alat pengukur koordinat (CMM).

\section{Pengukuran dengan dial-gauge.}

Pengukuran yang dilakukan untuk memverifikasi suatu toleransi geometri dengan menggunakan dial-gauge adalah metode yang konvensional. Namun demikian metode ini masih dan sering dipakai oleh para teknisi, yang berpengalaman dan terlatih, di lantai produksi karena metode ini (dengan tingkat keahlian teknisi yang tinggi) dapat memberikan hasil pengukuran yang akurat dan cepat. Dengan menggunakan dial-gauge, pengukuran tersebut dilakukan dengan cara menggerakkan (memindahkan) dial-gauge tersebut untuk mengkover sebanyak mungkin suatu permukaan yang ditoleransi dan membaca perubahan jarum yang ada di dial-gauge tersebut mempunyai nilai kurang dari nilai toleansi geometri pada fitur tersebut. Suatu fitur dikatakan berada dalam batas toleransi geometrinya apabila selama menggerakkan dial-gauge tersebut, perubahan maksimal jarumnya masih kurang dari atau sama dengan nilai toleransi geometri yang diberikan. Misalnya, apabila suatu permukaan diberikan toleransi flatness sebesar $0.1 \mathrm{~mm}$, maka selama menggerakkan dial-gauge pada seluruh permukaan tersebut, jarum dial-gauge tersebut hanya menunjukkan nilai maksimum (full indicator movement) $\leq 0.1 \mathrm{~mm}$.

Gambar 43 memperlihatkan pengukuran berbagai macam toleransi geometri dengan menggunakan dial-gauge yang diaplikasikan atau dipraktekkan di lantai produksi oleh seorang operator yang terlatih dan berpengalaman. Gambar 43 hanya memperlihatkan sebagian kecil dari aplikasi dial-gauge untuk memverifikasi toleransi geometri. Pada prakteknya, di industri, banyak metode dan teknik serta prosedur untuk memverifikasi berbagai macam toleransi geometri dengan menggunakan dial-gauge. 

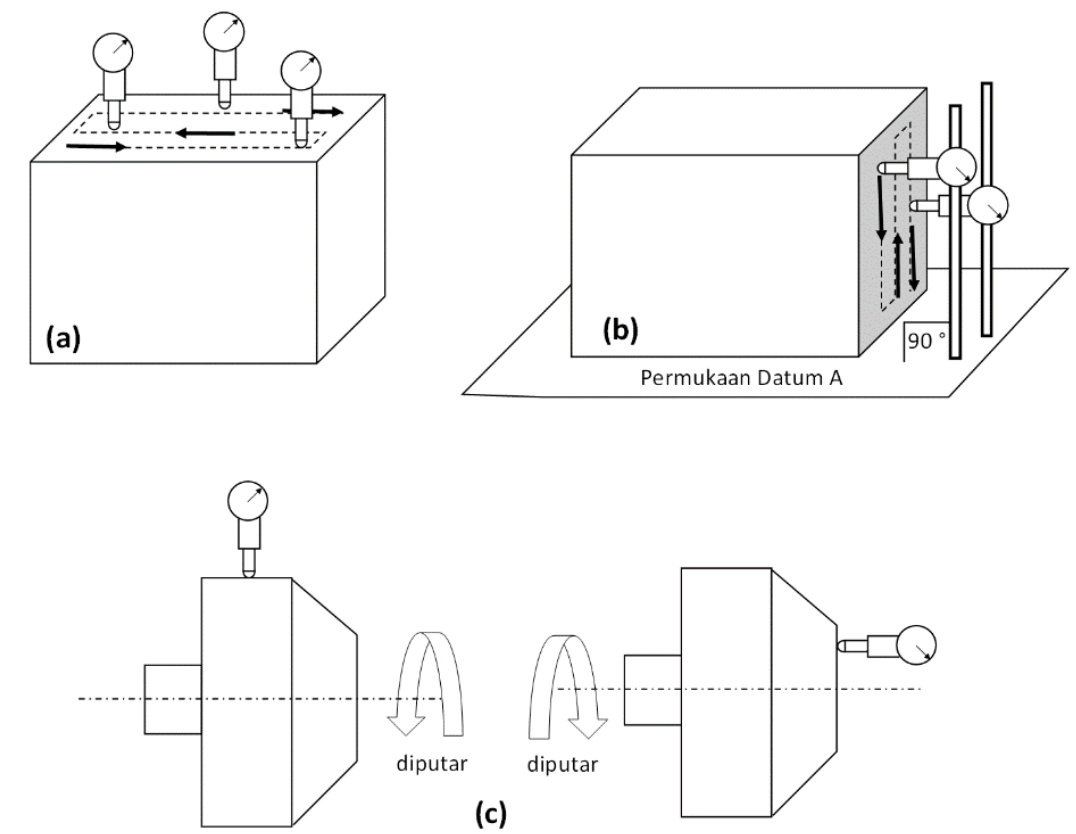

Gambar 43: Penggunaan dial-gauge untuk menverifikasi berbagai macam toleransi geometri. (a) flatness, (b) perpendicularity dan (c) run-out.

\section{Pengukuran dengan alat pengukur koordinat (CMM).}

Alat pengukur kooridnat (CMM) adalah metode modern untuk melakukan verifikasi geometri. Tidak hanya verifikasi geometri, CMM juga dapat digunakan untuk melakukan verifikasi dimensinal. Maka dari itu, CMM merupakan alat universal yang dapat digunakan untuk semua jenis pengukuran dimensi dan geometri.

Gambar 44 memperlihatkan salah satu contoh CMM yang digunakan untuk pengukuran dimensi dan geometri. Pada umumnya, CMM yang paling umum dan menjadi standar instrumen yang digunakan untuk verifikasi geometri dan dimensional di industri-industri adalah kontak (tactile) CMM. Kontak CMM mempunyai berbagai macam konfigurasi, seperti: kantilever, bridge dan gantry. Pengukuran dengan menggunakan CMM akan dibahas dengan detil pada bab 5 .
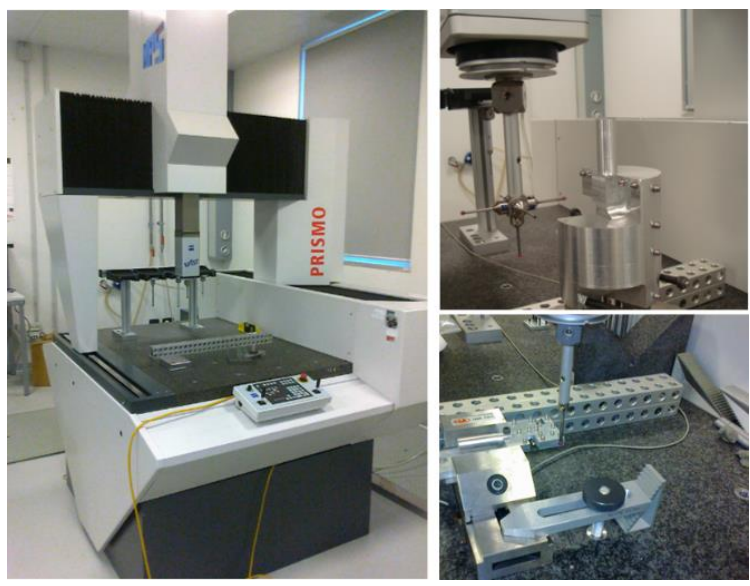

Gambar 44: Contoh CMM untuk memverifikasi berbagai macam toleransi geometri dan dimensional (3D and 2D). 
Pengukuran dimensi dan geometri

\section{BAB 4}

\section{Pengukuran dimensi dan geometri}

Bab ini membahas mengenai pengertian dan konsep dasar dari pengukuran dimensi dan geometri beserta jenisjenis alat pengukurannya. Jenis pengukuran lain ,yaitu pengukuran tekstur permukaan untuk mendapatkan kuantitas seperti $R_{a}, R_{q}, S_{a}$, dan $S_{q}$ tidak dibahas dalam buku ini. Pada prinsipnya, pengukuran dimensi dan geometri, dan pengukuran tekstur permukaan mempunyai data mentah (raw data) yang sama, yaitu berupa point cloud yang berisi titik-titik koordinat diskrit dari suatu permukaan. Yang membedakan kedua jenis pengukuran tersebut adalah langkahlangkah pemrosesan data dan beberapa prosedur pengukuran.

Tipe pengukuran dimensi dan geometri pada umumnya merupakan jenis pengukuran yang paling sering ditemui baik di industri-industri manufaktur maupun di industri-industri lainnya. Maka dari itu, pemahaman dan aplikasi pengukuran dimensi dan geometri sangat penting untuk mendukung dan meningkatkan fungsi industri-industri tersebut. Dalam buku ini, pembahasan mengenai pengukuran dimensi dan geometri tersebut difokuskan dan dikontekskan pada industri-industri manufaktur.

Pengukuran dimensi dan geometri adalah dua jenis pengukuran yang berbeda dan keduanya mempunyai peran yang sangat penting untuk menjaga kualitas dari suatu produk. Kedua jenis pengukuran tersebut tidak dapat dipisahkan satu sama lainnya, melainkan saling melengkapi untuk mendapatkan informasi bentuk suatu produk secara lengkap. Hanya dengan suatu produk yang berkualitas, baik secara fungsi dan reliabilitas, maka suatu industri manufaktur akan dapat bersaing di zaman modern sekarang ini. Bukan hanya produk yang berkualitas, efisiensi yang tinggi pada suatu industri manufaktur harus dicapai agar biaya manufaktur suatu produk dapat ditekan sehingga harga jual produk tersebut dapat tetap kompetitif dipasaran. Pengukuran dimensi dan geometri, yang tepat dan efisien, sangat dibutuhkan oleh industri-induttri manufaktur untuk mencapai tujuan: produk yang berkualitas tinggi dan prosess dengan efisiensi yang tinggi.

\subsection{Prinsip dasar pengukuran}

Pada prinsipnya, pengukuran adalah suatu proses komparasi suatu besaran suatu fitur yang diukur menggunakan suatu alat dengan suatu besaran referensi sehingga menghasilkan suatu kuantitas yang merepresentasikan besaran dari fitur tersebut. Dalam proses komparasi tersebut, terdapat error atau kesalahan, yang berasal dari berbagai macam sumber, yang mengurangi akurasi proses komparasi (pengukuran) tersebut. Gambar 1 memperlihatkan diagram dari prinsip dasar pengukuran.

Pada gambar 1, terdapat komponen-komponen yang berkontribusi terhadap suatu proses komparasi, yang merupakan suatu proses pengukuran. Komponen-komponen tersebut adalah:

- Fitur atau poperti yang diukur.

Adalah suat kuantitas atau besaran fisik yang ingin diukur, misalnya: panjang, radius, sudut dan flatness.

- $\quad$ Alat komparasi (alat ukur).

Alat yang digunakan untuk membandingkan besaran fisik suatu fitur dengan suatu besaran standar atau besaran yang telah diketahui untuk mengevluasi pengukuran tersebut.

- Referensi.

Suatu besaran fisik yang digunakan untuk membandingkan suatu besaran pada suatu fitur.

- Error atau kesalahan.

Faktor-faktor yang mengurangi akurasi suatu proses komparasi suatu besaran dengan suatu besaran referensi, 
misalnya: error geometri dari alat ukur, efek temperatur pengukuran dan kesalah seorang operator yang melakukan suatu pengukuran.

- Kuantitas yang terukur.

Adalah hasil dari suatu proses pengukuran dengan satuan tertentu.

Contoh pengukuran yang dikaitkan kepada komponen-komponen tersebut adalah sebuah pengukuran panjang suatu balok. Pada pengukuran ini, pengukuran dilakukan dengan cara membandingkan panjang balok tersebut dengan sebuah skala pada sebuah besi, yaitu skala sebuah jangka sorong (vernier caliper).

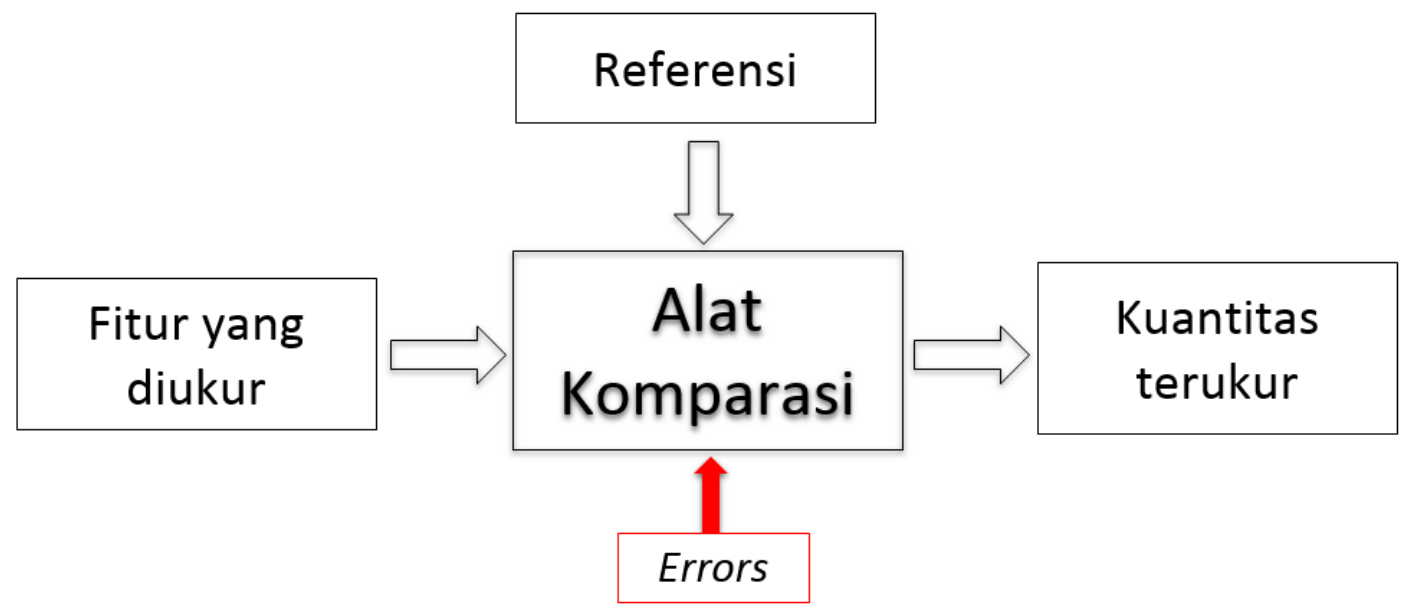

Gambar 1: Prinsip dasar pengukuran.

\subsection{Tipe pengukuran: dimensi dan geometri}

Jenis-jenis pengukuran suatu produk dalam industri manufaktur ada tiga jenis. Ketiga jenis pengukuran tersebut adalah sebagai berikut:

- Pengukuran dimensi.

Pengukuran dimensi (size measurement) adalah pengukuran yang mengukur panjang, diameter, sudut, kedalaman, lebar dan lain sebagainya. Pada prinsipnya, pengukuran dimensi adalah pengukuran size. Sifat dasar dari pengukuran dimensi adalah properti yang diukur akan secara proporsional bertambah seiring dengan peningkatan temperatur pada material yang diukur pada saat pengukuran dilangsungkan.

- Pengukuran geometri.

Pengukuran geometri (form measurement) adalah pengukuran yang dilakukan untuk memverifikasi toleransi geometri (lihat bab 3 mengenai toleransi geometri) atau geometric, dimensionaing and tolerancing (GD\&T). contoh dari pengukuran geometri adalah flatness, perpendicularity, orientation, location, dan run-out.

- Pengukuran tekstur permukaan.

Pengukuran tekstur permukaan adalah pengukuran yang mengukur dan mengkarakterisasi topografi suatu permukaan komponen. Pengertian dari tekstur permukaan adalah data dari suatu permukaan komponen yang sudah dihilangkan komponen bentuknya (form) melalui sebuah proses form filtering dari data point cloud suatu permukaan komponen. Contoh dari pengukuran tekstur permukaan adalah pengukuran kekasaran, seperti $R_{a}, R_{q}, P_{t}, P_{a}, R_{z}, S_{a}, S_{z}$ dan $S_{q}$.

Gambar 2 memperlihatkan jenis-jenis pengukuran tersebut dan beberapa contoh dari tiap-tiap jenis pengukuran tersebut. Pada gambar 2 tersebut, pengukuran dimensi dan geometri digambungkan menjadi satu kelompok dan sering disebut dengan dimensional metrology. 


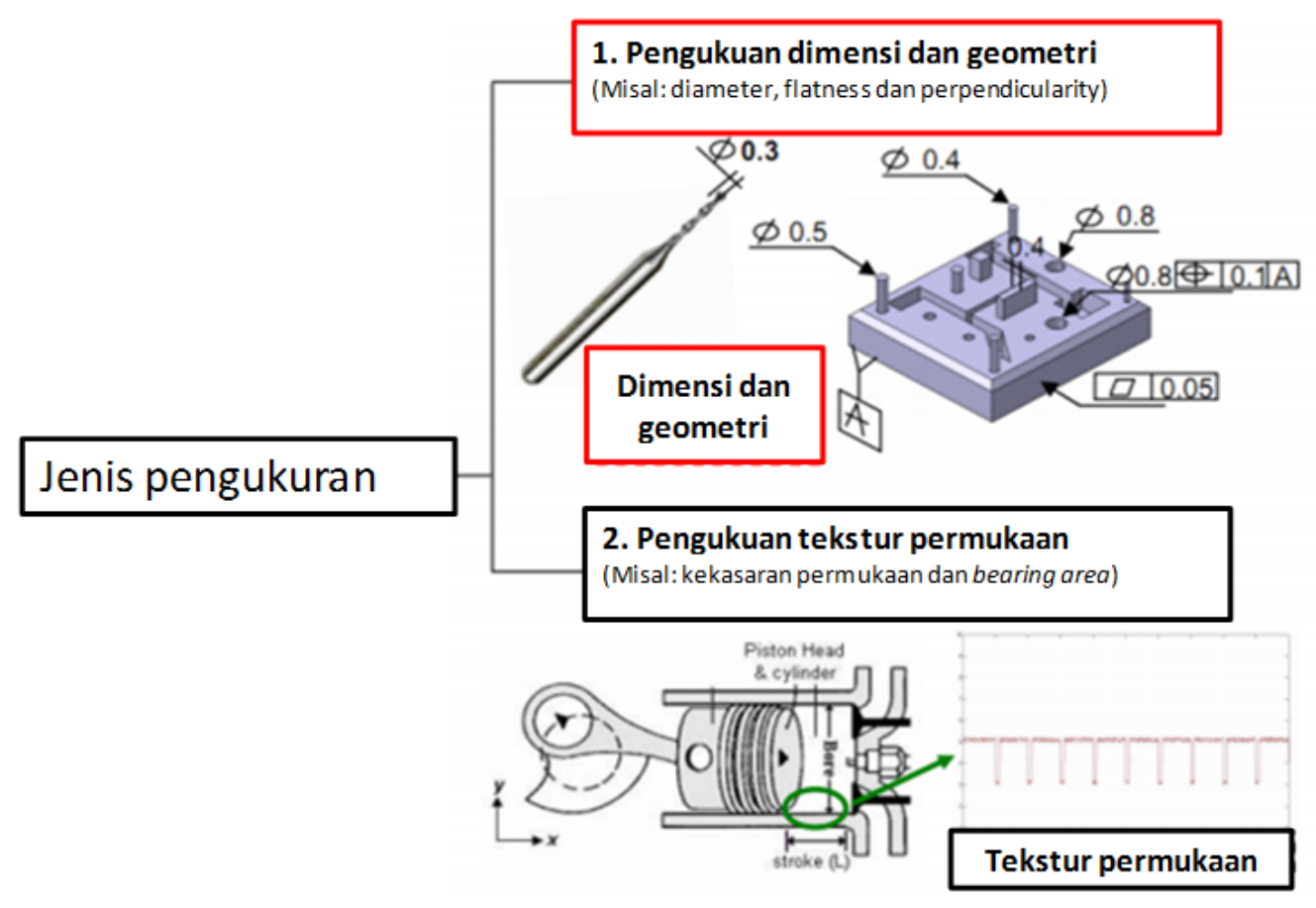

Gambar 2: Jenis-jenis pengukuran suatu produk.

\subsection{Pengukuran koordinat (coordinate measurement)}

Pengukuran koordinat adalah suatu pengukuran yang mengukur koordinate spasial (3D) dari suatu komponen atau benda kerja. Data-data dari pengukuran koordinat adalah poin-poin 3D dari suatu permukaan komponen yang didapatkan dari instrumen-instrumen pengukuran, baik kontak maupun non-kontak. Data-data dari hasil pengukuran koordinat diproses lebih lanjut untuk pengukuran dimensi dan geometri. Maka dari itu, pengukuran koordinat sering disamakan atau direlasikan dengan pengukuran dimensi dan geometri atau dimensional metrology.

Alat ukur utama untuk pengukuran koordinat adalah mesin pengukur koordinat (coordinate measuring machine/CMM). CMM merupakan standar "de facto" untuk alat ukur dimensi dan geometri. Berbagai macam bentuk komponen dan jenis pengukuran, seperti pajang, lebar, flatness, location dan orientation, dapat diukur dengan CMM. CMM sangat sering ditemui baik di industri-industri manufaktur maupun di laboratorium-laboratorium. Bab 5 membahas dengan detil mengenai CMM.

\subsection{Jenis-jenis kesalahan umum dalam pengukuran (error)}

Pada suatu pengukuran, terdapat berbagai macam sumber kesalahan (error) yang menyebabkan berkurangnya tingkat akurasi dari hasil pengukuran tersebut. Jenis kesalahan pengukuran dapat dibagi menjadi dua kelas: kesalahan yang berhubungan dengan prosedur pengukuran (Raghavendra dan krishnamurthy 2013) dan kesalahan yang berhubungan dengan struktur suatu instrumen pengukuran (Slocum 1992, Leach 2010, Mekid 2009). Kesalahan yang berhubungan dengan prosedur pengukuran adalah seperti error Abbe, error sine dan cosine, error referensi dan datum, error nol, efek misalignment, efek kekasaranpermukaan, dan efek debu. Sedangkan, kesalahan yang berhubungan dengan struktur suatu instrument pengukuran adalah seperti error geometri, error non-kinematic design atau join, efek dinamika instrumen, ekspansi termal material, error simetrisitas dan error yang berkaitan dengan structural loop. 


\subsubsection{Error Abbe (The first principle)}

Error Abbe adalah sumber error yang paling fundamental dalam pengukuran dan rekayasa presisi (precision engineering). Error Abbe merupakan kesalahan yang dapat dikategorikan sebagai kesalahan karena prosedur pengukuran atau kesalahaan karena struktur atau geometri instrumen pengukuran. Sesuai namanya, kata "Abbe" berasal dari nama orang pertama yang menemukan sumber kesalahan tersebut, yaitu Ernst Abbe, yang merupakan perekayasa pertama yang bekerja di perusahaan Carl Zeiss.

Error Abbe adalah error yang didapatkan karena sumbu pergerakantidak berhimpit atau koinsiden dengan sumbu pengukuran, sehingga setiap error angular yang kecil akan teramplifikasi dan menjadi error Abbe (gambar 3). Besarnya amplifikasi tersebut bergantun pada seberapa besar offset Abbe pada suatu pengukuran atau instrument. Offset Abbe adalah jarak antara sumbu pergerakan dan sumbu pengukuran. Sumbu pergerakan adalah sumbu yang merupakan arah dilakukannya suatu pengukuran dan sumbu pengukuran adalah skala pembacaan dari pengukuran tersebut. Gambar 3 memperlihatkan ilustasi dari error Abbe, offset Abbe, sumbu pengukuran, sumbu pergerakan dan error angular. Besarnya error Abbe (gambar 3) adalah:

$$
\varepsilon_{\text {Abbe }}=\varepsilon_{\text {offset }} \cdot \tan \theta
$$

dimana $\varepsilon_{\text {offset }}$ adalah offset Abbe dan $\theta$ adalah error angular.

Pada gamber 3 , suatu pengukuran yang menggunakan "tangan pengukuran" sepanjang $L$ dan mempunyai stylus untuk menyentuh permukaan suatu benda yan diukur. Pada pengukuran tersebut, sumbu pegerakan tidak berhimpit dengan sumbu pengukuran (yang pada umumnya berupa encoder linier), sehingga terdapat offset Abbe. Sehingga, ketika pengukuran bergerak ke arah kanan, terdapat error angular $\theta$ karena geometri suatu instrumen yang digunakan tidak sempurna. Dengan adanya offset Abbe tersebut, kesalahan pembacaan pada sumbu pengukuran teramplifikasi, sehingga menimbulkan error Abbe. Error Abbe tersebut meyebabkan panjang yang sebenarnya pada benda tersebut terbaca berbeda pada alat baca instrumen yang digunakan.

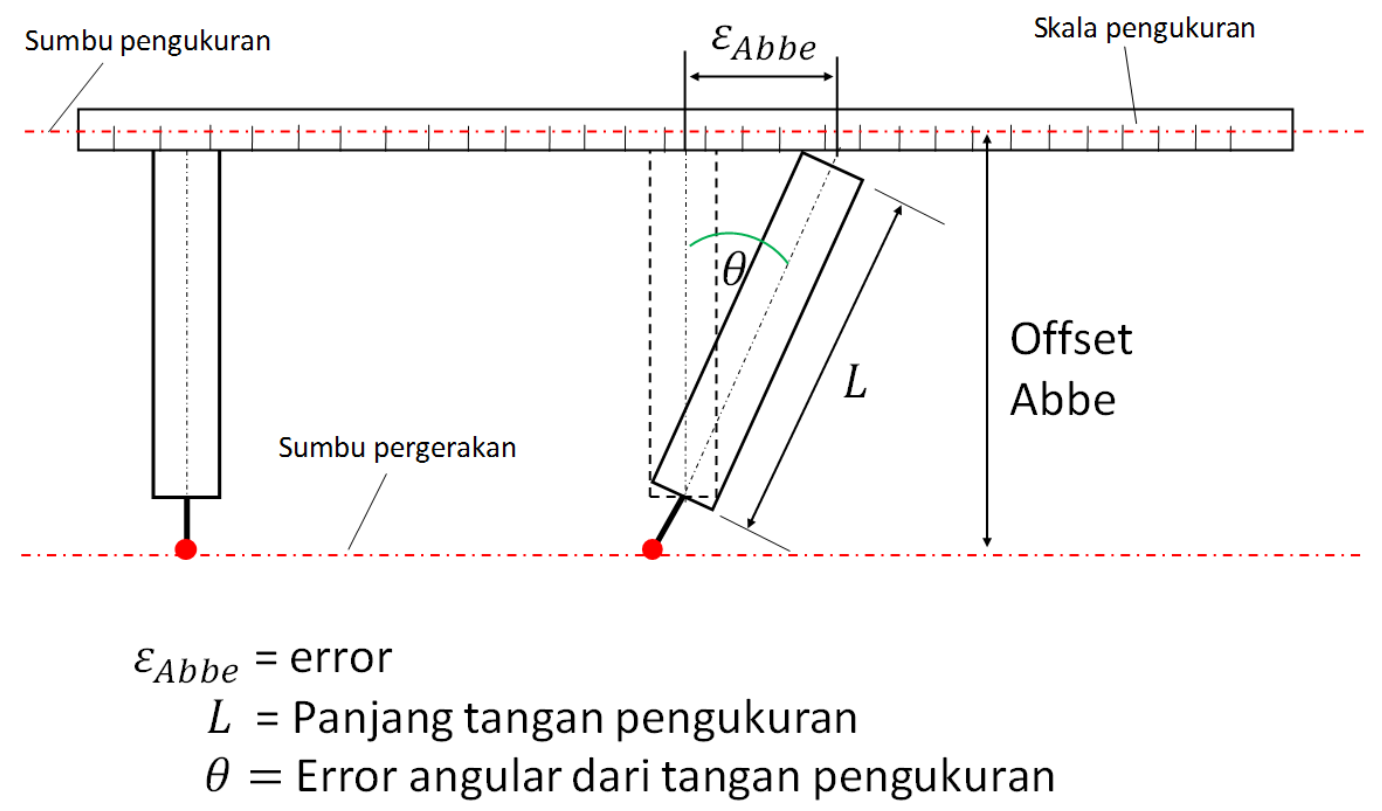

Gambar 3: Error Abbe dan offset Abbe. 


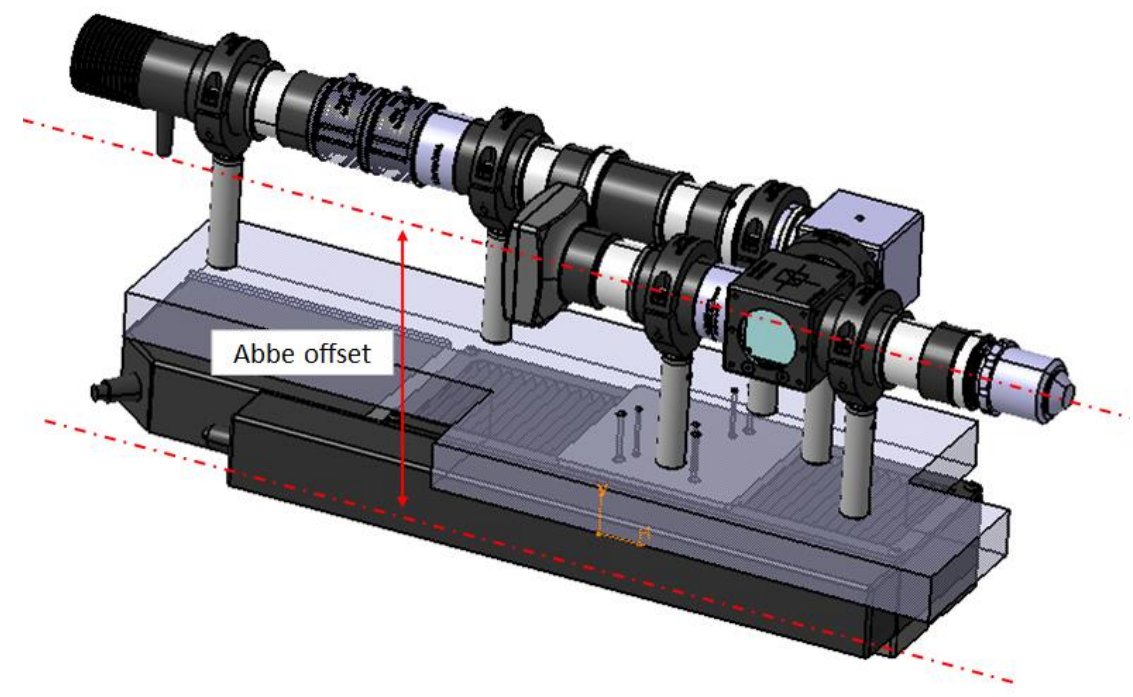

Gambar 4: Contoh riil error Abbe yang dimiliki oleh instrument pengukuran berbasis mikroskop. Sumbu sebelah atas adalah sumbu pergerakan dan sumbu sebelah bawah adalah sumbu pengukuran (encoder linier). Offset Abbe adalah jarak antara sumbu pergerakan dan sumbu pengukurna tersebut.

Contoh riil dari error Abbe yang terdapat pada suatu instrument pengukuran berbasis mikroskop diperlihatkan pada gambar 4. Pada gambar 4, sumbu pergerakan yang merupakan aksis optikal dari instrument tersebut tidak berhimpit dan mempunyai offset dengan sumbu pengukurannya yang merupakan encoder linier.

\subsubsection{Error sine dan error cosine}

Error sine dan cosine merupakan salah satu error pengukuran yang paling umum dan berhubungan dengan kesalahan penjajaran (alignment) pada suatu pengukuran (atau suatu instrumen pengukuran). Gambar 5 memperlihatkna ilustrasi dari error sine dan cosine. Error sine mempunyai kemiripan dengan error Abbe. Error cosine paling umum ditemukana pada suatu pengukuran menggunakan interferometri laser. Interferometri laser akan dijelaskan pada bagian berikutnya dalam bab ini.

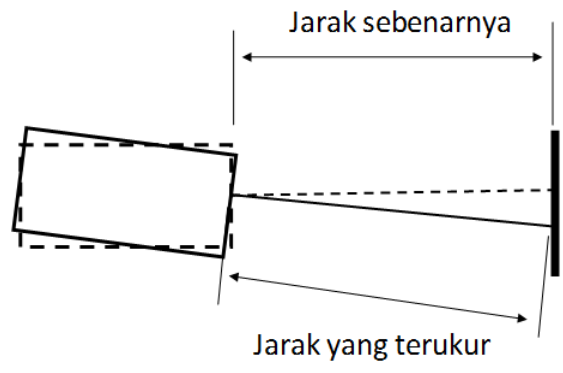

(a)

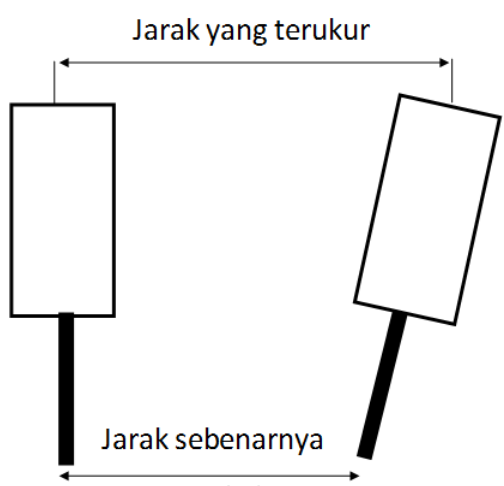

(b)

Gambar 5: (a) error cosine dan (b) error sine. 
Pada gambar 5, error cosine didapatkan pada suatu pengukuran dimana sumbu pergerakan dan sumbu pengukuran berhimpit. Tetapi, arah pengukuran tidak tegak lurus dengan suatu fitur yang diukur karena misalnya ada sedikit ketidaksejajaran antara suatu instrumen pengukuran pada saat proses setup instrumen tersebut. sedangkan, error sine adalah error yang serupa dengan abbe error.

\subsubsection{Error referensi dan datum}

Error referensi atau datum adalah error yang disebabkan karena kesalahan pemilihan datum pengukuran. Misalnya, sesuai dengan bab 3 mengenai toleransi geometri, apabila suatu toleransi geometri ingin diukur, misalnya pengukuran perpendicularity, maka hal pertama yang dilakukan adalah memilih datum. Apabila datum yang dipilih tidak sesuai dengan yang diberikan pada gambar tekninya, maka akan ada error tambahan pada hasil pengukuran perpendicularity tersebut.

Contoh lain adalah suatu pengukuran jarak. Untuk pengukuran suatu jarak, pada umumnya titik referensi harus ditentukan sebagai acuan seberapa besar jarak yang diukur tersebut. Apabila penentuan titik referensi tersebut tidak benar, maka jarak yang diukur adalah berbeda dengan jarak sebenarnya yang ingin diukur. Hal ini adalah untuk pengukuran absolut, yaitu pengukuran yang mempunyai titik awal atau referensi tetap.

\subsubsection{Error nol (Zeroing error)}

Error nol adalah error yang terjadi karena nilai bacaan awal suatu instrumen pengukuran mempunyai nilai yang bukan nol. Misalnya, suatu pengukuran panjang dengan menggunakan jangka sorong dijital, nilai bacaan pada jangka sorong tersebut harusnya bernilai nol. Apabila tidak bernilai nol, maka skala pembacaan jangka sorong dijital tersebut haruslah di-reset menjadi nol.

Apabila nilai bacaan jangka sorong tersebut tidak bernilai nol, misalnya $0.001 \mathrm{~mm}$, maka akan terdapat kesalahan tetap, yaitu nilai bacaan ter-offset-kan sebesar $0.001 \mathrm{~mm}$ untuk semua pengukuran yang menggunakan jangka sorong dijital tersebut pada kondisi tersebut. error yang disebabkan karena skala bacaan tidak di-reset menjadi nilai nol merupakan kesalahan yang sistematik dan bersifat tetap untuk setiap pengukuran.

\subsubsection{Efek misalignment}

Efek misalignment akan mengurangi tingkat akurasi suatu pengukuran karena efek tersebut akan terimplementasi dalam bentuk error sine dan atau error cosine. Efek misalignment adalah efek yang bisa disebabkan oleh beberapa sumber, baik yang berasal dari prosedur pengukuran yang dilakukan atau berasal dari suatu instrumen pengukuran yang digunakan. Sumber yang berasal dari prosedur pengukuran adalah misalnya kesalahan penempatan suatu benda kerja yang akan diukur, tidak tepat dalam mengkonfigurasi fixture yang digunakan untuk memegang benda kerja dan tidak tepatnya memilih koordinat benda kerja pada suatu pengukuran dengan CMM. Cara ideal untuk memegang part adalah dengan mengikuti konsep 3-2-1 (kontak 6 titik). Sedangkan sumber yang berasal dari instrument pengukuran adalah rusaknya permukaan anvil suatu mikrometer, rusaknya permukaan jangka sorong dan ketidaklurusan antara dua axis suatu alat gerak linier (linear motion stage).

\subsubsection{Efek kekasaran permukaan (roughness effect)}

Kondisi kekasaran permukaan suatu benda yang diukur mempengaruhi hasil pengukuran, terutama untuk pengukuran pada skala mikro dan yang lebih kecil. Pengukuran dengan CMM dengan stylus mikro akan dapat mengukur tingkat kekasaran permukaan, sehingga dapat mempengaruhi hasil pengukuran dimensi dan geometri dengan CMM tersebut. Misalnya, suatu pengukuran diameter silinder mikro menggunakan stylus mikro, maka hasil kalkulasi diameter silinder tersebut akan terpengaruh dengan kekasaran permukaan silinder tersebut. Selain itu, kekasaran permukaan sangat berpengaruh untuk pengukuran berbasis optik karena cahaya yang direfleksikan dari suatu permukaan benda yang diukur sangat dipengaruhi oleh kekasaran permukaan benda tersebut.

Ilustrasi dari efek kekasaran permukaan pada suatu pengukuran berbasis kontak maupun non-kontak diperlihatkan pada gambar 6. Pada gambar 6a, diperlihatkan suatu stylus mikro mengukur suatu permukaan datar. 
Karena permukaan tersebut tidak mulus, maka stylus mikro tersebut membaca data kekasaran permukaan tersebut, sehingga mengurangi tingkat akurasi pengukuran kedataran (flatness) permukaan benda tersebut. Pada gambar 6b, diperlihatkan efek kekasaran permukaan terhadap suatu pengukuran berbasis non-kontak (optik). Pada pengukuran berbasis non-kontak, pengukuran tersebut menggunakan cahaya yang diiluminasikan pada suatu permukaan benda yang diukur. Apabila permukaan benda tersebut sangat mulus, maka cahaya yang datang akan dipantulkan satu arah dan pantulan tersebut mengikuti hukum "Snell". Sedangkan, apabila permukaan tersebut kasar, maka cahaya yang datang akan dipantulkan menyebar ke berbagai arah. Pantulan cahaya yang menyebar tersebut akan mempengaruhi hasil pengukuran berbasis non-kontak (optik).

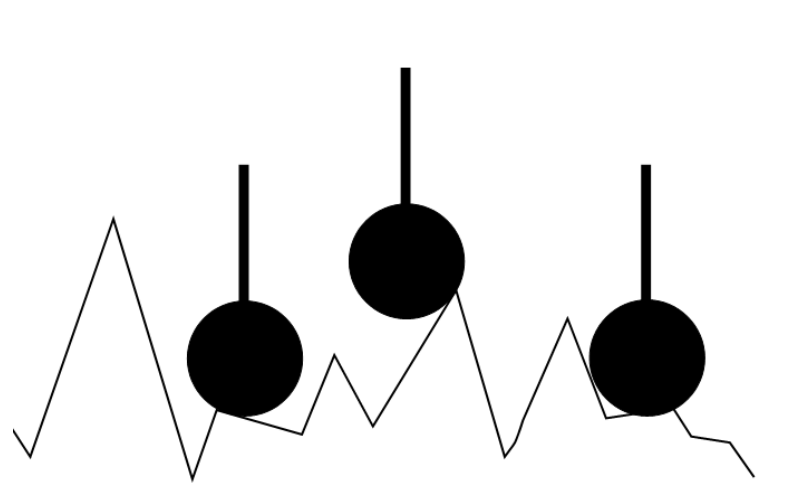

(a)
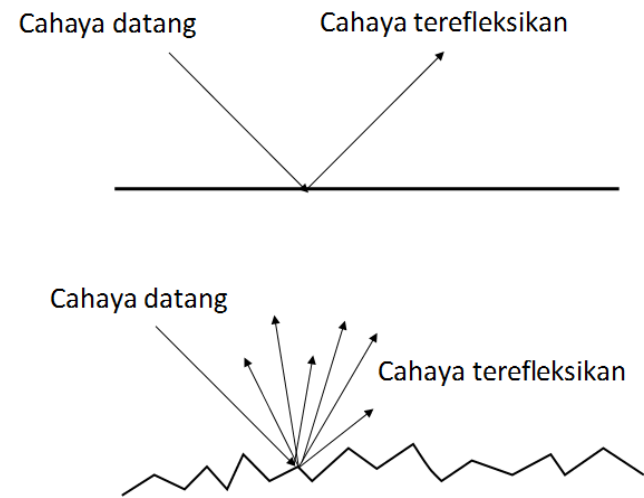

(b)

Gambar 6: (a) efek kekasaran permukaan pada pengukuran berbasis kontak dan (b) efek kekasaran permukaan pada pengukuran berbasis non-kontak (optik).

\subsubsection{Efek debu}

Pada pengukuran skala mikro atau yang lebih kecil, efek debu akan menyebabkan bacaan pengukuran menjadi salah. Misalnya, suatu pengukuran dengan menggunakan CMM dengan stylus, maka suatu debu yang menempel pada stylus mikro tersebut akan mengurangi akurasi hasil pengukuran karena debu tersebut berada di antara stylus tersebut dan suatu permukaan benda kerja yang diukur. Gambar 7 memperlihatkan efek debu akan menyebabkan sensor suatu CMM menandakan stylusnya sudah menyentuh permuukaan suatu benda kerja, padahal pada kondisi riilnya, stylu stersebut belum menyentuk permukaan benda tersebut, sehingga menyababkan kesalahan pengukuran. Maka dari itu, kebersihan suatu instrumen pengukuran dan suatu benda yang diukur harus dijaga untuk mendapatkan hasil penukuran yang akurat.
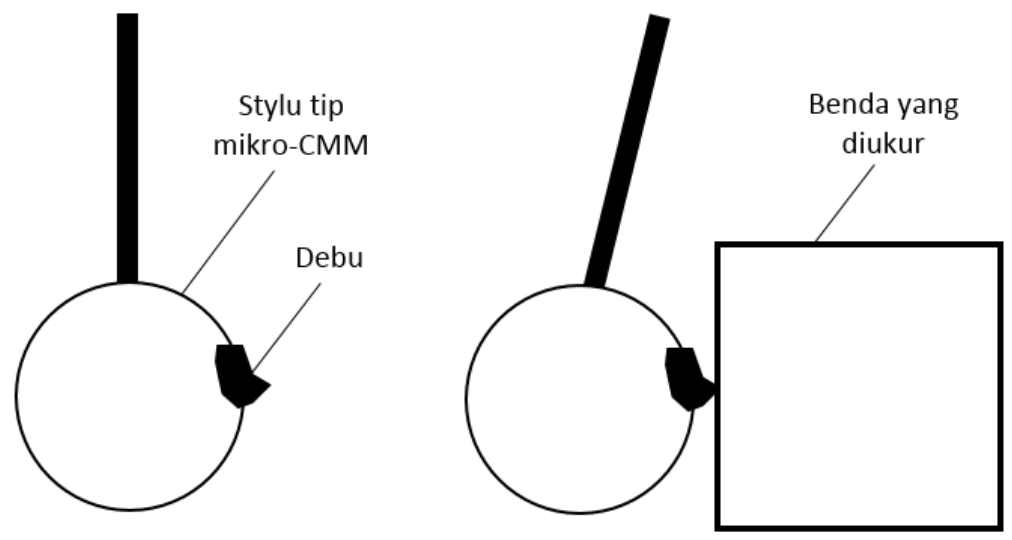

Gambar 7: efek debu pada pengukuran dengan CMM yang dilengkapi dengan stylus berukuran mikro. 


\subsubsection{Error struktur instrumen pengukuran}

Error yang berasal dari suatu instrument pengukuran mempunyai kontribusi yang besar pada jumlah total error yang terdapat pada suatu hasil pengukuran. Pada umumnya, untuk mengurangi error yang berasal dari struktur suatu instrumen, diperlukan komponen dengan tingkat akurasi dan presisi yang tinggi, sehingga biaya produksi untuk komponen-komponen tersebut menjadi mahal. Hal ini yang menjadi penyebab utama mengapa suatu instrumen pengukuran mempunyai harga yang sangat tinggi. Jenis error struktur yang akan dibahas singkat pada bab ini meliputi: error geometri, deviasi dari desain kinematik, dinamika struktur, material, epansi termal, deformasi struktur dan kompresi elastik, simetri, loop struktur. Namun demikian, Pada bab ini, error-error yang berasal dari struktur suatu instrumen pengukuran dijelaskan secara singkat. Untuk lebih detilnya, pembaca bisa merujuk pada (Leach 2010, Slocum 1992 dan Mekid 2009).

\section{- $\quad$ Error geometri}

Komponen utama dari suatu instrumen pengukuran dimensi dan geometri adalah penggerak aksis yang membawa sensor untuk mengukur suatu benda. Error geometri dari penggerak aksis tersebut secara langsung mempengaruhi hasil pengukuran dimensi dan geometri. Pada kondisi riil, error-error geometri tersebut adalah pada skala mikro atau bahkan lebih kecil lagi. Walaupun error geometri aksis tersebut berada dalam skala mikro atau kurang, untuk pengukuran yang membutuhkan presisi yang sangat tinggi, baik pengukuran makro dan mikro, error-error tersebut sangat berpengaruh. Selain itu, error-error tersebut juga sangat mempengaruhi ketidakpastian suatu hasil pengukuran, sehingga akan berakibat sangat merugikan untuk jenis-jenis penukuran yang mempunyai toleransi yang sangat kecil, walaupun benda yang diukur mempunyau ukuran makro, sebagai contoh komponen pesawat terbang yang memiliki dimensi besar, tetapi mempunyai toleransi yang sangat kecil.

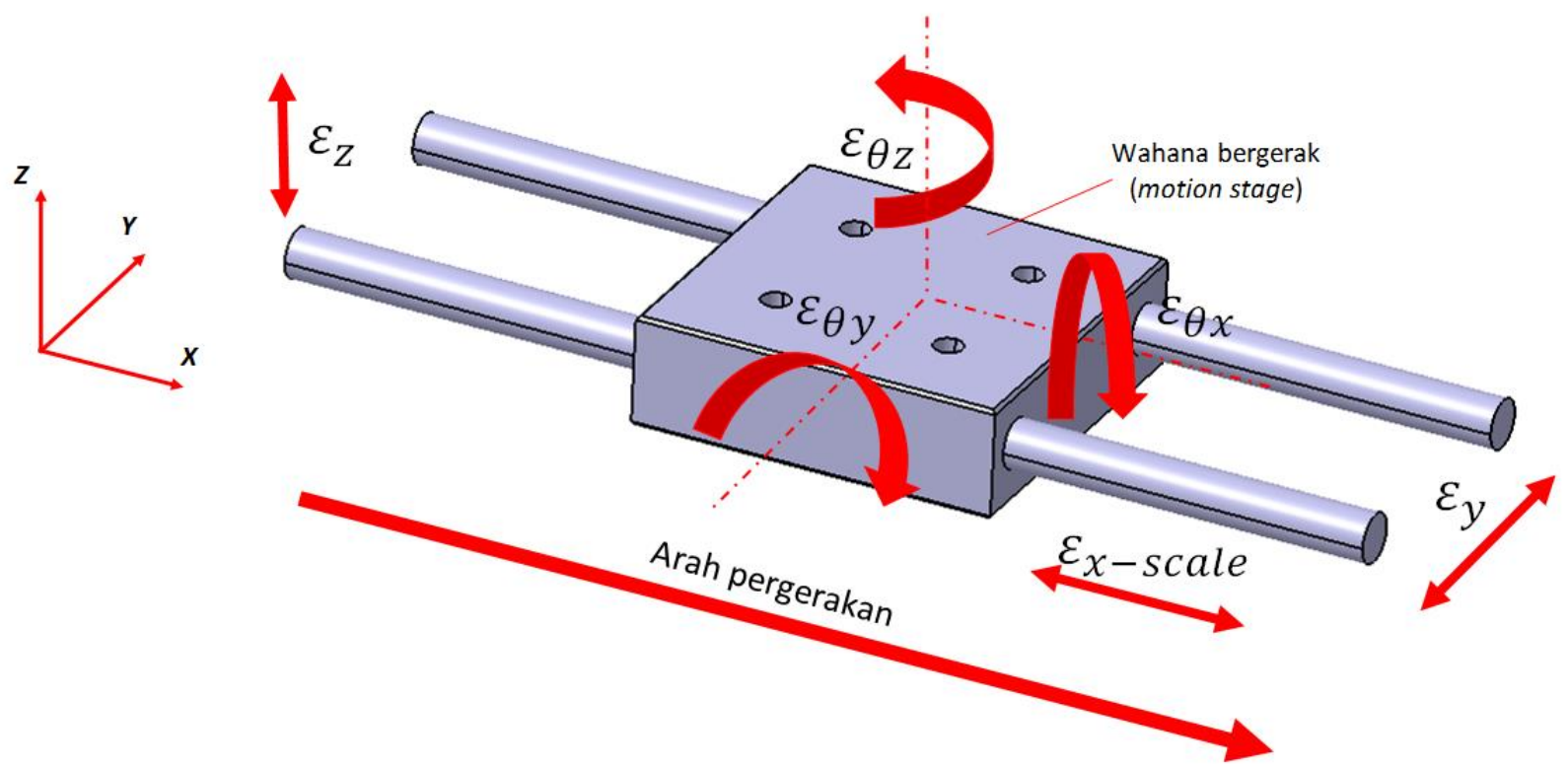

Gambar 8: Enam jenis error untuk setiap aksis pergerakan: satu error skala, dua error straighness dan tiga error rotasi (roll, pitch dan yaw).

Untuk setiap aksis pergerakan, terdapat enam jenis error geometri yang selalu ditemukan pada kondisi riil, yaitu satu error skala, dua error straighness dan tiga error rotasi. Gambar 8 memperlihatkan enam jenis error tersebut. Pada gambar 8 , diperlihatkan contoh sebuah aksis pergerakan pada sumbu $-x$. Untuk sumbu-x, error skala terdapat pada arah pergerakan aksis, yaitu sumbu- $x\left(\varepsilon_{x-\text { scale }}\right)$. Dua error straigness adalah pada arah sumbu- $y\left(\varepsilon_{y}\right)$ dan $-z\left(\varepsilon_{z}\right)$. 
Dan terakhir, tiga error rotasi adalah error rotasi terhadap sumbu $-x\left(\varepsilon_{\theta x}\right),-y\left(\varepsilon_{\theta y}\right)$ dan $-z\left(\varepsilon_{\theta z}\right)$. Error geometri untuk aksis lainnya adalah tetap memiliki enam komponen error hanya berbeda pada arah error-nya saja.

Pada umumnya, alat-alat pengukuran dimensi dan geometri untuk 3D membutuhkan minimal konfigurasi tiga aksis pergerakan (3-axes configuration), yaitu pergerakan pada sumbu- $x,-y$ dan $-z$. Untuk sebuah instrumen dengan tiga aksis pergerakan, total error geometri yang berasal dari ketiga aksis tersebut adalah total sebanyak 21 error. Total 21 error tersebut adalah enam error untuk masing-masing aksis seperti gambar 8 (total 18 error) dan tiga error perpendicularity (ketegaklurusan) antara aksis $X Y, X Z$ dan $Y Z$. Untuk mengurangi error-error geometri tersebut, dua cara dapat digunakan, yaitu dengan membuat geometri komponen penyusun aksis-aksis seakurat mungkin dengan biaya sangat tinggi atau dengan kompensasi error yang pada umumnya membutuhkan biaya yang jauh lebih rendah. Kompensasi error adalah sebuah metode untuk mengkuantifikasi error-error pada suatu aksis kemudian mengkompensasinya secara numerik, biasanya melalui perangkat lunak (software) yang mengontrol pergerakan instrumen tersebut, untuk mengkoreksi error-error tersebut. cara ini pada umumnya digunakan untuk instrumeninstrumen pengukuran komersial, seperti CMM. Bab 8 akan membahas detil mengenai kompensasi error.

\section{- Deviasi dari desain kinematik}

Sebuah instrument pengukuran pasti terdiri dari banyak komponen yang dirakit menjadi suatu kesatuan sistem yang berfungsi. Kondisi ideal untuk menyambung dua komponen yang berbeda adalah dengan menggunakan metode paksaan kinematik (kinematic constraint). Paksaan kinematik merupakan bagian dari keimuan desain kinematik.

Suatu sambungan, idealnya hanya membatasi atau menahan komponen tersebut agar tidak bergerak pada arah selain dari arah yang diinginkan untuk bergerak. Misalnya, sebuak aksis yang bergerak pada sumbu- $x$ haruslah bergerak hanya pada arah sumbu- $x$ dan tidak dapat bergerak (rigid) pada arah lainnya. Sebuah sambungan yang baik adalah sambungan yang bisa menahan komponen-komponen untuk tidak bergerak ke arah selain dari arah yang diinignkan dan tidak memberikan beban (force) tambahan pada komponen-komponen tersebut (Slocum 1992).

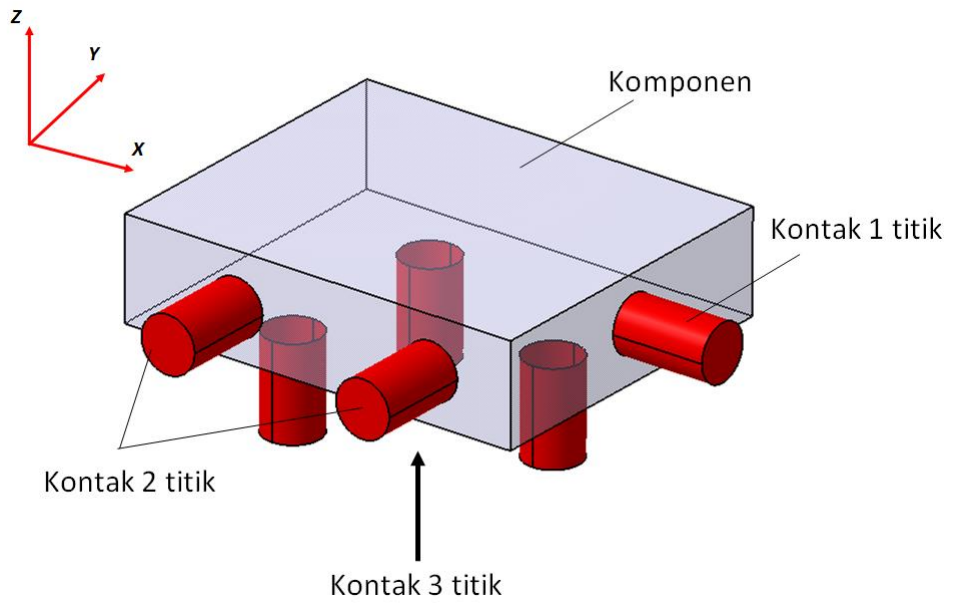

Gambar 9: paksaan kinematik (kinematic constraint

Apabila suatu sambungan bertujuan untuk menahan komponen-komponennya agar tidak bergerak ke segala arah, maka sambunagn ideal adalah sambungan yang menerapkan paksaaan kinematik. Paksaan kinematik adalah paksaan yang menahan suatu komponen pada enak-titik seperti yang diperlihatkan gambar 9. Pada gambar 9, suatu paksaan kinematik yang terdiri dari 6 titik dibagi-bagi sebagai berikut:

- 3-titik pada bagian bawah komponen (permukaan yang paling staibil atau luas).

Paksaan ini akan menahan suatu komponen untuk 1 arah pererkaan linier (sumbu-z) dan 2 arah pergerakan rotasi (rotasi terhadap sumbu- $x$ dan $-y$ ). 
- 2-titik pada bagian samping yang panjang.

Paksaan ini akan menahan suatu komponen untuk 1 arah pergerakan linier (sumbu-y) dan 1 arah pergerakan roatsi (terhadap sumbu-z)

- 1-titik pada bagian samping yang pendek.

Paksaan ini akan menahan suatu komponen untuk 1 arah pergerakan linier (sumbu- $x$ )

Perlu diingat bahwa paksaan untuk 3- dan 2-titik harus diposisikan sedemikain rupa sehingga bisa menjangkau area yang luas pada permukaan yang ditahannya agar mempunyai tingkat stabilitas yang baik. Pada kondisi riil, kontak titik tidaklah praktis karena akan menyebabkan tekan permukaan yang besar, sehingga pada kondisi riil, paksaan pada umumnya mempunya bentuk sehingga bagian yang menyentuh permukaan berupa garis (bukannya titik).

Setiap sambungan yang terdeviasi dari konfigurasi paksaan kinematik akan menyebabkan beban tambahan terhadap komponen-komponen yang disambungnya, sehingga bisa menyebabkan deformasi pada skala mikro dan menyebabkan error geometri pada komponen-komponen tersebut. Namun demikian, pada kondisi tertentu, deviasi dari paksaan kinematik pada suatu komponen dengan lebih dari 6 titik (over-constraint) diperlukan untuk menambah tingkat kekakuan (stiffness) dari komponen tersebut (slocum 1992), contohnya adalah pre-load bearing dan planetary gear.

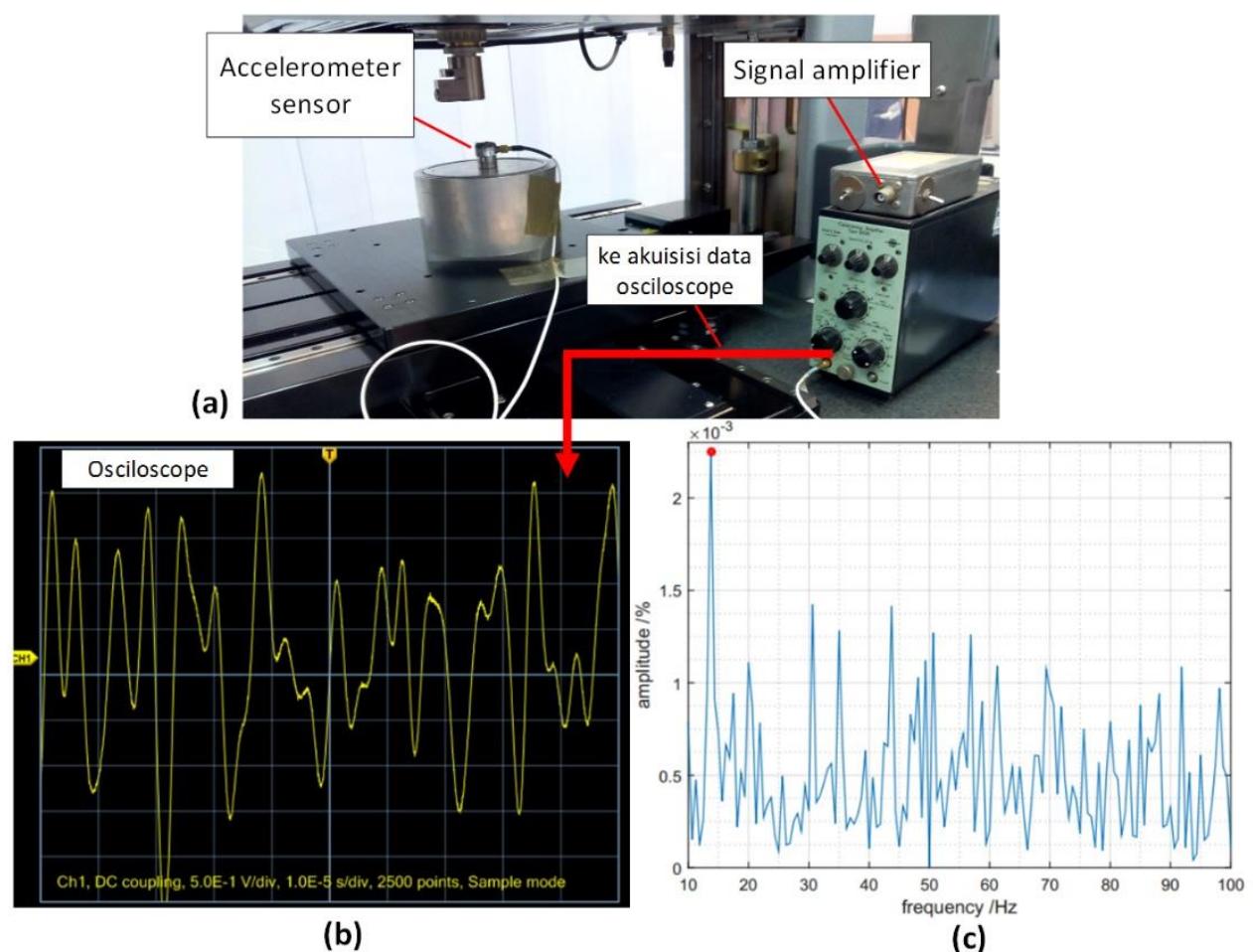

Gambar 10:

\section{- Dinamika struktur dan vibrasi}

Pada suatu pengukuran dengan tingkat akurasi yang sangat tinggi, efek vibrasi lingkungan sangat berpengaruh kepada hasil pengukuran walaupun besarnya vibrasi tersebut sangat kecil, seperti vibrasi yang berasal dari lantai (ground vibration). Bahkan, pada suatu laboratorium dengan kondisi terkontrolpun masih terdapat vibrasi yang dapat menggangu suatu proses pengukuran dengan tingkat akurasi yang sangat tinggi (Barker et al 2016). Masalah vibrasi bukanlah hal yang mudah untuk diatasi, apalagi kalau vibrasi tersebut merupakan vibrasi dengan banyak arah (lebih dari dua derajat kebebasan) dan merupakan vibrasi multi-modal (Schmitz and Smith 2012). Vibrasi juga disebabkan 
karena dinamika struktur suatu instrument pengukuran, yaitu yang disebabkan oleh percepatan (acceleration) dan perlambatan (deceleration) dari instrument tersebut.

Gambar 10 memperlihatkan suatu pengukuran vibrasi dengan menggunakan sensor accelerometer dan hasil bacaan pengukuran tersebut. Pada gambar 10a, sebuah pengukuran vibrasi dengan metode kontak menggunakan sebuah accelerometer diperlihatkan. Setiap pergerakan sekecil apapun akan dikonversi menjadi suatu arus listrik dengan kekuatan yang sangat kecil, sehingga sebuah signal amplifier dibutuhkan untuk dapat membaca data hasil dari pergerakan tersebut oleh sebuah osciloscope (gambar 10b). Pada gambar 10c, analisis signal hasil pengukuran vibrasi tersebut dianalisis dalam domain frekuensi, sehingga komponen-komponen setiap signal dalam data getaran tersebut dapat dianalisis. Tipe analisis tersebut berguna untuk menginvestigasi dari mana sumber getaran yang terjadi tersebut. ada beberapa metode lain yang digunakan untuk mengukur suatu vibrasi atau getaran, seperti inductance sensor dan vibrometer laser (Schmitz and Smith 2012).

\section{- Material}

Jenis material yang digunakan sebagai struktur sebuah instrumen pengukuran sangatlah mempengaruhi tingkat akurasi instrumen pengukuran tersebut. Jenis material yang dipilih harus dapat menahan beban dari struktur instrument tersebut dan beban dari benda-benda yang akan diukurnya. Apabila material yang digunakna tidak cukup kuat, maka akan terdapat deformasi elastik, dan bahkan, deformasi plastik ketika suatu benda diletakkan pada meja suatu instrumen pengukuran. Sehingga, deformasi tersebut akan menyebabkan error (pada umumnya error sine dan cosine) pada instrumen tersebut dan mengurangi tingkat akurasi dari hasil pengukuranya.

\section{- Expansi termal}

Setiap pengukuran dimensi sebuah benda yang dilakukan pada suhu selain suhu standar yaitu pada $20^{\circ} \mathrm{C}$, maka hasil pengukuran tersebut harus dikoreksi terhadap suhu standar tersebut sesuai dengan koefisien ekspansi termal material benda yang diukur tersebut (Leach 2010, Mekid 2009). Setiap material, apabila berada pada temperatur > $20{ }^{\circ} \mathrm{C}$, material tersebut akan terekspansi. Sedangkan, setiap material, apabila berada pada temperatur $<20{ }^{\circ} \mathrm{C}$, material tersebut akan mengecil.

Ekspansi material langsung dipengaruhi oleh jenis material yang digunakan. Idealnya, material yang digunakan untuk merekonstruksi suatu instrumen pengukuran adalah material yang mempunya koefisein ekspansi termal nol. Material Zerodour mempunyai koefisein ekspansi termal yang paling dekat dengan nol, namun material ini mempunyai harga yang sangat mahal, sehingga tidak cocok digunakan untuk instrumen-instrumen komersial karena harga jual instrumennya akan sangat tinggi. Material yang paling sering digunakan untuk merekonstruksi instrumeninstrumen pengukuran adalah: Invar ( $\alpha=$ koefisien ekspansi termal $\left./ \mu \mathrm{m} \cdot \mathrm{m}^{-1}=0.8 /{ }^{\circ} \mathrm{C}\right), 440 \mathrm{C}$ stainless steel $\left(\alpha=10.2 /{ }^{\circ} \mathrm{C}\right)$ dan Aluminium alloy cast $201\left(\alpha=19.3 /{ }^{\circ} \mathrm{C}\right)$. Salah satu cara untuk mengurangi efek ekspansi termal adalah dengan menggunaka konsep bi-material, dimana dua jenis material yang berbeda didempetkan satu sama lain untuk saling mengkompensasi termal ekspansi yang terjadi pada material tersebut.

\section{- Deformasi struktur dan kompresi elastik}

Setiap benda pejal yang diberikan beban akan mengalami kompresi, walaupun beban yang diberikan sangat kecil. Sehingga, setiap instrumen pengukuran akan mengalami kompresi yang termanifestasi dalam bentuk dformasi elastik, dalam skala mikro atau nano. Kompresis tersebut berasal dari struktur instrumen itu sendiri, walaupun belum ada beban dari sebuah benda yang akan diukur. Deformasi yang kecil tersebut akan menyebabkan suatu error geometri pada instrumen tersebut.

Maka dari itu, setiap deformasi struktur yang terdapat pada setiap instrumen pengukuran harus sudah diestimasi sehingga error geometri yang dihasilkan akan dapat dikoreksi untuk mendapatkan suatu hasil pengukuran yang sangat akurat. Metode yang paling umum untuk mengestimasi deformasi tersebut adalah dengan menggunakan simulasi elemen hingga. Gambar 11 memperlihatkan contoh dari analisis elemen hingga untuk mengetahui besarnya deformasi elastik pada suatu struktur instrumen pengukuran. 


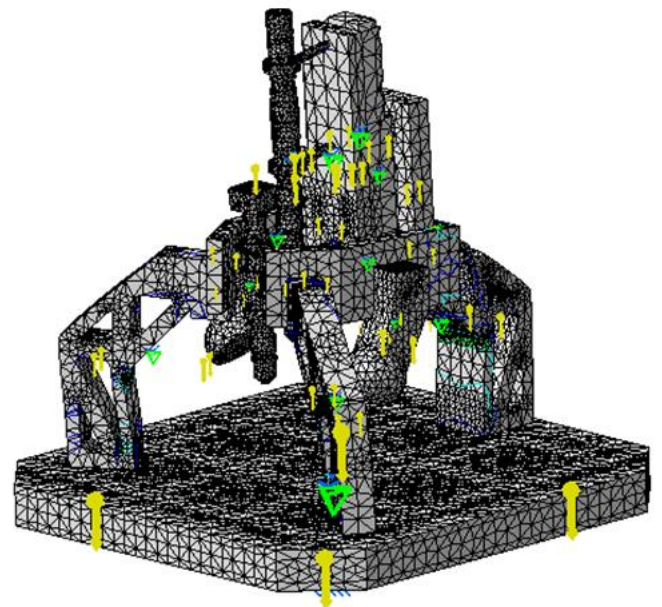

Gambar 11: Simulasi berbasis elemen hingga untuk mengetahui besarnya deformasi statik sebuah struktur instrumen pengukuran.

\section{- $\quad$ Simetri}

Desain struktur simetri mempunyai keuntungan yang bisa mengurangi error geometri suatu instrumen pengukuran. Keuntungan disain simetri adalah seperti distribusi beban yang merata. Selain itu, dengan menggunakan metode desain simetri, pusat termal dan pusat rotasi suatu struktur dapat dibuat berhimpit, sehingga apabila terjadi ekspansi termal, maka error geometri yang muncul dapat diminimalisasi atau dihilangkan. Sebagai contoh seperti yang diperlihatkan pada gamabr 12. Pada gambar 12, desain yang diperlihatkan memiliki simterisitas sehingga pusat termal dan pusat rotasi berhimpit satu sama lain, sehingga apabila terjadi ekspansi termal, maka error geometri yang menyebabakan perpindahan pada bidang $X Y$ dapat diminimalisasi atau dihilangkan.

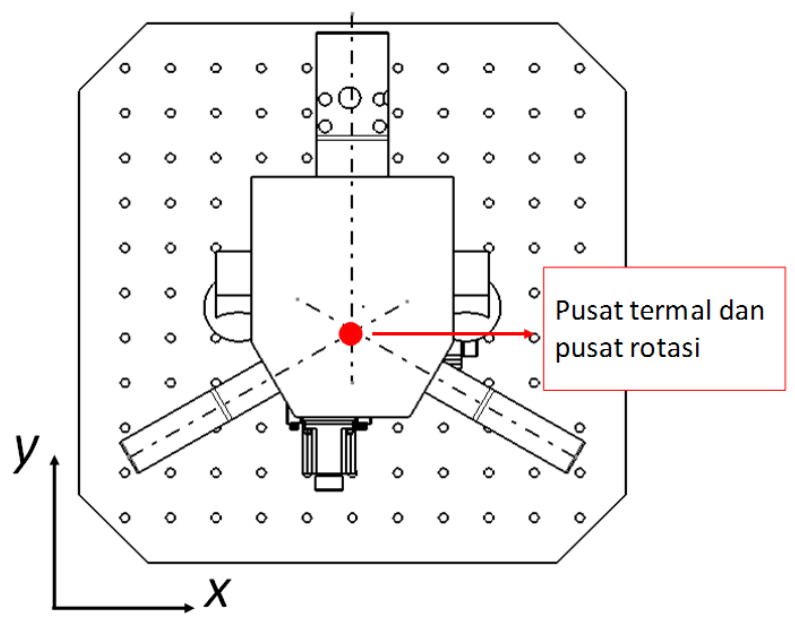

Gambar 12: Keuntunga desain simteri sehingga pusat termal dan pusat rotasi berhimpit pada titik yang sama. 


\section{- Siklus gaya (force loop)}

Struktur suatu instrumen pengukuran mempunyai tiga jenis siklus gaya (force loop), yaitu siklus struktur (structural loop), siklus pengukuran (metrology loop) dan siklus termal (thermal loop). Ketiga siklus tersebut bisa sama satu dengan lainnya atau pun berbeda (Leach 2010). Kondisi idealnya, desain suatu instrumen yang diinginkan adalah siklus pengukuran terpisah dengan siklus struktur dan siklus termal. Karena, apabila siklus struktur dan termal terpisah dari siklus metrologinya, maka efek-efek error geometri, seperti deformasi statik, dan efek-efek ekspansi termal terhadap keakuratan proses pengukuran akan dapat diminimalisasi.

Siklus struktur adalah sebuah siklus (path) gaya yang melewati susunan dari komponen-komponen mekanik yang menentukan posisi relatif antara dua objek, misalnya antara sebuah stylus dengan sebuah benda yang diukur. Siklus termal adalah sebuah siklus yang melewati susunan dari komponen-komponen mekanik yang menentukan posisi relatif antara dua objek yang terpengaruhi oleh perubahan temperatur. Siklus metrology adalah siklus yang melewati komponen-komponen mekanik yang merupakan referensi untuk membaca suatu perpindahan (siklus yang melewati semua elemen antara sebuah sensor dan benda kerja yang mempengaruhi proses pengukuran). Dalam kondisi riilnya, siklus metrology adalah siklus yang melewati encoder, baik linear maupun rotasi, yang memnaca perbindahan suatu aksis yang bergerak. Gambar 13 memperlihatkan suatu desain yang mempunyai siklus metrology dan siklus struktur yang terbisah, sehingga apabila ada deformasi statik pada struktur tersebut karena beban dari suatu benda kerja yang diukur, maka deformasi tersebut tidak akan mempengaruhi pengukuran dengan instrumen tersebut. tetapi, desain tersebut masih mempunyai siklus termal yang berhimpit dengan siklus struktur dan metrologi, sehingga setiap ekspansi termal akan mempengaruhi proses pengukuran dengan instrumen tersebut.

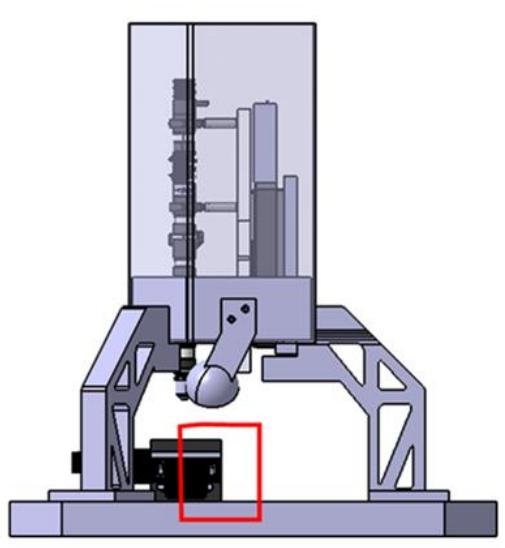

Siklus struktur (structural loop)

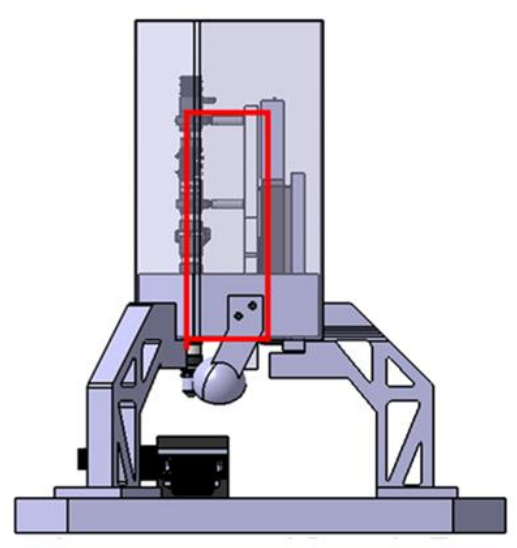

Siklus pengukuran (metrology loop)

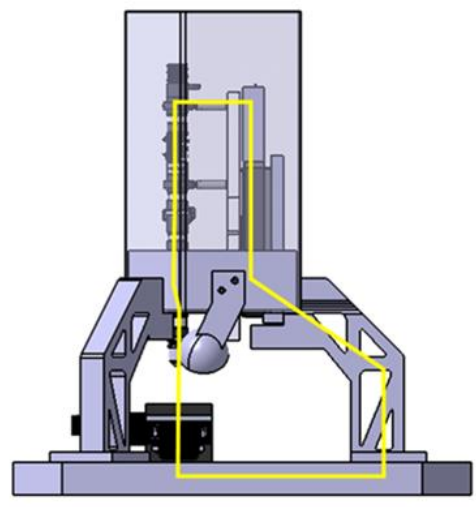

Siklus termal (thermal loop)

Gambar 13: Jenis-jenis siklus gaya (force loop) pada struktur instrumen pengukuran: siklus struktur, siklus pengukuran dan siklus termal.

\subsubsection{Error pengontrolan instrumen pengukuran}

Suatu instrumen pengukuran yang mempunyai tingkat akurasi tinggin pasti menggunakan teknik kompensasi error. Teknik kompensasi error terdiri dari dua macam: off-line dan on-line. Sistem kompensasi error dengan metode off-line dilakukan dengan cara mengkuantifikasi error sistematik (systematic error) suatu instrumen dengan proses kalibrasi dengan nilai ketidakpastian tertentu. Metode ini umum digunakan untuk meningkatkan nilai akurasi suatu instrumen dengan mengkompensasi, misalnya error geometri instrumen tersebut.

Namun demikian, dengan kompensasi error secara off-line, hanya error sistematik yang dapat dikompensasi dan dikoreksi, sedangkan error acak (random error) tidak dapat dikompensasi dengan metode off-line. Error acak hanya 
dapat dikompensasi dengan menggunakan metode kontrol real-time dan close -loop. Metode kontrol real-time adalah suatu metode kontrol posisi yang membaca posisi komponen (dalam hal ini wahana pergerakan/motion stage) pada saat itu dan memberikan informasi balik ke kontroler untuk segera mengkoreksi posisi komponen tersebut agar sesuai dengan posisi yang diinginkan. Hal ini adalah proses yang tidak mudah. Untuk kontrol posisi dengan akurasi mikro atau lebih kecil, dinamika dari instrumen, kerena percepatan dan perlambatan, membuat proses kontrol tersebut sangat sulit sehingga, pada kondisi akhir, posisi komponen yang bergerak masih berbeda dari posisi yang diinginkan, walaupun hanya dalam besaran yang sangat kecil, misalnya sub-mikrometer. Hal ini merupakan salah satu kontributor pada total error suatu prosess pengukuran.

\subsubsection{Error non-teknis}

Error non-teknis adalah error yang disebabkan kesalahan operator atau orang yang melakukan suatu pengukuran dengan suatu instrumen tertentu. Jenis error non-teknis yang paling sering terjadi adalah error pembacaan dan error paralaks. Maka dari itu, pelatihan yang baik dan proses suatu pengukuran harus diterapkan oleh orang yang melakukan pengukuran tersebut.

Error pembacaan adalah error yang terjadi karena operator atau seseorang salah membaca hasil pengukuran dari suatu instrumen, misalnya kesalahan pembacaan skala jangka sorong atau mikrometer. Untuk mengurangi hal ini, skala pembacaan berbasis dijital digunakan pada instrumen-instrumen pengukuran.

Error paralaks adalah error yang terjadi karena penglihatan tidak tegak lurus terhadap skala pembacaan suatu instrumen pengukuran, dengan kata lain, seseorang membaca skala pengukuran dari sudut tertentu. Hal ini paling sering terjadi pada instrument yang skala pembacaannya berupa garis-garis skala, seperti penggaris, jangka sorong dan mikrometer. Selain itu, error paralaks juga dapat disebabkan karena seseorang atau operator yang membaca suatu skala pengukuran memakai kacamata sehingga terjadi paralaks terhadap hasil bacaan skala pengukuran tersebut.

\subsection{Jenis-jenis alat ukur dimensi dan geometri}

Pada bagian ini, berbagai macam instrumen pengukuran dimensi dan geometri yang selalu atau paling umum ditemukan di industri-industri dibahas. Bukan hanya berbagai macam instrumen pengukuran, tetapi juga beberapa perlengkapan pembantu untuk mendukung fungsi dari suatu instrumen pengukuran akan dibahas.

\subsubsection{Standar End dan standar line}

Pengukuran dimensi dan geometri bermula dengan standar end dan standar line. Pentingnya standar untuk pengukuran dimensi dan geometri (dan untuk pengukuran tekstur permukaan) adalah:

- Sebagai nilai referensi untuk mengkomparasi atau memverifikasi hasil suatu pengukuran, sehingga menghasilkan sebuah hasil pengukuran yang bermakna.

- Sebagai nilai satuan terdefinisi yang disepakati secara internasional.

- Sebagai referensi untuk keterlacakan ke definisi “meter" yang telah ditetapkan oleh GCWM pada tahun 1983 (lihat bab 1).

Gambar 14 memperlihatkan contoh riil dari standar line dan standar end. Pada gambar 14a, bentuk dari standar line adalah seperti penggaris yang digunakan sehari-hari. Akan tetapi, standar line mempunyai skala dengan tingkat akurasi yang sangat tinggi dan terbuat dari material yang sangat stabil dalam jangka waktu yang sangat lama. Sedangkan standar end, bentuk dari standar end adalah gauge block yang mempunyai berbagai macam panjang ynag bisa dikombinasikan (wringing) untuk menghasilkan suatu panjang tertentu. Kedua standar tersebut terkalibrasi pada suatu kondisi pengukuran terkontrol dengan temperatur sekitar $(20 \pm 0.5){ }^{\circ} \mathrm{C}$ atau dengan variasi temperatur yang lebih kecil lagi. 


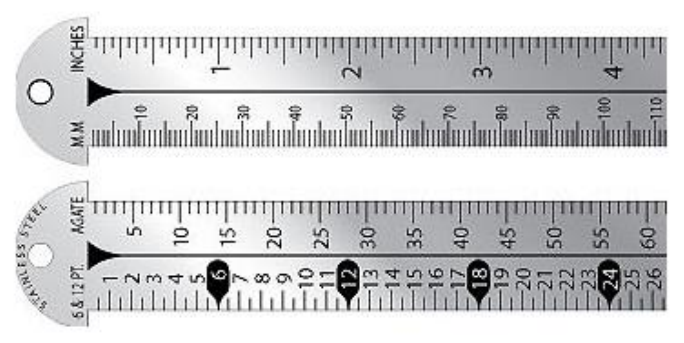

(a)

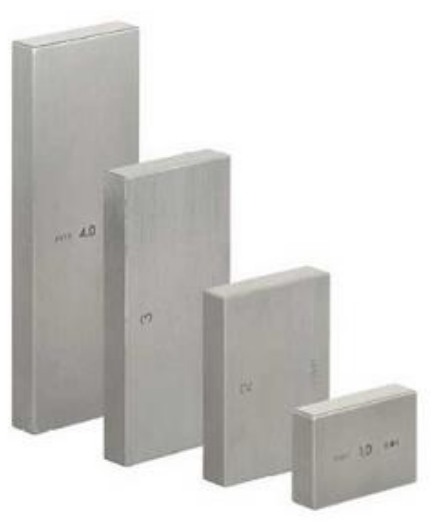

(b)

Gambar 14: (a) Standar line dan (b) standar end. Kedua standar ini (dan berbagai macam standar lainnya untuk pengukuran dimensi dan geometri) dikalibrasi pada teperatur $(20 \pm 0.5)^{\circ} \mathrm{C}$.

\section{Standar end.}

Standar end adalah suatu standar panjang yang menggunakan jarak antara dua permukaan datar yang saling paralel untuk mengukur suatu panjang, contohnya gauge block dan slip gauge. Standar end adalah standar yang sangat akurat dan sangat cocok untuk suatu pengukuran dengan tingkat toleransi yangs sangat ketat. Kedua permukaan datar tersebut akna menjadi aus seiring dengan waktu penggunaan standar tersebut karena adanya gaya gesekan denagn permukaan suatu benda yang diukur.

Penggunaan standar end, misalnya gauge block, untuk mengukur suatu panjang membutuhkan waktu yang lama karena sebuah standar end hanya mengukur satu jenis dimensi pada satu waktu dan apabila dimensi yang akan diukur tidak tersedia oleh salah satu standar end, maka standar end tersebut harus dikombinasikan untuk dapat mengukur panjang yang diinginkan tersebut. proses kombinasi tersebut merupakan salah satu sumber error dan merupakan sumber ketidakpastian dari hasil pengukuran dengan menggunakan metode kombinasi tersebut.

Kelebihan standar end adalah standar tersebut memiliki datum yang terintegarsi, yaitu datum yang berasal dari kedua permukaan datar yang saling paralel tersebut. kemudian, standar ini tidak mempunyai error paralaks yang terdapat pada standar line. Akurasi dari standar end dapat mencapai tingkat sub-mikrometer, sehingga cocok digunakna untuk pengukuran panjang dengan tingkat toleransi yang sangat ketat.
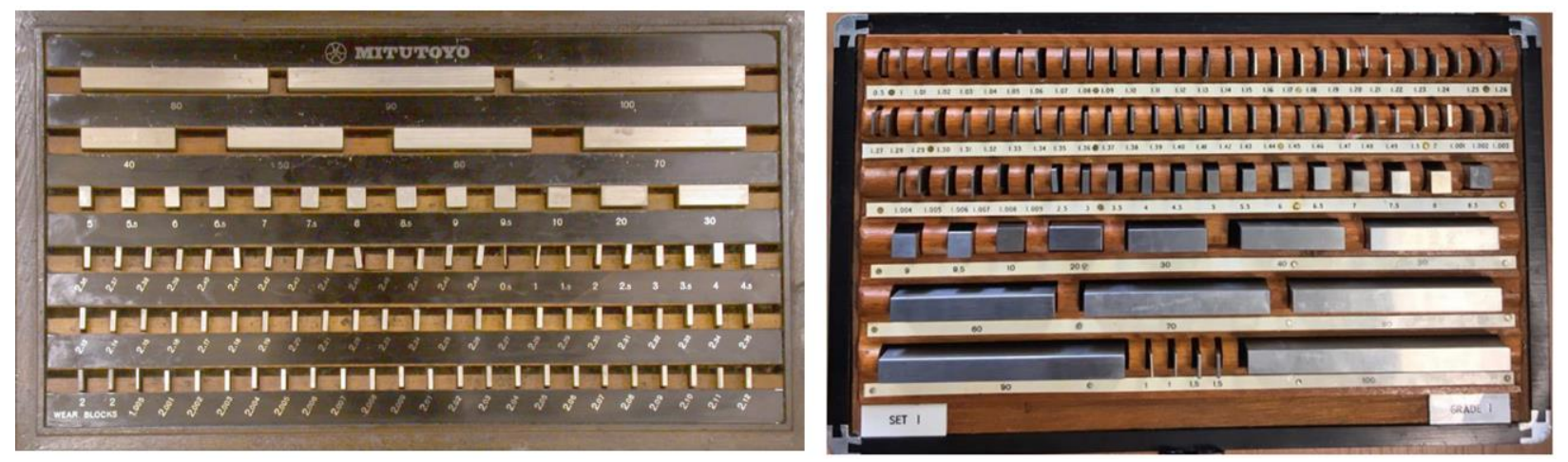

Gambar 15: contoh dari set standar end berupa gauge block yang memiliki berbagai macam panjang yang dapat saling dikombinasikan untuk menghasilkan panjang yang lain. 
Gambar 15 memperlihatkan contoh standar end berupa gauge block dalam suatu kesatuan set yang terdiri dari berbagai macam jenis satuan panjang. Pada kondisi riil di lantai produksi, para teknisi selalu menggunakan gauge block untuk mengukur panjang dan mengeset alat-alat permesinan agar mempunyai konfigurasi yang presisi sebelum suatu proses permesinan dimulai.

Proses manufaktur dan kalibrasi standar end berupa gauge block menggunakan suatu metode yang diajukan oleh AJC Brookes pada tahun 1920. Proses tersebut menggunakan sebuah standar master yang jauh lebih akurat dari gauge block yang akan dimanufaktur dan dikalibrasi sebagai referensi. Standar referensi tersebut adalah master gauge block dengan tingkat akurasi yang tinggi. Gambar 16 memperlihatkan proses manufaktur dan kalibrasi suatu gauge block. Pada gambar 16, sebuah gauge block dan sebuah master gauge block ditempatkan pada sebuah meja dangan permukaan yang sangat rata. Kemudian, posisi dari kedua gauge block tersebut dibalik dengan memutar meja tersebut sebesar $180^{\circ}$ untuk memisahkan error yang berasal dari ketidakrataan meja tersebut. proses pemisahan error tersebut menggunakan seuah spirit level untuk mengukur suatu tingkat ketadataran relatif.

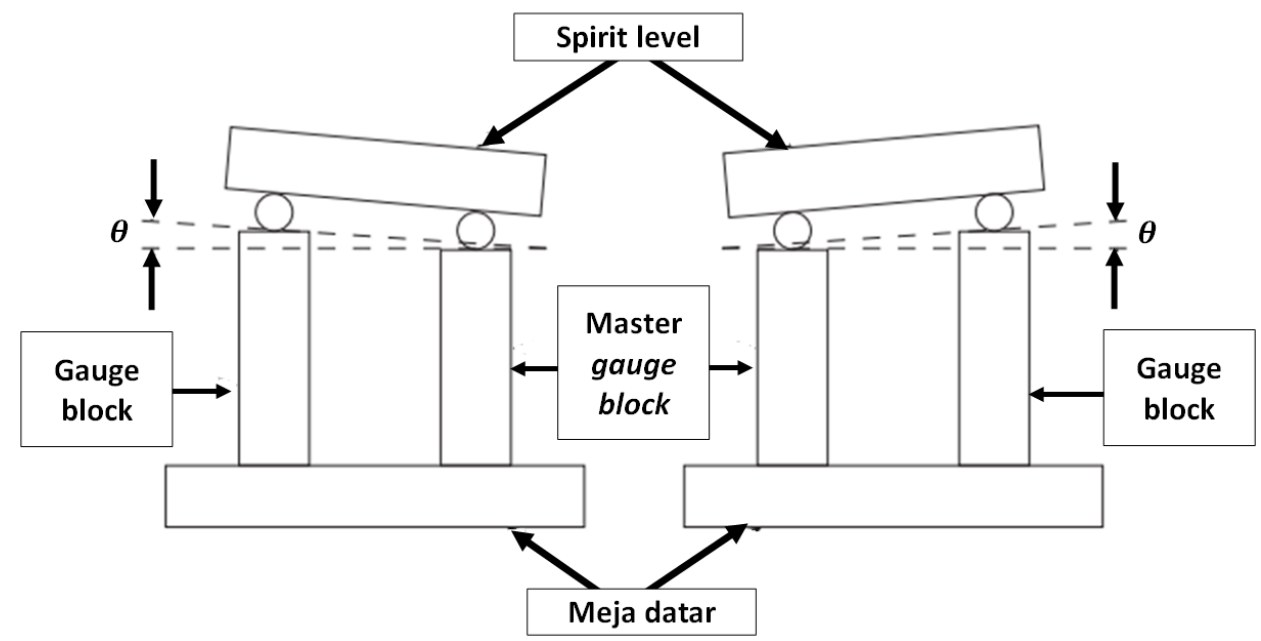

Gambar 16: proses manufaktur dan kalibrasi gauge block dengan metode Brook. Adalah error ketidak rataan yang berasal dari meja dan gauge block yang diproduksi sehingga harus dipisahkan antara error dari meja atau error dari gauge block yang diproduksi

Selain dapat dikombinasikan antar-gauge block, gauge block tersebut dapat dikombinasikan dengan berbagai macam instrumen pengukuran dasar lainnya, seperi sine gauge untuk menghasilakan suatu sudut yang presisi. Gambar 17 memperlihatkan contoh dari kombinasi gauge block dengan sine bar untuk menghasilkan suatu derajat kemiringan yang sangat presisi. Pada gambar 17, sine bar tersebut memiliki jarak terkalibrasi $l$ pusat-ke-pusat dari kedua kakinya yang berbentuk silinder. Jarak pusat-ke-pusat tersebut merupakan jarak yang terkalibrasi dengan nilai ketidakpastian yang sangat kecil. Sine bar tersebut juga terbuat dari material yang sangat stabil, terutama terhadap variasi temperatur, seperti material yang digunakna untuk membuat gauge block. Material tersebut misalnya adalah hardened steel.

Untuk mendapatkan sudut kemiringan $\theta$ yang presisi, salah satu kaki sine bar tersebut disisipkan satu atau beberapa gauge block dengan panjang (dalam hal ini ketinggian) tertentu sesuai dengan seberapa besar derajat kemiringan yang diinginkan. Sehingga, kemiringan $\theta$ yang dihasilkan dari kombinasi sine bar dan gauge block tersebut dapat dikalkulasi sebagai arcus sinus dari jarak pusat-ke-pusat $l$ kedua kaki sine gauge tersbeut dan ketinggian $h$ dari kombinasi gauge block tersebut. 


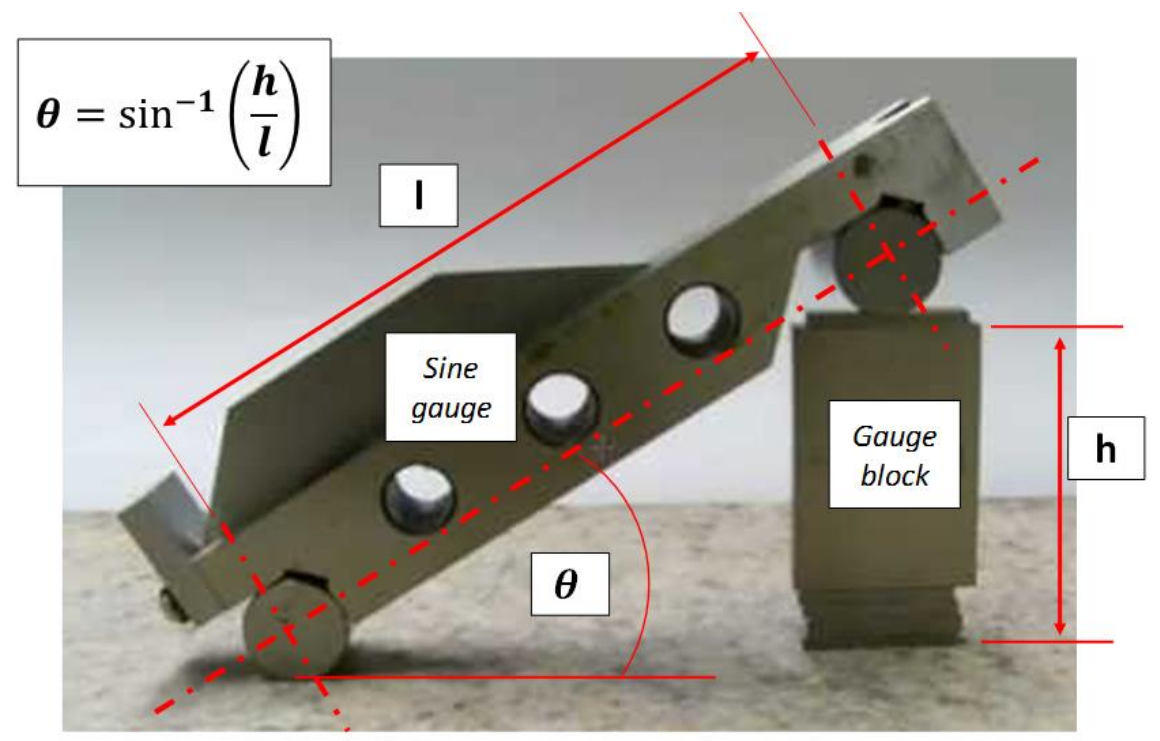

Gambar 17: kombinasi sine bar dan gauge block untuk menghasilkan suatu derajat kemiringan yang sangat presisi.

\section{Standar line.}

Standar line adalah suatu standar panjang yang menggunakan jarak antara dua garis untuk mengukur suatu panjang, contohnya adalah penggaris. Gambar 18 memperlihatkan contoh dari standar line. Seperti yang terlihat pada gambar 18, standar line adalah sangat mirip dengan penggaris yang kita gunakan sehari-hari. Yang berbeda adalah, standar line mempunyai tingkat akurasi dan presisi yang jauh lebih tinggi dari penggaris biasa dan terbuat dari material yang sangat stabil pada lingkungan dengan temperatur yang sangat bervariasi.

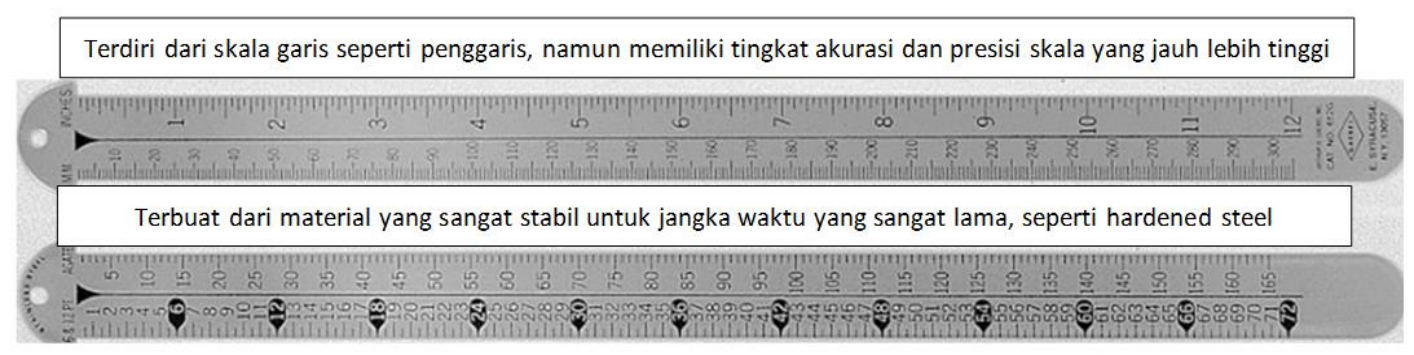

Gambar 18: Contoh dari standar line.

Dibandingkan dengan standar end, standar line mempunyai tingkat akurasi yang lebih rendah karena garis skala pada standar line mempunyai ketebalan yang menyebabkan sulit untuk menentukan dimana letak pembacaan skala yang sebenarnya. Selain itu, kelemahan dari standar line adalah skala garis pada standar line dapat rusak atau aus sehingga dapat menyebabkan susuahnya pembacaan suatu pengukuran, tidak mempunyai datum internal sehingga pengepasan antara aksis pengukuran dan garis skala lebih sulit dilakukan, skala pada standar line mempunyai efek error paralaks dan lensa pembesar diperlukan untuk meningkatkan tingkat akurasi pengukuran. Namun demikian, standar line mempunya kelebihan-kelebihan yaitu pengukuran dengan standar line lebih cepat dari pada pengukuran dengan standar end dan pengukuran dengan sebuah standar line dapat mencakupi berbagai macam panjang tanpa diperlukan kombinasi standar seperti pada standar end. 
Perbandingan antara standar end dan standar line diperlihatkan pada tabel 1. Pada tabel 1, kelebihan dan kelemahan dari standar end dan standar line dijabarkan dengan lebih jelas dalam bentuk perbandingan head-to-head.

Tabel 1: Perbandingan antara standar line dan standar end.

\begin{tabular}{|c|c|c|}
\hline Karakteristik & Standar line & Standar end \\
\hline Prinsip pengukuran & Jarak antara dua garis skala & $\begin{array}{l}\text { Jarak antara dua permukaan datar yang saling } \\
\text { paralel }\end{array}$ \\
\hline Akurasi pengukuran & $\begin{array}{c} \pm 0.2 \mathrm{~mm} \text { (dibutuhkan sebuha kaca } \\
\text { pembesar atau mikroskop untuk melihat } \\
\text { skala garis sehingga mempunyai tingkat } \\
\text { akurasi yang lebih tinggi) }\end{array}$ & $\pm 0.0005 \mathrm{~mm}$ \\
\hline $\begin{array}{l}\text { Kemudahan penggunaan } \\
\text { dan waktu pengukuran }\end{array}$ & $\begin{array}{l}\text { Pengukuran dapat dilakukan dengan } \\
\text { mudah dan cepat }\end{array}$ & $\begin{array}{c}\text { Pengukuran membutuhkan operator yang } \\
\text { terlatih dan membutuhkan waktu yang lebih } \\
\text { lama (misalnya harus mengkombinasikan } \\
\text { beberapa gauge block) }\end{array}$ \\
\hline Tingkat keausan & $\begin{array}{l}\text { Keausan dapat muncul pada garis skala } \\
\text { (yang menyebabkan under-sizing) }\end{array}$ & $\begin{array}{c}\text { Dua permukaan datar dari permukaan standar } \\
\text { akan aus karena gesekan dengan suatu } \\
\text { permukaan benda yang diukur }\end{array}$ \\
\hline Pengepasan (alignment) & $\begin{array}{c}\text { Tidak mempunyai datum internal, susah } \\
\text { untuk mengepaskan dengan aksis } \\
\text { pengukuran }\end{array}$ & $\begin{array}{l}\text { Mempunyai datum internal yaitu dua } \\
\text { permukaan datar yang saling paralel }\end{array}$ \\
\hline Manufaktur & Proses manufakturnya mudah & $\begin{array}{c}\text { Proses manufakturnya jauh lebih rumit } \\
\text { karena harus melalui berbagai macam proses } \\
\text { untuk mendapatkan permukaan datar yang } \\
\text { sangat akurat }\end{array}$ \\
\hline Biaya & Biaya rendah & Biaya tinggi \\
\hline Efek paralaks & ya & tidak \\
\hline Wringing & Tidak ada & $\begin{array}{c}\text { Standar end dapat dikombinasikan (wrung) } \\
\text { untuk mendapatkan sautu panjang yang } \\
\text { diinginkan }\end{array}$ \\
\hline Contoh & Penggaris, yard, meteran & $\begin{array}{l}\text { Gauge block, slip gauge, end bar, jangka } \\
\text { sorong (vernier caliper), mikrometer }\end{array}$ \\
\hline
\end{tabular}

\subsubsection{Standar 2D}

Sesuai dengan namanya, standar 2D adalah standar yang digunakan untuk mengukuran dimensi dan geometri dalam 2D. Pada umumnya, standar 2D digunakan untuk mengukur straightness dari suatu permukaan. Alat standar 2D yang paling umum digunakan adalah straight edge. Gambar 19 memperlihatkan contoh dari straight edge. straight edge mempunyai bentuk seperti gauge block, namun memiliki panjang yang lebih besar. Kedua sisi straight edge yang paling luas mempunyai tingkat kedataran (straightness) yang sangat akurat. Seperti gauge block, straight edge terbuat dari material yang sangat stabil pada kondisi temperatur yang bervariasi. straight edge dibagi menjadi empat tingkatan: tingkat 00, 0, 1 dan 2. Tabel 2 memperlihatkan jenis-jenis tingkatan tersebut berikut dengan nilai toleransi straightnessnya. Pada tabel 2, straight edge tingkat 00 mempunyai tingkat akurasi yang paling tinggi, yaitu sebesar $1+(L / 150) \mu m$, dimana $L$ dalam $m m$. 


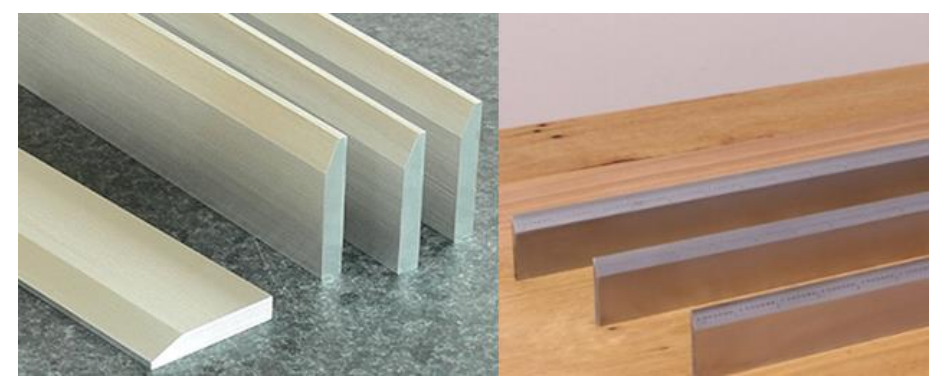

Gambar 19: Contoh dari stadar 2D: straight edge.

Tabel 2: Spesifikasi dari straight edge. $L$ adalah panjang straight edge dalam $\mathrm{mm}$.

\begin{tabular}{|c|c|c|c|c|}
\hline & Tingkat 00 & Tingkat 0 & Tingkat 1 & Tingkat 2 \\
\hline Toleransi flatness $/ \mu \mathrm{m}$ & $1+(L / 150)$ & $2+(L / 100)$ & $4+(L / 60)$ & $8+(L / 40)$ \\
\hline Toleransi parallelism $/ \mu \mathrm{m}$ & $2[1+(L / 150)]$ & $2[2+(L / 100)]$ & $2[4+(L / 60)]$ & $2[8+(L / 40)]$ \\
\hline
\end{tabular}

\subsubsection{Alat bantu pengukuran dimensi}

\section{- Permukaan datar (surface plate)}

Permukaan datar digunakan untuk dijadikan sebagai referensi utama untuk suatu pengukuran dimensi dan geometri. Permukaan datar selalu dimiliki oleh instrumen-instrumen pengukuran dimensi dan geometri dengan akurasi tinggi, seperti CMM. Gambar 20 memperlihatkan contoh dari permukaan datar. Permukaan datar tersebut memiliki empat kaki dimana tiga dari empat kaki tersebut dapat diatur ketinggiannya.

Permukaan datar tersebut pada umumnya terbuat dari besi tuang (cast iron) atau granit (sejenis keramik). Permukaan datar yang terbuat dari besi tuang memiliki biaya atau harga yang lebih murah daripada permukaan datar yang terbuat dari granit. Namun demikian, tingkat akurasi dari permukaan datar yang terbuat dari besi tuang tidak sebaik dengan tingkat akurasi dari permukaan datar yang terbuat dari granit. selain itu, permukaan datar dari besi tuang memiliki tingkat stabilitas terhadap variasi dari kondisi lingkungan yang lebih rendah dari tingkat staibilitas permukaan datar yang terbuat dari granit. Table 3 memperlihatkan spesifikasi permukaan datar dari besi tuang dan tabel 4 memperlihatkan spesifikasi permukaan datar dari Granit.

Tabel 3: Spesifikasi permukaan datar yang terbuat dari besi tuang (cast iron).

\begin{tabular}{|c|c|c|c|c|}
\hline \multirow{2}{*}{ Size/mm } & \multicolumn{3}{|c|}{ Error flatness/ $\mathbf{\mu m}$} & \multirow{2}{*}{ Massa/Kg } \\
\cline { 2 - 4 } & Tingkat 0 & Tingkat 1 & Tingkat 2 & 21 \\
\hline $300 \times 300$ & 4 & 7 & 15 & 50 \\
\hline $400 \times 400$ & 4.5 & 9 & 17 & 39 \\
\hline $450 \times 300$ & 4 & 8 & 16 & 62 \\
\hline $450 \times 450$ & 4.5 & 9 & 18 & 79 \\
\hline $600 \times 450$ & 5 & 10 & 20 & 96 \\
\hline $630 \times 400$ & 5 & 10 & 20 & 128 \\
\hline $600 \times 600$ & 5 & 10 & 20 & 156 \\
\hline $630 \times 630$ & 5 & 10 & 21 & 204 \\
\hline $900 \times 600$ & 6 & 12 & 23 & 986 \\
\hline $1500 \times 1200$ & 8 & 16 & 33 & \\
\hline
\end{tabular}




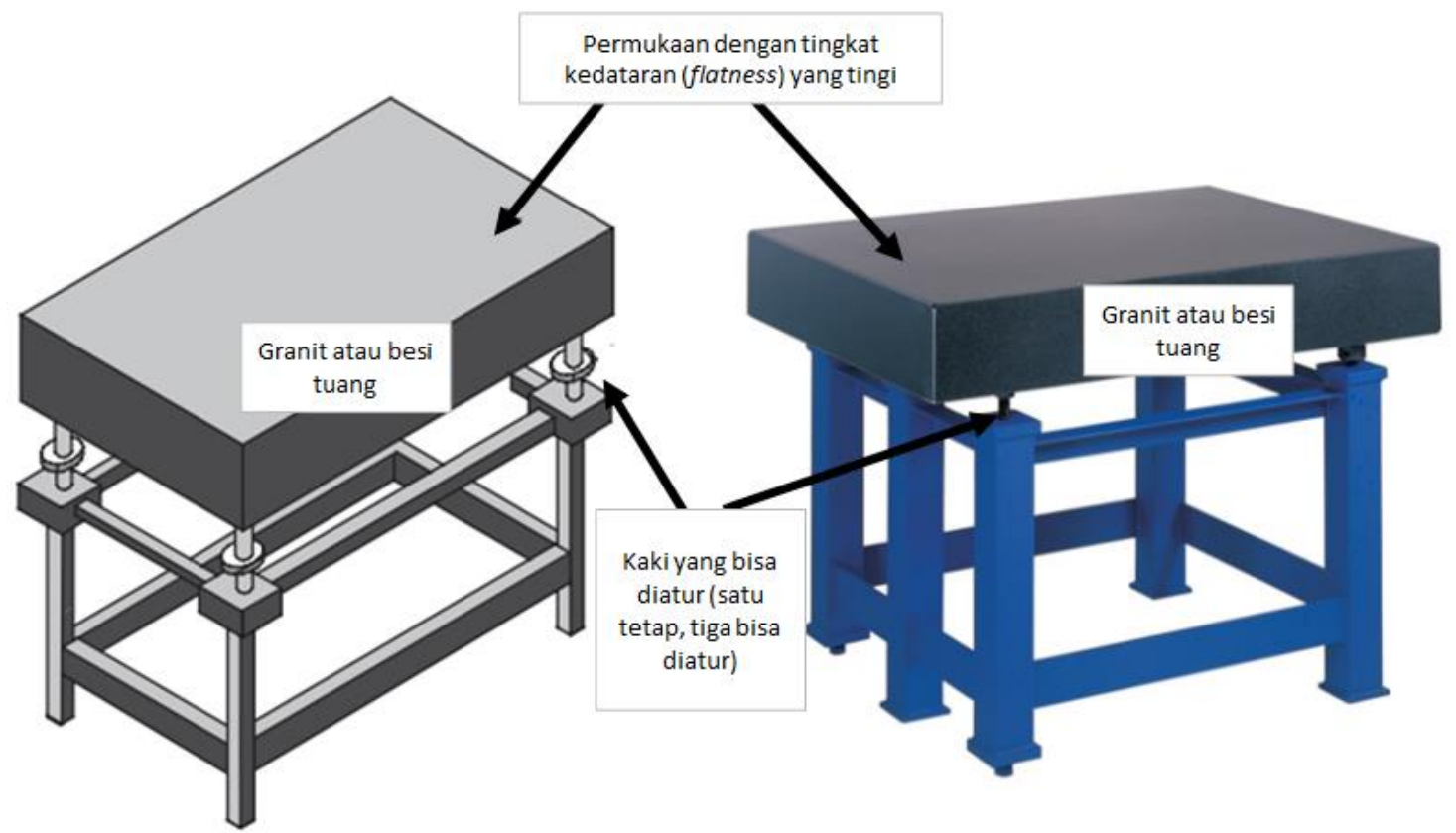

Gambar 20: Permukaan datar (surface plate) yang umum ditemukan di lantai produksi dan laboratorium pengukuran.

Tabel 4: Spesifikasi permukaan datar yang terbuat dari Granit.

\begin{tabular}{|c|c|c|c|c|}
\hline \multirow{2}{*}{ Size/mm } & \multicolumn{3}{|c|}{ Error flatness/ $\mathbf{\mu m}$} & \multirow{2}{*}{ Massa/Kg } \\
\cline { 2 - 4 } & Tingkat 00 & Tingkat 0 & Tingkat 1 & 27 \\
\hline $300 \times 300 \times 100$ & 2 & 3 & 5 & 40 \\
\hline $450 \times 300 \times 100$ & 2 & 3 & 6 & 146 \\
\hline $750 \times 500 \times 130$ & 3 & 5 & 9 & 900 \\
\hline $1500 \times 1000 \times 200$ & 4 & 8 & 16 & 900 \\
\hline $3000 \times 2000 \times 500$ & 7 & 14 & 27 & \\
\hline
\end{tabular}

\section{- Balok-V (V-block)}

Balok-V digunakan untuk memegang atau menahan sebuah benda berbentuk silinder secara kinematik. Balok-V merupakan salah satu alat bantu wajib untuk suatu pengukuran dimensi dan geometri di lantai produksi. Dengan menggunakan balok-V untuk memegang atau menahan sebuah benda yang berbentu silinder, maka kontak antara balok-V dan permukaan silinder tersebut akan berupa dua buah garis. Sehingga, balok-V ini dapat menahan sebuah benda berbentuk silinder secara kinematik dan silinder tersebut hanya mempunyai dua derajat kebebasan dalam pergerakannya (empat derajat kebebasan dapat ditahan), yaitu rotasi terhadap sumbu silinder tersebut dan pergerakan linier searah sumbu silinder tersebut. Dengan menahan sebuah silinder secara kinematik, maka beban berlebih yang disebabkan karena over-constraint tidak dirasakan oleh silinder tersebut.

Gambar 21 memperlihatkan balok-V dan sebuah silinder yang ditahan oleh balok-V tersebut. pada gambar 21, balok-V mempunyai alur berbentu huruf "V", dimana alur "V" tersebut mempunyai sudut $90^{\circ}$. Apabila sebuah silinder 
diletakkan pada balok-V tersebut, maka silinder tersebut mempunyai kontak dengan balok-V tersebut berupa garis disebelah sisi kanan dan kirinya. Dengan demikian, tekanan permukaan pada permukaan silinder tersebut dapat dikecilkan (dibandingkan apabila menggunakan metode kontak titik, dimana dengan metode kontak titik, tekanan permukaan yang dialami oleh silinder tersebut akan sangat besar dan dapat menyebabkan kerusakan pada permukaan silinder tersebut).
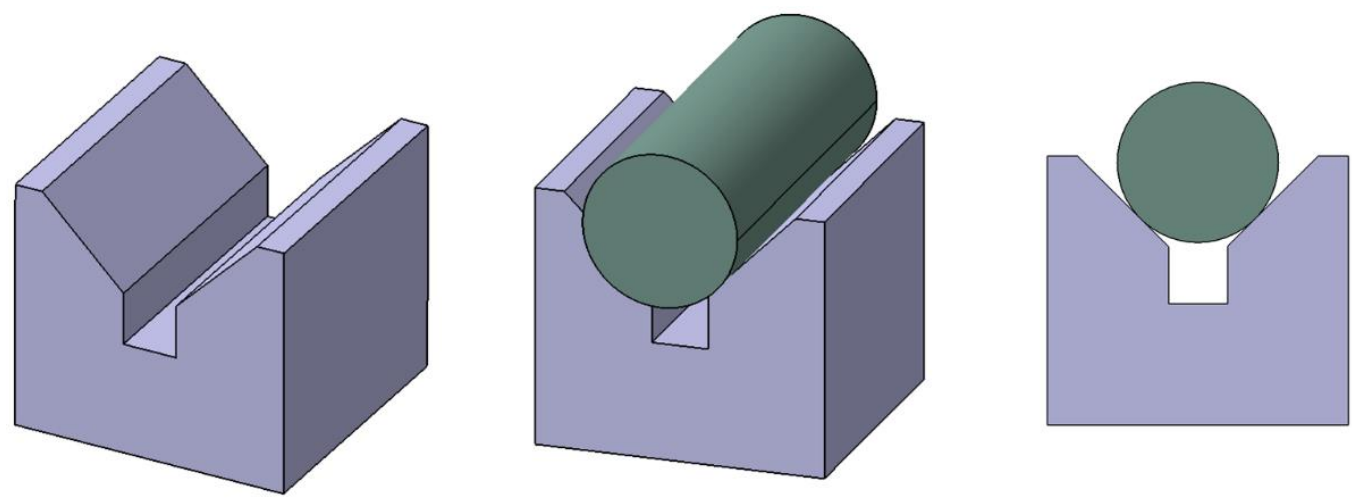

Gambar 21: Balok-V dan sebuah silinder yang ditahan dengan balok-V tersebut.

\section{- Sine bar dan angle gauge.}

Sine bar merupakan alat bantu dan ukur sudut yang sangat penting pada lantai produksi, terutama dengan mesinmesin perkakas. Sine bar, yang dikombinasikan dengan gauge block, dapat memberikan dan mengukur suatu sudut kemiringan secara akurat. Tabel 5 memperlihatkan bagaimana kombinasi sine bar dan gauge block (slig gauge) dapat memberikan suatu sudut kemiringan dengan tingkat error yang sangat kecil (lihat gambar 17).

Tabel 5: Error sudut yang didapatkan dengan menggunakan sine bar dan slip atau gauge block.

\begin{tabular}{|c|c|c|c|c|}
\hline Sudut yang diinginkan/ $^{\circ}$ & Panjang sine bar/mm & Tinggi slip atau gauge block & Sudut aktual & error $^{\circ}$ \\
\hline \multirow{2}{*}{30} & \multirow{2}{*}{100} & 50 & 30 & \\
\cline { 3 - 5 } & \multirow{2}{*}{400} & 50.1 & 30.066 & 0.066 \\
\cline { 2 - 5 } & \multirow{2}{*}{45} & 70.71 & 45 & \\
\hline \multirow{2}{*}{60} & \multirow{2}{*}{100} & 70.81 & 45.08 & 0.08 \\
\cline { 2 - 5 } & & 86.6 & 60 & \\
\hline
\end{tabular}

Selain sine bar, angle gauge juga merupakan alat ukur (dan bantu) untuk mendapatkan suatu sudut tertentu. Seperti gauge block, angle gauge terdiri dari berbagai macam plat dengan berbagai kemiringan sudut terkalibrasi. Angle gauge dapat saling dikombinasikan untuk mendapatkan suatu sudut kemiringan tertentu. Gambar 22 memperlihatkan dua buah angle gauge yang saling dikombinasikan untuk mendapatkan dua jenis sudut yang berbeda. Pada gambar 22, setiap kombinasi dapat dikonfigurasi untuk saling menambahkan atau saling mengurangkan sudut dari kedua angle gauge tersebut. 

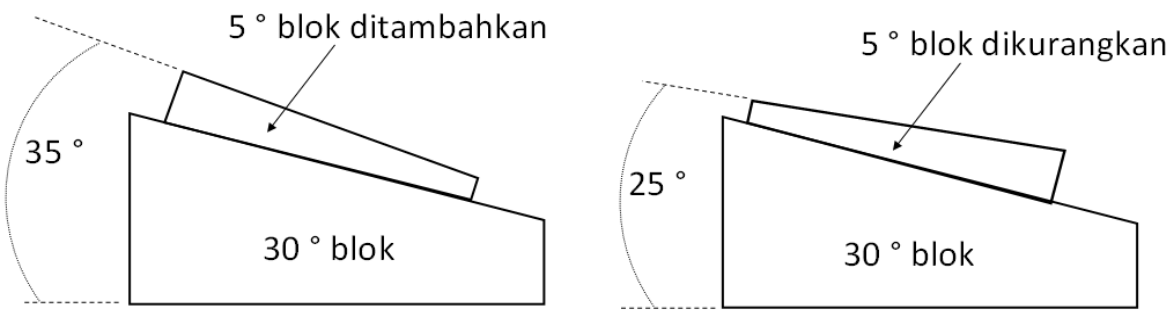

Gambar 22: Contoh kombinasi dari dua buah angle gauge.

\subsubsection{Jangka sorong (vernier caliper)}

Awal mula ditemukannya jangka sorong adalah dimulai dari ditemukannya sebuah sistem skala yang mempunyai kemampuan untuk mengamplifikasi tingkat resolusi suatu skala. Sistem skala tersebut ditemukan oleh seorang matematikawan Prancis yang bernama Pierre Vernier pada tahun 1631, sehingga sistem skala tersebut dinamakan skala Vernier. Kemudian, dalam jangka waktu dua abad dari ditemukannya skala Vernier, seorang perekayasa dari Amerika yang bernama Joseph Brown menemukan jangka sorong (Vernier Calliper).

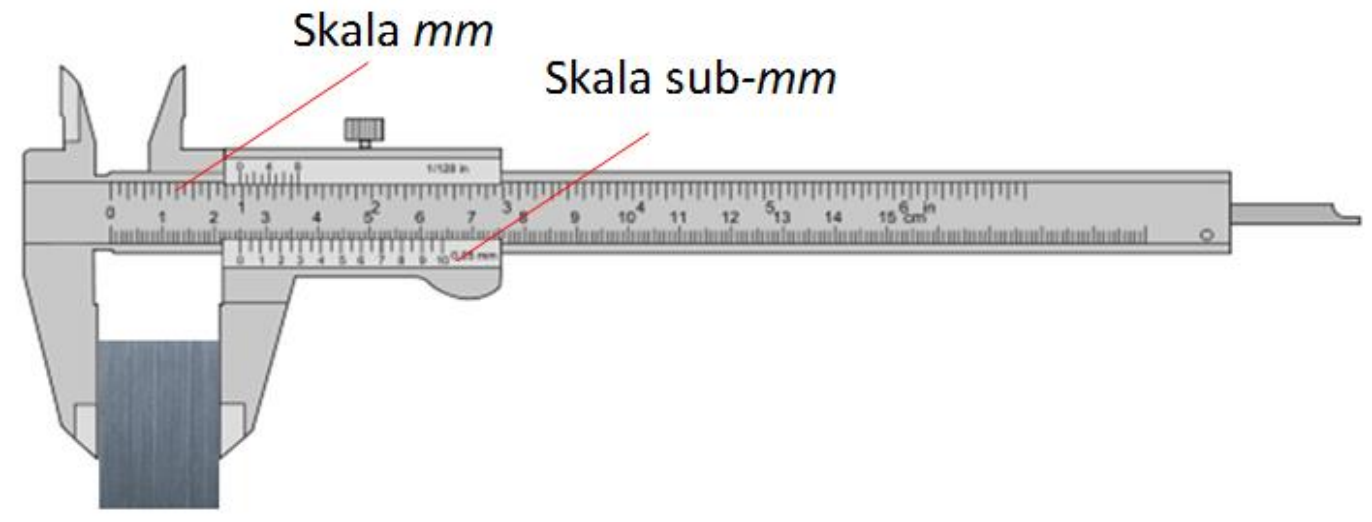

Gambar 23: Sebuah jangak sorong dengan dua jenis skala: skala $m m$ (skala utama) dan skala sub-mm (skala vernier).

Jangka sorong mempunyai dua jenis skala, yaitu skala dengan resolusi $1 \mathrm{~mm}$ (skala $\mathrm{mm}$ ) dan skala dengan resolusi sub-mm (skala Vernier). Resolusi dari skala Vernier sebuah jagka sorong pada umumnya adalah $0.05 \mathrm{~mm}(50 \mu \mathrm{m})$ dan skaal Vernier tersebut dapat mencapai $0.01 \mathrm{~mm}(10 \mu \mathrm{m})$. Jangka sorong memiliki dua buah sisi datar yang saling parallel satu dengan lainnya, sehingga jangka sorong termasuk jenis alat ukur standar end.

Gambar 23 memperlihatkan sebuah jangka sorong. Pada gambar 23, bagian utama dan sekaligus sebagai rangka utama jangka sorong tersebut adalah sebuah metal yang berbentuk " $L$ ". terdapat dua jenis jaw, jenis pertama adalah jaw yang tetap dan jenis kedua adalah jaw yang bergerak. Jaw yang bergerak juga membawa skala Vernier yang dapat digeser sepanjang skala $\mathrm{mm}$ (skala utama). Pada gambar 23 juga terlihat sebuah baut pengencang (clamping screw) yang berfungsi untuk menahan jaw yang bergerak agar memudahkan untuk pembacaan skala pengukuran Vernier tersebut.

Banyak variasi dari jangka sorong yang terdapat di industri, seperti jangka sorong dengan skala pembacaan dijital dan jangka sorong dengan skala pembacaan berupa dial gauge. Jangka sorong dengan skala pembacaan dijital sudah umum ditemui di industri-industri karena jangka sorong jenis ini sangat mudah untuk digunakan. Dengan skala pembacaan dijital, seorang operator sangat mudah untuk langsung mengetahui hasil suatu pengukuran. Jangka sorong dengan dial gauge mempunyau resolusi yang tinggi, namun memiliki resiko kerusakan yang lebih besar karena sistem dial gauge yang lebih kompleks. 


\subsubsection{Mikrometer}

Mikrometer adalah suatu alat pengukuran panjang berbasis metode sekrup. Mikrometer pertama kali ditemukan oleh William Gascoigne pada abad ke-17 di daerah Yorkshire, Inggris. Pada saat itu, William menggunakan mikrometer temuannya untuk alat bantu pengukuran sudut antar-bintang yang dilihat dengan sebuah teleskop. Namun demikian, komersialisasi mikrometer baru terjadi lebih dari seabad setelahnya, yaitu pada tahun 1867, yang dilakukan oleh perusahaan Browne and Sharpe.

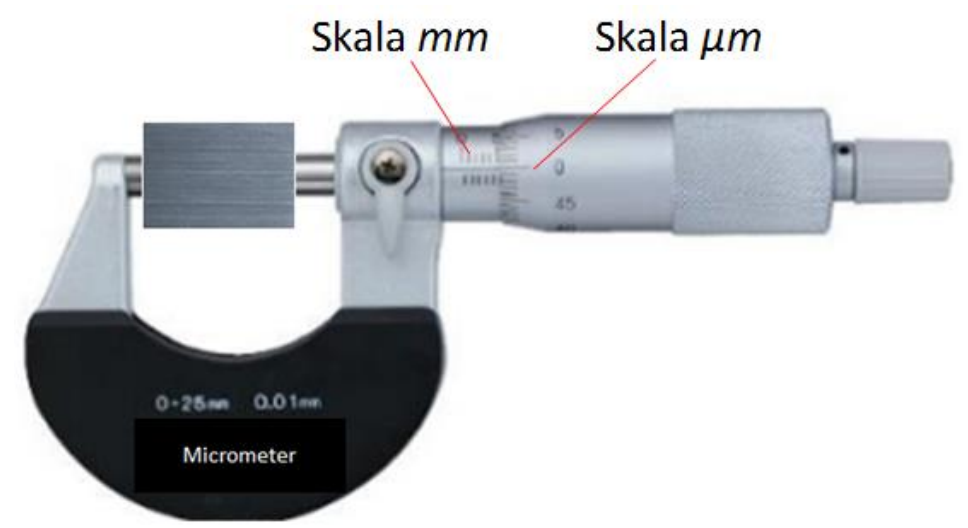

Gambar 24: Sebuah mikrometer dengan dua jenis skala: $m m$ dan $\mu m$.

Mikrometer mempunyai resolusi yang lebih baik dari jangka sorong. Pada umumnya, mikrometer memiliki resolusi $2-10 \mu \mathrm{m}$. Resolusi yang lebih tinggi dari pada resolusi jangka sorong didapatkan dari mekanisme sekrup. Mikrometer mempunyai dua permukaan datar yang saling paralel pada bagian pemegang suatu benda yang diukur, sehingga mikrometer juga dikelompokkan sebagai standar end.

Gambar 24 memperlihatkan contoh sebuah mikrometer. Pada gambar 24, terlihat bahwa suatu benda yang akan diukur dipegang atau dijepit oleh dua buah silinder yang mempunyai permukaan datar dan saling paralel. Ada dua jenis skala pada mikrometer, yaitu skala utama yang mempunyai resoluti $1 \mathrm{~mm}$ dan skala mikro yang mempunyai resolusi 2-10 $\mu \mathrm{m}$. Rangka utama dari mikrometer berbentu huruf "C". Salah satu silinder pemegang suatu benda yang ingin diukur mempunyai posisi tetap dan satu silinder lainnya dapat bergesar dengan memutar sekrup pada pegangan mikrometer tersebut. Salah satu hal penting yang harus diingat ketika seseorang menggunakan mikrometer adalah sekrup mikrometer tersebut harus diputar sampai kedua permukaan datar untuk memegang suatu benda yang diukur menyentuh benda yang diukur dan sampai terdengar 2-3 kali bunyi "klik".

Seperti halnya jangka sorong, mikrometer juga mempunyai banyak jenis. Jenis-jenis mikrometer dapat dibedakan dari bentuk dua permukaan yang berfungsi untuk memegang suatu benda yang ingin diukur dan jenis dari skala pembacaan (berupa alur garis, dijital atau dial gauge).

\subsubsection{Perbedaan fundamental antara jangka sorong (vernier caliper) dan mikrometer}

Jangka sorong dan mikrometer merupakan dua alat yang selalu ditemukan di lantai produksi dan di laboratorium untuk pengukuran suatu panjang dengan tingkat akurasi yang tinggi, yaitu pada tingkat akurasi sub-mm sampai $\mu m$. mikrometer mempunyai tingkat akurasi yang lebih tinggi dibandingkan dengan jangka sorong. Tingkat akurasi mikrometer yang lebih tinggi dari jangka sorong bukan hanya disebabkan karena resolusi mikrometer lebih tinggi dari jangka sorong, tetapi juga disebabkan oleh perbedaan fundamental antara mikrometer dan jangka sorong.

Perbedaan fundamental antara mikrometer dan jangka sorong adalah, konfigurasi mikrometer mempunyai sumbu pengukuran dan sumbu skala pembacaan yang saling berhimpit, sehingga tidak menimbulkan error Abbe. Lain halnya dengan jangka sorong, pada konfigurasi jangka sorong, sumbu pengukuran dan sumbu skala pembacaan tidak berhimpit satu sama lain, melainkan memiliki offset atau jarak tertentu. Dengan tidak berhimpitnya antara sumbu 
pengukuran dan sumbu skala pembacaan, maka terdapat error Abbe pada jangka sorong. Karena konfigurasi mikrometer yang meminimalisasi (atau idealnya menghilangkan) error Abbe, mikrometer menghasilkan pengukuran panjang yang labih akurat dibandingkan dengan jangka sorong.

Gambar 25 memperlihatkan dengan jelas mengenai perbedaan mendasar antara mikrometer dan jangka sorong. Pada gambar 25, terlihat bahwa

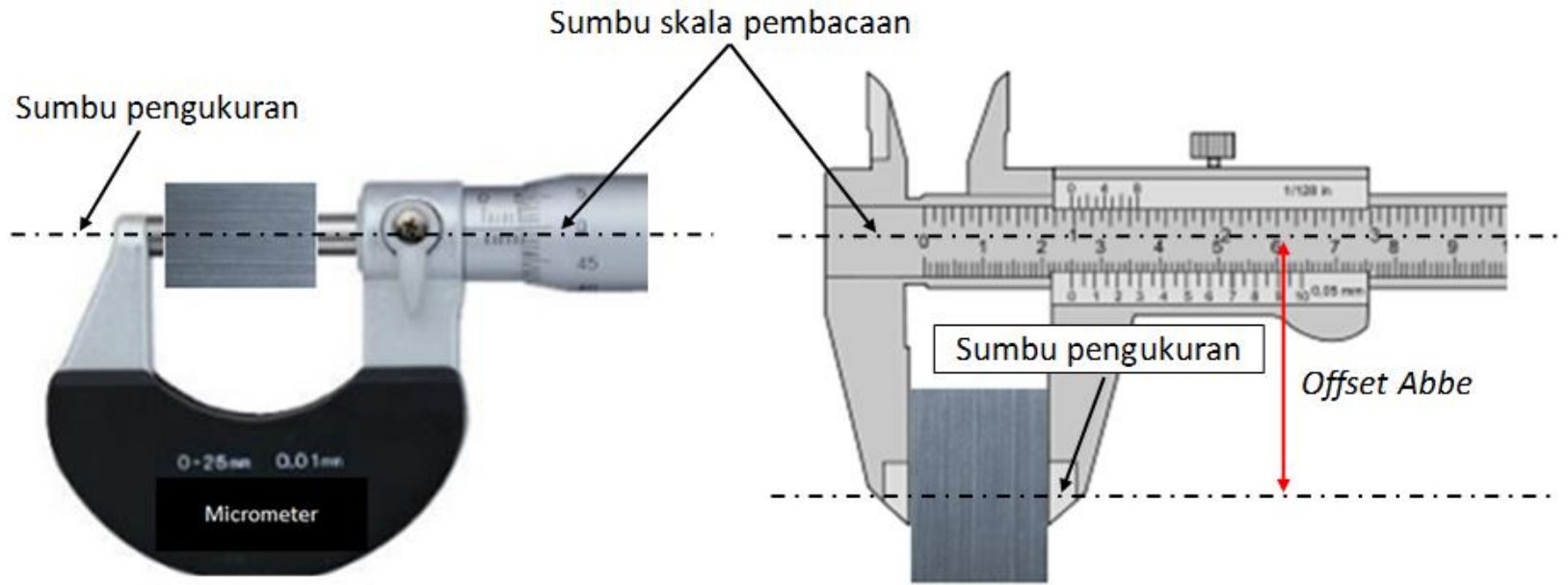

Mikrometer

Jangka sorong

Gambar 25: Perbedaan fundamental dari mikrometer dan jangka sorong. Pada jangka sorong, terdapat offset Abbe yang menyebabkan error Abbe karena sumbu pengukuran tidak berhimpit dengan sumbu skala pembacaan.

\subsubsection{Komparator}

Komparator adalah sebuah instrumen yang digunakan untuk melakukan pengukuran relatif. Pengukuran relatif berlawanan dengan pengukuran langsung. Hasil pengukuran dengan komparator (pengukuran relatif) tidak memberikan hasil seberapa besar panjang atau properti suatu fitur yang diukur, melainkan memberikan informasi seberapa jauh deviasi suatu benda yang diukur tersebut dari suatu nilai referensinya. Dengan kata lain, komparator adalah suatu instrumen untuk membandingkan suatu kuantitas yang tidak diketahui dengan suatu kuantitas yang diketahui (pada umumnya berupa standar atau nilai kalibrasi). Gambar 26 memperlihatkan perbedaan antara suatu pengukuran langsung (absolut) dan pengukuran relatif (komparasi). Pada gambar 26, pada pengukuran langsung, hasil pengukuran yang didapatkan adalah besarnya nilai suatu fitur atau benda yang diukur. Sedangkan, pada pengukuran relatif, hasil pengukuran yang didapatkan adalah besarnya perbedaan atau deviasi dari suatu nilai referensi.

Ada berbagai macam komparator yang sering ditemui di lantai produksi. Klasifikasi dari komparator dapat dibagi berdasarkan sistem mekanikal, meknaikal-optikal, elektrikal dan elektronik, penumatic dan tipe lainnya (seperti komparator berbasis proyektor). Jenis-jenis dari komparator yang akan dibahas pada bagian ini adalah dial gauge, proyektor optik, linear variable differential transformer (LVDT), komparator panjang dan komparator 3D. Sifat-sifat penting yang harus dimiliki oleh komparator adalah mempunyai tingkat akurasi dan presisi yang tinggi (karena pengukuran relatif dengan komparator harus mempunyai akurasi dan presisi yang lebih tinggi dari pada pengukuran langsung), mempunyai skala pembacaan yang linier, memiliki skala pembacaan dengan jangkauan yang lebar, mempunyai tingkat amplifikasi yang tinggi sehingga memudahkan pembacaan perubahan skala pengukuran yang sangat kecil, mempunyai resolusi yang tinggi dan mempunyai fleksibilitas dalam artian mempunyai jangkauan pengukuran yang bisa dipilih. 


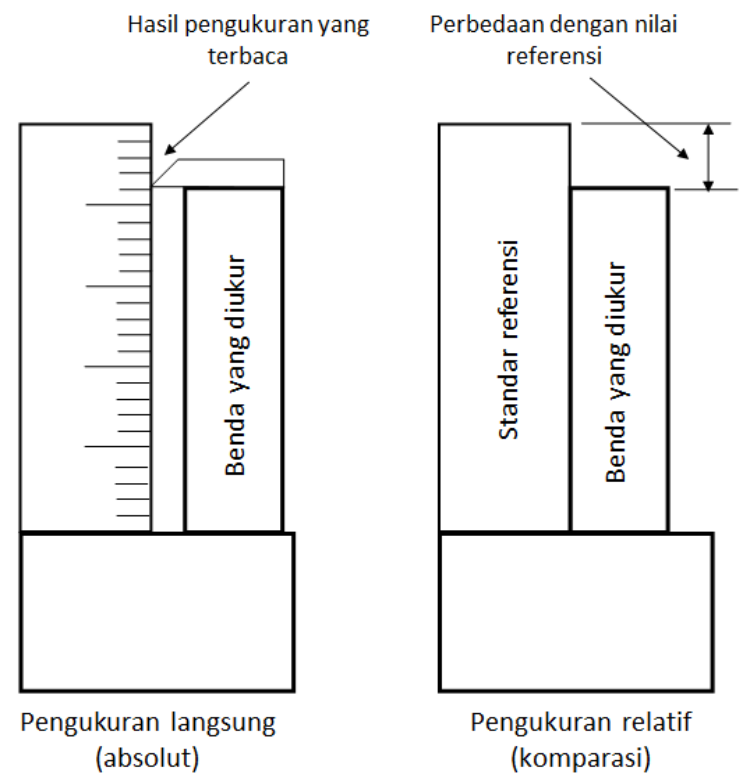

Gambar 26:Perbedaan antara pengukuran langung (absolut) dan pengukuran relatif (komparasi).

\section{- Dial gauge.}

Dial gauge merupakan jenis komparator yang paling sederhana dan paling banyak digunakan dilantai produksi. Walaupun dial gauge merupakan instrumen yang sederhana, dial gauge mempunyai performansi yang sangat baik untuk pengukuran relatif dengan tingkat akurasi dan presisi yang tinggi. Dial gauge terdiri dari sebuah komponen dengan skala pembacaan melingkar, komponen untuk kontak dengan permukaan suatu benda dan skala pembacaan yang membaca perpindahan linier dari komponen kontak tersebut. Dial gauge sering digunakan untuk memverifikasi toleransi geometrik, seperti flatness, perpendicularity, orientation, location dan run out.

Gambar 27 memperlihatkan contoh dari dial gauge. Pada gambar 27, diperlihatkan beberapa jenis dial gauge, yaitu dial gauge dengan skala pembacaan dijital dan skala pembacaan mekanial. Selain itu, gambar 27 memperlihatkan berbagai macam jenis komponen kontak pada dial gauge yang menyentuh permukaan suatu benda yang akan diukur. Dial gauge adalah instrumen dengan tingkat resolusi dan presisi yang tinggi, namun demikian instrumen tersebut sangat sensitif terhadap benturan yang diterimanya. Bentuk benturan dari luar yang dirasakan oleh dial gauge akan menggangu sistem dial yang kompleks sehingga akan mengurangi tingkat akurasi dial gauge.
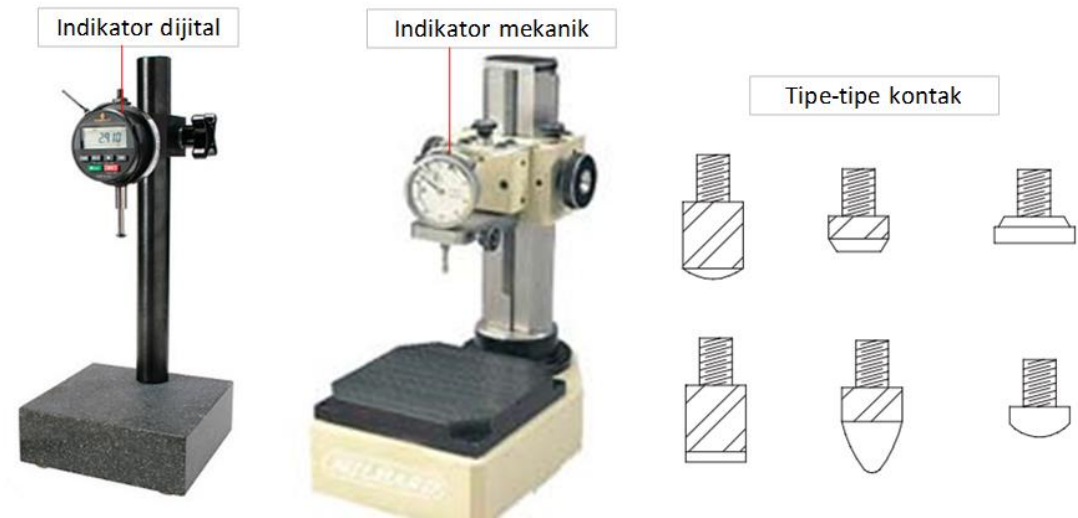

Gambar 27: Indikator dial dengam berbagai macam kontaknya. 


\section{- Proyektor optik.}

Proyektor optik merupakan suatu instrumen yang digunakan untuk menginspeksi sebuah cutting tool, sehingga instrumen tersebut masih sering ditemui di dalam ruang tool. Proyektor optik terdiri dari tiga komponen utama, yaitu proyektor (terdiri dari lampu, lensa, lensa proyeksi dan telesentrik), meja kerja untuk menempatkan benda atau tool yang ingin diukur dan layar transparan untuk komparasi benda yang diukur dengan suatu nilai toleransi. Proyektor optik berkerja dengan memproyeksikan gambar 2D yang diperbesar dari suatu benda atau tool yang diukur ke sebuah layar transparan untuk melakukan suatu pengukuran. Proyektor optik juga dapat digunakan untuk melakukan pengukuran langsung (pengukuran absolut), seperti panjang dan diameter.
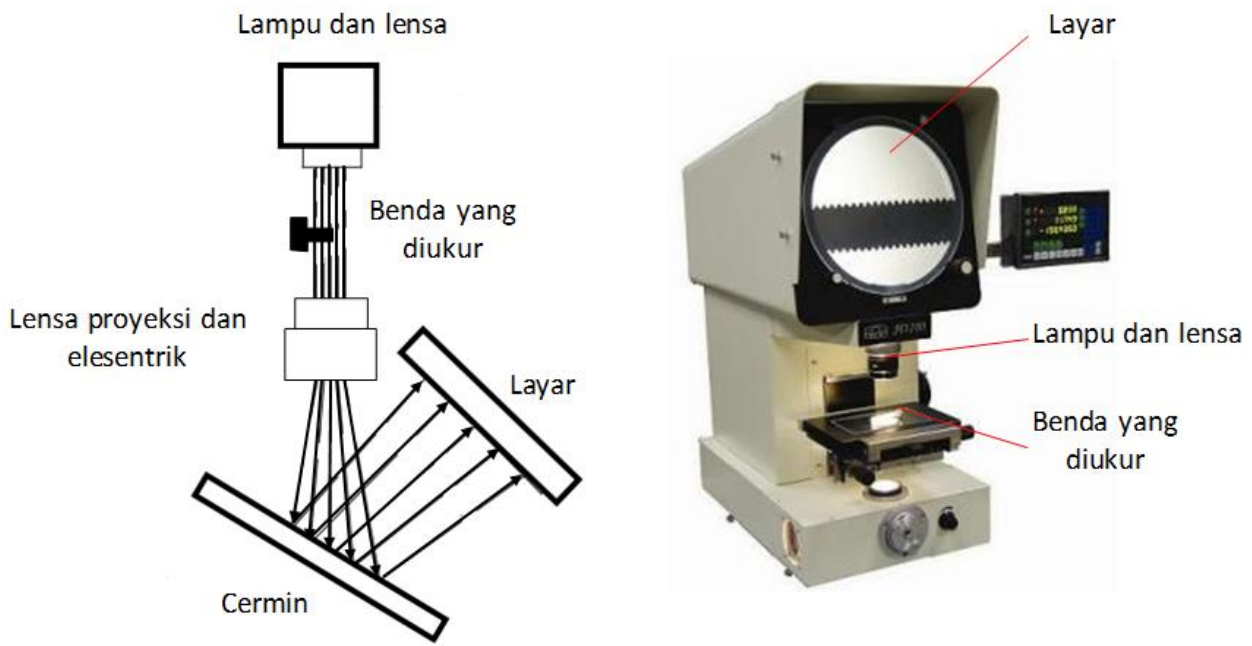

Gambar 28: Skema dan contoh dari suatu proyeksi optik.

Gambar 28 memperlihatkan skema dan contoh dari suatu proyeksi optik. Pada gambar 28 (kiri), skema dari sebuah proyektor optik diperlihatkan. Skema tersebut terdiri dari lampu dan lensa yang bertujuan untuk menghasilkan sumber pencahayaan yang homogen (collimated), kemudian lensa proyeksi dan telesentrik yang diletakkan dibawah meja pengukuran yang transparan untuk memproyeksikan bayangan benda yang diukur ke layar, cermin yang memantulkan hasil proyeksi ke layar dan layar yang memperlihatkan hasil gambar 2D yang diperbesar dari suatu benda yang diukur untuk kemudian dilakukan komparasi atau pengukuran. Gambar 28 (kanan), diperlihatkan contoh riil dari sebuah proyektor optik yang sangat umum ditemukan di ruang tool.

Proyektor optik pada lantai produksi, pada umumnya digunakan untuk mengukur:

- Inspeksi cutting tool, sekrup dan roda gigi (gear).

- Pengukuran titik tanah suatu lingkaran pada suatu komponen.

- Pengukuran dan suetu fitur dengan bentuk yang kompleks, seperti fitur dengan bentuk involut atau cycloidal.

- Pengukuran tingkat keausan cutting tool dengan cara mengkomparasi antara gambar cutting tool yang diproyeksikan dengan gambar teknik cutting tool tersebut pada kondisi nominalnya, sehingga deviasi dari gambar teknik nominanya merupakan tingkat keausan dari cutting tool tersebut.

\section{- Linear variable differential transformer.}

Linear variable differential transformer (LVDT) diklasifikasikan ke dalam komparator elektrikal yang mempunyai kelebihan seperti konversi langsung dari perpindahan mekanikal ke dalam tegangan listrik secara proporsional (dalam suatu batasan tertentu), tidak dapat diberikan beban berlebih secara mekanikal, mempunyai tingkat sensitifitas yang tinggi, mempunyai sistem magnifikasi sinyal yang besar, tidak terlalu sensitif terhadap 
perubahan temperatur, dapat digunakan kembali dan mempunyai tingkat ekonimi pengukuran yang baik (perbandingan antara fungsi dan harga LVDT).

LVDT bekerja dengan cara menghasilkan suatu tegangan listrik yang proporsional dengan perpindahan sebuah inti yang berbentuk silinder terhadap sepasang kumparan elektrik. LVDT mempunyai tingkat pembesaran sinyal tegangan listrik tersebut. LVDT sangat popular karena mudah untuk digunakan dan mempunyai reoslusi permindahan linier yang tinggi. Pada LVDT, ketika inti silinder dari LVDT tersebut bergerak dari posisi awalnya (posisi seimbang), tegangan, yang dihasilkan dari perubahan medan listrik pada kumparan LVDT tersebut, menghasilkan sinyal tegngan listrik yang berbeda dari tegangan awalnya. LVDT mengikuti prinsip induktansi.

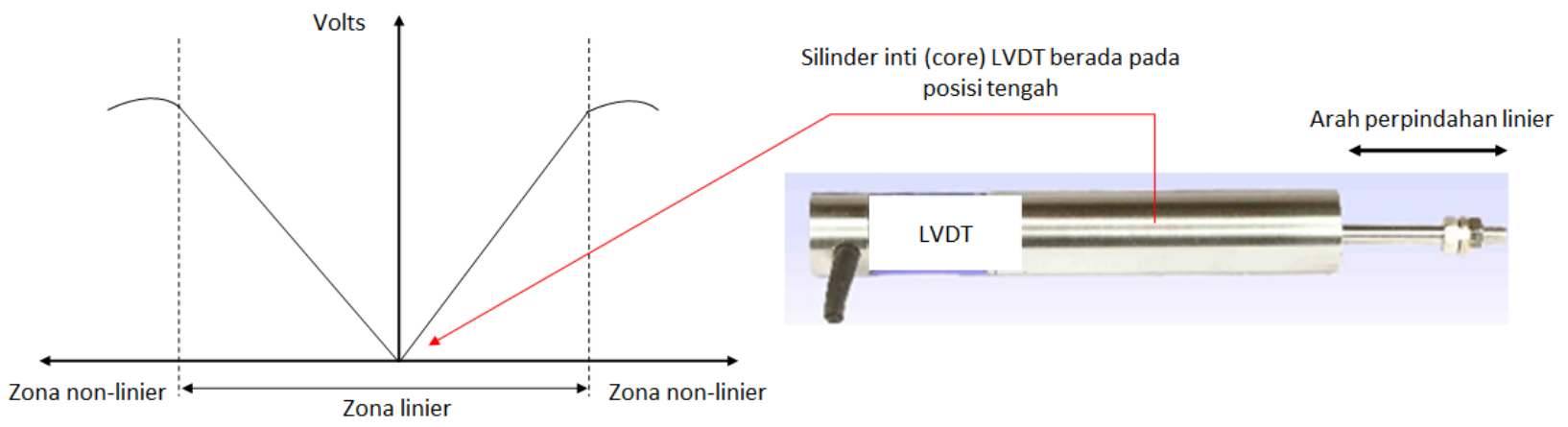

Gambar 29: Kurva karakteristik dari sebuah LVDT dan contoh riil dari sebuah LVDT.

Gambar 29 memperlihatkan kurva karakteristk dan contoh riil dari sebuah LVDT. Pada kurva karakteristik LVDT, terlihat bahwa pergerakan inti silinder dari sebuah LVDT dibatasi dalam jangkaun jarak tertentu, yaiu zona linier, dimana sinyal tegangan listrik yang dihasilkan masih proporsional secara linier terhadap perpindahan dari inti silinder LVDT tersebut. Suatu LVDT harus digunakan hanya dalam zona liniernya. Gambar 29 kanan, diperlihatkan sebuah contoh LVDT yang inti silindernya dilindungi oleh sebuah lembaran metal (casing).

\section{- Komparator panjang.}

Komparator panjang merupakan komparator mekanikal-elektrikal. Komparator panjang mempunyai dua permukaan datar yang saling paralel untuk memegang suatu benda yang ingin diukur. Komparator panjang terdiri dari bagian yang tetap dan bagian yang bergerak untuk menyesuaikan panjang suatu benda yang diukur. Dengan kombinasi dengan suatu sistem elektornik, komparator panjang memiliki resolusi yang sangat tinggi yang dapat mencapai resolusi $10 \mathrm{~nm}$. Selain pengukuran komparasi, komparator panjang dapat digunakna untuk melakukan pengukuran langsung (abslut). Selain resolusi yang tinggi, komparator panjang mempunyai tingkat presisi yang sangat tinggi karena tersusun dari suatu sistem mekanik yang mempunyai bentuk geometri yang sangat akurat. dengan tingginya tingkat akurasi dan resolusi dari sebuah komparator panjang, komparator tersebut sering juga digunakan untuk mengkalibrasi dan mengecek suatu gauge block.

Gambar 30 memperlihatkan sebuah komparator panjang. Pada gambar 30, komparator tersebut mempunyai dua wahana, yaitu wahana tetap dan wahana bergerak. Sebuah benda yang ingin diukur ditempatkan pada sebuah meja pengukuran dan benda tersebut dijepit oleh dua buah permukaan datar yang saling paralel. Komparator panjang dilengkapi dengan skala pembacaan dijital untuk memudahkan operator membaca hasil perpindahan dari wahana bergerak tersebut dengan tingkat resolusi mencapai $10 \mathrm{~nm}$. Sebuah komparator panjang harus ditempatkan apda suatu ruangan yang terkontrol $\left(20 \pm 0.5{ }^{\circ} \mathrm{C}, \mathrm{RH} 50 \%\right)$ karena resolusi dan tingkat akurasi dari sebuah komparator panjang. 


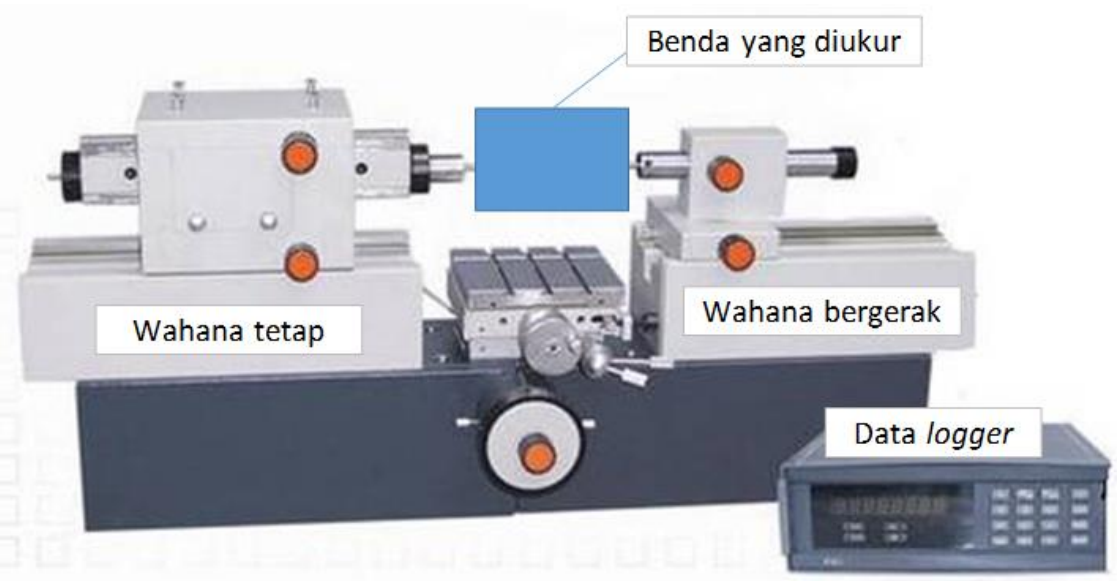

Gambar 30: Komparator panjan yang dapat mencapai resolusi $0.01 \mathrm{um}$.

\section{- Komparator 3D.}

Jenis komparator yang sudah dibahas sebelumnya merupakan komparator 1D dan 2D. Sedangkan, jenis komparator yang lain adalah komparator 3D. Dengan komparator 3D, pengukuran komparatif dapat dilakukan pada benda yang mempunyai geometri yang kompleks. Komparator 3D adalah instrumen yang mirip dengan CMM. Yang membedakan antara komparator 3D dan CMM adalah komparator 3D hanya melakukan pengukuran relatif suatu geometri benda dengan suatu geometri benda referensi.
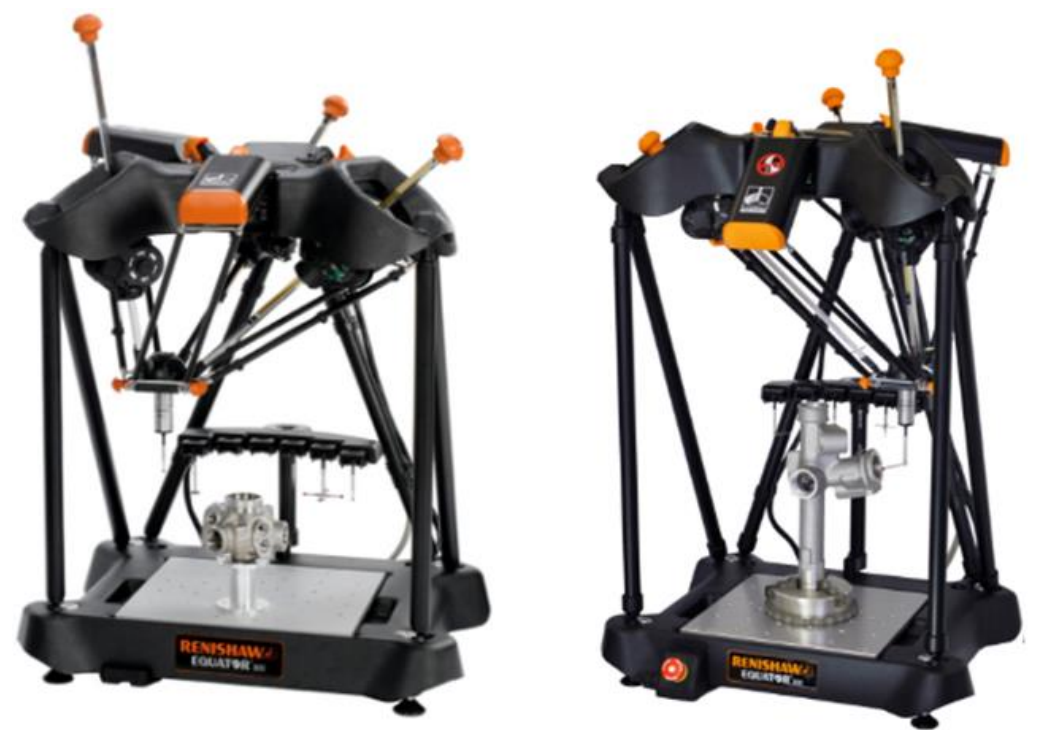

Gambar 31: Contoh dari sebuah komparator 3D yang diproduksi oleh Renishaw (www.renishaw.com).

Gambar 31 memperlihatkan contoh dari komparator 3D yang diproduksi oleh Renishaw. Komparator 3D tersebut bernama Equator. Equator (komparator 3D) tersebut mempunya konfigurasi parallel kinematik dan mempunya 6derajat-kebebasan dalam pergerakan stylus yang dimilikinya. Sebuah stylus pada Equator mempunya fungsi yang sama dengan stylus pada CMM yaitu untuk menyentuh permukaan sebuah benda yang diukur. Ketika stylus Equator (komparator 3D) menyentuh permukaan suatu benda, Sistem sensor pada stylus tersebut akan mengirimkan sinyal ke 
sistem pergerakan Equator untuk berhenti bergerak dan menyimpan posisi 3D (dalam bentuk koordinat spasial $X, Y$ dan $Z$ ) dari ujung stylus tersebut (stylus tip).

\subsubsection{Laser interferometer}

Interferometri laser (laser interferometer) merupakan suatu alat pengukuran panjang yang sangat penting dalam pengukuran dimensi dan geometri. Beberapa alasan yang menyebabkan interferometri laser sangat penting dan fundamental adalah laser interferometri mempunyai resolusi yang sangat tinggi, tingkat akurasi yang sangat tinggi dan merupakan instrumen yang digunakan untuk merealisasikan rantai keterlacakan hasil suatu pengukuran dimensi dan geometri. Sehingga, laser interferometri selalu dibutuhkan ketika rantai keterlacakan suatu hasil pengukuran ingin direalisasikan (Hansen et al 2006, Harding 2013).

Realisasi dari definisi meter (bab 1) adalah dengan menggunakan laser Iodin dengan frequensi yang terstabilkan (frequency-stabilised Iodine laser). Laser tersebut merupakan standar panjang primer. Seluruh laser-laser industri mempunyai panjang gelombang yang dikalibrasi dengan membandingkan panjang geombang laser-laser tersebut dengan panjang gelombang laser yang dihasilkan dari laser Iodin tersebut. Laser-laser industri tersebut, misalnya laser merah dan laser hijau, digunakan untuk merekonstruksi suatu sistem interferometri laser, dimana sistem tersebut digunakan untuk mengukur panjang dan mengkalibrasi instrumen-instrumen pengukuran dimensi dan geometri.

Sesuai dengan namanya interferometri laser, laser merupakan komponen utama pada sistem tersebut. Laser adalah salah satu sistem berbasis foton dan optikal yang paling penting dalam sejarah pengembanannya selama lebih dari 50 tahun yang dimulai pada tahun 1960-an (Pedrotti et al 1993). Perkembangan pesat keilmuan optik untuk pengembangan ilmu pengetahuan dan teknologi sangat bergantung pada teknologi laser. Laser memiliki aplikasi yang sangat luas di bidang teknologi, seperti teknologi radar, teknologi manufaktur cutting (material removal manufacturing), teknologi additive manufacturing berbasis laser sampai dengan teknlogi untuk pengukuran dimensi dengan tingkat presisi dan akurasi yang sangat tinggi, yaitu interferometri laser.

Definisi laser adalah cahaya yang teramplifikasi oleh emisi radiasi yang terstimulasi. Laser merupakan gelombang berupa kumpulan foton yang dihasilkan dari suatu medium laser yang terstimulasi oleh suatu emisi radiasi. Gambar 32 memperlihatkan proses terbentuknya foton-foton yang membentuk suatu laser. Pada gambar 32, suatu foton yang berasal dari suatu radiasi terstimulasi dengan energi $h v(h=$ konstanta Plank dan $v=$ frekuensi foton yang meradiasi tersebut) menabrak atau masuk ke suatu media laser, maka sebuah atom di dalam media laser tersebut tereksitasi dari keadaan energi $E_{0}$ ke energi $E_{1}$, dimana $E_{1}>E_{0}$. Kemudian, atom tersebut kembali dari keadaan energi $E_{1}$ ke energi $E_{0}$, yaitu keadaan seimbang (equilibrium). Ketika atom tersebut berpindah dari keadaan energi $E_{1}$ ke energi $E_{0}$, atom-atom tersebut melepaskan sebuah foton dengan energi $h v=E_{1}-E_{0}$. Foton yang dilepaskan tersebut mempunyai karakteristik-karakteristik tertentu yaitu foton tersebut mempunyai energi, arah, fase dan polarisasi (keadaan-keadaan tersebut adalah coherent) yang sama dengan foton yang menstimulasi atom tersebut (yaitu foton yang berasal dari emisi radiasi yang terstimulasi). Sehingga, hasil akhir proses tersebut adalah dua buah foton yang identik satu sama lain (foton yang menstimulasi dan foton yang dihasilkan dari perpindahan keadaan energi tersebut) dan kedua foton tersebut mengahsilkan intensitas yang lebihg tinggi dari hanya satu foton saja (Pedrotti et al 1993). Kemudian, proses amplifikasi dalam suatu medium resonator, yaitu medium yang merefleksikan berulang-ulang foton-foton hasil dari proses stimulasi tersebut, dilakukan sebelum suatu laser dihasilkan. 


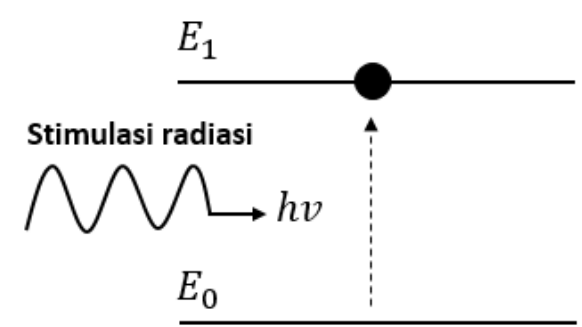

Proses 1:

Foton menyerap energi radiasi yang terstimulasi dan foton tersebut tereksitasi ke tingkat energi $E_{1}$
$E_{1}$

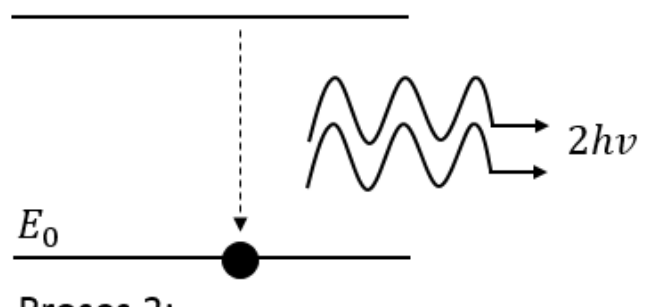

Proses 2:

Foton kembali ke tingkat energi

stabil $E_{1}$ dan melepaskan sebuah

foton yang mempunyai energi,

fase, polarisasi dan arah yang

sama dengan stimulasi foton

yang meradiasinya

Gambar 32: Proses terbentuknya suatu laser karena suatu stimulasi emisi radiasi.

Dari proses pembentukan laser yang telah dijelaskan sebelumnya, ada tiga komponen utama suatu sistem laser, yaitu: sumber emisi radiasi, media laser dan resonator (gambar 33). Penjelasan gambar 33 adalah sebagai berikut. Sumber emisi radiasi tersebut adalah suatu "pompa" yang memberikan energi foton kepada suatu medium laser sehingga atom-atom di dalam medium laser tersebut tereksitasi ke dalam tingkat energi yang lebih tinggi. Media laser adalah suatu material, seperti zat gas atau zat padat yang menampung atom-atom yang bisa tereksiatsi oleh suatu stimulasi emisi radiasi. Resonator adalah suatu rongga (cavity), yang terdiri dari dua buah cermin (yang satu dapat merefleksikan seluruh radiasi foton/full-reflection dan yang satu hanya merefleksikan sebagain foton/half-reflection), yang berfungsi untuk memantulkan berkali-kali foton-foton yang dihasilkan sehingga foton-foton tersebut teramplifikasi sebelum keluar dari rongga tersebut dan kemudian menjadi laser. Pada umumnya, sumber emisi radiasi untuk medium laser solid adalah lampu "flash" (flash lamp) dan sumber emisi radiasi untuk medium laser gas adalah electric arc. 


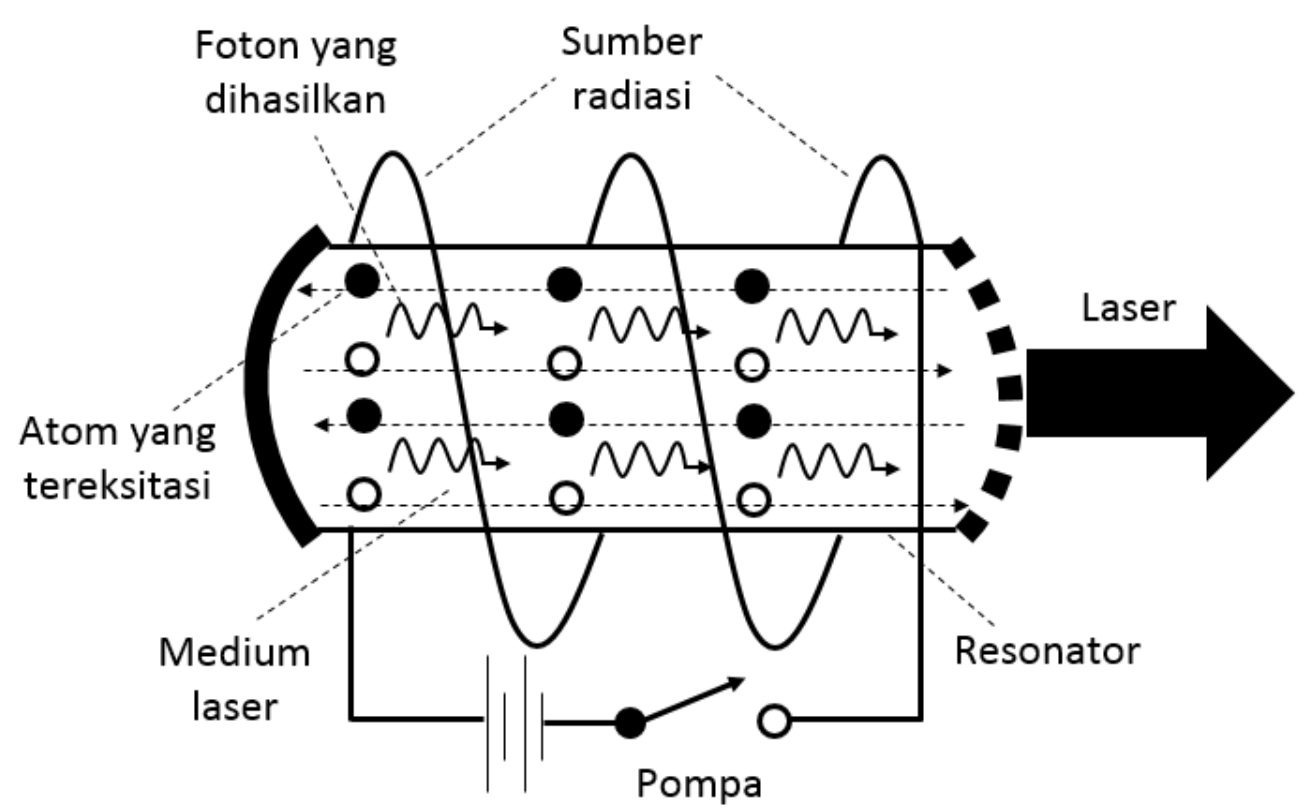

Gambar 33: Suatu sistem laser: sumber radiasi, medium laser dan resonator.

Sifat-sifat laser adalah:

- Monokromatik.

Laser memiliki satu jenis panjang gelombang, yaitu laser memiliki satu warna saja tergantung panjang gelombang yang dihasilkan.

- Koheren.

Laser memiliki derajat koheren yang tinggi, yaitu laser memiliki foton-foton dengan fase yang sama pada lokasi dan waktu yang berbeda dengan jangkaun tertentu.

- Dapat diarahkan.

Laser dapat diarahkan dengan mudah, yaitu dengan menggunakan komponen-komponen optik seperti cermin. Properti ini dimiliki laser karena laser bersifat monokromatik dan koheren.

- Dapat difokuskan.

Laser dapat difokuskan sehingga ukuran diamater suatu laser dapat dibuat sangat kecil.

- Memiliki intensitas yang tinggi.

Karena laser dapat difokuskan, energi laser dapat dikonsentrasikan sehingga mempunyai intensitas yang tinggi dibandingkan sebelum difokuskan.

Tipe-tipe laser dibagi berdasarkan jenis medium untuk menghasilkan laser tersebut, seperti Rubi, Helium-neon, Nd-Yag laser, Argond, Krypton, ion Xenon, Nitrogen, $\mathrm{CO}_{2}$ laser, eximer dan Fiber laser. Tipe laser yang paling umum digunakan untuk sistem interferometri laser adalah Helium-Neon laser.

Interferometri laser untuk mengukur suatu panjang adalah suatu sistem yang terdiri dari laser dan seperangkat optik yang dikonfigurasi sedemikian rupa sehingga sistem interferometri tersebut dapat merekam interferensi dua buah laser yang berasal dari dua jalur ( $p a t h$ ) yang berbeda. Maka dari itu, konsep interferensi dua buah gelombang yang saling koheren harus dimengerti terlebih dahulu.

Gambar 34 memperlihatkan dua jenis interferensi dari dua gelombang koheren, yaitu interferensi positif dan negatif. Pada gambar 34 sebelah atas, apabila dua gelombang yang koheren dan mempunyai fase yang sama, maka kedua gelombang tersebut akan bersuperposisi positif menghasilkan intensitas yang lebih besar dari kedua gelombang tersebut. Dan sebaliknya, pada gambar sebelah bawah, apabila kedua gelombang koheren tersebut mempunyai fase yang berlawanan, maka kedua gelombang tersebut akan bersuperposisi negatif dan saling melemahkan. 


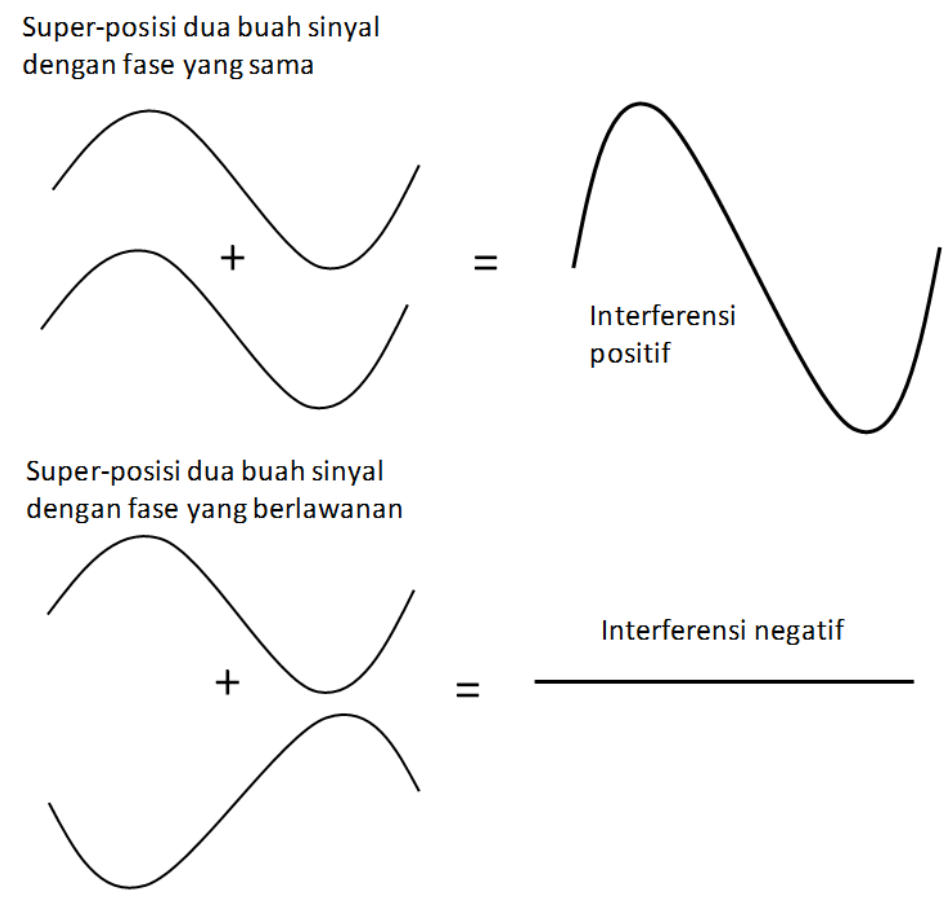

Gambar 34: Interferensi positif dan negatif dari dua buah laser.

Intensitas dari dua gelombang, yaitu gelombang 1 dan gelomang 2, yang saling berinterferensi, baik interferensi positif maupun negatif, dapat diformulasikan sebagai berikut (Harding 2013):

$$
I=I_{1}+I_{2}+2 \sqrt{I_{1} I_{2}} \cos (\Delta \varphi)
$$

dimana $I$ adalah intensitas hasil interferensi dua buah gelombang dengan intensitas $I_{1}$, untuk gelombang 1 , dan $I_{2}$, untuk gelombang 2. $\Delta \varphi$ adalah perbedaan fase dari kedua gelombang tersbut. $\Delta \varphi$ diformulasikan sebagai:

$$
\Delta \varphi=\varphi_{2}-\varphi_{1}
$$

dimana $\varphi_{1}$ adalah fase dari gelombang 1 dan $\varphi_{2}$ adalah fase dari gelombang 2 . Fase suatu gelombang menunjukkan dimana "posisi foton saat itu" pada gelombang tersebut.

Dengan memanfaatkan sifat interferensi dua gelombang yang saling koheren, maka interferometri laser dapat direkonstruksi untuk mengukur jarak dengan tingkat akurasi yang sangat tinggi. Gambar 35 memperlihatkan konfigurasi utama dari suatu interferometri laser. Pada gambar 35 (sebelah atas), suatu interferometri laser terdiri dari sebuah sumber laser, elemen optik (retroreflektor) tetap sebagai "beam" referensi dan retroreflektor bergerak sebagai "beam" pengukuran. Sumber laser tersebut bisa mempunyai frekuensi satu atau dua jenis. Apabila sumber laser tersebut memiliki satu jenis frekuensi, maka interferometri tersebut dinamakan interferometri homodyne, sedangkan apabila sumber laser tersebut memiliki dua jenis frekuensi, maka interferometri tersebut dinamakan interferometri heterodyne (Haitjema 2008). Laser yang dihasilkan bisa berupa laser yang terpolarisasi ataupun tidak. Namun, konfigurasi yang paling umum adalah laser terpolarisasi. Konfigurasi dari interferometer tersebut dinamakan interferometri Michelson yang merujuk pada nama seseorang yang pertama kali merekonstruksi interferometri tersebut.

Gambar 35 sebelah bawah memperlihatkan contoh riil dari sistem interferometer laser modern yang sedang 
mengukur pergerakan satu aksis oleh sebuah $2 D$ motion stage. Sistem interferometri modern mempunyai resolusi antara 10 dan $0.1 \mathrm{~nm}$. Resolusi tersebut merupakan resolusi pada arah perambatan laser. Total jarak yang dapat diukur bergantung pada panjang koheren dari laser yang digunakan dan bisa mencapai sampai $80 \mathrm{~m}$.
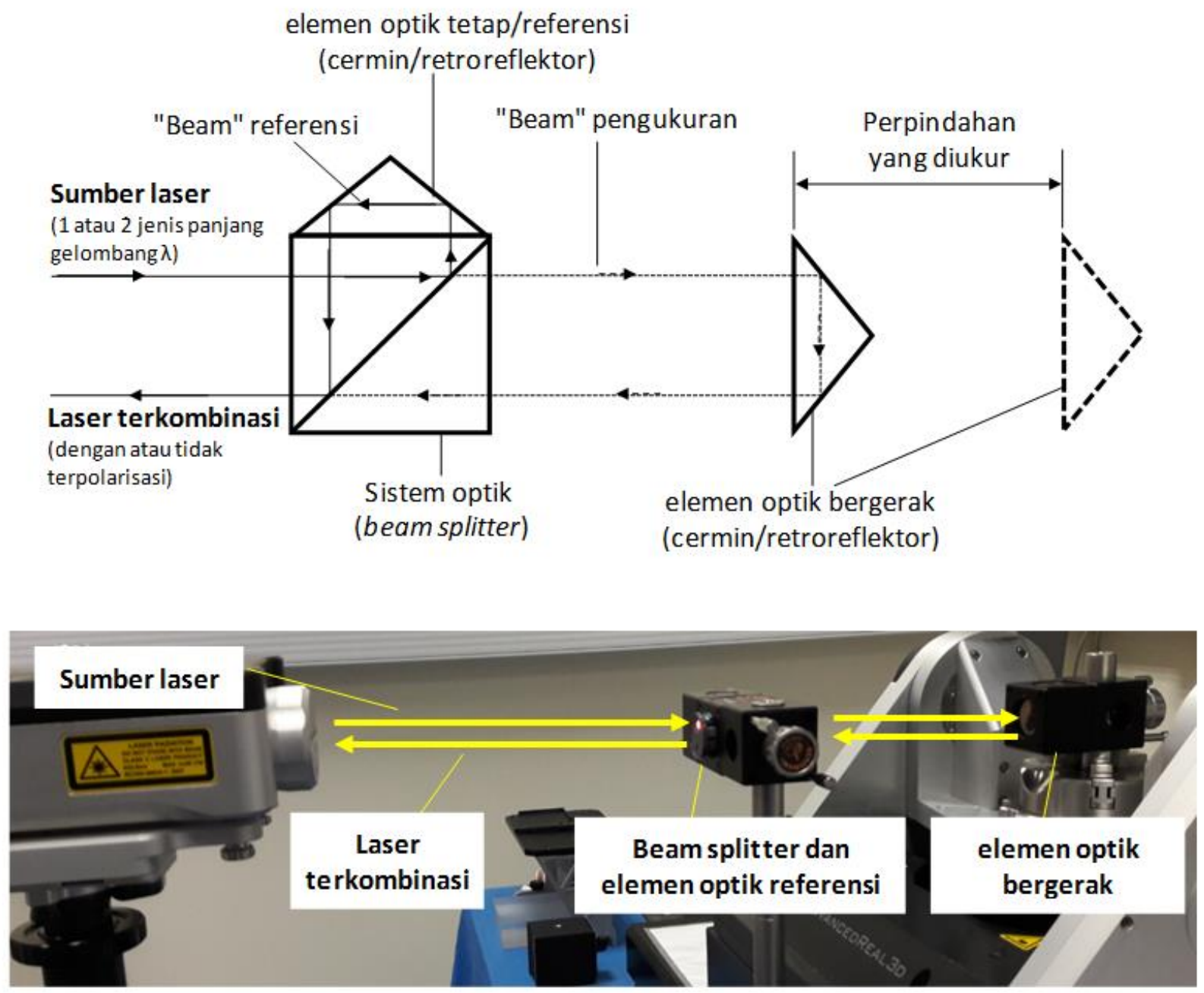

Gambar 35: Diagram cara kerja interferomteri laser (atas) dan contoh riil suatu instrument interferometri laser (bawah).

Laser terkombinasi yang terekam pada sensor cahaya (photo detector) pada suatu interferometri laser diperlihatkan pada gambar 36. Jarak yang terukur dengan interferomteri laser tersebut didapatkan dari menganalisis sinyal gelomang yang terekam tersebut. Pada gambar 36, jarak antara puncak-ke-puncak atau jarak satu periode sinyal dari data intensitas yang terekam merepresentasikan jarak perpindahan dari retroreflektor bergerak pada "beam" pengukuran adalah sebesar $\lambda / 2$. Sebab dari besarnya jarak perpindahan dari retroreflektor tetap tersebut $\lambda / 2$ dan direpresentasikan dengan satu periode gelombang pada sinyal terekam tersebut didapatkan karena panjang lintasan laser pada "beam" pengukuran adalah bolak-balik. 


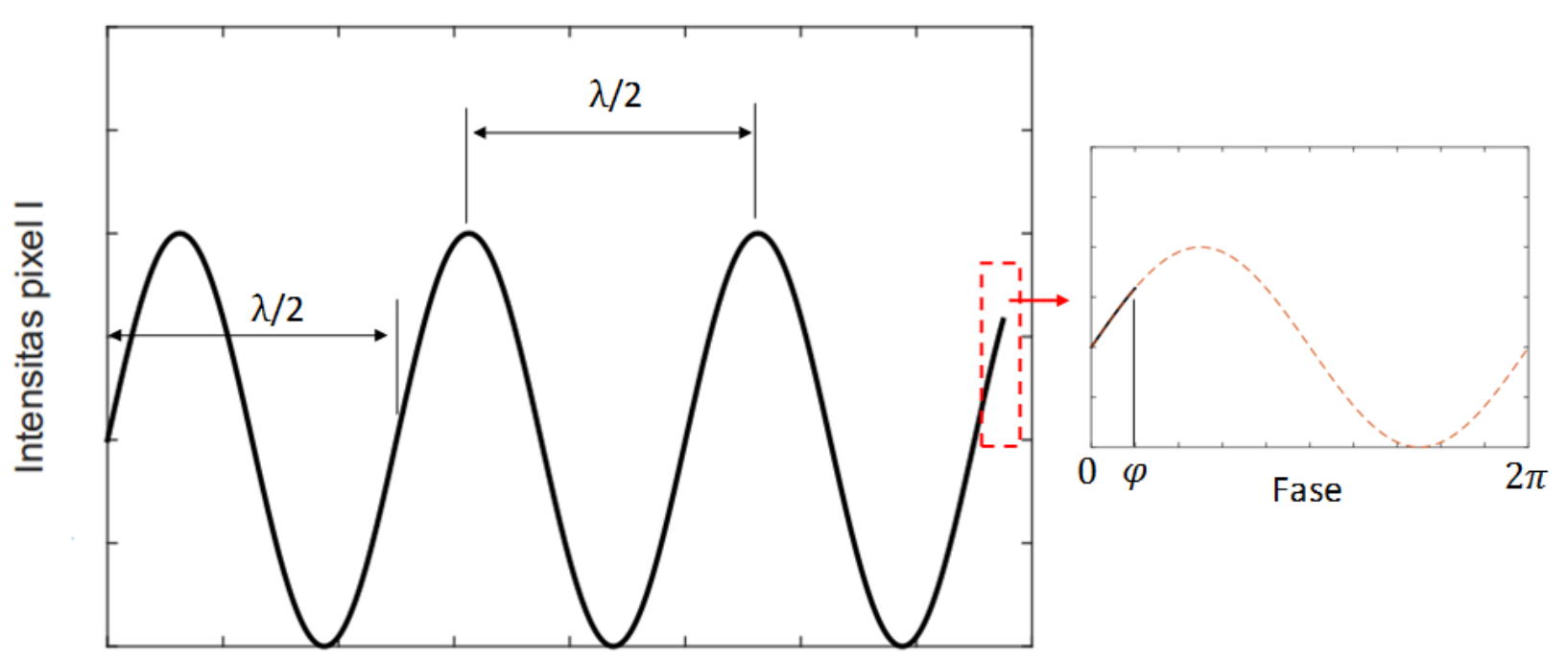

$\mathrm{Jarak} / \mu \mathrm{m}$

Gambar 36: Analisis sinyal intensitas piksel pada suatu detektor cahaya (photo detector) yang menangkap sinyal balik laser terkombinasi (lihat gambar 35).

Berdasarkan analisis sinyal terekam dari data intensitas dari interferensi dua gelombang (gambar 36), maka suatu jarak $d$ dapat diukur sebagai berikut (Haitjema 2008):

$$
d=\frac{\lambda}{2} \cdot\left(N+\frac{\Delta \varphi}{2 \pi}\right)
$$

dimana $\lambda$ adalah panjang gelombang dari suatu jenis laser yang digunakan. $N$ adalah jumlah periode penuh (misal jumlah puncak-ke-puncak atau banyaknya transisi gelap-terang) dari siyal yang terekam, yaitu jumlah dari $\frac{\lambda}{2} . \Delta \varphi$ adalah perubahan atau perbedaan fase yang merupakan fraksi dari jumlah periode penuh dari sinyal terekam tersebut. merupakan komponen yang menyebabkan jarak yang terukur dengan interferometri laser mempunyai resolusi yang sangat tinggi.

Dari persamaan (4) yang digunakan untuk mengukur jarak oleh suatu interferometri laser, dapat langsung dilihat bahwa sumber error utama (dan yang merupakan sumber ketidakpastian atau uncertainty utama) dari suatu pengukuran interferometri laser adalah panjang gelombang laser $\lambda$, jumlah periode penuh yang dihitung $N$ dan perbedaan fase $\Delta \varphi$. Perlu diketahui bahwa pada jarak yang terukur $d$ pada persamaan 4 adalah berdasarkan panjang gelombang di dalam medium pengukuran, dalam hal ini udara, sehingga $\lambda=\lambda_{a} \cdot \lambda_{a}$ adalah panjang gelombang laser yang digunakan pada medium udara.

Pada kenyataannya, sebuah interferometri laser hanya mengetahui panjang gelombang sesuai dengan laser yang dihasilkan, dengan kata lain interferometri tersebut hanya mengetahui panjang gelombang lasernya pada medium vakum (ruang hampa) $\lambda_{v}$. Panjang gelombang pada medium vakum tersebut, $\lambda_{v}$, adalah panjang gelomang yang digunakna untuk mengkalkulasi suatu jarak $d$ yang diukur dengan interferometri tersebut.

Sehingga, untuk menghasilkan suatu pengukuran jarak $d$ dengan suatu interferometri laser, indeks refraktif udara $n_{a}$ harus diukur untuk untuk dapat mengkompensasi $\lambda_{v}$. Karena, pada kondisi riilnya, panjang gelombang suatu laser 
di vakum $\lambda_{v}$, yang digunakan untuk mengkalskulasi jarak $d$, adalah berbeda dengan panjang gelombang laser tersebut pada medium udara $\lambda_{a}$. Hubungan $\lambda_{a}$ dan $\lambda_{v}$ dapat diturunkan dari persamaan-persamaan berikut:

$$
\begin{aligned}
& \lambda_{a}=\frac{c}{n_{a} \cdot f} \\
& \lambda_{v}=\frac{c}{f}
\end{aligned}
$$

dimana $C$ adalah kecepatan cahaya di ruang vakum, $f$ adalah frekuensi dari laser yang digunakan dan $n_{a}$ adalah indeks refraktif dari udara tempat pengukuran berlangsung. Dengan membandingkan persamaan (5) dan persamaan (6), maka didapatkan:

$$
\lambda_{a}=\frac{\lambda_{v}}{n_{a}}
$$

Sehingga, perhitungan jarak $d$ dari persamaan (4) menjadi:

$$
\begin{aligned}
& d=\frac{\lambda_{a}}{2} \cdot\left(N+\frac{\Delta \varphi}{2 \pi}\right)=\frac{\lambda_{v}}{2 n_{a}} \cdot\left(N+\frac{\Delta \varphi}{2 \pi}\right) \\
& d=\frac{1}{n_{a}}\left[\frac{\lambda_{v}}{2} \cdot\left(N+\frac{\Delta \varphi}{2 \pi}\right)\right] \\
& d=\frac{1}{n_{a}} \cdot L_{\text {Meas }}
\end{aligned}
$$

dimana $L_{\text {Meas }}$ adalah hasil perhitungan jarak yang dihasilkan oleh suatu interferometri laser. Dapat dilihat bahwa $d$ dipengaruhi oleh indeks refraktif udara $n_{a}$, karena $\lambda_{a}$ dipengaruhi oleh $n_{a}$.

Indeks refraktif udara $n_{a}$ adalah fungsi dari $T_{a}$, kelembapan relatif pada suatu tempat pengukuran $R h$ dan tekanan atmosfer $P_{a}$ pada tempat pengukuran tersebut (Bonsch dan Potulski 1998). Dengan kata lain, $n_{a}$, $=$ $f\left(T_{a}, R h, P_{a}\right)$. Maka dari itu, untuk dapat menghasilkan suatu pengukuran interferometri laser dengan tingkat akurasi yang tinggi, maka pengukuran-pengukuran parameter $T_{a}, R h$ dan $P_{a}$ tersebut harus dilakukan untuk dapat mekompensasi efek lingkungan dan untuk mengkalkulasi secara akurat panjang gelombang $\lambda_{a}$ dari laser yang digunakan. Gambar 37 memperlihatkan konfigurasi lengkap dari sebuah pengukuran dengan interferometri laser yang dilengkapi dengan sensor pembaca kondisi lingkungan (atmosfir). Dari laporan yang diterbitkan oleh Bonsch dan Potulski tersebut, sebuah rumus empirik yang panjang dibutuhkan untuk dapat mengestimasi $n_{a}$. Untuk memudahkan estimasi pada kondisi riil, pengetahuan dari sensitifitas dari jarak yang diukur terhadap variasi kondisi lingkungan (atmosfer) dapat digunakan seperti yang diperlihatkan pada tabel 6. Gambar 38 memperlihatkan contoh error pada suatu wahana bergerak (linear stage) yang diukur dengan menggunakan sebuah interferometri laser. 
Tabel 6: Sensitifitas dari suatu jarak yang diukur $d$ terhadap variasi kondisi lingkungan.

\begin{tabular}{lcc}
\hline Kondisi lingkunan & Perubahan atau ketidakpastian & $\begin{array}{l}\text { Perubahan atau ketidakpastian pada suatu jarak yang } \\
\text { terukur } d \text { per metre. }\end{array}$ \\
\hline Temperatur udara, $T_{a}$ & $1{ }^{\circ} \mathrm{C}$ & $0.93 \mu \mathrm{m}$ \\
Tekanan udara, $p_{a}$ & $1 \mathrm{hPa}$ & $-0.27 \mu \mathrm{m}$ \\
kelembapan Rh & $1 \% \mathrm{Rh}$ & $0.009 \mu \mathrm{m}$ \\
\hline
\end{tabular}

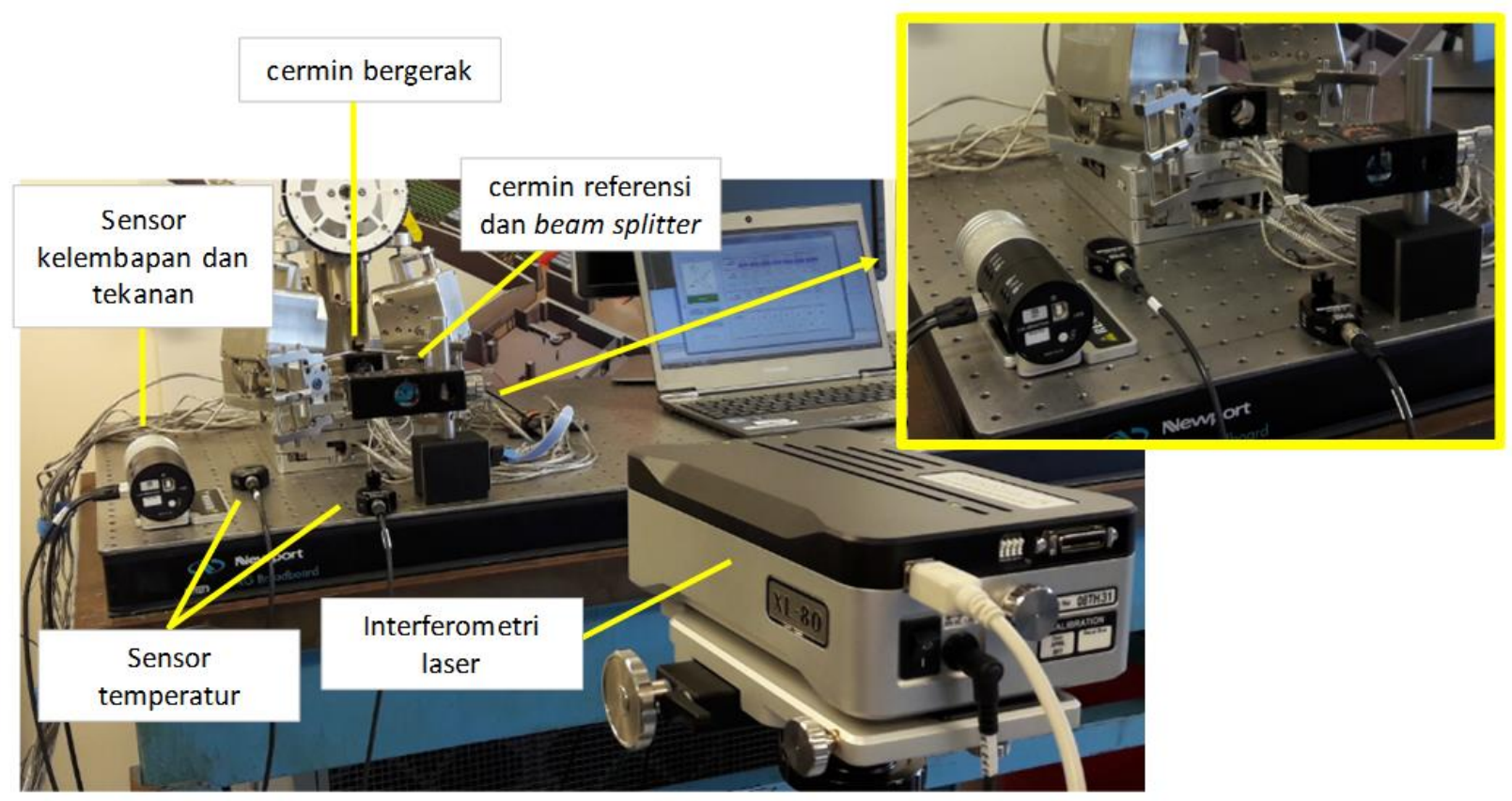

Gambar 37: Konfigurasi lengkap dari interferomteri laser dengan sensor pengukur keadaan lingkungan (temperatur udara, tekanan udara dan kelembapan relatif udara). 


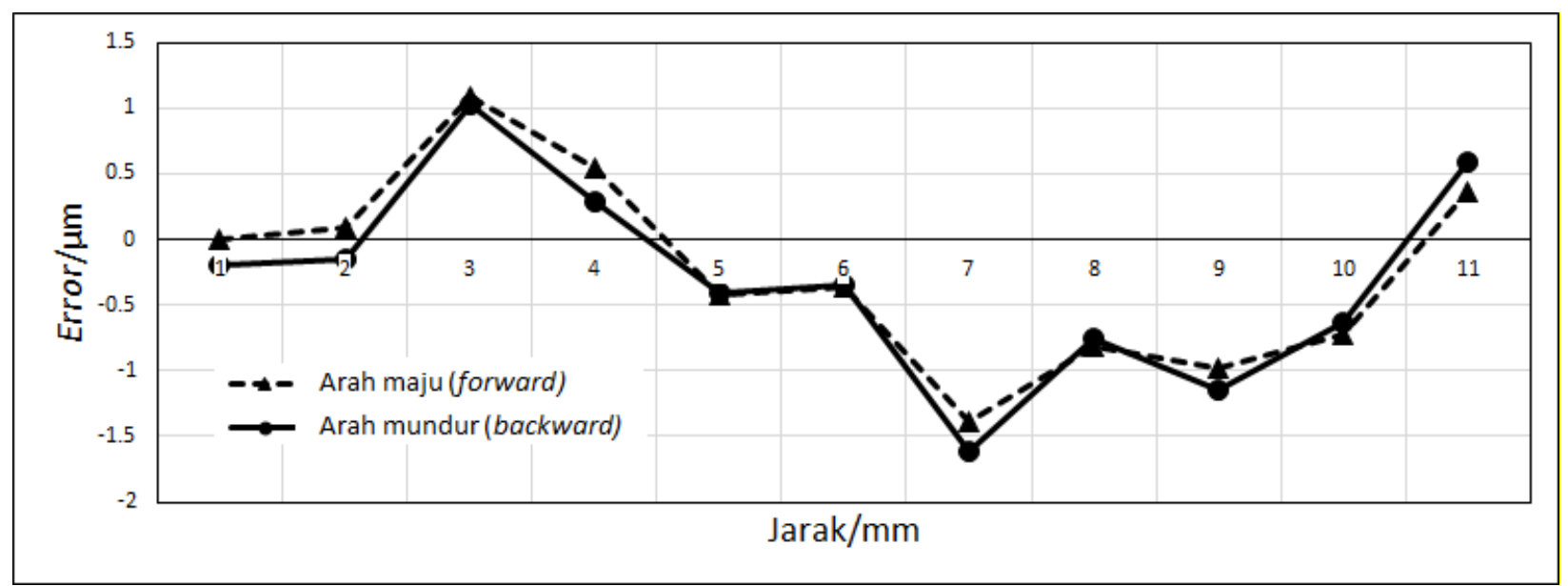

Gambar 38: Contoh error skala pada sebuah wahan bergerak (motion stage) yang diukur dengan sebuah interferometri laser.

\section{Model pengukuran panjang dari sebuah interferometri laser.}

Untuk dapat mengestimasi ketidakpastian (uncertainty) dari hasil pengukuran panjang dengan menggunakan suatu interferometri laser, maka model pengukuran panjangnya harus dikonstruksi terlebih dahulu. Model pengukuran panjang yang diukur menggunakan sebuah interferometri laser adalah:

$$
\begin{aligned}
& d=d_{\text {meas }}+d_{\text {meas }} \cdot \alpha \cdot\left(T_{m}-20{ }^{\circ} \mathrm{C}\right) \\
& d=\frac{L_{\text {Meas }}}{n_{a}}+\frac{L_{\text {Meas }}}{n_{a}} \cdot \alpha \cdot\left(T_{m}-20{ }^{\circ} \mathrm{C}\right) \\
& d=\frac{L_{\text {Meas }}}{n_{a}}\left[1+\alpha \cdot\left(T_{m}-20{ }^{\circ} \mathrm{C}\right)\right] \\
& d=\frac{L_{\text {Meas }}}{n_{a}\left(T_{a}, P_{a}, R_{h}\right)}\left[1+\alpha \cdot\left(T_{m}-20{ }^{\circ} \mathrm{C}\right)\right]
\end{aligned}
$$

dimana $\alpha$ adalah koefisian ekspansi termal dari sebuah material yang diukur dan $T_{m}$ adalah temperatur dari material tersebut.

Maka, summber-sumber ketidakpastian (uncertainty) dari hasil pengukuran jarak/panjang dengan interferometri laser adalah: $T_{a}, P_{a}, R_{h}, \alpha, T_{m}$ dan repeatability dari pengukuran tersebut.

\subsubsection{Mesin pengukur coordinate (coordinate measuring machine /CMM)}

Mesin pengukur koordinat (coordinate measuring machine/CMM) adalah sebuah instrumen yang mendeteksi (mengukur) koordinate spasial (posisi titik dalam ruang 3D) pada suatu permukaan benda yang diukur, baik dengan metode kontak (tactile) maupun metode non-kontak (optikal). Sesuai dengan definisinya, CMM adalah jenis instrumen untuk pengukuran 3D. Bab 5 akan membahas secara khusus dan detil mengenai CMM.

CMM pertamakali dibuat pada kisaran akhir tahun 1950-an sampai dengan awal 1960-an. CMM pertama yang dibagun adalah CMM buatan perushaan Ferranti Ltd di Skotlandia. Awal mula motivasi dibuatnya CMM adlaah untuk mendukung otomatisasi sistem manufaktur sebagai instrumen untuk mendukung mesin-mesin produksi berbasis kontrol numerik (computer numerical controlled/CNC). CMM buatan Ferranti belum merepresentasikan CMM seperti zaman sekarang karena belum terintegarasi dengan sistem CNC dan belum sepenuhnya dapat digunakan untuk 
pengukuran 3D. Pada tahun 1963, seorang perekayasa dari Italia yang bernama Franco Sartorio (yang bekerja pada perusahaan FIAT pada saat itu) mempunyai ide untuk membuat sebuah CMM sebagai alat ukur universal yag dapay mengukur berbagai macam jenis pengukuran dimensi dan geometri. Kemudian, Sartori membentuk perusahaan Digital Electronic Automation (DEA) di Torino (Italia) dan membuat pertama kali CMM 3D dengan konstruksi bridge. Sampai saat ini, perusahaan DEA eksis sebagai salah satu manufaktur CMM terkemuka dunia, disamping Zeiss dan Leitz.

CMM merupakan instrumen fundamental untuk pengukuran dimensi dan geometri. Secara khusus untuk GDNT (Bab 3), salah satu tujuan utama penggunaan CMM adalah untuk memverifikasi GD\&T (toleransi geometrik). Pada saat ini, CMM digunakan untuk mengukur suatu komponen dari ukuran makro sampai mikro, yaitu dari ukuran sebuah bus sampai ukuran sebuah roda gigi mikro yang mempunyai diamater sekitar $>100 \mu \mathrm{m}$. Tipe-tipe aplikasi umum dari penggunaan CMM adalah seperti pengukuran diameter suatu lingkaran atau silinder, pengukuran flatness suatu permukaan, pengukruan roundess suatu silinder, pengukuran orientasi suatu permukaan datar, pengukuran ketegaklurusan dari suatu permukaan benda, pengukuran lokasi dari titik tengah suatu silinder pada suatu komponen, pengukuran run-out suatu komponen dan pengukuran suatu permukaan benda yang mempunya bentuk yang kompleks (free-form surface).

Standar ISO utama yang mengatur mengenai CMM adalah seri ISO 10360 dan ISO 15530. Seri ISO 10360 adalah standar ISO yang mengatur mengenai verifikasi performansi CMM (baik kartesian maupun non-kartesian dan baik kontak maupun non kontak) untuk megentahui atau mengecek apakah suatu CMM berfungsi sesuai dengan tingkat akurasi yang berada pada spesifikasinya. Seri ISO 15530 adalah standar ISO yang mengatur bagaimana menentukan nilai ketidakpastian dari suatu hasil pengukuran menggunakan CMM (yang bisa diaplikasikan untuk berbagai macam instrumen pengukuran non-CMM). Selain itu, standar Jerman mengenai CMM yang umum digunakan (terutama pada manufaktur yang berasal dari Jerman) adalah VDI/VDE 2630 mengenai CT-Scan dan VDI/VDE 2634 mengenai sistem pengukuran CMM berbasis optik.

Berdasarkan sistem koordinat, CMM dibagi menjadi dua kelas, yaitu:

- $\quad$ Sistem Kartesian

CMM berbasis sistem kartesian pada umumnya terdiri dari 3-, 4- dan 5-aksis untuk sistem pergerakannya (motion stage). Sistem pergerakan tersebut berbasis sistem koordinate kartesian dimana sistem pergerakan tersebut mempunyai suatu titik referensi sebagai titik nolnya. CMM berbasis kartesian dapat terbagi menjadi CMM berbasis kontak dan non-kontak (termasuk CMM yang dilengkapi pemindaian berbasis laser/laser scanner). Tipe-tipe CMM berbasis kartesian adalah seperti (ISO 10360-1): CMM berbasis kantilever, CMM berbasis moving-bridge, CMM berbasis gantry, CMM berbasis bridge bentuk-'L' dan CMM berbasis fixed bridge.

Gambar 39 memperlihatkan contoh dari CMM berbasis kartesian yang sering ditemu di industri. Pada gambar 39, jenis CMM yang diperlihatkan adalah CMM berbasis moving-bridge, kantilever, gantry dan fixed-bridge. Masing-masing jenis konfigurasi CMM tersebut memiliki kelebihan dan kekurangan masing-masing. Jenis CMM tersebut mempunyai kecocokan untuk suatu situasi pengukuran tertentu. Moving bridge CMM sangat cocok untuk pengukuran suatu benda pada skala medium sampai besar. Tipe CMM moving bridge adalah yang paling umum digunakan. Tingkat akurasi CMM jenis moving bridge merupakan salah satu yang paling tinggi setelah CMM jenis fixed-bridge. Tipe CMM kenis kantilever mempunyai tinkat akurasi yang lebih rendah. Namun demikian, jenis CMM ini mempunyai tingkat aksesibilitas yang tinggi, sehingga umum digunakan untuk pengukuran body mobil. Jenis CMM gantry mempunyai kelebihan dapat mengukur benda yang sangat besar, bahkan benda seukuran bus. Namun, tingkat akurasi CMM jenis ini lebih rendah dibandingkan CMM lainnya. CMM jenis fixed-bridge merupakan CMM dengan tingkat akurasi yang paling tinggi. Kelemahan jenis CMM ini adalah CMM tersebut mempunyai kecepatan pengukuran yang rendah dibandingkan dengan jenis CMM kartesian lainnya. 

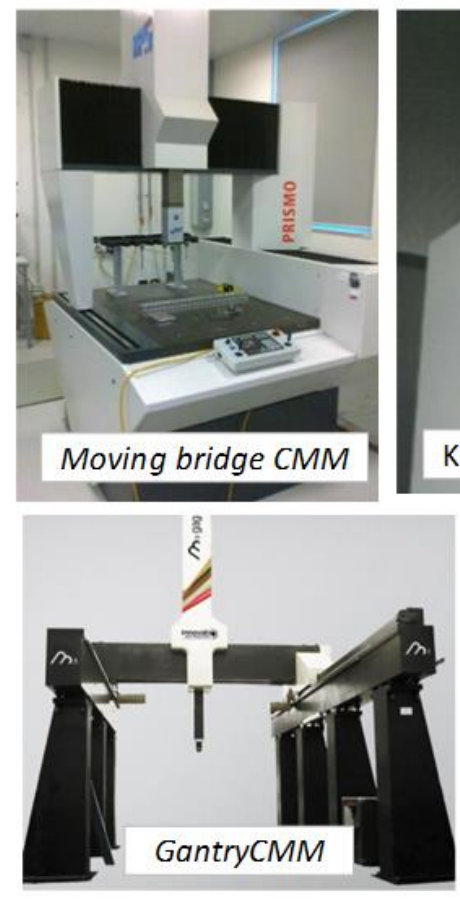
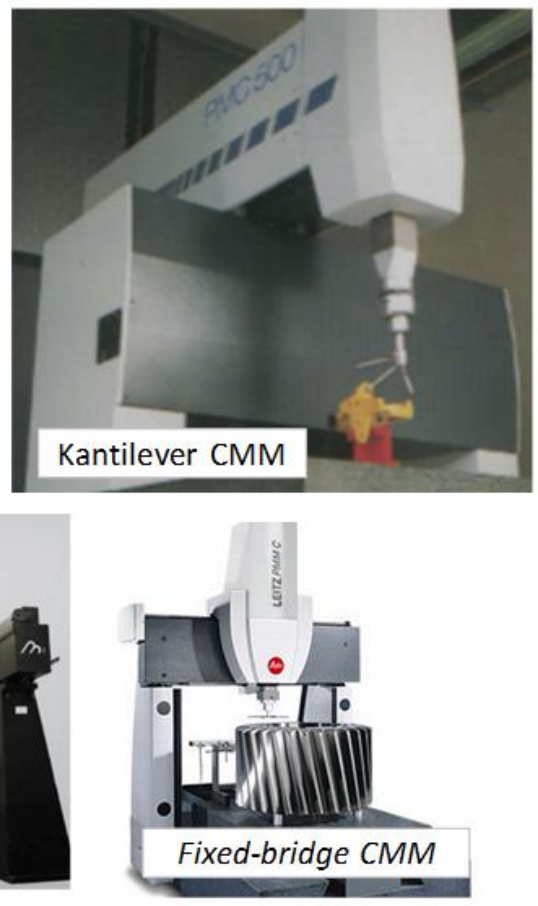
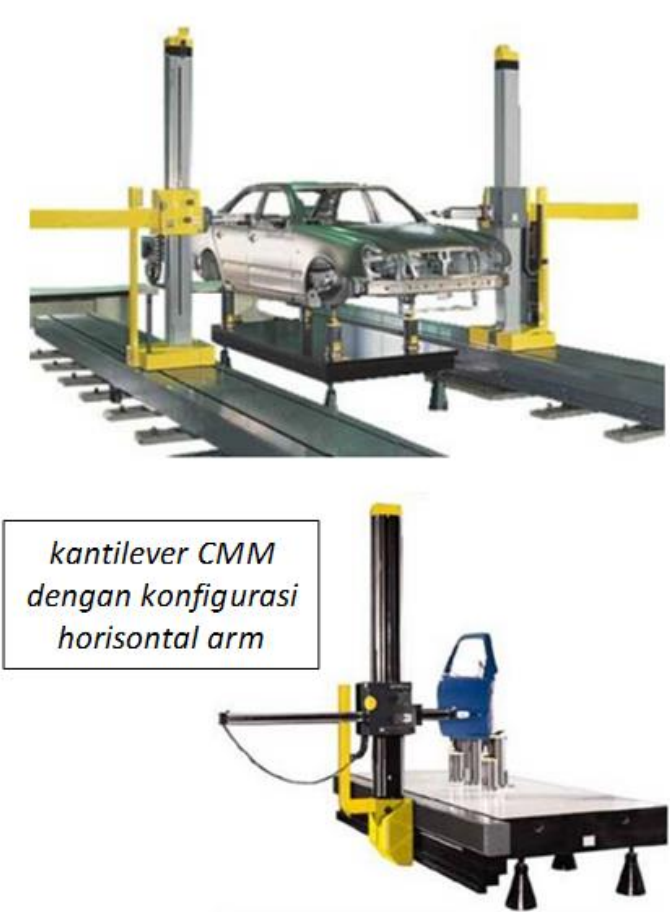

Gambar 39: CMM berbasis kartesian.

- $\quad$ Sistem Non-kartesian

CMM berbasis non kartesian adalah CMM yang tidak berdasarkan sistem koordinat spasial (X, Y and Z). pada umumnya, CMM dengan sistem kartesian berdasarkan sistem koordinat silinder atau spherical. Jenis lain CMM non kartesian adalah CMM tersebut tidak bergerak melainkan tetap pada satu posisi ketika melakukan pengukuran. Seperti sistem kartesian, CMM dengan sistem non-kartesian juga terdiri dari sistem kontak dan non-kontak. Contoh CMM berbasis non-kartesian adalah CMM berbasis articulated arm, CMM berbasis photogrammtery, CMM berbasis fringe projection dan CMM berbasis laser-tracker.

Gambar 40 memperlihatkan beberapa jenis CMM non-kartesian, yaitu CMM berbasis articulated arm, laser tracker, photogrammtery dan fringe projection. CMM berbasis articulated arm mempunyai sistem kooridnat silinder, sedangkan CMM berbasis laser tracker mempunyai sistem koordinat sphrerical. CMM berbasis photogrammtery dan fringe projection pada umumnya berada pada lokasi tetap ketika pengukuran berlangung. Pada umumnya, CMM berbasis non-kartesian adalah berbasis optik, kecuali CMM berbasis articulated arm yang berbasis kontak (tactile). CMM berbasis non-kartesian pada umumnya mempunyai tingkat akurasi yang lebih rendah dari pada CMM berbasis kartesian, kecuali CMM berbasis laser tracker yang merupakan CMM berbasis non-kartesian dengan tingkat akurasi yang tinggi. 


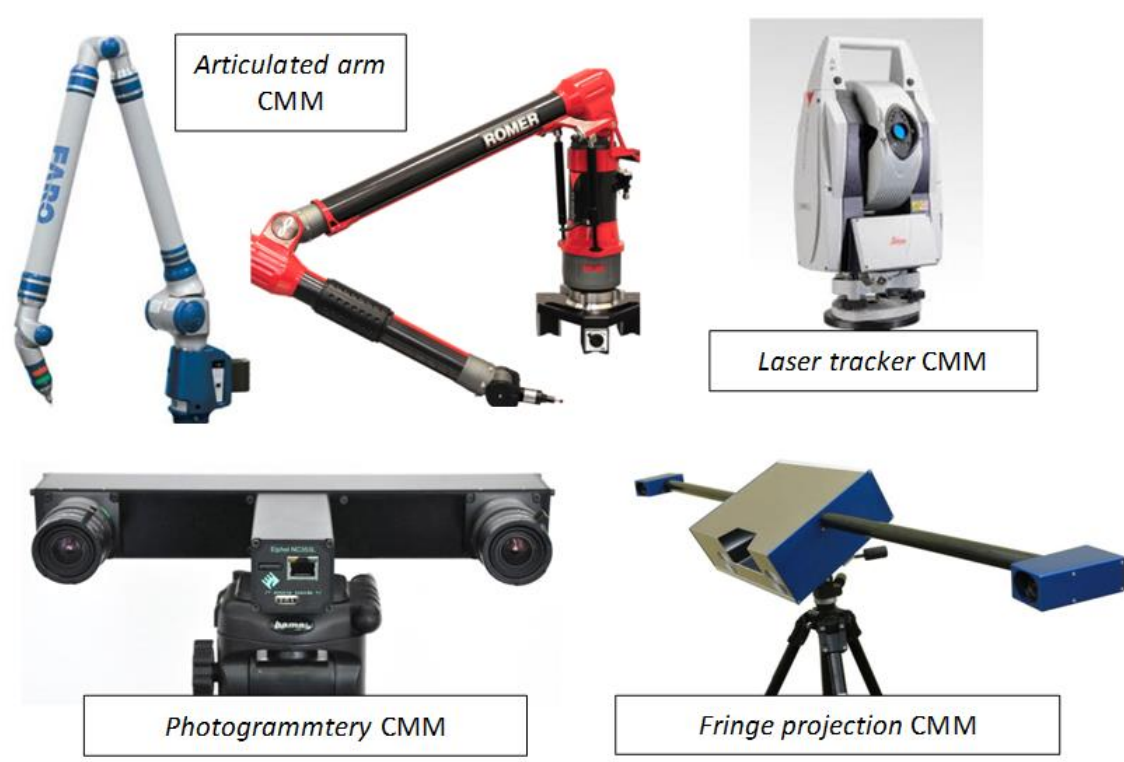

Gambar 40: CMM berbasis non-kartesian.

\subsection{Analisis sistem pengukuran (Gauge $R \& R$ )}

Contoh analisis sistem pengukuran (GR\&R) ini memperlihatkan salah satu contoh riil dari aplikasi analisis tersebut pada sebuah pengukuran menggunakan jangka sorong. Landasan teori dan rumus-rumus kalkulasi untuk analisis GR\&R diperlihatkan pada bab 2. GR\&R adalah salah satu metode analisis yang paling sering digunakan pada industri-industri manufaktur, sehingga sangat penting untuk memahami metode tersebut.

Seperti yang sudah dijelaskan pada bab 2, analisis sistem pengukuran (GR\&R) adalah sebuah metode yang digunakan untuk mengevaluasi sebuah sistem pengukuran dan untuk menentukan apabila sistem pengukuran tersebut dapat digunakan (efektif) untuk mengukur suatu measurand (properti dari suatu fitur yang ingin diukur). Yang termasuk dengan "sistem pengukuran" adalah suatu instrumen pengukuran yang akan dianalisis, operator yang menggunakan sistem pengukuran tersebut dan prosedur yang digunakan untuk melakukan suatu pengukuran. Maka dari itu, metode GR\&R merupakan suatu metode yang komprehensif untuk menganalisis suatu instrumen berikut dengan faktor-faktor yang terlibat langsung dengan penggunaan instrumen tersebut.

Ada dua konsep dasar yang perlu dipahami dalam melakukan analisis GR\&R, yaitu:

- GR\&R mengevaluasi sebuah sistem pengukuran (intrumen, operator dan prosedur pengukuran) dan bukan mengevaluasi suatu produk atau komponen.

- GR\&R memberikan informasi total variasi yang berkaitan dengan seluruh faktor-faktor pada sebuah sistem pengukuran yang dianalisis, yaitu variasi yang berasal dari instrumen dan operator.

Ada lima hal yang diperlukan untuk mengaplikasikan analisis GR\&R pada suatu sistem pengukuran. Kelima hal tersebut adalah:

- Lima atau sepuluh komponen dengan dimensi yang sengaja divariasikan dari batas bawah sampai batas atas toleransinya. Hal ini bertujuan untuk mengevaluasi apakah suatu sistem pengukuran (instrumen, operator dan prosedur pengukuran) yang digunakan dapat membaca variasi dari komponen tersebut, karena pada intinya, suatu sistem pengukuran dikatakan efektif apabila sistem tersebut dapat membaca variasi dari suatu komponen yang diukur dengan sistem tersebut dan bukan variasi yang berasal dari sistem pengukuran tersebut.

- Dua atau lebih operator yang melakukan pengukuran dengan sistem yang akan dianalisis. Hal ini bertujuan untuk memperhitungkan variasi yang berasal dari operator yang berbeda.

- Sebuah instrumen pengukuran yang akan dianalisis. 
- Tiga atau lebih pengulangan pengukuran untuk setiap komponen dan setiap operator.

Tabel 7: Komponen-komponen (sumber-sumber) variasi dalam analis GR\&R.

\begin{tabular}{|c|l|l|}
\hline Tipe variasi & \multicolumn{1}{|c|}{ Penjelasan } & \multicolumn{1}{c|}{ Aksi } \\
\hline Komponen (part) & $\begin{array}{l}\text { Perbedaan antara tiap-tiap komponen } \\
\text { (part-to-part variation) }\end{array}$ & \multicolumn{1}{|c|}{ - } \\
\hline Operator (reproducibility) & $\begin{array}{l}\text { Variasi pengukuran dari operator } \\
\text { yang berbeda pada komponen yang } \\
\text { sama dan instrumen yang sama }\end{array}$ & $\begin{array}{l}\text { Jika variasinya lebih dari variasi } \\
\text { yang bersumber dari instrumen, } \\
\text { maka operator tersebut harus di- } \\
\text { training lagi. }\end{array}$ \\
\hline Instrumen (repeatability) & $\begin{array}{l}\text { Repeatability dari instrumen yang } \\
\text { dianalisis dengan mengukur } \\
\text { komponen yang sama oleh operator } \\
\text { yang sama }\end{array}$ & $\begin{array}{l}\text { Jika variasinya lebih dari variasi } \\
\text { yang bersumber dari operator, } \\
\text { maka instrumennya harus } \\
\text { diperbaiki atau di-maintanance } \\
\text { ulang. }\end{array}$ \\
\hline
\end{tabular}

Penjelasan dari komponen-komponen variasi dalam analisis GR\&R (tabel 7) adalah sebagai berikut. Apabila variasi dari instrumen dan operator (total nilai GR\&R) dibandingkan dengan total variasi analisis:

- $\quad<10 \%$ : Instrumen yang dianalisis dapat digunakan untuk pengukuran yang diinginkan.

Nilai $10 \%$ tersebut merupakan kesepakatan bahwa suatu instrumen pengukuran dikatakan dapat digunakan untuk mengukur apabila variasi instrumen tersebut lebih kecil satu magnitud dari variasi komponen yang diukur. Dengan kata lain, variasi dari suatu instrumen tidak lebih dari $10 \%$ dari variasi komponen-komponen yang diukur.

- $\quad<20 \%$ : Instrumen yang dianalisis masih cukup digunakan untuk pengukuran yang diinginkan walaupun efisiensi pengukuran tersebut akan berkurang.

- $\quad>20 \%$ : Instruman yang dianalisis tidak dapat digunakan untuk pengukuran yang diinginkan.

Pada umumnya, hal tersebut menunjukkan bahwa instrumen tersebut harus diperbaiki atau suatu instrumen lain yang lebih akurat harus digunakan untuk menggantikan instrumen tersebut.

\section{Contoh kasus 1 analisis sistem pengukuran (GR\&R): Total nilai GR\&R $>20 \%$, yaitu sistem pengukuran tidak dapat (tidak efektif) digunakan.}

Sebuah pengukuran dengan menggunakan jangka sorong dilakukan untuk mengukur suatu benda berbentuk silinder yang mempunyai nilai diamater antara $49 \mathrm{~mm}-51 \mathrm{~mm}$. Sebelum jangka sorong tersebut digunakan untuk mengukur, jangka sorong tersebut dilakukan tes GR\&R. Tes tersebut dilakukan dengan dua orang operator, dengan lima jenis ukuran silinder yang sengaja divariasikan dan tiga pengulangan pada setiap pengukuran. Tabel 8 memperlihatkan data hasil pengukuran untuk tes GR\&R tersebut. 
Tabel 8: Hasil-hasil pengukuran diamater silinder dengan sebuah jangka sorong oleh dua operator.

\begin{tabular}{|c|c|c|}
\hline Operator & Diameter nominal silinder & Hasil pengukuran \\
\hline 1 & 49 & 49.1 \\
\hline 1 & 49 & 49.05 \\
\hline 1 & 49 & 48.99 \\
\hline 1 & 49.5 & 49.4 \\
\hline 1 & 49.5 & 49.4 \\
\hline 1 & 49.5 & 49.6 \\
\hline 1 & 50 & 50.1 \\
\hline 1 & 50 & 50.05 \\
\hline 1 & 50 & 50.1 \\
\hline 1 & 50.5 & 50.6 \\
\hline 1 & 50.5 & 50.55 \\
\hline 1 & 50.5 & 50.53 \\
\hline 1 & 51 & 51.1 \\
\hline 1 & 51 & 49.95 \\
\hline 1 & 51 & 50.95 \\
\hline 2 & 49 & 49.03 \\
\hline 2 & 49 & 49.05 \\
\hline 2 & 49 & 48.99 \\
\hline 2 & 49.5 & 49.6 \\
\hline 2 & 49.5 & 49.4 \\
\hline 2 & 49.5 & 49.6 \\
\hline 2 & 50 & 50.1 \\
\hline 2 & 50 & 50.1 \\
\hline 2 & 50 & 50.1 \\
\hline 2 & 50.5 & 50.6 \\
\hline 2 & 50.5 & 50.52 \\
\hline 2 & 50.5 & 50.53 \\
\hline 2 & 51 & 51.02 \\
\hline 2 & 51 & 49.95 \\
\hline 2 & 51 & 50.95 \\
\hline
\end{tabular}

Proses detil dari kalkulasi data-data tersebut telah dijelaskan pada Bab 2, dimana formula yang digunakan untuk mengalkulasi data tersebut telah diperlihatkan. Untuk memudahkan perhitungan, sebuah perangkat lunak komersial Minitab digunakan untuk menganalisis data tersebut. Hasil analisis GR\&R dengan perangkat lunak tersebut diperlihatkan pada gambar 41 dan 42. Pada gambar 41, diperlihatkan bahwa total variaiu GR\&R adalah $38.3 \%$. Total variasi GR\&R tersebut lebih dari $20 \%$, sehingga dapat disimpulkan bahwa instrumen tersbeut tidak bisa dipakai untuk melakukan pengukuran silinder tersebut. Gambar 42 memperlihatkan kontribusi variasi dari berbagai sumber 
pada pengukuran silinder tersebut dengan tes GR\&R.

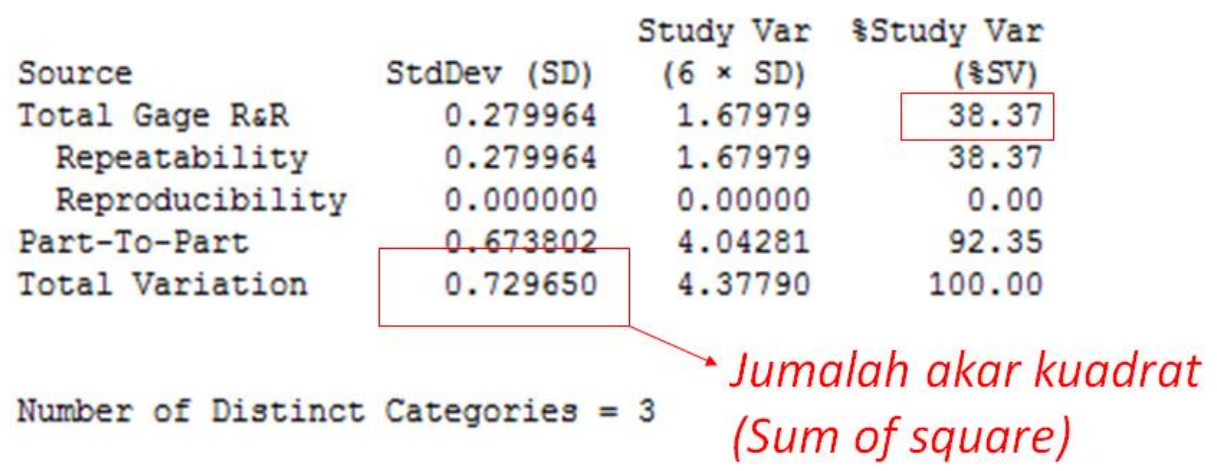

Gambar 41: Hasil analisis GR\&R dengan menggunakan Minitab untuk data pada tabel 8.

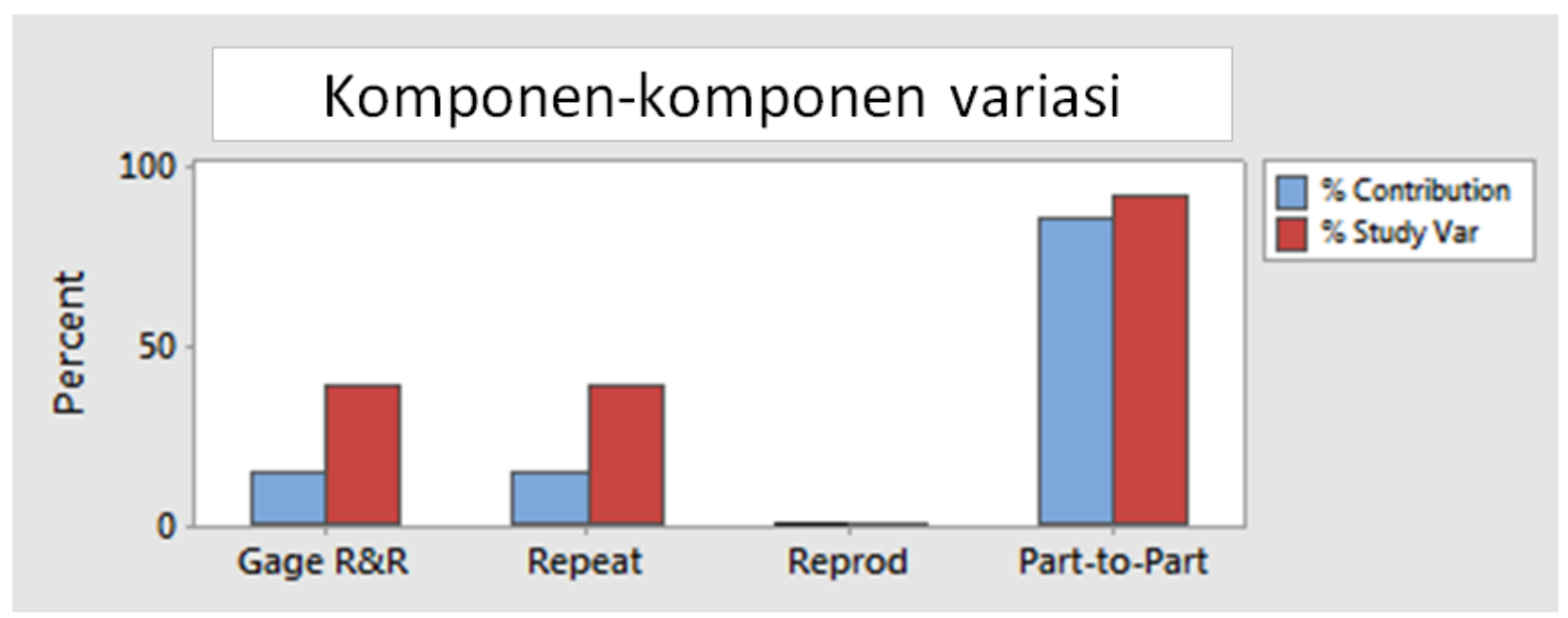

Gambar 42: Komponen-komponen variasi hasil dari Minitab untuk data pada tabel 8.

\section{Contoh kasus 2 analisis sistem pengukuran (GR\&R): Total nilai GR\&R $<10 \%$ (sistem pengukuran dapat (efektif) digunakan)}

Contoh 2 mempresentasikan contoh kasus yang sama dengan contoh 1 namun dengan menggunakan jangka sorong yang berbeda dengan tingkat akurasi yang tinggi. Jangka sorong tersebut dilakukan tes GR\&R dan hasilnya diperlihatkan pada tabel 9. Prosedur test GR\&R tersebut sama dengan contoh 1.

Gambar 43 dan 44 memperlihatkan hasil tes GR\&R tersebut. pada gambar 43, diperlihatkan bahwa total variasi GR\&R adalah sebesar $4 \%$. Hal ini mengindikasikan bahwa jangka sorong tersebut dapat digunakan untuk mengukur silinder tersebut. Gambar 44 memperlihatkan kontribusi variasi dari berbagai sumber pada pengukuran silinder tersebut dengan tes GR\&R. Dari gambar 44, dapat terlihat bahwa sumber variasi dari pengukuran tersebut sebagian besar berasal dari variasi dari silinder yang diukur. 
Tabel 9: Hasil-hasil pengukuran diamater silinder dengan sebuah jangka sorong oleh dua operator.

\begin{tabular}{|c|c|c|}
\hline Operator & Diameter nominal silinder & $\begin{array}{c}\text { Hasil } \\
\text { pengukuran }\end{array}$ \\
\hline 1 & 49 & 49.05 \\
\hline 1 & 49 & 49.08 \\
\hline 1 & 49 & 49.08 \\
\hline 1 & 49.5 & 49.51 \\
\hline 1 & 49.5 & 49.53 \\
\hline 1 & 49.5 & 49.54 \\
\hline 1 & 50 & 50.04 \\
\hline 1 & 50 & 50.02 \\
\hline 1 & 50 & 50.02 \\
\hline 1 & 50.5 & 50.53 \\
\hline 1 & 50.5 & 50.54 \\
\hline 1 & 50.5 & 50.53 \\
\hline 1 & 51 & 49.95 \\
\hline 1 & 51 & 49.85 \\
\hline 1 & 51 & 49.85 \\
\hline 2 & 49 & 48.99 \\
\hline 2 & 49 & 48.99 \\
\hline 2 & 49 & 48.99 \\
\hline 2 & 49.5 & 49.55 \\
\hline 2 & 49.5 & 49.55 \\
\hline 2 & 49.5 & 49.55 \\
\hline 2 & 50 & 50.08 \\
\hline 2 & 50 & 50.04 \\
\hline 2 & 50 & 50.08 \\
\hline 2 & 50.5 & 50.51 \\
\hline 2 & 50.5 & 50.55 \\
\hline 2 & 50.5 & 50.55 \\
\hline 2 & 51 & 50.98 \\
\hline 2 & 51 & 50.97 \\
\hline 2 & 51 & 50.95 \\
\hline
\end{tabular}




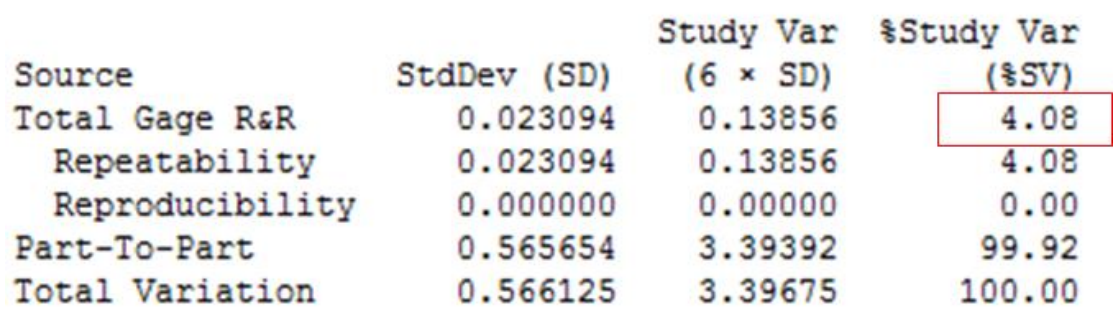

Gambar 43: Hasil analisis GR\&R dengan menggunakan Minitab untuk data pada tabel 9.

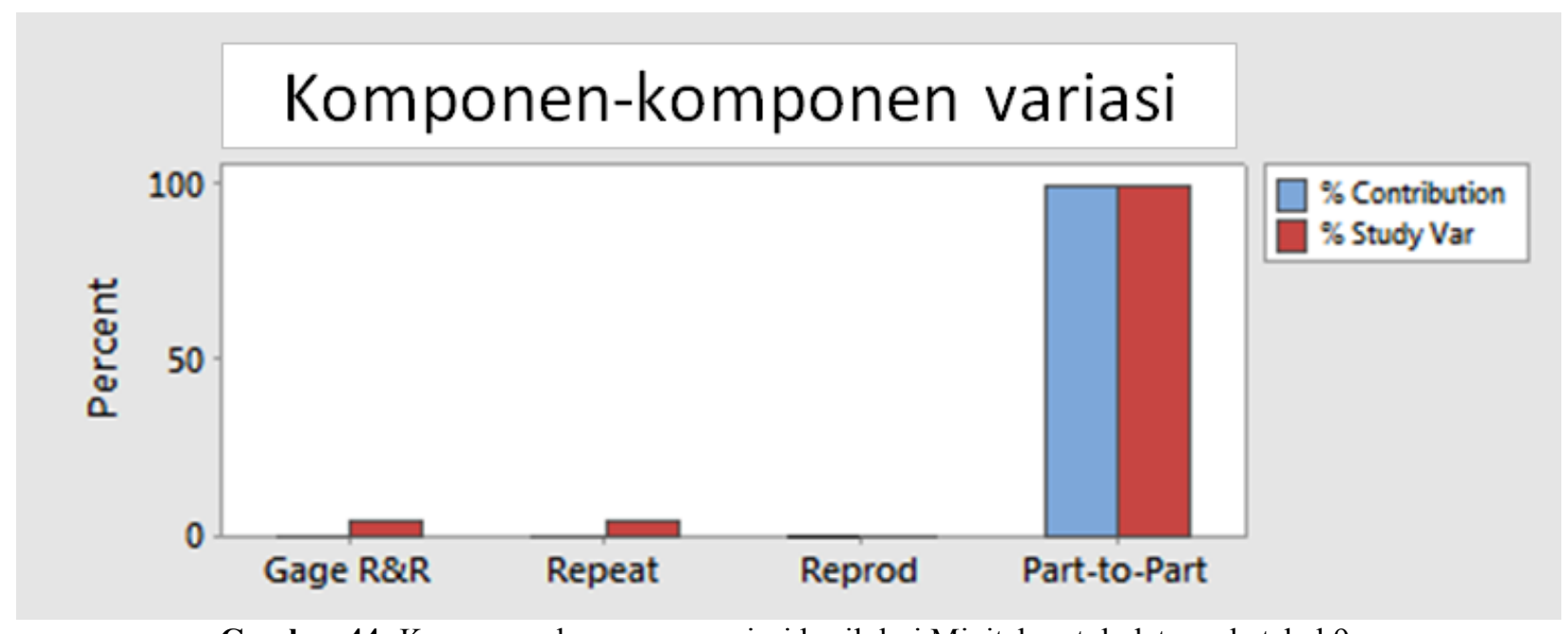

Gambar 44: Komponen-komponen variasi hasil dari Minitab untuk data pada tabel 9.

\subsection{Aspek-aspek penting dalam pengukuran pada skala mikro/nano}

Pengukuran dimensi dan geometri pada skala mikro/nano mempunyai beberapa karakteristik penting yang perlu selalu diperhitungkan. Karakteristik-karakteristik tersebut tidak terdapat pada pengukuran dengan skala makro/meso. Maka dari itu, pengukuran dimensi dan geometri pada skala mikro/nano membutuhkan tingkat ketelitian dan presisi serta prosedur khusus untuk mendapatkan hasil pengukuran yang akurat.

Hal-hal penting yang harus diperhatikan secara khusus untuk pengukuran dimensi dan geometri pada skala mikro/nano adalah:

- Rasio antara ketidakpastian dan toleransi.

Suatu pengukuran pada suatu fitur akan dikatakan efisien apabila nilai ketidakpastian dari hasil pengukuran tersebut tidak lebih dari seperlima $(<20 \%)$ dari nilai toleransi fitur tersebut. dengan kata lain, suatu pengukuran secara umum dikatakan efisien apabila nilai rasio antara ketidakpastian pengukuran tersebut dan nilai toleransinya $<20 \%$. Maka dari itu, pada skala mikro/nano, nilai toleransinya akan semakin kecil dan nilai ketidakpastian dari pengukuran tersebut akan lebih kecil lagi untuk menjaga nilai rasio antara ketidakpastian dan toleransi $<20 \%$, sehingga tingkat keakuratan suatu instrumen pengukuran yang digunakan akan semakin tinggi

- $\quad$ Effek size.

Komponen pada skala mikro/nana mempunyai properti khusus dibandingkan apabila komponen tersebut mempunyai ukuran pada skala makro/mesa, seperti: efek dari gaya gravitasi menjadi tidak relevan dan ukuran diameter stylus yang sangat kecil pada kontak CMM akan menempel pada permukaan yang diukurnya karena gaya tensi permukaan semakin relevan. 
- Penanganan komponen (part handling).

Penanganan komponen pada skala mikro/nano haruslah dilakukan secara otomatis dan tidak dilakukan oleh seorang operator. Hal ini disebabkan komponen-komponen pada skala mikro/nano sangat kecil dan sensitif.

- Metode pengukuran.

Pengukuran dengan metode kontak pada skala mikro/nano akan mencapai limitnya, sehingga pengukuran dengan metode kontak menjadi tidak efisien untuk pengukuran pada skala mikro/nano. Beberapa contoh limitasi instrumen kontak untuk pengukuran skala mikro/nano adalah stylus yang menempel pada permukaan yang diukurnya, gaya kontak Hertian yang dihasilkan dari stylus yang kecil sehingga merusak permukaan suatu komponen dan masalah akses fitur-fitur yang kecil. Pengukuran dengan metode non-kontak (berbasis optik) merupakan suatu solusi yang menjanjikan untuk pengukuran pada skala mikro/nano.

- Prosedur pengukuran.

Berbeda metode pengukuran, maka berbeda pula prosedur untuk melakukan pengukurannya. Sebagai contoh, proses alignment untuk menentukan sistem koordinat komponen hanya dilakukan pada instrumen berbasis kontak. Selain itu, pengukuran suatu fitur dengan sudut $90^{\circ}$, sampai saat ini tidak bisa dilakukan dengan metode non-kontak.

- Aksesibilitas fitur yang ingin diukur pada suatu komponen.

Contoh masalah aksesibilitas suatu fitur dengan instrumen berbasis kontak adalah sebuah stylus suatu instrumen kontak dengan diameter $125 \mu \mathrm{m}$ tidak dapat digunakan untuk mengukur diameter suatu lubang yang mempunyai diameter $100 \mu \mathrm{m}$.

- $\quad$ Rasio dengan aspek tinggi (high aspect ratio).

Fitur dengan aspek rasio yang tinggi adalah fitur yang mempunyai tinggi yang jauh lebih besar dari lebarnya. Pengukuran suatu fitur dengan rasio aspek yang tinggi merupaka suatu tugas pengukuran yang sulit, baik untuk instrumen berbasis kontak maupun non-kontak. Untuk instrumen berbasis kontak, pada umumnya masalah pengukuran fitur dengan rasio aspek yang tinggi adalah masalah aksesibilitas. Sedangkan, untuk instrumen non-kontak berbasis optik, pada umumnya masalahnya adalah cahaya yang direfleksikan balik dari suatu fitur yang ingin diukur adlaah sangat kecil, sehingga pengukuran sulit untuk digunakan.

- Efek kondisi lingkungan.

Untuk pengukuran pada skala mikro, efek variasi kondisi lingkungan yang kecil pun mempengaruhi hasil pengukuran tersebut. Misalnya, efek debu yang kecil sangat mempengaruhi tingkat akurasi instrumen kontak karena ukuran stylus-nya hampir sama dengan ukuran debu tersebut, variasi temperatur menyebabkan komponen mikro/nano yang diukur berekspansi dan gangguan vibrasi yang kecil mendominasi hasil pengukuran pada skala sub-mikro/nano-meter.

Sedangkan, untuk pengukuran pada skala nano, terdapat fenomena-fenomena fisik yang hanya terjadi pada pengukuran skala nano tersebut. Fenomena-fenomena khusus tersebut sangat mempengaruhi pengukuran pada skala nano. Beberapa contoh fenomena khusus tersebut adalah (Raghavendra dan Krishnamurthy 2013):

- Besi akan kehilangan sifat magnetiknya pada skala nano-meter.

- Emas tidak akan bersinar dan mempunyai sifat netral pada skala $1 \mathrm{~nm}$.

- Partikel-partikel dengan ukuran $<50 \mathrm{~nm}$ tidak menunjukkan sifat dan perilaku yang sama apabila komponen-komponen tersebut dalam skala makro dan mikro.

Gambar 45 memperlihatkan bagaimana sifat dan perilaku suatu partikel pada skala nano dan skala makro/mikro. Pada gambar 45, suatu pertikal akan selalu bergerak (vibrasi) ketika partikel tersebut berukuran $<10 \mathrm{~nm}$ dan partikel tersebut akan stabil apabila ukuran partikel tersebut $>50 \mathrm{~nm}$. Tabel 10 memperlihatkan bebera jenis dari material nano. 


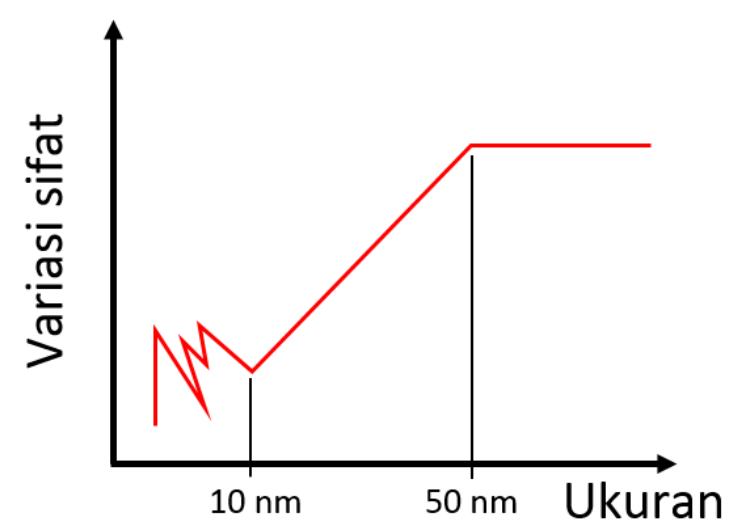

Gambar 45: Sifat dan perilaku suatu partikel pada berbagai macam skala ukuran.

Tabel 10: Berbagai macam tipe material nano.

\begin{tabular}{|l|c|c|}
\hline Tipe-tipe matrial nano & Material & Ukuran/nm \\
\hline Nanocrystals & Metal, material inorganik & $1-50$ \\
\hline Nanofilms & $\begin{array}{c}\text { Lapisan-lapisan dari quantum dots (e.g. } \\
\text { indium arsenide) }\end{array}$ & $1-10$ \\
\hline Nanowires & Metal, oxida, nitrida, sulfur, etc & $1-100$ \\
\hline Nanotubes & Karbon, material inorganik, metal & $1-1000$ \\
\hline Nanosurfaces & $\begin{array}{c}\text { Berbagai macam material (metal, } \\
\text { polimer, etc) }\end{array}$ & $1-100$ \\
\hline
\end{tabular}

Tabel 11: Jenis-jenis pengukuran pada skala nano dan metode-metode pengukurannya.

\begin{tabular}{|l|c|}
\hline \multicolumn{1}{|c|}{ Properti yang diukur (measurand) } & Metode pengukuran \\
\hline $\begin{array}{l}\text { Morfologi: ukuran, bentuk, cacat pada skala atomik, informasi } \\
\text { kristalografi. }\end{array}$ & TEM \\
\hline $\begin{array}{l}\text { Topografi permukaan: pengukuran kualitatif dari tekstur } \\
\text { permukaan, elemen-elemen pada suatu permukaan, informasi } \\
\text { kristalografi. }\end{array}$ & SEM \\
\hline $\begin{array}{l}\text { Topografi permukaan 3D: ukuran, bentuk, kekasaran, cacat, } \\
\text { struktur, elastisitas permukaan. }\end{array}$ & $\begin{array}{l}\text { AFM (dan metode scaning- } \\
\text { probe microscopy lainnya) }\end{array}$ \\
\hline $\begin{array}{l}\text { Informasi kristalografi: Tipe struktur kristal, ketebalan film, } \\
\text { kekasaran antarmuka. }\end{array}$ & XRD \\
\hline
\end{tabular}

Instrumen-instrumen yang digunakan untuk pengukuran pada skala nano yang umum adalah:

- Scanning electron microscope (SEM).

- Atomic force microscope (AFM).

- Transmission electron microscope (TEM). 
- $\quad X$-ray diffraction system (XRD).

Jenis-jenis pengukuran pada skala nano dan metode pengukuran dari instrument-instrumen di atas diperlihatkan pada tabel 11. 


\section{BAB 5}

\section{Coordinate measuring machine (CMM)}

Coordinate measuring machine (CMM) adalah sebuah sebuah instrumen pengukuran yang bisa mengukur berbagai macam jenis pengukuran dimensi dan geometri dengan menentukan koordinat spasial $(X, Y, Z)$ pada permukaan sebuah benda (objek). CMM merupakan instrument yang paling umum digunakan untuk pengukuran universal baik di industri-industri maupun di laboratorium metrology. CMM dapat melakukan pengukuran 2D dan 3D suatu produk dengan cara merekam koordinat spasial titik-titik pada suatu permukaan benda yang diukur.

CMM merupakan instrumen utama yang digunakan untuk melakukan verifikasi GD\&T (lihat Bab 3). Dengan satu jenis CMM, berbagai macam jenis GD\&T, seperti flatness, perpedicularity, orientation, location dan run-out, dapat diukur dan diverifikasi. Selain itu, CMM pada umumnya mempunya tingkat akurasi yang tinggi sehingga sering digunakan sebagai instrumen referensi untuk mengecek suatu hasil pengukuran dimensi dan geometri yang dilakukan dengan instrumen lain.

Perkembangan teknologi CMM terus berlanjut sampai sekarang. Mulai dari jenis CMM manual tanpa kontrol numerik. Pada awal dibuatnya CMM, sampai dengan jenis CMM yang terkontrol penuh secara numerik (terotomatisasi) dan memiliki berbagai macam jenis sensor (multi-sensor), seperti kontak (tactile), Pemindai laser (laser sanning) dan sensor optik (optical sensor) dalam satu mesin CMM. Tingkat akurasi CMM juga semakin meningkat pada zaman sekarang. Pada tahun 2017, mesin CMM dapat mencapai tingkat akurasi tertinggi sebesar $0.3 \mu \mathrm{m}$ dengan penurunan tingkat akurasi sebesar $1 \mu \mathrm{m}$ per meter.

Awal mula cikal bakal CMM adalah sebuah instrumen yang dibuat untuk mendukung sebuah mesin perkakas dengan kontrol numerik. Instrumen tersebut dibuat oleh perusahaan Feranti di Skotlandia. Namun, awal mula CMM yang merepresentasikan CMM zaman sekarang adalah CMM yang dibuat oleh Franco Sartorio, yang merupakan perekayasa/engineer di Fiat-Italia. CMM buata Sartorio tersebut merupakan bridge-type CMM yang terotomatisasi dengan kontrol numerik yang bisa menambil titik-titik koordinat spasial pada permukaan suatu benda yang dikur secara 3D (Hocken dan Pereira 2012).

Sampai saat ini, banyak variasi-variasi CMM yang dibuat untuk tujuan yang spesifik, misalnya untuk meyesuaikan dengan bentuk komponen-komponen yang akan diukur, untuk menyesuaikan dengan ukuran komponenkomponen yang diukur, untuk menyesuaikan dengan tempat beroperasinya CMM (di lantai produksi atau dilaboratorium) dan untuk menyesuaikan dengan tingkat akurasi yang diinginkan. Standar internasional utama yang mengatur CMM adalah seri ISO-10360 untuk verifikasi performansi CMM dan ser ISO-15530 untuk estimasi ketidakpastian hasil pengukuran dengan CMM.

\subsection{Introduksi tentang CMM}

Sebelum CMM dibuat, pengukuran dimensi dan geometri di industri-industri merupaka suatu pekerjaan yang kompleks dan berulang-ulang. Selain itu, tanpa CMM, pengukuran dimensi dan geometri tersebut membutuhkan banyak pekerja. Sebelum dibuatnya CMM, pengukuran dimensi dan geometri membutuhkan alat-alat pengukuran konvensional, seperti meja datar, dial gauge, gauge block, slip gauge, sine bar dan instrumen konvensional lainnya. Alat-alay pengukuran konvensional tersebut saling dikombinasikan satu sama lain untuk mengukur suatu dimensi atau geometri tertentu. Dibutuhkan konfigurasi yang berbeda dari kombinasi alat-alat ukur konvensioanal tersebut untuk setiap jenis pengukuran yang berbeda. Hal-hal tersebut menyebabkan rumitnya dan lamanya pengukuran dimensi dan geometri sebuah produk di lantai produksi. Penyebab lain rumitnya pengukuran dimensi dan geometri suatu produk tanpa CMM adalah kombinasi dari alat-alat konvensional tersebut tidak dapat diotomatisasi. 


\subsubsection{Jenis-jenis CMM}

Jenis-jenis CMM tergantung berdasarkan dari karakteristik yang digunakan untuk mengklasifikasikan berbagai jenis CMM. Pada umumnya ada dua jenis klasifikasi CMM, yaitu berdasarkan sistem koordinat yang digunakan dan berdasarkan metode interaksi dengan permukaan suatu benda.

Jenis-jenis CMM berdasarkan sistem koordinat yang digunakan adalah:

- $\quad$ CMM berbasis kartesian (Cartesian CMM)

Adalah CMM yang menggunakan sistem koordinat kartesian dan terdiri dari minimal 3-aksis (sumbu $X, Y$ dan $Z$ ) sampai dengan sistem 4- atau 5-axis. Tipe CMM ini mempunyai titik referensi nol absolut. Gambar 1 memperlihatkan berbagai jenis konfigurasi dari CMM kartesian. Dari gambar 1, CMM kartesian terbagi menjadi lima kategori: moving-bridge, fixed-bridge, cantilever, gantry dan L-shaped.

- $\quad \mathrm{CMM}$ berbasis non-kartesian (Non-cartesian CMM)

Adalah CMM yang menggunakan selain sistem koordinat kartesian, seperti menggunakan sistem koordinat silinder atau bola. Pada umumnya, jenis CMM ini adalah optical, seperti sistem photogrammetry, fringe projection dan laser tracker. CMM kontak untuk tipe non-kartesian adalah articulated-arm CMM.

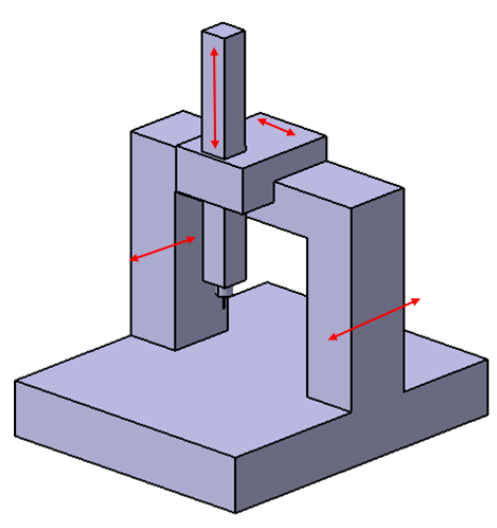

Moving-bridge CMM

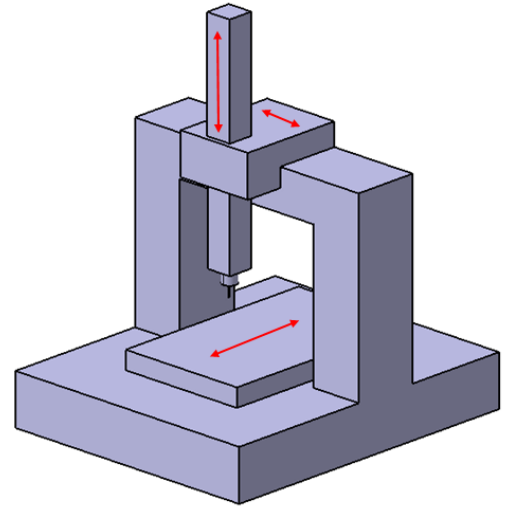

Fixed-bridge CMM

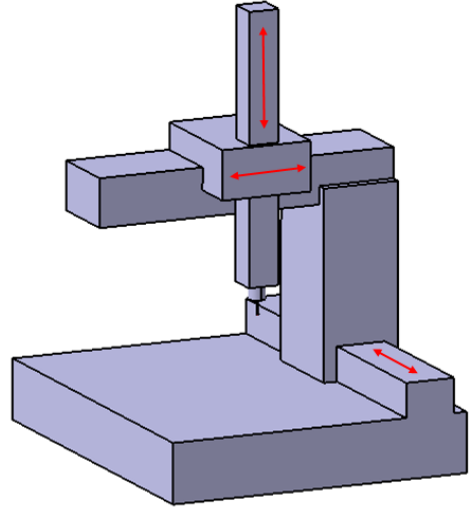

Cantilever CMM

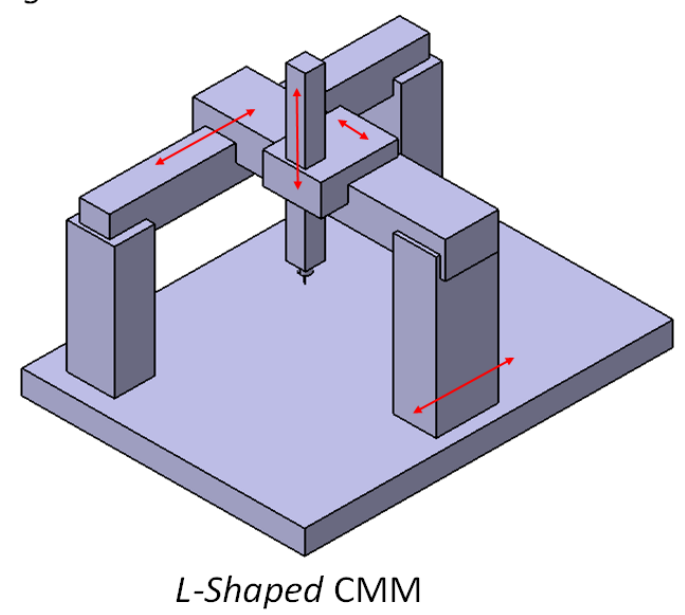

Gantry CMM

Gambar 1: Berbagai-macam konfigurasi CMM kartesian. 
Jenis-jenis CMM berbasis kartesian tersebut dapat dijelaskan sebagai berikut (Lihat gambar 1):

- $\quad$ Moving-bridge CMM

CMM jenis ini merupakan jenis CMM yang paling umum ditemui di industri-industri maupun laboratorium metrologi. Populernya jenis CMM ini disebabkan karena jenis CMM tersebut mempunyai keseimbangan antara tingkat akurasi yang tinggi, kecepatan pengukuran yang relatif cepat (dibandingkan jenis CMM kartesian lainnya), dan kemampuan mengukur berbagai ukuran benda. CMM jenis ini mempunyai dua kaki yang bergerak secara bersamaan untuk memberikan pergerakan satu aksis. Pergerakan dua aksis lainnya adalah pada bagian bridge-nya dan bagian aksis vertikalnya (sumbu-Z)

- $\quad$ Fixed-bridge CMM

CMM jenis ini merupakan CMM dengan tingkat akurasi yang paling tinggi dibandingkan dengan CMM kartesian lainnya. Per tahun 2017, tingkat akurasi CMM ini bisa mencapai $\pm(0.3+L / 1000) \mu m$ dan $L$ dalam milimiter. CMM jenis ini mempunyai dua tiang yang tetap (tidak bergerak-fixed bridge), sehingga meja CMM tersebut yang dapat bergerak untuk menghasilkan satu aksis pergerakan. Pergerakan dua aksis lainnya adalah pada bagian bridge-nya dan bagian aksis vertikalnya (sumbu-Z). CMM jenis ini merupakan CMM dengan kecepatan pengukuran yang paling rendah.

- $\quad$ Cantilever CMM

CMM jenis ini sangat popular ditemui pada industri-industri otomotif untuk mengukur body suatu mobil dalam kondisi sudah dirakit. CMM catilever dengan horisontal arm mempunyai arm/tangan yang panjang yang dapat menjangkau sudut-sudut suatu komponen dengan ukuran besar, seperti mobil. Namun demikian, tingkat akurasinya menurun karena adanya efek lendut (bending) pada cantilever arm-nya.

- Gantry CMM

CMM jenis ini merupakan CMM dengan ukuran yang sangat besar. Pada umumnya, jenis CMM ini digunakan untuk mengukur benda-benda dengan ukuran $>10 \mathrm{~m}$. Namun demikian, tinkat akurasi CMM ini merupakan yang terendah dibandingkan dengan CMM kartesian lainnya karena efek error geometri yang besar seiring dengan besarnya ukuran komponen-komponen CMM ini.

- $\quad$ L-shaped CMM

CMM jenis ini merupakan CMM yang paling jarang ditemui di industri-industri. CMM jenis ini didisain untuk mengukur benda-benda dengan bentuk tertentu. Kaki dengan bentuk ' $L$ ' berfungsi untuk mengurangi lendutan dari cantilever arm-nya.

Sedangkan, jenis-jenis CMM berdasarkan metode insterkasi dengan permukaan suatu benda adalah:

- $\quad$ CMM berbasis kontak (Tactile CMM)

Adalah CMM yang menyentuh secara mekanik permukaan suatu benda yang diukur. Contoh CMM kartesian jenis kontak adalah moving-brige, cantilever dan gantry CMM. Sedangkan, contoh CMM non-kartesian jenis kontak adalah articulated-arm CMM.

Keuntungan CMM berbasis kontak adalah CMM tersebut menyentuh permukaan suatu benda secara mekanik. Proses ini dapat dimodelkan secara analitik, sehingga error yang dihasilkan dapat dengan mudah diprediksi atau diverifikasi. Pada umumnya, CMM berbasis kontak selalu dijadikan referensi untuk memverifikasi hasil pengukuran dengan CMM non-kontak.

Kerugian CMM berbasis kontak adalah terdapat resiko rusaknya permukaan suatu benda karena sentuhan dari stylus CMM tersebut, apalagi apabila stylus tersebut sangat kecil, maka tekanan yang diberikan kepada permukaan benda tersebut semakin besar (yang disebabkan oleh gaya Hertzian). Selain itu, CMM berbasis kontak mempunyai proses pengukuran yang lambat dan jumlah keluaran data dari titik-titik permukaan suatu benda yang diukur sangat sedikit dibandingkan dengan CMM berbasis non-kontak (sebagai perbandingan, CMM berbasis kontak dapat membutuhkan waktu dalam gitungan jam untuk menghasilkan ribuan titik data, sedangkan CMM berbasis non-kontak hanya membutuhkan satu atau dua menit untuk mengkasilkan jutaan data). Kerugian lainnya juga adalah aksesibilitas suatu fitur yan diukur dengan CMM berbasis kontak terbatas pada ukuran diameter dari stylus yang digunakan (misalnya dengan stylus berdiameter $1 \mathrm{~mm}$, CMM kontak tidak dapat mengukur diameter internal silinder dengan diamater $<1 \mathrm{~mm}$ ). 
- $\quad$ CMM berbasis non-kontak/optik (Optical CMM)

Adalah CMM yang tidak menyentuk permukaan benda yang diukur. CMM jenis ini menggunakan metode berbasis optik untuk meraba permukaan suatu benda. Contoh CMM non-kontak adalah sistem photogrammetry, fringe projection dan laser tracker.

Keuntungan CMM berbasis non-kontak adalah CMM tersebut dapat menghasilkan data dengan jumlah yang sangat banyak dalam hitungan beberapa menit, dapat menghasilkan data berupa titik-titik kooridinat suatu permukaan tapa menyentuh permukaan suatu benda sehingga tidak ada resiko rusaknya permukaan benda tersebut, walaupun benda tersebut mmepunyai permukaan yang lunak. Selain itu CMM berbasis non-kontak dapat mengakses fitur-fitur pada suatu benda dengan ukuran yang sangat kecil. Limitasi ukuran fitur yang dapat diukur adalah batas difraksi optik yang dimiliki dari suatu sistem optik yang digunakan CMM tersebut.

Kerugian yang paling mendasar dari CMM berbasis non-kontak adalah CMM tersebut mendeteksi permukaan suatu benda dengan cara menyinari permukaan tersebut dan menganalisis refleksi cahaya yang dipantulkan oleh permukaan tersebut. Proses mendeteksi permukaan tersebut dengan analisis cahaya yang terrefleksikan merupakan suatu proses yang sangat kompleks, sehingga sangat sulit untuk memverifikasi seberapa akurat hasil pendeteksian permukaan tersebut. selain itu, CMM berbasis non-kontak sangat dipengaruhi oleh jenis material yang diukur (hal ini tidak demikian dengan CMM berbasis kontak). Material yang berbeda akan memberikan refleksi yang berbeda terhadap CMM non-kontak, sehingga performansi CMM tersebut berbeda antara satu material dengan material lainnya. Kerugian lainnya CMM berbasis nonkontak adalah kemampuan untuk mengukur permukaan yang miring. CMM non-kontak tidak dapat mengukur permukaan dengan kemiringan yang sangat tinggi, apalagi untuk mengukur permukaan dengan sudut kemiringan $90^{\circ}$, hal ini karena keterbatasan apertur numerik (numerical aperture/NA) dari sistem optik yang digunakan (CMM berbasis kontak dapat mengukur suatu permukaan dengan sudut kemiringan hingga $90^{\circ}$ ).

Pada bab ini, penjelasan CMM dibagi berdasarkan kontak (tactile) dan non-kontak (optical).

\subsubsection{Pertimbangan untuk aplikasi CMM}

Terdapat berbagai macam jenis CMM yang terdapat dipasaran, sehingga memilih CMM yang paling tepat untuk suatu aplikasi pengukuran dimensi dan geometri tidaklah mudah. Hal-hal yang harus dipertimbangkan dalam memilih CMM untuk suatu aplikasi tertentu adalah:

- Tingkat akurasi CMM.

- Karakteristik instrumen CMM.

- Kemampuan perangkat lunak CMM.

- Strategi pengukuran (sampling strategy) CMM.

- Hal-hal lainnya.

\section{$\underline{\text { Tingkat akurasi CMM }}$}

Hal pertama yang harus dipertimbangkan adalah tingkat akurasi yang dibutuhkan untuk mengukur suatu fitur. Tingkat akurasi ini bisa didapatkan dari seberapa besar nilai toleransi dari fitur tersebut. Untuk CMM, menurut ISO 10360, akurasi CMM dapat direpresentasikan dengan nilai error maksimum yang diizinkan (maximum permissible error/MPE). Berdasarkan ISO 10360, MPE didefinisikan sebagai $\pm(X+L / K)$, dimana $X$ adalah tingkat akurasi sebuah CMM dengan unit $\mu m, K$ adalah sebuah konstanta dan $L$ adalah panjang yang diukur dengan unit $m m$. Hal penting yang harus diingat adalah adanya variabel panjang sautu fitur yang diukur $L$ yang berkontribusi terhadap tingkat akurasi suatu CMM. Untuk menentukan nilai MPE suatu CMM, verifikasi performansi suatu CMM berdasarkan ISO 10360 harus dilakukan.

Selain tingkat akurasi, nilai ketidakpastian (uncertainty) dari suatu hasil pengukuran dengan CMM juga harus diperhitungkan (lihat Bab 9 untuk pembahasan detil mengenai ketidakpastian suatu hasil pengukuran). Hasil suatu pengukuran memiliki suatu nilai ketidakpastian yang merepresentasikan ketidaktahuan kita terhadap proses 
pengukuran tersebut. Hal-hal yang berkontribusi terhadap nilai ketidakpastian hasil suatu pengukuran adalah seperti variasi temperatur pada saat sebuah pengukuran berlangsung, variasi strategi dari pengambilan data (sampling strategy), error geometri dari suatu CMM, dan variasi bentuk suatu benda yang berasal dari variasi dari proses manufaktur benda tersebut. Maka dari itu, ketika memilih CMM mana yang paling tepat untuk suatu pengukuran, tidak hanya tingkat akurasi yang memadai yan perlu diperhitungkan, tetapi juga estimasi nilai ketidakpastian yang dihasilkan dari suatu pengukuran tersebut. Dengan kata lain, tingkat akurasi CMM yang dibutuhkan harus lebih tinggi dari tingkat akurasi yang dibutuhkan untuk memberikan ruang kepada nilai ketidakpastian dari suatu pengukuran.

Salah satu contoh menentukan tingkat akurasi dari sebuah CMM adalah sebagai berikut. apabila kita ingin mengukur suatu fitur berupa diamater sebuah silinder dengan spesifikasi $(500 \pm 0.01) \mathrm{mm}$. Dari spesifikasi tersebut,kita dapatkan nilai jangkaun toleransi sebesar $0.01 \times 2=0.02 \mathrm{~mm}$. CMM yang tepat untuk mengukur silinder tersebut adalah CMM yang mempunyai tingkat akurasi (termasuk nilai ketidakpastian dari hasil pengukuran silinder tersebut) maksimal $10 \%$ dari $0.04 \mathrm{~mm}$ total toleransi tersebut. Dengan demikian, tingkat akurasi pengukuran termasuk estimasi nilai ketidakpastian dari pengukuran tersebut adalah sebesar $0.002 \mu \mathrm{m}$ untuk panjang $L=$ $500 \mathrm{~mm}$. Sehingga, tingkat akurasi CMM yang dibutuhkan adlah sebesar $\leq 0.002 \mu \mathrm{m}$ untuk panjang $L=500 \mathrm{~mm}$ untuk memberikan ruang terhadap nilai ketidakpastian suatu pengukuran tersebut.

Selajutnya adalah memilih sebuah CMM yang mempunyai tingkat akurasi $\leq 0.002 \mu \mathrm{m}$ untuk panjang $L=$ $500 \mathrm{~mm}$. Misalnya suatu CMM jenis A mempunyai spesifikasi akurasi sebesar $\pm(1.2+L / 5000) \mu \mathrm{m}$. Tingkat akurasi CMM jenis A tersebut tidak cukup untuk digunakan mengukur silinder tersebut, karena total akurasi CMM jenis A tersebut adalah $=(1.2+500 / 500)=2.2 \mu \mathrm{m}$. Misalkan jenis CMM lainnya, yaitu CMM jenis B, mempunyai tingkat akurasi sebesar $\pm(1.3+L / 1000) \mu \mathrm{m}$. Maka, tingkat akurasi CMM jenis B tersebut untuk pengukuran silinder tersebut adalah $=(1.3+500 / 1000)=1.8 \mu \mathrm{m}$. Sehingga, $\mathrm{CMM}$ jenis B adalah CMM yang tepat untuk pengukuran silinder tersebut.

Dari contoh diatas, nilai ketidakpastian berperan penting untuk menentukan jenis CMM mana yang paling tepat digunakan untuk suatu pengukuran dimensi dan geometri. Maka dari itu, budget nilai ketidakpastian suatu pengukuran harus dilakukan terlebih dahulu untuk dapat menentukan jenis CMM yang paling tepat. Selain itu, dengan adanya budget nilai ketidakpastian suatu pengukuran, budget tersebut dapat digunakan sebagai alat bantu untuk menentukan bagian mana dari suatu proses inspeksi produk yang butuh perhatian lebih atau yang butuh perbaikan. Misalnya, apabila dari budget nilai ketidakpastian tersebut memperlihatkan bahwa sumber ketidakpastian terbesar adalah dari variasi temperatur pada saat pengukuran berlangsung, maka solusi terbaik adalah temperatur ruangan tempat pengukuran tersebut dapat lebih dikontrol, daripada membeli CMM dengan tingkat akurasi yang lebih tinggi dengan harga yang jauh lebih mahal.

\section{Karakteristik instrumen CMM}

Karakteristik CMM yang paling penting untuk dipertimbangakn ketika memilih CMM adalah volume pengukuran CMM, konfigurasi CMM, massa benda yang diukur, kecepatan pengukuran dan tipe probing (sensor). Penjelasan dari karakteristik CMM adalah sebagai berikut:

- Volume pengukuran CMM

Volume pengukuran suatu CMM adalah area dimana sensor (probing) CMM dapat menjangkaunya untuk mengambil data permukaan suatu benda. Volume pengukuran CMM berbentu balok yang menggambarkan maximum panjang, lebar dan tinggi suatu benda untuk diukur dengan CMM tersebut. Gambar 2 memperlihatkan ilustrasi dari volume pengukuran CMM. Pada gambar 2, diperlihatkan volume pengukuran untuk CMM jenis moving-bridge dan gantry. CMM jenis gantry memiliki volume pengukuran yang paling besar yang mencapai puluhan meter untuk ukuran panjang, lebar dan tinggi suatu benda yang dapat diukur. Sedangkan moving bridge CMM pada umumnya mempunyai volume pengukuran sebesar 1-2 meter. Volume pengukuran $\mathrm{CMM}$ yang paling kecil dapat mencapai hanya $(100 \times 100 \times 100) \mathrm{mm}$ yang digunakan untuk pengukuran benda pada skala mikro. 


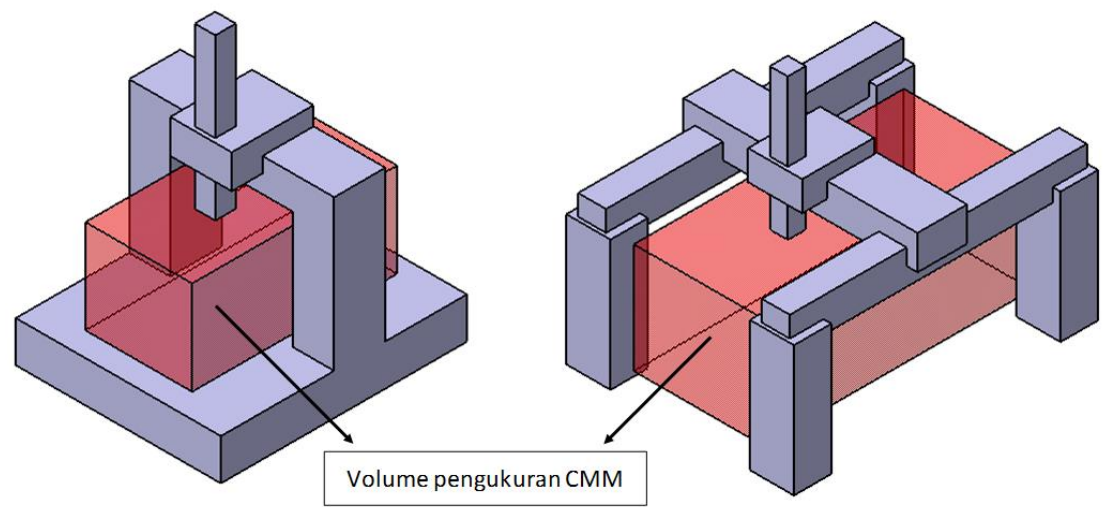

Gambar 2: Volume pengukuran CMM yang menggambarkan ukuran maksimum benda yang dapat diukur.

- Konfigurasi CMM

Konfigurasi CMM yang paling umum dalah dengan aksis pengukuran (measuirng ram) vertikal, karena konfigurasi tersebut tidak dipengaruhi oleh gaya gravitasi pada berbagaimacam posisi yang berbeda. Sedangkan, CMM dengan aksis pengukuran horisontal dipengaruhi gaya gravitasi ketika aksis pengukuran tersebut memanjang.

Konfigurasi CMM sangat penting untuk dipertimbangkan dalam memilih CMM yang paling tepat untuk suatu aplikasi. Pentingnya konfigurasi CMM diperlihatkan pada gambar 3. Pada gambar 3, diperlihatkan bagaimana konfigurasi sebuah CMM dapat menentukan fleksibilitas CMM tersebut dalam mengukur suatu benda dengan ukuran tertentu. Cantilever CMM (gambar 3 kanan) adalah jenis CMM dengan fleksibilitas tinggi dalam hal kemampuan menampung berbagai ukuran benda. Cantilever CMM mempunyai halangan minimum karena hanya mempunyai satu tiang untuk menyangga aksis pengukuran sehingga mempunyai banyak ruang untuk meletakkan suatu benda.

Selain itu, konfigurasi CMM juga menentukan fleksibilitas CMM tersebut untuk menjangkau suatu benda yang diukur. Misalnya, untuk pengukuran body mobil, jenis CMM yang paling sering digunakan adalah cantilever CMM dengan aksis pengukuran horisontal, sehingga dapat menjangkau bagian body mobil tersebut.

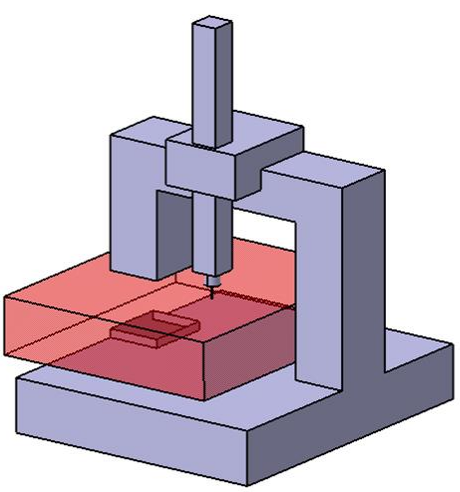

Moving-bridge CMM tidak dapat menampung ukuran benda

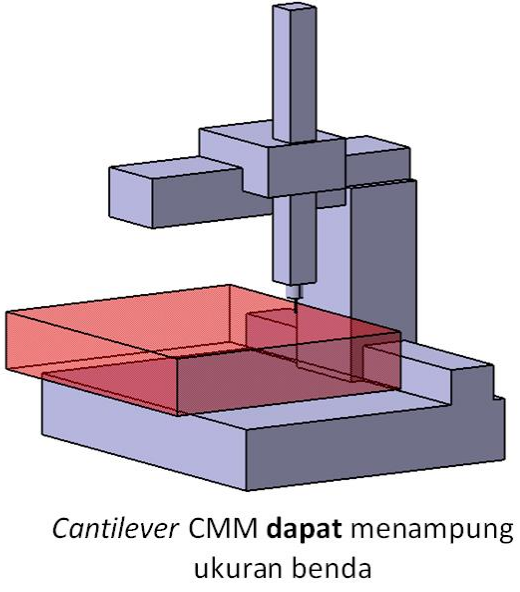

ukuran benda

Gambar 3: Konfigurasi CMM menentukan fleksibilitas untuk megnukur suatu benda dengan berbagai ukuran.

- Massa benda yang diukur

Setiap jenis CMM memiliki kapasitas maksimum untuk menahan benda dengan massa tertentu. Apabila 
massa benda yang diukur melebihi batas maksimum kemampuan meja CMM, maka akan terjadi deformasi (dalam ukuran mikro- atau milimiter), sehingga tingkat akurasi CMM tersebut akan berkurang. Kondisi terburuk adalah, konstruksi CMM akan rusak apabila massa benda yang diletakkan jauh lebih tinggi dari maksimum massa benda yang dapat ditahan suatu CMM.

- Kecepatan pengukuran

Ada berbagaimacam ukuran kecepatan CMM, yaitu kecepatan pergerakan CMM, akselerasi dan deselerasi dan pengambilan titik per menit. Ada dua jenis utama pengambilan titik permukaan suatu benda dengan CMM dengan metode kontak, yaitu point-to-point dan scanning (gambar 4). Pada gambar 4, kontak pointto-point mempunyai kecepatan pengukuran yang lambat, tetapi pada umumnya tingkat akurasinya lebih tinggi dibandingkan dengan kontak scanning, karena efek dinamika dari pergerakan CMM kecil. Sedangkan, kontak scanning mempunyai kecepatan pengambilan titik suatu permukaan dengan cepat, tetapi dengan tingkat akurasi yang lebih rendah dibandingkan dengan kontak point-to-point karena efek dinamika pergerakan CMM yang tinggi.

Ada beberapa hal penting yang harus diingat dalam menggunakan CMM jenis kontak adalah melakukan perbandingan pengukuran suatu benda dengan suatu referensi (misalnya supplier suatu CMM) untuk mengetahui effisiensi progam CMM dalam mengukur benda tersebut, mengevaluasi waktu yang dibutuhkan untuk mengambil satu titik data permukaan (termasuk akselerasi dan deselerasi probing) dan mengevaluasi kecepatan pergerakan CMM untuk mengukur suatu benda yang sangat besar (untuk suatu benda dengan ukuran besar, waktu yang dibutuhkan untuk pergerakan perpindahan CMM menjadi signifikan)
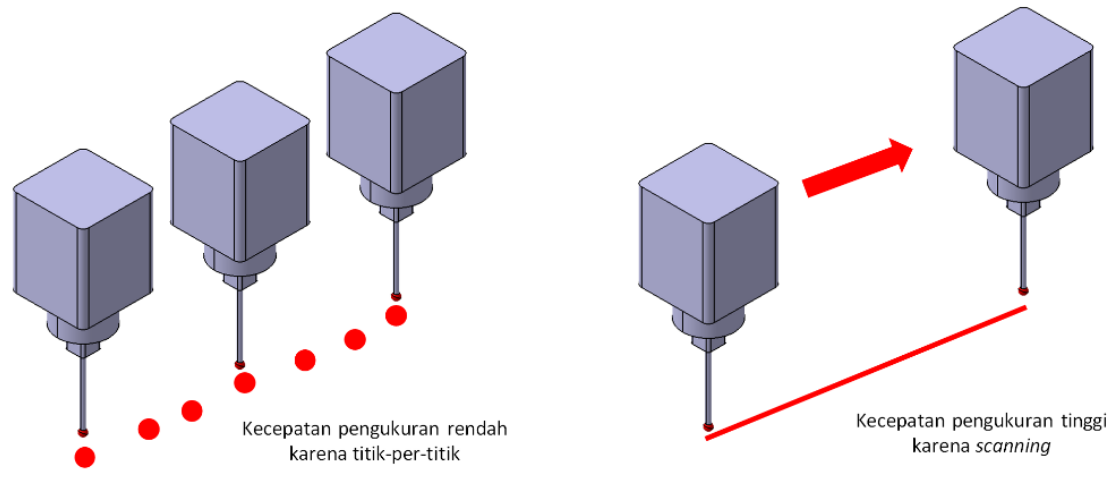

Gambar 4: Dua jenis utama pengukuran CMM: (kiri) point-to-point dan (kanan) scanning.

- $\quad$ Tipe probing (sensor)

Probing adalah bagian CMM yang merupakan sensor untuk mengetahui apabila stylus/scanning head sudah menyentuh permukaan benda dan merekam (mengambil) koordinat spasial titik-titik permukaan suatu benda. Untuk CMM, ada dua jenis probing: kontak (tactile) dan non-kontak (optikal). Gambar 5 memperlihatkan probing kontak dengan dilengkapi sebuah stylus untuk menyentuh suatu permukaan benda dan probing nonkontak yang dilengkapi dengan laser-scaning head. Probing kontak mempunyai tingkat troughput (kemampuan merekam titik-titik koordinat permukaan) yang lebih kecil dari probing non-kontak, tetapi probing kontak mempunya tingkat resolusi dan akurasi yang jauh lebih tinggi dari probing non-kontak.

Probing kontak mempunyai kelemahn untuk mengukur suatu permukaan yang lunak, misalnya sheet metal, dan menjangkau fitur-fitur yang kecil. Sedangkan, probing non-kontak dapat mengukur suatu permukaan benda yang lunak karena tidak ada resiko merusak permukaan benda tersebut (tidak ada gaya permukaan). Untuk prbing non-kontak, pada umumnya menggunakan laser-scanning head. Laser scannig head tersebut mempunyai kelemahan utama ukuran diameter spot laser yang cukup besar, yaitu sekitar $0.2 \mathrm{~mm}$, sehingga membatasi ukuran suatu fitur yang dapat diukur. Selain itu, probing non-kontak tidak dapat mengukur suatu 
permukaan benda yang vertikal karena tidak ada laser atau cahaya yang dapat direfleksikan balik ke sistem probing non-kontak tersebut. Sedangkan, probing kontak (tactile) dapat mengukur suatu permukaan dengan sudut kemiringan berapapun, termasuk permukaan vertikal gambar 6 memperlihatkan kemampuan probing kontak untuk mengukur permukaan vertikal suatu silinder dengan menggunakan stylus horisontal.

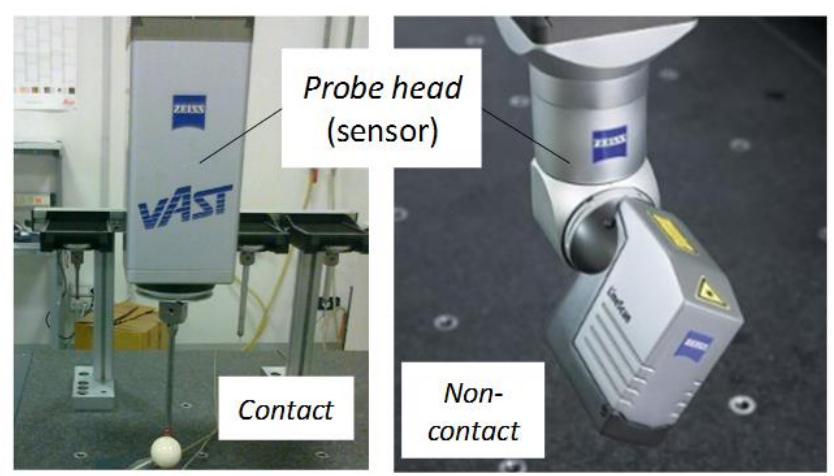

Gambar 5: (kanan) probing tike kontak dan (kanan) probing tipe non-contact (optikal).

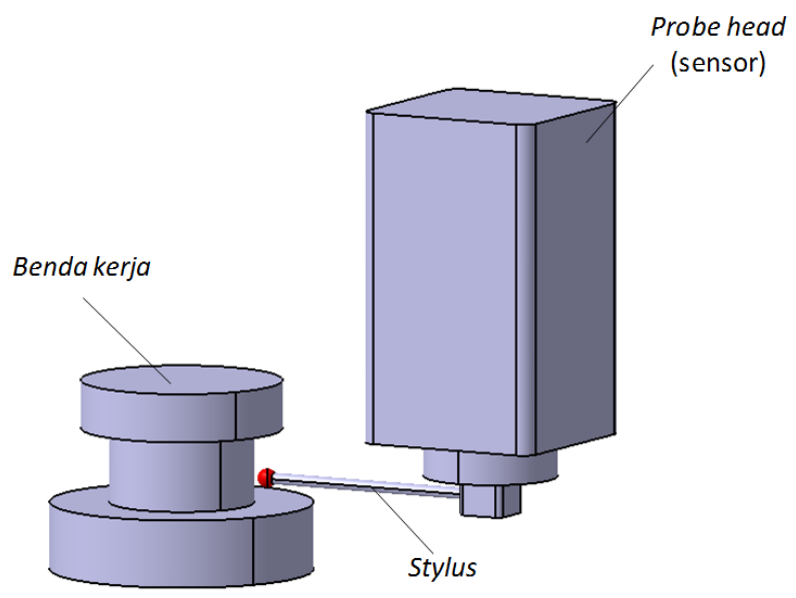

Gambar 6: Stylus CMM dengan konfigurasi horisontal.

\section{Kemampuan perangkat lunak CMM}

Kemampuan perangkat lunak CMM yang paling penting untuk dipertimbangakn ketika memilih CMM adalah cara pemrograman $\mathrm{CMM}$, antarmuka perangkat lunak dengan operator, sistem evaluasi data, antarmuka data dan format keluaran data. Penjelasan dari kemampuan perangkat lunak CMM adalah sebagai berikut:

- Cara pemrograman CMM

Salah satu keuntungan utama CMM adalah kemampuan CMM untuk diprogram sehingga dapat melakukan pengukuran secara otomatis. Biaya pengukuran CMM otomatis biasanya lebih kecil dari setengah biaya pengukuran manual atau non-otomatis (Hocken dan Pereira 2012). Namun demikian, tidak semua CMM dapat diprogram untuk mengukur secara otomatis. Hanya CMM yang dilengkapi dengan kontrol-numerik dan perangkat lunak yang memadai yang dapat diprogram untuk bekerja secara otomatis.

Selain itu, CMM yang dapat bekerja secara otomatis mempunyai hasil yang lebih konsisten karena mengurangi efek operator. CMM yang terporgram dapat bekerja secara otomatis dan dapat menyentuh target 
yang sama dalah jangkaun $0.005 \mathrm{~mm}-0.05 \mathrm{~mm}$ (tergantung kecepatan, akselerasi dan deselerasi yang diprogram), sehingga meminimalkan efek dari variasi lokal pada alignment dan suatu benda yang diukur. Manual CMM, pada umumnya mempunyai variasi menyentuh target yang sama dalam kisaran $5 \mathrm{~mm}$. Ada tiga jenis cara pemrograman CMM, yaitu Pemrograman berbasis teaching, pemrograman berbasis parametrik dan pemrograman berbasis off-line.

- Pemrograman berbasis teaching adalah pemrograman dimana operator memposisikan secara manual probing untuk mencapai target posisi pada suatu permukaan. Kemudian, pergerakan tersebut direkam oleh komputer suatu CMM untuk kemudian dapat bekerja secara otomatis.

- Pemrograman berbasis parametrik adalah pemrograman yang berbasis pada tingkat similaritas suatu benda yang diukur. Pemrograman jenis ini pada umumnya dikembangkan dari suatu program CMM berbasis teaching yang kemudian dikembangkan berdasarkan tingkat similaritas suatu benda sehingga tidak perlu dilakukan re-teaching lagi.

- Pemrograman berbasis off-line adalah pemrograman CMM berbasis model CAD dari suatu benda. Dari model CAD tersebut, berbagai fitur, misalnya suatu permukaan, benda tersebut dapat ditentukan. Posisi dan pengukuran CMM pada benda tersebut dapat ditentukan berdasarkan model CAD tersebut, sehingga manual teaching tidak perlu dilakukan. Selain itu, dengan adanya CAD data, perbandingan bentuk nominal benda tersebut dengan hasil pengukurannya dapat dibandingkan, sehingga deviasi dari nominal benda tersebut dapat langsung divisualisasikan.

- Antarmuka perangkat lunak dengan operator

Terdapat berbagaimacam perangkat lunak untuk sistem CMM karena terdapat berbagai jenis produsen pembuat CMM komersial, seperti Zeiss, Mitutoyo, DEA, Leitz, Brawn and Sharpe, Nikon metrology, Werth dan lain sebagainya. Pada umumnya, setiap produsen mempunyai perangkat lunak untuk sistem CMM mereka masing-masing, walaupun ada perangkat lunak CMM yang dapat digunakan untuk berbagai macam jenis CMM, seperti PC Demis. Maka dari itu, pertimbangan seberapa mudah dan intuitif suatu antarmuka perangkat lunak CMM sangat penting untuk memudahkan operator belajar dan menggunakan suatu CMM.

- $\quad$ Sistem evaluasi data

Kemampuan evaluasi data perangkat lunak suatu CMM adalah kemampuan untuk mengolah titik-titik koordinat spasial $(X, Y$ dan $Z$ ) suatu permukaan benda yang direkam agar dari titik-titik tersebut, suatu pengukuran dapat dilakukan, seperti diameter, panjang, flatness, perpendiculariy dan posisiton. Kemampuan tersebut yang paling utama adalah fitting, yaitu mengasosiasikan suatu geometri pada kumpulan titik-titik koordinat spasial suatu permukaan benda.

Setiap perangkat lunak CMM minimal mempunyai fungsi dasar untuk fititng lingkaran, bidang, konik, silinder, bola dan elips. Proses fitting tersebut dapat dilakukan dengan berbagai metode (untuk detilnya lihat bab 7 mengenai algoritma), misalnya least-square (yang paling umum), maximum inscribe feature, minimum circumscribe feature sampai dengan fitting permukaan free-form dengan metode NURBS. Untuk perangkat lunak suatu CMM yang sudah mapan, perangkat lunak mereka sudah dites, sehingga algoritma tersebut stabil dan melakukan kalkulasi yang benar (Shakarji 2002).

- Antarmuka data

Pengertian antarmuka data adalah bagaimaca data hasil pengukuran suatu CMM dapat ditransfer dan diimport untuk keperluan lainnya dengan suatu perangkat lunak lainnya. Transfer data tersebut adalah untuk keperluan, misalnya untuk kontrol proses berbasis statistik (statistical process control/SPC), untuk perbandingan dengan suatu $\mathrm{CAD}$, untuk keperluan kontrol suatu proses manufaktur dan untuk keperluan pengambilan keputusan.

- Format keluaran data

Format keluaran data hasil pengukuran suatu CMM mempunyai berbagai macam bentuk.Hal pertama adalah format data titik-titik suatu permukaan yang diukur ke dalam suatu format text file. Format data tersebut bisa 
berupa hanya posisi $X, Y$ dan $Z$ atau bisa berupa informasi yang lebih lengkap, misalnya posisi $X, Y$ dan $Z$ dan vektor arah pendekatan suatu probe. Selain itu, kemampuan perangkat lunak untuk merepresentasikan data dalam bentuk suatu laporan formal merupaka suatu fitur perangkat lunak yang sangat bermanfaat.

\section{$\underline{\text { Strategi pengukuran (sampling strategy) CMM }}$}

Strategi pengukuran CMM adalah prosedur yang digunakan untuk mengambil data permukaan suatu benda yang akan diukur. Strategi pengukuran dengan CMM terbagi menjadi dua macam, yaitu strategi pengambilan titik-titik permukaan benda dan strategi seberapa sering suatu benda diukur (Hocken dan Pereira 2012). Penjelasan dari dua jenis strategi pengukuran CMM tersebut adalah sebagai berikut:

- Strategi pengambilan titik-titik permukaan benda (strategi sampling)

Hasil pengukuran suatu CMM adalah berdasarkan suatu proses fitting suatu geometri terhadap titik-titik koordinat spasial suatu permukaan yang diukur dengan CMM tersebut. Untuk mendapatkan titik-titik tersebut, berbagai macam strategi sampling dapat dilakukan seperti yang diperlihatkan oleh gambar 7. Pada gambar 7, sebuah contoh untuk mengukur suatu bidang datar dengan mengambil titik-titik koordinat dari bidang tersebut dengan probing kontak, mulai dari minimum tiga titik untuk menentukan suatu bidang, grid sampling, random sampling dan scanning sampling. Berbeda jenis sampling, maka berbeda pula tingkat akurasi dari hasil pengukuran tersebut, sehingga strategi sampling sangat mempengaruhi hasil pengukuran CMM (Phillips et al 2003, Weckenmann et al 1998). Selain itu, berapa banyak jumlah titik yang harus diambil untuk melakukan suatu pengukuran juga sangat penting untuk dipertimbangkan, misalnya untuk melakukan pengukuran suatu diameter silinder yang besar hanya dengan menambil beberapa titik pada suatu area yang kecil, maka error hasil pengukuran diameter tersebut akan sangat besar (Phillips et al 1998, Hocken et al 1993).
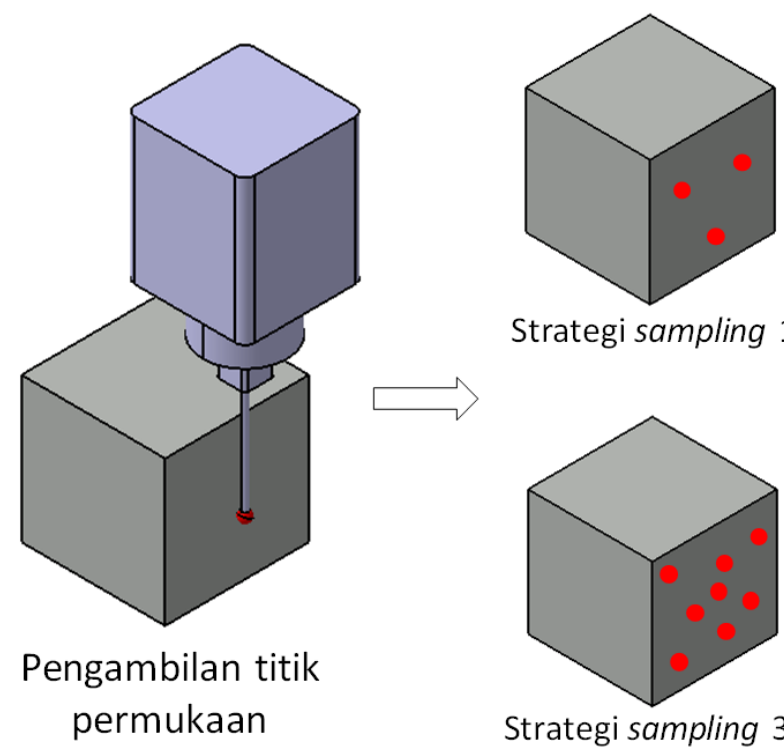

Strategi sampling 1

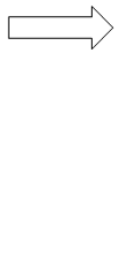

permukaan

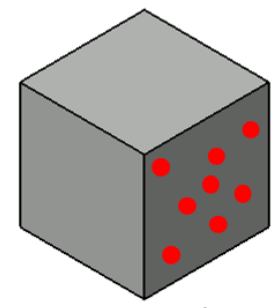

Strategi sampling 3

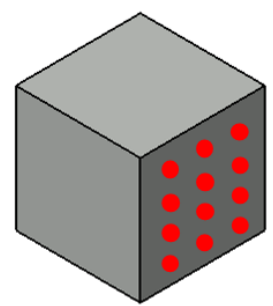

Strategi sampling 2

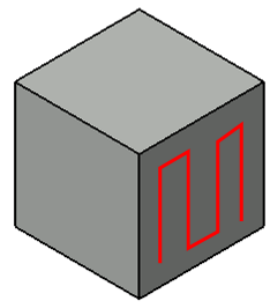

Strategi sampling 4

Gambar 7: Berbagai macam strategi sampling.

- Strategi seberapa sering suatu benda diukur

Seberapa banyak suatu komponen haris diinspeksi dengan CMM (atau dengan instrumen lainnya) adalah tergantung seberapa kritikal komponen tersebut pada suatu produk. Pada umumnya, komponen yang diproduksi dengan jumlah sedikit dan mempunyai fungsi yang sangat kritikan, misalnya komponen mesin jet 
pesawat, komponen-komponen tersebut selalu dilakukan cek satu-per-satu. Untuk komponen dengan produksi masal, pada umumnya tidak semua komponen di inspeksi, melainkan hanya beberapa komponen di-sampling dari setiap kelompok produksi untuk diinspeksi. Dari seberapa seringnya suatu komponen harus di cek, maka total waktu yang dibutuhkan untuk inspeksi dapat dikalkulasi. Dari kalkulasi waktu inspeksi tersebut, jenis CMM yang tepat untuk digunakan dapat dipilih sesuai dengan berapa kecepatan CMM yang diperlukan untuk memenuhi syarat waktu inspeksi.

\section{$\underline{\text { Hal-hal lainnya }}$}

Hal-hal lainnya yang perlu diperhatikan ketika memilih CMM adalah hal-hal yang berhubungan dengan waktu pelatihan operator, sistem jig dan fixture untuk memgang benda yang diukur, kondisi lingkungan, garansi dan dukungan purna jual CMM dan sub-kontraktor pengukuran CMM.

- Waktu pelatihan operator

Pengoperasian suatu CMM adalah sangat rumit. Sehingga, waktu yang banyak harus diinvestasikan untuk melatih operator untuk dapat menggunakan CMM dengan benar. Bukan hanya itu, waktu yang lama juga harus diinvestasikan pada operator untuk mengerti mengenai bagaimana cara pengukuran yang tepat dan efisien dan bagaimana cara memahami estimasi ketidakpastian (lihat Bab 9) dari suatu hasil pengukuran CMM.

- $\quad$ Sistem jig dan fixture untuk memgang benda yang diukur

Setiap produsen CMM melengkapi mesin-mesin CMM mereka dengan berbagai macam jig dan fixture. Jig dan fixture adalah suatu instrumen yang sangat penting untuk melakukan pengukuran dengan CMM karena instrumen tersebut sangat penting untuk dapat memposisikan dan memegang suatu benda yang diukur secara tepat.

- Kondisi lingkungan

Kondisi lingkungan dimana suatu CMM akan diletakkan menjadi penting untuk memilih CMM. Misalnya, CMM untuk diletakkan di laboratorium mempunya spesifikasi yang berbeda untuk CMM yang diletakkan di lantai produksi. CMM yang dilengkapi dengan air bearing hanya cocok untuk CMM di dalam laboratorium dengan kondisi lingkungan terkontrol, sedangkan CMM yang dilengkapi dengan ball bearing cocok untk CMM di lantai produksi.

- Garansi dan dukungan purna jual CMM

Garansi dan dukungan purna jual merupakan hal penting untuk memilih vendor CMM, karena pada prakteknya, dukungan dan garansi apabila terjadi masalah pada CMM dari vendor selalu dibutuhkan.

- Sub-kontraktor pengukuran CMM

Investasi untuk CMM membutuhkan dana yang sangat besar, sebagai contoh, pada umumnya harga movingbridge CMM adalah dikisaran $£ 250000$. Dengan demikian, apabila volume pengukuran rendah dan dukungan operator terlatih yang tidak ada, mungkin cara yang lebih tepat adalah untuk menggunakan jasa servis pengukuran untuk komponen-komponee suatu perusahaan yang tidak memiliki CMM.

\subsubsection{Aplikasi umum CMM}

CMM pada umumnya dianggap sebagai "cost center" di industri-industri karena tidak menghasilkan suatu produk seperti misalnya bagian produksi. Namun demikian, CMM pada kenyataannya merupakan "profit center" apabila diterapkan dengan tepat dan effisien. Dengan CMM, berbagai macam jenis dan bentuk suatu komponen atau produk (dalam artian komponen-komponen yang telah dirakit bersama) dapat diinspeksi, sehingga kualitas dari komponen atau produk tersebut dapat dijaga. Dengan kualitas yang terjamin tersebut, perusahaan dapat berkompetisi di pasar global dan mengurangi komponen atau produk cacat yang lolos ke konsumen. Selain itu, data hasil dari pengukuran CMM dapat digunakan untuk meningkatkan proses produksi sehingga lebih efisien yang menyebabkan biaya produksi menurun dan dapat digunakan untuk meningkatkan desain suatu komponen agar berfungsi lebih baik.

CMM dapat digunakan untuk pengukuran yang sangat sederhana, misalnya pengukuran diameter dan panjang, sampai dengan pengukuran yang sangat komplek, seperti pengukuran permukaan free-form, pengukuran mesin mobil, 
pengukuran turbin mesin jet dan lain-lain. Beberapa contoh pengukuran CMM di industri-industri, seperti pengukuran lokasi pusat dari lubang pendinginan pada aerofoil turbin mesin jet, pengukuran roda gigi, pengukuran turbin udara dengan ukuran skala $>10 \mathrm{~m}$, pengukuran komponen metal yang di casting, pengukuran implant medis, pengukuran sculpture surface, pengukuran komponen-komponen optik, pengukuran artifak referensi dengan presisi yang sangat tinggi, pengukuran presisi komponen-komponen pada skala mikro dan lain sebagainya. Gambar 8 memperlihatkan berbagai macam pengukuran dengan CMM dari pengukuran yang sederhana, yaitu diameter suatu silinder, sampai pengukuran yang sangat kompleks, yaitu mesin silinder 2-tak.
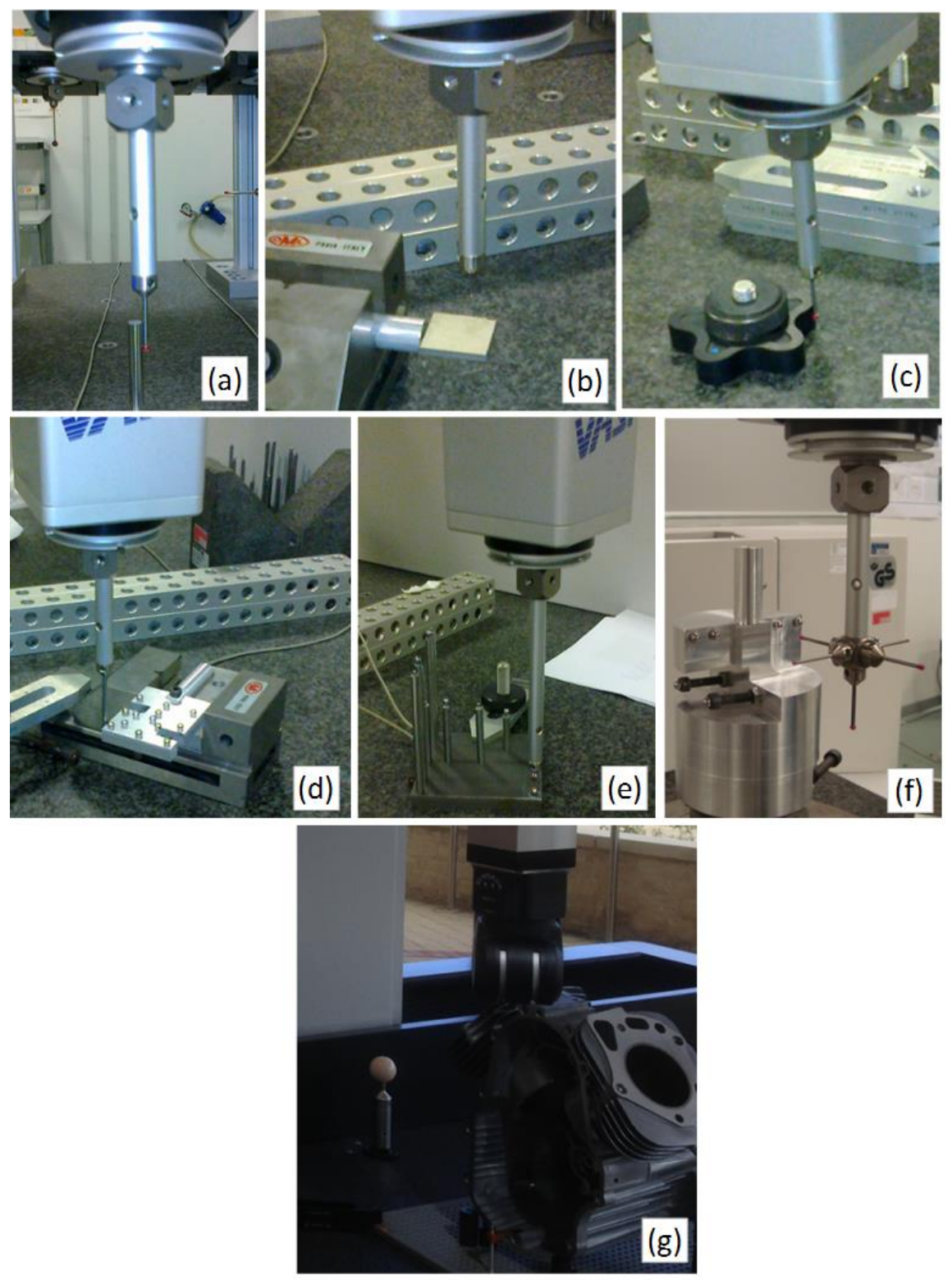

Gambar 8: Contoh-contoh aplikasi CMM: (a) pengukuran diameter, (b) pengukuran flatness, (c) pengukuran profilroda gigi, (d) pengukuran lokasi pusat bola, (e) pengukuran lokasi pusat bola pada berbagai ketinggian, (f) pengukuran lokasi pusat bola dengan berbagai ketinggian dan orientasi dan $(\mathrm{g})$ pengukuran mesin mobil. 


\subsection{Cartesian tactile CMM}

Komponen-komponen yang merekonstruksi CMM diperlihatkan pada gambar 9. Pada gambar 9, komponenkomponen CMM tersebut diperlihatkan dengan suatu CMM berjenis moving-bridge, karena CMM jenis ini merupakan jenis CMM yang paling umum di industri dan laboratorium metrologi. Pada prinsipnya, CMM terbagi menjadi tiga bagian besar, yaitu: struktur mekanik, sensor (probe), dan kontroler dan komputer.

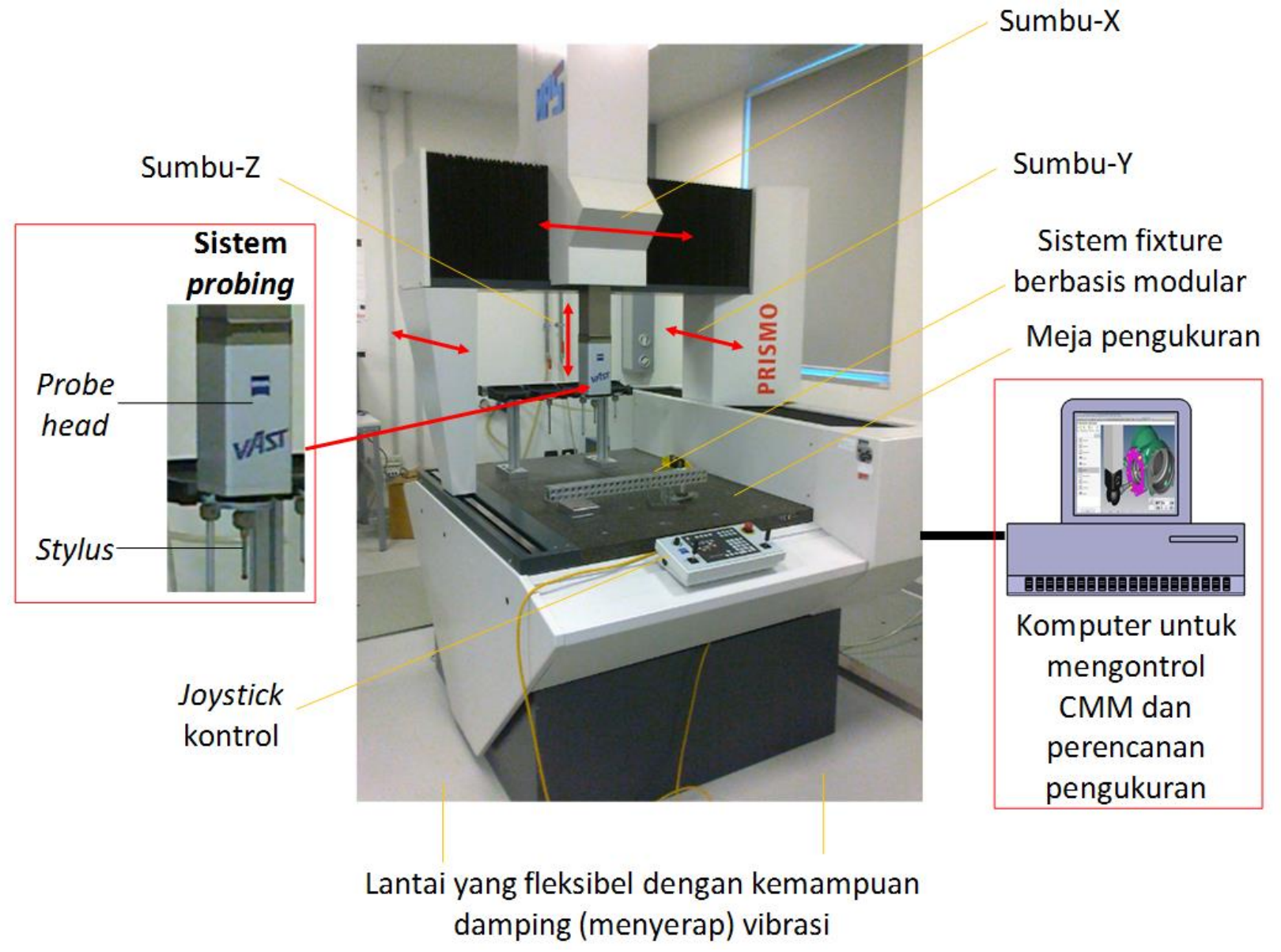

Gambar 9: Konstruksi dasar CMM.

\section{Struktur mekanik}

Pada gambar 9, struktur mekanik CMM adalah meja pengukuran, sumbu $X, Y$ dan $Z$, sistem fixture dan rangka struktur. Bagian-bagian dari struktur mekanik CMM dijelaskan sebagai berikut.

Sistem pergerakan aksis terdiri dari sumber pergerakan dan transfer pergerakan. Sumber pergerakan adalah motor listrik yang terbagi menjadi dua, yaitu motor rotasi dan motor linear. Pada umumnya, motor rotasi lebih cocok untuk CMM karena posisinya bisa diletakkan jauh dari aksis pergerkaan sehingga dapat mengurangi efek panas dari motor tersebut. sedangkan, motor linier selala diletakkan pada sumbu pergerakan, sehingga panas yang dihasilkan lebih besar. Selain itu, linear motor selalu membutuhkan arus listrik untuk menahan posisi tertentu, sehingga hal ini dapat menghasilkan panas yang tinggi ke sistem CMM.. Keuntungan motor linier adalah dapat menghasilkan kecepatan pergerakan yang tinggi dan tidak membutuhkan sistem drive yang kompleks. 
Di lain pihak, motor rotasi membutuhkan sistem drive untuk menstransfer pergerakan dari pergerakan rotasi ke pergerakan linier. Tipe-tipe drive tersebut adalah rack-and-pinion, belt, friction dan leadscrew drive. Leadscrew drive adalah jenis drive yang paling umum untuk mentransfer pergerakan rotasi ke linier.

Bearing merupakan komponen yang vital pembentuk sistem pergerakan (Slocum 1992). Ada dua jenis bearing yang paling umum, yaiu air bearing (non-kontak) dan mechanical-contact bearing (kontak). Contoh mechanicalcontact bearing adalah ball bearing dan roller bearing. Untuk memilih jenis bearing yang tepat untuk suatu CMM, kriteria desain yang paling utama adalah: kekakuan dinamik (dynamic stiffness), kemampuan menahan beban, damping vibrasi dan efek friksi atau gesekan. Air bearing menggunakan suatu lapisa tipis udara (thin-film layer) dengan suatu tekanan tertentu (pada umumnya 6 bar) untuk dapat menahan beban. Lapisan tipis tersebut adalah sebesar $(1-10) \mu m$. Mechanical-contact bearing mempunyai kemampuan menahan beban yang jauh lebih tinggi daripada air bearing, tetapi juga memiliki gesekan yang lebih tinggi daripada air bearing yang dapat menyebabkan munculnya sumber panas. Untuk mengurangi panas tersebut, kecepatan pergerakan suatu aksis yang menggunakan mechanical-contact bearing adalah rendah. Air bearing digunakan untuk CMM yang diletakkan di dalam laboratorium terkontrol, sedangkan mechanical-contact bearing digunakan untuk CMM yang diletakkan pada kondisi lingkungan yang berat, seperti lantai produksi. Untuk pemeliharaan, air bearing tidak membutuhkan pelumas, tetapi membutuhkan sumber tekanan udara terkompresi. Mechanical-contact bearing membutuhkan pelumas, tetapi tidak membutuhkan tekanan udara terkompresi.

Sistem sensor untuk membaca pergerakan aksis (displacement transduscer) juga merupaka komponen vital dari CMM, karena dengan sensor tersebut, posisi stylus CMM dapat ditentukan. Terdapat berbagai jenis sistem sensor untuk membaca pergerakan, yaitu: encoder linier, encoder rotasi, inductosyns, magnetic scale dan interferometri laser. Sistem sensor yang paling sering digunakan adalah encoder linier, interferometri laser dan encoder rotasi (apabila suatu CMM mempunyai aksis rotasi). Untuk encoder, baik linier maupun rotasi, encoder terdiri dari dua komponen utama, yaitu transmission scale dan reading head (untuk membaca skala pada transmission scale tersebut). Sistem transmission scale dan reading head tersebut terdiri dari berbagai jenis, yaitu: phototransmission scale (yang paling umum), reflection scale, interferential scale dan laser interferometrer scale. Gambar 10 memperlihatkan contohcontoh dari sistem encoder (sistem sensor untuk membaca pergerakan aksis) yang diproduksi oleh Renishaw. Pada gambar 10, terdapat dua jenis encoder, yaitu encoder dengan skala pitch $20 \mu \mathrm{m}$ dan $40 \mu \mathrm{m}$. Karena skala pitch encoder tersebut adalah pada tingkat micrometer, maka untuk mendapatkan resolusi mencapai nanometer, dibutuhkan sebuah interpolator yang akan membagi skala pitch tersebut menjadi jauh lebih kecil.

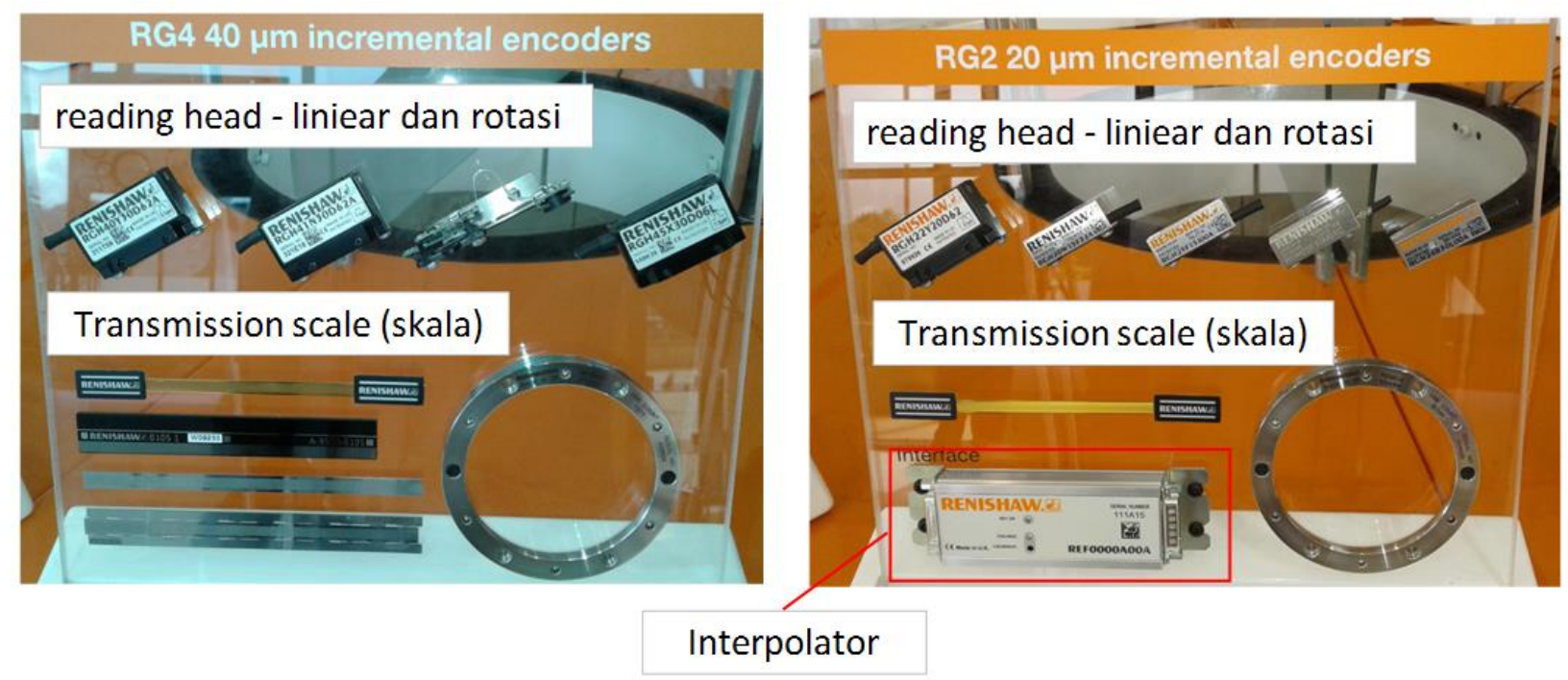

Gambar 10: Contoh jenis-jenis sistem encoder. 
Meja pengukuran pada umumnya terbuat dari granite (mempunyai koefisien ekspansi termal yang sangat kecil), karena sangat stabil terhadap variasi temperatur dalma jangka yang sangat lama. Ada juga beberapa jenis CMM yang menggunakan komposit sebagai material meja pengukurannya.

Rangka struktur CMM merupakan penyangga utama agar struktur CMM tetap utuh dan tidak terjadi deformasi. Properti yang utama untuk sebuah struktur CMM adalah stabilitas dimensi dalam jangka waktu pendek dan panjang, kekakuan struktur (stifness) yang tinggi, massa struktur yang rendah, kapasitas damping vibrasi dari struktur yang tinggi, koefisien termal ekspansi yang rendah dan konduktivitas termal yang tinggi. Pada kenyataannya, sangat sulit membuat struktur CMM yang memenuhi semua kriteria tersebut, maka dari itu selalu ada trade-off antara kriteriakriteria tersebut untuk suatu kasus tertentu. Kestabilan dimensi suatu struktu CMM dalam jangka waktu yang lama dalam berbagai variasi temperatur dan tekanan udara sangat penting. Kestabilan dimensi tersebut juga bergantung pada koefisien ekspansi termal material struktur CMM tersebut yang harus bernilai kecil. Untuk mengurangi efek gangguan vibrasi, struktur CMM harus mempunyai damping vibrasi yang besar serta tingkat kekakuan yang tinggi. Sumber-sumber panas pada suatu CMM yang berasal dari, misalnya: motor pergerakan sumbu dan gesekan pada guide suatu sumbu pergerakan harus dihilangkan dengan cepat, maka dari itu material suatu struktur CMM harus mempunyai koefisien konduktivitas yang tinggi agar bisa mentransfer panas dari struktur tersebut ke lingkungan.

Untuk struktur CMM, dua material umum yang dipertimbangkan adalah granit dan aluminium. Aluminium mempunyai koefisien termal ekspansi yang besar dibandingkan dengan granit, tetapi aluminium juga mempunyai koefisien konduktivitas termal yang jauh lebih tinggi dari granit (aluminium $=120-167 \mathrm{~W} \cdot \mathrm{m}^{-1} \cdot{ }^{\circ} \mathrm{C}^{-1}$, granit $=$ $1-2 \mathrm{~W} \cdot \mathrm{m}^{-1} \cdot{ }^{\circ} \mathrm{C}^{-1}$ ), sehingga bagus untuk disipasi panas dari dalam struktur (misalnya yang disebabkan oleh friksi) ke lingkungan. Struktu yang terbuat dari aluminium dapat dengan cepat mencapai kestabilan termal yang disebabkan oleh temperatur dari lingkungan.

\section{$\underline{\text { Sensor (probe) }}$}

Sensor (probe) adalah bagian dari CMM yang berfungsi untuk mendeteksi titik-titik pada permukaan suatu benda yang diukur. Sensor tersebut merupakan suatu kesatuan sistem yang terdiri dari beberapa komponen penyusunnya. Sensor pada CMM terbagi menjadi dua bagian utama, yaitu probe (probing head), stylus dan elektronik (lihat gambar 9). Probe adalah suatu komponen berbasis mekanikal dan elektronik yang berfungsi mendeteksi apakah permukaan suatu benda sudah dicapai dan merekam posisis titik pada permukaan tersebut ke dalam memori komputer di dalam kontroler suatu CMM. Stylus, baik yang berbasis kontak/mekanikal dan non-kontak, adalah komponen yang berinteraksi dengan permukaan suatu benda yang diukur.

Gambar 11 memperlihatkan probe yang terdiri dari probing head dan stylus kontak, dimana stylus kontak tersebut mempunyai gerakan rotasi dua-aksis. Dengan tambahan stylus dengan rotasi dua-aksis, maka suatu CMM yang menggunakan sensor atau sistem probing tersebut akan mempunyai kemampuan pergerakan 5-aksis. Jenis stylus tersebut dilengkapi dengan dua buah motor dipangkal stylus tersebut (yang tersambung pada probing head) untuk melakukan rotasi dua aksis. Dengan dapatnya stylus diposisikan pada berbagai macam orientasi, maka kemampuan aksesibilitas permukaan suatu benda akan semakin tinggi. Pada gambar 11, diperlihatkan stylus kontak dua aksis REVO yang diproduksi oleh Renishaw.

Gambar 12 memperlihatkan probe yang terdiri dari probing head dan stylus non-kontak. Stylus non-kontak tersebut bisa berupa laser scanning atau sensor visi. Pada umumnya, stylus non-kontak mempunyai kemampuan untuk berotasi pada berbagai macam orientasi untuk dapat menjangkau permukaan suatu benda yang diukur. Suatu probing head yang sama dapat digunakan untuk kedua jenis stylus tersebut, baik stylus kontak maupun non-kontak. Pada gambar 12, berbagai macam jenis stylus non-kontak dari berbagai manufakturer diperlihatkan. Stylus non-kontak dapat menghasilkan deteksi titik-titik permukaan yang sangat banyak dibandingkan dengan stylus kontak, namun demikian stylus kontak mempunyai tingkat akurasi yang jauh lebih tinggi dibandingkan dengan stylus non-kontak. 

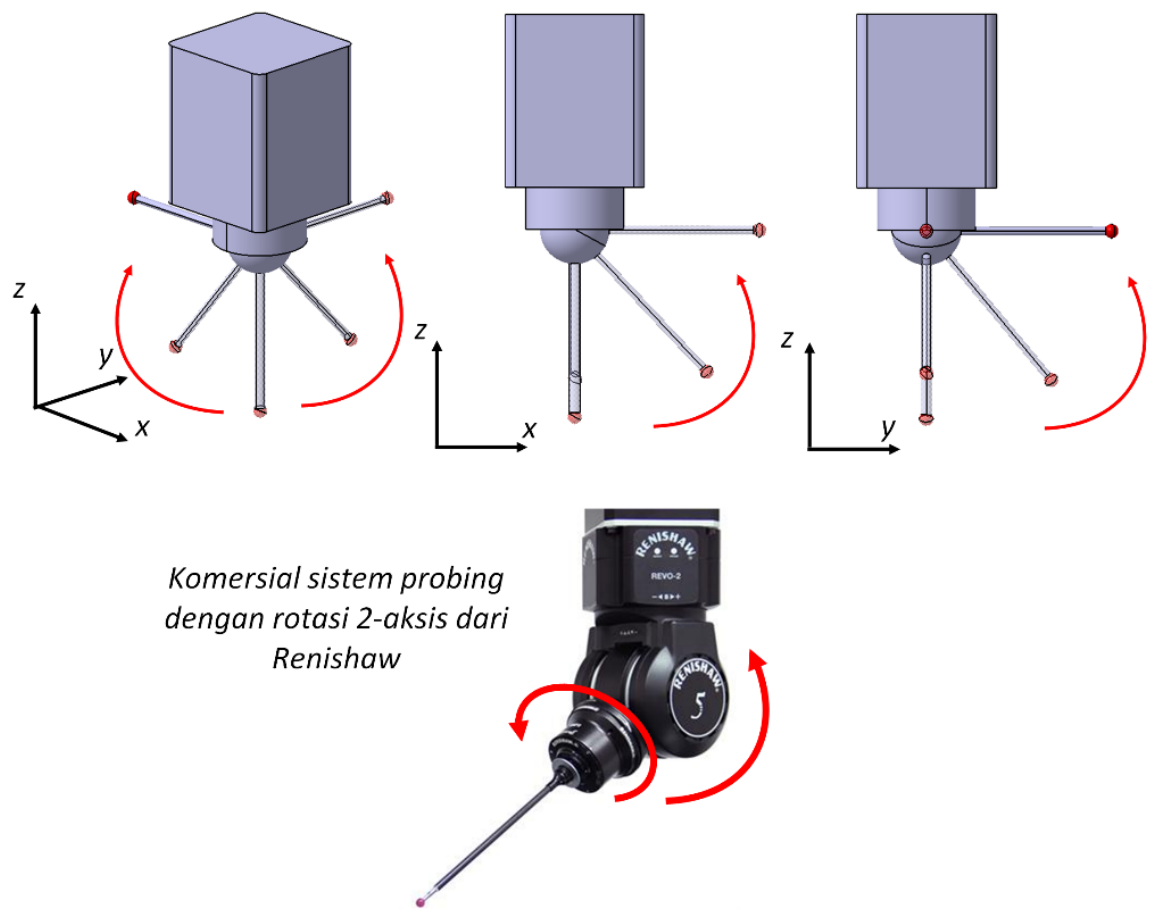

Gambar 11: Sistem probing dengan dua aksis rotasi.

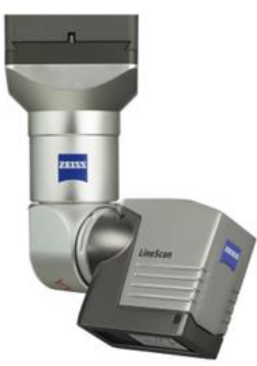

Zeiss

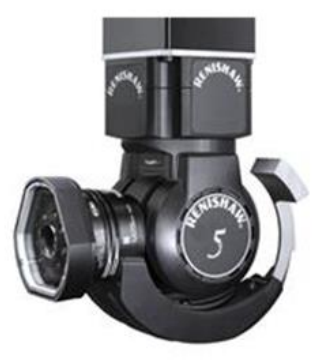

Renishaw

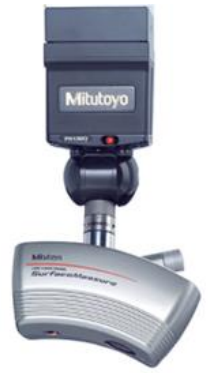

Mitutoyo

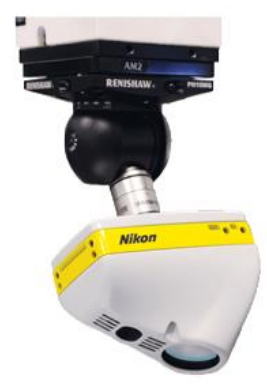

Nikon

Gambar 12: Sistem probing komersial dengan stylus non-contact (virtual stylus) dari berbagai produsen.

\section{$\underline{\text { Kontroler dan komputer }}$}

Sistem kontrol pergerakan dan pendeteksian titik-titik permukaan suatu benda terdiri dari kontroler dan komputer. Sistem kontrol tersebut mengatur dan mengsinkronisasikan berbagai komponen pada CMM, seperti sistem pergerakan aksis (drive system), sensor perpindahan (displacement sensor), sistem probing dan komponen-komponen lainnya.

Jenis kontrol suatu CMM dapat diklasifikasikan menjadi tiga jenis:

- $\quad$ CMM dengan pengoperasian manual.

- CMM dengan pengoperasian berdasarkan kontrol numerik (CMM otomatis)

- CMM yang dapat terhubung dengan CAD dan terintegrasi dengan sistem manufaktur.

Pada umumnya, jenis CMM otomatis merupakan baik CMM dengan pengoperasian berbasis kontrol numerik danyang dapat terhubung dengan CAD dan sistem manufaktur. 
Proses utama sistem kontrol numerik tersebut adalah mengsinkronisasikan pergerakan sistem aksis, pembacaan skala dari sensor perpindahan dan komunikasi data dari sistem probing ke kontroler dan komputer CMM. CMM dengan kontrol numerik dapat menentukan jenis strategi pendeteksian titik-titik pada permukaan suatu benda, yaitu: kontrol titik-ke-titik, kontrol lintasan kontinu dan kontrol vektor. Untuk kontrol lintasan kontinu, kontrol tersebut terdiri dari dua aktivitas kontrol: kontrol scanning, yang sudah ditentukan sebelumnya (kecepatan, jumlah titik, akselerasi/deselerasi, dan lain sebagainya), dan kontrol adaptif (kecepatan, jumlah titik dan parameter lainnya dapat berubah-ubah tergantung fitur suatu permukaan yang diukur).

CMM dengan kemampuan berfungsi secara otomatis sangat memudahkan operator, terutama apabila benda dengan bentuk yang serupa ingin diukur berjumlah banyak, karena suatu program pengukuran dapat disimpan dan dapat dipakai berulang-ulang. Keuntungan-keuntungan pengukuran dengan CMM dibandingkan dengan pengukuran dengan surface plate (konvensional) diperlihatkan pada tabel 1.

Tabel 1: Perbadingan pengukuran dengan surface plate dan CMM.

\begin{tabular}{|l|l|}
\hline \multicolumn{1}{|c|}{$\begin{array}{c}\text { Pengukuran dengan surface plate } \\
\text { (konvensional) }\end{array}$} & \multicolumn{1}{c|}{ Pengukuran dengan CMM } \\
\hline $\begin{array}{l}\text { alignment benda yang diukur dilakukan } \\
\text { secara manual }\end{array}$ & Aligntment manual tidak diperlukan \\
\hline $\begin{array}{l}\text { Proses alignment membutuhkan waktu } \\
\text { yang lama }\end{array}$ & Proses alignment membutuhkan waktu yang singkat \\
\hline $\begin{array}{l}\text { Setiap setup hanya untuk satu pengukuran } \\
\text { tertentu }\end{array}$ & $\begin{array}{l}\text { Fleksibel untuk mengukur berbagai macam bentuk benda dengan } \\
\text { perangkat lunak }\end{array}$ \\
\hline $\begin{array}{l}\text { Pengukuran dilakukan dengan } \\
\text { membandingkan suatu benda yang diukur } \\
\text { denan suatu artifak referensi: gauge block, } \\
\text { ring gauge, slip gauge, etc }\end{array}$ & $\begin{array}{l}\text { Pengukuran dilakukan dengan membandingkan suatu benda yang } \\
\text { diukur dengan suatu model numerik (matematik) hasil dari proses } \\
\text { fitting }\end{array}$ \\
\hline $\begin{array}{l}\text { Setiap jenis pengukuran geometri, misalnya } \\
\text { form, location, run-out dan } \\
\text { perpendicularity, membutuhkan setup } \\
\text { berbeda }\end{array}$ & $\begin{array}{l}\text { Berbagai jenis pengukuran geometri dilakukan dengan satu setup } \\
\text { CMM dengan satu sistem referensi }\end{array}$ \\
\hline $\begin{array}{l}\text { Membutuhkan operator yang } \\
\text { berpengalaman dan sangat ahli untuk } \\
\text { melakukan setiap jenis pengukuran }\end{array}$ & $\begin{array}{l}\text { Apabila program pengukuran sudah ada, maka tidak diperlukan } \\
\text { operator yang ahli dan berpengalaman }\end{array}$ \\
\hline Produktifitas pengukuran rendah & produktifitas pengukuran tinggi karena bisa diotomatisasi \\
\hline
\end{tabular}

\subsection{Pengoperasian CMM}

Pengoperasia CMM yang akan dijelaskan pada bagian ini adalah fokus pada CMM kontak (tactile CMM). Pada CMM kontak, titik-titik (points) pada suatu permukaan benda dideteksi secara individual, sedangkan CMM nonkontak mendeteksi kumpulan titik-titik (point cloud) dimana kumpulan titik-titik tersebut akan diproses kemudian untuk memilih titik-titik yang relevan. Pada prakteknya, setiap industri atau laboratorium mungkin mempunyai prosedur khusus yang dikostumasi untuk kebutuhan mereka yang spesifik, sedangkan pada bagian ini, pengoperasian CMM secara umum akan dijelaskan. Gambar 13 memperlihatkan proses pengukuran dengan CMM kontak untuk mengukur dimensi dan geometri suatu benda. 


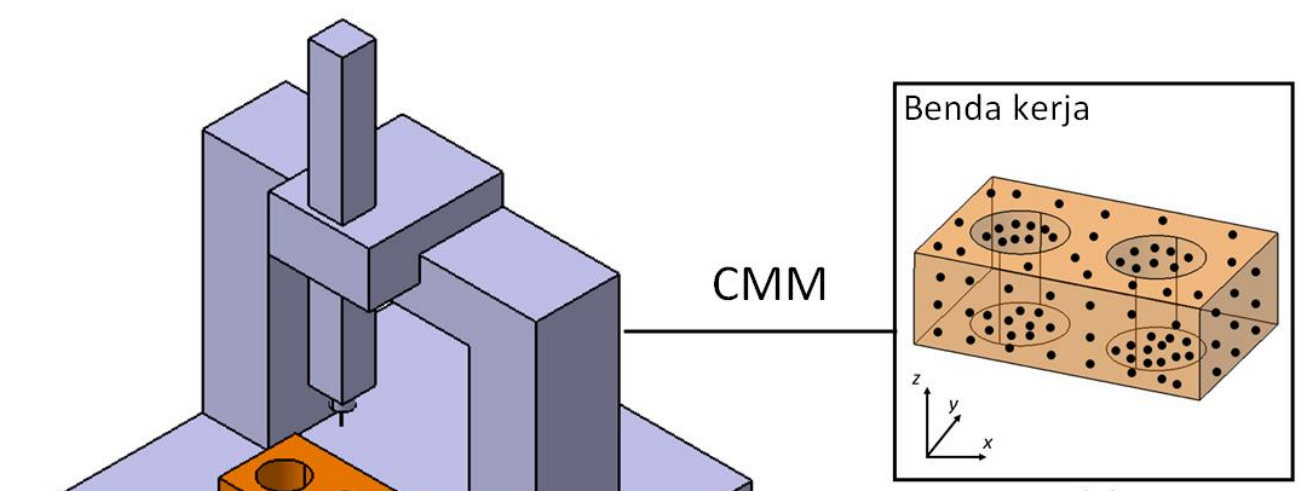

(a)

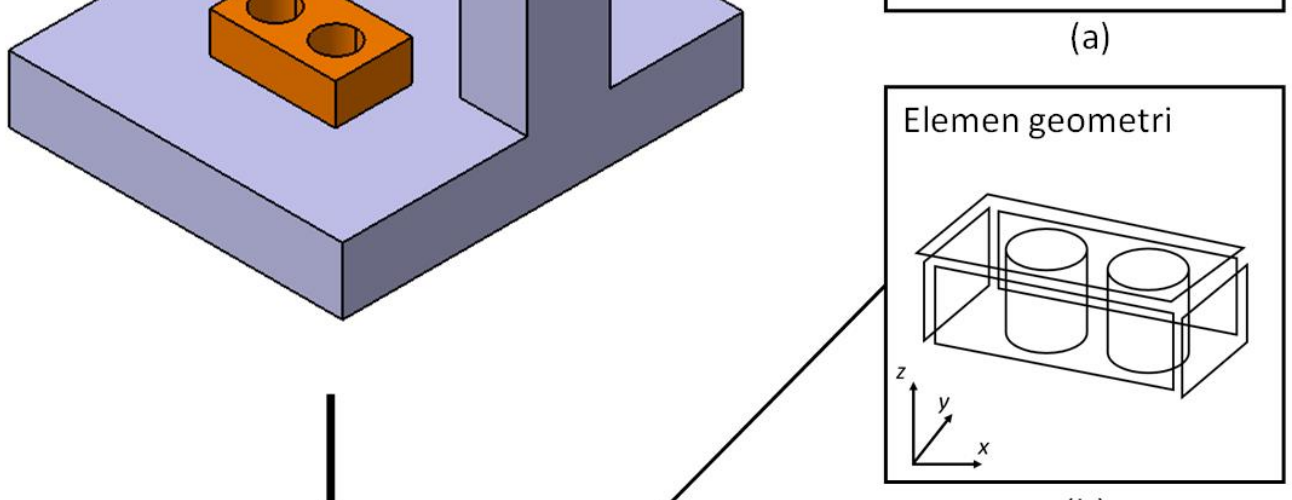

(b)

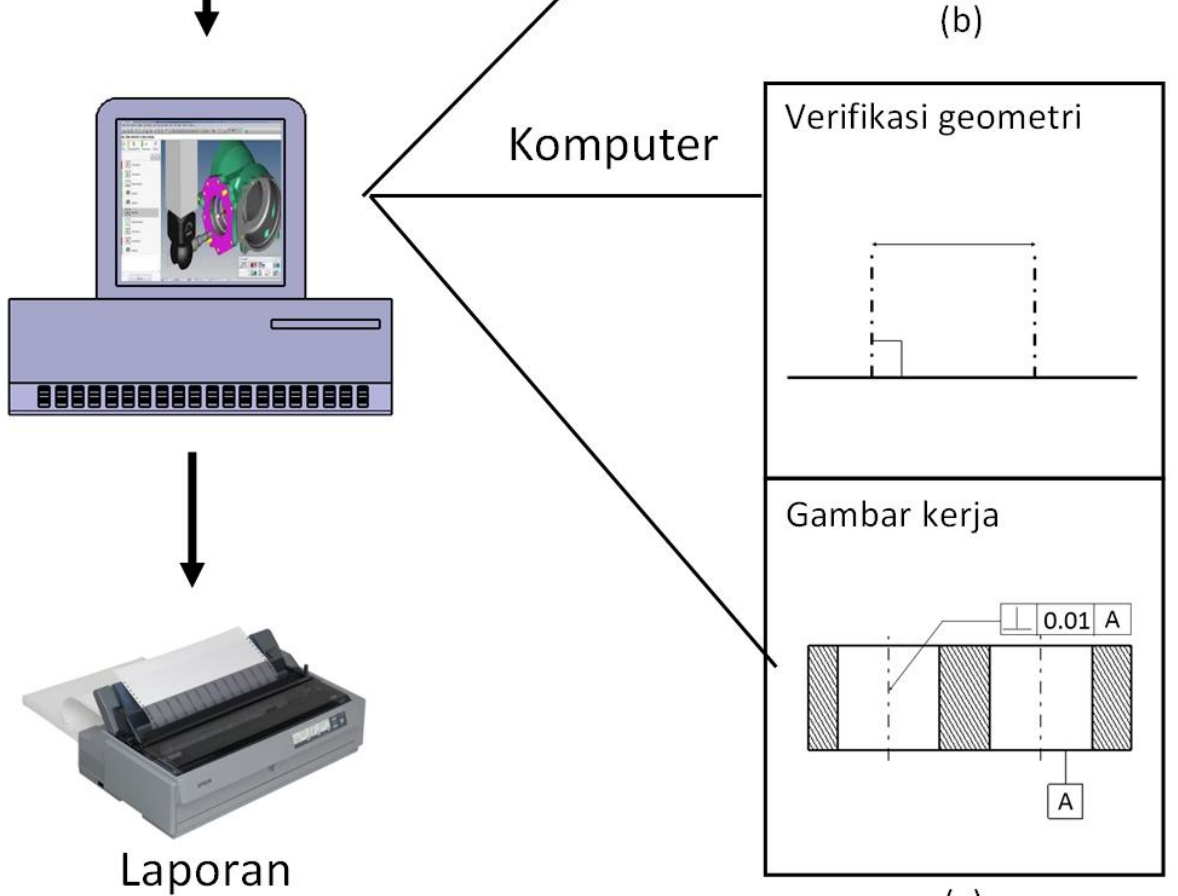

(c)

Gambar 13: Prosedur umum proses pengukuran dimensi dan geometri dengan CMM. 
Pada gambar 13, prosedur umum proses pengukuran dimensi dan geometri dengan CMM terbagi menjadi tiga proses utama, dengan urutan sebagai berikut (lihat gambar 13):

a. Pendeteksian titik-titik pada suatu permukaan benda sesuai dengan rencana pengukuran (measurement planning) yang sudah ditetapkan sebelumnya. Proses ini dilakukan oleh mesin CMM.

b. Proses mengasosiasikan titik-titik permukaan tersebut pada suatu elemen geometri (proses fitting) yang diinginkan, misalnya bidang datar, silinder dan bola. Proses ini dilakukan oleh komputer yang terhubung dengan CMM tersebut. Gambar 14 memperlihatkan contoh fitting titik-titik sebuah permukaan benda pada elemen geometri lingkaran. Pada gambar 14, dapat dilihat bahwa dengan menggunakan metode fitting yang berbeda, jari-jari (radius) dan titik pusat lingkaran yang didapatkan juga berbeda-beda. Metode fitting yang tepat yang harus digunakan tergantung pada jenis verifikasi geometri dan fungsi desain dari suatu produk. Bab 7 (algoritma) membahas secara detil mengenai berbagai macam proses fitting.
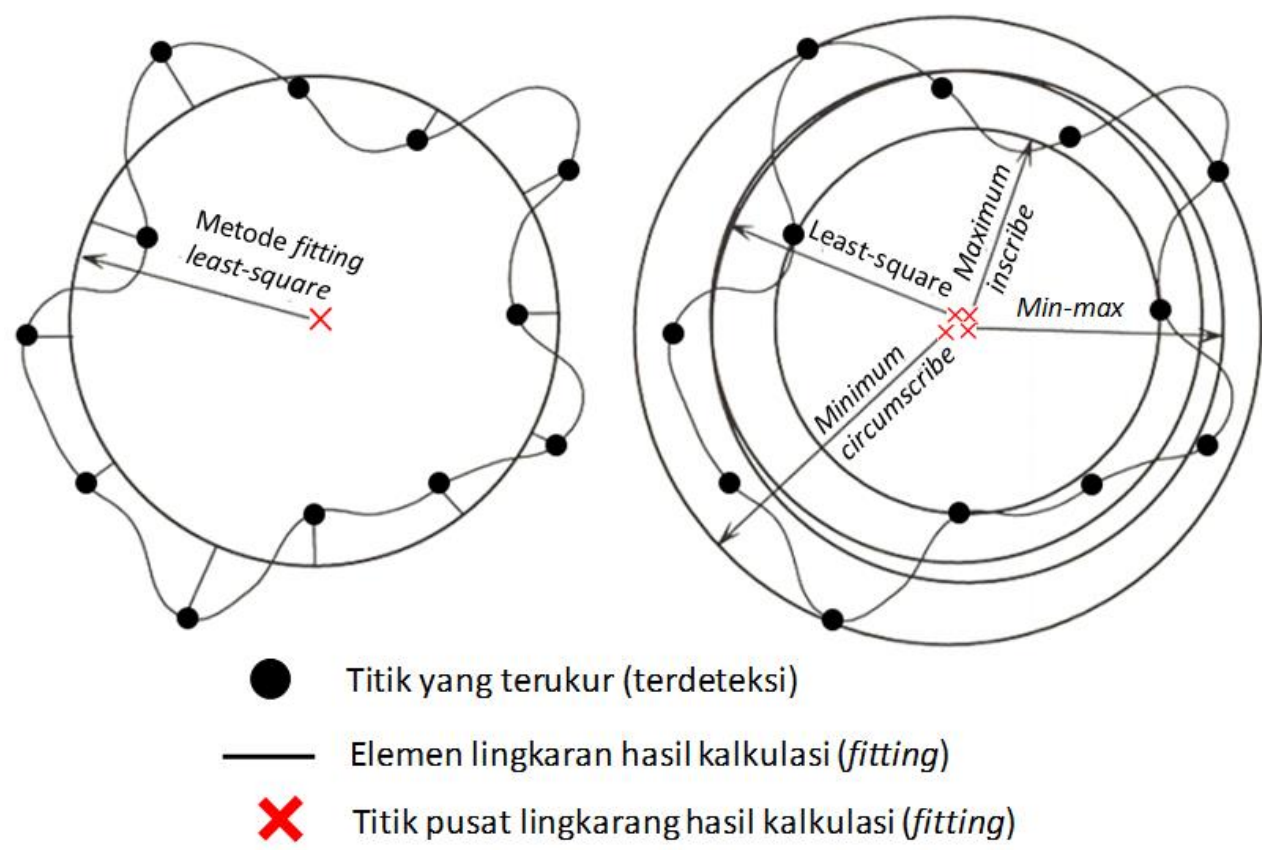

Gambar 14: Proses fitting untuk mengasosiasikan titik-titik pada suatu elemen geometri. Pada contoh ini diperlihatkan contoh fitting lingkaran dari titik-titik suatu permukaan benda yang dideteksi dari sebuah CMM.

c. Proses verifikasi geometri yang dilakukan dengan mengkalkulasi dimensi dan geometri yang ingin diketahui dari benda yang diinspeksi tersebut dan membandingkannya dengan gambar teknik benda tersebut. setelah itu, proses pembuatan laporan inspeksi dapat dibuat. Proses ini dilakukan oleh komputer yang terhubung dengan CMM tersebut.

Proses pembuatan rencana pengukuran (measurment planning), proses mengasosiasikan titik-titik permukaan tersebut pada suatu elemen geometri (proses fitting) dan proses verifikasi geometri dilakukan oleh perangkat lunak yang spesifik mengontrol suatu CMM yang digunakan untuk pengukuran. Contoh-contoh perangkat lunak tersebut adalah Calypso untuk CMM Zeiss, Quindos untuk CMM Leitz dan PC-Demis untuk CMM DEA dan lainnya.

Untuk pengoperasian CMM, pengoperasian tersebut dibagi menjadi dua tahap:

1. Persiapan pengukuran.

Proses persiapan yang harus dipertimbangkan dan dilakukan sebelum mengoperasikan CMM adalah proses 
pengkondisian mesin CMM, mengecek gambar teknik suatu benda yang akan diukur, memilih probe dan stylus, memilih fixture, pembuatan laporan dan keamanan.

2. Pembuatan program pengukuran.

Program pengukuran terbagi menjadi kualifikasi stylus, alignment, inspeksi, analisis, laporan, tes program pengukuran, dan revisi dan perbaikan program pengukuran tersebut.

\section{Persiapan pengukuran}

Sebelum menggunakan CMM, CMM tersebut harus dikondisikan agar berada dalam kondisi operasi terbaiknya. Debu-debu yang melekat pada CMM, terutama permukaan bearing harus dibersihkan dengan prosedur khusus. Untuk CMM dengan air bearing, suplai udara terkompresi harus dipastikan sesuai dengan spesifikasi yang dibutuhkan CMM. Stylus dan bole referensi untuk proses kualifikasi stylus harus selalu dibersihkan, biasanya menggunakan alkohol. Sebelum CMM digunakan, CMM tersebut harus diposisikan pada home position-nya. Memposisikan CMM pada posisi home-nya adalah penting karena skala pengukuran adalah inkrimental dan agar pengaplikasian peta error (error map) dapat dilakukan dengan benar di dalam volume pengukuran CMM tersebut.

Gambar teknik suatu benda yang akan diukur harus dicek terlebih dahulu untuk mengetahui jenis pengukuran apa yang akan dilakukan dan untuk menentukan program pengukuran yang paling efektif dan efisien. Pemrogram CMM yang baik adalah yang mengetahui GD\&T (Lihat Bab 3) dan perangkat lunak suatu CMM. Pemrogram CMM harus mempertimbangkan hal-hal berikut dalam membuat rencana pengukuran: datum apa saja yang harus diukur untuk melakukan pengukuran geometri, apakah pengukuran akan dilakukan dengan satu jenis atau lebih setup, apa saja grup fitur-fitur yang akan diukur dan bagaimana caranya untuk mendapatkan nilai ketidakpastian hasil pengukuran CMM sekecil mungkin (Lihat Bab 9).

Pemilihan probe dan stylus adalah sangat tergantung kepada jenis fitur pada suatu benda yang akan diukur. Hal pertama yang harus dipertimbangkan dalam memilih stylus adalah kemampuan untuk mengakses permukaan suatu benda yang akan diukur. Untuk probe, pemilihannya bergantung pada apakah pengukuran membutuhkan kemmapuan mengatur besarnya gaya menyentuh suatu permukaan benda atau tidak. Pada umumnya, penggunaan satu jenis stylus untuk melakukan suatu pengukuran lebih baik daripada menggunakan beberapa jenis stylus, karena apabila menggunakan beberapa jenis stylus, nilai ketidakpastian hasil pengukuran akan meningkat (akurasi berkurang) karena ada proses pergantian stylus. Kadang-kadang, merubah posisi suatu benda yang diukur untuk dapat diakses dengan suatu stylus yang digunakan lebih baik daripada mengganti stylus untuk mengakses fitur pada benda tersebut (dengan tidak merubah posisi atau orientasi benda tersebut). Terdapat stylus dengan konfigurasi star dengan berbagai orientasi stylus yang dapat digunakan untuk mengukur berbagai jenis fitur suatu benda.

Fixture untuk pengukuran CMM tidak membutuhkan gaya tahan yang besar seperti fixture untuk suatu benda pada mesin-mesin perkakas dan bubut. Gaya tahanan untuk menahan posisi benda harus tidak berlebihan agar benda yang ditahan tersebut tidak terdeformasi. Fixture juga harus digunakan tidak secara berlebihan karena fixture yang berlebihan akan menghalangi akses stylus untuk menjangkau suatu permukaan benda yan diukur. Tips untuk menahan benda yang kecil adalah dengan menggunakan super glue.

Menyiapkan jenis laporan yang dibutuhkan untuk pengukuran adalah penting. Laporan tersebut terbagi menjadi dua jenis, laporan untuk mendokumentasikan proses pengukuran dan laporan untuk mempresentasikan hasil pengukuran.

Keamanan pengoperasian CMM sangat penting untuk diperhatikan layaknya keamanan untuk pengoperasian mesin-mesin bubut dan perkakas. Keamanan tersebut untuk operator dan fungsionalitas CMM. Operator harus memperhatikan benda-benda yang berada di meja CMM jangan sampai menghalangi pergerakan aksis CMM sehingga menyebabkan benda-benda tersebut jatuh. Permukaan bearing CMM juga harus dijaga jangan sampai rusak karena bergesekan dengan benda-benda. Tombol emergency stop CMM harus selalu diletakkan dalam jangkauan operator.

\section{Pembuatan program pengukuran}

Tahapan pembuatan program pengukuran CMM diperlihatkan pada gambar 15. Tahapan-tahapan tersebut adalah kualifikasi probe dan stylus, alignment, proses inspeksi, analisis data (fitting dan verifikasi), desain laporan hasil 
pengukuran, tes program pengukuran, dan revisi dan perbaikan program pengukuran. Tahapan-tahapan tersebut harus dilakukan untuk setiap pengoperasian CMM kontak.

Program CMM sering disebut juga sebagai rencana pengukuran (measurement planning). ASME B89.7.2-1999 (ASME 1999) memberikan petunjuk yang baik untuk membuat suatu program atau rencana pengukuran CMM. Penjelasan untuk tiap-tiap tahapan tersebut adalah sebagai berikut:
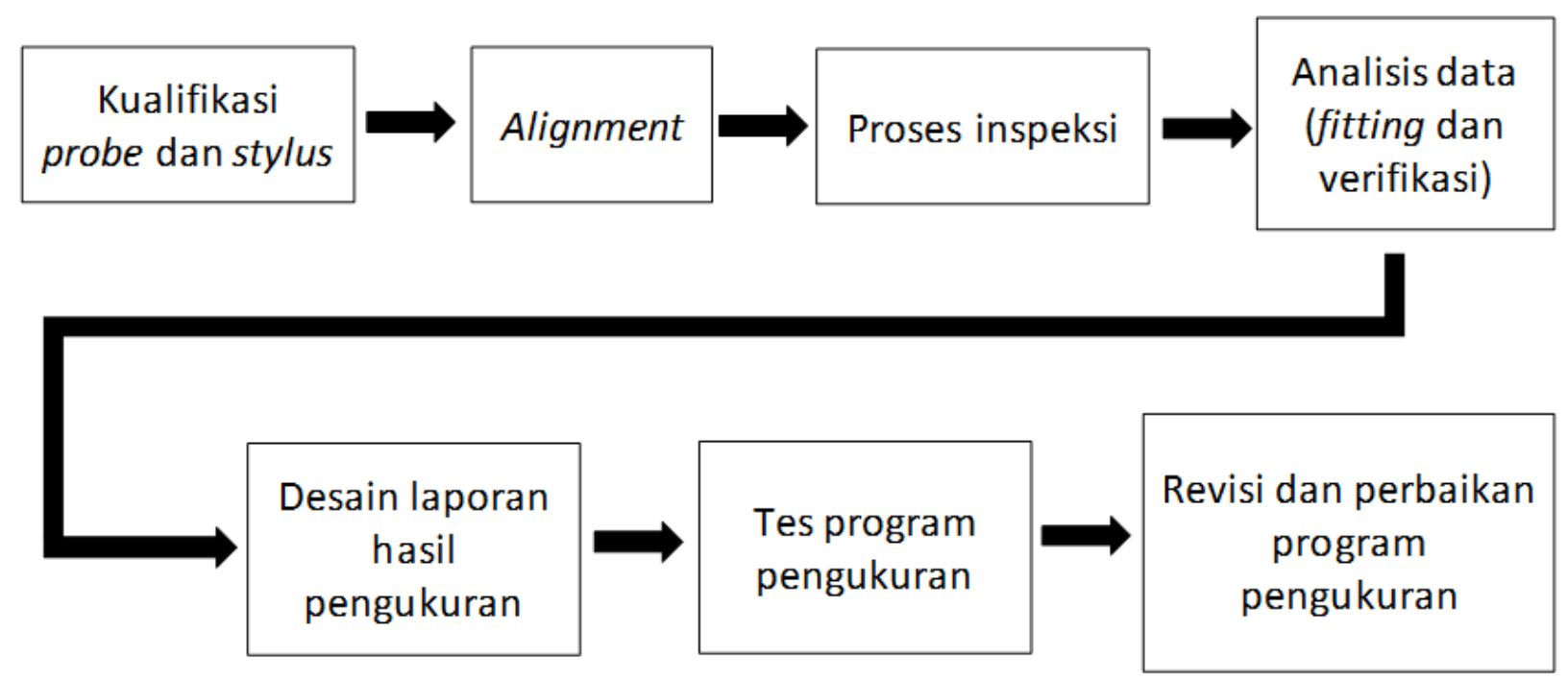

Gambar 15: Tahapan pembuatan program pengukuran CMM.

1. Kualifikasi probe dan stylus.

Proses kualifikasi probe dan stylus adalah proses untuk mengetahui diameter efektif dari stylus tip yang berbentuk bola dan untuk mengetahui bentuk atau orientasi dari stylus tersebut. Beberapa perangkat lunak komersial menyebut proses ini sebagai kalibrasi probe atau stylus, dimana penamaan ini tidak tepat. Gambar 16 memperlihatkan contoh dari kualifikasi probe dan stylus CMM. Proses kualifikasi tersebut membutuhkan tiga elemen: bola referensi (reference sphere) yang terkalibrasi dan diketahui diameter (ukurannya), stylus referensi yang terkalibrasi yang diketahui diameter tip-nya dan panjangnya dan stylus yang akan dikualifikasi untuk digunakan pada proses pengukuran.

Dua tahapan utama proses kualifikasi adalah:

1. Pengukuran posisi absolut titik tengah daru bole referensi tersebut dengan menggunakan stylus referensi tersebut.

2. Pengukuran bola referensi dengan menggunakan stylus yang ingin dikualifikasi (stylus yang akan digunakan pada pengukuran). Proses ini pada umumnya mengambil 25 titik pada permukaan bola referensi tersebut. kemudian, dengan proses kalkulasi numerik, orientasi (bentuk) stylus dan diameter efektif stylus tip tersebut akan didapatkan. Detil dari proses ini akan dijelaskan pada bagia berikutnya.

Apabila terdapat multipel stylus pada satu probe dan akan digunakan pada suatu pengukuran, sebaiknya semua stylus pada probe tersebut dikualifikasi dalam satu proses kualifikasi yang sama (posisi bola referensi sama) untuk mengurangi sumber ketidakpastian untuk proses kualifikasi stylus CMM. 


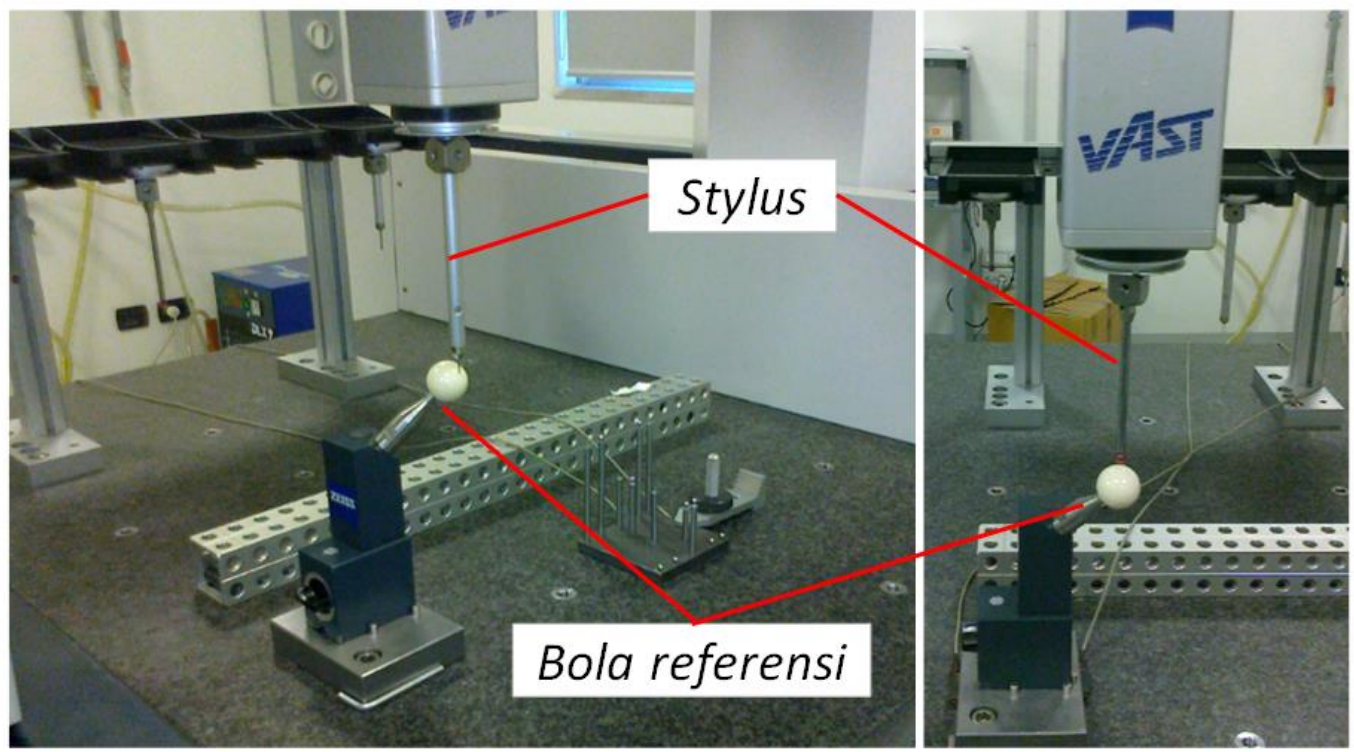

Gambar 16: Kualifikasi probe dan stylus.

2. Alignment.

Proses alignment adalah suatu proses untuk mentransformasi sistem koordinat pengukuran dari sistem koordinat absolut mesin CMM (machine coordinate system/MCS) ke sistem koordinat benda kerja (part coordinate system/WCS). MCS adalah sistem koordinat absolut yang bersifat tetap untuk setiam mesin CMM. MCS sudah terdefinisikan waktu suatu CMM direkonstruksi. Gambar 17 memperlihatkan transformasi sistem koordinat dari MCS ke WCS. Untuk mennetukan pusat dari WCS, beberapa fitur (biasanya tiga jenis bidang datar dengan orientasi yang berbeda pada suatu benda yang ingin diukur) diambil titik-titiknya, kemudian dengan kalkulasi numerik, pusat dari WCS akan ditentukan.

Proses alignment pada umumnya terbagi menjadi dua tahap:

1. Proses pengambilan secara manual titik-titik permukaan fitur-fitur pada sebuah benda yang diukur.

Untuk mesin CMM dengan sistem kontrol otomatis, titik-titik tersebut direkam kedalam memori kontroller CMM tersebut. proses ini sering dinamakan sebagai coarse alignment, yaitu alignment tahap awal yang belum presisi.

2. Proses pengambilan secara otomatis titik-titik permukaan fitur-fitur tersebut. proses ini dinamakan precise atau fine alignment karena pada saat titik-titik permukaan tersebut diambil, pergerakan CMM dapat dikontrol secara konstan, sehingga mempunyai tingkat akurasi yang lebih tinggi dalam mendeteksi titik-titik permukaan tersebut.

Penjelsan lebih detil mengenai proses alignment CMM akan dijelaskan pada bagian selanjutnya. 


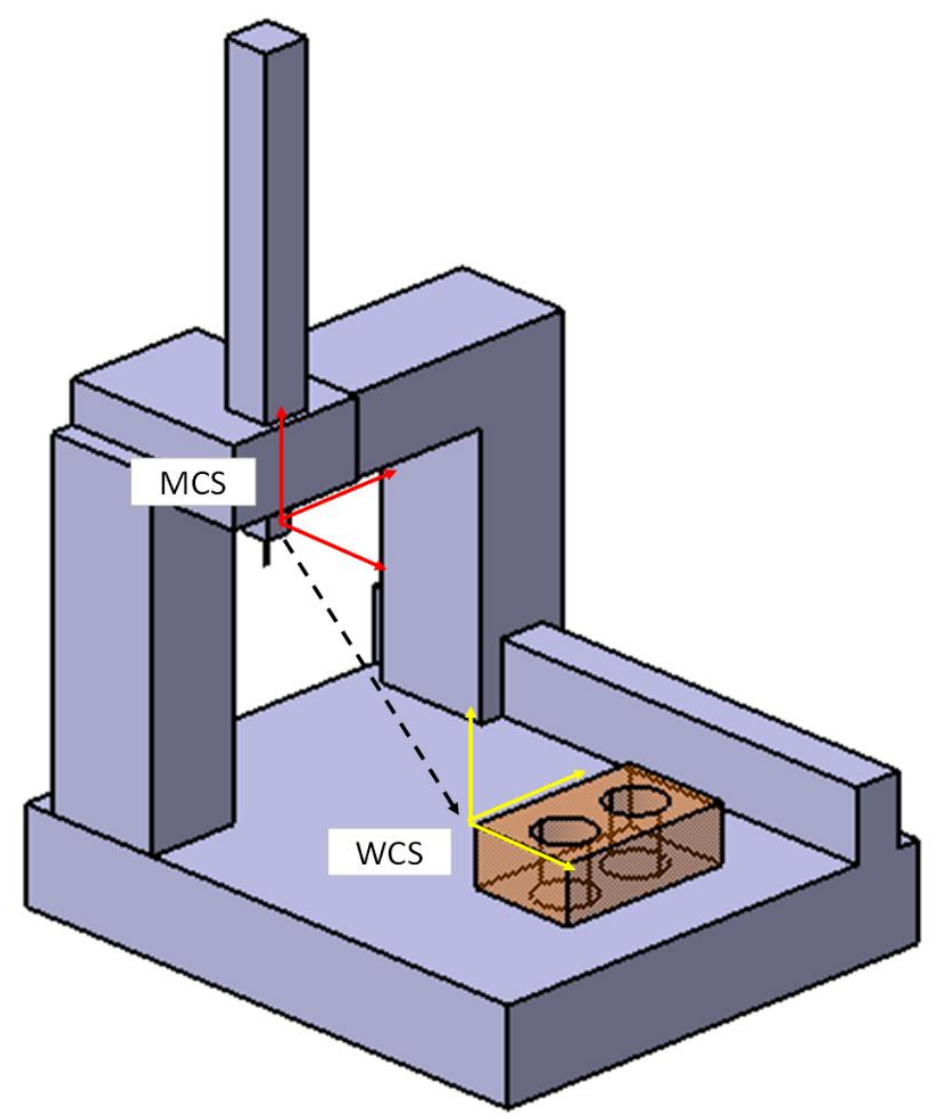

Gambar 17: Proses alignment CMM.

3. Proses inspeksi.

Proses ini merupakan proses untuk menentukan strategi pengukuran, misalnya mengukuran posisi suatu silinder pada suatu benda terhadap suatu datum. Pada umumnya, desain proses pengukuran ditentukan dengan mengukur fitur-fitur yang saling berdekatan terlebih dahulu. Hal ini bertujuan untuk mengurangi jarak pergerakan CMM, sehingga mengurangi efek dinamis CMM tersebut dan untuk menghemat waktu pengukuran. Pada proses ini, semua fitur-fitur yang berhubungan untuk memberikan hasil suatu pengukuran geometri dan dimensi harus didefinisikan. Strategi pengambilan titik-titik permukaan suatu benda (sampling strategy) juga didefinisikan pada tahap ini, misalnya dengan menggunakan strategi point-to-point atau point scanning.

4. Analisis data (fitting dan verifikasi).

Proses ini adalah suatu proses untuk memproses data (berupa titik-titik koordinat spasial pada permukaan suatu fitur yang diukur) hasil pengukuran. Pada proses ini, kalkulasi numerik yang kompleks untuk mengasosiasikan suatu elemen geometri ideal (misalnya bidang datar, lingkaran dan silinder) pada titik-titik permukaan benda yang diukur (proses fitting), sehinga dari hasil rekonstruksi elemen-elemen geometri tersebut, sebuah dimensi (misalnya panjang dan diameter) dan geometri (misalnya flatness, orientasi, posisi dan run-out) dapat ditentukan dan diverifikasi dengan nilai yang terdapat pada gambar teknik. Pada umumnya, perangkat lunak sebuah CMM memberikan kemungkinan operator untuk memilih jenis fitting apa yang akan digunakan, misalnya least-square atau minimum-zone fitting. Proses fitting akan dijelaskan dengan detil pada bab 7 mengenai algoritma. 
5. Desain laporan hasil pengukuran.

Proses ini adalah proses untuk mennetukan jenis dan format laporan hasil pengukuran yang akan ditampilkan. Laporan hasil pengukuran dapat didesain dari berupa laporan yang sederhana hanya berupa teks, misalnya diameter suatu silinder, sampai dengan laporan yang sangat kompleks dengan berbagai macam grafik. Pada umumya, di industri-industri volume laporan hasil pengukuran sangat banyak, sehingga otomatisasi untuk menghasilkan dan menampilkan laporan hasil pengukuran sangatlah penting.

6. Tes program pengukuran.

Setelah program pengukuran CMM selesai, maka langkah selanjutnya adalah mengetes apakah program tersebut dapat berjalan dan memberikan hasil-hasil pengukuran sesuai dengan yang diharapkan atau tidak. Hal utama yang harus diperhatikan pada tahap ini adalah untuk mengecek agar tidak terjadi tabrakan antara stylus dengan benda yang diukur. Selain itu, kecepatan pergerakan CMM juga dapat diobservasi apakah terlalu cepat atau terlala lambat. Pada umumnya, ketika pertama kali program CMM di tes, kecepatan CMM (yang dapat diset dari joystik CMM) diset lambat.

7. Revisi dan perbaikan program pengukuran.

Setelah suatu program CMM selesai dan sudah dites dan memberikan hasil-hasil pengukuran sesuai dengan yang diharapkan, program CMM yang telah dibuat tersebut dapat dioperasikan secara berulang-ulang. Sepertihalnya membuat program suatu perangkat lunak, setelah suatu program selesai dibuat, selalu terdpaat celah-celah dari program tersebut yang dapat direvisi, sehingga program tersebut dapat menjadi lebih efisien ketika dijalankan. Untuk mendapatkan satu jenis hasil pengukuran, terdapat sangat banyak kemungkinankemungkinan program yang berbeda untuk menghasilkan pengukuran yang sama tersebut. Maka dari itu, revisi program dapat dilakukan secara periodik, minimal mendokumentasikan setiap lagkah program CMM yang telah dibuat sebelumnya.

\subsection{Sistem probing CMM}

Sistem probing adalah suatu komponen pada suatu CMM yang berfungsi sebagai sensor untuk mendeteksi suatu stylus ketika menyentuh permukaan suatu benda dan merekam koordinat spasial titik-titik permukaan tersebut ke dalam memori sistem kontrol CMM tersebut. Sistem probing merupakan bagian penting dan integral dari suatu CMM karena sistem tersebut adalah sistem yang menghubungkan antara mesin CMM dan suatu benda yang diukur (Weckenmann et al 2004).

\section{Sejarah singkat sistem probing CMM}

Pada awalnya, sistem probing adalah hanya terdiri dari sebuah stylus yang merupakan sebuah komponen mekanikal. Pada saat itu, sistem probing belum mempunyai komponen elektornik. Stylus tersebut diposisikan secara manual oleh seorang operator untuk menyenruh sebuah permukaan benda dan secara manual menekan sebuah tombol untuk membaca posisi ketiga aksis CMM sebagai posisi koordinat spasial titik pada permukaan tersebut. Proses probing manual yang dilakukan oleh seorang operator merupakan sebuah proses yang lambat, subjetif dan tidak akurat.

Revolusi sistem probing bermula pada tahun 1972, yaitu pada saat Sir David McMurtry menemukan sistem probing berbasis resistansi kinematic yang merupakan sebuha touch-trigger probe. Motivasi McMurtry untuk membuat sistem probing tersebut adalah ketika dia ingin mengukur geometri dari pipa-pipa bahan bakar yang berukuran kecil. Penemuam sistem probing tersebut adalah sebuah faktor yng mendorong berkembangnya sistem probing modern dan mesin-mesin CMM modern pada saat ini.

Dalam sejarah, tidak berselang lama dari ditemukannya sistem probing revolusioner oleh Sir David McMurtry tersebut, perusahaan ZEISS memproduksi sistem CMM pertama mereka UMM500 pada tahun 1973. Sistem probing UMM500 tersebut merupakan sistem probing dengan kemampuan menghasilkan gaya probing aktif (active force 
probing), sehingga besarnya gaya sentuh stylus yang diberikan pada suatu permukaan benda dapat diatur sesuai dengan tingkat kekerasan dan kekakuan permukaan tersebut. Touch-triggered probe hasil temuan Sir McMurtry dan active-force probe hasil temuan ZEISS yang menjadi landasan sistem probing modern pada saat ini.

\section{Konfigurasi dasar dan mekanisme sistem probing CMM dengan metode kontak}

Sistem probing terbagi menjadi dua bagian: probe head (sensor) dan stylus. Gambar 18 memperlihatkan konfigurasi dasar dari sebuah sistem probing. Konfigurasi pada gambar 18 adalah sebuha konfigurasi touch-trigger probe dan force generating probe. Pada gambar 18, konfigurasi dasar dari sistem probing adalah:
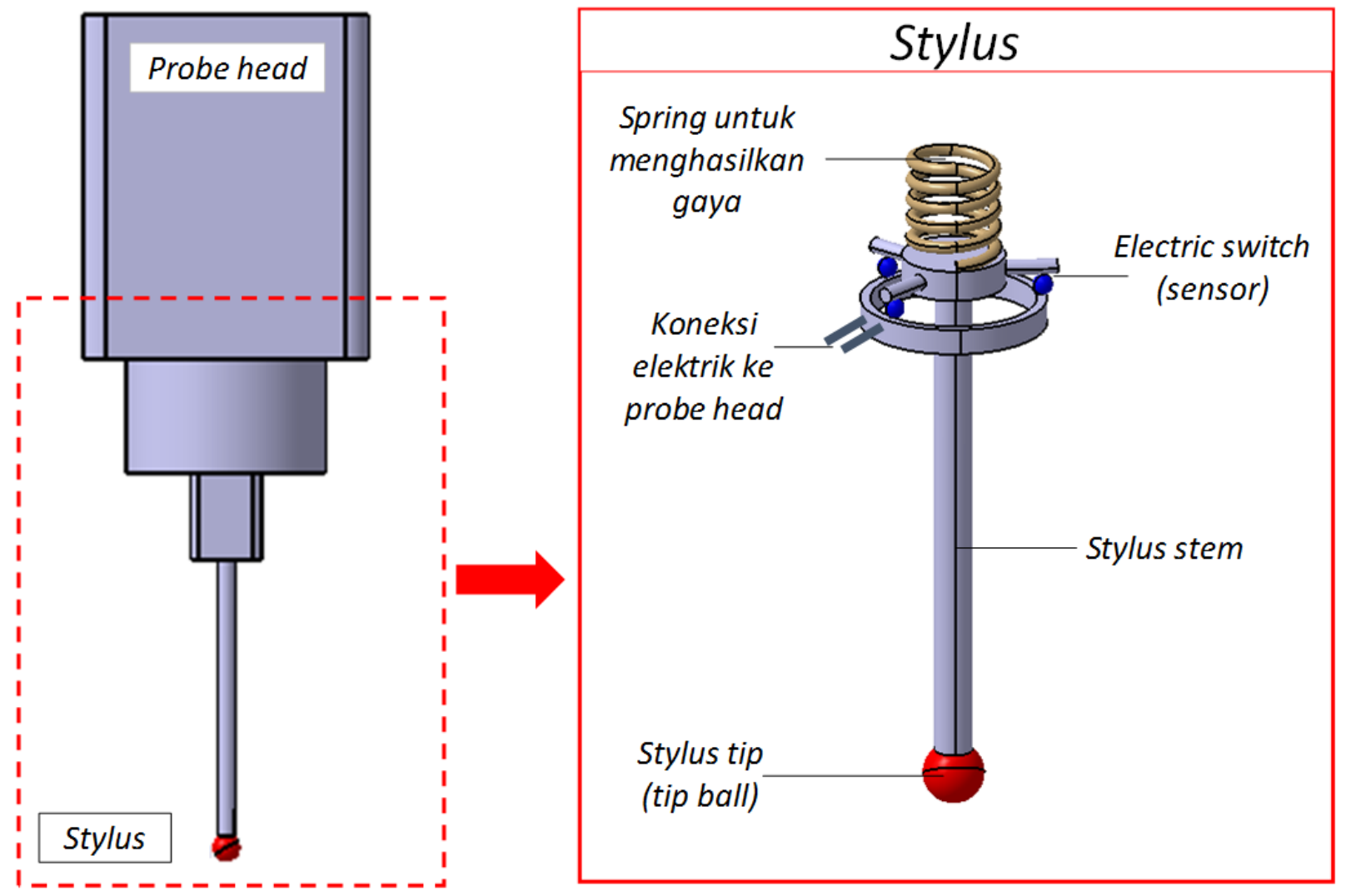

Gambar 18: Konsep dari konfigurasi probe head dan stylus.

1. Stylus tip (tip ball).

Komponen ini berfungsi untuk berinteraksi (menyentuh) suatu permukaan benda yang diukur. Stylus tip padau umumnya terbuat daru material ruby (berwarna merah) dan pada umumnya mempunyai karakteristik sebagai berikut: mempunyai tingkat kekakuan yang tinggi, daya tahan aus yang tinggi, mempunyai deviasi geometri yang sangat kecil dan stabil dalam kondisi temperatur dan variasi tekanan lingkungan yang besar.

2. Stylus stem (stylus shaft).

Komponen ini berfungsi untuk mentrafer informasi kontak dengan suatu permukaan benda (misalnya gaya sentuhan atau defleksi) ke sensor yang berdada didalam probe head. Karakteristik utama untuk sebuah stylus shaft adalah mempunyai ekspansi termal yang kecil, tingkat kekakuan yang tinggi, kekuatan yang tinggi dan massa yang rendah. Material yang sering dipakai untuk stylus shaft adalah hardened steel, keramik, serat 
karbon, tungtes carbide.

3. Sensor.

Komponen ini berfungsi untuk mengeveluasi informasi kontak. Beberapa metode sensor tersebut adalah berbasis electrical switch, gaya sentuh, atau sensor perpindahan. Sensor-sensor probing modern sekarang ini pada umumnya bisa membaca besarnya perpindahan stylus dan arah pergerakan pengukuran stylus.

4. Antarmuka atau koneksi ke sistem CMM.

Komponen ini berfungsi untuk mentransfer informasi, yang dihasilkan dari sensor yang mendeteksi bersentuhannya stylus tip dengan suatu permukaan benda, ke sistem kontrol CMM untuk kemudian diproses lebih lanjut, seperti mengtransformasi posisi titik probe ke dalam machine coordinate system (MCS).

5. Generator gaya.

Komponen ini berfungsi untuk memberikan pre-load pada stylus dan, untuk sistem probin gaktif, dapat menghasilkan gaya sentuh pada stylus tip ke permukaan suatu benda dan mengontrol agar gaya sentuh yang diberikan ke permukaan tersebut konstan. Pada umumnya gaya tersebut dihasilkan dengan mekanisme aktuator berbasi voice coil. Komponen ini biasanya hanya terdapat untuk sistem probing aktif (yang akan dijelaskan kemudian). Pada aplikasinya, generator gaya ini dapat berupa spring atau pun flexure.

Mekanisme umum dari sistem probing adalah sebagai berikut. Terdapat sebuah sistem kinematik yang terdiri dari tiga bola yang duduk pada suatu pelat metal. Pada kondisi stylus tidak menyentuh suatu permukaan, maka ketiga bola tersebut bersentuhan dengan pelat tersebut. Sistem ketiga bola tersebut adalah seperti electrical switch. Apabila staylus bersentuhan dengan permukaan tersebut, maka salah satu bol atersebut akan terlepas dari dudukannya sehingga tidak ada kontak dengan pelat tersebut. Keadaan ini akan memicu informasi ke sistem kontrol bahwa stylus sudah menyentuh permukaan tersebut. Komponen spring pada gambar 18 memungkinkan untuk memberikan pre-load kepada stylus, sehingga gaya kontak stylus tip dengan permukaan tersebut dapat dibatasi dan juga untuk memungkinkan over-travel stylus ketika menyentuh benda (memberikan waktu untuk deselerasi atau perlambatan CMM). Spring tersebut bisa berupa spring atau sistem flexure. Dengan sistem flexure, kemampuan tambahan sistem probing adalah dapat merekam arah sentuh permukaan benda tersebut, dengan menempel suatu sistem strain gage pada flexure tersebut.

Pada sistem probing modern, terdapat dua jenis sistem probing, yaitu sistem probing pasif dan sistem probing aktif. Sistem probing pasif dan aktif diperlihatkan pada gambar19. Penjelasan dari kedua sistem probing tersebut adalah sebagai berikut:

- $\quad$ Sistem probing pasif

Pada sistem probing pasif, sistem probing tersebut tidak dapat menghasilkan gaya dan hanya bisa mendeteksi arah sentuh ke suatu permukaan benda. Sistem probing ini menggunakan sistem flexure (sistem elastik) dengan menempel sensor strain gage untuk merasakan sentuhan pada arah X, Y dan Z. Strain gage tersebut mengukur defleksi dari sistem flexure/elastik tersebut karena gaya yang dirasakan proporsional terhadap defleksi sistem flexure tersebut. pada gambar 19 kiri, gaya sentuh pada suatu permukaan benda dengan sistem pasif adalah tidak konstan.

- Sistem probing aktif

Pada sistem probing aktif, terdapat kemampuan untuk menghasilkan gaya pada stylus ketika menyentuh suatu permukaan benda. Dengan sistem ini, gaya yang dihasilkan dapat dikontrol untuk menyesuaikan dengan gaya respon dari suatu permukaan benda. Dengan sistem ini, sistem probing dapat merapa suatu permukaan yang belum pernah disentuh sebelumnya. Pada gambar 19 kanan, dengan sistem aktif, gaya yang dihasilkan pada permukaan dapat dikontrol secara konstan.

Pada gambar 20, diperlihatkan dua sistem probing komersial dari ZEISS, yaitu sistem pasif dan aktif. Pada gambar 20, kedua sistem probing tersebut adalah berdasarkan sistem flexure/elastik. Pada gambar 20, diperlihatkan bahwa sistem probing aktif mempunyai komponen tambahan untuk menghasilkan gaya (secara fisik, probe head-nya lebih panjang karena adanya tambahan komponen penghasil gaya tersebut). 


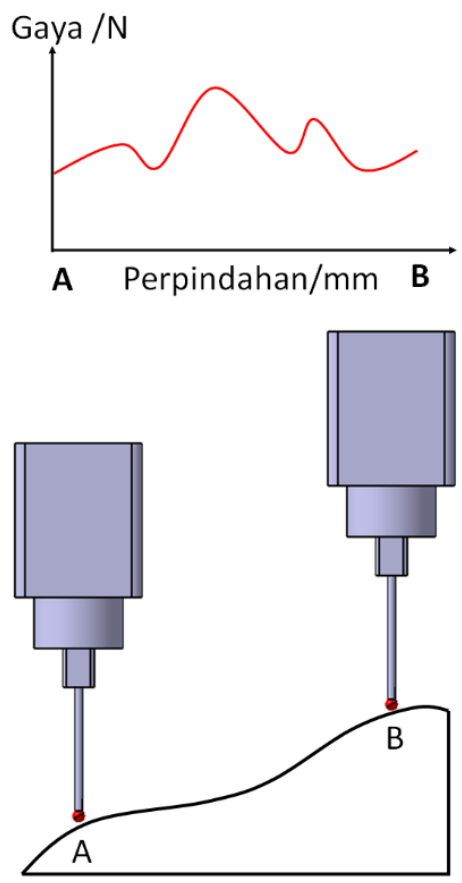

Sistem probing pasif
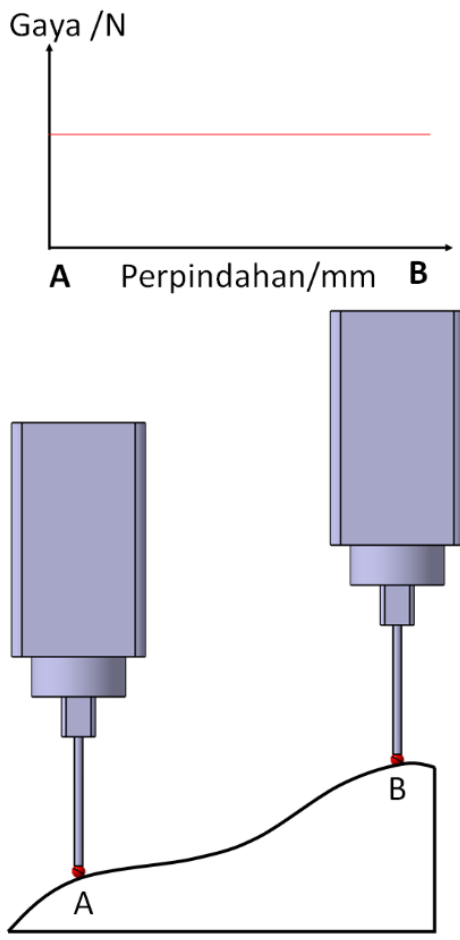

Sistem probing aktif

Gambar 19: (kiri) sistem probing pasif dan (kanan) sistem probing aktif. Pada sistem probing aktif, gaya sentuh ke permukaan suatu benda adalah konstan.

Sistem probing pasif

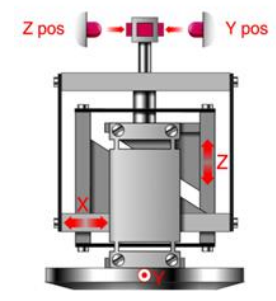

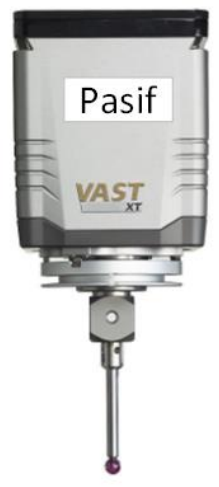

Sistem probing aktif

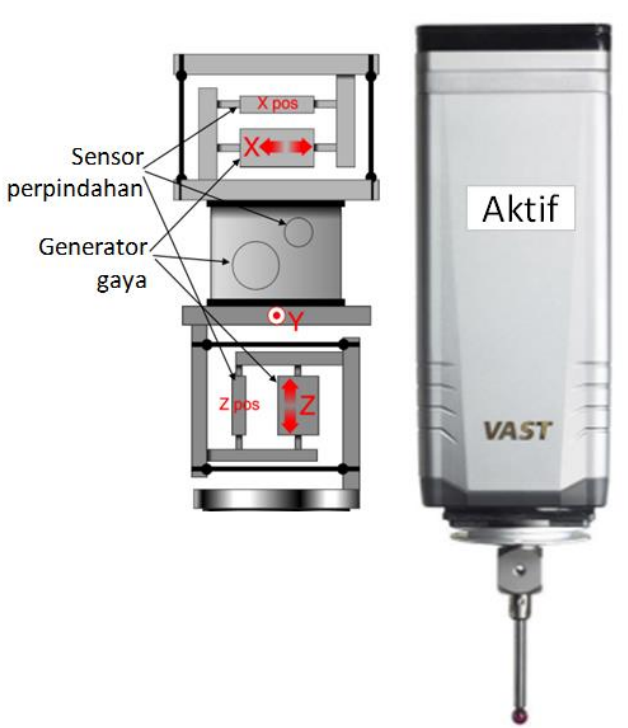

Gambr 20: Contoh probing sistem dari ZEISS. (kiri) sistem probing pasif dan (kanan) sistem probing aktif. 
Hal penting yang perlu diingat adalah jarak antara sensor kontak di dalam probe head dan stylus tip (ujung stylus) idealnya adalah sependek mungkin untuk mengurani efek Abbe dan defleksi dari stylus stem. Namun demikian, stylus stem yang terlalu pendek akan mengurangi aksesibilitas stylus untuk mencapai fitur tertentu pada suatu permukaan benda yang diukur.

\section{Aspek-aspek dari sistem probing}

1. Langkah-langkah proses probing Proses probing dapat dmenjadi empat tahapan, yaitu:

a) Pergerakan stylus tip dengan kecepatan tertentu ke suatu permukaan benda yang diukur.

b) Kontak antara stylus tip dengan permukaan tersebut.

c) Identifikasi dari koordinat spasial titik kontak antara stylus tip dan permkaan tersebut.

d) Pergerakan menjauhi titik kontak tersebut (menuju posisi referensi atau menuju posisi titik lain permukaan tersebut).

2. Prinsip operasional sistem probing

Pada CMM modern sekarang ini, sistem probing terbagi menjadi dua jenis utama: touch-triggered probe dan measuring probe. Touch-triggered probe adalah probe yang pertama kali ditemukan oleh Sir McMurtry dan hanya mempunyai respon kontak atau tidak kontak. Sedangkan measuring probe mempunyai kemampuan tambahan selain respon kontak atau non-kontak, yaitu respon vektor arah probing (arah menyentuh permukaan suatu benda). Measuring probe dibagi menjadi: probe aktif dan probe non-aktif (telah dijelaskan sebelumnya).

Keunggulan touch-triggered probe adalah sistem tersebut lebih sederhana, sehingga ukuran dan massa probe menjadi kecil dan ringan. Selain itu, touch-triggered probe mempunyai biaya produksi yang jauh lebih rendah. Touch-triggered probe cocok untuk penugkuran dimensi dan geometri yang sederhana. Measuring probe terdiri dari sistem flexsure yang dipasang strain-gages, sehingga measuring probe dapat mendeteksi vektro arah pada saat menyentuh suatu permukaan benda (gambar 19). Measuing probe sangat cocok untuk mengukur permukaan free-form.

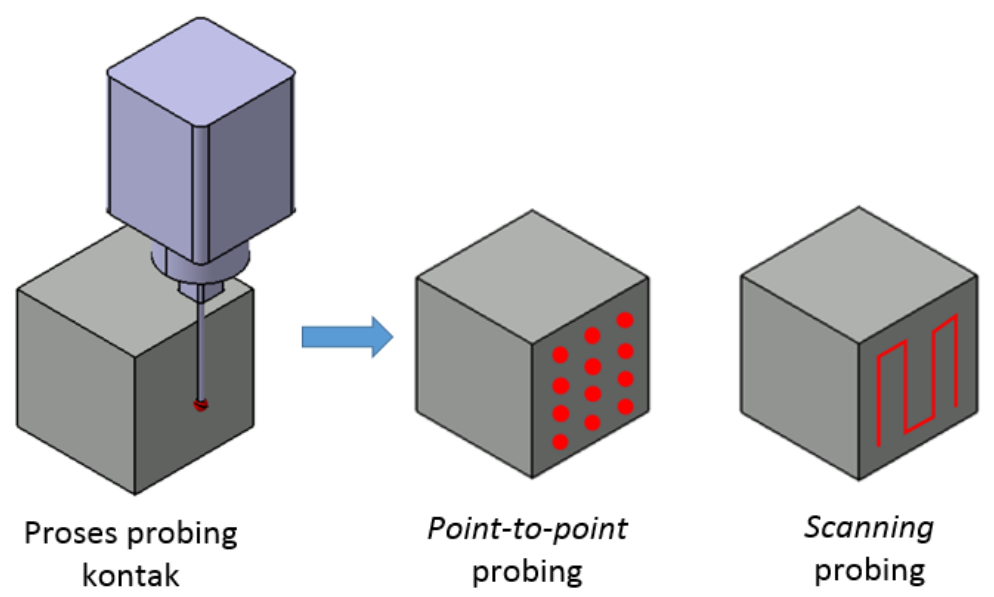

Gambar 21: Metode point-to-point dan scanning probing.

3. Moda operasi

Moda operasi probing terbagi menjadi dua: point-to-point probing dan scanning probing. Point-to-point probing adalah pendeteksian titik-titik suatu permukaan benda satu-demi-satu. Sedangkan, scanning probing beroperasi dengan mengikuti suatu permukaan (tetap menyentuh permukaan tersebut) sambil mengumpulkan titik-titik koordinat spasial permukaan tersebut. Scanning probing hanya dapat dilakukan oleh measuring 
probe.

Point-to-point probing mempunyai nilai ketidakpastian hasil pengukuran yang lebih kecil dibandinkan dengan scanning probing. Karena, dengan scanning probing, efek dinamik dari CMM mempunyai efek signifikan terhadap hasil pengukuran. Scanning probing dpaat mendeteksi titik-titik suatu permukaan benda jauh lebih banyak dari point-to-point probing. Gambar 21 memperlihatkan contoh metode point-to-point dan scanning probing.

4. Kinematik

Konfigurasi sistem probing terdiri dari dua jenis, yaitu: kinematik serial dan parallel. Serial kinematik mempunyai konfigurasi stack dari komponen-komponen yang mengukur pergerakan aksis-aksis. Konfigurasi kinematik serial biasanya digunakan untuk jenis measuring probe (seperti dicontohkan pada gambar 20). Sedangkan, touch-triggered probe pada umumnya menggunakan konfigurasi kinematik parallel, karena tidak penting untuk memisahkan pergerakan aksis-aksis, sehingga touch-triggered probe tidak memberikan informasi mengenai vektor probing (arah kontak stylus tip dengan suatu permukaan benda).

5. Gaya probing dan tekanan kontak Hertzian

Gaya probing mempunyai efek yang signifikan terhadap repeatability titik-titik suatu permukaan benda yang diukur. Hal ini disebabakan karena gaya probing sangat mempengaruhi bending dari stylus, deformasi (baik elastik maupun plastik) dari stylus tip dan liniearity dari sensr kontak di dalam probe head. Maka dari itu, measurement probing aktif sangat berguna untuk mengurangi ketidakpastian yang berasal dari sistem probing karena dapat menghasilkan gaya probing yang konstan ke suatu permukaan benda yang diukur.

Selain itu, ukuran dari stylu stip sangat mempengaruhi gaya kontak antara stylus tip dan suatu permukaan benda yang diukur. Untuk kasus-kasus umum untuk pengukuran konvensional pada skala makro, seperti pengukuran roda gigi, komponen-komponen mesin dan komponen-komponen mekanikal lainnya, pada umumya, stylu stip yang digunakan adalah sebesar $(1-8) \mathrm{mm}$ dengan gaya probing statik yang besarnya antara $50 \mathrm{mN}$ sampai $200 \mathrm{mN}$. Nilai repeatability dari satu titik koordinat spasial pada umumnya berada pada $0.1 \mu m-10 \mu m$.

CMM kontak juga dapat mengukur komponen-komponen pada skala meso dan nano, seperti lensa mikro, roda gigi mikro dan nozzle dari injektor bahan bakar pada mesin kendaraan (Weckennmann et. al. 2006). Solusi CMM kontak untuk mengukur komponen-komponen pada skala mikro tersebut adalah dengan menggunakan stylus tip dengan diamater yang sangat kecil, biasanya dengan diameter $(0.1-0.5) \mathrm{mm}$, dan menggunakan gaya probing yang sangat kecil juga. Dengan stylus tip yang sangat kecil tersebut, maka tekanan stylus tip pada suatu permukaan benda akan menjadi sangat besar, sehingga akan mempengaruhi topografi permukaan yang diukur tersebut. Tekanan stylus tersebut dinamakan tekanan kontak Hertzian (yang dapat mempunyai nilai yang sangat besar walaupun gaya kontak yang diberikan sangat kecil). Tekanan kontak Hertzian $\sigma$ diformulasikan sebagai:

$$
\sigma=\frac{1}{\pi} \sqrt{\frac{1.5 \times F E^{2}}{r^{2}\left(1-v^{2}\right)^{2}}}
$$

Sedangkan, deformasi elastis $w_{0}$ dari stylus tip pada saat kontak dengan suatu permukaan diformulasikan sebagai:

$$
w_{0}=\sqrt[3]{\frac{2.25 \times\left(1-v^{2}\right)^{2} F^{2}}{E^{2} r}}
$$

Dimana: $F$ adalah gaya kontak, $r$ adalah jari-jari stylus tip, $E$ adalah modulus Young efektif dari material stylus tip, $v$ adalah rasio Poison, $E_{1}$ dan $E_{2}$ adalah modulus Young untuk stylus tip dan benda yang diukur. $E$ dikalkulasi sebagai berikut: 


$$
E=2 \frac{E_{1} E_{2}}{E_{1}+E_{2}}
$$

6. Defleksi stylus stem

Selain efek gaya Hertzian stylus tip pada suatu permukaan benda, defleksi pada stylus stem juga dapat mengurangi tingkat akurasi sistem probing. Defleksi tersebut diakibatkan karena momen bending yang mempunyai besaran proporsional pada panjang suatu stylus stem. Bending stylus $w_{s}$ pada arah normal probing (arah sentuhan pada suatu permukaan benda) diformulasikan sebagai:

$$
w_{S}=\frac{64 \cdot F \cdot I^{3}}{3 \pi \cdot E \cdot d^{4}}
$$

dimana $F$ = gaya probing, $l=$ panjang stylus, $E=$ modulus Young material stylus stem dan $d=$ diameter stylus stem (pada umumnya berupa diameter silinder). Semakin panjang stylus stem, maka akan semakin besar bending pada stylus stem tersebut dan semakin besar diameter stylus stem, maka akan semakin kecil besar bending pada stylus stem tersebut.

7. Efek lingkungan

Kondisi lingkungan diaman suatu pengukuran dilakukan sangat mempengaruhi performansi sistem probing. Debu yang tersebar di atmosfer dan menempel pada permukaan suatu benda dan atau stylus tip dapat secara signifikan mengurangi tingkat akurasi pengukuran tersebut. Untuk sistem probing berbasis optik (atau nonkontak), getaran pada permukaan benda dapat mengakibatkan efek blur pada gambar yang diterima sensor optik tersebut, sehingga bisa menyebabkan false trigger, yaitu situasi dimana sistem probing berbasis optik tersebut salah mendeteksi permukaan yang diukur karena efek perpindahan (pada skala mikro) posisi permukaan tersebut yang diakibatkan oleh gangguan getaran dari lingkungan. Variasi dan perbedaan temperatur akan menyebabkan ekspansi termal pada sistem probing, baik komponen-komponen di dalam probe head maupun komponen-komponen pada stylus stem and tip.

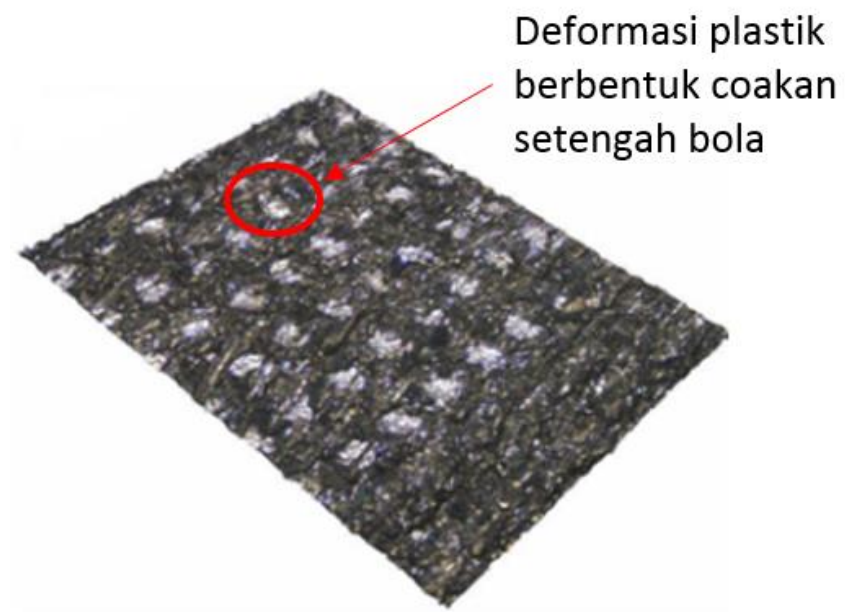

Gambar 22: Deformasi plastik pada suatu permukaan akibat tekanan stylus tip.

8. Aus dan deformasi plastik

Efek aus dan deformasi plastik lebih dominan pada sistem probing berbasis kontak. Stylus tip akan mengelamai deformasi plastik karena efek aus yang disebabkan secara berulang-ulang bersentuhan dan bergesekan dengan suatu permukaan benda yang diukur. Aus akan sangat signifikan apabila suaty stylus tip digunakan untuk mengukur suatu permukaan yang keras dan kasar dengan metode scanning. Selain itu, stylus 
tip yang berukuran kecil dan terbuat dari material yang keras mempunyai kecenderungan untuk menyebabkan suatu deformasi plastip pada bagian suatu permukaan yang disentuhnya. Contoh dari deformasi plastik pada suatu pemrukaan akibat efek tekanan Hertzian dari stylus tip diperlihatkan pada gambar 22. Pada gambar 22, terlihat suatu permukaan yang tercoak kedalam akibat tekana yang diberikan oleh suatu stylus tip.

9. Pre-travel dan over-travel

Pre-travel adalah disposisi sebuah stylus ketika menyentuh suatu permukaan benda sebelum deteksi kontak aktif (triggered). Sedangkan, over-travel adalah disposisi sebuah stylus ketika menyentuh suatu permukaan benda setelah deteksi kontak aktif (triggered).

Pre-travel mempunyai variasi yang dipengaruhi oleh suspensi stylu syang asimetrik, momen inersia dari stylus, senor, penaturan aksis CMM dan gaya probing. Besarnya pre-travel harus dikuantifikasi dan harus dikompensasi. Proses kuantifikasi dan kompensasi stylus dilakukan pada proses kualifikasi sistem probing yang akan dijelaskan pada bagian selanjutnya.

Over-travel diperlukan untuk memberikan waktu deselerasi suatu CMM ketika sistem probing-nya sudah menyentuh dan mendeteksi suatu permukaan benda. Pada prinsipnya, over-travel harus lebih besar apabila kecepatan mendekati suatu permukaan besar. Over-travel pada umumnye mempunyai besar $s u b-m m$ atau kurang dari itu.

10. Sumber-sumber error proses probing

Sumber error utama dari sistem probing terbagi menjadi dua jenis, yaitu error yang berhubungan dengan fitur suatu benda yang diukur dan error yang berhubungan dengan konstruksi sistem probing (Sladek 2016). Error-error yang berhubungan dengan fitur suatu benda yang diukur adalah: kondisi dari suatu permukaan yang diukur (kekasaran dan deviasi geometrinya), deformasi stylus tip ketika kontak dengan suatu permukaan, defleksi stylus karena gaya kontak dengan suatu permukaan, efek dari deviasi geometri dari stylus tip. Sedangkan, error-error yang berhubungan dengan konstruksi sistem probing adalah: efek nonlinier dari transducer untuk mengukur defleksi stylus, efek dari sesitivitas transduser tersebut, reaksi dari distribusi beban probe head yang tidak merata dan antarmuka antara probe head dengan stylus ketika mengganti stylus.

ISO 10360-4 memberikan petunjuk untuk mengevaluasi error probing untuk pengukuran dengan metode scanning dan ISO 10360-5 untuk pengukuran dengan metode point-to-point. Histerisis dari sistem probing juga harus dikuantifikasi. Kuantifikasi dari histerisis sistem probing biasanya dilakukan dengan menggunakan tiga gauge block yang disambung sevara bersamaan. Ketiga gauge block tersebut diatus sedemikian rupa sehingga gauge block yang ditengah mempunyai fitur panjang external dan internal. Histerisis tersebut dikuantifikasi dnegan cara mengukura panjang external dan internal tersebut yang membutuhkan dua jenis arah probing untuk mengukur kedua panjang tersebut (lihat gambar 23).
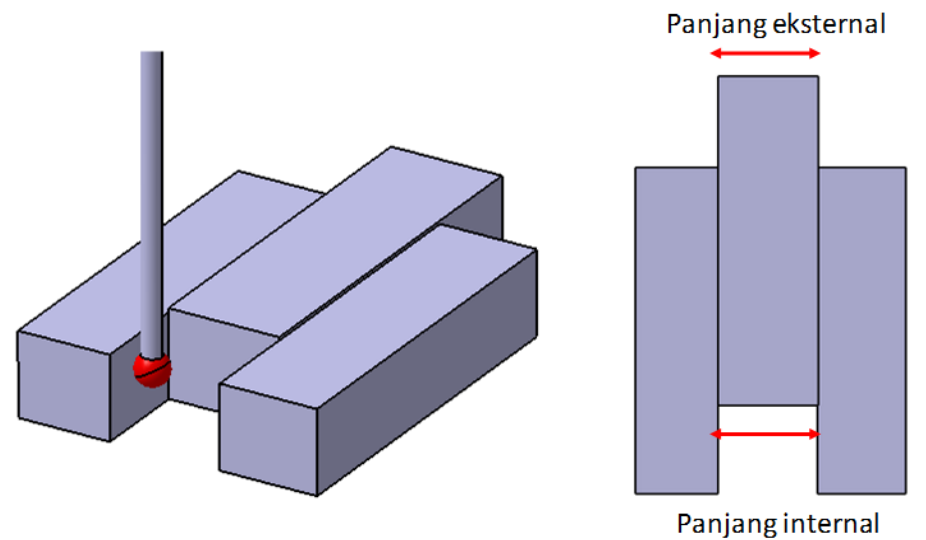

Gambar 23: Proses kuantifkasi histerisis dari sistem probing dengan mengguakan tiga gauge block. 


\section{Diagram vektor dari sistem probing}

Untuk dapat mengerti cara kerja mesin CMM, diagram vektor dari sistem probing harus diketahui. Untuk mengetahui dan mengerti diagram vektor tersebut, dasar-dasar matriks homogenous dan operasinya, dan transformasi sistem koordinat harus dimengerti terlebih dahulu (lihat bab 3 bagian 3.4.7). Gambar 24 memperlihatkan secara umum diagram vektor dari sistem CMM dengan probing kontak.

Pada gambar 24, terdapat tiga sistem koordinat pada pengukuran CMM dengan probing kontak, yaitu:

1. Machine coordinate system (MCS).

2. Workpiece coordinate system (WCS).

3. Probing coordinate system (PCS).

Pada prinsipnya, pengukuran dengan CMM mempunyai referensi atau berdasarkan WCS. Namun demikian, kontroller mesin CMM tersebut membaca semua posisi encoder pada aksis $X, Y$ dan $Z$ berdasarkan MCS. Oleh karena itu, terdapat transformasi sistem koordinat dari MCS ke WCS (dan sebaliknya) melalui sistem koordinat probing PCS.

Berdasarkan gambar 24, proses-proses transformasi sistem koordinat tersebut dijelaskan sebagai berikut. Tujuan utama dari berbagai transformasi sistem koordinat tersebut adalah untuk mengetahui posisi titik kontak $\mathbf{O}$ antara suatu permukaan dan stylus tip terhadap MCS. Posisi $\mathbf{O}$ terhadap MCS yang direpresentasikan dengan $T_{M O}$. Sedangkan, semua pengukuran CMM, setelah melalui proses alignment (yang akan dijelaskan pada bagian berikutnya), posisi $\mathrm{O}$ mempunyai referensi pada WCS yang direpresentasikan dengan $T_{W O}$. Maka dari itu, rangkaian transformasi sistem koordinat dari MCS ke WCS harus dibangun terlebih dahulu.

Proses membangun rangkain transformasi sistem koordinat dari MCS ke WCS dijelaskan sebagai berikut. Transformasi koordinat dari MCS ke $\mathbf{O}$ dibangun terlebih dahulu dan diformulasikan sebagai:

$$
\begin{aligned}
& T_{M O}=T_{M P}+T_{P O} \\
& T_{M O}=T_{M P}+T_{P b}+T_{b O}
\end{aligned}
$$

Dimana $T_{M P}$ adalah transformasi koordinat dari MCS ke PCS pada probe head, $T_{P O}$ transformasi koordinat dari PCS ke titik $\mathbf{O}, T_{P b}$ adalah transformasi koordinat dari PCS ke pusat stylus tip dan $T_{b o}$ adalah transformasi koordinat dari pusat stylus tip ke titik $\mathbf{O}$. Rangkaian transformasi koordinat tersebut terbangun setelal proses kualifikasi stylus dan probe head dilakukan (akan dijelaskan pada bagian berikut).

Setelah rangkaian transfomasi koordinat dari MCS ke titik $\mathbf{O}$ melalui sistem probing terbangun, rangkaian transfomrasi koordinat dari MCS ke WCS, yang dipresentasikan sebagai $T_{M W}$, dapat dibangun. Rangkaian transformasi koordinat dari MCS ke WCS tersebut dapat terbangun dengan proses aligntment. Proses tersebut dapat diformulasikan sebagai:

$$
\begin{aligned}
& T_{M O}=T_{M W}+T_{W O} \\
& T_{M W}=T_{M O}-T_{W O}
\end{aligned}
$$

dimana $T_{M W}$ adalah transformasi koordinat dari MCS ke WCS dan $T_{W O}$ adalah transformasi koordinat dari WCS ke titik $\mathbf{O}$.

dengan demikian, untuk membangun rangkain transformasi koordinat yang saling terhubung antara MCS, PCS dan WCS, proses kualifikasi stylus dan probe head, dan proses alignment adalah dua proses yang harus dilakukan agar pengukuran dengan CMM dapat dilakukan. 
MCS $=$ Machine coordinate system WCS $=$ Workpiece coordinate system PCS = Probing coordinate system
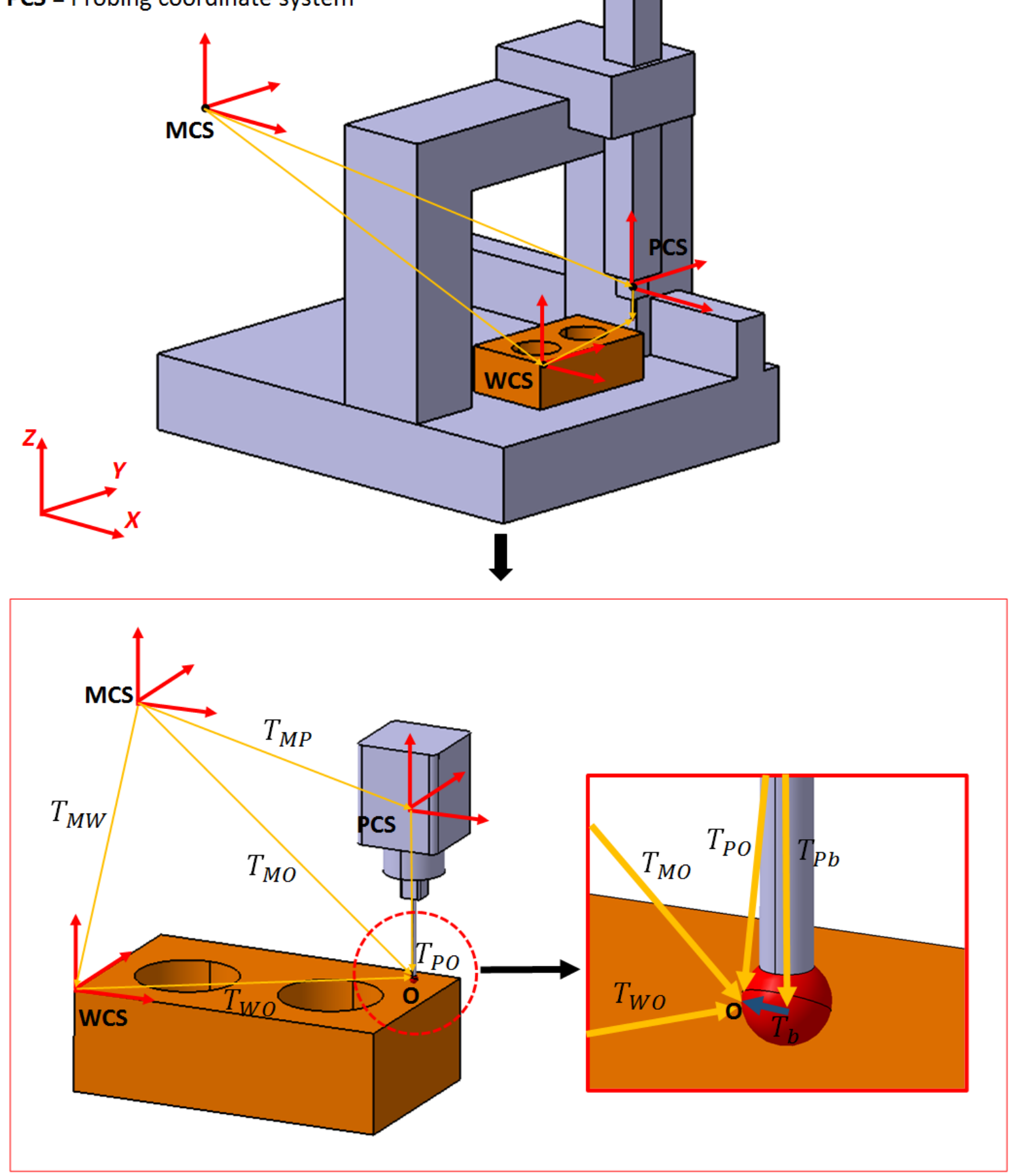

Gambar 24: Detil dari diagram vektor dari sistem probing kontak CMM. 


\section{Proces kualifikasi sistem probing}

Proses kualifikasi sistem probing adalah suatu proses untuk mengetahui secara kuantitatig karakteristik dari stylus dan probing head. Sama seperti diagram vektor sistem probing, untuk dapat mengerti proses kualifikasi tersebut, dasar-dasar matriks homogenous dan transformasi sistem koordinat harus dipahami terlebih dahulu (lihat bab 3 bagian 3.4.7).

Tujuan utama dari kualifikasi sistem probing (stylus dan probe head) adalah untuk mengetahui panjang dan orientasi stem dari suatu stylus dan besar diameter dari stylus tip tersebut. dengan kata lain, proses kualifikasi tersebut bertujuan untuk menentukan nilai matriks transformasi $T_{P b}$, yaitu transformasi dari PCS ke pusat bola dari stylus tip (panjang dan orientasi stylus stem), dan $T_{b o}$, yaitu transformasi dari pusat bola dari stylus tip ke titik $\mathbf{O}$ (diameter stylus tip), seperti yang diperlihatkan pada gambar 24.

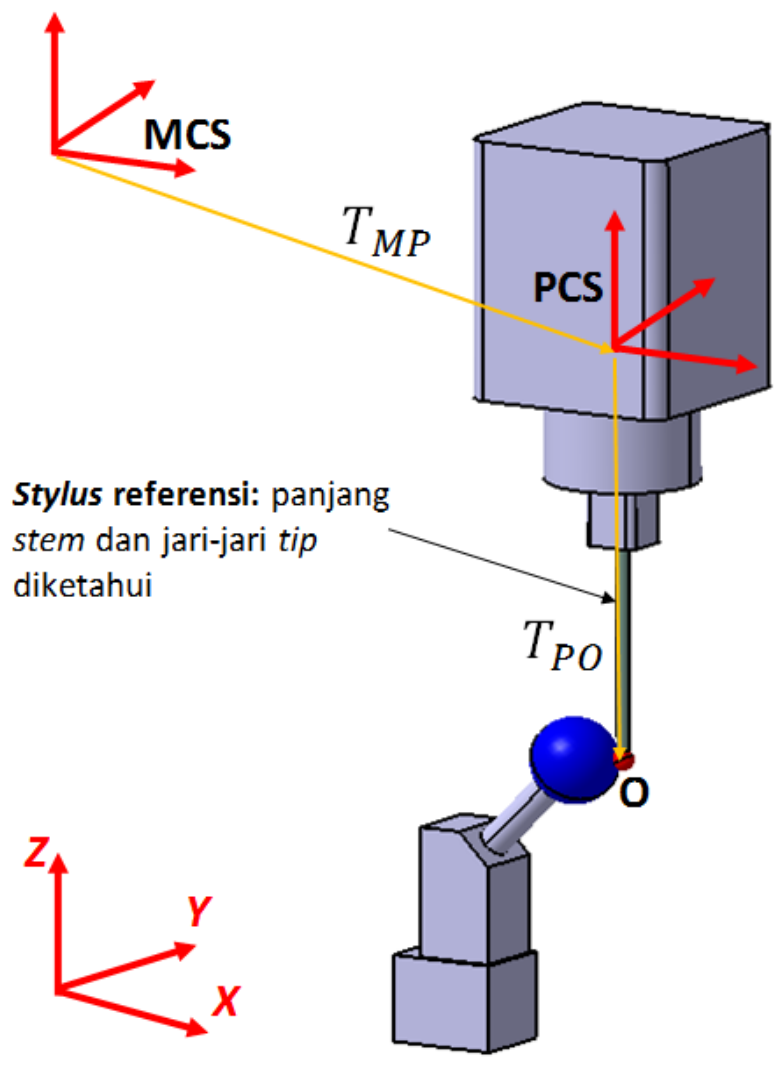

Gambar 25: Detil dari proses kualifikasi sistem probing kontak CMM.

Gambar 25 memperlihatkan rantai transformasi pada sistem probing untuk menghubungkan MCS dan titik $\mathbf{O}$. Hasil dari proses kualifikasi sistem probing adalah untuk menentukan nilai $T_{P O}=T_{P b}+T_{b O}$. Ada dua tahap utama dari proses kualifikasi sistem probing, yaitu:

- Tahap 1: untuk mengetahui posisi titik tengah bola referensi (lihat gambar 26). Bola referensi tersebut terkalibrasi dan diameternya diketahui).

- Tahap 2: untuk mengetahui panjang dan orientasi stem, dan diameter stylus tip (lihat gambar 27). 


\section{Tahap 1:}

Tahap 1 dari proses kualifikasi sistem probing adalah mengkalkulasi posisi atau lokasi titik pusat dari bola referensi yang terkalibrasi. Pada tahap ini, panjang stylus dan orientasinya $\left(T_{P b}\right)$, diameter stylus tip $\left(T_{b o}\right)$, serta diameter bola referensi sudah diketahui (terkalibrasi dengan nilai ketidakpastian yang sangat kecil). Pada proses ini, stylus yang digunakan adalah stylus spesial yang selalu ada di setiap CMM. Stylus terkalibrasi tersebut terbuat dari material yang lebih kuat dan lebih stabil terhadap variasi lingkungan untuk jangka waktu yang sangat lama. Karena panjang dan orientasi stylus stem diketahui, maka transformasi dari MCS ke titik $\mathbf{O}$ (dalam kasus ini adalah titik kontak antara stylus tip dan permukaan bola referensi) melalui PCS sudah terbentuk, yang direpresentasikan sebagai $T_{P O}=$ $T_{P b}+T_{b o}$ (lihat gambar 24 dan 25).

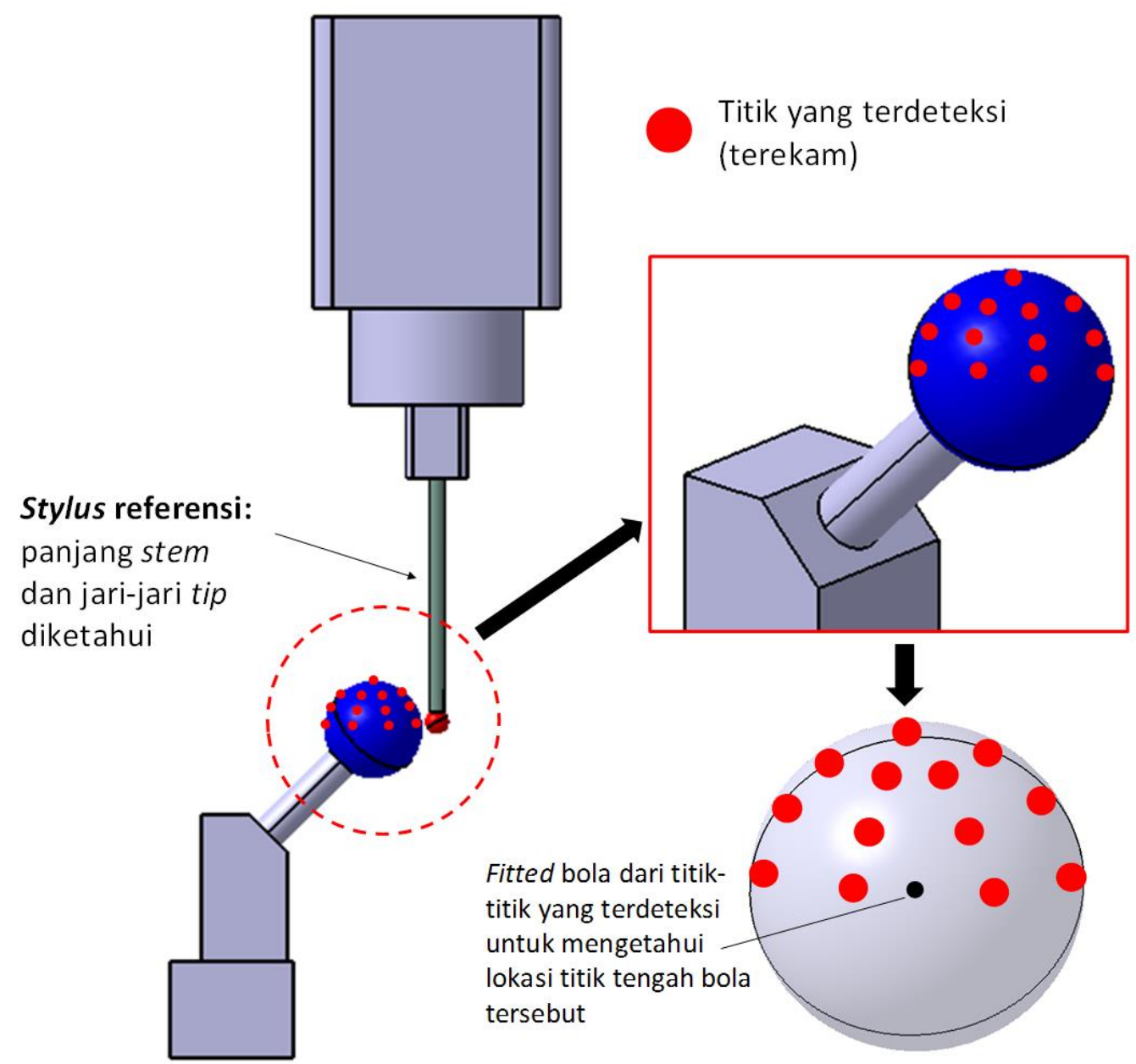

Gambar 26: Proses kualifikasi tahap 1: untuk mengetahui posisi titik tengah bola referensi (yang terkalibrasi dan diameternya diketahui).

Gambar 26 memperlihatkan proses kualifikasi sistem probing tahap 1. Pada gambar 26, proses kualifikasi tersebut dilakukan dengan mengambil titik-titik pada permukaan bola referensi sebanyak 32 titik-titik yang meliputi setengah luas permukaan bola tersebut. karena proses ini menggunakan stylus referensi yang diketahui panjang dan orientasi stem-nya, dan diameter stylus tip-nya, maka titik-titik tersebut dapat diketahui lokasinya berdasarkan MCS 
dari CMM. Dari titik-titik tersebut, untuk menentukan lokasi titik pusat bola referensi tersebut, proses fitting untuk geometri bola berbasis least-square dilakukan. Setelah proses fitting bola tersebut dilakukan, informasi lokasi titik pusat bola tersebut dapat ditentukan. Proses fitting tersebut adalah proses optimisasi dari persamaan:

$$
\begin{gathered}
\underset{\boldsymbol{p}}{\arg \min } F\left(\boldsymbol{p}, \boldsymbol{x}_{\boldsymbol{i}}\right)=\sum_{i=1}^{n} d_{i}^{2}(\boldsymbol{p}) \\
\underset{\boldsymbol{x}_{\mathbf{0}}, \boldsymbol{r}}{\arg \min } F\left(\boldsymbol{x}_{\mathbf{0}}, r, \boldsymbol{x}_{\boldsymbol{i}}\right)=\sum_{i=1}^{n}\left\|\boldsymbol{x}_{\boldsymbol{i}}-\boldsymbol{x}_{\mathbf{0}}\right\|-r \\
\underset{\boldsymbol{x}_{\mathbf{0}}, \boldsymbol{r}}{\arg \min } F\left(\boldsymbol{x}_{\mathbf{0}}, r, \boldsymbol{x}_{\boldsymbol{i}}\right)=\sum_{i=1}^{n} \sqrt{\left(x_{i}-x_{0}\right)^{2}+\left(y_{i}-y_{0}\right)^{2}+\left(z_{i}-z_{0}\right)^{2}}-r
\end{gathered}
$$

dimana $\boldsymbol{x}_{\mathbf{0}}=\left[x_{0}, y_{0}, z_{0}\right]^{T}$ adalah pusat bola, $r$ adalah jari-jari dari bola dan $\boldsymbol{x}_{\boldsymbol{i}}=\left[x_{i}, y_{i}, z_{i}\right]^{T}$ adalah titik ke-i. proses fitting akan dijabarkan lebih detil pada pada bab 7 mengenai algoritma.

\section{Tahap 2:}

Pada proses kualifikasi sistem probing tahap 2, tujuan utama dari proses tersebut adalah untuk menentukan panjang dan orientasi stylus, dan diameter tip-nya dari suatu stylus yang ingin digunakan untuk suatu pengukuran. Dengan kata lain, transformasi $T_{P b}$ dan $T_{b o}$ (lihat gambar 24 dan 25) untuk stylus yang akan digunakan untuk suatu pengukuran akan ditentukan. dari hasil proses tahap 1, lokasi dari pusat bola referensi terhadap MCS sudah diketahui. Kemudian, stylus referensi yang digunakan pada tahap 1 diganti dengan stylus yang akan dikualifikasi untuk tahap 2 ini.

Gambar 27 memperlihatkan proses tahap 2 dari kualifikasi sistem probing. Ketika stylus referensi diganti dengan stylus yang ingin dikualifikasi, transformasi $T_{P b}$ dan $T_{b o}$ menjadi tidak diketahui lagi karena panjang dan orientasi stylus, dan diameter tip-nya tidak diketahui. Pada gambar 27, $T_{P b}$ dan $T_{b O}$ direpresentasikan sebagai $T_{P b 1}$ dan $T_{p b 2}$. Namun demikian, lokasi dari titik pusat bola referensi sudah diketaui. Proses selanjutnya adalah mengukur ulang, yaitu mengambil 32 titik-titik pada permukaan bola referensi tersebut, dengan menggunakan stylus yang ingin dikualifikasi tersebut. Kemudian, proses fitting suatu geometri bola pada 32 titik tersebut diakukan lagi. Proses fitting dikalkulasi dengan menggunakan persamaan 11 di atas. Ke-32 titik-titik tersebut, pada saat ini, adalah posisi PCS (lihat gambar 24 dan 25) yang direkam dan disimpan dalam memri kontroller CMM berdasarkan MCS mesin CMM. Hal ini disebabkan karena pada saat ini, panjang dan orientasi serta diameter stylus yang sedang dikualifikasi belum diketahui, sehingga lokasi titik $\mathbf{O}$ (lihat gambar 24 dan 25) berdasarkan MCS tidak dapat diketahui.

Setelah proses fitting tersebut dilakukan, maka lokasi dan diameter pusat bola referensi tersebut dapat diketahui. Lokasi dan diameter dari bola referensi hasil dari pengukuran dengan stylus referensi dan stylus yang sedang dikualifikasi berbeda. Dari perbedaan tersebut, maka panjang dan orientasi serta diameter stylus yang sedang dikualifikasi dapat diketahui.

Pertama, jari-jari (dan juga diameter) $T_{b o}$ stylus-tip yang sedang dikualifikasi ditentukan sebagai perbedaan antara jari-jari bola referensi hasil dari pengukuran dengan stylus referensi $r_{0}$ dengan jari-jari bola referensi hasil dari pengukuran dari stylus yang sedang dikualifikasi $r_{S}$, yaitu (lihat gambar 24 dan 27):

$$
T_{b o}=T_{p b 2}=r_{s}-r_{0}
$$

Kedua, panjang dan orientasi dari stylus yang sedang dikualifikasi $T_{P b}$ dapat diketahui sebagai offset posisi dari pusat bola referensi tersebut hasil dari pengukuran dengan menggunakan stylus referensi dan stylus yang sedang dikualifikasi, yaitu:

$$
T_{p b}=T_{p b 1}=T_{p o}-T_{b o}
$$

Akhirnya, panjang dan orientasiserta diameter stylus yang dikualifikasi dapat diketahui. 


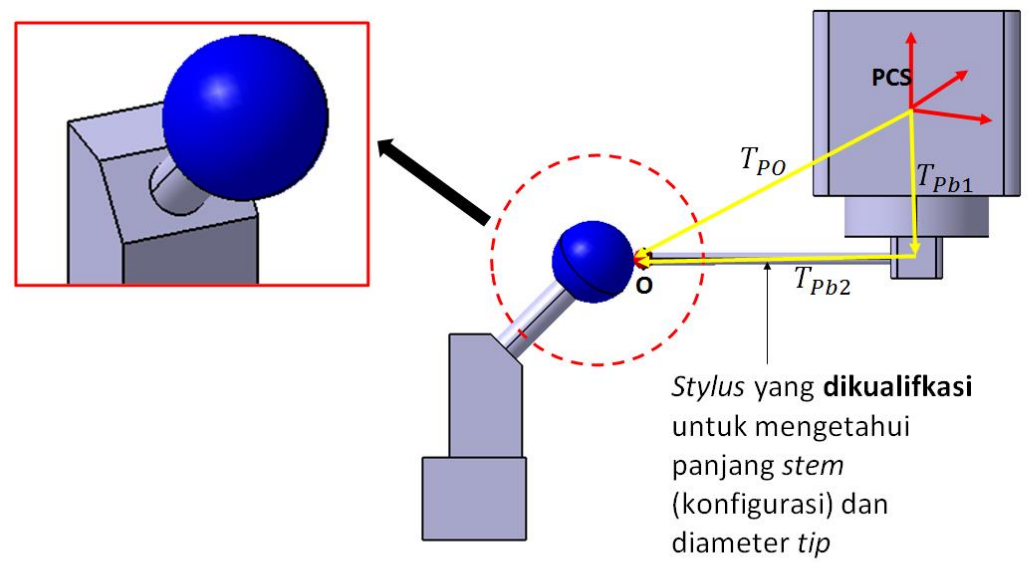

(a)

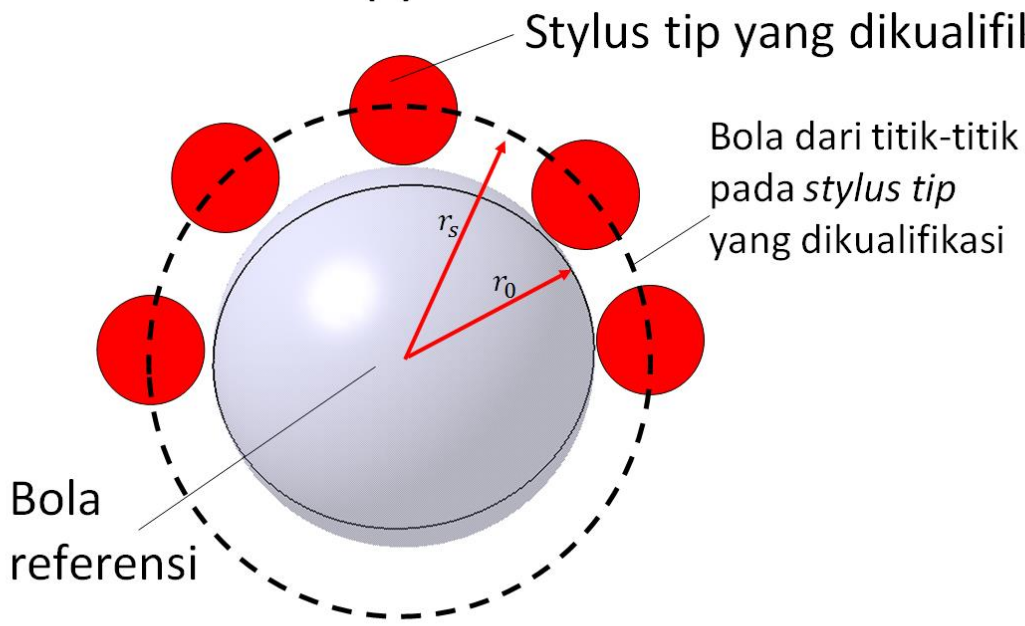

(b)

Gambar 27: Proses kualifikasi tahap 2: untuk mengetahui panjang dan orientasi stem, dan diameter stylus tip.

\subsection{Alignment pengukuran CMM}

Alignment adalah proses wajib yang harus dilakukan setelah proses kualifikasi sistem probing sebelum melakukan pengukuran dengan CMM. Seperti halnya prose kualifikasi sistem probing, untuk mengetahui dan mengerti konsep alignment benda kerja pada CMM, dasar-dasar matriks homogenous dan operasinya, dan transformasi sistem koordinat harus dimengerti terlebih dahulu (lihat bab 3 bagian 3.4.7).

Proses alignment (yaitu alignment yang dilakukan pada benda kerja) bertujuan untuk membangun sistem transofrmasi koordinat dari MCS ke WCS. Dengan terbangunnya sistem transformasi dari MCS ke WCS, koordinat proses pengukuran dapat dialihkan berdasarkan sistem koordinat pada benda kerja, yaitu MCS. Keuntungan fundamental dengan menggunakan WCS pada saat pengukuran adalah kesalahan-kesalahan pada saat melakukan penempatan dan fixturing benda kerja dapat dihilangkan, karena pada kenyataannya ketika suatu benda kerja ditempatkan pada meja CMM untuk dilakukan suatu pengukuran, pada skala mikro, benda kerja tersebut berpindah tempat (karena misalnya gaya yang diberikan saat fixturing dan lain sebagainya). Perpindahan tersebut signifikan terhadap MCS, tetapi tidak signifikan terhadap WCS. 
Gambar 28 memperlihatkan proses alignment pada CMM, yaitu membangun hubungan transformasi dari MCS ke WCS. Proses alignment menurut suatu CMM adalah cara mesin CMM tersebut mengetahui posisi dan orientasi suatu benda yang akan diukur yang berada di atas meja CMM.
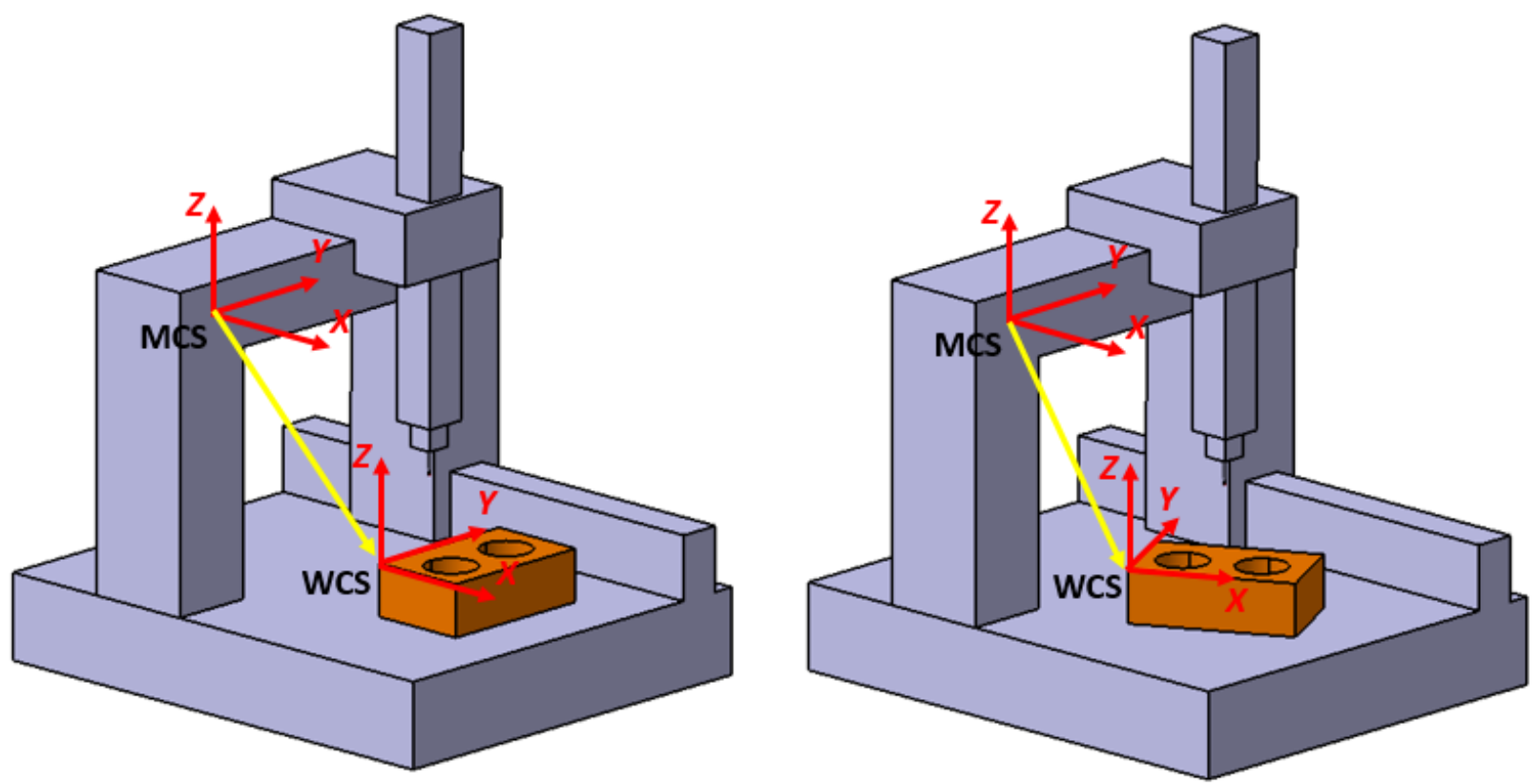

Gambar 28: Proses alignment, yaitu membangun sistem transformasi koordinat dari MCS ke WCS. Dengan terbentuknya WCS, maka CMM dapat mengetahui posisi dan orientasi suatu benda kerja yang akan diukur.

\section{Proses pembentukan workpiece coordinate system (WCS)}

Seperti yang sudah dikatakan sebelumnya, dari sudut pandang CMM, alignment berfungsi agar CMM mengetahui lokasi dan orientasi suatu benda kerja yang akan diukur (dengan kata lain agar CMM dapat "melihat" benda yang akan diukurnya) dan dari sudut pandang presisi, alignment bertujuan untuk memindahkan referensi sistem koordinat dari MCS ke WCS pada saat pengukuran berlangsung untuk menghilangkan error yang bersumber dari fixturing. Maka dari itu, titik pusat WCS harus ditempatkan pada suatu benda kerja yang akan diukur.

Untuk mendefinisikan lokasi dan orientasi sebuah benda yang akan diukur, dua parameter utama yang harus dikuantifikasi pada saat proses alignment, yaitu: koordinat spasial titik dari WCS (untuk lokasi benda kerja) dan vektor satuan arah pada titik tersebut (untuk orientasi benda kerja). untuk mendapatkan titik WCS dan vektor arah satuannya, lima parameter harus dikuantifikasi, yaitu (lihat gambar 29):

1. Koordinat $X$ dari titik WCS.

2. Koordinat $Y$ dari titik WCS.

3. Koordinat $Z$ dari titik WCS.

4. Vecktor arah satuan $1\left(\vec{N}_{1}\right)$.

5. Vecktor arah satuan $2\left(\vec{N}_{2}\right)$.

Hal penting yang harus dicatat adalah, sebuah referensi koordinat membutuhkan tiga vektor arah satuan. Vektor arah satuan $3\left(\vec{N}_{3}\right)$ dapat didefinisikan secara matematik dari dua vektor arah satuan sebelumnya (vektor arah satuan 1 dan 2) yang sudah ditentukan dari proses alignment, yaitu $\vec{N}_{3}=\vec{N}_{1} \times \vec{N}_{2}$. Vektor arah satuan 3 tersebut adalah hasil dari cross-product dari dua vektor arah satuan sebelumnya. Gambar 29 memperlihatkan proses pembentukan WCS 
pada suatu benda kerja. Pada gambar 29, diperlihatkan suatu benda kerja berupa balok (yang merupakan kasus umum sebuah pengukuran CMM).

Untuk menentukan Koodinat $X, Y$ dan $Z$ dari titik pusat WCS, ketiga koordinat tersebut pada umumnya dapat berupa:

- Titik potong antara tiga bidang datar.

- Titik pusat sebuah lingkaran.

- Titik pusat sebuah bola.

- Titik perpotongan antara dua aksis.

- Titik perpotongan antara aksis atau garis dengan suatu bidang datar.

Untuk menentukan vektor arah satuan $1\left(\vec{N}_{1}\right)$ dan vektor arah satuan $2\left(\vec{N}_{2}\right)$ untuk orientasi WCS, kedua vektor tersebut tersebut pada umumnya dapat berupa:

- Vektor normal dari dua bidang datar.

- Vektor arah dari aksis suatu silinder.

- Vektor arah dari garis rusuk suatu balok.

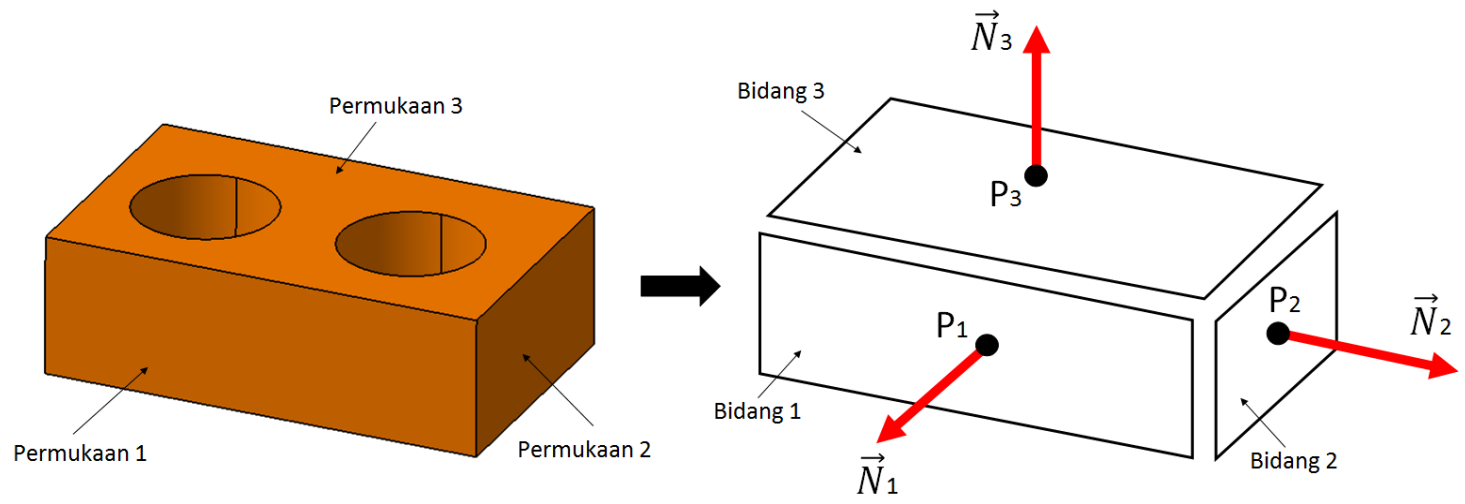

(a)

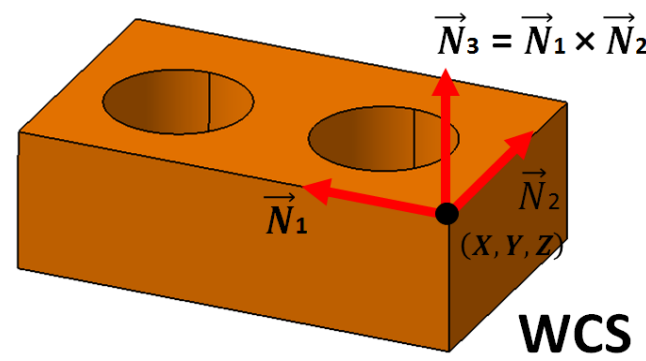

(b)

Gambar 29: Proses pembentukan WCS: (a) menentukan titik pusat WCS dan ketiga vektor arah satuannya dan (b) hasil WCS yang didapatkan.

Gambar 29 memperlihatkan cara menentukan WCS dari perpotongan antara tiga bidang datar dan vektor normal dari dua bidang datar tersebut. Pada gambar 29, WCS ingin ditempatkan pada salah satu titik di sudut balok tersebut. untuk merealisasikan hal ini, titik-titik pada permukaan 1,2 dan 3 diambil. Jumlah titik-titik pada masing-maisng permukaan minimal tiga titik. Pada umumnya minimal empat titik diambil agar terdpaat efek rata-rata pada proses 
fitting metode least-square untuk bidang datar pada permukaan-permukaan tersebut. Hasil proses fitting bidang datar pada ketiga permukaan tersebut adlalah berupa sebuah titik dan sebuah vektor normal (yang berasal dari titik tersebut) pada masing-masing bidang datar tersebut (lihat gambar 29 sebelah kanan).

Kemudian, ketika titik-titik dan vektor normalnya pada ketiga bidang datar tersebut telah diketahui, maka titik referensi untuk WCS dapat ditentukan dengan mengkalkulasi titik potong dari ketiga bidang datar tersebut. Titik tersebut menggambarkan lokasi dari benda tersebut terhadap MCS. Kemudian, dua vektor normal dari kedua bidang datar tersebut digunakan sebagai vektor arah satuan pada titik WCS tersebut. vektor arah satuan ketiga didapatkan dengan cara kalkulasi matematik, yaitu hasil dari cross-product dari kedua vektor arah satuan tersebut $\left(\vec{N}_{3}=\vec{N}_{1} \times \vec{N}_{2}\right)$.

\section{Penentuan WCS yang benar}

Contoh penentuan WCS yang benar dan yang tidak benar diperlihatkan pada gambar 30. Penempatan WCS yang benar adalah apabila ke-5(+1) elemen dari WCS tersebut, yaitu titik pusat WCS X, Y dan Z serta ketiga vektor arah normalnya $\left(\vec{N}_{1}, \vec{N}_{2}, \vec{N}_{3}=\vec{N}_{1} \times \vec{N}_{2}\right)$ telah terdifiniskan. Pada gambar 30 bagian atas, terlihat bahwa seluruh elemen WCS sudah terdefinisikan dengan baik, sehingga ketika benda kerja tersebut berubah lokasi dan orientasinya, WCS tersebut dapat merepresentasikan lokasi dan orinetasi benda tersebut (dapat terlihat dengan lokasi dan arah WCS yang berubah ketika posisi dan orientasi benda berubah).
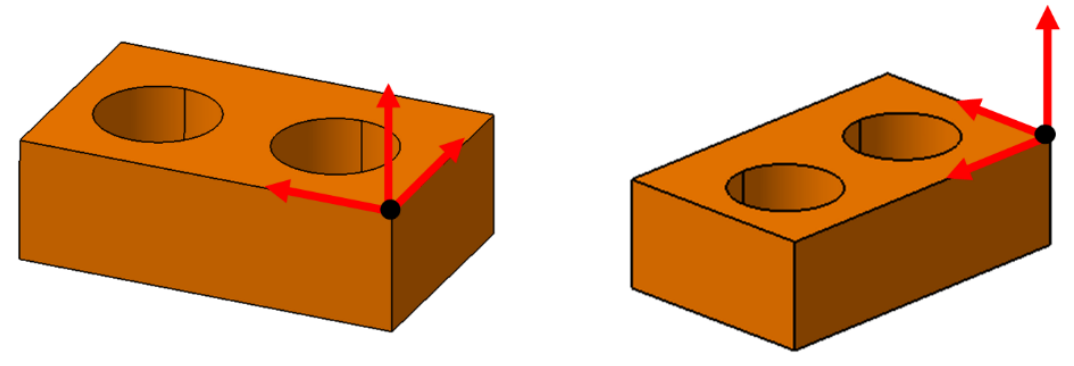

Benar
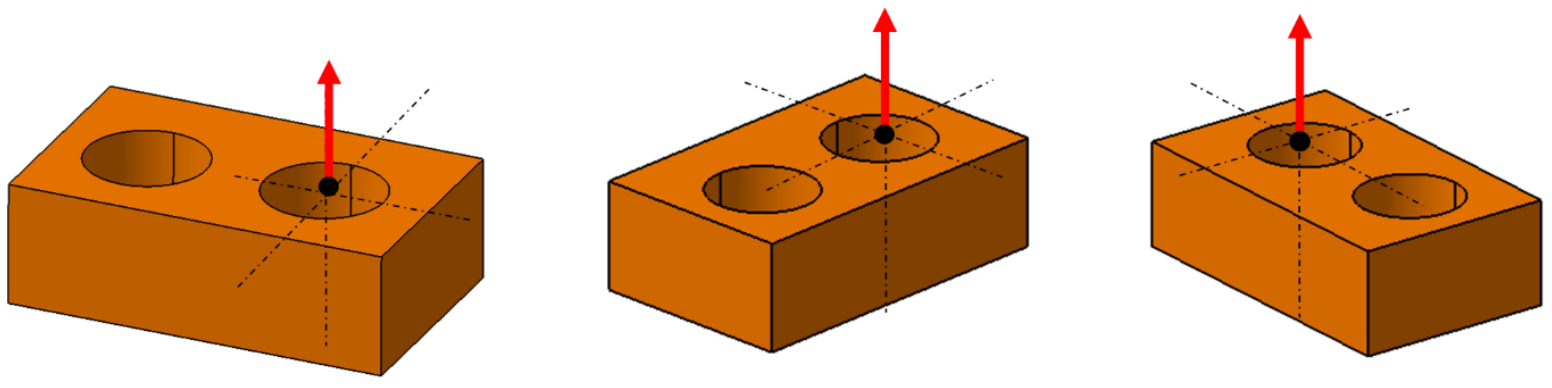

\section{Tidak benar}

Gambar 30: Contoh pennetuan WCS yang benar (atas) dan tidak benar (bawah).

Namun demikian, pada gambar 30 sebelah bawah, apabila WCS tidak didefinisikan dengan sempurna, yaitu ketika seluruh elemen-elemen (5+1) suatu WCS tidak terdefinisikan secara lengkap. Pada gambar 30 sebelah bawah, terlihat bahwa WCS yang didefinisikan kurang dua vektor arah normal, sehingga ketika lokasi dan orientasi benda tersebut berubah, WCS tidak dapat merepresentasikan perubahan tersebut (WCS tetap terlihat sama walaupun lokasi dan orientasi benda tersebut berubah). 


\section{Penentuan WCS untuk benda berbentuk kompleks}

Gambar 31 memperlihatkan contoh penentuan atau pemilihan WCS yang benar pada suatu benda yang memiliki bentuk yang kompleks. Pada gambar 31, bentuk benda tersebut adalah kompleks, sehingga tidak terdapat tiga bidang datar yang dapat dipilih untuk menentukan posisi WCS. Maka dari itu, pada kasus ini, titik pusat WCS dan vektor arah satuannya dipilih berdasarkan prosedur sebagai berikut:

1. Titik pusat WCS (yaitu koordinat $X, Y$ dan $Z$ ) dipilih sebagai titik potong antara aksis silinder dan bidang daar 2 (lihat gambar 31). Maka dari itu, bidang datar 2 dan silinder tersebut harus di-probe menggunakan stylus CMM untuk diambil titik-titiknya.

2. Dua vektor arah satuannya dipilih sebagai vektor arah satuan dari aksis silinder (lihat gambar 31) dan vektor normal dari bidang datar (lihat gambar 31).

3. Vektor arah satuan ketiga ditentukan sebagai hasil dari cross-product vektor arah satuan satu dan dua, yait $\left(\vec{N}_{3}=\vec{N}_{1} \times \vec{N}_{2}\right)$.

Sehingga, seluruh elemen WCS yang dibutuhkan dapat didefiniskan dengan benar.

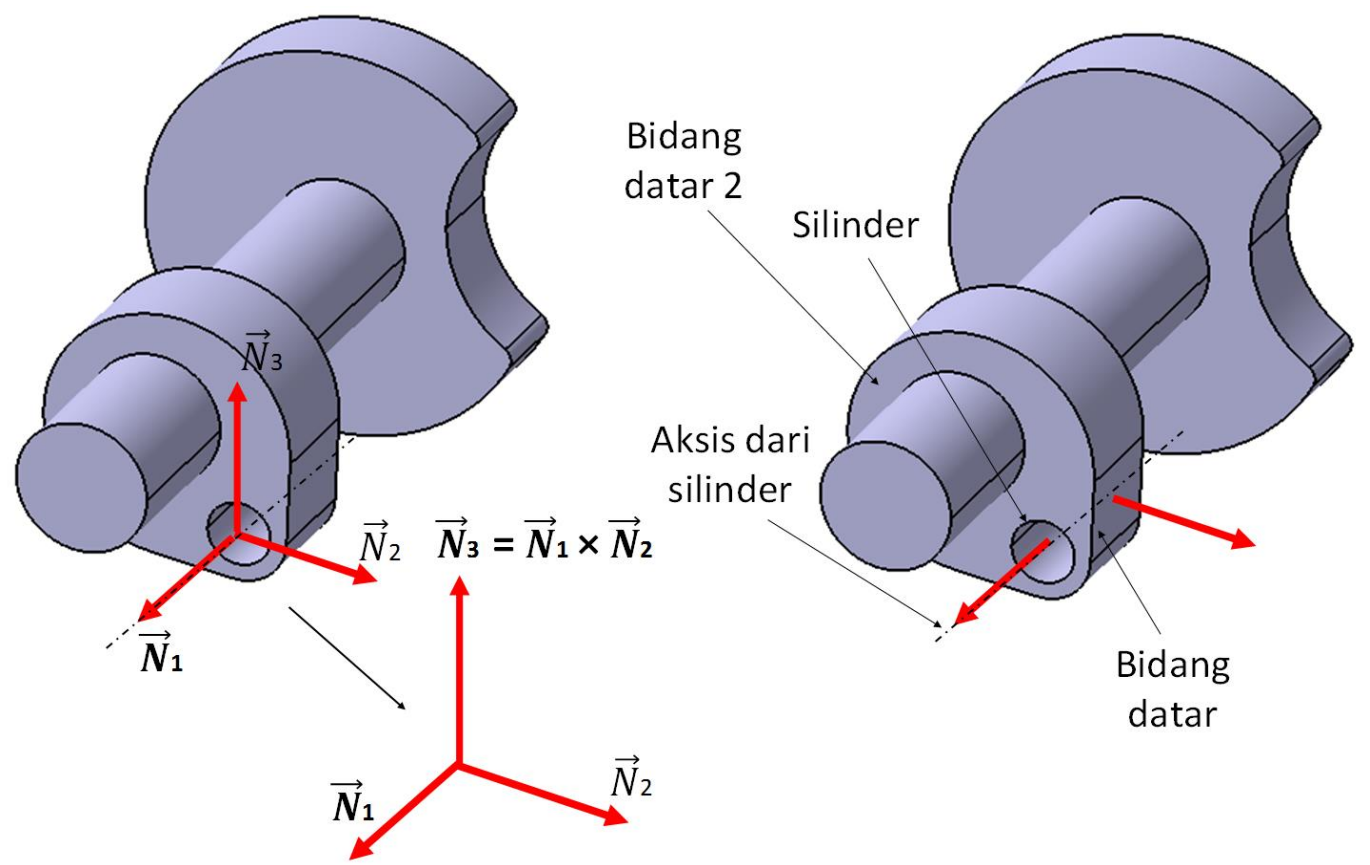

Gambar 31: Pemilihan WCS yang benar pada suatu benda dengan bentuk kompleks.

\subsection{Strategi sampling}

Strategi sampling adalah strategi bagaimana pengambilan titik-titik permukaan suatu benda yang diukur oleh CMM. Strategi sampling dibagi menjadi tiga jenis (Colosimo dan Senin 2011), yaitu:

- Strategi blind.

- Strategi berbasis process fingerprint.

- Strategi adaptif. 


\section{$\underline{\text { Strategi blind }}$}

Strategi blind adalah strategi sampling (pengambilan data titik-titik) yang paling umum. Strategi ini digunakan karena informasi pengukuran yang akan dilakukan adalah hanya nilai nominal geomtri dan toleransi dari suatu benda. Pola (pattern) dari sampling blind sudah ditentukan sebelum pengukuran dan tidak berubah pada saat pengukuran berlangsung.

Pada umumnya, sampling blind dilakukan dengan cara mengambil titik-titik suatu permukaan benda secara homogen (uniform) dan tersebar pada seluruh permukaan geometri yang ingin diukur. Gambar 32 memperlihatkan contoh smapling blind dengan pola sampling secara homogen (uniform). Pada gambar 32, beberapa geometri yang akan diukur dan pola sebaran titik-titik sampling untuk geometri garis, lingkaran, bidang datar dan silinder diperlihatkan.

\section{Uniform sampling}

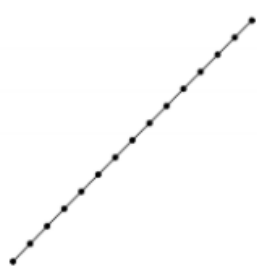

Garis

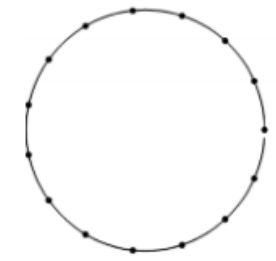

Lingkaran

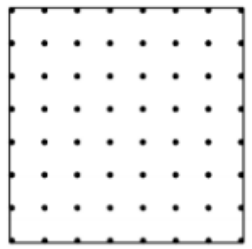

Bidang

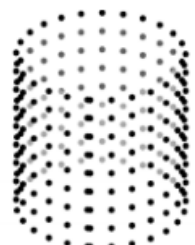

Silinder

Gambar 32: Contoh dan smapling blind dengan pola homogen (uniform).

Untuk sampling blind dengan pola homogen tersebut, sampling tersebut selalu mengikuti teori Nyquist untuk menentukan banyaknya jumlah titik yang harus diambil agar bentuk riil suatu geometri yang diukur dapat direkonstruksi secara utuh (melalui proses fitting) dan pengukuran yang diinginkan dapat dilakukan. Teori Nyquist menyatakan bahwa apabila suatu geometri (misalnya berbentuk sinus) di-sampling dengan pola homogen (diambil titik-titiknya) dengan frekuensi sampling (banyaknya jumlah titik yang diambil/sample size) lebih dari dua kali dari frekuensi geometri yang di-sampling, maka geometri tersebut dapat direkonstruksi secara sempurna. Sedangkan, apabila frekuensi sampling kurang dari dua kali frekuensi geometri yang diukur, maka bentuk geometri tersebut tidak dapat direkonstruksi secara utuh (Bracewell 2000).

Untuk menggambarkan teori Nyquist lebih jelas lagi, gambar 33 memperlihatkan suatu geometri berbentuk sinusoid yang di-sampling dengan frekuensi sampling kurang dari frekuensi dari sinusoid tersebut. Hal ini menyebabkan bentuk riil dari sinusoid tersebut tidak dapat direkonstruksi secara utuh.

Metode sampling homogen apabila dilakukan dengan jumlah titik sampling yang tepat, merupakan metode yang baik karena metode tersebut menjamain semua titik-titik yang diambil merepresentasikan semua fitur suatu benda yang diukur. Namun demikian, pada umumnya metode ini mengambil jumlah titik yang besar, sehingga waktu pengukuran menjadi lama. Hal ini menyebabkan biaya inspeksi meningkat.

Oleh karena itu, beberapa metode sampling semi-acak digunakan untuk mengurangi jumlah pengambilan titik, tetapi tetap meliputi fitur-fitur suatu benda yang diukur. Beberapa metode sampling semi-acak adalah metode Hammersley dan metode Halton-Zaremba.

Strategi sampling Hammersley untuk menentukan lokasi titik-titik sampling adalah:

$$
x_{i}=\frac{1}{n}, \quad y_{i}=\sum_{j=0}^{k-1} b_{i j} 2^{-j-1}, i \in\{0,1, \ldots, n-1\}
$$

Dimana $x_{i}$ dan $y_{i}$ adalah koordinat dari titik ke- $i$ yang ternormalisasi (bernilai antara 0 dan 1 dan harus diskala ulang untuk mendapatkan koordinat aktual dari lokasi $x$ dan $y$ tersebut). $n$ adalah jumlah titik sampling. $b_{i}$ adalah 
representasi biner dari $i$ dan $b_{i j}$ adalah bit ke-j dari $b_{i}$ dan bernilai antara 0 dan $1 . k=\left[\log _{2} n\right]$,

Strategi sampling Halton-Zaremba untuk menentukan lokasi titik-titik sampling adalah:

$$
x_{i}=\sum_{j=0}^{k-1} b_{i j} 2^{-k-j}, \quad y_{i}=\sum_{j=0}^{k-1} b_{i j}{ }^{\prime} 2^{-j-1}, i \in\{0,1, \ldots, n-1\}
$$

Dimana $b_{i j}{ }^{\prime}$ sama dengan $1-b_{i j}$ jika $j$ ganjil, atau sama dengan $b_{i j}$ jika $j$ genap. Gambar 34 memperlihatkan perbandingan antara teknik sampling blind dengan pola acak, Hammersley dan Halton-Zaremba. Strategi HaltonZaremba diklaim menghasilkan hasil pengukuran flatness yang lebih baik dari strategi acak dan Hammersley (Kim dan Raman 2000).

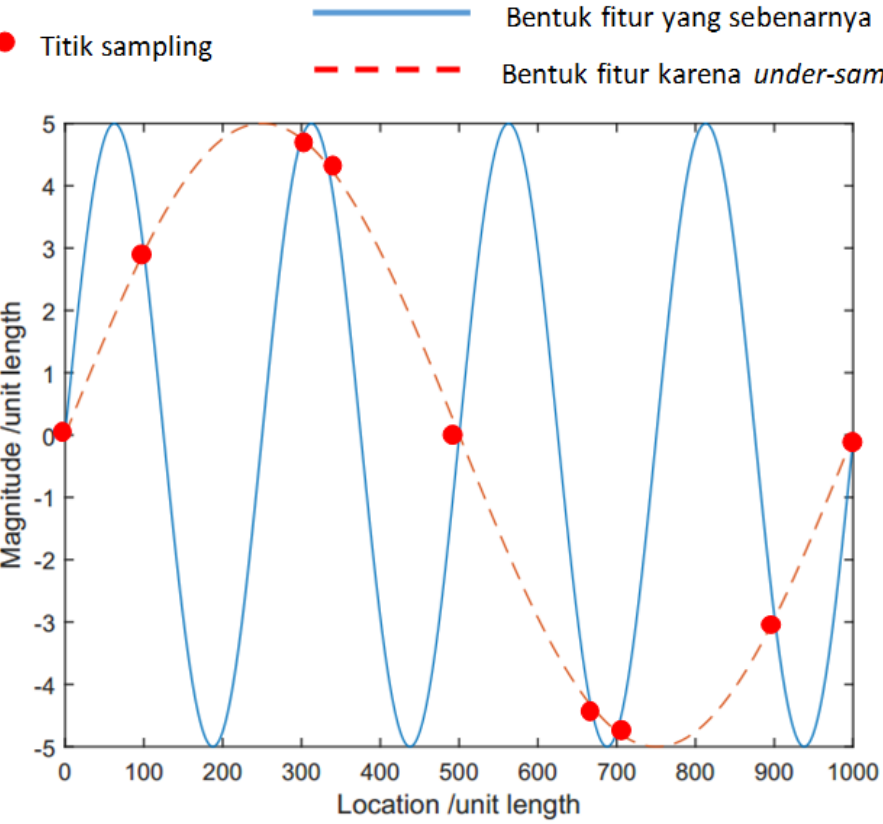

Gambar 33: Contoh dari teori Nyquist untuk sampling. Apabila frekuensi sampling kurang dari dua kali frekuensi geoetri yang diukur, maka bentuk geoetri tidak dapat direkonstruksi secara utuh.

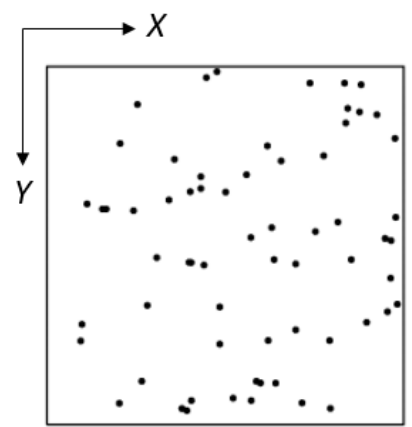

Sampling acak
Titik sampling

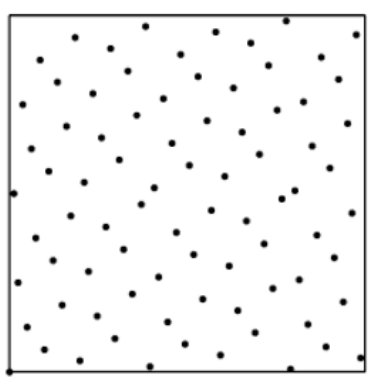

Sampling Hammersley

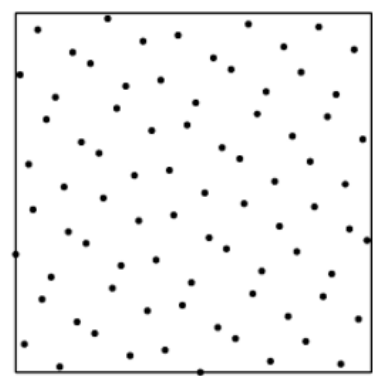

Sampling Halton-Zaremba

Gambar 34: Perbandingan antara sampling acak, Hammersley dan Halton-Zaremba. 


\section{Strategi berbasis process fingerprint}

Strategi berbasis process fingerprint didefiniskan sebagai strategi sampling yang menggunakan sejumlah pengetahuan dari process fingerprint dari suatu proses manufaktur untuk mengoptimalisasi proses pengukuran sehingga mempunyai akurasi yang lebih baik untuk benda-benda yang diproses dengan proses manufaktur tersebut. Process fingerprint adalah jejak yang khas yang terdapat pada benda hasil suatu proses produksi. Contohnya adalah, proses side milling meninggalkan "jejak" berbentu gergaji pada permukaan suatu benda yang diprosesnya (Moroni dan Petro 2013).

Strategi sampling ini juga mempunyai jumlah dan lokasi titik-titik sampling yang sudah ditentukan sebelumya dan bersifat tetap. Tetapi, penentuan jumlah dan lokasi titik-titik tersebut dipilih berdasarkan "jejak berulang" dari suatu proses produksi, sehingga lokasi titik tersebut berada pada area dimana deviasi geomtri maksimum muncul. Pengaplikasian strategi berbasis process fingerprint tidaklah sulit dan memungkinkan untuk diaplikasikan dengan mesin-mesin CMM pada umumnya.Kelemahan utama strategi ini adalah strategi ini spesifik untuk suatu proses tertentu dengan pengaturan tertentu, apabila pengaturan parameter proses berubah, maka strategi sampling juga akan berubah.

Gambar 35 memperlihatkan contoh sampling berbasis proces fingerprint. Pada gambar 35, diperlihatkan sebuah proses side milling pada sebuah permukaan metal. Permukaan tersebut mempunyai toleransi flatness yang harus diverifikasi dengan CMM. Apabila sampling blind dilakukan, pngambilan titik disebar ke seluruh permukaan benda secara merata. Padahal, untuk flatness, area yang paling menentukan nilai flatness adalah titik-titik pada puncak dan lembah dari permukaan tersebut. proses side milling mempunya fingerprint berupa fitur gergaji yang berbekas pada permukaan tersebut. apabila strategi sampling berbasis process fingerprint dilakukan, maka pengambilan titik-titik tersebut hanya difokuskan pada area puncak dan lembah pada permukaan tersebut. Dengan cara ini, jumlah pengambilan titik-titik dapat dikurangi, sehingga waktu pengukuran akan berkurang.
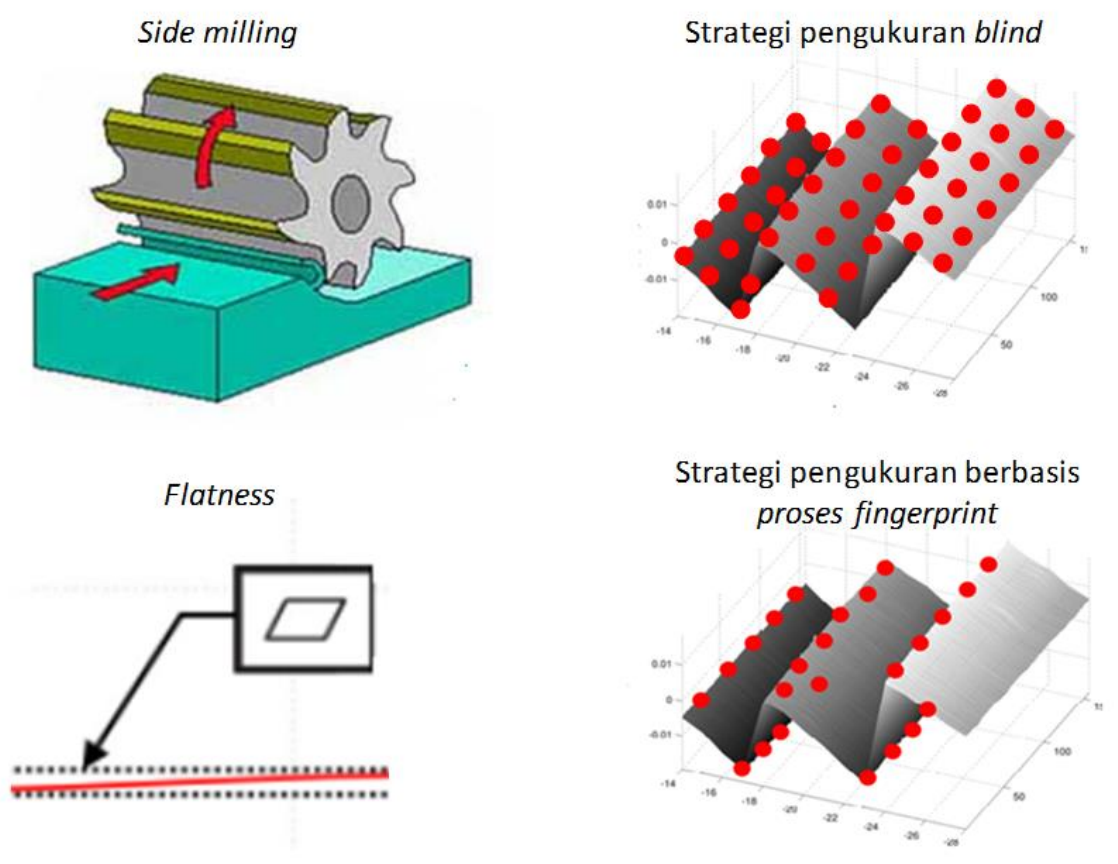

Titik sampling

Gambar 35: Contoh perbandingan antara strategi sampling pengukuran blind dan berbasis process fingerprint. 


\section{$\underline{\text { Strategi adaptif }}$}

Strategi sampling adaptif adalah strategi sampling dimana jumlah dan lokasis pengambilan titik-titik pada suatu permukaan benda tidak tetap, namun bisa berubah sesuah dengan keadaan riil dari fitur suatu benda yang sedang diukur. Strategi sampling dengan metode ini dimulai dengan mengambil beberapa titik-titik pada permukaan yang diukur. Kemudian, analisis matematik dilakukan pada titik-titik tersebut untuk menentukan berapa jumlah dan lokasi titik-titik berikutnya. Tujuan utama dari teknik ini adalah untuk menemukan fitur-fitur kritikal yang ingin diukur dengan jumlah titik seminimum mungkin untuk mengurangi waktu pengukuran. Sampai sekarang, strategi adaptif masih merupakan topik riset yang aktif karena untuk dapat merelaisasikan strategi adaptif, integrasi dengan metode perencanaan-jalur probe head secara otomatis harus dilakukan.

Strategi adaptif memerlukan suatu prosedur analisis dan kalkulasi untuk menentukan jumlah dan lokasi pengambilan titik-titik berikutnya. Beberapa kriteria untuk menentukan titik-titik berikutnya adalah:

- Dengan melakukan fitting spline pada titik-titik yang telah diambil untuk memprediksi pengambilan titiktitik berikutnya.

- Dengan metode direct search seperti pada proses optimisasi numerik untuk menentukan titik maksimum dan minimum dari sebuah persamaa permukaan yang dikalkulasi dari titik-titik yang telah diambil.

- Dengan metode krigging berbasis statistik spasial.

\subsection{Non-Cartesian tactile dan non-contact CMM}

Non-Cartesian CMM adalah jenis CMM yang tidak mengikuti koordinat sistem kartesian (yaitu CMM dengan konfigurasi tiga aksis yang saling tegak lurus satu dengan lainnya), melainkan mengikuti sistem koordinat lainnya, misalnya sistem koordinat spherical dan silinder. Motivasi utama munculnya non-cartesian CMM adalah:

- Kebutuhan protabilitas. Pada kasus pengukuran untuk skala sangat besar, misalnya pengukuran hasil perakitan badan pesawat, dibutuhkan sebuah CMM yang portabel dan dapat dibawa langsung ke bagian badan pesawat yang ingin diukur dari pada membawa bagian pesawta tersebut ke meja CMM.

- Kebutuhan CMM dengan biaya rendah. CMM non-Kartesian pada umumnya mempunyai tingkat akurasi yang lebih rendah dari pada CMM berbasis Kartesian, sehingga biaya pembuatan CMM non-Kartesian menjadi lebih rendah.

- Kebutuhan CMM lightweight dan fleksibel. Pada kasus pengukuran in-line untuk proses produksi dengan tact time yang cepat, CMM non-Kartesian yang ringan dan fleksibel menjadi pilihan utama, walaupun tingkat akurasinya tidak setinggi akurasi CMM berbasis Kartesian.

Metode CMM non-kartesian pada umumnya terbagi menjadi empat (Hocken dan Pereira 2012), yaitu: menggunakan sistem articulated arm (misalnya articulated arm CMM), menggunakan metode triangulation (misalnya laser scanner, teodolit dan photogrammetry), menggunakn metode koordinat spherical (misalnya laser tracker) dan menggunakan metode komparasi suatu jarak titik yang diukur dengan beberapa titik referensi (misalnya fringe projection).

\section{Articulated arm CMM}

Articulated arm CMM adalah suatu jenis CMM yang dapat menjangkai suatu lokasi spasial berdasarkan kombinasi join rotasi kinematik (Sladek 2016) yang dilengkapi dengan rotary encoder. Ciri utama dari articulated arm CMM adalah CMM tersebut dapat menjangkau suatu lokasi tip yang sama dengan jumlah kombinasi tak hingga dari posisi dan konfigurasi dari elemen-elemen arm-nya. Pada umumnya, articulated arm CMM terdiri dari minimal tiga articulated arm. Gambar 36 memperlihatkan contoh dari sistem komersial dari articulated arm CMM yang diproduksi oleh FARO dan ROMER. 


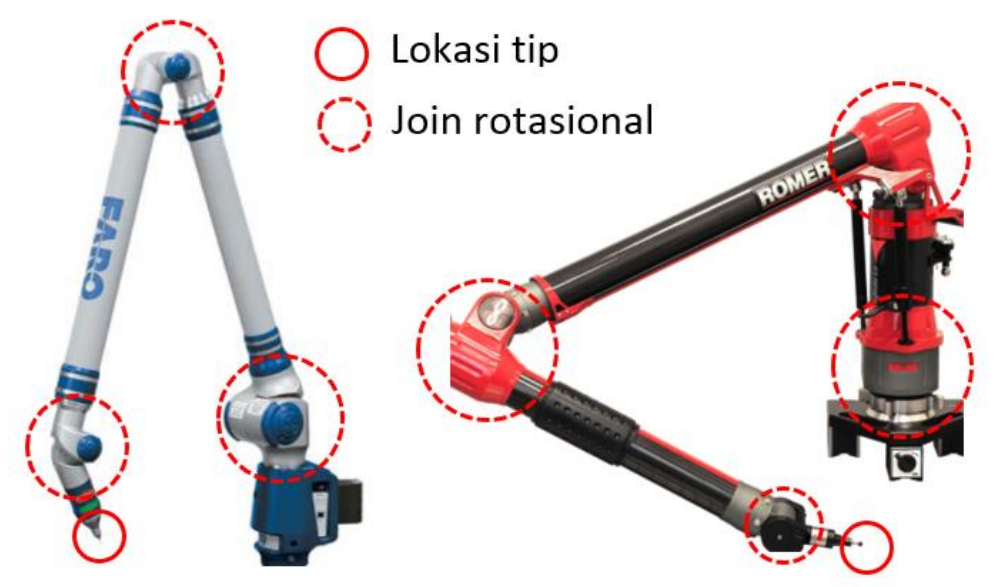

Gambar 36: Contoh komersial articulated arm CMM dari FARO dan ROMER.

Articulated arm CMM direpresentasikan dengan panjang arm $\left(l_{1}, l_{2}, \ldots, l_{n}\right)$ dan rotasi dari setiap arm tersebut $\left(\theta_{1}, \theta_{2}, \ldots, \theta_{n}\right)$. Formulasi dari koordinat spasial tip, yang merupakan fungsi dari panjang dan rotasi arm-arm-nya, suatu articulated arm, dengan tiga arm, diformulasikan sebagai berikut:

$$
\mathbf{P}=\mathbf{R}_{\mathbf{1}}^{-\mathbf{1}}\left(\mathbf{L}_{\mathbf{1}}+\mathbf{R}_{\mathbf{2}}^{-\mathbf{1}}\left(\mathbf{L}_{\mathbf{2}}+\left(\mathbf{R}_{\mathbf{3}}^{-\mathbf{1}} \mathbf{L}_{3}\right)\right)\right)
$$

dimana $\mathbf{P}=[x, y, z]^{T}$ adalah koordinat spasial dari tip, $\mathbf{R}_{\boldsymbol{i}}$ adalah matrik rotasi untuk join ke- $i$ dan $\mathbf{L}_{\mathbf{i}}$ adalah vektor dari panjang articulated arm ke-i.

kelebihna utama dari articulated arm CMM adalah lightweight, fleksibel dan low cost (pada umumnya harganya sekitar US\$20000-US\$50000). Sedangkan, kekurangannya adalah tingkat akurasi yang lebih rendah dari CMM Kartesian, harus sering dikalibrasi dan sulit untuk diterapkan sistem kontrol numerik karena algoritma pengontrolannya lebih sult dibandingkan dengan CMM Kartesian.

\section{$\underline{\text { Sistem Teodolit }}$}

Sistem teodolit berfungsi berdasarkan metode triangulasi. Pada dasarnya, teodolit adalah sebuah pointing device yang diarahkan pada sebuah target. Sumber yang digunakan sebagai pointer adalah sebuah laser. Orientasi dari kepala teodolit-teodolit ketika menunjuk pada suatu target diketahui. Maka dari itu, dibutuhkan minimum dua teodolit untuk dapat menghasilakn suatu pengukuran lokasi sebuah titik. Teodolit sangat cocok digunakan untuk mengukuran posisi titik dengan skala yang sangat besar.

Gambar 37 memperlihatkan konfigurasi dasar dari sebuah teodolit dan konfigurasi dari dua teodolit untuk melakukan suatu pengukuran lokasi titik. Pada gambar 37a, diperlihatkan bahwa kepala dari teodolit dapat memancarkan laser yang digunakna sebagai pointer ke suatu target. Kepala teodolit tersebut dapat berotasi lateral dan aksial. Kemudian, pada gambar 37b, dua buah teodolit digunakan untuk melakukan kalkulasi triangulasi untuk menentukan posisi dari target tersebut. Jarak horisontal dan vertikal dari kedua teodolit tersebut harus diketahui. 


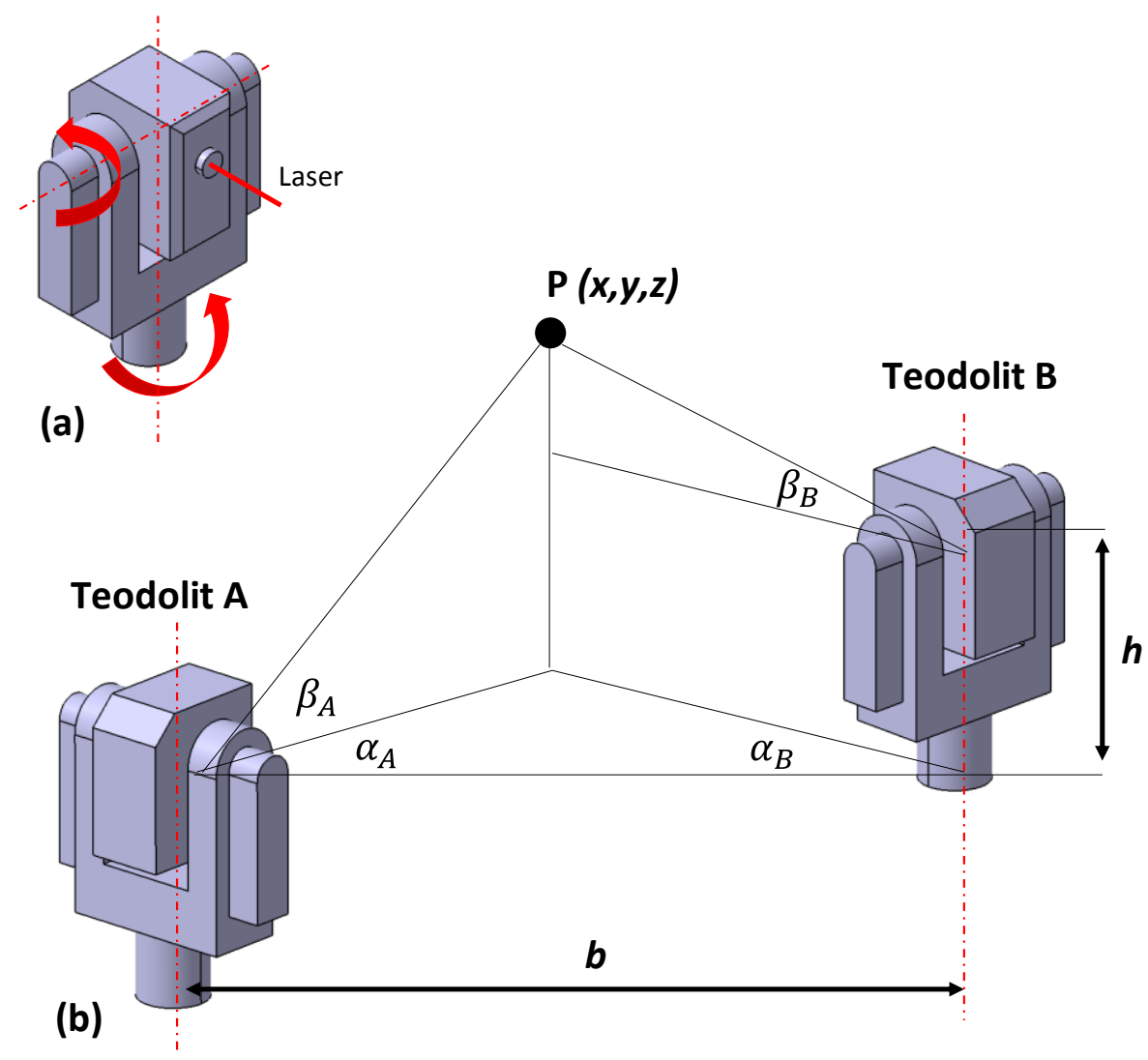

Gambar 37: (a) Konfigurasi dari kepala sebuah teodolit dan (b) Konfigurasi dari dua buah teodolit untuk melakukan suatu pengukuran.

Proses kalkulasi untuk mendapatkan posisi target tersebut dari kedua teodolit pada gambar 37b adalah:

$$
\begin{aligned}
& \mathrm{X}_{P}=b \frac{\cos \alpha_{A} \sin \alpha_{B}}{\sin \left(\alpha_{A}+\alpha_{B}\right)} \\
& \mathrm{Y}_{P}=b \frac{\sin \alpha_{A} \sin \alpha_{B}}{\sin \left(\alpha_{A}+\alpha_{B}\right)} \\
& \mathrm{Z}_{P}=\mathrm{h}+b \frac{\sin \alpha_{A} \tan \beta_{B}}{\sin \left(\alpha_{A}+\alpha_{B}\right)}
\end{aligned}
$$

\section{Laser tracker}

Laser tracker adalah suatu CMM non-Kartesian yang berbasiskan pada koordinat spherical. Motivasi utama dikembangkannya sistem ini adalah karena sistem triangulasi harus dikalibrasi base length-nya, yaitu misalnya jarak anatar dua teodolit, dan sistem triangulasi membutuhkan waktu untuk dapat menunjuk suatu target.

Konfigurasi utama dari sebuah laser tracker adalah sebuah sistem interferometer, sebuah sistem pengukuran sudut rotasi, sebuah mekanisme tracking dan sebuah target. Pada laser tracker, fungsi utama dari sistem tracking adalah agar laser dari interferometer dapat mengikuti target, sehingga laser interferometer tersebut dapat mengukur 
jarak suatu target dari titik referensi laser tracker tersebut, kemudian, sistem pengukuran sudut mengukur arah dari laser beam tersebut. Kemudian, setelah jarak titik referensi ke target dan arah orientasi dari laser diketahui, sebuah sistem koordinat spherical kemudian dapat direkonstruksi. Karena berbasis laser interferometer dan encoder rotasi yang presisi, laser tracker dapat menghasikan suatu pengukuran dengan tingkat presisi yang tinggi. Namun demikian, sebuah sistem laser tracker mempunyai harga yang tinggi. Keuntungan dari laser tracker adalah sistem tersebut langsung terlacak sampai dengan definisi meter. Hal ini disebabkan karena laser tracker menggunakan laser interferometer untuk mengukur jarak dari suatu target.

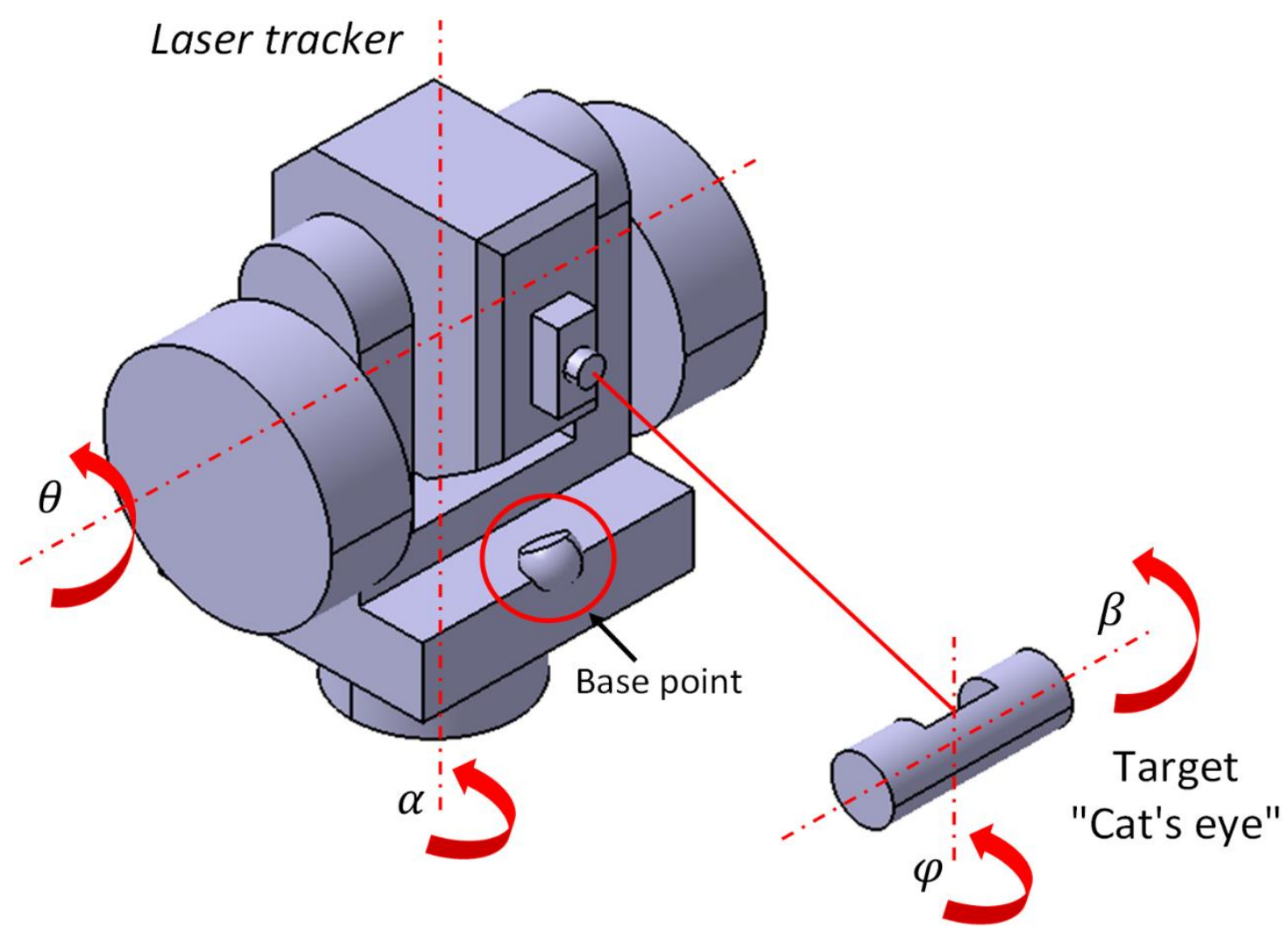

Gambar 38: Konfigurasi utama dari sebuah laser traker, yaitu laser tracker head dan cat's eye sebagai target yang harus selalu diikuti..

Gambar 38 memperlihatkan konfigurasi utama dari sebuah laser tracker. Prinsip kerja laser tracker adalah sebagai berikut. Sebuah laser dihasilkan dari sebuah apertur untuk menuju sebuah target yang bernama cat's eye yang dilengkapi dengan sebuah lensa reflektor. Laser yang ditujukan kepada cat's eye tersebut dipantulkan kembali ke apertur tersebut. laser yang terpantulkan tersebut dikombinasikan dengan laser yang ditujukan kepada base point dan dipantulkan kembali ke laser tracker tersebut. Kemudian jarak yang dihasilkan dikalkulasi berdasarkan perhitungan fringe untuk interferometer (liha Bab 4 mengenai detil dari perhitungan jarak pada sebuah interferometer). Maka dari itu, laser tracker merupkana laser interferometer. Laser tracker dan cat's eye tersebut dilengkapi dengan motor rotasi dua arah yang bertujuan untuk mengatur posisi dan orientasi laser tracker dan cat's eye tersebut selalu dalam line-ofsight (garis lurus).

Laser tracker banyak digunakan untuk mengkalibrasi posisi suatu efektor dari suatu articulated robot dan untuk kalibrasi CMM berbasis Kartesian yang berukuran sangat besar. Hal ini disebabkan karena laser tracker berbasis laser interferometer, sehingga laser tracker mempunyai rantai keterlacakan ke definisi meter. 


\section{Photogrammetry dan fringe projection}

Sistem photogrammtery dan fringe projection adalah suatu CMM yang dapat mengambil atau mendeteksi titiktitik pada suatu permukaan benda dalam jumlah banyak pada waktu yang bersamaan. Jenis CMM ini dapat mengambil titik-titik secara area, bukan berdasarlan point-by-point seperti jenis CMM lainnya. Sistem photogrammtery dan fringe projection dibahas dengan detil pada bab 6 mengenai non-contact CMM.

\subsection{Multi-sensor CMM}

Multi-sensor CMM adalah suatu CMM yang dilengkai dengan berbagai macam sensor atau probe, seperti sensor kontak (tactile), sensor triangulasi laser (laser scanner), sensor 2D imaging dan lain sebagainya. Tujuan utama dari multi-sensor CMM adalah untuk megukur berbagai macam fitur dari suatu benda dengan satu jenis mesin CMM saja. Karena, setiap fitur dari suatu benda ada yang cocok diukur dengan sensor kontak dan ada yang cocok diukur dengan sensor lainnya. Bukan hanya fitur, pemilihan jenis sensor pada CMM bergantung juga pada kebutuhan akurasi yang dingingkan dan kebutuhan seberapa cepat pengambilan data titik-titik suatu permukaan.

Gambar 39 memperlihatkan ilustrasi dari sebuah benda yang mempunyai berbagai macam bentuk fitur yang diukur dengan satu mesin CMM yang mempunyai berbagai macam sensor, yaitu sensor kontak, triangulasi laser dan imaging. Contoh komersial mesin CMM dengan multi-sensor adalah ZEISS O-Inspect dan Wertch Video Check. Gambar 40 memperlihatkan sebuah CMM dari Werth dilengkapi dengan multi-sensor.

Pada umumnya, jenis-jenis sensor yang terdapat pada suatu jenis multi-sensor CMM adalah kombinasikombinasi dari snesor-sensor pengukuran sebagai berikut: sensor gambar berbasis 2D, triangulasi laser, sensor kontak, sensor laser, sensor auto-focus, sensor jarak, tomografi berbasis sinar-X (X-ray computed tomography) dan lain sebagainya.

Multi sensor CMM sangat bergantung pada kemampuan kalkulasi perangkat lunak dari CMM tersebut untuk melakukan penggabungan data dari berbaga macam sensor (data fusion). Penggabungan data dari berbagai macam sensor merupakan topik rise yang sangat aktif sampai sekarang. Tujuan utama dari penggabungan data tersebut adalah untuk memanfaatkan banyaknya data pengukuran dari berbagai macam sensor pada suatu CMM. Salah satu fungsi utama adalah untuk memilih mana data terbaik yang digunakan untuk mengkalkulasi suatu pengukuran dari berbagai macam sensor. Dengan demikian, tujuan utama dari penggabungan data adalah untuk meningkatkan akurasi hasil pengukuran dan untuk meningkatkan kecepatan suatu pengukuran.

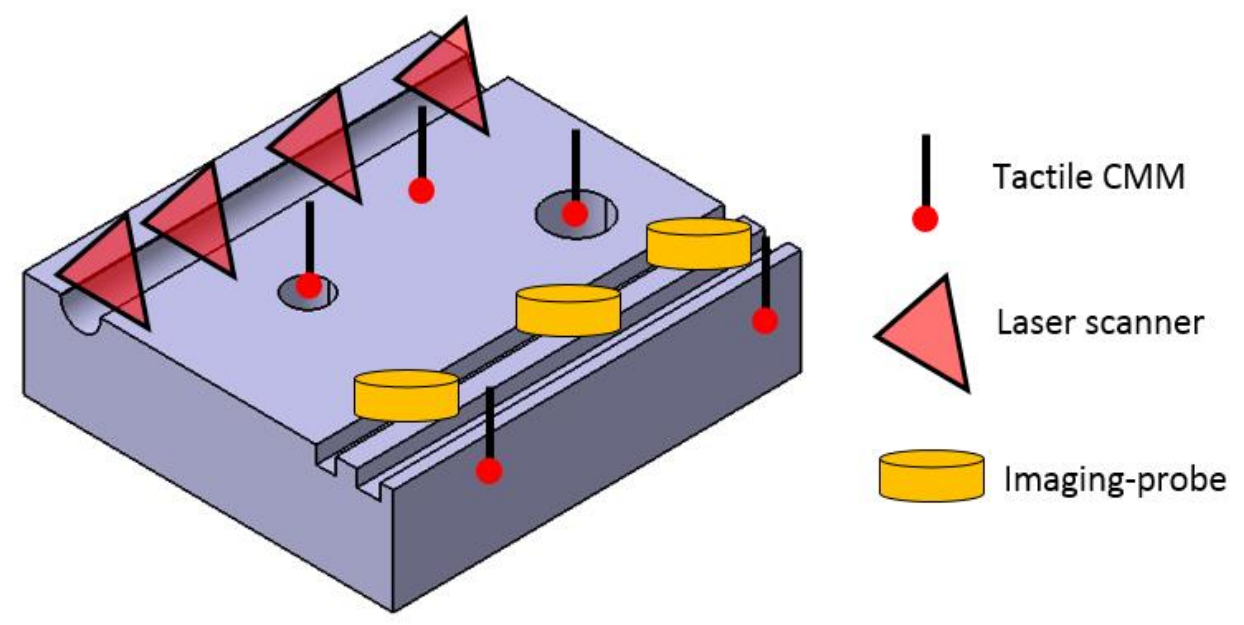

Gambar 39: Ilustrasi suatu benda yang diukur dengan berbagai macam snesor sesuai dengan bentuk fitur dan kebutuhan pengukuran lainnya, seperti kecepatan dan tingkat akurasi pengukuran. 


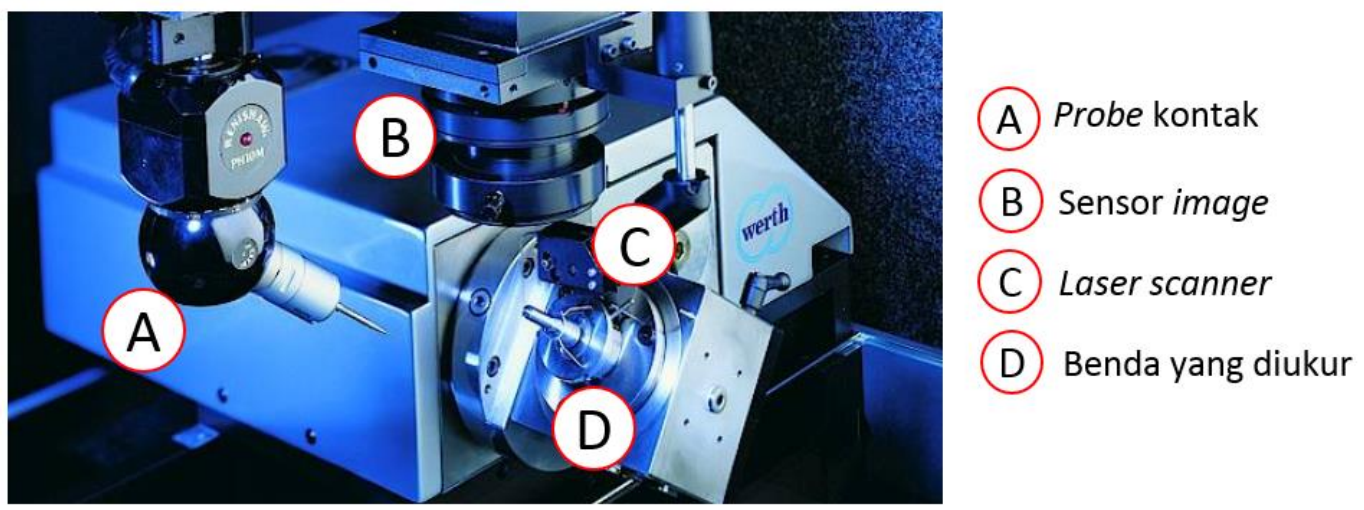

Gambar 40: Contoh komersial multi-sensor CMM dari Werth Messetechnik, Jerman.

\subsection{Sumber-sumber error (error sources)}

Mesin CMM kontak dan non-kontak merupakan suatu alat pengukuran yang kompleks. Maka dari itu, banyak sumber-sumber error yang menyebabkan berkurangnya tingkat akurasi mesin CMM tersebut dan menigkatnya nilai ketidakpastian dari hasil pengukuran yang diukur dengan CMM tersebut. Maka dari itu, untuk dapat memaksimalkan efektifitas dan efisiensi dari penggunaan CMM, pemahaman tentang sumber-sumber error yang terdapat pada CMM adalah sangat penting.

Sumber-sumber error utama yang terdapat pada CMM berasal dari: Hardware (mesin CMM), benda kerja (yang diukur), strategi sampling, algoritma fitting dan faktor-faktor ektrinsik. Gambar 41 memperlihatkan peta dari sumbersumber error tersebut beserta beberapa rincian lebih detilnya. Penjabaran dari sumber-sumber error tersebut adalah sebagai berikut:

\section{Hardware}

Sumber error yang berasal dari hardware adalah hal-hal yang berhubungan dengan konstruksi fisik suatu mesin CMM dan pemilihan parameter pengukuran. Sumber-sumber error yang termasuk ke dalam hardware adalah seperti settinggan pengukuran, probing error, geometric error, dynamic error, variasi temperatur dan vibrasi (getaran).

Settingan pengukuran adalah misalnya pemilihan kecepatan aksis CMM untuk menjangkau suatu permukaan benda. Hal ini berkaitan langsung dengan dynamic error yang disebabkan oleh efek percepatan dan perlambatan aksis CMM. Pada prinsipnya, pemilihan kecepatan pengukuran adalah bergantung pada nilai kompromi antara kecepatan dan akurasi. Semakin tinggi kecepatan pengukuran, maka tingkat akurasi hasil pengukuran akan semakin berkurang karena adanya efek dinamik tersebut. Probing error adalah error yang bersumber pada sistem probing, misalnya tingkat akurasi sistem pengukuran perpindahan pada probe head atau error yang disebabakan diameter stylus tip tidak sempurna, bisa karena aus atau karena deviasi dari proses manufaktur stylus tip tersebut (stylus tip pada kenyataannya tidak berupa bola yang sempurna).

Variasi temperatur tempat pengukuran berlangsung mempengaruhi ekspansi dari komponen-komponen suatu CMM. Karena, semua material mempunyai koefisien ekspansi termal yang menyebabkan komponen-komponen tersebut bertambah panjang atau pendek ketika temperatur lingkungan berubah-ubah. Vibrasi (getaran) yang disebabkan karena percepatan dan perlambatan ketika suatu CMM bergerak juga berkontribusi pada error CMM.

Geometric error adalah deviasi geometri dari komponen-komponen pembentuk suatu CMM dari dimensi nominalnya. Untuk CMM dengan tiga aksis, total geometric error yang didapatkan berjumlah 21 error. Rincian dari error-error tesebut adalah 6 error per aksis (scale error, 2 straighness error, 3 rotational error). Karena total aksis adalah 3, maka total error yang berasal dari setiap aksis adalah 18 error. Tiga error sisanya dalah error yang berasal dari perpendicularity error antara aksis $X Y, X Z$ dan $Y Z$. Gambaran dari 21 error tersebut diperlihatkan pada gambar 42. 


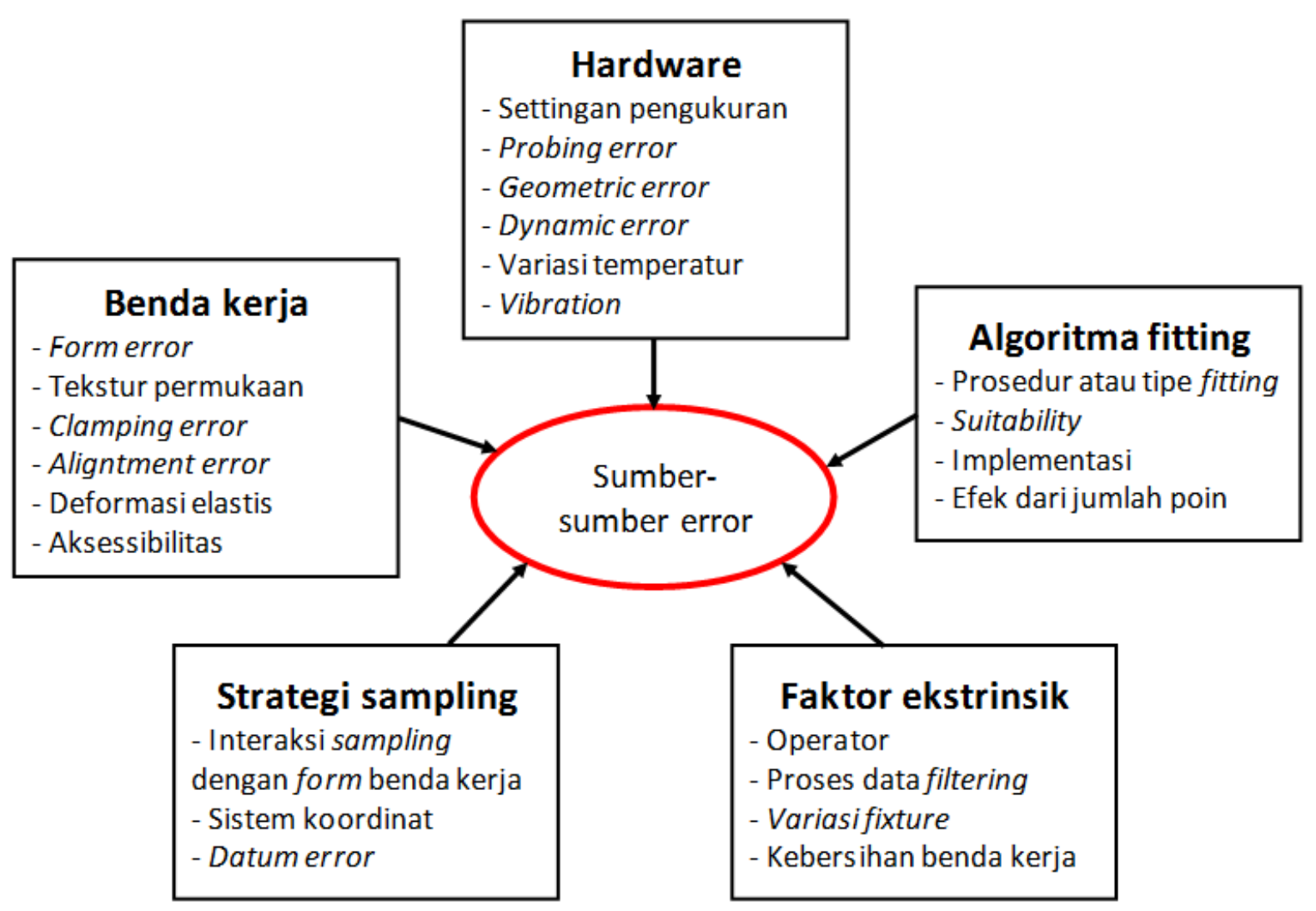

Gambar 41: Sumber-sumber error yang terdapat pada mesin CMM.

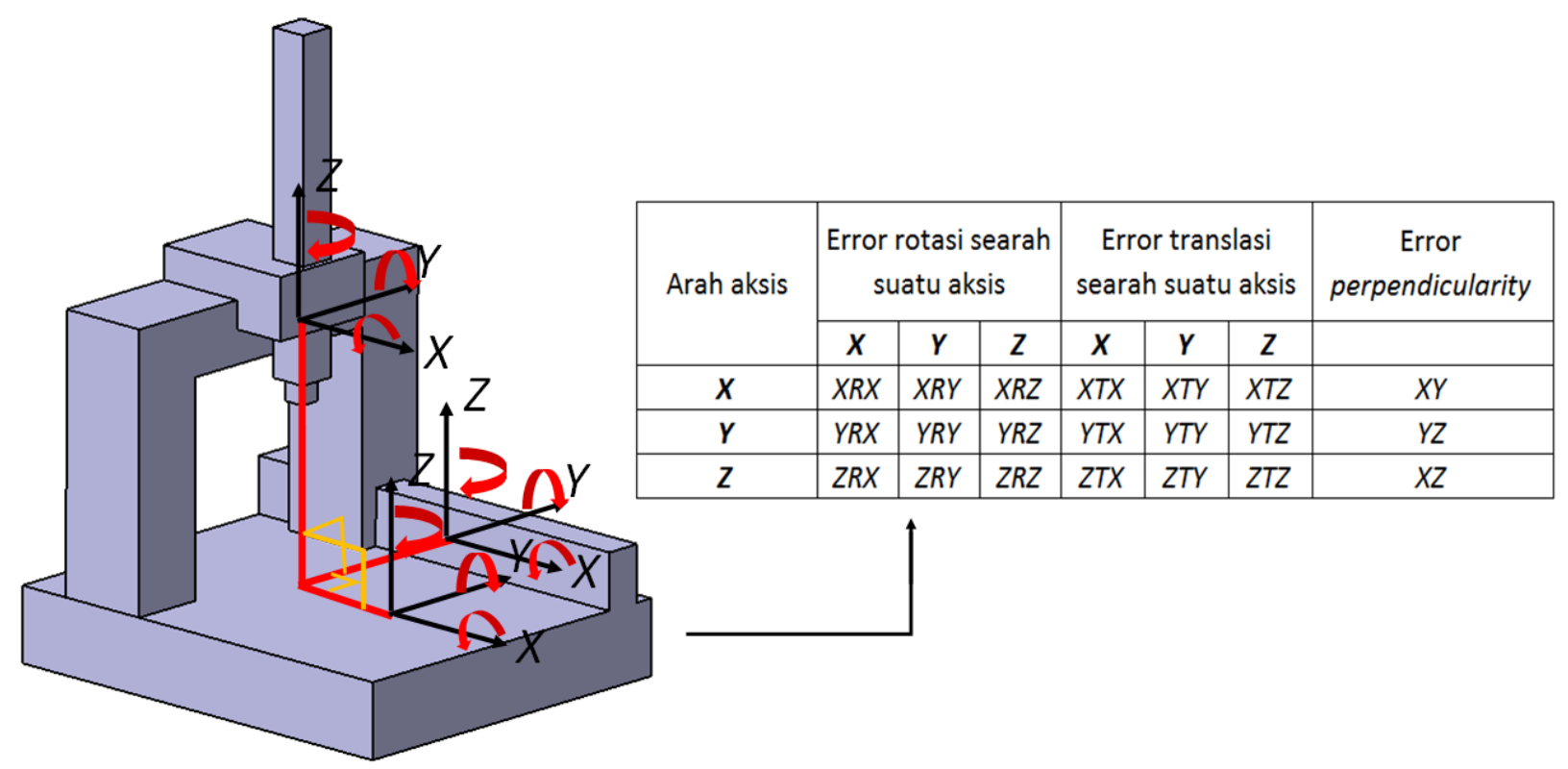

Gambar 42: Gambaran 21 error geometri pada 3-aksis CMM. 


\section{Benda kerja}

Sumber-sumber error yang termasuk ke dalam kelompok benda kerja adalah seperti form error, tesktur permukaan, clamping error, alignment error, deformasi elastis dan aksessibilitas. Error dari form benda kerja itu sendiri mempengaruhi total error yang berkontribusi kepada hasil pengukuran. Dengan kata lain, error dari form suatu benda akan mengakibatkan bertambahnya nilai ketidakpastian dari pengukuran benda tersebut. Bukan hanya itu, tingkat kekasaran permukaan suatu benda dapat mempengaruhi tingkat akurasi suatu pengukuran.

Error dari clamping untuk memegang suatu benda yang diukur juga berkontribusi terhadap total error suatu pengukuran. Gaya clamping yang terlalu besar akan menyebabkan benda yang ditahannya mengalami deformasi elastis atau bahkan plastik. Alignment error pada umumnya terjadi karena operator tidak tepat dalam mendefinisikan WCS (workpiece coordinate system) dan/atau tidak tepat dalam memilih lokasi penempatan WCS.

\section{Strategi sampling}

Strategi sampling juga merupakan sumber error utama dari suatu pengukuran CMM. Error-error yang termasuk ke dalam strategi sampling adalah: interaksi sampling dengan form dari sebuah benda kerja yang diukur, sistem koordinat dan datum error. Yang dimaksud dengan interaksi sampling dengan form dari sebuah benda adalah untuk pengukuran geometrik, lokasi titik-titik permukaan (sampling) pada suatu permukaan benda yang diukur harus meliputi area kritikal dimana deviasi geometri dari benda tersebut berada. Karena, pengukuran geometri hanya bergantung pada titik-titik kritikal tersebut dan titik-titik lainnya tidak berkontribusi untuk mengkalkulasi deviasi geometrik dari benda tersebut (lihat Bab 3 untuk lebih jelasnya). Apabila titik-titik permukaan yang diukur tidak meliputi area dengan deviasi terbesar, maka seberapa banyak titik-titik yang diukur tidak akan dapat menggambarkan deviasi geometri dari benda tersebut.

Datum error sangat relevan untuk melakukan pengukuran geometri yang berelasi, seperti perpendicularity, paralellism dan run-out. Untuk melakukan pengukuran geometri yang berelasi tersebut, penentuan datum sangat penting dan wajib dilakukan untuk dapat mengkalkulasi deviasi geometri tersebut. Apabila datum yang diukur salah atau terdapat error, maka hasil pengukuran geometri yang berelasi tersebut juga akan salah atau berkurang tingkat akurasinya.

\section{Algoritma fitting}

Error-error yang termasuk ke dalam kategori algoritma fitting adalah tipe fitting yang dilakukan, suitability (ketepatan dalam penggunaan suatu algoritma), implemetasi suatu algoritma dan efek dari jumlah titik yang diukur. Tipe-tipe algoritma untuk proses fitting ada berbagai jenis. Setiap jenis dari tipe fitting tersebut akan memberikan hasil kalkulasi parameter sebuah geometri yang berbeda-beda, misalnya fitting berbasis least-square dan fitting berbasis minimum zone. Ketepatan dalam memilih sebuah algoritma untuk fitting juga sangat penting untuk diketahui, misalnya apabila kita ingin melakukan fitting sebuah bola, tetapi kita memilih menggunakan algoritma untuk fitting silinder, maka hasil yang kita dapatkan akan sangat berbeda dari yang diinginkan. Jumlah titik-titik yang digunakan untuk proses fitting juga sangat mempengaruhi hasil proses fitting tersebut. Idealnya, untuk proses fitting menggunakan metode least square, jumlah titik yang dibutuhkan adalah sebanyak mungkin untuk mendapatkan efek averaging (ratarata), sehingga error yang terdapat pada geometri hasil fitting tersebut akan semakin berkurang. Contoh lainnya adalah fitting sebuah bidang datar. Secara matematik, untuk dapat mem-fitting atau mendifinisikan suatu geometri berupa bidang datar, jumlah titik minimal yang dibutuhkan adalah berjumlah tiga titik. Namun demikian, apabila fitting leastsquare tersebut hanya dilakukan dengan menggunakan tiga titik, maka tidak ada efek averaging pada proses fitting tersebut. Hal ini menyebabkan, error pada geometri hasil fitting akan sangat besar dan sangat signifikan terhadap nilai hasil suatu pengukuran.

Gambar 43 menjelaskan komponen-komponen yang terlibat pada suatu proses fitting geometri. Komponenkomponen tersebut adalah titik-titik yang terukur, elemen geometri hasil proses fitting, elemen geometri yang sebenarnya dan error dari proses fitting tersebut. Error dari fitting didefinisikan sebagai jarak ortogonal dari titik yang terukur ke elemen geometri hasil kalkulasi (fitting). Error dari fitting tersebut sangat berkontirbusi pada total error pada pengukuran dengan CMM. 


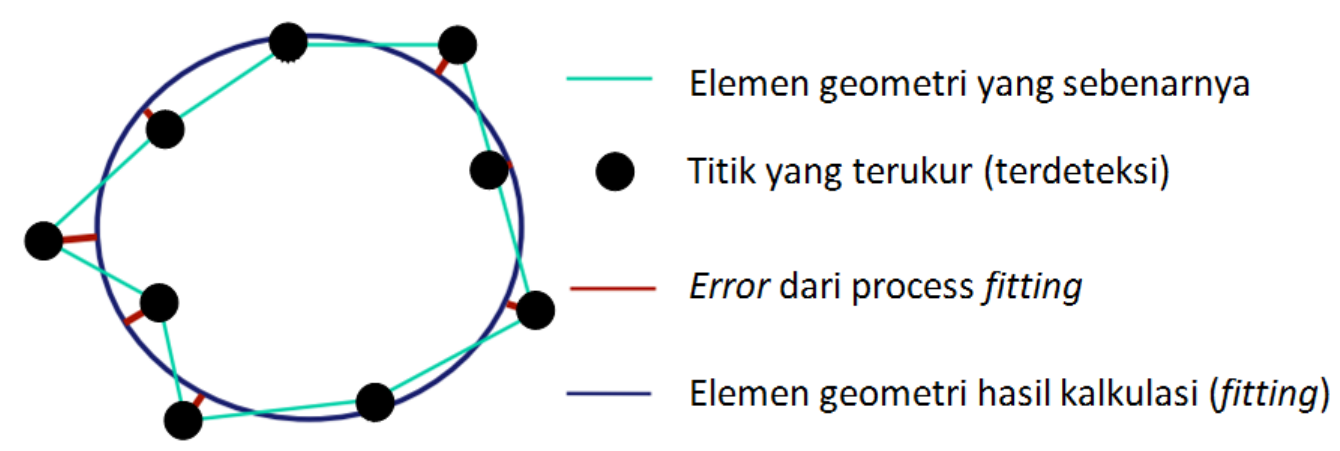

Gambar 43: Deskripsi dari elemen-elemen yang berhubungan dengan suatu proses fitting.

\section{Faktor-faktor ekstrinsik}

Faktor-faktor ekstrinsik adalah faktor-faktor yang bersifat non-teknis yang berkontribusi terhadap error pada suatu pengukuran yang menggunakan CMM. Error-error yang termasuk ke dalam kategori faktor-faktor ekstrinsik adalah operator, proses filtering data, variasi fixture dan kebersihan benda kerja. Faktor-faktor tersebut walaupun terlihat sederhana, namun pada kenyataannya di industri-industri masih banyak error-error pada pengukuan CMM yang disebabkan oleh faktor-faktor tersebut.

Pengetahuan yang cukup pada operator yang menggunakan sebuah mesin CMM sangat dibutuhkan untuk menghindari kesalahan-kesalahan non-teknis pada pengukuran CMM. Investasi yang cukup untuk melatih seorang operator CMM untuk agar memiliki pengetahuan yang cukup mengenai prinsip-prinsip pengukuran, GD\&T dan cara pengoperasian CMM harus dilakukan.

Ketelatenan seorang operator untuk memposisikan atau menempatkan sebuah benda kerja yang akan diukur, untuk membersihkan permukaan benda kerja tersebut dan untuk mendefinisikan alignment, datum dan prosedur pengukuran dengan CMM sangat penting untuk dimiliki oleh setiap operator CMM. Pemilihan prosedur yang tepat untuk proses fitting dan data filetring (yang dipilih melalui perangkat lunak sebuah mesin CMM) yang dilakukan oleh seorang operator sangat penting untuk mendapatan suatu hasil pengukuran yang benar. Hal-hal tersebut membutuhkan sebuah pelatihan khusus untuk operator-operator mesin-mesin CMM.

\subsubsection{Efek temperatur}

Temperatur, baik yang berasal dari lingkungan maupun yang berasal dari CMM itu sendiri, mempunyai peran yang sangat besar terhadap akurasi suatu hasil pengukuran. Pada umumnya, temperatur merupakan salah satu penyebabab berkurangnya repeatbility dari sutu CMM (Hocken dan Pereira 2012). Hal ini disebabkan karena setiap material mempunyai koefisien ekspansi termal yang menggambarkan seberapa besar suatu material akan bertambah panjang apabila suhunya terdapat peningkatan temperatur pada material tersebut.

Gambar 43 memperlihatkan rincian dari komponen-komponen yang berkontribusi terhadap total error karena efek temperatur. Pada gambar 43, dapat terlihat bahwa total error karena efek temperatur berasal dari tiga bagian dari suatu proses pengukuran, yaitu: error karena efek temperatur pada benda kerja, pada master scale (skala encoder) dan pada frame CMM. Seluruh error karena efek temperatur pada benda kerja, master scale dan frame CMM dapat dikelompokkan menjadi due janis, yaitu yan disebabkan oleh tempertur uniform dan non-uniform. 


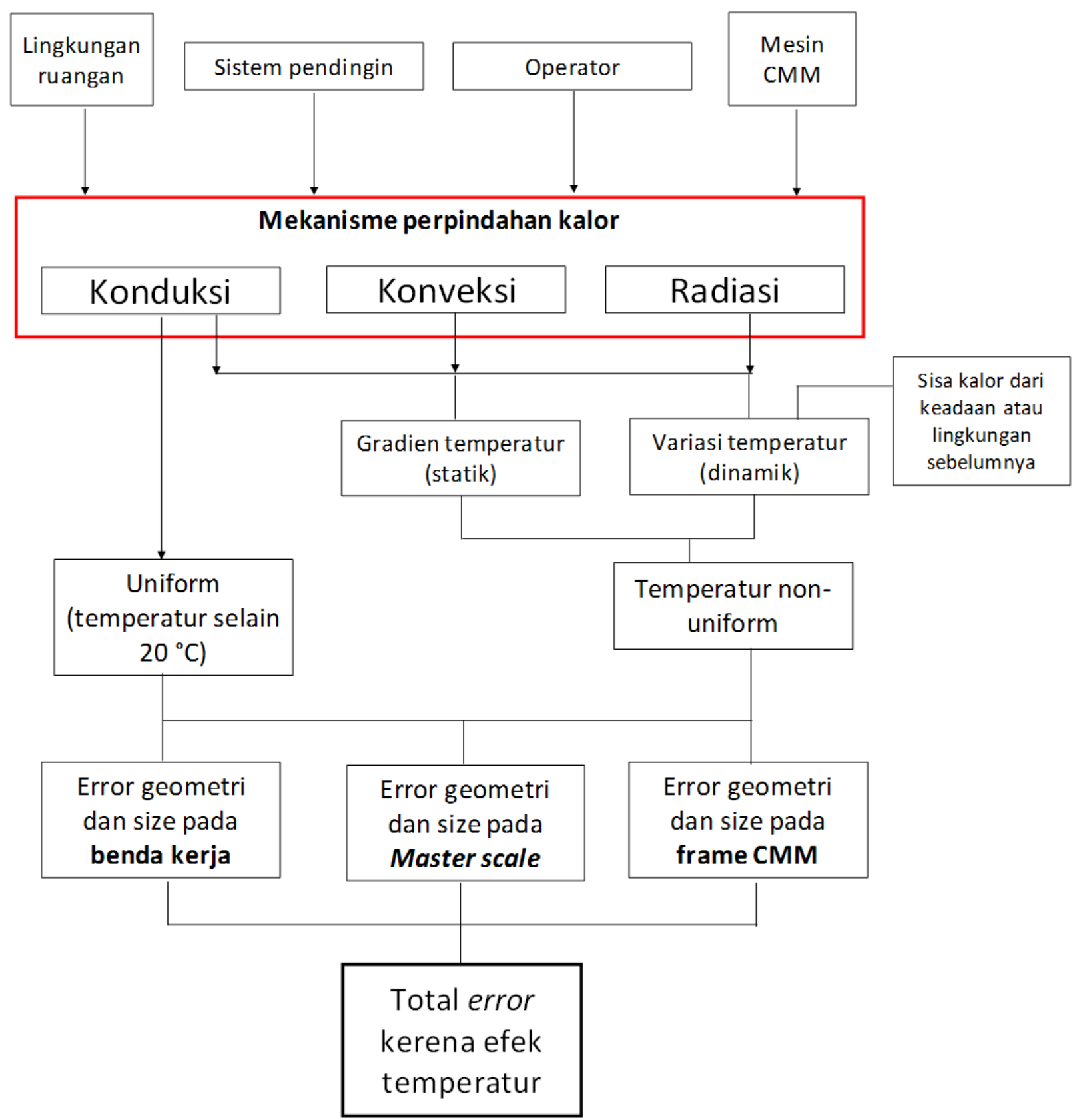

Gambar 43: Komponen-komponen yang berkontribusi terhadap total error karena efek temperatur.

fek temperatur uniform merupakan hasil dari perpindahan kalor secara konduksi, sedangkan efek temperatur nonniform merupakan hasil dari perpindahan kalor secara konduksi, konveksi dan radiasi. Efek temperatur uniform lebih mudah untuk dikontrol karena dapat diprediksi seberapa besar efeknya terhadap perubahan dimensi suatu benda, master scale dan frame CMM. Sedangkan, efek temperatur non-uniform lebih sulit untuk dikontrol karena efek konveksi dan radiasi berkontribusi terhadap efek tersebut.. Tiga sumber utama dari efek temperatur non-uniform adalah gradien temperatur, variasi temperatur dan sisa kalor dari keadaan atau lingkungan sebelumnya. 
Pada gambar 43, sumber-sumber utama kalor (panas) yang mempengaruhi suatu proses pengukuran dikelompokkan menjadi empat bagian, yaitu sumber kalor yang berasal dari lingkungan ruangan, sistem pendingin, operator (temperatur badan) dan mesin CMM. Kalor yang berasal dari lingkungan bisa disebabkan misalnya sumber kalor yang dihasilkan dari mesin-mesin produksi yang berada di ruangan yang sama dan dapat juga disebabkan oleh ekposur sinar matahari pada ruangan tempat proses pengukuran berlangsung. Sistem pendingin pada ruangan atau pendingin pada mesin CMM juag mempengaruhi suklus perpindahan kalaor pada proses pengukuran tersebut. Temperatur badan seorang operator juga merupakan sumber kontirbutor panas utama dari seluruh total panas yang mempengaruhi proses pengukuran. Sumber-sumber panas yang berasal dari mesin CMM merupakan sumber-sumber panas yang berasal dari, misalnya, gesekan antara komponen-komponen CMM, panas dari sistem elektronik CMM dan panas yang bersumber dari motor penggerak aksis CMM. Seluruh sumber-sumber utama panas tersebut akan berinterkasi dengan suatu proses pengukuran dalam tiga moda, yaitu: konduksi, konveksi dan radiasi.

\section{Indeks error termal}

Indeks error termal adalah suatu index yang bertujuan untuk mengestimasi kontribusi dari error karena efek termal terhadap total toleransi dari suatu dimensi nominal. Indeks tersebut merupakan jumlah total dari ekspansi linear benda kerja dan skala pengukuran (skala encoder), drift termal mesin CMM dan ketidakpastian dari koeffisien termal ekspansi dari material benda dan skala pengukuran. Sebuah proses pengukuran, baik kalibrasi, pengukuran benda dan evaluasi performansi akan dianggap valid apabila nilai dari index termal errornya mencapai suatu nilai yang wajar (nilai ini tergantung kebijakan masing-masing industri, misalnya $5 \%, 10 \%$ atau $20 \%$ dari total nilai toleansi suatu dimensi).

Contoh aplikasi dari indeksx error termal adalah sebagai berikut. Misalkan sebuah aluminium dengan panjang $500 \mathrm{~mm} \pm 45 \mu \mathrm{m}$ diukur panjangnya pada suhu ruangan $24^{\circ} \mathrm{C} \pm 2{ }^{\circ} \mathrm{C}$. Koefisien ekspansi termal (CTE) aluminium tersebut adalah $24 \mu \mathrm{m} \cdot \mathrm{m}^{-1}{ }^{\circ} \mathrm{C}^{-1}(24 \mathrm{ppm})$. Mesin $\mathrm{CMM}$ yan digunakan untuk pengukuran adalah sebuah $\mathrm{CMM}$ yang mempunyai skala pengukuran terbuat dari suatu jenis steel (baja) dengan koefisien ekspansi termal (CTE) $11 \mu \mathrm{m} \cdot \mathrm{m}^{-1}{ }^{\circ} \mathrm{C}^{-1}(11 \mathrm{ppm})$. Mesin CMM tersebut mempunyai drift termal sebesar $2.5 \mu \mathrm{m}$. Tidak ada koreksi error karena efek temperatur pada pengukuran tersebut. dengan demikian, indeks error termal pada pengukuran tersebut adalah sebagai berikut:

- Ekspansi gabungan benda kerja dan skala pengukuran $=L \times \Delta C T E \times \Delta T=0.5 \times 12.5 \times(24-20)=$ $25 \mu \mathrm{m}$.

- $\quad$ Ketidakpastian CTE skala pengukuran (biasanya $10 \%$ ) $=L \times C T E$ baja $\times 10 \% \times \Delta T=0.5 \times 11.5 \times$ $10 \% \times(24-20)=2.3 \mu \mathrm{m}$.

- Ketidakpastian CTE benda kerja (biasanya $20 \%$ ) $=L \times C T E$ aluminium $\times 10 \% \times \Delta T=0.5 \times 24 \times$ $20 \% \times(24-20)=9.6 \mu m$.

- $\quad$ Drift termal $=2.5 \mu \mathrm{m}$.

- $\quad$ Total error dari efek termal adalah $E=25+2.3+9.6+2.5=39.4$

dengan demikian, maka indeks error termal pada pengukuran tersebut adalah Total error $E /$ toleransi $=$ $39.4 / 45=87.5 \%$. Apabila operator mengimplemnetasikan koreksi error karena ekspansi gabungan benda kerja dan sakala pengukuran, maka indeks tersebut menjadi $39.4 / 45=32 \%$. Dari sini dapat terlihat bahwa dengan mengaplikasikan koreksi error karena efek termal, makakontribusi error dari efek termal tersebut dapat secara signifikan direduksi.

\subsubsection{Kontrol lingkungan}

Seperti yang sudah dijabarkan sebelumnya bahwa kontrol lingkungan tempat suatu proses pengukuran berlangsung sangatlah penting. Hal-hal utama yang harus dikontrol yang berhubungan dengan lingkungan adalah seperti temperatur, kelembapan (humidity), debu, vibrasi dan level kekerasan suara. Efek temperatur sangat jelas akan mempengaruhi ekspansi dimensi dari suatu benda yang diukur, kelembapan sangat mempengaruhi pengukuran yang menggunakan laser karena kelembapan akan mempengaruhi indeks refraktis medium udara yang dilewati laser 
tersebut, vibrasi dapat memberikan error pada suatu proses pengukuran, misalnya akna mengganggu proses pre dan post travel dari stylus probing, dan level suara dapat menimpulkan vibrasi dengan frekuensi tinggi.

Temperatur ruangan tempat proses suatu pengukuran dapat dikontrol dengan memperhatkan aspek-aspek: arah dari aliran udara, arah masuk dan arah keluar dari sirkulasi udara, kecepatan dari sirkulasi udara, sistem kontrol temperatur pada ruangan tersebut dan lokasi dari penempatan sensor temperatur. Untuk menanggulangi masalah vibrasi, ada tiga strategi utama untuk menyelesaikan masalah tersebut, yaitu identifikasi dan pengurangan besarnya vibrasi dari sumber-sumber vibrasi, isolasi dari sumber-sumber vibrasi tersebut dan isolasi mesin CMM dari sumbersumber vibrasi tersebut. Kontrol vibrasi dapat dilakukan secara pasif dan aktif. Kontrol vibrasi pasif tepat digunakan untuk mengisolasi vibrasi dengan frekuensi tinggi, sedangkan kontrol vibrasi aktif tepat digunakan untuk mengisolasi vibrasi dengan frekuensi rendah $<10 \mathrm{~Hz}$.

\subsection{Kalibrasi CMM}

Kalibrasi CMM pada umumnya dilakukan untuk mengkuantifikasi error volumetrik dari suatu CMM berikut dengan nilai ketidakpastian dari error volumetrik tersebut. Proses kalibrasi tersebut dapat dilakukan dengan menggunakan metode-metode, seperti: menggunakan artefak terkalibrasi (yang dikalibrasi dengan suatu alat ukur yang jauh lebih akurat dari pada CMM yang diuji), menggunakan laser tracker dan menggunakan laser interferomter. Contoh kalibrasi dari error volumetrik CMM dengan menggunakan laser tracker dan artefak terkalibrasi berupa ball plates diperlihatkan pada gambar 44.

Pada prinsipnya, error volumetrik adalah error lokasi ujung stylus tip dari suatu sistem probing CMM yag merupaka perbedaan antara nilai yang terbaca oleh kontroler CMM dan lokasi tip yang sebenarnya di dalam suatu volume pengukuran CMM. Ilustrasi dari error voluemtrik diperlihatkan pada gambar 45.

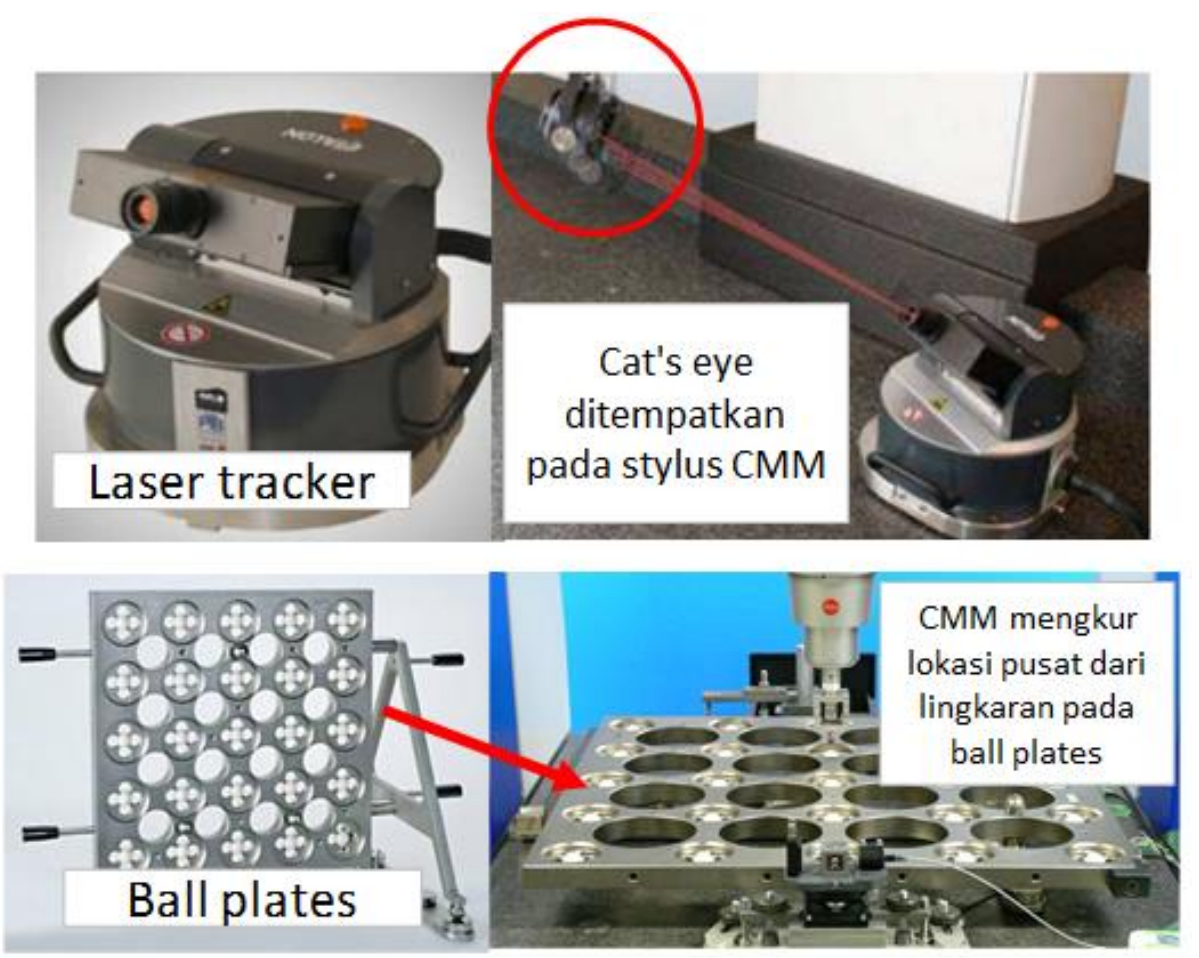

Gambar 44: Contoh kalibrasi pengukuran error volemtrik sebuah CMM dengan menggunakan laser tracker dan artifak ball plates. 

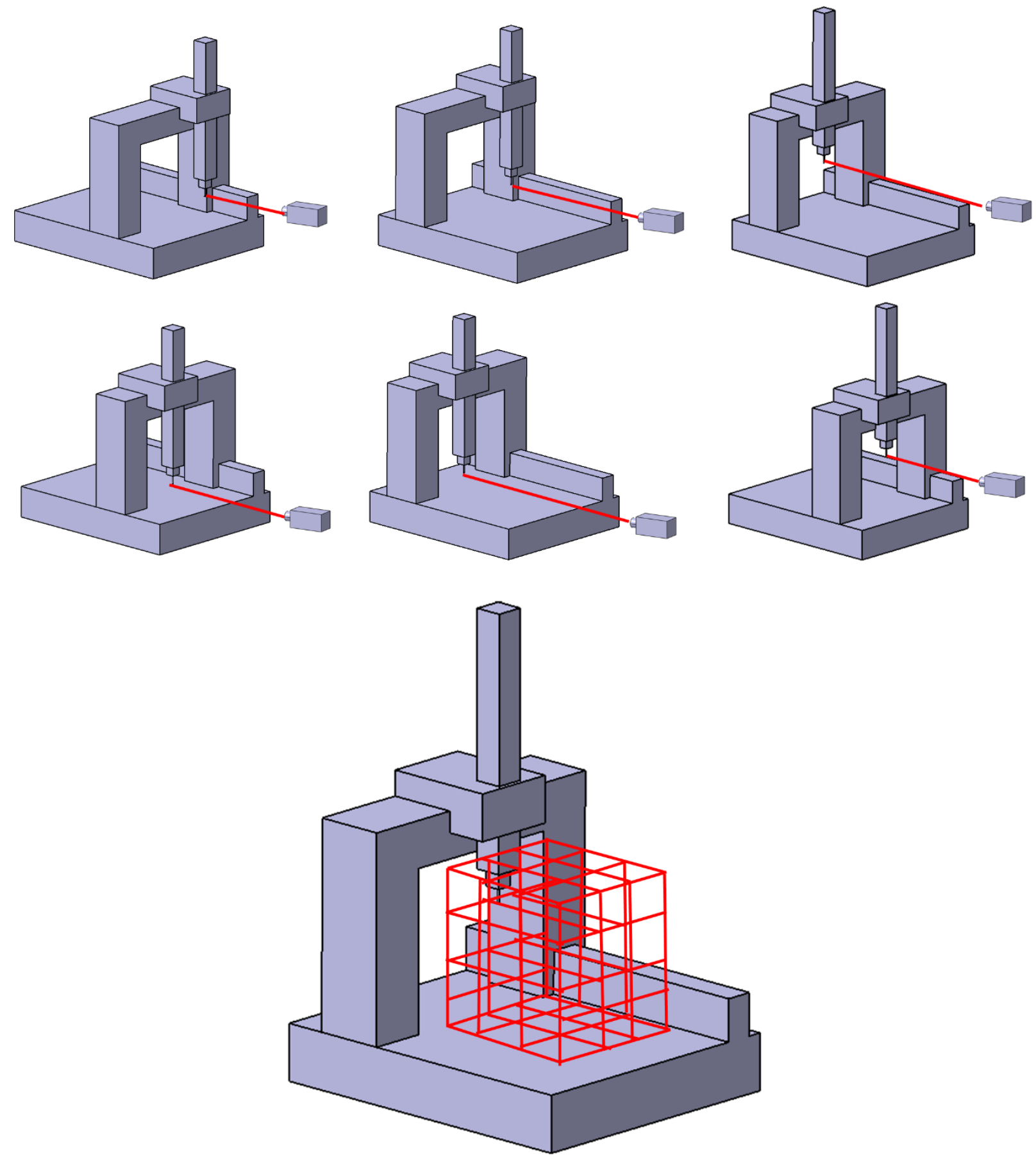

Gambar 45: Proses kalibrasi CMM, yaitu pengukuran error mengguanakan laser interferometer pada sejumlah lokasi didalam volume pengukuran untuk mendapatkan peta dari error volumetrik (volumetric error map). 
Gambar 45 memperlihatkan contoh kalibrasi dari error volumetrik CMM dengan menggunakan laser interferometer. Lokasi error tip dari stylus $\mathrm{CMM}$ diukur untuk setiap posisi tip tersebut di dalam volume pengukuran CMM tersebut. Banyaknya titik-titik pengukuran yang harus dilakukan bergantung pada seberapa besar resolusi dari error volumetrik yang ingin didapatkan. Semakin tinggi resolusi error tersebut, maka akan semakin akurat proses kalibrasi error vollumetrik tersebut, tetapi hal tersebut akan menyebabkan waktu dan proses kalibrasi yang semakin lama. Untuk lebih detilnya mengani kalibrasi volumetrik error CMM, pembaca dapat merujuk pada Sladek 2016.

Untuk mereduksi jumlah titik-titik pengukuran untuk mengetahui error volumetrik suatu CMM, model matematis dari CMM tersebut dikembangkan. Dengan menggunakan model matematis tersebut, maka hanya sejumlah titik-titik ujung stylus tio yang diukur dan dengan menggunakan model matematis tersebut, seluruh error volumetrik loaksi tip tersebut dapat diketahui.

\subsection{Verifikasi performansi CMM}

Verifikasi performansi adalah suatu prosedur tes yang sangat penting untuk CMM, baik kontak dan non-kontak. Verifikasi performansi adalah suatu tes untuk memngecek apakah suatu CMM mempunyai akurasi pengukuran sesuai dengan spesifikasi dari manufakturnya. Dengan kata lain, verifikasi performansi adalah suatu proses untuk menguji kemampuan suatu CMM untuk melakukan pengukuran, bukan untuk menguji tingkat akurasi dari kemampuan positioning stylus tip suatu CMM.

Standard internasional yang paling umum digunakan untuk verifikasi performansi CMM berbasis kontak (tactile CMM) adalah seri ISO 10360 bagian 1 sampai dengan bagian 6. Detil dari standard-standard tersebut adalah:

- ISO 10360-1: berisi tentang istilah-istilah yang digunakan di dalam standard seri standard ISO 10360 (dalam hal ini bagian 2 sampai dengan bagian 6 untuk CMM berbasis kontak). Selain itu, standard ini juga berisi mengenai format dari sheet untuk laporan hasil proses suatu verifikasi performansi CMM.

- ISO 10360-2: berisi tentang panduan untuk melakukan verifikasi performansi CMM untuk pengukuran panjang. Hal ini berkaitan dengan verifikasi performansi struktur dari suatu CMM. Untuk verifikasi performansi pengukauran panhang (length measurement) tersebut, dibutuhkan pengukuran lima jenis panjang yang berbeda untuk tujuh arah pengukuran yang berbeda. Ketujuh arah pengukuran tersebut adalah tiga arah aksis $X, Y$ dan $Z$ dan empat arah diagonal ruang pada volume penukuran suatu CMM. Untuk setiap arah pengukuran, panjang maksimum pengukuran dari lima panjang tersebut adalah minimal $67 \%$ dari total panjang arah pengukuran tersebut. Jenis artifak terkalibrasi pada verifikasi ini pada umumnya berupa gauge bar atau ball bar.

- ISO 10360-3: berisi tentang panduan verifikasi performansi untuk CNC-controlled rotary table pada CMM. Rotary table tersebut pada umumnya dinamakan aksis ke-empat dari CMM. Pada verifikasi ini, pengukuran yang dilakukan adalah pengukuran relatif, sehingga artifak referensi yang terkalibrasi tidak dibutuhkan asalkan artifak tersebut rigid selama proses verifikasi berlangsung.

- ISO 10360-4: berisi tentang panduan untuk verifikasi performansi sistem probing yang digunakan untuk pengukuran dengan moda scanning. Proses verifikasi ini mengukur sebuat bola refernesi dengan moda scanning dengan lintasan scanning yang telah ditentukan.

- ISO 10360-5: berisi tentang panduan untuk verifikasi performansi sistem probing yang digunakan untuk pengukuran dengan moda point-to-point (discrete) Proses verifikasi ini mengukur sebuat bola refernesi dengan moda point-to-point dengan dengan jumlah titik yang telah ditentukan lokasi dan jumlahnya.

- ISO 10360-6: berisi tentang panduan proses fitting geometri yang digunakan untuk proses verifikasi berdasarkan ISO 10360-2, ISO 10360-3, ISO 10360-4 dan ISO 10360-5.

Gambar 46 memperlihatkan tujuh arah pengukuran untuk melakukan verifikasi performansi pengukuran panjang berdasarkan ISO 10360-2 di dalam volume pengukuran suatu CMM. Ketujuh arah pengukuran tersebut adlaah tiga arah sejajar dengan aksis $\mathrm{X}, \mathrm{Y}$ dan $\mathrm{Z} \mathrm{CM}$ dan empat arah diagonal ruang dalam volumen pengukuran CMM. Gambar 47 memperlihatkan contoh riil proses verifikasi performansi untuk pengukurna panjang (ISO 10360-2) dengan menggunakan gauge bar sebagai referensi panjang. 

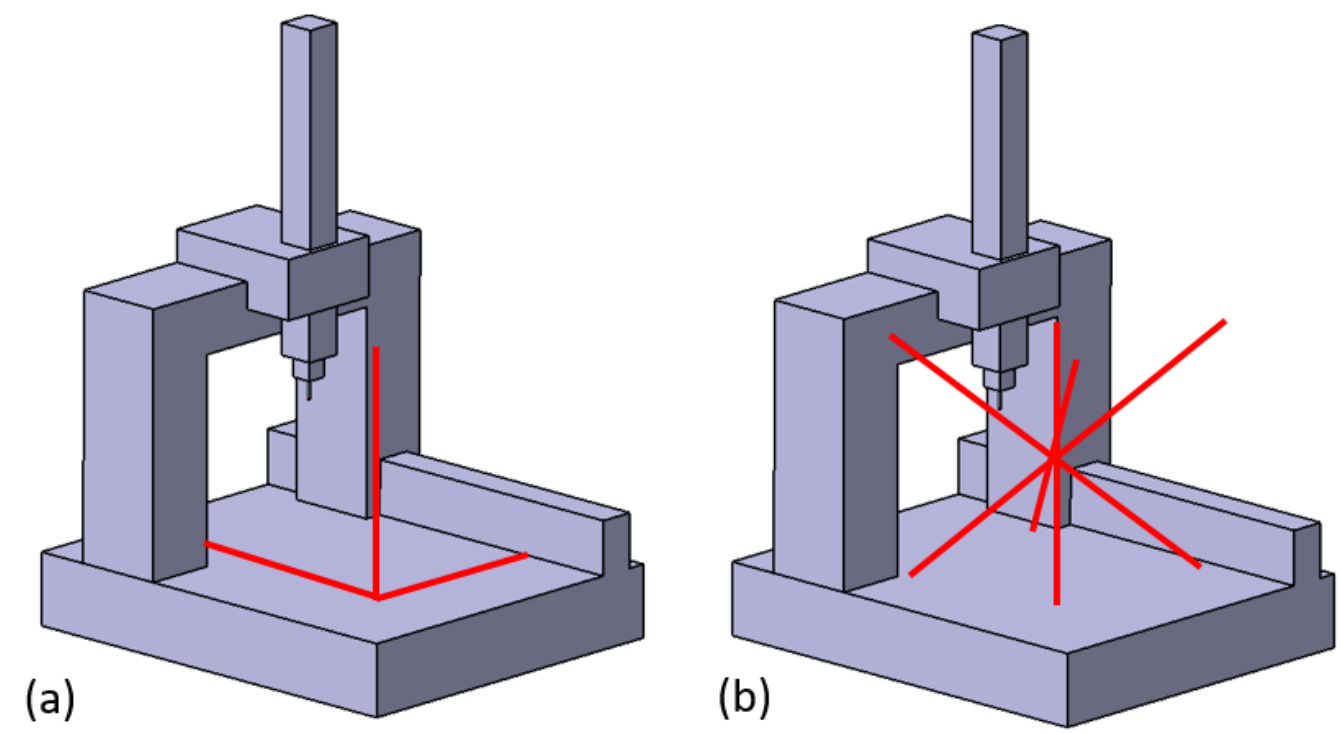

Gambar 46: (a) pengukuran tiga arah linier untuk aksis $X, Y$ dan $Z$, dan (b) pengukuran empat diagonal ruang.
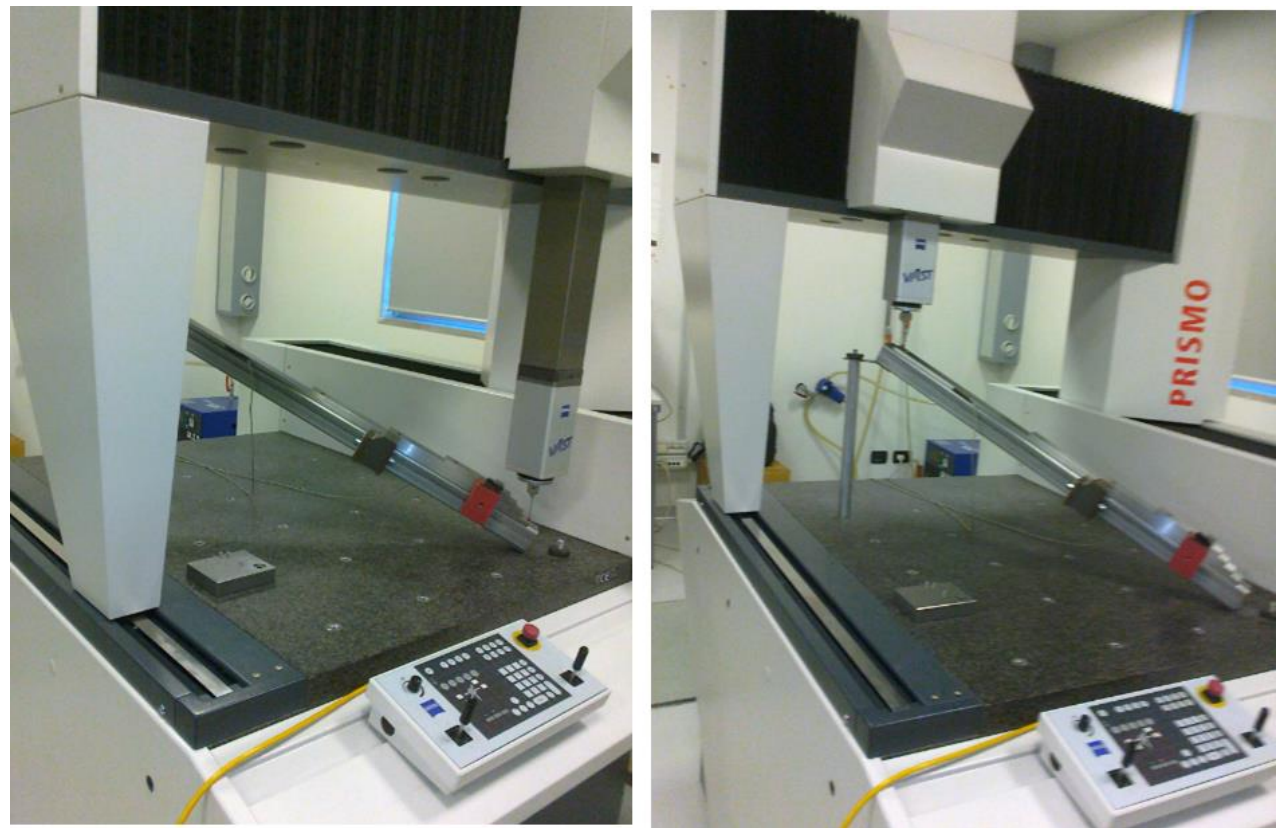

Gambar 47: Proses verifikasi performansi pada CMM untuk salah satu pengukuran untuk arah diagonal ruang. 
Parameter verifikasi performansi untuk pengukuran panjang (ISO 10360-2) adalah $M P E_{E, 0}$. MPE adalah maximum permissible error yang berarti maksimum error yang didapatkan untuk pengukuran panjang dengan suatu CMM. $M P E_{E, 0}$ adalah parameter umum untuk menggambarkan tingkat akurasi suatu CMM untuk melakukan pengukuran panjnag (dimensional). Contoh hasil verifikasi performansi ISO 10360-2 pada suatu CMM berbasis kontak diperlihatkan pada gamabr 48. Pada gambar 48, untuk pengukuran panjang suatu dimensi sampai dengan 900 $\mathrm{mm}$, maksimum error yang mungkin didapatkan adalah $\pm(2+L / 300) \mu m$ dimana $L$ dalam $\mathrm{mm}$. Dengan kata lain, MPE dari CMM tersebut adalah $M P E_{E, 0}= \pm(2+L / 300) \mu m$.

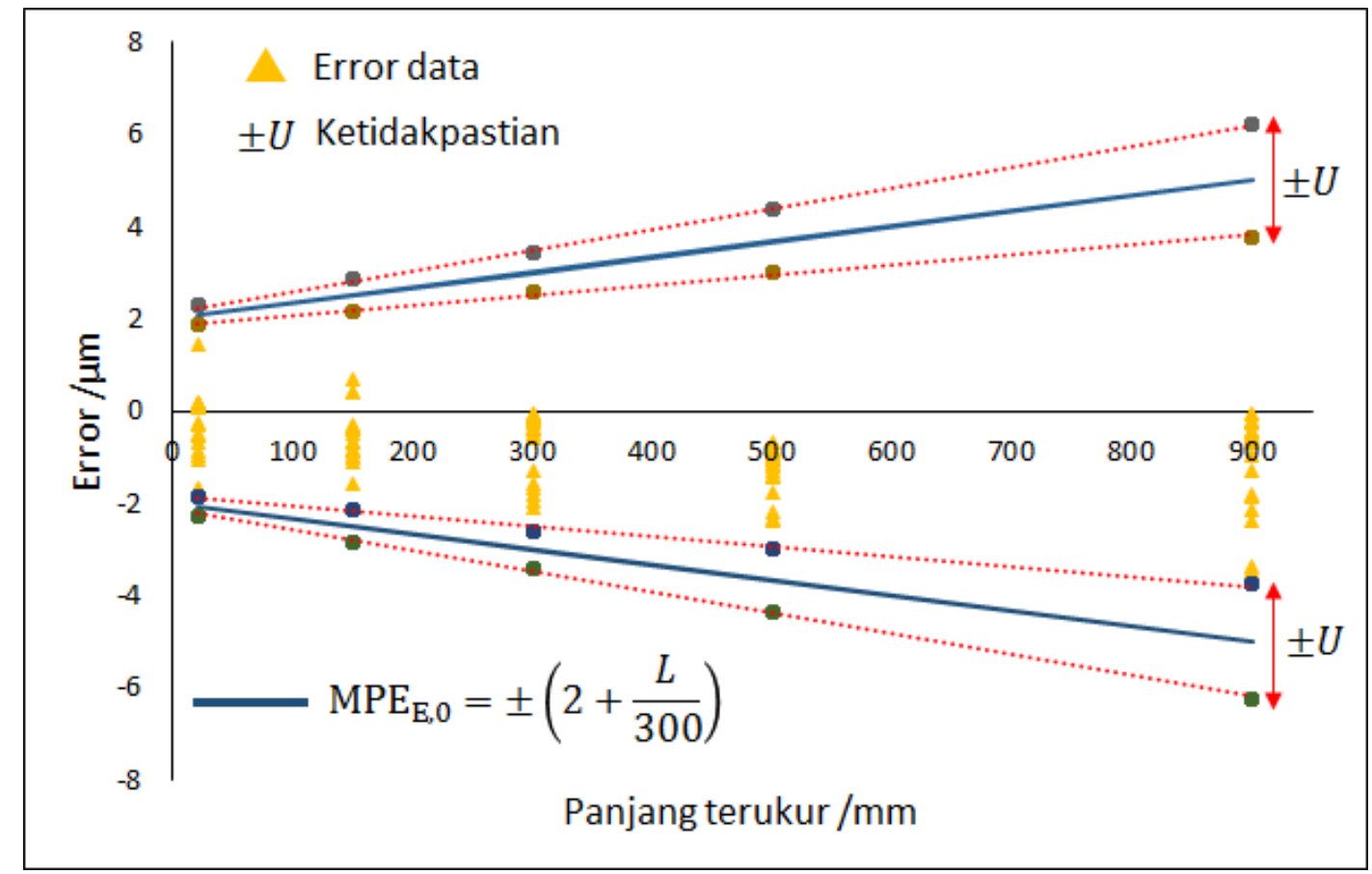

Gambar 48: Contoh hasil verifikasi sebuah CMM untuk pengukuran panjang sesuai dengan ISO10360-2.

Nilai ketidakpastian $U$ (pada gambar 48) dari hasil proses evaluasi performansi dapat diestimasi dengan mengikuti standard ISO/TS 23165 (ISO/TS 23165 2006). Nilai ketidakpastian $U$ tersebut dikalkulasi sebagai berikut:

$$
\begin{gathered}
u(E)=\sqrt{u^{2}\left(\varepsilon_{\text {cal }}\right)+u^{2}\left(\varepsilon_{a}\right)+u^{2}\left(\varepsilon_{\text {temp }}\right)+u^{2}\left(\varepsilon_{\text {align }}\right)+u^{2}\left(\varepsilon_{\text {fixture }}\right)} \\
U=2 \times u(E)
\end{gathered}
$$

dimana adalah $u(E)$ total kombinasi ketidakpastian, adalah $u\left(\varepsilon_{c a l}\right)$ ketidakpastian dari dimensi artifak terkalibrasi, $u\left(\varepsilon_{a}\right)$ adalah ketidakpastian yang disebabkan oleh kesalahan koefisin ekspansi termal (CTE), $u\left(\varepsilon_{\text {temp }}\right)$ adalah ketidakpastian yang berasal dari variasi temperatur dari lingkungan tempat evaluasi performansi dilakukan, $u\left(\varepsilon_{\text {align }}\right)$ adalah ketidakpastian yang berasal dari error proses alignment benda kerja terhadap sistem koordinat mesin (MCS) dan $u\left(\varepsilon_{\text {fixture }}\right)$ adalah ketidakastian yang berasal dari error akibat fixturing, misalnya deformasi benda kerja karena gaya clamping yang terlalu besar. 


\subsection{Estimasi ketidakpastian CMM}

Estimasi ketidakpastian dari hasil pengukuran dengan menggunakan suatu CMM diatur dalam standar internasioanl seri ISO 15530. Metode-metode yang terdapat pada ISO 15530 mempunyai landasan utama pada metode GUM (BIPM 2008). Metode GUM adalah landasan utama sampai saat ini untuk mengestimasi nilai ketidakpastian suatu hasil pengukuran. Dari metode GUM tersebut, berbagai macam metode estimasi ketidakpastian, seperti metode ISO 15530, dikembangkan. Metode ISO 15530 terbagi menjadi tiga jenis metode: ISO/DTS 15530-2, ISO 15530-3 dan ISO 15530-4.

Metode pada ISO/DTS 15530-2 dan ISO 15530-3 mengestimasi nilai ketidakpastian dengan mengikuti metode tabel (spreadsheet) dengan kalkulasi-kalkulasi yang spesifik untuk suatu pengukuran dengan CMM. Sedangkan metode ISO 15530-4 adalah berlandaskan metode simulasi Monte-Carlo. Metode ISO 15530 adalah metode yang paling sering ditemukan di industri karena pada indutsri-inudtsri tersebut banyak terdapat CMM untuk pengukuran dimensi dan geometri. Metode dan contoh estimasi ketidakpastian dari suatu hasil pengukuran dijelaskan dengan detil pada Bab 9 mengenai ketidakpastian (uncertainty). 


\section{BAB 6}

\section{Non-contact CMM}

CMM berbasis kontak merupakan sebuah teknologi yang sudah diterima dan diaplikasikan secara luas di industriindustri. Tingkat akurasi yang tinggi dan keterlacakan sampai pada definisi meter merupakan dua hal utama yang membuat CMM berbasis kontak menjadi sebuah referensi pengukuran dimensi dan geometri. Namun demikian, CMM berbasis kontak memiliki kekurangan-kekurangan yang menjadi kendala untuk menggunakan CMM tersebut untuk melakukan pengukuran dimensi dan geometri, misalnya pengukuran pada skala-mikro dan yang lebih kecil lagi.

Ada tiga kekurangan utama CMM berbasis kontak, yaitu: resiko rusaknya permukaan benda kerja yang lembut karena goresan stylus tip, terbatasnya aksesibilitas stylus tip untuk menjangkau fitur-fitur suatu benda yang kecil dan kecepatan pengukuran yang rendah apabila suatu pengukuran membutuhkan sampling titik yang sangat banyak. CMM berbasis non-kontak (non-contact $\mathrm{CMM}$ ) muncul untuk mengatasi ketiga kekurangan utama CMM berbasis kontak tersebut. CMM berbasis non-kontak juga sering disebut dengan CMM berbasis optik (optical CMM).

Bab ini memfokuskan pada pembahasan CMM berbasis non-kontak untuk pengukuran pada skala makro dan pengukuran pada skala mikro. Selain itu, pengukuran dengan menggunakan tomografi berbasis sinar-X akan dibahas juga pada bab ini. Verifikasi perfomansi berdasarkan seri ISO 10360 dan estimasi ketidakpastian berdasarkan seri ISO 15530 dibahas dengan mempresentasikan berbagai macam artefak untuk verifikasi performansi dan metode untuk estimasi ketidakpastian hasil pengukuran dengan CMM berbasis non-kontak.

Pada bab ini, konsep matriks homogenous dan sifat-sifat transformasinya sangat banyak digunakan untuk melakukan rekonstruksi 3D berbagai macam metode non-contact CMM. Maka dari itu, pembaca diharapkan dapat merujuk pada bab 3.4.6 apabila ingin mengetahui mengenai konsep matriks homogenous dan sifat-sifat transformasinya tersebut.

\subsection{Optical CMM}

Optical CMM (CMM berbasis non-kontak) yang akan dibahas untuk pengukuran skala makro adalah laser triangulation, phogrammtery dan fringe projection. Namun demikian, optical CMM untuk pengukuran tersebut tidak sebatas pada ketiga metode ini, terdapat metode-metode lainnya, seperti optical CMM berbasis konoskopik. Namun demikian, laser triangulation, phogrammtery dan fringe projection merupakan optical CMM yang paling sering ditemui di industri-industri. Nama lain dari ketiga metode tersebut adalah 3D scanner.

\subsubsection{Laser triangulation/laser scanner}

Laser triangulation atau yang sering disebut juga sebagai laser scanner merupakan salah satu optical CMM yang paling pertama dikembangkan untuk pengukuran dimensi dan geometri. Teknologi laser scanner sudah berusia sekitar 60 tahun. Bukan hanya pada industri manufaktur, laser scanner juga banyak digunakan pada bidang teknik sipil dan geografi untuk merekonstruksi model 3D dari suatu gedung atau suatu wilayah. Selain itu, laser scanner juga sering digunakan pada bidang arkeologi untuk membuat model 3D dari berbagai jenis benda antik. 


\section{Prinsip kerja}

Laser line diproyeksikan pada sebuah permukaan benda dan deviasi dari laser line tersebut dianalisis untuk mendapatkan tinggi $z$ dari titik pada suatu lokasi $x$ dan $y$. Analisis untuk mendapatkan tinggi $z$ pada lokasi $x$ dan $y$ tersebut adalah dengan menggunakan metode triangulasi. Gambar 1 memperlihatkan komponen-komponen dan prinsip kerja dari laser trinagulation.

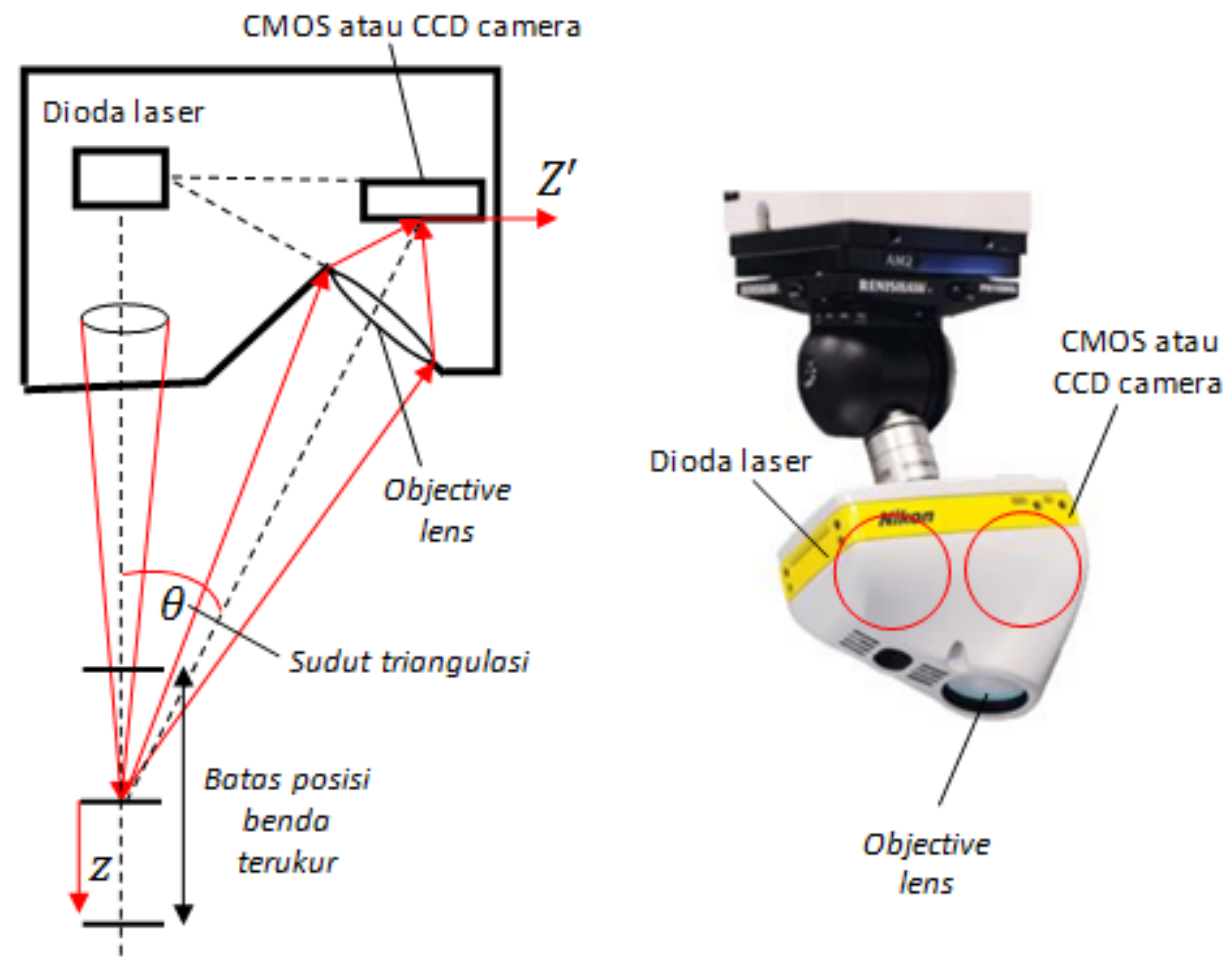

Gambar 1: Komponen-komponen dan prinsip kerja dari laser triangulation

Pada gambar 1, komponen-komponen utama dari laser triangulation adalah: Dioda laser dan sensor kamera (CMOS / CCD). Dioda laser adalah komponen yang menghasilkan laser yang merupakan sumber cahaya koheren. Kelebihan dari laser untuk aplikasi ini adalah rasio signal-to-noise yang baik. Laser tersebut bersifat monokromatik, koheren terhadap jarak dan waktu, collimated (plane-wave), kontinu dan tahan lama. Sumer laser tersebut dapat dimodifikasi dengan menggunakan sumber laser dengan multipel laser atau dengan menggunakan sebuah lensa agar laser terproyeksikan menjadi sebuah garis. Dengan modifikasi tersebut, proses pengukuran dapat dipercepat. Sensor kamera adalah sebuah komponen yang terdiri dari matrik yang berisi sensor cahaya berukuran kecil. Setiap sensor cahaya tersebut akan mengkonersi energi foton dari cahaya ke daam bentuk pixel.

Selanjutnya, pada gambar 1, cara kerja laser triangulation adalah sebagai berikut. Sebuah sumber laser memancarkan laser yang difokuskan ke permukaan suatu benda. Kemudian, permukaan benda tersebut merefleksikan balik laser tersebut secara terdifusi. Refleksi balik dari laser tersebut difokuskan pada sebuah sensor cahaya, yaitu kamera berbasis sensor CMOS atau CCD. Kemudian, berbasiskan posisi refleksi laser pada sensor kamera tersebut, kalkulasi matematis dilakukan untuk mendapatkan posisi tinggi $z$ titik tersebut. Setiap perpindahan posisi suatu permukaan dari posisi nominal, maka titik spot laser yang tertangkap kamera akan bergeser ke arah $x$ atau $y$. Mampu tidaknya suatu permukaan dapat diukur dengan metode laser triagnulation adalah permukaan suatu benda yang diukur harus berada pada jangkaun/batas posisi benda terukur dan laser yang direfleksikan oleh permukaan tersebut harus 
dapat ditangkap oleh sensor kamera. Situasi umum yang membuat laser yang direfleksikan oleh suatu permukaan pada pengukuran dengan laser triangulation adalah permukaan tersebut sangat reflektif atau laser yang direfleksikan tersebut terhalang oleh suatu fitur under-cut.

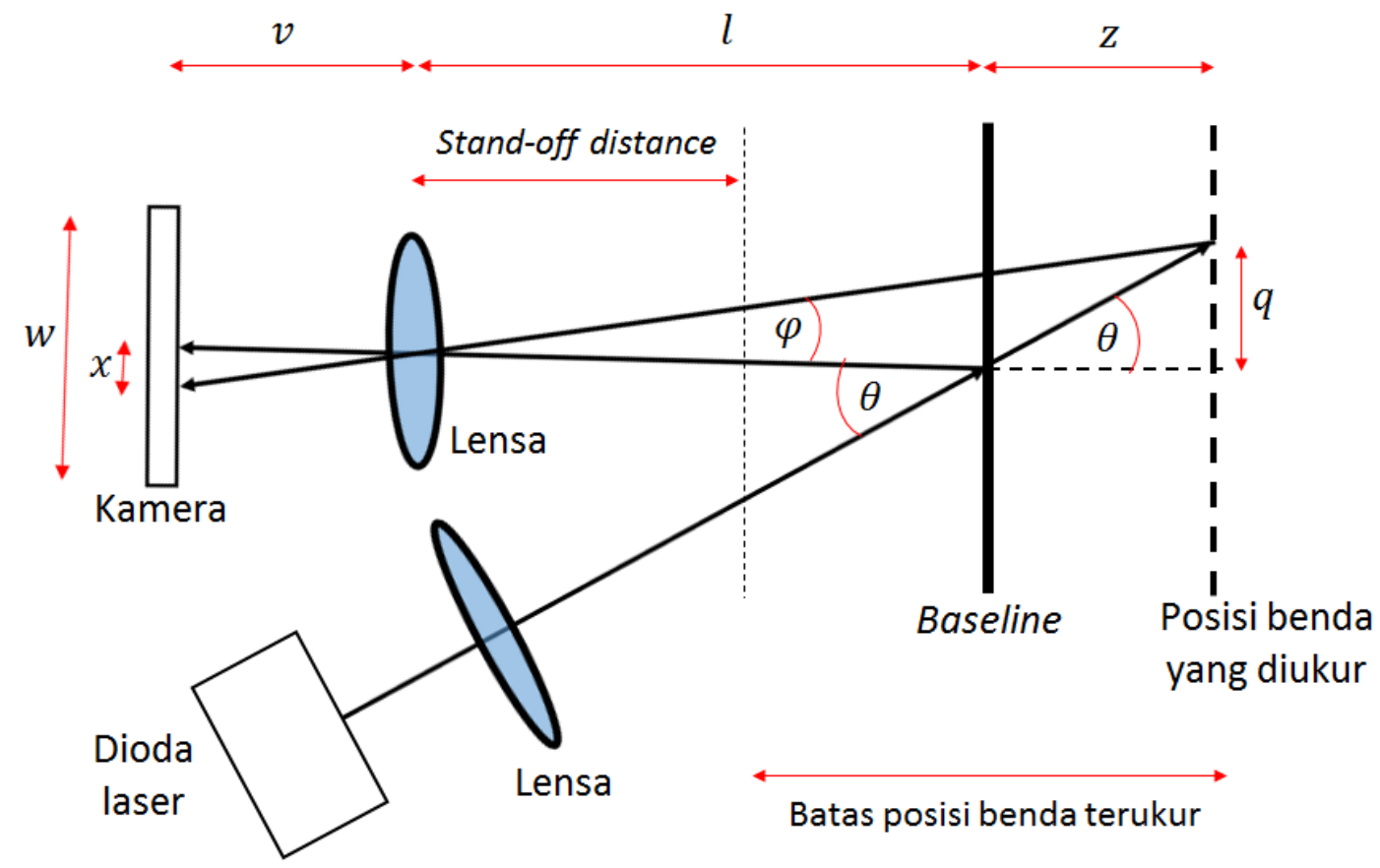

\section{$x=$ Jarak pixel ke pusat sensor kamera \\ $w=$ Lebar dari sensor kamera \\ $v=$ Jarak antara lensa 1 dengan kamera \\ $l=$ Jarak nominal antara surface (baseline) dengan lensa 1 \\ (sistem pengukuran) \\ $\theta=$ Sudut antara aksis optikal dari laser dan aksis optical \\ kamera}

Gambar 2: Kalkulasi matematis untuk mendapatkan posisi tinggi $z$ pada laser triangulation.

Proses kalkulasi matematis untuk mendapatkan posisi tinggi $z$ pada laser triangulation diperlihatkan pada gambar 2. Penurunan persamaan untuk mengkalkulasi $z$ adalah:

$$
\begin{aligned}
& \tan \varphi=\frac{q}{z+l} \\
& \tan \theta=\frac{q}{z}
\end{aligned}
$$


Dengan demikian, dari persamaan (1) dan (2) didapatkan:

$$
\begin{aligned}
& \mathrm{q}=\mathrm{z} \cdot \tan \theta=(z+l) \cdot \tan \varphi \\
& \tan \varphi=z \cdot \frac{\tan \theta}{z+l}
\end{aligned}
$$

Dari persamaan (4), apabila $z \ll l$, yaitu nilai $z$ jauh lebih kecil dari $l$, maka:

$$
\tan \varphi \cong z \cdot \frac{\tan \theta}{l}
$$

Dengan demikian, relasi antara perpindahan posisi pixel pada sensor kamera (yang bisa dideteksi dengan algoritma analisis image) dengan relasi geometrik suatu sistem laser triangulation adalah (gambar 2):

$$
x=v \cdot \tan \varphi \cong \frac{v \cdot z}{l} \tan \theta
$$

Sehingga, posisi $z$ dapat dikalkulasi dengan:

$$
Z \cong \frac{x \cdot l}{v \cdot \tan \theta}
$$

Dimana variabel-variabel pada persamaan di atas dijelaskan pada gambar 2.

Selanjutnya, analisis sensitifitas $S$ suatu laser triangulation, yaitu variasi antara input dan output dari sistem tersebut dapat dianalisis sebagai berikut:

$$
S=\frac{x}{z}=\frac{v \cdot \tan \theta}{l}=m \cdot \tan \theta ; \quad m=\frac{v}{l}
$$

Dimana $m$ adalah gradien yang mempunyai relasi dengan $z$ sebagai berikut (dari persamaan (7)):

$$
z=\frac{x}{m \cdot \tan \theta}
$$

Nilai $x$ harus berada pada batas dari ukuran sensor kamera $W$, sehingga:

$$
x_{\min } \geq-W / 2 \text { dan } x_{\max } \leq W / 2
$$

Sehingga, batas posisi benda terukur pada arah $z$ adalah:

$$
z_{\max }-z_{\min }=\frac{\left(x_{\max }-x_{\min }\right)}{m \cdot \tan \theta}=\frac{W}{m \cdot \tan \theta}
$$

Resolusi pada sensor kamera $\Delta x$ menentukan variasi pada posisi $z(\Delta z)$ yang dapat dikalkulasi sebagai berikut:

$$
\Delta z=\frac{\Delta x}{m \cdot \tan \theta}
$$




\section{$\underline{\text { Aplikasi }}$}

Aplikasi dari laser triangulation untuk pengukuran dimensi dan geometri sangat banyak, terutama untuk industri otomotif dan untuk industri desain produk. Pada bidang desain produk, laser triangulation sangat sering digunakan sebagai alat bantu proses reverse engineering, dimana suatu produk jadi dipindai dengan suatu sistem laser triangulation. Kemudian, 3D CAD model dari produk tersebut direkonstruksi ulang. Dengan direkonstruksinya 3D CAD model tersebut, deviasi geometri produk tersebut dapat di cek atau 3D CAD model tersbut dapat diproses untuk proses permesinan berbasis CNC. Gambar 3 memperlihatkan beberapa contoh hasil dari pemindaian suatu permukaan benda dengan sistem suatu laser triangulation.

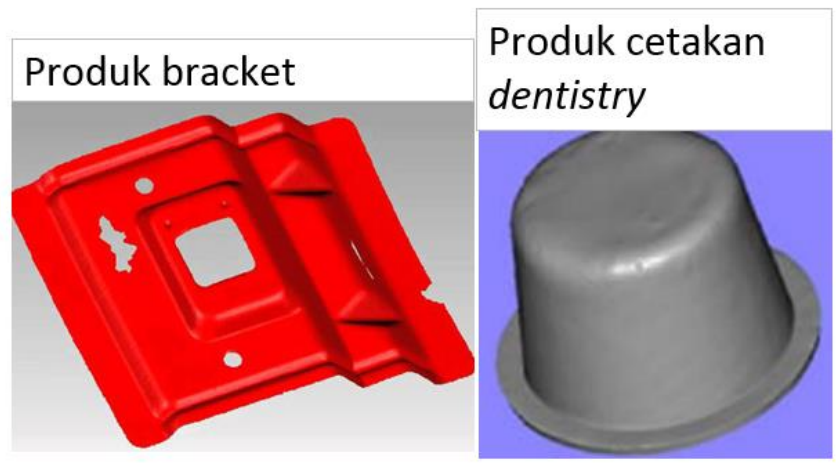

Gambar 3: Contoh dari 3D model yang telah diproses dari data hasil pemindain dengan suatu sistem laser triangulation.

Kelebihan dari laser trinagulation adalah:

- Dapat meng-sample titik-titik berjumlah banyak dalam waktu yang relatif singat, yaitu bisa mencapai 20000 titik/s.

- Kecepatan pemindaian yang relatif cepat. Untuk meningkatkan kecepatan pemindaian, sumber laser dengan multipel titik atau dengan memproyeksikan laser tersebut menjadi sebua garis.

- Harga yang realtif medium.

- Tingkat akurasi yang cukuo tinggi, dapat mencapai sekitar $50 \mu \mathrm{m}$.

- Mempunyai sifat portabilitas.

- Dapat mengakomodasi pengukuran untuk benda yang besar.

- Dapat digabungkan dengan CMM (lihat gambar 1).

Kekurangan dari laser triangulation adalah:

- Sangat terpengaruh dengan kondisi cahaya dan reflektifitas benda yang diukur.

- Sulit untuk mengukur sebuah permukaan yang mempunyai gradient permukaan yang besar.

- Tidak bisa mengukur benda yang bergerak.

- Mempunyai potensi bahaya terhadap kesehatan mata, karena menggunakan sumber laser.

- Sulit untuk mengukur sebuah permukaan yang terlalu silau (specular) karena tidak ada atau sedikit laser yang bisa tertangkap kamera.

\subsubsection{Photogrammetry}

Photogrammetry adalah sebuah metode untuk merekonstruksi bentuk 3D dari minimal dua atau lebih gambar 2D (2D image). Pembahasan ini memfokuskan pada metode photogrammtery dengan menggunakan dua gambar, atau yang disebut sebagai stereo vision atau stereo photogrammetry. Pada prinsipnya, metodenya berbasis teknik 
triangulasi (seperti pada laser triangulation) dari dua gambar 2D (atau lebih). Stereo photogrammtery terinspirasi dari kemmapuan penglihatan seseorang yang dapat menciptakan perspesi 3D dari dua gambar yang terlihat dari kedua mata orang tersebut. Gambar 4 memperlihatkan contoh dari pengukuran dengan stereo photogrammtery.

Untuk merekonstruksi 3D dengan sistem stereo photogrammtery, masalah fundamental yang harus diatasi adalah masalah korespondensi antar-titik (points correspondence). Masalah tersebut disebabkan karena sistem ini menggunakan dua gambar yang mengkap suatu benda yang sama, sehingga proyeksi benda tersebut pada kedua gambar berbeda sehingga terdapat perpedaan koordinat suatu titik pada benda tersebut pada kedua gambar tersebut. Masalah korespondensi antar-titik didefinisikan sebagai masalah untuk menentukan perbedaan koordinat titik-tiitk pada kedua gambar tersebut (Zhang 2013). Pada gambar 4, titik 3D pada suatu benda w pada sebuah permukaan benda diproyeksikan pada bidang gambar dua buah kamera. Sehingga, $\mathbf{p}_{\mathbf{1}}$ dan $\mathbf{p}_{\mathbf{2}}$ adalah titik-titik 2D hasil proyeksi dari $\mathbf{w}$. Masalah korespondensi antar-titik adalah bagaimana menentukan koordinat $\mathbf{p}_{\mathbf{1}}$ dan $\mathbf{p}_{\mathbf{2}}$ pada pada kedua gambar tersebut.

Proses kalkulasi untuk menentukan semua titik $\mathbf{p}_{1}$ dan $\mathbf{p}_{2}$ membutuhkan sebuah proses komputasi yang sangat besar. Untuk mengurangi beban komputasi, kedua kamera pada sistem tersebut harus dikalibrasi untuk mengetahi relasi geometri antara kedua kamera tersebut (rotasi dan translasi antara satu kamera dengan kemera lainnya). Setelah kedua kamera tersebut dikalibrasi, maka kordinat titik-titik $\mathbf{p}_{\mathbf{1}}$ dan $\mathbf{p}_{\mathbf{2}}$ terbatas hanya pada garis epipolar (epipolar geometry) seperti yang terlihat pada gamar 5. Untuk lebih mempercepat proses kalkulasi korespondensi titik-titik tersebut, garis epipolar yang tidak parallel dapat ditransformasikan sehingga menjadi parallel dengan melakukan proses rektifikasi stereo (stereo rectification). Proses rektifikasi stereo mengtransformasi semua garis epipolar pada kedua gamar stereo menjadi parallel terhadap aksis horisontal pada kedua image tersebut. Keseluruha proses menentukan korespondensi titik-titik tersebut dinamakan stereo matching.

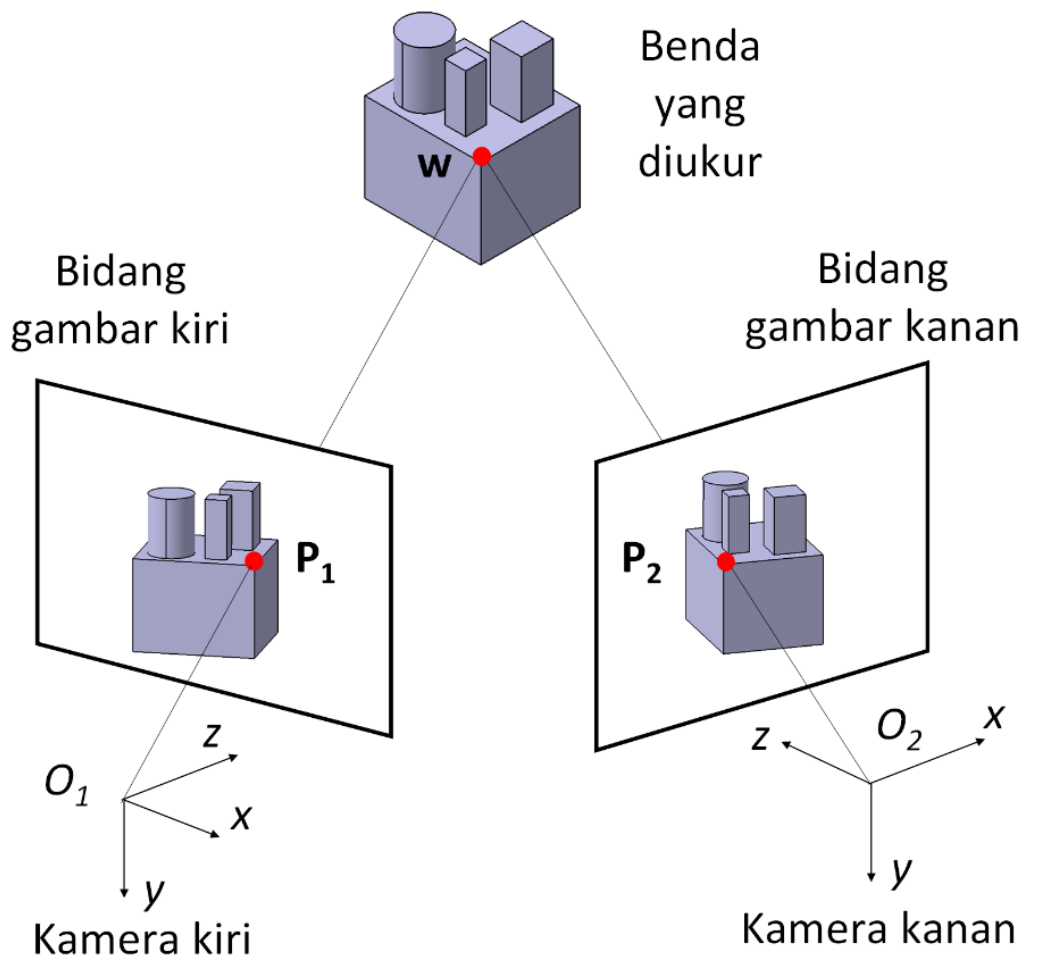

Gambar 4: Contoh pengukuran dengan sebuah stereo photogrammtery. 


\section{Prinsip kerja}

Komponen-komponen (pada umumnya) stereo photogrammtery hanya terdiri dari dua kamera yang identik dan komponen penyangga kedua kamera tersebut atau terdiri dari satu kamera tetapi dapat digerakkan untuk mengambil dua buah gambar suatu benda dari sudut yang berbeda. Langkah-langkah dari proses kerje stereo photogrammtery adalah sebagai berikut.

\section{Penentuan geometri epipolar}

Gambar 5 memperlihatkan prinsip dari geometri epipolar dan batasannya. Pada prinsipnya, dua korespondensi titik pada kedua gambar kira dan kanan sistem stereo photogramtry selalu terletak pada garis epipolarnya. Variabelvariabel yang terlibat dalam penentuan epipolar geometri dijelaskan sebagai berikut. $\pi_{1}$ dan $\pi_{1}$ adalah dua bidang gambar kiri dan kanan. $O_{1}$ dan $O_{2}$ adalah titik pusat dari kamera kiri dan kanan. $\mathbf{P}_{\mathbf{1}}$ dan $\mathbf{P}_{\mathbf{2}}$ Adalah proyeksi titik 3D pada objek $\mathbf{W}$ pada gambar kiri dan kanan.

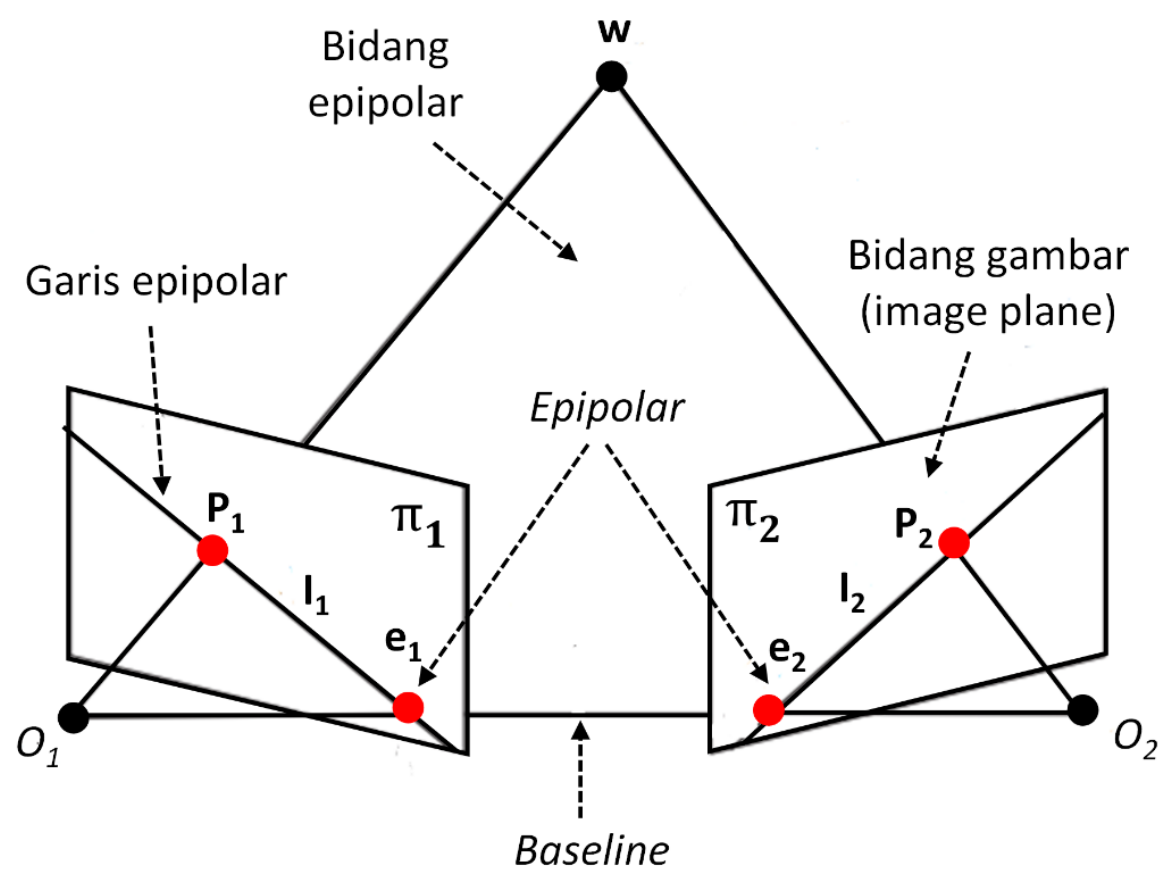

Gambar 5: Prinsip kerja stereo photogrammtery.

Pada gambar 5, sebuah bidang 3D terbentuk oleh tiga titik $\mathbf{W}, O_{1}$ dan $O_{2}$ yang memotong kedua bidang gambar kiri dan kanan. Bidang 3D tersebut dinamakan bidang epipolar dan perpotongan dengan kedua bidang gambar tersebut dinamakan garis epipolar $\mathbf{I}_{\mathbf{1}}$ dan $\mathbf{I}_{\mathbf{2}}$ (gambar 5). Sehingga, dapat terlihat bahwa kedua titik yang saling berkorespondensi terletak pada garis epipolarnya yang merupakan batasan penting untuk menentukan dua titik yang saling berkorespondensi pada kedua gambar tersebut.

Kedua titik $\mathbf{P}_{\mathbf{1}}$ dan $\mathbf{P}_{\mathbf{2}}$ dapat direpresentasikan sebagai vektor 2D pada sistem kooridnat gambar dan sebagai vektor 3D pada sistem kooridnat kamera. berdasarkan sistem koordinat kamera, komponen $z$ pada adalah jarak focal (focal length) dari masing-masing kameranya $O_{\mathbf{1}}$ dan $O_{\mathbf{2}}$. Transformasi dari $\mathbf{P}_{\mathbf{1}}$ ke $\mathbf{P}_{\mathbf{2}}$ dapat diformulasikan sebagai:

$$
\mathbf{P}_{\mathbf{2}}=R \cdot \mathbf{P}_{\mathbf{1}}+\mathbf{t}
$$


dimana adalah $\mathbf{t}$ vektor translasi dan adalah $\mathbf{R}$ vektor rotasi antara kedua kemera tersebut. Produk cross dari vektor $\mathbf{t}$ dan $\mathbf{P}_{\mathbf{2}}$, yaitu $\mathbf{T} \mathbf{P}_{\mathbf{2}}$, tegak lurus terhadap vektor $\mathbf{t}$ dan $\mathbf{P}_{\mathbf{2}}$. $\mathbf{T} \mathbf{P}_{\mathbf{2}}$ didefinisikan sebagai:

$$
\mathrm{T}=\left[\begin{array}{ccc}
0 & -t_{z} & t_{y} \\
t_{z} & 0 & -t_{x} \\
-t_{y} & t_{x} & 0
\end{array}\right]
$$

Dimana $t_{x}, t_{y}, t_{z}$ adalah komponen $\mathrm{x}, \mathrm{y}$, dan $\mathrm{z}$ dari vektor $\mathbf{t}$. dengan demikian, $\mathbf{T P}_{\mathbf{2}}$ adalah representasi matriks dari produk cross antara dua vektor

$\mathbf{P}_{\mathbf{1}}, \mathbf{P}_{\mathbf{2}}$ dan T terletak pada bidang epipolar yang sama, maka relasi antara ketiga komponen tersebut adalah:

$$
\begin{aligned}
\mathbf{P}_{2} \cdot\left(\mathrm{T} \mathbf{P}_{2}\right)=0 & \text { karena produk dot dari dua vektor yang tegak lurus adalah } 0 . \\
& \mathbf{P}_{\mathbf{2}} \cdot\left(\mathrm{T}\left(\mathbf{R P}_{\mathbf{1}}+\mathbf{t}\right)\right)=0 \\
& \mathbf{P}_{\mathbf{2}} \cdot\left(\mathbf{T}\left(\mathbf{R P}_{\mathbf{1}}\right)\right)=0 \\
& \mathbf{P}_{\mathbf{2}}{ }^{\mathbf{T}} \mathbf{E} \mathbf{P}_{\mathbf{1}}=0
\end{aligned}
$$

dimana $\mathbf{E}$ adalah matriks essential yang didefinisikan sebagai:

$$
\mathbf{E}=\mathbf{T R}
$$

Dari persamaan (16), didapatkan bahwa:

$$
\mathbf{I}_{2}=\mathbf{E P}_{1}
$$

Dengan demikian, dengan memasukkan persamaan (19) ke persamaan (18), didapatkan:

$$
\mathbf{P}_{2}{ }^{T} \mathbf{I}_{2}=0
$$

Dari sini, dapat dilihat bahwa apabila sebuah titik di gambar kiri $\mathbf{P}_{\mathbf{1}}$ terdifinisikan, maka titik korespondensinya di gambar kanan $\mathbf{P}_{\mathbf{2}}$ akan berada pada garis epipolar kanan $\mathbf{I}_{\mathbf{2}}$. Untuk mengetahui sebuah titik $\mathbf{P}_{\mathbf{2}}$ berada pada garis epipolar $\mathbf{I}_{\mathbf{2}}$, produk dot dari $\mathbf{P}_{\mathbf{2}}$ dan $\mathbf{I}_{\mathbf{2}}$ harus 0 . Pada kenyataannya, produk dot tersebut tidak bisa berupa angka 0 secara eksak, karena koordinat gambar yang bersifat diskrit dan kemungkinan rouding error pada proses kalkulasi. Sehingga, apabila $\mathbf{P}_{\mathbf{2}}{ }^{\boldsymbol{T}} \mathbf{I}_{\mathbf{2}}$ sangat dekat dengan 0, maka $\mathbf{P}_{\mathbf{2}}$ dianggap berada pada haris epipolar $\mathbf{I}_{\mathbf{2}}$.

Denan demikian, garis epopolar pada gambar kiri didefinisikan sebagai:

$$
\mathbf{I}_{1}=\mathbf{P}_{2}{ }^{T} E
$$

Dengan demikian, dengan memasukkan persamaan (21) ke persamaan (18), didapatkan:

$$
\mathbf{I}_{1} \mathbf{P}_{1}=\mathbf{0}
$$

Representasi titik-titik pada kedua gambar stereo akan lebih pas apabila merujuk pada sistem koordinat pixel yang merujuk pada kedua kamera tersebut dari pada merujuk pada sistem koordinat gambar. Maka dari itu, konfersi dari sistem koordinat gambar ke sistem koordinat piksel dilakukan sebagai berikut: 


$$
\begin{aligned}
& \mathbf{P}_{\mathbf{1}}{ }^{\prime}=\mathbf{K}_{\mathbf{1}} \mathbf{P}_{\mathbf{1}} \\
& \mathbf{P}_{\mathbf{2}}{ }^{\prime}=\mathbf{K}_{\mathbf{2}} \mathbf{P}_{\mathbf{2}}
\end{aligned}
$$

dimana $\mathbf{K}_{\mathbf{1}}$ dan $\mathbf{K}_{\mathbf{1}}$ adalah matriks intrinsik dari kedua kamera kiri dan kanan, $\mathbf{P}_{\mathbf{1}}{ }^{\prime}$ dan $\mathbf{P}_{\mathbf{2}}{ }^{\prime}$ adalah koordinat $\mathbf{P}_{\mathbf{1}}$ dan $\mathbf{P}_{2}$ pada sistem koordinat piksel. Sehingga, persamaan (18) ditransformasi menjadi:

$$
\mathbf{P}_{2}{ }^{\prime T} \mathrm{FP}_{1}{ }^{\prime}=\mathbf{0}
$$

dimana $\mathbf{F}$ adalah matrik fundamental yang didefinisikan sebagai:

$$
\mathbf{F}=\left\{\mathbf{K}_{\mathbf{2}}^{-1}\right\}^{\mathbf{T}} \mathbf{E K}_{\mathbf{1}}^{-1}
$$

Persamaan (25) lebih sering digunakan dari pada persamaan (18) karena persamaan (25) dalam bentuk sistem piksel daripada persamaan (18) yang dalam bentuk sistem metrik. Untuk mendapatkan matrik fundamental $\mathbf{F}$, maka matrik essenstial $\mathbf{E}$ harus diketahui terlebih dahulu dan kalibrasi geometrik dari kedua kamera stereo harus dilakukan.

Untuk mengatasi masalah tersebut, beberapa metode menggunakan korespondensi beberapa titik pada kedua gambar stereo untuk menenentukan matrik fundamental F. Metode tersebut adalah sebagai berikut. Dengan mendefinisikan $\widetilde{\mathbf{p}}_{\mathbf{1}}^{\prime}=\left[\begin{array}{lll}u & v & 1\end{array}\right]^{\boldsymbol{T}}$ dan $\widetilde{\mathbf{p}}_{\mathbf{1}}^{\prime}=\left[\begin{array}{lll}u^{\prime} & v^{\prime} & 1\end{array}\right]^{\boldsymbol{T}}$, Maka persamaan (25) menjadi:

$$
\left[\begin{array}{lll}
u^{\prime} & v^{\prime} & 1
\end{array}\right]\left[\begin{array}{lll}
F_{11} & F_{12} & F_{13} \\
F_{21} & F_{22} & F_{23} \\
F_{31} & F_{32} & F_{33}
\end{array}\right]\left[\begin{array}{l}
u \\
v \\
1
\end{array}\right]=0
$$

Yang dapat ditulis ulang sebagai:

$$
\left[\begin{array}{lllllllll}
u u^{\prime} & u v^{\prime} & u & u^{\prime} v & v v^{\prime} & v & u^{\prime} & v^{\prime} & 1
\end{array}\right]\left[\begin{array}{l}
F_{11} \\
F_{12} \\
F_{13} \\
F_{21} \\
F_{22} \\
F_{23} \\
F_{31} \\
F_{32} \\
F_{33}
\end{array}\right]=0
$$

pada persamaan (28) di atas, nilai $F_{33}$ dapat di set menjadi 1, karena sifat singularitas dari matrik fundamental. Hal ini menyebabkan bahwa hanya ada delapan variabel yang tidak diketahui dari persamaan tersebut. Apabila ada setidaknya 8 titik korespondensi, maka kedelapan variabel tersebut data ditentukan. Metode ini dinamakan eight-point algorithm, yaitu: 


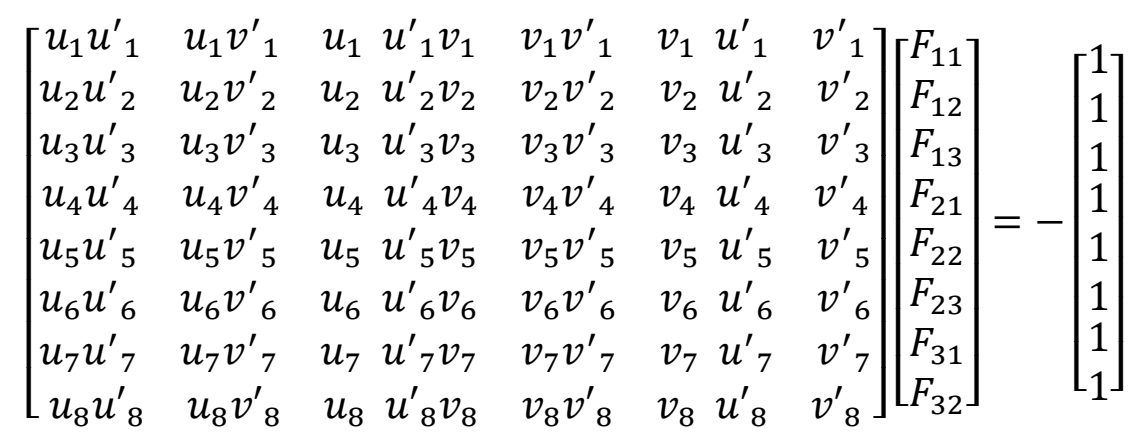

\section{Kalibrasi dari dua sistem kamera}

Tujuan dari kalibrasi ini adalah untuk mengetahui relasi geometri antara kedua sistem koordinat kamera tersebut (apabila eight-point algorithm tidak digunakan). Setelah relasi geometri tersebut diketahui, maka lankah berikutnya, yaitu rektifikasi dari gambar stereo dan rekonstruksi 3D dari dua gambar stereo dapat dilakukan. Untuk melakukan kalibrasi, model kamera harus ditentukan terlebih dahulu.

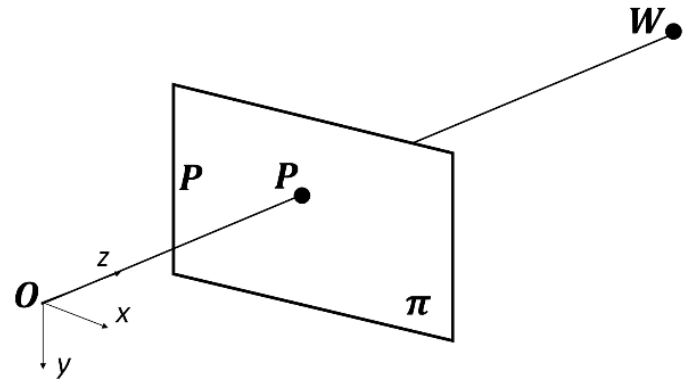

(a)

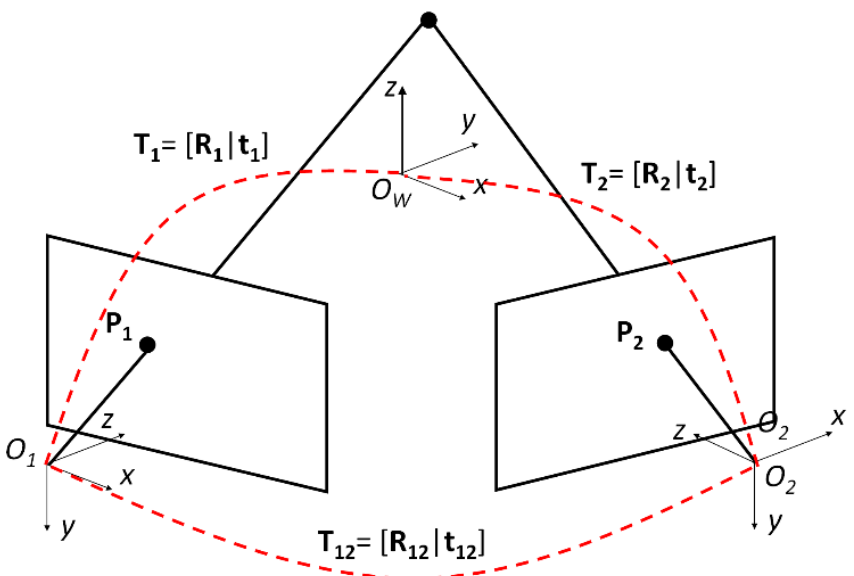

(b)

Gambar 6: (a) Model kamera pin-hole dan (b) Relasi sistem koordinat world, pixel dan gambar.

Model kamera paling umum dan simpel yang digunakan untuk proses kalibrasi ini adalah model kamera pin-hole (gambar 6a). Pada gambar 6a, model kamera tersebut adalah sebuah titik pusat optik $\mathbf{O}$ dan bidang gambarnya $\boldsymbol{\pi}$. W adalah sebuah titik 3D dan $\mathbf{P}$ adalah titik 2D pada gambar yang merupakan titik potong antara $\boldsymbol{\pi}$ dan garis yang melalui $\mathbf{W}$ dan $\mathbf{O}$. titik-titik $\mathbf{W}, \mathbf{P}$ dan $\mathbf{P}^{\prime}$ dalam bentuk homogenous koordinat adalah $\mathbf{W}=\left[\begin{array}{lll}x & y & z\end{array}\right]^{T}$ terhadap sistem koordinat world, $\mathbf{P}=\left[\begin{array}{lll}u & v & 1\end{array}\right]^{T}$ terhadap bidang gambar (pada sensor kamera) dan $\mathbf{P}^{\prime}=\left[\begin{array}{ll}u^{\prime} & v^{\prime} \\ 1\end{array}\right]^{T}$ terhadap bidang piksel. Pemetaan dari koordinat 3D (W) ke koordinat 2D (P) tersebut merupakan proyeksi perspektif yang formulasikan sebagai:

$$
\widetilde{\mathbf{P}}^{\prime}=\mathbf{K} \mathbf{P}^{\prime} \cong \mathbf{K} \widetilde{\mathbf{M}} \widetilde{\mathbf{W}}
$$

dimana $\mathbf{P}=\left[\begin{array}{lll}u & v & 1\end{array}\right]^{T}, \mathbf{P}^{\prime}=\left[\begin{array}{lll}u^{\prime} & v^{\prime} & 1\end{array}\right]^{T}$ dan $\mathbf{W}=\left[\begin{array}{llll}x & y & z & 1\end{array}\right]^{T}$ adalah koordinat homogenous dari $\mathbf{P}, \mathbf{P}^{\prime}, \mathbf{W}$. Arti dari persamaan (30) adalah kamera tersebut dimodelkan oleh matriks skala dan translasi $\mathbf{K}$ dan matriks 
transofmrasi perspektif M. Matriks $\mathbf{M}$ diformulasikan sebagai:

$$
\widetilde{\mathbf{M}}=\mathbf{A}[\mathbf{R} \mid \mathbf{t}]
$$

Matriks $\mathbf{K}$ dan $\mathbf{A}$ merupakan matriks yang berisi tentang parameter intrinsik kamera. Kedua matriks tersebut diformulasikan sebagai:

$$
\begin{aligned}
\mathbf{K} & =\left[\begin{array}{ccc}
k_{u} & 0 & 0 \\
0 & k_{v} & p \\
0 & 0 & 1
\end{array}\right] \\
\mathbf{A} & =\left[\begin{array}{ccc}
f_{u} & \gamma & u_{0} \\
0 & f_{v} & v_{0} \\
0 & 0 & 1
\end{array}\right]
\end{aligned}
$$

dimana $f_{u}, f_{v}$ adalah panjang fokal pada arah horisontal dan vertikal, $k_{u}, k_{v}$ adalah faktor skala pada bidang gambar dan bidang piksel, $\left(u_{0}, v_{0}\right)$ adalah koordinat dari titik prinsipal pada bidang piksel, dan $\gamma$ adalah faktor skew/kemiringan.

Tujuan utama dari kalibrasi stereo kamera adalah untuk menentukan parameter intrinsik dari kamera pada suatu sistem stereo photogrammtery. Pembaca dirujuk pada (Hartley dan Zisserman 2003) untuk melihat dengan detil beberapa metode kalibrasi kamera tersebut. Pada umumnya, proses kalibrasi menggunakan sebuah checkerboard yang mudah untuk dideteksi lokasi titik pojok dari kotak-kotak pada checkerboard tersebut.

\section{Rektifikasi dari gambar stereo}

Tujuannya adalah untuk menselaraskan garis-garis epipolar pada garis horisontal di kedua gambar stereo 2D. dengan demikian, proses untuk mencari titik-titik korespondesi menjadi sangat cepat karena proses pencarian titiktitik tersebut hanya dilakukan pada garis horisontal pada suatu gambar stereo. Salah satu metode yang paling sering digunakan untuk proses rektifikasi gambar stereo adalah metode dari (Fusiello et al 2000).

Metode tersebut di representasikan sebagai berikut. Misalnya, kamera stereo kiri dan kanan yang terkalibrasi mempunyai matriks transformasi perspektif sebagai $\widetilde{\mathbf{M}}_{01}$ dan $\widetilde{\mathbf{M}}_{02}$. Rektifikasi akan mengestimasi matriks transformasi tersebut menjadi matriks transformasi perspektif yang baru, yaitu $\widetilde{\mathbf{M}}_{n 1}$ dan $\widetilde{\mathbf{M}}_{n 2}$. Hal ini dilakukan dengan merotasi matriks transformasi pada pusat optikalnya sampai bidang fokalnya menjadi co-planar. Matriks A dan $\mathbf{R}$ adalah sama. Untuk kedua kondisi sbeelum dan sesudah rektifikasi dilakukan.

Agar garis-garis epipolar menjadi horisontal, maka baseline (lihat gambar 5) harus parallel terhadap X-axis yang baru pada kedua kamera tersebut dan titik-titik korespondensi harus berada pada koordinat vertikal yang sama (Yaksis). Sehingga, matriks transformasi perspektif hanya berbeda posisi titik pusat optikalnya saja. $\widetilde{\mathbf{M}}_{n 1}$ dan $\widetilde{\mathbf{M}}_{n 2}$ ditulis sebagai:

$$
\begin{aligned}
\widetilde{\mathbf{M}}_{n 1} & =\mathbf{A}\left[\mathbf{R} \mid-\mathbf{R O}_{1}\right] \\
\widetilde{\mathbf{M}}_{n 2} & =\mathbf{A}\left[\mathbf{R} \mid-\mathbf{R} \mathbf{0}_{2}\right]
\end{aligned}
$$

Setiap aksis untuk proses rektifikasi tersebut dikalulasi sebagai berikut ( $\boldsymbol{r}$ adalah komponen matriks rotasi):

1. X-aksis yang baru adalah parallel terhadap baseline: $\mathbf{r}_{\mathbf{1}}=\frac{\left(\mathbf{0}_{\mathbf{1}}-\mathbf{O}_{2}\right)}{\mathbf{P 0}_{\mathbf{1}}-\mathbf{O}_{2} \mathbf{P}}$.

2. Y-aksis yang baru tegak lurus terhadap $X$-aksis dan ke $\mathbf{k}: \mathbf{r}_{\mathbf{2}}=\mathbf{k} \wedge \mathbf{r}_{\mathbf{1}} \cdot \mathbf{k}$ adalah sebuah vektor satuan yang sama dengan unit vektor satuan $\mathrm{z}$-aksis sistem koridnat kemare kiri sebelum rektifikasi.

3. Z-aksis yang baru tegak lurus terhadap bidang XY: $\mathbf{r}_{\mathbf{2}}=\mathbf{r}_{\mathbf{1}} \wedge \mathbf{r}_{\mathbf{2}}$. 
Untuk setiap titik 3D W, diketahui bahwa:

$$
\begin{aligned}
& \widetilde{\mathbf{P}}_{0 i} \cong \widetilde{\mathbf{M}}_{0 i} \widetilde{\mathbf{W}} \\
& \widetilde{\mathbf{P}}_{n i} \cong \widetilde{\mathbf{M}}_{n i} \widetilde{\mathbf{W}}
\end{aligned}
$$

Persamaan ray optik didefinisikan sebagai:

$$
\begin{aligned}
& \mathbf{W}=\mathbf{0}_{\boldsymbol{i}}+\lambda_{0} \mathbf{Q}_{0 \mathrm{i}}^{-1} \widetilde{\mathbf{P}}_{0 i}, \lambda_{0} \in^{\circ} \\
& \mathbf{W}=\mathbf{0}_{\boldsymbol{i}}+\lambda_{n} \mathbf{Q}_{\mathrm{ni}}^{-1} \widetilde{\mathbf{P}}_{n i}, \lambda_{n} \in^{\circ}
\end{aligned}
$$

Sehingga,

$$
\widetilde{\mathbf{P}}_{n i}=\lambda \mathbf{Q}_{n i} \mathbf{Q}_{0 \mathrm{i}}^{-1} \widetilde{\mathbf{P}}_{0 i}, \quad \lambda \in^{\circ}
$$

Matris transformasi $\mathbf{Q}_{\boldsymbol{n} i} \mathbf{Q}_{\mathbf{0}}^{-1}$ diaplikasikan pada gambar stereo sebelumnya untuk menghasilkan gambar stereo tersebut yang terrektifikasi.

\section{Komputasi untuk rekonstruksi 3D dari dua gambar stereo}

Setelah proses rektifikasi dilakukan, penentuan titik-titik korespondensi dapat dilakukan di dalam garis horisontal yang sama pada gambar stereonya dan proses rekosntruksi 3D dapat dilakukan. Ada beberapa metode 3D rekontruksi untuk stereo photogrammtery (Hartley dan Zisserman 2003). Pada bagian ini, metode rekonstruksi yang paling sederhana dengan metode triangulasi kaan dijelaskan sebagai berikut.

Kedalaman D pada arah Z suatu untuk setiap titik-titik korespondensi $d_{u}^{\prime}$ dapat dikalkulasi dengan:

$$
D=\frac{f \cdot B}{d_{u}^{\prime} / k_{u}+\left(u_{n 1}^{\prime}-u_{n 2}^{\prime}\right)}
$$

dimana $B=\left\|\mathbf{O}_{1}-\mathbf{O}_{2}\right\|$ adalah panjang baseline (lihat gamabr 5) antara dua kamera stereo, dimana nilai $f$ dapat menggunakan $f_{u}, f_{v}$.

\section{$\underline{\text { Aplikasi }}$}

Aplikasi (stereo)-photogrammtery sangat luas. Karena terinspirasi dari sistem penglihatan manusia, sistem tersebut mempunyai aplikasi seperti navigasi robot, pengenalan objek dan rekonstruksi 3D dari sebuah scene (benda yang terlihat pada sebuah kamera). Untuk lebih detil mengenai stereo photogrammtery, pembaca bisa merujuk pada (Zhang 2013).
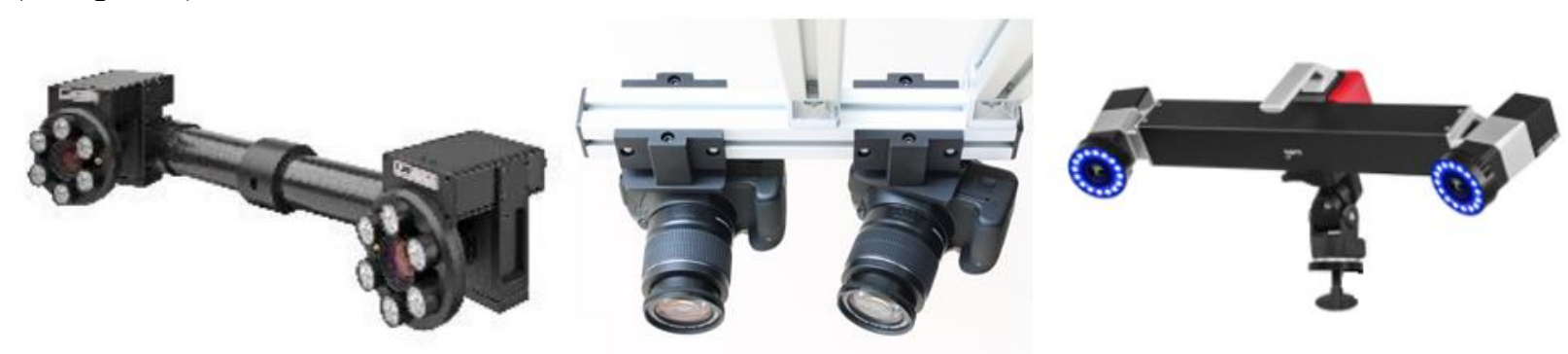

Gambar 7: Contoh sistem stereo photogrammtery. 
Kelebihan dari stereo photogrammeetry adalah:

- Biaya untuk membagun sistem stereo photogrammtery sangat murah karena dapat menggunakan kamera apapun, seperti kamera dijital pada umumnya, kamera smartphone atau kamera raspberry pi.

- Sistem stereo photogrammtery sangat portabel karena ukurannya yang relatif kecil.

- Kecepatan pengukuran sebuah permukaan relatif cepat karena pengukuran dilakuakn berdasarkan pengambilan data area.

- Sistem stereo photogrammtery mempunyai skalabilitas yang baik karena bisa didisain untuk pengukuran skala kecil sampai dengan skala yang besar.

- Kemampuan untuk mengukur benda yang bergerak dengan menggunakan target fisik yang ditempatkan pada benda bergerak tersebut.

- Kemampuan untuk mengambil data titik-titik dengan densitas yang tinggi.

Kekurangan dari stereo photogrammeetry adalah:

- Untuk pengukuran skala besar sampai menengah, akurasi sistem tersebut tidak setinggi akurasi, misalnya CMM berbasis kontak.

- Sangat dipengaruhi oleh variasi cahaya lingkungan.

- Sangat dipengaruhi oleh tingkat refleksivitas permukaan suatu benda yang diukur.

- Membutuhkan waktu setup apabila pengukuran menggunakan target fisik.

\subsubsection{Fringe projection (structure light scanner)}

Fringe projection atau structured-light projection adalah sebuah sistem pengukuran geometri non-kontak yang bekerja dengan cara memproyeksikan cahaya yang berpola (terstruktur) ke sebuah permukaan benda yang akan diukur. Rekonstruksi 3D (posisi z) dari permukaan tersebut dikalkukasi dengan menganalisis deformasi cahaya yang berpola tersebut ketika mengenai permukana yang tidak rata.

Komponen-komponen dari sebuah sistem fringe projection adalah (gambar 8):

1. Proyektor

Adalah komponen yang membentuk sebuah pola (fringe) atau suatu struktur deterministik. Pola atau struktur tersebut akan dianalisis secara matematik untuk merekonstruksi suatu permukaan benda dalam bentuk 3D. Gambar 9 memperlihatkan berbagai macam jenis pola yang ditembakkan pada suatu permukaan benda yan diukur.Proyektor yang bisa dipakai adalah mulai dari proyektor umum dengan harga rendah sampai dengan suatu proyektor dengan harga yang sangat tinggi. Contoh umumnya adalah proyektor LCD (liquid crystal device) yang memiliki harga rendah dan proyektor slide (resolusi tinggi) yang memiliki harga yang tinggi.

2. Sistem kamera

Adalah komponen yang berfungsi untuk mendeteksi gambar pola yang terdeformasi karena suatu permukaan yang tidak rata dibandingkan dengan permukaan referensi.

3. Komputer

Adalah komponen yang menjalankan suatu algoritma untuk mengkalkulasi secara matematis untuk merekonstruksi 3D suatu permukaan yang diukur.

Ketiga komponen tersebut tidak bergerak ketika suatu pengukuran berlangsung. Maka dari itu, setiap pergerakan pada sebuah benda yang diukur atau pada proyektor atau pada kamera (misalnya, karena vibrasi) akan menimbulkan error pada proses pengukuran tersebut. 


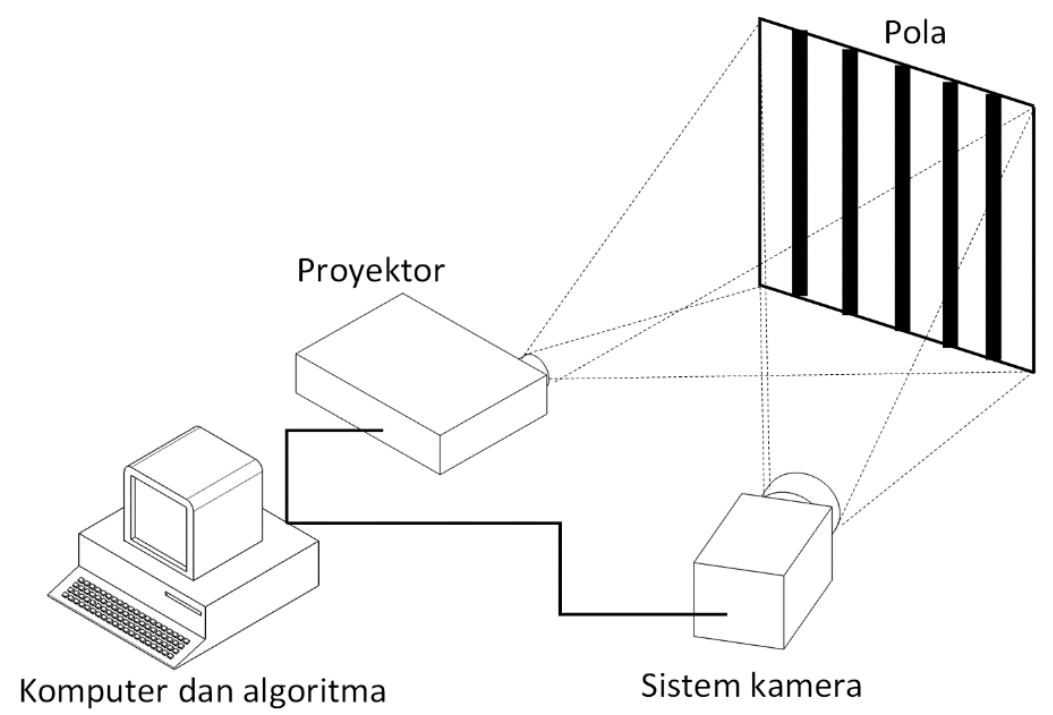

Gambar 8: Konfigurasi into dari suatu sistem fringe projection.

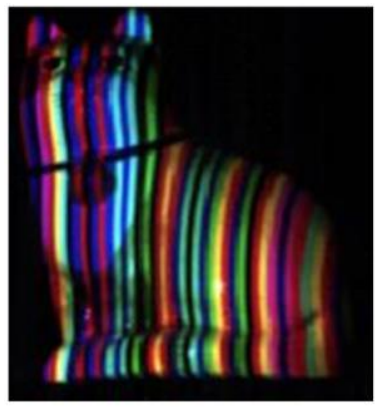

Pola kode berwarna

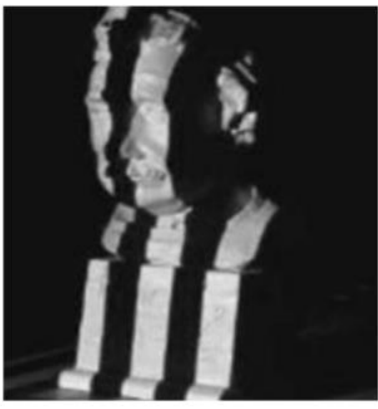

Pola kode hitam-

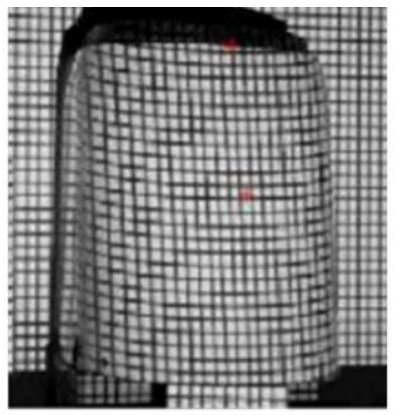

Pola Kotak-kotak

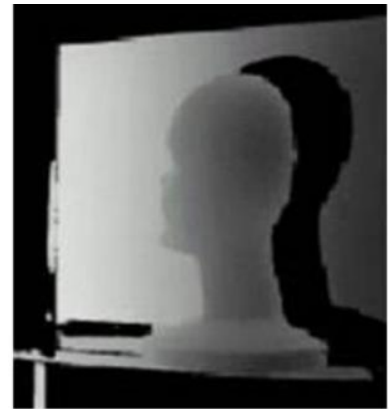

Pola linier

Gambar 9: Berbagai macam contoh pola (struktur) yang dihasilkan oleh suatu proyekor dan ditembakkan pada suatu permukaan benda yang diukur.

\section{Prinsip kerja}

Seperti yang sudah dijerlaskan sebelumnya, prinsip dasar fringe projection adalah menganalsis deformasi dari gambar pola atau struktur deterministik yang ditembakkan pada sebuah permukaan yan diukur untuk merekonstruksi 3D suatu permukaan. Maka dari itu, pola yang ditembakkan pada suatu permukaan tersebut mempunyai peran utama pada suatu sistem fringe projection.

Pada dasarnya, fringe projection dibagi menjada dua kelompok metode (lihat gambar 10):

1. Rekonstruksi sparse dengan metode diskrit (triangulasi): Pola binari dan pola De Bruijn.

Metode sparse menghasilkan jumlah titik yang tidak begitu banyak (relatif terhadap metode dense). Namun demikian, metode ini lebih mudah dikalkulasi dan membutuhkan waktu pemprosesan yang cepat. Metode sparse menggunakan prinsip yang sama dengan stereo photogrammtery dan laser scanner, yaitu berbasiskan pada metode triangulasi.

Pola yang digunakna untuk metode ini adalah pola binari dan pola De Bruijn.

2. Rekonsturksi dense dengan metode kontinu (analisis fase): pola sinusoidal dan pola trapezoidal.

Metode dense dapat menghasilkan jumlah titik-titik yang sangat banyak dalam merekonstruksi 3D suatu 
permukaan. Namun demikian proses komputasi yang dibutuhkah lebih lama dan lebih kompleks.Pola yang digunakna untuk metode ini adalah pola sinusoidal dan pola trapezoidal.

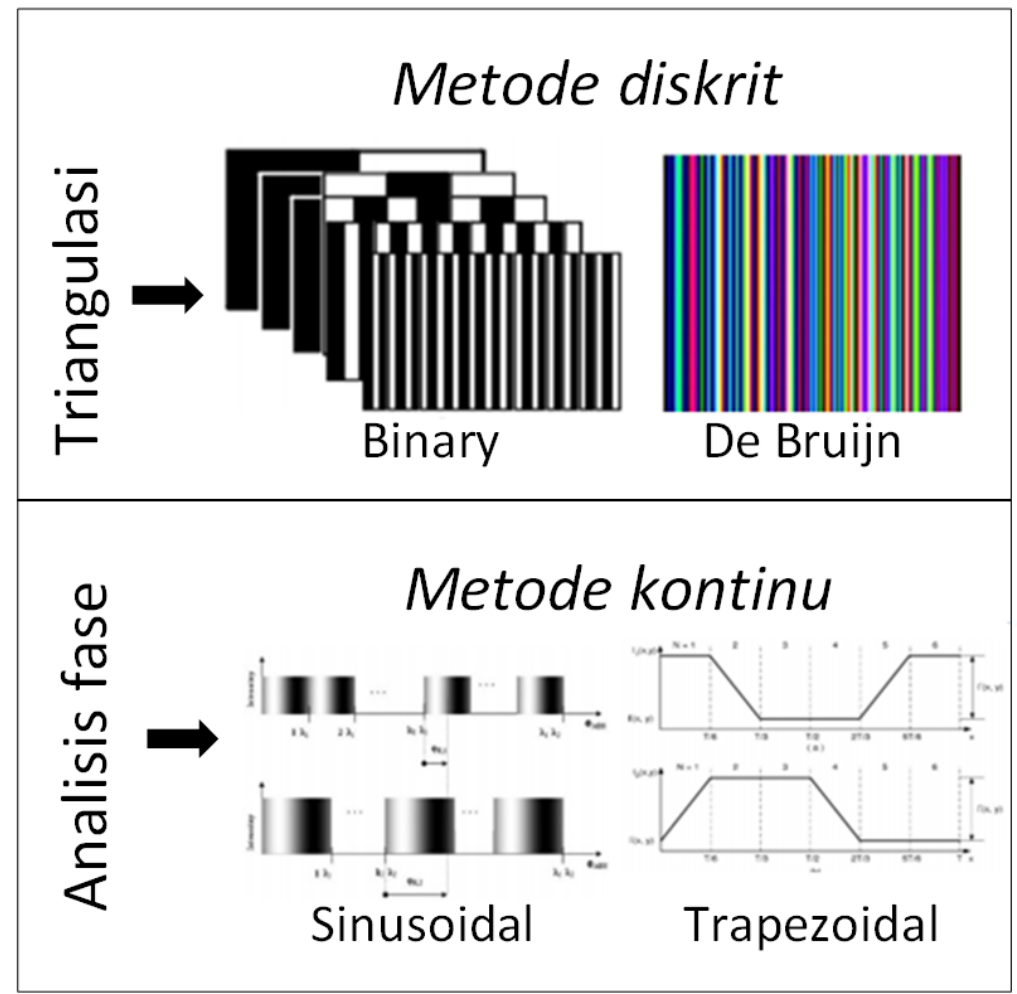

Gambar 10: Dua jenis prinsip kerja fringe projection.

Metode fringe projection berbasiskan metode sparse dengan pola disktrit akan dijelaskan dengan detil sebagai berikut. Metode tersebut adalah metode paling sederhana untuk rekonstruksi 3D untuk sistem fringe projection. Gambar 11 memperlihatkan prinsip kerja fringe projection dengan metode diskrit dengan pola binari. Hal penting yang harus diingat adalah posisi geometrik antara proyektor dan kamera harus dikuantifikasi terlebih dahulu dengan proses kalibrasi (seperti pada stereo photogrammtery). Dari gambar 11, variabel-variabel didefinisikan sebagai:

- $H$ adalah sebuha titik pada suatu permukaan yang diukur.

- $\quad P$ adalah titik fokal dari proyektor.

- $\quad C$ adalah titik fokal dari kamera yang menangkap pola yang terproyesikan.

- $\pi_{\mathrm{R}}$ Adalah bidang datar referensi pada bidang $X Y$.

- $\pi_{\mathrm{i}}$ Adalah bidang gambar pada sensor kamera dan diasumsikan paralel terhadap $\pi_{\mathrm{R}}$.

- $\quad 0$ adalah titik pusat bidang pada bidang $\pi_{\mathrm{R}}$.

- $\mathrm{O}^{\prime}$ adalah titik pusat bidang pada bidang $\pi_{\mathrm{i}}$.

- $f$ adalah jarak antara ke titik fokal $C$.

- $\quad h$ adalah ketinggian antara bidang $\pi_{\mathrm{R}}$ dan garis yang menghubungkan $P$ dan $C$.

- $\quad d$ adalah jarak antara titik fokal proyektor $P$ dan titik fokal kamera $C$.

- $\quad Z_{h}$ adalah ketinggian yang inging dikalkulasi. 
Berdasarkan variabel-variabel tersebut, rekonstruksi posisi-z suatu titik pada kamera (rekonsturksi 3D) adalah sebagai berikut (merujuk pada gambar 11).

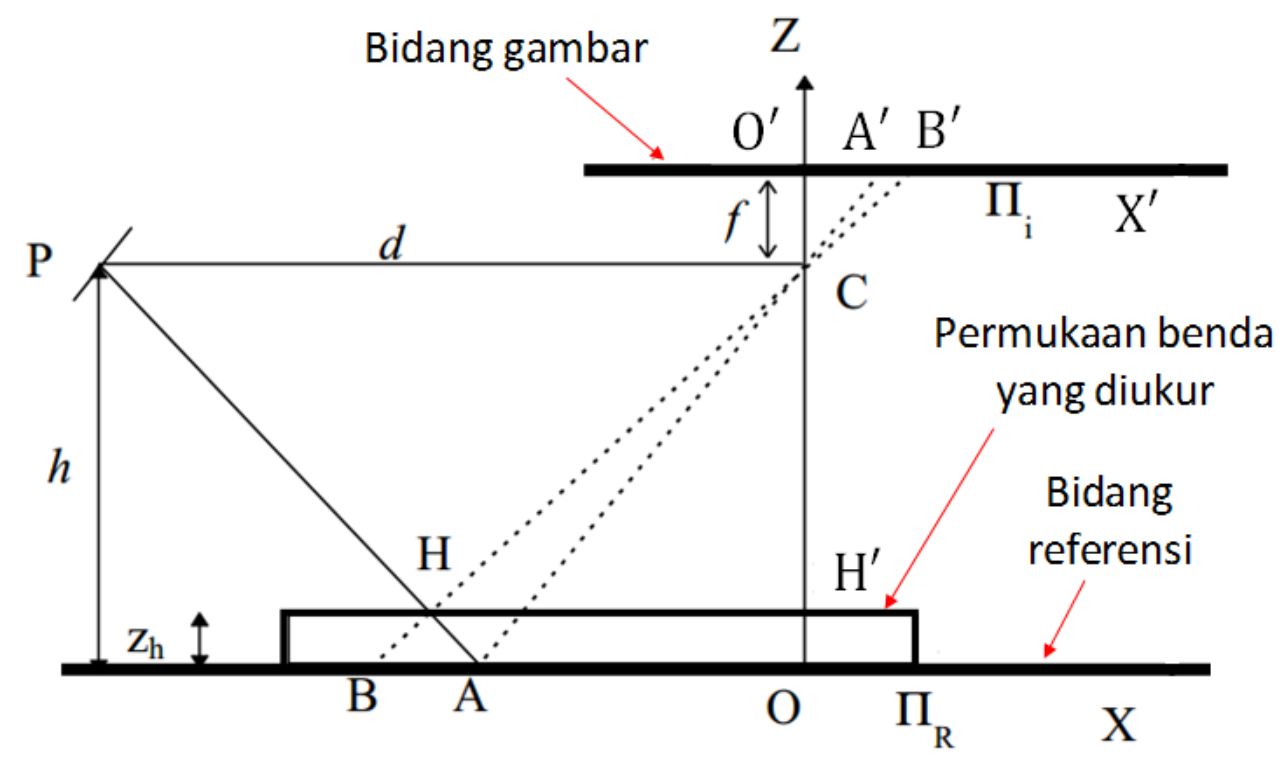

Gambar 11: Prinsip kerja fringe projection dengan metode diskrit - triangulasi.

Dengan menggunakan prinsip kesesuaian segitiga $P H C$ dan $A H B$, didapatkan (gambar 11):

$$
\frac{h-z_{h}}{d}=\frac{z_{h}}{A-B}
$$

Sehingga didapatkan $Z_{h}$ :

$$
Z_{h}=\frac{h \cdot(A-B)}{A-B+d} \cong \frac{h}{d} \cdot(A-B)
$$

Kemudian, dengan menggunakan prinsip kesesuaian segitiga $H C H^{\prime}$ dan $B^{\prime} C O^{\prime}$, didapatkan $x_{h}$ dan $y_{h}$ (gambar 11):

$$
\begin{gathered}
x_{h}=\frac{B^{\prime} x}{f} \cdot\left(h-z_{h}\right)=\frac{B^{\prime} x}{f} \cdot h \cdot\left(1-\frac{z_{h}}{h}\right) \cong \frac{B^{\prime} x}{f} \cdot h \\
y_{h}=\frac{B^{\prime} y}{f} \cdot\left(h-z_{h}\right) \cong \frac{B^{\prime} y}{f} \cdot h
\end{gathered}
$$

Gambar 12 memperlihatkan contoh rekonstruksi 3D suatu permukaan dengan metode diskrit dengan pola binari. Pada gambar 12, diperlihatkan bahwa apabila suatu permukaan yang diukur tidak rata, maka gambar pola binari yang ditembakkan pada permukaan tersebut akan terdeformasi. Deformasi tersebut dianalisis untuk merekonstruksi 3D permukaan tersebut. 


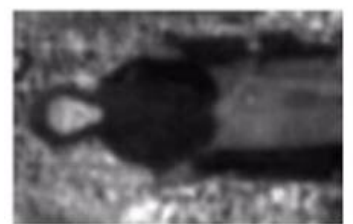

Gambar tanpa pola proyeksi

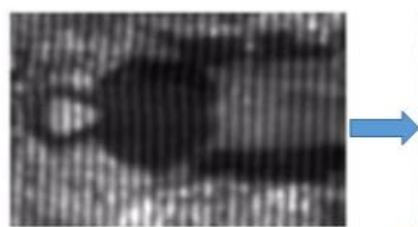

Gambar dengan pola proyeksi

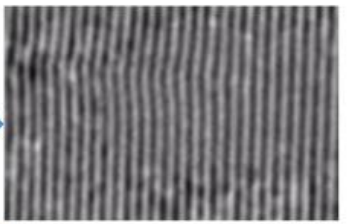

Gambar pola proyeksi yang terdeformasi

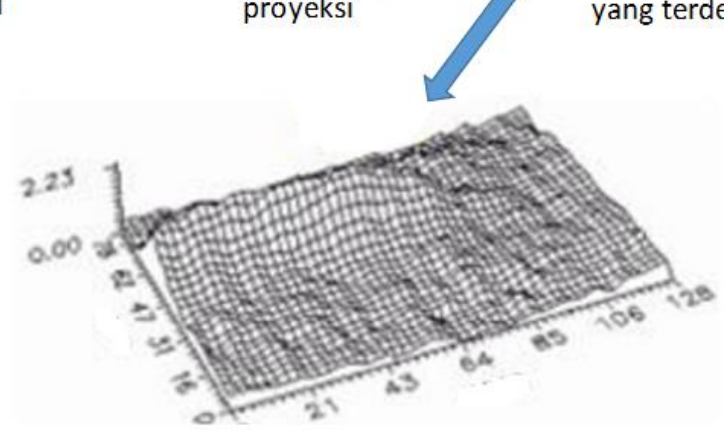

Rekonstruksi 3D dari permukaan yang diukur

Gambar 12: Contoh rekosntruksi 3D sebuah fringe projection dengan metode diskrit-pola binari.

\section{$\underline{\text { Aplikasi }}$}

Aplikasi dari sistem pengukuran fringe projection sangat banyak. Aplikasi yang paling pas untuk saat ini adalah untuk pengukuran dimensi dan geometri benda-benda yang mempunyai dimensi makro sampai meso. Gambar 13 memperlihatkan berbagai macam sistem fringe projection komersial yang sedang beroperasi untuk mengukur suatu benda dengan ukuran makro.

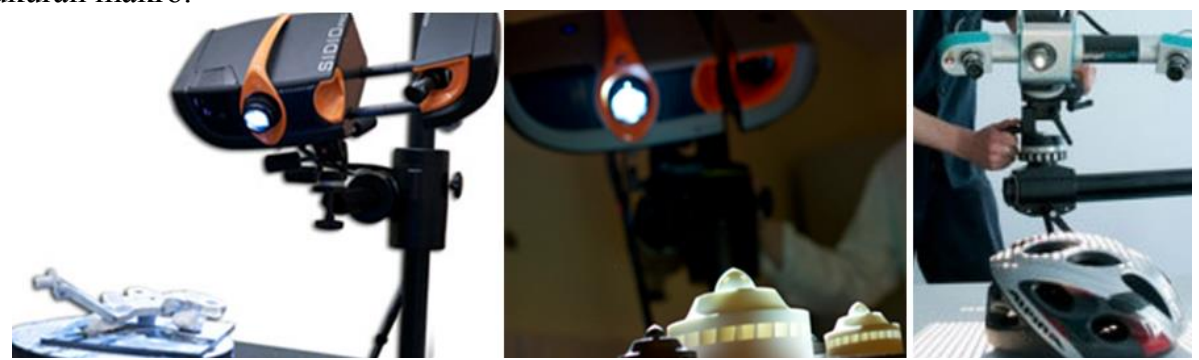

Gambar 13: Contoh pengukuran dengan menggunakan sistem fringe projection.

Kelebihan dari fringe projection adalah:

- Kemampuan untuk meng-sampling titik-titik suatu permukaan benda dengan densitas yang tinggi.

- Kecepatan pemindaian suatu permukaan yang cepat.

- Tingkat akurasi yang cukup tinggi.

- Kemampuan portabel yang cukup baik tergantung dengan ukuran sistem tersebut.

- Kemampuan untuk melakukan pengukuran dengan skala yang besar.

Kelebihan dari fringe projection adalah:

- Sangat dipengaruhi oleh variasi cahaya lingkungan.

- Sangat dipengaruhi oleh tingkat refleksivitas permukaan suatu benda yang diukur.

- Sulit untuk mengukuran suatu benda dengan gradien permukaan yang besar.

- Tidak dapat mengukur suatu benda yang bergerak (sensitif terhadap vibrasi). 


\subsection{Optical CMM untuk pengukuran skala mikro}

Optical CMM untuk pengukuran pada skala mikro pada awalnya merupakan sebuah instrumen untuk melakukan pengukuran teksture permukaan (Richard 2011). Namun demikian, instrumen-instrumen tersebut memiliki karakteristik yang dapat digunakan untuk melakukan pegukuran dimensi dan geometri pada skala mikro. Karakteristik-karakteristik tersebut adalah mempunyai working-distance yang besar, dapat mengukur sebuah permukaan dengan kemiringan yang sangat tinggi (slope angle) dan/atau mempunyai pergerak aksis untuk rotasi (lebih dari 3-aksis linier). Pergerak aksis untuk rotasi sangat berguna untuk melakukan pengukuran secara 3D sebuah komponen yang berbentuk silinder, seperti cutting tool dan poros pada skala meso samapai mikro (syam 2015).

Pada bagian ini, dua optical CMM untuk skala mikro yang umum digunakan akan dibahas. Kedua optical CMM tersebut adalah focus variation microscopy (FVM) dan point auto-focus (PAI). Pada saat buku ini ditulis, FVM merupakan optical CMM pada skala-mikro yang sudah umum digunakan, tetapi penggunaannya sebagian besar masih untuk pengukuran tekstur permukaan.

\subsubsection{Focus variation microscopy (FVM)}

FVM merupakan optical CMM yang memiliki wahana pergerakan sampai dengan 5-aksis. Gambar 14 memperlihatkan komersial sistem dari FVM, yaitu Alicona Infinite Focus G5. Pada gambar 14 (sebelah kanan), dua aksis rotasi tambahan terdiri dari aksis tilting dan rotasi. Sehingga, total keseluruhan aksis dari FVM tersebut berjumlah lima: tiga linier dan dua rotasi. Instrument FVM tersebut tidak membutuhkan udara bertekanan karena tidak menggunakan table air untuk isolasi vibrasi, melainkan menggunakan sistem isolasi vibrasi pasif. Terdapat tiga jenis sistem pencahayaan (llumination) untuk FVM tersebut: axial light, ring-light dan polarized light. Axial light adalah jenis pencahyaan yang paling umum melalui aksis mikroskop dari FVM tersebut. Ring-light adalah jenis pencahayaan tambahan yang mengelilingi lensa objektif dari FVM tersebut. Polarized light adalah jenis filtering cahaya untuk mengurangi refleksi cahaya yang berlebihan pada suatu permukaan benda yang sangat silau.
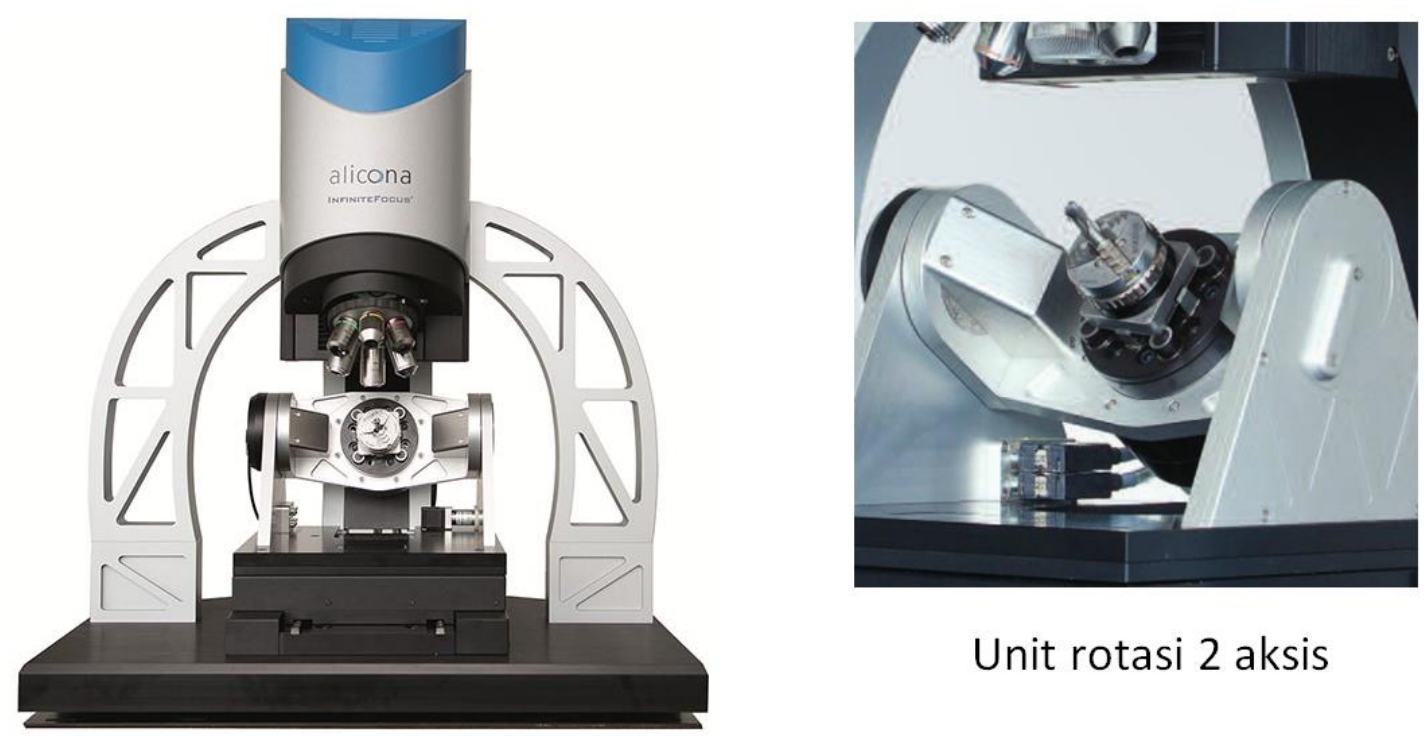

\section{Unit rotasi 2 aksis}

Gambar 14: (kiri) Komersial focus variation microscope Alicona Infinite Focus G5 dan (kanan) unit rotasi 2 aksis (rotation dan tilting) (Sumber: Alicona Imaging GmBH). 


\section{Prinsip kerja}

Prinsip kerja FVM adalah sebagai berikut (gambar 15 kiri). FVM meng-scan secara vertikal, dengan suatu resolusi vertikal yang ditentukan, sebuah permukaan benda dan mengambil sekumpulan gambar 2D dari permukaan tersebut di setiap posisi scan tersebut. Untuk setiap gambar 2D yang didapatkan, nilai fokus (nilai kontras atau ketajaman piksel) untuk setiap piksel pada gambar-gambar 2D tersebut dikalkulasi. Deteksi dari permukaan yang diukur tersebut untuk setiap piksel pada snesor kamera FVM didapatkan dengan cara mencari posisi-z yan memiliki nilai fokus (kontras/ketajaman piksel) yang paling tinggi (Richard 2011).

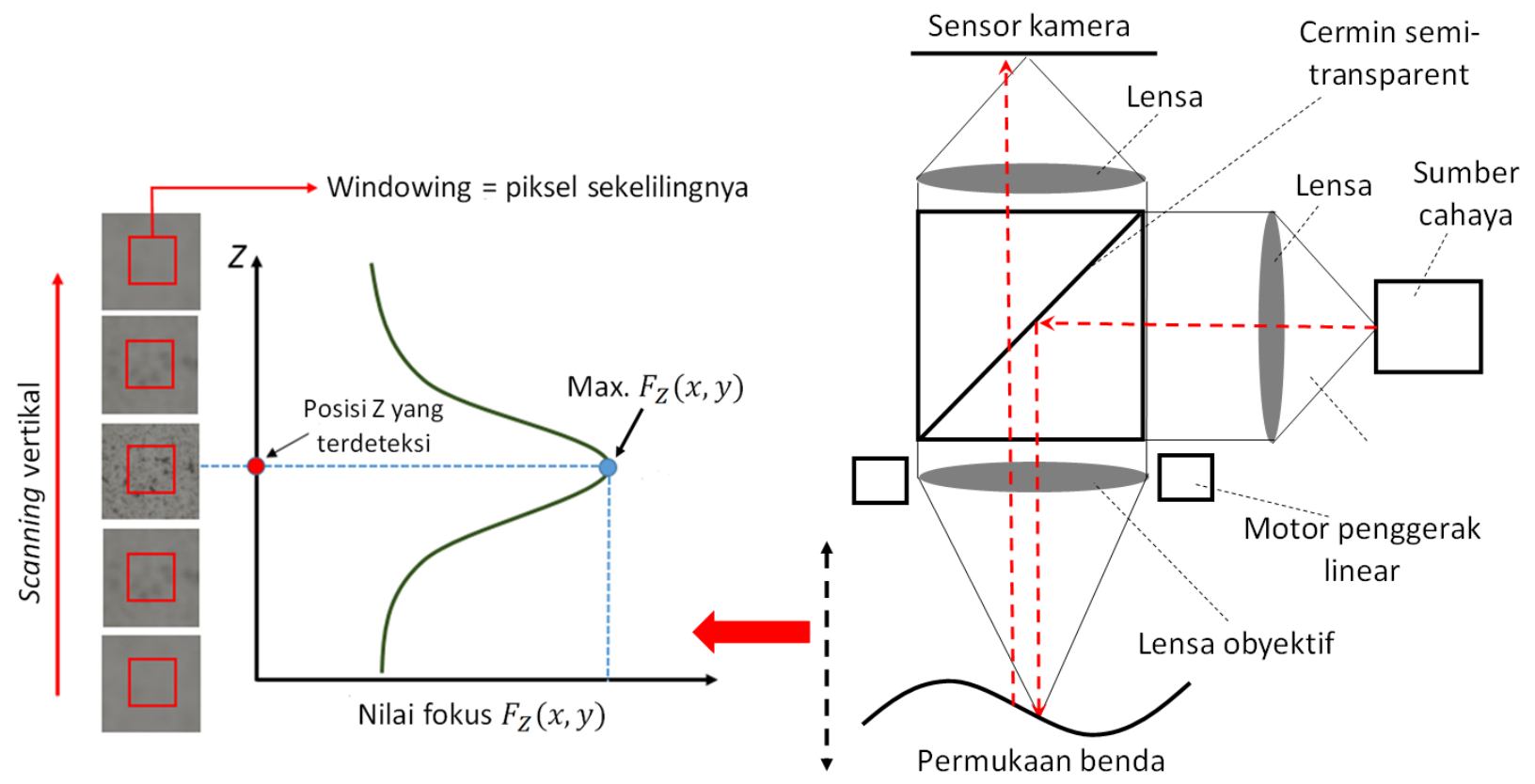

Gambar 15: (kiri) prinsip dasar scanning permukaan untuk menentukan nilai kontrats (posisi fokus) yang terbesar dan (kanan) konfigurasi optikal dari FVM.

Nilai fokus (kontras atau ketajaman piksel) $F_{Z}(X, Y)$ diformulasikan sebagai:

$$
F_{Z}(X, Y)=F M\left(\operatorname{reg}_{W}\left(I_{Z}, x, y\right)\right)
$$

dimana $I_{Z}$ adalah nilai intensitas suatu piksel pada posisi- $z$. Nilai intensitas tersebut diasosiasikan pada sebuah lokasi lateral dari $(x, y)$ pada bidang gambar sensor kamera FVM. FM( adalah sebuah ukuran fokus untuk mengkalkulasi atau menentukan nilai fokus $F_{Z}(X, Y)$. Gambar 15 kiri memperlihatkan proses menentukan nilai fokus setiap piksel untuk pengukuran FVM. Pada gambar 15 kiri, terlihat bahwa apabila posisi gambar 2D pada posisi permukaan yang diukur, maka seuatu piksel pada gambar 2D tersebut akan terlihat jelas taua tajam (mempunyai nilai fokus yang besar), yaitu $F_{Z}(X, Y)$.

Terdapat beberapa metode $(F M())$ untuk mengkalkulasi nilai fokus suatu piksel. Beberapa diantaranya yang paling umum adalah:

1. Metode maximum point.

2. Metode polynomial curve fitting.

3. Metode point spread function fitting. 
Metode maximum point adalah metode yang paling sederhana dan paling cepat untuk menentukan loaksi-z $Z_{\text {posisi }}$. Tetapi, metode ini memiliki tingkat akurasi yang paling rendah. Metode maximum point diformulasikan sebagai:

$$
Z_{\text {posisi }}=\arg \left(\max F_{Z}\right) \forall Z_{i,} \operatorname{dimana} Z_{1}<Z_{i}<Z_{n}
$$

Metode polynomial curve fitting adalah metode untuk mendeteksi lokasi-z $Z_{\text {posisi }}$ dengan cara melakukan fitting sebauh kurva kuadratic atau polynomial pada titik-titik nilai fokus pada setiap gambar 2D di dalam kumpulan gambargambar 2D. dari hasil fitting tersebut, nilai maksimum fokus akan ditentukan. Metode polynomial curve fitting diformulasikan sebagai:

$$
F(z)=a z^{2}+b z+c
$$

Dari persamaan (47), lokasi-z $Z_{\text {posisi }}$ yang mempunyai nilai focus maksimum ditentukan sebagai

$$
Z_{\text {posisi }}=-\frac{b}{2 a}
$$

Metode fitting kuadratik untuk menentukan persamaan (47) adalah dengan menggunakan metode least-square:

$$
\arg \min _{a, b, c} \sum_{Z_{1} \leq Z \leq Z_{n}}\left(F_{z}-\left[a z^{2}+b z+c\right]\right)^{2}
$$

dimana $a, b, c$ adalah parameter-parameter kuadratik yang ingin ditentukan dengan metode fitting tersebut (persamaan (49).

Metode point spread function fitting adalah metode yang memiliki tingkat akurasi yang paling tinggi, tetapi membutuhkan proses kalkukasi yang banyak juga, untuk menentukan lokasi-z $Z_{\text {posisi }}$. Proses fitting untuk menentukan nilai fokus tertinggi menggunakan point spread function (PSF) yang ditentukan dari komponenkomponen optik mikroskop dari FVM.

Konfigurasi optik dari FVM diperlihatkan pada gambar 15 kanan. pada gambar 15, pada prinsipnya, konfigurasi optik untuk FVM adalah sama dengan mikrokope biasa, namun dimikian, mikroskop pada FVM dapat digerakkan secara linier dengan menggunakan sebuah motor penggerak yang mempunyai resolusi yang tinggi.

\section{Aplikasi}

Aplikasi dari FVM untuk pengukuran pada skala mikro sangat luas. Aplikasi tersebut mulai dari pengukuran tekstur permukaan sampai dengan pengukuran dimensi dan geometri. FVM sangat cocok digunakan untuk mengukur sebuah permukaan yang mempunyai nilai $R a>20 \mathrm{~nm}$ (Richard 2011). Permukaan-permukaan hasil proses permesinan sangat baik untuk diukur dengan menggunakan metode FVM. Kelebihan FVM dibandingkan dengan optical microscopy pada umumnya adalah FVM dapat digunakan untuk melakukan pengukuran dimensi dan geometri pada skala mikro.

Gambar 16 memeprlihatkan contoh-conoth hasil pengukuran dengan menggunakan instrumen FVM. Pada gambar 16 (a,b,c) diperlihatkan contoh pengukuran geometri 3D dari sebuah drilling tool, permukaan flank dari milling tool dan permukaan free-form. Sedangkan, gambar $16(\mathrm{~d}, \mathrm{e})$ memperlihatkan hasil pengukuran tekstur permukaan hasil dari proses spray coating dan additive manufacturing dari metal. Hasil pengukuran pada gambar 16a (pengukuran drilling tool) dilakukan dengan menggunakan dua rotasi aksis pada instrumen FVM tersebut. 


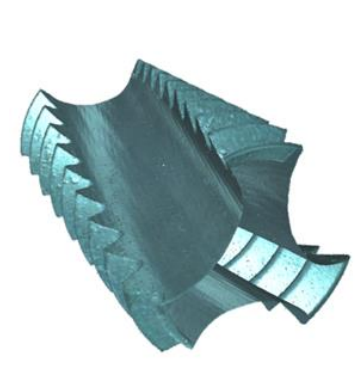

(a)

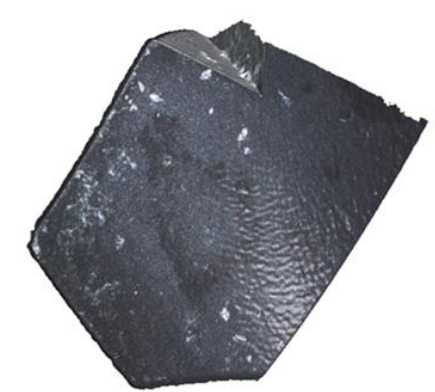

(b)

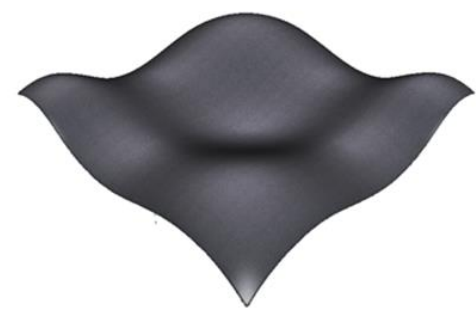

(c)

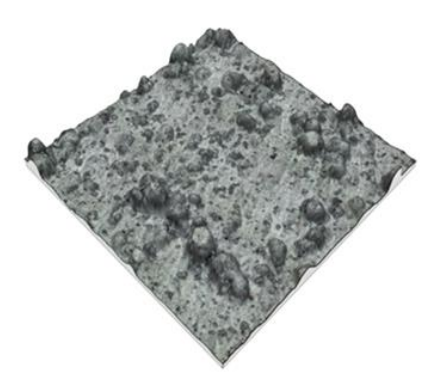

(d)

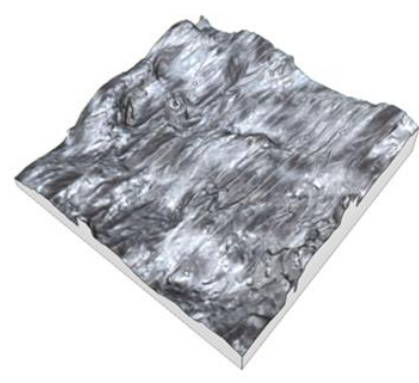

(e)

Gambar 16: Contoh-contoh hasil pengukuran dengan FVM (a) geometri sebuah cutting tool, (b) permukaan dan geometri flank, (c) geometri free-form, (d) permukaan blast-coating sebuah permukaan dan (e) permukaan sebuah permukaan benda yang dibuat dengan metode metal additive manufacturing.

Kelebihan dari FVM adalah:

- Mempunyai aplikasi yang sangat luas: mulai dari pengukuran tekstur permukaan sampai dengan pengukuran dimensi dan geometri. Alicona G5 mempunyai lensa objektif $5 \times$ yang mempunyai working distance mencapai $23 \mathrm{~mm}$. hal ini merupakan kelebihan yang signifikan karena kemampuan aksis fitur-fitur pada suatu benda menjadi tinggi tanpa terjadi coalision (tabrakan) anatar lensa objektif dengan permukaan fitur-fitur pada permukaan tersebut.

- Mempunyai ketahanan terhadap gangguan vibrasi, temperatur dan tekanan udara karena FVM berkerja hanya berdasarkan pemmrosesan gambar 2D (image processing). FVM tidak menggunakan sistem laser interferometer yang sangat sensitif terhadap gangguan lingkungan (getaran, temperatur dan tekanan udara).

- Mempunyai waktu pengukuran yang singkat. Secara umum, pengukuran untuk satu area tertentu pada suatu permukaan adalah kurang dari satu menit.

- Mempunyai dua-aksis pergerakan rotasi. Dengan tambahan dua aksis tersebut, instrumen FVM dapat mengukur sutau benda secara full $3 D$. sebagai contoh, seluruh permukaan silindrikal sebuah cutting tool dapat dilakukan (gambar 16a).

- Mempunyai berbagai macam jenis pencahayaan. Instrumen FVM komersial dilengkapi dengan tiga jenis pencahayaan, yaitu axial light, ring-light dan polarized light. Ketiga jenis pencahayaan tersebut sangat bermanfaat untuk mengukur berbagai macam jenis material, dari material dengan reflektifitas rendah sampai tinggi.

Kekurangan dari FVM adalah:

- Kesulitan untuk mengukur surface yang super halus dengan $R a<10 \mathrm{~nm}$. Hal ini disebabkan karena prinsip kerja FVM yang membutuhkan tekstur (berupa kekasaran) pada permukaan yang diukurnya untuk mengkalkulasi niali fokus (kontras) untuk menentukan lokasi-z pada setiap loaksi $(x, y)$ nya. Selain itu, 
keterbatasan depth-of-focus dari lensa objetif sebuah FVM mengakibatkan ketajaman piksel pada loasi depthof-focus-nya mempunyai nilai ketajaman yang sama, sehingga lokasi- $x$ piksel tersebut tidak dapat ditentukan.

- Kesulitan untuk mengukur suatu permukaan transparan. Hal ini diesebabkan, selain karena permukaan transparan mempunyai tingkat kekasaran permukaan yang sangat kecil, instrumen FVM tidak dapat melihat permukaan transparan tersebut.

\subsubsection{Point auto-focus instrument (PAI)}

Point auto-focus instrument (PAI) pada dasarnya merupakan instrument yang mengikuti posisi fokus sebauh miroskop yang mengikuti sebuah permukaan benda yang diukur, atau dinamakan juga focus follower. Kalau dibandingkan dengan stylus instrument, yaitu alat ukur tekstur permukaan dengan metode kontak, PAI adalah stylus instrument, tetapi menggunakan metode non-kontak (optikal) bukannya memakai stylus.

Gambar 17 memperlihatkan sistem komersial PAI yang diproduksi oleh perusahaan Mitaka dengan produknya MLP-3SP. Pada gambar 17, sistem MLP-3SP tersebut terdiri dari empat aksis linier dan satu aksis rotasi (pada jenis lain juga dilengkapi dengan dua aksis rotasi). Pada sistem tersebut, terdapat empat aksis liner, yaitu tiga aksis liner untuk arah $x, y$ dan $z$ dan satu aksis linear dengan presisi tinggi untuk menggerakkan sistem auto-focus pada PAI tersebut. Aksis linear auto-focus merupakan aksis linear vertikal yang mempunyai resolusi yang sangat tinggi, yaitu $1 \mathrm{~nm}$. Aksis auto-focus inilah yang digunakan untuk mengikuti posisi fokus dari lensa objektif sistem PAI tersebut dan merekam posisi aksis auto-focus tersebut sebagai ketinggian dari permukaan pada titik-titik yang dilaluinya.

Gambar 18 memperlihatkan konfigurasi lengkap dari sistem PAI MLP-3SP dari Mitaka. Pada gambar 18, sistem PAI tersebut dilengkapi dengan table air (floating table) yang menggunakan air bearing untuk mengisolasi getaran pada frekuensi rendah yang biasanya berasal dari lantai produksi.

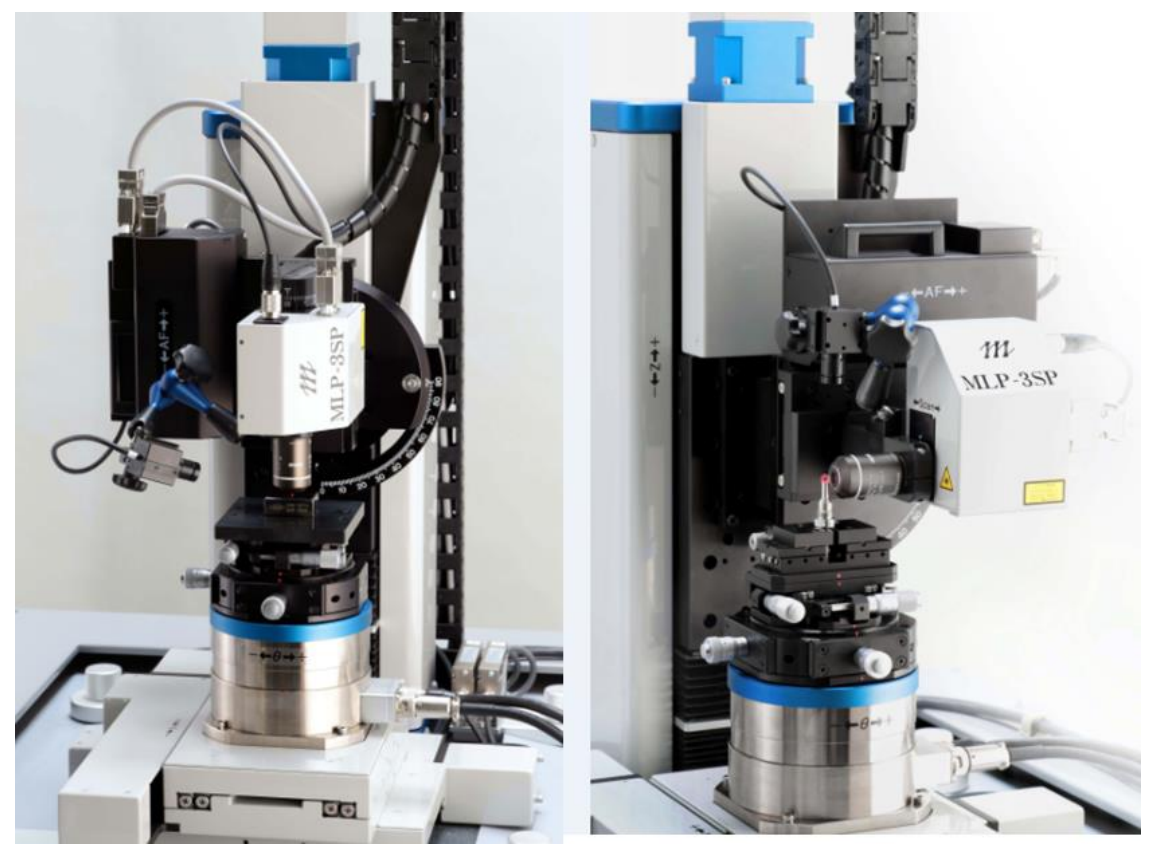

Gambar 17: Komersial point auto-focus instrument: MITAKA MLP-3SP yang mempunyai 5-aksis pergerakan (Sumber: Mitaka Kohki). 


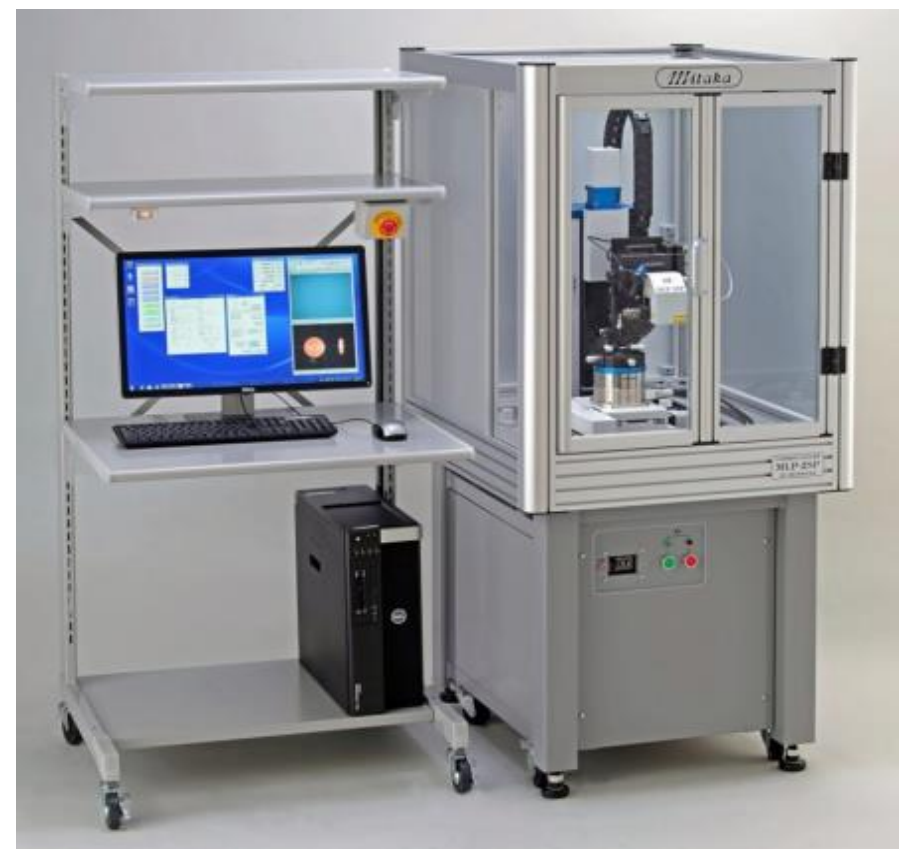

Gambar 18: Konfigurasi lengkap dari sebuah komersiap PAI MITAKA MLP-3SP dengan sistem table air untuk isolasi vibrasi (Sumber: Mitaka Kohki).

\section{Prinsip kerja}

PAI mengukur tekstur permukaan dengan cara memfokuskan sebuah laser beam pada sebuha titik pada suatu permukaan benda yang diukur. Pada posisi titik tersebut, mekanisme aksis linear auto-focus akan secara otomatis menggerakkan lensa objektif dan komponen optik untuk auto-focus ke atas atau ke bawah sampai laser beam tersebut berada pada posisi fokus dari lensa objektif tersebut. Ketika posisi lensa objektif dan komponen optiknya berapa pada posisi fokus, maka encoder untuk aksis linier auto-focus tersebut akan merekam posisi lokasi-z-nya yang merupakan tinggi permukaan pada titik yang difokuskan tersebut. Proses ini kemudian diulang untuk suatu jalur atau profil permukaan, sehingga lokasi-z dari profil tersebut dapat diketahui.

Sumber cahaya pada sistem PAI adalah menggunakan cahaya koheren, yaitu laser. Laser yang umum digunakana adlaah jenis laser merah dengan panjang gelombang sekitar $632 \mathrm{~nm}$. Besarnya diameter spot laser tersebut setelah difokuskan adalah bergantung pada jenis lensa objektif yang digunakan. Dengan menggunakan 100× lensa objektif, diameter spot yang difokuskan dapat mencapai $1 \mu \mathrm{m}$.

Gambar 19 memperlihatkan konfigurasi optik dan proses auto-focus dari PAI. Konfigurasi dari PAI adalah seperti mikroskop tetapi tidak dilengkapi sebuah sensor kamera, melainkan dilengkapi oleh sensor fokus. Selain itu, komponen yang unik pada PAI adalah adanya aksis linier auto-focus yang mempunyai resolusi yang sangat tinggi untuk dapat mendeteksi tinggi suatu permukaan dengan tingkat akurasi yang sangat tinggi.

Pada gambar 19 kiri, diperlihatkan posisi laser beam PAI berada pada posisi fokus pada suatu titik pada suatu permukaan benda. Apabila posisi laser beam PAI berada pada posisi fokusnya, maka posisi laser beam yang terrefleksikan dari suatu permukaan benda akan menuju pada titik tengah atau lokasi tengah dari sensor fokus yang berupa detektor cahaya. Sedangkan, gambar 19 kanan, diperlihatkan posisi laser beam PAI tidak berada pada posisi fokusnya, sehingga laser beam yang terpantulkan balik ke sistem PAI akan jatuh tidak pada posisi tengahnya melainkan agar bergeser ke kiri atau ke kanan. Pada situasi tidak fokus tersebut, sistem aksis linier auto-focus akan menggerakkan lensa objektif dan komponen optiknya ke atas atau ke bawah sampai laser beam tersebut jatuh pada posisi tengah sensor auto-focus tersebut. 


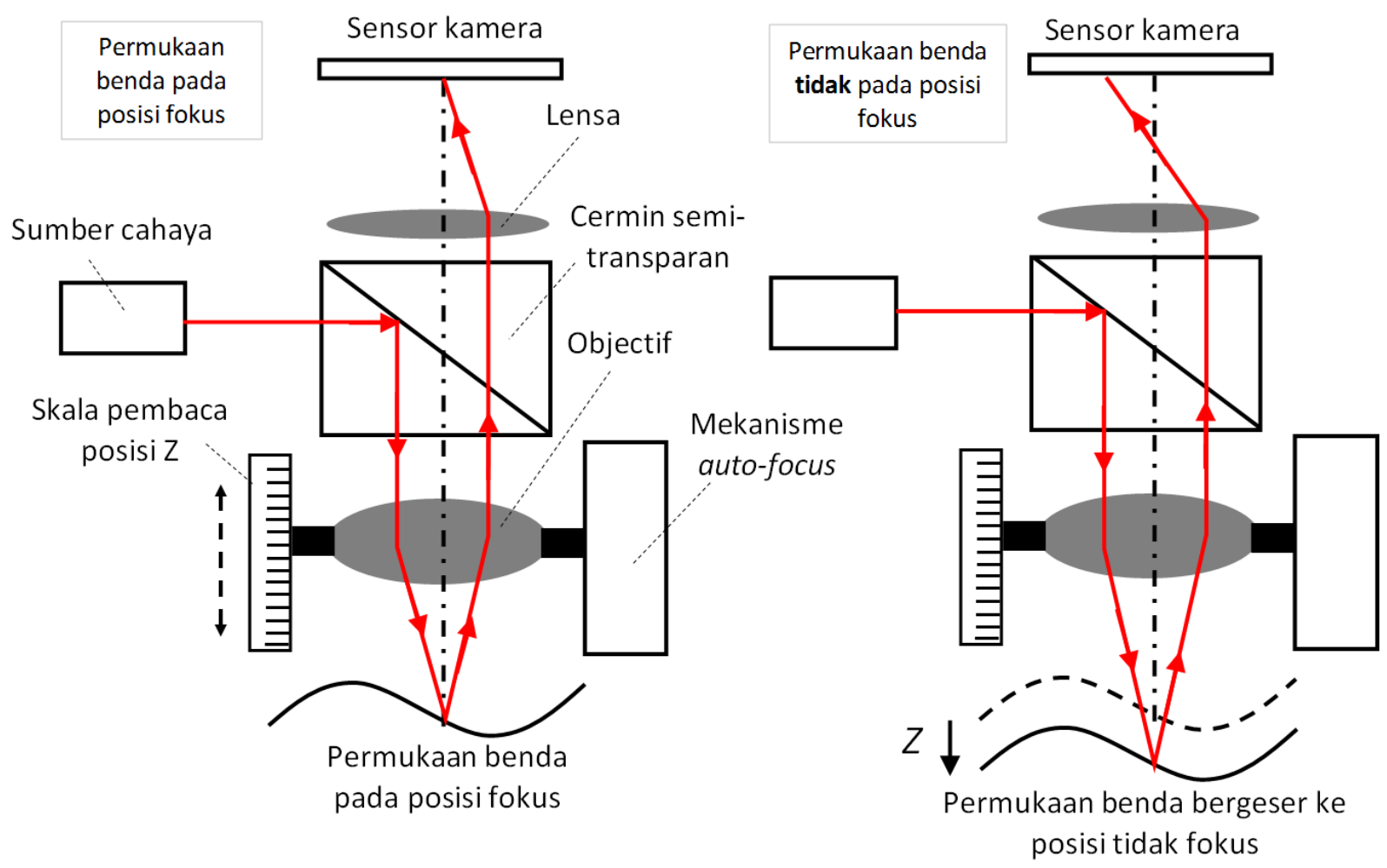

Gambar 19: Prinsip kerja PAI (kiri) pada posisi fokus dan (kanan) pada posisi tidak fokus.

\section{$\underline{\text { Aplikasi }}$}

Aplikasi PAI mencakup pengukuran dimensi dan geometri, dan tekstur permukaan. Gambar 20 memperlihatkan contoh-contoh pengukuran yang dilakukan dengan PAI. Pada gambar 20a, diperlihatkan suatu pengukuran geometri dari suatu benda yang berbentu silinder. Benda tersebut adalah sebuah poros yang memiliki fitur berupa slot yang berfungsi sebagai mating pada komponen pasangannya. Gambar 20 (b dan c) memperlihatkan pengukuran diamater internal dan diameter sebuah bola dengan ukuran mikro. Gambar 20 (d dan e) memperlihatkan pengukuran tekstu permukaan sebuah sampel hasil indentasi nano dan permukan tekstur gigi suatu hewan.

Kelebihan dari $P A I$ adalah:

- Memiliki volume pengukuran yang besar, yaitu $(120 \times 120 \times 130) \mathrm{mm}$. jangkaun aksis linier auto-focus adlaah $40 \mathrm{~mm}$, sehingga tinggi fitur pada suatu benda yang dapat diukur adalah mencapai $40 \mathrm{~mm}$.

- Memiliki kecepatan pengukuran kontur (profil 2D) yang sangat cepat.

- Memiliki kemampuan untuk mengukur permukaan dengan kemiringan yang tinggi. PAI dapat mengukur kemiringan suatu permkaan sampai dengan $45^{\circ}$ dengan menggunakan lensa objektif $100 \times$ dengan numerical aperture (NA) $=0.8$.

- Memiliki repeatbility auto-focus yang sangat tinggi. Repeatbility tersebut dapat mencapai level nanometer, yaitu sekitar $15 \mathrm{~nm}$.

- Memiliki kompatabilitas untuk mengukur suatu permukaan yang silau atau high-reflection.

- Memiliki setup spesial untuk mengukur diameter internal. 


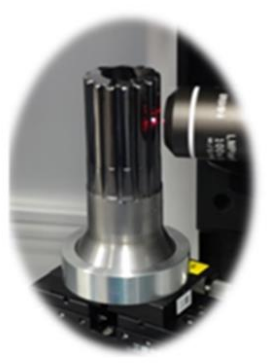

(a)

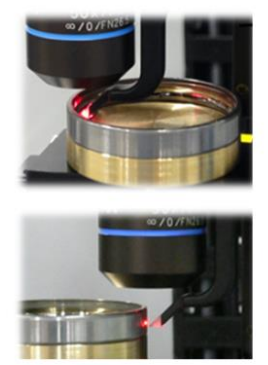

(b)

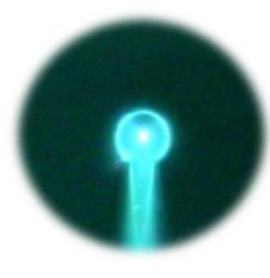

(c)

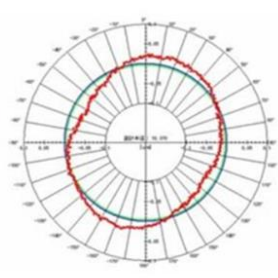

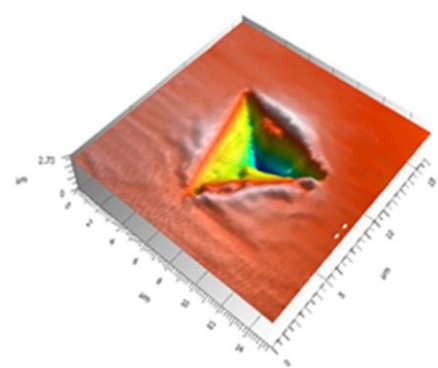

(d)

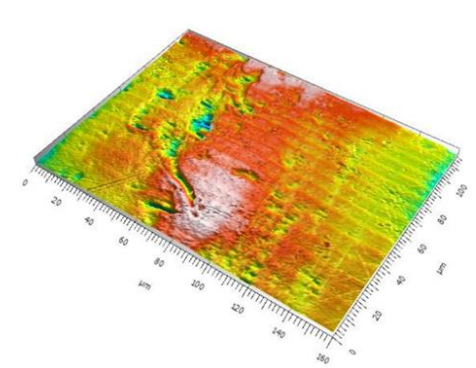

(e)

Gambar 20: Contoh aplikasi pengukuran dengan PAI. (a) pengukuran geometri benda berbentuk silinder, misalnya roda gigi, (b) pengukuran diameter internal, (c) pengukuran diameter sebuah micro-sphere, (d) pengukuran geometri dari indentasi nano dan (e) pengukuran tekstur permukaan.

Kekurangan dari $P A I$ adalah:

- Pengukuran untuk 2D area (XY-direction) adalah sangat lama karena PAI harus memindai seluruh area per kontur.

- Kemampuan pengukuran kemiringan permukaan berkurang apabila permukaan tersebut mempunyai highreflectance.

- Hanya satu atau dua lensa objektif yang dapat dipasang pada sistem PAI.

\subsection{Tomografi berbasis sinar-X (X-ray computed tomography)}

Pada saat buku ini ditulis, tomografi berbasis sinar-X (XCT) untuk pengukuran dimensi dan geometri merupakan salah satu topik yang paling utama dalam riset metrologi. Hal ini disebabkan karena dengan menggunakan XCT, pengukuran dimensi dan geometri suatu benda tidak hanya dapat dilakukan pada permukaan benda tersebut, tetapi juga dapat dilakukan pada bagian dalam benda tersebut, misalnya pengukuran diameter dari sebuah fitur silinder internal di dalam benda tersebut (yang tidak dapat dilakukan dengan menggunakan CMM konvesional). XCT merupakan salah satu metode non-destructive test (NDT), terutama untuk analisis material (Carmignato et al 2018).

Dengan kamampuan untuk melakukan pengukuran dari fitur-fitur internal suatu benda, XCT menjadi salah satu metode yang paling menjanjikan untuk pengukuran dimensi dan geometri komponen-komponen yang dibuat dengan prosess additive manufacturing (AM). Karena, dengan proses AM, hampir semua bentuk yang rumit (yang tidak dapat dibuat dengan metode konvensional) dapat dibuat, misalnya cetakan (mould) yang memiliki fitur-fitur internal untuk saluran pendingin yang sangat kompleks. Selain itu, XCT dapat mengkombinasikan kontrol kualitas dimensi dan geometri, dan kontrol kualitas material (seperti tingkat porositas di dalam suatu material) (Kruth et al 2011). 
Selain itu, tidak seperti CMM konvensioanl, lamanya waktu pengukuran dengan menggunakan XCT tidak bergantung pada banyaknya fitur-fitur pada suatu objek yang akan diukur. Sehingga, pengukuran suatu objek dengan jumlah fitur yang sedikit dan objek dengan jumlah fitur yang banyak adalah hampir sama. Gambar 21 memperlihatkan perbandingan waktu pengukuran XCT dengan CMM konvensional lainnya. Pada gamabr 21, diperlihatkan bahwa lamanya waktu pengukuran dengan XCT, yaitu waktu untuk memindai objek yang diukur untuk mendapatkan data pengukuran, cenderung konstan walaupun jumlah fitur yang ingin diukur bertambah. Tetapi, XCT mempunyai waktu pengukuran yang kurang efisian apabila jumlah fitur yang ingin diukur sedikit.

Secara umum, kemampuan XCT yang paling utama dapat dirangkum sebagai berikut:

- Kemampuan untuk mengukur fitur-fitur internal suatu objek atau komponen.

- Kemampuan untuk melakukan pengukuran dimensi dan geometri, dan analisis material.

- Lama waktu pengukuran tidak bergantung pada banyaknya fitur-fitur pada suatu objek yang ingin diukur.

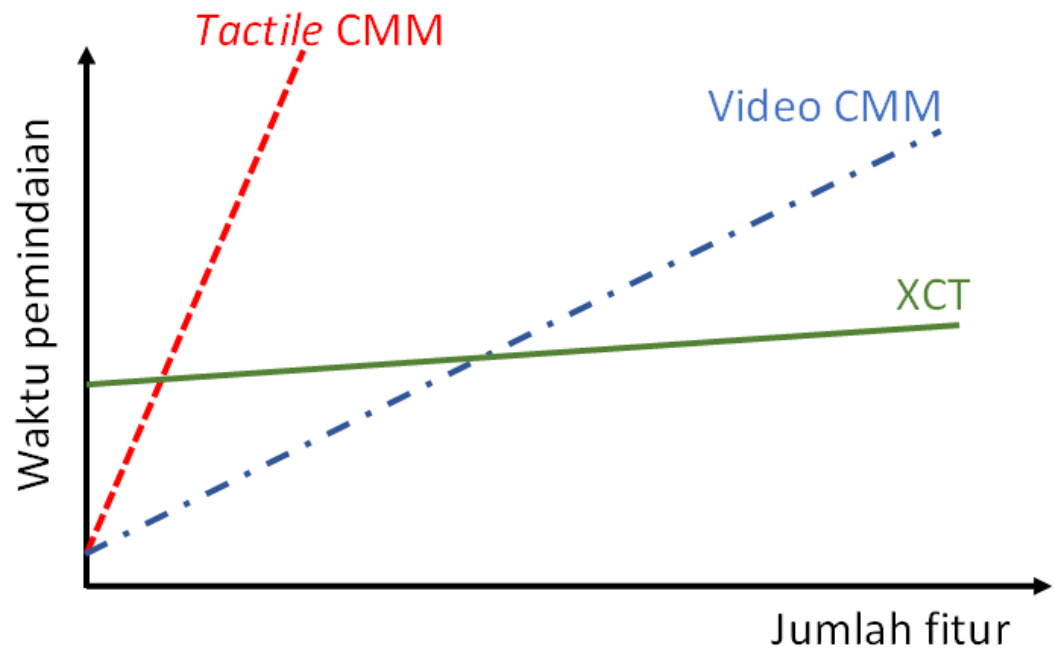

Gambar 21: Lamanya waktu pengukuran terhadap banyaknya fitur yang ingin diukur pada XCT, tactile CMM dan video CMM (De Chiffre et al 2014).

\subsubsection{Sejarah}

Sinar-X (X-ray) pertama kali diteliti secara sistematis oleh Wilhelm Röntgen pada tahun 1895. Sinar-X tersebut merupakan dasar dari XCT. Sinar-X digunakan sebagai sumber energi dan radiasi pada sebuah sistem XCT. Kemampuan utama dari XCT (secara spesifiksinar-X) adalah kemampuan radiasinya yang dapat menembus suatu material, baik lunak ataupun keras tergantung pada energi dari sumber radiasi yang dipancarkan, sehingga bagian dalam dari material-material tersebut dapat diketahui dengan menganalsis sisa radiasi, yang melewati materialmaterial tersebut, pada sebuah detektor radiasi.

Sampai sekarang, aplikasi utama XCT yaitu pada tiga bidang: medis, analisis material, dan pengukuran dimensi dan geometri (Kruth et al 2011). Penggunaan XCT pada bidang medis dipelopori oleh Hounsfield pada tahun 1970. Penggunaan XCT untuk analisis material pada umumnya untuk menganalsis struktur internal suatu material untuk mengetahui, misalnya, jumlah dan tingkat porositas di dalam material tersebut. Selain itu, penggunaan XCT untulk analisis makanan termasuk pada kategori ini. Contoh dari penggunaan XCT untuk analsis makanan adalah untuk mengetahui distribusi daging dan tulang pada sebuah karkas hewan (De Chiffre et al 2014). dan yang ketiga, penggunaan XCT untuk pengukuran dimensi dan geometri, yang merupaka fokus pada pembahasan ini, menjadi sangat populer karena kemampuan XCT yang dapat melakukan pengukuran internal fitur dari suatu komponen atau objek. Pengukuran dimensi dengan menggunakan XCT pertama kali dilakukan pada tahun 1991 dengan akurasi sekiatr $0.1 \mathrm{~mm}$. Baru pada tahun 2005, penggunaan XCT untuk pengukuran dimensi dan geometri menjadi salah satu fokus 
penggunaan XCT setelah mesin XCT pertama yang didedikasikan untuk pengukuran dimensi dan geometri (yaitu XCT dengan energi sinar-X yang tinggi, sampai dengan skala $450 \mathrm{KV}$ dan rotational table untuk memutar suatu objek yang diukur) dipasarkan pada sebuah pameran teknologi kontrol di Jerman (Kruth et al 2011).

\subsubsection{Prinsip kerja}

Prinsip kerja dan alur pengukuran XCT lebih kompleks dibandingkan dengan CMM lainnya. Selain itu, pengukuran XCT membutuhkan kemampuan komputer yang tinggi untuk melakukan proses kalkulasi data untuk merekonstruksi volume 3D dari suatu objek yang diukur. Gambar 23 memperlihatkan alur pengukuran XCT dari proses pemindaian objek sampai dengan proses pengukauran dimensi dan geometri.

Prinsip kerja dan alur pengukuran dengan XCT adalah (lihat gambar 23):

- Pemindaian dan pengakuisisian gambar-gambar 2D X-ray.

- Rekonstruksi volume 3D dari gambar-gambar 2D X-ray dengan metode radon transformation.

- Penentuan permukaan dari volume 3D yang terrekonstruksi.

- Fitting geometri, pengukuran dimensi dan geometri, dan perbandingan antara model yang diukur dengan model CAD.

Langkah 1: Pemindaian dan pengakuisisian gambar-gambar 2D X-ray.

Gambar 22 memperlihatkan dua jenis sistem XCT: cone-beam dan fan-beam (Kruth et al 2011). Komponen dasar dari sistem XCT adalah: Sumber sinar-X, meja rotasi, meja translasi, detektor X-ray dan perangkat lunak untuk merekonstruksi volume 3D dari suatu objek yang diukur (gambar 22). Terlepas dari kedua jenis XCT tersebut, kedua sistem tersebut mempunayi prinsip kerja yang sama. Prinsip kerja XCT adalah sebagai berikut.

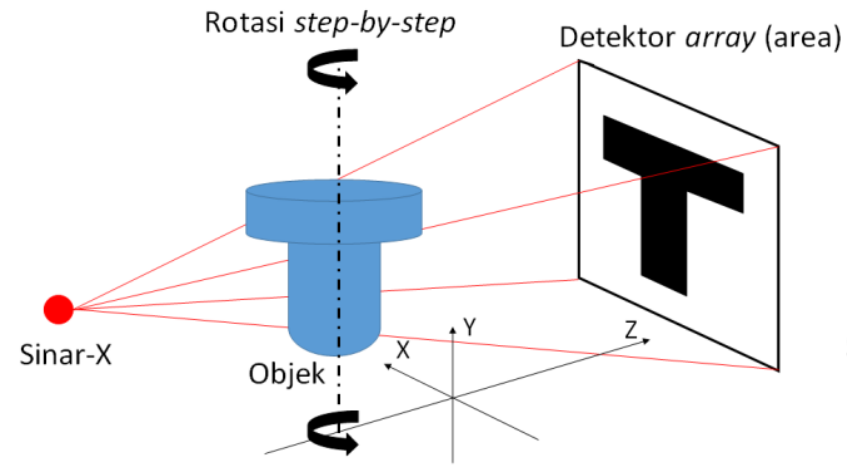

Cone-beam XCT

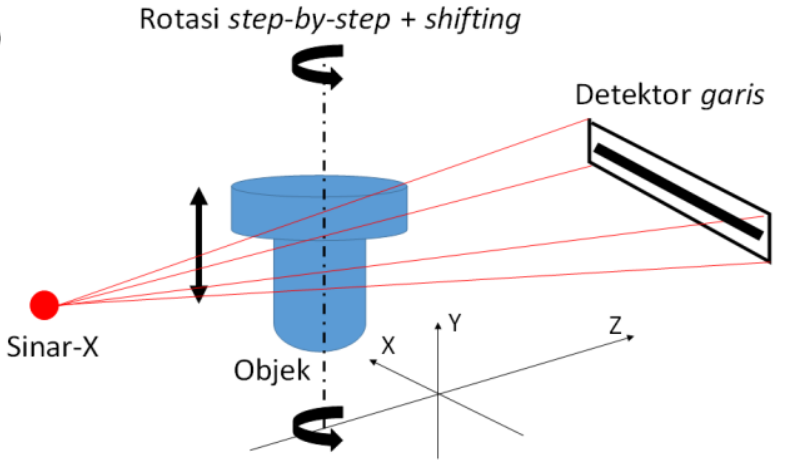

Fan-beam XCT

Gambar 22: Dua jenis XCT: cone-beam dan fan-beam.

Sebuah sumber menghasilkan suau sinar-X. Sinar-X tersebut dipancarkan ke sebuah objek yang diukur. Ketika sinar-X tersebut melalui material dari objek tersebut, sinar-X tersebut akan mengalami pelemahan (pengurangan energi) yang diakibatkan oleh proses absorbi energi oleh material objek tersebut dan scattering (pemancaran) energi oleh atom-atom material tersebut. Besarnya pelemahan energi sinar-X tersebut bergantung pada panjang material yang dilalui sinar-X tersebut, komposisi material, kepadatan material dan besarnya energi awal yang dimiliki oleh sinar-X tersebut. Sinar-X yang terlemahkan setelah melewati material objek tersebut dideteksi oleh sebuah detektor sinar-X. hasil dari proses deteksi dengan detektor tersebut adalah gambar 2D gray-scale (untuk tipe detektor array pada cone beam XCT) dan 1D profil gray-scale (untuk tipe detektor garis pada fan beam XCT).

Gambar-gambar 2D atau 1D tersebut ditangkap dari posisi rotasi objek tersebut yang berbeda-beda (ditambah posisi shifting objek untuk tipe fan-beam XCT). Kemudian, proses kalkulasi matematik untuk merekonstruksi volume 
3D dari (model vokselel) banyak gambar tersebut dilakukan. Volume 3D tersebut terdiri dari unit-unit voksel (disebut piksel dalam 2D) yang merupakan ukuran seberapa besar penyerapan energi sinar-X tersebut oleh material objek tersebut. Proses pelemahan energi sinar-X ketika melewati panjang suatu material adalah non-linier. Fenomena ini dinamakan beam hardening (Dewulf et al 2012).

Langkah 2: Rekonstruksi volume 3D dari gambar-gambar 2D X-ray dengan metode radon transformation.

Hasil dari proses pemindaian XCT adalah sekumpulan gambar-gambar 2D gray-level (hitam/putih) yang merupakan sinar-X yang terlemahkan yang ditangkap oleh detektor sinar-X. suatu proses kalkulasi matematis dilakukan untuk merekonstruksi sebuah volume 3D dari suatu objek yang dipindai dengan XCT dari gambar-gambar 2D tersebut.

Proses rekonstruksi volume 3D berdasarkan metode filtered back-propagation yang berdasarkan pada metode transformasi Radon (transformasi integral linier). Transformasi integral linier tersebut pertama kali dikembangkan oleh J. Radon pada tahun 1917. Model tersebut merupakan model penyerapan atau absorpsi sinar-X ketika melewait suatu medium dengan koefisien pelemahan linier $\mu$ (lihat gamabar 22):

$$
I=I_{0} \exp \left(-\int \mu(z) d z\right)
$$

dimana $I$ adalah besarnya absorpi sinar-X pada suatu medium. $I_{0}$ adalah intensitas awal sinar-X yang melewati suatu jarak $z$ pada sebuah medium $\mu$. Besarnya $I$ pada suatu jarak $z$ adalah:

$$
I(z)=I_{0} e^{-\mu z}
$$

Resolusi voksel dari rekonsturksi volume 3D bergantung pada ukuran piksel pada detektor sinar-X, banyaknya piksel pada detektor sinar-X, banyakya potongan piksel pada arah Y, banyaknya posisi angular suatu objek ketika objek tersebut dipindai oleh sinar-X, banyaknya gambar projeksi 2D yang diambil per pose angular (averaging), binning pada sensor kamera detektor, dan lain-lain (Kruth et al 2011).

Langkah 3: Penentuan permukaan dari volume 3D yang terrekonstruksi.

Setelah volume 3D direkonstruksi, langkah selanjutnya adalah menentukan edge atau tepi untuk menentukan permukaan objek terukur yang memisahkan antara material dengan udara atau batas antara material yang berbeda pada objek tersebut. untuk menentukan edge tersebut, proses thresholding untuk mennetukan status tiap-tiap voksel apakah sebagai material atau udara. Proses thresholidng tersebut dapat dilakukan dengan berbagai macam cara. Proses deteksi edge merupakan langkah yang krusial yang menentukan tingkat akurasi dan keterlacakan hasil pengukuran suatu XCT.

Metode yang paling umum untuk menentukan batas thresholding adalah metode ISO-50\%. Metode ini dilakukan berdasarkan histogram yang merupakan plot antara banyaknya voksel dan intensitas voksel. Hasil dari histogram tersebut pada umumnya akan mempunyai dua puncak. Metode ISO-50\% menentukan nilai threshold sebagai nilai tengah antara kedua puncak histogram tersebut (Kruth et al 2011).

Langkah 4: Fitting geometri, pengukuran dimensi dan geometri, dan perbandingan antara model yang diukur dengan $\underline{\text { model CAD. }}$

Hasil dari deteksi edge adalah berupa point cloud 3D, yaitu koordinat spasial titik-titik pada permukaan benda tersebut dalam format 3D. dari point cloud tersebut, berbagai macam fitting data dapat dilakukan untuk melakukan pengukuran dimensi dan geometri. Faktor-faktor yang mempengaruhi hasil pengukuran XCT adalah: sumber sinar-X, energi sinar-X, material objek dan bentuknya, variasi temperatur, startegi pemindaina dan efek operator. 

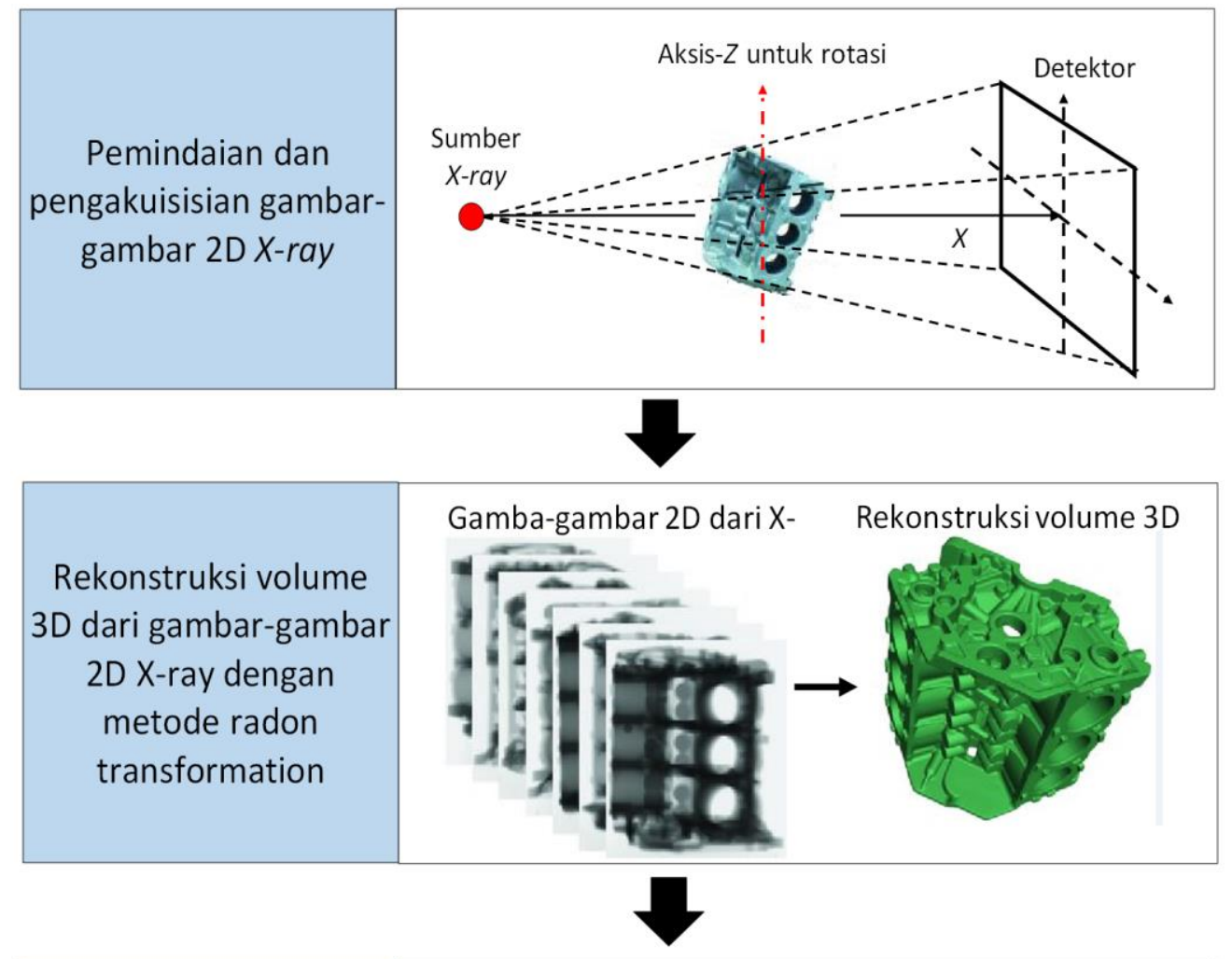

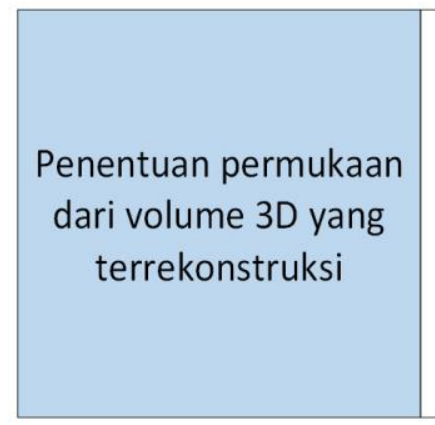

Thersholding untuk menentukan permukaan
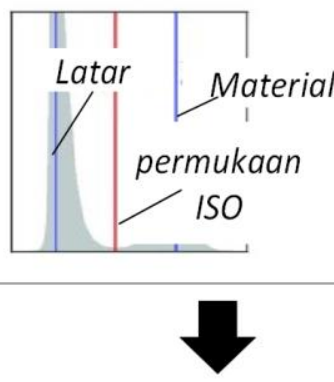

Fitting geometri, pengukuran dimendi dan geometri, dan perbandingan antara model yang diukur dengan model CAD
Pengukuran dimensi dan Perbandingandengan model

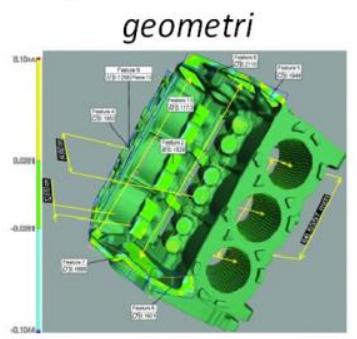

Segmentasi antara material dengan latar (permukaan)

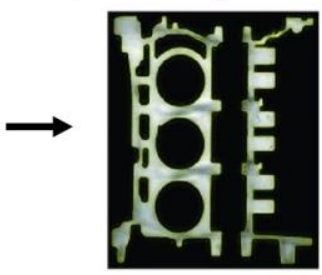

Gambar 23: Prinsip kerja dan alur pengukuran dengan X-ray CT. 


\subsubsection{Aplikasi}

Terdapat beberapa jenis XCT komersial yang sudah beredar di pasaran, seperti XCT yang diproduksi oleh Nikon, Zeiss, Werth Messhtechnik dan GE. Gambar 24 memperlihatkan sebuah sistem XCT komersial yang diproduksi oleh Nikon. Untuk XCT komersial, pada umumnya XCT tersebut dilengkapi dengan sumber sinar-X berkekuatan energi $150 \mathrm{kV}, 250 \mathrm{kV}$ dan $450 \mathrm{kV}$. Semakin tinggi kekuatan energi suatu sinar-X, maka kemampuan untuk menembus material dengan densitas atau kepadatan yang lebih tinggi akan semakin baik.

Aplikasi-aplikasi pengukuran XCT sangat luas, seperti visualisasi objek 3D, analisis cacat material, karakterisasi material, reverse engineering, pengukuran dimensi dan geometri, analsisi toleransi dan analisis wall-thickness (De Chiffre et al 2014). Khususnya untuk pengukuran dimensi dan geometri, XCT sangat bermanfaat untuk menginspeksi cacat-cacat internal dari sebuah produk manufaktur dan sebuah komponen mekanikal. Gambar 25 memperlihatkan aplikasi XCT untuk mengukur dimensi internal sebuah komponen aluminium dan komponen pendingin internal berbentuk kompleks pada sebuah cetakan. Contoh aplikasi XCT lainnya dapat merujuk pada (Carmignato et al 2018).

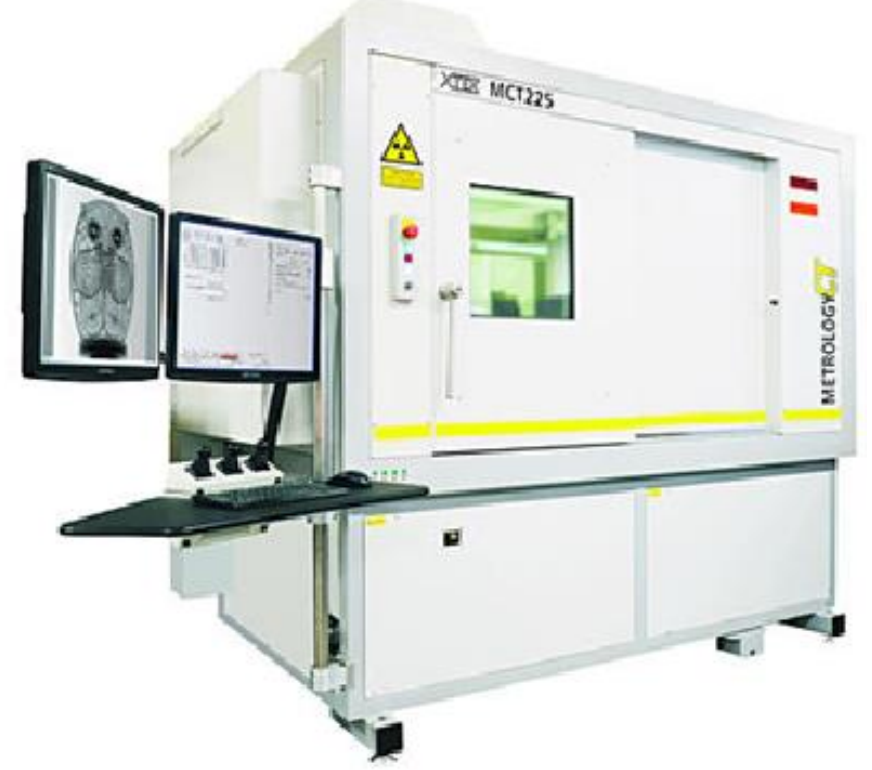

Gambar 24: Contoh sebuah XCT komersial (Sumber: Nikon Metrology).

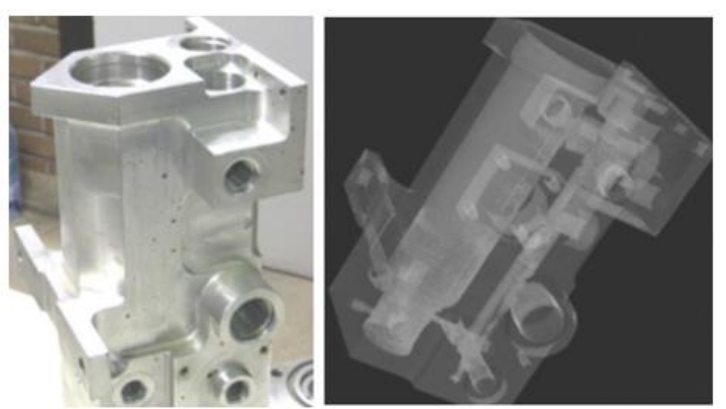

(a)

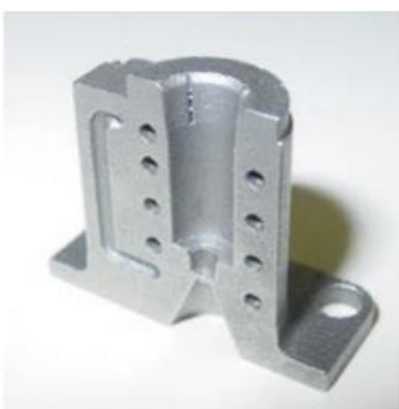

(b)

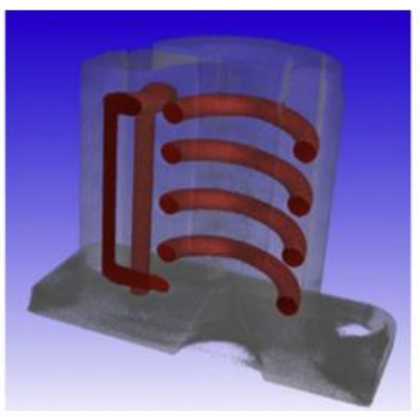

Gambar 25: Contoh pengukuran dimensi dan geometri untuk fitur internal. (a) sebuah komponen alumunium dan (b) saluran pendingin internal dengan tinggi $\pm 30 \mathrm{~mm}$ (De Ciffre et al 2014). 


\subsubsection{Karakteristik}

Pada saat penulisan, XCT komersial relatif memiliki tingkat akurasi yang lebih rendah bila dibandingkan dengan CMM konvensional pada umumnya. Namun demikian, kemampuan XCT untuk mengukur fitur-fitur internal sebuah benda tidak dimiliki oleh jenis CMM lainnya. Maka dari itu, riset-riset bagaimana untuk mengecek dan meningkatkan akurasi XCT serta menciptakan rantai keterlacakan (traceability) hasil pengukuran XCT menjadi fokus utama pada saat penulisan ini.

Untuk mengecek akurasi, berbagai macam artifak diusulkan untuk berbagai macam jenis pengukuran XCT (termasuk pengukuran untuk berbagai macam jenis material). Gambar 26 memperlihatkan berbagai macam artifak yang telah diusulkan untuk mengecek tingkat akurasi suatu XCT. Namun demikian, usulan artifak untuk XCT tidak hanya artifak-artifak tersebut, terdapat juga jenis artifak-artifak lainnya yang telah diusulkan untuk mengecek tingkat akurasi XCT. Pada gambar 26, contoh-contoh artifak terkalibrasi yang diusulkan adalah artifak collet cube dan bola pentagram untuk mengecek akurasi XCT untuk pengukuran suatu jarak, silinder flute untuk mengecek akurasi XCT untuk pengukuran fitur-fitur internal dan artifak geometri kompleks untuk mengecek tingkat akurasi XCT ketika mengukur geometri-geometri dengan bentuk yang kompleks, seperti roda gigi.

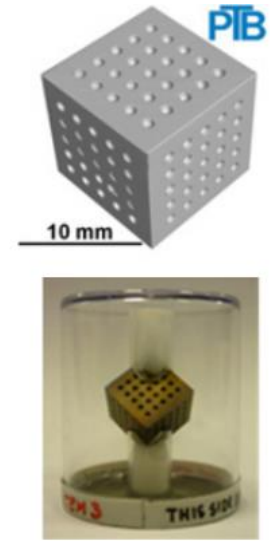

(a)

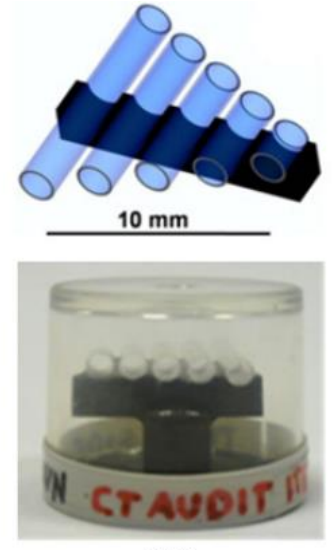

(b)

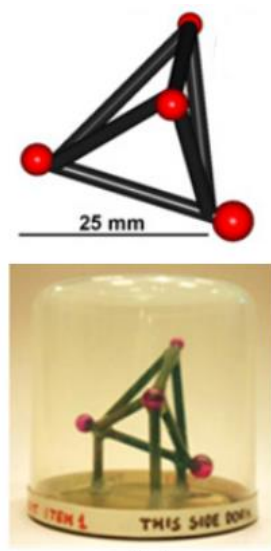

(c)

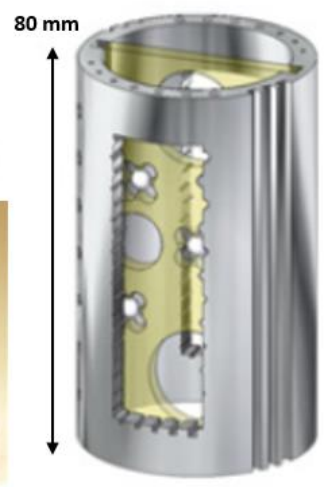

(d)

Gambar 26: Contoh proposal untuk mengecek akurasi dan komparasi XCT. (a) collet cube, (b) silinder flute, (c) bola pentagram dan (d) geometri kompleks (Carmignato and Pierobon 2010).

Gambar 27 memperlihatkan salah satu contoh akurasi sebuah XCT untuk pengukuran jarak antara dua buah titik (Bartscher et al 2007). Pada gambar 27, diperlihatkan bahwa, sebuah XCT yang digunakan untuk mengukur suatu jarak antara dua buat titik-tangah bola (dengan menggunakan artifak collet cube) menghasilkan error sebesar maksimal $\pm 6 \mu \mathrm{m}$ untuk mengukur suatu jarak sampai sebesar $18 \mathrm{~mm}$.

Pengukuran XCT merupakan suatu proses pengukuran yang sangat kompleks. Estimasi ketidakpastian dari suatu hasil pengukuran XCT tidaklah mudah untuk diestimasi. Dewulf et al 2013 mengusulkan metode untuk mengestimasi nilai ketidakpastian dari hasil pengukuran suatu XCT. Metode mereka berdasarkan pada pengukuran dengan XCT adalah pengukuran pada sebuah volume 3D benda yang diukur, dimana volume 3D tersebut terdiri dari voksel (piksel 3D). maka dari itu, hal-hal yang mempengaruhi rekonstruksi voksel-voksel tersebut merupakan kontributor dari ketidakpastian hasil pengukuran XCT. Kontributor-kontributor ketidakpastian XCT terbagi mejadi dua bagain, yaitu: ketidakpastian dari ukuran voksel (resolusi voksel) dan jumlah dari voksel (Dewulf et al 2013). Ketidakpastian ukuran voksel adalah panjang jarak terkalibrasi, repeatability dari penentuan ukuran voksel, error dari form probing pada bola kalibrasi. Ketidakpastian jumlah voksel adalah variasi acak, ofset edge dan ofset edge yang tidak uniform. 


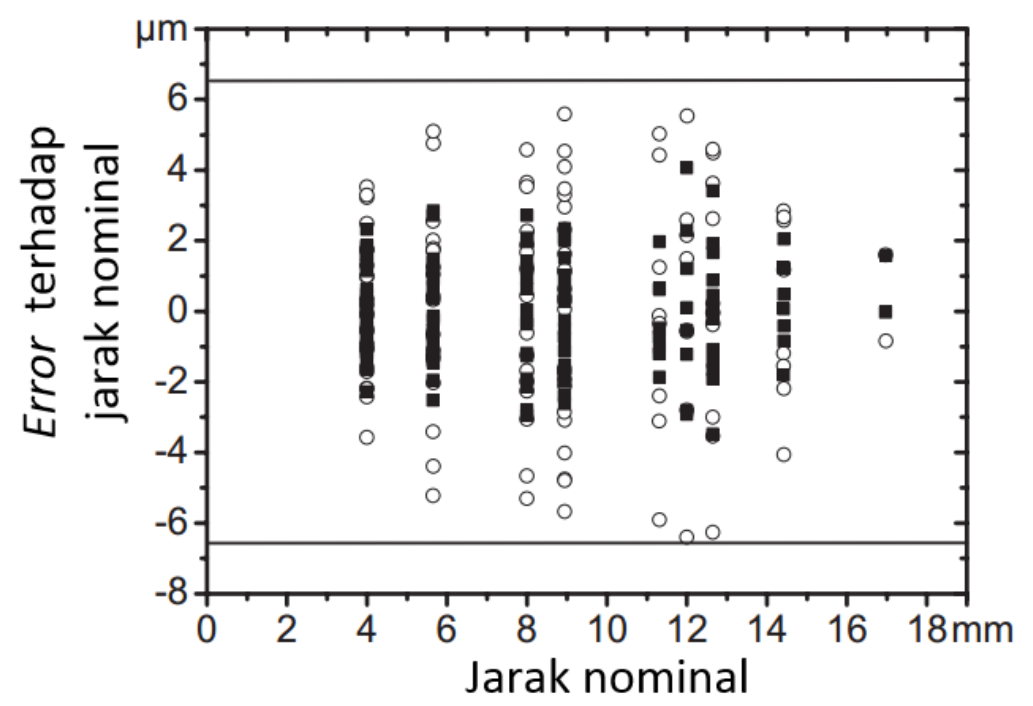

Gambar 27: Salah satu hasil pengecekan akurasi sebuah XCT pada pengukuran panjang (Bartscher et al 2007).

\subsection{Dua keterbatasan fundamental dari sistem optik}

Semua instrumen pengukuran dengan metode non-kontak yang menggunakan prinsip pembesaran dari gambar sebuah permukaan yang diukur dengan menggunakan sistem lensa objektif (terutama sistem berbasis mikroskop), kecuali tomografi berbasis sinar-X, mempunyai dua keterbatasan fundamental. Batasan fundamental tersebut adalah (Richard 2010): numerical aperture (NA) dan kemampuan untuk mengukur seberapa besar kemiringan (slope) sebuah permukaan, dan besarnya resolusi optik yang merupakan batas dari resolusi lateral $(\operatorname{arah} X Y)$.

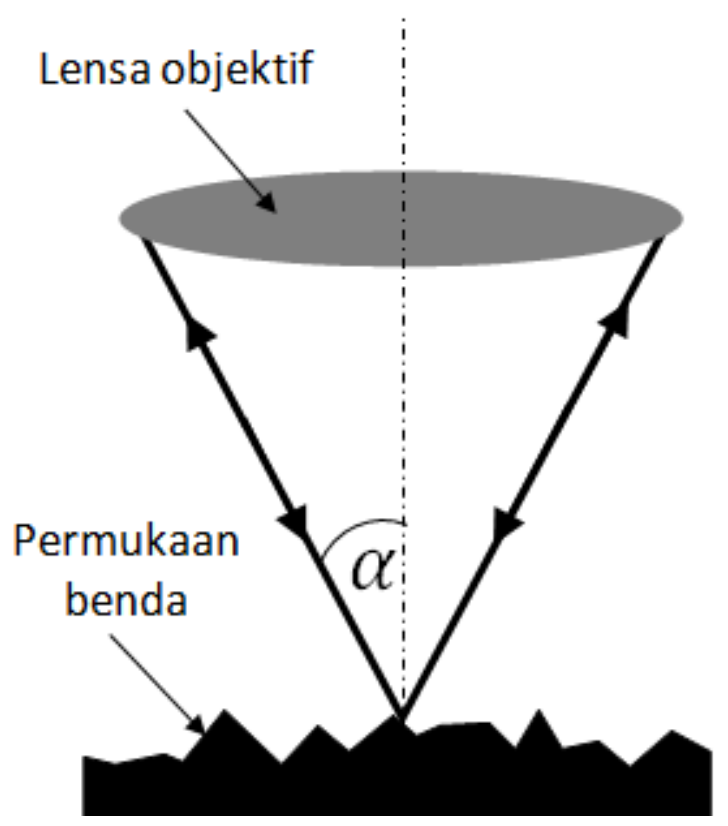

Gambar 28: Numerical aperture (NA) dari sebuah lensa objektif mikroskop. 


\section{Slope atau kemiringan suatu permukaan}

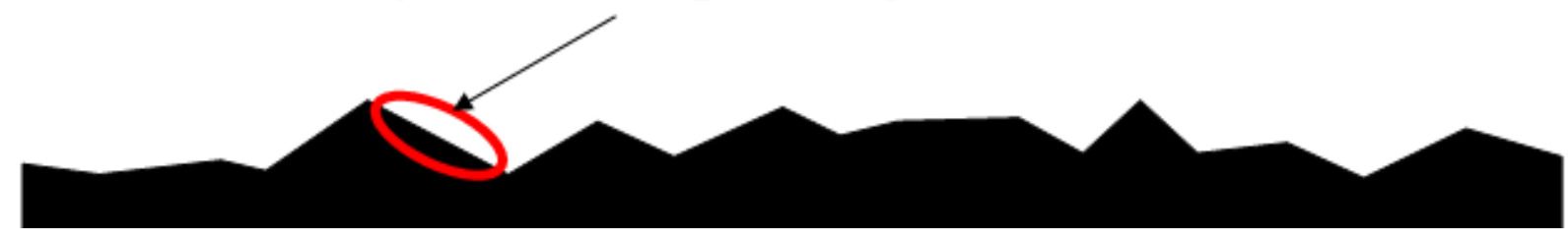

Gambar 29: Ilustrasi dari "slope" atau kemiringan fitur pada suatu permukaan.

- $\quad$ Numerical aperture dan kemampuan untuk mengukur seberapa besar kemiringan (slope) sebuah permukaan. Numerical aperture (NA) sebuah lensa objektif menentukan seberapa besar kemiringan sebuah permukaan yang dapat diukur dan menentukan juga resolusi optikal sebuah sistem berbasis mikroskop. NA merupakan ukuran seberapa besar cahaya yang terrefleksikan dari suatu permukaan dapat ditangkap oleh sebuah lensa objektif. Gambar 28 memperlihatkan NA pada sebuah lensa objektif pada suatu sistem mikroskop. Pada gambar 28, NA ditentukan oleh seberapa besar lebar suatu lensa objektif dan properti suatu medium yang dilalui oleh suatu cahaya, dalam hal ini indek bias medium tersebut.

NA diformulasikan sebagai:

$$
N A=n \sin \alpha
$$

dimana $N A$ adalah numerical aperture, $n$ adalah indeks bias dari medium yang dilalui oleh suatu cahaya dan $\sin \alpha$ adalah acceptance angle dari sebuah aperture atau bukaan sebuah lensa objektif.

Besarnya kemiringan (slope) dari suatu permukaan yang daat diukur bergantung pada seberapa besar nilai NA tersebut. Gambar 29 memperlihatkan ilustrasi dari kemiringan suatu fitur pada sebuah permukaan. Semakin besar slope suatu fitur pada permukaan, maka permukaan tersebut semakin kasar.

- $\quad$ Resolusi optik merupakan batas dari resolusi lateral ( $\operatorname{arah} X Y)$.

Resolusi lateral adalah minimum jarak antara dua fitur lateral $(\operatorname{arah} X Y)$ pada sebuah permukaan yang masih daat diukur. Dengan kata lain, resolusi lateral adalah jarak minimum dua buah titik sehingga kedua titik tersebut masih dapat dibedakan satu dengan lainnya. Resolusi optika diformulasikan sebagai:

$$
r_{\text {optikal }}=\frac{\lambda}{2 \cdot N A}
$$

dimana $r_{\text {optikal }}$ adalah resolusi optikal suatu sistem mikroskop (resolusi lateral) tdan $\lambda$ adalah pajang gelombang dari cahaya yang digunakan pada suatu sistem mikroskop (untuk jenis cahaya dengan satu jenis panjan gelombang) atau rata-rata dari panjang gelombang (untuk jenis cahaya dengan lebih dari satu jenis panjang gelombang).

Untuk sebuah sistem berbasis mikroskop yang menggunakan sensor kamera, resolusi lateral untuk lensa objektif dengan pembesaran rendah $(5 \times$ dan $10 \times)$ dibatasi oleh jarak antar piksel karena jarak antar-pikselnya lebih besar dari resolusi optikal lensa objektif tersebut. untuk lebih jelasnya, table 1 memperlihatkan perbandingan antara jarak-antar piksel dan resolusi optikal (yang dikalkulasi dengan menggunakan persamaan(53)) untuk berbagai tipe pembesaran dari lensa objektif. Pada tabel 1, pada lensa objektif dengan pembesaran 20×, optikal resolusinya lebih besar dari jarak antar-piksel pada sensor kamera sehingga resolusi lateralnya ditentukan oleh resolusi optikalnya, bukannya jarak antar-piksel. Jarak antar piksel ditentukan oleh: 


$$
\text { Jarak }- \text { antar }- \text { piksel }=\frac{\text { besarnya field-of-view }(\text { FOV })}{\text { densitas pikesel dari senso kamera }}
$$

Table 1: Perbandingan jarak antar-piksel dan resolusi optikal dari berbagai lensa objektif.

\begin{tabular}{|c|c|c|c|}
\hline Tipe pembesaran lensa & NA & Resolusi optikal / $\boldsymbol{\mu m}$ & Jarak antar-piksel $/ \boldsymbol{\mu m}$ \\
\hline $10 \times$ & 0.3 & 1 & 1.75 \\
\hline $20 \times$ & 0.4 & 0.75 & 0.8 \\
\hline $50 \times$ & 0.5 & 0.6 & 0.3 \\
\hline
\end{tabular}

Selain itu, hal penting yang mempengaruhi resolusi lateral sebuah sistem pengukuran non-kontak berbasiskan mikroskop adalah ukuran spot dari cahaya yang terfokuskan yang keluar dari sebuah lensa objektif. Ukuran (diameter) spot tersebut merupakan besarnya area dari suatu permukaan yang dapat dilihat di bawah suatu sistem mikroskop. Diameter (ukuran) spot dari cahaya yang difokuskan oleh lensa objektif adalah:

$$
d_{0}=\frac{f \cdot \lambda}{w_{0}}
$$

dimana $d_{0}$ adalah diameter spot atau cahaya yang terfokuskan pada sebuah permukaan, $f$ adalah jarak fokal dari suatu lensa objektif, $\lambda$ adalah panjang gelombang cahaya dan $w_{0}$ adalah beam waist, yaitu radius dari $1 / e^{2}$ dari kontur irradiasi pada sebuah bidang ketika wavefront-nya datar.

\subsection{Verifikasi performansi CMM non-kontak}

Verifikasi performansi sebuah CMM adalah suatu proses untuk mengecek (memverifikasi) bahwa CMM tersebut beroperasi sesuai dengan spesifikasi yang ditulis dari produsen CMM tersebut. Parameter yang merepresentasikan spesifikasi suatu CMM adalah maximum permissible error (MPE). MPE adalah nilai maksimum error pada suatu hasil pengukuran dari suatu CMM. Standar internasional de facto mengenai verifikasi performansi adalah seri ISO 10360.

Sesuai anduan dari ISO 10360, proses verifikasi performansi dilakukan dengan cara mengukur suatu jarak (bisa berupa jarak antartitik tengah bola atau jarak antardua bidang pada sebuah artifak terkalibrasi) pada minimal tujuh arah, yaitu tiga arah aksis linier ( $\operatorname{arah} \mathrm{X}, \mathrm{Y}$ dan Z) dan empat arah diagonal ruang dari volume pengukuran. Volume pengukuran minimal meliputi $67 \%$ dari total volume pengukuran yang dimiliki suatu CMM. Pada setiap arah pengukuran panjang, minimal lima jarak yang berbeda harus diukur dan minimal meliputi $67 \%$ dari maksimum jarak pada arah pengukuran tersebut (lihat seri ISO 10360).

Proposal artifak dan prosedur untuk verifikasi performansi non-contact CMM masih merupakan topik riset dan belum semapan verifikasi performansi untuk CMM berbasis kontak. Syam 2015 membuat proposal untuk verifikasi performansi suatu CMM non-kontak berbasiskan FVM (focus variation microscopy). Konfigurasi FVM tersebut terbagi menjadi dua jenis, yaitu konfigurasi untuk melakukan pengukuran 3-aksis dan 1-rotasi aksis secara terpisah dan konfigurasi untuk melakukan pengukuran dengan menggerakkan 4-aksis (3-aksis linier dan 1-aksis rotasi) secara bersamaan. Perbedaan konfigurasi pengukuran tersebut menyebabkan artifak dan prosedur untuk melakukan verifikasi performansi FVM tersebut berbeda untuk masing-masing jenis konfigurasi tersebut. Syam 2015 mengusulkan solusi untuk verifikasi performansi dengan konfigurasi pengukuran 3-aksis dan 1-rotasi aksis secara terpisah dan Moroni et al 2017 mengusulkan solusi untuk pengukuran dengan menggerakkan 4-aksis (3-aksis linier dan 1-aksis rotasi) secara bersamaan. 

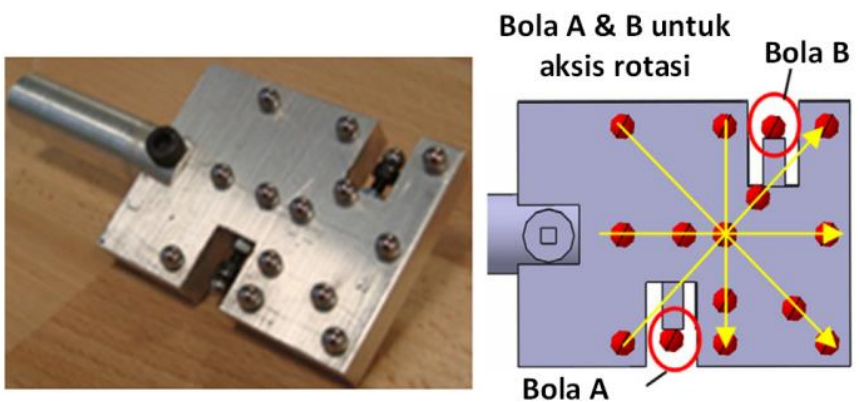

Gambar 30: Artifak referensi untuk memverivikasi performansi sebuah FVM untuk pengukuran 3-aksis linear dan 1aksis rotasi (Syam 2015).

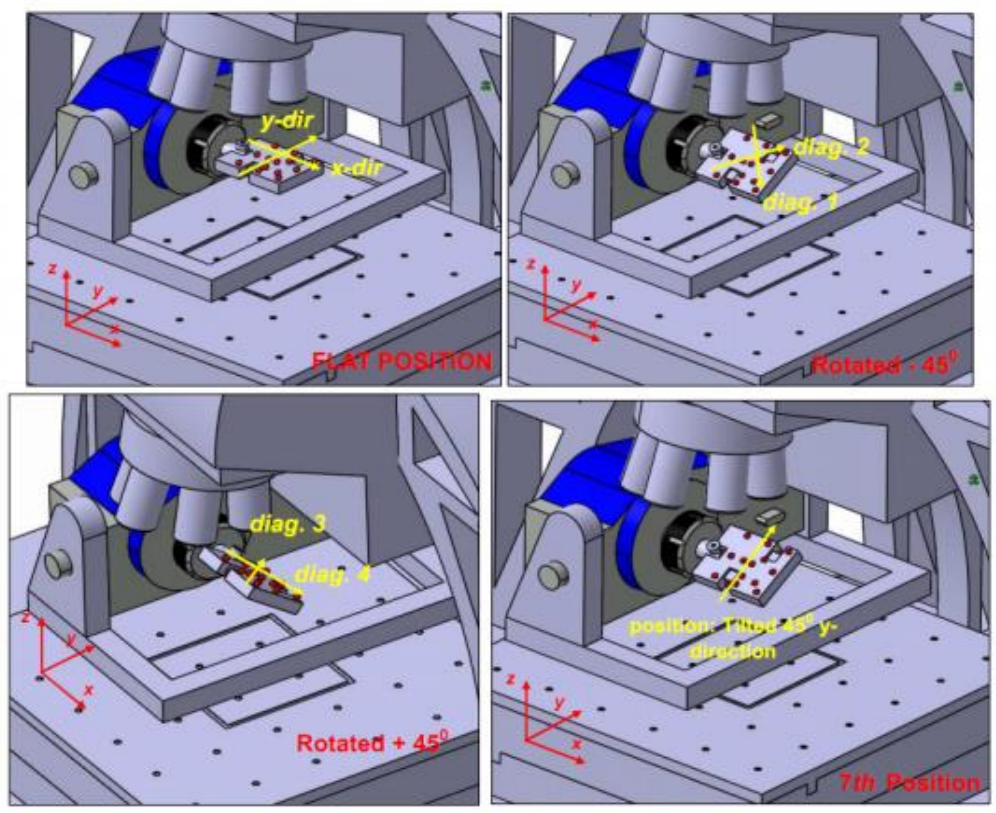

Gambar 31: Prosedur verifikasi performansi FVM dengan menggunakan artifak pada gambar 30 (Syam 2015).
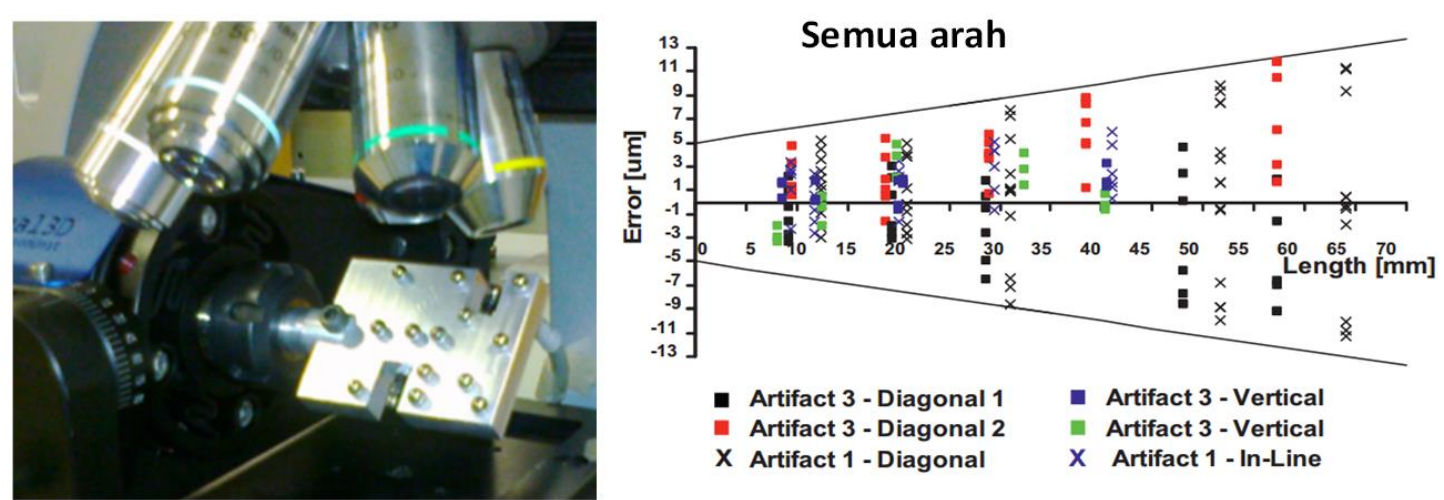

Gambar 32: Proses verifikasi performansi FVM dan hasil verifikasi performansi tersebut dengan menggunakan 
prosedur dan artifak pada gambar 31 dan gambar 30 (Syam 2015).

Untuk verifikasi performansi dengan konfigurasi pengukuran 3-aksis dan 1-rotasi aksis secara terpisah, artifak dan prosedur untuk proses verifikasi tersebut diperlihatan pada gambar 30 dan 31 (Syam 2015). Untuk verifikasi jenis konfigurasi ini, susunan bola-bola metal disusun sedemikain rupa sehingga pada setiap arah pengukuran, terdapat lima jenis jarak yang berbeda. Artifak tersebut didisain untuk memverifikasi 2 aksis linier (arah X dan Y, dalam hal ini arah $\mathrm{Z}$ tidak bisa diverifikasi) dan 4 aksis diagonal ruang. Selain itu, artifak tersebut didisain mempunyau dua bola disisisisinya yang digunakan untuk memverifikasi aksis rotasi FVM tersebut sesuai dengan ISO 10360-3. Gambar 31 memperlihatkan prosedur varifikasi tersebut dengan artifak tersebut.

Gambar 32 (kiri) memperlihatkan proses verifikasi. Artifak tersebut dipasang pada sebuah chuck spindle FVM tersebut. untuk pengukuran diagonal ruang, artifak tersebut diputar $45^{\circ}$ searah dan berlawanan arah jarum jam. Gambar 32 (kanan) memperlihatkan hasil verifikasi FVM tersebut. pada gambar 32, MPE dari FVM tersebut adalah $\pm(5+L / 8) \mu m ; L$ dalam $m m$.
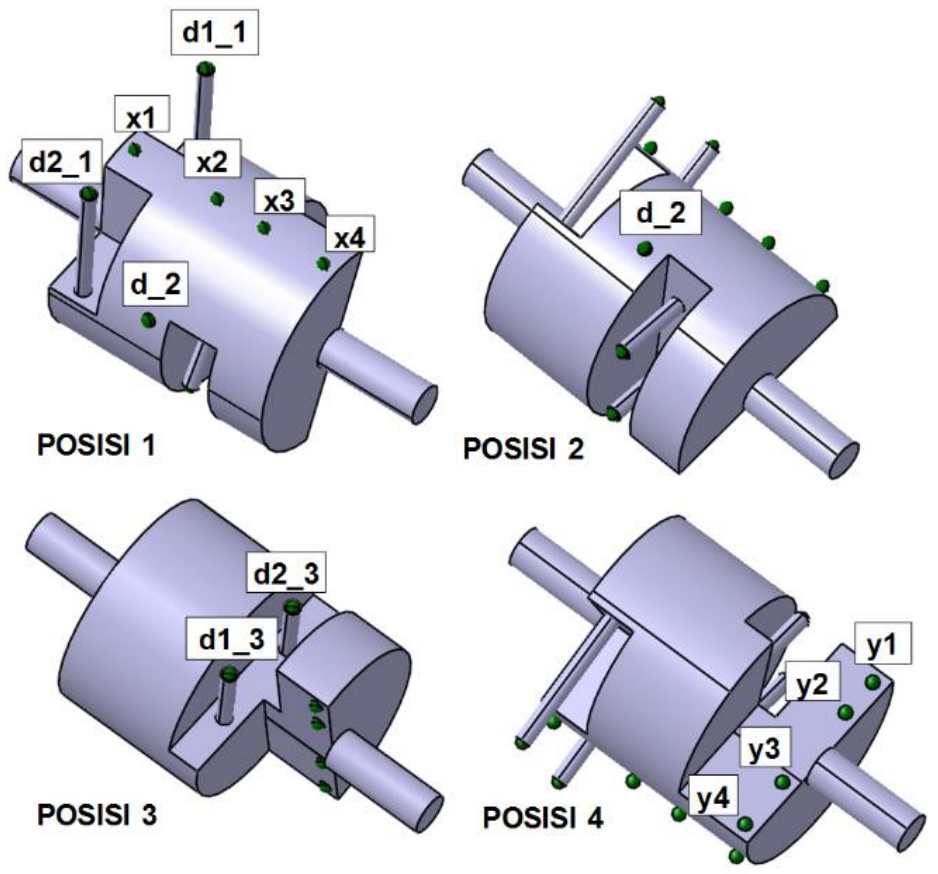

Gambar 33: Artifak referensi untuk FVM dengan moda pengukuran 4-aksis secara bersamaan (Moroni et al 2017).

Untuk verifikasi performansi untuk konfigurasi pengukuran dengan menggerakkan 4-aksis (3-aksis linier dan 1- aksis rotasi) secara bersamaan, artifak dan prosedur untuk proses verifikasi tersebut diperlihatan pada gambar 33 dan 34 (Moroni et al 2017). Prinsip dasar dari disain artifak untuk verifikasi tipe ini (pada gambar 33) ini adalah susunan bola-bola metal disusun sedemikian rupa sehingga ketika bola-bola tersebut diukur dengan instrumen FVM, maka lintasannya akan berbentuk diagonal ruang. Namun demikian, untuk mencapai lintasan diagonal ruang tersebut, dibutuhkan kombinasi dari pergerakan 3-aksis dan 1-aksis rotasi secara bersamaan.

Gambar 34 memperlihatkan prosedur verifikasi jenis ini dengan artifak tersebut. pada gambar 34, diperlihatkan bahwa dengan artifak tersebut (gambar 33), verifikasi untuk pergerakan linier 2-aksis (arah X dan Y) dan 4 arah diagonal ruang dapat dilakukan. Prosedur tersebut melibatkan pertukaran posisi pegang artifak tersebut pada chuck spindle. Pada gambar 34, terdapat dua silinder yang digunakan untuk memegang artifak tersebut pada dua posisi tersebut. Gambar 35 memperlihatkan hasil manufaktur dari artifak tersebut dan proses verifikasi performansi menggunakan artifak tersebut. 

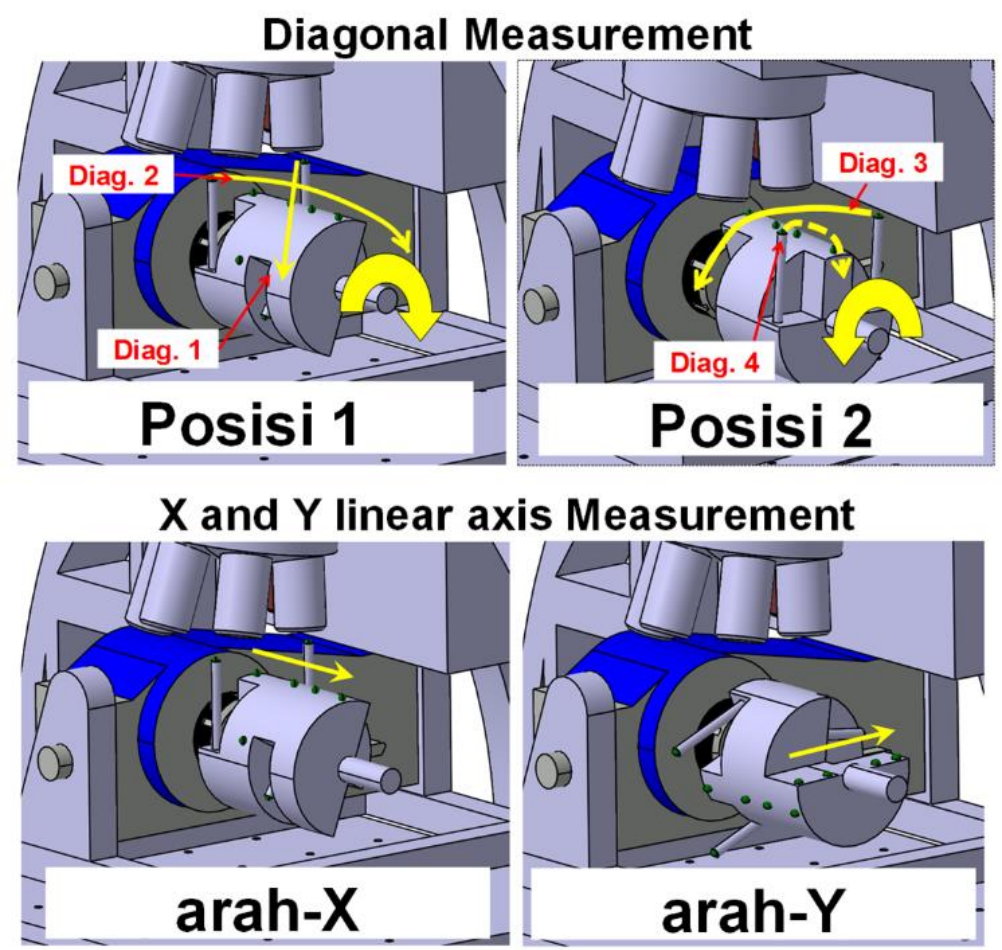

Gambar 34: Prosedur verifikasi performansi FVM dengan menggunakan artifak pada gambar 33 (Moroni et al 2017).

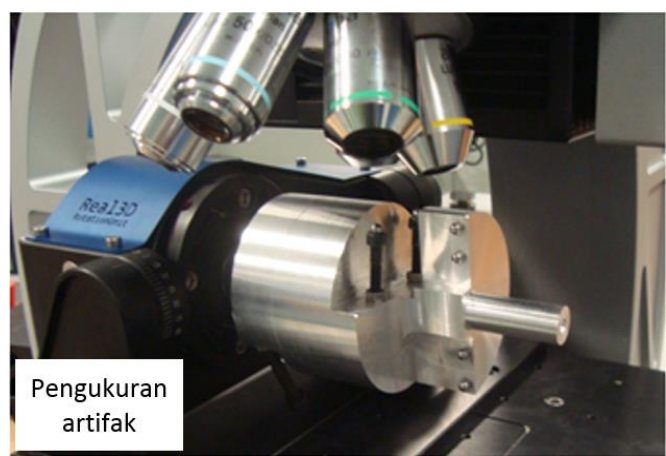

Gambar 35: Proses verifikasi performansi FVM dengan menggunakan prosedur dan artifak pada gambar 34 dan gambar 33 .

\subsection{Estimasi ketidakpastian CMM non-kontak}

Estimasi ketidakpastian untuk sebuah CMM non-kontak juga merupakan salah satu fokus riset pada saat penulisan buku ini. Estimasi ketidakpastian untuk non-kontak CMM melibatkan aspek-aspek cahaya dan material sebagai kontributor-kontributor tambahan pada total ketidakpastian hasil pengukuran dengan CMM non-kontak tersebut.

Untuk estimasi ketidakpastian "task-specifik" untuk CMM non-kontak berbasiskan mikroskop, Syam 2015 mengusulkan metode simulasi Monte-Carlo dan memperhitungkan aspek korelasi pada data hasil pengukuran suatu 
CMM non-kontak. Gambar 36 memperlihatkan skema alur dan prosedur dari estimasi ketidakpastian "task-specific" yang diusulkan oleh Syam 2015. Metode simulasi tersebut adalah berdasarkan prinsip estimasi ketidakpastian dengan simulasi yang terdapat pada ISO 15530-4. Pada ISO 15530-4, dijabarkan mengenai metode simulasi Monte-Carlo untuk estimasi ketidakpastian hasil pengukuran dengan menggunakan suatu CMM kontak. Bab 9 mengenai ketidakpastian membahas lebih detil mengenai prinsip-prinsip estimasi ketidakpastian dengan metode ISO 15530-4.

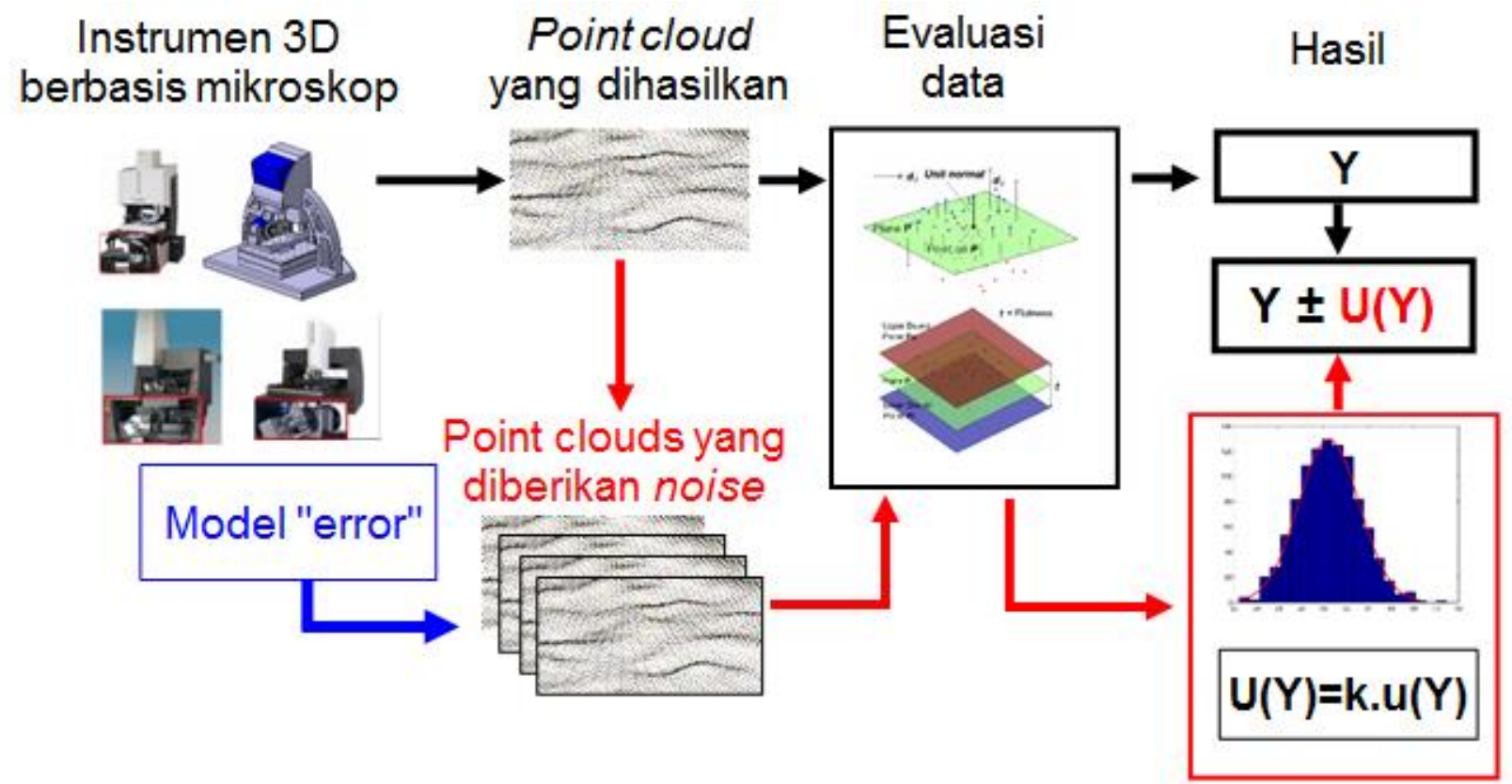

Gambar 36: Prosedur estimasi ketidakpastian "task-specifik" untuk hasil pengukuran dimensi dan geometri dengan menggunakan instrumen 3D berbasiskan mikroskop (diusulkan oleh Syam 2015).

Secera singkat, gambar 36 dijelaskan sebagai berikut. sebuah pengukuran suatu permukaan benda diukur dengan suatu CMM non-kontak barbasiskan sistem mikroskop. Dari pengukuran tersebut, suatu point cloud data didapatkan. Dari point cloud data tersebut, suatu pengukuran dimensi dan geometri dilakukan, misalnya flatness. Dari point cloud data yang sama tersebut, simulasi error diberikan pada data tersebut, sehingga posisi spasial (dalam hal ini koordinat $\mathrm{XYZ}$ data tersebut) berubah. Simulasi error tersebut dilakukan secara berulang-ulang dengan jumlah yang banyak. Setiap pengulangan simulasi tersebut, pengukuran yang sama tersebut, dalam hal ini pengukuran flatness, dilakukan dan hasilnya disimpan. Dari sekian banyak hasil yang disimpan tersebut pada setiap pengulangan simulasi, deviasi standar dari hasil pengukuran dengan simulasi tersebut dikalkulasi. Nilai dari deviasi standar tersebut merupaka estimasi dari ketidakpastian "task-specific" dari hasil pengukuran tersebut. 


\section{BAB 7}

\section{Algoritma}

Metrologi untuk pengukuran dimensi, geometri dan tekstur permukaan sangat berkaitan dengan algoritma. Karena, untuk setiap pengukuran, hasil pengukuran didapatkan dari suatu proses dan kalkulasi data dengan menggunakan suatu algoritma tertentu. Salah satu algoritma utama yang terdapat pada bidang metrologi tersebut adalah algoritma untuk fitting, yaitu proses mengasosiasikan suatu geometri nominal pada suatu point cloud yang didapatkan dari hasil suatu pengukuran. Maka dari itu, bidang metrologi merupakan bidang yang inter-disiplin keilmuan. Untuk seorang berkeahlian dibidang ilmu komputer, terdapat kesempatan yang besar untuk mengembangkan keilmuan komputernya untuk bidang metrologi.

Algoritma adalah bagian penting dari keseluruhan sistem pengukuran. Untuk CMM, algoritma berperan penting dalam memberikan kemampuan suatu CMM dapat melakukan berbagai macam pengukuran dari point cloud yang didapatkannya. Bab ini akan membahas esensi dari algoritma berikut beberapa contoh aplikasinya. Pembaca dengan latar belakang ilmu komputer akan sangat tertarik dengan pembahasan mengenai algoritma ini. Namun demikain, para pembaca yang tidak mempunyai latar belakang ilmu komputer dan pemrograman akan dapat mengikuti bab ini sehingga esensi dasar dari peran algoritma pada suatu CMM dan alat pengukuran lainnya dapat dipahami oleh pembaca tersebut.

Bab ini menerangkan prinsip dasar dari algoritma fitting, yaitu definisi jarak antara suatu titik dengan titik estimasinya yang terdpaat pada fungsi objektif dari algoritma fitting tersebut. tipe definisi jarak tersebut yang paling umum adalah berbasis jarak total maksium, least-square dan minimum-zone. Suatu algoritma didasarkan pada defini jarak tersebut pada fungsi objektifnya. Dua kelompok utama dari geometri dasar dibagi menjadi dua tipe: geometri linier dan geometri non-linier.

Selain algoritma fitting, bab ini juga membagahas tipe algoritm alainnya untuk filtering data. Filtering data selalu terdapat pada pemrosesan data hasil dari suatu instrumen pengukuran. Masalah estimasi solusi awal untuk fitting geometri non-linier akan dibahas berikut dengan suatu algoritma yang dapat mengurangi secara signifikan masalah estimasi solusi awal tersebut. terakhit, bab ini akan ditutup dengan memperlihatkan conteh aplikasi-aplikasi dari berbagai macam kombinasi algoritma untuk suatu aplikasi pengukuran.

\subsection{Fitting geometri dasar}

Algoritma fitting merupakan bagian inti dari perangkat lunak sebuah CMM atau instrumen pengukuran lainnya. Karena, hanya dengan proses fitting yang dilakukan oleh perangkat lunak sebuah CMM atau instrument pengukuran, maka suatu pengukuran, misalnya panjang, diameter, lokasi dan flatness, dapat dilakukan. Proses fitting ditentukan oleh fungsi objectifnya yang pada umumnya meminimalkan residu, yaitu jarak ortogonal dari suatu titik ke suatu bidang geometri nominalnya atau meminimalkan jarak antar-dua bidang dimana seluruh titik-titik hasil pengukuran berada diantara dua bidang tersebut (Hocken dan Pereira 2012).

Pada prinsipnya, proses fitting adalah proses untuk menentukan suatu geometri nominal dimana residu dari titiktitik yang dilakukan prosess fitting menjadi minimum. Pada umumnya, semua perangkat lunak CMM atau instrumen pengukuran lainnya menggunakan fitting least-square atau minimum-zone untuk proses fitting bentuk-bentuk standar. Bentuk-bentuk standar tersebut adalah garis, bidang datar, lingkaran, bola, silinder, kerucut dan torus (Hocken dan Pereira 2012). Dari keseluruhan bentuk standar tersebut, mereka dibagi menjadi dua bagian besar: geometri linier dan geometri non-linier. Yang termasuk geometri linier adalah garis dan bidang datar. Sedangkan yang termasuk geometri non-linier adalah lingkaran, bola, silinder, kerucut dan torus. 


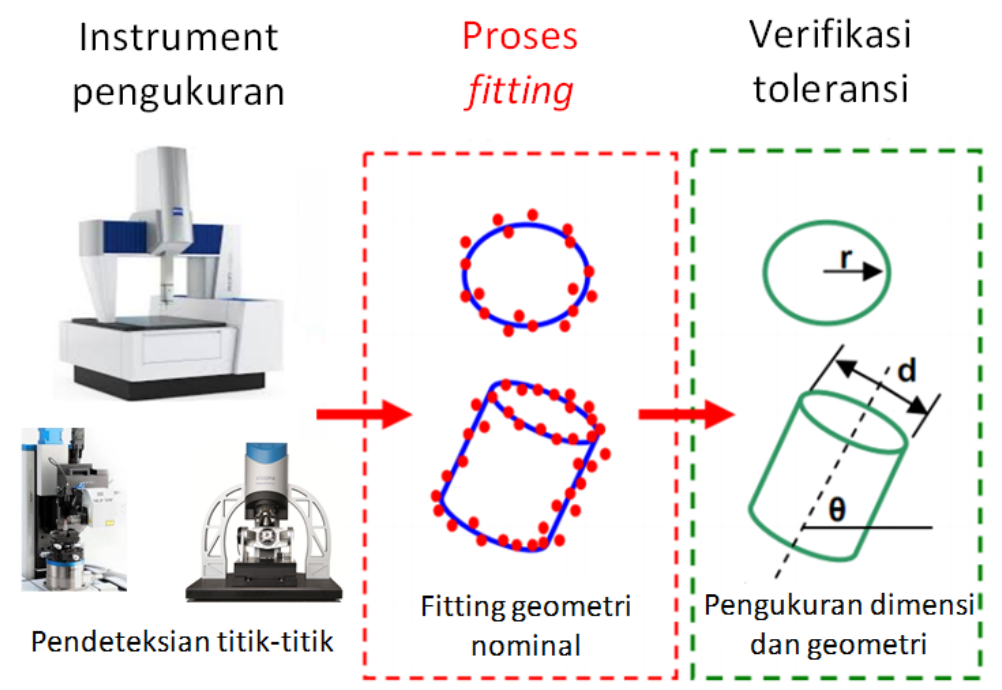

Gambar 1: Fungsi dari "Proses fitting" dalam sebuah siklus pengukuran.

Gambar 1 memperlihatkan peran dari proses fitting dalam suatu siklus pengukuran dari pendeteksian titik-titik suatu permukaan sampai dengan verifikasi toleransi. Pada gambar 1, diperlihatkan bahwa titik-titik yang didapatkan dari suatu instrumen pengukuran, baik kontak maupun non-kontak, diasosiasikan dengan suatu geometri nominal yang akan diukur, misalnya lingkaran dan silinder. Proses asosiasi tersebut merupakan proses fitting. dari hasil proses fitting, geometri nominal tersebut didapatkan dan dari geometri tersebut, suatu pengukuran dimensi dan geometri, misalnya diameter dan roundness, dapat dilakukan.

\subsubsection{Fitting berbasis jarak total maksimum (JTM)}

Fitting berbasis jarak total maksimum mempunyai fungsi objektif untuk meminimalkan total dari jumlah absolut dari residu-residu. Fitting jenis ini juga dinamakan $L_{1}$ atau $l_{1}$. Fitting jenis ini memiliki median dari residunya sebesar nol.

Fungsi objektif dari fitting berbasis jarak total maksimum adalah:

$$
\min _{\boldsymbol{p}} F=\sum_{i=1}^{n}\left|d_{i}(\boldsymbol{p})\right|
$$

dimana $\boldsymbol{p}$ adalah parameter dari suatu geometri nominal yang akan diassosiasikan atau di-fitting dan $d_{i}(\boldsymbol{p})$ adalah residu ke- $i$ atau jarak ortogonal dari titik-titik hasil pengukuran ke suatu geometri nominal yang akan diassosiasikan atau di-fitting.

Gambar 2 memperlihatkan properti dari fitting berbasis jarak total maksium yang diaplikasikan pada fitting garis dari tiga titik. Pada gambar 2, jarak total maksimum residu dari ketiga titik tersebut ke garis tersebut yang minimal adalah 1, yaitu pada posisi garis melewati kedua titik pada bagian bawah. Posisi garis pada posisi lainnya akan membuat jarak total maksimum dair residu ketiga titik tersebut ke garis tersebut menjadi $>1$. Misalnya, apabila garis tersebut berada pada pertengahan ketiga titik tersebut (pada posisi 1/2), maka jarak total maksimum dari residunya adalah $1.5(>1)$. 


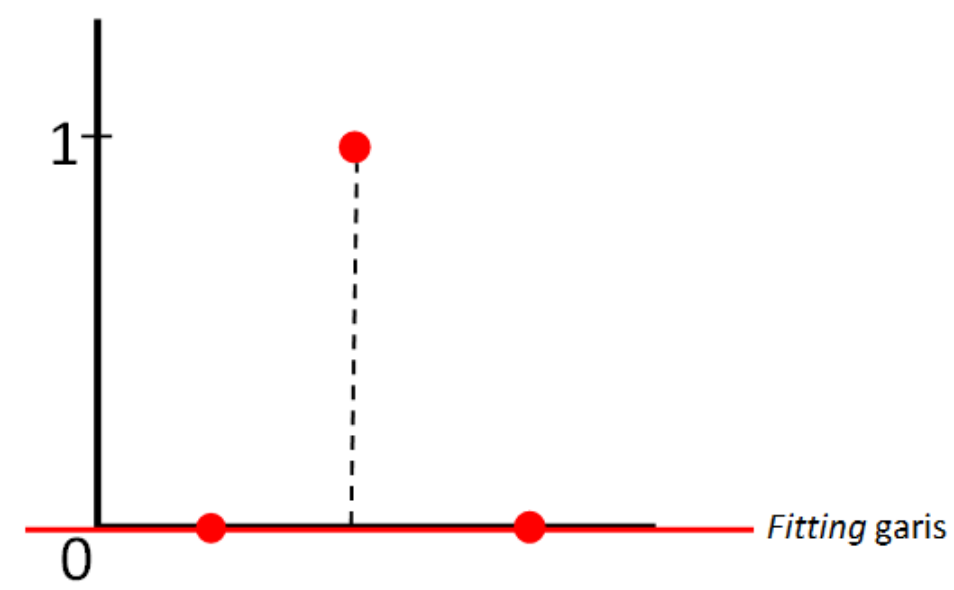

Gambar 2: Ilustrasi sebuah fitting garis berbasis jarak total maksimum dari tiga titik.

Karakteristik unik dari fitting jenis ini adalah kemampuan fitting tersebut untuk mengabaikan outliers. Outlier adalah sebuah data yang mempunyai jarak numerik sangat jauh dibandingkan dengan jarak numerik data lainnya. Kemampuan untuk mengabaikan data outlier sangat penting untuk menghasikan hasil pengukuran akurat dimana terdapat banyak data outlier dari suatu instrumen atau dari sebuah debu yang menempel pada permukaan yang diukur. Gambar 3 memperlihatkan contoh bagaimana fitting berbasis jarak total maksimum dapat menabaikan outlier (titiktitik merah) ketika proses fitting diaplikasikan pada titik-titik hasil pengukuran yang didapatkan dari sebuah instrumen pengukuran (titik-titik merah dan hitam). Pada gambar 3, dapat terlihat bahwa hasil fitting garis dan lingkaran tidak terpengaruh outlier. Hal ini disebabkan karena outlier akan secara signifikan menambah hasil total jarak maksimum residu titik-titik tersebut pada garis atau lingkaran yang akan di-fitting.

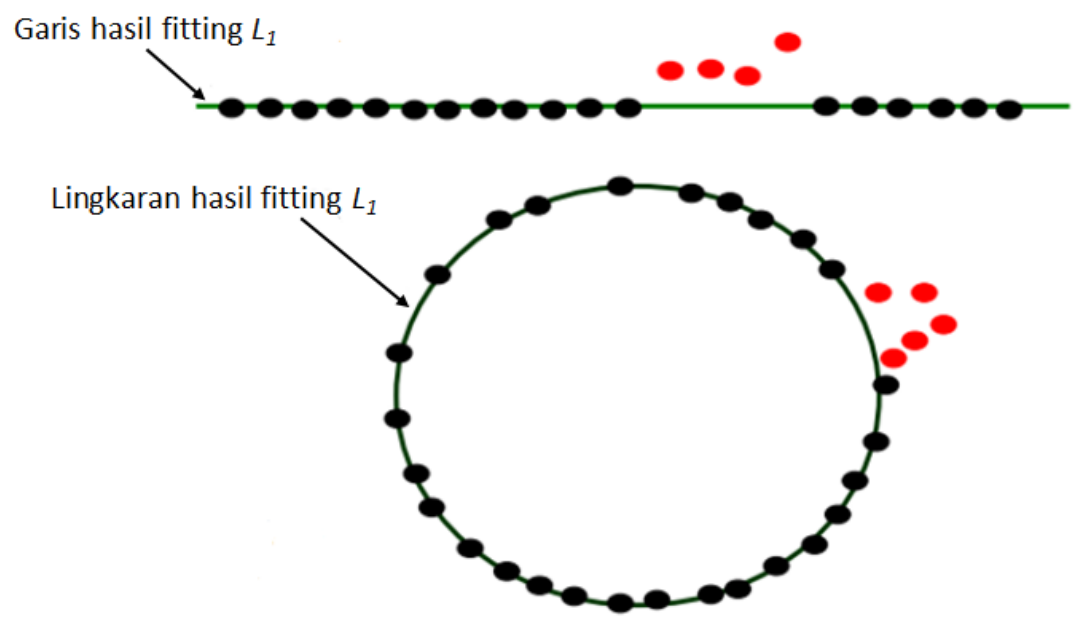

Gambar 3: Karakteristik fitting berbasis jarak total maksimum yang dapat mengabaikan outlier (titik-titik merah).

\subsubsection{Fitting berbasis least-square}

Fitting berbasis least-squre merupakan fungsi objektif fitting yang paling sering digunakan. Pada fitting berbasis least-square, residu-residu dari titik-titik terukur pada suatu gemetri nominal yang akan di-fitting mempunyai nilai rata-rata nol untuk fitting least-square yang tidak mempunyai fungsi batas. Dengan kata lain, residu-residu dengan 
nilai rata-rata nol adalah untuk geometri linier: garis dan bidang datar. Untuk geometri non-linier, residu-residunya tidak selalu mempunyai nilai rata-rata nol. Nama lain dari fitting berbasis least-square adalah fitting Guassian. Selain itu, fitting jenis ini dinamakan juga fitting $L_{2}$ atau $l_{2}$.

Fungsi objektif dari fitting berbasis least-square adalah:

$$
\min _{\boldsymbol{p}} F=\sum_{i=1}^{n} d_{i}(\boldsymbol{p})^{2}
$$

dimana $\boldsymbol{p}$ adalah parameter dari suatu geometri nominal yang akan diassosiasikan atau di-fitting dan $d_{i}(\boldsymbol{p})$ adalah residu ke- $i$ atau jarak ortogonal dari titik-titik hasil pengukuran ke suatu geometri nominal yang akan diassosiasikan atau di-fitting.

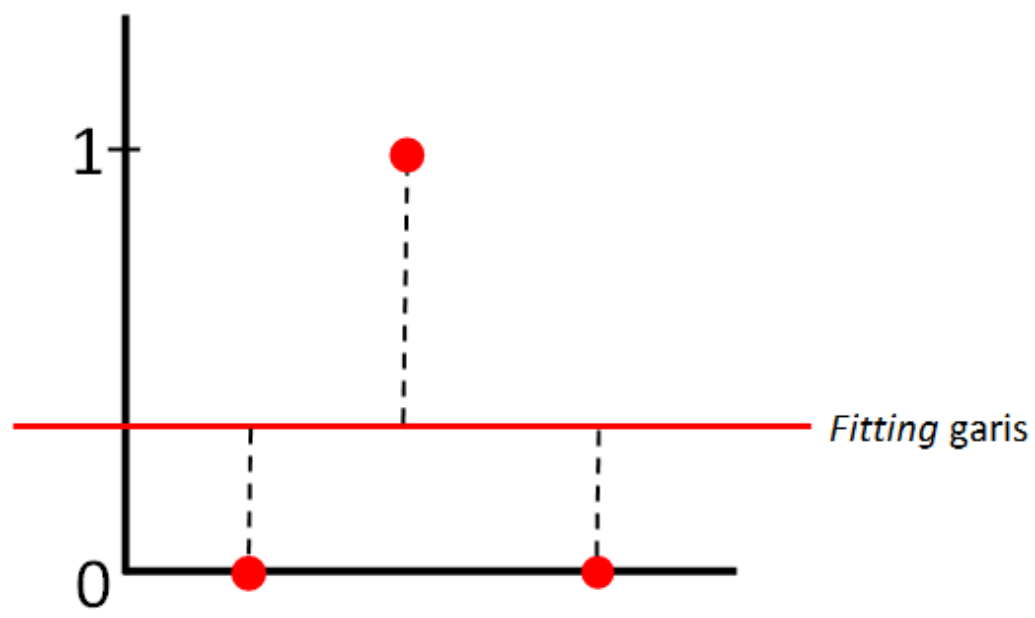

Gambar 4: Ilustrasi sebuah fitting garis berbasis least-square dari tiga titik.

Untuk fitting least-square untuk gemetri linier, ada satu solusi fitting yang optimal (global minimum). Namun demikian, hal ini tidak berlaku pada geometri non-linier yang mempunyai lebih dari satu atau beberapa solusi optimal dari proses fitting. Gambar 4 memperlihatkan ilustrasi sebuah fitting garis berbasis least-square dari tiga titik. Pada gambar 4, posisi garis hasil fitting least-square adalah berada pada posisi $1 / 3$, karena pada posisis ini total jumlah kuadrat dari residu-residu titiknya menjadi minimum. Pada prinsipnya, fitting berbasis least-square merupakan ratarata dari titik-titik yang di-fitting-nya. Dengan kata lain, fitting berbasis least-square mengikut sertakan seluruh titiktitik pengukuran yan di-fitting-nya dan tidak dapat membedakan antara outlier dan titik-titik lainnya.

\subsubsection{Fitting berbasis minimum-zone}

Fitting berbasis minimum-zone dinamakan juga fitting min-max atau fitting $L^{\infty}$ atau $l_{\infty}$. Fitting berbasis minimum-zone fitting dipakai untuk merekonstruksi zona toleransi untuk memverifikasi toleransi geometri (lihat bab 3 mengenai tolernasi dimensi dan geometri). Landasan fitting minimum-zone untuk verifikasi toleransi geometri tersebut terdapat pada ASME Y14.5.1 (ASME 1994).

Fungsi objektif dari fitting berbasis minimum-zone adalah:

$$
t=\min _{\boldsymbol{p}}\left(\max d_{i}(\boldsymbol{p})-\min d_{i}(\boldsymbol{p})\right)_{j}
$$

Dimana $t$ adalah besarnya jarak antara dua geometri (bisa bidang, lingkaran, silinder atau bola) dimana seluruh titiktitik hasil pengukuran berada diantaranya, $\boldsymbol{p}$ adalah parameter dari suatu geometri nominal yang akan diassosiasikan 
atau di-fitting dan $d_{i}(\boldsymbol{p})$ adalah residu ke- $i$ atau jarak ortogonal dari titik-titik hasil pengukuran ke suatu geometri nominal yang akan diassosiasikan atau di-fitting. $j$ adalah indeks solusi untuk setiap titik-titik ke- $i$.

Gambar 5 memperlihatkan ilustrasi sebuah fitting garis berbasis minimum-zone dari tiga titik. Pada gambar 5, posisi fitting garis dari ketiga titik tersebut adalah pada posisi $1 / 2$. Hal ini disebabkan karena pada posisi tersebut, garis tersebut merupakan pertengahan dari dua garis yang saling sejajar yang terpisah dengan jarak minimum yang meliputi ketiga titik tersebut. dengan kata lain, garis stersebut berada pada pertengahan zona toleransi dari ketiga titik tersebut. karakteristik penting dari fitting berbasis minimum-zone adalah fitting tersebut hanya dipengaruhi oleh titik-titik ekstrim atau titik-titik esensial, sehingga titik-titik di antara titik-titik ekstrim tersebut diabaikan dan tidak mempengaruhi proses fitting tersebut. Tabel 1 memperlihatkan perbandingan antara fitting least-sqaure dan minimumzone.

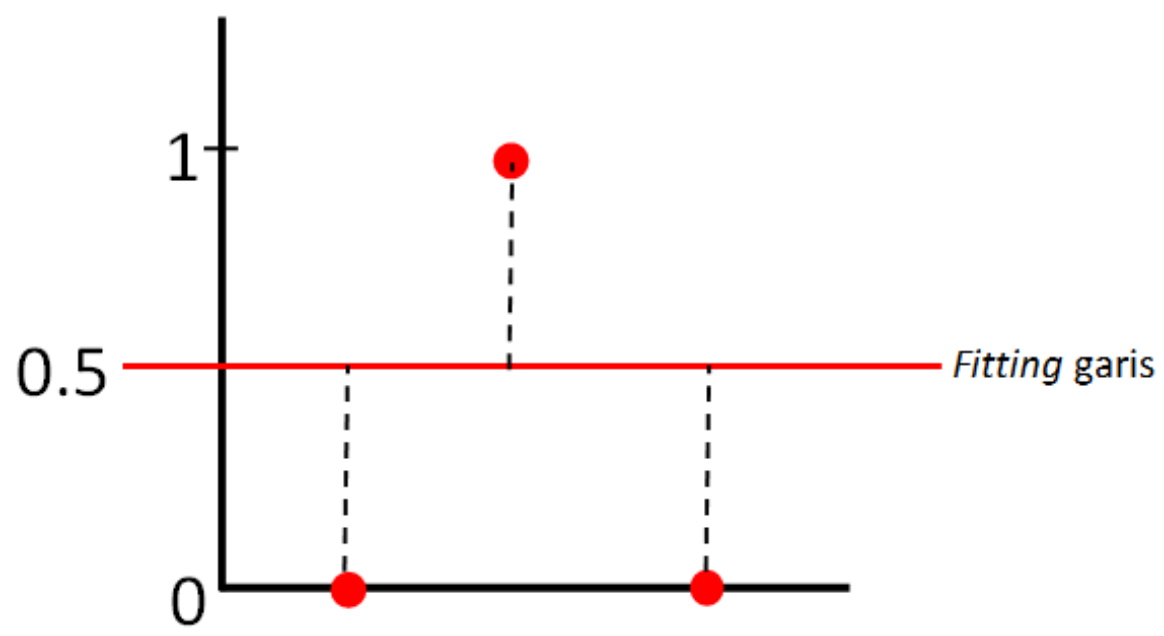

Gambar 5: Ilustrasi sebuah fitting garis berbasis minimum-zone dari tiga titik.

Tabel 1: Perbandingan antara fitting least-square dan minimum-zone.

\begin{tabular}{|l|l|}
\hline \multicolumn{1}{|c|}{ Least-square } & \multicolumn{1}{c|}{ Minimum-zone } \\
\hline $\begin{array}{l}\text { Aproksimasi dari implementasi zona toleransi pada } \\
\text { ASME Y14.5 } 2009\end{array}$ & $\begin{array}{l}\text { Representasi dari implementasi zona toleransi pada } \\
\text { ASME Y14.5 2009 }\end{array}$ \\
\hline Seidkit dipengaruhi oleh outlier & Sangat dipengaruhi oleh outlier \\
\hline $\begin{array}{l}\text { Pada umumnya tidak atau sedikit terpengaruh oleh } \\
\text { CMM noise }\end{array}$ & Pada umumnya sangat terpengaruh oleh CMM noise \\
\hline Algoritma referensi untuk bentuk dasar tersedia & $\begin{array}{l}\text { Algoritma referensi untuk bentuk dasar belum tersedia } \\
\text { (masih tahap pengembangan) }\end{array}$ \\
\hline Proses komputasi yang cepat & Proses komputasi yang sangat instensif \\
\hline
\end{tabular}




\subsubsection{Fitting Minimum-Circumscribed}

Fitting Minimum-Circumscribe (MC) adalah sebuah proses fitting untuk mencari sebuah lingkaran dengan diameter minimum yang di dalamnya terdapat semua titik-titik pengukuran. Gambar 6 memperlihatkan ilustrasi dari fitting MC pada suatu titik-titik hasil pengukuran. Apabila suatu titik-titik berbentuk oval, maka lingkaran hasil fitting $\mathrm{MC}$ akan menyentuh hanya dua titik, yaitu titik-titik pada kedua ujung terjauh bentuk oval tersebut.

\subsubsection{Fitting Maximum-Inscribed}

Fitting Maximum-Inscribed (MI) adalah sebuah proses fitting untuk mencari sebuah lingkaran dengan diameter terbesar dimana seluruh titik-titik hasil pengukuran berada di luar lingkaran MI tersebut. Gambar 6 memperlihatkan ilustrasi dari fitting MI pada suatu titik-titik hasil pengukuran. Hal yang perlu diperhatikan pada jenis fitting MI adalah, terdapat situasi dimana solusi fitting MI tidak unik. Dengan kata lain, terdpaat situasi dimana ada lebih dari satu jenis lingkaran MI yang dapat di-fitting pada suatu titik-titik hasil pengukuran. Dari sejumlah jenis fitting yang dibahas, masih terdapat jenis-jenis fitting lainnya yang tidak dibahas dalam buku ini.

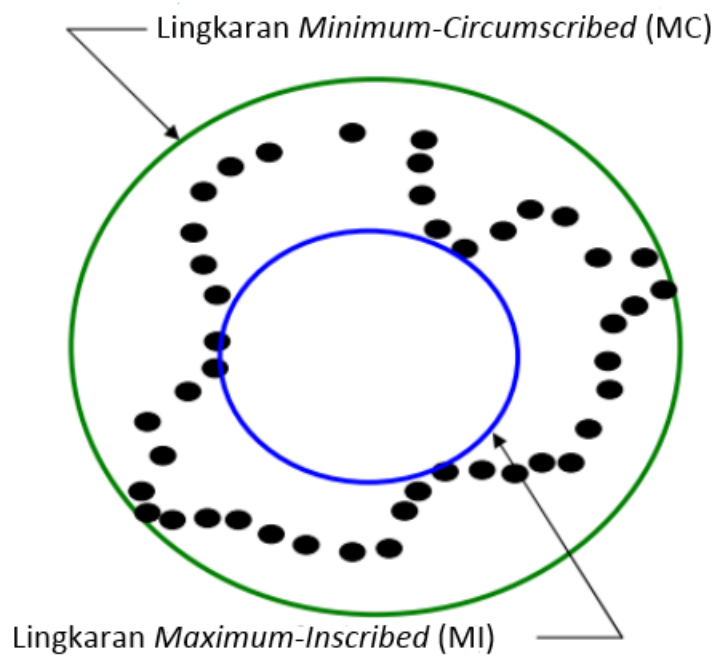

Gambar 6: Ilustrasi dari fitting lingkaran Minimum-Circumscribed (MC) dan Maximum-Inscribed (MI).

\subsubsection{Fitting geometri linier berbasis least-square: garis dan bidang datar}

Proses fitting geometri linear berbasis least-square diselesaikan dengan mengubah fungsi objektif yang non-linier menjadi linier. Proses perubahan dari non-linier ke linier dilakukan dengan menggunakan metode Lagrange dengan menambahkan fungsi batasan. Sehingga, fitting geometri linier dapat disederhanakan menjadi sebuah permasalahan nilai Eigen yang dapat diselesaikan dengan mudah dan menghasilkan suatu solusi fitting yang optimum. Secara umum, fungsi objektif untuk fitting berbasis least-square, baik untuk geometri linier dan geometri non-linier terdapat pada persamaan (2). Namun demikian, definisi residu (jarak ortogonal suatu titik ke bidang geometri nominal yang akan di-fitting) dari setiap jenis geometri akan berbeda-beda. Gambar 7 memperlihatkan definisi residu $(d)$ untuk sebuah geometri garis. 


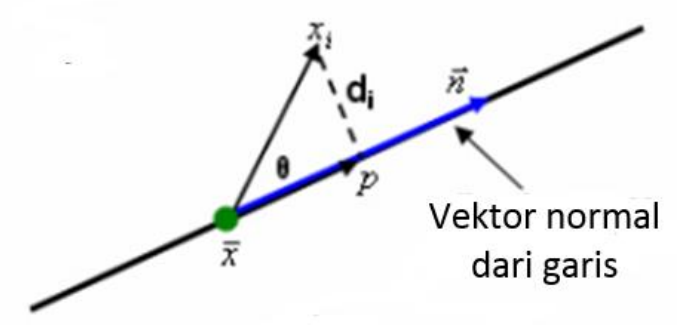

Gambar 7: Residu (jarak ortogonal titik ke geometri) untuk sebuah garis.

\section{Bidang datar}

Fungsi jarak atau residu untuk fitting bidang datar adalah:

$$
d_{i}=d\left(\mathbf{x}_{\mathbf{i}}\right)=d\left(\mathbf{x}_{\mathbf{i}}, \mathbf{x}, \mathbf{a}\right)=\mathbf{a} \cdot\left(\mathbf{x}_{\mathbf{i}}-\mathbf{x}\right)
$$

dimana $d_{i}$ adalah residu ke-i atau jarak ortogonal titik ke- $i$ ke geometri nominal yang di-fitting, $\mathbf{x}=(x, y, z)$ adalah titik pada bidan datar yang merupakan titik pusat (centroid) dari titik-titik seluruhnya, dan $\mathbf{a}=(a, b, c)$ adalah vektor normal dari bidang datar tersebut, dimana $|\mathbf{a}|=1$. $\mathbf{a}$ adalah parameter dari bidang datar yang ingin diestimasi dari proses fitting tersebut.

Sehingga, fungsi objektif untuk fitting bidang datar adalah:

$$
\min _{\boldsymbol{a}} F=\sum_{i=1}^{n}\left[\mathbf{a} \cdot\left(\mathbf{x}_{\mathbf{i}}-\mathbf{x}\right)\right]^{2}
$$

Pada persamaan (5), tujuan dari minimalisasi fungsi objektifnya adalah $\mathbf{a} \cdot\left(\mathbf{x}_{\mathbf{i}}-\mathbf{x}\right)=0$. Dengan mengaplikasikan metode Langrange (Shakarji 1998), maka nilai a didapatkan dari minimalisasi fungsi Lagrange dengan suatu fungsi batasan. Dengan mengaplikasikan metode Lagrange, $F=\lambda G$ dengan fungsi batasan $|\mathbf{a}|=1$. Fungsi $G$ adalah $G=|\mathbf{a}|^{2}-1$. Solusi fitting a yang merupakan nilai minimum dari $F=\lambda G$ didapatkan dengan $\nabla F=\lambda \nabla G=0 . \nabla$ adalah operator dari gradien fungsi skalar $\nabla=(\partial / \partial a, \partial / \partial b, \partial / \partial c)$. Sehingga, $\nabla F=$ $2\left(\mathbf{M}^{\mathbf{T}} \mathbf{M}\right) \mathbf{a}$ dan $\nabla G=2 \mathbf{a}$. Hal ini menghasilkan suatu permasalahan nilai Eigen $\left(\mathbf{M}^{\mathbf{T}} \mathbf{M}\right) \mathbf{a}=\lambda \mathbf{a}$, yang sering disebut sebagai persamaan normal (Shakarji 1998).

Vektor Eigen, yang merupakan representasi dari $\mathbf{a}$, dari $\mathbf{M}^{\mathbf{T}} \mathbf{M}$ dapat dihasilkan dengan melakukan operasi dekomposisi nilai singular (singular value decomposition/SVD) pada $\mathbf{M}$. Adalah sebuah matriks $(n \times 3)$ yang berisi koordinat spasial $(x, y, z)$ dari setiap titik-titik yang terlibat dalam proses fitting tersebut. Vektor Eigen atau a yang merupakan solusi minimum dari fungsi objektif fitting ini merefer pada nilai Eigen yang paling kecil (hasil dari proses SVD tersebut). Hal penting yang perlu diingat adalah, terdapat suatu kondisi Ill-condition, yaitu proses fitting bidang datang dilakukan pada titik-titik yang segaris (kolinier). Maka dari itu, proses fitting bidang datar harus diakukan pada titik-titik yang menyebar dan tidak saling kolinier (berada pada garis yang sama). 


\section{Garis}

Fungsi jarak atau residu untuk fitting garis adalah:

$$
d_{i}=d\left(\mathbf{x}_{\mathbf{i}}\right)=d\left(\mathbf{x}_{\mathbf{i}}, \mathbf{x}, \mathbf{a}\right)=\left|\mathbf{a} \times\left(\mathbf{x}_{\mathbf{i}}-\mathbf{x}\right)\right|=\sqrt{\left|\mathbf{x}_{\mathbf{i}}-\mathbf{x}\right|^{2}-\left[\mathbf{a} \cdot\left(\mathbf{x}_{\mathbf{i}}-\mathbf{x}\right)\right]^{2}}
$$

dimana $d_{i}$ adalah residu ke- $i$ atau jarak ortogonal titik ke- $i$ ke geometri nominal yang di-fitting, $\mathbf{x}=(x, y, z)$ adalah titik pada garis yang merupakan titik pusat (centroid) dari titik-titik seluruhnya, dan $\mathbf{a}=(a, b, c)$ adalah vektor normal dari garis tersebut, dimana $|\mathbf{a}|=1$. $\mathbf{a}$ adalah parameter dari bidang datar yang ingin diestimasi dari proses fitting tersebut.

Sehingga, fungsi objektif untuk fitting bidang datar adalah:

$$
\min _{\boldsymbol{a}} F=\sum_{i=1}^{n} \sqrt{\left|\mathbf{x}_{\mathbf{i}}-\mathbf{x}\right|^{2}-\left[\mathbf{a} \cdot\left(\mathbf{x}_{\mathbf{i}}-\mathbf{x}\right)\right]^{2}}
$$

Sama seperti pada fitting bidang datar, persamaan normalnya dalam entuk permasalahan nilai Eigen adalah $\left(\mathbf{M}^{\mathbf{T}} \mathbf{M}\right) \mathbf{a}=\lambda \mathbf{a}$. Hanya saja, solusi $\mathbf{a}$, yang merupakan vektor Eigen dari $\mathbf{M}^{\mathbf{T}} \mathbf{M}$, adalah vektor Eigen yang merujuk pada nilai Eigen yang terbesar dari hasil proses SVD (Shakarji 1998).

Untuk fitting geometri non-linier, fungsi objektifnya tidak dapat dilinierisasikan, sehingga suatu solusi fitting geometri non-linier tidak selalu optimal. Selain itu, proses kalkulasi fitting harus dilakukan dengan proses iterasi. Halhal tersebut akan dijelaskan pada bagain berikutnya.

\subsubsection{Fitting geometri non-linier berbasis least-square: lingkaran, bola dan silinder}

Fitting geometri non-linier berbasis least-square memiliki prosedur fitting yang lebih kompleks dari prosedur fitting untuk geometri linier. Hal ini disebabkan karena fungsi objektif dari fitting non-linier tidak dapat dilinierisasikan. Gambar 8 memperlihatkan ilustrasi dari residu sebuah titik untuk geometri non-linier lingkaran (geometri 2D) dan silinder (geometri 3D). pada gambar 8, diperlihatkan bahsa sebuah residu (d) merupakan sebuah jarak ortogonal sebuah titik ke suatu geometri nominal yang akan di-fitting.

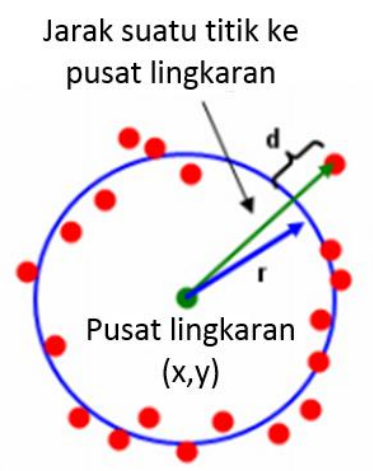

Lingkaran

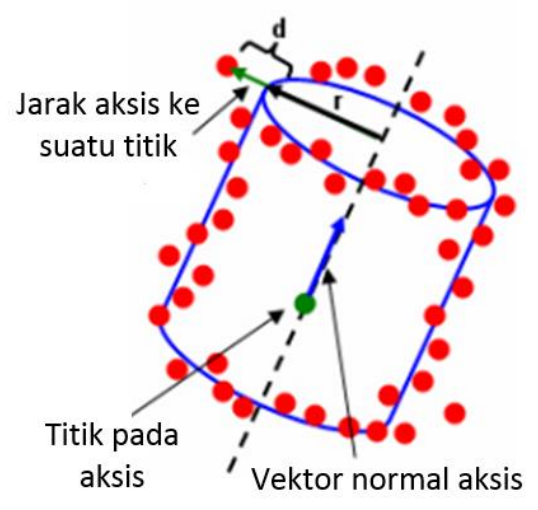

Silinder

Gambar 8: Residu (jarak ortogonal titik ke geometri) untuk sebuah lingkaran (geometri 2D) dan silinder (geometri 3D). 


\section{Lingkaran}

Fungsi jarak atau residu untuk fitting lingkaran adalah (gambar 8 kiri):

$$
d_{i}=d\left(\mathbf{x}_{\mathbf{0}}, r\right)=\left\|\mathbf{x}_{\mathbf{i}}-\mathbf{x}_{\mathbf{0}}\right\|-r=\sqrt{\left(x_{i}-x_{0}\right)^{2}+\left(y_{i}-y_{0}\right)^{2}}-r
$$

dimana $\mathbf{x}_{\mathbf{0}}=\left[x_{0}, y_{0}\right]^{T}$ adalah titik pusat lingkaran, $r$ adalah jari-jari lingkaran, $\mathbf{x}_{\boldsymbol{i}}=\left[x_{i}, y_{i}\right]^{T}$ adalah titik ke- $i$ dan $\|\mathbf{x}\|$ adalah $L_{2}-$ norm dari sebuah vektor $\mathbf{x}$, sebagai contoh $\|\mathbf{v}\|=\sqrt{v_{1}^{2}+v_{2}^{2}+v_{3}^{2}}$. Sehingga, fungsi objektif untuk fitting lingkaran adalah:

$$
\min _{\mathbf{x}_{0}, r} F=\sum_{i=1}^{n} \sqrt{\left(x_{i}-x_{0}\right)^{2}+\left(y_{i}-y_{0}\right)^{2}}-r
$$

\section{$\underline{\text { Bola }}$}

Fungsi jarak atau residu untuk fitting bola adalah seperti pada lingkaran dengan ditambahkan komponen-z:

$$
d_{i}=d\left(\mathbf{x}_{0}, r\right)=\left\|\mathbf{x}_{\mathbf{i}}-\mathbf{x}_{\mathbf{0}}\right\|-r=\sqrt{\left(x_{i}-x_{0}\right)^{2}+\left(y_{i}-y_{0}\right)^{2}+\left(z_{i}-z_{0}\right)^{2}}-r
$$

dimana $\mathbf{x}_{\mathbf{0}}=\left[x_{0}, y_{0}, z_{0}\right]^{T}$ adalah titik pusat lingkaran, $r$ adalah jari-jari lingkaran dan $\mathbf{x}_{\boldsymbol{i}}=\left[x_{i}, y_{i}, z_{i}\right]^{T}$ adalah titik ke-i. Sehingga, fungsi objektif untuk fitting lingkaran adalah:

$$
\min _{\mathbf{x}_{0}, r} F=\sum_{i=1}^{n} \sqrt{\left(x_{i}-x_{0}\right)^{2}+\left(y_{i}-y_{0}\right)^{2}+\left(z_{i}-z_{0}\right)^{2}}-r
$$

\section{Silinder}

Fungsi jarak atau residu untuk fitting silinder adalah (gambar 8 kanan):

$$
d_{i}=d_{i}(3 d-a k s i s)-r=\frac{\left\|\left(\mathbf{x}_{\mathbf{i}}-\mathbf{x}_{\mathbf{0}}\right) \times \mathbf{n}\right\|}{\|\mathbf{n}\|}-r
$$

dimana $d_{i}(3 d-a k s i s)$ adalah jarak antara sebuah titik 3D $\mathbf{x}_{\mathbf{i}}$ ke aksisnya silinder yang di-fitting (sebuah garis) dan $r$ adalah jari-jari lingkaran. Sehingga, fungsi objektif untuk fitting lingkaran adalah:

$$
\min _{\mathbf{x}_{\mathbf{0}}, \mathbf{n}, r} F=\sum_{i=1}^{n} \frac{\left\|\left(\mathbf{x}_{\mathbf{i}}-\mathbf{x}_{\mathbf{0}}\right) \times \mathbf{n}\right\|}{\|\mathbf{n}\|}-r
$$

Fungsi-fungsi objektif fitting geometri non-linier lainnya, yaitu Konik dan Torus, dapat dirujuk pada Shakarji 1998.

\section{$\underline{\text { Solusi numerik }}$}

Karena fungsi objektif untuk fitting geometri non-linier tidak dapat dilinierkan, maka proses fitting untuk geometri tersebut adalah dengan menggunakan sebuah metode iteratif (pengulangan). Degan metode iterasi, sebuah nilai solusi awal harus diberikan. Hal yang menambah komplesitas fitting geometri non-linear adalah fungsi objektif 
dari geometri tersebut mempunyai lebih dari satu atau banyak titik optimal. Sehingga, proses optimisasi fitting dapat berhenti pada suatu titik optimal lokal. Apabila proses optimisasi fitting berhenti pada titik optimal lokal, maka geometri yang diestimasi atau di-fitting tersebut bukanlah suatu solusi yang optimal. Gambar 9 memperlihatkan sebuah contoh fungsi non-linier yang mempunyai banyak lokal optimal, yaitu memiliki lebih dari satu nilai maksimum dan minimum.

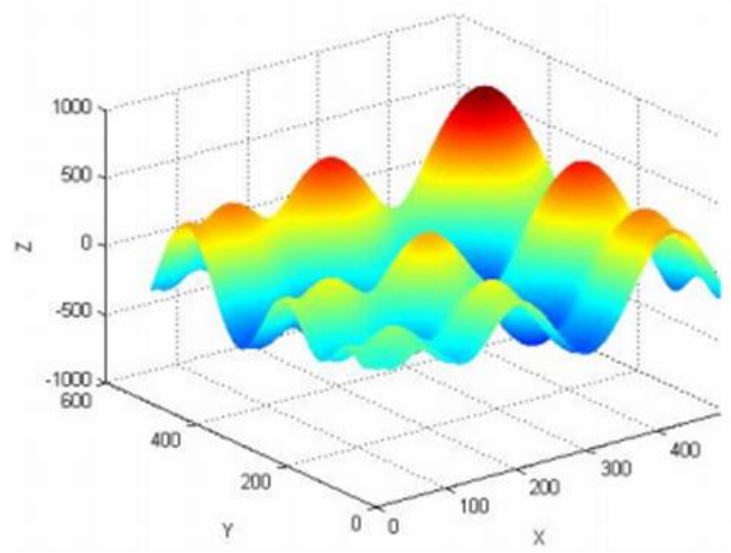

Gambar 9: Visualisasi dari sebuah fungsi yang memiliki banyak nilai maksimum atau minimum (terdapak banyak nilai optimum lokal).

Titik lokal optimal adalah sebuah titik dimana proses pengulangan ke iterasi berikutnya dalam mencari solusi optimal (dalam hal ini minimum) tidak menghasilkan solusi yang lebih baik. Sehingga, keadaan ini membuat suatu algoritma pencarian solusi optimal berbasis pengulangan menghentikan proses pencarian solusi tersebut. Hal ini menyebabkan proses optimisasi tersebut hanya memberikan solusi sub-optimal, dengan kata lain solusi yang lebih optimal untuk proses fitting tersebut tidak didapatkan. Hal ini pada prakteknya akan membuat suatu proses fitting menjadi over-estimation atau under-estimation, misalnya diameter lingkaran hasil kalkulasi menjadi jauh lebih kecil dari yang diharapkan.

Solusi numerik berbasiskan proses iterasi yang paling umum digunakan untuk fitting geometri non-linier adalah algorithma Levenberg-Marquardt (LM). Algoritma LM pertamakali dipresentasikan oleh Marquardt 1963. Ide dasar dari algoritma LM adalah dengan mengkombinasikan metode stepest-descent (Gradient search) dan metode GaussNewton. Algoritma LM akan berkerja berbasiskan metode stepest-descent ketika solusi terkini dari proses iterasi masih jauh dari nilai optimalnya. Sedangkan, ketika solusi tersebut sudah dekat dengan nilai optimalnya, maka algoritma LM akan berkerja berdasarkan metode Gauss-Newton.

Dasar dari metode stepest-descent adalah mencari solusi berdasarkan arah gradient dari fungsi objetifnya. Apabila suatu sungsi objektif yang harus dioptimalisasi $F$ dan $x_{k}$ adalah solusi terkini (solusi kandidat) pada iterasi ke- $k$, maka dalam kasis minimalisasi, proses pencarian solusi berikutnya adalah:

$$
x_{k+1}=x_{k}-\lambda_{s} \nabla F
$$

dimana $\nabla F=(\partial F / \partial x, \partial F / \partial y, \partial F / \partial z)$ adalah gradien dari fungsi objektif dan arah pencarian solusi disetiap iterasinya dan $\lambda_{s}$ adalah besaran langkah yang menggambarkan seberapa jauh kandidat solusi berikutnya dari kandidat solusi terkini. Pemilihan besarnya $\lambda_{s}$ sangat mempengaruhi proses optimalisasi. Karena, apabila $\lambda_{s}$ diset terlalu besar, maka akan besar kemungkinannya proses pencarian kandidat solusi akan melampaui suatu solusi optimal. Dan sebaliknya, apabila $\lambda_{s}$ diset terlalu kecil, maka proses pencarian akan menjadi sangat lama untuk 
mencapai suatu solusi yang konvergen.

Dasar dari metode Gauss-Newton adalah gradien fungsi objektif non-linier dilinierisasikan dengan menggunakan deret ekspansi Taylor. Untuk suatu fungsi objektif $F$, maka ekspansi deret Taylor untuk gradiennya adalah:

$$
\nabla \mathrm{f}(\mathbf{p})=\nabla \mathbf{f}\left(\mathbf{p}_{0}\right)+\left(\mathbf{p}-\mathbf{p}_{0}\right)^{\mathrm{T}} \nabla^{2} \mathrm{f}\left(\mathbf{p}_{0}\right)+\underbrace{\ldots+\left[\left(\mathbf{p}-\mathbf{p}_{0}\right)^{\mathrm{T}}\right]^{\mathrm{n}} \nabla^{\mathrm{n}} \mathrm{f}\left(\mathbf{p}_{0}\right)}_{\text {Higher order term }}
$$

dimana "Higher order term", yaitu komponen dengan pangkat $>1$, tidak dipertimbangkan, sehingga persamaan (15) menjadi suatu persamaan linier (ter-linier-kan). Dengan berubahnya persamaan (15) menjadi persamaan linier, algoritma Gauss-Newton akan menjadi lebih cepat mencapai solusi konvergen dan fungsi matematis persamaan tersebut menjadi mudah untuk dikalkulasi (tractable) untuk mencari solusi p. Vektor $\mathbf{p}$ adalah parameter-parameter dari suatu geometri non-linier yang ingin diestimasi dengan proses fitting.

Proses penentuan kandidat solusi berikutnya pada metode Gauss-Newton adalah dengan mengeset $\nabla \mathrm{f}(\mathbf{p})=0$. Sehingga, kandidat solusi berikutnya diformulasikan sebagai:

$$
\mathbf{p}_{j+1}=\mathbf{p}_{j}-\left(\mathbf{J}_{\mathrm{d}}^{\mathrm{T}} \mathbf{J}_{\mathbf{d}}\right) \mathbf{J}_{\mathbf{d}}^{\mathrm{T}} \mathbf{d}\left(\mathbf{p}_{j}\right)
$$

dimana $\mathbf{d}\left(\mathbf{p}_{j}\right)$ adalah vektor residu pada iterasi ke-j dan $\mathbf{J}_{\mathbf{d}}$ adalah matriks Jacobian dari $\mathbf{d}\left(\mathbf{p}_{j}\right)$. Hal penting yang harus diketahui adalah deret ekspansi Taylor hanya akurat pada jangkaun nilai fungsi yang sangat kecil. Jangkaun tersebut adalah sebuah jangkauan nilai fungsi objektif dimana linierisasi fungsi objektif tersebut masih valid. Hal ini berarti bahwa metode Gauss-Newton hanya efektif untuk mencari solusi pada suatu area yang sangat kecil didalam runag solusi. Sehingga, metode Gauss-Newton hanya efektif apabila inisialisasi solusi awal dekat dengan solusi optimalnya. Algoritma LM mengkombinasi kelebihan dari kedua metode stepest-decsent dan Gauss-Newton.

Algoritma LM yang digunakan di NIST (Shakarji 1998) dipresentasikan dalam Tabel 2. Pada Tabel 2, sebuah solusi awal $\mathbf{p}_{0}$ diberikan pada algoritma LM pada saat iterasi pertama. Selain itu, input dari algoritma LM adalah sebuah matriks M, yang mempunyai ukuran $n \times 3$, yang berisi titik-titik yang terlibat pada proses fitting. Matriks $\mathbf{M}$ didefinisikan sebagai $\left[\begin{array}{lllllllll}x_{1} & y_{1} & z_{1} & \ldots & \ldots . & \ldots\end{array} x_{n} y_{n} z_{n}\right]$. Hasil dari algoritma LM adalah sebuah vektor parameter $\mathbf{p}$ optimum dari sebuah geometri non-linier.

Penjelasan algoritma LM pada Tabel 2 adalah sebagai berikut. $\lambda$ adalah variabel LM. Variabel $\lambda$ diset untuk berkurang sebesar 0.04 dan bertambah sebesar 10 pada proses iteratif optimisasi seusia dengan yang diusulkan NIST (Shakarji 1998). $\mathbf{J}_{0}$ adalah matiks Jacobian dimana elemen-elemen dari baris ke-i-nya adalah $\nabla d_{i}\left(\mathbf{p}_{0}\right) . \nabla d_{i}\left(\mathbf{p}_{0}\right)$ adalah turunan parsial pertama dari $d_{i}$ terhadap setiap parameter geometrinya. Jumlah kolom dari matriks $\mathbf{J}_{0}$ sesuai dengan jumlah paramater yang akan diestimasi dengan proses fitting dan jumlah barisnya sebanyak $n$, yaitu jumlah titik-titik yang terlibat dalam proses fitting.

Ide utama algoritma LM terletak pada persamaan $\mathbf{H x}=-\mathbf{v}$ pada Tabel 2. Bentuk lengkap pada persamaan tersebut adalah $\mathbf{J}_{0}^{T} \mathbf{J}_{0}+\lambda\left(\mathbf{I}+\operatorname{diag}\left(\mathbf{J}_{0}^{T} \mathbf{J}_{0}\right) \mathbf{x}\right)=-\mathbf{J}_{0}^{T} \mathbf{d}\left(\mathbf{p}_{0}\right)$. Dari bentuk lengkap tersebut, dapat terlihat bahwa jika $\lambda$ bernilai kecil, maka algoritma LM akan menjadi metode Gauss-Newton. Sebaliknya, apabila $\lambda$ bernilai besar, maka elemen non-diagonal dari $\mathbf{J}_{0}^{T} \mathbf{J}_{0}$ akan mempunyai efek yang kecil, sehingga algoritma LM akan menjadi metode stepest-descent. $\mathbf{J}_{0}^{T} \mathbf{J}_{0}+\lambda\left(\mathbf{I}+\operatorname{diag}\left(\mathbf{J}_{0}^{T} \mathbf{J}_{0}\right) \mathbf{x}\right)=-\mathbf{J}_{0}^{T} \mathbf{d}\left(\mathbf{p}_{0}\right)$ adalah positive-definite (Nash 1979). 
Tabel 2: Algoritma LM yang digunakan oleh NIST.

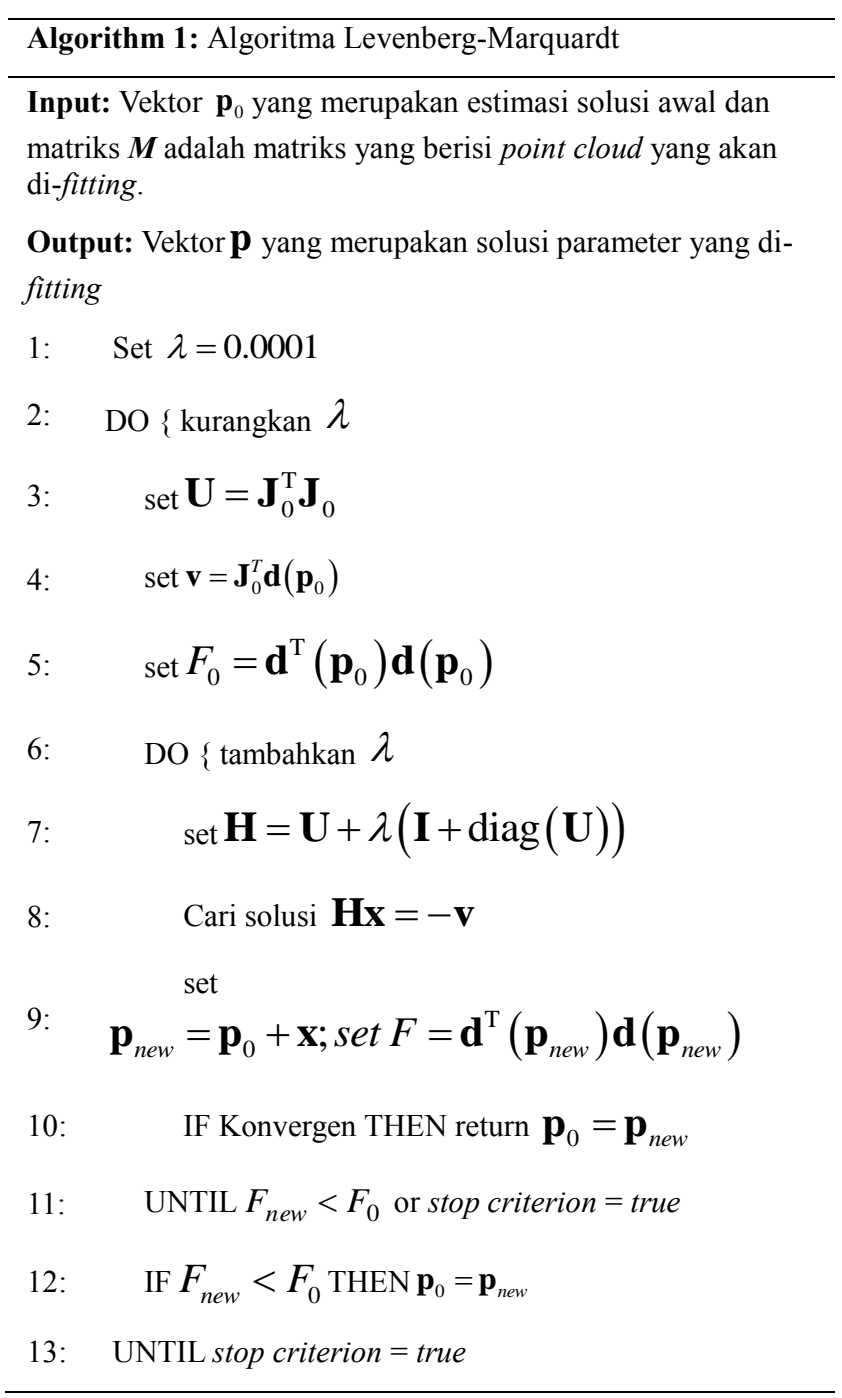

\subsection{Filtering data}

Filtering data adalah suatu proses untuk menghilangkan atau mengurangi efek dari gangguan (noise) di dalam data hasil pengukuran dengan menggunakan suatu "kernel/filter". Gangguan (noise) adalah data yang tidak diharapkan karena pengaruh dari berbagai macam kondisi yang tidak terkontrol (misalnya: variasi temperatur dan gangguan vibrasi). Definisi yang lebih umum untuk sebuah proses filtering data adalah suatu proses untuk menbedakan berbagai macam efek yang muncul pada berbagai macam skala yang berbeda (Hocken dan Pereira 2012). Pada umumnya, filtering data terbagi menjadi dua macam: filtering berbasis konvolusi dan filtering berbasis morfologi.

Pada suatu pengukuran dengan menggunakan CMM, banyaknya titik-titik yang didapatkan dari proses pengukuran pada umumnya mengandung noise, yaitu titik-titik yang tidak merepresentasikan kondisi aktual dari suatu permukaan yang diukur. Misalnya, noise tersebut pada umumnya berupa data "jump", yaitu data atau titik yang secara tiba-tiba mempunyai nilai-z yang sangat besar dibandingkan dengan titik-tiitk disekitarnya. Proses filtering bertujuan untuk menghilangkan titik "jump" tersebut, sehingga hasil pengukuran akan menjadi lebih akurat. 


\subsubsection{Filtering berbasis konvolusi}

Filtering berbasis konvolusi adalah suatu proses filtering (pemisahan atau pemilahan) data yang menggunakan suatu kernel dengan ukuran (jendela/windowing) tertentu. Filtering berbasis konvolusi adalah suatu operasi matematis linier dan merupakan jenis filtering yang paling umum digunakan. Kernel dengan ukuran tertentu tersebut diaplikasikan pada semua titik yang didapatkan dari suatu hasil pengukuran. Kemudian, kernel tersebut dikonvolusikan dengan titik-titik yang diliputi kernel tersebut. proses konvolusi didefinisikan sebagai:

$$
z_{\text {filter }}(a)=\int_{-\infty}^{\infty} z(x) k_{a}(x) d x
$$

dimana $Z_{\text {filter }}(a)$ adalah nilai $z$ hasil filtering, $z(x) k_{a}$ adalah nilai-z pada suatu posisi $x$ dan $k_{a}(x)$ adalah sebuah kernel (denga lebar tertentu) yang berpusat pada $a$. Filtering berbasis konvolusi disebut juga sebagai mean filter karena pada prinsipnya, filter tersebut adalah me-rata-rata kan beberapa titik. Karena filtering berbasis konvolusi akan meloloskan data yang mempunya frekuensi rendah, misalnya form dan waviness, maka filtering tersebut dinamakan juga low-pass filter.

Contoh sederhana dari proses filtering berbasis konvolusi adalah sebagai berikut. apabia suatu titik-titik data berupa ketinggian pada suatu lokasi tertentu $z$ : $\left[\begin{array}{llllllll}1 & 2 & 1 & 2 & 1 & 2 & 1 & 2\end{array}\right]$. Data tersebut berjumlah 8 titik. Apabila filtering berbasis konvolusi diaplikasikan pada data tersebut, yaitu berupa nilai rata-rata dari 3 titik, titik tersebut, titik disebelah kirinya dan titik disebelah kanannya. Maka hasil filtertersebut akan mengasilkan data yang terfilter, yaitu: [4/3 5/3 4/3 5/3 4/3 5/3]. Data yang terfiter mejadi 6 titik karena kedua titik diujungnya tidak dapat dikalkulasi (keadaan ini disebut sebagai efek tepi/edge effect). Proses filtering tersebut sama dengan melakukan proses konvolusi

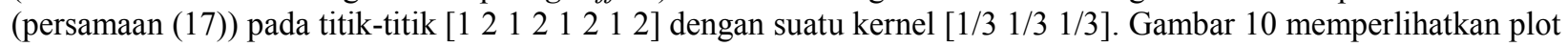
dari data awal dan terfiltrasi tersebut. Pada gambar 10, data awal dari 8 titik tersebut diperlihatkan dengan simbol '. , sedangkan data terfiltrasinya diperlihatkan dengan simbol ' + '. Dapat terlihat pada gambar 10 bahwa data hasil filtrasi adalah rata-rata dari 3 titik dari data awal dan nilainya menjadi lebih kecil dari data awal. Nilai yang lebih kecil tersebut adalah karena efek rata-rata.

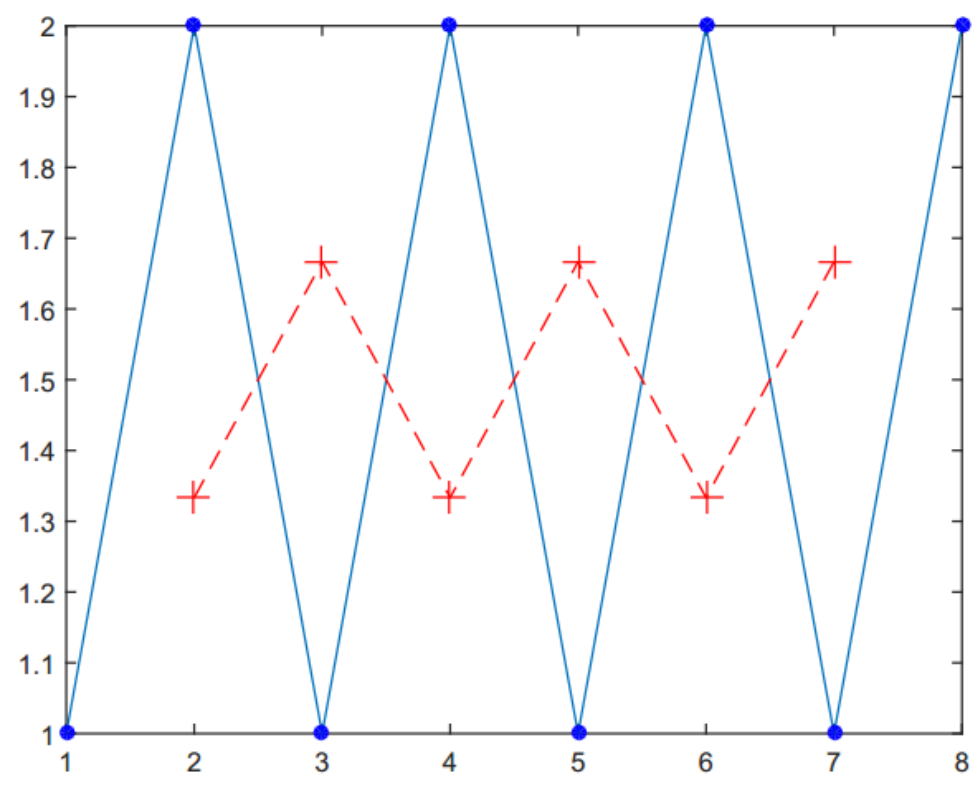

Gambar 10: Contoh filtering berbasis konvolusi. Data '.' Adalah data awal (biru) dan data '+' adalah data terfiltrasi (merah). 
Gambar 11 memperlihatkan contoh lain mengenai filtering berbasis konvolusi. Pada gambar 11, sebuah kurna sinusoid yang mempunyai noise dilakukan filtering konvolusi dengan kernel [1/3 1/3 1/3]. Gambar 12 memperlihatkan filtering dalam 2D dengan kernel: $\left[\begin{array}{lll}1 / 3 & 1 / 3 & 1 / 3 \\ 1 / 3 & 1 / 3 & 1 / 3 \\ 1 / 3 & 1 / 3 & 1 / 3\end{array}\right]$. Kernel 2D tersebut meliputi area titik-titik atau data. Maka dari itu, filtering 2D tersebut diaplikasikan pada sebuah gambar 2D. Filter 2D tersebut melakukan rata-rata pada suatu area titik-titik atau data. Gambar 12 memperlihatkan contoh filtering 2D berbasis konvolusi yang diaplikasikan pada suatu gambar 2D "FILTERING". Pada gambar 12, dapat dilihat bahwa hasil filter dari gambar 2D tersebut berupa efek pengkaburan (blurring) pada suatu gambar, yaitu fitur-fitur yang tajam, seperti geris tepi, akan tampak kabur. Hal ini kenapa filter berbasis konvolusi dinamakan low-pass filter.

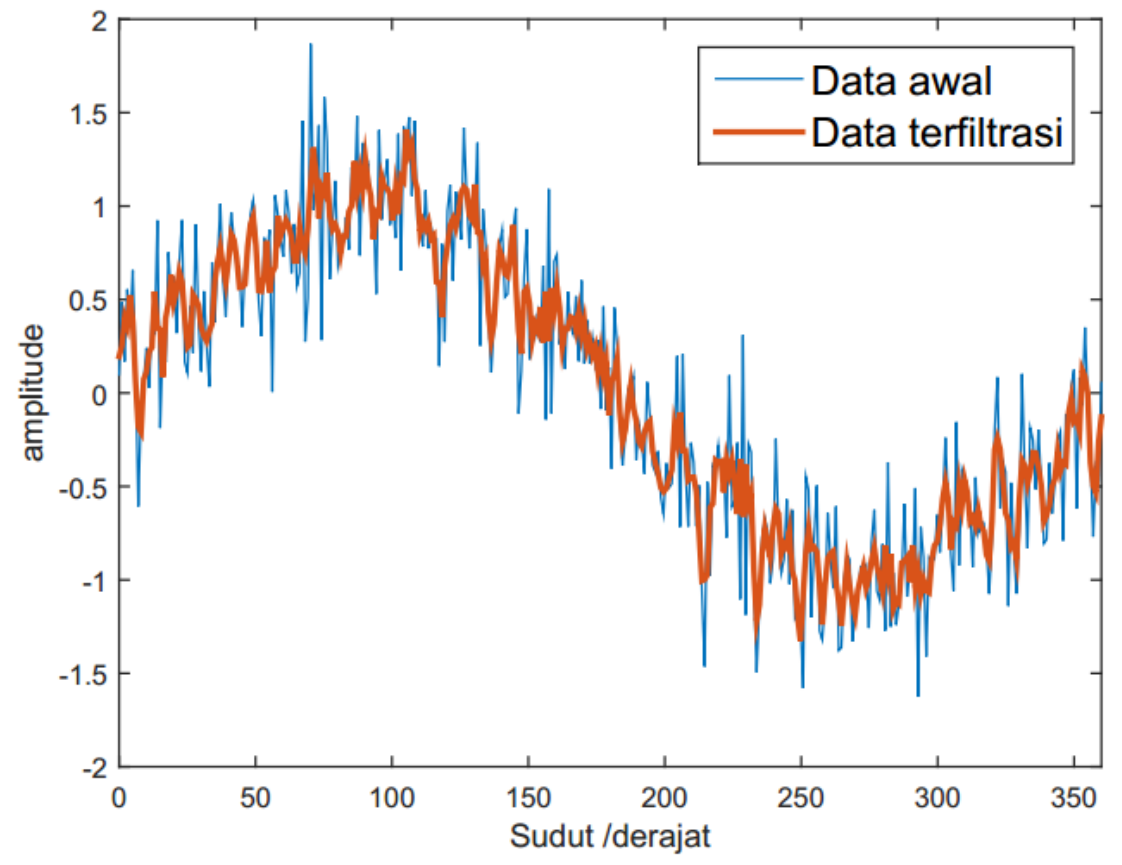

Gambar 11: Filtering konvolusi. (biru) data awal yang banyak noise, (merah) data terfiltrasi.

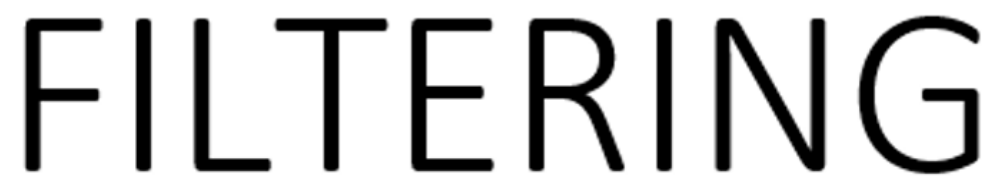

(a)

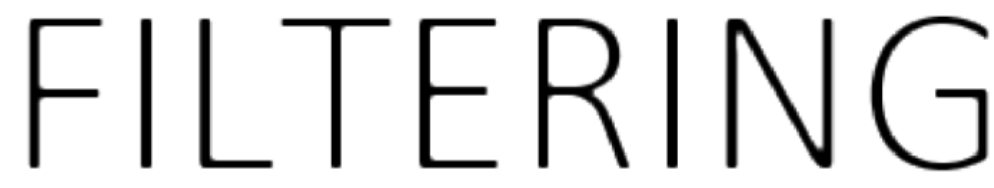

(b)

Gambar 12: (a) Gambar 2D sebelum difilter dan (b) gambar 2D sesudah difilter. 


\subsubsection{Filtering berbasis morfologi}

Filtering berbasis morfologi merupakan suatu proses matematik yang non-linier. Filter jenis ini juga terdiri dari sebuah kernal, namun demikian, kernel tersebut bukanlah operasi rata-rata. Ada dua jenis utama dari filter berbasis morfologi, yaitu: dilatasi dan erosi. Dilatasi adalah suatu proses filtering berbasis morfologi dimana sebuah kernel dengan ukuran panjang dan lebar tertentu titik pusatnya melewati suatu titik, maka setiap daerah dibawah kernel tersebut merupakan sebuah himpunan set baru. Erosi adalah suatu proses filtering berbasis morfologi dimana sebuah kernel dengan ukuran panjang dan lebar tertentu titik pusatnya melewati suatu titik, maka setiap daerah dibawah kernel tersebut akan keluar dari set titik tersebut. untuk mudahnya, filter dilatasi adalah seperti kuas cat yang akan mewarnai setiap titik lintasan yang dilaluinya dan filter erosi adalah seperti penghapus.

Gambar 13 memperlihatkan suatu proses filtering morfologi dilatasi. Pada gambar 13, terlihat bahwa area yang dilewati kernel dari filter tersebut menjadi aktif, sehingga bentuk yang terfilter tersebut menjadi lebih besar. Gambar 14 memperlihatkan suatu proses filtering morfologi erosi. Pada gambar 14, terlihat bahwa area yang dilewati filter erosi tersebut menjadi tidak aktif, dengan kata lain bentuk hasil proses filtering tersebut menjadi lebih kecal dan terdapat ditur yang tererosi atau terhapouskan.

Pada proses pengukuran dimensi dan geometri, serta tekstru permukaan, proses filtering berbasis morfologi sangat umum ditemui. Proses filtering tersebut adalah ketika suatu pengukuran menggunakan suatu sistem kontak. Sistem kontak tersebut adalah berupa bola stylus tip yang sangat kecil yang memindai sebuah permukaan benda yang sedang diukur. Suatu instrumen pengukuran akan membaca titik-titik pada permukaan tersebut berupa lokasi titik pusat dari bola stylus tip tersebut. maka dari itu, permukaan yang terbaca merupakan suatu permukaan yang sudah terfiltrasi oleh bola stylus tip tersebut. gambar 15 memperlihatkan proses filtering morfologi oleh sebuah bola stylus tip pada suatu profil permukaan. Pada gambar 15, terlihat bahwa profil permukaan yang terukur tidak sama dengan profil permukaan awalnya karena terjadi proses filtrasi morfologi.
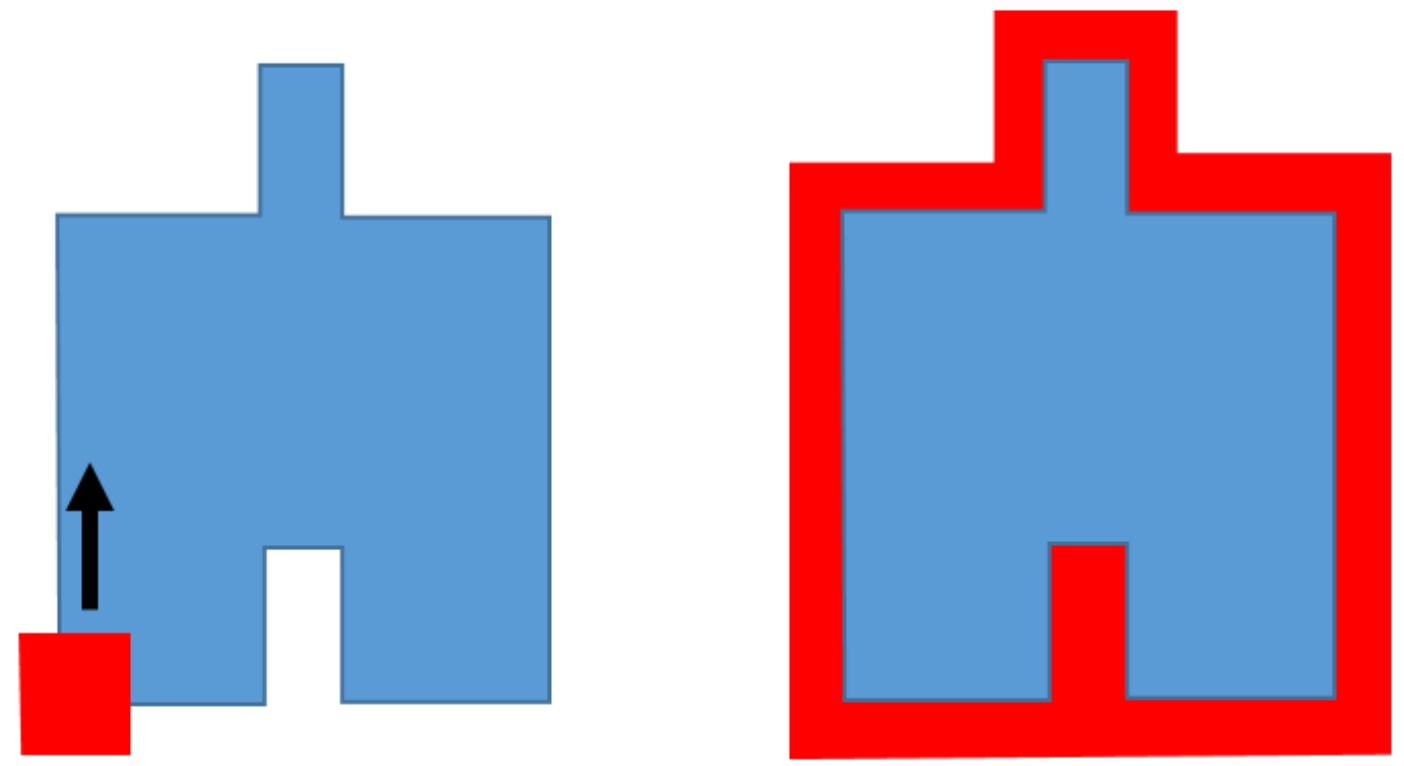

Gambar 13: Ilustrasi dari proses filter dilatasi. Daerah dengan warna merah adalah daerah penambahan hasil proses dilatasi. 

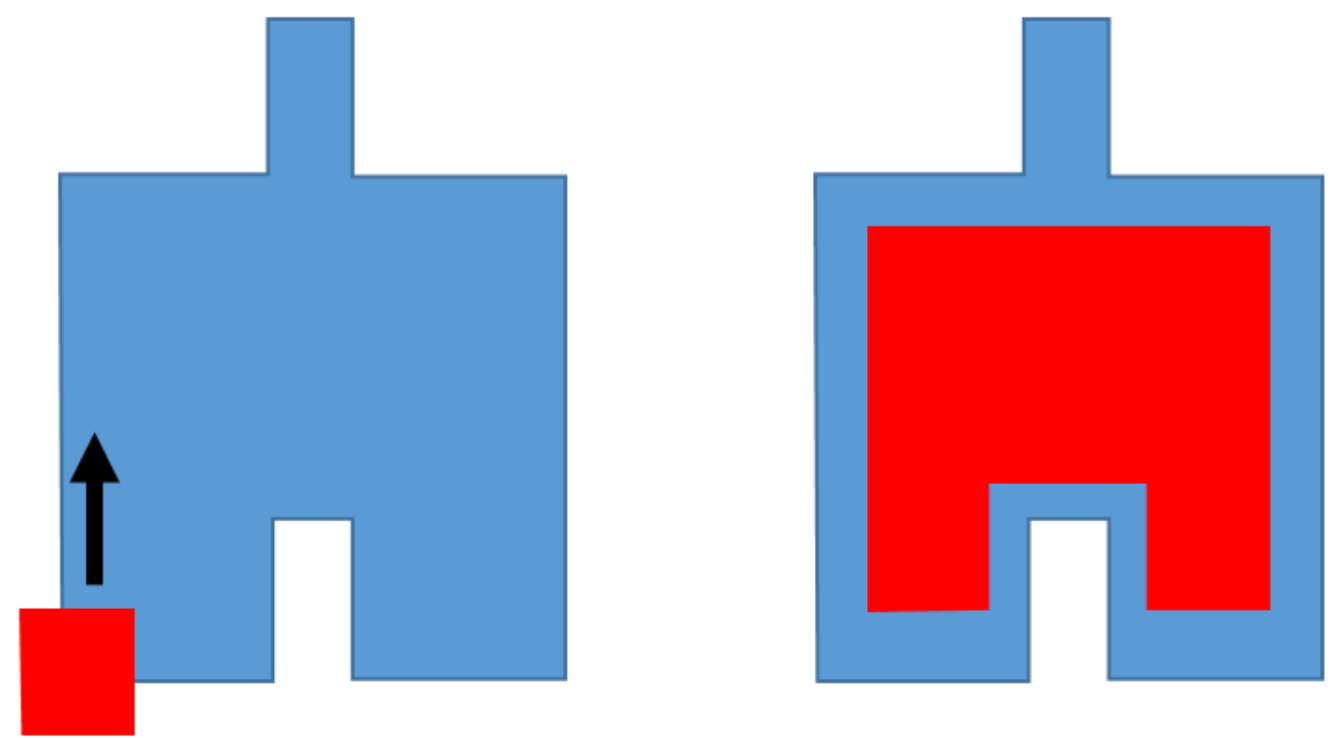

Gambar 14: Ilustrasi dari proses filter erosi. Daerah dengan warna merah adalah daerah hasil pengurangan dari proses erosi.

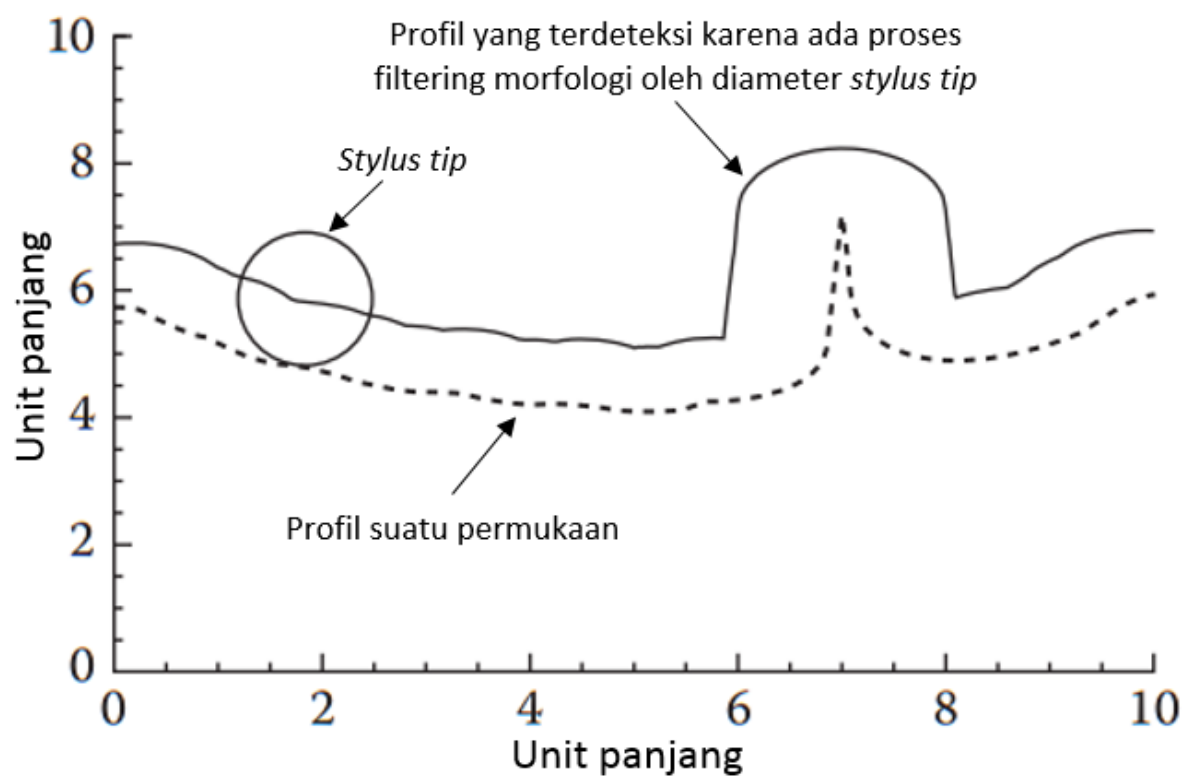

Gambar 15: Proses filtering morfologi oleh stylus tip pada suatu profil sebuah permukaan benda. Profil yang terbaca merupakan data posisi titik pusat dari stylus tip.

Selain filtering berbasis konvolusi dan morfologi, terdapat juga jenis-jenis filtering lainnya yang tidak dibahas dalam buku ini, seperti median filter, high-pass filter, band-pass filter dan lain sebagainya. 


\subsection{Masalah estimasi solusi awal untuk fitting non-linier}

Kembali pada proses fitting geometri non-linier (menyambung dari bagian 7.1.7), algoritma LM (Tabel 2) sangat bergantung pada estimasi nilai awal dari solusi parameter $\mathbf{p}_{0}$ suatu geometri yang akan di-fitting (Rardin 2006). Dari solusi awal tersebut, algoritma LM akan mencari solusi yang lebih baik dalam setiap iterasinya sampai suatu kondisi tertentu terpenuhi (stopping criteria). Estimasi nilai dari solusi awal merupakan syarat semua algoritma berbasis pengulangan, bukan hanya untuk algoritma LM saja. Proses optimisasi berbasis iterasi diperlukan karena fungsi objektifnya merupakan fungsi multi-modal yang mempunyai banyak solusi lokal optimum (lihat gambar 9 untuk contoh).

\subsubsection{Estimasi solusi awal}

Algoritma LM terdiri dari proses menglinierkan suatu fungsi yang non-linier (persamaan (15)), sehingga metode Gauss-Newton lebih cepat untuk mencapai kondisi konvergen dan lebih mudah dikalkulasi. Namun demikian, proses liniearisasi tersebut mengabaikan "high-order term" dari ekspansi deret Taylor. Hal ini menyebabkan proses iterasi LM, yang salah satu metodenya berbasis Gauss-Newton, akan terjebak (trapped) pada solusi yang merupakan lokal optimal. Terjebaknya proses iterasi pada suatu solusi lokal optimal menyebabkan hasil dari proses fitting akan mengasosiasikan titik-titik pada suatu geometri yang tidak diharapkan, misalnya, hasil fitting suatu lingkaran memiliki diameter atau titik pusat yang jauh dari yang diharapkan.

Gambar 16 memperlihatkan contoh hasil fitting dari dua estimasi solusi awal paramater lingkaran (koordinat $x$ dan $y$ dari titik pusat dan radiusnya). Pada gambar 16 (kiri) terlihat bahwa hasil geometri lingkaran yang di-fitting tidak sesuai dengan yang diharapkan. Hal tersebut disebabkan karena estimasi solusi awal jauh dari nilai optimumnya. Sedangkan, pada gambar 16 (kanan) terlihat bahwa hasil fitting geometri lingkarannya sesuai dengan yang diharapkan. Hasil fitting sesuai dengan yang diharapkan tersebut disebabkan karena estimasi nilai awalnya dekat dengan nilai optimum (dari fungsi objektifnya terhadap parameter lingkaran awal).

Dari hasil fitting dengan nilai solusi awal yang jauh dari nilai optimumnya, error suatu pengukuran akan secara langsung bertambah. Maka dari itu, estimasi nilai awal yang baik mempunyai peran yang sangat penting untuk menghasilkan suatu hasil pengukuran yang akurat dan metode untuk meningkatkan estimasi solusi awal dibutuhkan.

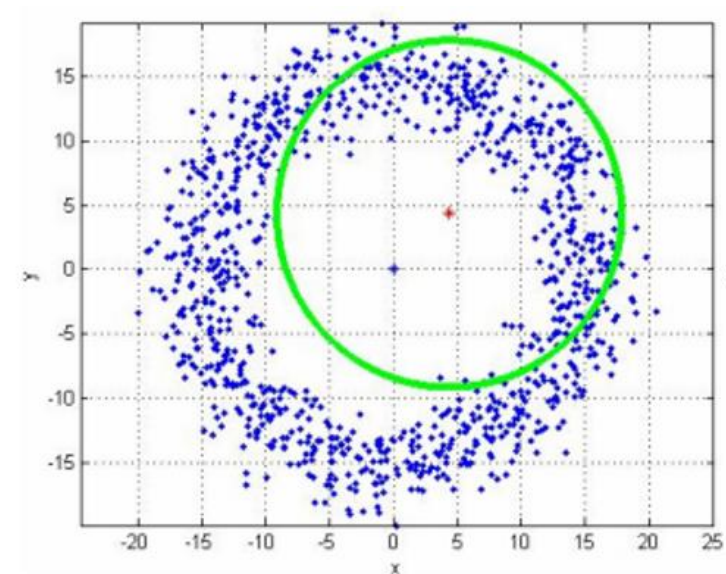

(a)

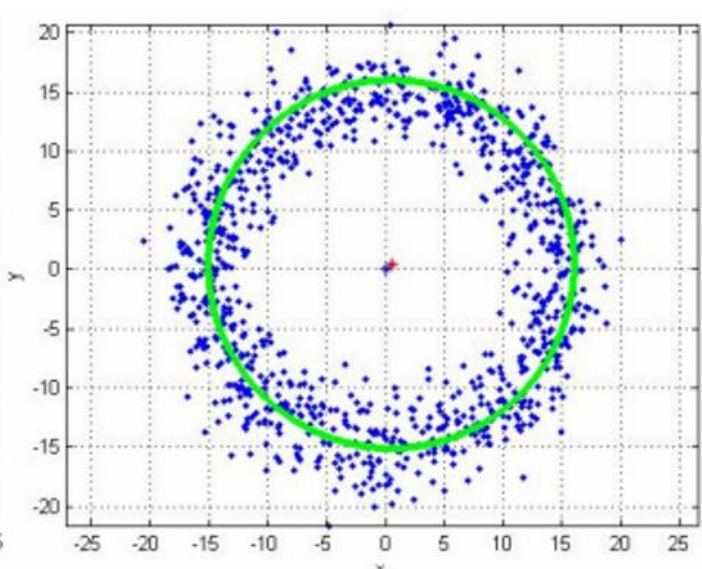

(b)

Gambar 16: (kiri) Estimasi nilai awal parameter lingkaran jauh dari nilai optimumnya sehingga hasil fitting-nya tidak sesuai dengan yang diharapkan dan (kanan) estimasi nilai awal parameter lingkaran dekat dari nilai optimumnya sehingga hasil fitting-nya sesuai dengan yang diharapkan. Titik-titik biru adalah titik-titik yang terlibat dalam proses fitting dan gairs hijau adalah geometri lingkarang yang di-fitting. 


\subsubsection{Optimasi solusi awal berbasis algoritma chaos}

Improvisasi estimasi solusi awal untuk algoritma LM dapat diimprovisasi dengan menggunakan optimisasi berbasis Chaos (Moroni et al 2013, Moroni et al 2014, Syam 2015). Chaos didefinisikan sebagai suatu property yang semi-acak yang dihasilan oleh sebuah persamaan nonlinier. Persamaan nonlinier tersebut menghasilkan sebuah langkah dinamis yang bersifat Chaos (pergerakan yang tidak dapat diprediksi). Optimisasi berbasis Chaos adalah sebuah proses optimisasi berbasis iterasi dimana dalam setiap iterasinya, solusi berikutnya dicari berdasarkan pergerakan Chaos (Luo et al 2008), sehingga setiap langkah iterasi optimisasi akan dapat keluar dari jebakan atau situasi lokal optimal. (Tavazoei dan Haeri 2007). Optimisasi Chaos mengimprovisasi estimasi solusi awal untuk menjadi sebuah solusi awal yang lebih baik dan lebih dekat kepada solusi global optimum yang melakukan proses iterasi pencarian yang tidak berulang pada sebuah domain yang terbatasi (Jiang 1998).

Pergerakan yang bersifat Chaos dihasilkan oleh suatu fungsi 1-dimensi yang nonlinier. Fungsi 1-dimensi yang nonlinier tersebut pada umumnya menggunakan fungsi logistik, yaitu:

$$
\mathbf{t}_{k+1}=\lambda_{c} \mathbf{t}_{k}\left(1-\mathbf{t}_{k}\right)
$$

dimana $\lambda_{c} \in\{3.56,4\}$ adalah argumen kontrol dan $k$ adalah urutas iterasi dengan rekomendasi $0 \leq \mathbf{t}_{0} \leq 1$ dimana $\mathbf{t}_{0} \notin\{0,0.25,0.5,0.75,1.0\}$. Properti dari persamaan (18) menjadi bersifat Chaos dalam artian nilai $\mathbf{t}_{k}$ berubah secara drastis dalam batasan nilai $\lambda_{c}$ dan $\mathbf{t}_{k}$. Gambar 17 memperlihatkan contoh langkah atau pergerkana numerik yang bersifat Chaos. Pada gambar 17 (kiri), diperlihatkan plot tnilai $\mathbf{t}_{k}$ nilai terhadap iterasi ke- $i$ dan, pada gambar 17 (kanan), diperlihatkan plot nilai dair variable chaos $\mathbf{t}_{k}$ yang berdampingan. Terdapat juga fungsi-fungsi 1-dimensi yang nonlinier lainnya untuk menghasilkan langkah yang bersifat Chaos, seperti fungsi tent, fungsi Bernoulli dan fungsi Chebyshev (Moroni et al 2016).

Tabel 3 memperlihatkan secara detil dari algoritma optimisasi Chaos. Pada tabel 3, input atau nilai masukan dari optimisasi Chaos adalah berupa estimasi solusi awal yang belum optimal (dalam artian jauh dari solusi optimalnya). Dan, keluaran dari algoritma Chaos adalah suatu nilai estimasi awal yang lebih baik yang mendekati solusi optimalnya. Solusi awal yang lebih baik tersebut kemudian dimasukkan ke dalam algoritma LM untuk meningkatkan hasil fitting dengan algoritma LM tersebut.
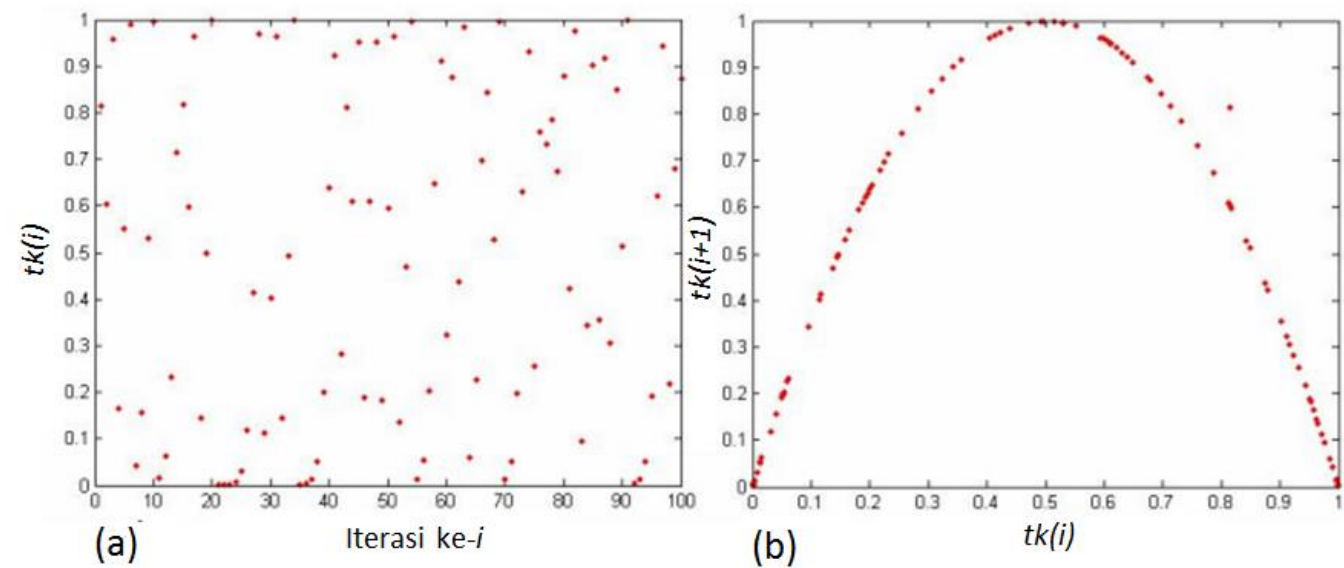

Gambar 17: (kiri) Nilai $\mathbf{t}_{k}$ pada setiap iterasi ke $-i$ dan (kanan) nilai $\mathbf{t}_{k}$ dan $\mathbf{t}_{k+1}$. 
Tabel 3: Optimisasi solusi awal dengan algoritma Chaos.

Algorithm 2: Algoritma optimisasi Chaos untuk meningkatkan estimasi solusi awal algoritma LM.

Input: Vektor $\mathbf{p}_{0}$ adalah estimasi solusi awal (1:n-param)

Goal: Vektor $\mathbf{p}_{0}$ baru yang telah ditingkatkan dengan algoritma Chaos

$$
\begin{aligned}
& \operatorname{MinF}\left(\mathbf{p}_{i}\right), \mathbf{p}_{i} \in\left\{\mathbf{a}_{i}, \mathbf{b}_{i}\right\}, \operatorname{Let} \mathbf{p}^{k}=\left(\mathbf{p}^{1}: \mathbf{p}^{k}\right), \mathbf{t}^{k}=\left(\mathbf{t}^{1}: \mathbf{t}^{k}\right) \\
& \text { where }: \mathbf{p}=\left(p_{1}, \ldots, p_{n}\right) \text { and } \mathbf{t}=\left(t_{1}, \ldots, t_{n}\right) \\
& \text { 1: } \quad \text { Set } k=0, r=0 \text {, Set } k_{\text {max }}=10, r_{\max }=30 \\
& \text { 2: Hasilkan secara acak . } \\
& \mathbf{t}_{0} \in\{0,1\} \text { and } \notin\{0,0.25,0.5,0.75,1.0\} \text {. } \\
& 3: \\
& \text { Set } \mathbf{t}^{k}=\mathbf{t}^{0}, \mathbf{t}^{*}=\mathbf{t}^{0}, \mathbf{a}^{\mathbf{0}}=\mathbf{p}-M P E, \mathbf{b}^{\mathbf{0}}=\mathbf{p}+M P E \\
& \text { where }: \mathbf{a}=\left(a_{i}, \ldots, a_{n}\right), \mathbf{b}=\left(b_{i}, \ldots, b_{n}\right) \\
& \text { 4: } \quad \text { Set } \mathbf{p}^{*}=\mathbf{p}_{0} \rightarrow \text { Estimasi solusi awal } \\
& \text { 5: } \\
& \text { DO WHILE }\left\{r<r_{\max }\right. \text {; } \\
& \text { DO WHILE }\left\{k<k_{\text {max }}\right. \text {; }
\end{aligned}
$$$$
\text { Set } p_{i}=a_{i}^{r}+t_{i}^{r}\left(b_{i}^{r}-a_{i}^{r}\right)
$$

6:

Hitung $F^{k}=\sum_{i=0}^{N} d_{i}^{2}\left(p_{i}\right)$

$7:$

IF $F^{k}<F^{*}$ THEN

$$
F^{*}=F\left(p^{k}\right), p^{*}=p^{k}, t^{*}=t^{k}
$$

8:

$$
k=k+1 ; t_{i}^{k}=\lambda t_{i}^{k-1}\left(1-t_{i}^{k-1}\right), \lambda \in\{3.56,4\}
$$

9:

\}END iterasi ke- $k ; r=r+1$

$$
a_{i}^{r+1}=p_{i}^{*}-\gamma\left(b_{i}^{r}-a_{i}^{r}\right)
$$

10:

dan

$$
b_{i}^{r+1}=p_{i}^{*}+\gamma\left(b_{i}^{r}-a_{i}^{r}\right)
$$

11:

$$
\text { IF } a_{i}^{r+1}>a_{i}^{r} \text { THEN } a_{i}^{r+1}=a_{i}^{r}, \gamma \in\{0,0.5\}
$$




$$
k=0, \mathbf{t}^{k}=\mathbf{t}^{0} \operatorname{GOTO}(7)
$$

ELSE Algoritma Chaos selesai,

14: $\left.\quad \operatorname{return} \mathbf{p}_{0}=\mathbf{p}^{*} ;\right\}$

END iterasi ke-r;

15: $\quad$ Masukkan $\mathbf{p}_{0}$ yang baru ke dalam Algoritma LM.

\subsubsection{Peningkatan performansi fitting dengan algoritma chaos}

Algoritma optimisasi Chaos untuk meningkatkan estimasi solusi awal sangat efektif untuk meningkatkan hasil suatu proses fitting (Moroni et al 2013, Moroni et al 2014, Syam 2015). Gambar 18 memperlihatkan hasil peningkatan proses fitting setelah algoritma LM dikombinasikan dengan algoritma Chaos. Pada gambar 18, terlihat bahwa hasil proses fitting dengan hanya menggunakan algoritma LM memberikan hasil yang tidak diharapkan. Sedangkan, pada gambar 18, hasil proses fitting algoritma LM menjadi sesuai dengan yang diharapkan setelah dikombinasikan dengan algoritm Chaos. Hal yang sama didapatkan pada proses fitting dari titik-tiitk yang tidak utuh (parsial). Gambar 19 memperlihatkan bahwa peningkatan algoritma LM setelah dikombinasikan dengan algoritma Chaos menjadi semakin relevan untuk aplikasi fitting titik-titik yang tidak merepresentasikan suatu geometri (dalam hal ini lingkaran) yang tidah utuh (parsial).

Selain itu, dengan dikombinasikannya algoritma LM dan algoritma Chaos, efisiensi dari komputasi proses optimisasi algoritma LM semakin tinggi. Hal ini disebabkan karena estimasi solusi awal sudah dekat dengan solusi optimalnya sehingga mengurangi proses iterasi dari algoritma LM. Selain itu, dengan dikombinasikannya algoritma Chaos dengan algoritma LM, maka algoritma LM dapat keluar dari jebakan nilai lokal optimal. Gambar 20 memperlihatkan perbandingan komputasi antara algoritma LM dan algoritma LM yang dikombinasikan dengan algoritma Chaos. Pada gambar 20, terlihat bahwa proses fitting yang hanya menggunakan algoritma LM terjebak pada suatu lokal optimal sehingga walaupun proses iterasi dilanjutkan, hasil proses fitting tidak membaik. Berbeda dengan algoritma LM yang dikombinasikan dengan algoritma Chaos, algoritma LM tersbeut dapat keluar dari jebakan solusi lokal optimal dan dpaat menghasilkan suatu solusi konvergen yang lebih baik. Perbandingan performansi algoritma Chaos dengan berbagai jenis fungsi 1-dimensi linier dapat dilihat di Moroni et al 2016.

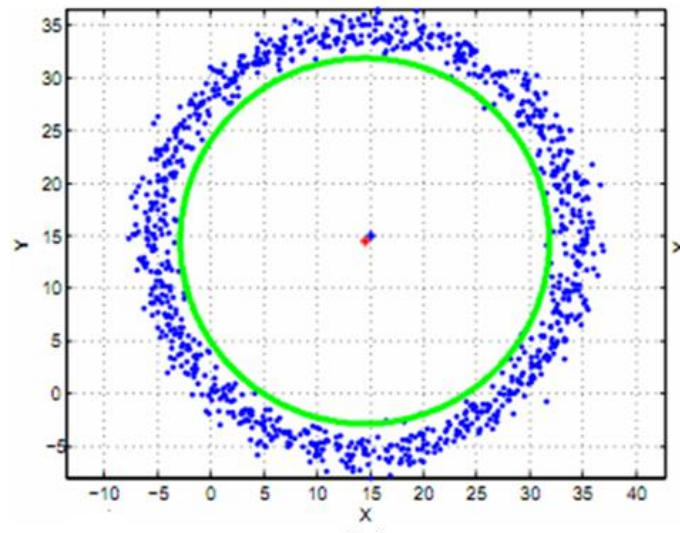

(a)

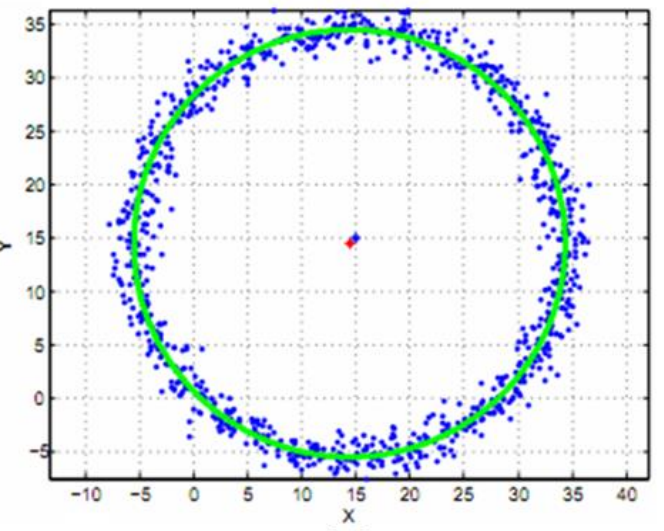

(b)

Gambar 18: (kiri) Hasil fitting dengan hanya menggunakan algoritma LM dan (kanan) Hasil fitting dengan menggunakan algoritma LM yang dikombinasikan dengan algoritma Chaos untuk titik-titik yang utuh merepresentasikan sebuah lingkaran. 


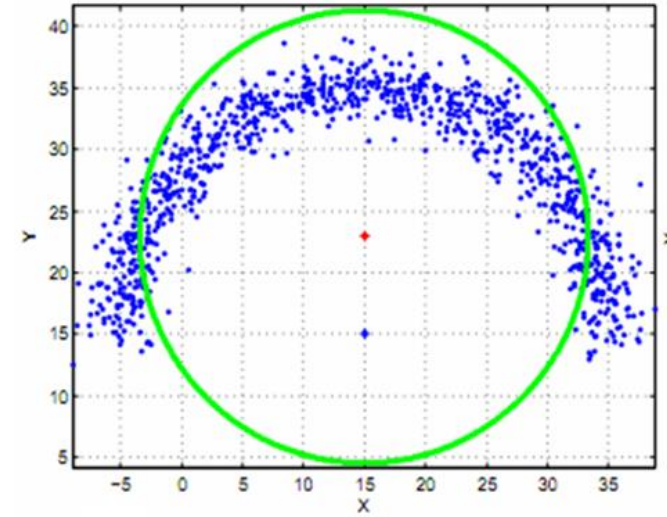

(a)

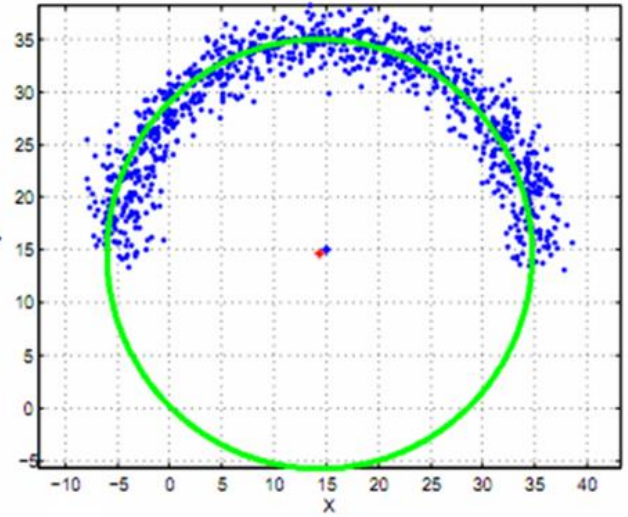

(b)

Gambar 19: (kiri) Hasil fitting dengan hanya menggunakan algoritma LM dan (kanan) Hasil fitting dengan menggunakan algoritma LM yang dikombinasikan dengan algoritma Chaos untuk titik-titik yang tidak utuh merepresentasikan sebuah lingkaran (parsial).

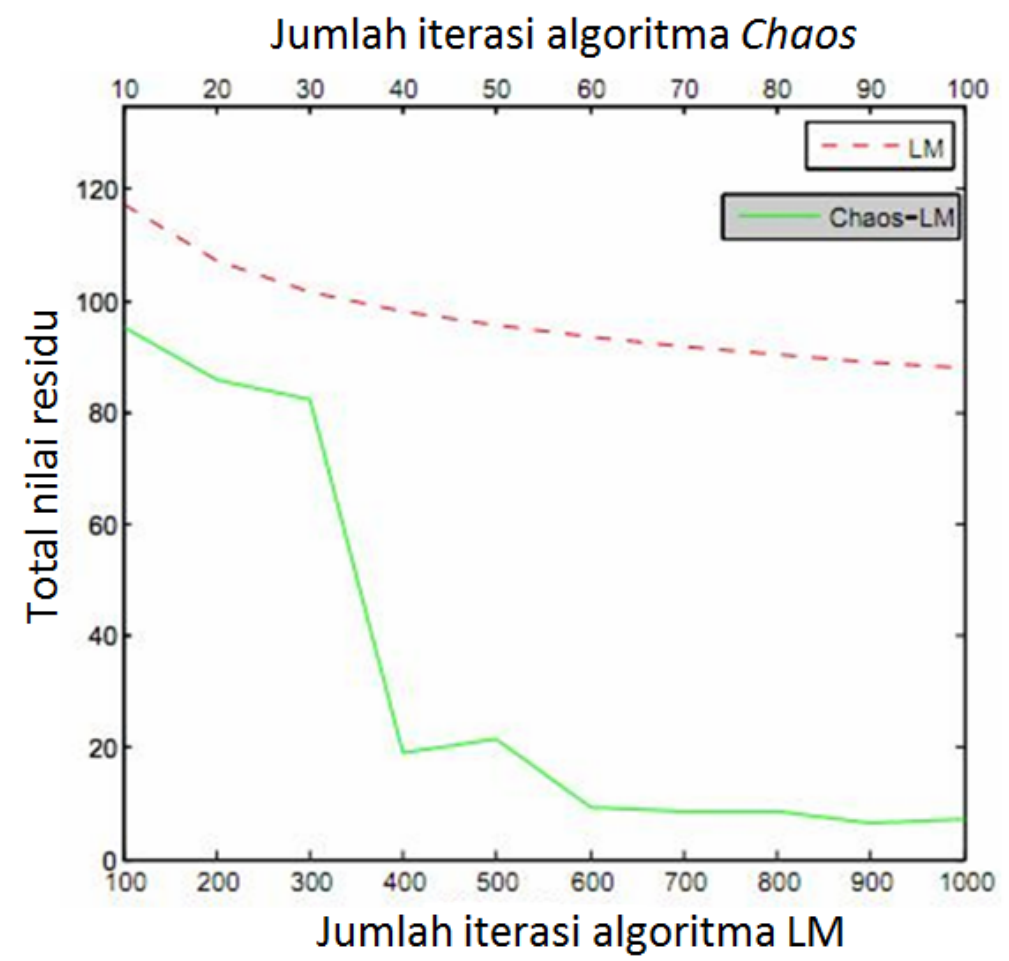

Gambar 20: Konvergensi dari komputasi fitting. Algoritma Chaos menyebabkan peningkatan efisiensi kompuasi dari algoritma LM.

\subsection{Algoritma untuk aplikasi pengukuran}

Pada bagian ini, dua contoh aplikasi algoritma untuk suatu pengukuran sudut dan perpendicularity akan dibahas. Dalam prakteknya, suatu pengukuran membutuhkan kombinasi dari berbagai jenis algoritma pengukuran. Sebuah algoritma pra-pemrosesan dibutuhkan sebelum algoritma fitting diaplikasikan. Algoritma pra-pemrosesan yang paling umum adalah algoritma segmetasi. Algoritma segmentasi adalah suatu algoritma yang bertujuan untuk memilih titik- 
titik yang relevan untuk suatu pengukuran tertentu. Algoritma segmentasi sangat diperlukan terutama apabila suatu kalklasi pengukuran ingin dilakukan secara otomatis dan tidak melibatkan seorang operator untuk secara manual memilah data yang relevan untuk suatu pengukuran.

Pada bagian ini, dua aplikasi algoritma yang dibahas adalah algoritma untuk mendapatkan hasil pengukuran perpendicularity dan algoritma untuk pengukuran sudut rake suatu cutting tool secara otomatis.

\subsubsection{Algoritma pengukuran sudut rake (cutting tool) secara otomatis}

Pengukuran perpendicularity adalah suatu pengukuran geometri yang memerlukan definis datum. Pada contoh ini, pengukuran perpendicularity pada sebuah komponen berskala meso dengan tolernasi bersakal mikro dipresentasikan (Syam 2015). Komponen tersebut diperlihatkan pada gambar 21. Pada gambar 21, terlihat gambar 3D dari komponen tersebut beserta dengan gambar teknik 2D nya. Perpendicularity yang ingin diukur mempunyai toleransi $0.02 \mathrm{~mm}(20 \mu \mathrm{m})$. Bidang referensi (datum) dari bidang yang akan diverifikasi perpendicularity-nya adalah datum A seperti pada gambar 21.

Komponen tersebut diukur dengan menggunakan instrumen CMM non-kontak berbasiskan focus variation microcopy/FVM (lihat bab 6). Pada pengukuran perpendicularity ini, dibutuhkan dua bidang yang harus diukur, yaitu bidang referensi dan bidang terukur yang akan diverifikasi perpendicularity-nya.Gambar 22 memperlihatkan hasil pengukuran titik-titik (point cloud) dari dua bidang pada komponen tersebut yang berjumlah sekitar 1000000 titik.

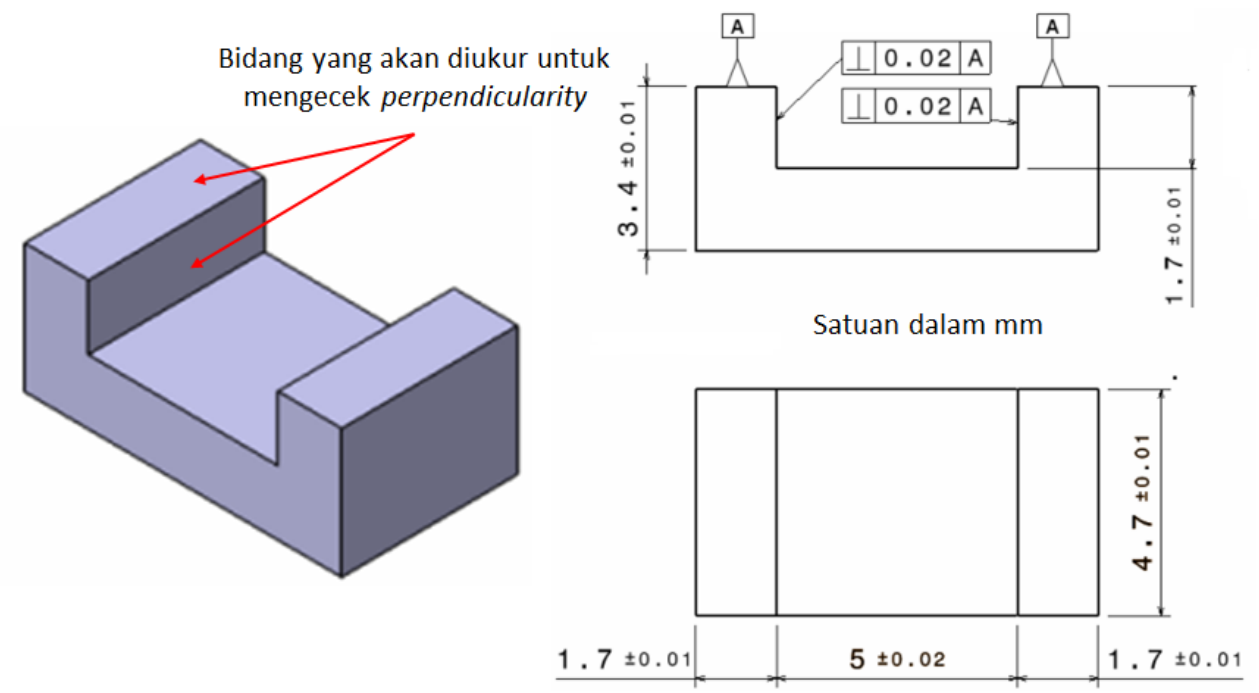

Gambar 21: Sebuah komponen dengan toleransi berskala mikro: gambar 3D dan gabar teknik 2D-nya.

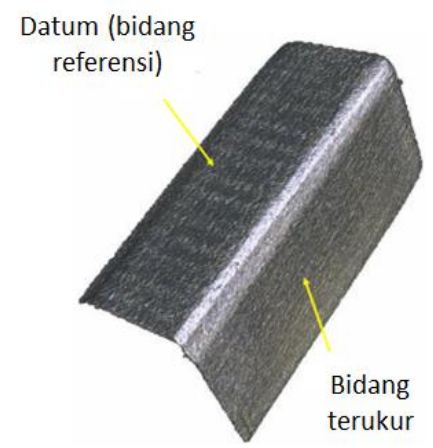

Gambar 22: Hasil titik-titik (point cloud) yang didapatkan dengan menggunakan sebuah instrumen bebrasis focus variation microscopy (FVM). 


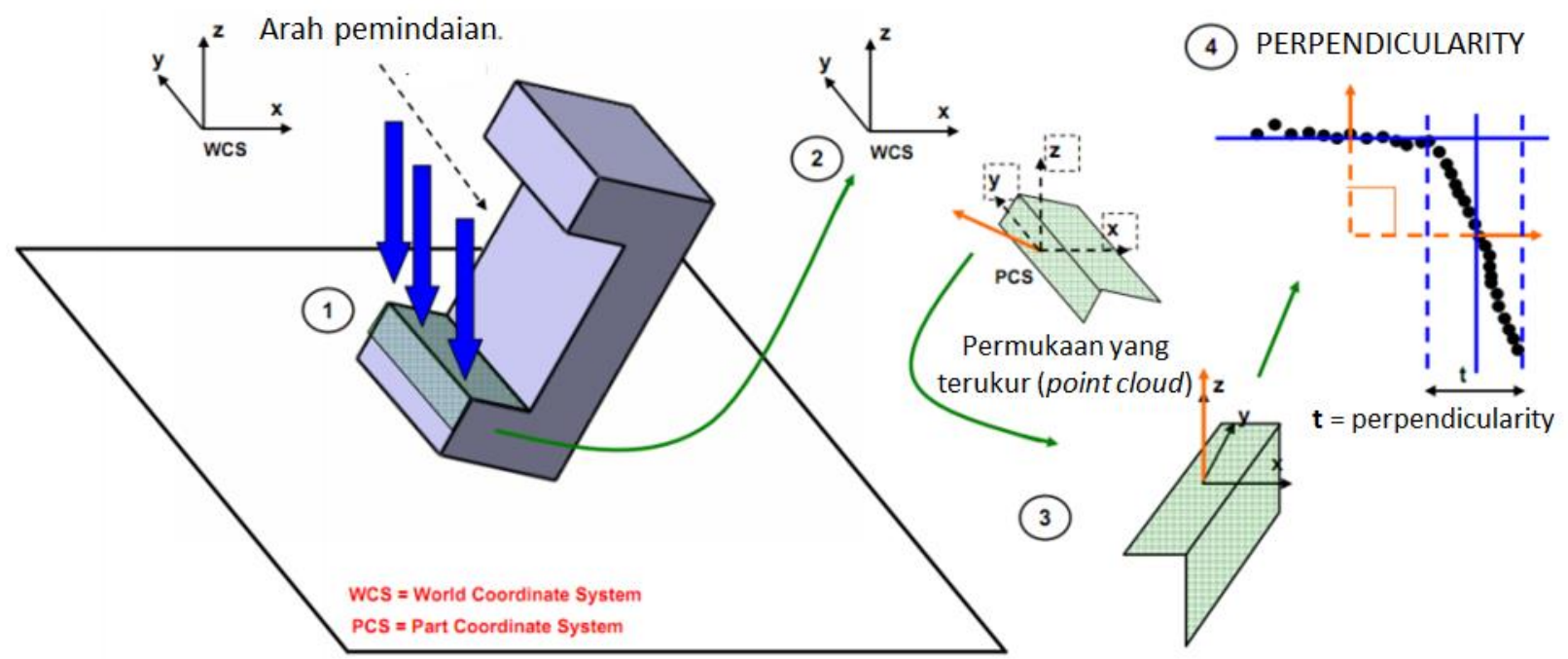

Gambar 23: Prosedur untuk memproses pengukuran perpendicularity.

Dibutuhkan beberapa langkah untuk memproses titik-titik dari permukaan komponen tersebut untuk menghasilkan hasil pengukuran perpendicularity. Gambar 23 memperlihatkan langkah-langkah dari proses pengukuran, pemrosesan data sampai dengan perhitungan perpendicularity. Algoritma untuk melakukan perhitungan perpendiculairty dari titik-titik 3D komponen tersebut adalah (lihat gambar 23):

1. Fitting sebuah bidang datar pada titik-titik bidang referensi (gambar 22) dan dapatkan vektor satuan normal dari bidang referensi tersebut $\mathrm{a}_{r e f}$.

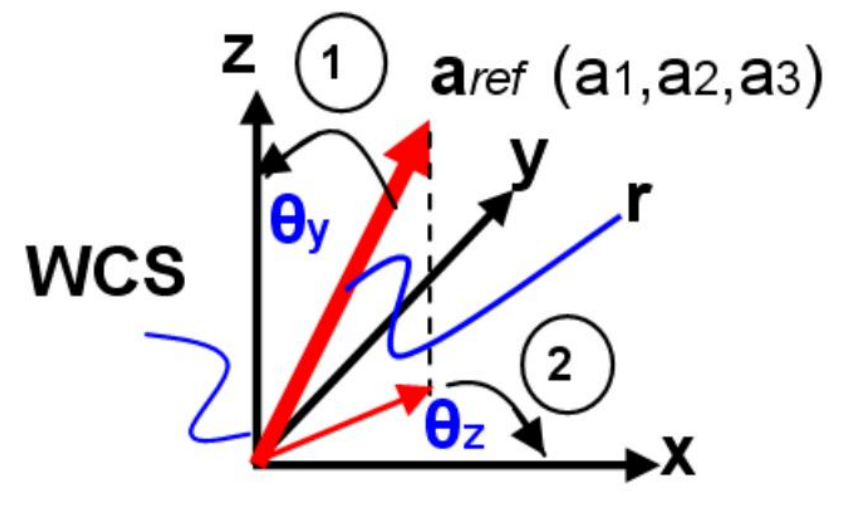

Gambar 24: Ilustrasi dari $\theta_{y}$ dan $\theta_{z}$.

2. Kalkulasi sudut $\mathrm{a}_{\text {ref }}$ terhadap world coordinate system (WCS) untuk mendapatkan rotasi spasial $\theta_{y}$ dan planar $\theta_{z}$ dari bidang referensi tersebut. kalkulasi dari rotasi spasial dan planar tersebut adalah (gambar24):

$$
\begin{aligned}
& \theta_{y}=\tan ^{-1}\left(r / a_{3}\right) \\
& r=\sqrt{a_{1}^{2}+a_{2}^{2}+a_{3}^{2}}
\end{aligned}
$$




$$
\begin{aligned}
& \theta_{z}=\tan ^{-1}\left(r_{2} / a_{2}\right) \\
& r_{2}=\sqrt{a_{1}^{2}+a_{2}^{2}}
\end{aligned}
$$

3. Transofrmasi invers (rotasi) $\mathrm{a}_{\text {ref }}$ terhadap rotasi spasial dan planarnya sehingga part coordinate system (PCS) selaras dengan WCS (langkah 3 pada gambar 23). Rotasi tersebut dilakukan dengan:

$$
\begin{aligned}
& \mathrm{a}_{\text {ref }}^{\prime}=\mathbf{T}_{\text {rotasi }} \cdot \mathrm{a}_{\text {ref }} \\
& \mathbf{T}_{\text {rotasi }}=\mathbf{R}_{y}\left(\theta_{y}\right) \cdot \mathbf{R}_{z}\left(\theta_{z}\right)
\end{aligned}
$$

Dimana $\mathbf{R}_{y}\left(\theta_{y}\right)$ dan $\mathbf{R}_{z}\left(\theta_{z}\right)$ adalah matriks rotasi searah sumbu- $y$ dan sumbu-z.

4. Rotasi $\mathrm{a}_{r e f}^{\prime}$ sebesar $90^{\circ}$ searah sumbu- $y$. Hasil rotasi $\mathrm{a}_{r e f}^{\prime}$ tersebut adalah vektor satuan normal dari bidang terukur $\mathrm{a}_{\text {mea }}$ (lihat gambar 22).

$$
\mathrm{a}_{m e a}=\mathbf{T}_{90^{0} y=a k s i s} \mathrm{a}_{r e f}^{\prime}
$$

5. Transformasi balik (invers) semua titik (pada bidang referensi dan bidang terukur) terhadap rotasi spasial $\theta_{y}$ dan planar $\theta_{z}$ yang telah didapatkan sebelumnya.

$$
\mathbf{X}_{i}^{\prime}=\mathbf{T}_{\text {rotasi }} \cdot \mathbf{X}_{\boldsymbol{i}}
$$

6. Fitting sebuah bidang datar pada titik-titik pada bidang terukur. Titik pada bidang terukur tersebut adalah centroid (titik pusat) dari bidang datar yang di-fitting tersebut dan vektor satuan normalnya adalah $\mathrm{a}_{m e a}$.

7. Kalkulasi jarak maksimum titik disebelah kanan dan kiri bidang datar tersebut. total kedua jarak tersebut merupakan perpendicularity dari bidang terukur tersebut terhadap bidang referensi (gambar 22).

\subsubsection{Algoritma untuk menentukan sebuah error perpendicularity}

Pada bagian ini, sebuah studi kasus pengembangan algoritma pengukuran sebuah sudut rake dari sebuah cutting tool secara otomatis (Syam 2015, Moroni et al 2014). Pengukuran untuk memindai titik-titik pada permukaan cutting edge dari cutting tool tersebut adalah sebuah CMM non-kontak berbasis FVM. Jumlat total titik-titik yang didapatkan adalah 450000 data. Gambar 25 memperlihatkan titik-titik dalam format koordinat spasial $X, Y$ dan $X$ (yang diukur), dan format triangulasinya.

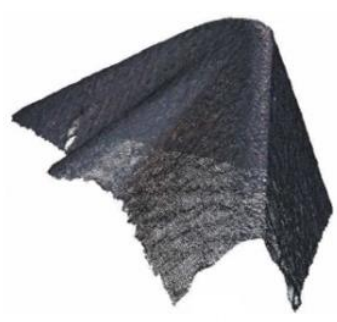

Point cloud

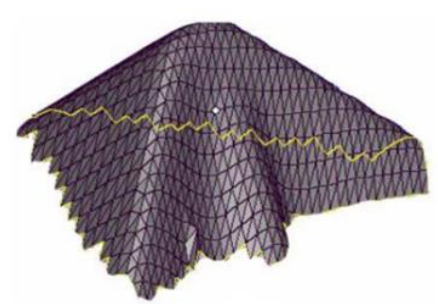

Format triangulasi

Gambar 25: Titik-titik (point cloud) dari sebuah cutting tool. 
Karena pengukuran dilakkan secara otomatis tanpa campur tangan seorang operator untuk memilah titik mana yang relevan terhadap pengukuran sudut tersebut, maka langkah-langkah algoritma dari pengukuran sudut rake ini menajdi lebih panjang. Proses segmentasi titik-titik untuk menentukan titik mana yang relevan untuk dikalkulasi merupakan langkah pertama dari algoritma pengukuran sudut tersebut.

Sebuah algoritma yang dikembangkan untuk melakukan pengukuran sudut tersebut memproses data dalam format triangulasi. Maka dari itu, data berupa titik-titik koordinat spasial dari permukaan cutitng edge tersebut harus dirubah ke dalam format triangulasi. Format data triangulasi merupakan suatu format yang sangat umum dalam merepresentasikan sebuah model objek atau permukaan 3D. Algoritma pengukuran sudut rake secara otomatis tersebut adalah sebagai berikut:

1. Estimasi dari vektor normal setiap titik dan nilai kurvaturnya.

Algoritma untuk mengkalkulasi kurvatur sebuah titik 3D diadaptasi dari Hamman 1993. Langkah-langkah untuk mengestimasi kurvatur tersebut adalah sebagai berikut (lihat gambar 26). Untuk setiap titik $\mathbf{P}_{i}$, vektor normalnya $\mathbf{n}$ diestimasi dengan $\sum_{i=1}^{N} \mathbf{n}_{i} / N$ dimana $\mathbf{n}_{i}$ adalah vektor normal untuk setiap bidang yang bersebelahan (adjacent faces) dan $\mathrm{N}$ adalah jumlah dari bidang yang bersebelahan tersebut pada titik $\mathbf{P}_{i}$ tersebut (gambar 26 kiri).

Selanjutnya, rata-rata kurvatur $H=\left(k_{1}+k_{2}\right)$ dikalkulasi untuk setiap titik $\mathbf{P}_{i} . k_{1}$ dan $k_{2}$ adalah dua kurvatur prinsipal dari titik $\mathbf{P}_{i}$. Dengan demikian, setiap titip pada edge akan mempunyai nilai $\mathrm{H}$ yang secara signifikan lebih besar daripada titik-titik lain yang tidak terletak pada edge (gambar 26 tengah). $k_{1}$ dan $k_{2}$ ditentukan dari platelet yang merupakan semua titik-titik yang bersebelahan dengan titik $\mathbf{P}_{i}$ (gambar 26 kanan).
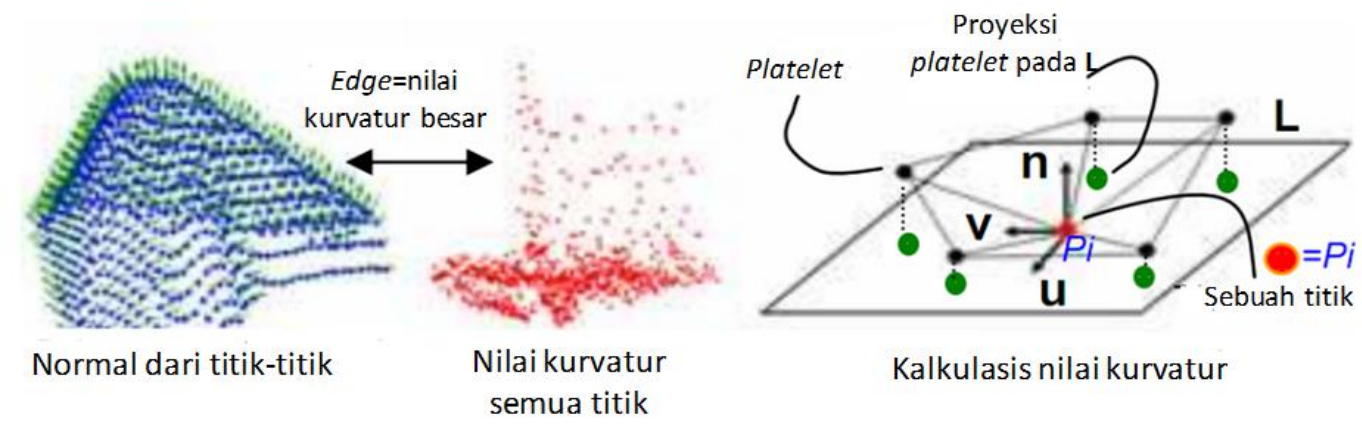

Kalkulasis nilai kurvatur

Gambar 26: Kalkulasi vektor normal dan nilai kurvatur.

Prosedur untuk mengkalkulasi $k_{1}$ dan $k_{2}$ adalah sebagai berikut. Untuk setiap titik $\mathbf{P}_{i}$, sebuah bidang datar PL didefinisikan dalam bentuk fungsi implisit:

$$
\left(\mathbf{n} \cdot\left(\mathbf{x}-\mathbf{P}_{i}\right)\right)=n_{x}\left(x-P_{x}\right)+n_{y}\left(y-P_{y}\right)+n_{z}\left(z-P_{z}\right)
$$

Kemudian, Platelet $t_{j}$ yang merupakan semua platelet dari titik $\mathbf{P}_{i}$ diproyeksikan pada bidang datar PL.

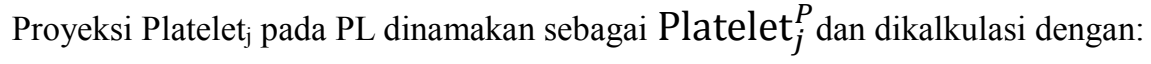

$$
\text { Platelet }_{j}^{P}=\text { Platelet }_{j}-\mathbf{d}_{j} \cdot \mathbf{n}
$$

dimana $\mathbf{d}_{j}$ adalah jarak ortogonal dari Platelet ${ }_{j}$ ke bidang PL. Setiap titik Platelet $_{j}^{P}$ dari kemudian 
ditranslasikan pada suatu sistem koordinat baru yang berpusat di titik $\mathbf{P}_{i}$ denganvektor unit basis didefinisikan dengan $\langle\mathbf{u}, \mathbf{v}\rangle$. Untuk melakukan translasi tersebut, sebuah vektor perbedaan $\mathbf{d}_{j}$ antara Platelet $_{j}^{P}$ dan $\mathbf{P}_{i}$ dikalkulasi dengan $\mathbf{d}_{j}=$ Platelet $_{j}^{P}-\mathbf{P}_{i}$. Vektor perbedaan $\mathbf{d}_{j}$ ini dapat direpresentasikan dalam bentuk kombinasi linier dari $\langle\mathbf{u}, \mathbf{v}\rangle$ sebagai berikut:

$$
\mathbf{d}_{j}=\left(\mathbf{d}_{j} \cdot \mathbf{u}\right) \mathbf{u}+\left(\mathbf{d}_{j} \cdot \mathbf{v}\right) \mathbf{v}
$$

Sehingga, koordinat lokal setiap komponen Platelet $_{j}^{P}$ berdasarkan $\langle\mathbf{u}, \mathbf{v}\rangle$ adalah:

$$
\left(p_{j}, q_{j}\right)^{T}=\left(\mathbf{d}_{j} \cdot \mathbf{u}, \mathbf{d}_{j} \cdot \mathbf{v}\right)^{T}
$$

Dikalkulasi sebagai berikut:

$$
\mathbf{u}=\frac{\mathbf{a}}{\|\mathbf{a}\|} \operatorname{dan} \mathbf{v}=\mathbf{n} \times \mathbf{u}
$$

dimana $\mathbf{a}$ adalah sebuah vektor yang tegak lurus kepada $\mathbf{n}(\mathbf{a} \cdot \mathbf{n})=\mathbf{0}$, yaitu:

$$
\mathbf{a}=\left\{\begin{array}{l}
\frac{1}{n_{x}}\left(-\left(n_{y}+n_{z}\right), n_{x}, n_{x}\right)^{T} \\
\frac{1}{n_{y}}\left(n_{y},-\left(n_{x}+n_{z}\right), n_{y}\right)^{T} \\
\frac{1}{n_{z}}\left(n_{z}, n_{z},-\left(n_{x}+n_{y}\right)\right)^{T}
\end{array}\right.
$$

Sebuah fungdi polinomial derajat 2 , yaitu $f$, yang mempunyai absis dan ordinat terdefinisikan sebagai:

$$
f(p, q)=\frac{1}{2}\left(c_{1} p_{j}^{2}+2 c_{2} p_{j} q_{j}+c_{3} q_{j}^{2}\right)
$$

Dalam bentuk matriks direpresentasikan sebagai:

$$
\left[\begin{array}{ccc}
p_{1}^{2} & 2 p_{1} q_{1} & q_{1}^{2} \\
\vdots & \vdots & \vdots \\
p_{n}^{2} & 2 p_{n} q_{n} & q_{n}^{2}
\end{array}\right]\left[\begin{array}{c}
c_{1} \\
c_{2} \\
c_{3}
\end{array}\right]=\left[\begin{array}{c}
d_{1} \\
\vdots \\
d_{n}
\end{array}\right]
$$

Dengan menyelesaikan persamaan (33) dengan metode least-square, persamaan (33) menjadi:

$$
\left[\begin{array}{ccc}
p_{1}^{2} & 2 p_{1} q_{1} & q_{1}^{2} \\
\vdots & \vdots & \vdots \\
p_{n}^{2} & 2 p_{n} q_{n} & q_{n}^{2}
\end{array}\right]\left[\begin{array}{ccc}
p_{1}^{2} & 2 p_{1} q_{1} & q_{1}^{2} \\
\vdots & \vdots & \vdots \\
p_{n}^{2} & 2 p_{n} q_{n} & q_{n}^{2}
\end{array}\right]\left[\begin{array}{c}
c_{1} \\
c_{2} \\
c_{3}
\end{array}\right]=\left[\begin{array}{ccc}
p_{1}^{2} & 2 p_{1} q_{1} & q_{1}^{2} \\
\vdots & \vdots & \vdots \\
p_{n}^{2} & 2 p_{n} q_{n} & q_{n}^{2}
\end{array}\right]\left[\begin{array}{c}
d_{1} \\
\vdots \\
d_{n}
\end{array}\right]
$$

Sehingga, dengan mencari solusi $c_{1}, c_{2}$ dan $c_{3}$, kedua kurvatur prinsipal $k_{1}$ dan $k_{2}$ adalah akar dari $k_{1}-\left(c_{1}+c_{3}\right) k+c_{1} c_{3}-c_{2}^{2}$. 
2. Konstruksi bidang referensi $\mathbf{P}_{\mathbf{r}}$ dan bidang potong $\mathbf{P}$.

Bidang referensi $\mathbf{P}_{\mathbf{r}}$ dikalkulasi dari titik-titik pada edge yang sudah terdeteksi dari nilai kurvatur titik-titik edge tersebut. untuk menentukan titik-titik edge tersebut, titik-tiitk dengan nilai kurvatur $\mathrm{H}>10$ dipilih. Bidang tersebut dikonstruksi dengan menentukan sebuah titik pada bidang $\mathbf{P}_{\mathbf{r}}$ tersebut dan vektor normal titik tersebut (gambar 27 kiri).

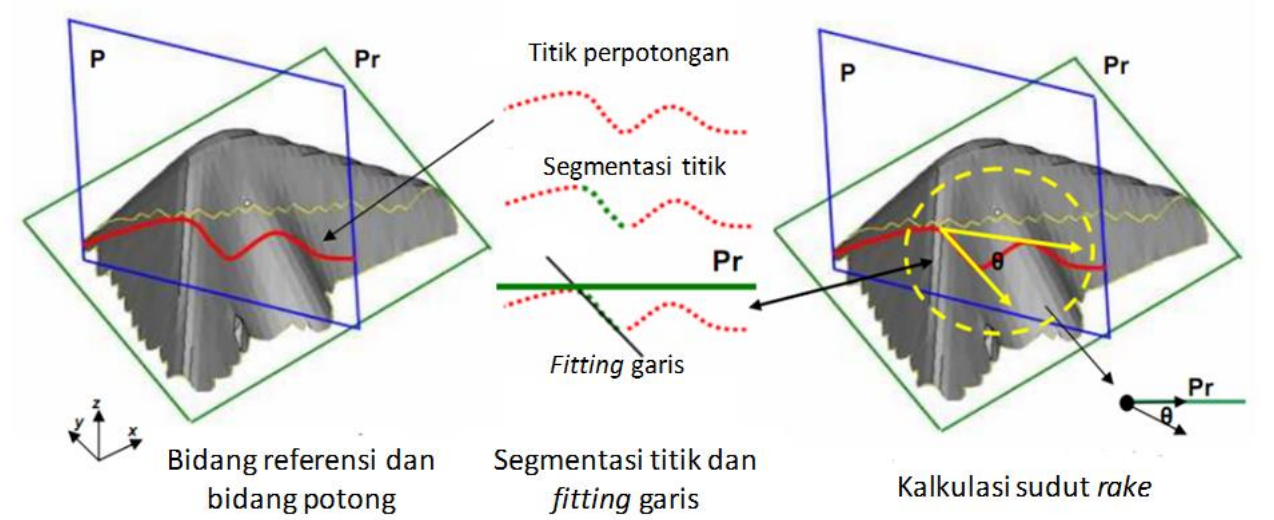

Gambar 27: Rekonstruksi bidang, segmentasi titik dan fitting dan kalkulasi sudut rake.

Untuk menentukan bidang tersebut, fitting ortogonal berbasis least-square untuk bidang datar digunakan. Proses fitting tersebut dilakukan dengan mencari vektor Eigen yang berkoresponsendi dengan nilai Eigen terkecil dari matriks $\mathbf{M}$, yaitu matriks yang berisi koordinat spasial titik-titik pada edge $\mathbf{P}_{i}$ yang terlibat dalam fitting tersebut. Dimana, titik pada bidang $\mathbf{P}_{\mathbf{r}}$ adalah centroid (rata-rata) dari semua titik-titik $\mathbf{P}_{i}$ tersebut. Persamaan bidang datar yang digunakan adalah:

$$
\mathbf{n} \cdot\left(\mathbf{P}_{i}-\widehat{\mathbf{P}}_{l}\right)=\mathbf{0}
$$

dimana $\widehat{\mathbf{P}}_{\boldsymbol{l}}$ adalah centroid dari $\mathbf{P}_{i}$.

Bidang $\mathbf{P}_{\mathbf{r}}$ tersebut (yang merupakan bidang yang terletak pada edge dari suatu cutting tool) digunakan untuk mennetukan bidang $\mathbf{P}$ (gambar 27 kiri) yang merupakan bidang yang tegak lurus terhadap $\mathbf{P}_{\mathbf{r}}$. Vektor satuan dari bidang $\mathbf{P}$ didapatkan dengan cara merotasi vektor normal bidang $\mathbf{P}_{\mathbf{r}}$ sebesar $90^{\circ}$ searah sebuah sumbu yang tegak lurus dengan garis edge. Dan, titik pada bidang $\mathbf{P}$ adalah sama dengan titik pada bidang $\mathbf{P}_{\mathbf{r}}$.

3. Segmentasi titik-titik dan fitting garis.

Proses segmentasi titik-titik dilakukan pada titik-titik potong antara bidang potong $\mathrm{P}$ dan model triangulasi dari cutitng tool tersebut (gambar 27 tengah). Untuk mendapatkan titik-titik potong tersebut, sebuah persamaan parametrik digunakan. Sebuah garis yang melalui dua titik $\mathbf{P} \mathbf{t}_{\mathbf{1}}$ dan $\mathbf{P t}_{\mathbf{2}}$ didefinisikan dalam persamaan parametrik sebagai:

$$
\mathbf{P t}=\mathbf{P} \mathbf{t}_{\mathbf{1}}+t \cdot\left(\mathbf{P t}_{\mathbf{2}}-\mathbf{P} \mathbf{t}_{\mathbf{1}}\right)
$$

dimaan $t$ adalah suatu kuantitas skalar yang digunakan untuk menentukan sebuah titik pada garis tersebut. 
dengan memasukkan persamaan parametrik garis (persamaan (36)) tersebut ke dalam persamaan bidang (persamaan (35)), maka $t$ dapat dikalkulasi sebagai:

$$
t=\frac{-\left[A \cdot P t_{1 x}+B \cdot P t_{1 y}+C \cdot P t_{1 z}+D\right]}{A\left(P t_{2 x}-P t_{1 x}\right)+B\left(P t_{2 y}-P t_{1 y}\right)+C\left(P t_{2 z}-P t_{1 z}\right)}
$$

Setelah mendapatkan $t$, titik-titik perpotongan antara bidang potong $\mathbf{P}$ dan data cutitng tool tersebut dalam format triangulasi (mesh) didapatkan. Kemudian, proses segmentasi titik-titik tersebut dapat dilakukan. Langkah-langkah proses segmentasi tersebut adalah sebagai berikut. titik-titik yang berjarak sangat jauh terhadap bidang $\mathbf{P}_{\mathbf{r}}$ diabaikan. Kemudian, titik-titik potong tersebut diurut, dari kecil ke besar, terhadap nilai koordinat $x$ dan $y$-nya dengan menggunakan algoritma selection sort. Selanjutnya, titik-tiitk potong tersebut dicek satu per satu dari mulai titik yang palin kiri (gambar 27 tengah). Titik yang tersegmentasi dikenali sebagai titik yang memiliki nilai korrdinat y yang terkecil. Sejumlah 15 titik didapatkan dan kemudian sebuah geometri garis di-fitting secara ortogonal dan least-square. Kemudian, titik selanjutnya dicek, standar deviation dari residu-residu $\sigma_{\text {baru }}$ setelah penambahan titik baru dikalkulasi. Apabila $\sigma_{\text {baru }}<\sigma_{\text {sebelumnya }}$, maka titik baru tersebut termasuk dalam himpunan titik-titik yang tersegmentasi. Proses ini diulang-ulang sampai tiga titik secara berurutan mempunyai nilai $\sigma_{\text {baru }}>\sigma_{\text {sebelumnya }}$.

4. Kalkulasi sudut rake.

Akhirnya, sudut rake dapat dikalkulasi. Sudut rake adalah sudut $\theta$ antara garis yang di-fitting dari titik-titik yang tersegmentasi tersebut dan garis potong yang diproyeksikan pada bidang $\mathbf{P}_{\mathbf{r}}$ (gambar 27 tengah dan kanan). Untuk mengkalkulasi sudut tersebut, vektor satuan normal $\mathbf{n}_{\text {line }}$ dari garis yang di-fitting pada langkah 3 diproyeksikan pada bidang $\mathbf{P}_{\mathbf{r}}$ (Gambar 27 kanan). Proyeksi $\mathbf{n}_{\text {line }}$ pada bidang $\mathbf{P}_{\mathbf{r}}$ dikalkulasi sebagai berikut:

$$
\mathbf{n}_{\text {line_projected }}=\mathbf{n}_{\text {line }}-\mathbf{n}_{\text {bidang_Pr }}\left\|\mathbf{n}_{\text {bidang_Pr }}\left(\mathbf{n}_{\text {line }} \cdot \mathbf{n}_{\text {bidang_Pr }}\right)\right\|
$$

Akhirnya, sudut rake $\theta$ dapat dikalkulasi sebagai sudut antara $\mathbf{n}_{\text {line }}$ dan $\mathbf{n}_{\text {bidang_Pr. }}$. 


\section{BAB 8}

\section{Kompensasi error}

Kompensasi error merupakan suatu proses yang sangat penting untuk menghasilkan suatu instrumen pengukuran, misalnya CMM, yang menghasilkan suatu hasil pengukuran yang akurat. Setiap instrumen pengukuran, walaupun instrumen tersebut terdiri dari komponen-komponen yang sangat presisi dan akurat, pasti memiliki error. Pada kenyataannya error pada suatu instrumen pengukuran pasti akan muncul yang disebabkan oleh berbagai sumber, misalnya error pada proses manufaktur dan error pada saat proses perakitan (assembly).

Semua instrumen pengukuran, apalagi suatu instrumen dengan presisi yang sangat tinggi, telah diaplikasikan suatu kompensasi error. Dengan proses kompensasi error, error-error yang terdapat pada suatu instrumen pengukuran dapak dikurangi, sehingga hasil pengukuran dengan instrumen tersebut akan bertambah tingkat akurasinya. Proses kompensasi error pada umumnya dilakukan oleh pembuat atau produsen suatu instrumen pengukuran setelah instrumen tersebut dirakit dan sebelum instrumen tersebut dikirim ke konsumen atau pembeli.

Secara umum, jenis-jenis kompensasi error terbagi menurut metode penerepannya dan menurut ukuran waktu pengaplikasiannya. Metode penerapan kompensasi error terbagi menjadi berbasis perangkat keras atau lunak. Sedangkan, menurut ukuran waktu responnya, kompensasi error terbagi menjadi non-real-time (offline) dan real-time.

\subsection{Kenapa kompensasi?}

Pada awalnya, instrumen-instrumen presisi dibuat dari komponen-komponen yang sangat presisi juga. Namun demikian, dengan menggunakan komponen-komponen yang presisi untuk membangun sebuah instrumen yang presisi, biaya produksi instrument tersebut akan sangat tinggi. Hal tersebut disebabakan karena untuk membuat suatu komponen yang presisi, dibutuhkan suatu proses permesinan yang lama dan berulang-ulang. Proses berulang-ulang tersebut biasanya merupakan proses untuk finishing komponen tersebut untuk mencapai tingkat akurasi yang sangat tinggi.

Selain itu, tingkat presis suatu instrumen tidak hanya bergantung kepada tingkat presisi komponen-komponen penyusunan, tetapi bergantung juga dengan faktor-faktor lain, misalnya untuk CMM, sistem probing sangat mempengaruhi tingkat akurasi suatu CMM. Selain itu, faktor-faktor yang berasal dari suatu sistem elektronik untuk memproses sinyal pengukuran juga berpengaruh. Maka dari itu, apabila setiap komponennya ingin dibuat presisi, berikut dengan sistem-sistem lainnya (sistem probing, sistem elektronik, efek lingkungan dan lain-lain), maka akan sangat sulit untuk membuat suatu instrumen yang sangat presisi. Dan juga, biaya produksi instrumen tersebut kana sangat tinggi sehingga instrumen yang diproduksi tidak dapat kompetitif secara ekonomi di pasaran.

Ada dua hal yang harus dipahami perbedaannya, yaitu "Penghindaran/eleminasi error" dan "kompensasi error". "Penghindaran/eleminasi error" adalah suatu proses untuk membuat suatu geometri komponen dengan seakurat mungkin (seperti yang sudah dijelaskan sebelumnya). Dengan strategi "penghindaran error", dibutuhkan biaya yang sangat tinggi untuk mencapai suatu tingkat akurasi yang tinggi. Sedangkan, "Kompensasi error" adalah suatu proses untuk memisahkan dan mengkuantifikasi suatu error dari suatu signal/hasil pengukuran, sehingga error yang terkuantifikasi dapat ditambahkan atau dikurangi sebesar nilai error tersebut, sehingga pada akhirnya, hanya sinyal/hasil pengukuran yang didapatkan (karena error pada sinyal/hasil pengukuran yang ada sudah dikompensasi sebesar nilai error tersebut). dengan metode "kompensasi error" suatu instrumen dengan tingkat akurasi yang tinggi dapat dibuat dengan biaya produksi yang jauh lebih rendah.

Hal yang perlu dipahami untuk "kompensasi error" adalah error-error pada instrumen (misalnya yang berasal 
dari error geometri setiap komponennya dan error-error dari sumber lainnya) harus bersifat sistematik, yaitu konstan dan dapat diprediksi dan hanya sedikit dari error acak. Hanya error sistematik yang bisa dikompensasi karena error tersebut konsisten (repeatable). Sedangkan, error acak tidak dapat dikompensasi karena tidak dapat diprediksi. Error acak hanya bisa diatasi dengan startegi kontrol berbasis real time yang merupakan seusatu yang kompleks.

Suatu intrumen pengukuran haruslah mempunyai tingkat akurasi yang sangat tinggi. Sebuah instrumen pengukuran dikatakan dapat mengukur suatu benda secara efektif dan efisien apabila tingkat akurasi instrumen tersebut minimal satu magnutude lebih besar dari benda yang diukur. Sebagai contoh, untuk pengukuran roundness suatu silinder dengan nilai roundness nominalnya sebesar $0.05 \mathrm{~mm}$, maka besarnya error roundness dari spindle suatu instrumen pengukuran yang digunakan maksimal boleh bernilai $0.005 \mathrm{~mm}$ atau lebih kecil lagi. Apabila error roundness dari spindle instrumen tersebut besar (misalnya $0.1 \mathrm{~mm}$ ), maka hasil pembacaan pengukuran roundness silinder tersebut akan tidak mempunyai arti karena yang terbaca adalah error roundness dari spindle intrumen tersebut. Target utama dari kompensasi error adalah untuk mebuat suatu instrumen dengan tingkat akurasi dan presisi yang tinggi dengan biaya serendah mungkin (atau rasional).

Terdapat berbagai macam cara untuk dapat memisahkan, mengkuantifikasi dan mengkompensasi suatu error pada suatu instrumen pengukuran yang sebagian akan dibahas dalam bab ini.

\subsection{Jenis-jenis kompensasi error}

Pada kenyataannya, setiap instrumen yang bergerak akan mencapai suatu posisi yang diperantahkan, misalnya oleh sistem kontrol, pada akhirnya akan bergerak mencapai suatu posisi yang tidak sesuai dengan yang diperintahkan. Perbedaan antara posisi yang diperintahkan dan posisi aktualnya adalah error posisi, yang ingin dikompensasi. Terdapat berbagai macam jenis atau strategi untuk kompensasi error. Selain itu, terdabat banyak metode untuk klasifikasi dari jenis-jenis kompensasi error tersebut. Namun demikian, terdapat dua jenis klasifikasi dari kompensais error yang paling umum, yaitu berdasarkan perangkat keras atau lunak dan berdasarkan non-real-time dan real-time.

\subsubsection{Kompensasi berbasis perangkat keras dan lunak}

Kompensasi error berdasarkan bagaimana penerapannya pada suatu instrumen dibagi menjadi dua jenis, yaitu: kompensasu error berbasis perangkat keras (hardware) dan perangkat lunak (software). Kompensasi error berbasis perangkat lunak disebut juga sebagai kompensasi numerik (numerical compensation). Pada umumnya, kedua metode kompensasi error tersebut membutuhkan sebuah model matematis dari sistem kinematik sebuah instrumen. Dari model matematis tersebut, error pada setiap lokasi posisi aktuator dari suatu instrumen dapat dipetakan. Hasil dari pemetaan error tersebut dinamakan peta error (error map). Peta error adalah sebuah fungsi yang memberikan nilai error pada setiap posisi aktuator dari sebuah instrument.

Kompensasi berbasis perangkat keras adalah suatu proses untuk mengkompensasi error dari suatu lokasi aktiator dengan cara menerapkan sebuah sistem pernagkat keras ke aktuator tersebut. Gambar 1 memperlihatkan contoh dari implementasi kompensasi error berbasis perangkat keras. Pada gambar 1, diperlihatkan sebuah wahan gerak linier (linear motion stage) yang bergerak pada sebuah jalur (guide). Tentu saja dalam aplikasinya, baik jalur dan wahana tersebut mempunyai suatu error geometri yang disebabkan dari ketidaksempurnaan sebuah proses manufaktur yang membuat komponen-komponee tersebut. Pada kasus ini, apabila sebuah proses finishing dilakukan untuk memperbaiki error geomerti dari jalur atau wahan tersebut (misalnya dengan proses scrapping), maka proses tersebut dinamakan "penghidaran/eleminasi error" dan bukan "kompensasi error". Untuk kompensasi error, sebuah model matematis yang memetakan error pada setiap lokasi pergerakan wahana tersebut digunakan untuk mengkuantifikasi atau memprediksi error pada setiap lokasi wahana tersebut terhadap jalur-nya (guide). Setelah itu, sebuah sistem perangkat keras diaplikasikan pada wahan tersebut sedemikian rupa sehingga apabila ada error pergerakan wahana tersebut pada suatu lokasi di jalurnya, maka sistem perangkat keras tersebut akan mengkompensasi wahan tersebut dengan mengatur jarak (gap) antara wahana tersebut dan kedua dinding dari jalur wahana tersebut (gambar 1). 


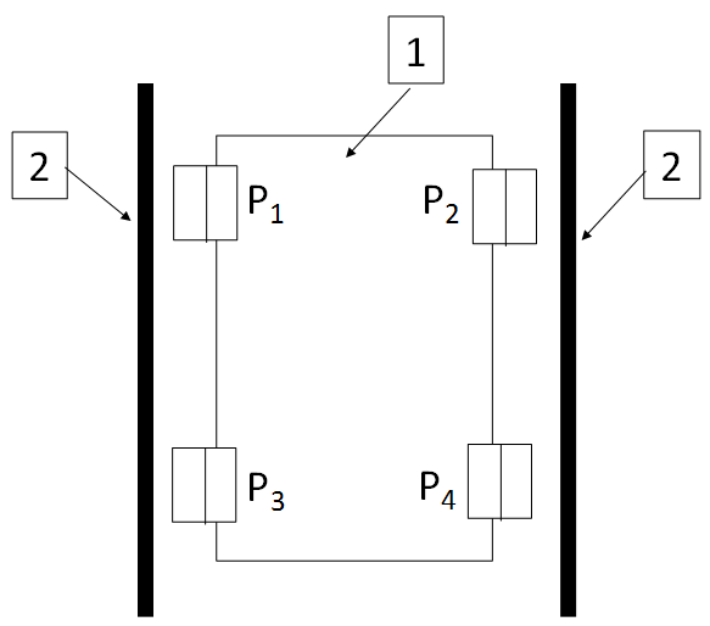

Gambar 1: Kompensasi error berbasis perangkat keras: elemen piezzo-electric digunakan untuk mengatur gap antara stage (nomor 1) dan guide way (nomor 2) untuk mengurangi error straigthness.

Pada gambar 1 , terdapat empat elemen piezzo yang dipasang pada wahana tersebut, yaitu $\mathrm{P}_{1}, \mathrm{P}_{2}, \mathrm{P}_{3}$ dan $\mathrm{P}_{4}$. $\mathrm{P}_{1}$ dan $\mathrm{P}_{3}$ adalah aktuator elemen piezzo yang mengatur jarak antara wahana tersebut dengan dinding jalur sebelah kirinya. Sedangkan, $\mathrm{P}_{2}$ dan $\mathrm{P}_{4}$ adalah elemen piezo yang mengatur jarak antara wahana tersebut dengan dinding disebelah kanannya. Ketika wahana tersebut (nomor 1 pada gambar 1) bergerak pada posisi tertentu, error straigthness dari wahana tersebut yang didapatkan dari peta errornya, akan didapatkan. Sehingga, apabila wahana tersebut mempunyai error ke arah dinding jalur kirinya, maka elemen piezzo $\mathrm{P}_{1}$ dan $\mathrm{P}_{3}$ akan mendorong balik wahana tersebut ke arah kanan, sehingga posisi wahana tersebut pada lokasi tersebut dapat dikoreksi, dan sebaliknya. Kompensasi error berbasis perangkat keras membutuhkan biaya yang lebih tinggi dari pada berbasis perangkat lunak.

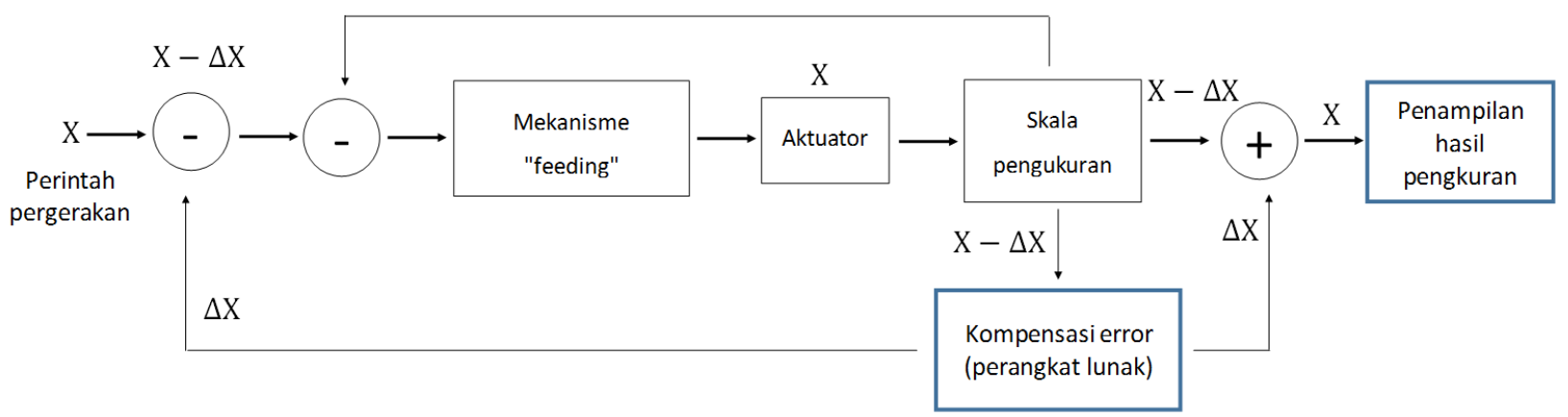

Gambar 2: Kompensasi error berbasis perangkat lunak: kompensasi error dengan memodifikasi perintah pergerakan dari sistem kontrol numerik.

Kompensasi error berbasis perangkat lunak adalah suatu proses kompensasi error dengan cara mengkoreksi error posisi, yan didapatkan dari peta error pada lokasi tertentu, aktuator sebuah instrumen dengan cara mengkoreksi posisi aktuator tersebut dengan memerintahkan sistem kontrol numerik untuk bergerak sebesar lawan dari error tersebut. proses tersebut tidak menggunakan pernagkat keras yang dipasang pada aktuator tersebut, melainkan hanya mengandalkan perangkat lunak untuk memerintahkan sistem kontrol untuk mengkoreksi posisi yang diperintahkan ke aktuator tersebut.

Gambar 2 memperlihatkan kompensasi error berbasis perangkat lunak. Pada gambar 2, diperlihatkan bahwa suatu sistem kontrol numerik memerintahkan aktuator untuk bergerak sebesar X. dari sinyal perintah tersebut, mekanisme 
feeding menggerakkan aktuator sehingga aktuator bergerak sebesar X. Namun demikian, pada kenyataannya, posisi aktual dari aktuator tersebut tidak tepat sebesar X karena terdapat error sebesar $\Delta \mathrm{X}$. Sehingga, posisi aktual dari aktuator tersebut adalah sebesar $\mathrm{X}+\Delta \mathrm{X}$. dengan sistem kompensasi error berbasis perangkat lunak, error $\Delta \mathrm{X}$ tersebut pada lokasi aktual aktuator tersebut didapatkan dari peta error yang sudah dibangun sebelumnya. Dengan demikian, sistem pernagkat lunak tersebut memberikan feedback kepada sistem kontrol numerik tersebut agar mengkoreksi posisinya sebesar $\Delta \mathrm{X}$. Dengan demikian, posisi aktual dari aktuator tersebut setelah terkompensasi adalah sebesar $\mathrm{X}-\Delta \mathrm{X}+\Delta \mathrm{X}=\mathrm{X}$. Dengan demikian posisi aktuator yang diperintahkan oleh sistem kontrol numerik sama dengan posisi aktual dari aktuator tersebut.

Namun demikian, kompensasi error berbasis perangkat lunak mempunyai suatu batasan, yaitu kompensasi error berbasis perangkat lunak hanya dapat diaplikasikan pada suatu proses permesinan "titik" (misalnya proses bubut/turning) dan suatu proses pengukuran "titik" (misalnya CMM berbasis kontak dengan sistem tactile probing). "titik" terebut adalah aktuator dari instrumen hanya berinteraksi dengan suatu benda pada satu titik lokasi dipermukaan benda tersebut. namun demikian, pada kasus lainnya, misalnya untuk kasus pengeboran (drilling) dan kasus pengukuran menggunakan non-kontak CMM yang mendeteksi titik berupa area, sulit untuk mengkoreksi error posisi pada posisi yang diperintahkan oleh sistem kontrol numeriknya (Hocken dan Pereira 2012).

\subsubsection{Kompensasi berbasis non-real-time dan real-time}

Kompensasi error, berdasarkan kapan waktu kuantifikasi error dilakukan pada suatu instrumen pengkuran, terbagi menjadi dua jenis, yaitu: non-real-time dan real-time. Pada prinsipnya, kompensasi error berbasis non-realtime hanya dapat mengkompensasi dan mengoreksi error yang bersifat sistematik. Sedangkan, kompensasi error berbasis real-time dapat mengkompensasi dan mengoreksi error baik yang sistematik maupun acak (random error). Pada aplikasinya, kompensasi error berbasis real-time pada umumnya lebih sulit untuk diterapkan karena berhubungan langsung dengan noise-noise yang bersifat non-linier dan susah untuk diprediksi, misalnya variasu temperatur, variasi tekanan atmosfir lingkungan dan efek dinamika dari pergerakan komponen-komponen yang menyebabkan vibrasi.

Kompensasi error berbasis non-real-time dilakukan dengan menyimpan sistematik error suatu instrumen dalam sebuah memori komputer. Sistematik error tersebut sudah dikuantifikasi sebelumnya. Misalnya error posisi sebuah CMM dikuantifikasi dengan mengukur sebuah gauge block atau artifak terkalibrasi lainnya. Perbedaan hasil pengukuran CMM tersebut dengan gauge block tersebut merupakan error pada posisi pengukuran atau lokasi pengukuran tersebut. Proses ini dilakukan pada setiap lokasi pengukuran dalam volume pengukuran CMM tersebut dan peta error untuk volume pengukuran tersebut dapat dikonstruksi. Dengan adanya peta error tersebut, maka setiap pengukuran yang dilakukan CMM tersebut akan dipetakan pada peta error terebut untuk suatu lokasi pengukurna tersebut. sehingga, untuk lokasi pengukuran tersebut, errro dari CMM tersebut diketahui dan kompensasi error tersebut dapat dilakukan. Pembuatan peta error dengan melakukan pengukuran gauge block pada setiap lokasi volume pengukuran atau pengukuran error dengan menggunakan interferometri laser membutuhkan waktu dan sumber daya operator yang lama. Alternatif lainnya adalah dengan menggunakan model kinematik dari CMM tersebut dan hanya mengkuantifikasi error CMM tersebut pada beberapa posisi atau lokasi pengukuran. Dengan adanya model kinematik CMM tersebut, maka error pada lokasi lainnya dapat diprediksi dengan menggunakan model kinematik tersebut.

Kompensasi error berbasis real-time adalah suatu metode kompensasi error yang dilakukan pada saat suatu pengukuran berlangsung. Dengan metode kompensasi real-time tersebut, maka error suatu proses pengukuran langsung dikuantifikasikan pada saat itu juga (Huang dan Ni 1995). Pada umumnya, definisi error dengan metode tersebut adalah perbedaan posisi suatu komponen instrumen pengukuran dengan posisi yang diperintahkan oleh sistem kontrol numerik (numerical control/NC). Maka dari itu, sebuah sistem close-loop wajib dibutuhkan untuk kompensasi error real-time. Karena, sebuah sistem untuk memberikan informasi balik posisi suatu komponen instrumen pengukuran saat itu ke sistem kontrol numerik untuk dapat mengkoreksi posisi komponen tersebut agar sesuai dengan posisi atau lokasi yang diperintahkan. Kompensasi error real-time sulit untuk diterapkan karena terdapat berbagai sumber error lainnya yang tidak linier dan sulit untuk diprediksi seperti yang telah dijelaskan sebelumnya. Selain itu, penerapan kompensasi error secara real-time membutuhkan biaya yang mahal. Namun demikian, apabila kompensasi error real-time dapat diterapkan, maka error sistematik dan acak dapat dikompensasi. Sehingga, suatu instrumen pengukuran yang menerapkan metode kompensasi error real-time tersebut akan mempunyai tingkat akurasi yang sangat tinggi. 


\subsection{Tahapan kompensasi error}

Untuk menerapkan suatu sistem kompensasi error pada suatu instrumen untuk meningkatkan akurasi dari instrumen tersebut melebihi dari tingkat akurasi geomtri komponen-komponen penyusunnya, terdapat tahapantahapan yang harus dilakukan, yaitu: pembuatan model matematis dari error untuk suatu instrumen (peta error), kalibrasi dari instrumen tersebut dan, perangkat lunak dan peralatan lainnya yang dibutuhkan untuk menerapkan suatu sistem kompensasi error pada instrumen tersebut.

\subsubsection{Pembuatan model matematis dari error: analitik atau empiris}

Pembuatan peta error dengan membuat sebuah model matematis yang menrepresentasikan suatu error pada suatu posisi atau lokasi tertetu pada suatu volume pengukuran dapat dilakukan secara analitik atau empiris. Seperti yang sudah dijelaskan sebelumnya, pembuatan peta error tersebut untuk proses kompensasi error hanya berlaku untuk error sistematik (Sartori dan Zhang 1995). Kondisi-kondisi suatu error sistematik yang layak untuk dikompensasi adalah:

- Besarnya sistematik error yang akan dikompensasi harus secara signifikan lebih besar dari error acak, dengan kata lain, instrumen yang akan dikompensasi harus "repeatable".

- Keuntungan yang diekspektasi harus dapat menjustifikasi biaya tambahan untuk melakukan kompensasi error.

- Laju perubahan spasial dari suatu error harus harus jauh lebih rendah dibandingkan interval standar dimensi yang digunakan untuk mengkuantifikasi error tersebut. Hal ini menunjukkan pentingnya memilih peralatan yang digunakan untuk mengkompensasi suatu error, misalnya apakah menggunakan standar kontinu yaitu interferometri laser atau menggunakan standar diskontinu, seperti ball bars, ball-plates dan gauge-block.

- Suatu instrumen yang dikompensasi harus mempunyai koordinat sistem absolut. Selain itu, nilai ketidakastian pusat dari sistem koordinat absolut tersebut harus lebih rendah dari laju perubahan spatial dari suatu error yang akan dikompensasi.

- Performansi komputer (kecepatan hitung, resolusi, frekuensi koreksi spasial, dan lain-lain) dan servo (dan perlatan lainnya yang dibutuhkan) harus cukup untuk memenuhi kebutuhan suatu proses kompensasi error.

- Model dari error pada suatu instrumen (model dari peta error) harus tersedia. Model tersebut adalah sebuah model matematis dari error yang merelasikan sumber-sumber error dan nilai akhir dari error-error dan untuk menentukan parameter mana dari model tersebut yang dapat ditentukan secara eksperimen.

Model matematis berbasis analitik dari error suatu instrumen bergantung pada jenis sumber error apa yang diperhutungkan atau dipertimbangkan dalam membuat model matematis tersebut (Schwenke et al 2008). Jenis-jenis sumber error yang terdapat pada suatu instrumen pengukuran adalah:

- $\quad$ Error kinematik

Error kinematik didefinisikan sebagai error yang berasal dari ketidaksempurnaan geometri dari komponenkomponen karena variasi dari proses-proses manufaktur. Selain itu, error kinematik disebabkan oleh kesalahan konfigurasi, seperti kesalahan alignment antara dua aksis. Error kinematik merupakan error utama yang paling pertama dipertimbangkan dalam merekonstruksi suatu model matematis error suatu instrumen.

- $\quad$ Error termo-mekanik

Error termo-mekanik adalah error yang diakibatkan ekspansi atau penyusutan dimensi dari geometri suatu komponen. Hal tersebut disebabkan karena adanya perubahan temperatur dari dalam atau luar suatu instrumen. Pada dasarnya, sebuah material mempunyai suatu koefisien ekspansi termal yang menringidikasikan seberapa besar material tersebut akan berekspansi atau menyusut proporsional terhadap naik turunnya temperatur pada material tersebut.

- Error beban (load)

Error beban adalah deformasi suatu komponen karena adanya beban yang diberikan kepadanya. Error ini diikutsertakan apabila suatu model matematis error mengasumsikan suatu instrumen sebagai "non-rigid 
body". Hal tersebut disebabkan karena setiap material mempunyai tingkat stifness (kekakuan) yang terbatas (finite stifness). Error beban tersebut pada situasi tertentu dapat lebih besar dari pada error kinematik suatu komponen karena, misalnya, adanya bending atau lendutan pada komponen tersebut.

- Error dinamik

Errro dinamik adalah error yang disebabkan karena adanya percepatan dan atau perlambatan dari pergerakan suatu instrumen. Efek dari error dinamik adalah adanya vibrasi pada komponen-komponen suatu instrumen yang mengakibatkan adanya pergeseran atau perpindahan posisi komponen-komponen tersebut. Maka dari itu, pada umumnya kecepatan pergerakan suatu instrumen diset pelan.

- Error kontrol pergerakan

Error kontrol pergerakan adalah error yang disebabkan karena kesalah sistem pengontrolan yang bisa disebabkan karena kesalahan komponen pengontrol, misalnya aktuator, atau karena kesalahan perangkat lunak dan algoritma kontrol.

Kelebihan dari model matematis berbasis analitik adalah kuantifikasi error tidak dilakukan dalam jumlah yang sangat banyak, tetapi jumlah error yang dikuantifikasi adalah sejumlah titik yang cukup untuk mengestimasi parameter-parameter dari model analitik tersebut. Hal ini sangat mengurangi biaya kalibrasi instrumen. Kelemahan model analitik adalah tingkat akurasi model analitik tersebut tergantung pada asumsi dari sumber error yang mana yang diangkap penting, misalnya error kinematik dan error beban. Semakin banyak asumsi sumber error untuk suatu model analitik, maka model analitik tersebut akan semakin kompleks.

Model matematis berbasis empiris dari error suatu instrumen adalah model pemetaan error pada suatu grid posisi di dalam volume pengkuran suatu insrumen (gambar 3). Pada pemodean empiris tersebut, error-error dipetakan pada setiap posisi di dalam suatu volume pengukuran dengan suatu kepadatan tertentu, misalnya, error dikuantifikasi dan dipetakan pada setiap poisisi dengan kepadatan $1 \mathrm{~mm}$. sebagai contoh, apabila volume pengukuran suatu instrumen adalah sebesar $(100 \times 100 \times 100) \mathrm{mm}$, maka jumlah error yang harus dikuantifikasi dan dipetakan dengan kepadatan setiap $1 \mathrm{~mm}$ berjumlah 1000000 titik posisi!. Error pada suatu titik diantara grid titik-titik posisi tersebut akan diinterpolasi dengan suatu fungsi tertentu, misalnya dengan interpolasi linier.
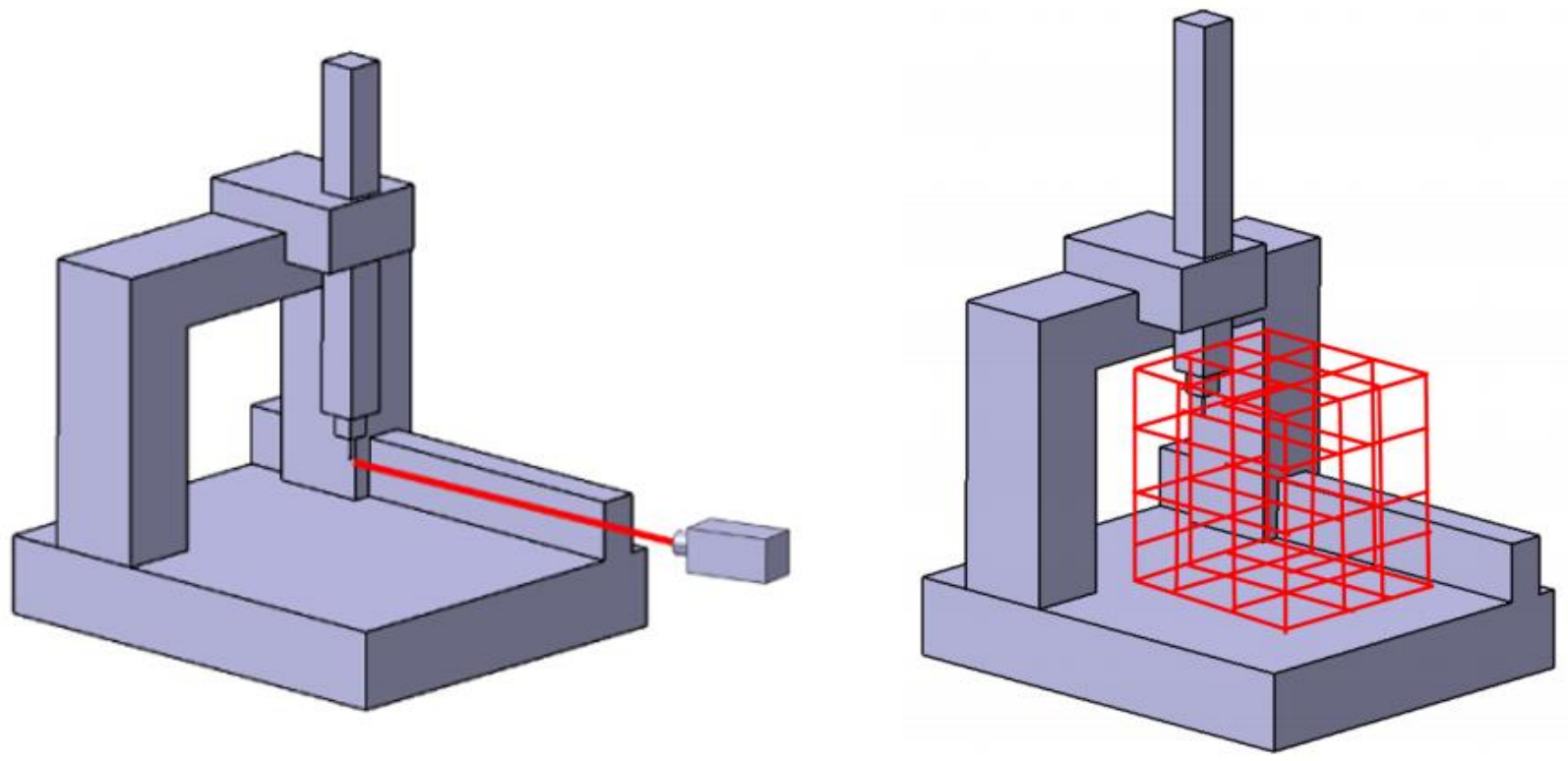

Gambar 3: Pemodelan error berbasis empiris pada suatu instrumen berdasarkan grid posisi di dalam volume pengukurannya. Gambar kanan adalah peta error pada sejumlah titik-tiitk lokasi di dalam volume pengukurannya.

Error pada lokasi dinatar titik-tiitk posisi tersebut akan diinterpolasi, misalnya dengan interpolasi linier untuk mengestimasi error pada titik yang belum terpetakan. 
Kelebihan model empiris adalah peta error yang didapatan merupakan representasi error pada kondisi riil suatu instrumen yang sedang dimodelkan dan model empiris tersebut tidak berupa fungsi matematis yang kompleks. Namun demikian, model error empiris membutuhkan sangat banyak kuantifikasi error pada titik-titik posisi di dalam suatu volume pengukuran. Apabila peta error dari model empiris tersebut ingin dibuat untuk suatu volume pengukuran dengan tingkat kepadatan titik-titik yang sangat tinggi, maka jumlah kuantifikasi error menjadi akan sangat banyak. Hal ini menyebabkan biaya untuk kalibrasi instrumen tersebut menjadi sangat tinggi.

\subsubsection{Perangkat lunak dan peralatan untuk kompensasi}

Peran dari perangkat lunak untuk mengkompensasi error adalah sangat penting, bukan hanya untuk kompensasi error berbasis perangkat lunak saja, tetapi juga untuk kompensasi error berbasis perangkat keras. Peran perangkat lunak untuk kompensasi error berbasis perangkat keras adalah untuk menentukan error pada suatu lokasi atau posisi tertentu dibutuhkan sebuah perangkat lunak untuk menentukan besarnya error dari suatu peta error yang telah tersimpan sebelumnya didalam perangkat lunak tersebut.

Namun demikian, perangkat keras (atau peralatan-peralatan) sangat penting perannya untuk mengkuantifikasi error-error, yang merupakan parameter-parameter dari model matematis suatu error, secara eksperimental. Tabel 1 memperlihatkan contoh-contoh dari peralatan-peralatan yang umumnya digunakan untuk menentukan suatu error secara eksperimental. Error-error yang ditentukan secara eksperimental pada umumnya adalah error-erorr geometri dari komponen-komponen suatu instrumen.

Table 1: Peralatan-peralatan untuk mengkuantifikasi error secara eksperimental (Sartori dan Zhang 1995).

\begin{tabular}{|c|c|}
\hline Tipe dari error geometrik & $\begin{array}{c}\text { Peralatan yang digunakan untuk menentukan error } \\
\text { tersebut }\end{array}$ \\
\hline Error posisi (error skala pembacaan) & $\begin{array}{l}\text { - Interferometri laser } \\
\text { - Set dari end-bar atau gauge-block } \\
\text { - Ball arrays } \\
\text { - Step Gauges }\end{array}$ \\
\hline Error straightness & $\begin{array}{l}\text {-Mekanikal dan optikal straightedge } \\
\text { - Reflektor } \\
\text { - Laser beam } \\
\text { - Capacitance gauge } \\
\text { - Gauge elektronik (LVDT) } \\
\text { - Interferometri laser berbasis plane mirror } \\
\text { - Photodiode }\end{array}$ \\
\hline Error angular & $\begin{array}{l}\text { - Autocolimator } \\
\text { - Interferometri laser angular } \\
\text { - Level mekanik } \\
\text { - Level elektronik } \\
\text { - Alat ukur straighness yang terpisah dengan jarak tertentu }\end{array}$ \\
\hline Error squareness & $\begin{array}{l}\text {-Square mekanikal yang dilengkapi dengan colimator } \\
\text { - Pengukuran diagonal }\end{array}$ \\
\hline
\end{tabular}




\author{
\begin{tabular}{l|l} 
Error Parallelism & - Colimator yang dilengkapi dengan square optikal
\end{tabular} \\ - Interferometri laser dengan square optik
}

\title{
8.3.3 Kalibrasi instrumen
}

Kuantifikasi error-error pada suatu instrumen secara eksperimental adalah tidak mudah. Terdapat berbagai macam metode atau prosedur untuk mengkuantifikasi secara eksperimental untuk setiap jenis error (Schwenke et al 2008). Hal penting yang perlu diingat adalah instrumen yang digunakan untuk mengukur atau mengkuantifikasi errorerror suatu instrumen haruslah mempunyai tingkat akurasi dan presisi yang tinggi serta mempunyai rantai keterlacakan (traceable) ke definisi meter. Karena, esensi dari kalibrasi adalah untuk menciptakan rantai keterlacakan dengan terkuantifikasinya ketidakpastian dari error yang terukur tersebut. Selain itu, pada umumnya error-error pada suatu instrumen pengukuran adalah kecil, sehingga untuk menghasilkan suatu kuantifikasi error yang rasional, maka suatu instrumen pengukuran untuk mengukur error tersebut haruslah mempunyai error sepuluh kali lipat lebih kecil dari error yang akan diukur tersebut.

Terdapat dua jenis metode untuk melakukan kalibrasi suatu instrumen, yaitu metode pengukuran langsung dan metode pengukuran tidak langsung (Schwenke et al 2008). Metode pengukuran langsung adalah pengukuran error yang memungkinkan dilakukan untuk sebuah aksis pada satu waktu tanpa mengikutsertakan aksis-aksis lainnya. Sedangkan, metode pengukuran tidak langsung adalah pengukuran error yang melibatkan lebih dari satu aksis (multipel aksis). Pada umumnya, pengukuran langsung menggunakan sebuah sistem interferometri laser dan pengukuran tidak langsung menggunakan artifak, seperti ball-bar dalam R-test, gauge block dan kalibrated artifak lainnya.

\section{Metode pengukuran langsung}

Pengukuran error secara langsung Dengan interferometri unuk mengukur error posisi, angular, straightness dan perpendicularity (squareness). Pembahasan detil mengenai suatu sistem interferometri laser dapat dilihat pada bab 4 tentang pengukuran dimensi dan geometri. Gambar 5a, gambar 5b dan gambar 5c memperlihatkan metode pengukuran langsung error posisi, angular dan perpendicularity suatu aksis dengan menggunakan sistem interferomateri laser.

Pada gambar 5a, pengukuran error posisi suatu aksis yang dilakukan dengan suatu sistem interferometri laser diperlihatkan. Pada pengukuran tersebut, dibutuhkan sebuah sistem optik yang terdiri dari beam splitter, untuk membagi laser ke reference mirror dan ke reflektor, dan lensa reflektor untuk memnatulkan balik laser ke sumbernya untuk dianalisis. Posisi error adalah perbedaan antara posisi aksis yang diperintahkan sistem kontrol dan posisi aksis yang terbaca oleh interferometri tersebut.

Pada gambar 5b, pengukuran error straigthness diperlihatkan dengan sebuah sistem interferometri laser. Pada pengukuran error tersebut, sistem optik yang digunakan berbeda dengan sistem optik untuk pengukuran error posisi. Pada pengukuran straigthness, lensa reflektornya tidak rata, melainkan berbentuk "V" yang lebih besar. Apabila terdapat error straigthness pada aksis yang terukur, maka laser yang dipantulkan balik tidak akan menuju titik tengah dari sistem optiknya.

Pada gambar 5c, pengukuran error angular diperlihatkan dengan sebuah sistem interferometri laser. Error pengukuran angular yang diukur adalah error pitch and yaw, dan bukan roll. Pada pengukuran error tersebut, lensa reflektor yang digunakan terdiri dari dua reflektor yang berbentuk "V". Pada bagian beam splitter, laser terbagi menjadi dua bagian, sehingga terdapat dua jalur laser. Apabila terdapat error angular pada suatu aksis yang diukur, maka kedua bagian laser tersebut akan mempunyai panjnag jalur yang berbeda, sehingga kedua bagian laser tersebut yang terpantulkan akan sampai ke sensor detektor laser pada waktu yang berbeda (terdapat perbedaan fase).

Hal yang paling penting untuk diingat adalah pengukuran dnegan sistem interferometri laser adalah sangat sensitif. Bukan hanya variasi temperatur, perubahan tekanan udara dan kelembapan lingkungan akan berpengaruh terhadap hasil pengukurannya. Selain itu, gangguan vibrasi yang kecil juga akan mempengaruhi hasil pengukurannya. 


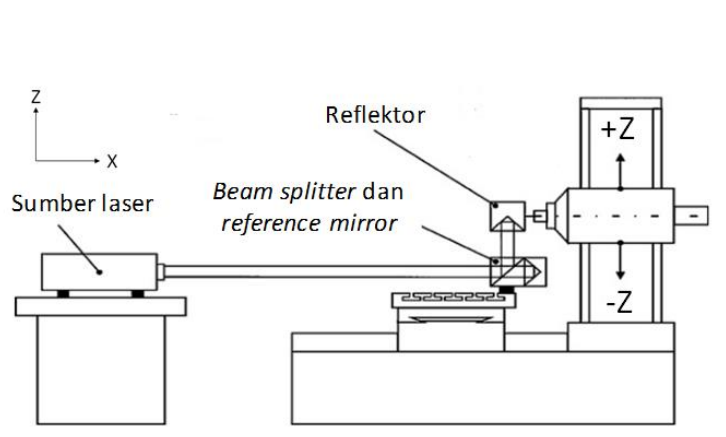

(a) Pengukuran error posisi

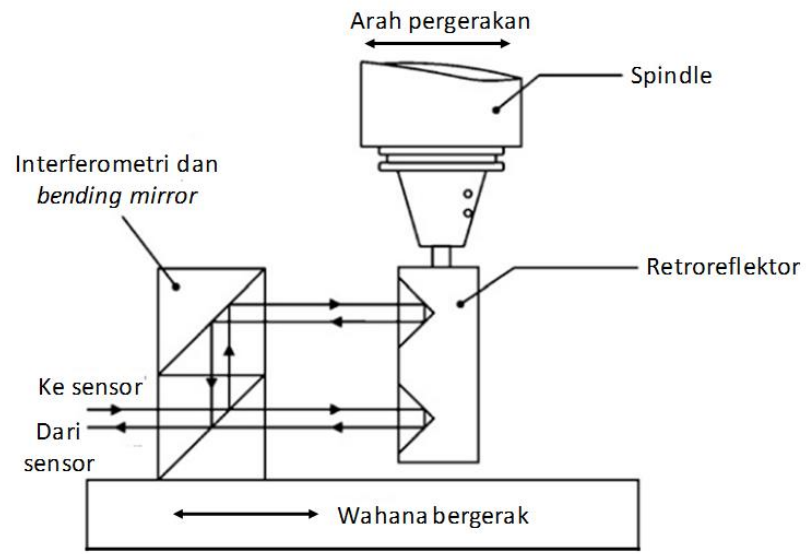

(c) Pengukuran error angular (pitch dan yaw)

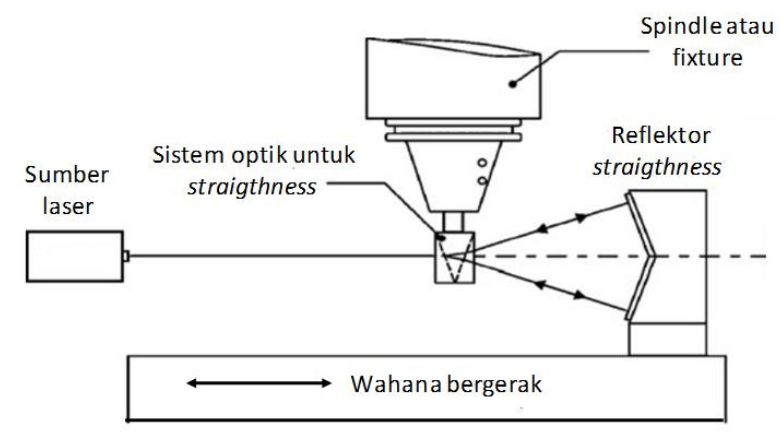

(b) Pengukuran error straightness

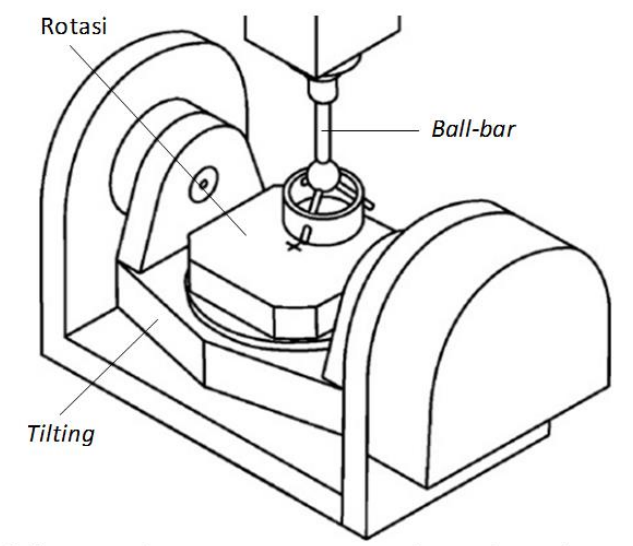

(d) Pengukuran error rotasi dan tilting ( $R$-Test)

Gambar 4: Proses kuantifikasi error dengan menggunakan sebuah interferometri laser dan ball-bar. Kuantifikasi error tersebut terbagi menjadi dua jenis: kuantifikasi error secara langsung dan tidak langsung. Kuantifikasi error secara langsung: (a), (b) dan (c). Kuantifikasi error secara tidak langsung: (d) (Schwenke et al 2008).

\section{Metode pengukuran tidak langsung}

Metode pengukuran tidak langsung memberikan hasil bacaan error terkombinasi yang bersasal dari pergerakan lebih dari satu aksis (pergerakan dari multipel aksis). Metode pengukuran tidak langsung diperlihatkan pada gambar 4d untuk sebuah R-test dan gambar 5 untuk pengukuran artifak terkalibrasi. Pada gambar 4d, R-test menggunakan sebuah ball-bar yang terdiri dari load-cell dan pada umumnya digunakan untuk mengukur error rotasi. $R$-test dilakukan dengan menempatkan salah satu ujung ball-bar pada meja rotasi dan ujung lainnya pada spindle atau sesuatu yang diam atau tetap. Kemudian, meja rotasi yang diukur dirotasi, apabila ada error rotas, maka load cell pada ball-bar tersebut akan membaca atau mendeteksi adanya axial stress. $R$-test membutuhkan pergerakan dari dua aksis sehingga error yang terbaca merupakan kombinasi error daru pergerakan dua aksis. 


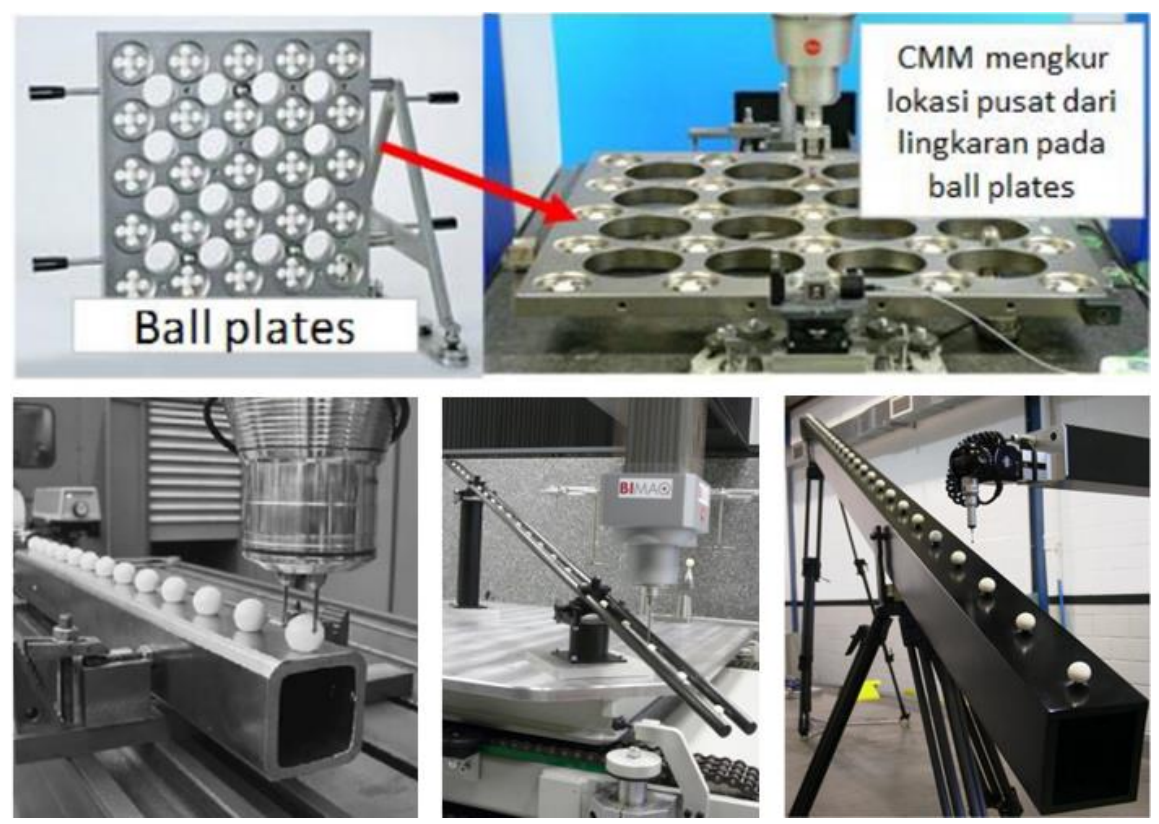

Gambar 5: Contoh lain dari kuantifikasi error secara tidak langsung (selain dengan $R$-test) berdasarkan pengukuran suatu artifak terkalibrasi.

Pada gambar 5, diperlihatkan pengukuran error secara tidak langsung dengan mengukur artifak-artifak terkalibrasi. Pada gambar 5, diperlihatkan artifak terkalibrasi yang pada umumnya berbentuk lingkaran atau bola. Pada umumnya, dengan metode ini, error didefinisikan sebagai perbedaan jarak antara dua titik tengah lingkaran atau bola yang terkalibrasi dan yang terukur dengan suatu instrumen yang sedang dites. Untuk mengukur fitur-fitur lingkaran dan bola tersebut, diperlukan pergerakan dari dua aksis, sehingga error yang terukur berasal dari kombinasi dari kedua aksis tersebut. hal penting yang perlu diingat adalah fitur lingkaran dan bola paling sering digunakan sebaga fitur untuk suatu artifak terkalibrasi. Hal ini disebabkan karena untuk mengukur fitur lingkaran atau bola tersebut, dibutuhkan pergerakan yang berasal dari dua arah yang saling simteri pada setiap titiknya, sehingga error sistematik dari pergerakan aksis atau lainnya dapat diminimalisasikan.

\subsection{Model matematis dari error instrument pengukuran CMM}

Pada bagian ini, model matematis yang dipresentasikan adalah untuk konfigurasi CMM FXYZ dan hanya membertimbangkan error kinemtik (Zhang et al 1985). Konfigurasi FXYZ CMM adalah jenis konfigurasi yang paling umum di industri-industri. Pada konfigurasi tersebut, benda kerja yang diukur tetap dan sistem probing CMM dapat bergerak relatif terhadap benda kerja tersebut pada arah X, Y dan Z. Konfiguras CMM FXYZ dan konfigurasi lainnya yang melibatkan tiga aksis mempunyai total error kinematik sebanyak 21 error. Gambar 6 memperlihatkan total 21 error tersebut, yang berjumlah 18 error dari setiap aksisnya dan 3 error perpendicularity antara dua dari tiga aksis tersebut. Model matematis error berdasarkan suber error kinematik hanya memperhitungkan error geometri pada komponen-komponen suatu CMM dan tidak memperhitungkan sumber-sumber error lainnya, seperti beban, efek termal dan lainnya, sehingga model jenis ini dinamakan juga sebagai model "rigid-body. Model "Rigid body" mengasumsikan bahwa geometri CMM tidak terjadi lendutan atau lendutan yang terjadi sangat kecil dan dapat diabaikan.

Terdapat juga model matematis untuk berbagai jenis konfigurasi CMM dan mempertimbangkan berbagai jenis error lainnya: error thermo-mekanik, error bebad, error dinamik dan error kontrol pergerakan (Hocken dan Pereira 2012). 


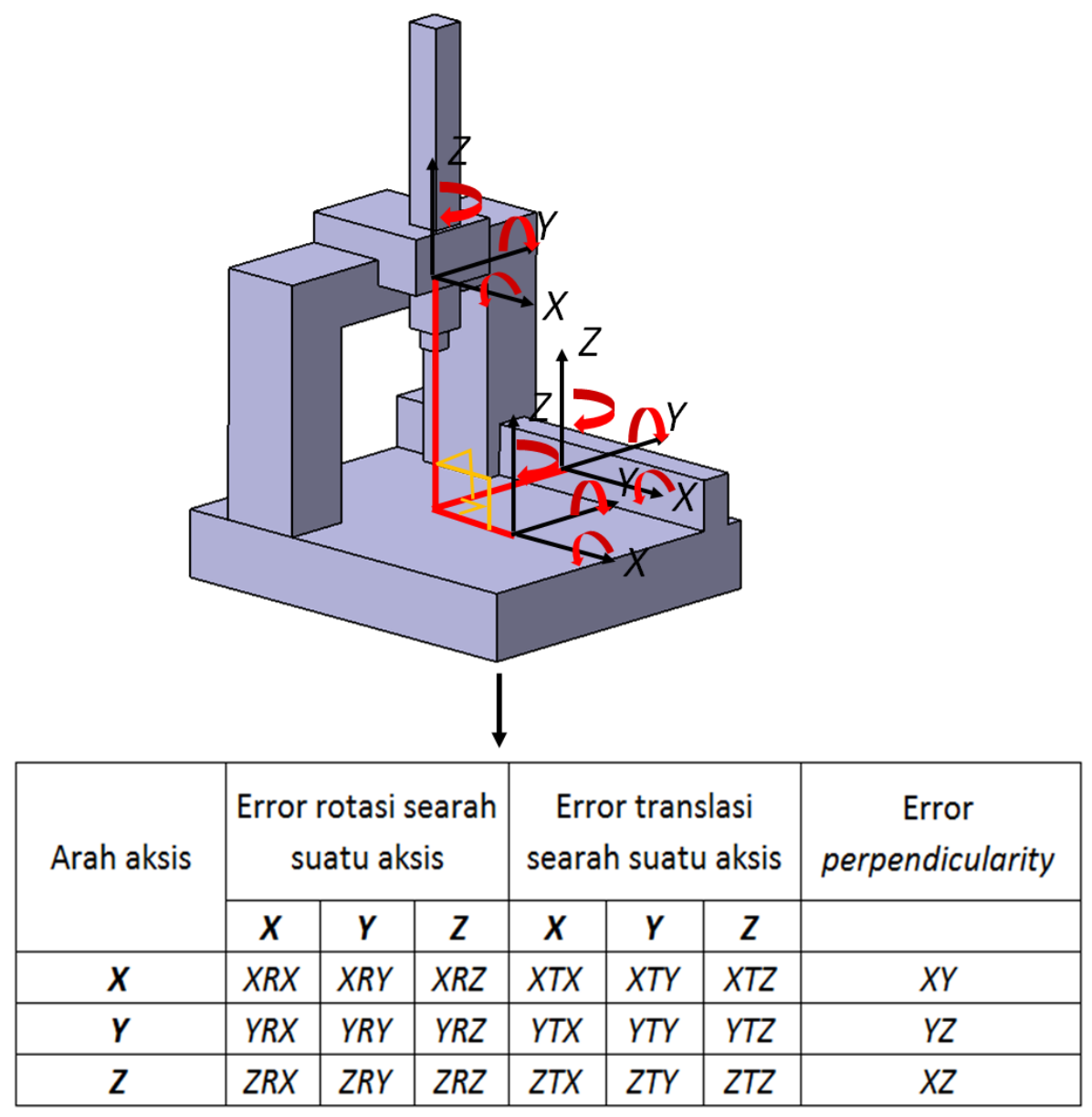

Gambar 6: Total 21 error kinematik untuk tiga aksis CMM.

Model matematis yang mempertimbangkan model "rigid body", yaitu hanya mempertimbangkan sumber error kinematik dibahas oleh Zhang et al 1985. Pada laporan dari Zhang tersebut, dengan kompensasi error yang diterapkan, dapat meningkatkan akurasi dari suatu CMM dengan konfigurasi FXYZ sebanyak 10 kali lipat dibandingkan dengan apabila tidak dilakukan kompensasi error.

Model matematis tersebut adalah sebagai berikut (lihat gambar 7). Pada gambar 7, terdapat empat sistem koordinat yang saling independen, yaitu: sistem koordinat pada meja $\mathrm{CMM}(\mathrm{O}, \mathrm{X}, \mathrm{Y}, \mathrm{Z})$, sistem koordinat pada aksis$\mathrm{Y} /$ bridge $\left(\mathrm{O}_{1}, \mathrm{X}_{1}, \mathrm{Y}_{1}, \mathrm{Z}_{1}\right)$, sistem koordinat pada aksis $\mathrm{X}\left(\mathrm{O}_{2}, \mathrm{X}_{2}, \mathrm{Y}_{2}, \mathrm{Z}_{2}\right)$ dan sistem koordinat pada aksis-Z/Ram $\left(\mathrm{O}_{3}, \mathrm{X}_{3}, \mathrm{Y}_{3}, \mathrm{Z}_{3}\right)$. Konfigurasi wahana bergerak dari $\mathrm{CMM}$ tersebut adalah wahana aksis-X ditempatkan pada wahana aksis-Y dan wahana aksis-Z ditempatkan pada wahana aksis-X.

Notasi matematis pada pemodelan error tersebut adalah sebagai berikut: Argumen atau variabel merepresentasikan arah pergerakan dan subscript merepresentasikan arah dari error. Misalnya, $\delta_{x}(Y)$ adalah error straightness pada arah $x$ untuk pergerakan arah $Y . \varepsilon_{x}(Y)$ adalah error rotasi terhadap sumbu $x$ untuk pergerakan pada arah $Y$.

Asumsi awal adalah semua ke-empat aksis tersebut saling berhimpit pada posisi awal. Dengan kata lain, posisi awal dari probe CMM tersebut berada pada pojok depan CMM tersebut pada gambar 7. Pergerakan awal untuk mencapai posisi pada gambar 7 adalah dimulai dengan menggerakkan aksis-Y. Sehingga, ketiga bridge/aksis-Y bergerak sebanyak jarak $\mathrm{Y}$, maka posisi aktual dari sistem koordinat bridge/aksis-Y, yaitu $\mathrm{O}_{1}$, adalah direpresentasikan 


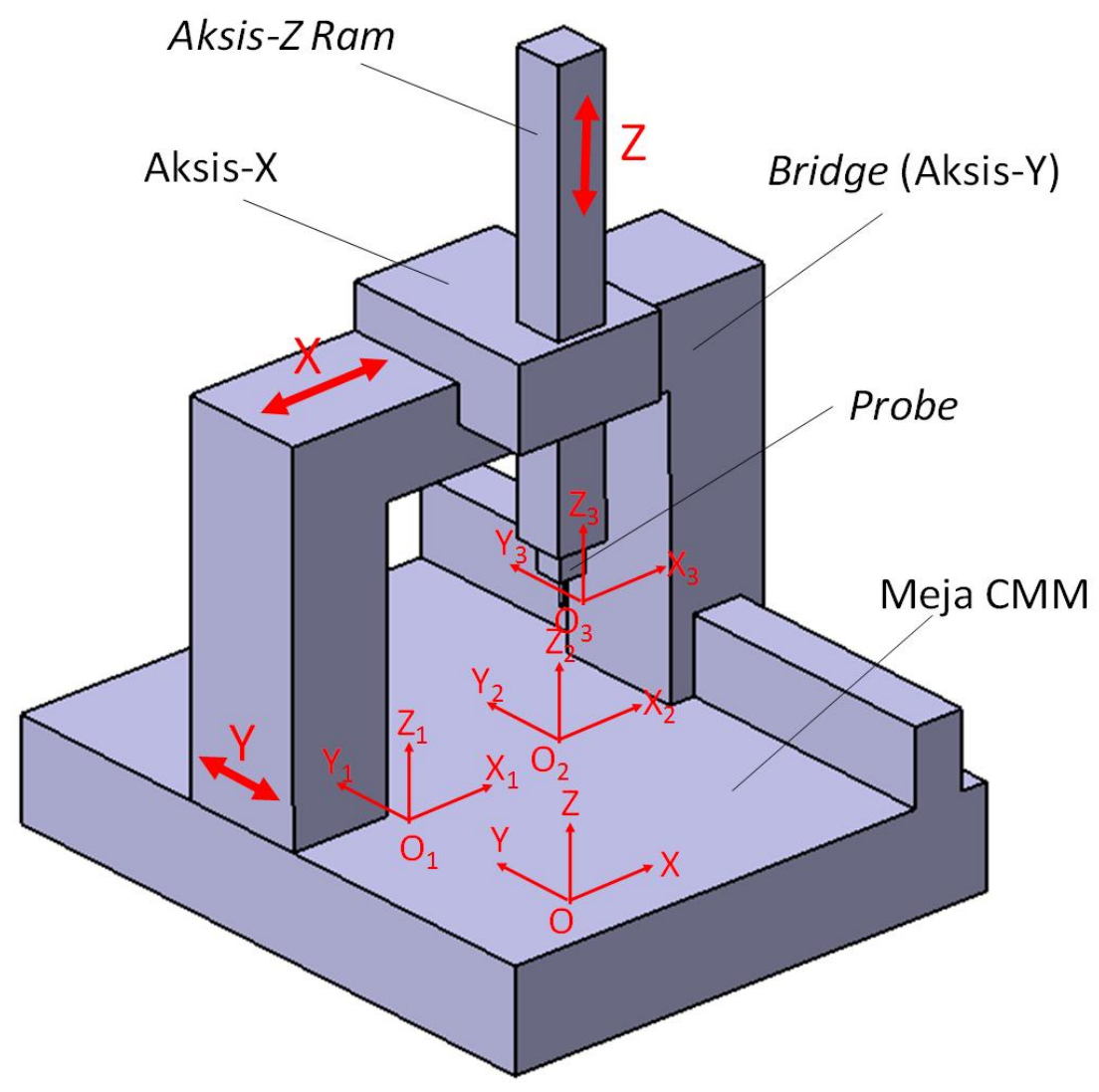

Gambar 7: Diagram dari CMM dengan konfigurasi FXYZ yang akan dimodelkan sebagai "rigid body".

dengan sebuah vektor:

$$
\overrightarrow{O O_{1}}=\left[\begin{array}{c}
\delta_{x}(Y) \\
Y-\delta_{y}(Y) \\
\delta_{z}(Y)
\end{array}\right]
$$

Bukan hanya error straightness, ketika aksis-Y bergerak, maka akan ada rotasi aksis-Y/bridge terhadap sistem koordinat meja. Error rotasi tersebut dapat direpresentasikan sebagai:

$$
R_{1}=\left[\begin{array}{ccc}
1 & \varepsilon_{z}(Y) & -\varepsilon_{y}(Y) \\
-\varepsilon_{z}(Y) & 1 & \varepsilon_{x}(Y) \\
\varepsilon_{y}(Y) & -\varepsilon_{x}(Y) & 1
\end{array}\right]
$$

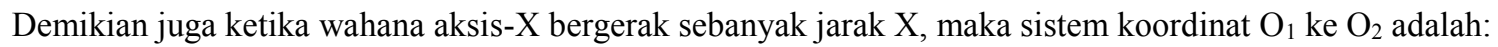




$$
\overrightarrow{O_{1} O_{2}}=\left[\begin{array}{c}
X-\delta_{x}(X) \\
-X \cdot \alpha+\delta_{y}(X) \\
\delta_{z}(X)
\end{array}\right]
$$

dimana sudut $\alpha$ adalah errro squareness (perpendicularity) antara aksis-X dan aksis-Y. Demikian juga ketika wahana aksis- $\mathrm{Z}$ bergerak sebanyak jarak $\mathrm{Z}$, maka sistem koordinat $\mathrm{O}_{2}$ ke $\mathrm{O}_{3}$ adalah:

$$
\overrightarrow{O_{2} O_{3}}=\left[\begin{array}{c}
-Z \cdot \beta_{1}+\delta_{x}(Z) \\
-Z \cdot \beta_{2}+\delta_{y}(Z) \\
Z-\delta_{z}(Z)
\end{array}\right]
$$

dimana sudut $\beta_{1}$ dan $\beta_{2}$ adalah errro squareness (perpendicularity) $\mathrm{Z}$ terhadap bidang-XY. Error rotasi untuk $O_{2}$ dan adalah $O_{3}$ :

$$
\begin{aligned}
R_{2} & =\left[\begin{array}{ccc}
1 & \varepsilon_{z}(X) & -\varepsilon_{y}(X) \\
-\varepsilon_{z}(X) & 1 & \varepsilon_{x}(X) \\
\varepsilon_{y}(X) & -\varepsilon_{x}(X) & 1
\end{array}\right] \\
R_{3} & =\left[\begin{array}{ccc}
1 & \varepsilon_{z}(Z) & -\varepsilon_{y}(Z) \\
-\varepsilon_{z}(Z) & 1 & \varepsilon_{x}(Z) \\
\varepsilon_{y}(Z) & -\varepsilon_{x}(Z) & 1
\end{array}\right]
\end{aligned}
$$

Titik $\mathrm{P}$ didefinisikan sebagai sebuah titik yang mempunyai koordinat $\left(X_{p}, Y_{p}, Z_{p}\right)$ pada sistem koordinat ram/aksis-Z. Maka, koordinat titik $\mathrm{P}$ berdasarkan sistem koordinat meja CMM tersebut, yaitu $\left(X^{\prime}, Y^{\prime}, Z^{\prime}\right)$, ditentukan sebagai berikut:

$\overrightarrow{O P}=\overrightarrow{O O_{1}}+R_{1}^{-1}\left(R_{2}^{-1}\left(R_{3}^{-1} \overrightarrow{O_{3} P}+\overrightarrow{O_{2} O_{3}}\right)+\overrightarrow{O_{1} O_{2}}\right)(7)$

Dari persamaan (7), maka fungsi-fungsi error terhadap suatu posisi adalah sebagai berikut:

$$
\begin{aligned}
\Delta X & =-\delta_{x}(X)+\delta_{x}(Y)+\delta_{z}(X)-Z \cdot \beta_{1}+Z \cdot \varepsilon_{y}(X)+Z \cdot \varepsilon_{y}(Y) \\
& -Y_{P}\left(\varepsilon_{z}(X)+\varepsilon_{z}(Y)+\varepsilon_{z}(Z)\right)+Z_{P}\left(\varepsilon_{y}(X)+\varepsilon_{y}(Y)+\varepsilon_{y}(Z)\right) \\
\Delta X & =X-X^{\prime}-X_{P} \\
\Delta Y & =-\delta_{y}(Y)+\delta_{y}(X)+\delta_{y}(Z)-X \cdot \alpha-Z \cdot \beta_{2}+X \cdot \varepsilon_{z}(Y)-Z \cdot \varepsilon_{x}(Y) \\
& +X_{P}\left(\varepsilon_{z}(X)+\varepsilon_{z}(Y)+\varepsilon_{z}(Z)\right)-Z_{P}\left(\varepsilon_{x}(X)+\varepsilon_{x}(Y)+\varepsilon_{x}(Z)\right)-Z \cdot \varepsilon_{x}(X) \\
\Delta Y & =Y-Y^{\prime}-Y_{P} \\
\Delta Z & =-\delta_{z}(Z)+\delta_{z}(X)+\delta_{z}(Y)-X \cdot \varepsilon_{y}(Y)-X_{P}\left(\varepsilon_{y}(X)+\varepsilon_{y}(Y)+\varepsilon_{y}(Z)\right) \\
& +Y_{P}\left(\varepsilon_{x}(X)+\varepsilon_{x}(Y)+\varepsilon_{x}(Z)\right) \\
\Delta Z & =Z-Z^{\prime}-Z_{P}
\end{aligned}
$$


dimana $\Delta X, \Delta Y$ dan $\Delta Z$ adalah error suati titik P pada arah-X, -Y dan $-Z$. nilai dari $\Delta X, \Delta Y$ dan $\Delta Z$ itulah yang akan dikompensasipak pada sistem kontrol numerik untuk suatu posisi yang diperintahkan. Sehingga, apabila suatu posisi akan dicapai, maka sistem kontrol numerik akan memerintahkan pergerakan ke posiis tersebut setelah dikurangkan dengan $\Delta X, \Delta Y$ dan $\Delta Z$ pada posisi tersebut. Interferometri laser atau pengukuran artifak terkalibrasi digunakan untuk mengkuantifikasi 21 error dari parameter-parameter model matematis tersebut.

\subsection{Dasar-dasar metode rehearsal untuk pemisahan error dan self-calibration}

Metode rehearsal adalah sebuah metode untuk memisahkan suatu error yang terkombinasi menjadi komponenkomponen error yang terpisah, sehingga kuantifikasi error-error suatu instrumen dapat dilakukan tanpa menggunakan artifak terkalibrasi atau instrumen kalibrasi, seperti interferometri laser. Kuantifikasi error-error suatu instrument tanpe menggunakan artifak atau instrument kalibrasi dinamakan self-calibration.

Pada bagian ini, metode rehearsal paling dasar dipresentasikan untuk menggambarkan secara lebih nyata tentang metode rehearsal tersebut. Pada dasarnya, metode rehearsal (yang mencakup self-calibration) akan melakukan sejumlah pengukuran (minimal dua pengukuran) pengukuran dengan merubah posisi instrumen atau posisi artifak tidak terkalibrasi yang diukur atau kedua-duanya. Syarat utama artifak yang digunakan untuk metode rehearsal adalah artifak tersebut mempunyai geometri yang stabil. Dua metode dasar dari rehearsal yang akan dibahas adalah: Straightedge rehearsal dan Donaldson rehearsal (Hocken dan Pereira 2012).
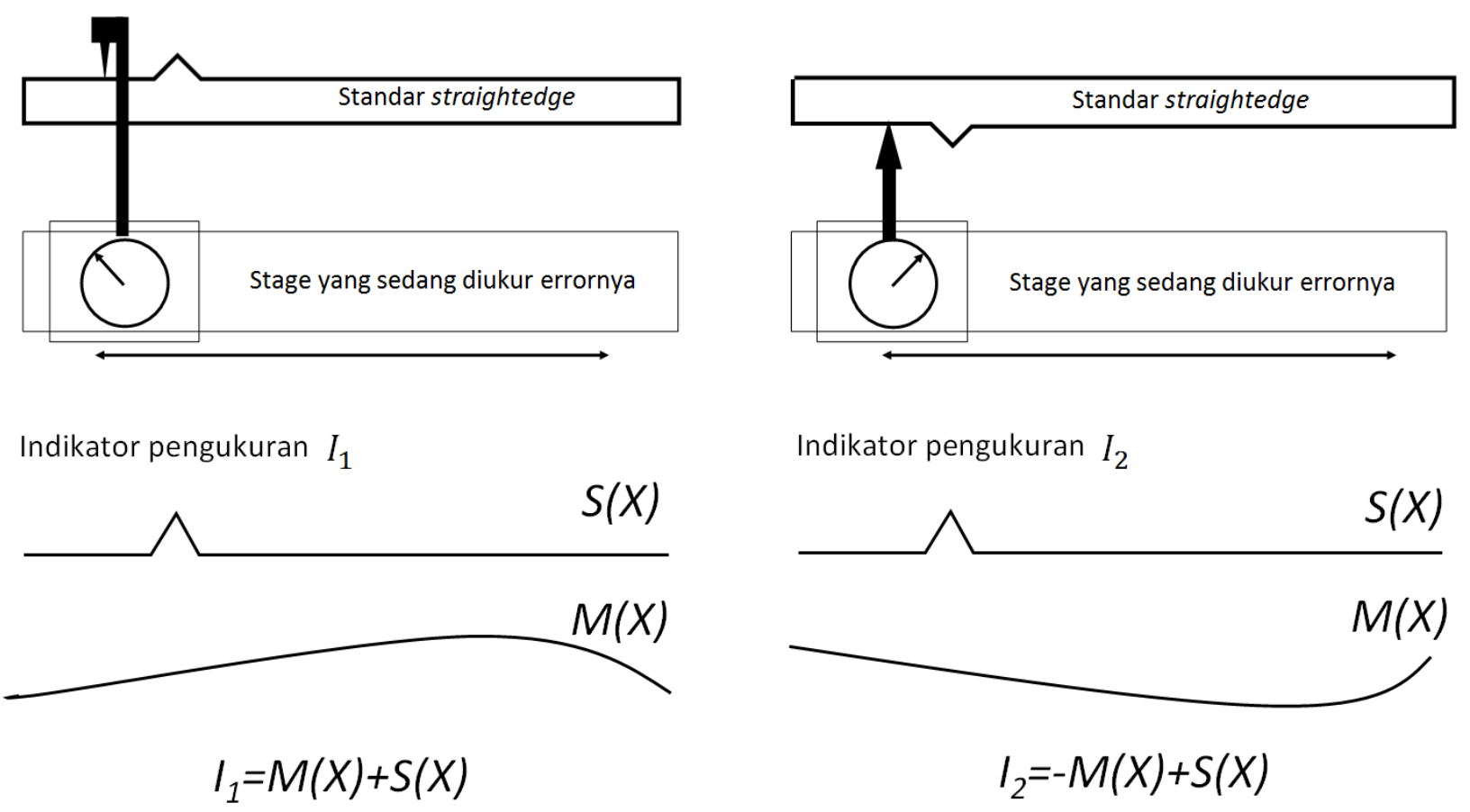

Gambar 8: Metode Straightedge rehearsal.

Straightedge rehearsal digunakan untuk mengukur error straightness sebuah wahana bergerak (tanpa menggunakan suatu artifak terkalibrasi atau interferometri laser). Gambar 8 memperlihatkan metode Straightedge rehearsal. Pada gambar 8 , sebuah wahana bergerak yang akan diukur error straightnessnya dipasang sebuah dialgauge. Kemudian, sebuah straightedge, yang dipasang sejajar, diukur dengan dial-gauge tersebut. tentu saja penempatan straigtedge tersebut tidak akan paralel secara sempurna dengan wahana bergerak tersebut, sehingga ada 
error misalignment. Selain itu, terdapat juga ketidaksempurnaan geometri dari straightedge tersebut. sehingga, error yang terbaca pada dial-gauge tersebut merupakan erorr straightness dari wahana bergerak tersebut dan error dari misaligntment dan error geometri straightedge tersebut.

Kemudian, straightedge tersebut dibalik $180^{\circ}$ dan kemudian diukur kembali dengan dial-gauge tersebut. pada prinsipnya, bentuk geometri dair straightedge tersebut adalah sama pada kedua posisi straightedge tersebut. Apabila error straigthness wahana bergerak tersebut dinotasikan sebagai $M(X)$, error straightness dari straightedge tersebut dinotasikan sebagai $S(X)$, hasil pembacaan pertama dial-gauge $I_{1}$ dan hasil pembacaan kedua dial-gauge $I_{2}$, maka error straightness $M(X)$, dari wahana bergerak tersebut dapat dikalkulasi dengan:

$$
\begin{aligned}
& I_{1}-I_{2}=M(X)+S(X)-[-M(X)+S(X)] \\
& M(X)=\left(I_{1}-I_{2}\right) / 2
\end{aligned}
$$
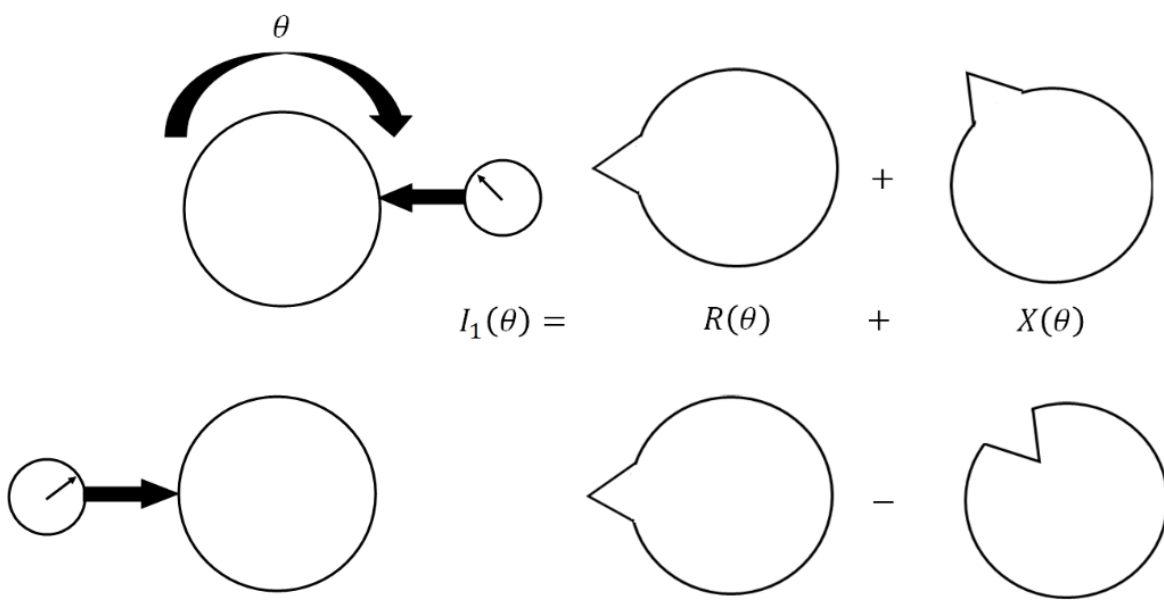

$I_{2}(\theta)=$
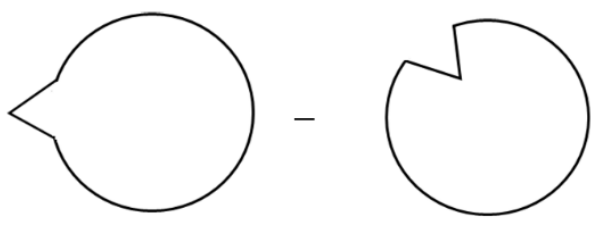

$$
R(\theta) \quad-\quad X(\theta)
$$

Gambar 9: Metode Donaldson rehearsal.

Donaldson rehearsal digunakan untuk mengukur error radial (roundness) dari sebuah wahana rotasi. Gambar 9 memperlihatkan metode Donaldson rehearsal. Metode tersebut menggunakan sebuah bola yang tidak terkalibrasi untuk menentukan error radial dari sebuah wahana rotasi. Pada gambar $9, X(\theta)$ adalah error radial dari suatu wahana bergerak, $R(\theta)$ adalah error roundness dari sebuah bola yang ditempatkan pada wahana rotasi tersebut, $I_{1}(\theta)$ adalah hasil pembacaan dial-gauge pertama dan $I_{2}(\theta)$ adalah hasil pembacaan dial-gauge kedua.

Metode Donaldson rehearsal adalah sebagai berikut (gambar 9). error roundness dari bola tersebut diukur dengan sebuah dial-gauge dengan memutar bola tersebut sebanyak $360^{\circ}$. Kemudian, posisi bola tersebut diputar sebesar $180^{\circ}$ dari posisi awalnya pada wahana rotasi tersebut dan kemudian error roundness-nya diukur lagi dengan dial-gauge tersebut dengan memutar bola tersebut sebanyak $360^{\circ}$. Dengan demikian, seperti persamaan (14) dan (15), error radial (roundness) dari wahana rotasi tersebut adalah:

$$
\begin{aligned}
& I_{1}-I_{2}=R(\theta)+X(\theta)-[R(\theta)-X(\theta)] \\
& X(\theta)=\left(I_{1}-I_{2}\right) / 2
\end{aligned}
$$

Terdapat jenis-jenis metode rehearsal lainnya yang tidak dibahas dalam bab ini, seperti metode untuk wahana pergerakan 2D (Ye et al 1997). 


\section{BAB 9}

\section{Ketidakpastian (uncertainty)}

Dalam setiap pengukuran, ketidakpastian (uncertainty) dari hasil pengukuran selalu didapatkan. Dengan kata lain, setiap pengukuran, seperti pengukuran geometri, tekanan dan gaya, yang kita lakukan akan menghasilkan hasil yang berbeda-beda walaupun pengukuran tersebut diulang dan dilakukan oleh operator, alat dan prosedur yang sama. Hasil yang berbeda-beda tersebut biasanya didapatkan dalam kuantitas yang sangat kecil, contoh dalam pengukuran geometri, perbedaan hasil pengukuran dari setiap pengulangan biasanya dalam skala mikro atau bahkan nano (tergantung jenis dan skala pengukuran).

Definisi standar dari ketidakpastian (uncertainty) adalah sebuah parameter non-negatif yang merepresentasikan sebaran atau dispersi suatu kuantitas nilai yang diatribusikan ke sebuah measurand (properti yang diukur, seperti panjang, diameter, gaya, dan temperatur) berdasarkan informasi yang tersedia (hasil pengukuran) (BIPM 2008a). Definisi aplikatif yang sering dipakai, ketidakpastian adalah sebuah nilai interval dimana kita yakin bahwa nilai yang sebenarnya (the true value) dari hasil pengukuran berada di antara interval tersebut.

Ketidakpastian merepresentasikan seberapa besar ketidakpahaman kita terhadap sebuah proses pengukuran. Semakin kecil nilai ketidakpastian dari suatu hasil pengukuran, maka semakin besar pemahaman kita terhadap proses pengukuran tersebut, dan sebaliknya. Ketidakpastian adalah sebuah kuantifikasi dari keraguan kita terhadap hasil pengukuran.

Perlu diketahui bahwa ketidakpastian diasosiasikan hanya kepada sebuah hasil pengukuran, sedangkan kesalahan (error) diasosiasikan kepada sebuah sistem atau instrumen pengukuran. Konsep dasar ini perlu diingat untuk menghidari kesalahpahaman dalam komunikasi yang berkaitan dengan sistem dan hasil pengukuran.

\subsection{Ekspresi hasil pengukuran yang ideal}

Setiap hasil pengukuran dapat direpresentasikan dalam format:

$$
y=x \pm U
$$

dimana $y$ adalah kuantitas fisik yang diukur (measurand), $x$ adalah hasil pengukuran dan $U$ adalah ketidakpastian dari hasil pengukuran (interval hasil pengukuran). Apabila hasil pengukuran tidak disertai dengan nilai ketidakpastiannya, maka hasil pengukuran tersebut tidak reliabel. Dalam bab ini, bagaimana cara mengestimasi $U$ (ketidakpastian) agar mempunyai nilai yang akurat, sehingga dapat diasosiasikan dengan suatu hasil pengukuran, akan dibahas secara detil, dengan kata lain estimasi $U$ yang akurat sehingga tidak melebihi atau kurang dari nilai yang sebenarnya.

Estimasi $U$ yang melebihi atau kurang dari nilai yang sebenarnya mempunyai dampak langsung dalam proses inspeksi kualitas dari suatu produk. Apabila estimasi $U$ terlalu melebihi hasil yang sebenarnya, maka akan banyak produk yang baik, tetapi tidak lolos inspeksi (di bagian selanjutnya akan dibahas lebih detil mengenai aturan inspeksi). Di sisi lain, apabila nilai $U$ terlalu kurang dari nilai yang sebenarnya, maka akan banyak produk yang cacat, tetapi akan lolos inspeksi dan sampai ke konsumen.

Contoh ekspresi hasil pengukuran yang ideal adalah sebagai berikut. Misal kita melakukan pengukuran panjang suatu produk dengan suatu alat ukur, maka ekspresi hasil pengukuran yang ideal adalah:

- $\quad$ Panjang dari produk tersebut $=(5 \pm 0.5) \mathrm{mm}$.

- Interval $0.5 \mathrm{~mm}$ adalah ketidakpastian $U$ dengan nilai perbesaran $k=2$ (expanded uncertainty) meliputi $95 \%$ interval kepercayaan (confidence interval), diasumsikan terdistribusi normal.

- Panjang $5 \mathrm{~mm}$ adalah rata-rata dari lima pengulangan pengukuran. Nilai ketidakpastian diestimasi 
menggunakan metode spreadsheet (akan dijelaskan lebih lanjut). Pengukuran dilakukan di dalam ruangan dengan suhu $(20 \pm 0.5)^{\circ} \mathrm{C}$ oleh operator berpengalaman dan berkeahlian.

Contoh di atas menggambarkan bagaimana cara yang ideal untuk merepresentasikan suatu hasil pengukuran lengkap dengan nilai ketidakpastiannya. Dengan representasi pengukuran yang lengkap, maka hasil pengukuran tersebut dinyatakan reliabel dan dapat dikomparasikan dengan hasil lain yang lebih akurat untuk mengetahui tingkat keakuratan pengukuran tersebut. Bab ini akan menjelaskan bagaimana cara mendapatkan nilai-nilai tersebut.

Penetapan nilai pembesaran $k=2$ berbasis dari pengetahuan kita tentang distribusi hasil pengukuran tersebut (pada umumnya distribusi normal) dan deviasi standar statistik dari hasil pengukuran tersebut. Nilai pembesaran $k$ pada umumnya dibagi menjadi tiga kelas, dengan asumsi distribusi normal (Montgomery 2003), yaitu:

- $\quad k=1$ untuk interval kepercayaan sekitar $68 \%$ (biasa disingkat $\sigma$ )

- $\quad k=2$ untuk interval kepercayaan sekitar $95 \%$ (biasa disingkat $2 \sigma$ )

- $\quad k=3$ untuk interval kepercayaan sekitar $99.7 \%$ (biasa disingkat $3 \sigma$ )

Dua jenis ketidakpastian yang terdapat di dalam standard internasional GUM (BIPM 2008b) adalah:

- $\quad$ Tipe A

Ketidakpastian tipe A berbasis perhitungan statistik, yaitu deviasi standar dari data hasil pengulangan pengukuran. Tipe A pada umumnya berbasis distribusi normal. Ketidakpastian tipe A diformulasikan sebagai:

$$
S=\frac{\sigma}{\sqrt{N}} ; \sigma=\sqrt{\frac{\sum_{i=1}^{N}\left(x_{i}-\bar{x}\right)^{2}}{N-1}}
$$

Dimana $i$ adalah index pengukuran $(i=1,2,3, \ldots, N), x_{i}$ adalah nilai pengukuran ke- $i$ dan $\bar{x}$ adalah rata-rata (mean) dari sejumlah $N$ pengukuran. $\sigma$ adalah deviasi standar dari sejumlah data pengukuran. $S$ adalah ketidakpastian tipe A yang merupakan deviasi standar $(\sigma)$ dari rata-rata $\bar{x}$

- $\quad$ Tipe B

Ketidakpastian tipe B adalah semua yang bukan tipe A atau dengan metode lain, seperti: estimasi berdasarkan pengalaman dan keahlian, sertifikasi kalibrasi, toleransi pada gambar desain, hasil yang terpublikasi, data historis hasil pengukuran, estimasi rasional, atau berdasarkan kesalahan (error) sistematik. Ketidakpastian tipe B pada umumnya berbasis distribusi rectangular, distribusi bentuk-U dan distribusi triangular.

\subsection{Model pengukuran}

Dalam situasi ideal, nilai yang sebenarnya dari suatu pengukuran dapat dimodelkan dengan:

$$
y=\text { Bacaan dari instrumen }- \text { jumlah dari seluruh kesalahan (error) dalam pengukuran tersebut }
$$

dimana jumlah dari seluruh kesalahan meliputi kesalahan sistematik, kesalahan kalibrasi dan kesalahan lain yang tidak diketahui. Model ini tidak bisa diterapkan secara riil karena ada faktor kesalahan lain yang tidak kita ketahui. Maka dari itu, dalam situasi riil, model pegukuran menjadi:

$$
y=\text { Bacaan dari instrumen }+ \text { kesalahan yang diketahui (known errors) } \pm \text { ketidakpastian (uncertainty) }
$$

model ini diringkas menjadi model yang dipresentasikan dalam persamaan (1).

Menurut salah satu standar ISO (ISO 5725:1 1994), definisi keakuratan (accuracy) meliputi kebenaran (trueness) dan presisi. Dengan demikian, pernyataan akurasi sudah meliputi kebenaran dan presisi dibanding definsi sebelumnya bahwa akurasi hanya merepresentasikan kebenaran.

Definisi kesalahan menurut VIM (BIPM 2008a) adalah perbedaan antara nilai yang diukur dan nilai yang sebenarnya (biasanya merujuk pada nilai kalibrasi). Total kesalahan dibagi menjadi dua bagian, yaitu kesalahan sistematik (systematic error) dan kesalahan acak (random error) dan dapat dimodelkan sebagai:

$$
\text { Total kesalahan }\left(\varepsilon_{\text {total }}\right)=\text { Kesalahan sistematik }\left(\varepsilon_{\text {sistematik }}\right)+\text { kesalahan acak }\left(\varepsilon_{\text {acak }}\right)
$$

Sehingga, model pengukuran dari persamaan (1) menjadi:

$$
\begin{aligned}
y & =x+\varepsilon_{\text {total }} \\
y & =x+\varepsilon_{\text {sistematik }}+\varepsilon_{\text {acak }} \\
\left(y-\varepsilon_{\text {sistematik }}\right) & =x+\varepsilon_{\text {acak }}
\end{aligned}
$$




$$
\left(y-\varepsilon_{\text {sistematik }}\right)=x \pm U
$$

Dari persamaan (9), dapat terlihat bahwa ketidakpastian mengkuantifikasi kesalahan acak dengan syarat bahwa kesalahan sistematik sudah dikompensasi dari hasil pengukuran. Apabila kesalahan sistematik tidak dikompensasi, maka ketidakpastian harus meliputi kesalahan sistematik dan akan menyebabkan estimasi ketidakpastian menjadi besar.

Kesalahan sistematik (systematic error) adalah nilai deviasi dari nilai yang sebenarnya (the true value) dari suatu pengukuran dan bersifat konstan atau tetap dalam setiap pengulangan pengukuran. Kesalahan sistematik mempunyai pola khusus yang dapat diestimasi dan dikompensasi untuk meningkatkan keakuratan suatu pengukuran. Sedangkan kesalahan acak (random error) adalah nilai deviasi yang bersifat acak dan tidak dapat diprediksi pada suatu pengulangan pengukuran. Kesalahan acak tidak mempunyai pola khusus sehingga tidak dapat dikompensasi. Kesalahan acak dapat diestimasi hanya dengan menggunakan metode statistik, seperti rata-rata dan deviasi standar. Tabel 1 merangkum perbedaan antara kesalahan sistematik dan kesalahan acak.

Tabel 1: perbedaan antara kesalahan sistematik dan kesalahan acak.

\begin{tabular}{|l|l|}
\hline \multicolumn{1}{|c|}{ Kesalahan sistematik (Systematic error) } & \multicolumn{1}{c|}{ Kesaahan acak (Random error) } \\
\hline Dapat dikompensasi & $\begin{array}{l}\text { Tidak dapat dikompensasi (kecuali dengan } \\
\text { sebuah kompensasi real-time dengan metode } \\
\text { kontrol close-loop) }\end{array}$ \\
\hline Tidak dapat dideteksi dengan mudah & Dapat dideteksi dengan mudah \\
\hline $\begin{array}{l}\text { Tidak dapat direduksi dengan menambah } \\
\text { pengulangan pengukuran }\end{array}$ & $\begin{array}{l}\text { Dapat direduksi atau diminimalkan dengan } \\
\text { menambah pengulangan pengukuran }\end{array}$ \\
\hline Dapat dikalkulasi dengan mudah & Membutuhkan analisis statistik dan probabilitas \\
\hline $\begin{array}{l}\text { Keakuratan meningkat setelah meminimalkan } \\
\text { kesalahan sistematik }\end{array}$ & $\begin{array}{l}\text { Kemampuan pengulangan (repeatability) } \\
\text { instrumen akan meningkat setelah meminimalkan } \\
\text { kesalahan acak }\end{array}$ \\
\hline $\begin{array}{l}\text { Kalibrasi dan penyesuaian (adjustment) dapat } \\
\text { mereduksi kesalahan sistematik }\end{array}$ & $\begin{array}{l}\text { Kalibrasi dan penyesuaian (adjustment) tidak } \\
\text { mempengaruhi kesalahan acak }\end{array}$ \\
\hline Karakterisasi tidak dibutuhkan & $\begin{array}{l}\text { Butuh karakterisasi dalam bentuk distribusi } \\
\text { probabilitas, rata-rata dan varian }\end{array}$ \\
\hline $\begin{array}{l}\text { Inkonsistensi muncul pada arah tertentu } \\
\text { (memiliki pola tertentu) }\end{array}$ & $\begin{array}{l}\text { Inkonsistensi muncul secara acak (tidak memiliki } \\
\text { pola tertentu) }\end{array}$ \\
\hline
\end{tabular}

\subsection{Sumber-sumber ketidakpastian (uncertainty sources)}

Dalam setiap pengukuran, sumber-sumber yang berkontribusi kepada ketidakpastian berasal dari berbagai sumber, termasuk ketidakpastian dari definisi apa yang akan diukur (measurand). Maka dari itu, dalam setiap pengukuran, definisi dari apa yang akan diukur haruslah dipastikan terlebih dahulu. Gambar 1 menampilkan berbagai macam sumber ketidakpastian untuk suatu pengukuran dimensi dan geometri. Sumber-sumber ketidakpastian dikelompokkan menjadi lima bagian:

- Instrumen atau sistem pengukuran

- Operator (user)

- Benda kerja (part)

- Metode atau prosedur pengukuran

- Lingkungan

Dari lima pengelompokan tersebut, masing-masing bagian mempunyai sumber-sumber ketidakpastian yang akan dijelaskan lebih detil lagi.

Bagian pertama adalah sumber ketidakpastian dari instrumen pengukuran. Sumber ini merupakan sumber 
ketidakpastian yang berasal dari properti atau karakteristik sebuah instrumen pengukuran, seperti kesalahan geometri dari komponen-komponen penyusun sebuah instrument pengukuran, kesalahan kinematika instrumen yang berkaitan dengan sambungan antara dua komponen yang bergerak (over-constrained, under-constrained), kesalahan Abbe, kesalahan Cosine, keterbatasan resolusi dari suatu instrumen dan deformasi struktur sebuah instrumen pengukuran (complience pada sambungan anatar komponen-komponen). Pada umumnya, pembuat instrumen pengukuran kelas atas selalu mengkuantifikasi kesalahan-kesalahan tersebut setelah instrumen mereka asembli di pabrik mereka sehingga mereka bisa mengkuantifikasi dan menyesuaikan pengaturan komponen-komponen untuk mereduksi kesalahan-kesalahan yang berasal dari geometri komponen.

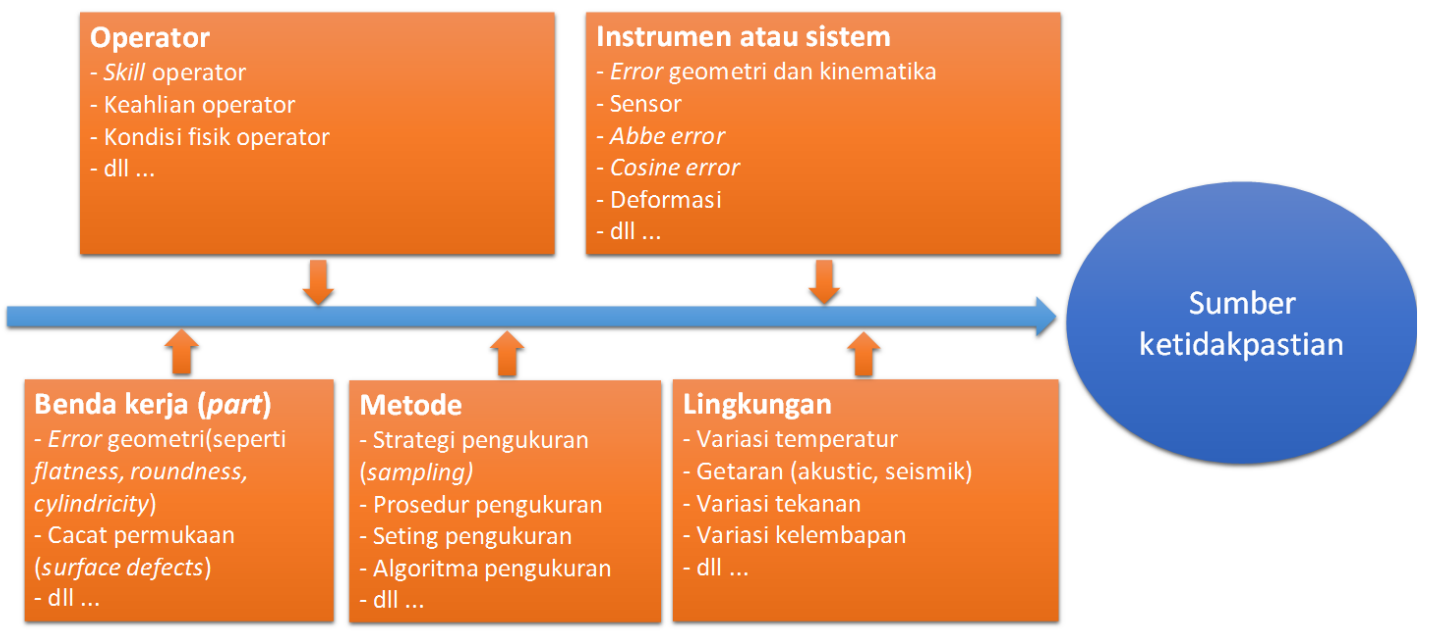

Gambar 1: Berbagai macam sumber ketidakpastian pada sebuah pengukuran.

Bagian kedua dari sumber ketidakpastian adalah operator yang menggunakan suatu instrumen pengukuran. Pengaruh operator terhadap ketidakpastian pengukuran sangatlah penting. Hal-hal yang berhubungan dengan operator tersebut seperti keahlian, kondisi fisik dan pengalaman operator dalam hal menggunakan suatu alat ukur. Sebagai contoh, keahlian dan pengalaman operator untuk memposisikan benda kerja secara benar saat pengukuran dilakukan sangat mempengaruhi hasil pengukuran benda kerja tersebut. Contoh lain adalah keahlian operator membaca skala hasil pengukuran dengan cermat dan teliti akan mempengaruhi hasil pengukuran.

Bagian ketiga adalah ketidakpastian yang bersumber dari benda kerja (part) yang diukur. Sumber-sumber ketidakpastian dari benda kerja seperti kesalahan atau cacat geometri dari benda kerja yang diukur (contoh flatness, roundness dan cylindricity) dan cacat pada tekstur permukaan benda kerja (contoh pengaruh efek kekasaran pada benda kerja sangat berpengaruh pada ukuran berskala mikro- atau nano-meter). Pada prinsipnya, tingkat kesalahan alat pengukuran harus minimal sepuluh kali lebih kecil dari tingkat kesalahan atau cacat dari benda yang diukur.

Bagian keempat adalah ketidakpastian yang bersumber dari metode pengukuran. Sumber ketidakpastian yang berasal dari metode pengukuran seperti strategi pengambilan data atau titik (sampling), prosedur pengukuran, seting instrumen pengukuran dan algoritma pengukuran. Strategi pengambilan titik pada mesin pengukur coordinate (CMM) sangat penting karena mempengaruhi proses asosiasi geometri ideal pada titik data yang diambil. Prosedur dan seting pengukuran sangat mempengaruhi hasil pengukuran seperti seting kecepatan pengukuran. Dan terakhir, algoritma untuk memproses titik data yang dihasilkan semua alat pengukuran juga sangat mempengaruhi hasil pengukuran yang kemudian berkontribusi kepada ketidakpastian. Algoritma berbeda yang diterapkan untuk memproses data yang sama, akan menghasilkan hasil pengukuran yang berbeda pula.

Terakhir, bagian kelima adalah ketidakpastian yang bersumber dari kondisi lingkungan tempat pengukuran dilakukan. Lingkungan sangat mempengaruhi variasi hasil pengukuran. Sebagai contoh, variasi temperatur pada lingkungan pengukuran akan mengakibatkan benda kerja memiliki panjang yang bervariasi karena pengaruh ekspansi termal. Gangguan yang berasal dari getaran akan langsung mempengaruhi hasil pengukuran, seperti getaran yang 
berasal dari lantai tempat pengukuran. Variasi tekanan dan kelembapan akan mempengaruhi hasil pengukuran yang menggunakan laser, seperti interferometer laser, karena properti laser sangat dipengaruhi oleh tekanan dan kelembapan dari lingkungan.

Dari penjelasan di atas, maka dapat terlihat bahwa ketidakpastian adalah masalah yang tidak mudah dan sangat penting untuk diestimasi. Ketidakpastian adalah bersifat spesifik terhadap pengukuran tertentu (task specific). Arti dari ketidakpastian adalah spesifik karena setiap estimasi ketidakpastian, estimasi tersebut hanya berlaku untuk pengukuran tertentu, pada benda kerja tertentu, dengan prosedur dan kondisi lingkungan tertentu (Wilhelm 2001). Apabila salah satu faktor yang disebutkan berbeda, maka estimasi nilai ketidakpastian akan berbeda pula, walaupun tingkat perbedaannya mungkin tidak terlalu signifikan untuk suatu pengukuran tertentu. Maka dari itu, setiap estimasi dari ketidakpastian harus diikuti penjelasan detil bagaimana estimasi tersebut dilakukan, apa jenis pengukurannya, bagaimana prosedur pengukurannya, apa yang diukur dan informasi lain yang berkaitan dengan pengukuran tersebut (seperti yang sudah dijelaskan pada bagian 9.1).

\subsection{Tujuan estimasi ketidakpastian}

Pada bagian ini, pentingnya ketidakpastian harus diestimasi akan dijabarkan lebih lanjut. Tujuan estimasi ketidakpastian berlaku untuk semua tipe pengukuran. Tujuan estimasi ketidakpastian adalah sebagai berikut (tetapi tidak terbatas pada):

\section{Untuk komparasi hasil antar-pengukuran.}

Hal yang paling pertama mengapa ketidakpastian harus dikuantifikasi adalah untuk mengkomparasi beberapa pengukuran yang berbeda pada benda kerja yang sama. Hal ini menjadi sangat penting, terutama pada zaman sekarang, pertukaran antar-suku cadang atau komponen yang diproduksi oleh mesin yang berbeda dari tempat yang berbeda. Selain itu, komparasi pengukuran sangat penting untuk persetujuan bisnis antara dua atau lebih perusahaan manufaktur yang ingin membeli dan menjual produk atau komponen dari pabrik atau manufaktur yang lain.

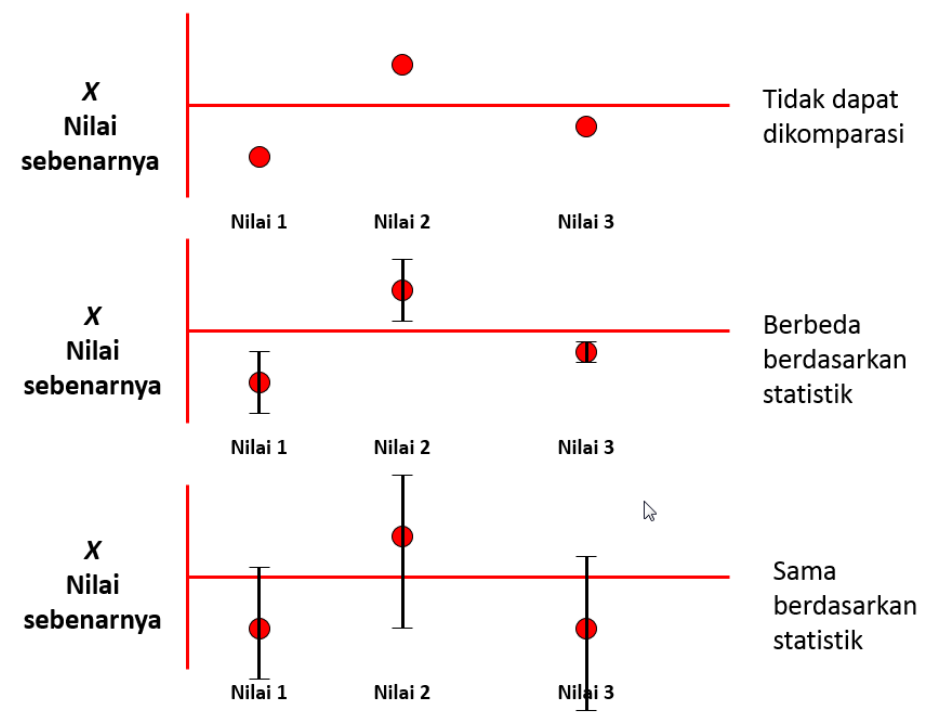

Gambar 2: Ilustrasi suatu komparasi antar-pengukuran.

Contoh kasus komparasi antar-pengukuran adalah sebagai berikut. Ada dua perusahaan manufaktur: perusahaan A dan perusahaan B. Perusahaan B membeli suatu komponen berbentuk silinder dari perusahaan A. Silinder tersebut mempunyai spesifikasi diameter $(5 \pm 0.1) \mathrm{mm}$. Perusahaan A kemudian membuat silinder tersebut kemudian mengukur diameter silinder tersebut sebelum dikirim ke perusahaan B. Perusahaan A mengukur diameter silinder tersebut yaitu $5.1 \mathrm{~mm}$ (masih dalam batas toleransi) dan kemudian mengirim silinder tersebut ke perusahaan B. Pada waktu silinder tersebut sampai di perusahaan B, perusahaan B kemudian mengukur silinder yang diterima mereka 
untuk mengecek apakah silinder tersebut sesuai dengan spesifikasi dan bisa dikirim ke bagian perakitan. Ternyata, hasil pengukuran perusahaan B, silinder tersebut memiliki diameter $5.15 \mathrm{~mm}$. Dari hasil pengukuran perusahaan B, silinder tersebut tidak diterima (reject). Dalam situasi ini, kedua perusahaan tidak mencantumkan nilai ketidakpastian pada hasil pengukuran mereka, sehingga kedua pengukuran diameter pada silinder tersebut tidak dapat dikomparasi.

Seperti yang sudah dijelaskan sebelumnya, hasil pengukuran tidaklah lengkap apabila tidak disertai dengan nilai ketidakpastian. Gambar 2 menunjukkan ilustrasi pentingnya nilai ketidakpastian untuk komparasi antar-pengukuran pada suatu kasus komparasi antara tiga hasil pengukuran pada benda yang sama dan dengan instrumen atau operator yang berbeda. Pada gambar 2 (bagian atas), ketiga hasil pengukuran tidak disertai oleh nilai ketidakpastian, sehingga kesimpulan apakah ketiga hasil pengukuran tersebut sama atau berbeda.

Pada gambar 2 (bagian tengah dan bawah), nilai ketidakpastian dari ketiga pengukuran tersebut dicantumkan. Dengan dicantumkannya nilai ketidakpastian, maka ketiga hasil pengukuran tersebut dapat dikomparasi atau dibandingkan. Pada gambar 2 (bagian tengah), ketiga pengukuran tersebut menunjukkan hasil yang berbeda karena hasil pengukuran tersebut, dengan nilai ketidakpastiannya, menunjukkan bahwa interval hasil pengukuran tersebut tidak beririsan satu sama lain. Karena nilai interval hasil pengukuran tersebut tidak beririsan (atau sangat kecil daerah irisannya), hal ini dapat disimpulkan bahwa ketiga pengukuran tersebut berbeda satu sama lain. Sedangkan pada gambar 2 (bagian bawah), interval hasil pengukuran tersebut saling beririsan satu sama lain sehingga dapat disimpulkan bahwa ketiga hasil pengukuran tersebut adalah sama (perbedaannya tidak signifikan secara statistik).

\section{Untuk keterlacakan hasil pengukuran (traceability).}

Keterlacakan (traceability) suatu hasil pengukuran sangatlah penting. Seperti yang sudah dijelaskan pada Bab 1, keterlacakan hasil pengukuran adalah properti dari suatu hasil pengukuran yang dapat direlasikan ke suatu nilai referensi, biasanya standar nasional atau internasional, melalui suatu rangkaian komparasi tercatat yang tidak terputus ke nilai referensi internasional, untuk pengukuran geometri referensi tersebut adalah definisi dari meter (lihat Bab 1, BIPM 1983), dan semua rangkaian komparasi tersebut mencantumkan nilai ketidakpastian (BIPM 2008a). Dari definisi keterlacakan, nilai ketidakpastian adalah sangat penting. Selain itu, rangkaian komparasi untuk keterlacakan dilakukan dengan proses kalibrasi. Maka dari itu, ketidakpastian, keterlacakan dan kalibrasi adalah sangat berkaitan satu sama lainnya.

Apabila suatu hasil pengukuran dapat terlacak sampai ke definisi meter, maka hasil pengukuran tersebut reliabel dan dapat dikomparasi (seperti point 1 sebelumnya). Keterlacakan adalah dasar semua pengukuran untuk dapat dideklarasikan akurat. Gambar 3 memperlihatkan bagaimana rantai keterlacakan mempunyai suatu rantai yang tidak terputus sampai ke definisi dari meter (lihat Bab 1).

Pada gambar 3, rantai keterlacakan untuk pengukuran dimensi (geometri) sampai dengan definisi dari meter dipresentasikan. Dari gambar tersebut, dapat terlihat bahwa batas akhir dari rantai keterlacakan adalah sampai pada definisi dari meter. Definisi meter adalah definisi nominal (teoritikal) sehingga pada batas ini, nilai ketidakpastiannya adalah nol. "Tanda panah" ke atas pada gambar 3 menunjukkan rantai keterlacakan. Untuk merealisasikan rantai keterlacakan ini, proses kalibrasi harus dilakukan. Secara praktis, pengertian kalibrasi adalah mengkomparasikan suatu hasil pengukuran dengan hasil lain yang lebih akurat dengan mencantumkan nilai ketidakpastian dari proses komparasi tersebut. Apabila seluruh rantai keterlacakan tidak terputus sampai dengan definisi meter, maka hasil pengukuran tersebut bisa dikatakan "terlacak" dan reliabel. Dapat terlihat bahwa semakin rendah tingkat keterlacakan (pada gambar 3), maka nilai ketidakpastian dari tingkat keterlacakan tersebut semakin tinggi, atau dengan kata lain semakin rendah tingkat akuratannya.

Penjelasan bagaimana sebenarnya realisasi dari rantai keterlacakan pada gambar 3 adalah sebagai berikut (untuk lebih detilnya dapat dilihat pada Bab 1). Langkah pertama adalah merealisasikan meter dari sebuah definisi teoritis ke sebuah nilai praktis. Untuk merelisasikan meter, sebuah eksperimental instrumen berbasis laser dengan frekuensi terstabilisasi (frequency stabilised laser) dan tingkat presisi yang tinggi digunakan untuk menghasilkan suatu panjang gelombang yang terkalibrasi $(\lambda)$. Hal ini diterapkan dengan berdasarkan formula $f=c / \lambda_{0}$; dimana $f$ adalah frekuensi laser yang terstabilisasi, $c$ adalah kecepatan cahaya di ruang hampa yaitu $1 / 299792458 \mathrm{~m} \cdot \mathrm{s}^{-1}$ dan $\lambda_{0}$ adalah suatu panjang gelombang terkalibrasi yang akan dihasilkan. Dari hasil eksperimen ini, sebuah $\lambda_{0}$ akan didapatkan dan kemudian digunakan sebagai "penggaris" untuk mengetahui panjang gelombang cahaya yang lain, misalnya laser untuk kepentingan industri. Pada level ini, nilai ketidakpastiannya pada order $10^{-11} \mathrm{~m}$. 


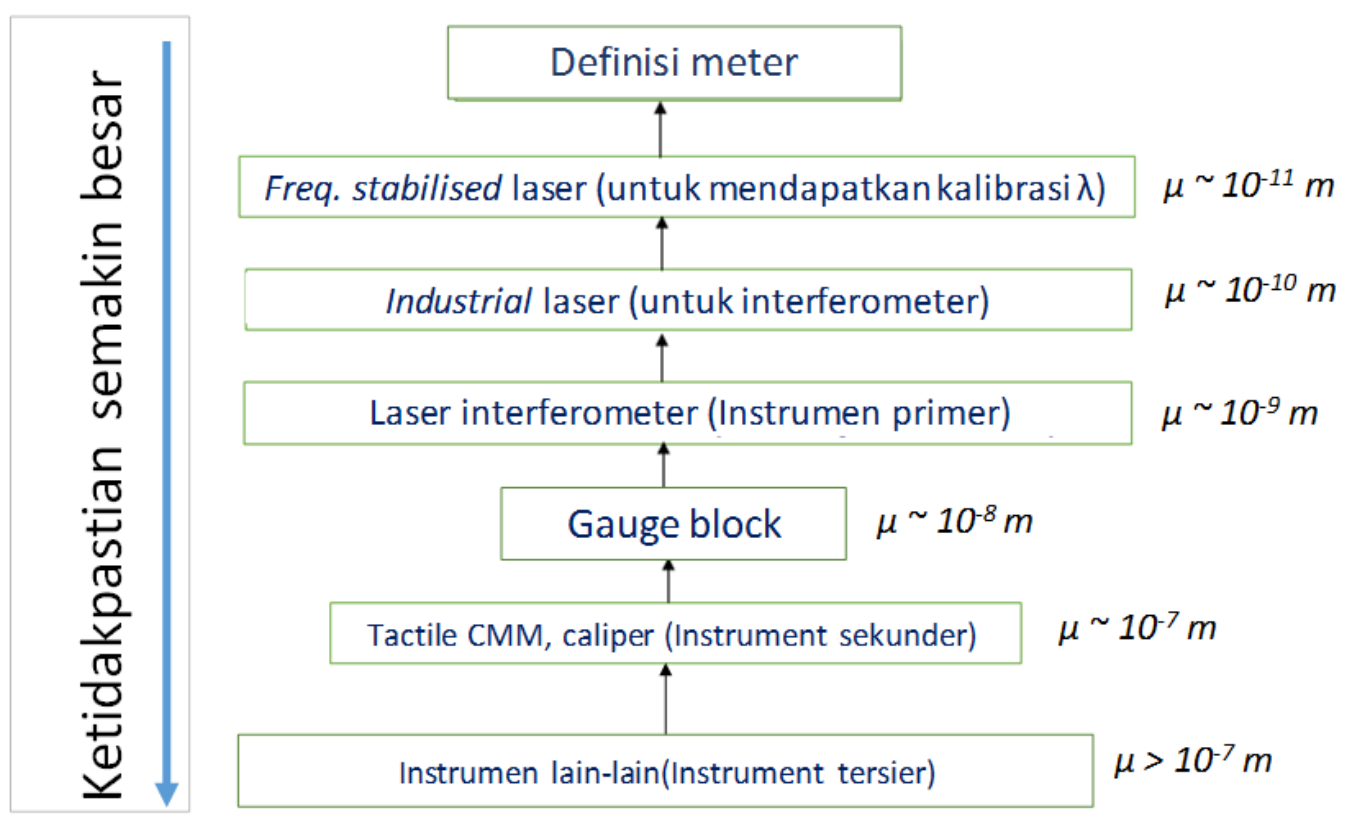

Gambar 3: Rantai keterlacakan suatu pengukuran ( $\mu=$ order dari ketidakpastian).

Pada tingkat selanjutnya, hasil dari $\lambda_{0}$ digunakan untuk menentukan nilai $\lambda$ untuk gelombang yang lain, misal gelombang dari suatu laser merah atau laser hijau (red/green laser). Gambaran praktisnya, $\lambda_{0}$ digunakan sebagai "penggaris" untuk mengukur suatu $\lambda$ lainnya. Nilai ketidakpastian dari pengukuran suatu $\lambda$ tersebut berada pada order $10^{-10}$ (berada pada level sub-nanometer).

Ketika suatu $\lambda$ telah diketahui nilainya, misalnya laser merah dengan $\lambda=633 \mathrm{~nm}$, sebuah interferometri dapat dikontruksi dengan menggunakan laser merah tersebut (Yoshizawa 2009). Laser interferometri tersebut dapat digunakan untuk mengukur suatu panjang (Lihat Bab 4). Pada tahap ini, ketika sistem interferometer sudah dibuat, maka realisasi suatu panjang sudah dapat direalisasikan secara fisik. Pada tingkat ini nilai ketidakpastiannya berada pada order $10^{-9} \mathrm{~m}$ (berada pada level nanometer).

Tingkat keterlacakan sisanya berada pada level laboratorium pada umumnya sampai pada level lantai produksi (shopfloor). Tingkat di bawah interferometer laser adalah gauge block atau artifak referensi lainnya. Gauge block dikalibrasi menggunakan laser interferometer dengan tingkat nilai ketidakpastian berada pada level $10^{-8} \mathrm{~m}(10 \mathrm{~nm})$. Gauge block yang terkalibrasi tersebut digunakan untuk mengkalibrasi instrumen pengukuran kontak, seperti mesin pengukuran koordinat $(C M M)$ dan vernier caliper (jangka sorong). Kalibrasi pengukuran berbasis instrumen kontak berada pada level $10^{-7} \mathrm{~m}$ (sub-mikrometer). Dan terakhir, instrumen-intrumen pengukuran berbasis kontak tersebut digunakan untuk mengkalibrasi instrumen-instrumen pengukuran berbasis optik dengan menggunakan suatu artifak referensi. Artifak tersebut diukur dan dikalibrasi menggunakan instrumen pengukuran berbasis kontak dengan tingkat ketidakpastian berada pada level $>10^{-7} \mathrm{~m}$ (mikrometer).

Penjelasan lebih detil berikut ilustrasi bagaimana suatu keterlacakan hasil pengukuran dilakukan secara praktis dapat dilihat di dalam Bab 1.

\section{Untuk kepentingan pra-produksi.}

Ketidakpastian hasil pengukuran mempunyai peran yang sangat penting dalam hal pengambilan keputusan pada level sistem untuk suatu kasus studi kapabilitas mesin-mesin produksi (Kunzman et al. 2005). Ilustrasi pentingnya nilai ketidakpastian pada level pra-produksi diperlihatkan pada gambar 4. Pra-produksi adalah suatu proses untuk mempelajari kapabilitas mesin-mesin produksi pada suatu industri. Uji kapabilitas mesin produksi bertujuan untuk mengetahui apakah mesin-mesin produksi tersebut mampu memproduksi suatu produk sesuai dengan tingkat keakuratan yang diinginkan. 


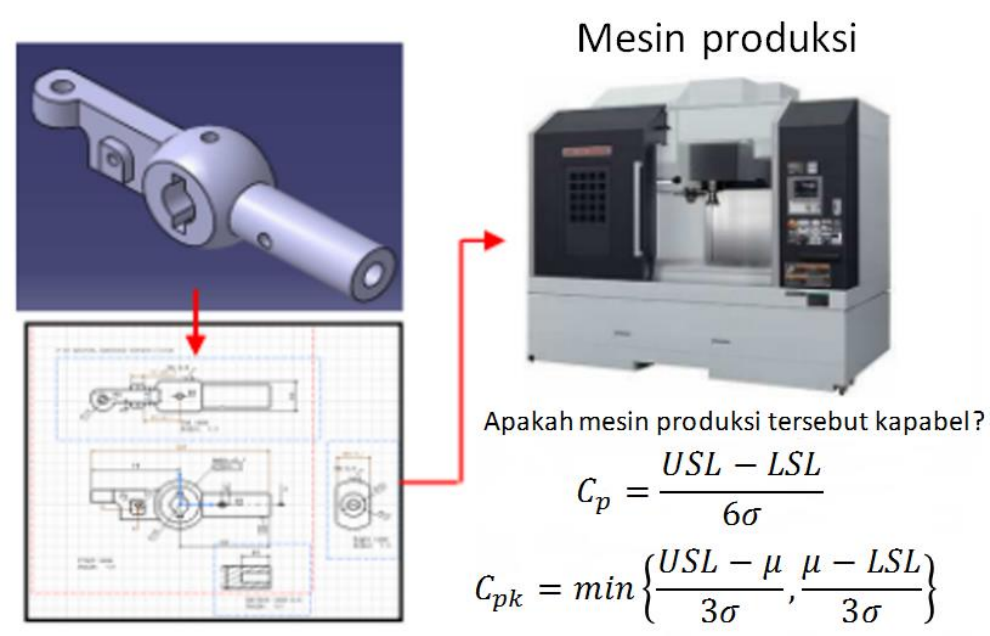

Gambar 4: Ilustrasi pengaruh ketidakpastian pada kapabilitas mesin produksi.

Pada gambar 4, sebuah contoh uji kapabilitas mesin milling otomatis (CNC milling) dilakukan untuk menguji apakah mesin tersebut dapat memproduksi sebuah komponen otomotif. Komponen tersebut memiliki suatu batas toleransi, yaitu USL sebagai batas atas toleransi dan $L S L$ sebagai batas bawah toleransi. Properti yang diukur, misalnya, panjang komponen total tersebut. Uji kapabilitas dilakukan dengan mencoba membuat, misalnya, 50 komponen otomotif tersebut. Setelah komponen-komponen tersebut dibuat, setiap komponen tersebut diukur dengan suatu sistem pengukuran, misalnya, mesin pengukur koordinat.

Setelah komponen-komponen tersebut diukur, indeks kapabilatas mesin tersebut dikalkulasi, yaitu $C_{p}$ dan $C_{p k}$ (lihat gambar 4). $C_{p}$ adalah suatu indeks untuk mengetahui variasi proses produksi komponen tersebut masih dalam batas toleransi spesifikasi. $C_{p k}$ adalah suatu indeks untuk mengetahui seberapa jauh rata-rata proses produksi tersebut bergeser dan nilai tengah dari batas toleransi spesifikasi (Kotz dan Johnson 1993).

Dari formula $C_{p}$ dan $C_{p k}$, dapat terlihat bahwa $\sigma$ (deviasi standar dari pengukuran) mengandung nilai ketidakpastian dari hasil pengukuran. Dengan kata lain, kualitas hasil pengukuran sangat berpengaruh pada uji kapabilitas. Apabila mesin yang digunakan sangat akurat, tetapi sistem pengukuran yang digunakan tidak presisi (kualitas rendah), maka ketidakpastian yang besar, yang disebabkan oleh sistem pengukuran yang berkualitas rendah, mempengaruhi nilai $\sigma$ tersebut. Nilai ketidakpastian yang besar tersebut membuat nilai $C_{p}$ dan $C_{p k}$ menjadi kecil sehingga keputusan yang salah dapat diambil; yaitu memutuskan bahwa mesin berkualitas tinggi tersebut tidak kapabel untuk membuat komponen otomotof tersebut. Padahal, mesin produksi tersebut sangat mampu untuk membuat komponen-komponen tersebut namun tingginya nilai ketidakpastian hasil pengukuran dari sistem pengukuran yang tidak bagus menghasilkan keputusan yang salah.

\section{Untuk kepentingan paska-produksi (inspeksi kualitas).}

Ketidakpastian juga mempunyai fungsi yang sangat penting pada fase paska-produksi, atau dengan kata lain pada fase inspeksi kualitas. Ketidakpastian berpengaruh pada semakin kecilnya zona toleransi dari aktual zona toleransi yang terdapat pada gambar desain suatu produk (ISO 14253-1 2010). Gambar 5 memperlihatkan pengaruh nilai ketidakpastian kepada mengecilnya zona toleransi suatu measurand, misalnya diameter.

Pada gambar 5, sebuah spesifikasi sebuah properti (measurand) pada suatu komponen. Spesifikasi tersebut mempunyai dua batas: batas bawah (LSL) dan batas atas (USL). Batas toleransi ini menunjukkan zona variasi dimensi dari measurand tersebut yang masih dapat diterima. Pada gambar 5 terdapat dua fase, yaitu fase desain (garis hijau) dan fase verifikasi (garis coklat). Pada fase desain, zona toleransi adalah USL-LSL karena tidak ada variasi pada fase desain. Sedangkan pada fase verifikasi, lebar dari zona toleransi berkurang sebanyak dua kali nilai ketidakpastain. Dengan kata lain, zona toleransi pada fase verifikasi menjadi $U S L-L S L-2 U$ (dimana $U$ adalah nilai ketidakpastian hasil pengukuran tersebut dengan $95 \%$ interval kepercayaan). Berkurangnya zona toleransi ini disebabkan oleh nilai ketidakpastian, yang berasal misalnya dari variasi proses permesinan dan variasi proses pengukuran. Dari gambar 5, 
agar tidak terjadi perselisihan, sebuah part akan dinyatakan bagus apabila hasil pengukurannya berada pada zona USL$L S L-2 U$ (zona diterima) dan sebuah part akan dinyatakan cacat apabila hasil pengukuran $>U S L+U$ atau hasil pengukuran $<L S L-U$ (zona tidak diterima).

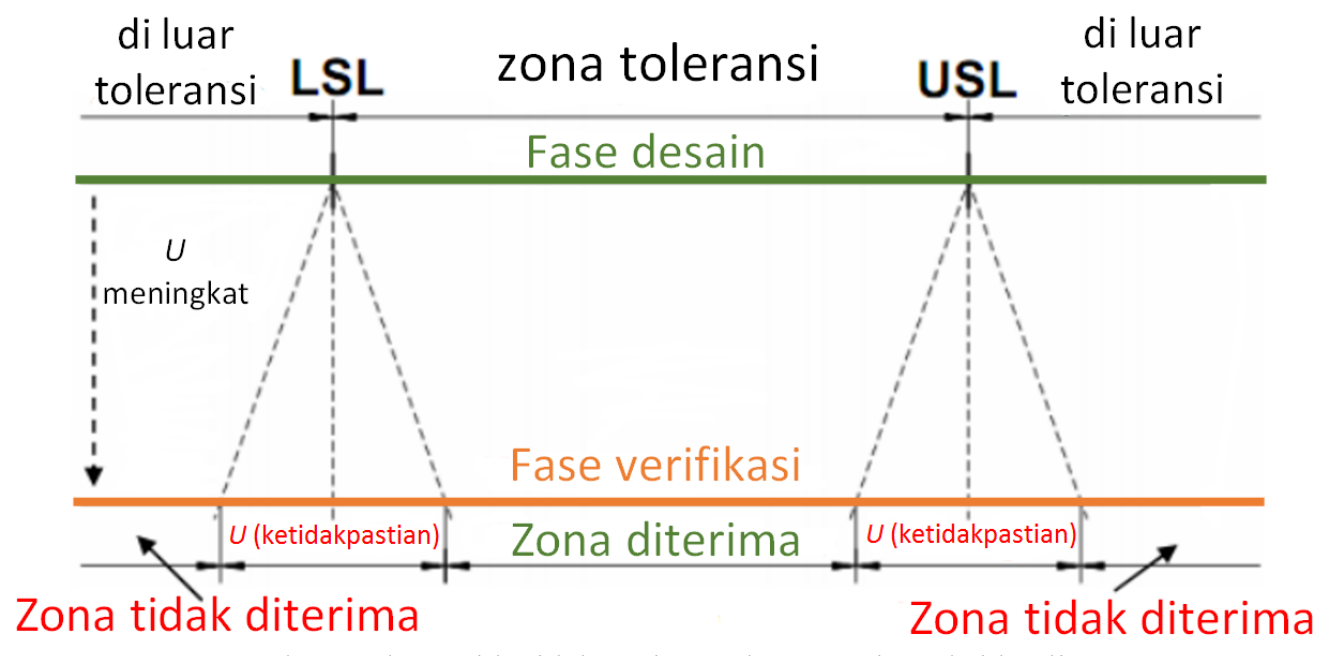

Gambar 5: Ilustrasi ketidakpastian pada proses inspeksi kualitas.

Sangat jelas bahwa nilai ketidakpastian dari hasil pengukuran berperan penting dalam pengambilan keputusan pada suatu proses inspeksi karena dapat mengakibatkan kesalahan dalam pengambilan keputusan. Kesalahan pada pengambilan keputusan suatu proses inspeksi adalah operator atau manajer inspeksi memutuskan menerima (accept) suatu komponen padahal komponen tersebut tidak bagus (di luar zona toleransi) atau sebaliknya, menolak suatu komponen (reject) padahal komponen tersebut bagus. Kesalahan pengambilan keputusan pada proses inspeksi sangat berakibat negatif pada total biaya produksi karena komponen yang sudah dibuat harus dibuang (scrapped) atau komponen tersebut harus diperbaiki yang mengakibatkan biaya tambahan. Atau, apabila proses inspeksi meloloskan part yang sebenarnya tidak bagus, maka pengguna tersebut akan merasakan dampak buruknya komponen tersebut dan reputasi produk tersebut akan berkurang.

ISO standard (ISO 14253-1 2010) memberikan petunjuk untuk membuat keputusan proses inspeksi dengan mempertimbangkan nilai ketidakpastian. Apabila suatu inspeksi mendapatkan hasil suatu pengukuran melebihi batas toleransinya (lihat gambar 5), namun masih di dalam zona ketidakpastian hasil pegukuran, maka inspeksi tersebut harus tetap menerima komponen tersebut karena ada kemungkinan hasil inspeksi sebenarnya masih di dalam batas toleransi (yang diakibatkan karena variasi hasil pengukuran). Dan sebaliknya, apabila proses inspeksi mendapatkan hasil inspeksi masih di dalam batas toleransi, tetapi berada dalam zona ketidak pastian $U$ (gambar 5), maka inspeksi harus menolak komponen tersebut karena ada kemungkinan keadaan sebenarnya dari komponen tersebut tidak bagus.

\section{Untuk merevisi dan meningkatkan keakuratan sistem pengukuran.}

Dalam proses estimasi nilai ketidakpastian (yang akan dijelaskan lebih lanjut), tiap-tiap kontributor ketidakpastian pada suatu proses pengukuran akan diidentifikasi dan dikuantifikasi. Proses ini dinamakan uncertainty budgetting. Hasil dari proses identifikasi dan kuantifikasi ini menghasilkan sebuah daftar hal-hal apa saja yang menyebabkan nilai ketidakpastian suatu pengukuran menjadi tinggi.

Apabili sumber-sumber ketidakpastian sudah teridentifikasi dan terkuantifikasi, proses analisis lanjutan terhadap proses suatu pengukuran dapat dilakukan. Hasil dari proses budgetting tersebut dapat memperlihatkan apa saja yang menjadi sumber ketidakpastian yang paling dominan, seperti mungkin sumber ketidakpastian hasil pengukuran berasal dari seting instrumen yang kurang tepat, kesalahan prosedur ataupun keterbatasan resolusi dari instrumen yang digunakan. 


\subsection{Contoh kasus}

Contoh kasus yang dipresentasikan adalah sebuah kasus perselisihan antara dua perusahaan dimana perusahaan yang satu memproduksi suatu komponen dan perusahaan yang lain membeli komponen tersebut untuk dirakit dengan komponen lainnya. Dua perusahaan itu adalah perusahaan A sebagai pembuat komponen dan perusahaan B sebagai pembeli komponen tersebut.

Perusahaan A membuat dan mensuplai sebuah silinder. Silinder tersebut mempunyai spesifikasi diameter $(10 \pm$ $0.2) \mathrm{mm}$. Setelah memproduksi silinder tersebut, sebuah pos inspeksi kualitas di perusahaan A mengecek silinder yang telah dibuat tersebut. Hasil dari proses inspeksi, silinder tersebut mempunyai diameter $(10.3 \pm 0.15) \mathrm{mm}$.

Pertanyaannya adalah:

- Apa keputusan dari proses inspeksi kualitas di perusahaan A terhadap komponen buatannya?

- Dapatkah perusahaan tersebut menjual/mengirimkan komponennya ke perusahaan B?

- Dapatkah perusahaan B mengembalikan komponen yang berasal dari perusahaan A itu?

- Berapa nilai ketidakpastian dari hasil pengukuran agar hasilnya tidak menimbulkan perselisihan antara kedua belah pihak?

Jawaban dari pertanyaan di atas adalah sebagai berikut:

Untuk permasalahan ini, cara terbaik untuk menganalisisnya adalah dengan menggunakan diagram toleransi. Ada dua macam jenis diagram toleransi dimana kedua-duanya mempunyai hasil yang sama dengan presentasi yang sedikit berbeda. Jenis pertama adalah dengan mengasosiasikan nilai ketidakpastian pada LSL dan USL yang terlihat pada gambar 6 bagian atas (seperti pada gambar 5). Jenis kedua adalah dengan mengasosiasikan nilai ketidakpastian pada hasil pengukuran yang terlihat pada gambar 6 bagian bawah.

- Hasil pengukuran silinder tersebut berada di dalam daerah perselisihan (gambar 6 bagian atas). Pada gambar 6 , terlihat bahwa, dengan nilai ketidakpastian yang didapatkan, hasil pengukuran mempunyai variasi yang memungkinkan masih berada di dalam batas toleransi. Pada umumnya, proses inspeksi akan menolak komponen tersebut karena berada di luar batas toleransi. Akan tetapi, berdasarkan standar ISO 14253-1, komponen tersebut masih dianggap berada di dalam batas toleransi dengan nilai ketidakpastian yang ada. Karena apabila pengukuran diulang, maka ada kemungkinan hasil pengukuran jatuh di dalam batas toleransi (gambar 6 bagian bawah). Begitu juga sebaliknya, apabila hasil pengukuran berada pada batas antara 10.05 $\mathrm{mm}-10.2 \mathrm{~mm}$ (gambar 6 bagian atas), maka silinder tersebut harus ditolak karena ada kemungkinan apabila pengukuran tersebut diulang, maka hasil pengukuran akan berada di luar batas $10.2 \mathrm{~mm}$. Hasil ini menunjukkan bahwa nilai ketidakpastian yang besar menghasilkan kemungkinan perselisihan, terhadap hasil pengukuran, menjadi tinggi.

- Apabila mengikuti standar ISO 14253-1, perusahaan A dapat mengirimkan silinder tersebut ke perusahaan B, apabila di dalam perjanjian jual beli tidak mencantumkan kondisi perselisihan seperti ini. Apabila ada perjanjian khusus antara perusahaan A dan B yang mengatakan bahwa semua komponen akan ditolak apabila berada di luar batas toleransi berapapun nilai ketidakpastian dari hasil pengukuran, maka perusahaan A harus menolak silinder tersebut. Namun demikian, perusahaan B harus mengerti mengenai ISO 14253-1.

- Dengan mengikuti ISO 14253-1, apabila tidak ada klausul khusus yang mengatur kondisi seperti ini di dalam perjanjian jual beli antara perusahaan A dan B, maka perusahaan B dapat menerima komponen tersebut.

- Untuk menghindari perselisihan seperti ini, dengan toleransi diameter silinder yang diberikan, yaitu (10 $\pm 0.2) \mathrm{mm}$, apabila hasil pengukuran tersebut adalah 10.3, hasil ketidakpastian yang tidak menimbulkan perselisihan haruslah $<0.1 \mathrm{~mm}$. Misal, apabila hasil pengukuran dari proses inspeksi diameter silinder tersebut mempunyai nilai 0.05 , yaitu hasil pengukuran adalah $(10.3 \pm 0.05) \mathrm{mm}$, maka silinder tersebut jelas dapat ditolak dan dianggap berada di luar batas toleransi. Hal ini disebabkan karena apabila pengukuran tersebut diulang, hasil pengukuran tidak ada berada di dalam batas toleransi (gambar 7). 

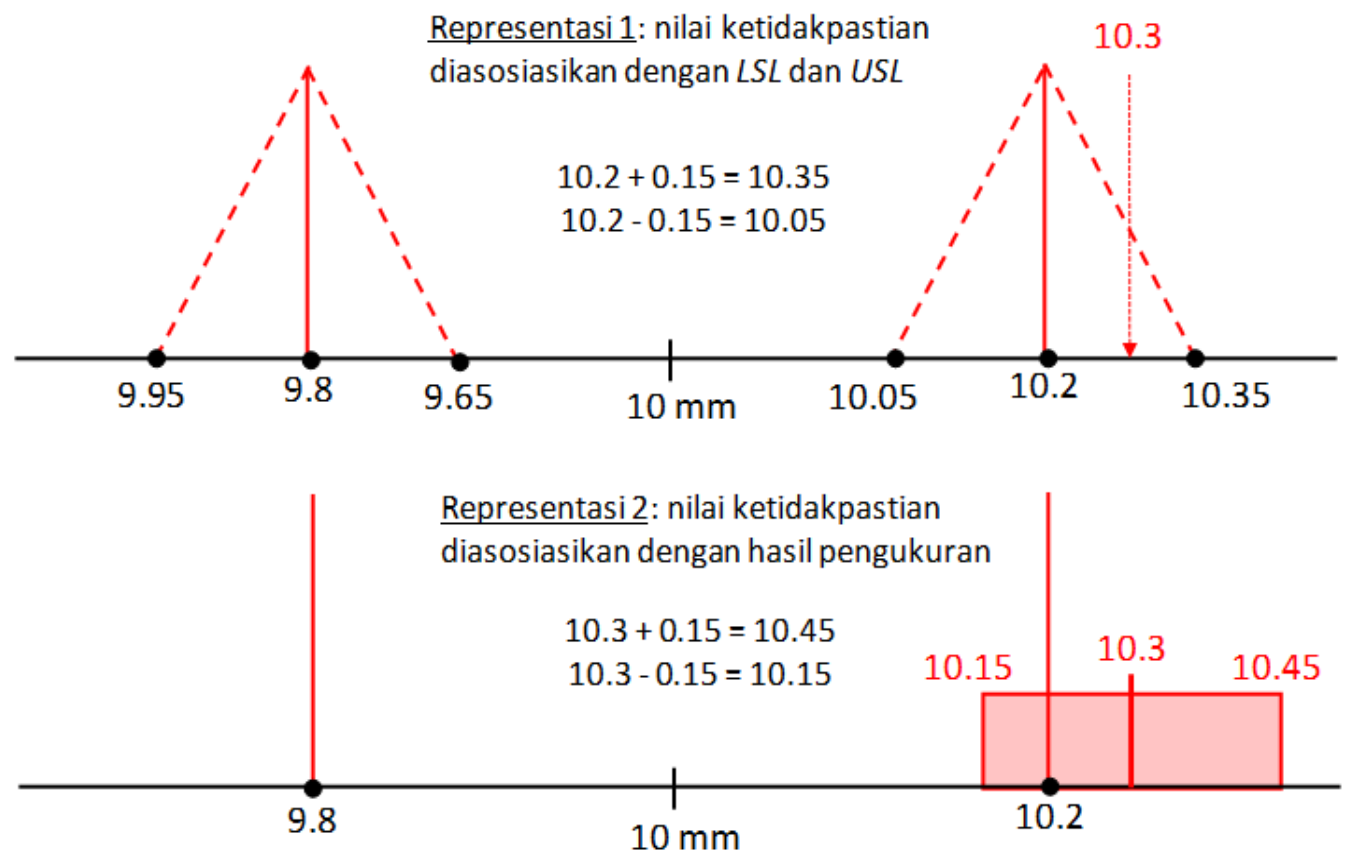

Gambar 6: Analisis untuk pengambilan keputusan accept/reject suatu komponen menggunakan dua macam grafik analisis untuk merepresentasikan ketidakpastian dalam proses pengambilan keputusan tersebut. Kedua grafik analisis tersebut dipresentasikan dengan dua macam model representasi yang bisa dipilih salah satunya.
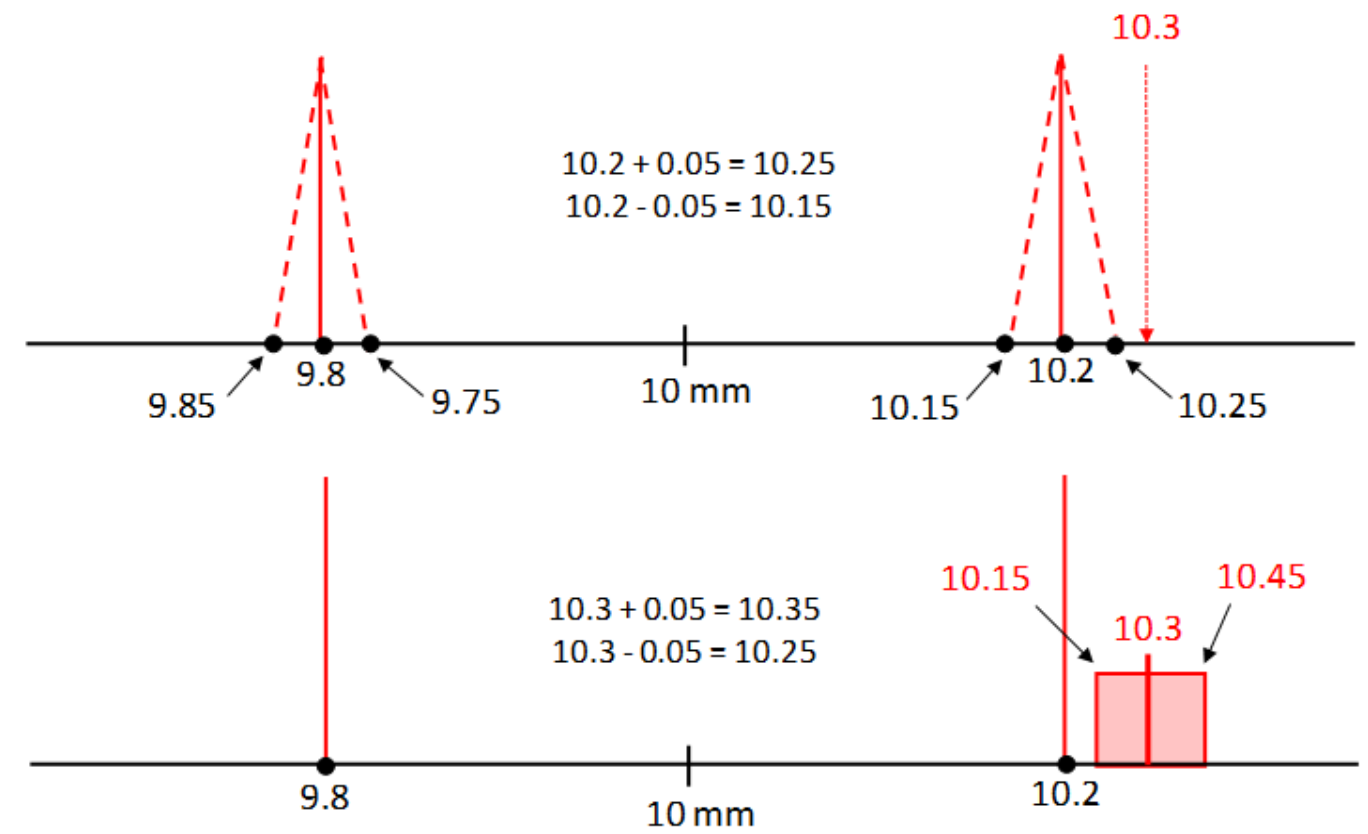

Gambar 7: Illustrasi dimana silinder tersebut dapat di-reject tanpa terjadi perselisihan. Hal ini menggambarkan bahwa semakin kecil nilai ketidakpastian, maka perselisihan dari suatu hasil pengukuran akan dapat dihindarkan. 


\subsection{Metode estimasi ketidakpastian}

Metode-metode ketidakpastian seluruhnya menggunakan metode-metode analisis statistik. Maka dari itu, pembaca diharapkan untuk membaca buku-buku statistik untuk mengetahui lebih dalam mengenai teori-teori dasar statistik, salah satunya buku yang ditulis oleh Montgomery (Montgomery 2003).

Untuk mengestimasi nilai ketidakpastian, pemahaman yang tinggi terhadap suatu proses pengukuran adalah sangat penting. Seluruh faktor-faktor utama yang paling berpengaruh (uncertainty sources) terhadap hasil pengukuran haruslah diperhitungkan. Ketidakpastian tidak cukup hanya mengukur beberapa kali dan mengkalkulasi $S$ deviasi standar dari rata-rata (persamaan 2). $S$ adalah hanya salah satu nilai yang berkontribusi terhadap nilai ketidakpastian secara keseluruhan.

Ketidakpastian adalah spesifik untuk suatu pengukuran tertentu (task specific) yang artinya bahwa nilai suatu ketidakpastian hanya diasosiasikan terhadap suatu hasil pengukuran tertentu, dengan alat ukur tertentu, pada kondisi lingkungan tertentu, oleh operator tertentu, dan kondisi lain yang spesifik untuk pengukuran tersebut. Nilai ketidakpastian haruslah reliabel untuk memprediksi bahwa hasil pengukuran tertentu akan bervariasi dalam batas interval tertentu dengan interval kepercayaan (confidence interval) minimal $95 \%$.

Metode untuk estimasi ketidakpastian dibagi menjadi dua bagian utama, yaitu:

- Formulasi

Pada tahap ini, metode untuk mengevaluasi ketidakpastian didefinisikan (misalnya: metode GUM, spreadsheet atau simulasi Monte-Carlo). Setelah metodenya ditentukan, semua kontributor utama (yang berpengaruh) kepada nilai ketidakpastian harus diikutsertakan. Hal ini harus berlandaskan pada pengetahuan yang menyeluruh terhadap suatu instrument dan proses pengukuran.

- Evaluasi

Pada tahap ini, proses kalkulasi nilai ketidakpastian yang spesifik (task specific) untuk suatu hasil pengukuran pada kondisi tertentu dilakukan.

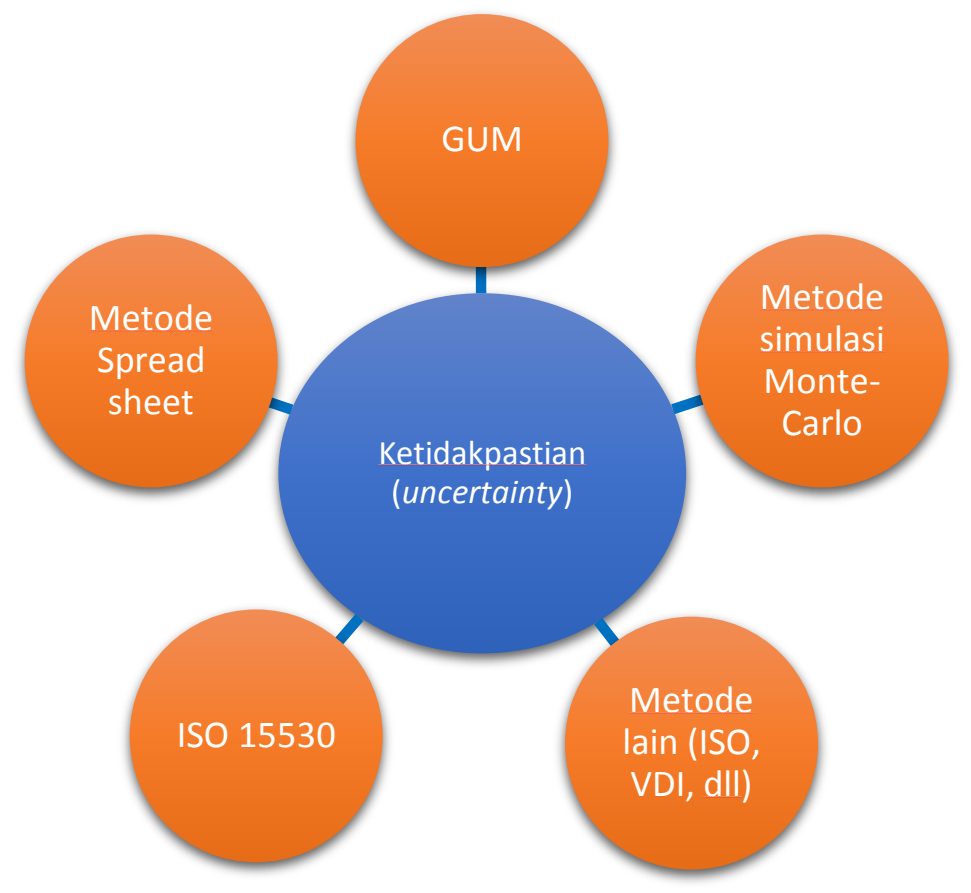

Gambar 8: Berbagai macam metode untuk mengestimasi nilai ketidakpastian suatu hasil pengukuran. 
Dari dua metode utama untuk mengestimasi ketidakpastian, dua langkah utama tersebut dapat dijabarkan dengan lebih detil ke dalam delapan langkah evaluasi (estimasi) ketidakpastian (Bell 1999), yaitu:

1. Berpikir ke depan (instrumen dan prosedur yang digunakan, aspek keselamatan)

2. Proses pengukuran

3. Estimasi faktor-faktor yang merupakan kontributor ketidakpastian

4. Pertimbangan faktor korelasi (pada umumnya korelasi diabaikan)

5. Kalkulasi hasil pengukuran (termasuk koreksi error)

6. Tentukan ketidakpastian yang terekspansi (95\% interval kepercayaan)

7. Ekspresikan hasil pengukuran dengan interval kepercayaan (dari nilai ketidakpastian)

8. Simpan dan dokumentasikan hasil pengukuran dan nilai ketidakpastiannya (untuk improvisasi ke depannya)

Metode-metode yang dapat digunakan untuk mengestimasi nilai ketidakpastian (langkah 3 - 6) adalah (Gambar 8):

1. Metode GUM

2. Metodel tabel (spreadsheet)

3. Metode simulasi Monte-Carlo

4. Metode ISO 15530

5. Metodel lain (standard ISO lain, standar VDI, dan lain-lain)

\subsection{Metode GUM}

Metode GUM (Guide to the Expression of Uncertainty in Measurement) adalah metode yang paling dasar, yang merupakan referensi utama, untuk mengevaluasi nilai ketidakpastian (BIPM 2008b). Metode GUM seluruhnya berdasarkan metode statistik. Sebelum membahas metode GUM dan metode-metode lainnya untuk menentukan ketidakpastian, konsep-konsep statistik dasar akan dibahas ulang secara singkat terlebih dahulu.

Setiap distribusi statistik, dua parameter utama yang paling umum untuk merepresentasikan distribusi tersebut adalah rata-rata (mean) dan variasi (variance) dari distribusi tersebut. Deviasi standar hanyalah akar kuadrat dari suatu nilai variasi. Nilai rata-rata (expected value) dan variasi dari sebuah distribusi statistik dapat diformulasikan sebagai:

$$
\begin{aligned}
& \mu=E(x)=\int_{-\infty}^{\infty} x f(x) d x \\
& \sigma^{2}=\operatorname{Var}(x)=\int_{-\infty}^{\infty}(x-E(x)) f(x) d x
\end{aligned}
$$

Dimana $x$ adalah variabel acak dengan suatu nilai distribusi statistik tertentu, $E(x)$ adalah nilai rata-rata (expected value) dari $\mathrm{x}$ dan $\operatorname{Var}(x)$ adalah variasi dari $x$. Ada dua properti utama dari $E(x)$ dan $\operatorname{Var}(x)$ yang sangat penting, yaitu:

$$
\begin{gathered}
E\left(C_{1} x_{1}+C_{2} x_{2}\right)=C_{1} E\left(x_{1}\right)+C_{2} E\left(x_{2}\right) \\
\operatorname{Var}\left(C_{1} x_{1}+C_{2} x_{2}\right)=C_{1}^{2} \operatorname{Var}\left(x_{1}\right)+C_{2}^{2} \operatorname{Var}\left(x_{2}\right)+2 C_{1} C_{2} \operatorname{Cov}\left(x_{1}, x_{2}\right)
\end{gathered}
$$

Formula dari persamaan $10-13$ akan digunakan untuk menurunkan formula GUM. Sebelum menurunkan formula GUM, penjelasan singkat mengenai fungsi kepadatan probabilitas (probability density function) dan fungsi kepadatan komulatif (comulative density function) akan dibahas terlebih dahulu.

Fungsi kepadatan probabilitas adalah sebuah fungsi yang menggambarkan probabilitas sebuah variabel acak akan sama dengan suatu sampel yang diambil dari ruang sampel tersebut. Sedangkan fungsi kepadatan kumulatif adalah sebuah fungsi probabilitas suatu variabel acak untuk mempunyai nilai kurang dari atau sama dengan suatu nilai $x$. Dengan kata lain, nilai maksimum dari fungsi kepadatan kumulatif sama dengan satu (integral dari fungsi kepadatan probabilitas). Bentuk kurva fungsi kepadatan probabilitas untuk distribusi normal (Gaussian) adalah menyerupai bentuk sebuah bel. Gambar 9 memperlihatkan bentuk kurva dari fungsi kepadatan probabilitas dan kepadatan kumulatif. Pada gambar 9, kurva fungsi kepadatan probabilitas memperlihatkan sebuah variabel acak yang mempunyai nilai rata-rata 0 dan mempunyai deviasi standar $\sigma$.

Kurva fungsi kepadatan probabilitas dibagi menjadi beberapa bagian. Gambar 10 memperlihatkan pembagian 
kurva fungsi kepadatan probabilitas. Total luas daerah di bawah kurva fungsi kepadatan probabilitas adalah 1. Apabila interval kepercayaan adalah $\sim 68 \%$, maka luas daerah di bawah kurva tersebut adalah sebanyak daerah yang dibatasi oleh $-\sigma$ sampai $\sigma$, dimana $\sigma$ adalah standar deviasi dari variabel acak $X$ (gambar 9 kiri). Pada umumnya, ketidakpastian direpresentasikan untuk mempunyai nilai interval kepercayaan sebesar $95 \%$, yaitu sebesar $2 \sigma(k=2)$. K adalah faktor ekspansi yang menunjukkan seberapa besar interval kepercayaan dari perhitungan statistik suatu variabel acak.

Fungsi kepadatan probabilitas

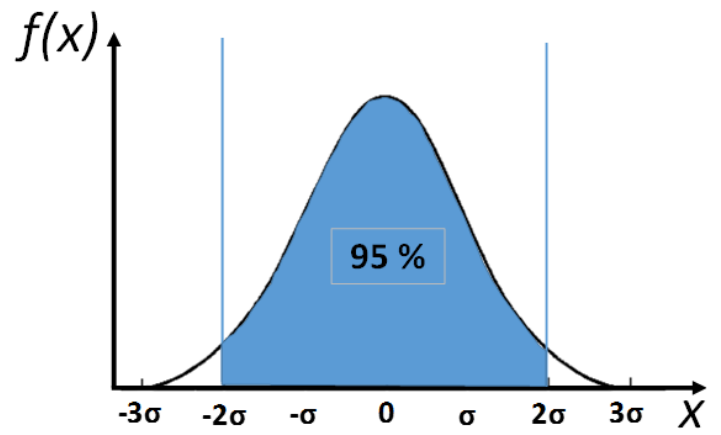

Fungsi kepadatan komulatif

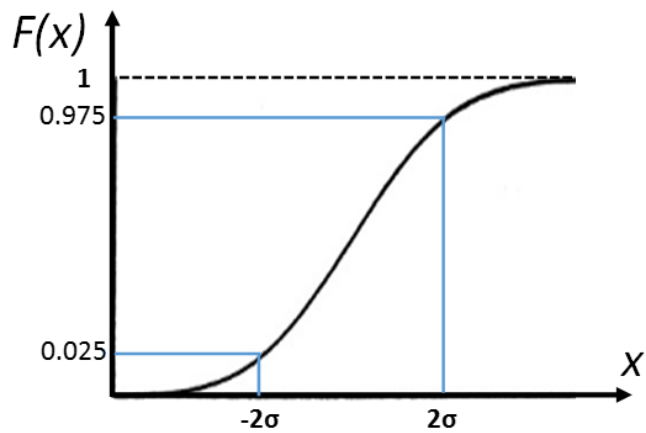

Gambar 9: (kiri) gambar kurva fungsi kepadatan probabilitas dan (kanan) kurva fungsi kepadatan kumulatif.

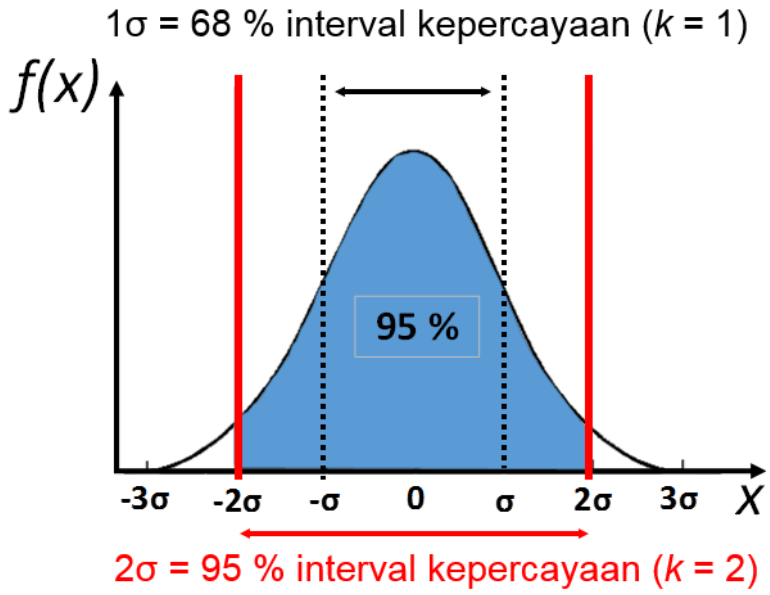

Gambar 10: Pembagian area dari kurva kepadatan probabilitas $(1 \sigma \sim 68 \%$ dan $2 \sigma \sim 95 \%)$. Daerah yang diarsir biru meliputi $95 \%$ dari seluruh luas di bawah kurva fungsi kepadatan probabilitas tersebut.

\section{Formula GUM}

Metode GUM menyatakan bahwa ketidakpastian dari sebuah hasil pengukuran harus dipropagasikan dari nilai ketidakpastian (uncertainty propagation) setiap komponen atau variabel yang mempengaruhi suatu pengukuran (BIPM 2008b). Metode GUM berlandaskan pada formula:

$$
u(Y)=\sqrt{\sum_{i=1}^{n}\left(\frac{\partial f}{\partial X_{i}}\right)^{2} u^{2}\left(X_{i}\right)+2 \sum_{i=1}^{n-1} \sum_{j=i+1}^{n} \frac{\partial f}{\partial X_{i}} \frac{\partial f}{\partial X_{j}} u\left(X_{i}, X_{j}\right)}
$$

Dimana $u(Y)$ adalah nilai ketidakpastian dari hasil pengukuran $Y$ atau sering disebutkan dengan standard uncertainty. $X_{i}$ adalah komponen ke- $i$ dari $n$ komponen yang mempengaruhi pengukuran. $u\left(X_{i}, X_{j}\right)$ adalah korelasi antara komponen $i$ dan $j$. 
Pada umumnya, ketidakpastian direpresentasikan dalam bentuk $95 \%$ interval kepercayaan. Maka dari itu, pada umumnya ketidakpastian direpresentasikan dengan $U$, yaitu ketidakpastian terekspansi (extended uncertainty). $U$ diformulasikan dengan:

$$
U=k \times u ; \quad k=2
$$

Proses untuk mendapatkan formula GUM adalah sebagai berikut. Formula GUM berasal dari sebuah proses ekspansi Taylor (Taylor expansion). Ekspansi Taylor adalah sebuah metode numerik yang bertujuan untuk melinearkan suatu fungsi yang non-linear. Misalkan sebuah fungsi non-linear $y$ :

$$
y=f\left(x_{1}, x_{2}, x_{3}, \ldots, x_{n}\right)
$$

Fungsi $y$ dapat dilinearkan dengan menggunakan metode ekspansi Taylor sampai dengan orde-pertama (Kreyszig 1999), yaitu menjadi:

$$
y=C_{1} x_{1}+C_{2} x_{2}+C_{3} x_{3}+\cdots+C_{n} x_{n}
$$

Dimana $C_{i}$ adalah koefisien ekspansi Taylor. Dengan menerapkan properti variasi (persamaan 13) kepada hasil ekspansi Taylor orde pertama dari fungsi y (persamaan 17), didapatkan:

$\operatorname{var}(y)=\operatorname{var}\left(C_{1} x_{1}\right)+\operatorname{var}\left(C_{2} x_{2}\right)+\cdots+2 \operatorname{cov}\left(C_{1} x_{1}, C_{2} x_{2}\right)+2 \operatorname{cov}\left(C_{2} x_{2}, C_{3} x_{3}\right)+\cdots$

Dimana $\operatorname{var}(c y)=C^{2} \mu^{2}$, Sehingga didapatkan:

$$
\begin{aligned}
& \mu_{y}^{2}=C_{1}^{2} \mu_{1}^{2}+C_{2}^{2} \mu_{2}^{2}+\cdots+2 C_{1} C_{2} \mu\left(x_{1}, x_{2}\right)+2 C_{2} C_{3} \mu\left(x_{2}, x_{3}\right)+\cdots \\
& u_{y}=\sqrt{C_{1}^{2} \mu_{1}^{2}+C_{2}^{2} \mu_{2}^{2}+\cdots+2 C_{1} C_{2} \mu\left(x_{1}, x_{2}\right)+2 C_{2} C_{3} \mu\left(x_{2}, x_{3}\right)+\cdots}
\end{aligned}
$$

Dari persamaan (20), persamaan metode GUM (persamaan 14) didapatkan. Sebagai kesimpulan, seperti dapat terlihat pada persamaan 14, evaluasi ketidakpastian dengan metode GUM membutuhkan sebuah fungsi yang mendefinisikan suatu proses pengukuran.

\section{Contoh 1: pengukuran dengan menggunakan jangka sorong (vernier caliper)}

Untuk lebih memahami metode GUM, sebuah contoh pengukuran dengan jangka sorong dipresentasikan. Pada sebuah pengukuran panjang gauge block, sebuah jangka sorong digunakan seperti diperlihatkan pada gambar 11. Pada gambar 10, memperlihatkan panjang dari gauge block yang diukur merupakan selisih dari dua skala ukur yang terbaca pada jangka sorong tersebut. Sehingga, fungsi pengukuran $Y$ dengan jangka sorong dapat diformuasikan dengan:

$$
Y=X_{2}-X_{1}
$$

$X_{1}$ dan $X_{2}$ adalah merupakan skala pengukuran dari jangka sorong tersebut. Hasil pembacaan pengukuran $X_{1}=0 \mathrm{~mm}$ dan $X_{2}=2.5 \mathrm{~mm}$. Maka panjang $Y$ adalah $2.5 \mathrm{~mm}$. Pengaruh temperatur diasumsikan dapat diabaikan.

Setelah fungsi pengukuran tersebut telah didefinisikan, maka metode GUM dapat diimplementasikan sebagai berikut:

$$
\begin{aligned}
& u(Y)=\sqrt{\left(\frac{\partial Y}{\partial X_{1}}\right)^{2} u\left(X_{1}\right)^{2}+\left(\frac{\partial Y}{\partial X_{2}}\right)^{2} u\left(X_{2}\right)^{2}} \\
& u(Y)=\sqrt{(-1)^{2} u\left(X_{1}\right)^{2}+(1)^{2} u\left(X_{2}\right)^{2}} \\
& u(Y)=\sqrt{u\left(X_{1}\right)^{2}+u\left(X_{2}\right)^{2}}
\end{aligned}
$$

Dengan asumsi bahwa ketidakpastian dari jangka sorong tersebut adalah sama untuk semua skala pengukuran, termasuk $X_{1}$ dan $X_{2}$, sehingga diasumsikan $u\left(X_{1}\right)=u\left(X_{2}\right)=0.1 \mathrm{~mm}$. Korelasi antara skala pengukuran diasumsikan 
dapat diabaikan. Ketidakpastian dari setiap skala $X_{1}$ dan $X_{2}$ diasumsikan didapatkan dari hasil kalibrasi jangka sorong tersebut. Maka, ketidakpastian dari pengukuran tersebut menjadi:

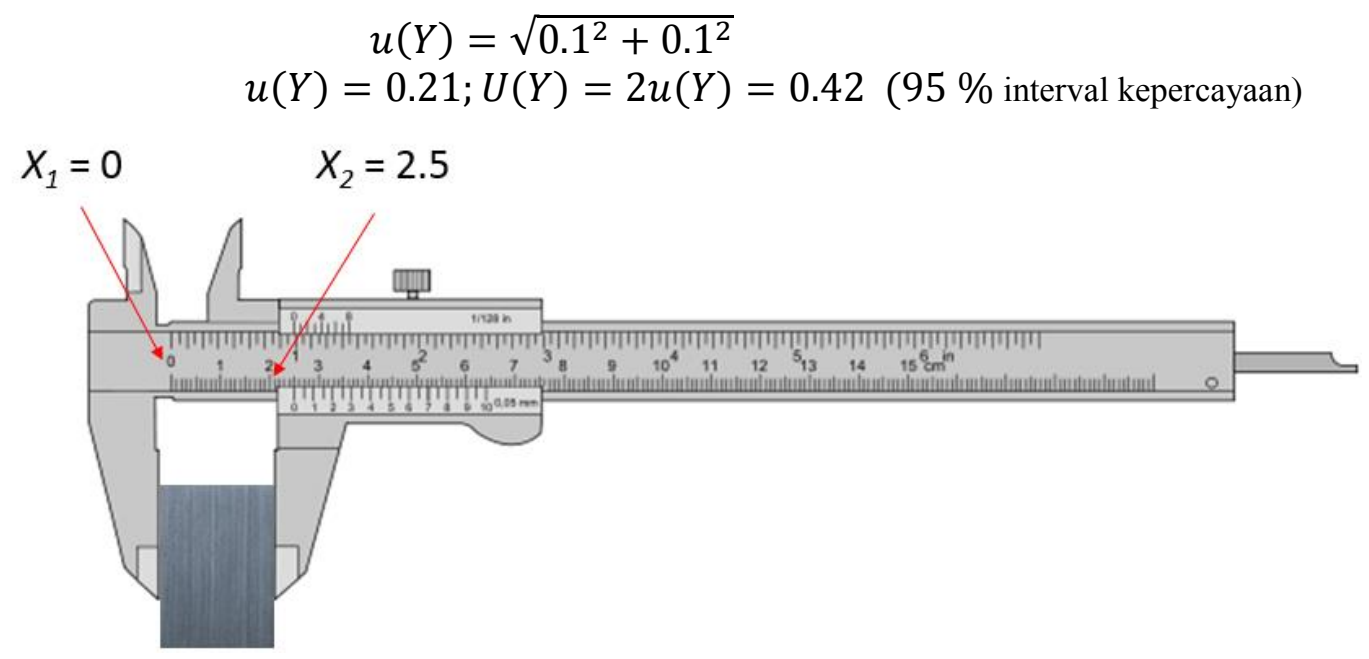

Gambar 11: Sebuah pengukuran gauge block dengan jangka sorong.

Akhirnya, hasil pengukuran tersebut adalah sebagai berikut:

- $\quad$ Panjang dari gauge block $=Y=(2.5 \pm 0.42) \mathrm{mm}$.

- Interval $0.42 \mathrm{~mm}$ adalah ketidakpastian $U$ dengan nilai perbesaran $k=2$ (expanded uncertainty) meliputi $95 \%$ interval kepercayaan (confidence interval), diasumsikan terdistribusi normal.

- Panjang $2.5 \mathrm{~mm}$ adalah rata-rata dari lima pengulangan pengukuran. Nilai ketidakpastian diestimasi menggunakan metode GUM. Pengukuran dilakukan di lantai produksi pada suhu $(25 \pm 0.5){ }^{\circ} \mathrm{C}$ oleh operator berpengalaman dan berkeahlian.

\section{Contoh 2: Pengukuran kekasaran $\boldsymbol{R}_{a}$ dan waviness $\boldsymbol{W}_{a}$.}

Tekstur permukaan adalah data hasil dari proses pengukuran yang sudah dipisahkan (filtered) dari komponen geometrinya (form) (Leach 2013). Misal, apabila kita mengukur sebuah permukaan bola, maka data mentah hasil pengukuran tersebut ( $3 \mathrm{D}$ point cloud) akan mempunyai bentuk permukaan berupa parabola. Bentuk parabola ini adalah form yang harus dipisahkan untuk mendapatkan data tekstur permukaan. Setelah form tersebut dipisahkan, maka data yang terukur menjadi datar karena komponen form-nya sudah dihilangkan. Pada saat kondisi inilah suatu tekstur permukaan didapatkan. Data tekstur permukaan tersebut yang sudah dipisahkan komponen form-nya dinamakan primary profile (profil primer). Primary profile $\left(P_{i}\right)$ dapat dibagi menjadi waviness profile $\left(W_{i}\right)$ dan roughnes profile $\left(R_{i}\right)$ dengan suatu proses filtering.

Pada proses pengukuran tekstur permukaan, proses filtering data adalah esensial untuk memisahkan data yang terukur (dalam hal ini merupakan spatial point cloud) ke dalam berbagai macam skala (Leach 2013). Sebagai contoh, apabila kita ingin mengukur kekasaran suatu tekstur permukaan, proses filtering dari data tekstur permukaan tersebut harud dipisahkan menjadi dua bagian, bagian data dengan frekuensi tinggi (kekasaran/roughness) dan bagian data dengan frekuensi rendah (waviness). Dari data dengan frekuensi tinggi (kekasaran) tersebut, proses kalkulasi parameter kekasaran permukaan, seperti $R_{a}, R_{q}$ dan $R_{z}$, dapat dilakukan.

Pada contoh ini, nilai ketidakpastian dari suatu poin data kekasaran permukaan dipresentasikan. Gambar 12 memperlihatkan proses pemisahan dari primary profile menjadi dua macam profil yang berbeda skala, yaitu waviness profile dan roughness profile. Nilai ketidakpastian dari data poin suatu waviness dan roughness akan dipresentasikan. Contoh ini memfokuskan pada lima poin data dari primary profile $\left(P_{i}\right)$ yang diterapkan proses filtering menjadi waviness profile $\left(W_{i}\right)$ dan roughnes profile $\left(R_{i}\right)$. 


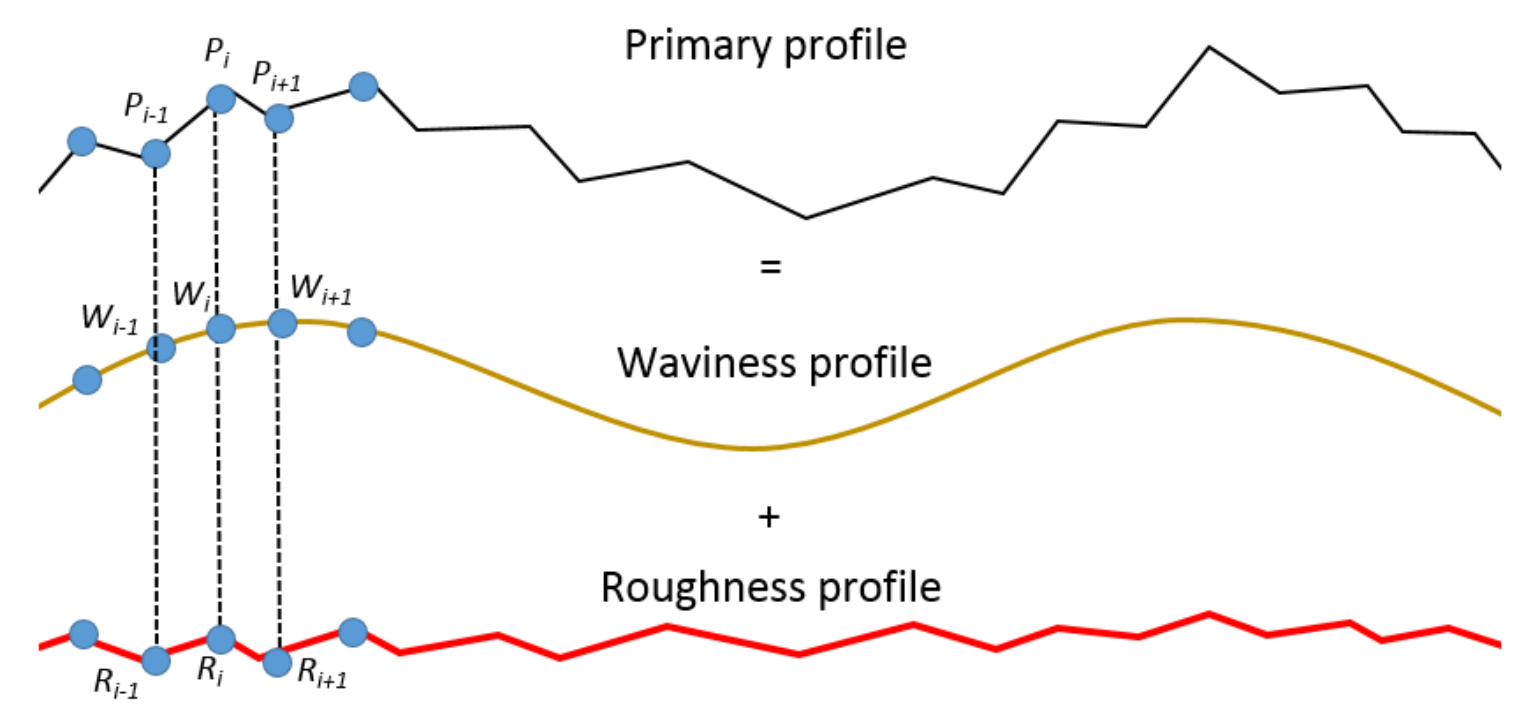

Gambar 12: Proses filtering data dari primary profile menjadi waviness profile dan roughness profile.

\section{Ketidakpastian dari poin data waviness $W_{i}$}

Diasumsikan sebuah filter rectangular digunakan untuk proses filtering atau pemisahan dari primary profile ke waviness profile. Filter rectangular tersebut terdiri dari tiga elemen $\left(S_{1}, S_{2}, S_{3}\right)$. Setiap filter $S_{i}$ mempunyai berat (weight) sebesar $1 / 3$ bagian, sehingga $S_{I}=S_{2}=S_{3}=1 / 3 . W_{a}$ adalah sebuah weighted average dari data poin primary profile dengan suatu filter, dalam contoh ini sebuah filter rectangular digunakan. Fungsi matematik dari proses filtering untuk mendapatkan poin data $W_{i}$ adalah sebagai berikut:

$$
Y=W_{i}=S_{1} P_{i-1}+S_{2} P_{i}+S_{3} P_{i+1}
$$

Dimana $W_{i}$ adalah data poin ke-i dari waviness profile yang didapatkan dari proses filtering primary profile. Maka, dengan menerapkan propogasi ketidakpastian dengan metode GUM, ketidakpastian dari fungsi $Y$ (yaitu poin data $W_{i}$ ) adalah:

$$
\begin{aligned}
& u(Y)=\sqrt{\left(\frac{\partial Y}{\partial P_{i-1}}\right)^{2} u\left(P_{i-1}\right)^{2}+\left(\frac{\partial Y}{\partial P_{i}}\right)^{2} u\left(P_{i}\right)^{2}+\left(\frac{\partial Y}{\partial P_{i+1}}\right)^{2} u\left(P_{i+1}\right)^{2}} \\
& u(Y)=\sqrt{S_{1}^{2} u\left(P_{i-1}\right)^{2}+S_{2}^{2} u\left(P_{i}\right)^{2}+S_{3}^{2} u\left(P_{i+1}\right)^{2}}
\end{aligned}
$$

Diasumsikan bahwa $u\left(P_{i-1}\right)=u\left(P_{i}\right)=u\left(P_{i+1}\right)=u(P)=1 . u(P)$ adalah nilai ketidakpastian setiap point dari hasil pengukuran (yang diasumsikan sudah diketahui untuk contoh kasus ini). Jika pengaruh nilai korelasi antara point $P_{i}$ diabaikan, maka didapatkan:

$$
u(Y)=u(P) \sqrt{\sum_{i=1}^{3} S_{i}}
$$

Sehingga didapatkan:

$$
u(Y)=u\left(W_{i}\right)=0.058
$$

Apabila nilai ketidakpastian dari $W_{i}$ dan $P_{i}$ dibandingkan, maka akan terlihat bahwa $u\left(W_{i}\right)<u\left(P_{i}\right)$. Hal ini disebabkan karena pada proses mendapatkan nilai $W_{i}$, efek dari pengrata-rataan (averaging effect) dari proses filtrasi data menurunkan nilai ketidakpastian yang terdapat pada data poin $P_{i}$. 


\section{Ketidakpastian dari poin data roughness $R_{i}$}

Dengan asumsi yang sama pada contoh waviness sebelumnya, seperti jenis filtrasi data dan jumlah elemen filtrasi data, nilai ketidakpastian dari poin data dapat $R_{i}$ dievaluasi. Dimulai dari penetapan fungsi matematik dari proses filtering untuk mendapatkan poin data $R_{i}$ sebagai berikut:

$$
\begin{aligned}
& Y=R_{i}=P_{i}-W_{i} \\
& Y=P_{i}-\left(S_{1} P_{i-1}+S_{2} P_{i}+S_{3} P_{i+1}\right) \\
& Y=-S_{1} P_{i-1}+\left(1-S_{2}\right) P_{i}-S_{3} P_{i+1} \\
& Y=\frac{2}{3} P_{i}-\frac{1}{3} P_{i-1}-\frac{1}{3} P_{i+1}
\end{aligned}
$$

Maka, dengan menerapkan propogasi ketidakpastian dengan metode GUM, ketidakpastian dari fungsi $Y$ adalah sebagai berikut:

$$
\begin{aligned}
& u(Y)=\sqrt{\left(\frac{\partial Y}{\partial P_{i-1}}\right)^{2} u\left(P_{i-1}\right)^{2}+\left(\frac{\partial Y}{\partial P_{i}}\right)^{2} u\left(P_{i}\right)^{2}+\left(\frac{\partial Y}{\partial P_{i+1}}\right)^{2} u\left(P_{i+1}\right)^{2}} \\
& u(Y)=\sqrt{\left(\frac{2}{3}\right)^{2} u\left(P_{i}\right)^{2}+\left(\frac{1}{3}\right)^{2} u\left(P_{i-1}\right)^{2}+\left(\frac{1}{3}\right)^{2} u\left(P_{i+1}\right)^{2}}
\end{aligned}
$$

Diasumsikan bahwa $u\left(P_{i-1}\right)=u\left(P_{i}\right)=u\left(P_{i+1}\right)=u(P)=1$ dan $S_{1}=S_{2}=S_{3}=1 / 3$. Jika pengaruh nilai korelasi antara point $P_{i}$ diabaikan, maka didapatkan:

$$
u(Y)=u(P) \sqrt{\frac{6}{9}}
$$

Sehingga didapatkan:

$$
u(Y)=u\left(R_{i}\right)=0.058
$$

Dari kedua contoh di atas, dapat dilihat bahwa untuk menerapkan metode GUM, fungsi matematik yang menghubungkan suatu entitas dengan sesuatu yang diukur (measurand) adalah sangat dibutuhkan secara mutlak.

\section{Kelemahan metode GUM}

GUM adalah metode yang menjadi rujukan utama dalam mengevaluasi nilai ketidakpastian. Namun demikian, metode GUM mempunyai beberapa kelemahan yang menyulitkan untuk diterapkan pada kondisi praktis yang sering ditemukan di industri. Beberapa kelemahan metode GUM adalah:

- Fungsi matematik yang merepresentasikan suatu pengukuran adalah mutlak dibutuhkan. Hal ini menyebabkan metode GUM pada umumnya sangat sulit diterapkan pada banyak kasus pengukuran pada umumnya. Pada umumnya, kasus pengukuran sangatlah kompleks untuk dimodelkan secara matematik, seperti pengukuran dengan CMM adalah suatu proses yan sangat rumit, sehingga fungsi matematik yang menggambarkan suatu pengukuran dengan CMM tidak ada.

- Walaupun fungsi matematik suatu pengukuran dapat direkonstruksi, namun pada umumnya fungsi matematik tersebut tidak dapat diturunkan secara matematik (atau dengan kata lain, fungsi matematik tersebut tidak kontiniu). Hal ini menyebabkan metode GUM tidak dapat diterapkan karena metode GUM membutuhkan turunan orde pertama dari fungsi matematik suatu pengukuran.

- Metode GUM membutuhkan perhitungan dan kalkulasi yang rumit, bahkan untuk contoh kasus paling sederhana seperti yang telah diperlihatkan pada dua contoh sebelumnya.

Karena metode GUM tidak dapat atau tidak efisien diterapkan untuk banyak kasus pengukuran, maka metode- 
metode lain untuk mengestimasi nilai ketidakastian dibutuhkan. Salah satu metode yang paling umum ditemui di industri dan banyak diterapkan dalam aplikasi-aplikasi praktis suatu pengukuran adalah metode tabel (spreadsheet).

\subsection{Metode tabel (spreadsheet)}

Metode tabel (spreadsheet) merupakan metode yang paling umum digunakan untuk mengevaluasi (mengestimasi) nilai ketidakpastian dari suatu hasil pengukuran. Metode tabel adalah alternatif dari metode GUM untuk suatu hasil pengukuran yang fungsi matematik dari pengukuran tersebut tidak atau belum tersedia. Pada prinsipnya, metode tabel mendaftar seluruh komponen-kompoen kontributor ketidakpastian yang paling berpengaruh kepada suatu hasil pengukuran.

Elemen-elemen utama metode tabel (spreadsheet) adalah (lihat tabel 2):

1. Sumber ketidakpastian (kontributor).

2. Nilai interval $( \pm)$.

Nilai interval $u\left(X_{i}\right)^{\prime}$ merupakan estimasi ketidakpastian dari setiap kontributor $X_{i}$.

3. Konversi dan deskripsi.

Proses konversi adalah proses untuk merubah suatu kontrobutor ketidakpastian $X_{i}$ apabila kontributor tersebut mempunyai satuan (unit) yang berbeda dengan fungsi suatu pengukuran $Y$. Untuk proses konversi, metode kalkulasi langsung (direct calculation) yang merupakan turunan parsial matematik dari $Y$ terhadap salah satu kontributor ketidakpastian $X_{i}$. Metode kalkulasi langsung adalah sebagai berikut:

$$
u\left(X_{i}\right)=\frac{\partial Y}{\partial X_{i}}=\left|f\left(X_{i}+u\left(X_{i}\right)\right)-f\left(X_{i}\right)\right|
$$

Apabila nilai ketidakpastian suatu kontributor $X_{i}$ sudah memiliki satuan yang sama dengan fungsi $Y$, maka proses konversi tidak perlu dilakukan.

4. Distribusi probabilitas dari kontributor ketidakpastian (poin 1).

5. Pembagi (divisor) $d_{i}$.

Pembagi bergantung kepada jenis distribusi ketidakpastian pada poin 4.

6. Koefisien sensitivitas $\mathrm{Ci}$.

Koefisien sensitivitas adalah suatu konstanta yang menggambarkan seberapa besar suatu kontributor ketidakpastian $X_{i}$ mempengaruhi nilai pengukuran $Y$. Koefisien sensitifitas didapatkan dari hasil turunan parsial Y terhadap $X_{i}$ sehingga pangkat dari suatu kontributor $X_{i}$ akan menjadi koefisien sensitivitas.

$$
C_{i}=\frac{\partial Y}{\partial X_{i}}
$$

7. Ketidakpastian standar (standard uncertainty $u$ ).

$$
u_{i}=C_{i} \frac{u\left(X_{i}\right)}{d_{i}}
$$

Tabel 2 memperlihatkan susunan dari tabel yang memuat seluruh elemen-elemen metode tabel yang disertakan dengan elemen-elemen yang harus dikalkulasi untuk mengevaluasi nilai ketidakpastian. Tabel 3 memperlihatkan beberapa pembagi (divisor) dari beberapa distribusi probabilitas yang umum dipakai. Untuk mengetahui lebih dalam megenai divisor ini, teorinya dapat dilihat di buku statistik (Montgomery dan Runger 2003).

Untuk ketidakpastian tipe A, distribusi normal selalu digunakan. Sedangkan untuk ketidakpastian tipe B, pada umumnya distribusi yang dipakai adalah rectangular (biasanya untuk ketidakpastian yang diturunkan dari suatu nilai toleransi dimensi), triangular dan U-shape.

Untuk nilai koefisien sensitivitas $C_{i}$, pada umumnya koefisien tersebut memiliki nilai satu. Hal ini lebih utama untuk menentukan koefisien sensitivitas untuk suatu ketidakpastian tipe B. Alasan lainnya adalah pada umunya metode tabel (spreadsheet) digunakan karena fungsi matematik dari suatu pengukuran $Y$ tidak tersedia. Sedangkan, untuk mengetahui nilai koefisien sensitivitas $C_{i}$, fungsi $Y$ tersebut harus diketahui karena turunan parsial akan diterapkan. Oleh sebab itu, maka pada umumnya nilai $C_{i}$ adalah satu.

Untuk mengetahui lebih jelas mengenai penggunaan metode tabel untuk evaluasi ketidakpastian, beberapa contoh yang sering ditemukan baik di industri maupun pada banyak kasus praktis pengukuran akan dipresentasikan. 
Tabel 2: Bentuk tabel metode spreadsheet (metode tabel) untuk evaluasi ketidakpastian.

\begin{tabular}{|c|c|c|c|c|c|c|}
\hline $\begin{array}{c}\begin{array}{c}\text { Kontributor } \\
\text { ketidakpastian }\end{array} \\
X_{i}\end{array}$ & $\begin{array}{c}\text { Nilai } \\
\text { interval } \\
u\left(X_{i}\right)^{\prime}\end{array}$ & $\begin{array}{c}\text { Konversi dan deskripsi } \\
u\left(X_{i}\right)=\left|f\left(X_{i}+u\left(X_{i}\right)\right)-f\left(X_{i}\right)\right|\end{array}$ & $\begin{array}{c}\text { Distribusi } \\
\text { probabilitas }\end{array}$ & $\begin{array}{c}\text { Divisor } \\
d_{i}\end{array}$ & $C_{i}=\frac{\partial Y}{\partial X_{i}}$ & $\begin{array}{c}\text { standard } \\
\text { uncertainty } \\
u_{i}=C_{i} \frac{u\left(X_{i}\right)}{d_{i}}\end{array}$ \\
\hline$X_{1}$ & $u\left(X_{I}\right)^{\prime}$ & & & & $C_{l}$ & $u_{1}$ \\
\hline$X_{2}$ & $u\left(X_{2}\right)^{\prime}$ & & & & $C_{2}$ & $u_{2}$ \\
\hline$\ldots$ & $\ldots$ & & & & $\ldots$ & $\ldots$ \\
\hline$X_{n}$ & $u\left(X_{n}\right)^{\prime}$ & & & & $C_{n}$ & $u_{n}$ \\
\hline $\begin{array}{l}\text { Combined } \\
\text { standard } \\
\text { uncertainty } \mu_{c}\end{array}$ & \multicolumn{5}{|c|}{ Asumsi distribusi normal } & $\begin{array}{l}u(Y)= \\
\sqrt{\sum_{i=1}^{N} u_{i}^{2}}\end{array}$ \\
\hline $\begin{array}{l}\text { Expanded } \\
\text { uncertainty } \\
U=k \mu_{c} \\
(95 \% \text { interval } \\
\text { kepercayaan } \\
k=2)\end{array}$ & \multicolumn{5}{|c|}{ Asumsi distribusi normal $k=2$} & $\begin{array}{l}U(Y)= \\
k \cdot u(Y)= \\
2 \cdot u(Y)\end{array}$ \\
\hline
\end{tabular}

Tabel 3: Divisor untuk beberapa distribusi statistik yang umum.

\begin{tabular}{|c|c|c|c|}
\hline Distribusi & Nilai & Divisor & standard uncertainty \\
\hline Normal & $\pm \mathrm{a}$ & 2 & $\mathrm{a} / 2$ \\
\hline Rectangular & $\pm \mathrm{a}$ & $\sqrt{ } 3$ & $\mathrm{a} / \sqrt{ } 3$ \\
\hline Triangular & $\pm \mathrm{a}$ & $\sqrt{ } 6$ & $\mathrm{a} / \sqrt{ } 6$ \\
\hline U-shaped & $\pm \mathrm{a}$ & $\sqrt{ } 2$ & $\mathrm{a} / \sqrt{2}$ \\
\hline
\end{tabular}

\section{Contoh 1: pengukuran $50 \mathrm{~mm}$ gauge block dengan menggunakan mikrometer.}

Pada contoh ini, sebuah proses kalibrasi mikrometer dengan mengukur sebuah gauge block terkalibrasi dengan panjang $50 \mathrm{~mm}$ dipresentasikan. Gambar 13 memperlihatkan proses pengukuran gauge block tersebut dengan sebuah mikrometer.

Langkah pertama untuk menerapkan metode tabel adalah dengan mendaftar semua kontributor-kontributor ketidakpastian suatu hasil pengukuran yang dianggap paling berpengaruh terhadap hasil pengukuran tersebut. Pada proses kalibrasi mikrometer tersebut, kontributor-kontributor ketidakpastian yang paling berpengaruh adalah:

- Ketidakpastian dari kalibrasi gauge block tersebut.

- Resolusi dari mikrometer tersebut

- Deviasi standar dari rata-rata (standard deviation of mean) dari pengulangan pengukuran dengan mikrometer tersebut

- Variasi temperatur pengukuran (berhubungan dengan ekspansi termal gauge block yang diukur)

- Error dari koefisien ekspansi termal gauge block tersebut. 


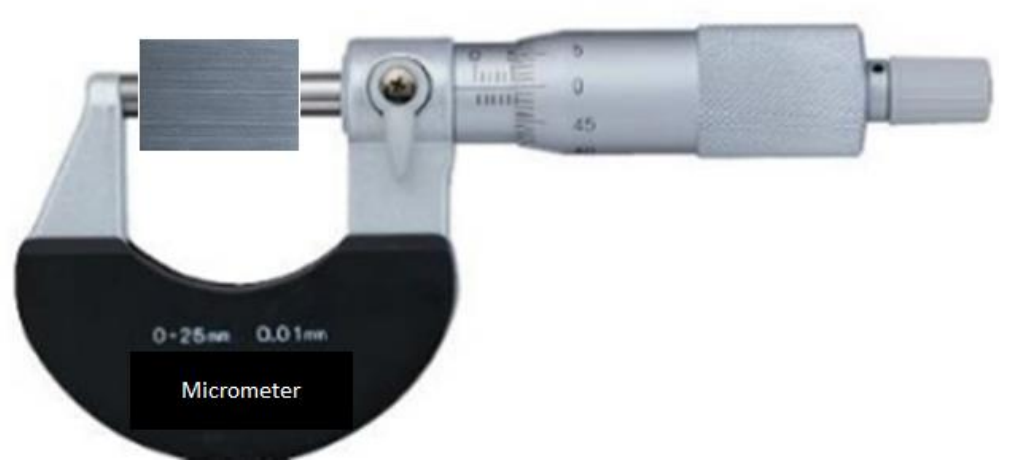

Gambar 13: Pengukuran sebuah gauge block dengan mikrometer.

Langkah pertama untuk mengetahui sumber-sumber ketidakpastian yang paling berpengaruh adalah dari model matematik pengukuran tersebut (apabila tersedia). Model pengukuran dari pengukuran mikrometer tersebut adalah:

$$
L=X_{\text {read }}+X_{\text {read }} \times \alpha \times \Delta T
$$

Dari model pengukuran tersebut, dapat terlihat bahwa resolusi dari skala pengukuran mikrometer tersebut $X_{\text {read }}$, koefisien ekspansi termal $\alpha$, temperature $T$ pada saat pengukuran berlangsung dan hasil kalibrasi gauge block (dari sertifikasi kalibrasi) adalah sumber-sumber ketidakpastian yang paling utama. Maka dari itu, uncertainty budget (anggaran ketidakpastian) dari pengukuran mikrometer tersebut dapat dipresentasikan seperti yang terdapat pada tabel 4 .

Penjelasan dari tabel ketidakpastian pada tabel 4 adalah sebagai berikut:

- Ketidakpastian dari kalibrasi gauge block.

Setiap benda kerja (artefak) yang terkalibrasi harus memiliki sertifikasi. Di dalam sertifikasi kalibrasi tersebut akan tercantum nilai ketidakpastian terekspansi (extended uncertainty). Pada umumnya, distribusi normal diasumsikan sehingga untuk mendapatkan $u_{i}$, maka ketidakpastian terekspansi tersebut dibagi dua.

- Resolusi dari mikrometer tersebut.

Ketidakpastian dari resolusi selalu menjadi salah satu sumber ketidakpastian suatu pengukuran panjang. Karena keterbatasan resolusi, hasil pengukuran yang berada di antara skala resolusi tidak dapat ditentukan. Ketidakpastian yang bersumber dari resolusi pada umumnya diasumsikan terdistribusi rectangular, sehingga nilai $u_{i}$ didapatkan dari setengah dari resolusi dibagi dengan $\sqrt{3}$.

- Deviasi standar dari rata-rata (standard deviation of mean).

Untuk ketidakpastian yang bersumber dari pengulangan pengukuran, deviasi standar dari rata-rata digunakan untuk mengestimasi kontribusi ketidakpastian dari proses pengulangan pengukuran tersebut. Perlu diperhatikan bahwa hal ini berbeda dengan standar deviasi. Sumber ketidakpastian dari pengulangan pengukuran juga meliputi sumber-sumber ketidakpastian lain yang tidak termasuk di dalam daftar ketidakpastian dalam metode tabel ini, seperti kesalahan operator membaca skala.

- Variasi temperatur pengukuran.

Variasi temperatur dan error dari koefisien ekspansi termal mempunyai satuan yang berbeda dengan hasil pengukuran $Y$. Maka dari itu, proses konversi satuan harus dilakukan. Untuk mengkonversi variasi temperatur dan error koefisien ekspansi termal tersebut menjadi satuan panjang $(\mu \mathrm{m})$, metode kalkulasi langsung (direct calculation method) harus diterapkan (seperti yang telah dijelaskan sebelumnya). Metode kalkulasi langung dapat diterapkan pada fungsi dengan variabel tunggal maupun dengan multi variabel, yaitu: 
Tabel 4: Uncertainty budget dan estimasi ketidakpastian dengan metode tabel.

\begin{tabular}{|c|c|c|c|c|c|c|}
\hline $\begin{array}{c}\text { Kontributor } \\
\text { ketidakpastian } \\
X_{i} \\
\end{array}$ & $\begin{array}{c}\text { Nilai } \\
\text { interval } \\
u\left(X_{i}\right)^{\prime}\end{array}$ & $\begin{array}{c}\text { Konversi dan deskripsi } \\
u\left(X_{i}\right)=\left|f\left(X_{i}+u\left(X_{i}\right)\right)-f\left(X_{i}\right)\right|\end{array}$ & $\begin{array}{c}\text { Distribusi } \\
\text { probabilitas }\end{array}$ & $\begin{array}{c}\text { Divisor } \\
d_{i}\end{array}$ & $C_{i}=\frac{\partial Y}{\partial X_{i}}$ & $\begin{array}{c}\text { standard } \\
\text { uncertainty } \\
u_{i}=C_{i} \frac{u\left(X_{i}\right)}{d_{i}}\end{array}$ \\
\hline $\begin{array}{l}\text { Ketidakpastian } \\
\text { kalibrasi gauge block }\end{array}$ & $0.03 \mu \mathrm{m}$ & \begin{tabular}{|l|} 
Nilai dari ketidakpastian \\
kalibrasi yang terdapat dari \\
sertifikat kalibrasi adalah \\
nilai expanded uncertainty $U$ \\
dengan $k=2$. TYPE B. \\
\end{tabular} & Normal & 2 & 1 & $0.015 \mu \mathrm{m}$ \\
\hline $\begin{array}{l}\text { Resolusi skala } \\
\text { pengukuran } \\
\text { mikrometer }\end{array}$ & $0.005 \mathrm{~mm}$ & $\begin{array}{l}\text { Resolusi diasumsikan } \\
\text { sebagai distribusi rectangular } \\
\text { dengan } \sigma(\text { deviasi standar })= \\
\text { half-resolution } / \sqrt{ } 3 \text {. TYPE B. }\end{array}$ & Rectangular & $\sqrt{3}$ & 1 & $1.44 \mu \mathrm{m}$ \\
\hline $\begin{array}{l}\text { Deviasi standar dari } \\
\text { rata-rata dari } n=10 \\
\text { pengukuran } \\
\text { (repeatability) }\end{array}$ & $3.162 \mu \mathrm{m}$ & $\begin{array}{c}u\left(X_{i}\right)=\frac{\sigma}{\sqrt{n}} ; \sigma=\sqrt{\frac{\left(\bar{x}-x_{i}\right)^{2}}{N-1}} \\
\text { TYPE A. }\end{array}$ & Normal & 1 & 1 & $3.162 \mu \mathrm{m}$ \\
\hline $\begin{array}{l}\text { Variasi temperatur } \\
\mu(\text { temp })\end{array}$ & $0.5^{\circ} \mathrm{C}$ & 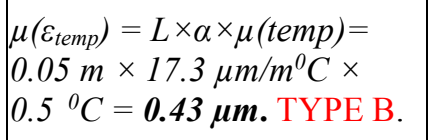 & Normal & 1 & 1 & $0.43 \mu \mathrm{m}$ \\
\hline $\begin{array}{l}\text { Error dari koefisien } \\
\text { termal ekspansi atau } \\
\text { CTE } \mu(\alpha) \text { (umumnya } \\
\text { diasumsikan } 10 \% \\
\text { dari nilai CTE } \\
\text { tersebut) } \\
\end{array}$ & $\begin{array}{l}10 \% \text { of } \\
\text { SS304 } \\
\text { CTE }\end{array}$ & 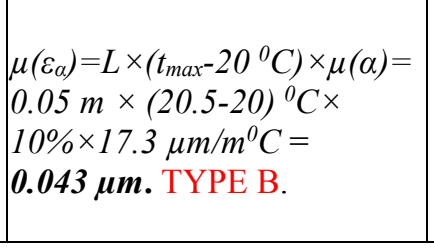 & Normal & 1 & 1 & $0.043 \mu \mathrm{m}$ \\
\hline $\begin{array}{l}\text { Combined standard } \\
\text { uncertainty } \mu_{c}\end{array}$ & \multicolumn{5}{|c|}{ Asumsi distribusi normal } & $3.5 \mu \mathrm{m}$ \\
\hline $\begin{array}{l}\text { Expanded uncertainty } \\
U=k \mu_{c} \\
(95 \% \text { interval } \\
\text { kepercayaan } k=2)\end{array}$ & \multicolumn{5}{|c|}{ Asumsi distribusi normal $k=2$} & $7 \mu \mathrm{m}$ \\
\hline
\end{tabular}


Fungsi satu variabel:

Sebuah fungsi pengukuran $Y=f(X)$, dimana $X$ mempunyai satuan yang berbeda dengan $Y$. Maka dengan proses konversi satuan, nilai ketidakpastian $\mathrm{u}(\mathrm{Y})$ akibat dari variasi $X$, dinotasikan dengan $u(X)$, adalah:

$$
u(Y)=|f(X+u(X))-f(X)|
$$

Fungsi multi-variabel:

Sebuah fungsi pengukuran $Y=f\left(X_{1}, X_{2}, X_{3}, \ldots, X_{n}\right)$, dimana $X_{i}$ mempunyai satuan yang berbeda dengan $Y$. Maka dengan proses konversi satuan, nilai ketidakpastian $\mathrm{u}(\mathrm{Y})$ akibat dari variasi $X_{i}$, dinotasikan dengan $u\left(X_{i}\right)$, adalah:

$$
\begin{aligned}
& u\left(Y_{1}\right)=\left|f\left(X_{1}+u\left(X_{1}\right), X_{2}, \ldots, X_{n}\right)-f\left(X_{1}, X_{2}, \ldots, X_{n}\right)\right| \\
& u\left(Y_{n}\right)=\left|f\left(X_{1}, X_{2}, \ldots, X_{n}+u\left(X_{n}\right)\right)-f\left(X_{1}, X_{2}, \ldots, X_{n}\right)\right|
\end{aligned}
$$

Sehingga, konversi variasi temperatur terhadap variasi panjang gauge block adalah:

$u\left(\varepsilon_{\text {temp }}\right)=\left|f\left(X_{1}+u\left(X_{1}\right), X_{2}, \ldots, X_{n}\right)-f\left(X_{1}, X_{2}, \ldots, X_{n}\right)\right|$

$\mu\left(\varepsilon_{\text {temp }}\right)=L \times \alpha \times \mu($ temp $)=0.05 \mathrm{~m} \times 17.3 \mu \mathrm{m} / \mathrm{m}^{0} \mathrm{C} \times 0.5^{0} \mathrm{C}=\mathbf{0 . 4 3} \boldsymbol{\mu m}$

- $\quad$ Error dari koefisien ekspansi termal gauge block.

konversi error dari koefisien ekspansi termal terhadap variasi panjang gauge block adalah:

$u\left(\varepsilon_{\alpha}\right)=\left|f\left(X_{1}+u\left(X_{1}\right), X_{2}, \ldots, X_{n}\right)-f\left(X_{1}, X_{2}, \ldots, X_{n}\right)\right|$

$u\left(\varepsilon_{\alpha}\right)=\left|\left(X_{\text {read }}+X_{\text {read }}\left(\alpha+\varepsilon_{\alpha}\right) \Delta T\right)-\left(X_{\text {read }}+X_{\text {read }} \times \alpha \times \Delta T\right)\right|$

$u\left(\varepsilon_{\alpha}\right)=\left|\left(X_{\text {read }} \times \Delta T\right) \varepsilon_{\alpha}\right|$

$\mu\left(\varepsilon_{\alpha}\right)=L \times\left(t_{\max }-20{ }^{0} \mathrm{C}\right) \times \mu(\alpha)=0.05 \mathrm{~m} \times(20.5-20){ }^{0} \mathrm{C} \times 10 \% \times 17.3 \mu \mathrm{m} / \mathrm{m}^{0} \mathrm{C}=\mathbf{0 . 0 4 3} \boldsymbol{\mu m}$

Akhirnya, hasil pengukuran mikrometer tersebut adalah sebagai berikut:

- $\quad$ Panjang dari gauge block $=Y=(50 \pm 0.007) \mathrm{mm}$.

- Interval $0.007 \mathrm{~mm}$ adalah ketidakpastian $U$ dengan nilai perbesaran $k=2$ (expanded uncertainty) meliputi $95 \%$ interval kepercayaan (confidence interval), diasumsikan terdistribusi normal.

- Panjang $50 \mathrm{~mm}$ adalah rata-rata dari sepuluh pengulangan pengukuran. Nilai ketidakpastian diestimasi menggunakan metode tabel (spreadsheet). Pengukuran dilakukan di laboratorium terkontrol pada suhu ( $25 \pm$ $0.5)^{\circ} \mathrm{C}$ oleh operator berpengalaman dan berkeahlian.

\section{Contoh 2: pengukuran berat jenis (density) $\rho$ suatu bola dengan volume $V$ dan massa $m$.}

Pada contoh ini, sebuah pengukuran berat jenis $\rho$ dipresentasikan. Model pengukuran berat jenis tersebut adalah sebagai berikut:

$$
\rho=\frac{m}{v}=\frac{6 m}{\pi d^{3}}
$$

dari model pengukuran tersebut, dapat terlihat bahwa komponen yang berkontribusi terhadap ketidakpastian dari pengukuran berat jenis bola tersebut adalah masa $m$ dan diameter $d$ dari bola tersebut.

Misalkan hasil estimasi berat jenis $\rho$ tersebut adalah dengan menggunakan nilai rata-rata pengukuran masa $m$ dan diameter $d$ bola tersebut dari beberapa pengulangan, yaitu:

- $\quad$ Nilai rata-rata dari diameter $d$ bola tersebut $=2.475 \mathrm{~cm}$.

- $\quad$ Nilai rata-rata dari masa $m$ bola tersebut $=19.7 \mathrm{~g}$.

- Maka, dari formula perhitungan mas ajneis bola tersebut, didapatkan masa jenis $\rho=2.49 \mathrm{~g} . \mathrm{cm}^{-3}$.

Nilai ketidakpastian dari masa jenis bola tersebut dianalisis dengan menggunakan metode tabel seperti yang 
diperlihatkan pada tabel 5. Pada tabel 5, hanya ada dua kontributor ketidakpastian terhadap hasil pengukuran ketidakpastian tersebut. Untuk kontributor ketidakpastian dari diameter $d$, dapat terlihat bahwa diameter $d$ tersebut mempunyai pangkat tiga pada persamaan model pengukuran masa jenis $\rho$ tersebut. Maka dari itu, Koefisien sensitivitas dari variabel $d$ tersebut mempunyai nilai tiga.

Tabel 6 memperlihatkan beberapa relasi yang umum dalam menentukan suatu nilai koefisien $C_{i}$ dalam metode tabel. Perlu diperhatikan bahwa nilai yang paling umum untuk koefisien $C_{i}$ tersebut adalah satu atau nilai pangkat dari variabel yang merupakan kontributor dari ketidakpastian.

Tabel 5: Uncertainty budget dan estimasi ketidakpastian dari hasil pengukuran $\rho$.

\begin{tabular}{|c|c|c|c|c|c|c|}
\hline $\begin{array}{c}\text { Kontributor } \\
\text { ketidakpastian } \\
X_{i}\end{array}$ & $\begin{array}{c}\text { Nilai } \\
\text { interval } \\
u\left(X_{i}\right)^{\prime}\end{array}$ & $\begin{array}{c}\text { Konversi dan deskripsi } \\
u\left(X_{i}\right)=\left|f\left(X_{i}+u\left(X_{i}\right)\right)-f\left(X_{i}\right)\right|\end{array}$ & $\begin{array}{c}\text { Distrib } \\
\text { usi } \\
\text { probab } \\
\text { ilitas }\end{array}$ & $\begin{array}{c}\text { Divisor } \\
d_{i}\end{array}$ & $C_{i}=\frac{\partial Y}{\partial X_{i}}$ & $\begin{array}{c}\text { standard } \\
\text { uncertainty } \\
u_{i}=C_{i} \frac{u\left(X_{i}\right)}{d_{i}}\end{array}$ \\
\hline Diameter & $\begin{array}{c}0.0022 \\
\mathrm{~cm}\end{array}$ & $\begin{array}{l}\text { Konversi dengan menggunakan } \\
\text { direct method }\end{array}$ & normal & 1 & $\begin{array}{c}3(d \\
\text { berpang } \\
\text { kat 3) }\end{array}$ & $0.0066 \mathrm{~g} . \mathrm{cm}^{-3}$ \\
\hline Masa & $0.03 \mathrm{~g}$ & $\begin{array}{l}\text { Konversi dengan menggunakan } \\
\text { direct method }\end{array}$ & normal & 1 & 1 & $0.0038 \mathrm{~g} . \mathrm{cm}^{-3}$ \\
\hline $\begin{array}{l}\text { Combined } \\
\text { standard } \\
\text { uncertainty } \mu_{c}\end{array}$ & \multicolumn{5}{|c|}{ Asumsi distribusi normal } & $0.0076 \mathrm{~g} . \mathrm{cm}^{-3}$ \\
\hline $\begin{array}{l}\text { Expanded } \\
\text { uncertainty } \\
U=k \mu_{c} \\
(95 \% \text { interval } \\
\text { kepercayaan } \\
k=2)\end{array}$ & \multicolumn{5}{|c|}{ Asumsi distribusi normal $k=2$} & $0.0152 \mathrm{~g} . \mathrm{cm}^{-3}$ \\
\hline
\end{tabular}

Tabel 6: Beberapa relasi dari koefisien sensitivitas $\mathrm{C} i$.

\begin{tabular}{|c|c|l|}
\hline $\begin{array}{c}\text { Fungsi } y=f(x), \\
\text { dimana } c \text { adalah } \\
\text { konstanta }\end{array}$ & $\begin{array}{c}\text { Propagasi ketidakpastian } \\
\text { (uncertainty propagation })\end{array}$ & \multicolumn{1}{|c|}{ Deskripsi } \\
\hline$y=x+c$ & $u(y)=u(x)$ & Ketidakpastian tidak terpengaruh \\
\hline$y=c \cdot x$ & $\frac{u(y)}{y}=\frac{u(x)}{x}$ & Ketidakpastian relatif tidak terpengaruh \\
\hline$y=x^{c}$ & $\frac{u(y)}{y}=c \frac{u(x)}{x}$ & $\begin{array}{l}\text { Ketidakpastian relatif menjadi besar dengan faktor } c . \\
\text { Efek ini sangat umum ditemui dan harus selalu } \\
\text { diperhatikan }\end{array}$ \\
\hline$y=\log (x)$ & $u(y)=\frac{u(x)}{x}$ & $\begin{array}{l}\text { Ketidakpastian absolut pada } y \text { adalah ketidakpastian } \\
\text { relatif pada } x\end{array}$ \\
\hline$y=e^{x}$ & $\frac{u(y)}{y}=x$ & $\begin{array}{l}\text { Ketidakpastian relatif pada } y \text { adalah ketidakpastian } \\
\text { absolut pada } x\end{array}$ \\
\hline
\end{tabular}


Akhirnya, hasil pengukuran berat jenis tersebut adalah sebagai berikut:

- $\quad$ Masa jenis $\rho$ dari bola tersebut $=(2.49 \pm 0.0152) \mathrm{g} . \mathrm{cm}^{-3}$.

- Interval $0.0152{\mathrm{~g} . \mathrm{cm}^{-3}}^{3}$ adalah ketidakpastian $U$ dengan nilai perbesaran $k=2$ (expanded uncertainty) meliputi $95 \%$ interval kepercayaan (confidence interval), diasumsikan terdistribusi normal.

- Masa jenis $\rho=2.49 \mathrm{~g} . \mathrm{cm}^{-3}$ dikalkulasi dari nilai masa $m$ dan diameter $d$ yang merupakan rata-rata dari sepuluh pengulangan pengukuran dari $m$ dan $d$ tersebut. Nilai ketidakpastian diestimasi menggunakan metode tabel (spreadsheet). Pengukuran dilakukan di laboratorium terkontrol pada suhu $(25 \pm 0.5){ }^{0} \mathrm{C}$ oleh operator berpengalaman dan berkeahlian.

Karena suatu hasil pengukuran adalah "task specific", dengan metode tabel (spreadsheet), setiap jenis pengukuran membutuhkan pengulangan langkah-langkah yang sama. Maka dari itu, dibutuhkan sebuah metode universal dan fleksibel untuk mengevaluasi ketidakpastian "task specific" dari berbagai macam situasi dan jenis pengukuran. Metode simulasi Monte-Carlo merupakan salah satu solusi untuk situasi ini.

\subsection{Metode simulasi Monte-Carlo}

Metode simulasi Monte-Carlo merupakan metode yang paling ideal untuk mengevaluasi nilai ketidakpastian suatu hasil pengkuran yang bersifat "task specific" (Syam 2015). Keuntungan-keuntungan metode simulasi MonteCarlo adalah metode ini fleksibel dan dapat diterapkan untuk semua jenis pengukuran, walaupun fungsi matematik dari suatu pengukuran tidak tersedia (Syam 2015, Moroni et al 2015). Salah satu kelemahan metode simulasi MonteCarlo adalah metode ini membutuhkan komputasi yang sangat intensif, tetapi dengan kemajuan teknologi komputasi sekarang ini dan dengan semakin turunnya biaya komputasi, maka kelemahan ini dapat teratasi. Gambar 14 memperlihatkan tahapan-tahapan metode simulasi Monte-Carlo untuk mengestimasi nilai ketidakpastian.
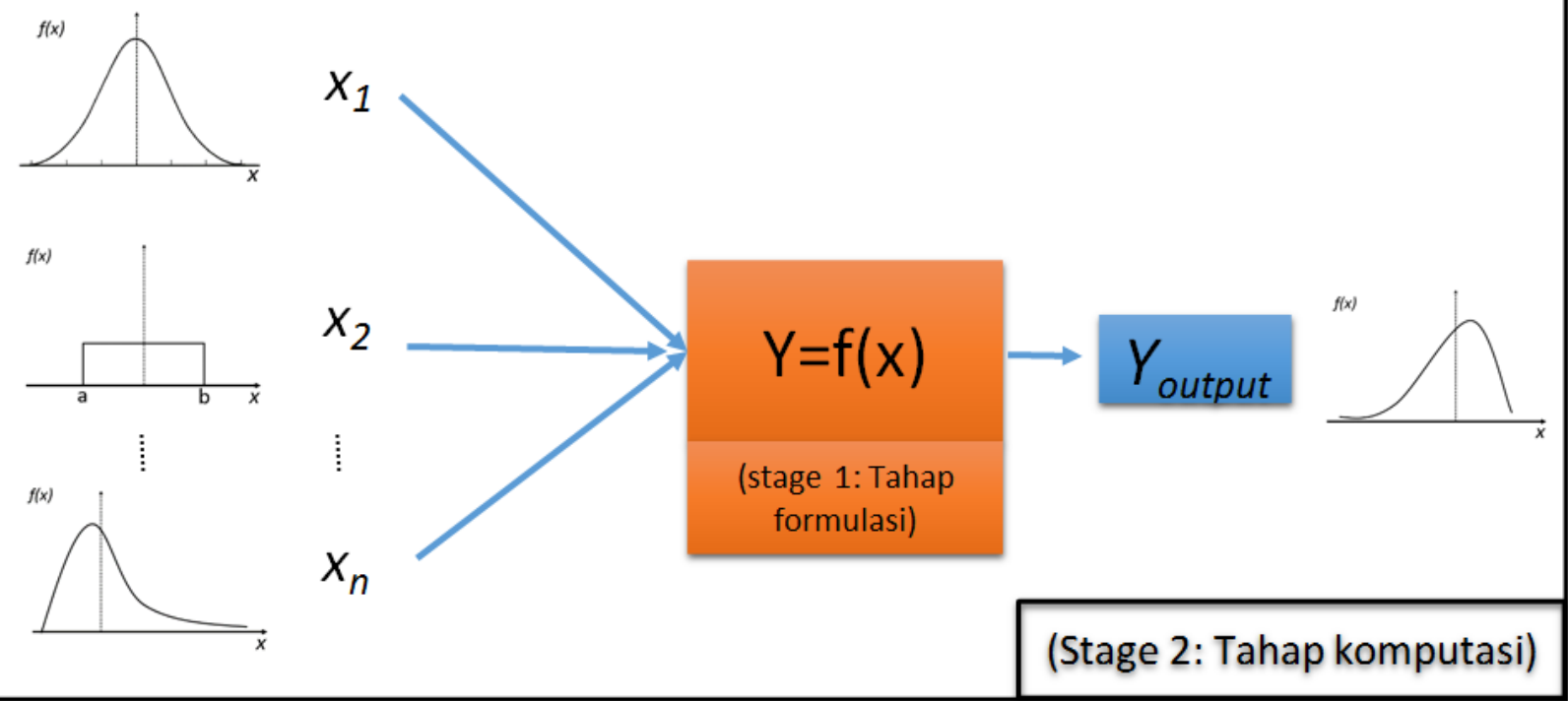

Gambar 14: Infrastruktur metode simulasi Monte-Carlo.

Tahapan dari metode simulasi Monte-Carlo adalah (gambar 14):

1. Tahapan formulasi.

Pada tahap ini, formulasi suatu pengukuran dilakukan. Formulasi pada tahap ini tidak harus untuk menentukan fungsi matematis dari suatu proses pengukuran. Karena, seperti yang telah disebutkan sebelumnya, salah satu keuntungan metode simulasi Monte-Carlo yang utama adalah fungsi matematik dari suatu pengukuran tidak diperlukan. Yang paling utama, pada tahap ini, measurand atau properti yang akan 
diukur harus didefinisikan dengan jelas.

2. Tahapan komputasi.

Tahap ini merupakan inti dari metode simulasi Monte-Carlo. Pada tahap ini, proses propagasi ketidakpastian dari setiap kontributor dilakukan. Proses propagasi ini dilakukan dengan memberikan noise (gangguan) acak, yang mengikuti suatu distribusi probabilitas tertentu (berikut parameter-parameter distribusi tersebut), pada setiap variabel yang berkontribusi kepada ketidakpastian suatu pengukuran. Tahap ini merupakan proses kalkulasi yang dilakukan berulang-ulang (dengan komputer) dan setiap hasil dari pengulangan kalkulasi tersebut disimpan. Dari setiap hasil kalkulasi yang disimpan tersebut, deviasi standar dari hasil yang tersimpan tersebut dikalkulasi dan digunakan sebagai estimasi nilai ketidakpastian pengukuran tersebut. Untuk lebih jelasnya, contoh praktis dari metode simulasi Monte-Carlo akan dipresentasikan.

Dua jenis distribusi probabilitas yang paling sering digunakan dalam metode simulasi Monte-Carlo adalah distribusi normal dan distribusi rectangular. Kedua distribusi tersebut diperlihatkan dengan lebih detil pada gambar 15 untuk distribusi normal dan gambar 16 untuk distribusi rectangular (uniform).

\section{Distribusi normal}

\section{Fungsi kepadatan probabilitas}

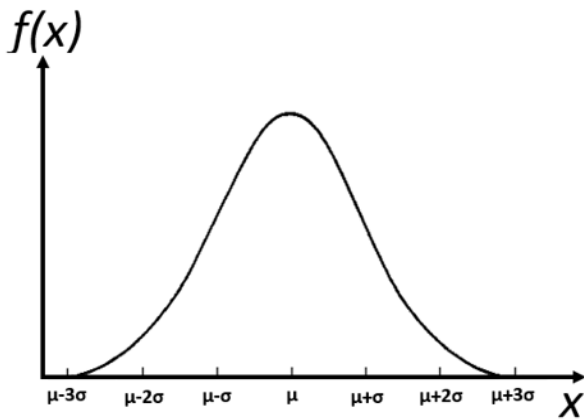

Fungsi kepadatan komulatif

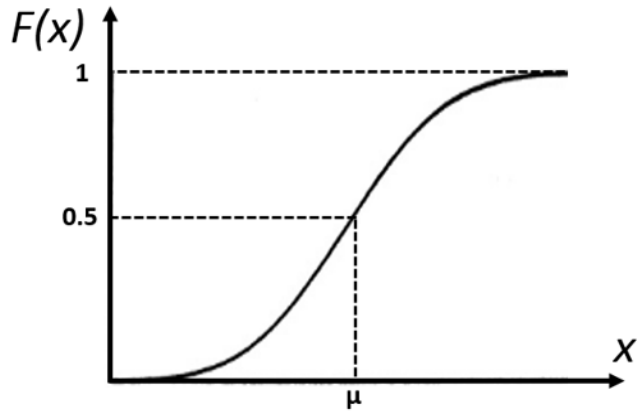

Gambar 15: (kiri) Fungsi kepadatan probabilitas dan (kanan) fungsi kepadatan komulatif dari distibusi normal suatu variabel acak.

Distribusi Rectangular (uniform)

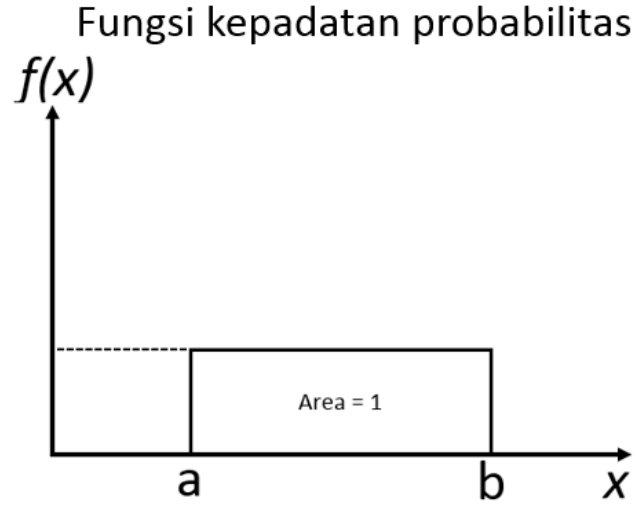

Fungsi kepadatan komulatif

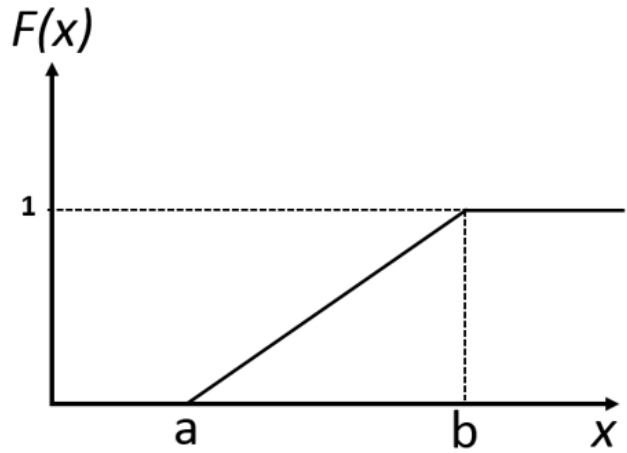

Gambar 16: (kiri) Fungsi kepadatan probabilitas dan (kanan) fungsi kepadatan komulatif dari distibusi rectangular (uniform) suatu variabel acak. 
1. Distribusi normal.

Distribusi normal adalah distribusi yang paling umum digunakan untuk menghasilkan variabel acak yang merepresentasikan berbagai macam sumber ketidakpastian, yang berasal dari, misalnya, variasi temperatur, variasi tekanan dan repeatability dari suatu instrumen.

Model matematik dari fungsi kepadatan probabilitas distribusi normal adalah (referensi gambar 15):

$$
f(x)=\frac{1}{\sigma \sqrt{2 \pi}} \exp \left(\frac{-(x-u)^{2}}{2 \sigma^{2}}\right)
$$

Model matematik dari fungsi kepadatan komulatif distribusi normal adalah:

$$
F(x)=\frac{1}{\sigma \sqrt{2 \pi}} \int_{-\infty}^{\infty} \exp \left(\frac{-(x-u)^{2}}{2 \sigma^{2}}\right) d x
$$

2. Distribusi rectangular (uniform).

Pada umumnya digunakan untuk menghasilkan variabel acak yang merepresentasikan ketidakpastian yang bersumber dari resolusi suatu pengukuran dan dari hasil kalibrasi (sertifikat kalibrasi) suatu artefak referensi. Model matematik dari fungsi kepadatan proabilitas distribusi rectangular adalah (referensi gambar 16):

$$
f(x)=\left\{\begin{array}{c}
0, x \leq a \\
\frac{1}{b-a}, a<x<b \\
0, x>a
\end{array}\right.
$$

Model matematik dari fungsi kepadatan komulatif distribusi rectangular adalah:

$$
f(x)=\left\{\begin{array}{c}
0, x \leq a \\
\frac{x-a}{b-a}, a<x<b \\
0, x>a
\end{array}\right.
$$

\section{Prosedur dan validasi metode simulasi Monte-Carlo.}

Pada umumnya semua metode estimasi ketidakpastian berbasis simulasi Monte-Carlo mempunyai prosedur dan metode validasi yang sama. Prosedur tersebut dapat dikorelasikan dengan diagram yang terdapat pada gambar 14 . Prosedur metode simulasi Monte-Carlo secara umum adalah (Cox et al 2010):

1. Tentukan banyaknya jumlah kalkulasi $n$ (run).

Pada umumnya, $n$ adalah suatu nilai konstan yang sangat besar, seperti $10^{6}$.

2. Ulang sebanyak $n$ kali:

2.1 hasilkan secara acak semua nilai kontributor (input) $X=\left\{X_{1}, X_{2}, X_{3}, \ldots, X_{n}\right\}$ yang dihasilkan (drawn) dari fungsi kepadatan probabilitas kontributor $X$ masing-masing, seperti distribusi normal, distribusi rectangular atau distribusi exponential.

2.2 Aplikasikan kalkulasi dari sebuah pengukuran $Y$ sesuai dengan model matematik pengukuran $Y_{i}=f\left(X_{i}\right)$ apabila tersedia atau dari poin data hasil riil dari satu proses suatu pengukuran yang sudah ditambahkan noises (apabila mode matematik pengukuran tidak tersedia).

3. Dari semua hasil perhitungan (output) dari $Y_{i}$, yang diulang sebanyak $n$ kali:

- Jika distribusi statistik dari hasil kalkulasi $Y_{i}$ dari simulasi diketahui (pada umunya diasumsikan sebagai sebuah distribusi normal), maka kalkulasi deviasi standar dari semua hasil $Y_{i}$. Deviasi standar tersebut adalah sebagai estimasi nilai ketidakpastian $u$ (standard uncertainty)

- Atau jika distribusi statistik dari $Y_{i}$ tidak diketahui dan tidak bisa diasumsikan, maka urutkan semua nilai dari $Y_{i}$ dari yang paling kecil sampai dengan yang paling rendah $G=\left\{Y_{i}, i=1, \ldots, n\right\}$ dan ambil nilai dari $Y_{i}$ dari himpunan $G$ tersebut pada posisi $2.5 \%$ (sebagai batas bawah) dan $97.5 \%$ (sebagai batas atas) sebagai batas interval ketidakpastian (95\% interval kepercayaan). 
Karena metode simulasi Monte-Carlo merupakan metode dengan perhitungan komputer, maka validasi dari hasil ketidakpastian dengan metode tersebut harus dilakukan. Metode validasi untuk simulasi Monte-Carlo adalah sebagai berikut:

1. Membandingkan hasil estimasi ketidakpastian dari metode Monte-Carlo dengan hasil estimasi dari GUM (apabila fungsi matematik suatu pengukuran diketahui).

Metode validasi ini tidak banyak digunakan karena pada umumnya metode simulasi Monte-Carlo digunakan karena fungsi matematik suatu pengukuran yang kompleks tida diketahui.

2. Membandingkan hasil estimasi ketidakpastian dari metode Monte-Carlo dengan hasil ketidakpastian dengan metode eksperimen menggunakan suatu instrumen pengukuran yang lebih akurat (ISO 15530-4).

3. Membandingkan hasil estimasi ketidakpastian dari metode Monte-Carlo dengan hasil estimasi dari suatu perangkat lunak sebagai referensi menggunakan suatu data referensi (ISO 15530-4).

Contoh 1: Estimasi nilai ketidakpastian pada hasil pengukuran menggunakan jangka sorong dengan metode simualsi Monte-Carlo yang divalidasi dengan membandingkan dengan metode GUM.

Pada contoh ini, kasus yang sama pada pengukuran sebuah gauge block dengan suatu jangka sorong dipresentasikan. Gambar 11 memperlihatkan proses pengukuran gauge block tersebut. Model matematik dari pengukuran tersebut dapat dilihat pada persamaan (21) dengan diasumsikan bahwa pengaruh temperatur terhadap ekspansi termal gauge block tersebut dapat diabaikan.

Estimasi nilai ketidakpastian dengan menggunakan metode simulasi Monte-Carlo untuk pengukuran gauge block tersebut diimplementasikan dalam bentuk kode pemrograman MATLAB. Kode pemrograman MATLAB untuk mengimplementasikan metode simulasi Monte-Carlo tersebut diperlihatakan pada tabel 7. Proses kalkulasi pemrograman MATLAB tersebut mengikuti langkah-langkah yang telah dibahas sebelumnya dalam prosedur simulasi Monte-Carlo.

Tabel 7: Kode pemrograman MATLAB untuk simulasi Monte-Carlo pada kasus pengukuran dengan jangka sorong.

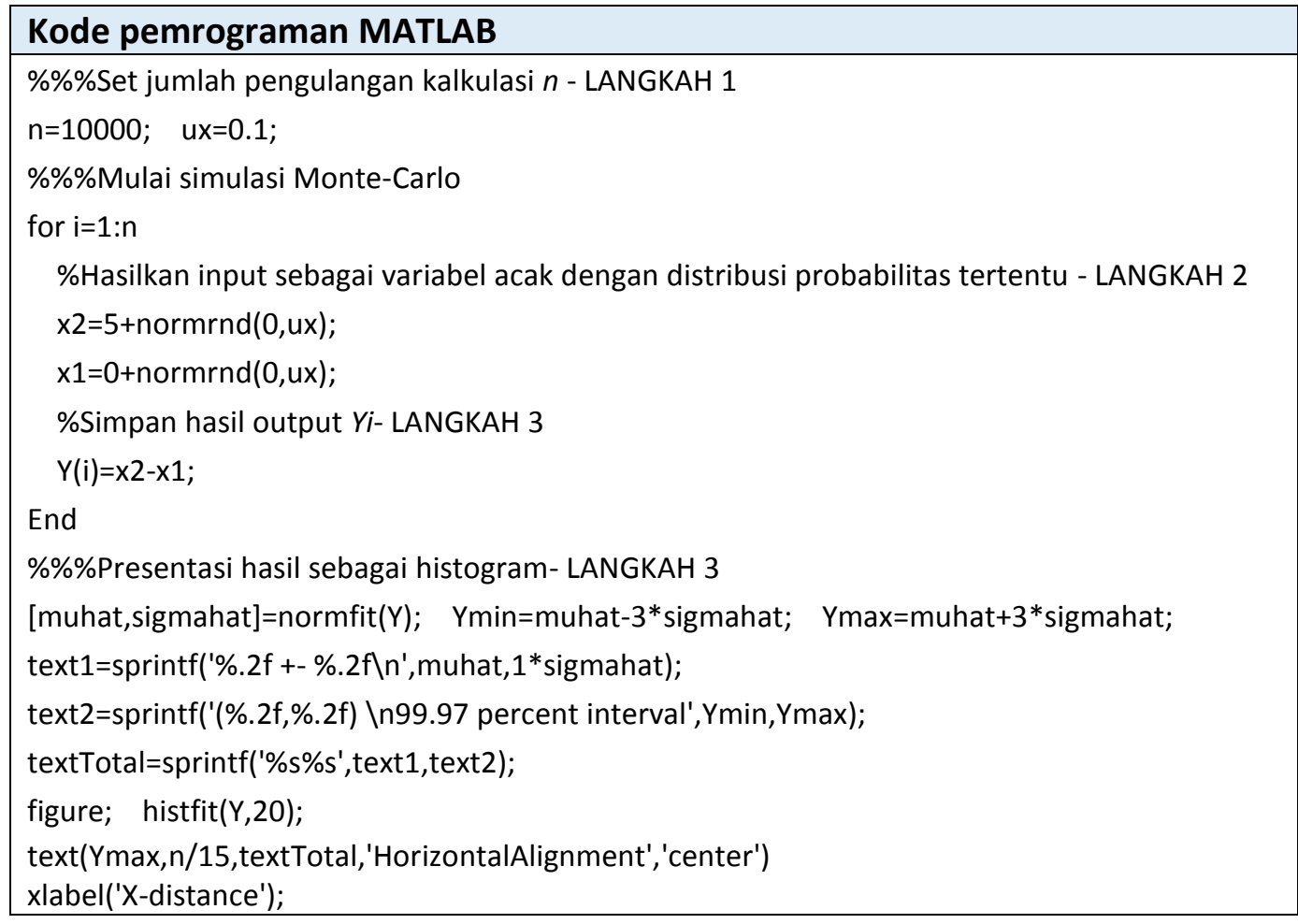


Pada kode MATLAB di tabel 7, jumlah pengulangan kalkulasi untuk proses simulasi Monte-carlo tersebut adalah 10000 kali. Dari fungsi matematik pengukuran jangka sorong tersebut, ada dua kontributor (variabel) yang menentukan hasil pengukuran dari jangka sorong tersebut. Kedua variabel tersebut dihasilkan dengan mengambil sampel secara acak dari distribusi normal dengan nilai rata-rata 0 dan deviasi standar $0.1 \mathrm{~mm}$. Hasil dari setiap proses kalkulasi $Y_{i}$ disimpan, sehingga total nilai $Y_{i}$ yang didapatkan adalah sejumlah 10000 nilai. Dari 10000 nilai $Y_{i}$, deviasi standar $Y_{i}$ dari adalah $0.21 \mathrm{~mm}$. Sehingga, estimasi ketidakpastian dari pengukuran gauge block tersebut adalah $u=0.21 \mathrm{~mm}$. Hasil dari perhitungan GUM adalah $u=0.21 \mathrm{~mm}$. Hal ini menunjukkan bahwa hasil dari metode simulasi tersebut tervalidasi dengan metode GUM. Kurva histogram dari seluruh $Y_{i}$ yang disimpan dari setiap pengulangan kalkulasi sebanyak 10000 nilai diperlihatkan pada gambar 17.

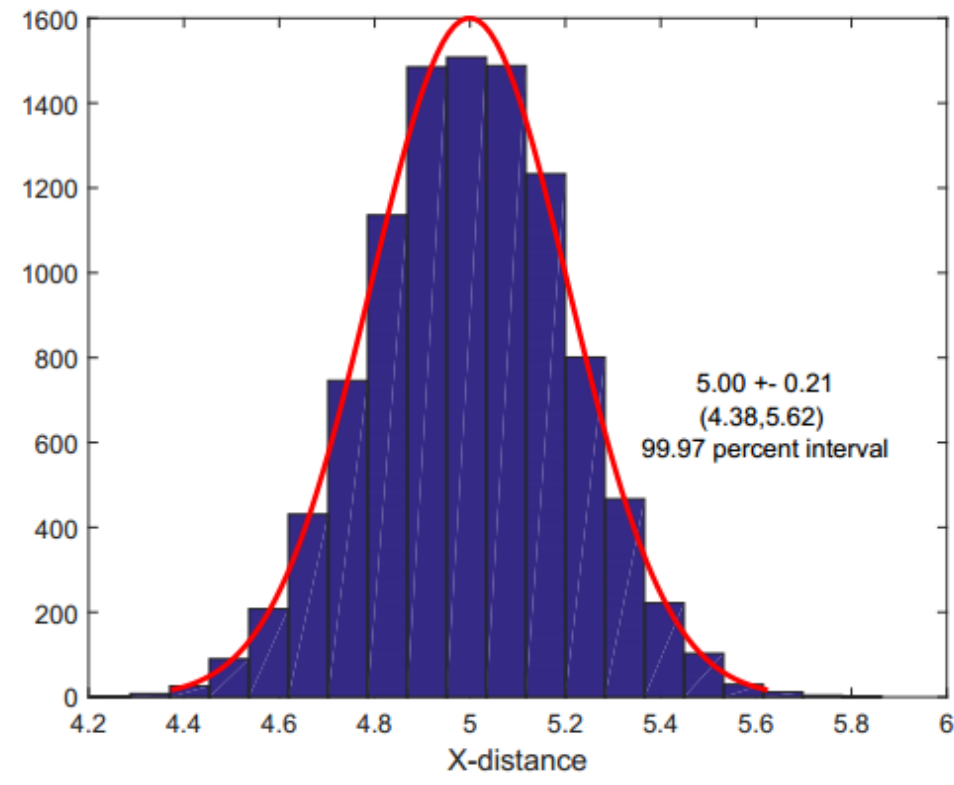

Gambar 17: Hasil estimasi ketidakpastian dengan disertakan kurva histogram dari $Y_{i}$.

Contoh 2: Estimasi nilai ketidakpastian poin data pada pengukuran tekstur permukaan (profile rougness dan waviness) dengan metode simualsi Monte-Carlo yang divalidasi dengan membandingkan dengan metode GUM.

Contoh ini menggunakan kasus yang sama pada proses kalkulasi roughness dan waviness yang telah dibahas sebelumnya dengan menggunakan metode GUM. Ilustrasi dari proses kalkulasi untuk mendapatkan data roughness dan waviness diperlihatkan pada gambar 12. Persamaan (27) merepresentasikan fungsi matematik suatu proses filtering untuk mendapatkan profile waviness dan persamaan (35) merepresentasikan fungsi matematik suatu proses filtering untuk mendapatkan profile roughness. Tabel 8 memperlihatkan proses estimasi nilai ketidakpastian dengan menggunakan metode simulasi Monte-Carlo untuk kalkulasi profile waviness dan profil roughness yang diimplementasikan dalam bentuk kode pemrogramna MATLAB.

Pada kode MATLAB tersebut, jumalah pengulangan kalkulasi adalah sebanyak 10000 kali. Dari setiap pengulangan, data $W_{i}$ dan $R_{i}$ disimpan, sehingga jumlah $W_{i}$ dan $R_{i}$ adalah sebanyak 10000 nilai. Kontributor dari proses kalkulasi tersbeut adalah ketidakpastian dari posisi-z setiap poin, yaitu $u_{z}$. Nilai $u_{z}$ dihasilkan secara acak dari distribusi normal dengan rata-rata 0 dan deviasi standar $0.1 \mu \mathrm{m}$. Hasil ketidakpastian poin untuk roughness $u \_\operatorname{sim}\left(R_{i}\right)$ dan waviness $u \_\operatorname{sim}\left(W_{i}\right)$ adalah $u \_\operatorname{sim}\left(R_{i}\right)=0.082 \mu \mathrm{m}$ dan $u \_\operatorname{sim}\left(W_{i}\right)=0.058 \mu \mathrm{m}$. Sedangkan hasil estimasi ketidakpastian dengan metode GUM adalah $u\left(R_{i}\right)=0.08 \mu \mathrm{m}$ dan $u\left(\bar{W}_{i}\right)=0.058 \mu \mathrm{m}$. Dengan membandingkan dengan hasil GUM, maka hasil dari simulasi tersebut dapat tervalidasi. Kurva histogram dari seluruh $W_{i}$ diperlihatkan pada gambar 18 dan histogram dari seluruh $R_{i}$ diperlihatkan pada gambar 19. 
Tabel 8: Kode pemrograman MATLAB untuk simulasi profile roughness and waviness.

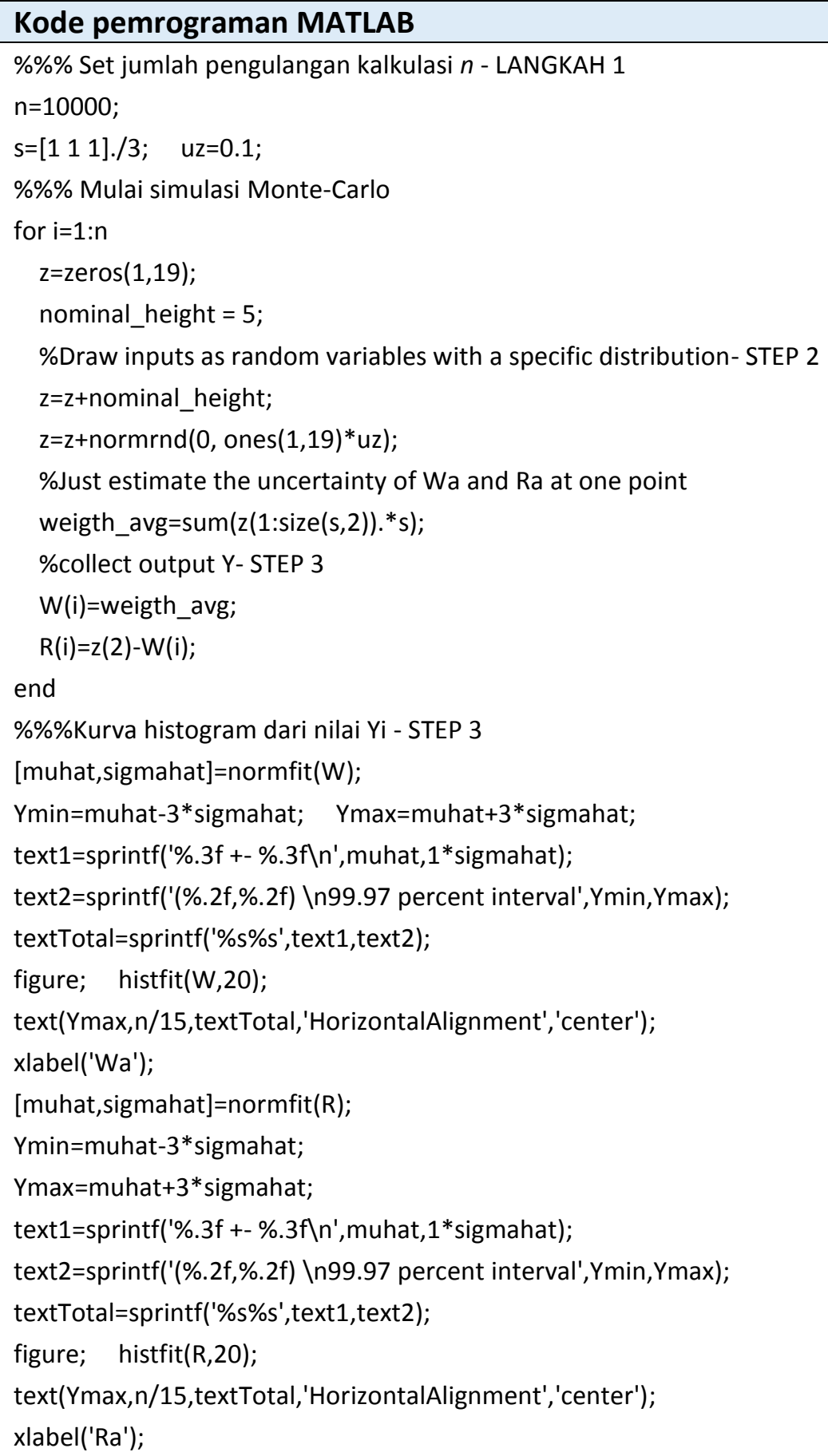




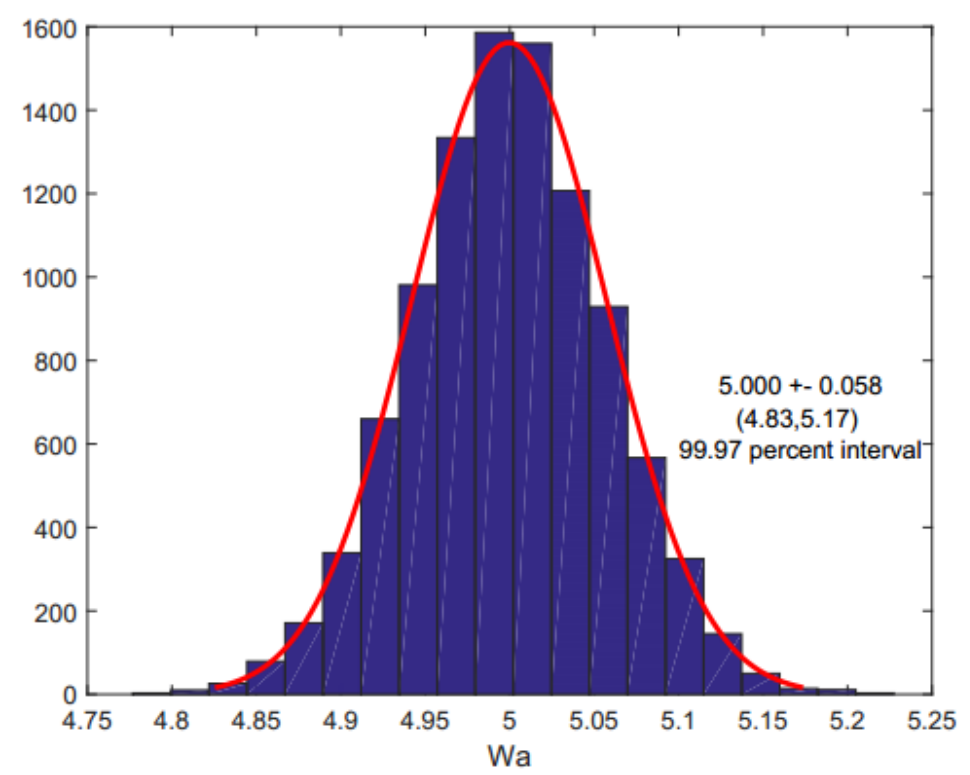

Gambar 18: Kurva histogram dari data $W_{i}$.

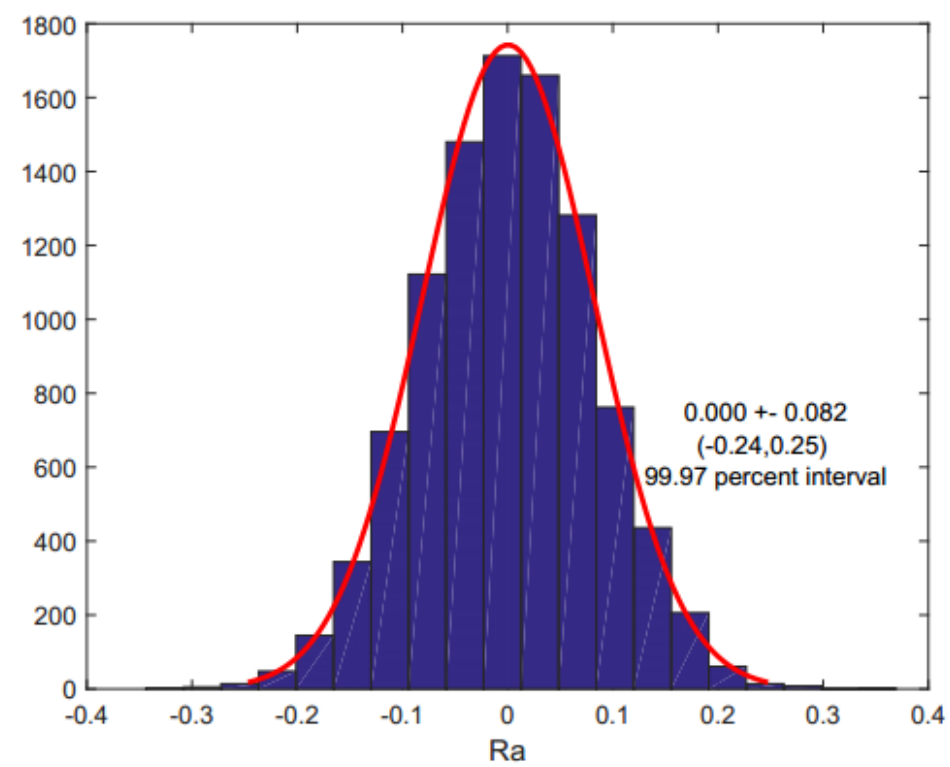

Gambar 19: Kurva histogram dari data $R_{i}$.

Dari kedua contoh di atas, metode simulasi merupakan metode yang sangat berguna untuk estimasi nilai ketidakpastian, terutama apabila suatu pengukuran merupakan suatu proses yang sangat kompleks sehingga fungsi matematik dari pengukuran tersebut tidak tersedia. Pada banyak aplikasi praktis, misalnya pengukuran dengan sebuah instrumen CMM, proses pengukuran tersebut sangat kompleks dan fungsi matematik yang dapat mendeskripsikan proses pengukuran CMM tersebut tidak tersedia. Maka dari itu, metode simulasi Monte-Carlo sangat berguna untuk kasus-kasus seperti ini.

Untuk mengetahui lebih lanjut mengani prinsip dasar statitsik dan simulasi Monte-Carlo, pembaca dapat merujuk ke dua laporan yang ditulis oleh Cox and Harris 2010 dan Cox et al 2010. 


\subsection{Metode ISO 15530}

Metode evaluasi nilai ketidakpastian dengan metode ISO 15530 termotivasi untuk diterapkan pada hasi-hasil pengukuran dengan menggunakan intrumen CMM, baik CMM berbasis kontak maupun berbasis non-kontak serta CMM berbasis $X$-ray CT (gambar 20). Metode-metode yang terdapat pada ISO 15530 mempunyai landasan utama pada metode GUM dan termotivasi dari metode tabel (spreadsheet) dan simulasi Monte-Carlo yang telah dibahas sebelumnya. Metode pada ISO/DTS 15530-2 dan ISO 15530-3 adalah seperti metode tabel (spreadsheet) dengan kalkulasi-kalkulasi yang spesifik untuk suatu pengukuran dengan CMM. Sedangkan metode ISO 15530-4 adalah berlandaskan metode simulasi Monte-Carlo. Metode ISO 15530 adalah metode yang paling sering ditemukan di industri karena aplikasi CMM di industri sudah menjadi standar sebagai intrumen inspeksi kualitas.

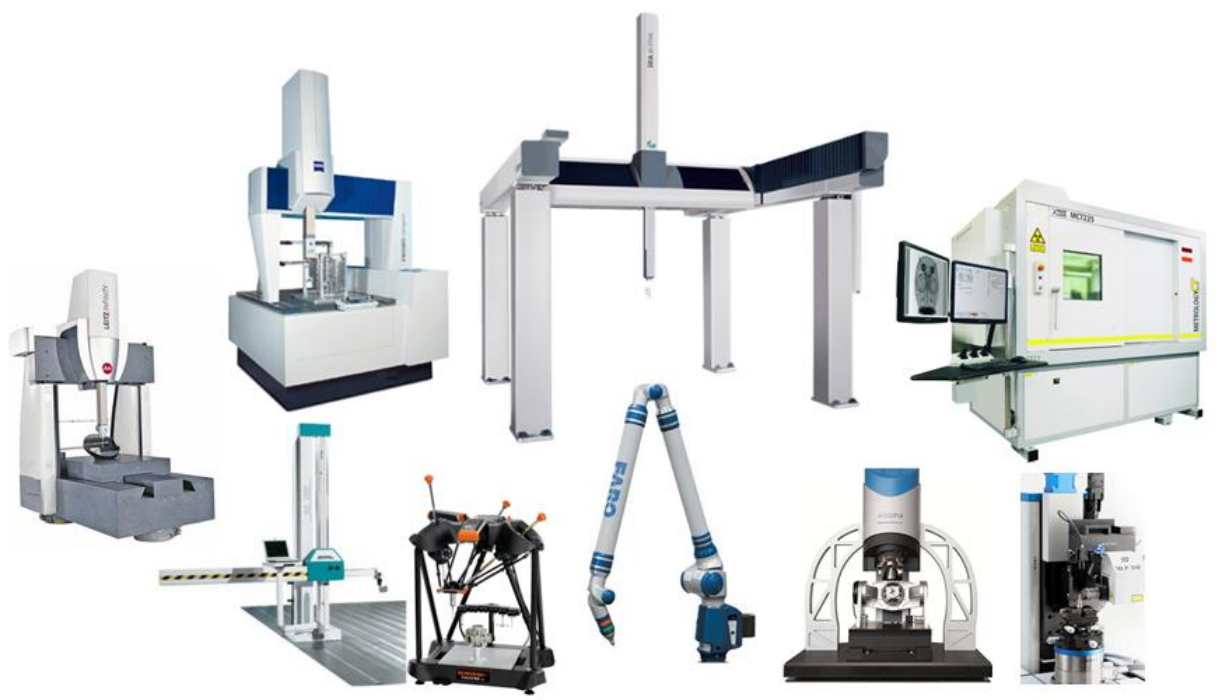

Gambar 20: Berbagai macan jenis instrumen CMM yang bisa menerapkan metode ISO 15530 untuk menentukan nilai ketidakpastian hasil pengukurannya.

Sebelum membahas secara detil metode-metode ISO 15530 untuk menentukan nilai ketidakpastian, kontributorkontributor utama (uncertainty sources) yang mempengaruhi nilai ketidakpastian suatu hasil pengukuran dengan CMM akan dibahas terlebih dahulu. Gambar 21 memperlihatkan kontributor-kontributor utama pada ketidakpastian dari hasil-hasil pengukuran CMM. Kontributor-kontributor tersebut pertama kali dipresentasikan dalam sebuah laporan (Wilhelm et al 2001). Kontributor-kontributor (uncertainty sources) tersebut dikelompokkan dalam:

- $\quad$ Coordinate measuring machine/system (CMS) hardware.

Kontributor-kontirbutor yang berasal dari suatu instrumen CMS adalah: Seting pengukuran atau parameter pengukuran, seperti: scanning speed dan gaya touching stylus CMS terhadap permukaan benda kerja. Error yang berkaitan dengan suatu CMS seperti geometric error, dynamic error dan probing error. Selain itu, pengaruh lingkungan terhadap suatu instrumen CMS juga mempengaruhi ketidakpastian, seperti: variasi temperatur yang mengakibatkan elemen-elemen suatu instrumen CMS terekspansi dan vibration noises.

- Benda kerja.

Kontributor-kontributor yang bersumber dari suatu benda kerja adalah cacat-cacat geometri pada benda kerja tersebut. Cacat-cacat yang terdapat pada benda kerja yang mempengaruhi ketidakpastian adalah: cacat geometrik (contoh: flatness error dan roundness error), surface finish (tekstur permukaan), clamping error (contoh: clamping force yang terlalu besar sehingga mengakibatkan benda kerja terdeformasi), alignment error (contoh: kesalahan dalam memilih koordinat benda kerja yang tepat), deformasi elastis (misal karena benda kerja yang terlalu berat sehingga suatu instrument CMS terdeformasi dan karena clamping force yang terlalu besar) dan accessability (misalnya ketidakmampuan stylus tip dari suatu CMS menjangkau permukaan 
suatu benda kerja yang ingin diukur sehingga mengakibatkan kurangnya data untuk memproses hasil pengukuran).

- $\quad$ Strategi sampling.

Untuk intrumen CMS yang berbasis kontak, strategi sampling sangat berpengaruh terhadap nilai ketidakpastian. Hal ini disebabkan kerena CMM berbasis kontak, waktu yang dibutuhkan untuk mengsample poin-poin dari permukaan suatu benda kerja adalah cukup lama dibandingkan dengan intrumen CMS berbasis optik (non-kontak). Maka dari itu, untuk meminimalkan waktu sampling, jumlah poin yang disampel dari permukaan suatu benda kerja sangatlah terbatas. Maka dari itu, sampling yang optimal harus diterapkan (Moroni dan Petro 2014). Proses sampling sangat berpengaruh dengan bentuk permukaan suatu benda kerja karena untuk dapat menginspeksi cacat suatu benda kerja, maka proses sampling yang terbatas harus dapat menangkap permukaan benda kerja yang cacat tersebut. Selain itu, sistem koordinat dan datum sangat penting dalam menentukan inspeksi geometri (form) seperti perpendicularity, location dan paralelism.

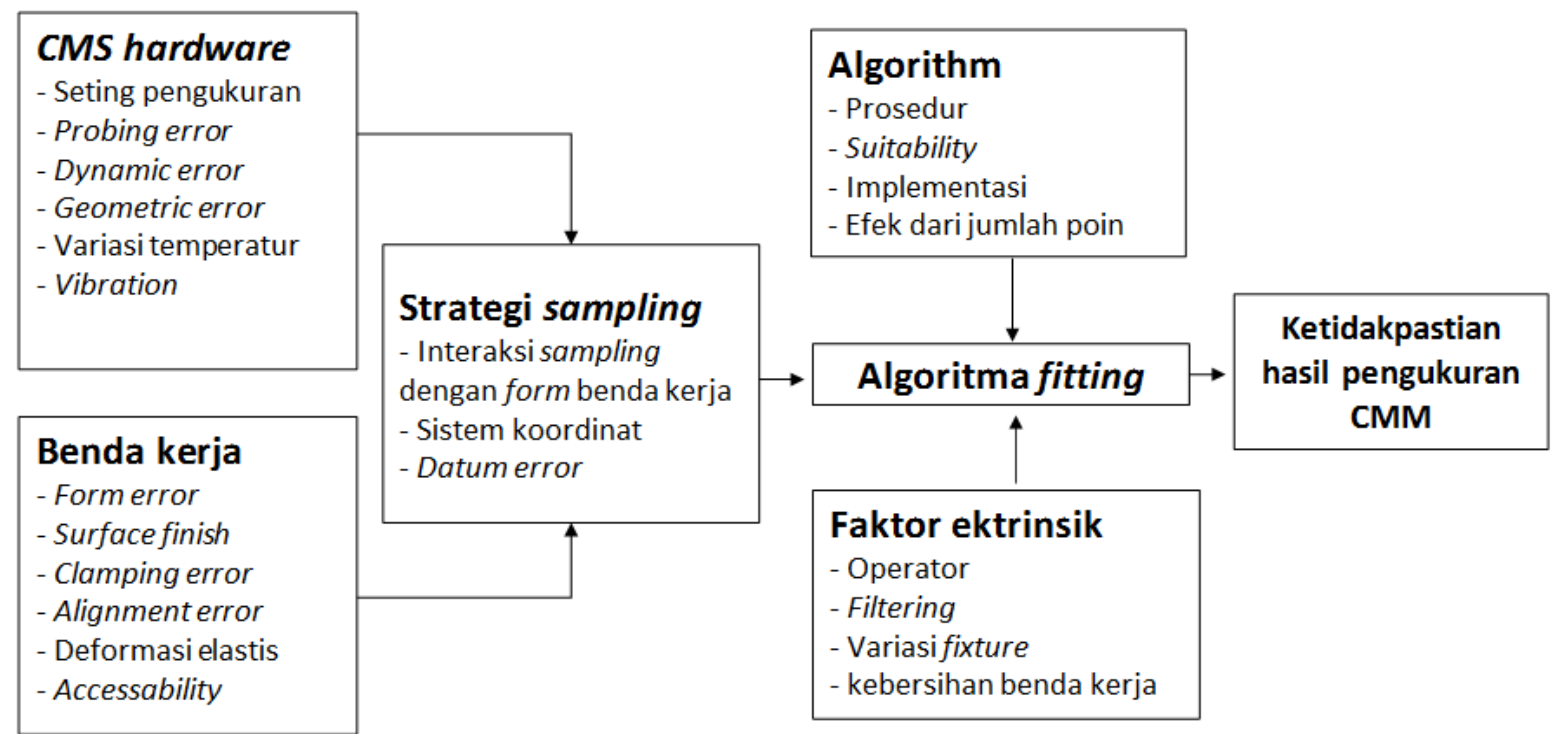

Gambar 21: Kontributor-kontributor terhadap nilai ketidakpastian yang "task specific" dari hasil suatu pengukuran CMM.

- Algoritma fitting.

Untuk dapat menghasilkan suatu nilai pengukuran dari suatu CMS, proses fitting sangatlah penting. Proses fitting adalah untuk mengasosiasikan suatu geometri, misalnya lingkaran, dari poin data agar suatu measurand dapat diukur, misalnya diameter. Ada dua aspek yang harus diperhatikan dalam proses fitting:

○ Algoritma

Jenis algoritma yang digunakan untuk suatu jenis pengukuran sangatlah mempengaruhi hasil pengukuran. Misalkan, untuk inspeksi geometri (form), algoritma fitting yang harus digunakan adalah minimum-zone fitting (MZ) dan bukan least-square fitting (LSQ). Selain itu, algoritma yang terdapat pada perangkat lunak suatu CMS sangat terpengaruh dengan jumlah poin data yang diberikan kepada suatu algoritma untuk diproses.

○ Faktor intrinsik

Faktor intrinsik pada umumnya terabaikan walaupun sebenarnya faktor ini juga sangat mempengaruhi hasil pengukuran. Misalnya keahlian operator menggunakan suatu instrumen CMS, jenis filtering data yang dipilih operator untuk mengkalkulasi suatu hasil pengukuran, cara operator menempatkan dan mengklam suatu benda kerja dan kebersihan benda kerja ketika diukur karena pada pengukuran berskala mikro, sedikit debu sangat mempengaruhi hasil pengukuran. 


\subsubsection{Metode ISO/DTS 15530-2}

Metode ISO/DTS 15530-2 merupakan sebuah metode untuk evaluasi ketidakpastian suatu pengukuran (dimensi dan geometri) sebuah benda kerja dengan menggunakan sebuah instrumen CMS yang dilakukan dengan mengukur benda kerja tersebut menggunakan berbagai macam pengukuran dengan posisi dan orientasi benda kerja yang berbeda (ISO/DTS 15530-2 2003). Konsep ini dinamakan strategi multi-pengukuran. Instrumen CMS yang digunakan untuk menerapkan metode ini adalah harus merupakan sebuah CMS yang terverifikasi secara periodik, karena rantai keterlacakan dengan metode ini langsung dari instrumen CMS terverifikasi yang digunakan dan dengan mengukur gauge block yang terkalibrasi. Metode ISO/DTS 15530-2 tidak menggunakan sebuah artefak khusus yang terkalibrasi, melainkan hanya sebuah atau beberapa gauge block yang terkalibrasi. Hal ini yang membuat metode ISO/DTS 155202 berbeda dengan metode lainnya.

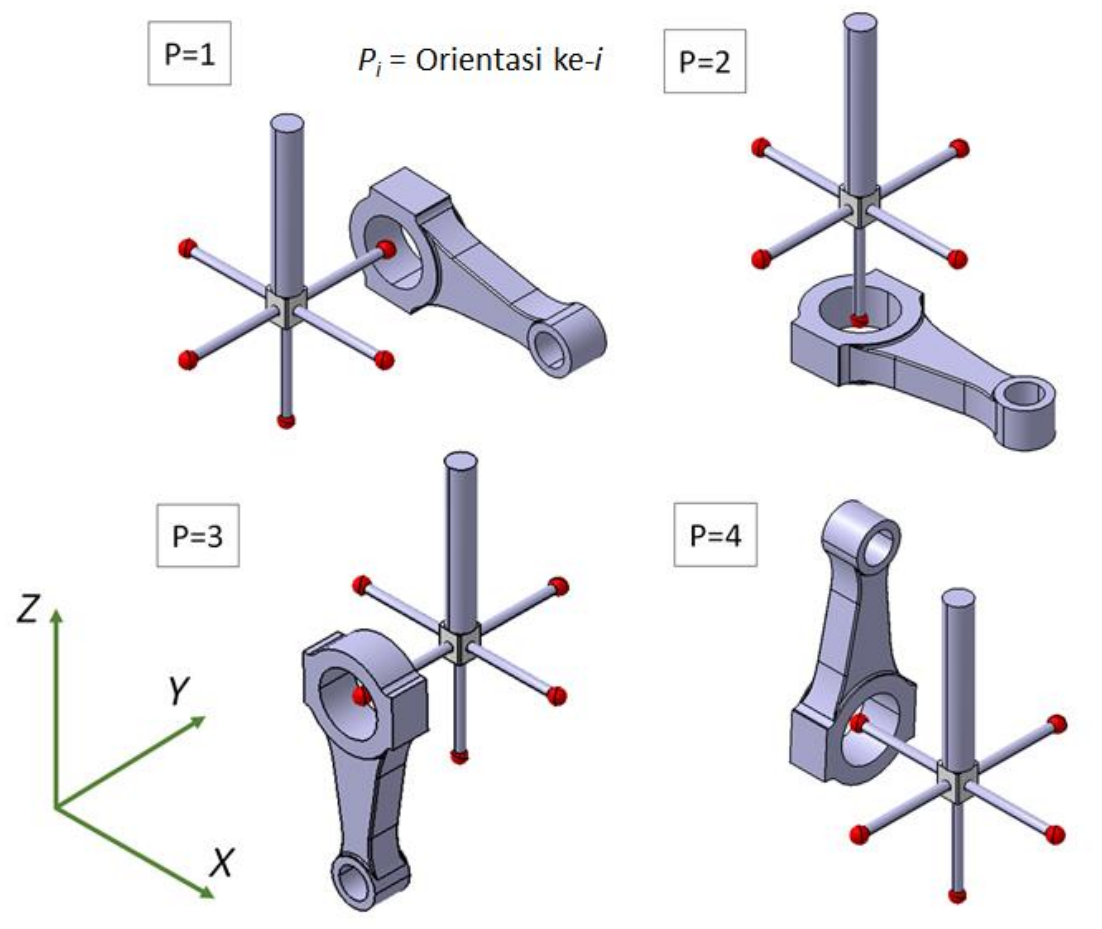

Gambar 22: Metode dengan multipel strategi sampling dengan empat jenis orientasi.

Prosedur untuk menentukan nilai ketidakpastian dengan metode ISO/DTS 15530-2 adalah sebagai berikut:

- Jumlah pengukuran yang dibutuhkan adalah total 20 pengukuran.

Total 20 pengukuran terdiri dari pengukuran dengan 4 orientasi yang berbeda dan masing-masing 5 pengulangan pengukuran untuk setiap orientesi tersebut. Gambar 22 memperlihatkan 4 orientasi pengukuran yang berbeda pada suatu instrumen CMS. Tabel 9 merepresentasikan manajemen data hasil 20 pengukuran dengan metode ISO/DTS 15530-2.

- Stylus tip yang digunakan (yang berbentuk bola merah pada gambar 22) haruslah dikualifikasi terlebih dahulu (jangan menggunakan data kualifikasi stylus dari yang sebelumnya).

Hal ini harus dilakukan untuk meminimalisasi ketidakpastian yang bersumber dari probing error atau stylus tip yang sudah terdegradasi sehingga tidak memiliki bentuk yang bagus.

- Sangat direkomendasikan untuk menggunakan berbagai macam strategi sampling poin untuk setiap orientasi yang berbeda.

Hal ini dilakukan untuk mengikutsertakan sumber ketidakpastian yang berasal dari jenis sampling yang digunakan untuk meng-sample poin data dari suatu permukaan benda kerja. 
Tabel 9: Metode pengukuran untuk metode ISO/DTS 15530-2.

\begin{tabular}{|c|c|c|c|c|}
\hline & Posisi $j=1$ & Posisi $j=2$ & Posisi $j=3$ & Posisi $j=4$ \\
\hline Pengukuran $i=1$ & $Y_{11}$ & $Y_{12}$ & $Y_{13}$ & $Y_{14}$ \\
\hline Pengukuran $i=2$ & $Y_{21}$ & $Y_{22}$ & $Y_{23}$ & $Y_{24}$ \\
\hline Pengukuran $i=3$ & $Y_{31}$ & $Y_{32}$ & $Y_{33}$ & $Y_{34}$ \\
\hline Pengukuran $i=4$ & $Y_{41}$ & $Y_{42}$ & $Y_{43}$ & $Y_{44}$ \\
\hline Pengukuran $i=5$ & $Y_{51}$ & $Y_{52}$ & $Y_{53}$ & $Y_{54}$ \\
\hline Rata-rata $Y_{i}$ & $Y_{1}$ & $Y_{2}$ & $Y_{3}$ & $Y_{4}$ \\
\hline Deviasi standar $S_{i}$ & $S_{1}$ & $S_{2}$ & $S_{3}$ & $S_{4}$ \\
\hline
\end{tabular}

Pada gambar 22, total empat posisi dengan orientasi yang berbeda-beda bertujuan agar sumber ketidakpastian yang berasal dari error geometri CMS yang digunakan, seperti squareness error, angular error dan scale error, juga diperhitungkan agar nilai ketidakpastian yang dihasilkan menjadi komprehensif. Pada umumnya, untuk menerapkan metode ISO/DTS 15530-2, stylus tip berbentuk star dari suatu CMS selalu digunakan untuk dapat melakukan pengukuran dengan berbagai macam orientasi (gambar 22).

Tabel 9 memperlihatkan bagaimana cara mengolah data yang dihasilkan dalam proses pengukuran untuk estimasi ketidakpastian dengan mengikuti metode ISO/DTS 15530-2. Dari tabel 9, pengukuran dikelompokkan menjadi empat bagian berdasarkan orientasi suatu benda kerja yang diukur $\{j=1,2,3,4\}$. Pada setiap orientasi, lima pengulangan pengukuran dilakukan $\{i=1,2,3,4,5\}$. Pada setiap orientasi, strategi sampling disarankan berbeda-beda agar ketidakpastian dari efek strategi sampling terhadap hasil pengukuran dapat diperhitungkan juga. Dari setiap kelompok orientasi, rata-rata dan deviasi standar dari lima pengulangan pengukuran dikalkulasi.

Kalkulasi-kalkulasi selanjutnya yang diturunkan dari hasil kalkulasi pada tabel 9 adalah sebagai berikut:

- $u_{\text {rep: }}$

$$
u_{\text {rep }}=\sqrt{\frac{1}{n_{1}} \sum_{i=1}^{n_{1}} S_{i}^{2}}
$$

Dimana $n_{l}$ adalah jumlah pengulangan pada setiap orientasi. Kalkulasi $Y_{i}$ dan $S_{i}$ adalah:

$$
\begin{aligned}
& Y_{i}=\frac{1}{n_{1}} \sum_{i=1}^{n_{1}} Y_{i j} \\
& S_{i}=\sqrt{\frac{1}{n_{1}-1} \sum_{i=1}^{n_{1}}\left(Y_{i j}-Y_{i}\right)^{2}}
\end{aligned}
$$

- $u_{g e o}$ :

$$
u_{g e o}=\frac{1}{\sqrt{n_{2}}} \sqrt{\frac{1}{\left(n_{2}-1\right)} \sum_{i=1}^{n_{2}}\left(Y_{i}-Y\right)^{2}}
$$

Dimana $n_{2}$ adalah jumpal posisi orientasi yang berbeda. Nilai $Y$ diformulasikan sebagai:

$$
Y=\frac{1}{n_{1} \cdot n_{2}} \sum_{j=1}^{n_{2}} \sum_{i=1}^{n_{1}} Y_{i j}
$$

- $u_{\text {corr }}$ :

$$
u_{\text {corr }}=\frac{L}{L_{s t d}} \sqrt{\left(\frac{U_{s t d}}{2}\right)^{2}+\frac{u_{\text {meas }}^{2}}{n_{3}}}
$$

Dimana $L_{\text {std }}$ adalah panjang suatu gauge block yang terkalibrasi, $L_{i}$ panjang gauge block hasil dari pengukuran 
ke $-i$ dan $U_{\text {std }}$ adalah ketidakpastian terekspansi $(k=2)$ yang terdapat pada sertifikat gauge block tersebut. Nilai $u_{\text {meas }}$ dan $\bar{L}$ diformulasikan sebagai:

$$
\begin{aligned}
& u_{\text {meas }}=\sqrt{\frac{1}{n_{3-1}} \sum_{i=1}^{n_{3}}\left(L_{i}-\bar{L}\right)^{2}} \\
& \bar{L}=\frac{1}{n_{3}} \sum_{i=1}^{n_{3}} L_{i}
\end{aligned}
$$

- Perhitungan koreksi panjang:

$$
\begin{aligned}
& E_{L \text { proportion }}=\frac{1}{n_{3}} \sum_{i=1}^{n_{3}} \frac{L_{i}-L_{s t d}}{L_{s t d}} \\
& E_{L}=L \cdot E_{L \text { proportion }}
\end{aligned}
$$

Dimana $n_{3}$ adalah jumlah pengukuran panjang gauge block, pada umumnya $n_{3}=3$, dan $L$ adalah suatu panjang/size yang diukur pada suatu benda kerja.

Penjelasan variabel-variabel tersebut adalah:

- $u_{\text {rep }}$ adalah sumber ketidakpastian yang berasal dari CMM repeatability, properti benda kerja (misal form dan roughness), strategi sampling dan kotor pada permukaan benda kerja.

- $u_{\text {geo }}$ adalah sumber ketidakpastian yang berasal dari CMM geometry error, stylus error, tip error, fixturing error dan alignment error.

- $\quad u_{\text {corr }}$ adalah sumber ketidakpastian yang berasal dari error akibat kesalahan pengukuran panjang referensi (gauge block). Sumber ketidakpastian $u_{\text {corr }}$ hanya diperhitungkan untuk pengukuran panjang dan size saja.

- $\quad u_{\text {temp }}$ adalah sumber ketidakpastian yang berasal dari variasi temperatur dan error pada koefisien ekspansi termal dari benda kerja yang diukur.

- Untuk pengukuran panjang dan size, panjang/size yang diukur $L$ adalah

$$
L=L-E_{\text {L proportion }}
$$

Akhirnya, kalkulasi untuk mengevaluasi ketidakpastian dengan metode ISO 15530-2 adalah sebagai berikut:

- Ketidakpastian untuk pengukuran panjang, jarak dan size (seperti: diameter dan kedalaman):

$$
U=k \sqrt{\frac{u_{r e p}^{2}}{n_{1}}+\frac{u_{g e o}^{2}}{n_{2}}+u_{c o r r}^{2}+u_{\text {temp }}^{2}}
$$

- Ketidakpastian untuk pengukuran geometri (form) dan untuk pengukuran sudut (angle):

$$
U=k \sqrt{\frac{u_{r e p}^{2}}{n_{1}}+\frac{u_{g e o}^{2}}{n_{2}}}
$$

Nilai $k=2$ untuk $95 \%$ interval kepercayaan dengan asumsi hasil pengukurannya mempunyai distribusi normal.

\section{Keuntungan dan kerugian metode ISO/DTS 15530-2.}

Kuntungan metode ISO/DTS 15530-2 adalah:

- Metode ini hanya bisa diterapkan secara efisien pada kasus produksi dengan jumlah volume yang sedikit.

- Metode ini dapat mereduksi ketidakpastian dari error volumetrik CMM dengan menggunakan efek rata-rata (averaging effect) dari banyak pengukuran dengan orientasi yang berbeda-beda.

- Metode ini sangat cocok untuk mengkalibrasi suatu benda kerja dengan menggunakan CMM. 
Kerugian metode ISO/DTS 15530-2 adalah:

- Prosedur untuk menerapkan metode ini membutuhkan waktu yang relatif lama apabila dibandingkan dengan metode ISO 15530-3.

- Metode ini sangat tidak efisien apabila diterapkan untuk pengukuran suatu produk yang diproduksi dalam jumlah besar.

\subsubsection{Metode ISO 15530-3}

Metode ISO 15530-3 adalah salah satu metode untuk mengevaluasi nilai ketidakpastian suatu pengukuran sebuah benda kerja dengan menggunakan artefak terkalibrasi yang mempunyai bentuk serupa (seperti panjang, geometri dan besaran sudut) dengan benda kerja tersebut (ISO 15530-3 2011). Proses kalibrasi suatu benda kerja harus mempunyai kondisi yang serupa dengan proses pengukuran benda kerja yang serupa di lantai produksi. Metode ISO 15530-3 adalah metode estimasi ketidakpastian yang paling umum diadopsi oleh industri-industri manufaktur.

Gambar 23 memperlihatkan bagaimana metode ISO 15530-3 diterapkan di lantai produksi. Pada gambar 23, sebuah instrumen CMM digunakan untuk menginspeksi suatu geometri benda kerja yang diletakkan in-line di dalam sebuah siklus manufaktur. In-line CMM tersebut digunakan untuk mengukur sejumlah benda kerja (berwarna abuabu pada gambar 23) yang diproduksi dalam jumlah yang cukup atau sangat banyak. Untuk mengestimasi nilai ketidakpastian dari pengukuran tersebut, maka sebuah benda kerja (berwarna merah pada gambar 23), yang mempunyai bentuk yang serupa dengan benda kerja yang diukur oleh in-line CMM tersebut, harus dikalibrasi oleh sebuah CMM yang mempunyai tingkat keakuratan yang lebih baik dari in-line CMM tersebut. Proses estimasi ketidakpastian dengan metode ISO 15530 melibatkan pengukuran benda kerja terkalibrasi tersebut dan beberapa benda kerja hasil produksi.

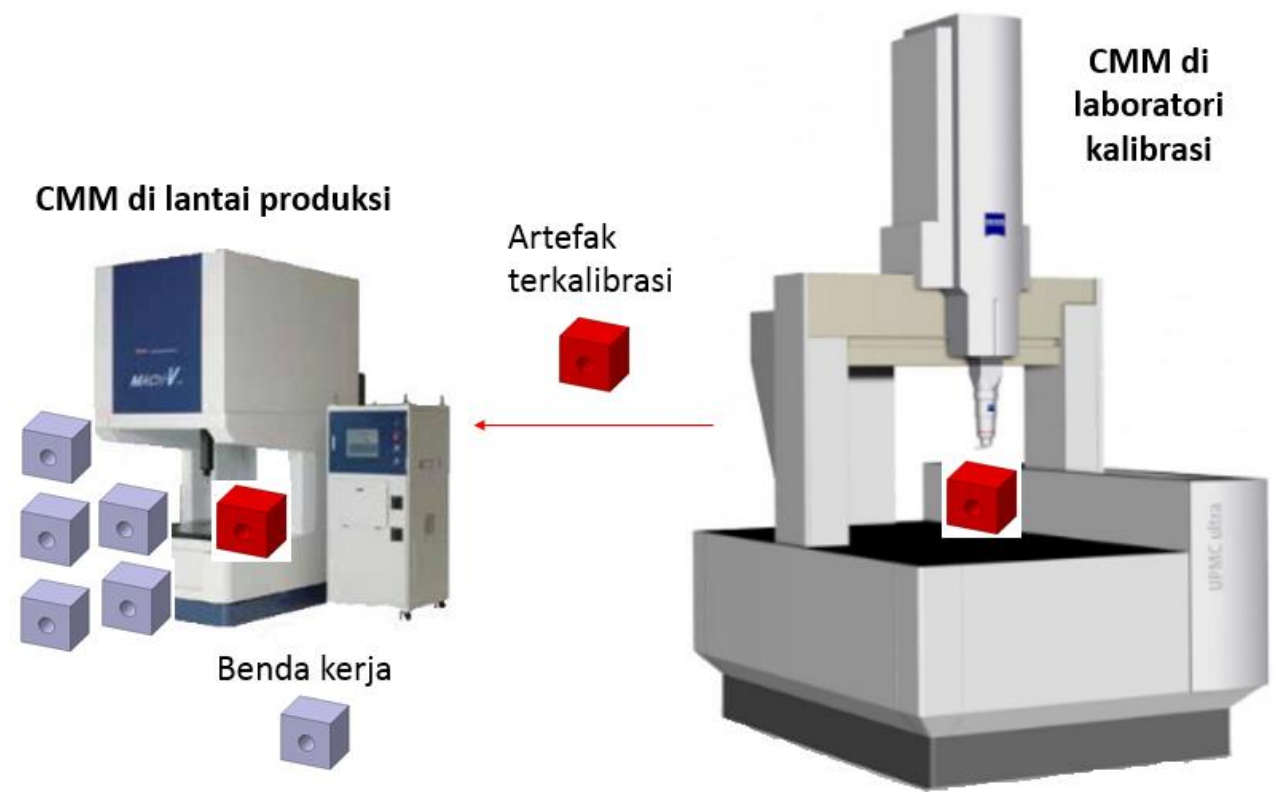

Gambar 23: Ilustrasi metode ISO 15530-3 untuk estimasi ketidakpastian.

Kalkulasi-kalkulasi metode ISO 15530-3 adalah sebagai berikut:

- Pengukuran artefak (benda kerja) terkalibrasi sebanyak minimal 10 kali dengan strategi sampling dan waktu pengukuran yang berbeda untuk mendapatkan $u_{p} . u_{p}$ diformulasikan sebagai berikut:

$$
u_{p}=\sqrt{\frac{1}{n_{p}-1} \sum_{i=1}^{n_{p}}\left(Y_{i}-\bar{Y}\right)^{2}}
$$


Dimana $Y_{i}$ adalah pengukuran artefak terkalibrasi ke-i, $n_{p}=10$, dan $\bar{Y}$ adalah:

$$
\bar{Y}=\frac{1}{n} \sum_{i=1}^{n_{p}} Y_{i}
$$

- Pengukuran artefak terkalibrasi sebanyak 20 kali. Kemudian, perbedaan antara satuan yang diukur dengan yang terkalibrasi dikalkulasi. Perhitungan ini adalah untuk mendapatkan $u_{b}$ sebagai berikut:

$$
u_{b}=\sqrt{\frac{1}{n_{b}-1} \sum_{i=1}^{n_{b}}\left(\operatorname{diff}-\overline{\operatorname{dlff})^{2}}\right.}
$$

Dimana $n_{b}=20$, diff dan $\overline{\operatorname{dlff}}$ didefinisikan sebagai:

$$
\begin{aligned}
& \overline{d l f f}=\frac{1}{n} \sum_{i=1}^{n_{b}} \operatorname{diff} \\
& \text { diff }=L_{\text {meas }}-L_{s t d}
\end{aligned}
$$

- Pengukuran benda kerja yang berbeda-beda yang diproduksi dari batch yang berbeda-beda. Hal ini untuk memperhitungkan variasi yang berasal dari proses produksi termasuk variasi ekspansi termal benda kerja. Pengukuran tersebut untuk mengkalkulasi $u_{w}$ sebagai berikut:

$$
u_{w}=\sqrt{\frac{1}{n_{w}-1} \sum_{i=1}^{n_{w}}\left(Y_{\text {part } i}-\overline{Y_{\text {part }}}\right)^{2}}
$$

Dimana $n_{w}$ adalah jumlah pengukuran dari beberapa benda kerja, $Y_{p a r t i}$ adalah hasil pengukuran benda kerja ke- $i$ dan $\overline{Y_{\text {part }}}$ adalah:

$$
\overline{Y_{\text {part }}}=\frac{1}{n_{w}} \sum_{i=1}^{n_{w}} Y_{\text {part } i}
$$

Penjelasan variabel-variabel tersebut adalah:

- $\quad u_{c a l}$ adalah sumber ketidakpastian yang berasal dari sertifikat dari artefak (benda kerja) terkalibrasi.

- $u_{p}$ adalah sumber ketidakpastian yang berasal dari error geometri CMM, stylus error, dan sampling error.

- $\quad u_{b}$ adalah sumber ketidakpastian yang berasal dari error koreksi pengukuran panjang dan size.

- $u_{w}$ adalah sumber ketidakpastian yang berasal variasi part-to-part, misalnya error akibat proses produksi, variasi temperatur, dan efek lingkungan.

Akhirnya, kalkulasi untuk mengevaluasi ketidakpastian dengan metode ISO 15530-3 adalah sebagai berikut:

$$
U=k \times \sqrt{u_{c a l}^{2}+u_{p}^{2}+u_{b}^{2}+u_{w}^{2}}
$$

Nilai $k=2$ untuk $95 \%$ interval kepercayaan dengan asumsi hasil pengukurannya mempunyai distribusi normal.

\section{Keuntungan dan kerugian metode ISO 15530-3.}

Kuntungan metode ISO 15530-3 adalah:

- Metode ini hanya membutuhkan untuk diterapkan satu kali saja dan dapat diterapkan untuk semua pengukuran yang mempunyai bentuk benda kerja yang serupa, baik bentuk maupun proses produksinya.

- Semua pengukuran dilakukan pada kondisi yang serupa, seperti: lingkungan dan strategi sampling.

Kerugian metode ISO 15530-3 adalah:

- Metode ini membutuhkan artefak terkalibrasi yang mempunyai bentuk serupa dengan benda kerja yang akan diukur untuk setiap properti yang ingin diukur. Hal ini akan menyebabkan meningkatnya biaya inspeksi kualitas untuk menentukan nilai ketidakpastian.

- Metode ini sangat sulit untuk diterapkan pada benda kerja yang mempunyai bentuk free-form. Hal ini disebabkan karena untuk memproduksi artefak terkalibrasi (reference artefact) yang mempunyai bentuk freeform adalah sangat sulit ataupun sangat mahal biayanya.

- Biaya untuk menerapkan metode ini hanya bisa terjustifikasi untuk produksi berskala medium sampai besar. 


\subsubsection{Metode ISO 15530-4}

Metode ISO 15530-4 untuk mengestimasi nilai ketidakpastian yang bersifat "task spesifik" termotivasi dari beberapa kekurangan yang terdapat pada dua metode ISO sebelumnya, yaitu ISO 15530-2 dan ISO 15530-3. Kekurangan yang paling utama dari metode ISO 15530-2 adalah metode tersebut membutuhkan waktu yang cukup lama sehingga tidak efisien untuk sistem produksi yang singkat. Selain itu, metode ISO 15530-2 membutuhkan pengukuran dengan orientasi yang berbeda, sehingga apabila benda kerja yang diukur berskala besar, maka sangat susah untuk memposisikan benda kerja tersebut terhadap suatu orientasi tertentu. Metode ISO 15530-3 mempunyai kelemahan utama karena membutuhkan artefak terkalibrasi yang memiliki bentuk serupa dengan suatu benda yang akan diukur. Apabila benda kerja tersebut mempunyai bentuk yang kompleks, maka biaya untuk membuat artefak terkalibrasi yang serupa dengan benda kerja tersebut sangatlah mahal. Biaya yang sangat mahal ini hanya bisa dijustifikasi apabila produksi benda kerja tersebut adalah dalam jumlah yang sangat banyak.

Oleh sebab itu, untuk mengevaluasi nilai ketidakpastian suatu hasil pengukuran, dibutuhkan sebuah metode yang mempunyai sifat-sifat:

- Fleksibel.

Metode yang fleksibel adalah metode yang bisa diterapkan untuk berbagai macam jenis dan kondisi pengukuran tanpa merubah proses-proses dari metode tersebut, seperti tidak membuat artefak baru atau melakukan pengukuran ulang.

- Murah.

Metode yang murah di sini bermaksud apabila dibandingkan dengan metode lain, misal metode ISO 15530-

3 membutuhkan benda kerja yang terkalibrasi sehingga meningkatkan total biaya inspeksi kualitas.

- Mudah diaplikasikan.

Mudah diaplikasikan bermaksud bahwa metodenya dapat digunakan oleh banyak operator tanpa harus memiliki keahlian yang tinggi untuk menerapkan metode tersebut.

- Sedikit campur tangan operator.

Hal ini bermaksud bahwa dalam menerapkan proses estimasi ketidakpastian, seorang operator tidak harus selalu menggunakan atau memonitor proses estimasi tersebut.

- Cepat.

Metode yang diharapkan adalah metode yang relatif cepat dibandingkan metode lainnya, misal metode ISO 15530-2 membutuhkan waktu untuk melakukan sejumlah pengukuran dan metode ISO 15530-3 membutuhkan waktu untuk membuat dan mengkalibrasi artefak yang serupa dengan suatu benda kerja yang diukur.

Metode ISO 15530-4 adalah sebuah metode untuk mengevaluasi atau mengestimasi nilai ketidakpastian yang berbasiskan simulasi Monte-Carlo yang difokuskan untuk hasil pengukuran dengan sebuah mesin CMM (ISO 155304 2008). Metode ISO 15530-4 memiliki kelebihan-kelebihan yang telah dijelaskan sebelumnya, yaitu fleksibel, murah, mudah diaplikasikan, sedikit campur tangan operator dan cepat.

Langkah-langkah untuk menerapkan metode ISO 15530-4 diperlihatkan pada gambar 24. Metode ISO 15530-4 terdiri dari dua bagian utama, seperti yang diperlihatkan pada gambar 24, yaitu langkah-langkah yang diperlihatkan dengan garis biru dan langkah-langkah yang diperlihatkan dengan garis merah. Awal dari metode ISO 15530-4 adalah sebuah pengukuran riil benda kerja yang akan dievaluasi hasil ketidakpastian dari benda kerja tersebut. Pengukuran benda kerja tersebut dilakukan dengan suatu mesin CMM.

Aspek yang sangat penting dari metode ISO 15530-4 adalah proses simulasi dimulai dari data hasil pengukuran riil suatu CMM. Hal ini merupakan aspek utama untuk dapat melakukan simulasi Monte-Carlo walaupun detil dari fungsi matematik suatu pengukuran CMM tidak tersedia. Dengan menggunakan hasil pengukuran riil suatu mesin CMM, data hasil pengukuran tersebut merepresentasikan model atau fungsi matematik dari pengukuran tersebut. Untuk melakukan proses simulasi dengan metode ISO 15530-4, poin-poin data ( $3 D$ point cloud) yang dihasilkan dari pengukuran riil tersebut dengan suatu CMM akan diberi ganguan (perturbed) yang disebabkan oleh sumber-sumber ketidakpastian. Ganguan-gangguan tersebut dihasilkan dari variabel-variabel acak yang mempunyai distribusi statistik tertentu. Proses penggangguan poin-poin tersebut (point perturbation) diulang dalam jumlah yang sangat besar. 
(1)

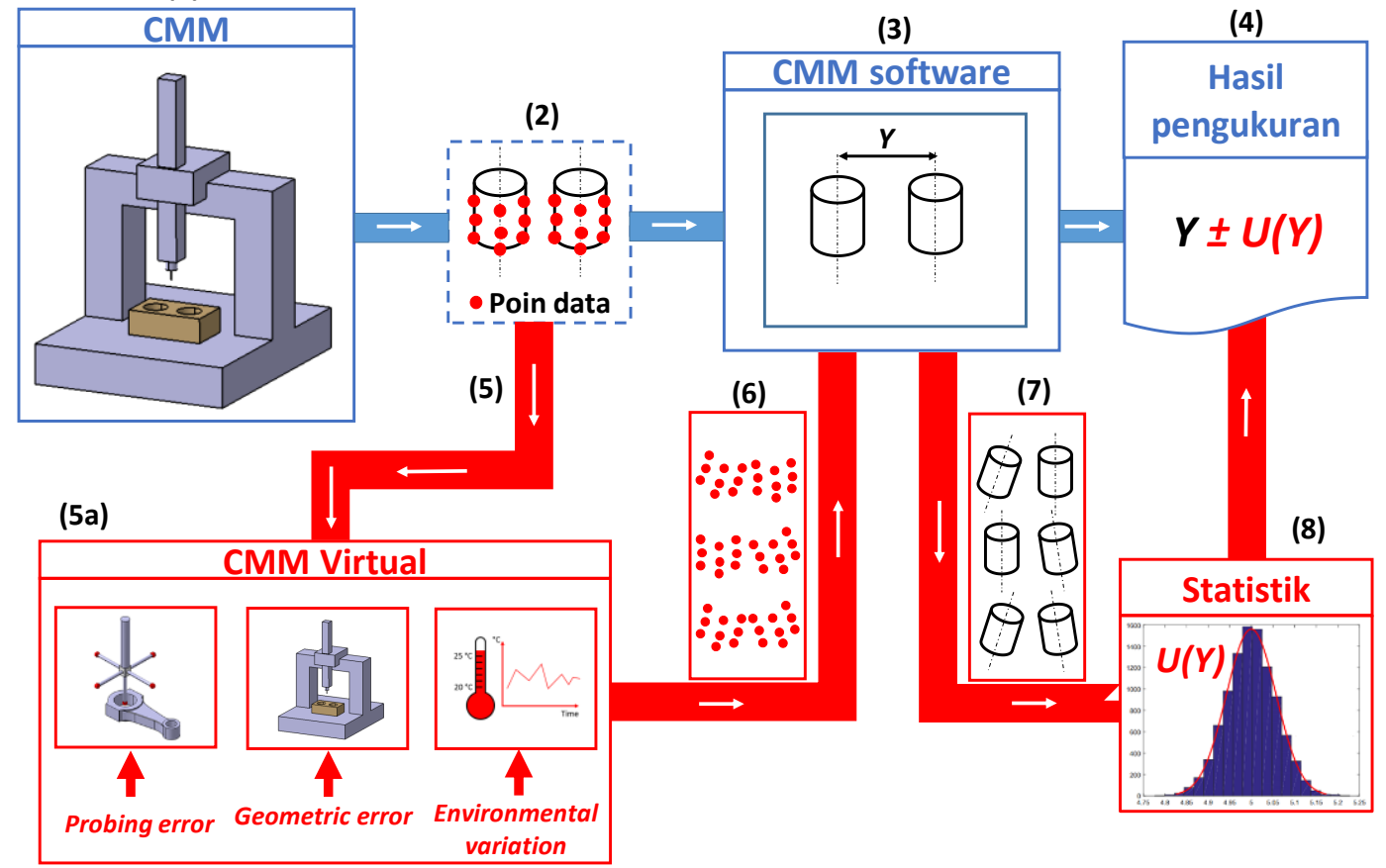

Gambar 24: Langkah-langkah estimasi nilai ketidakpastian dengan metode ISO 15530-4.

Penjelasan detil dari langkah-langkah metode ISO 15530-4 adalah sebagai berikut (sesuai dengan gambar 24):

1. Bagian 1 (garis biru).

Bagian ini merupakan langkah pertama dalam menerapkan metode ISO 15530-4 untuk menentukan hasil suatu pengukuran $Y$. Tahapan-tahapan Bagian 1 adalah:

(1) Sebuah pengukuran riil suatu benda kerja dilakukan dengan CMM, baik kontak maupun non-kontak.

(2) Poin-poin data 3D (3D point cloud) didapatkan dari pengukuran suatu CMM.

(3) Poin-poin data tersebut kemudian diproses dengan suatu algoritma pengukuran, misalnya least-square fitting atau minimum-zone fitting, untuk mengkalkulasi suatu measurand, misal flatness, rounfness, length dan location.

(4) Dari hasil proses data tersebut, sebuah hasil pengukuran $Y$ didapatkan. Pada tahap ini, hanya hasil pengukuran $Y$ didapatkan, tetapi nilai ketidakpastiannya belum terestimasi. Untuk mengestimasi hasil pengukuran tersebut, maka Bagian 2 dari metode ISO 15530-4 harus dilakukan, yaitu dengan simulasi Monte-Carlo.

2. Bagian 2 (garis merah).

Bagian ini merupakan tahapan untuk mengestimasi nilai ketidakpastian $U(Y)$ dengan menggunakan metode simulasi Monte-Carlo. Bagian 2 ini dilakukan secara berulang-ulang dalam jumlah yang sangat banyak untuk dilakukan analisis statistk dari data-data hasil simulasi tersebut. Tahapan-Tahapan dari (5a) sampai (8) dilakukan secara berulang-ulang. Tahapan-tahapan Bagian 2 adalah:

(5) Pada tahap ini, data-data poin ( $3 D$ point cloud) hasil dari suatu pengukuran riil CMM digunakan sebagai input untuk proses simulasi. Data poin tersebut merupakan representasi dari fungsi matematik suatu pengukuran CMM.

(5a) Tahap ini merupakan tahapan inti dari proses simulasi Monte-Carlo untuk metode ISO 15530-4.

Pada tahap ini, data-data poin yang didapatkan diberikan ganguan-ganguan yang bersumber dari 
berbagai sumber utama ketidakpastian yang mempengaruhi hasil suatu pengukuran dengan CMM, misal yang berasal dari error geometri, probing error dan error akibat efek dari lingkungan. Proses pemberian ganggun tersebut merupakan suatu proses matematik yaitu dengan menerapkan transformasi geometri pada data-data poin tersebut.

(6) Pada tahap ini, berbagai macam data-data poin dihasilkan setelah memberikan gangguan-gangguan terhadap data-data poin yang dihasilkan dari hasil pengukuran riil suatu CMM. Data-data poin yang dihasilkan tersebut lalu diproses dengan menggunakan algoritma yang sama untuk memproses data hasil pengukuran riil.

(7) Setelah data-data poin yang dihasilan, maka hasil pengukuran dari simulasi $Y_{\text {sim }}$ didapatkan dan disimpan.

(8) Dari banyaknya $Y_{\text {sim }}$ yang dihasilkan dari proses simulasi, standar deviasi $\sigma$ dari $Y_{\text {sim }}$ dikalkulasi untuk mendapatkan estimasi dari ketidakpastian $U(Y)$. Sehingga, hasil pengukuran yang lengkap didapatkan, yaitu $Y \pm U(Y)$

\section{Evaluasi metode ISO 15530-4.}

Hasil akhir estimasi ketidakpastian dengan metode ISO 15530-4 yang didapatkan dari simulasi harus dikombinasikan dengan nilai-nilai ketidakpastian yang berasal dari faktor-faktor lain yang tidak diperhitungkan di dalam proses simulasi. Apabila proses simulasi dianggap sudah memperhitungkan seluruh sumber-sumber utama yang berkontribusi terhadap nilai ketidakpastian suatu hasil pengukuran, maka hasil akhir estimasi tersebut adalah ketidakpastian yang berasal dari simulasi tersebut.

Untuk mengkombinasikan nilai ketidakpastian hasil simulasi dengan nilai ketidakpastian yang berasal dari faktor lain, hal ini dapat dikalkulasi dengan:

$$
U_{s i m}=k \times \sqrt{u_{s i m}^{2}+\sum_{i=1}^{n} u_{i}^{2}}
$$

dimana $u_{\text {sim }}$ adalah ketidakpastian standar (standard uncertainty) yang berasal dari simulasi dan $u_{i}$ adalah ketidakpastian standar dari sumber ke- $i$ yang tidak diperhitungkan di dalam proses simulasi $\{i=1,2,3, \ldots, n\}$.

\section{Validasi metode ISO 15530-4.}

Ada beberapa metode untuk validasi apakah suatu metode simulasi Monte-Carlo untuk mengestimasi nilai ketidakpastian dapat merepresentasikan hasil riil yang sebenarnya. Di dalam ISO 15530-4, metode-metode validasi tersebut adalah:

- Validasi dengan suatu pengukuran riil dengan CMM.

- Validasi dengan mengkomparasi hasil estimasi ketidakpastian dari simulasi dengan sebuah nilai referensi.

- Validasi dengan investigasi secara statistik hasil historis dari banyak hasil pengukuran.

Validasi dengan suatu pengukuran riil CMM akan dijelaskan sebagai berikut. Validasi dengan metode ini dikuantifikasikan dengan suatu nilai kriteria kecocokan (plausibility) E. Kriteria kecocokan tersebut adalah:

$$
E=\frac{\left|y-y_{\text {cal } C M M}\right|}{\sqrt{U_{\text {cal } C M M}^{2}+U_{\text {sim }}^{2}}} \leq 1
$$

dimana $y$ adalah hasil pengukuran CMM standar (baik kontak maupun non-kontak), $y_{\text {calCMM }}$ adalah nilai terkalibrasi dengan CMM dengan tingkat akurasi yang tinggi (akurasi lebih tinggi dari CMM standar), $U_{\text {calCMM }}$ adalah ketidakpastian terekspansi dari proses kalibrasi dengan CMM dengan tingkat akurasi yang tinggi dan $U_{\text {sim }}$ adalah ketidakpastian terekspansi hasil dari simulasi Monte-Carlo sesuai dengan ISO 15530-4.

Jumlah pengukuran $y$ direkomendasikan untuk diulang sebanyak minimal 100 kali. Dari setiap hasil pengulangan, nilai $E$ dikalkulasi. Hasil ketidakpastian dari simulasi $U_{\text {sim }}$ dianggap dapat merepresentasikan situasi riil apabila kriteria kecocokan $E \leq 1$ haruslah $\geq 95 \%$ dari total jumlah $E$ yang terkalkulasi (sebanyak jumlah pengulangan $y$ ). 


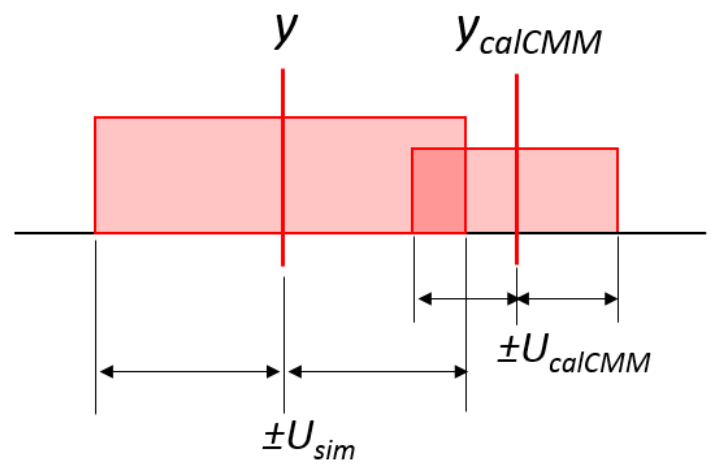

Gambar 25: Ilustasi dari kriteria kecocokan (plausibility).

Ilustrasi dari nilai kecocokan (plausibility) diperlihatan pada gambar 25. Arti dari gambar 25 dan persamaan 79 adalah nilai ketidakpastian hasil dari simulasi $U_{\text {sim }}$ dianggap merepresentasikan situasi riil (tervalidasi) apabila ada irisan antara interval $y$ yang terasosiasikan dengan $U_{\text {sim }}$ dan interval $y_{\text {calCMM }}$ yang terasosiasikan dengan $U_{\text {calCMM }}$.

\subsection{Metode berbasis standard yang lain}

Beberapa metode selain metode ISO untuk mengestimasi ketidakpastian hasil pengukuran dengan menggunakan suatu CMM juga tersedia. Contoh metode lain selain metode standar ISO adalah metode yang terdapat pada standar Jerman adalah sebagai berikut:

- VDI/VDE 2617 part 7 untuk evaluasi ketidakpastian hasil pengukuran menggunakan CMM dengan metode simulasi (VDI/VDE 2617-7 2007).

- VDI/VDE 2617 part 11 untuk evaluasi ketidakpastian hasil pengukuran menggunakan CMM menggunakan metode uncertainty budget (berbasis metode tabel/speadsheet) (VDI/VDE 2617-11 2011).

- VDI/VDE 2629 part 2 untuk evaluasi ketidakpastian hasil pengukuran menggunakan CMM dengan menggunakan artefak terkalibrasi (VDI/VDE 2629-2 2012).

- VDI/VDE 2630 part 2.1 untuk evaluasi ketidakpastian hasil pengukuran menggunakan CMM berbasis $X$-ray computed tomography (VDI/VDE 2630-2.1 2015).

Serupa dengan metode ISO, metode VDI/VDE mempunyai landasan utama GUM dan merupakan pengembangan dari metode tabel dan simulasi Monte-Carlo. Namun pada prakteknya, metode berbasis ISO 15530 lebih banyak diadaptasi dan digunakan karena mempunyai level standardisasi yang lebih tinggi.

Terdapat riset-riset yang menggunakan metode ISO 15530 untuk menentukan nilai ketidakpastian. Beberapa contoh dari riset-riset tersebut adalah sebagai berikut: riset-riset yang menggunakan metode ISO 15530-2 dapat dirujuk di Moroni et al 2014 dan Moroni et al 2017, riset-riset yang menggunakan metode ISO 15530-3 dapat dirujuk di Tosello et al 2009 dan Tosello et al 2010 dan riset-riset yang menggunakan metode ISO 15530-4 dapat dirujuk di Syam 2015, Moroni et al 2015, Jakubiec dan Plowucha 2013. Beaman dan Morse 2010 mempresentasikan hasil komparasi nilai ketidakpastian yang diestimasi dengan menggunakan metode simulasi dari beberapa perangkat lunak komersial dan yang diestimasi dengan menggunakan hasil eksperimen dengan menggunakan CMM.

Kesimpulan dari bab ini adalah nilai ketidakpastian adalah mutlak diperlukan agar suatu hasil pengukuran apapun dapat dipercaya, dikomparasi, terlacak dan reliabel. Metode untuk menentukan nilai ketidakpastian dari suatu hasil pengukuran dapat dilakukan dengan salah satu metode yang telah dipresentasikan dalam bab ini ataupun dengan menggunakan kombinasi dari metode-metode tersebut. 


\subsection{Contoh kasus: estimasi ketidakpastian hasil pengukuran laser interferometer}

Bagian ini akan memberikan contoh kasus riil estimasi ketidakpastian hasil pengukuran laser interferometer dengan menggunakna metode spreadsheet (Haitjema 2008). Seperti yang sudah dijelaskan sebelumnya pada bab 4.5.8 tentang laser interferometer, model pengukuran jarak yang diukur dengan laser interferometer adalah:

$$
d=\frac{L_{\text {Meas }}}{n_{a}\left(T_{a}, P_{a}, R_{h}\right)}\left[1+\alpha \cdot\left(T_{s}-20^{\circ} \mathrm{C}\right)\right]
$$

dimana $L_{\text {Meas }}$ adalah hasil perhitungan jarak yang dihasilkan oleh suatu interferometri laser, $d$ adalah indeks refraktif udara $n_{a}, T_{s}$ adalah temperatur benda yang diukur, $T_{a}$ adalah temperature lingkungan (atmosphere), $R h$ adalah kelembapan relatif pada suatu tempat pengukuran, $P_{a}$ adalah tekanan atmosfer pada tempat pengukuran tersebut. Bedasarkan (Bonsch dan Potulski 1998), hal penting yang harus diketahuia adalah bahwa $n_{a}=f\left(T_{a}, R h, P_{a}\right)$. Maka dari itu, untuk dapat menghasilkan suatu pengukuran interferometri laser dengan tingkat akurasi yang tinggi, maka pengukuran-pengukuran parameter $T_{a}, R h$ dan $P_{a}$ tersebut harus dilakukan untuk dapat mekompensasi efek lingkungan dan untuk mengkalkulasi secara akurat panjang gelombang $\lambda_{a}$ dari laser yang digunakan. Dengan demikian, summber-sumber ketidakpastian (uncertainty) dari hasil pengukuran jarak/panjang dengan interferometri laser adalah: $T_{a}, P_{a}, R_{h}, \alpha, T_{m}$ dan repeatability dari pengukuran tersebut.

untuk memudahkan penentuan nilai ketidakpastian dari variasi factor lingkungan, berdasarkan (Bonsch dan Potulski 1998), tabel 10 untuk mengkonversi variasi dari faktor lingkungan menjadi variasi dalam satuan jarak digunakan.

Tabel 10: Konversi variasi dari faktor lingkungan menjadi variasi dalam satuan jarak.

\begin{tabular}{lcc}
\hline Kondisi lingkunan & Perubahan atau ketidakpastian & $\begin{array}{l}\text { Perubahan atau ketidakpastian pada suatu jarak yang } \\
\text { terukur } d \text { per metre. }\end{array}$ \\
\hline Temperatur udara, $T_{a}$ & $1{ }^{\circ} \mathrm{C}$ & $0.93 \mu \mathrm{m}$ \\
Tekanan udara, $p_{a}$ & $1 \mathrm{hPa}$ & $-0.27 \mu \mathrm{m}$ \\
kelembapan Rh & $1 \% \mathrm{Rh}$ & $0.009 \mu \mathrm{m}$ \\
\hline
\end{tabular}

Sebagai contoh, sebuah pengukuran benda yang mempunyai panjang nominal $80 \mathrm{~mm}$ dilakukan dengan sebuah laser interferometer. Pengukuran dilakukan pada suatu ruangan dengan temperatur $(20 \pm 1)^{\circ} \mathrm{C}$, kelembapan relatif $(50 R h \pm 10 \%)$ dan pada tekanan atmosphere $(1020 \pm 2) \mathrm{hPa}$. Estimasi nilai ketidakpastian dari pengukuran tersebut dengan metode spreadsheet diperlihatkan pada tabel 11. Dari hasil estimasi nilai ketidakpastian pada tabel 11, total kombinasi dari standard ketidakpastian (combined standard uncertainty) adalah $0.24 \mu \mathrm{m}$. dengan demikian, total nilai ketidakpastian terekspansi adalah $2 \times 0.24=0.48 \mu \mathrm{m}$. 
Tabel 11: Kalkulasi nilai ketidakpastian hasil pengukuran laser interferometer.

\begin{tabular}{|c|c|c|c|c|}
\hline$X_{i}$ & $\begin{array}{l}\text { Estimasi } \\
x_{i}\end{array}$ & $\begin{array}{l}\text { Ketidakpastian } \\
u_{i}\end{array}$ & $\begin{array}{l}\text { Koefisien } \\
\text { sensitifitas (dapat } \\
\text { dilakukan dengan } \\
\text { direct method) } \\
c_{i}=\frac{\partial P_{20}}{\partial X_{i}}\end{array}$ & $\begin{array}{l}\text { Kontribusi pada } \\
\text { nilai ketidakpastian } \\
\text { pada kondisi standar } \\
u_{i} \cdot c_{i} \text { in } \mu \mathrm{m}\end{array}$ \\
\hline$L_{\text {lin }}$ & $80 \mathrm{~mm}$ & 0 & 1 & 0 \\
\hline$L_{20}$ & $80.000575 \mathrm{~mm}$ & $0.085 \mu \mathrm{m}$ & 1 & 0.085 \\
\hline$T_{s}$ & $20.5^{\circ} \mathrm{C}$ & $0.2^{\circ} \mathrm{C}$ & $L_{20} \cdot \alpha_{s}$ & 0.184 \\
\hline$\alpha_{s}$ & $11.5 \cdot 10^{-6} \mathrm{~K}^{-1}$ & $0.7 \cdot 10^{-6} \mathrm{~K}^{-1}$ & $L_{20} \cdot\left(T_{s}-20^{\circ} \mathrm{C}\right)$ & 0.028 \\
\hline$T_{a}$ & $21^{\circ} \mathrm{C}$ & $1^{\circ} \mathrm{C}$ & $0.93 \cdot 10^{-6} \cdot L_{20}$ & 0.074 \\
\hline$p_{a}$ & $1020 \mathrm{hPa}$ & $2 \mathrm{hPa}$ & $2 \times 0.27 \cdot 10^{-6} \cdot L_{20}$ & 0.086 \\
\hline$H$ & $50 \% \mathrm{Rh}$ & $10 \% \mathrm{Rh}$ & $10 \times 0.9 \cdot 10^{-8 \cdot} L_{20}$ & 0.07 \\
\hline & $\mu \mathrm{m}$ & \multicolumn{2}{|c|}{$u\left(L_{1,20}\right)=\sqrt{\sum\left(u_{i} \cdot c_{i}\right)^{2}}$} & 0.24 \\
\hline
\end{tabular}




\section{Keuntungan ekonomi metrologi manufaktur}

Metrologi pada umumnya hanya dianggap sebagai "cost center" dan harus diminimisasi sebanyak mungkin. Namun demikian, paradigma metrologi sebagai "cost center" adalah sangat keliru. Karena, terdapat banyak sekali manfaat atau nilai tambah yang dapat diberikan oleh metrologi pada suatu industri, misalnya manufaktur, dan untuk suatu konsumen.

Beberapa manfaat nyata dari metrologi, misalnya untuk menjamin kualitas suatu produk agar sesuai dengan spesifikasi desain sehingga konsumen dapat membei suatu produk dengan kualitas yang tinggi, mengimprovisasi suatu proses manufaktur berdasarkan data inspeksi produk yang dilakukan dengan metrologi, dan masih banyak lagi contohcontoh keuntungan metrologi dalam industri.

Bab ini akan membahas mengenai pentingnya metrologi sehingga mempunyai nilai ekonomi yang sangat penting dalam suatu industri. Beberapa contoh nyata dari manfaat ekonomi dari metrologi manufaktur juga dibahas dalam bab ini. Tujuan utama dari bab ini adalah untuk merubah paradigma metrologi sebagai "cost center" menjadi "profit center" yang menghasilkan suatu keuntunagn ekonomi dalam industri seperti halnya produk yang dihasilkan industri tersebut dan dijual ke konsumen.

\subsection{Integrasi pengukuran dan CMM}

Metrologi sangat berperan penting dalam meingkatkan produktivitas suatu industri, misalnya manufaktur, dalam berbagai aspek (Kunzmann et al 2005). Metrologi mempunyai peran di semua tahapan proses manufaktur, mulai dari tahapan pra-produksi, produksai sampai dengan paska-produksi. Pada tahapan pra-produksi, metrologi sangat berperan penting pada proses estimasi kapabilitas suatu mesin produksi. Pada estimasi kapabilitas mesin produksi tersebut, aplikasi metrolog yang tidak tepat akan mengakibatkan kesalahan estimasi kapabilitas mesin tersebut (lihat bab 9). Pada tahapan produksi, metrologi sangat penting untuk menentukan suatu produk atau komponen yang dibuat memenuhi spesifikasi desain atau tidak. Selain itu, data-data hasil proses metrologi dapat digunakan untuk menigkatkan kinearja dari mesin-mesin produksi sehingga tingkat efisienasi produksinya meningkat (cost saving). Dan terakhir, metrologi berperan sangat penting untuk menjamin barak akhir yang akan dikirim ke suatu konsumen sesuai dengan spesifikasi yang diminta oleh konsumen tersebut, sehingga resiko pengembalian atau perbaikan barang dapat dikurangi. Contoh-contoh yang telah diberikan merupakan hanya sebagian kecil dari keuntungan metrologi dalam suatu industri, sehingga jelas bahwa metrologi bukanlah sebagai "cost center" pada sebuah industri. Metrologi harus dianggap sama pentingnya dengan proses produksi karena peran metrologi dapat dikuantifikasikan secara nilai ekonomi layaknya keuntungan yang didapatkan dari penjualan produk-produk hasil manufaktur.

Toleransi sangat mempengaruhi pemilihan jenis instrumen yang tepat digunakan untuk suatu pengukuran dan keseluruhan biaya dari proses inspeksi (Moroni et al 2011). Pada prinsipnya, semakin besar nilai toleransi yang diberikan pada suatu fitur dalam suatu produk, maka biaya inspeksi fitur tersebut semakin murah (tidak membutuhkan suatu instrumen pengukuran yang sangat presisi) dan biaya manufaktur produk tersebut juga akan semakin murah. Namun demikian, nilai toleransi yang besar tersebut akan mengurangi fungsionalitas produk tersebut karena produks tersebut kurang presisi (nilai toleransinya besar). Dan sebaliknya apabila nilai toleransi suatu fitur sangat kecil, maka biaya inspeksi dan produksi fitur tersebut akan sangat tinggi, tetapi produk yang dihasilkan akan sangat presisi dan mempunyai fungsionalitas yang baik juga. Maka dari itu, biaya suatu proses inspeksi juga bergantung dari spesifikasi desain suatu produk. 
Gambar 1 memperlihatkan hubungan antara strategi pengukuran dengan menggunakan CMM kontak dengan biaya produksi serta nilai ketidakpastian hasil suatu pengukuran. Pada gambar 1(kiri) diperlihatkan pengaruh dari jumlah sampel titik-titik yang diukur dengan CMM kontak tersebut terhadap nilai ketidakpastiannya. Dari gambar 1 (kiri), semakin banyak jumlah titik-titik akan mengurangi nilai ketidakpastian sampai batas tertentu, dimana apabila jumlah titik-titik yang diukur melebihi batas tersebut, maka nilai ketidakpastian dari hasil pengukuran tersebut tidak akan berkurang lagi, melainkan akan menambah biaya inspeksi (karena bertambahnya waktu pengukuran, biaya energi mesin CMM, dan lain-sebagainya). Gambar 1(kanan) memperlihatkan bahwa, semakin banyak titik-titik yang diukur, maka pertama-tama biaya inspeksi berkurang (biaya inseksi berkurang seiring dengan berkurangnya nilai ketidakpastian, sehingga hasil pengukuran semakin terpercaya yang menghasilkan berkurangnya biaya karena kesalahan pengambilan keputusan: menerima komponen yang sebenarnya cacat atau menolak/meng-scrap komponen yang sebenarnya bagus). Namun demikian, sampai pada suatu batas dimana bertambahnya sampel titik-titik yang diukur tidak meningkatkan kualitas hasil pengukuran (nilai ketidakpastiannya stabil, tidak berkurang) melainkan hanya menambah biaya inspeksi. Maka dari itu, setiap pengukuran, baik dengan CMM atau instrumen lainnya, terdapat jumlah sampel titik-titik yang optimum, dimana terjadi keseimbangan antara nilai ketidakpastian yang dihasilakn (lihat bab 9 mengenai ketidakpastian/uncertainty) dan biaya inspeksi yang harus dikeluarkan.
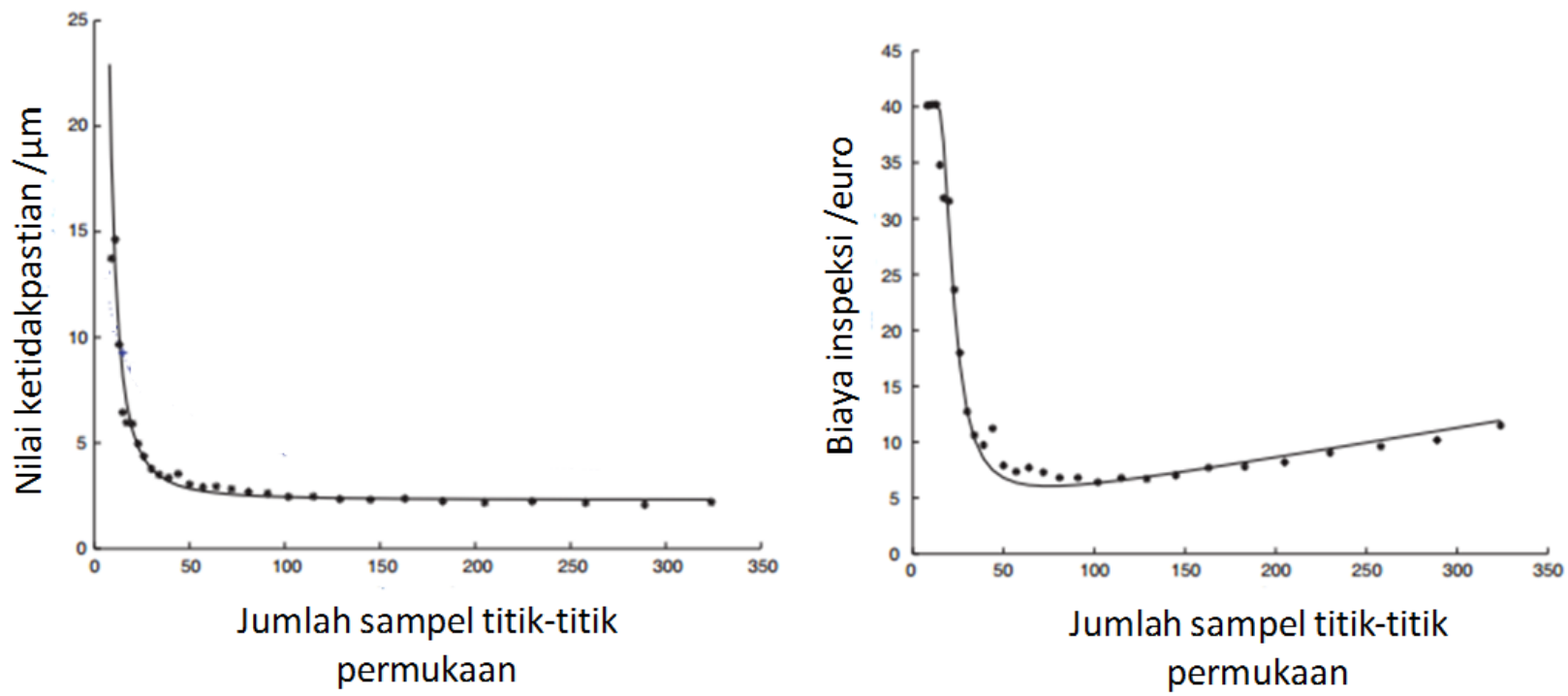

Gambar 1: Relasi antara: (kiri) Biaya inspeksi terhadap jumlah dari sampel titik-titik dan (kanan) nilai ketidakpastian terhadap jumlah dari sample titik-titik (Moroni et al 2011).

Untuk pemilihan dan integrasi suatu instrument pengukuran di dalam suatu proses produksi, terdapat dua faktor utama yang menentukan tipe atau jenis dari pemilihan dan integrasi tersebut, yaitu banyaknya variasi dari suatu produk dan banyaknya jumlah produksi dari produk tersebut. Gambar 2 memperlihatkan jenis-jenis instrumen pengukuran yang tepat untuk berbagai macam kondisi dari variasi suatu produk dan jumlah produksinya. Pada gambar 1, terlihat bahwa otomatisasi akan semakin signifikan apabila jumalh variasi suatu produk semakin sedikit dan jumlah produk produk tersebut semakin banyak. Maka dari itu, berdsarkan gambar 2, pemilihan jenis instrumen pengukuran untuk suatu situasi tertentu adalah tidak sama. Analisis yang dalam diperlukan untuk menentukan instrumen tipe apa yang paling tepat untuk suatu kebutuhan pengukuran dengan suatu kondisi tertentu. Tidak ada suatu instrumen pengukuran yang cocok untuk segala jenis kebutuhan inspeksi. 


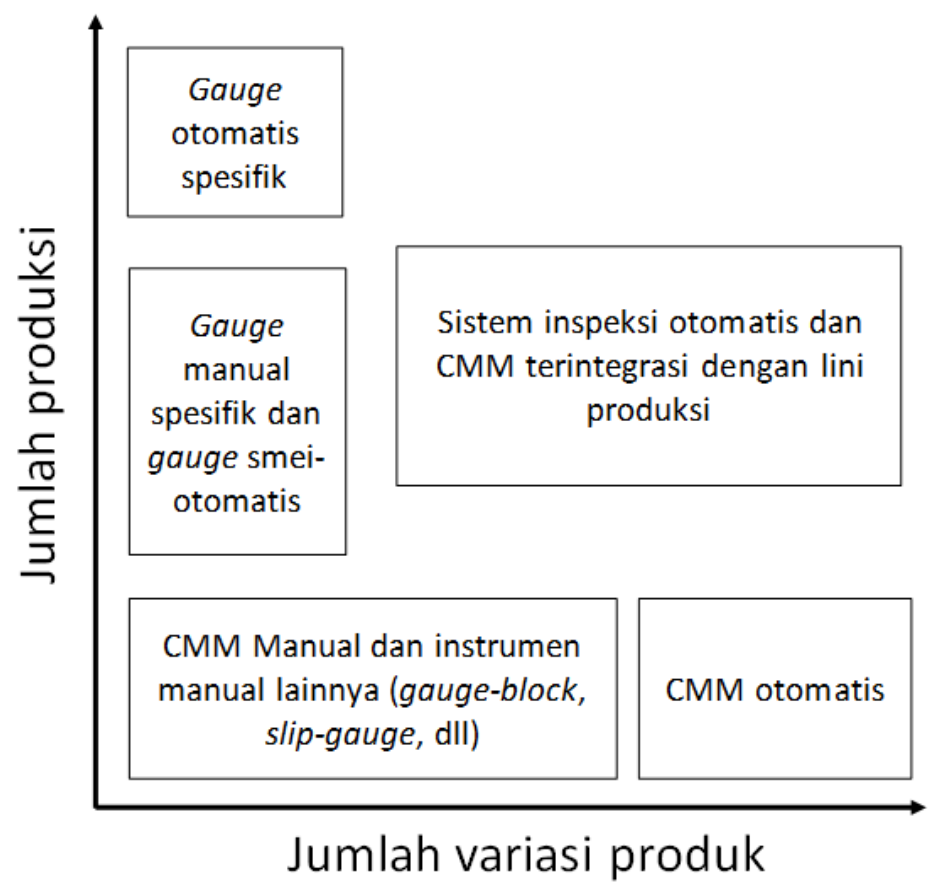

Gambar 2: Jenis-jenis pemilihan dan integrasi sistem pengukuran terhadap banyaknya variasi suatu produk dan jumlah produksinya (Hocken dan Pereira 2012).

Pada tahapan produksi, metrologi dapat dibagi lagi menjadi beberapa jenis berdasarkan dimana dan/atau kapan metrologi tersebut diaplikasikan pada tahapan produksi tersebut. Metrologi dalam produksi dapat dibagi menjadi: pengukuran in-process, in-line dan on-machine/in-situ. Pengertian dari jenis-jenis pengukuran tersebut adalah sebagai berikut:

- Pengukuran in-process: adalah pengukuran dimensi atau geometri atau tekstur permukaan yang terintegrasi pada suatu proses manufaktur atau produksi. Level dari integrasi tersebut dapat berupa integrasi di dalam suatu volume proses produksi atau di pos sebelum atau sesudah proses produksi tersebut. Pengukuran inprocess terbagi menjadi dua macam, yaitu pengukuran in-line dan on-machine/in-situ.

- Pengkuran in-line: adalah pengukuran dimensi atau geometri atau tekstur permukaan yang terintegrasi pada suatu lini produksi, tetapi diluar dari suatu proses produksi di dalam lini tersebut. Pengukuran in-line dapat dilakukan pada sebuah komponen atau produk sebelum atau sesudah proses produksi tersebut.

- Pengukuran on-machine/in-situ: adalah pengukuran baik fitur suatu produk (dimensi, geometri atau tekstur permukaan) maupun parameter-parameter suatu mesin proses produksi yang diintegrasikan dan dilakukan di dalam volume proses produksi mesin tersebut yang dilakukan secara bersamaan (parallel) dengan proses produksi tersebut atau dilakukan setelah proses tersebut selesai.

Hanya dengan metrologi, suatu sistem kontrol berbasis close-loop dari suatu proses produksi dapat dilakukan.

\subsection{Pemilihan CMM dan evaluasi keuangan}

Investasi sebuah $\mathrm{CMM}$, dan jenis-jenis instument pengukuran lainnya yang mempunyai tingkat akurasi dan presisi yang tinggi, membutuhkan dana yang tidak sedikit. Maka dari itu, keputusan untuk membeli sebuah CMM harus berdasarkan analisis seberapa besar CMM tersebut dapat berkontribusi secara ekonomi pada sebuah industri manufaktur. Walaupun CMM bukanlah sebuah alat produksi yang menghasilkan suatu produk, namun nilai ekonomi yang diberikan CMM (dan instrumen pengukuran lainnya) dapat lebih tinggi dari suatu mesin produksi. Dengan 
pemilihan dan penggunaan CMM atau instrumen pengukuran yang tepat, produk dengan kualitas yang tinggi dan biaya produksi yang rendah dimungkinkan untuk direalisasikan. Dengan penerapan CMM dan instrument pengukuran yang tepat, proses produksi dapat dijaga selalu dalam kondisi yang baik, komponen-komponen scrap dan re-work dapat dikurangi, dan produk yang dihasilkan mempunyai kualitas yang tinggi sehingga bisa bertahan ditengah-tengah persaingan pasar yang semakin ketat.

Sebelum membahas hal-hal mengenai evaluasi ekonomi suatu CMM, terapat beberapa hal penting yang harus dipahami dan dipertimbangkan sebelum berinvestasi dengan membeli sebuah CMM:

- Harga dan aspek ekonomi.

Tentu saja, harga merupakan hal yang paling utama dipertimbangkan. Pembelian sebuah CMM dan instrumen pengkuran lainnya dengan tingkat akurasi dan presisi yang berbeda merupakan investasi yang besar. Namun demikian, investasi yang besar tersebut akan dapat balik dalam bentuk keuntungan ekonomi yang jauh lebih besar apabila jenis CMM yang dibeli dan peakainnya tepat guna.

Invetasi CMM harus dijustifikasi dengan nilai eknomi "tersembunyi" yang dapat diberikan CMM tersebut kepada perusahaan dalam kurun waktu 5-10 tahun ke depan. Misalnya, keuntungan yang didapatkan dari berkurangnya komponen-komponen yang di-scrap atau re-work, meningkatnya persepsi konsumen karena kualitas suatu produk yang dihasilkan sangat tinggi, meningkatnya efisiensi proses produksi, dan lain sebagainya.

- Fleksibilitas

Faktor flesibilitas CMM adalah termasuk ukuran volume pengukuraa, konfiguasi CMM dan jenis aksesoris CMM yang dapat mendukung fungsionalitas suatu CMM. Semakin besar volume pengukuran, maka semakin banyak jenis produk yang dapat diukur, namun semakin besar volume pengukuran, maka tingkat akurasi suau CMM akan semakin berkurang. Jenis konfigurasi CMM, misalnya bridge-type atau cantilever-type, sangat bergantung pada jenis produk yang ingi diukur, misalnya untuk pengukuran body-in-white suatu mobil, CMM jenis cantilever-type adalah lebih tepat karena dapat mengakses fitur-fitur dari body-in-white tersebut. Secara umum, jenis CMM yang paling sering digunakan adalah jenis bridge-type. Aksesoris CMM yang perlu dipertimbangkan adalah seperti jenis perangkat lunak yang digunakan, ketersediaan berbagai macam stylus, kemampuan untuk mengganti sistem probin gdari kontak ke non-kontak dan sebaliknya, dan lain sebagainya.

- Keandalan

Keandalan CMM adalah sebuah karakteristik yang mencakup tingkat akurasi dan kecepatan pengukuran dari sebuah CMM. Seberapa besar tingkat akurasi CMM yang dibutuhkan adalah sangat bergantung pada sbeerapa besar toleransi fitur dari suatu produk yang akan diukur. Prinsip umumnya adalah, tingkat akurasi CMM harus minimal10 kali lipat lebih tinggi dari toleransi yang akan diukur. Misalnya, toleransi suatu fitur yang akan diukur adalah $20 \mu \mathrm{m}$, maka tingkat akurasi CMM yang digunakan untuk mengukurnya haruslah mempunyai tingkat akurasi minimal $2 \mu \mathrm{m}$. Spesifikasi sebauh CMM adalah berdasarkan parameter $\mathrm{MPE}_{E}$ (lihat Bab 5 untuk lebih jelasnya). Kemudian, seberapa cepat suatu CMM dapat menyelesaikan suatu pengukuran sangat mempengaruhi total biaya inspeksi yang bersumber dari, misalnya upah dari operator dan biaya energi yang digunakan untuk melakukan suatu pengukauran.

- Dukungan after-sale dan pemeliharaan

CMM merupakan sebuah instrumen yang kompleks dan pemakaian CMM juga merupakan suatu proses yang rumit. Maka dari itu, dukungan after-sales suatu produsen CMM sangat bermanfaat. Dengan dukungan aftersales yang baik, apabila terjadi suatu masalah yang berkaitan dengan CMM tersebut, masalah tersebut dapat segera diselesaikan sehingga mengurangi waktu down-time. Selain itu, pemeliharaan komponen-komponen CMM harus juga dipertimbangkan karena terdapat biaya pemeliharaan dari setiap CMM. Jenis CMM yang berbeda mempunyai pemeliharaan yang berbeda pula, misalnya CMM yang memakai air-bearing dan ball - bearing akan mempunyai perbedaan biaya pemeliharaan yang berbeda 


\section{Evaluasi keuangan dengan parameter Net-present value}

Salah satu parameter yang paling umum digunakan untuk menjustifikasi sebuah investasi, dalam hal ini investasi CMM, adalah net-present value (NPV). NPV adalah perbedaan antara nilai sekarang dari kas masuk dan nilai sekarang dari kas keluar yang digunakan untuk menghitung tingkat keuntungan sebuah investasi atau proyek. Properti utama dari kalkulasi NPV adalah perhitungan NPV sangat dipengaruhi oleh seberapa besar nilai masa depan dari kas masuk yang akan diberikan oleh suatu investasi atau proyek. Pada hakekatnya, NPV membandingkan nilau uang sekarang dengan nilai uang tersebut pada masa yang akan datang dengan mempertimbangkan inflasi dan keuntungan. NPV dikalkulasi sebagai berikut:

$$
\mathrm{NPV}=\sum_{t=1}^{T} \frac{C_{t}}{(1+r)^{t}}-C_{0}
$$

dimana $T$ adalah durasi dari nilai suatu investasi atau proyek, $t$ adalah tahun dimana estimasi keuntungan (atau simpanan) dari $C_{t} . r$ adalah laju depresiasi nilai suatu investasi atau proyek dalam periode $T . C_{0}$ adalah besarnya investasi awal. Apabila NPV bernilai negatif, maka aliran kas juga akan negatif (rugi) sehingga suatu investasi atau proyek dapat ditolak.

\subsection{Keuntungan ekonomi}

Pada bagian ini, beberapa contoh kasus mengenai kuantifikasi nilai eknomi (misalnya biaya inspeksi, keuntungan inspeksi, kuantifikasi keuntungan dari inspeksi, dan lain sebagainya) suatu proses pengukuran akan dipresentasikan. Dengan memperlihatkan keuntungan ekonomi dari metrologi manufaktur dalam bentuk contoh kasus dan angka, diharapkan paradigma yang selama ini menganggap metrologi sebagai "cost center" dapat berubah. Untuk CMM, terdapat lima peran vital utama untuk suatu industri manufaktur, yaitu: inspeksi untuk post-process suatu produk, inspeksi untuk audit, pengukuran untuk analisis, pengukuran untuk kontrol proses dan pengukuran untuk kalibrasi gauge atau artifak.

\subsubsection{Berbandingan biaya inspeksi per komponen}

Berbagai jenis biaya yang berhubungan dengan suatu proses pengukuran terbagi menjadi dua kelompok utama, yaitu: biaya tetap dan biaya variabel. Komponen-komponen pembentuk biaya tetap dan biaya variabel adalah sebagai berikut (Brown \& Sharpe 2001):

- $\quad$ Biaya tetap

Biaya tetap terdiri dari biaya engineering (analisis), peralatan/sistem, nilai depresiasi, lama waktu depresiasi, tempat per tahun dan perlengkapan awal. Penjelasan dari setiap komponen biaya tersebut adlaah sebagai berikut:

- Biaya engineering: adalah biaya yang muncul untuk mendisai set up berbagai macam gauge untuk suatu pengukuran atau untuk melakukan perencanaan dan pemrograman CMM.

- Biaya peralatan/sistem: adalah biaya untuk membeli peralatan atau sistem pengukuran. Sebagai contoh, biaya untuk inspeksi manual seperti surface plate, gauge block, master gauge, dial gauge dan alat bantu pengukuran yang presisi lainnya mempunyai biaya sekitar \$20k sampai \$40k. Biaya untuk sebuah CMM manual adalah sekitar \$20k sampai \$100k. Sedangkan, biaya untuk CMM otomatis adalah sekitar \$80k sampai \$500k (Hocken dan Pereira 2012).

- Lama waktu depresiasi: adalah lamanya siklus suatu sistem pengukuran yang dianggap masih bisa beroperasi sesuai dengan spesifikasinya, pada umumnya lamanya depresiasi suatu sistem pengukuran adalah 7 sampai 10 tahun.

- Nilai depresiasi: adalah berkurangnya nilai suatu sistem pengukuran per tahunnya. Nilai depresiasi dapat dihitung dengan membagi harga dari suatu sistem pengukuran dan berapa lama (tahun) dari waktu depresiasi 
suatu sistem pengukuran.

- Biaya tempat per tahun: adalah biaya untuk penempatan sebush sistem pengukuran dan biaya untuk mengontrol tempat dimana sistem pengukuran tersebtu ditempatkan. Untuk CMM, pada umumnya biaya tempat pertahun (termasuk biaya untuk mengontrol lingkungan tersebut) adalah sekitar \$1000 sampai \$5000 per tahun (Hocken dan Pereira 2012).

- Biaya perlengkapan/aksesoris awal: adalah biaya yang berkaitan dengan perlengkapan awal suatu sistem pengukuran. Misalnya untuk CMM, dibutuhkan biaya awal untuk membeli berbagai macam jenis probe, stylus dan sistem fixturing.

- Biaya variabel

Biaya variabel terdiri dari biaya fixturing dan jig, tingkat pengoperasian (jumlah shift pekerja), pemeliharaan tahunan (maintanance), taris inspeksi, operator inspeksi dan pelatihan. Penjelasan dari setiap komponen biaya tersebut adlaah sebagai berikut:

- Biaya fixturing, jig dan perlengkapan lainnya: adalah biaya untuk memeliharan berbagai macam gauge yang dimiliki, misalnya untuk biaya kalibrasi ulang dan lain sebagainya.

- Tingkat pengoperasian: adalah jumlah shift dikalikan dengan berapa lama suatu sistem pengukuran digunakan. Sistem pengukuran otomatis mempunyai tingkat pengoperasian yang jauh lebih lama dari sistem pengukuran manual.

- Biaya pemeliharaan tahunan: adlaah biaya untuk melakukan perawatan fisik suatu sistem pengukuran dan juga untuk merevisi versi dari perangkat lunak yang digunakan. Pada umumnya jumlah biaya pemeliharaan diestimasi sejumlah persentase dari harga suatu sistem pengukuran.

- $\quad$ Biaya tarif inspeksi: adalah biaya yang muncul apabila suatu bagian pengukuran akan di-out-source ke pihak lain.

- $\quad$ Biaya operator inspeksi: adalah biaya upah pekerja yang melakukan inspeksi per jamnya.

- Biaya pelatihan: adalah biaya yang muncul karena melakukan pelatihan kepada operator untuk suatu kasus pengukuran yang baru atau kompleks.

Untuk lebih jelasnya, Tabel 1 memperlihtkan contoh dari perandingan biaya inspeksi suatu komponen dengan menggunakan beberapa sistem pengukuran yang berbeda. Dari Tabel 1, dapat dilihat bahwa dengan menggunakan CMM otomatis, biaya inspeksi per komponen menjadi lebih murah. Keuntungan utama CMM otomatis yang membedakan dengan jenis sistem pengukuran lainnya adalah CMM otomatis dapat bekerja tanpa $100 \%$ penjagaan seorang operator dan CMM otomatis dapat mengukur jumah komponen yang lebih bervairasi dan lebih banyak tanpa membutuhkan setup ulang yang lama.

Tabel 1: Perbandingan biaya inspeksi sebuah komponen dari beberapa sistem pengukuran.

\begin{tabular}{|c|c|c|c|c|c|}
\hline Jenis biaya & Unit & Keterangan & $\begin{array}{c}\text { Inspeksi } \\
\text { manual } \\
\text { berbasis } \\
\text { sistem gauge }\end{array}$ & $\begin{array}{c}\text { CMM } \\
\text { manual }\end{array}$ & $\begin{array}{c}\text { CMM } \\
\text { otomatis }\end{array}$ \\
\hline Biaya awal & $\mathrm{k} \$$ & Harga sistem & 126 & 140 & 280 \\
\hline $\begin{array}{c}\text { Biaya } \\
\text { engineering }\end{array}$ & $\mathrm{k} \$$ & $\begin{array}{c}\text { biaia persiapan setup gauge dan } \\
\text { lain-lain }\end{array}$ & 50 & 0 & 0 \\
\hline $\begin{array}{c}\text { Biaya } \\
\text { fixturing }\end{array}$ & $\mathrm{k} \$$ & $\begin{array}{l}\text { perlengkapan untuk menahan } \\
\text { benda dan penempatan benda }\end{array}$ & 102 & 30 & 30 \\
\hline $\begin{array}{c}\text { Lama } \\
\text { depresiasi }\end{array}$ & tahun & & 7 & 7 & 7 \\
\hline $\begin{array}{c}\text { Biaya } \\
\text { depresiasi }\end{array}$ & $\mathrm{k} \$$ & harga sistem / lama depresiasi & 18 & 20 & 40 \\
\hline
\end{tabular}




\begin{tabular}{|c|c|c|c|c|c|}
\hline Biaya tempat & $\mathrm{k} \$$ & $\begin{array}{l}\text { termasuk biaya listrik untuk } \\
\text { kontrol temperatur ruangan }\end{array}$ & 0.5 & 3 & 4 \\
\hline Biaya gedung & $\mathrm{k} \$$ & & 45 & 32 & 58 \\
\hline $\begin{array}{c}\text { Tingkat } \\
\text { penggunaan }\end{array}$ & shift & jumlah shift perkerja & 10 & 80 & 60 \\
\hline $\begin{array}{c}\text { Biaya } \\
\text { pemeliharaan }\end{array}$ & $\mathrm{k} \$$ & $(3 \%-7 \%) \times$ harga sistem & 6 & 8 & 8 \\
\hline $\begin{array}{c}\text { Biaya } \\
\text { perlengkapan } \\
\text { awal }\end{array}$ & $\mathrm{k} \$$ & $30 \%$ dari harga sistem & 31 & 2 & 2 \\
\hline $\begin{array}{l}\text { Biaya } \\
\text { operator }\end{array}$ & $\mathrm{k} \$$ & $\begin{array}{l}\text { CMM otomatis dapat bekerja } \\
\text { tanpa operator }\end{array}$ & 10.6 & 80.6 & 10.2 \\
\hline $\begin{array}{c}\text { Biaya } \\
\text { pelatihan }\end{array}$ & $\mathrm{k} \$$ & $\begin{array}{l}\text { pelatihan menggunakan sistem } \\
\text { pengkuran termasuk pelatihan } \\
\text { setup }\end{array}$ & 3 & 10 & 1 \\
\hline $\begin{array}{l}\text { Total biaya } \\
\text { per tahun }\end{array}$ & $\mathrm{k} \$$ & & 409.1 & 412.6 & 500.2 \\
\hline $\begin{array}{l}\text { Tota biaya } \\
\text { per jam }\end{array}$ & $\$ / h$ & 1200 jam per tahun & 341 & 344 & 417 \\
\hline $\begin{array}{c}\text { Jumlah } \\
\text { komponen } \\
\text { yang dapat } \\
\text { diukur per } \\
\text { jam } \\
\end{array}$ & komponen & & 1 & 1 & 3 \\
\hline $\begin{array}{c}\text { Biaya } \\
\text { inspeksi per } \\
\text { komponen }\end{array}$ & \$/komponen & & 341 & 344 & 139 \\
\hline
\end{tabular}

\subsubsection{Nilai balik investasi untuk CMM otomatis dan biaya kontrol proses.}

Salah satu prosedur umum untuk mengetahui investasi CMM atau siste pengukuran lainnya adalah layak atau tidak, analisis return-on-investment (ROI) digunakan. ROI juga sering digunakan untuk menganalisis alternatif pilihan dari berbagai macam peralatan kapital, yaitu peralatan yang harganya sangat tinggi, untuk memilih peralatan mana yang akan paling banyak mendatangkan keuntungan ke depannya.

Dalam menghitung ROI, keuntungan tidak hanya diitung dari berpapa jumlah penjualan atau keuntungan yang didapatkan, misalnya dari penjualan servis, tetapi juga, keuntungan, yang mencakup potensi kerugian yang dapat dicegah, harus diperhitungkan dan diikutsertakan sebagai keuntungan.

Kontributor-kontributor utama dalam perhitungan ROI yang dianggap sebagai pencegahan potensi kerugian dan penghematan biaya operasi adalah:

- Biaya karena proses produksi terhenti karena ditemukannya cacat produksi atau suatu proses produksi di luar batas toleransinya.

- Biaya pergantian komponen produk.

- Biaya pergantian setup karena perubahan toleransi.

- Biaya gauging lainnya, seperti: penambahan jumlah gauge untuk mengimbangai jumlah inspeksi yang bertambah.

- Biaya analisis hasil suatu inspeksi atau pengukuran. 
- Pengurangan dan atau penghilangan biaya produk yang di-scrap.

- Pengurangan dan atau penghilangan biaya perbaikan produk atau komponen.

- Pengurangan dan atau penghilangan biaya inspeksi atau pengukuran ulang.

CMM otomatis sangat berpotensi untuk mengurangi biaya-biaya yang disebutkan di atas. Beberapa contoh nyata dari potensi CMM otomatis tersebut adlaah sebagai berikut. Hasil pengukuran CMM dapat mendeteksi cacat produksi di awal-awal proses, sehingga solusi untuk menanggulangi cacat tersebut akan semakin mudah dan tidak perlu menghentikan suatu proses produksi dalam waktu yang lama. Dengan menggunakan CMM, berbagai macam bentuk suatu komponen atau produk dapat diukur, sehingga jumlah gauge yang dibutuhkan akan semakin sedikit. CMM otomatis pada umumnya dilengkapi dengan sebuah perangkat lunak yang mempunyai kemampuan untuk menganalisis hasil pengukuran, sehingga tidak dibutuhkan seorang pekerja untuk hanya menganalisis hasil suatu pengukuran. Dengan prosedur pengukuran dengan CMM otomatis yang benar, maka hasil suatu pengukuran akan mempunyai tingkat akurasi dan presisi yang tinggi, sehingga resiko kesalahan pengambilan keputusan terhadap suatu benda apakah benda tersebut harus di-scrap atau diperbaiki, akan semakin berkurang. Selain itu, CMM otomatis merupakan sebuah instrumen pengukuran yang sangat fleksibel sehingga hanya dibutuhkan waktu yang singkat untuk mengeset CMM tersebut untuk mengukur berbagai macam komponen dengan ukuran dan bentuk yang berbeda-beda.

\section{$\underline{\text { Biaya kontrol proses }}$}

CMM otomatis mempunyai keuntungan ekonomi yang sangat signifikan untuk biaya kontrol suatu proses produksi untuk megetahui apakah proses tersebut bekerja seusai dengan toleransi prosesnya. Tabel 2 memperlihatkan perbandingan dari kapabilitas target dan gauge (GR\&R) dari berbagai macam sistem pengukuran. Pada Tabel 2, dapat terlihat bahwa CMM otomatis mempunyai kapabilitas yang paling baik dibandingkan dengan sistem pengukuran lainnya (dalam hal ini, semakin kecil nilainya, maka kapabilitasnya akna semakin tinggi, karena nilai tersebut mereresetasikan variasi dari suatu sistem pengukuran terhadap hasil pengukurannya).GR\&R dibahas dengan detil di Bab 2 dan 4.

Tabel 2: Perbandingan dari kapabilitas target dan gauge (GR\&R) dari berbagai macam sistem pengukuran.

\begin{tabular}{|l|c|c|c|}
\hline \multicolumn{1}{|c|}{ Informasi } & Gauge manual & CMM manual & CMM otomatis \\
\hline Biaya awal /k\$ & 40 & 140 & 280 \\
\hline Kapabilitas target /\% & \pm 20 & \pm 10 & \pm 5 \\
\hline $\begin{array}{l}\text { Kapabilitas gauge (GR\&R) } \\
\text { /\% }\end{array}$ & 30 & 20 & 10 \\
\hline
\end{tabular}

Kuantifikasi keuntungan dari informasi pada Tabel 2 adalah sebagai beikut (berdasarkan properti dari kurva distribusi normal):

- Gauge manual.

Gauge manual tersebut mempunyai kapabilitas GR\&R sebesar $30 \%$ dan kapabilitas target sebesar $20 \%$. Dengan asumsi rencana kapabilitas awal sebesar $10 \%$, maka limit kontrol akan bergeser sebesar $30 \% / 2$ $10 \% / 2=10 \%$ yang setara dengan $0.8 \sigma$. Hal ini menyebabkan hasil pengukuran suatu produk hasil produksi menggunakan gauge tersebut akan mempunyai nilai rata-rata yang bergeser sebesar $1.6 \sigma$ (untuk kapabilitas target sebesar $20 \%$ ). Sehingga total pergeseran dari nilai rata-rata hasil pengukuran adalah sebesar $1.6 \sigma+$ $0.8 \sigma=2.4 \sigma$. apabila toleransi suatu produk adalah $\pm 4 \sigma$, maka nlai tengah dari hasil pengukuran alan bergeser sebesar $4-2.4=1.6 \sigma$ (yang disebut sebagai kerugian toleransi). Hal ini menyebabkan $5.5 \%$ total produk akan di-scrap karena di luar batas toleransi $4 \sigma$ tersebut karena kesalahan pengambilan keputusan. Padahal produkproduk tersebut sebenarnya masih dalam batas toleransi apabila instrumen yang digunakan mempunyai tingkat akurasi dan presisi yang lebih tinggi (Persentasi variasi kapabilitas target dan gauge yang lebih rendah). 
- CMM manual.

Dengan perhitungan yang sama seperti pada perhitungan gauge manual, dengan kapabilitas target $10 \%$ dan kapabilitas gauge $20 \%$, maka total kerugian toleransinya adalah sebesar $1.2 \sigma$. Hal ini menyebabkan $0.26 \%$ total produk akan di-scrap karena di luar batas toleransi $4 \sigma$ tersebut karena kesalahan pengambilan keputusan. Padahal produk-produk tersebut sebenarnya masih dalam batas toleransi apabila instrumen yang digunakan mempunyai tingkat akurasi dan presisi yang lebih tinggi (Persentasi variasi kapabilitas target dan gauge yang lebih rendah).

- CMM otomatis.

Dengan perhitungan yang sama seperti pada perhitungan gauge manual, dengan kapabilitas target $5 \%$ dan kapabilitas gauge $10 \%$, maka total kerugian toleransinya adalah sebesar $0.4 \sigma$. Hal ini menyebabkan $0.02 \%$ total produk akan di-scrap karena di luar batas toleransi $4 \sigma$ tersebut karena kesalahan pengambilan keputusan. Padahal produk-produk tersebut sebenarnya masih dalam batas toleransi apabila instrumen yang digunakan mempunyai tingkat akurasi dan presisi yang lebih tinggi (Persentasi variasi kapabilitas target dan gauge yang lebih rendah).

Jumlah total produk yang di-scrap karena pergeseran nilai tengah dari hasil pengukuran seluruh komponen dapat dikonversi menjadi nilai ekonomi secara langsung dengan mengalikan dengan jumlah total dari produksi komponen tersebut. Misalnya, jumlah produksi komponen tersebut adalah sebesar 1000 komponen dengan harga \$10/komponen, maka total kerugian dari $5.5 \%$ komponen yang di-scrap adalah sebesar $5.5 \% \times 1000 \times 10=\$ 550$.

\subsubsection{Evaluasi impak eknomi dari metrologi dalam manufaktur}

Sebuah metodologi untuk menkuantifikasi nilai tambah eknomi yang diberikan dari metrologi manufaktur diusulkan oleh Savio 2012. Dengan metode tersebut, biaya dan keuntungan dari metrologi dievaluasi. Untuk biaya, proses kuantifikasinya sangat jelas dan langsung. Namun demikian, kuantifikasi dari keuntungan dari metrologi tidaklah langsung dapat terlihat dan dihitung, karena keuntungan tersebut dapat berupa meingkatnya relaibilitas dari suatu produk dan berkurangnya biaya garansi dari produk tersebut (minimalisasi biaya produksi).

\section{Pemodelan biaya proses inspeksi}

Total biaya produksi suatu komponen dimodelkan sebagai:

$$
C_{T}=C_{m p}+C_{i p}
$$

dimana $C_{T}$ adalah total biaya produksi suatu komponen, $C_{m p}$ adalah biaya karena suatu proses manufaktur dan adalah $C_{i p}$ biaya inspeksi. Moroni et al 2011 membagi lagi $C_{i p}$ menjadi dua bagian, yaitu biaya inspkesi itu sendiri dan biaya kesalahan inspeksi, yaitu:

$$
C_{\text {ip }}=C_{\text {inspection }}+C_{\text {error }}
$$

dimana $C_{\text {inspection }}$ adalah biaya penggunaan suatu sistem pengukuran (baik biaya tetap maupun biaya variabel, lihat bagian 10.3.1) dan $C_{\text {error }}$ adalah biaya yang muncul karena kesalahan pengambilan keputusan karena hasil pengukuran yang tidak akurat (kesalahan tipe I dan tipe II). $C_{\text {error }}$ dibagi menjadi dua bagian, yaitu:

$$
C_{\text {error }}=C_{\alpha}+C_{\beta}
$$

dimana $C_{\alpha}$ adalah biaya yang muncul karena membuang/meng-scrap suatu komponen yang sebenarnya bagus 
(Type I: discarding conforming parts) dan $C_{\beta}$ adalah biaya yang muncul karena menerima/mengirim suatu komponen yang sebenarnya cacat (Type II: accepting non-conforming parts). $C_{\text {error }}$ sangat bergantung pada nilai ketidakpastian suatu hasil pengukuran (Moroni et al 2011). Nilai ketidakpastian suatu hasil pengukuran yang terlalu tinggi (dari yang sebenarnya) mengakibatkan resiko membuang komponen yang bagus akan semakin tinggi. Sebaliknya, nilai ketidakpastan yang terlalu kecil (dari yang sebenarnya) mengakibatkan resiko menerima komponen yang cacat. Sehingga, total biaya produksi secara keseluruhan dihitung sebagai:

$$
C_{T}=C_{m p}+\left[C_{\text {inspection }}+\left[C_{\alpha}+C_{\beta}\right]\right]
$$

Dalam pemilihan suatu sistem pengukuran, maka analisis biaya produksi secara keseluruhan harus dilakukan sehingga keputusan mengenai sistem dan prosedur pengukuran dapat berakibat positif bagi ekonomi suatu industri, mislanya manufaktur. Dari persamaan (4) dapat dilihat bahwa pemilihan suatu sistem pengukuran yang tidak tepat akan mengakibatkan banyaknya biaya srapping komponen-komponen yang bagus atau turunnya persepsi konsumen terhadap suatu produk karena produk yang didapatkannya sebenarnya cacat, tetapi lolos dari inspeksi kualitas dari produsen yang membuatnya.

\section{Pemodelan keuntungan proses inspeksi}

Persamaan (5) mengenai perhitungan biaya produksi dan proses inspeksi tidak cukup untuk menjustifikasi suatu investasi sistem pengukuran. Hal ini disebabkan karena tidak adanya komponen dari nilai-tambah ekonomi yang dapat diberikan dari suatu proses inspeksi. Nilai tambah eknomi dari suatu proses inspeksi adalah sebagai berikut:

- Penghematan biaya produksi karena meningkatnya efisiensi proses.

Contoh dari penghematan ini adalah misalnya suatu produk yang diproses lansung di kirim ke bagian perakitan tanpa melalui proses pengukuran mengakibatkan jalur perakitan terhenti karena terdapat cacat pada produkt tersebut sehingga produk tersebut tidak dapat dirakit. Contoh lainnya adalah suatu komponen ditemukan bermasalah ketika dilakukan sebuah tes pada suatu produk yang sudah terakit, sehingga mengakibatkan biaya tambahan karena harus mengganti produk yang cacat tersebut. Pada prinsipnya, semakin cepat sebuah cacat produk ditemukan (semakin pada tahapan awal suatu cacat ditemukan), maka semakin kecil biaya untuk menanggulangi cacat tersebut.

Metode kuantifikasi dari jenis penghematn ini adalah sebagai berikut:

$$
S_{T}=N_{p} \cdot P_{n c} \cdot \sum_{m=1}^{M}\left[\sum_{m^{\prime}=1}^{m}\left(1-P_{i d, m^{\prime}-1}\right) \cdot P_{i d, m^{\prime}} \cdot C_{n c, m}\right]
$$

dimana $S_{T}$ adalah total penghematan yang didapatkan, $N_{p}$ adalah jumlah komponen yang diproduksi dalam suatu periode tertentu, $P_{C}$ adalah fraksi dari komponen yang bagus yang bergantung pada stabilitas suatu proses produksi. Diasumsikan bahwa semua komponen yang bagus (lolos inspeksi) akan berfungsi sesuai dengan yang diinginkan sesuai desain. $P_{n c}=1-P_{c}$ adalah fraksi dari komponen cacat. $M$ adalah jumlah dari proses produksi atau manufaktur. Komponen-komponen yang cacat akan sebagian diestimasi dari setiap tahapan produksi dengan probabilitasnya $P_{i d, m}$ dan biayanya $C_{n c, m}$, dimana $P_{i d, m}=0$.

Data yang dibutuhkan untuk mengkalkulasi persamaan (6) adalah nilai $P_{i d, m}$ dan $C_{n c, m}$, pada setiap tahapan proses produksi. Nilai dari variabel-variabel tersebut dapat ditentukan dari analisis data historis produksi suatu industri manufaktur. Untuk suatu produk yang baru, dapat menggunakan estimasi dari produk yang mirip dan juga saran dari estimasi seseorang yangahli dan berpengalamna di proses produksi.

Selain itu, pilihan lainnya adalah untuk meng-oursource suatu komponen ke perusahaan lain dengan meminta biaya ganti rugi apabila komponen yang diorder dari perusahaan tersebut cacat. Hal ini dapat mendorong suplier tersebut untuk dapat meningkatkan kualitas produk mereka. 
- Penghematan biaya garansi dari pengembalian suatu produk cacat yang sampai ke pasaran.

Apabila tidak ada proses inspeksi produk, maka cacat pada produk tersebut akan lolos ke konsumen sehingga terjadi pengembalian produk dari konsumen. Tentu saja, pengembalian suatu produk tidak hanya berimplikasi pada biaya riil, tetapi juga dapat menurunkan reputasi suatu perusahaan. Jumlah pengembalian suatu produk oleh konsumen $N_{n c, w}$ dapat dimodelkan dengan:

$$
N_{n c, w}=N_{p} \cdot P_{n c} \cdot \prod_{m=1}^{M}\left(1-P_{i d, m}\right)
$$

Total penghematin dari pengurangan jumlah pengembalian suatu produk adalah biaya produksi produk dapat dikalkulasi sebagai berikut:

$$
S_{w}=N_{n c, w} \cdot P_{n c, f} \cdot C_{f}
$$

dimana adalah jumlah penghematan yang didapatkan, $P_{n c, f}$ adalah probabilitas suatu produk akan dikembalikan dalam masa garansi produk tersebut. $P_{n c, f}$ dapat ditentukan dengan analisis distribusi karakteristik dan analisis hubungan antara limit spesifikasi suatu komponen dan limit fungsionalitas komponen tersebut sesuai dengan ISO/TS 14253-4. $C_{f}$ adalah biaya dari setiap produk yang dikembalikan dalam masa garansinya, termasuk potensi kerugian akibat turunnya reputasi seuatu perusaan di pasaran.

Nilai dari variabel-variabel pada persamaan (7) dan (8) dapat ditemukan pada catatan historis suatu perusahaan terhadap data purna-jual selama masa garansi. Metode failure mode and effect analysis (FMEA) sangat bermanfaat untuk menentukan nilai variabel-variabel tersebut.

Sehingga, dari persamaan (6), (7) dan (8), potensi keuntungan $P B_{\text {ip }}$ yang didapatkan dari metrologu manufaktur adalah:

$P B_{i p}=N_{p} \cdot P_{n c} \cdot\left[\sum_{m=1}^{M}\left[\sum_{m^{\prime}=1}^{m}\left(1-P_{i d, m^{\prime}-1}\right) \cdot P_{i d, m^{\prime}} \cdot C_{n c, m}\right]+\prod_{m=1}^{M}\left(1-P_{i d, m}\right) \cdot P_{n c, f} \cdot C_{f}\right]$

- Penghematan yang didapatkan karena bertambahnya pengetahuan teknis mengenai suatu proses dan produk.

Jenis penghematan ini sangat sulit untuk dikuantifikasi karena sangat spesifik pada suatu kondisi perusahaan dan membutuhkan analisis subjektif dari para ahli produksi. Contoh penghematan ini adalah fungsionalitas dari produk yang diproduksi akan semakin bertambah sehingga dapat lebih meningkatkan pengalaman konsumen dalam menggunakan produk tersebut, pembesara dari nilai toleransi karena dengan pembesaran nilai suatu toleransi, maka biaya produksi semakin berkurang, dan peningkatan pengetahuan suatu proses produksi sehingga proses parameter yang optimum didapatkan yang mengekibatkan suatu proses yang stabil dna terkontrol.

- Penghematan yang didapatkan dari kerugian non-teknis.

Produk yang mengakibatkan cedera atau berkurangnya reputasi baik suatu industri karena konsumen menemukan atau mendapatkan produk yang cacat. Jenis pengehmatin ini juga sangat sulit untuk dikuantifikasi karena behubungan dnegan sistem hukum suatu negara dan persepsi publik megenai reputasi suatu perusahaan. 


\section{Pemodelan evaluasi investasi}

Setelah keuntungan ekonomi dari metrologi manufaktur didapatkan atau dikuantifikasi, maka analisis NPV dapat dilakukan (lihat bagian 10.2). Beberapa indikator lainnya yang sering digunakan adalah metode penentuan internal rate of return (IRR) dan payback period (Sulivan et al 2002).

\section{Pemodelan biaya error dari inspeksi $C_{\text {error }}$}

$C_{\text {error }}$ terbagi menjadi dua komponen, yaitu $C_{\alpha}$ dan $C_{\beta}$, yang merupakan biaya yang muncul karena menolak suatu produk yang sebenarnya bagus dan biaya yang muncul karena menerima atau meloloskan produk cacat. $C_{\alpha}$ dan $C_{\beta}$ didefiniskan sebagai:

$C_{\alpha}=N_{p} \cdot P_{c} \cdot c_{\alpha} \cdot \alpha(10)$

$C_{\beta}=N_{p} \cdot P_{n c} \cdot c_{\beta} \cdot \beta(11)$

dimana $\alpha$ adalah probabilitas dari error Tipe I (menolak produk yang bagus) dan $\beta$ adalah probabilitas dari error Tipe II (menerima produk yang cacat). Detil dari bagaimana cara mentuka probabilitas tipe I dan tipe II tersebut dapat merujuk pada Savio 2012.

\section{$\underline{\text { Contoh kasus untuk memutuskan investasi sistem pengukuran }}$}

Pada bagian ini, sebuah kasus untuk mengkuantifikasi keuntungan ekonomi dengan berinvestasi intuk meningkatkan performansi dari proses inspeksi. Kasus yang diperlihatkan adalah inspeksi komponen-komponen yang diterima pada suatu perusahaan produsen sepeda motor. Komponen tersebut diterima dari suatu suplier dari perusahaan lain. Komponen terseut adalah blok silinder dari suatu mesin motor bakar.

Dari data-data yang dimiliki perusahaan tersebut, variabel-variabel yang berhubungan dengan biaya proses inspeksi adalah sebagai berikut:

- $\quad P_{n c}=1 \%$ yang diestimasi dari kapabilitas proses $C_{p k}$ (lihat Bab 2 dan Bab 4) komponen-komponen blok silinder yang diterima berkisar 1 sampai 1.5. Total komponne yang diterima adalah sebanyak $N=23400$ komponen/tahun.

- $\quad P_{n c, f}=50 \%$ yang diestimasi berdasarkan saran dari seorang ekspert yang berpengalaman dalam kasus ini dan berdasrkan analisis FMEA.

- Biaya rata-rata yang muncul karena komponen yang cacat ditentukan berdasarkan data historis inspeksi komponen masuk pada divisi kualitas perusahaan tersebut.

Tabel 3: Biaya rata-rata komponen cacat dan komponen cacat yang lolos ke konsumen atau pasar.

\begin{tabular}{|l|c|c|c|c|c|}
\hline \multicolumn{1}{|c|}{ Tahapan proses manufaktur } & $\begin{array}{c}\text { Proses } \\
\text { inspeksi }\end{array}$ & $\begin{array}{c}\text { Perakitan } \\
\text { mesin }\end{array}$ & $\begin{array}{c}\text { Perakitas } \\
\text { sepeda motor }\end{array}$ & $\begin{array}{c}\text { Pengetesan } \\
\text { sepeda motor }\end{array}$ & $\begin{array}{c}\text { Periode } \\
\text { garansi }\end{array}$ \\
\hline $\begin{array}{l}\text { Biaya logistik dan manajemen } \\
\text { (termasuk biaya penurunan reputasi) } \\
\text { /EUR }\end{array}$ & 10 & 10 & 10 & 10 & 500 \\
\hline Biaya perbaikan/scrap /EUR & 90 & 130 & 175 & 386 & 724 \\
\hline $\begin{array}{l}\text { Total rata-rata komponen cacat/gagal } \\
\text { fungsi /EUR }\end{array}$ & 100 & 140 & 185 & 396 & 1224 \\
\hline
\end{tabular}


- Biaya rata-rata yang muncul karena komponen cacat yang lolos ke konsumen atau pasar ditentukan dari data historis jaminan garansi konsumen perushaan sepeda motor tersebut. Tabel 3 memperlihatkan estimasi dari biaya rata-rata komponen cacat dan komponen cacat yang lolos ke pasar tersebut.

- Komponen-komponen yang cacat dapat ditemukan di setiap tahapan produksi. Kemungkinan pendeteksian suatu cacat pada komponen disetiap tahapan produksi diperlihatkan pada Tabel 4. Pada tabel 4, dapat terlihat bahwa, engan kemampuan sistem pengukuran yang dimiliki perusahaan tersebut, cacat selalu lolos pada tahapan perakitan mesin dan perakitan sepeda motor dan baru ketahuan pada saat sepeda motor dites.

Tabel 4: Kemungkinan pendeteksian cacat pada setiap tahapan produksi.

\begin{tabular}{|c|c|c|c|}
\hline Tahapan proses manufaktur & $\begin{array}{c}\text { Perakitan } \\
\text { mesin }\end{array}$ & $\begin{array}{c}\text { Perakitas } \\
\text { sepeda motor }\end{array}$ & $\begin{array}{c}\text { Pengetesan } \\
\text { sepeda motor }\end{array}$ \\
\hline $\begin{array}{l}\text { Probabilitas pendeteksian suatu cacat } \\
\text { pada komponen-komponen }\left(P_{i d, s}\right)\end{array}$ & $0 \%$ & $0 \%$ & $20 \%$ \\
\hline
\end{tabular}

Tabel 5: Perbandingan keuntungan investasi untuk alternatif 1 (sistem pengukuran/gauge manual) dan 2 (CMM otomatis). Asumsi: pajak $=40 \%$, bunga pinjaman $=5 \%$ dan lama depresiasi peralatan $=10$ tahun.

\begin{tabular}{|l|c|c|}
\hline \multicolumn{1}{|c|}{ Biaya-biaya } & $\begin{array}{c}\text { Investasi 1: Sistem } \\
\text { pengukuran (gauge) manual }\end{array}$ & Investasi 2: CMM otomatis \\
\hline Nilai investasi awal /EUR & 5000 & 120000 \\
\hline Biaya variabel /EUR.Tahun ${ }^{-1}$ & 32200 & 39700 \\
\hline Jumlah dimensi yang dapat diukur & 5 & 14 \\
\hline Biaya error Tipe I $\left(\mathrm{C}_{\alpha}\right) /$ EUR.Tahun-1 & 22471 & 22309 \\
\hline $\begin{array}{l}\text { Biaya error Tipe I I }\left(\mathrm{C}_{\beta}\right) / \text { EUR.Tahun- } \\
1\end{array}$ & 85841 & $\mathbf{2 3 1 1 0 2}$ \\
\hline Net Present Valu $(\mathbf{N P V}) /$ EUR & $\mathbf{- 7 0 6 3 8}$ & $32 \%$ \\
\hline Internal Return Rate /EUR & - & 36 \\
\hline Periode Payback /bulan & - & \\
\hline
\end{tabular}

- Dari data pada Tabel 4, perusahaan tersebut dapat mengkuantifikasi potensi keuntungan apabila deteksi cacat dapat dilakukan pada tahapan lebih awal dan deteksi cacat pada tahap akhir, pengetesan sepeda motor, dapat dikurangi. Potensi keuntungan $P B_{i p}$ tersebut adalah sebesar $133108 \mathrm{EUR} /$ tahun.

- Untuk merealisasikan potensi keuntungan tersebut, maka perusahaan tersebut ingin berinvestasi untuk membeli sistem pengukuran baru yang dapat meningkatkan performansi proses inspeksi. Terdapat dua alternatif untuk investasi: alternatif 1 adalah membeli peralatan gauge manual yang baru (seperti: micrometer, go/no-go gauge, dan pneumatic gauge) dan alternatif 2 adalah membeli CMM otomatis.

- Alternatif 1 mempunyai nilai investasi awal yang jauh lebih murah. Tetapi, sistem gauge manual tersebut hanya dapat mengukur 5 dimensi kritikal dan mempunyai rasio U/T (lihat Bab 3 dan 9) sebesar 0.2.

- Alternatif 2 membutuhkan niai investasi awal yang jauh lebih besar dari pada alternatif 1. Dengan CMM, total 14 dimensi kritikal dapat diukur dan rasio U/T sebesar 0.13. Semakin kecil nilai rasio U/T, maka nilai ketidakpastian dari sistem pengukuran akan semakin kecil (hasil yang lebih reliabel), sehingga dapat mengurangi biaya error tipe I $\left(C_{\alpha}\right)$ dan tipe II $\left(C_{\beta}\right)$. 
- Tabel 5 memperlihatkan detil dari perbandingan keuntungan investasi dari kedua alternatif tersebut. pada Tabel 5, dapat terlihat bahwa alternatif 1 tidak memberikan keuntungan ekonomi dalam periode ke depannya (Nilai NPV negatif), sedangkan alternatif 2 memberikan keuntungan ekonomi yang sangat signifikan terhadap perusahaan kedepannya (Nilai NPV positif).

Pada contoh ini, dapat dilihat bahwa metorlogi yang tepat guna akan mejadi suatu kegiatan produktif dan akan menghasilkan keuntungan ekonomi bagi suatu perusahaan.

\subsubsection{Keuntungan interoperabilitas CMM}

Sistem pengukuran CMM otomatis merupaka suatu sistem yang sudah mapan dipasaran sebagai alat ukur standar dimensi dan geometri. Dengan banyaknya jenis CMM dari berbagai manufaktur yang berbeda, maka perangkat lunak dan tipe data yang digunakan pada setiap CMM tersebut berbeda-beda. Perbedaan tersebut dapat menimbulkan masalah interoperabilitas antar berbagai meisn CMM dan akan menimbulkan potensi kerugian ekonomi suatu perusahaan (Savio et al 2014). Masalah interoperabilitas tersebut dapat mengurangi reprodisibilitas hasil pengukuran dengan berbagai CMM dan akan menambah waktu yang diperlukan untuk menterjemahkan berbagai part program CMM yang berbeda-beda (yang menimbulkan biaya labor yang tidak efisien).

Pada zaman sekarang, banyak perusahaan yang mempunyai cabang diberbagai tempat, bahkan di berbagai negara. Pada umumnya, jenis-jenis CMM pada setiap cabangnya berbeda-beda, baik jenis dan produsen pembuatnya. Maka dari itu, masalah interoperabilitas CMM merupakan potensi kerugian yang cukup signifikan. Wujud dari kerugian tersebut akhirnya berupa bertambahnya waktu proses inspeksi dan analisis hasil pengukuran karena ada proses transfer data dari satu format ke format lainnya. Masalah lainnya adalah, dengan adanya transfer format data unuk berbagai jenis perangkat lunak CMM yang berbeda, reprodisibilitas hasil pengukuran menjadi rendah dan dapat mengakibatkan kesalahan pengambilan keputusan menerima atau menoka sebuah komponen yang diukur (error Tipe I dan Tipe II).

Salah satu solusi untuk maslaa interoperabilitas CMM adalah dengan memakai kebijakan suplier tunggal untuk sebuah CMM di setiap cabang dari suatu perusahaan. Namun demikian, hal ini tidak bisa diterapkan karena berbagai macam faktor, misalnya untuk perusahaan besar, kebijakan pembelian barang dari suplier tunggal tidak dibolehkan. Solusi yang potensial adalah dengan usaha disusunnya sebuah standar Dimensional Measuring Interface standard (DMIS) yang mendefinisikan bahasa netral untuk komunikasi dan pertukaran data antara sistem pengukuran, terutama CMM. Sementara itu, sebuah solusi yang bernama I++ DME sedang disusun. I++ DME memungkinkan suatu program CMM dapat dijalankan diberbagai jenis CMM yang berbeda produsen.

Keuntungan potensial dari peningkatan efisiensi interoperabilitas antar berbagai jenis CMM adalah (Savio et al 2014):

- Pengurangan biaya pemrograman CMM.

Pengurangan biaya dari pemrograman CMM didapatkan dari pengurangan waktu pembuatan ulang program CMM. Sebagai contoh, apabila terdapat CMM-A dan CMM-B yang merupaka jenis CMM yang berbeda produsennya, maka pada umumnya program yang dibuat CMM-A tidak bisa dijalankan pada CMM-B, dan sebaliknya. Sehingga, program CMM untuk komponen yang sama persis harus dibuat dua kali untuk CMMA dan CMM-B. Hal ini tentu saja akan menambah waktu yang tidak produktif untuk membuat ulang pogram CMM tersebut. Masalah ini secara konvensional dapat diminimalisasi dengan menggunakan programmer CMM yang handal dan pengelompokkan berbagai komponen yang mempunyai karakteristik yang sama. Gambar 3 memperlihatkan korelasi positif antara lamanya jam kerja seorang programmer CMM (dengan pengalaman 2 tahun) terhadap jumah fitur dari suatu produk yang diukur. 


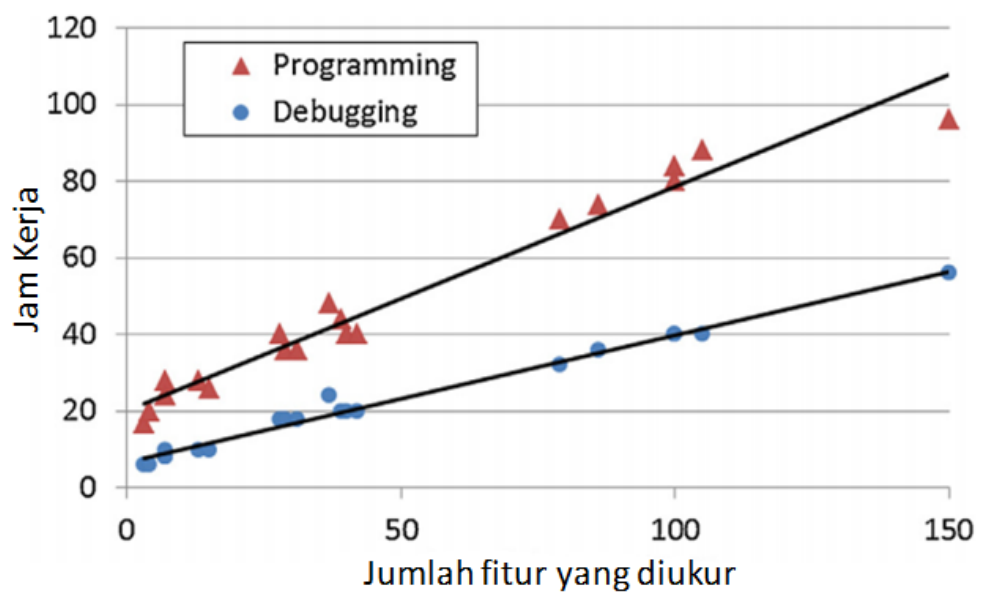

Gambar 3: Lamanya jam kerja yang dibutuhkan seorang programmer dengan pengalaman 2 tahun terhadap jumah fitur suatu produk yang diukur (Savio et al 2014).

- Pengurangan biaya operasi.

Penguranan biaya ini dapat berupa berkurangnya biaya pelatihan operator secara terus-menerus (karena setiap jenis CMM baru membutuhkan jenis pemrograman yang berbeda), biaya lisensi perangkat lunak dan biaya outsouring karena programmer CMM yang dimiliki sudah terlalu banyak beban kerja.

Biaya operasi yang muncul karena masalah interoperabilitas CMM adalah:

1. Biaya pelatihan untuk penggunaan jenis CMM baru.

2. Biaya pemeliharaan program CMM untuk setiap jenis CMM yang berbeda produsen.

3. Biaya upgrade setiap jenis CMM yang berbeda produsennya.

- Pengurangan biaya tidak produktif.

Contoh dari penghematan jenis ini adalah berkurangnya waktu pemrograman dan waktu tidak efisiensi dalam penggunaan CMM. Gambar 4 memperlihatkan perbandingan biaya pemrograman dengan dan tanpa masalah interoperabilitas. Maksud dari tanpa masalah interoperabilitas adalah program CMM-B dapat menggunakan ulang program CMM-A. Hal tersebut diwujudkan dengan menggunakan perangkat lunak CMM yang berbasis DMIS.

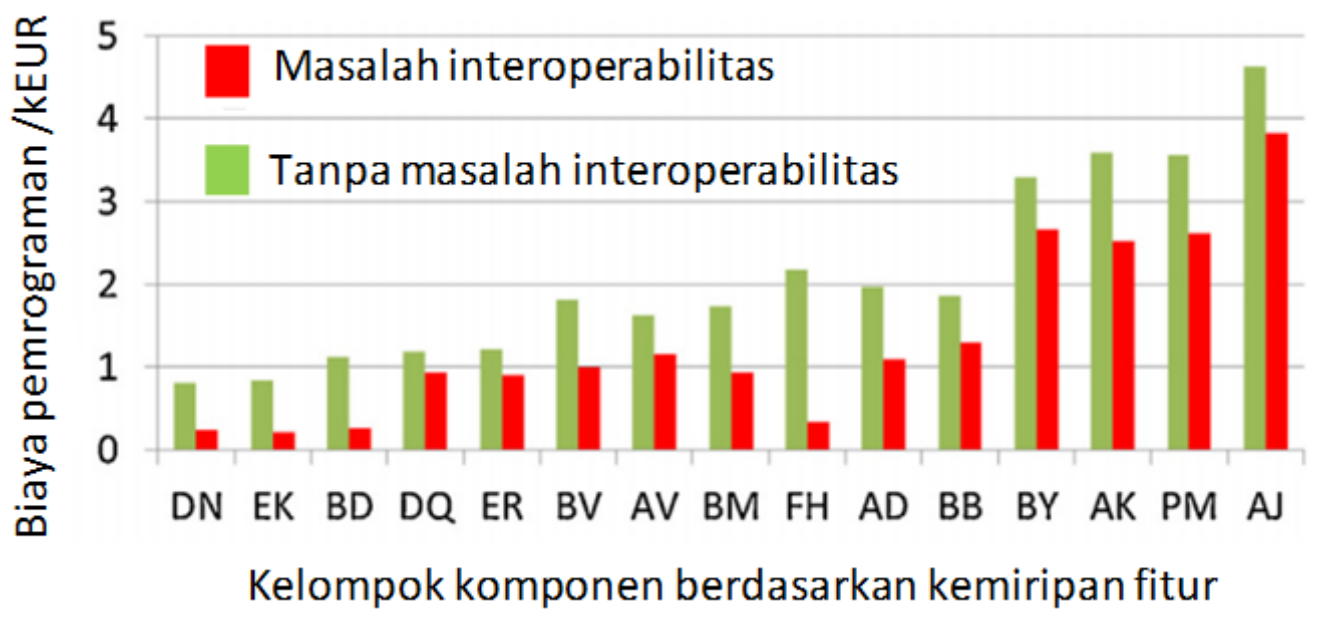

Gambar 4: Perbandingan biaya pemrograman CMM dengan dan tanpa masalah interoperabilitas. 
- Pengurangan ketergantungan dari satu vendor untuk membeli suatu sistem pengukuran.

Hal ini tentu saja akan mengurangi resiko putusnya dukungan pemeliharaan suatu mesin CMM apabila vendornya sudah tidak ada lagi, banyaknya alternatif pilihan investasi CMM dan lain sebagainya. Kuantifikasi dari pengurangan biaya ini sangat sulit untuk ditentukan.

- Pengurangan waktu pengembangan produk.

Contoh dari pengurangan biaya ini adalah mengurangi waktu time-to-market sebuah pengembangan produk baru, karena pada tahap pengembangan, akan terdapat banyak pengukuran yang dibutuhkan untuk berbagai macam bentuk dan lain sebagainya. Apabila setiap pengukuran harus melakukan banyak adaptasi program CMM, maka akan banyak waktu yang terbuang di dalam fase riset pengembangan produk. Contoh lainnya dari pengurangan jenis ini adalah berkurangnya work-in-progress (WiP) dan inventori komponen-komponen. Kuantifikasi dari pengurangan biaya ini juga sangat sulit untuk ditentukan.

Setelah potensi keuntungan dari interoperabilitas CMM ditentukan, maka penentuan NPV dari interoperabilitas tersebut dapat dikalkulasi untuk menentukan keputusan suatu investasi CMM.

\subsubsection{Value adding metrologi manufaktur untuk efisiensi rantai produksi}

Contoh lain dari potensi keuntungan dari metrologi manufaktur melalui peningkatan efisiensi dari rantai proses produksi dibahas oleh Savio et al 2016. Metrology mempuyai peran yang sangat vital di industri manufaktur karena fungsinya yang berperan sebagai penghubung antara proses produksi, desain produk dan fungsi produk. Gambar 5 memperlihatkan fungsi penghubung dari metrologi untuk ketiga komponen tersebut. Pada gambar 5, terlihat bahwa metrologi mempunyai peran yang sangat penting dari siklus suatu produk dan proses produksinya.

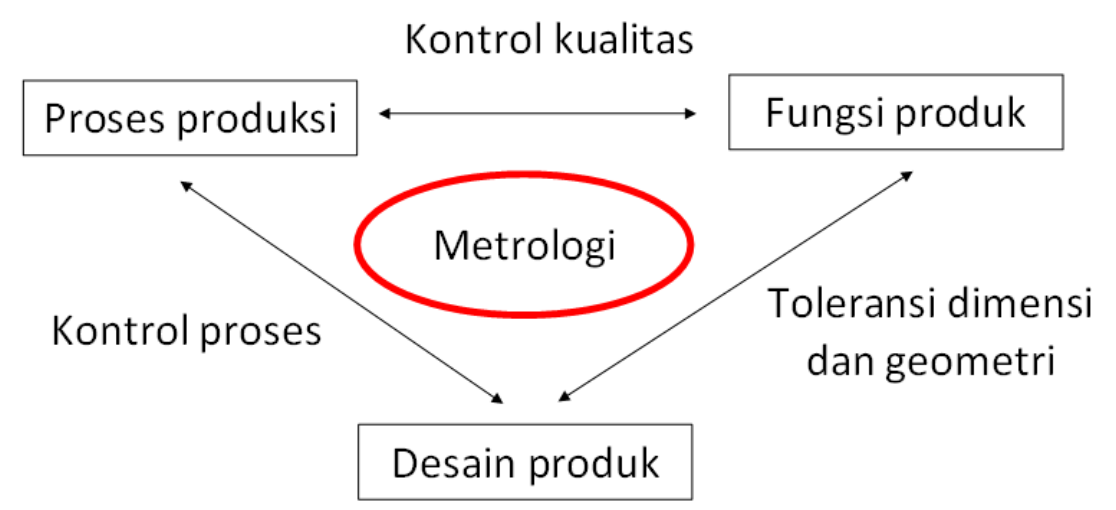

Gambar 5: Peran metrologi sebagai penghubung antara proses produksi, desain produk dan fungsi produk.

Industri otomotif merupakan industri yang paling nyata mendapatkan keuntungan dari metrologi. Karena, industri otomotif melibatkan suatu rantai produksi yang masif dan sangat peka terhadap penghematan berbagai macam biaya yang timbul selama proses produksi tersebut. Dalam proses permesisn, metrologi sangat berperan besar untuk menigkatkan akurasi suatu mein dengan memungkinkannya proses kompensasi error suatu mesin produksi (Kompensasi error dibahas dalam Bab 8).

Dalam berbagai fase proses produksi, peran metrologi terbagi menjadi tiga bagian (Savio et al 2016):

- Keuntungan eknomi metorologi untuk meningkatkan efisiensi dari suatu prosedur desain produk atau proses.

Metrologi dapat mendukung laju proses dari siklus desain dari suatu produk. Berbagai macam keuntungan didapatkan dengan metorlogi pada fase ini, seperti:

Spesifikasi desain. Peningkatan komunikasi teknikal dari GD\&T dan relasinya dengan metrologi menhasilkan analisis spesifikasi desain yang lebih detil dan cepat. 
Analisis kegagalan. Tahap ini adalah menganalisis dimensi-dimensi yang paling kritikal dan mengkorelasikan antara geometri produk dengan reliabilitas fungsinya. Tahap ini juga mengkelompokkan proses mana yang butuh $100 \%$ inspeksi atau inspeksi berbasis sampling. Metode analisis pada tahap ini menggunakan metode FMEA.

Pemilihan proses inspeksi. Tahap ini menganalisis jenis sistem pengukuran yang paling tepat untuk suatu jenis pengukuran tertenti. Metode analisis tahap ini adalah menggunakan analisis bias dan GR\&R.

Instruksi kontrol. Setiap prosedur pengukuran didokumentasikan sehingga menjadi prosedur yang standar untuk semua operator.

Kontrol process. Proses produksi dievaluasi dalam bentuk variasi geometri dari komponen yang dihasilkannya dengan menggunakan proses kontrol berasis statistik.

Verifikasi dari produk. Keputusan menerima atau menolak suatu komponen dilakukan dengan teliti dengan mempertimbangkan toleransi dan nilai ketidakpastian hasil suatu pengukuran.

Validasi periodik dari proses pengukuran. Setiap ada perubahan dalam proses produksi, misalnya parameter permesinan, material dan lain sebagainya, proses pengukuran divalidasi ulang untuk memastikan hasil pengukuran selalu pada tingkat akurasi yang sama.

Total keuntungan metrologi pada fase ini seperti berkurangnya pengembalian produk yang sampai ke konsumen dan pengurangan waktu kerja yang tidak produktif, misalnya: revisi gambar teknik, modifikasi fixture, scrap produk, dan lain sebagainya.

- Keuntungan eknomi metorologi untuk meningatkan efisiensi dari rantai produksi.

Keuntungan metrologi pada fase ini adalah berupa inspeksi $100 \%$ untuk produk bernilai tinggi dan berjumlah sedikit. Dengan begitu, kualitas dari produk tersebut dpaat selalau terkontrol. Untuk produksi masal yang tidak menerapkan $100 \%$ inspeksi, metrologi berperan untuk mengontrol kualitas produksi masal tersebut dengan teknologi pengukuran in-line di dalam jalaur produksi masal tersebut. Metrologi in-line memungkinkan untuk mendeteksi error geometri suatu komponen langsung setelah diproses oleh suatu mesin produksi dan memberikan informasi balik ke mesin tersebut untu dilakukan pengaturan ulang proses parameter sehingga error terseut tidak terjadi pada komponen berikutnya. Dalam hal ini, metrologi digunakna untuk menghasilkan suatu kontorl close-loop dari suatu proses produksi. Akan dibutuhkan investais awal untuk menerapkan sistem metorlogi in-line pada suatu proses produksi yang sudah berjalan. Namun demikian, keuntungan kedepannya sangat besar, seperti berkurangnya jumlah komponen yang cacat dan berkurangnya waktu setup ulang mesin produksi.

- Keuntungan eknomi metorologi untuk merevisi toleransi sutau produk barbasiskan parameter yang berkaitan dengan fungsinya.

Pada prinsipnya, semakin kecil toleransi dari dimensi suatu fitur pada suatu produk, maka biaya untuk proses inspeksi fitur tersebut (termasuk juga biaya proses produksinya) akan semakin meningkat. "The golden rule" dalam metorlogi adalah, suatu proses pengukuran untuk suatu fitur dinyatakan layak (secara nilai ekonomi) apabila rasio $\mathrm{U} / \mathrm{T}$ (uncertainty/tolerance) $\leq 0.2$.

Analisis untuk menentukan fitur mana pada suatu produk yang paling signifikan dan paramater pengukuran apa yang paling tepat menggambarkan properti fitur tersebut dapat mendatangkan keuntungan ekonomi yang sangat signifikan. Sebagai contoh, pada gambar 6, diperlihatkan data dari hasil dari suatu proses gerinda dair suatu permukaan benda. Pada gambar 6, dapat terlihat bahwa parameter $R k$ dapat merepresentasikan keadaan permukaan benda tersebut lebih baik dari parameter $R a$. Dengan parameter Rk, dapat terlihat bahwa proses gerinda diatas $20 \mathrm{~s}$ sudah tidak memberikan peningkatan kualitas permukaan benda tersebut secara signifikan, sehingga proses gerinda cukup selama $20 s$ saja. Hal ini dapat menghemat waktu proses gerinda secara signifiakn dan dapat mendatangkan keuntungan ekonomi dari berkurangnya jumlah jam kerja dan energi yang digunakan untuk proses gerinda tersebut. 


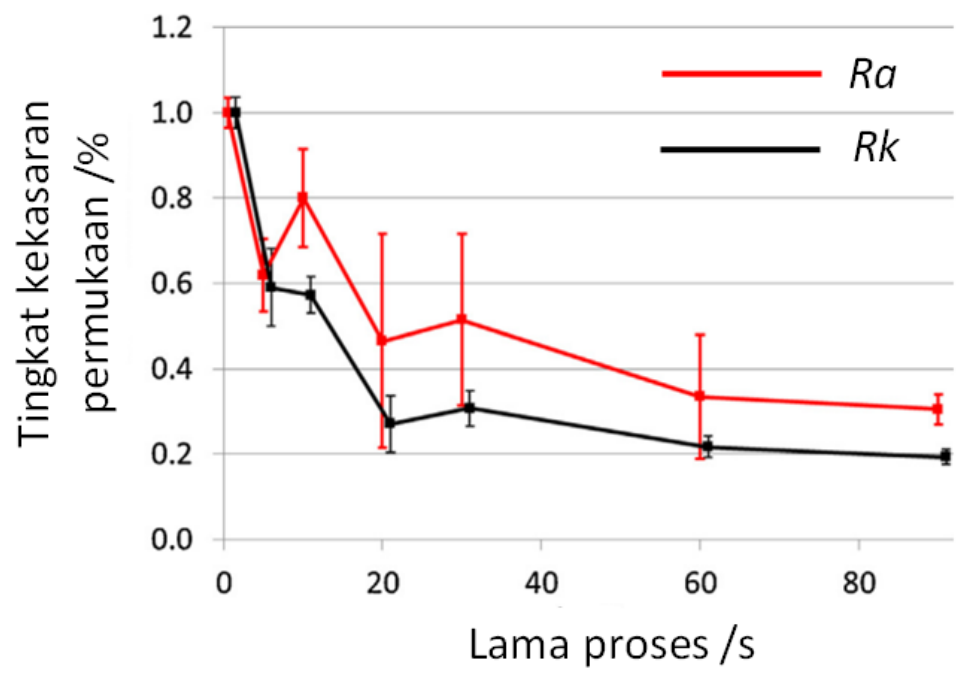

Gambar 6: Perbandingan parameter $R a$ dan $R k$ untuk merepresentasikan kekasaran suatu permukaan yang digerinda (savio et al 2016).

Sebagai rangkuman dari tiga bagian terakhir bab ini, telah dibahas berbagai potensi keuntungan proses inspeksi dan cara kuantifikasinya, yaitu:

- Bagian 10.3.3: potensi keuntungan dari berkurangnya biaya karena kesalahan keputusan menerima atau menolak sebuah komponen yang diukur.

- Bagian 10.3.4: potensi keuntungan dari interoperabilitas berbagai jenis CMM.

- Bagian 10.3.5: potensi keuntungan dari meningkatnya efisiensi suatu rantai produksi, siklus desain produk dan revisi toleransi suatu produk.

Sebagai penutup, contoh-contoh yang diberikan pada bab ini adalah hanya sebagian kecil dari banyaknya keuntungan ekonomi yang didapatkan dari metrologi manufaktur. Sehingga, diharapkan kedepannya metrologi harus dianggap juag sebagai "profit center" di dalam suatu industri, terutama industri manufaktur, dan harus dianggap sama pentingnya dengan proses produksi. 


\section{Daftar pustaka}

ASME B89.7.2 1999 Dimensional measurement planning American Society of Mechanical Engineering.

ASME Y14.5 2009 Dimensioning and tolerancing American Society of Mechanical Engineering.

ASME Y14.5-1 1994 Mathematical definition of dimensioning and tolerancing principles American Society of Mechanical Engineering.

Barker A, Syam WP, Leach RK 2016 Measurement noise of a coherence scanning interferometer in an industrial environtment $31^{\text {st }}$ ASPE Annual Meeting, 23-28 October, Portland, Oregon, USA.

Bartscher M, Hilpert U, Goebbels J, Weidemann G 2007 Enhancement and proof of accuracy of industrial computed tomography (CT) measurements Ann. CIRP 56 495-498.

Beaman J and Morse E 2010 Experimental evaluation of software estimates of task specific measurement uncertainty for CMMs Precis. Eng. 34 28-33.

Bell S 1999 A Beginner's guide to uncertainty of measurement NPL Good Practice Guide No. 11.

BIPM 1983 Unit of length (metre) CGPM Resolution 1. Link: http://www.bipm.org/en/publications/sibrochure/metre.html

BIPM 2008a International vocabulary of metrology basic and general concepts and associated terms (VIM). ISO, IEC, IFCC, IUPAC, IUPAP, OIML.

BIPM 2008b Evaluation of measurement data - Guide to the expression of uncertainty in measurement (GUM). JCGM-100.

Bracewell RN. 2000 The Fourier transform and its applications (McGraw-Hill: New York).

Brown \& Sharpe 2001 Justifying the CMM P/N 80-80059-2, Brown \& Sharpe Measuring Systems Division, Precision Park, North.Kingstown, RI.

Bonnans JF, Gilbert JC, Lemarechal C, Sagastizabal CA 2003 Numerical optimization (Springer-Verlag: Berlin).

Bonsch G, Potulski E 1998 Measurement of the refractive index of air and comparison with modified Edlen's formulae Metrologia 35 133-139.

Boothroyd G 2002 Product design for manufacture and assembly (Marcel Dekker: New York).

Bouras A, Syam WP 2013 Hybrid chaos optimization and affine scalling search algorithm for solving linear programming problems Applied Soft Computing 13 2703-2710.

Burdick RK, Borror CM, Montgomery DC 2005 Design and analysis of gauge R\&R studies: Making decisions with confidence intervals in random and mixed ANOVA models (ASA-SIAM: USA).

Carmignato S, Dewulf W, Leach R 2018 Industrial X-ray computed tomography (Springer-AG: Switzerland).

Carmignato S, Pierobon A 2010 International comparison of CT systems for dimensional metrology: The "CT Audit" Project. Industrielle Computertomografie, Tagung, FH Wels, Austria.

Colosimo BM, Senin N 2011 Geometric tolerances: Impact on product design, quality inspection and statistical process monitoring (Springer-Verlag: London). 
Cox MG and Harris PM 2010 Software support for metrology - NPL best practice guide no. 6 (NPL: Teddington). Cox MG, Harris PM, Smith IM 2010 Software specifications for uncertainty evaluation (NPL: Teddington).

De Chiffre L, Carmiganto S, Kruth JP, Schmitt R, Weckenmann A 2014 Industrial applications of computed tomography Ann. CIRP 63 655-677.

Del Castillo E 2007 Process optimization: A statistical approach (Springer: New York).

Dewulf W, Kiekens K, Tan Y, Welkenhuyzen F, Kruth JP 2013 Uncertainty determination and quantification for dimensional measurements with industrial computed tomography Ann. CIRP 62 535-538.

Dewulf W, Tan Y, Kiekens K 2012 Sense and non-sense of beam hardening correction in CT metrology Ann. CIRP 61 495-498.

Dorion T $200720^{\circ} \mathrm{C}-$ A short history of the standard reference temperature for industrial dimensional measurements J. Res. Natl. Inst. Stan. 112 1-23.

Dorion T 2008 Gauge blocks - A zombie technology J. Res. Natl. Inst. Stan. 113 175-184.

Dorion T and Stoup J 1997 Uncertainty and dimensional calibrations J. Res. Natl. Inst. Stan. 102 647-676.

Fischer BR 2011 Mechanical tolerance stackup and analysis (CRC Press: Boca Raton, Florida).

Folley JD, Dam AV, Feiner SK, Hughes JF, Phillips RL 1994 Introduction to computer graphics (Addison-Wesley: New York).

Fusiello A, Trucco E, Verri A 2000 A compact algorithm for rectification of stereo pairs Machine vision and applications 12 16-22.

Hamman B 1993 Curvature approxiamation for trinagulated surfaces Geometric modelling 139-153.

Haitjema H 2008 Achieving traceability and sub-nanometer uncertainty using interferometric techniques Meas. Sci. Technol. 19 6pp.

Hansen HN, Carneiro K, Haitjema H, De Chiffre L. 2006 Dimensional micro and nano metrology Ann. CIRP 55721 743.

Harding K 2013 Handbook of optical dimensional metrology (CRC Press: Boca Raton).

Hartley R, Zisserman 2003 A Multiple view geometry in computer vision (Cambridge University Press: Cambridge).

Hines WW, Montgomery DC, Goldsman DM, Borror CM 2003 Probability and statistics in engineering $4^{\text {th }}$ edition (John Wiley \& Sons: New York).

Hocken RJ, Raja J, Babu U 1993 Sampling issues in coordinate metrology Manuf. Rev. 6282

Hocken RJ, Pereira PH 2012 Coordinate measuring machines and systems: Second edition (CRC Press: Boca Raton).

Huang PS, Ni J 1995 On-line error compensation of coordinate measuring machines Int. J. Mach. Tools Manufact. 35 725-738.

Goodfellow I, Bengio Y, Courville A 2016 Deep learning (MIT Press: Massachussets).

ISO 11012017 Geometrical product specification (GPS) - Geometric tolerancing - Tolerances of form, orientation, location and run-out International Organization for Standardization.

ISO 10360-1 2000 Geometrical product specification (GPS) - Acceptance and reverification tests for coordinate measuring machine (CMM) - Part 1: Vocabulary International Organization for Standardization.

ISO 10360-2 2009 Geometrical product specification (GPS) - Acceptance and reverification tests for coordinate measuring machine (CMM) - Part 2: CMMs used for measuring linear dimension International Organization for 


\section{Standardization.}

ISO 10360-3 2000 Geometrical product specification (GPS) - Acceptance and reverification tests for coordinate measuring machine $(\mathrm{CMM})$ - Part 3: CMMs with the axis of a rotary table as the fourth axis International Organization for Standardization.

ISO 10360-4 2000 Geometrical product specification (GPS) - Acceptance and reverification tests for coordinate measuring machine (CMM) - Part 4: CMMs used in scanning measuring mode International Organization for Standardization.

ISO 10360-5 2010 Geometrical product specification (GPS) - Acceptance and reverification tests for coordinate measuring machine (CMM) - Part 5: CMMs using single and multiple stylus contacting probing systems International Organization for Standardization.

ISO 10360-6 2001 Geometrical product specification (GPS) - Acceptance and reverification tests for coordinate measuring machine (CMM) - Part 6: Estimasion of errors in computing Gaussian associated features International Organization for Standardization.

ISO 10360-7 2011 Geometrical product specification (GPS) - Acceptance and reverification tests for coordinate measuring machine (CMM) - Part 7: CMMS equiped with imaging probing systems International Organization for Standardization.

ISO 10360-8 2013 Geometrical product specification (GPS) - Acceptance and reverification tests for coordinate measuring machine (CMM) - Part 8: CMMs with optical distance sensors International Organization for Standardization..

ISO 10360-9 2013 Geometrical product specification (GPS) - Acceptance and reverification tests for coordinate measuring machine (CMM) - Part 9: CMMs with multiple probing systems International Organization for Standardization.

ISO 10360-10 2016 Geometrical product specification (GPS) - Acceptance and reverification tests for coordinate measuring machine (CMM) - Part 10: Laser trackers for measuring point-to-point distances International Organization for Standardization.

ISO 10360-12 2016 Geometrical product specification (GPS) - Acceptance and reverification tests for coordinate measuring machine (CMM) - Part 12: Articulated arm coordinate measurement machines (CMM) International Organization for Standardization.

ISO 14253-1 2013 Geometrical product specification (GPS) - Inspection by measurement of workpieces and measuring equipment - Part 1: Decision rules for proving conformity or nonconformity with specifications International Organization for Standardization.

ISO 14405-1 2016 Geometrical product specification (GPS) - Dimensional tolerancing - Part 1: Linear sizes International Organization for Standardization.

ISO 14405-2 2011 Geometrical product specification (GPS) - Dimensional tolerancing - Part 2: Dimensions other than linear sizes International Organization for Standardization.

ISO 14405-3 2016 Geometrical product specification (GPS) - Dimensional tolerancing - Part 3: Angular sizes International Organization for Standardization.

ISO 15530-1 2013 Geometrical product specification (GPS) - Coordinate measuring machines (CMM): Technique for determining the uncertainty of measurement - Part1: Overview and metrological characteristics International Organization for Standardization.

ISO/DTS 15530-2 2003 Geometrical product specification (GPS) - Coordinate measuring machines (CMM): Technique for determining the uncertainty of measurement - Part 2: Used of multiple measurement strategies 
International Organization for Standardization.

ISO 15530-3 2011 Geometrical product specification (GPS) - Coordinate measuring machines (CMM): Technique for determining the uncertainty of measurement - Part 3: Used of calibrated workpieces or measurement standards International Organization for Standardization.

ISO 15530-4 2008 Geometrical product specification (GPS) - Coordinate measuring machines (CMM): Technique for determining the uncertainty of measurement - Part 4: Evaluating task-specific measurement uncertainty using simulation International Organization for Standardization.

ISO/TS 231652006 Geometrical product specification (GPS) - Guidelines for the evaluation of coordinate measuring machine (CMM) test uncertainty International Organization for Standardization.

ISO 5725-1 1994 Accuracy (trueness and precision) of measurement methods and results - Part 1: General principles and definitions International Organization for Standardization.

Jakubiec W and Plowucha W 2013 First coordinate measurements uncertainty evaluation software fully consistent with the GPS philosophy Procedia CIRP 10 317-322.

Jiang BLW 1998 Optimizing complex functions by chaos search. Cybern. Syst. 29(4) 409-419.

Kim WS, Raman S. 2000 On the selection of flatness measurement points in coordinate measuring machine inspection. Int. J Mach Tools Manuf 40 427-443.

Kotz S and Johnson NL 1993 Process capability indices (Chapman and Hall: London).

Kreyszig E 1999 Advanced engineering mathematics (Wiley: USA).

Kruth JP, Bartscher M, Carmiganto S, Schmitt R, De Chiffre L, Weckenmann A 2011 Computed tomography for dimensional metrology Ann. CIRP 60 821-842.

Kunzmann H, Pfeifer T, Fluegge J. 1993 Scales vs. laser interferometers: Performance and comparison of two measuring systems Annals. CIRP 42 753-767.

Kunzman H, Pfeifer T, Schmitt R, Schwenke H, Weckenmann A 2005 Productive metrology - adding value to manufacture Annals. CIRP 54 155-168.

Leach R 2010 Fundamental principles of engineering nanometrology (Elsevier: Oxford).

Leach R 2011 Optical measurement of surface topography (Springer: Heidelberg).

Leach R 2013 Characterisation of areal surface texture (Springer: Heidelberg).

Luo YZ, Tang GJ, Zhou NL 2008 Hybrid approach for solving systems of nonlinear equations using chaos optimization and quasi-Newton method Applied Soft Computing 8(2) 1068-1073.

Mari L, Blattner P, Pavese F 2017 Improving the understandability of the next edition of the International System of Units (SI) by focusing on its conceptual structure Measurement 101 200-205.

Marquardt DW 1963 An algorithm for least-squares estimation of non-linear parameters J. Soc. Indust. Appl. Math. 11 431-441.

Meadows JD 1995 Geometric dimensioning and tolerancing: Applications and techniques for use in design, manufacturing, and inspection (Marcel Dekker: New York).

Mekid S 2009 Introduction to precision machine design and error assesment (CRC Press: Boca raton).

Montgomery DC 2001 Design and analysis of experiments $5^{\text {th }}$ edition (John Wiley \& Sons: New York).

Montgomery DC, Runger GC 2003 Applied statistics and probability for engineers $3^{\text {rd }}$ edition (John Wiley \& Sons: New York). 
Moroni G, Petro S, Tolio T. 2011 Early cost estimation for tolerance verification Annals. CIRP 60 195-198.

Moroni G, Petro S. 2013 Inspection strategies and multiple geometric tolerances Procedia CIRP 10 54-60.

Moroni G, Petro S. 2014 Optimal inspection strategy planning for geometric tolerance verification Precis. Eng. 38 71-81.

Moroni G, Petro S, Syam WP 2014 Performance improvement for optimization of the non-linear geometric fitting problem in manufacturing metrology Meas. Sci. Technol. 8

Moroni G, Petro S, Syam WP 2014 Toward an automatic measurement of micro cutting tool $14^{\text {th }}$ euspen International Conference, Dubrovnik, Croatia.

Moroni G, Petro S, Syam WP 2014 Four-axis micro measuring systems performance verification Annals. CIRP 63 485-488.

Moroni G, Syam WP, Petro S 2013 On combining chaos search and lavenberg-marquadrt algorithm for non-linear substituted geometric fitting problems $11^{\text {th }}$ International Conference on Measurement and Quality Control, 11-13 September 2013, Cracow, Poland.

Moroni G, Syam WP, Petro S 2015 Uncertainty in 3D micro measurement with focus variation microscopy Proceeding of 4M/ICOMM international conference 2015, Milan, Italy.

Moroni G, Syam WP, Petro S 2016 Comparison of chaos optimization functions for performance improvement of fitting of non-linear geometries Measurement 86 79-92.

Moroni G, Syam WP, Petro S 2017 Performance verification of a 4-axis focus variation co-ordinate measuring system IEEE T. Instrum. Meas. 66 113-121.

Nash JC 1979 Compact numerical methods for computers: Linear algebra and function minimization (Bristol: Adam Higler).

NPL History of length measurement link: http://www.npl.co.uk/educate-explore/factsheets/history-of-lengthmeasurement/.

Noughtin PA 2008 chronological history of the modern metric system link: www.metricationmaters.com.

Pedrotti FL, Pedrotti LS 1993 Introduction to optics (Prentice-Hall: New Jersey).

Phillips SD, Borchartd B, Estler WT, Buttress J 1998 The estimation of measurement uncertainty of small circular features measured by coordinate measuring machines Precis. Eng. 22 87-97.

Phillips SD et al 2003 The validation of CMM task specific measurement uncertainty software ASPE summer 51th topical meeting, Charlotte, NC.

Press WH, Teukolsky SA, Vetterling WT, Flannery BP 1992 Numerical recipes in C: The art of scientific computing $2^{\text {nd }}$ edition (Cambridge University Press: Cambridge).

Raghavendra NV, Krishnamurthy L. 2013 Engineering metrology and measurements (Oxford University Press: New Delhi).

Rardin R L 2006 Optimization in Operation Research (New York: Addison-Wesley).

Savio E 2012 A methodology for the quantification of value-adding by manufacturing metrology Annals CIRP 61 503-506.

Savio E, Carmignato S, De Chiffre L 2014 Benefit quantification of interoperability in coordinate metrology Annals CIRP 63 477-480.

Savio E, De Chiffre L, Carmignato S, Meinertz J 2016 Economic benefits of metrology in manufacturing Annals CIRP 
65 495-498.

Sartori S, Zhang GX 1995 Geometric error measurement and compensation of machines Annals CIRP 44 599-609.

Schmitz TL, Smith KS 2012 Mechanical vibrations: modeling and measurement (Springer: New York).

Selin H. 2008 Encyclopaedia of the history of science, technology and medicine in non-western cultures (SpringerVerlag: New York).

Shakarji CM 1998 Least-square fitting algorithms of the NIST algorithm testing system J. Res. Natl. Stand. Technol. 103 633-641.

Shakarji CM 2002 Evaluation of one- and two-sided geometric fitting algorithms in industrial software Proceeding of th e17th ASPE Annual Meeting, St. Louis, MO.

Sladek JA 2016 Coordinate metrology: Accuracy of systems and measurements (Springer-Verlag: Berlin).

Slocum AH 1992 Precision machine design (Prentice-Hall: New Jersey).

Schwenke H, Knapp W, Haitjema H, Weckenmann A, Schmitt R, Delbressine F 2008 Geometric error measurement and compensation of machines-An update Annals CIRP 57 660-675.

Sullivan WG, Wicks EM, Luxhoj J (2002) Engineering Economy, 13th ed. Prentice Hall.

Syam WP 2015 Uncertainty evaluation and performance verification of a 3D geometric focus-variation measurement $\mathrm{PhD}$ Thesis, Politecnico di Milano, Milan, Italy.

Link: https://www.politesi.polimi.it/handle/10589/100382.

Tavazoei MS and Haeri M 2007 An optimization algorithm based on chaotic behavior and fractal nature Comput. Appl. Math. 206(2) 1070-1081.

Tosello G, Hansen HN, Gasparin S 2009 Applications of dimensional micro metrology to the product and process quality control in manufacturing of precision polymer micro components Annals. CIRP 58 467-472.

Tosello G, Hansen HN, Marinello F, Gasparin S 2010 Replication and dimensional quality control of industrial nanoscale surfaces using calibrated AFM measurements and SEM image processing Annals. CIRP 59 563-568.

VDI/VDE 2617-7 2006 Accuracy of coordinate measuring machines: Parameters and their checking - Estimation of measurement uncertainty of coordinate measuring machines by means of simulation VDI/VDE-Richtlinien.

VDI/VDE 2617-11 2011 Accuracy of coordinate measuring machines: Characteristics and their checking Determination of the uncertainty of measurement for coordinate measuring machines using uncertainty budgets VDI/VDE-Richtlinien.

VDI/VDE 2629-2 2012 Accuracy of contour measuring systems: Characteristic and their checking- Determination of the uncertainty of specific contour measurements using standards/calibrated workpieces VDI/VDE-Richtlinien.

VDI/VDE 2630-2.1 2015 Computed tomography in dimensional measurement: Determination of the uncertainty measurement and the test process suitability of coordinate measurement systems with CT sensors VDI/VDERichtlinien.

Weckennmann A, Estler T, Peggs G, McMurthy D 2004 Probing systems in dimensional metrology Annals. CIRP 53 657-684.

Weckennmann A, Knauer M, Kunzmann H 1998 The influence of measurement strategy on the uncertainty of CMM measurements Ann. CIRP 47 451-454.

Weckennmann A, Peggs G, Hoffmann J 2006 Probing system for dimensional micro and nano metrology Meas. Sci. Technol 17:504. 
Whitney DE 2004 Mechanical assemblies: Their design, manufacture, and role in product development (Oxford University Press: New York).

Wilhelm RG, Hocken R, Schwenke H 2001 Task specific uncertainty in coordinate measurement Annals. CIRP 50 553-563.

Wikipedia https://commons.wikimedia.org/wiki/File:Platinum-Iridium_meter_bar.jpg Diakses: 2017.

Ye J, Takac M, Berglund CN, Owen G, Pease RF 1997 An exact algorithm for self-calibration of two-dimensional precision metrology stages Precis. Eng. 20 16-32.

Yoshizawa T 2009 Handbook of optical metrology: principles and applications (CRC press: USA).

Zhang G, Veale R, Charlton T, Borchardt B, Hocken R 1985 Error compensation of coordinate measuring machines Annals CIRP 34 445-448.

Zhang S 2013 Handbook of 3D machine vision: Optical metrology and imaging (CRC press: USA). 


\section{Biografi penulis}

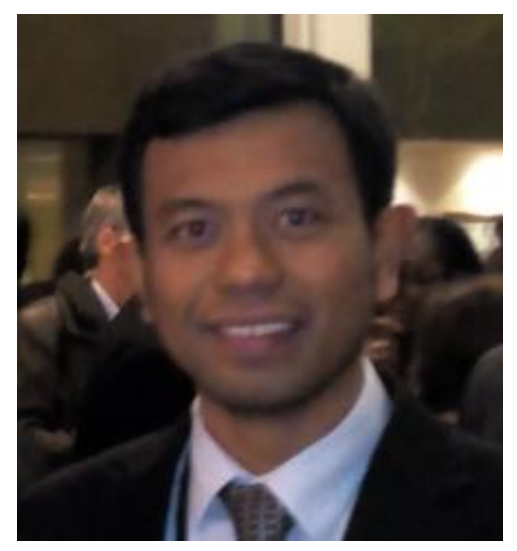

Wahyudin P. Syam dilahirkan di Patani-Gebe, Maluku, Indonesia, pada tahun 1984. Beliau mendapatkan gelar Ph.D. dalam bidang metrologi manufaktur di Politecnico di Milano, Milan, Italia, pada Januari 2015 dan melanjutkan riset post-doctoral di tempat yang sama sampai Juni 2015. Disertasi Ph.D. beliau adalah mengenai verifikasi performansi dan analisis ketidakpastian pada mesin pengukur koordinat (CMM) berbasis optik. Beliau menyelesaikan Ph.D di bawah supervisi Prof. Giovanni Moroni dan Prof. Stefano Petro. Selama menyelesaikan Ph.D., beliau mendalami berbagai macam standar international yang berhubungan dengan pengukuran dimensi dan geometri, seperti ISO 10360, ISO 15530, ISO 1101 dan ASME Y14.5. Selain metrologi, beliau juga meneliti dan mendalami bidang additive manufacturing dan desain inovatif.

Sejak Juli 2015, beliau bekerja sebagai peneliti di Manufacturing Metrology Team (MMT) di University of Nottingham, United Kingdom. Beliau bekerja dibawah supervisi Prof. Richard Leach. Beliau sekarang sedang mendesain, mengembangkan serta memproduksi sebuah CMM untuk pengukuran berskala mikro berbasiskan prinsip Information-Rich Metrology (IRM) untuk pengukuran geometri dan tekstur permukaan. Sebagai tambahan, beliau juga meneliti tentang desain inovatif sebuah struktur berbasis lattice untuk digunakan sebagai struktur metrologi untuk mengisoasi atau mengurangi gangguan vibrasi. Topik riset beliau adalah pengukuran geometri dan tekstur permukaan, desain instrumen presisi dan additive manufacturing.

Wahyudin P. Syam adalah anggota EUSPEN (European Society for Precision Engineering and nanotechnology) dan sebagai peneliti terafiliasi CIRP (College International Pour la Recherche en Productique) periode 2016-2019. 